\title{
Książka na łamach wybranych czasopism w Polsce \\ u progu XXI wieku
}


$\frac{3}{40}$ 


\section{Magdalena Przybysz-Stawska}

Książka
na tamach
wybranych
czasopism
w Polsce
u progu
XXI wieku


Magdalena Przybysz-Stawska - Katedra Bibliotekoznawstwa i Informacji Naukowej Uniwersytet Łódzki, 90-237 Łódź, ul. Matejki 34a

\author{
RECENZENT \\ Oskar Stanisław Czarnik \\ REDAKTOR WYDAWNICTWA UŁ \\ Ewa Siwińska \\ SKŁAD I ŁAMANIE \\ Leonora Wojciechowska \\ PROJEKT OKŁADKI \\ Barbara Grzejszczak
}

(C) Copyright by Uniwersytet Łódzki, Łódź 2013

Wydane przez Wydawnictwo Uniwersytetu Łódzkiego

Wydanie I. 6079/2013

ISBN (wersja papierowa) 978-83-7525-817-2

ISBN (ebook) 978-83-7969-606-2
Wydawnictwo Uniwersytetu Łódzkiego
90-131 Łódź, ul. Lindleya 8
www.wydawnictwo.uni.lodz.pl
e-mail: ksiegarnia@uni.lodz.pl

tel. (42) 6655863 , faks (42) 6655862 
Moim Najbliższym 



\section{SPIS TREŚCI}

Wstęp

Rozdział 1. Rynek książki i prasy w Polsce w latach 1989-2005 …………............................. 23

1.1. Rynek książki. Charakterystyka ogólna ........................................................................... 23

1.2. Rynek prasy. Głównie tendencje rozwojowe ................................................................... 35

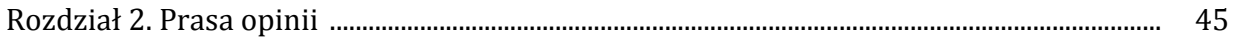

2.1. Prasa opinii. Krótka charakterystyka ……………........................................................... 45

2.2. „Polityka”: pismo pokoleń ......................................................................................... 49

2.2.1. Pół wieku „Polityki”: historia czasopisma .......................................................... 49

2.2.2. Zawartość, akcje i czytelnicy ............................................................................. 58

2.2.3. Ciało jedno, a myśli tysiące: książka na łamach pisma ...................................... 61

2.2.3.1. Tkanie słów: miejsce recenzji w układzie pisma ................................... 62

2.2.3.1.1. Zakres i charakter recenzji - przykłady ................................ $\quad 78$

2.2.3.2. Napiszę, jak się napatrzę: wywiady .......................................................... 84

2.2.3.3. Warto czytać: reklamy książek .............................................................. 88

2.2.3.4. Łańcuch książkowo-pokarmowy: inne formy informacji o książce ... 100

2.2.3.4.1. Dojść do stosu, nie dalej: sylwetki/portrety .......................... 100

2.2.3.4.2. Spotkanie z literaturą: teksty poświęcone książce i rynkowi wydawniczo-księgarskiemu ........................................... 103

2.2.3.4.3. Napisz książkę i odnieś sukces!: konkursy i akcje .................. 111

2.2.4. Kup gadżetę! Inne informacje: o prasie i środowisku dziennikarskim ............ 120

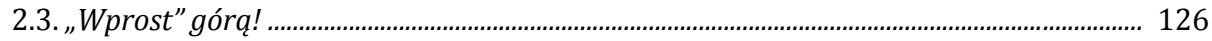

2.3.1. Z Poznania do Warszawy: historia czasopisma .................................................... 126

2.3.2. Zawartość, akcje i czytelnicy ................................................................................. 136

2.3.3. Czytam, więc jestem: książka na łamach pisma ..................................................... 140

2.3.3.1. Celna lektura: miejsce recenzji w układzie pisma .................................. 142

2.3.3.1.1. Zakres i charakter recenzji - przykłady .................................... 160

2.3.3.2. Dyskretny urok historyjek: wywiady ....................................................... 167

2.3.3.3. Supersensacja: reklamy książek ............................................................ 168

2.3.3.4. Literatura dopisana: inne formy informacji o książce ............................ 181

2.3.3.4.1. Nie gasić światła: sylwetki/portrety ....................................... 182

2.3.3.4.2. Arcydzieła nijakości: teksty, poświęcone książce i rynkowi wydawniczo-księgarskiemu ....................................................... 184

2.3.4.3. Pionierzy nowej epoki: konkursy i akcje ....................................................... 198

2.3.4. Gazeta $w$ niebezpieczeństwie: inne informacje: o prasie i środowisku

dziennikarskim ............................................................................................. 203

2.4. "NEWSWEEK POLSKA" - najlepsze medium ................................................................... 210

2.4.1. Historia pod tytułem „Newsweek" ............................................................................. 210

2.4.2. Zawartość, akcje i czytelnicy .................................................................................. 220 
2.4.3. Fabrykanci bestsellerów: książka na łamach pisma .............................................. 226

2.4.3.1. Muskajq̨c literaturę: miejsce recenzji w układzie pisma ......................... 229

2.4.3.1.1. Zakres i charakter recenzji - przykłady .................................... 239

2.4.3.2. Tajny przepis na sukces: wywiady ............................................................ 245

2.4.3.3. Czas na dobrq̨ książkę: reklamy książek .................................................. 247

2.4.3.4. Arcydzieła idq $w$ hurcie: inne formy informacji o książce ....................... 259

2.4.3.4.1. Mgnienie wieczności: sylwetki/portrety .................................. 260

2.4.3.4.2. Lekarstwo dla duszy: teksty, poświęcone książce i rynkowi wydawniczo-księgarskiemu ............................................... 263

2.4.3.4.3. Nasze skarby, nasze blizny: konkursy i akcje ............................. 279

2.4.4. Lepsza twarz mediów. Inne informacje: o prasie i środowisku dziennikar skim

2.5. „Polityka”, „Wprost”, „Newsweek Polska”: więcej opinii - wnioski porównawcze .. 291

Rozdział 3. Prasa kobieca ....................................................................................................... 299

3.1. Prasa kobieca. Krótka charakterystyka ...................................................................... 299

3.2. „Zwierciadło” w moim życiu ............................................................................................... 304

3.2.1. Spójrz w siebie: historia periodyku ........................................................................ 304

3.2.2. Zawartość, akcje, czytelnicy .................................................................................. 309

3.2.3. Miłość, zazdrość, literatura: książka na łamach pisma ........................................ 313

3.2.3.1. Nici światła między nami: miejsce recenzji w układzie pisma ............... 315

3.2.3.1.1. Zakres i charakter recenzji - przykłady .................................. 326

3.2.3.2. Czarownik swojego plemienia: wywiady ................................................ 334

3.2.3.3. Twoja książka, Twoja wiedza: reklamy książek .................................... 338

3.2.3.4. Tę książkę warto znać: inne formy informacji o książce ........................ 346

3.2.3.4.1. On rysuje jej sny: sylwetki/portrety ........................................ 346

3.2.3.4.2. Warto było chcieć: teksty, poświęcone książce i rynkowi wydawniczo-księgarskiemu ....................................................... 349

3.2.3.4.3. Kolory czasu: konkursy i akcje ..................................................... 353

3.2.4. Dowód artystycznej osobowości. Inne informacje: o prasie i środowisku

dziennikarskim ................................................................................................... 363

3.3. „Twój Styl”: luksus dostępny dla wszystkich ........................................................................ 370

3.3.1. Styl na lata: historia periodyku .................................................................... 370

3.3.2. Zawartość, akcje, czytelnicy ................................................................................. 380

3.3.3. Róża jest różą jest różą jest...: książka na łamach pisma .................................... 385

3.3.3.1. Eliksir pisania: miejsce recenzji w układzie pisma ................................ 387

3.3.3.1.1. Zakres i charakter recenzji - przykłady .................................. 393

3.3.3.2. Łagodnieję z biegiem lat: wywiady ........................................................ 398

3.3.3.3. Przeczytaj koniecznie!: reklamy książek .................................................. 401

3.3.3.4. Kto kupi buty dla noblistki?: inne formy informacji o książce ............... 406

3.3.3.4.1. Ksiq̨żę i róża: sylwetki/portrety ............................................. 407

3.3.3.4.2. Bez pouczania: teksty, poświęcone książce i rynkowi wydawniczo-księgarskiemu ............................................................... 409

3.3.3.4.3. Ksiq̨żka w prezencie! Konkursy i akcje ...................................... 417

3.3.4. Jadę tam, gdzie wojna. Inne informacje: o prasie i środowisku dziennikar-

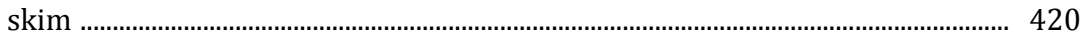

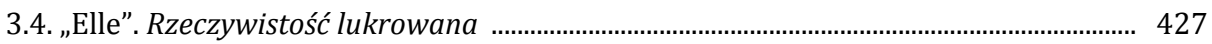

3.4.1. Mój wybór, moje „Elle”: historia periodyku .......................................................... 427

3.4.2. Zawartość, akcje, czytelnicy .................................................................................. 432 
3.4.3. Przeczytaj: książka na łamach pisma ................................................................. 437

3.4.3.1. Do czytania, i oglądania: miejsce recenzji w układzie pisma ................ 439

3.4.3.1.1. Zakres i charakter recenzji - przykłady ...................................... 446

3.4.3.2. Gonię kanarka na dachu: wywiady ............................................................. 453

3.4.3.3. Ksiq̨żka potrzebna czytelnikom: reklamy książek ................................... 455

3.4.3.4. Poezja dnia codziennego: inne formy informacji o książce .................... 460

3.4.3.4.1. Konkursy i akcje ........................................................................... 461

3.4.4. Gazeta jak rolls-royce. Inne informacje: o prasie i środowisku dziennikarskim 464

3.5. Po stronie kobiet: „Zwierciadło”, „Twój Styl”, „Elle” a książka - wnioski porównawcze 468

Rozdział 4. Prasa młodzieżowa 479

4.1. Prasa młodzieżowa. Krótka charakterystyka .................................................................... 479

4.2. „Filipinka”: Tylko dla dziewcząt ......................................................................................... 487

4.2.1. Była sobie Filipinka: historia czasopisma .......................................................... 487

4.2.2. Zawartość, czytelnicy, akcje .................................................................................. 494

4.2.3. Ile w Tobie z Bridget Jones?: książka na łamach pisma ....................................... 497

4.2.3.1. Czytasz i w lot chwytasz: miejsce recenzji w układzie pisma ................ 501

4.2.3.1.1. Zakres i charakter recenzji - przykłady ..................................... 511

4.2.3.2. Jagodowa tajemnica: wywiady .................................................................. 517

4.2.3.3. Super książka!: reklamy książek ............................................................ 520

4.2.3.4. Czego uczysz się od Harry'ego Pottera?: inne formy informacji o książce .................................................................................................... 526

4.2.3.4.1. Pani z Bullerbyn: sylwetki/portrety ......................................... 526

4.2.3.4.2. Teraz manga: teksty poświęcone książce ................................. 529

4.2.3.4.3. Wygraj ksiq̨żkę: konkursy i akcje ............................................. 532

4.2.4. Gazety na medal. Inne informacje: o prasie i środowisku dziennikarskim ..... 539

4.3. „Dziewczyna”: Jest wspaniała! ............................................................................................ 541

4.3.1. Dziewczyna taka jak Ty: historia czasopisma ................................................... 541

4.3.2. Zawartość, czytelnicy, akcje .................................................................................. 547

4.3.3. Batman zamiast Sienkiewicza: książka na łamach pisma ................................... 552

4.3.3.1. Proste życie: miejsce recenzji w układzie pisma ................................... 555

4.3.3.1.1. Zakres i charakter recenzji - przykłady .................................... 561

4.3.3.2. Tylko dla niegrzecznych...: reklamy książek ........................................... 569

4.3.3.3. Wiedźmin czy Winicjusz?: inne formy informacji o książce ................... 572

4.3.3.3.1. Nasi herosi: sylwetki/portrety .................................................. 573

4.3.3.3.2. Pod kolor: konkursy i akcje ........................................................ 575

4.3.4. Odpowiedź jest bliżej niż myślisz [pis oryg.]. Inne informacje: o prasie

i środowisku dziennikarskim ................................................................................... 580

4.4. „Cogito. Szkoła. Matura. Studia. Życie” .......................................................................... 585

4.4.1. Pomyśleli, zaistnieli: historia czasopisma .......................................................... 585

4.4.2. Zawartość, akcje, czytelnicy ................................................................................ 591

4.4.3. Jak wydać powieść?: książka na łamach pisma ..................................................... 594

4.4.3.1. Znajdź czas na bestseller: miejsce recenzji w układzie pisma ................ 597

4.4.3.1.1. Zakres i charakter recenzji - przykłady ..................................... 602

4.4.3.2. Mam pogodne usposobienie: wywiady ....................................................... 608

4.4.3.3. Idealny prezent: reklamy książek ........................................................... 612

4.4.3.4. Spotkaj swego pisarza: inne formy informacji o książce ........................ 618 
4.4.3.4.1. Wokół książki: teksty poświęcone książce

4.4.3.4.2. Zapamiętaj, co przeżyłeś: konkursy i akcje 623

4.4.4. Grunt to dobry pomyst. Inne informacje: o prasie i środowisku dziennikarskim

4.5. Przepis na prasę dla młodzieży: „Filipinka”, „Dziewczyna”, „Cogito” - wnioski porównawcze

Rozdział 5. ...aby nie ucichł szelest przewracanych kartek...: porównanie omówionych czasopism

5.1. Książka dla wszystkich?: recenzje, omówienia, streszczenia ........................................ 651

5.2. Warto czytać: reklamy książek .......................................................................................... 664

5.3. Autor pisze na własnq odpowiedzialność: wywiady ..................................................... 666

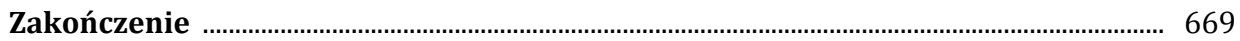

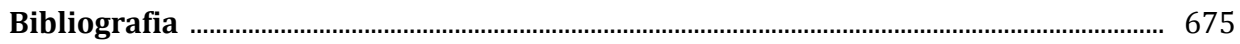

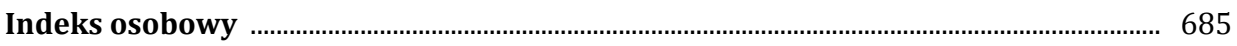

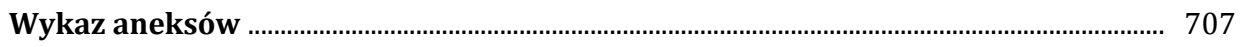

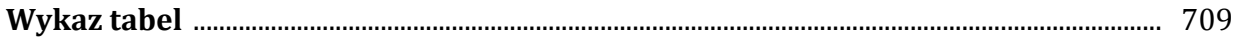

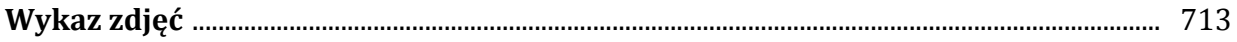

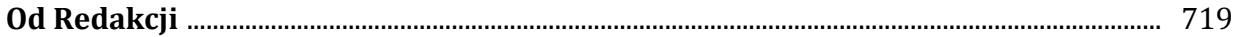




\title{
WSTĘP
}

\author{
Książka towarzyszy człowiekowi myślącemu \\ na wszystkich etapach jego rozwoju duchowego.
}

Karol Głombiowski ${ }^{1}$

Wypowiedziane w 1973 r. przez Karola Głombiowskiego słowa we współczesnym świecie zdają się odnosić do coraz bardziej kurczącej się grupy osób, wobec większości zaś wydają się pozostawać już tylko pobożnym życzeniem. Wieszczony od lat koniec słowa drukowanego ma, niestety, swoje podstawy. Można powiedzieć, że tak jak dawniej z niecierpliwością oczekiwano na nową książkę znanego i cenionego pisarza, a jej premiera była nierzadko wielkim wydarzeniem kulturalnym, tak dziś znaczna część społeczeństwa oczekuje w napięciu na nowy model samochodu, kosmetyk „na miarę XXI wieku” czy na zapowiadaną grę komputerową. Czytelnictwo książek każdego roku jest coraz niższe ${ }^{2}$, a jeżeli odnotowywany jest niewielki jego wzrost, to dzieje się tak głównie za sprawą jednego bestsellera, który na krótką chwilę jednoczy nie tylko stałych sympatyków książki, ale i przypadkowych, sporadycznych odbiorców. Dzisiejsze media, szczególnie Internet, dają szereg możliwości, które odpowiadają wielu współczesnym ludziom znacznie bardziej niż tradycyjna książka. Jednocześnie triumfy święci kultura masowa i wyłaniające się z niej nowe „autorytety”: zwycięzcy kolejnych edycji telewizyjnych reality show zdają się odpowiadać gustom większości społeczeństwa.

Dlaczego tak się dzieje? Wszak w dziejach literatury bywały (nierzadkie) chwile, gdy odgrywała ona znaczącą rolę, jak choćby w XIX w., pełniąc s. $29-30$.

${ }^{1}$ K. Głombiowski, Nauka o książce naukq o człowieku, „Studia o Książce” 1973, nr 4,

2 Jednym z nielicznych wyjątków był 1992 r., kiedy odnotowano 10-procentowy wzrost czytelnictwa w porównaniu z 1985 r. Zob. G. Straus, K. Wolff, Polacy i ksiaż́ki. Społeczna sytuacja książki w Polsce 1992, Biblioteka Narodowa, Warszawa 1996, s. 158. Badania nad czytelnictwem w Polsce prowadzone są m.in. przez Instytut Książki i Czytelnictwa Biblioteki Narodowej. 
funkcję patriotyczną, czy w okresie PRL, kiedy wbrew zakazom władz nie brakowało ludzi, którzy drukowali w podziemiu wydawniczym zakazane przez reżim książki. Czy spadek jej znaczenia wypływa wyłącznie z faktu, że zmieniła się sytuacja polityczna, a wolność, także słowa, nie wymaga już ofiar? Czyżby zatem, paradoksalnie, poprawa warunków życia spowodowała, że książki tak dawniej poszukiwane, dziś są coraz częściej zapominane? Łatwość dostępu do wielorakich dóbr zastąpiła niegdysiejsze potrzeby w zakresie literatury, a współczesny świat, oferujący tyle innych przyjemności, stworzył sytuację, w której „łatwiej niektórym książkę napisać, niż drugim ją przeczytać" (Alojzy F. Żółkowski).

Jednakże otuchą napawa fakt, iż książka nadal ma swoich sprzymierzeńców i wielbicieli, którzy, pomimo niesprzyjających warunków, starają się ocalić ją od zapomnienia. Rozmaite akcje zarówno w skali światowej, jak i obserwowane na polskim rynku pozwalają żywić nadzieję, że owe apokaliptyczne wizje końca książki są, być może, nieco przesadzone.

Dbają o to nie tylko czytelnicy, tworząc na przykład kluby książek, ale także wydawcy, inwestując w promocję swojej oferty. Na kwestię reklamy, a szerzej: marketingu na rynku książki, zwracają też uwagę badacze, podkreślając niejednokrotnie, że zarówno literaturze polskiej, jak i książce potrzebna jest promocja. Jest ona szczególnie ważna u progu XXI w., gdy

rzeczywistość na rynku książki to nadmiar podaży nad popytem, brak kapitału, wysokie ceny książek oraz gwałtownie i systematycznie malejący wzrost sprzedaży. Z jednej strony konsument jest świadkiem sprzedaży książek na kilogramy w supermarketach, z drugiej strony księgarze oczekują, że motywacja wewnętrzna klienta oraz uśmiech sprzedawcy to wystarczające elementy polityki marketingowej ${ }^{3}$.

W upowszechnianiu informacji o książce niebagatelną rolę może odgrywać prasa. Jej związki z książką znane są od dawna. 0 recenzji literackiej, także tej zamieszczanej w prasie, pisał m.in. Juliusz W. Gomulicki ${ }^{4}$, krytyce literackiej poświęcili swoje badania również Elżbieta Sarnowska-Temeriusz i Teresa Kostkiewiczowa ${ }^{5}$. Z kolei na znaczenie ogłoszeń wydawniczych, zamieszczanych na łamach wybranych periodyków, zwracali uwagę tacy badacze jak na przykład Jadwiga Czarkowska6, Danuta Hombek77, Iwona

${ }^{3}$ M. Świtała, Zachowania konsumentów i marketing na rynku ksiq̨żki, Biblioteka Analiz, Warszawa 2005, s. [13].

4 J. W. Gomulicki, Dwieście lat recenzji literackiej, „Nowe Książki” 1959, nr 24, s.1474-1489.

5 E. Sarnowska-Temeriusz, T. Kostkiewiczowa, Krytyka literacka $w$ Polsce $w$ XVI i XVII wieku oraz w epoce oświecenia, Zakład Narodowy im. Ossolińskich, Wrocław 1990.

6 J. Czarkowska, Reklama książki od poczęcia, „Wydawca” 1994, nr 10, s. 32.

7 Zob. np. D. Hombek, Reklama wydawnicza i księgarska w „Gazecie Warszawskiej” w latach 1764-1795, Wyższa Szkoła Pedagogiczna im. Jana Kochanowskiego, Kielce 1988. 
Imańska ${ }^{8}$, Artur Pilak ${ }^{9}$, Józef Szczepaniec i Zdzisław Staniszewski10. Z kolei rolę powieści odcinkowych, drukowanych w prasie, podkreślali m.in. Oskar St. Czarnik ${ }^{11}$ oraz Jerzy Jastrzębski ${ }^{12}$. Na znaczenie prasy $w$ krzewieniu literatury, popularyzowaniu książki wskazywali również Marek Burczyk ${ }^{13}$, Elżbieta Kwade ${ }^{14}$, Joanna Pyszny ${ }^{15}$, Janusz Termer ${ }^{16}$ oraz Katarzyna Wodniak $^{17}$.

Jakkolwiek zagadnienia związane z popularyzacją książki na łamach prasy bywały zatem niejednokrotnie przedmiotem opracowań, to jednak nadal problematyka ta wydaje się w znacznym stopniu nie opisana. Szczególnie współczesne czasopiśmiennictwo pozostaje zbadane pod tym kątem zaledwie w niewielkim stopniu. Niezwykle cenna analiza, dokonana przez wspomnianą K. Wodniak, dotyczy jedynie wybranych periodyków kobiecych, większość zaś pozostałych prac odnosi się do prasy dawnej, szczególnie $\mathrm{z}$ okresu lat 60. i 70. XX w., kiedy zagadnienia upowszechniania literatury na łamach wysokonakładowej, nieliterackiej prasy były przedmiotem ożywionej dyskusji w środowisku badaczy ${ }^{18}$. Analiza informacji o literaturze, zamieszczanych na łamach prasy współczesnej, wydaje się zatem w pełni uzasadniona. Stąd przedmiotem niniejszej rozprawy stało się badanie rozmaitych form obecności książki, które odnaleźć można w wybranych polskich czasopismach, dostępnych na rynku prasowym na początku XXI w.

8 I. Imańska, Ruch wydawniczo-księgarski w świetle ogłoszeń prasowych $w$ „Kurierze Polskim" (1729-1760), [w:] W kręgu prasy: przeszłość - teraźniejszość - przyszłość, Wydawnictwo Uniwersytetu Mikołaja Kopernika, Toruń 1999, s. 9.

${ }^{9}$ A. Pilak, Prasowe ogłoszenia księgarskie jako źródło do dziejów książki (na podstawie ogłoszeń prasowych z pierwszej połowy XIX w.), „Studia o Książce” 1976, t. 6, s. 70.

10 Z. Staniszewski, J. Szczepaniec, Ogłoszenia prasowe jako źródło wiedzy o książce w Polsce wieku XVIII, „Ze Skarbca Kultury” 1960, z. 1, s. 165-186.

11 0. St. Czarnik, Proza artystyczna a prasa codzienna (1918-1926), Zakład Narodowy im. Ossolińskich, Wydawnictwo Polskiej Akademii Nauk, Wrocław i in. 1982, s. 14-16.

12 M.in. J. Jastrzębski, Powieść odcinkowa, [w:] Słownik literatury popularnej, red. T. Żabski, Towarzystwo Przyjaciół Polonistyki Wrocławskiej, Wrocław 1997, s. 326

13 M. Burczyk, Prasa a sprawy książki. Niby sporo, a tak niewiele, „Przegląd Księgarski i Wydawniczy" 1972, nr 16, s. 6, 10.

${ }^{14}$ E. Kwade, Rola magazynów prasowych w komunikacji literackiej, Wydawnictwo UŚ, Katowice 1981.

15 J. Pyszny, „Czytać albo nie czytać...”. Informacje o literaturze i życiu literackim w popularnych magazynach ilustrowanych w latach 1967-1971, Wydawnictwo UW, Wrocław 1991.

16 J. Termer, Codzienne sprawy literatury, „Współczesność” 1968, nr 20, s. 5; nr 21, s. 7; Popularyzacja literatury $w$ niektórych tygodnikach ilustrowanych, „Biuletyn Zarządu Głównego RSW „Prasa” 1969, nr 123, s. 47-54.

17 K. Wodniak, Współczesna prasa kobieca a sprawy ksiqż̇ki. Treści literackie w czasopismach: „Przyjaciółka”, „Twój Styl”, „Cienie i Blaski”, Wydawnictwo SBP, Warszawa 2004.

18 J. Pyszny, „Czytać..., s. [3]. 
Cezura czasowa pracy obejmuje lata 2001-2005. Data początkowa stanowi jednocześnie początek nowego stulecia, zaś górna granica zamyka okres pięciu lat, tworząc pewien zamknięty przedział chronologiczny. Jest to okres ważny zarówno dla wydawniczo-księgarskiego, jak i prasowego rynku w Polsce, pomimo że od najważniejszych zmian, jakie się na nich dokonały, minęło 10 lat. Przeobrażenia, jakim podlegały sektory związane z książką i prasą, zostały dokładniej opisane w rozdziale $1, \mathrm{w}$ tym miejscu jednakże należy przypomnieć, że punktem przełomowym, który stał się początkiem tak istotnych zmian, był rok 1989. Transformacja ustrojowa, która się wówczas rozpoczęła się w Polsce, wpłynęła na zmiany we wszystkich niemal dziedzinach życia. Nie ominęła również rynku wydawniczoksięgarskiego i prasowego. Znaczenie przeobrażeń, które stały się ich udziałem, należy rozpatrywać w kontekście warunków, w jakich funkcjonowały w okresie PRL.

Poczynając od 1945 r., do końca lat 80. XX w., ruch wydawniczy podlegał niemalże absolutnej kontroli państwa. Książka, podobnie jak prasa, została uznana przez władze komunistyczne za środek pierwszej potrzeby, potrzeby propagandowej, za istotne narzędzie ideologiczne, mające służyć partii. Cenzura, nacjonalizacja przemysłu poligraficznego i papierniczego, centralizacja przydziału papieru gazetowego i drukarskiego powodowały, że stworzony został rodzaj monolitu, w którym decyzje dotyczące książki na wszystkich etapach jej powstawania i rozpowszechniania były skrupulatnie kontrolowane, poddane określonym zasadom i sterowane decyzjami politycznymi ${ }^{19}$. Podobnie wyglądała sytuacja prasy. Funkcjonowała ona zgodnie z zasadami i celami polityki PZPR w dziedzinie komunikowania ${ }^{20}$. Miała być ukierunkowana na realizację celów związanych z interesem partii. Wszechobecna cenzura doprowadziła w konsekwencji do ujednolicenia wydawanych wówczas gazet i czasopism, zaś w efekcie działania

${ }^{19}$ Rynkowi wydawniczo-księgarskiemu okresu PRL poświęcono wiele opracowań, zob. np. W. Adamiec, $O$ dostępności książki w latach siedemdziesiątych, „Rocznik Biblioteki Narodowej" 1986, t. 17/18, s. 133-157; idem, Otwartość i sprawność. Przyczynek do analizy i oceny polityki wydawniczej PRL, „Rocznik Biblioteki Narodowej” 1987, t. 19, s. 191-208; O. St. Czarnik, Między dwoma Sierpniami. Polska kultura literacka w latach 1944-1980, Wiedza Powszechna, Warszawa 1993, s. 194-254; S. A. Kondek, Władza i wydawcy, Biblioteka Narodowa, Warszawa 1993.

${ }^{20}$ Były to następujące zasady: 1) klasowego charakteru prasy i dziennikarstwa; 2) instrumentalności jako podstawy polityki komunikowania; 3) partyjnego kierowania prasą i jej odpowiedzialności przed partią; 4) ideowości; 5) udziału w budownictwie socjalistycznym, upowszechnianie przodujących doświadczeń; 6) współdziałania; 7) kontroli i koncepcja krytyki; 8) prawdziwości, zob. J. Lubiński, Najważniejsze zasady i cele polityki PZPR w dziedzinie komunikowania w latach 1948-1971, „Kwartalnik Historii Prasy Polskiej” 1991, nr 2. 
propagandy narodziła się swoista nowomowa, charakterystyczna dla okresu PRL ${ }^{21}$. Władze komunistyczne, poza rozgałęzionym systemem instytucji powiązanych z cenzurą i propagandą, dysponowały również innym jeszcze narzędziem, dzięki któremu mogły kontrolować rynek wydawniczoksięgarski i prasowy. Tym narzędziem była Robotnicza Spółdzielnia Wydawnicza „Prasa-Książka-Ruch”, największy monopolista wydawniczy w tej części Europy ${ }^{22}$. Podsumowując, powszechna nacjonalizacja i centralizacja, kontrola/cenzura i propaganda były czynnikami, kształtującymi funkcjonowanie książki i prasy oraz związanych z nimi instytucji.

Upadek komunizmu w Polsce przyniósł, poza innymi skutkami, także całkowite przeobrażenie interesującego nas obszaru. Grunt pod spektakularne zmiany stworzono już w latach 80. Nie wchodząc tu w szczegóły, wykraczające poza ramy zainteresowań podjętych w rozprawie, warto przypomnieć ustawę z 23 grudnia 1988 r. o działalności gospodarczej, przygotowaną przez Mieczysława Wilczka i Mieczysława Rakowskiego ${ }^{23}$. Umożliwiała ona na równych prawach wszystkim obywatelom podjęcie, zarejestrowanie i prowadzenie działalności gospodarczej. Dzięki wprowadzeniu jej w życie nastąpiło m.in. wyraźne zaktywizowanie drobnych przedsiębiorców. Ułatwiła ona też zakładanie prywatnych wydawnictw. Najważniejsze regulacje prawne zostały jednak podjęte już po 1989 r. Przyjmując porządek chronologiczny, należy wymienić przede wszystkim: tzw. nowelę grudniową z 29 grudnia 1989 r., wprowadzającą zmiany w Konstytucji24, ustawy: z 22 marca 1990 r. o rozwiązaniu RSW „Prasa-

21 Prasie PRL poświęcono wiele publikacji, tu warto zwrócić uwagę na jedną z nich: T. Goban-Klas, Niepokorna orkiestra medialna. Dyrygenci i wykonawcy polityki informacyjnej w Polsce po 1944 roku, Oficyna Wydawnicza ASPRA-JR, Warszawa 2004.

22 RSW publikowała większość wysokonakładowych gazet i czasopism, wydawała również kalendarze, pocztówki, reprodukcje dzieł sztuki, płyty i kasety z muzyką, kasety wideo. Jej działalność obejmowała też twórczość filmową. Początki RSW sięgają 1947 r. Wtedy powołano do życia RSW „Prasa”, początkowo jako małą spółdzielnię, która drukowała zaledwie 8 dzienników i 4 czasopisma. Już dwa lata później przekształcono ją w przedsiębiorstwo państwowe, a następnie (w 1973 r.) połączono z reaktywowanym w 1949 r. „Ruchem”, zajmującym się kolportażem prasy oraz z Wydawnictwem „Książka i Wiedza”. W ten sposób partia, będąca de facto właścicielem koncernu, kontrolowała rynek książki i rynek prasy. RSW podlegały również pozaprasowe instytucje, jak choćby Krajowa Agencja Wydawnicza, Młodzieżowa Agencja Wydawnicza oraz Polska Agencja Interpress. Koncern posiadał własne drukarnie, rozbudowaną sieć kolportażu. RSW podlegały również Kluby Książki i Prasy „Ruch”.

${ }^{23}$ Ustawa z 23 grudnia 1988 r. o działalności gospodarczej obowiązywała od 1 stycznia 1989 do 31 grudnia $2000 \mathrm{r}$.

${ }^{24}$ Formalnie przestaje istnieć PRL, zniesione zostają zapisy o międzynarodowych sojuszach Polski i o przewodniej roli PZPR, zmieniony zostaje wygląd narodowych symboli. 
Książka-Ruch"25, z 11 kwietnia 1990 r. o likwidacji cenzury²6, a także ustawę z 15 października 1992 r. Te akty prawne determinowały dalsze losy mediów w Polsce.

Nastąpił burzliwy rozwój rynku wydawniczo-księgarskiego i prasowego. Jednak, jak już wspomniano powyżej, poza krótkimi okresami, nie spowodowało to gwałtownego wzrostu czytelnictwa książek. „Świat przeżywa zalew informacji - prasa, radio, telewizja, teksty na CD-ROMach, w Internecie... Czy jest tu miejsce dla książki?" - pytała już w 1997 r. Grażyna Wolff27.

W niniejszej rozprawie pytanie to zawężono do wybranych czasopism, reprezentatywnych dla trzech typów prasy. Przedmiotem szczegółowej analizy stały się tygodniki opiniotwórcze, czasopisma kobiece oraz periodyki młodzieżowe. Podstawowym celem było zbadanie, czy na ich łamach znalazło się miejsce dla informacji związanych z książką, informacji niezwykle ważnych w czasach dla niej trudnych. Czy wobec swoistego „wyścigu o czytelnika”, w obliczu konkurencji, prasa chciała zajmować się literaturą? Czy mogła sobie na to pozwolić?

Następnym ważnym celem było zbadanie, jakie formy informacji o książce (jeśli się już pojawiały na łamach prasy) były preferowane? Czy obok podstawowych kategorii, takich jak recenzja i ogłoszenie wydawnicze, redakcje poszczególnych czasopism sięgały również po inne gatunki dziennikarskie, takie jak wywiad ze znanym pisarzem, portret wybranego twórcy? Czy nadal żywa była tradycja odcinków powieściowych?

Kolejnym pytaniem, jakie sobie postawiono, było, czy badane periodyki stosowały te same formy informacji o książce, a jeśli tak, to czy każda z nich pełniła w tym samym stopniu taką samą funkcję? A może zadania, które wynikają z definicji określonego typu prasy, determinowały w tym przypadku formę przekazu?

Postanowiono również zbadać, czy pomimo oczywistych różnic można wyodrębnić wspólną dla wszystkich analizowanych grup czasopiśmienniczych płaszczyznę zainteresowań, związaną z książką. Wszak

Różnorodne media na przestrzeni wieków ludzkiej komunikacji miały za zadanie dawać coś, pośredniczyć w przekazywaniu czegoś (wiadomości, informacji) po to, aby łączyć ludzi we wspólnotę [...]. Czy w dzisiejszych realiach komunikacyjnych owa wspólnota jest jeszcze możliwa?28

25 Ustawa o likwidacji Robotniczej Spółdzielni Wydawniczej „Prasa-Książka-Ruch” z 22 marca 1990 r. Zob. „Dziennik Ustaw” 1990, nr 21, poz. 125.

26 Ustawa o uchyleniu ustawy o kontroli publikacji i widowisk, zniesieniu tych organów i zmianie ustawy Prawo prasowe z 11 kwietnia 1990 r., zob. „Dziennik Ustaw” 1990, nr 29, poz. 173.

27 K. Wolff, Czy książki sq nam jeszcze potrzebne?, „Wydawca” 1997, nr 6/7, s. 16.

${ }^{28}$ Media w Polsce. Pierwsza władza IV RP?, red. M. Sokołowski, Wydawnictwa Akademickie i Profesjonalne, Warszawa 2007, s. [7]. 
I wreszcie, zdecydowano sprawdzić, w jakim stopniu poszczególne periodyki kształtowały poglądy swych czytelników na sprawy związane z książką, wpływały na ich wybory i preferencje lekturowe oraz gusta literackie.

Analizie poddano ogółem dziewięć czasopism: „Newsweek Polska”, „Polityka”, „Wprost” (jako tytuły reprezentujące prasę opinii), „Elle”, „Twój Styl”, „Zwierciadło” (zaliczane do prasy kobiecej) oraz „Cogito”, „Dziewczyna” i „Filipinka”(jako przedstawicieli prasy młodzieżowej). Pod względem częstotliwości było to pięć miesięczników, trzy tygodniki i jeden dwutygodnik.

Aby zdobyć optymalne odpowiedzi na postawione wcześniej pytania, przebadano wszystkie numery wybranych czasopism, zawierające się w wyznaczonym okresie. Było to w sumie 1140 numerów ${ }^{29}$. Analiza ich zawartości $\mathrm{w}$ kontekście tematu ujętego $\mathrm{w}$ tytule rozprawy pozwoliła wyodrębnić 24441 pozycji bibliograficznych, odnotowujących informacje o książce zawarte na łamach wybranych periodyków. Po dokonaniu niezbędnej selekcji liczba ta w pewnym stopniu uległa zmniejszeniu i posłużyła jako obiekt opisu zebranych danych. Jednocześnie podstawę źródłową niniejszej pracy stanowiły wcześniejsze roczniki badanych czasopism ${ }^{30}$. Duże znaczenie dla części opisowej związanej z przeobrażeniami, którym podlegał rynek wydawniczo-księgarski i rynek prasowy w Polsce, a także dla prezentacji omawianych czasopism $\mathrm{w}$ ich historycznym ujęciu, miały liczne publikacje zarówno bibliologów, jak i medioznawców, w tym prasoznawców. Bibliografia wykorzystanej literatury została przedstawiona na końcu pracy, w tym miejscu należy jednak przywołać przynajmniej kilka ważnych pozycji. Niezwykle cenne okazały się opracowania autorstwa m.in. Zbigniewa Bauera, Łukasza Gołębiewskiego, Jerzego Jarowieckiego, Tomasza Mielczarka, Walerego Pisarka, Zofii Sokół oraz Marii Wojtak. Pomocą służyły również wybrane artykuły z prasy naukowej, fachowej oraz branżowej (m.in. „Media i Marketing Polska”, „Wydawca”, „Zeszyty Prasoznawcze"). Kolejnymi źródłami były akty prawne, materiały statystyczne (jak choćby „Ruch Wydawniczy w Liczbach”, dane Związku Kontroli Dystrybucji Prasy za poszczególne lata) oraz bibliografie (m.in. „Polska Bibliografia

29 Wyszczególnienie liczby wydań, przypadających w badanym okresie na każdy z tytułów, zostało podane w każdym $\mathrm{z}$ odpowiadających im rozdziałów, a także w rozdziale porównawczym. Podstawę analizy stanowiły główne wydania poszczególnych czasopism wyłącznie w ich wersji drukowanej. Pominięto zatem m.in. rozmaitego rodzaju wkładki, dodatki (chyba że były one zszyte z wydaniem głównym i jednocześnie posiadały numerację ciągłą).

30 Kolejno: „Polityka” (1957-2000), „Wprost” (1982-2000), „Zwierciadło” (19572000), „Twój Styl” (1990-2000), „Elle” (1992-2000), „Filipinka” (1957-2000), „Dziewczyna” (1991-2000), „Cogito” (1994-2000). W każdym przypadku były to wybrane numery z każdego rocznika. 
Bibliologiczna" za poszczególne lata, Polska bibliografia prasoznawcza 1996-2001 pod redakcją Władysława M. Kolasy i J. Jarowieckiego, polska bieżąca bibliografia narodowa, szczególnie zaś „Bibliografia Zawartości Czasopism").

Zebrany materiał opracowano, wykorzystując wybrane metody badawcze. Pierwszą była metoda historyczna, która pozwoliła przedstawić każde czasopismo w kontekście ewolucyjnym. Druga, metoda statystyczna, dotyczyła rejestracji i selekcji zebranego materiału, zaś trzecia, metoda opisowa, pozwoliła ująć go w poszczególne kategorie, a następnie je opisać31. Służyły temu określone klucze kategoryzacyjne, wśród których najważniejszymi były: książka, recenzja, omówienie, adnotacja, ogłoszenie wydawnicze, wywiad, notatka prasowa, wzmianka ${ }^{32}$. Odmienny charakter każdej z badanych grup wymaga w tym miejscu bardziej szczegółowego opisania i wyjaśnienia kryteriów przyjętych przy gromadzeniu danych i prezentowaniu wyników. Warto zatem zwrócić uwagę na kilka zasad, które w odczuciu autorki pozwoliły uniknąć z jednej strony szumu informacyjnego, z drugiej podejrzenia o niekonsekwencję.

Ze względu na różnoraką pisownię, stosowaną na łamach badanych czasopism (fakt ten widoczny był m.in. w nazwach działów i rubryk, raz podawanych małymi literami, to znów wytłuszczoną czcionką albo drukowanymi literami), w niniejszej rozprawie ujednolicono ją zgodnie z ogólnie przyjętymi zasadami polskiej pisowni. Poza tym, wspomniane nazwy działów i rubryk podawano w pracy zawsze w kolejności alfabetycznej, nie zaś $\mathrm{w}$ kolejności pojawiania się ich $\mathrm{w}$ piśmie. Podobnie zasadę porządku alfabetycznego zastosowano w przypadku nazwisk dziennikarzy i współpracowników danych czasopism, pomijając kryterium kolejności ich współpracy z danym tytułem. Aby nie utrudniać czytelnikom odbioru prezentowanego tekstu, zdecydowano o numeracji przypisów w obrębie poszczególnych rozdziałów.

Praca ma w pewnym sensie charakter interdyscyplinarny: podejmowana problematyka dotyczy bowiem dwóch zagadnień: książki i prasy. Można

31 Przy wyborze metod badawczych pominięto propozycje Ireny Tetelowskiej, jako że dotyczyły one głównie dzienników, analizy materiałów informacyjnych, wykorzystywanych przede wszystkim w prasie codziennej. Metody te w niewielkim tylko stopniu ujmowały zagadnienia kulturalne (wspomina się odcinki powieściowe, eseje), ale brakuje dostatecznie przekonywującego wywodu, który uwzględniałby kryteria dotyczące materiałów kulturalnych i tego, jak należy je analizować. Stąd metody te nie mogły znaleźć zastosowania w prowadzonych w tym miejscu badaniach.

32 I w tym przypadku klucze kategoryzacyjne, proponowane przez niektórych badaczy, były odpowiednim narzędziem do analizy prasy codziennej, w związku z czym były nieadekwatne w stosunku do zamieszczanych na łamach czasopiśmiennictwa materiałów dotyczących promocji książki. 
wyodrębnić tu pewne cechy, charakterystyczne tylko dla związanych z nimi dziedzin wiedzy (bibliologii i prasoznawstwa). Tak szeroko zakrojone pole badawcze wymagało wytyczenia pewnych granic, które pozwoliły zachować odpowiedni stopień uogólnienia podjętego zadania, przy jednoczesnym jego dokładnym przeanalizowaniu. $\mathrm{W}$ tym miejscu należy zaznaczyć, że autorka nie rości sobie praw do pogłębionej analizy zebranego materiału pod kątem szczegółowego klasyfikowania i definiowania go pod względem dziennikarskim. Stosując wybrane określenia dotyczące gatunków dziennikarskich, nie podjęto jednak badań nad ich czysto prasoznawczymi funkcjami, ograniczając się do podstawowych cech, które powinny je wyróżniać. Podobnie nie badano szczegółowo warstwy językowej materiałów prasowych, dotyczących książki. Starano się przede wszystkich uchwycić pewne ogólne zjawiska, odpowiedzieć na pytania podane powyżej, uznając, że takie potraktowanie tematu, także ze względu na znaczną objętość zebranych danych, będzie wystarczająco obszerną prezentacją.

Nakreślony kierunek badań przesądził w znacznym stopniu o układzie pracy.

Składa się ona z pięciu rozdziałów. W pierwszym z nich przedstawiono główne nurty i tendencje rozwojowe, obserwowane na rynku wydawniczo-księgarskim i prasowym w Polsce w latach 1989-2005. Starano się, by zasygnalizowane zmiany stanowiły tło i pewien punkt odniesienia dla dalszych rozważań. Zasadnicza część książki zawiera się w rozdziałach 2-4, w których starano się zachować podobny schemat, chociaż (ze względu na znikomy bądź całkowity brak określonych kategorii poddanych analizie) nie w każdym przypadku do końca się to udało ${ }^{33}$.

Każdy ze wspomnianych trzech rozdziałów otwiera krótka charakterystyka danego typu prasy. Następnie prezentowany jest wybrany periodyk, omawiane są jego dzieje, w tym najważniejsze zmiany zarówno własnościowe, jak i dotyczące jego zawartości, programu i szaty graficznej. Dzięki temu zarysowane zostały pewne fakty, które w dużym stopniu wpływały na odbiór danego tytułu, jego popularność, a także określały typ adresata. Krótko przypomniano najważniejsze akcje i przedsięwzięcia realizowane przez omawiane czasopismo. Pozwoliło to ujrzeć w określonym świetle opisane dalej podejmowane przezeń inicjatywy związane z książką. Najważniejszą część każdego z tych rozdziałów stanowią jednakże rozważania, dotyczące obecności książki na łamach prezentowanego w danym rozdziale periodyku. $\mathrm{W}$ celu zwiększenia przejrzystości zawartych $\mathrm{w}$ tym miejscu

33 Np. w prasie młodzieżowej, w przypadku miesięczników „Filipinka” i „Dziewczyna”, pominięto tabele związane z najczęściej pojawiającymi się nazwiskami autorów w ogłoszeniach wydawniczych, ze względu na niewielką liczbę oficyn, które reklamy takie zamieściły. W przypadku „Dziewczyny” zrezygnowano także z podrozdziału dotyczącego wywiadów z pisarzami, bo takowych rozmów nie odnotowano. 
informacji zastosowano system podrozdziałów, które kolejno traktują o recenzjach, wywiadach, ogłoszeniach wydawniczych oraz innych formach informacji o książce (takich jak portrety/sylwetki, publikacje odnoszące się ogólnie do literatury i rynku wydawniczo-księgarskiego). Następnie krótki podrozdział poświęcono na prezentację informacji związanych $\mathrm{z}$ prasą i środowiskiem dziennikarskim, zamieszczanych w danym czasopiśmie. Jakkolwiek zagadnienie to nie zostało ujęte w tytule rozprawy, zdecydowano jednak zwrócić na nie uwagę, sygnalizując w ten sposób nowe, niezwykle interesujące pole badawcze.

Największy nacisk położono na omówienie recenzji ${ }^{34}$ i reklam ${ }^{35}$ ze względu na to, że stanowią one podstawowe formy informacji o książce. Natomiast specyfika każdej grupy czasopism decydowała każdorazowo o innym podejściu do pozostałych kategorii. Przesądzały o tym także względy ilościowe odpowiadające każdej z nich. I tak, w przypadku prasy opinii, poza wspomnianymi formami informacji o książce, szerzej omówiono publikacje komentujące kondycję współczesnej literatury i rynku wydawniczo-księgarskiego. Przy prezentacji tytułów pism kobiecych skoncentrowano się na dokładniejszej charakterystyce zamieszczanych na jej łamach wywiadów i kreślonych w prezentowanych periodykach portretów. $\mathrm{Z}$ kolei $\mathrm{w}$ przypadku czasopism młodzieżowych uwagę zwróciła forma proponowanych przez poszczególne redakcje konkursów, szczególnie zaś zamieszczanych na łamach dwutygodnika "Cogito”.

Przy omawianiu wyszczególnionych kategorii informacji związanych z książką starano się zwrócić szczególnie uwagę zarówno na ich formę, jak i funkcję, którą zdawały się sobą prezentować. Na przykład w odniesieniu do recenzji badano, czy na pierwszy plan wysuwał się w nich pierwiastek informacyjny, a może służyć miały one przede wszystkim propagowaniu cenionych przez pismo wartości, tym samym wpisując się w jego program, stanowiąc rodzaj puzzli wpasowujących się $\mathrm{w}$ określoną przez redakcję politykę?

${ }^{34}$ Warto już w tym miejscu zaznaczyć, że o ile w prasie opinii znajduje zastosowanie klasyczna recenzja, to jednak w odniesieniu do pism młodzieżowych (szczególnie dwóch tytułów: „Filipinki” i „Dziewczyny”) i w pewnym stopniu magazynów kobiecych (zwłaszcza miesięcznika „Elle”) określenie to zdewaluowało się i nie oddaje prawdziwej istoty omówienia książki. Tym samym niegdysiejsza definicja recenzji książkowej nie znajduje swego zastosowania w pismach tego typu. Unikając jednak zbędnego zamieszania terminologicznego, zdecydowano, by w przypadku wspomnianych czasopismach odpowiednią kategorię informacyjną określać mianem „recenzje”, „omówienia”, „adnotacje”, nie wyodrębniając dodatkowych grup i nie zamieszczając przy każdym przywoływanym przykładzie wyjaśnień, tłumaczących, czy odbiorca ma do czynienia z recenzją, omówieniem czy adnotacją.

35 Wyjaśnienia wymaga zastosowane w niniejszej pracy określenie „reklama”. Ze względów badawczych jest ona rozumiana jako pojedynczy tytuł, niezależnie od formy prezentacji ogłoszenia i liczby powtórzeń. 
Każdy typ prasy zamyka wstępne porównanie omówionych w danym rozdziale czasopism. W kolejnych podsumowujących rozdziałach porównano inne kategorie, choć jednocześnie w każdej znalazły się recenzje oraz ogłoszenia wydawnicze. Jednak pozostałe grupy informacji nierzadko były inne. Taki wybór wynikał z uzyskanych danych statystycznych: nie w każdym przypadku były one wystarczające, by stać się podstawą badawczą do dalszych analiz. Niekiedy (jak choćby w przypadku miesięcznika „Dziewczyna”, gdzie zabrakło wywiadów ze znanymi pisarzami) takich danych, jako podstawy badawczej, po prostu nie uzyskano.

Stosując opisany powyżej schemat, w rozdziale 2 przedstawiono wybrane periodyki z rodziny pism opiniotwórczych. Analizie poddano najpierw najstarszy z tej grupy tygodnik „Polityka”, następnie przedstawiono wyniki badań, dotyczące „Wprost”, i wreszcie zaprezentowano najmłodszy tygodnik, jakim był „Newsweek Polska”. Rozdział 3 poświęcono prasie kobiecej. Pierwszym przedstawionym tu tytułem był miesięcznik „Zwierciadło”, następnie uwagę poświęcono magazynowi „Twój Styl”, by rozważania w tym rozdziale zamknąć prezentacją czasopisma „Elle”. Rozdział 4 objął opisanie wyników badań, odnoszących się do prasy młodzieżowej. Najpierw zaprezentowano miesięcznik „Filipinka”, następnie magazyn „Dziewczyna” i wreszcie dwutygodnik „Cogito”. Zachowano konsekwentną kolejność omawiania periodyków w danej grupie pism, przedstawiając je od najstarszego do najmłodszego tytułu.

Ostatni rozdział książki to porównanie, w interesującym nas kontekście, wszystkich wybranych czasopism. Przypomniano w tym miejscu najważniejsze wnioski, zasygnalizowane w poszczególnych podrozdziałach, starając się jednocześnie przedstawić ogólne konkluzje, spostrzeżenia i uwagi, które nasunęły się autorce w trakcie badań.

Uznano, że przy tak obszernym materiale, zaprezentowanym w niniejszej książce, ważnym narzędziem pomocniczym będzie indeks osobowy. Poza nim, na aparat pomocniczy złożyły się również trzy wykazy: spis tabel, zdjęć, umieszczonych w tekście oraz aneksy, które (ze względu na liczbę - 58 - i niebagatelne rozmiary) dołączono do książki na płycie CD. Uzupełnieniem dopełniającym całość jest Bibliografia wykorzystanych publikacji.

Na koniec tych wstępnych rozważań warto dodać jeszcze pewne krótkie wyjaśnienia. $\mathrm{W}$ dwóch przypadkach zwrócono się do redaktorów, odpowiedzialnych $\mathrm{w}$ danych periodykach za sprawy związane $\mathrm{z}$ kulturą, w tym także z książką, by zechcieli odpowiedzieć na wybrane pytania. W pozostałych przypadkach zrezygnowano z tego pomysłu ze względu na dużą rotację wśród osób zajmujących się omawianiem książek na łamach pozostałych czasopism. 
Z żalem zrezygnowano z cytowania całości wybranych informacji, na przykład recenzji czy wypowiedzi odnoszących się do sytuacji na rynku wydawniczo-księgarskim w Polsce. Narzucając sobie surową dyscyplinę w tym względzie, ograniczono się w większości przypadków do przywoływania jedynie wybranych fragmentów poszczególnych publikacji. Czasami tylko, gdy na przykład uwagi dziennikarzy były szczególnie celne, przytaczano cytat w całości.

Konsekwentnie przywoływano natomiast wybrane tytuły opisywanych recenzji, wywiadów i innych tekstów, prezentowanych w pracy. Uznano je za istotny element informacji, nierzadko decydujący o tym, czy dany tekst zostanie dostrzeżony przez kapryśnego czytelnika, a następnie przez niego przeczytany. Wspomniane wcześniej czynniki powodują, że książka stała się w czasach współczesnych „towarem”, który, aby zainteresować, powinien być ładnie „opakowany”. Wydaje się, że w przypadku informacji pomieszczanych na łamach prasy funkcję takiego „opakowania” spełnia w dużym stopniu tytuł. Nierzadko świadczył on również o wyobraźni piszącego lub o jego nadziejach związanych $\mathrm{z}$ przypisywaną potencjalnemu odbiorcy wiedzą.

W Spisie treści poszczególne rozdziały rozpoczynają się tytułami, zaczerpniętymi z badanych periodyków. Fakt ten zaznaczono kursywą, pomijając $w$ tym przypadku stosowne przypisy odsyłające, które wprowadzałyby zbędne zamieszanie ${ }^{36}$. Wybór tytułów nie był przypadkowy. Stosując taką formę zapowiedzi, starano się jednocześnie już na początku sygnalizować zawartość poszczególnych części pracy. Tytuły uznano za ważny element, wskazujący $\mathrm{w}$ większości przypadków na charakter poszczególnych kategorii informacji, związanych z książką i specyfikę danego czasopisma.

„Z książkami jest tak, jak z ludźmi: bardzo niewielu ma dla nas ogromne znaczenie, reszta ginie w tłumie" (Voltaire). Autorka wyraża na zakończenie nadzieję, że prezentowana książka, dzięki przedstawieniu w niej bogatego materiału, zostanie zaliczona do pierwszej grupy.

W trakcie pisania niniejszej pracy spotkałam się z życzliwością i bezinteresowną pomocą wielu osób. Przede wszystkim serdecznie dziękuję Profesorowi Oskarowi St. Czarnikowi za nieocenioną pomoc, cenne wskazówki, cierpliwość i wyrozumiałość.

Dziękuję Dziekanowi Wydziału Filologicznego, Prof. Piotrowi Stalmaszczykowi, oraz Rektorowi Uniwersytetu Łódzkiego, Antoniemu Różalskiemu,

36 Przypisy $\mathrm{z}$ adresem bibliograficznym umieszczono $\mathrm{w}$ odpowiadających im rozdziałach. 
za dofinansowanie tej publikacji. Wyrażam wdzięczność Dyrekcji Biblioteki Uniwersyteckiej w Łodzi za udostępnienie materiałów, dzięki którym mogła powstać ta książka. Za okazaną życzliwość dziękuję również Pani Dyrektor Urszuli Dzieciątkowskiej.

Na koniec pragnę podziękować moim Bliskim, przede wszystkim Rodzicom za wsparcie i pomoc, a także mojemu Mężowi, który był pierwszym czytelnikiem książki, za uwagi i spostrzeżenia oraz za zrozumienie okazywane podczas pisania przeze mnie niniejszej rozprawy. 



\section{Rozdział 1}

\section{RYNEK KSIĄŻKI I PRASY W POLSCE W LATACH 1989-2005}

\subsection{Rynek książki. Charakterystyka ogólna ${ }^{1}$}

Współczesny rynek wydawniczo-księgarski, podobnie jak rynek prasowy, ma dziś postać diametralnie odmienną od tej sprzed 1989 r. Jego forma i sposób funkcjonowania ukształtowały się $\mathrm{w}$ większości pod wpływem tych samych wydarzeń, związanych bezpośrednio bądź pośrednio z obaleniem systemu komunistycznego w Polsce.

Przeobrażenia, którym ów sektor podlegał, były wynikiem wielu czynników, z których najważniejszymi wydają się być: zniesienie cenzury, prywatyzacja (będąca prostą konsekwencją wprowadzenia swobody działalności gospodarczej i zniesienia koncesji dla ruchu wydawniczego) i likwidacja reglamentacji papieru. Wpłynęły one zasadniczo na złamanie dotychczasowego monopolu i rozwój oraz ożywienie branży wydawniczej. Jednak jeszcze przed uchwaleniem ustawy znoszącej cenzurę, w roku 1988 wprowadzono w życie inne akty prawne, które liberalizowały przepisy dotyczące prowadzenia prywatnej działalności wydawniczej. Warto przywołać w tym miejscu m.in. wspomnianą już we Wstępie ustawę z 23 grudnia 1988 r. o działalności gospodarczej, opracowaną według projektu Mieczysława Wilczka i Mieczysława Rakowskiego. Ta regulacja prawna umożliwiała każdemu obywatelowi podejmowanie i prowadzenie działalności gospodarczej na równych prawach. Wprowadzenie jej w życie spowodowało m.in.

$1 \mathrm{~W}$ prezentowanym rozdziale ograniczono się do przedstawienia najistotniejszych, zdaniem autorki, faktów, charakterystycznych dla rynku wydawniczo-księgarskiego (z naciskiem na sektor wydawniczy). Pominięto liczne, istotne z innych punktów widzenia, kwestie, starając się wskazać tylko te czynniki, które miałyby wyraźny związek z zagadnieniami, poruszanymi w dalszych rozdziałach pracy. I tak na przykład, przypominano liderów list bestsellerów (od 1999 r., na podstawie zestawień, przygotowywanych przez Andrzeja Rostockiego) po to, by zaobserwować, czy najpopularniejsze wówczas książki znajdowały uznanie w oczach recenzentów omawianych periodyków, czy tytuły te były wcześniej (lub później) reklamowane na łamach wybranych pism. 
aktywizację drobnych przedsiębiorców, ale także wpłynęło na zakładanie prywatnych wydawnictw. Dzięki temu powstała Respublica i Vers, a kilka miesięcy później Amber. Jak pisze Marek Tobera,

Żywiołowo powstawały nowe oficyny, a także hurtownie i księgarnie. Fascynowała swoboda działalności gospodarczej, czytelniczych wyborów, decyzji o publikacjach. To był czas rewindykacji i nasycania wygłodzonego rynku².

Pierwsze dwa lata funkcjonowania w warunkach gospodarki wolnorynkowej oznaczały dla edytorów w Polsce intensywny rozwój, boom wydawniczy oraz wielkie zyski dla części wydawców. Powstawało wówczas wiele nowych oficyn ${ }^{3}$, książki, dotąd zakazane (głównie przekłady amerykańskich bestsellerów, poradniki i literatura popularnonaukowa), pojawiły się na rynku w olbrzymich ilościach. Kampanię reklamową, zakrojoną na szeroką skalę, rozpoczęło Wydawnictwo Harlequin. Równocześnie nastąpił żywiołowy rozwój przemysłu poligraficznego, a także, charakterystycznego dla owego okresu, ulicznego handlu książkami. Ten ostatni fakt wynikał w pewnej mierze z zarysowujących się już wówczas problemów z dystrybucją wydawanych książek. Ich dotychczasowe rozpowszechnianie za pośrednictwem Domu Książki ${ }^{4}$ i Składnicy Księgarskiej ${ }^{5}$ przestało wystarczać.

Dobra passa dla książki trwała przez trzy lata. Jednak jeszcze w 1992 r. (29 grudnia) ogłoszona została upadłość zadłużonej Składnicy Księgarskiej. Wyprzedaż po bardzo niskich cenach jej zapasów w dużym stopniu utrudniła zbyt nowych tytułów i wpłynęła na obniżenie zysków ówczesnych liderów rynku wydawniczego (BGW czy GiG). Jednocześnie nastąpiło oswojenie, a nawet nasycenie rynku nowościami. Wielu wydawców zban-

2 M. Tobera, Rynek książki w Polsce (1989-2000), „Przegląd Biblioteczny” 2001, z. 3, s. 28.

3 Więcej na ten temat, zob. W. Adamiec, Co się stało z rynkiem książki?, „Notes Wydawniczy" 2000, nr 8, s. 12.

${ }^{4}$ Dom Książki Polskiej to, utworzone w 1950 r., przedsiębiorstwo państwowe, działające w okresie PRL. Jego celem było „urzeczywistnianie zadań polityki kulturalnej, gospodarczej i socjalnej państwa w dziedzinie upowszechniania książki oraz oddziaływanie na wzrost czytelnictwa. [...] Przedmiotem działalności D.K. [była - przyp. M.P.S.] detaliczna sprzedaż wydawnictw, płyt gramofonowych itp." Zob. Encyklopedia wiedzy o książce, WrocławWarszawa-Kraków 1971, s. 538. Podlegało ono Ministerstwu Kultury i Sztuki.

5 Składnica Księgarska - przedsiębiorstwo państwowe, założone w 1958 r., którego celem była „hurtowa sprzedaż książek i in. wydawnictw nieperiodycznych oraz płyt gramofonowych, przejętych w komis lub zakupionych na własny rachunek w kraju i za granicą". Zob. ibidem, s. 538. Składnica Księgarska podlegała, podobnie jak Dom Książki, Ministerstwu Kultury i Sztuki. Obydwa przedsiębiorstwa stanowiły główne filary systemu dystrybucji książki w okresie PRL. W grudniu 1992 r. sąd ogłosił upadłość Składnicy Księgarskiej. Jej zadłużenie określono na 230 mld starych zł (zob. Ł. Gołębiewski, Rynek książki w Polsce. Edycja `98, Wydawnictwo „Herbud”, Warszawa 1998, s. 11). 
krutowało (m.in. Orbita czy Phantom Press), inni popadli w kłopoty finansowe (jak choćby wspomniany już Amber). Obniżyły się również nakłady wydawanych tytułów ${ }^{6}$. Wynikało to m.in. z tego, że niewielka dotąd oferta alternatywnych wobec książki „towarów” wyraźnie się zwiększyła, stając się dlań konkurencją. Obecność wielu nowych, kolorowych (i tańszych od książki) czasopism, zwiększenie oferty kanałów telewizyjnych, a także pojawienie się atrakcyjnych gier komputerowych, zaczęło odciągać dotychczasowego czytelnika od wystawy księgarni. Nie bez znaczenia było również jednoczesne ubożenie społeczeństwa (był to okres reform Leszka Balcerowicza). Wszystkie te czynniki zapoczątkowały trwający w latach 1992-1993 regres na rynku wydawniczo-księgarskim7.

Jednakże już w 1994 r. rynek odzyskał równowagę, a w konsekwencji ponownie wzrosła sprzedaż. Zaczęli pojawiać się inwestorzy zagraniczni (swoje oddziały otworzyli w Polsce m.in. Bertelsmann i Egmont), odgrywający coraz większą rolę, chociaż równocześnie wśród największych edytorów znalazły się dwie oficyny z tradycjami (Wydawnictwo Naukowe PWN oraz Wydawnictwa Szkolne i Pedagogiczne). W 1995 r. wzrosła liczba zarejestrowanych tytułów książek, ich objętość oraz nakłady. Odnotowano 521 nowych wydawców ${ }^{8}$.

Następne lata to ponowny wzrost sprzedaży książek i dynamiczny rozwój rynku oraz rosnąca liczba wydawców zagranicznych. Jednocześnie wysokie nakłady i znaczną poczytność uzyskiwały wtedy książki zawierające „wywiady-rzeki”, przeprowadzane przez dziennikarzy ze znanymi politykami wcześniejszego okresu (na przykład z Edwardem Gierkiem ${ }^{9}$ ), bądź publikacje prezentujące poglądy osób związanych z minionym syste-

6 K. Bańkowska-Bober, Produkcja wydawnicza '93, „Notes Wydawniczy” 1994, nr 4, s. 26-28; Ł. Gołębiewski, Rynek książki w Polsce. Edycja 1999, Wydawnictwo Magazyn Literacki, Warszawa 1999, s. [7].

7 Warto w tym miejscu przypomnieć, że badania dotyczące rynku wydawniczoksięgarskiego, czytelnictwa w Polsce prowadzone są przede wszystkim przez dwa ośrodki: Bibliotekę Analiz oraz Bibliotekę Narodową (Instytut Książki i Czytelnictwa oraz Instytut Bibliograficzny). Wydawane cyklicznie kolejne części Rynku książki w Polsce... Ł. Gołębiewskiego, opracowania dotyczące czytelnictwa autorstwa Grażyny Straus i Katarzyny Wolff, a także „Ruch Wydawniczy w Liczbach” są istotnymi publikacjami dla każdego badacza rynku wydawniczo-księgarskiego w Polsce. W tym miejscu jednak ograniczono się tylko do przekazania podstawowych informacji, a przywołane tytuły posłużyły głównie jako źródło informacji statystycznych. 0 innych publikacjach dotyczących poruszanych w tym miejscu zagadnień, zob. np. M. Tobera, Bibliologia wobec polskiego rynku książki w latach 1944-2007, „Przegląd Biblioteczny” 2008, z. 1, s. [42].

8 "Ruch Wydawniczy w Liczbach XLI: 1995” 1996, s. 6.

${ }^{9}$ Edward Gierek. Przerwana dekada. Był to wywiad, przeprowadzony przez Janusza Rolickiego, Wydawnictwo Fakt, Warszawa 1990. 
mem (m.in. Alfabet Urbana10). Jak pisał wówczas Łukasz Gołębiewski, „Sukcesy nie są już tak spektakularne, jak na początku lat 90., ale za to kondycja zarówno większości wydawnictw, jak i rynku dystrybucji, jest stabilna"11. W 1999 r. zarejestrowanych było już 13400 wydawnictw książkowych ${ }^{12}$, z czego aktywnie działających odnotowano $2850^{13}$.

Cechą charakterystyczną dla rynku wydawniczego w Polsce pod koniec ostatniej dekady XX w. było panujące na nim rozdrobnienie, brak płynności finansowej większości małych wydawnictw, problemy z systemem sprzedaży księgarskiej (bankructwo wielu firm dystrybuujących książkę), wzrost cen oraz nierównomierność w lokalizacji wydawnictw, przy jednoczesnym stałym wzroście ich sprzedaży i utrzymującej się na stosunkowo niskim poziomie nadprodukcji14. Równocześnie wraz z zapoczątkowaną w $1999 \mathrm{r}$. reformą oświaty nastąpił intensywny wzrost oferty edukacyjnej, zwiększyło się w znacznym stopniu zapotrzebowanie na podręczniki szkolne i książki fachowe, czego konsekwencją był dynamiczny rozwój tego typu publikacji. Była to duża (i wykorzystana) szansa dla małych i średnich wydawnictw, których działalność doprowadziła w efekcie do złamania monopolu WSiP.

Warto wspomnieć również o tym, że w tym czasie rozwinęła się także nowa forma dystrybucji: sprzedaż wysyłkowa, związana z powstającymi klubami książki. Jednocześnie w 1999 r. pojawiło się jeszcze jedno istotne zjawisko: małe, deficytowe księgarnie zaczęto zastępować tzw. megastorami15, które w mniejszych miastach nierzadko stawały się głównymi ośrodkami życia kulturalnego.

W grupie największych polskich wydawnictw znalazły się m.in. Amber, Prószyński i S-ka, Świat Książki, WSiP, Wydawnictwo Naukowe PWN16. Książki trzech pierwszych edytorów niejednokrotnie gościły na listach bestsellerów, odpowiednio wysokie budżety każdej z wymienionych oficyn przeznaczone na promocję pozwalały im na inwestycję w reklamę swej oferty. Niekwestionowanym zwycięzcą list bestsellerów w kategorii „literatury obcej" był w tym okresie Paulo Coelho, chociaż musiał on niejedno-

10 J. Urban, Alfabet Urbana, Wydawnictwo BGW, Warszawa 1994.

11 Ł. Gołębiewski, Po ośmiu latach wolnego słowa, „Wydawca” 1998, nr 5/6, s. 19.

12 Dane Biura ISBN Biblioteki Narodowej (maj 1999).

13 Za aktywne uważa się te wydawnictwa, które w roku 1998 opublikowały przynajmniej jedną książkę. Dane Centrum Informacji o Książce (maj 1999).

14 Ł. Gołębiewski, Rynek książki w Polsce. Edycja 1999, s. [15]-25.

15 Jednym z najlepszych przykładów megastorów zdaje się być sieć EMPiK.

16 Według danych zamieszczonych na łamach „Ruchu Wydawniczego w Liczbach”. Za największe uznano te oficyny, które w danym roku przekroczyły liczbę 200 wydanych tytułów. Kolejno: Amber (281), Prószyński i S-ka (355), Świat Książki (298), WSiP (608), Wydawnictwo Naukowe PWN (332). Zob. „Ruch Wydawniczy w Liczbach XLV: 1999” 2001, s. [11]-[12]. 
krotnie rywalizować z Williamem Whartonem oraz (w kategorii Literatury polskiej) Joanną Chmielewską i Andrzejem Sapkowskim ${ }^{17}$.

Ważną datą dla interesującego nas sektora był rok 2000. Na Targach Książki we Frankfurcie Polska była gościem honorowym, co w kontekście zbliżającego się wstąpienia naszego kraju do Unii Europejskiej nabierało szczególnego znaczenia (możliwość promocji kultury polskiej). Polska literatura była reprezentowana przez noblistów (Czesława Miłosza i Wisławę Szymborską), a także m.in. Joannę Chmielewską, Stefana Chwina, Henryka Grynberga, Julię Hartwig, Witolda Horwatha, Pawła Huelle, Ryszarda Kapuścińskiego, Antoniego Liberę, Ewę Lipską, Sławomira Mrożka, Jerzego Pilcha i Olgę Tokarczuk. Zwiedzający targi mieli zatem okazję poznać przedstawicieli różnych typów współczesnej literatury polskiej. Jednocześnie zorganizowano liczne wystawy, promujące polską kulturę. Tak szeroko zakrojona akcja przyniosła oczekiwane efekty, m.in. wzrost zainteresowania innych krajów literaturą polską, a to z kolei zaowocowało sprzedażą praw autorskich do ponad 100 polskich tytułów i ich przetłumaczeniem na inne języki ${ }^{18}$. Wraz ze zwiększeniem liczby tytułów książek nastąpił wzrost ich nakładów. Nadal wśród największych oficyn na rynku znajdowały się m.in. Amber, Prószyński i S-ka, Świat Książki, Wydawnictwo Naukowe PWN oraz WSiP'19.

Jednakże wspomniane targi i wypływające zeń korzyści były jednymi z nielicznych sukcesów rynku wydawniczo-księgarskiego $\mathrm{w}$ ostatnim roku XX w. Niestabilna sytuacja, coraz większe problemy z dystrybucją ${ }^{20}$ spowodowały, że w tym okresie koncentracja szczególnie małych wydawców stała się jednym z coraz częściej stosowanych sposobów na przetrwanie. I tak na przykład w maju 2000 r. zawiązano Grupę A5, w skład której weszło m.in. Studio Emka oraz Wydawnictwo Medium. Zaczęły również powstawać tzw. kluby tematyczne, łączące wydawców różnych książek (na przykład Klub Militaria czy Klub Miłośników Książki Historycznej lub Klub Książki Biznesu albo Klub Książki Katolickiej). Głównymi problemami rynku w tym okresie był m.in. system konsygnacyjny oraz rozdrobnienie systemu dystrybucji. Istotną kwestią stały się także rosnące koszty promocji oferty wydawniczej. Jak podkreślał Ł. Gołębiewski, „Jeszcze w połowie lat 90 . wydawcy przeznaczali na promocję ok. 1 proc. swoich rocznych przychodów, dziś budżety reklamowe sięgają 5 procent i będą rosły"21.

17 A. Rostocki, Nie do mnie te pretensje! Bilans 1999, „Notes Wydawniczy” 2000, nr 3/4, s. $50-51$.

18 Ł. Gołębiewski, Rynek książki w Polsce 2000, Biblioteka Analiz, Warszawa 2000, s. [7].

19 „Ruch Wydawniczy w Liczbach XLVI: 2000”, 2001, s. [3], [11], [12]. Kolejno: Wydawnictwo Naukowe PWN (253), Wydawnictwo Szkolne i Pedagogiczne (473), Prószyński i S-ka (409), Amber (348) oraz Świat Książki (321).

20 M.in. upadek hurtowni Liber.

21 Ł. Gołębiewski, Rynek ksiq̨żki w Polsce 2001, Biblioteka Analiz, Warszawa 2001, s. 19. 
W tym czasie widoczne było obniżenie nakładów książek wydawanych w małych oficynach ${ }^{22}$. Z drugiej strony jednak wyraźnie rosła sprzedaż bestsellerów. Należy w tym miejscu przypomnieć, że właśnie w roku 2000 niewielka oficyna, Media Rodzina, wprowadziła na rynek polski pierwszą część przygód małego czarodzieja. Harry Potter i kamień filozoficzny Joanne K. Rowling co prawda nie natychmiast podbił serca czytelników, ale już w drugiej połowie roku zajął na długie miesiące pozycję lidera na listach bestsellerów, co było dowodem na to, że „w świecie gier komputerowych działa jeszcze magia książki" 23 . Wraz z J. K. Rowling w kategorii Literatury obcej na listach bestsellerów znalazła się m.in. H. Fielding oraz P. Coelho ${ }^{24}$. Literaturę rodzimą godnie reprezentowała $\mathrm{w}$ dalszym ciągu m.in. Joanna Chmielewska, ale także Jan Parandowski i Tadeusz Różewicz ${ }^{25}$.

Rok 2001 rozpoczął się od wprowadzenia w życie (od 1 stycznia) 22\% stawki VAT na druk książek i czasopism. Jednak 5 lipca Sejm przyjął nowelizację tego aktu, która przywracała zerową stawkę, mającą obowiązywać do końca 2003 r. ${ }^{26}$ Rok ten upłynął pod znakiem bestsellerów zarówno autorów polskich, jak i obcych. Wiele z nich osiągało niespotykanie od lat wysokie nakłady. Pojawiły się kolejne tomy cyklu o Harrym Potterze ${ }^{27}$, powieści Helen Fielding28, Katarzyny Grocholi29, Małgorzaty Musierowicz $^{30}$, Jerzego Pilcha ${ }^{31}$ i Williama Whartona ${ }^{32}$. Miały one wpływ na kondycję rynku (uratowały wiele księgarń przed bankructwem, jednocześnie zaś złagodziły objawy zwiększającego się kryzysu) i panujące na nim trendy. Ekranizacje powieści J. K. Rowling i H. Fielding ożywiły rynek, a wydawcy (wykorzystując sukcesy najpopularniejszych tytułów) wprowadzili do obiegu nowe serie, promując przy okazji młodych twórców. Istotne dla dalszych rozważań jest przytoczenie komentarza Ł. Gołębiewskiego, który stwierdził, że

22 Wyjątek stanowiła Media Rodzina, wydawca cyklu o Harrym Potterze.

${ }^{23}$ A. Rostocki, zob. Bilans $2000 \ldots$, s. 35.

24 Ibidem, s. 34-35.

25 Ibidem, s. 36.

26 Jednak w rzeczywistości, w efekcie błędnego zapisu w ustawie, stawka 22\% obowiązywała do września $2001 \mathrm{r}$.

27 Harry Potter i więzień Azkabanu (styczeń 2001), Harry Potter i czara ognia (wrzesień 2001).

${ }^{28}$ Np. Dziennik Bridget Jones.

${ }^{29}$ M.in. Nigdy $w$ życiu!

30 Kolejna część cyklu Jeżycjada: Kalamburka.

31 Pod Mocnym Aniołem, za którą autor otrzymał Nagrodę Nike.

${ }^{32} \mathrm{Nigdy}$, nigdy mnie nie złapiecie, Niedobre miejsce. 
w Polsce wydawcami największych bestsellerów często są małe wydawnictwa, a rozproszenie dobrych tytułów wśród wydawców jest bardzo duże. [...] małe i średnie wydawnictwa wciąż odgrywają bardzo znaczącą rolę na polskim rynku książki, a o sukcesie rynkowym w większym stopniu decyduje „nos wydawniczy” niż środki zainwestowane w promocję33.

Jednak popularność bestsellerów dawała jedynie złudne wrażenie ożywienia rynku, na którym recesja była coraz bardziej widoczna (podobnie jak panująca $\mathrm{w}$ tym czasie stagnacja na rynku prasowym). Odnotowano zmniejszenie liczby wydawanych tytułów książek, któremu towarzyszył spadek nakładów ${ }^{34}$. Wydawcy musieli borykać się z problemami finansowymi (czego efektem był brak inwestycji w nowe tytuły i promocję oferty), wynikającymi z niesprawnie działającego systemu dystrybucji. Wielu edytorów, ratując się przed bankructwem, przeprowadzało redukcję zatrudnienia (dotyczyło to głównie wydawców rodzimych), zaś outsourcing35 zaczął stawać się coraz częściej stosowanym modelem pracy redakcyjno-marketingowej. Innym sposobem ratowania się przed recesją była koncentracja kapitału oraz stopniowa rezygnacja dużej liczby wydawców ze wspomnianych już rozliczeń konsygnacyjnych. $\mathrm{W}$ tym okresie nadal w grupie czołowych wydawnictw znajdowały się m.in. Polskie Wydawnictwo Muzyczne, Wydawnictwo Naukowe PWN i WSiP. Poza nimi istotną rolę odgrywały m.in. wydawnictwa: Amber, Prószyński i S-ka oraz Reader's Digest ${ }^{36}$.

Poza wymienionymi wcześniej bestsellerami, na listach najpopularniejszych książek znalazły się również obok tytułów znanych pisarzy (jak choćby Baudolino Umberto Eco), także nowe nazwiska (na przykład Doroty Terakowskiej, Poczwarka).

Rynek wydawniczo-księgarski w roku następnym popadł w stagnację: brakowało nowych bestsellerów (chociaż jednocześnie można było zauważyć rosnące zainteresowanie rodzimą literaturą współczesną i zmniejszenie popytu na beletrystykę tłumaczoną z języka angielskiego ${ }^{37}$ ), nie odnotowano znaczących wzrostów sprzedaży. Jedną z cech charakterystycznych stały się ekranizacje znanych książek (Harry Potter i kamień filozoficzny Joanne K. Rowling oraz Władca Pierścieni Johna R. Tolkiena). Pojawiły się również nowe nazwiska pisarzy, których książki osiągały wysokie nakłady (na przykład Barbary Kosmowskiej, Doroty Masłowskiej, Katarzyny Pisarzew-

33 Ł. Gołębiewski, Rynek książki w Polsce 2002 Wydawnictwa, Biblioteka Analiz, Warszawa 2002.

34 „Ruch Wydawniczy w Liczbach XLVII: 2001” 2002, s. [5].

35 Outsourcing - ang. skrót od outside-using. Oznacza korzystanie z zasobów zewnętrznych, pozwala na koncentrację procesów zarządczych na zasadniczych celach danej firmy, stanowi część szerszego zagadnienia, dotyczącego strategii danego przedsiębiorstwa w obszarze sourcingu.

36 „Ruch Wydawniczy w Liczbach XLVII: 2001” 2002, s. 11, 12.

37 Ł. Gołębiewski, Rynek książki w Polsce 2003. Wydawnictwa, Biblioteka Analiz, Warszawa 2003, s. 22. 
skiej, Janusza L. Wiśniewskiego). W tym okresie odnotowano wzrost czytelnictwa wśród młodszych odbiorców, głównie za sprawą wspomnianego cyklu o Harrym Potterze, ale także dzięki książkom Meg Cabot, Eoina Colfera czy Lemony Snicketa. W czołówce największych wydawców niewiele się zmieniło, nadal pierwsze miejsca zajmowali ci sami edytorzy, co rok wcześniej. Interesująca inicjatywa wydawnicza pojawiła się w lipcu (2002): kilku wydawców podpisało deklarację, która zainaugurowała powstanie Kanonu książek dla dzieci i młodzieży. Natomiast pod koniec roku uruchomiono Polską Bibliotekę Internetową. Inne przedsięwzięcie, mające na celu propagowanie książki, przybrało postać trzyletniego programu promocji czytelnictwa, przedstawionego w roku następnym (2003) przez ówczesnego ministra kultury Waldemara Dąbrowskiego. Tego typu pomysły były szczególnie cenne w obliczu badań, przeprowadzonych przez Instytut Książki i Czytelnictwa Biblioteki Narodowej, z których wynikało, że 56\% Polaków wykazuje jakiekolwiek kontakty z książką, a zaledwie $37 \%$ je kupuje ${ }^{38}$. W tym okresie organizowano liczne akcje, mające wpłynąć na zwiększenie zainteresowania książką w naszym kraju. Poza wspomnianymi, warto wymienić także warszawski Trzeci Festiwal Książki „Bibliomania” (inicjatywa Polskiego Bractwa Kawalerów Gutenberga), II Ogólnopolski Tydzień Czytania Dzieciom (akcja zorganizowana była przez Fundację ABC XXI). W II programie TVP rozpoczęto nadawanie nowego cyklicznego programu Lubię czytać.

Jednakże poza tego typu inicjatywami, będącymi wyraźnym dowodem na wzrost zainteresowania książką na szerszym, niż tylko wydawniczoczytelniczym, polu, rok 2003 był kolejnym, który cechowała stagnacja. Ze względu na temat pracy należy jednak podkreślić, że w tym okresie reklama książki coraz wyraźniej przekładała się na poziom zainteresowania danym tytułem i wysokość sprzedaży39. Rosnąca konkurencja, szczególnie w przypadku literatury beletrystycznej, powodowała, że promocja stawała się niezwykle ważnym elementem w działalności wydawniczej, zaś jej brak skutkował spadkiem sprzedaży. Tylko nieliczni edytorzy mogli pozwolić sobie na reklamę telewizyjną, która zazwyczaj służyła przede wszystkim promocji wydawnictwa, w mniejszym stopniu jego oferty. Podobnie było w przypadku reklamy zewnętrznej (outdoor). Z tej formy dotarcia do potencjalnego czytelnika skorzystali wówczas m.in. Albatros, Amber, Drzewo Babel, Muza, Świat Książki, Wydawnictwo W.A.B. Ale istniały również inne możliwości promocji, wykorzystywane przez wydawców. Najczęstszym było zaproszenie (zazwyczaj przy okazji targów) danego pisarza, także organizacja spotkania autorskiego czy wreszcie reklama w prasie lub radiu. W takim przypadku wydawcy chętnie podpisywali umowy, na

38 Ł. Gołębiewski, Rynek książki w Polsce 2004. Wydawnictwa, Biblioteka Analiz, Warszawa 2004, s. 14.

39 Więcej na ten temat, zob. Ł. Gołębiewski, Rynek książki w Polsce 2004..., s. 28-29. 
podstawie których wybrane media obejmowały patronat nad danym tytułem. W 2003 r. wypromowano w ten sposób kilku pisarzy obcych; wśród nich znalazł się m.in. Michael Cunningham, Eduardo Mendoza, Tony Parsons czy (dzięki otrzymaniu Literackiej Nagrody Nobla) John M. Coetzee. Nadal znaczna liczba bestsellerów ukazywała się nakładem małych wydawnictw $^{40}$. Dominowała polska literatura współczesna przy jednoczesnym zmniejszeniu zainteresowania beletrystyką tłumaczoną z języka angielskiego (wyjątkiem wciąż pozostawał Harry Potter) ${ }^{41}$. W dalszym ciągu ograniczano zatrudnienie w wydawnictwach, zmniejszyła się liczba nowych tytułów, chociaż równocześnie zaczął rozwijać się rynek tańszych edycji (np. w wydaniu kieszonkowym) wybranych książek, częściej też organizowano wyprzedaże zapasów. Wzrosła również w sposób wyraźny sprzedaż książek w hipermarketach i wspomnianych wcześniej megastorach, co z kolei spowodowało spadek sprzedaży w tradycyjnych księgarniach, i po raz pierwszy od kilku lat, także w klubach wysyłkowych.

Jak już wcześniej wspominano, w 2004 roku Polska stała się członkiem Unii Europejskiej. Na rynku wydawniczo-księgarskim nastąpiło wyraźne ożywienie. Było ono efektem m.in. nowego kierunku działań, podejmowanych przez wydawnictwa prasowe. Dzięki takim przedsięwzięciom, jak kolekcja książek „Gazety Wyborczej” czy dołączanie do gazet należących do Axel Springer Polska książek, rynek wydawniczy odnotował wzrost o $6 \%{ }^{42}$. Te inicjatywy doprowadziły w konsekwencji do roszad także wśród tradycyjnych edytorów ${ }^{43}$.

Nie bez wpływu na sytuację ówczesnego rynku pozostawały też bestsellery, sprzedawane w imponujących nakładach, a także nadal rosnące znaczenie promocji:

Bestsellery w coraz większym stopniu kreują rynek poprzez reklamy, informacje prasowe, działania promocyjne w księgarniach. Książka wydostaje się z getta dobra kulturalnego czy intelektualnego, staje się często pożądanym towarem i wydarzeniem medialnym ${ }^{44}$.

W tym okresie najlepiej sprzedającymi się książkami były tytuły związane z Janem Pawłem II. W zestawieniach najpopularniejszych książek znalazły się też, w kategorii Literatura polska, powieści K. Grocholi, M. Musierowicz i A. Sapkowskiego oraz J. Wiśniewskiego. W grupie tytułów

${ }^{40}$ Np. książki J. Chmielewskiej ukazywały się w Wydawnictwie Kobra Media, a debiutancki zbiór opowiadań K. Grocholi wydała oficyna Do.

${ }^{41}$ Należy jednak pamiętać, że zarówno listy bestsellerów, jak i analizy wzrostu sprzedaży nie obejmują tzw. partworków (książek sprzedawanych w kioskach jako kolekcje lub dodatki, dołączane do gazet lub czasopism).

42 Ł. Gołębiewski, Rynek książki w Polsce 2005. Wydawnictwa, Biblioteka Analiz, Warszawa 2005, s. [21].

43 Więcej na ten temat zob. ibidem.

${ }^{44}$ Ibidem, s. 22. 
autorów obcych hitem stał się Kod Leonarda da Vinci autorstwa Dana Browna. Nadal jednak ważną pozycję zajmowali P. Coelho, J. K. Rowling oraz W. Wharton. Największą liczbę zarejestrowanych tytułów odnotowali w tym roku m.in. Amber, Arlekin, C. H. Beck, Helion, Świat Książki, WSiP, Wydawnictwo Szkolne PWN oraz Zysk i S-ka45.

Wzrosło także zainteresowanie kapitału zagranicznego polskim rynkiem. Generalnie w 2004 r. nastąpił wzrost nakładów książek we wszystkich niemal segmentach rynku ${ }^{46}$, rozszerzył się również rynek zbytu dzięki nowej drodze dystrybucji książek (rozpowszechnianych wraz prasą). Nowością stał się druk cyfrowy, obniżający koszty własne wydawców, temu samemu celowi służyć miała nadal rosnąca koncentracja. Wszystko to sprawiało, że rynek książki stawał się coraz bardziej atrakcyjny dla osób i firm spoza branży.

Ostatni omawiany w pracy rok (2005) był dla rynku wydawniczo-księgarskiego szczególnie udany. Jak zaznaczył Ł. Gołębiewski w swym corocznym raporcie, „dobrą koniunkturę zawdzięczamy w dużej mierze nowym produktom i nowym systemom dystrybucji - książkom dołączanym do gazet i czasopism w formie tzw. kolekcji"47. Zacieśnieniu uległy związki pomiędzy wydawcami prasy i książek. Cechą charakterystyczną tego okresu stała się wielomedialność, także w przypadku interesującej nas płaszczyzny. Poprawiła się również sytuacja na rynku dystrybucji (unowocześnienie bazy technicznej, pojawienie się nowych kanałów sprzedaży).

Innym czynnikiem, wpływającym na wzrost rynku, był sukces książek poświęconych Janowi Pawłowi II oraz niesłabnąca popularność m.in. kolejnych powieści D. Browna i J. K. Rowling. Na listach bestsellerów znajdowali się również wcześniej wymieniani pisarzy, jak choćby J. Chmielewska czy M. Musierowicz, ale też R. Kapuściński i W. Szymborska. Po raz pierwszy od 2000 r. zwiększyła się liczba nowych wydań, wzrosło także zjawisko dywersyfikacji.

Podsumowując, lata 1989-2005 to okres szczególny w historii rynku wydawniczo-księgarskiego w Polsce. Przeobrażenia, którym w tym czasie podlegał, nie miały jednorodnego charakteru, w różnych okresach przebiegały z różnym nasileniem. Największe zmiany nastąpiły, co oczywiste, na początku lat 90 . XX w. Później rynek ulegał wahaniom zarówno pod wzglę-

45 Kolejno: Amber (265), Arlekin (227), C. H. Beck (256), Helion (301), Świat Książki (380), WSiP (619), Wydawnictwo Szkolne PWN (233) oraz Zysk i S-ka (216). Zob. „Ruch Wydawniczy w Liczbach: 2004" 2005, s. [17], 18. Nie należy również zapominać o Wydawnictwie Media Rodzina, które co prawda opierało swoją działalność głównie na wydawaniu cyklu o Harrym Potterze, ale właśnie dzięki temu tytułowi nabrało dużego znaczenia na rynku wydawniczym.

46 Ł. Gołębiewski, Rynek książki w Polsce 2005..., s. 46.

47 Dzięki temu rynek odnotował wzrost o $11 \%$. Więcej na ten temat zob. Ł. Gołębiewski, Rynek książki w Polsce 2006. Wydawnictwa, Biblioteka Analiz, Warszawa 2006, s. [25]. 
dem liczby wydawców, jak i charakteru oferty wydawniczej. Od roku 1990 do połowy 2005 zarejestrowano ok. 22909 edytorów, ale

znaczna ich liczba, po wydaniu jednej lub kilku pozycji, zniknęła z rynku. Były też takie, które od początku nie nastawiały się na zapewnienie sobie trwałej pozycji, a wykorzystały najlepszą koniunkturę na określony typ publikacji i po dwóch, trzech latach zawiesiły swoją działalnośćc ${ }^{4}$.

W tabeli 1 zaprezentowano zarówno liczbę tytułów książek wydanych w Polsce, jak i te oficyny, które w latach objętych cezurą czasową niniejszego opracowania zarejestrowały największą liczbę tytułów.

Tabela 1. Tytuły książek wydanych w Polsce oraz największe

(pod względem liczby publikowanych tytułów) oficyny wydawnicze w latach 2001-2005

\begin{tabular}{|c|c|c|}
\hline Rok & $\begin{array}{l}\text { Liczba tytułów książek } \\
\text { wydanych w Polsce }\end{array}$ & $\begin{array}{l}\text { Najwięksi wydawcy książek } \\
\text { (pod względem liczby } \\
\text { zarejestrowanych tytułów }{ }^{a} \text { ) }\end{array}$ \\
\hline 2001 & 19760 & $\begin{array}{l}\text { Wydawnictwa Naukowe PWN (357), } \\
\text { WSiP (316), PWM (227), Arlekin (216) }\end{array}$ \\
\hline 2002 & 19371 & $\begin{array}{l}\text { WSiP (445), Wydawnictwo Naukowe } \\
\text { PWN (272), Arlekin (266), REBIS (245) }\end{array}$ \\
\hline 2003 & 20780 & $\begin{array}{l}\text { WSiP (500), Świat Książki (345), Zysk } \\
\text { i S-ka (317), Arlekin (293), Wydawni- } \\
\text { ctwo Szkolne PWN (288), Prószyński } \\
\text { i S-ka (266), Wydawnictwo Naukowe } \\
\text { PWN (255), Amber (249), REBIS (207) }\end{array}$ \\
\hline 2004 & 22475 & $\begin{array}{l}\text { WSiP (619), Zielona Sowa (476), Świat } \\
\text { Książki (380), REBIS (302), Helion } \\
\text { (301), C.H. Beck (256), Wydawnictwo } \\
\text { Adam Marszałek (216), Wydawnictwo } \\
\text { Szkolne PWN (233), Zysk i S-ka (216) }\end{array}$ \\
\hline 2005 & 19999 & $\begin{array}{l}\text { WSiP (654), Świat Książki (321), Arlekin } \\
\text { (282), Zielona Sowa (259), Wydawni- } \\
\text { ctwo Naukowe PWN (247), C. H. Beck } \\
\text { (218), Wydawnictwo Adam Marszałek } \\
\text { (204) }\end{array}$ \\
\hline
\end{tabular}

a Przyjęto w tym przypadku granicę powyżej 200 tytułów, wydawanych przez określonego edytora w danym roku.

Źródło: „Ruch Wydawniczy w Liczbach” 1989-2006.

Jakkolwiek analiza zagadnień związanych z popularnością wydawców książek nie jest tematem pracy, należy odnotować, że wśród niekwestionowanych liderów w badanym okresie znalazły się trzy oficyny: Arlekin, WSiP, Wydawnictwo Naukowe PWN. Dwie z nich specjalizowały się $\mathrm{w}$ ofercie

48 „Ruch Wydawniczy w Liczbach L: 2004” 2005, s. [5]. 
przede wszystkim podręczników szkolnych i książek naukowych. Ten typ wydawnictw stanowił przez większą część badanego okresu znaczący udział w całej produkcji wydawniczej - zarówno pod względem liczby egzemplarzy wydanych tytułów, jak i liczby proponowanych pozycji49.

Transformacja ustrojowa wpłynęła na znaczące zwiększenie liczby tłumaczeń, zarówno z języka polskiego, jak i na język polski. Jakkolwiek tendencja ta w latach 2001-2005 nie była już tak wyraźna jak w latach 90., to jednak nadal istniała. Najwięcej książek przetłumaczono z języka angielskiego, niemieckiego i francuskiego ${ }^{50}$. Przeważały tytuły z literatury kobiecej. W latach 90 . XX w. triumf odniosły powieści m.in. Hedwig Courths-Mahler, niemieckiej autorki egzaltowanych romansów, Barbary Cortland, pisarki pochodzącej z Wielkiej Brytanii, a także Danielle Steel, autorki ze Stanów Zjednoczonych czy norweskiej autorki Margit Sandemo. Z kolei w latach 2001-2005 swego rodzaju fenomenem były powieści $\mathrm{H}$. Fielding, a na gruncie polskim K. Grocholi. Badany okres to lata największej popularności również takich autorów jak wspomniani wcześniej m.in. P. Coelho, J. Rowling, J. R. Tolkien, W. Wharton. Z polskich twórców wymienić w tym miejscu należy na przykład J. Chmielewską, St. Lema, M. Musierowicz, J. Pilcha, A. Sapkowskiego.

Były to lata nie tylko sukcesów niektórych wydawców, ale i czas bestsellerów, ciekawych debiutów i ich ekranizacji. 0 ilu z nich czytelnicy dowiadywali się z prasy?

W 2006 r. Ł. Gołębiewski stwierdził: „Coraz częściej ważnym tytułom towarzyszą wielkie kampanie promocyjne” 51 , dodając: „mali wydawcy coraz rzadziej decydują się na płatną reklamę, szukając w ramach umów barterowych patronów medialnych albo w ogóle rezygnując z promocji" ${ }^{52}$. W jakim stopniu obserwacje te sprawdziły się $\mathrm{w}$ badanym okresie $\mathrm{w}$ przypadku omawianych periodyków? Czy mniejsze oficyny wydawnicze rzeczywiście rezygnowały z reklamy swej oferty? Czy duże wydawnictwa, jak choćby wymienione wyżej, faktycznie korzystały między innymi z łamów wybranych pism, by zachęcić odbiorców do sięgnięcia po określone tytuły? Czy w badanych czasopismach informowano o wspomnianych autorach i ich książkach? Czy wydawcy książkowi i prasowi, w obliczu opisanych zmian ${ }^{53}$, zjednoczyli swe wysiłki, „aby nie ucichł szelest przewracanych kartek...” 54 ? Odpowiedzi na te pytania będą przedmiotem rozważań $w$ toku dalszych wywodów.

${ }^{49}$ Zob. „Ruch Wydawniczy w Liczbach” za lata 2001-2005.

50 Ibidem.

51 Ł. Gołębiewski, Rynek książki w Polsce 2006..., s. 44.

52 Ibidem, s. 79.

53 Zmiany te lapidarnie ujął Jarosław Rdzanek: „kiedyś trzeba było polować na książkę. Dziś - na czytelnika...”. Zob. J. Rdzanek, Reklamą rynek stoi, „Wydawca” 1997, nr 11, s. 31.

54 Tytuł wywiadu z Rafałem Skąpskim, zob. [rozm. Andrzej Palacz], „aby nie ucichł szelest przewracanych kartek...” [pis. oryg.], „Wydawca” 2002, nr 5, s. 5. 


\subsection{Rynek prasy w Polsce. Główne tendencje rozwojowe ${ }^{1}$}

Czynniki, wymienione we Wstępie, wpłynęły zasadniczo także na kształt rynku prasowego w Polsce. Wspomniane ustawy², które znalazły potwierdzenie w przyjętej 2 kwietnia 1997 r. Konstytucji, zdeterminowały dalsze losy mediów w Polsce. Artykuł 14 Konstytucji stwierdzał, że Rzeczpospolita Polska zapewnia wolność prasy i innych środków społecznego przekazu, wolność wyrażania poglądów oraz pozyskiwania i rozpowszechniania informacji ${ }^{3}$. Zlikwidowano cenzurę, zakazano koncesjonowania prasy4, zagwarantowano obywatelom dostęp do informacji publicznych. W następnym okresie znaczący wpływ na przepisy regulujące funkcjonowanie polskich mediów miało wejście Rzeczypospolitej Polskiej w struktury Unii Europejskiej, w wyniku czego nasz kraj zobowiązany był do stopniowego przejmowania określonych umów międzynarodowych ${ }^{5}$. Dzięki tym zmianom rynek prasowy w Polsce zaczął ulegać dynamicznym przeobrażeniom, wielokrotnie analizowanym i opisywanym w literaturze przedmiotu ${ }^{6}$. Jeden z badaczy, Ryszard Filas, podzielił interesujący nas okres na następujące fazy ${ }^{7}$ :

${ }^{1}$ Celem niniejszego rozdziału nie jest szczegółowe omawianie przemian, które nastąpiły na rynku prasy w Polsce w latach 1989-2005, a jedynie zasygnalizowanie najważniejszych zmian oraz najistotniejszych zjawisk, które miały wtedy miejsce, a które wpłynęły na funkcjonowanie omawianych $\mathrm{w}$ dalszej części pracy, periodyków. Nie poruszono w tym miejscu zagadnień, związanych z instytucjami, składającymi się na infrastrukturę mediów (pominięto np. kwestię kolportażu prasy czy funkcjonowanie agencji prasowych). Ich omawianie znacznie zwiększyłoby objętość niniejszego opracowania, a nie są one jego głównym przedmiotem.

2 Przede wszystkim Ustawa o likwidacji Robotniczej Spółdzielni Wydawniczej „PrasaKsiążka-Ruch" z 22 marca 1990 r. oraz Ustawa o uchyleniu ustawy o kontroli publikacji i widowisk, zniesieniu tych organów i zmianie Ustawy Prawo prasowe z 11 kwietnia 1990 r., zob. „Dziennik Ustaw” 1990, nr 29, poz. 173.

${ }^{3}$ Konstytucja Rzeczypospolitej Polskiej, Wydawnictwo Sejmowe, Warszawa 1997.

${ }^{4}$ Jednocześnie dopuszczając możliwość koncesjonowania mediów elektronicznych (art. 54).

5 Między innymi dotyczących ochrony praw autorskich; wśród tych umów znalazł się np. Akt paryski konwencji berneńskiej o ochronie dzieł literackich i artystycznych, zob. załącznik do „Dziennika Ustaw” 1990, nr 82, poz. 474, czy Porozumienie w sprawie handlowych aspektów praw własności intelektualnej, zob. załącznik do „Dziennika Ustaw” 1996, nr 32, poz. 143.

6 Zob. m.in. prace Zbigniewa Bajki, Ryszarda Filasa, Ignacego Fiuta, Jarosława Kani, Tomasza Mielczarka.

7 R. Filas, Dziesięć lat przemian mediów masowych w Polsce (1989-1999), „Zeszyty Prasoznawcze" 1999, nr 1-2, s. [31]-58; idem, Rośnie dominacja mediów elektronicznych - nowa faza przemian polskiego rynku, ibidem, 2003, nr 3-4, s. [7]-34; idem, Rynek prasy codziennej w Polsce przed „Faktem” i z „Faktem”, ibidem, s. [7]-32; idem, Polski rynek prasy codziennej w I dekadzie XXI wieku (w szczególności po roku 2003), ibidem, 2008, nr 3-4, s. [7]-26. 
1) „żywiołowego entuzjazmu i wymuszonych przekształceń starych tytułów"8,

2) „pozornej stabilizacji i zmian podskórnych w prasie i radiu”,

3) „otwartej walki o rynek mediów, zwłaszcza audiowizualnych”,

4) „zagospodarowania rynku po pierwszym procesie koncesyjnym i inwazji tygodników niemieckich"11,

5) „nowego podziału rynku mediów i postępującej specjalizacji”12,

6) „rosnącej dominacji mediów elektronicznych w warunkach kryzysu ekonomicznego"13,

7) „przebudowy oferty mediów tradycyjnych wobec spodziewanej inwazji nowych technologii medialnych"14.

Pierwszy etap obfitował $w$ najwięcej wydarzeń, które ukształtowały rynek prasowy. W tym czasie wprowadzono w życie dwie już wymienione ustawy.

Bezpośrednim efektem pierwszej z nich było przeprowadzenie przez specjalnie powołaną Komisję Likwidacyjną inwentaryzacji majątku RSW „Prasa-Książka-Ruch” i określenie możliwości jego prywatyzacji. Przewidziano trzy drogi: sprzedaż w drodze przetargu (adresowanego także do firm z kapitałem zagranicznym), przekazanie tytułów spółdzielniom dziennikarskim oraz ewentualne ich przejmowanie przez Skarb Państwa. Prywatyzacja koncernu wywołała wiele konfliktów i dyskusji. Krytykowano pośpiech, z jakim przygotowywano samą ustawę, przez co zabrakło w niej dostatecznie precyzyjnych określeń. To z kolei dawało dużą dowolność jej interpretacji, a w konsekwencji swobodę w działaniu Komisji15. Procesowi likwidacji RSW towarzyszyły także nierzadko roszady kadrowe w redakcjach sprzedawanych pism, co miało na celu zmianę dotychczasowego układu politycznego, widocznego szczególnie na stanowiskach redaktorów

8 Obejmujący okres od maja 1989 do połowy $1991 \mathrm{r}$.

9 To miesiące od połowy 1991 do końca $1992 \mathrm{r}$.

10 Okres od początku 1993 do końca sierpnia $1994 \mathrm{r}$.

11 Od września 1994 do końca 1996 r.

12 Faza trwająca w latach 1997-1999.

13 Lata 2000-2003.

14 To okres, częściowo wychodzący poza cezurę pracy: lata 2004-2008.

15 Teoretyczne założenia nie zawsze znajdowały zastosowanie w praktyce, wiele nieścisłości związanych było z kwestiami własnościowymi i majątkowymi. Dwa lata później Najwyższa Izba Kontroli wskazała Komisji wiele błędów, zaniedbań i naruszeń prawa, wśród których znalazł się m.in. zarzut nieekonomicznej sprzedaży tytułów. Na przykład, w 43\% przypadków nie wybrano ofert finansowo najkorzystniejszych. Za: O. Dąbrowska-Cendrowska, Niemieckie koncerny prasowe w Polsce w latach 1989-2008, Dom Wydawniczy ELIPSA, Warszawa 2009, s. 20. Zob. też Dziennikarstwo i świat mediów, red. Z. Bauer i E. Chudziński, Studium Dziennikarskie Akademii Pedagogicznej w Krakowie, Towarzystwo Autorów i Wydawców Prac Naukowych Uniwersitas, Kraków 2004, s. 86-87. 
naczelnych wydawanych dotąd tytułów. W ten sposób jedną z pierwszych wyraźnych konsekwencji wynikających z transformacji (w odniesieniu do prasy) stała się wymiana kadry dziennikarskiej. Inną było bardzo duże zainteresowanie koncernów zagranicznych inwestycjami prasowymi w Polsce, które przerosło oczekiwania ustawodawców.

Druga chronologicznie ustawa, dotycząca zniesienia cenzury, przyniosła wolność i niezależność prasy, zlikwidowała istniejący dotąd system mediów i wprowadziła długo oczekiwaną wolność słowa ${ }^{16}$. Odtąd

Prasa zgodnie z konstytucją Rzeczypospolitej Polskiej, korzysta z wolności wypowiedzi i urzeczywistnia prawa obywateli do ich rzetelnego informowania, jawności życia publicznego oraz kontroli i krytyki społecznej ${ }^{17}$.

Dotychczasowy porządek został złamany, pojawił się element konkurencji o czytelnika. Prasa musiała odtąd nauczyć się funkcjonowania w nowych, wolnorynkowych warunkach, opartych na pluralizmie politycznym.

Nastąpił gwałtowny i żywiołowy rozwój wielu niezależnych inicjatyw wydawniczych (głównie o zasięgu lokalnym). Pojawiły się również „balony sondażowe". Zaczęły powstawać wydawnictwa, publikujące przede wszystkim „kalki”, w znaczeniu kopii pism zachodnich (zwłaszcza niemieckich i szwajcarskich) w języku polskim. W stosunkowo krótkim czasie zdobyły one olbrzymią popularność wśród czytelników. Nowością stały się też periodyki, poświęcone zdrowiu, jego ochronie i higienie życia codziennego. Zaczęto wydawać także pisma feministyczne. Ważnym wydarzeniem tego okresu było pojawienie się na rynku „Gazety Wyborczej”. Pierwszy jej numer trafił do odbiorców 8 maja 1989 r., zyskując od początku grono czytelników ${ }^{18}$. Jednocześnie istniejące dotąd tytuły musiały poddać się licznym przekształceniom zarówno organizacyjnym (m.in. wspomniane już zmiany na szczeblu kierowniczym czy, z podobnych powodów, zmiany tytułów lub podtytułów), jak i własnościowym. Pod naporem ofensywy nowych, przeważnie niskonakładowych, pism nastąpiło znaczące zmniejszenie nakładów prasy.

Natomiast dla odbiorców mediów, szczególnie zaś czytelników prasy, były to czasy przewartościowań dotychczasowych, nierzadko wieloletnich, przyzwyczajeń. Czytelnictwo uległo załamaniu. Spadła liczba czytelników

16 Ustawa de facto zalegalizowała stan faktyczny, jako że działalność cenzury wyraźnie osłabła pod koniec 1989 i na początku $1990 \mathrm{r}$.

17 „Dziennik Ustaw” 1990, nr 29, poz. 173. Artykuł 1 Prawa prasowego.

18 Powstanie „Gazety Wyborczej”, zob. np. M. Przybysz-Stawska, „To się czyta”. Promocja $w$ dodatkach do wybranych polskich gazet codziennych w latach dziewięćdziesiatych $X X$ wieku, Wydawnictwo Ibidem, Łódź 2006, s. [42]-51. 
pism codziennych, poszerzył się jednak odbiór wielu czasopism, szczególnie ilustrowanych, kobiecych czy niektórych specjalistycznych.

Kolejne miesiące, pomimo braku stabilizacji politycznej19, były korzystne dla rynku prasy. Nastąpiły roszady własnościowe: rozproszone dotąd prawa własności do tytułów wcześniej sprzedanych lub oddanych spółdzielniom dziennikarskim zostały przekazane nowym wydawcom (głównie zagranicznym). Jednocześnie ustabilizowała się sytuacja w grupie starych periodyków: te, którym udało się przetrwać najtrudniejszy okres, wzmocniły się nie tylko pod względem organizacyjnym, ale również i technicznym. Wiele czasopism, szczególnie magazynów kobiecych i młodzieżowych, drukowano (z powodu braku dostatecznej bazy poligraficznej w kraju) za granicą, za to na lepszym jakościowo papierze; do czytelnika trafiały tytuły w odmienionej, bardziej kolorowej, szacie graficznej. Sukcesem zakończył się debiut nowych pism młodzieżowych: „Bravo” i „Dziewczyny”20. Pojawił się wówczas także nowy typ prasy (tzw. prasa serca i prasa rewolwerowa). W efekcie nastąpiło ożywienie czytelnictwa, chociaż jednocześnie spadło zainteresowanie odbiorców periodykami poważnymi (wyjątek stanowiły tygodniki „Polityka” i „Wprost”). Znaczenia zaczęły nabierać tytuły reprezentatywne dla nowego typu prasy, czego przykładem może być chociażby miesięcznik „Pani” czy „Twój Styl”.

Szczególnie dobry okres dla rozwoju czasopism, zwłaszcza tygodników, rozpoczął się w $1993 \mathrm{r}$. W tym czasie, wraz z „umacnianiem nowych tytułów kosztem starych i umiędzynarodowieniem form własności"21, nastąpiły istotne zmiany na rynku mediów elektronicznych ${ }^{22}$, które wpłynęły również na sytuację prasy. Uruchomienie nowych stacji radiowych i telewizyjnych spowodowało powstanie nowej grupy tytułów: były nimi tygodniki repertuarowe, oparte na wzorach swych zachodnich odpowiedników. Na nową sytuację szybko zareagowały również dzienniki ogólnopolskie, oferując czytelnikom wkładki telewizyjne, dołączane do wydań głównych. Jednocześnie był to okres szczególnie dobry dla prasy kobiecej i młodzieżowej: wiele tytułów z tego segmentu rynku wzmocniło swą pozycję (na przykład „Dziewczyna” i „Twój Styl”).

Jednak już w drugiej połowie 1993 r. poziom czytelnictwa uległ załamaniu i to zarówno w odniesieniu do gazet, jak i czasopism, co było w pewnej mierze spowodowane wzrostem zainteresowania odbiorców innymi mediami. Niekorzystna dla prasy sytuacja utrzymała się do końca sierpnia 1994 r. Wtedy to nastąpiły roszady wśród koncernów zagranicz-

19 Jesienią 1991 r. przeprowadzono przyspieszone wybory parlamentarne, trzykrotnie zmieniał się rząd, nastąpił zwrot ku centroprawicy, lustracja i dekomunizacja.

${ }^{20}$ Były to kolejne kalki pism zachodnich.

${ }^{21}$ R. Filas, Pięć lat..., s. 61.

22 Jedną z nich było powstawanie nowych, prywatnych stacji radiowych i telewizyjnych. 
nych, inwestujących w polską prasę. Dzienniki lokalne, wydawane przez Roberta Hersanta, zostały przejęte przez niemiecki koncern Passauer Neue Presse, swoją pozycję umocniła również norweska Orkla, zainteresowana podobnym segmentem rynku. Jednocześnie pojawiła się ogromna grupa nowych, bardzo tanich wysokonakładowych kolorowych tygodników (ogólnorodzinnych, kobiecych, sensacyjno-rozrywkowych i plotkarskich, w których nad tekstem dominowały ilustracje i zdjęcia), wydawanych głównie przez niemieckie koncerny medialne (Heinrich Bauer, G+J, Axel Springer). W krótkim czasie wpłynęły one na nowy sposób odbioru prasy. Jak pisze R. Filas:

W hierarchii najpoczytniejszych czasopism nastąpiła wręcz rewolucja [...], a co więcej ukształtował się nowy sposób recepcji prasy, który [...] nazwaliśmy [...] „oglądactwem”23.

Nowe pisma zyskały (kosztem starych tytułów) olbrzymią popularność. $\mathrm{W}$ odniesieniu do prasy opinii, która jest przedmiotem jednego $\mathrm{z}$ rozdziałów pracy, czytelnictwo dwóch wiodących tygodników („Polityki” i „Wprost”) ustabilizowało się na określonym poziomie. Był to przede wszystkim wynik starań redakcji; na przykład pierwszy ze wspomnianych tytułów przekształcił się w tym czasie w kolorowy magazyn, z nowoczesną grafiką. Natomiast w segmencie prasy kobiecej pojawił się m.in. miesięcznik „Elle”, stanowiący forpocztę magazynów, wzorowanych na tytułach zachodnich. Warto odnotować, że w tym okresie to właśnie czasopisma wpływały na ożywienie rynku.

Wiele znaczących zmian nastąpiło w latach 1997-1999. Niektóre z nich były konsekwencją przemian, zachodzących w mediach audiowizualnych. Rozdzielano wtedy nowe koncesje, następowała konsolidacja stacji radiowych, zwiększyła się liczba polskojęzycznych kanałów telewizyjnych, widoczna była jednocześnie postępująca specjalizacja mediów. Wszystko to miało wpływ na poziom czytelnictwa i wzrost rywalizacji na rynku prasy. Jednym z efektów tej sytuacji była wyraźna i gruntowna selekcja oferty, zwłaszcza w segmencie prasy codziennej. Natomiast wśród czasopism ukształtowała się wyraźna hierarchia tytułów, reprezentatywnych dla większości grup (głównie kobiecych, rozrywkowo-plotkarskich i telewizyjnych), a także widoczna redukcja nakładów wydawanych periodyków. W tym czasie zniknęły z rynku tytuły, które istniały na nim od kilkudziesięciu lat (m.in. „Słowo”, „Sztandar Młodych”). Czytelnicy prasy, podobnie jak widzowie telewizji, chętniej przyjmowali treści i obrazy, oparte na wzorach zachodnich ${ }^{24}$, chociaż wzrosło równocześnie zainteresowanie prasą specja-

\footnotetext{
${ }^{23}$ R. Filas, Dziesięć lat..., s. 46.

24 Więcej, zob. ibidem, s. 55.
} 
listyczną, co wpisywało się w ówczesną tendencję do zapełniania dotychczasowych nisz prasowych. Taką funkcję spełniały również powstające wówczas tzw. partworki, pisma kolekcjonerskie, mające zamknięty cykl wydawniczy (na przykład „Dinozaury”, „Życie Świata”). Warto również zwrócić uwagę na liczną grupę tytułów zaliczanych do pism lokalnych i sublokalnych ${ }^{25}$ oraz na pojawienie się pism alternatywnych (zinów).

Dwanaście ostatnich lat XX w., zapoczątkowanych transformacją ustrojową ze wszystkimi jej konsekwencjami, także w odniesieniu do rynku prasy, to okres niezwykle istotnych przemian, korzystny pod względem ilościowym, chociaż niezupełnie w odniesieniu do jakości wydawanej prasy. Jak pisał T. Mielczarek:

Z jednej strony media zyskały całkowitą niezależność i nie były już instrumentem do realizacji polityki władz państwowych, z drugiej zaś, niska efektywność polskiego sądownictwa otworzyła przed nimi możliwości nieprzewidziane przez ustawodawcę. Dziennikarze dość szybko poznali swoją siłę i niekiedy nadużywali przyznanej im wolności. [...]. Choć dzięki temu wielokrotnie udało się przeciwdziałać nadużyciom, a niekiedy i pospolitym przestępstwom, publikacje dotknęły też osoby o kryształowej wręcz uczciwości. To z kolei pociągnęło za sobą procesy sądowe i szeroką dyskusję o granicach wolności wypowiedzi 26 .

Niezależnie jednak od pozytywnych czy negatywnych efektów, okres ten przygotował grunt pod kolejne zmiany, zapoczątkowane rokiem 2001, a zatem dolną granicą czasową, obejmującą prezentowaną pracę.

W ciągu trzech pierwszych lat XXI w. funkcjonowanie rynku prasy w Polce w znaczący sposób kształtowała sytuacja w sferze gospodarki naszego kraju. Panował wówczas okres stagnacji, co dla mediów oznaczało m.in. spadek zainteresowania reklamodawców promocją własnej oferty, w konsekwencji zaś redukcję wpływów z reklam, zmniejszenie liczby czytelników (co wynikało także m.in. z ubożenia społeczeństwa), a to wszystko przekładało się na zmniejszenie nakładów prasy. Nie bez znaczenia były również zmiany, zachodzące w grupie nowych form komunikowania indywidualnego (telefonia komórkowa), które przełożyły się na przykład na nową formę kontaktu na poziomie media-ich odbiorca. Znalazło to swój wyraz choćby w konkursach typu audiotele, głosowaniu w rozmaitych plebiscytach i quizach, także w kontakcie sms-owym czytelników prasy z redakcjami wybranych tytułów. Kolejnym czynnikiem, kształtującym funkcjonowanie gazet i czasopism w owym okresie, była rosnąca popular-

25 Więcej na temat prasy lokalnej i sublokalnej zob. np. W. Chorązki, Polskie media lokalne i sublokalne 1989-1999, „Zeszyty Prasoznawcze” 1999, nr 1/2, s. 59-82; R. Kowalczyk, Prasa lokalna w systemie komunikowania społecznego, Instytut Nauk Politycznych i Dziennikarstwa Uniwersytetu im. Adama Mickiewicza, Poznań 2002.

26 T. Mielczarek, Monopol, pluralizm, koncentracja. Środki komunikowania masowego w Polsce w latach 1989-2006, Wydawnictwa Akademickie i Profesjonalne, Warszawa 2007, s. 17. 
ność nowego medium, jakim był Internet. Dla czwartej władzy stał się on wyzwaniem, któremu musiała sprostać, szczególnie że ponad 92\% czasu, przeznaczanego przez odbiorców na korzystanie z mediów, było przez nich wykorzystywane na media elektroniczne ${ }^{27}$. Reklamodawcy, opierając się na tym fakcie, chętniej korzystali z możliwości dotarcia do klientów, wykorzystując telewizję, radio, a także Internet, w niewielkim tylko stopniu sięgając do prasy. Z drugiej jednak strony, wraz ze zwiększeniem się liczby osób korzystających z Internetu, wzrosła również liczba potencjalnych odbiorców prasy w jej nowej formie. Gazety on-line, dziennikarstwo obywatelskie, portale internetowe czasopism - to znak czasu tamtych lat.

Naturalnie wydawcy w rozmaity sposób starali się zapobiegać niekorzystnej dla siebie sytuacji. Poza wspomnianą formą obecności w Interne$\mathrm{cie}^{28}$, konwergencją mediów ${ }^{29}$, coraz szerszym zjawiskiem stawała się tzw. gadżetomania (dołączanie do wybranych numerów pism „prezentów”). Początkowo ograniczała się ona do prasy kobiecej i codziennej, szybko jednak stała się cechą także innych typów czasopism.

Pomimo podjętych działań, okres ten charakteryzuje zastój w odniesieniu do wysokości nakładów drukowanych i kryzys sprzedaży na rynku prasy codziennej. Jej sytuację pogarszała także, rozwijająca się podówczas, prasa bezpłatna ${ }^{30}$. Pogłębiały się również zmiany na rynku czasopism, szczególnie w odniesieniu do tygodników i dwutygodników (sytuacja tytułów o rzadszej częstotliwości, zwłaszcza miesięczników, była korzystniejsza: nastąpił wzrost podaży zarówno tytułów, jak i nakładów drukowanych) ${ }^{31}$. Wyjątkiem była sprzedaż tygodników kobiecych, a także efektowny sukces „Przekroju” w jego nowej formule.

27 Za: R. Filas, Rośnie dominacja mediów elektronicznych - nowa faza przemian polskiego rynku, „Zeszyty Prasoznawcze” 2003, nr 3-4, s. 9.

${ }^{28}$ Zob. np. L. Olszański, Dziennikarstwo internetowe, Wydawnictwa Akademickie i Profesjonalne, Warszawa 2006, m.in. s. 29-32; M. Przybysz-Stawska, Prasa w Internecie, czyli interaktywne formy spędzania wolnego czasu, [w:] „Cudne manowce?” Kultura czasu wolnego we współczesnym społeczeństwie, red. nauk. W. Muszyński, Wydawnictwo Adam Marszałek, Olsztyn 2008; eadem, Wprost z Internetu. Budowanie nowego wizerunku prasy, [w:] Biblioteka, ksiq̨żka, informacja, Internet 2010, red. Z. Osiński, Instytut Bibliotekoznawstwa i Informacji Naukowej UMCS w Lublinie, Lublin 2010; eadem, Tradycja i nowoczesność czwartej władzy (na przykładzie tygodników opinii: „Polityki”, „Wprost” i „Newsweek Polska”), UMK, Wydział Politologii i Studiów Międzynarodowych UMK Katedra Dziennikarstwa i Komunikacji Społecznej [w druku].

${ }^{29}$ Konwergencja środków masowego przekazu była już wówczas zjawiskiem wyraźnym na rynku, opisywanym i analizowanym w literaturze. Zob. np. H. Jenkins, Kultura konwergencji. Zderzenie starych i nowych mediów, Wydawnictwa Akademickie i Profesjonalne, Warszawa 2007.

30 Więcej na temat zjawiska prasy bezpłatnej w Polsce zob. m.in. I. St. Fiut, Prasa bezpłatna $w$ Polsce $w$ latach 1999-2001, „Zeszyty Prasoznawcze” 2002, z. 1-2, s. 69-83; I. Marecka, Gazeta za darmo: nasila się rywalizacja na rynku prasy bezpłatnej, „Przegląd” 2001, nr 4, s. 45-46.

31 R. Filas, Rośnie dominacja mediów..., s. 20. 
W tym czasie umocnili swą pozycję na rynku polskim wydawcy zagraniczni ${ }^{32}$. W przypadku rynku regionalnego nastąpił jego podział pomiędzy dwa koncerny: Polskapresse (jako polskiego przedstawiciela Verlagsgruppe Passau) i norweską Orklę. Z kolei w odniesieniu do rynku czasopism należy podkreślić, pomimo wspomnianego kryzysu, wyraźną aktywność Wydawnictwa Bauer, które sięgnęło m.in. po kobiece tytuły z tzw. wyższej półki (jak choćby miesięcznik „Twój Styl”) oraz prasę młodzieżową (na przykład „Filipinkę"). Uaktywnił się także koncern G+J oraz Axel Springer, który dołączył do swego portfolio tygodnik opinii, wydawany na licencji amerykańskiej, „Newsweek Polska”, a także (wzorowany na niemieckim tabloidzie) „Fakt”. Pozostali wydawcy (m.in. Burda, Edipresse Polska czy Hachette-Filipacchi) również podejmowali próby wprowadzenia na rynek, z różnym skutkiem, nowych tytułów. Niektórzy (jak choćby Wydawnictwo Bauer), starając się zdobyć szersze grono czytelników, proponowali czytelnikom bardzo tanie tytuły pism repertuarowych (tzw. tw-quides), kobiecych (Burda) oraz rozrywkowo-plotkarskich.

Działania obcych koncernów zaktywizowały również rodzimych wydawców. Liczącym się wydawcą prasy stała się Agora SA: zainwestowała ona $\mathrm{w}$ wykupienie kilkunastu tytułów czasopism od Wydawnictwa Prószyński i S-ka. Jednocześnie Agencja Wydawniczo-Reklamowa „Wprost” oraz Spółdzielnia Wydawnicza „Polityka” podjęły w tym czasie walkę o czytelnika, przejmując nowe tytuły oraz inwestując (szczególnie tygodnik „Wprost”) w Internet.

Niemal wszyscy wydawcy, prowadząc działania, mające pomóc im przetrwać w okresie kryzysu gospodarczego, zmieniali również szaty graficzne wydawanych przez siebie pism, poprawiając tym samym ich atrakcyjność. Działania te zintensyfikowały się szczególnie w roku 2003, a widoczne były zwłaszcza w odniesieniu do periodyków kobiecych.

Kryzys na rynku reklamowym zakończył się w 2003 r., chociaż udział prasy w podziale zysków pozostał na wcześniejszym poziomie (zmieniły się jedynie proporcje $\mathrm{w}$ tym względzie pomiędzy prasą codzienną a czasopismami) ${ }^{33}$. Liczba tytułów gazet i czasopism zarejestrowanych w tym czasie zwiększyła się o 120 tytułów. Jednocześnie spadł ich jednorazowy nakład ${ }^{34}$. Nastąpiło wyraźne ożywienie na rynku gazet ogólnopolskich, co było m.in. pozytywnym efektem nowych inicjatyw marketingowych. Widoczna była

32 Więcej na temat kapitału zagranicznego w prasie polskiej zob. m.in. Z. Bajka, Kapitał zagraniczny w polskiej prasie - lata 90-te, „Zeszyty Prasoznawcze” 1998, nr 1-2, s. 21-35; K. Cira, Zagraniczne koncerny prasowe na polskim rynku dzienników regionalnych, ibidem, 2000, nr 1-2, s. [7]-33.

${ }^{33}$ Zob. R. Filas, Rynek prasy codziennej w Polsce przed Faktem i z Faktem, „Zeszyty Prasoznawcze" 2005, nr 3-4, s. [7].

34 „Ruch Wydawniczy w Liczbach XLIX: 2003” 2004, s. 7. 
jednak równoczesna tabloidyzacja pism codziennych. Zwiększeniu uległa liczba tytułów prasy bezpłatnej, wydań specjalnych niektórych magazynów, a także liczba mutacji wydań głównych danego tytułu.

Wśród liczących się koncernów pojawił się brytyjski Mecom, który przejął Orkla Press Polska i odtąd działał jako spółka Media Regionalne. Wraz z Polskapresse stał się największym wydawcą prasy codziennej w Polsce 35 .

$\mathrm{Na}$ ostatnie omawiane lata przypadł dynamiczny rozwój gospodarczy, związany m.in. ze wspomnianym wyżej wstąpieniem Polski do Unii Europejskiej36. Nastąpiło zrozumiałe $w$ takiej sytuacji ożywienie. Dominacja mediów elektronicznych, tak widoczna w poprzednim okresie, nadal istniała, chociaż równocześnie prasa tradycyjna w większości tytułów była już obecna także w Internecie w postaci stron www i wersji e-wydań ${ }^{37}$. Wydawcy odpowiedzieli w ten sposób na postępujący rozwój technologii i wzrost znaczenia Internetu. Rosnąca liczba internautów, możliwości interaktywne, jakie dawało nowe medium, stały się cechą charakterystyczną tego okresu i otwierały nowe perspektywy dla wydawców tradycyjnych, będąc dlań jednocześnie, jak pisał R. Filas, raczej wyzwaniem niż faktyczną konkurencją.

Prasa przebyła długą drogę od roku 1989: kwintesencją jej przeobrażeń wydaje się być tytuł opracowania T. Mielczarka ${ }^{38}$ (tu podany w nieco odmiennej postaci): przejście od monopolu do pluralizmu, a następnie proces koncentracji. Zmieniła się zarówno forma wydawanych periodyków, jak i ich zawartość merytoryczna. Prasa początku XXI w. różniła się już znacząco od tej wydawanej w 1989 r. Interesujący, a być może nawet znamienny, wydaje się przy tym fakt, że pomimo licznych zmian, którym podlegał rynek, przetrwało kilka pism z „peerelowskim rodowodem”. Wśród nich znajdują się dwa tytuły, będące m.in. przedmiotem niniejszej pracy.

Rok 2005 zamknął się liczbą 49 tytułów dzienników i 6672 tytułami czasopism, zarejestrowanych w Związku Kontroli Dystrybucji Prasy, przy czym największą grupę stanowiły dwumiesięczniki i kwartalniki (2156), zaś

35 Więcej na temat funkcjonowania prasy codziennej tego okresu, zob. R. Filas, Polski rynek prasy codziennej w I dekadzie XXI wieku (w szczególności po roku 2003), „Zeszyty Prasoznawcze" 2008, nr 3-4, s. [7]-26.

36 Polska stała się członkiem wspólnoty od 1 kwietnia 2004 r.

$37 \mathrm{Na}$ temat podobieństw i różnic pomiędzy prasą tradycyjną i jej wersjami on line powstało kilka interesujących prac, m.in. Z. Szkutnik, Czasopisma elektroniczne - szanse i problemy, „Biblioteka” 1998, nr 2, s. 71-84; M. Stepowicz, Cechy formalne czasopism internetowych w odniesieniu do analogicznych publikacji drukowanych, SBP, Warszawa 2000.

38 T. Mielczarek, Monopol, pluralizm, koncentracja. Środki komunikowania masowego w Polsce w latach 1989-2006, Wydawnictwa Akademickie i Profesjonalne, Warszawa 2007. 
tygodniki zajmowały w tej klasyfikacji miejsce przedostatnie (375) ${ }^{39}$. Warto jednakże zaznaczyć, że jakkolwiek ogólna liczba tytułów na rynku prasowym wzrosła ${ }^{40}$, to jednak równocześnie ich nakłady, w porównaniu z poprzednimi latami, były mniejsze.

Jak wyglądała sytuacja tych typów czasopism, które są przedmiotem prezentowanej pracy? Otóż ekskluzywne magazyny, adresowane do kobiet, zostały zaliczone przez R. Filasa do grupy pism „o znacznym potencjale wzrostu". Natomiast prasa ogólnomłodzieżowa znalazła się jego zdaniem na „drodze spadkowej”, zaś prasę opinii określił mianem „magazynów w stanie stagnacji"41.

Jakim okolicznościom i działaniom zawdzięczały one swój sukces lub porażkę? Jak w kontekście ich rosnącej lub słabnącej popularności wyglądała informacja na temat książki, zamieszczana na ich łamach? Czy problematyka związana z literaturą była ważnym punktem w polityce redakcyjnej każdego z nich?

Kolejne rozdziały pracy przyniosą odpowiedź na te pytania.

${ }^{39}$ Dane za: R. Filas, Polskie czasopisma w XXI wieku - rozwój czy kryzys?, „Zeszyty Prasoznawcze" 2007, nr 1-2, s. 14.

40 Po 2000 r. wprowadzono na rynek 40 nowych tytułów, za: ibidem, s. 23.

41 Ibidem, s. 29, 47, 40, 37. 


\title{
Rozdział 2
}

\section{PRASA OPINII}

\subsection{Prasa opinii. Krótka charakterystyka}

\author{
Zgodnie $\mathrm{z}$ definicją, prasa opinii to
}

określenie różnych typów prasy, komentującej uprzednio już rozpowszechnione przez gazety informacje o wydarzeniach w celu urabiania opinii publicznej i kształtowania postaw; prasa realizująca przede wszystkim funkcje propagandowe. W przeciwieństwie do prasy informacyjnej prasa opinii częściej bywa wyrazem świadomości indywidualnej, tzn. wyraża indywidualne przekonania autorskie. Wiąże się to m.in. z faktem, iż ten typ prasy (charakteryzujący się większą niż gazety amplitudą periodyczności) jest wyraźniej zindywidualizowany pod względem tematycznym i kręgu odbiorców. Do prasy opinii w Polsce można zaliczyć prasę społeczno-polityczną i społeczno-kulturalną ${ }^{1}$.

Ten typ prasy stosunkowo rzadko był przedmiotem publikacji ${ }^{2}$; $w$ tej niewielkiej grupie znaczna część tekstów odnosiła się do pism społecznokulturalnych, nie zaś prasy społeczno-politycznej, która jest przedmiotem niniejszego rozdziału ${ }^{3}$. Warto jednak zatrzymać się na chwilę przy wspólnej dla nich historii.

1 Encyklopedia wiedzy o prasie, red. J. Maślanka, Zakład Narodowy im. Ossolińskich, Wrocław-Warszawa-Kraków-Gdańsk 1976, s. 179.

2 Zob. np. 0. St. Czarnik, Między dwoma Sierpniami. Polska kultura literacka w latach 1944-1980, Wydawnictwo Wiedza Powszechna, Warszawa 1993, s. 255-276; I. St. Fiut, Pisma spot.-kulturalne $w$ latach 1989-2000, „Zeszyty Prasoznawcze” 2000, nr 3/4, s. 64-81; K. Koźniewski, Historia co tydzień. Szkice o tygodnikach społeczno-kulturalnych 1944-1950, Czytelnik, Warszawa 1977; T. Mielczarek, Od Nowej Kultury do Polityki. Tygodniki społeczno-kulturalne i społeczno-polityczne PRL, Wydawnictwo Akademii Świętokrzyskiej, Kielce 2003; J. Myśliński, Tygodniki społeczno-kulturalne. Lektura polskiej inteligencji, [w:] Valeriana. Eseje o komunikowaniu między ludźmi, red. J. Mikułowski-Pomorski, Z. Bajka, Ośrodek Badań Prasoznawczych Uniwersytetu Jagiellońskiego, Kraków 1996; B. Sordylowa i in., O sytuacji polskich czasopism kulturalnych i naukowych, „Rocznik Biblioteki Narodowej” 1996, t. 32, s. 33-46.

${ }^{3}$ Nie podejmowano w tym miejscu wątku prasy społeczno-literackiej, mieszczącej się w ramach czasopiśmiennictwa społeczno-kulturalnego. 
Tomasz Mielczarek stwierdził, że czasopisma społeczno-polityczne i społeczno-kulturalne były specyficznym wytworem lat Polski Ludowej4, choć jednocześnie przyznawał, że ich początki ${ }^{5}$ odnaleźć można już w wieku XVIII (w wydawanym w Anglii „Spectatorze” czy polskim „Monitorze”), a także w okresie XX-lecia międzywojennego (w postaci takich tytułów, jak choćby „Kultura” czy „Wiadomości Literackie”)6. W latach PRL pisma tego typu podlegały, podobnie jak wszystkie periodyki, silnej indoktrynacji, szczególnie zaś prasa opinii służyć miała szerzeniu określonych idei. Takie cele postawiono m.in. przed powołaną do życia w 1950 r. „Nową Kulturą” czy tygodnikiem „Polityka”, powstałym siedem lat później. Aż do 1970 r. władze partyjne bardzo uważnie śledziły zawartość periodyków tego typu. Wraz z rezygnacją z funkcji I sekretarza KC PZPR Władysława Gomułki interesująca nas grupa pism zaczęła się $\mathrm{w}$ sposób wyraźny rozwijać. Zmieniła się jej zawartość, na jej łamach coraz częściej pojawiały się materiały publicystyczne i reportaże. T. Mielczarek podkreślał znaczenie tego typu czasopism, wskazując na ich kulturową rolę $\mathrm{z}$ jednej strony, a przesycenie jej zagadnieniami ideologiczno-politycznymi z drugiej ${ }^{8}$. Należy zaznaczyć, że ich wartość wzrastała, ze zrozumiałych względów, szczególnie w okresach kryzysów politycznych:

w latach Polski Ludowej zakres oddziaływania czasopism społeczno-kulturalnych i społeczno-politycznych był zaskakująco duży [...]. Choć według politycznych decydentów prasa ta miała być „pasem transmitującym” ideologię marksistowską do polskiej inteligencji, efekty takiej działalności były problematyczne9.

Dalszy rozwój tej grupy pism nastąpił w połowie lat 70. Wzrosła wówczas ich liczba dzięki pojawieniu się konspiracyjnych tytułów, m.in. „Krytyki”, „Postępu”, „Res Publiki” czy „Zapisu”. W sierpniu 1980 r. prasa „drugiego obiegu” przybrała postać niezależnych biuletynów (na przykład „Informator Kulturalny Solidarności” czy „Obserwator Wielkopolski”). Wiele z nich miało charakter periodyków, zaliczanych do typu opiniotwórczego. Po wprowadzeniu stanu wojennego wszystkie one zostały zawieszone, dzieląc los całej ówczesnej prasy. Część z nich w 1981 r. reaktywowano

${ }^{4}$ Warto jednak wskazać, że, jak podkreślił jeden z badaczy, samo określenie „prasa opinii" nie funkcjonowało $\mathrm{w}$ potocznym obiegu w tym okresie, pomimo iż pojawiło się jako hasło w wydanej w 1976 r. Encyklopedii wiedzy o prasie. Zob. Tygodniki opinii - co to takiego?, http://www.wirtualnemedia.pl/artykul/tygodniki-opinii-co-to-takiego, luty 2005.

5 Uwaga ta odnosiła się zwłaszcza do pierwszej grupy.

6 T. Mielczarek, Od Nowej Kultury..., s. [79].

7 Trzeba jednak zaznaczyć, że „Polityka” została powołana głównie jako narzędzie walki z opozycyjnym tygodnikiem „Po prostu”.

8 T. Mielczarek, Od Nowej Kultury do..., s. 349.

${ }^{9}$ Ibidem, s. 107. 
w zmienionej formie. Powstawały także nowe tygodniki społeczno-kulturalne i społeczno-polityczne; większość tego typu przedsięwzięć wydawniczych kończyła się jednak niepowodzeniem (jak choćby w przypadku periodyków „Tu i teraz” czy „Spraw i Ludzi”). Ciekawym, a zarazem kontrowersyjnym pomysłem był tygodnik „Rzeczywistość”, który powstał w $1981 \mathrm{r}$. z inicjatywy S. Olszowskiego, sekretarza KC PZPR ${ }^{10}$.

W połowie lat 80. pisma tego typu (szczególnie zaś tytuły, zaliczane do społeczno-kulturalnych) przeżywały głęboki kryzys, który trwał do upadku komunizmu w Polsce. Pomimo, iż ich nakłady systematycznie rosły, to jednak zawartość merytoryczna prezentowała sobą coraz niższy poziom. W drugiej połowie lat 80. zaczęto wydawać konspiracyjne, „trzecioobiegowe" pisma społeczno-kulturalne (na przykład „Czas Kultury”). Charakterystyczną cechą tego okresu był również rozwój prasy katolickiej, której wybrane tytuły także można zaliczyć do periodyków społeczno-kulturalnych (reaktywowany „Tygodnik Powszechny”, „Znak”).

Po 1989 r. nastąpiło wyraźne oddzielenie obydwu rodzajów, zaliczanych do tej grupy. Czytelnicy pamiętali rolę, jaką władze minionego ustroju przypisywały czasopismom społeczno-kulturalnym i społeczno-politycznym. Stąd kondycja i znaczenie oddziaływania tytułów reprezentujących szczególnie pierwszą grupę wyraźnie osłabły, a większość z nich uległa likwidacji (tak było chociażby z „Tygodnikiem Kulturalnym”).

Natomiast prasa społeczno-polityczna zaczęła rozwijać się innym nurtem, odgrywając coraz poważniejszą rolę na rynku prasowym w Polsce. Poza innymi czynnikami, nie bez znaczenia był fakt, że jej odbiorcami była przede wszystkim inteligencja, której wzrastająca z czasem liczba zwiększała zapotrzebowanie na tego typu prasę. W latach 2001-2005 do tej grupy zaliczano m.in. takie tytuły, jak „Arcana”, „Arka”, „Fakty”, „Newsweek Polska”, „Nie”, „Ozon”, „Polityka”, „Przekrój”, „Nowa”, „Więź”, „Wprost” i „Znak”.

Dzięki jakim staraniom dwa z nich - tygodniki „Polityka” i „Wprost” - przetrwały najtrudniejsze lata? Dzięki czemu trzeci z nich - „Newsweek Polska" - zdobył grupę wiernych czytelników, będąc przez pewien czas liderem grupy? Jak każdy $\mathrm{z}$ nich poradził sobie na rynku wydawniczo-prasowym u progu nowego tysiąclecia?

$\mathrm{W}$ jakim stopniu prezentowane $\mathrm{w}$ rozprawie pisma realizowały, wynikające z definicji, funkcje opiniotwórcze? Po jakie środki wyrazu, gatunki dziennikarskie sięgały redakcje każdego z nich? Czy czasopisma te rzeczywiście kształtowały poglądy swych odbiorców także w zakresie problematyki, związanej z książką? Czy każdy z nich zachował swój indywidualny charakter? A może ówczesne warunki wpłynęły nie tylko na ujednolicenie 
formy tego typu pism, upodabniając je do kolorowych magazynów, ale również spowodowały unifikację proponowanych treści? Czy wobec tego, teksty zamieszczane na ich łamach „wyrażały indywidualne przekonania autorskie"? Czy wybrane do analizy tytuły spełniały, wynikające z definicji tego typu prasy, funkcje opiniotwórcze, również w dziedzinie kultury, literatury, promocji książki? Aby odpowiedzieć na te pytania, analizie poddano zawartość każdego z nich pod kątem ujętej w tytule opracowania problematyki. 


\section{2. „Polityka”: pismo pokoleń}

Przez 50 lat swego istnienia tygodnik „Polityka” przechodził bardzo różnorodne, nieraz burzliwe koleje losu, towarzysząc nieprzerwanie polskiemu społeczeństwu w ważnych wydarzeniach politycznych i społecznych, zawsze - w granicach możliwości - służąc debacie politycznej, będąc znaczącym głosem polskiej inteligencji1 ${ }^{1}$.

\subsubsection{Pół wieku „Polityki”: historia czasopisma}

Jednym z najstarszych w Polsce powojennej przedstawicieli pism opiniotwórczych jest tygodnik „Polityka”.

Pomysł jego utworzenia pojawił się już pod koniec listopada 1956 r., ale pierwszy numer ukazał się dopiero kilka miesięcy później: 27 lutego $1957 \mathrm{r}$. Tytuł został powołany do życia w swoistej sytuacji politycznej Polski: kilka miesięcy po Październiku`56, w czasie, gdy uformowała się ekipa I sekretarza KC PZPR Władysława Gomułki, który w nowym piśmie widział przede wszystkim narzędzie walki z dogmatykami i rewizjonistami partyjnymi. Pomysłodawcą przedsięwzięcia był Jerzy Putrament.

Intencje W. Gomułki były jasne dla środowiska dziennikarskiego, dlatego też zanim jeszcze tygodnik ukazał się na rynku, został oceniony i skrytykowany przez prasę. Pisano, że nowy periodyk ma tylko jeden cel: służyć wiernie nowemu sekretarzowi i partii, stanowiąc jednocześnie przeciwwagę dla opozycyjnego tygodnika młodzieżowego „Po prostu”.

„Polityka” w zamyśle władz miała być jedyną prawidłową wykładnią gomułkowskiego socjalizmu, drogowskazem dla innych ${ }^{2}$. Z dokumentów KC PZPR wynika, że nowo powstałe pismo miało grać na dwa fronty. [...] Cenzura zdejmowała szczególnie napastliwe artykuły pod adresem „Polityki”, które pojawiały się w innych pismach ${ }^{3}$.

Związki z partią rządzącą były wyraźne: redakcja otrzymała drogi lokal na 11. piętrze Pałacu Kultury i Nauki, dwa samochody i pozwolenie na kilka milionów złotych strat rocznie, nadto w stopce redakcyjnej pierwszego numeru pojawiły się nazwiska ośmiu członków KC PZPR ${ }^{4}$, których łączyła

1 Urodzinowa Księga Życzeń, „Polityka” 2007, nr 10, s. 86.

2 M. Iłowiecki, Pół wieku w służbie..., „Nowe Państwo” 2007, nr 2, s. 54.

3 J. Podgórska, E. Wilk, Raport wewnętrzny Polityki, „Polityka” 1997, nr 10, s. 3.

${ }^{4}$ Byli wśród nich: Franciszek Blinowski, Leonard Borkowicz, Romana Granas, Stanisław Kuziński, Mieczysław Rakowski, Andrzej Werblan, Stefan Żółkiewski. 
„Swoiście rozumiana partyjna dyspozycyjność i gotowość poparcia W. Gomułki”.

Redaktorem naczelnym został Stefan Żółkiewski, zaś wśród członków redakcji i współpracowników znaleźli się znani publicyści i naukowcy, m.in.: Kazimierz Koźniewski, Leon Kruczkowski, Oskar Lange i Adam Schaff. Pierwszy zespół redakcyjny „Polityki” tworzyli również na przykład Zygmunt Kałużyński, Szymon Kobyliński i Michał Radkowski.

„Początkowo >Polityka< była nudną, marksistowską piłą, wypełnioną dywagacjami ideologów i działaczy"6, co przekładało się bezpośrednio na nakład pisma, który liczył średnio 20 tys. sprzedawanych egzemplarzy. Jednak, jak pisze Tomasz Mielczarek, „opowiadając się za W. Gomułką, $>$ Polityka< próbowała zaprezentować swój plan naprawy socjalistycznej Rzeczypospolitej"7, a jej pomysły reformatorskie można było odnaleźć $\mathrm{w}$ tekstach, pojawiających się na łamach tygodnika już w kilka miesięcy po jego powstaniu ${ }^{8}$. Pretendował on do roli subtelnego krytyka, niekoniecznie atakującego sam system, co raczej starającego się go w pewnym stopniu korygować.

Wraz ze zmianą sytuacji w kraju, zmieniał się również powoli, ale systematycznie kierunek pisma. Redakcję opuszczali członkowie partii, a na ich miejsce pojawiali się nowi dziennikarze, m.in. Dariusz Fikus, Ryszard Kapuściński, Zygmunt Szeliga, Marian Turski czy niezwykle popularny, choć budzący duże kontrowersje, Jerzy Urban. Bez wątpienia znaczący wpływ na zmiany w „Polityce” miał jej nowy (od 1958 r.) redaktor naczelny - Mieczysław F. Rakowski.

Pismo nadal sympatyzowało z partią, zaś redaktor naczelny nierzadko spotykał się z I sekretarzem (choć, trzeba to przyznać, wielokrotnie po to, by ratować „Politykę" przed zamknięciem z powodu wydrukowania „źle widzianego" przez cenzurę tekstu). Jednocześnie, dzięki nowatorskim pomysłom, a przede wszystkim zawartości, która stawała się mniej propagandowa, a bliższa istniejącej rzeczywistości, tygodnik stawał się coraz bardziej popularny, acz nadal postrzegany był jako organ sprzyjający partii.

Kolejne lata $w$ historii pisma to rosnący profesjonalizm jego zespołu redakcyjnego, nowe działy, rubryki i kolumny (na przykład Listy od czytel-

5 T. Mielczarek, Od Nowej Kultury do Polityki. Tygodniki społeczno-kulturalne i społeczno-polityczne PRL, Wydawnictwo Akademii Świętokrzyskiej, Kielce 2003, s. 253.

6 J. Podgórska, E. Wilk, Raport..., s. 3.

7 T. Mielczarek, Od Nowej Kultury..., s. 255.

8 Przykładem może być tekst, który pojawił się na łamach tygodnika po decyzji partii o zamknięciu „Po prostu”: na łamach „Polityki”, cytując treść tej decyzji, podkreślono takie oto zdanie: „Nie uniemożliwiamy głoszenia różnych poglądów, jeśli nie godzą w podstawy ustrojowe państwa. Występujemy i będziemy występować przeciwko tym, co nie chcą, aby Polska szła po tej drodze, na którą wprowadził ją Październik". Cyt. za: ibidem, s. 256. 
ników), dyskusje inicjowane na jego łamach, akcje, którym patronowało, a z drugiej strony, przy całym poparciu dla władz, nierzadkie zatargi z nią, kończące się przeprosinami redakcji, drukowanymi w periodyku' ${ }^{9}$.

W 1962 r. nakład „Polityki” zwiększył się do 84 tys. egz., a w roku 1969 osiągnął już liczbę 200 tys. egz..10 Dużą popularność zyskała ona dzięki publikacji pamiętników Adolfa Eichmanna, drukowi tłumaczeń rzadkiej i interesującej literatury piękniej i wielu innym dziennikarskim przedsięwzięciom zespołu, wykraczającym poza ówczesne „dziennikarstwo socjalistyczne" i zasady polityki prasowej PZPR. Nie bez znaczenia była także coraz atrakcyjniejsza szata graficzna pisma. Wszystkie te zabiegi, przy jednoczesnym, wspomnianym już, ale niezwykle istotnym, stopniowym odchodzeniu od posłuszeństwa wobec partii poprzez drukowanie kontrowersyjnych, nierzadko niezgodnych z obowiązującą linią polityczną tekstów (na przykład dotyczących demonstracji studentów w 1968 r. ${ }^{11}$ ), sprawiało, że tygodnik zyskiwał większą liczbę odbiorców.

Pismo sukcesywnie dryfowało od ideałów partyjnych i paradoksalnie zbliżało się do stanowisk i haseł głoszonych wcześniej przez „Po prostu”12.

„Polityka” ześlizgiwała się z gomułkowskiego kursu. Pierwszy okres w jej historii kończy pierwszy paradoks: pismo, które powstało jako anty-Po prostu, zaczyna być postrzegane jako jego kontynuator i inkasuje zarzut rewizjonizmu, przed którym miało być bastionem ${ }^{13}$.

Redakcja „Polityki” starała się jednak nie przekraczać pewnej granicy politycznej, którą naruszyło wcześniej „Po prostu”.

Lata 70. okazały się dla tygodnika bardzo korzystne, mimo że ich początek na to nie wskazywał. Podobnie, jak większość społeczeństwa, tak i sam M. Rakowski powitał zmianę ekipy rządzącej z dużymi nadziejami. $\mathrm{Na}$ początku stycznia 1971 r. redakcja uznała program I sekretarza KC Edwarda Gierka za własny, choć jednocześnie, realizując funkcje propagandowe, nie zapominała o innych sferach życia społecznego. Wydawano dodatki, jak choćby Polityka - Export - Import, Polityka Społeczna czy Polityka - Ksiaż́ki. Zmieniało się również grono współpracowników, wśród których znaleźli się

9 Jedno z takich „nieposłuszeństw” kosztowało M. Rakowskiego utratę stanowiska redaktora naczelnego w 1960 r. Po wielu perturbacjach, listach i osobistym spotkaniu M. Rakowskiego m.in. z E. Ochabem, „Polityka” odzyskała swego redaktora naczelnego. Więcej: zob. m.in. T. Mielczarek, Od Nowej Kultury..., s. 264-266.

10 Cyt. za ibidem, s. 291.

11 Redakcja pisma nie potępiła, wbrew oczekiwaniom partii, owych wystąpień.

12 A. Głombiowska, Przemiany tygodnika Polityka w latach 1990-1999, Praca magisterska, Uniwersytet Łódzki, Katedra Bibliotekoznawstwa i Informacji Naukowej, promotor: Oskar St. Czarnik, Łódź 2004, s. 9.

13 J. Podgórska, Raport..., s. 4. 
m.in.: Jan Bijak (zastępca redaktora naczelnego), Wojciech Giełżyński, Jacek Maziarski i Marta Wesołowska.

Sytuacja w kraju, stopniowa utrata zaufania do nowego przywódcy, rosnące rozgoryczenie i rozczarowanie znalazły swe odbicie także w redakcji periodyku. M. Rakowski nabierał coraz większych wątpliwości, pozostali członkowie zespołu przeżywali rozterki duchowe. Sytuacji nie poprawiała wzmożona działalność cenzury, „w kraju wrzało, a oni pisali o kulturze i zagranicy. Po raz pierwszy od lat $>$ Polityka< nie nadążała za rzeczywistością"14. Rozwój tygodnika uległ zahamowaniu, w redakcji nastąpiła stagnacja, spadł poziom publikowanych tekstów i ich wartość opiniotwórcza. Przeważała w nich ogólnikowość, a sposób opisywania rzeczywistości wyraźnie podporządkowany był kontroli władzy ${ }^{15}$.

W całym zespole i w każdym z nas z osobna były wtedy dwie dusze: dusza człowieka prawdomównego, przyzwoitego i dusza złamanego przez ten zawód i przez system oportunisty, dusza z plasteliny ${ }^{16}$.

W efekcie owych rozterek redakcja „Polityki” stanęła po stronie wewnątrzpartyjnej opozycji, rozstając się tym samym z ekipą E. Gierka. Koniec lat 70. to dla pisma już zupełnie inny okres: to czas częstych kłopotów $\mathrm{z}$ cenzurą, wynikających w dużej mierze $\mathrm{z}$ faktu, że publikacje zamieszczane wówczas na łamach pisma były wobec władzy zbyt krytyczne ${ }^{17}$.

Miesiące te zaznaczyły się $\mathrm{w}$ historii periodyku również istotnymi zmianami personalnymi. Redakcję zasilili m.in.: Magdalena Bajer, Barbara Pietkiewicz i Ernest Skalski. Jednocześnie wyraźniejsze stały się różnice poglądowe w zespole, co miało swoje konsekwencje na początku lat 80 . W państwie narastał wtedy kryzys ekonomiczny, co doprowadziło do wystąpień robotników na Wybrzeżu w 1980 r. W „Polityce” zachowano duży dystans wobec „Solidarności”. Z jednej strony postulowano reformy państwa, z drugiej ostrzegano przed eskalacją żądań, co mogło, zdaniem redakcji, doprowadzić do anarchii. Jednocześnie na łamach pisma zaczęły pojawiać się nazwiska wcześniej zakazane, na przykład Pawła Jasienicy, Czesława Miłosza czy Wiktora Woroszylskiego.

Wraz z wprowadzeniem stanu wojennego, tygodnik, podzielając losy innych tytułów, został zawieszony, choć jego dziennikarzy, dzięki pozycji M. Rakowskiego, ominęła weryfikacja. Jednocześnie w zespole nastąpiły podziały na zwolenników opcji partyjno-rządowej, „Solidarności” oraz na

\footnotetext{
14 J. Podgórska, E. Wilk, Raport..., s. 6.

15 Np. tygodnik odniósł się niechętnie do wystąpień robotniczych w czerwcu $1956 \mathrm{r}$.

${ }^{16}$ J. Podgórska, E. Wilk, Raport..., s. 6.

17 Jednak, pomimo owych „niesubordynacji”, w 1979 r. (podczas pierwszej wizyty papieża) redakcja tygodnika pozostała posłuszna dyrektywom partii.
} 
grupę tych, którzy starali się zachować neutralne pozycje polityczne. Redakcję opuściło kilkunastu dziennikarzy (m.in. Wanda Falkowska, Hanna Krall, Andrzej K. Wróblewski). Wydawanie pisma wznowiono w lutym 1982 r. Zatrudnienie znaleźli w nim ludzie z opozycji, na przykład Jerzy Baczyński, Stanisław Podemski i Jagienka Wilczak.

We wrześniu 1982 r. M. Rakowski został wicepremierem rządu, odpowiedzialnym za kontakty z "Solidarnością”. Jego miejsce w redakcji zajął J. Bijak. W latach 80. pojawili się kolejni nowi współpracownicy, m.in.: Ryszard Marek Groński, Ewa Nowakowska, Marek Rostocki, Piotr Sarzyński, Krzysztof T. Teoplitz i Wiesław Władyka. Powrócił Kazimierz Koźniewski, a przez pewien czas współpracował z pismem Tomasz Raczek. „Polityka” wydawana była w zmniejszonym nakładzie, co wynikało z niedoborów papieru.

Pismo, podobnie jak w latach ubiegłych, lawirowało pomiędzy rozmaitymi postawami i poglądami. I tak na przykład, z jednej strony zwalczano „ekstremistów” reprezentujących „Solidarność”, a z drugiej potępiano podobnych radykałów, wywodzących się z PZPR.

Jak się wydaje, antidotum na wszechobecny kryzys, frustracje, bunt i zniecierpliwienie „Polityka” upatrywała w pracy u podstaw. Pismo aż roiło się od różnorodnych wywiadów i reportaży, przedstawiających ludzi, którzy nie zważając na okoliczności, próbowali coś robić. [...] Z dzisiejszego punktu widzenia można stwierdzić, że „Polityka” miała znaczne zasługi na polu zmagań o wolność słowa i odkłamywania polskiej historii. [...] Można nawet stwierdzić, że u schyłku lat osiemdziesiątych pismo zaczęło specjalizować się w odnajdywaniu i zapełnianiu „białych plam” - przekłamań i przemilczeń związanych z historią XX wieku18.

Wydarzenia roku 1988 spowodowały kolejne zmiany w periodyku. Formuła tygodnika stała się bliższa magazynowi informacyjnemu. Koncentrowano się bardziej na odnotowywaniu wydarzeń, brakowało czasu na ich głębszą analizę. Liczba tekstów odnoszących się do partii uległa widocznemu zmniejszeniu; te, które sporadycznie się pojawiały, pisane były przez reformatorów partyjnych, m.in. Zygmunta Czarzastego i Leszka Millera. Mimo że nadal ważne, pismo zaczęło jednak stopniowo tracić popularność. Nie bez znaczenia było odejście z redakcji M. Rakowskiego. „Polityka”

walczyła z marazmem i stagnacją, demaskowała swą oraz peerelowską historię. Lecz w końcu lat osiemdziesiątych historia biegła tak szybko, iż tygodnik nie mógł jej już dogonić19.

18 T. Mielczarek, Od Nowej Kultury..., s. 335.

19 Ibidem, s. 343. 
Rok 1989, podobnie jak w przypadku całej prasy polskiej, wpłynął także na „Politykę”. Redakcja musiała odnaleźć się w zupełnie nowej dla siebie sytuacji, zastanowić się nad sposobami funkcjonowania, w jakże odmiennych od poprzednich, warunkach.

Walkę o czytelnika rozpoczęto od rezygnacji (w lutym 1990 r.) z towarzyszącego pismu od roku 1957 nagłówka „Proletariusze wszystkich krajów łączcie się!” i zarejestrowania nowego wydawcy, którym stała się „Polityka” Spółdzielnia Pracy. W jej składzie znalazła się większość dotychczasowych pracowników pisma. W 1991 r. powołano pięcioosobowy zarząd, na czele którego stanął J. Bijak (nadal pełniący funkcję redaktora naczelnego), zaś wiceprezesami zostali J. Baczyński i J. Poprzeczko. W zarządzie znaleźli się również Piotr Adamczewski i Wiesław Władyka. Dzięki pożyczce, otrzymanej od Komisji Likwidacyjnej RSW, „Polityce” udało się spłacić dług w wysokości ok. 500 mln PLZ.

Wraz ze zmianą właściciela zmienił się również nieco styl i tematyka tekstów, zamieszczanych na łamach pisma. W listopadzie 1991 r. pojawił się nowy dodatek do tygodnika: Kultura. Jakkolwiek zniknął on po kilku miesiącach, to zapoczątkował jednak podobne przedsięwzięcia pisma w latach następnych (m.in. Niezbędnik inteligenta czy Pomocnik historycz$n y$ ). W tym czasie redakcję zasilili również nowi współpracownicy, m.in. Jan Zbigniew Łojewski, Mirosław Pęczak, Zdzisław Pietrasik.

W celu utrzymania pozycji jednego z najważniejszych pism opiniotwórczych w Polsce, a także sprostania nowym wymogom czytelników, redakcja podejmowała liczne inicjatywy.

Jedną z nich były Paszporty Polityki, wręczane od 1993 r. Poczynając od pierwszej edycji, przyznawane były one wyróżniającym się artystom, reprezentującym następujące kategorie: literaturę, film, teatr, muzykę poważną, muzykę popularną, sztuki wizualne oraz od roku 2002 tytuł Kreator Kultury dla szczególnie wyróżniających się menedżerów tej dziedziny życia. Kandydatów, którzy w poprzednim roku uzyskali cenny dorobek w poszczególnych rodzajach twórczości, zgłaszali krytycy zaproszeni przez redakcję, reprezentujący odpowiednie dziedziny kultury. Następnie z grupy nominowanych kapituła redakcyjna wybierała laureatów. Na łamach pisma omawiano kolejne etapy konkursu i przedstawiano sylwetki twórców wskazanych do nagrody20. Jak pisze W. Władyka, „,Paszporty< od razu stały się bardzo prestiżowym wyróżnieniem i, bez przesady, wielu twórcom bezsprzecznie ułatwiły dalszą karierę"21.

20 Zob. np. Paszporty Polityki 2000. Nominacje, „Polityka” 2001, nr 1, s. 41-45; Paszporty Polityki 2000: laureaci, ibidem, nr 2, s. 48-49.

21 W. Władyka, Polityka i jej ludzie, „Polityka” Spółdzielnia Pracy, Warszawa 2007, s. 129. 
Jednocześnie zmieniał się wygląd zewnętrzny i struktura wewnętrzna pisma. Od numeru 29 (1992) zmniejszony został jego format, przy jednoczesnym zwiększeniu objętości pojedynczego numeru (z 16 do niemal 30 stron). W miejsce dotychczasowych obszernych analiz i polemik pojawiły się zwięzłe teksty i większa liczba zdjęć.

Jednak pomimo starań „Polityka” traciła swą dotychczasową pozycję ${ }^{22}$. Etykieta pisma komunistów w sposób wyraźny nadal jej szkodziła.

Sytuacja uległa zmianie w 1994 r., gdy nowym redaktorem naczelnym został J. Baczyński. Podjęto wówczas decyzję o kolejnej zmianie szaty graficznej tygodnika, dzięki czemu 14 października 1995 r. do czytelnika trafiło pismo przypominające kolorowy magazyn, o zmniejszonym formacie, ale za to w zwiększonej (do 100 stron) objętości. Pomysł okazał się trafiony; nowa formuła „Polityki” została korzystnie przyjęta przez odbiorców, co przełożyło się najpierw na zahamowanie tendencji spadkowej nakładu, a następnie na jego wzrost ${ }^{23}$ oraz zwiększenie zainteresowania ze strony reklamodawców i w konsekwencji na poprawę kondycji finansowej pisma. Dzięki temu udało się skomputeryzować pracę redakcyjną i usprawnić logistykę wydawnictwa.

Kilka miesięcy później, od stycznia 1996 r., zmieniła się też winieta pisma: tytuł, dotąd drukowany kursywą, zastąpiono prostą czcionką.

Zmiany te, o charakterze technicznym, dotyczyły formy tygodnika, natomiast jego merytoryczna treść pozostawała w zasadzie bez zmian. Nadal żywo interesowano się polityką, gospodarką i kulturą w Polsce i na świece. Jak wykazała przeprowadzona przez redakcję w 1996 r. ankieta, zmieniła się jednak opinia czytelników dotycząca kierunku politycznego, reprezentowanego przez pismo. Okazało się, że aż 41,4\% odbiorców określało „Politykę" jako centrolewicową, 22,6\% jako centrową, tylko 5,6\% - lewicową, 3,6\% jako centroprawicową i $0,4 \%$ jako prawicową. Około $17 \%$ pytanych nie potrafiło zdefiniować w sposób zdecydowany profilu politycznego pisma $^{24}$.

Z okazji 40-lecia jego istnienia (w 1997 r.) prezydent Aleksander Kwaśniewski wręczył dziennikarzom „Polityki” odznaczenia państwowe ${ }^{25}$.

220 ile w roku 1989 jej nakład wynosił 426 tys. egz., o tyle na początku lat 90. liczba czytelników spadła do 130 tys. Zob. T. Mielczarek, Od Nowej Kultury..., s. 343.

${ }^{23}$ Już w 1995 r. sprzedaż wzrosła do 157 tys. egz., a sześć lat później do 250 tys. Cyt. za: T. Mielczarek, Monopol pluralizm koncentracja. Środki komunikowania masowego w Polsce w latach 1989-2006, Wydawnictwa Akademickie i Profesjonalne, Warszawa 2007, s. 151.

24 A. Głombiowska, Przemiany tygodnika..., s. 30.

25 Otrzymali je m.in. Mieczysław F. Rakowski (Krzyż Wielki Orderu Odrodzenia Polski), Jan Bijak, Zygmunt Kałużyński i Marian Turski (Krzyż Komandorski z Gwiazdą Orderu Odrodzenia Polski), Piotr Adamczewski i Ewa Nowakowska-Butrym (Krzyż Kawalerski Odrodzenia Polski). 
Redakcja ze swej strony wprowadziła nagrodę Kamienia Milowego, przyznawaną tym, którzy w opinii tygodnika wpłynęli znacząco na bieg zdarzeń w Polsce, Europie i na świecie 26.

W tym samym roku „Polityka” zaistniała w Internecie. Odtąd można ją było czytać na stronie http: //www.polityka.pol.pl ${ }^{27}$.

Pismo ugruntowało swą pozycję na rynku, a dowodem na jego finansowy sukces była m.in. inwestycja w Inforadio (dziś Radio Tok FM), dzięki której Spółdzielnia została udziałowcem w tej stacji28.

Koniec lat 90. XX w., mimo zmian personalnych, był zatem czasem korzystnym dla tytułu. Na miejsce odchodzących dziennikarzy (m.in. P. Adamczewskiego, St. Podemskiego, M. Turskiego) pojawili się Mariusz Czubaj, Tadeusz Olszański, Jerzy Pilch, Adam Szostkiewicz, Maja Wolny, Janusz Wróblewski, Krzysztof Zanussi i Jacek Żakowski29.

Pod koniec 1999 i na początku 2000 r. tygodnik osiągnął rekordową sprzedaż w wysokości 280 tys. egz., a w porównaniu z okresem wcześniejszym liczba czytelników pisma zwiększyła się o $1 / 4^{30}$. Korzystna pozycja „Polityki” na rynku umożliwiła wydawcy przejęcie w marcu 2000 r. miesięcznika społeczno-kulturalnego „Res Publica Nowa”31, a w roku następnym, od 1 kwietnia 2001 r. kolejnego periodyku, tygodnika „Forum”32. W tym czasie redakcja przeprowadziła się do swej kolejnej siedziby, na ulicę Słupecką nr 6, gdzie mieści się do dziś. 0 wszystkich tych posunięciach skrupulatnie informowano czytelników ${ }^{33}$. wiecki.

26 Pierwszymi laureatami zostali Jacques Delors, Michaił Gorbaczow i Tadeusz Mazo-

27 Adres internetowy „Polityki” kilkakrotnie ulegał zmianie; i tak np. w 2005 r. po rozstaniu z portalem Onet.pl, utworzono własną witrynę, budowaną od podstaw przez pracowników pisma z działu Internet Tygodnika „Polityka”. Więcej zob. np.: http: www. internetstandard.pl/news/102175/TygodnikPolityka.mainternetowe.ambicje.html.

28 W 2005 r. Spółdzielnia posiadała 33,95\% udziałów (pozostałą częścią dysponowała Agora SA). Zob. P. Sierpiński, „Polityka” Spółdzielnia Pracy, „Press” 2006, nr 8, Dodatek specjalny: Ranking wydawców.

${ }^{29}$ Więcej o zmianach personalnych zob. W. Władyka, Polityka..., s. 156-159.

30 „Polityka” 2000, nr 7, s. 12.

31 „Res Publica Nowa” - pismo założone w 1979 r. przez Marcina Króla, ukazujące się poza cenzurą; wówczas wydawane pt. „Res Publica”. Był to tytuł opozycyjny wobec PRL, adresowany do ówczesnej elity intelektualnej. Do 2000 r. pismo wydawane było dzięki dotacji Ministerstwa Kultury i Fundacji im. Stefana Batorego, a także wydawnictwa Harlequin. Od stycznia 2000 r. periodykowi groziło zamknięcie.

32 „Forum” - periodyk wydawany od 1965 r., publikujący najciekawsze artykuły z prasy światowej. Więcej na temat tej inwestycji - zob. A. Krzemiński, Polityka wydawca "Forum”, „Polityka” 2001, nr 14, s. 33.

33 Np. przejęcie tygodnika Forum: zob. ibidem; zmiana siedziby, zob. np. K. Lubelska, Polityka we własnym domu, „Polityka” 2001, nr 51/52, s. 164-165; J. Pilch, Słupecka 6, ibidem, nr 50, s. 93. 
Jednocześnie J. Baczyński otrzymał Nagrodę im. Dariusza Fikusa w kategorii „twórcy mediów”, za „przekształcenie >Polityki< w nowoczesny tygodnik polityczno-społeczny i bezpieczne przeprowadzenie spółdzielni dziennikarzy >Polityki< przez rafy gospodarki rynkowej"34. Świętowanie tej nagrody zbiegło się $\mathrm{z}$ jubileuszem 45-lecia pisma. Odeszło ono $\mathrm{w}$ tym przypadku od tradycyjnych $\mathrm{w}$ takich sytuacjach deklaracji i wspomnień, prezentując w zamian pracę redakcji „od kuchni”. Pojawiły się zdjęcia dziennikarzy tworzących pismo, podczas pracy nad jego zawartością, opatrzone krótkimi komentarzami ${ }^{35}$.

W sierpniu 2002 r. ponownie zmodyfikowano szatę graficzną tygodnika. Obok dotychczasowych rubryk i działów (niektórych w ulepszonej formie) pojawiły się te zarzucone $\mathrm{w}$ latach ubiegłych, dodano też kilka nowych, wprowadzono ciekawe wyróżniki graficzne i ulepszono czcionkę. Dzięki temu zawartość pisma stała się czytelniejsza i bardziej kolorowa. Jednocześnie redakcja obiecywała, że nadal będzie ono periodykiem „do czytania, a nie tylko do przeglądania, gazetą autorów, gdzie wciąż najważniejsze jest to, co mamy do powiedzenia (oczywiście w możliwie najatrakcyjniejszej formie)"36.

W 2003 roku „Polityka” było najczęściej cytowanym tygodnikiem ${ }^{37}$, rok później zajmowała I miejsce pod względem sprzedaży wśród polskich tytułów społeczno-politycznych ${ }^{38}$. W listopadzie 2004 r. średnia sprzedaż pisma wynosiła ok. 203 tys. egz. ${ }^{39}$ Jakkolwiek liczba ta zmniejszyła się w latach następnych, to i tak „Polityce” udało się utrzymać pozycję lidera ${ }^{40}$.

W 2005 roku świętowano 10-lecie kolorowej edycji pisma. Zorganizowano wtedy Dzień otwarty, zapraszając czytelników na cykl spotkań z dziennikarzami pisma i proponując zwiedzanie siedziby redakcji.

Rok później (2006) „Polityka” stała się dostępna także w postaci e-wydania, będącego wierną, elektroniczną kopią wydania tradycyjnego, dostępną jednak w tej formie dzień wcześniej (we wtorek wieczorem) niż wydanie tradycyjne, trafiające do kiosków w środę. W 2007 r. przypadał jubileusz 50-lecia istnienia pisma. $\mathrm{Z}$ tej okazji, w numerze 10 zamieszczono raport, w którym znalazło się krótkie podsumowanie półwiecznej historii

34 W. Pawłowski, Nagroda im. Fikusa dla Jerzego Baczyńskiego „Polityka” 2002, nr 9, s. 13.

35 J. Baczyński, 45 lat. Tygodnik Polityka, „Polityka” 2002, nr 9, s. 99-[105].

36 „Polityka” 2002, nr 32, s. 11.

37 „Polityka” 2003, nr 42, s. 18.

38 „Polityka” 2004, nr 29, s. 18.

39 „Polityka” 2005, nr 6, s. 18.

40 W I kwartale 2006 r. liczba sprzedanych egzemplarzy wynosiła ok. 170 tys. („Newsweek Polska” - ok. 143 tys. egz.), zaś na początku 2007 r. ok. 160 tys. (analogicznie „Newsweek Polska” - ok. 145 tys.), w 2008 r. ok. 150 tys. sprzedanych egz. („Newsweek Polska” - ok. 122). Zob. „Polityka” 2006, nr 24, s. 109; ibidem, 2007, nr 7, s. 92. 
tytułu, a na następnych stronach wydrukowano opinie dziennikarzy, polityków i samych czytelników pisma na jego temat. Redakcja przygotowała Jubileuszowq Kolekcję Polityki, na którą składać się miały bezpłatne, cotygodniowe dodatki do tygodnika pod wspólnym tytułem: Cywilizacja. W tym też roku wydana została książka jednego z wieloletnich współpracowników periodyku, W. Władyki: Polityka i jej ludzie ${ }^{41}$.

„Polityka” przez 50 lat zmieniała się nieustannie i to pod każdym względem. Wystarczy wziąć do ręki jakikolwiek numer sprzed lat, nawet 10, żeby te różnice zobaczyć. Wszystko jest już inne, a w jakimś sensie jednak takie samo ${ }^{42}$.

\subsubsection{Zawartość, akcje i czytelnicy}

Zawartość pisma jest od lat podobna i zawiera się w trzech blokach tematycznych: polityka, gospodarka i kultura w Polsce i na świecie. Od chwili, gdy w tygodniku przyjęto formułę magazynową, stał się on bardziej atrakcyjny wizualnie, zmieniono również formę publicystyki i rodzaj oferty dziennikarskiej. Obok tradycyjnych, charakterystycznych dla prasy opinii tematów, znalazły się nowe, na przykład technika, sport czy zdrowie.

$\mathrm{W}$ badanym okresie newsy, komentarze, analizy, w formie krótkich informacji, artykułów, komentarzy i reportaży pojawiały się następujących działach ${ }^{43}$ : Gospodarka, Historia, Kraj, Kultura, Ludzie i Wydarzenia, Na własne oczy, Nauka, Raport Polityki, Społeczeństwo, Świat i rubrykach: Afisz, Fusy, plusy i minusy, Kadry, Komentarze: Do i od redakcji, Ksiq̨żki, Listy, Ludzie i wydarzenia, Ogląd i pogląd, Polityka i obyczaje, Rynek, Tematy tygodnia, Tydzień na świecie, Tydzień w kraju, Za stołem. W ramach stałych elementów pisma drukowano też felietony Ryszarda Grońskiego, Zygmunta Kałużyńskiego, Jerzego Pilcha, Ludwika Stommy i Krzysztofa Zanussiego.

Na popularność periodyku wpływ miały bez wątpienia organizowane przezeń liczne cykliczne konkursy i akcje ${ }^{44}$.

Jedną z najstarszych inicjatyw są ustanowione w 1959 r. Nagrody Historyczne, przyznawane do dziś, za wybitne publikacje z zakresu historii. Kolejnym pomysłem są wspomniane wcześniej Paszporty Polityki i związane z nimi Letnie Ogrody Polityki (organizowane wspólnie z Biblioteką

41 W. Władyka, Polityka...

42 W. Władyka, Historia Polityki dla dorosłych, „Polityka” 2007, nr 9, s. 8.

43 Jak już wspomniano we Wstępie, nazwy działów i rubryk podano w porządku alfabetycznym, nie zaś w kolejności, w jakiej występowały one w tygodniku. Uwaga ta dotyczy także kolejnych analogicznych sytuacji.

${ }^{44} \mathrm{~W}$ pracy przedstawiono tylko kilka (spośród wielu) przykładów, jedynie dla zilustrowania ożywionej działalności kulturalno-wydawniczej pisma. Konkursy literackie zostaną omówione w kolejnych podrozdziałach. 
w Elblągu). Jest to kilkudniowy festiwal artystów - laureatów nagrodzonych w kolejnych edycjach Paszportów.

Innym przedsięwzięciem, któremu „Polityka” patronowała, tym razem wespół z Fundacją ABCXXI, była akcja: Cała Polska czyta dzieciom. W jej ramach tygodnik wydał kolekcję książek dla rodziców i dzieci. Będzie to przedmiotem rozważań $w$ dalszej części pracy.

Warto wspomnieć także o Salonach Polityki. Były to organizowane przez redakcję, prowadzone przez jej dziennikarzy, a następnie omawiane na łamach pisma spotkania czytelników ze znanymi naukowcami, artystami i politykami. Spotkania odbywały się w różnych miastach Polski, na przykład w Krakowie (pierwszy Salon w Klubie pod Jaszczurami zorganizowano w 2001 r.), Elblągu, Lublinie, Łodzi, Pile, Poznaniu i Warszawie. Podobny charakter miał Międzynarodowy Klub czy Kawiarnia Naukowa Polityki.

Ciekawym pomysłem była akcja (pierwsza edycja odbyła się także w 2001 r.) adresowana do młodych naukowców: „Zostańcie z nami”, w ramach której najlepsi z nich otrzymywali stypendia ${ }^{45}$. Kolejnym przedsięwzięciem były organizowane wspólnie ze Związkiem Nauczycielstwa Polskiego Lekcje z Politykq ${ }^{46}$.

$\mathrm{Na} ł a m a c h$ pisma inicjowano również akcje okazjonalne, na przykład przed Świętami Bożego Narodzenia: „Pomyśl o biedniejszych od siebie”. Redakcja zwracała się do firm i osób prywatnych o przekazywanie pieniędzy, dzięki którym udawało się zapełnić prezentami worek Świętego Mikołaja i podarować je najbardziej potrzebującym.

Ponadto w „Polityce” patronowano ważnym wydarzeniom kulturalnym: wystawom, koncertom, filmom i nowo wydanym książkom. Autorami niektórych z nich byli dziennikarze pisma ${ }^{47}$. Współpracowano z licznymi wydawnictwami, zaś Spółdzielnia Pracy publikowała utwory, nagrodzone Paszportem Polityki.

W tygodniku ustanowiono również nagrody i wyróżnienia dziennikarskie. Od 2002 r. wspólnie z „Tygodnikiem Powszechnym” przyznawano nagrodę im. Beaty Pawlak za publikacje dotyczące spotkań różnych kultur, cywilizacji i religii. W 2004 r. po raz pierwszy wręczona została nagroda im. Barbary Łopieńskiej za najlepszy wywiad prasowy. Tę nagrodę ufundowały

$45 \mathrm{~W}$ ramach akcji wybranym, najzdolniejszym młodym naukowcom przyznawane było jednorazowe stypendium w wysokości 25 tys. zł.

$46 \mathrm{Na}$ łamach tygodnika zamieszczano teksty, opatrzone umownym znakiem: Lekcje z Politykq, które mogły posłużyć nauczycielom jako materiał inicjujący uczniów do dyskusji na temat interesujących zjawisk, związanych z życiem obywatelskim i publicznym w Polsce.

47 Np. A. Garlicki, Historia 1815-2004. Polska i świat. Podręcznik dla III klas liceów ogólnokształcacych, Scholar, Warszawa 1998; E. Bendyk, Zatruta studnia: rzecz o władzy i wolności, Wydawnictwo W.A.B., Warszawa 2002; P. Adamczewski, Rok na stole, Wydawnictwo Nowy Świat, Warszawa 2006. 
redakcje pism, z którymi autorka była związana („Gazeta Wyborcza”, „Polityka”, „Press”, „Res Publika Nowa”, „Viva!”).

Na łamach pisma przygotowywano także systematyczne, coroczne rankingi, na przykład Ranking 500 największych polskich firm, Ranking szkół wyższych i cykliczne wkładki do wydania głównego, na przykład wspomniany wyżej Niezbędnik inteligenta czy Pomocnik historyczny.

Dzięki staraniom redakcji „Polityka” stała się tytułem kilku pokoleń, czytanym zarówno przez młodszych, jak i starszych odbiorców. Badania wykazały, że ponad 55\% czytelników tygodnika to mężczyźni, a zarazem spośród wszystkich odbiorców ponad $60 \%$ stanowią osoby z wyższym wykształceniem. Około $24 \%$ to odbiorcy powyżej 54 lat, nieco mniej $(22 \%)$ to czytelnicy w wieku 25-34 lata. Osoby pomiędzy 15. a 24. rokiem życia to grupa 22\%, podobnie jak czytelnicy w wieku 25-34 lat. Czytający „Politykę” w 52\% są mieszkańcami dużych (powyżej 100 tys. mieszkańców) miast ${ }^{48}$.

Potwierdzeniem popularności tygodnika są liczne nagrody dla pisma i jego współpracowników. W grupie wyróżnionych pojawili się m.in. Jerzy Baczyński, Edwin Bendyk, Adam Krzemiński, Krzysztof Mroziewicz, Janina Paradowska, Joanna Podgórska, Piotr Sarzyński, Paweł Walewski, Jagienka Wilczak, Ewa Wilk, Jerzy Wróblewski.

W 2000 r. w konkursie organizowanym w ramach Targów Media Trend nagrodzono Ikoną Medialną ' 99 jedną z okładek „Polityki”: „Stu najbiedniejszych Polaków”. W roku następnym zespół redakcyjny otrzymał Kryształowe Zwierciadło

za umiejętność dotarcia z elitarną autorską formułą pisma do bardzo szerokiego grona czytelników, a także za niepowtarzalny charakter pisma, skupiającego wielu wybitnych dziennikarzy [...] za mądre dialogi z ludźmi o różnych poglądach, za wrażliwość na problemy społeczne i odwagę w podejmowaniu trudnych tematów ${ }^{49}$.

W 2003 r. tygodnikowi przyznano nagrodę i tytuł Mecenasa Kultury w kategorii „Promotor” za zorganizowanie Festiwalu Kulturalnego, a w 2004 r. pismo otrzymało Główną Nagrodę w konkursie im. Mieczysława Orłowicza na najlepsze materiały prasowe, radiowe i telewizyjne, promujące polską turystykę krajową ${ }^{50}$. W roku 2005 docenione zostało Biuro Reklamy „Polityki”, uzyskując najwyższą ocenę w trzeciej edycji badania, dotyczącego poziomu satysfakcji klientów, a realizowanego przez SMG/KRC.

48 Polityka. Tygodnik trzech pokoleń, Folder wewnątrzredakcyjny, s. 15. Źródło: PBC General - SMG/KRC (2006 r., CCS).

49 [br. aut.], Kryształowe zwierciadło dla zespołu „Polityki”, „Polityka” 2001, nr 22, s. 92.

50 Więcej na temat nagród przyznawanych pismu i jego dziennikarzom: zob. W. Władyka, Polityka..., s. 182-188. 
Dziś „Polityka” jest pismem opinii o ugruntowanej pozycji na rynku prasowym w Polsce. Współtworzy ją zespół dziennikarzy o znanych nazwiskach, a jej swoisty fenomen zdaje się polegać m.in. na umiejętności dostosowania się do zmieniających się wymogów rynku, a także do coraz bardziej wyszukanych potrzeb i wymagań czytelników i to pomimo zarzutów dotyczących najpierw przeszłości, a później prolewicowych sympatii pisma. Redakcję, podobnie jak w latach ubiegłych, tworzą poczytni dziennikarze, publicyści i felietoniści.

„Polityka” wciąż, choć w zupełnie innych warunkach, mierzy się ze swoim czasem. Stara się sprostać konkurencji, zmieniającym się preferencjom odbiorców i konieczności opisywania rzeczywistości w sposób tyle pogłębiony, co atrakcyjny51.

\subsubsection{Ciało jedno, a myśli tysiące ${ }^{52}$ : książka na łamach pisma}

Pomimo iż w tygodniku koncentrowano się w znacznej mierze na problematyce polityczno-gospodarczo-społecznej, to jednak niemal od początku dysponowano ciekawym działem kultury, w którym stosunkowo dużo miejsca poświęcano literaturze. Jak już wspomniano, w latach wcześniejszych ukazywał się nawet dodatek poświęcony książkom.

W badanym okresie dział Kultura otwierał Afisz, w którym znajdowały się krótkie rubryki, m.in.: na Ekranie, na Estradzie, na Płycie, na Scenie, a także Niskie loty, gdzie zamieszczano krytykę wybranego przez autora aktualnego wydarzenia kulturalnego. Na kolejnych stronach pojawiały się dłuższe informacje, prezentowane $\mathrm{w}$ różnej formie (recenzji, wywiadu, artykułu, komentarza) związane $\mathrm{z}$ teatrem, muzyką, filmem oraz literaturą. Dogłębna analiza zawartości pisma pozwoliła stwierdzić, że w latach 20012005 na jego łamach drukowano niezwykle bogate i zróżnicowane informacje o książce. W tabeli 2 zaprezentowano formy obecności literatury wraz $\mathrm{z}$ ich liczbą w omawianym okresie 53 .

Zdumiewające jest bogactwo i różnorodność informacji związanych z książką w piśmie, w którym z założenia koncentrowano się głównie na innych zagadnieniach. Obok zwyczajowych recenzji (których jest najwięcej), wywiadów z pisarzami, krytykami literatury i anonsów wydawniczych, zamieszczano również artykuły poświęcone literaturze, portrety pisarzy, wiersze, listy bestsellerów, konkursy oraz informacje dotyczące akcji związanych z książką.

51 R. Habielski, [w:], „Press” 2006, nr 8. Dodatek specjalny. Ranking wydawców.

52 Tytuł jednej z publikacji, zob. „Polityka” 2005, nr 25, s. 107.

53 Przyjęto porządek podawania poszczególnych kategorii według kolejności ich omawiania. 
Tabela 2. Formy obecności książki i informacji o niej na łamach „Polityki” w latach 2001-2005

\begin{tabular}{|l|c|}
\hline \multicolumn{1}{|c|}{ Rodzaj publikacji } & Liczba ogółem \\
\hline Recenzje & 792 \\
\hline Wywiady & 97 \\
\hline Reklamy książek & 696 \\
\hline Sylwetki/portrety & 113 \\
\hline $\begin{array}{l}\text { Artykuły, poświęcone sprawom książki lub rynku wydawniczo-księ- } \\
\text { garskiego }\end{array}$ & 296 \\
\hline Ekranizacje, adaptacje, inscenizacje znanych dzieł & 121 \\
\hline Konkursy i akcje & 49 \\
\hline Listy bestsellerów & 12 \\
\hline $\begin{array}{l}\text { Listy czytelników, nawiązujące do zamieszczonej informacji związanej } \\
\text { z książką }\end{array}$ & 58 \\
\hline Inne ${ }^{a}$ & 447 \\
\hline Ogółem & 2681 \\
\hline
\end{tabular}

${ }^{a} \mathrm{~W}$ tej kategorii uwzględniono wszelkiego rodzaju informacje, zazwyczaj $\mathrm{w}$ postaci krótkich notek, donoszących np. o nagrodach, otrzymanych przez ludzi związanych z książką, nadaniu imienia twórcy szkole, instytucji itd., ale także informujące o jubileuszach pisarzy.

Źródło: badania własne.

Ogółem, w ciągu badanych 5 lat w 256 numerach pojawiło się w sumie 2681 tego typu informacji. Ich objętość była rozmaita: poczynając od krótkich, jedno- lub kilkuzdaniowych wzmianek, poprzez dłuższe, około półstronicowe komentarze, a kończąc na wnikliwych analizach i ocenach, zajmujących niekiedy kilka stron. Prezentowano je nie tylko na stronach poświęconych kulturze. Odnaleźć je można było niemal w całym tygodniku, na przykład w działach: Dział kadr, Historia, Ludzie, Media, Na własne oczy, Opinie, Tydzień w kraju, Wspomnienie i rubrykach: Fusy plusy i minusy, Kadry nominacje denominacje, Komentarze: Do i od Redakcji, Listy.

\subsubsection{Tkanie słó $w^{54}$ : miejsce recenzji w układzie pisma}

W badanym okresie na łamach pisma pojawiły się 792 recenzje ${ }^{55}$. Zamieszczano je niemal w całym periodyku. Najwięcej, co oczywiste, znalazło się ich w dziale Kultura, ale odnaleźć je można również w innych miejscach pisma $^{56}$. W tabeli 3 przedstawiono ich liczbę wraz z lokalizacją $\mathrm{w}$ tygodniku.

54 Tytuł recenzji. Zob. „Polityka” 2002, nr 50, s. 57.

55 Ciekawą krytykę formy, jaką przybiera czasem współczesna recenzja, zamieścił J. Pilch w felietonie: Grucha nie kocha Gliny, „Polityka” 2003, nr 25, s. 100.

${ }^{56}$ Np. w dziale Nauka (przedstawiono tu książkę J. Hołówki, Etyka w działaniu, Wydawnictwo Prószyński i S-ka, Warszawa 2001. Recenzent: Ewa Nowakowska, Igła $w$ kompasie, „Polityka” 2001, nr 10, s. 76); Historia (omówiono w tym miejscu książkę Komunizm. Ideo- 
Tabela 3. Recenzje w dziale Kultura oraz w innych miejscach w „Polityce”

\begin{tabular}{|c|c|c|c|c|}
\hline Rok & Ogółem & $\begin{array}{c}\text { W rubryce specjalnej, } \\
\text { poświęconej książce }\end{array}$ & $\begin{array}{c}\text { W dziale Kultura, } \\
\text { poza rubryką } \\
\text { poświęconą książce } b\end{array}$ & $\begin{array}{c}\text { W innych } \\
\text { miejscach } \\
\text { w piśmie }\end{array}$ \\
\hline 2001 & 175 & 128 & 26 & 21 \\
\hline 2002 & 136 & 84 & 23 & 29 \\
\hline 2003 & 146 & 107 & 15 & 24 \\
\hline 2004 & 155 & 107 & 16 & 32 \\
\hline 2005 & 180 & 115 & 45 & 20 \\
\hline Ogółem & 792 & 541 & 125 & 126 \\
\hline
\end{tabular}

${ }^{a}$ To znaczy rubryce poświęconej wyłącznie na recenzje książek. W badanym okresie zmieniała ona kilkakrotnie nazwę oraz formę. Dokładniej zostanie omówiona w dalszej części rozdziału.

${ }^{b}$ Do działu tego, ze względu na charakter zamieszczanych informacji, zaliczono również poprzedzający go Afisz, ale bez mieszczącej się w jego ramach przez pewien czas rubryki związanej z recenzjami książek.

Źródło: badania własne.

Jak widać, największa liczba recenzji pojawiała się każdego roku w specjalnej rubryce poświęconej książce, w ramach działu Kultura. Przez cały badany okres kierował nim Zdzisław Pietrasik, zaś książkami zajmowali się kolejno: Maja Wolny (do 24 numeru w 2001 r.), Jerzy Wróblewski (od numeru 25 w 2001 r.) i Mariusz Czubaj (od nr 2003 r. do końca badanego okresu).

Rubryka, z założenia poświęcona recenzjom, w ciągu pięciu lat pięciokrotnie zmieniała swą nazwę i w niewielkim stopniu formę oraz miejsce w tygodniku, co (jak twierdzi Z. Pietrasik) podyktowane było względami graficznymi (pomysł redaktora graficznego), nie zaś merytorycznymi ${ }^{57}$. W 2001 r. od numeru 1 do 33 włącznie były to Wieczne pióra. Znajdowały się tu przeważnie trzy recenzje, na które składała się krótka adnotacja treściowa, kopia okładki omawianej książki, dane bibliograficzne zamieszczane zazwyczaj nad recenzją (autor, ewentualnie tłumacz, tytuł, miejsce wydania, nazwa wydawcy, rok wydania, liczba stron) i ocena prezentowanej książki. Funkcję ocen spełniały symbole wiecznych lub gęsich piór: trzy wieczne oznaczały lekturę obowiązkową, dwa określały ją jako tę, którą „warto mieć w biblioteczce”, jedno: „nie zaszkodzi przeczytać”. Lektura adresowana "tylko dla znawców" oznaczona była jednym gęsim piórem,

logia, system, ludzie, red. T. Szarota, Wydawnictwo Neriton, Instytut Historii PAN, [b.m.w.] 2001. Recenzent: A. Garlicki, Polacy, Żydzi, komunizm, „Polityka” 2001, nr 12, s. 70) czy Edukacja (recenzji poddano książkę J. McDowelle`a, Mity edukacji seksualnej [brak danych bibliograficznych]. Recenzent: Julia Butrym, Pupa czy dusza, „Polityka” 2001, nr 13, 93).

57 Informacje uzyskane dzięki korespondencji ze Zdzisławem Pietrasikiem. 
natomiast jedno wieczne pióro z kleksem, oznaczało „czytadło” i wreszcie „złamane pióro” sugerowało książkę, której w odczuciu recenzenta nie warto poświęcać czasu.

Recenzje znajdowały się przeważnie na jednej z ostatnich stron działu. Graficznie prezentowano je w postaci szerokiej kolumny $\mathrm{z}$ tekstem na jasnym tle. W takiej formie zrecenzowano 95 książek.

Od numeru 34 w 2001 r. rubryka zmieniła nazwę na Kultura/ksiq̨żki. W tym czasie ukazało się tu 76 recenzji. Zmieniła się też nieco ich forma.

0 ile w poprzednim przypadku zazwyczaj drukowano trzy recenzje, o tyle teraz częściej pojawiały się dwie, ale za to poświęcano im całą stronę. Zdarzało się też, że $\mathrm{w}$ jednej z nich prezentowano dwa lub trzy tytuły, nie zawsze jednego autora, choć przeważnie wydane przez tę samą oficynę; mogły to być książki zbliżone do siebie tematem ${ }^{58}$. Do elementów formalnych, podobnych jak w poprzednim przypadku, dodano zdjęcie autora prezentowanej książki, zaś pod jedną z recenzji (zazwyczaj pierwszą), tuż pod informacjami bibliograficznymi, pojawiał się odsyłacz do Czytelni On Line na stronie „Polityki” w Internecie ${ }^{59}$. Wtedy też po raz pierwszy wydrukowano listę bestsellerów ${ }^{60}$, którą zamieszczano zazwyczaj przy jednej z recenzji. Składało się na nią 15 tytułów podzielonych na trzy grupy. Przeważnie były to: 1. Literatura polska, 2. Literatura zagraniczna, 3. Literatura popularnonaukowa, encyklopedie. Każda z nich obejmowała pięć pozycji, w których znajdowało się nazwisko i imię autora, tytuł książki i nazwa wydawcy. U dołu podawano źródło, z którego korzystano, a były nim przeważnie dane z hurtowni Azymut albo lista sprzedaży merlin.pl, sieci Empik i sieci księgarni Matras ${ }^{61}$. Ta forma informacji o książce pojawiła się na łamach pisma w ciągu lat 2001-2002 zaledwie 12 razy $^{62}$. Zaniechano jej, bo, jak twierdzi Z. Pietrasik,

58 Zob. np. J. Jarniewicz, Proza jeźdźców i szeryfów, „Polityka” 2001, nr 42, s. 58.

59 www.polityka.onet.pl. Czytelnia On Line.

${ }^{60}$ Bestsellery lata, „Polityka” 2001, nr 34, s. 49.

61 Zob. np. „Polityka” 2001, nr 34, s. 49.

62 Bestsellery lata („Polityka” 2001, nr 34, s. 49), Bestsellery września (ibidem, nr 41, s. 56), Bestsellery jesieni ( ibidem, nr 46, s. 52), Bestsellery grudnia (ibidem, 2002, nr 2, s. 53), Bestsellery stycznia (ibidem, nr 9, s. 53), Bestsellery lutego (ibidem, nr 11, s. 50), Bestsellery marca (ibidem , nr 17, s. 60), Bestsellery maja (ibidem, nr 24, s. 54), 35, Bestsellery grudnia (ibidem, nr 2, s. 53), Bestsellery 2004 (ibidem, nr 52/53, s. [80]), Bestsellery (ibidem, 2005, nr 51/52, s. 70). Raz w nr 43 (2001) pojawiły się Bestsellery nowego sezonu, zaprezentowane w innej, bardziej rozbudowanej formie. Każdy tytuł został opatrzony adnotacją treściową, kopią okładki przedstawionej książki wraz z jej danymi bibliograficznymi. Ze względu na formę i brak danych źródłowych, które pojawiały się przy podobnych okazjach, można sądzić, że nie była to typowa rubryka, o której wspomniano powyżej, a raczej jednorazowa informacja o zbieżnym tytule (ibidem, 2001, nr 43, s. 52). 
$\mathrm{Z}$ bestsellerami w Polsce problem jest taki, że nikt dokładnie nie wie, co nim jest. Często tak nazywa się książki najpopularniejsze. Po prostu trudno znaleźć właściwą metodologię, gdyż rynek książki jest u nas potwornie rozproszony63.

Obydwie propozycje związane $\mathrm{z}$ omawianiem książek zaprezentowano na zdjęciu 1-2.

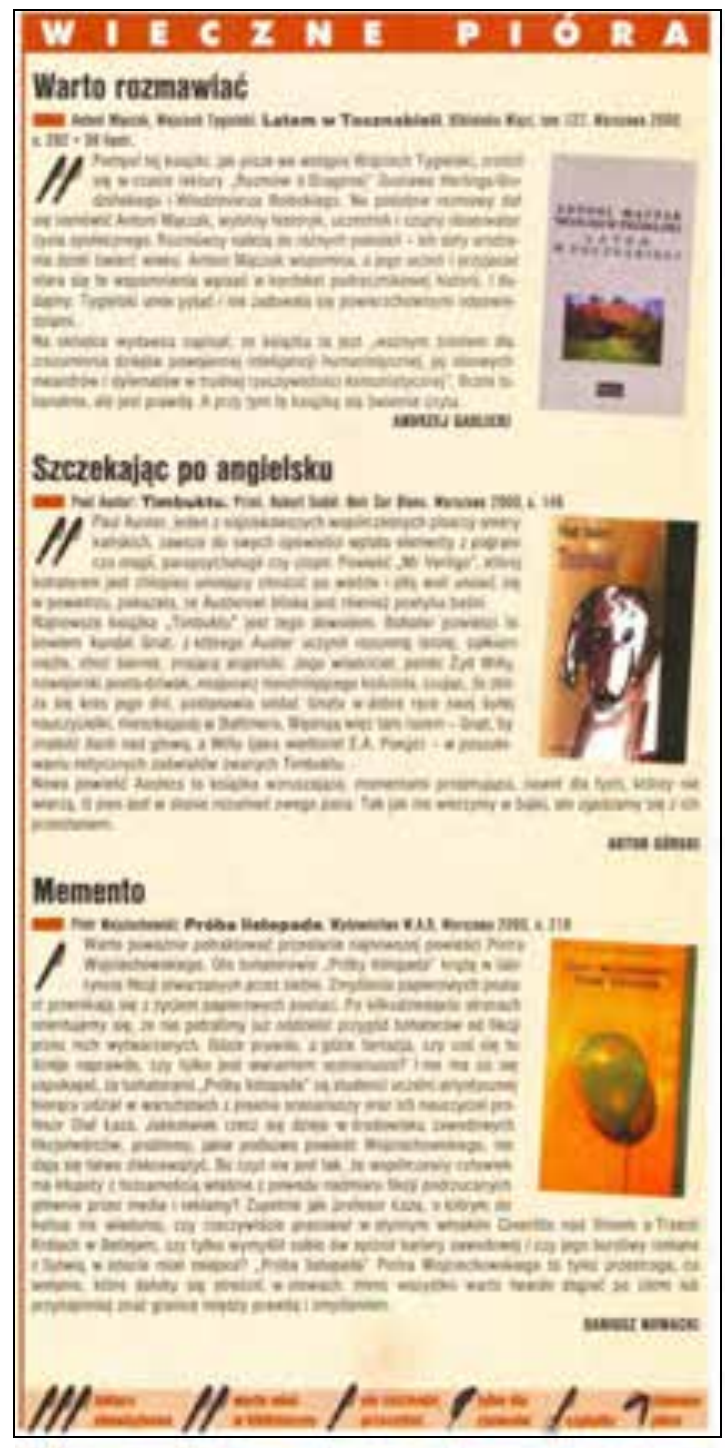

murne "Zdjęcie 1. Rubryka Wieczne Pióra

57 „Polityka” 2001, nr 1, s. 57

${ }^{63}$ Informacje uzyskane dzięki korespondencji ze Zdzisławem Pietrasikiem. 


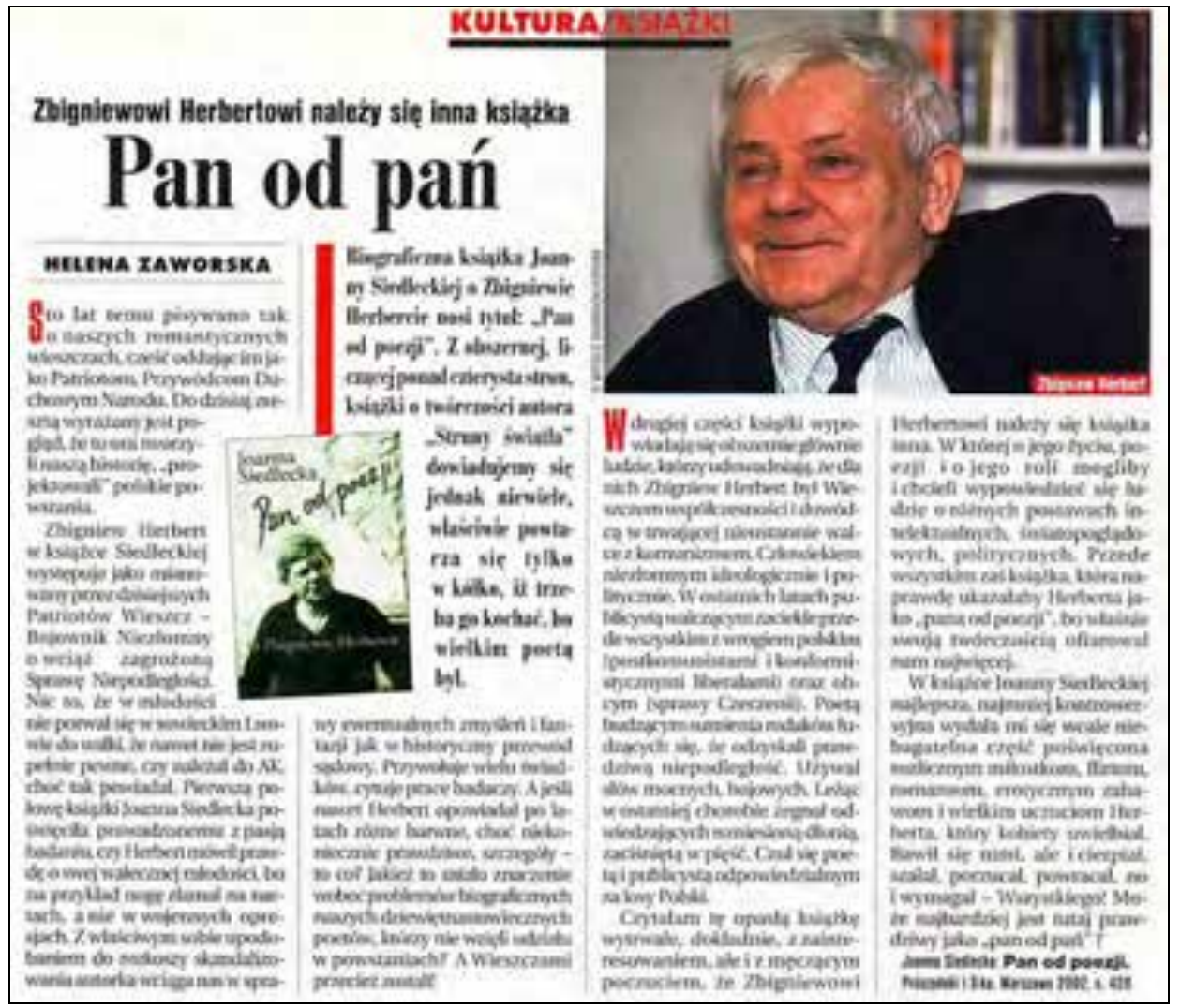

Zdjęcie 2. Rubryka Kultura/książki

„Polityka” 2002, nr 31, s. 54

Jak już wspomniano wcześniej, w sierpniu 2002 r., od numeru 33 zmieniła się formuła całego tygodnika, a wraz z nią i postać rubryki poświęconej recenzjom książek. Od tej chwili nosiła ona nazwę Afisz [książki], przeniesiono ją też na początek całego działu, związanego z kulturą, anonsowanego w postaci Afisza. W tej postaci zrecenzowano zaledwie siedem książek, ponieważ zachowała ona swą nazwę tylko przez trzy kolejne numery. Już od numeru 36 tego roku (2002) ponownie zmodyfikowano jej tytuł, tym razem skracając go, pozostawiając same Książki (omówiono wtedy 171 tytułów). Obydwie zmiany prezentują zdjęcia 3 i 4. 


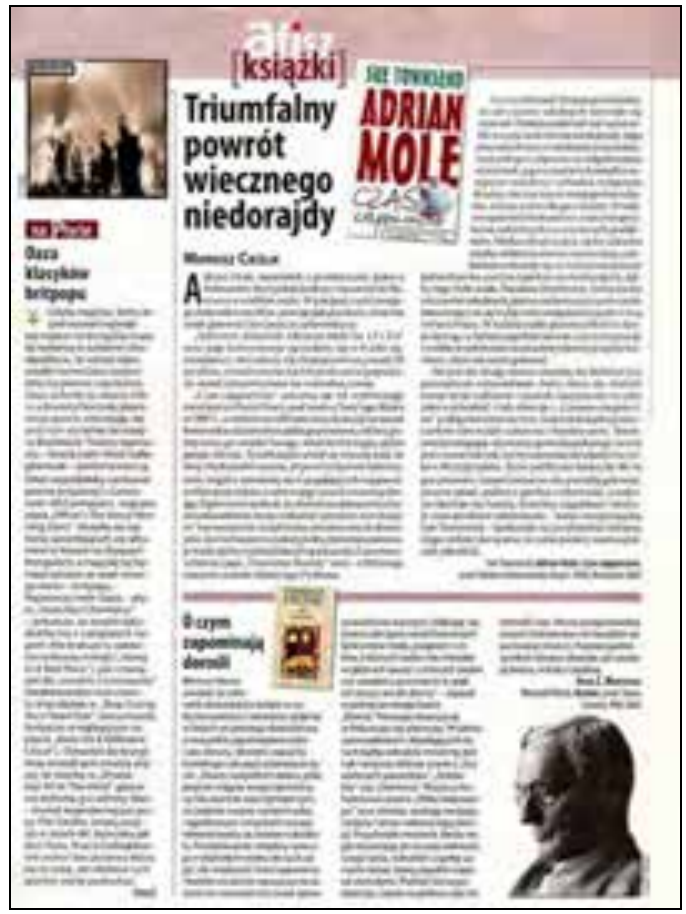

Zdjęcie 3. Strona recenzyjna na łamach „Polityki”

„Polityka” 2002, nr 33, s. 53

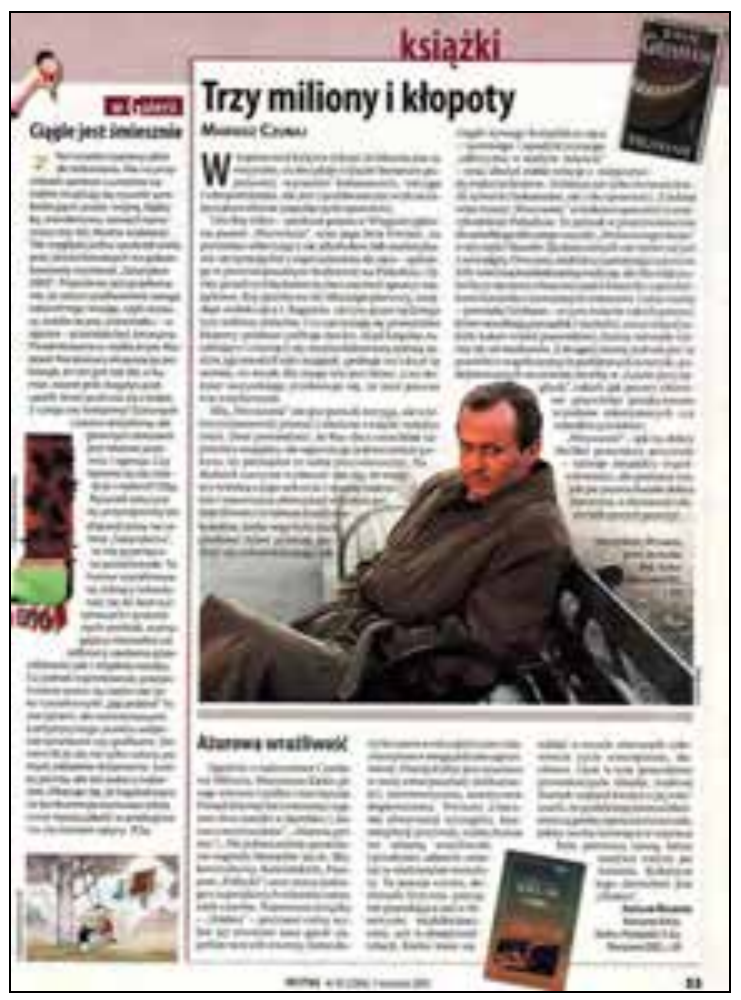

Zdjęcie 4. Strona recenzyjna na łamach "Polityki”

„Polityka” 2002, nr 36, s. 53 
Obydwa przytoczone przykłady różnią się między sobą tylko nieznacznie. W ramach nowej formuły omawianej strony pojawiały się najczęściej dwie recenzje, na które $\mathrm{w}$ dalszym ciągu składała się krótka adnotacja treściowa dotycząca prezentowanej książki, kopia jej okładki, dane bibliograficzne (umieszczane już tradycyjnie u dołu recenzji), czasem zdjęcie jej autora. Podobnie jak było wcześniej, nieraz w ramach jednej recenzji prezentowano dwa lub trzy tytuły, ale zdarzało się to stosunkowo rzadko. Nowością było pojawiające się niekiedy zaproszenie na spotkanie internetowe $\mathrm{z}$ autorem przedstawianej książki ${ }^{4}$. Zachowano również miejsce, w którym zamieszczano recenzje: była to druga strona Afisza, ale już nie cała, bowiem obok pojawiała się kolumna poświęcona innym wydarzeniom kulturalnym.

Ostatnia zmiana w badanym okresie dotycząca rubryki strony specjalnie poświęconej recenzji miała miejsce od numeru 17 (2004). W dalszym ciągu pojawiała się ona w ramach Afisza, ale nosiła już tytuł: $W$ księgarni. W tej postaci zrecenzowano 184 książki.

W tym czasie rubrykę zredukowano do niewielkich w porównaniu z poprzednim okresem rozmiarów, tworząc z niej w zasadzie jeden z elementów Afisza, graficznie zbliżony do innych, wcześniej wspomnianych (na przykład $W$ Galerii). Z reguły zamieszczano w niej dwie recenzje, rzadziej wykorzystując jedną $\mathrm{z}$ nich do przedstawienia dwóch książek ${ }^{65}$. Pomimo zmniejszonej objętości postać recenzji pozostawała bez zmian, aczkolwiek obok adnotacji treściowej nie pojawiało się już, podobnie jak w ostatnim okresie, zdjęcie autora prezentowanej książki. W porównaniu z poprzednimi latami, jej opis bibliograficzny często bywał niepełny (pomijano zazwyczaj miejsce lub rok wydania).

Pojawił się jednak, zarzucony wcześniej element oceny, choć dotyczył on już wszystkich informacji kulturalnych, recenzowanych w ramach Afisza. Nie zawsze też stosowano go w odniesieniu do książek. Odtąd przyjął on postać symbolicznych znaków, z których 3 plusy oznaczały, że recenzowane wydarzenie (film, płyta, sztuka, książka) jest „świetne”, 2: „dobre”, 1: „średnie”, zaś minus określał je jako „złe”. Już w numerze 22 (2005) skala ocen została zwiększona do 6, oceny zaś zmieniono na symbole strzałek: 6 oznaczało, że przedmiot recenzji jest „wybitny!”, 5: „bardzo dobry”, 4: „dobry”, 3: „średni”, 2: „słaby”, 1: „dno!”. Od numeru 33 (2004) pojawił się nad recenzją odsyłacz: „Fragmenty książek na stronie: www.polityka.pl//czytelnia”66. Przykładową stronę recenzyjną z tego okresu przedstawia zdjęcie 5.

64 Zob. np. A. Kosowska, Redaktor Niwiński na tropie. Recenzowana książka: T. Piątek, Kilka nocy poza domem, Czarne, Wołowiec 2002, s. 219. Pod opisem bibliograficznym znalazło się wspomniane zaproszenie.

65 Np. „Polityka” 2004, nr 38, s. 60.

66 „Polityka” 2005, nr 29, s. 52. 


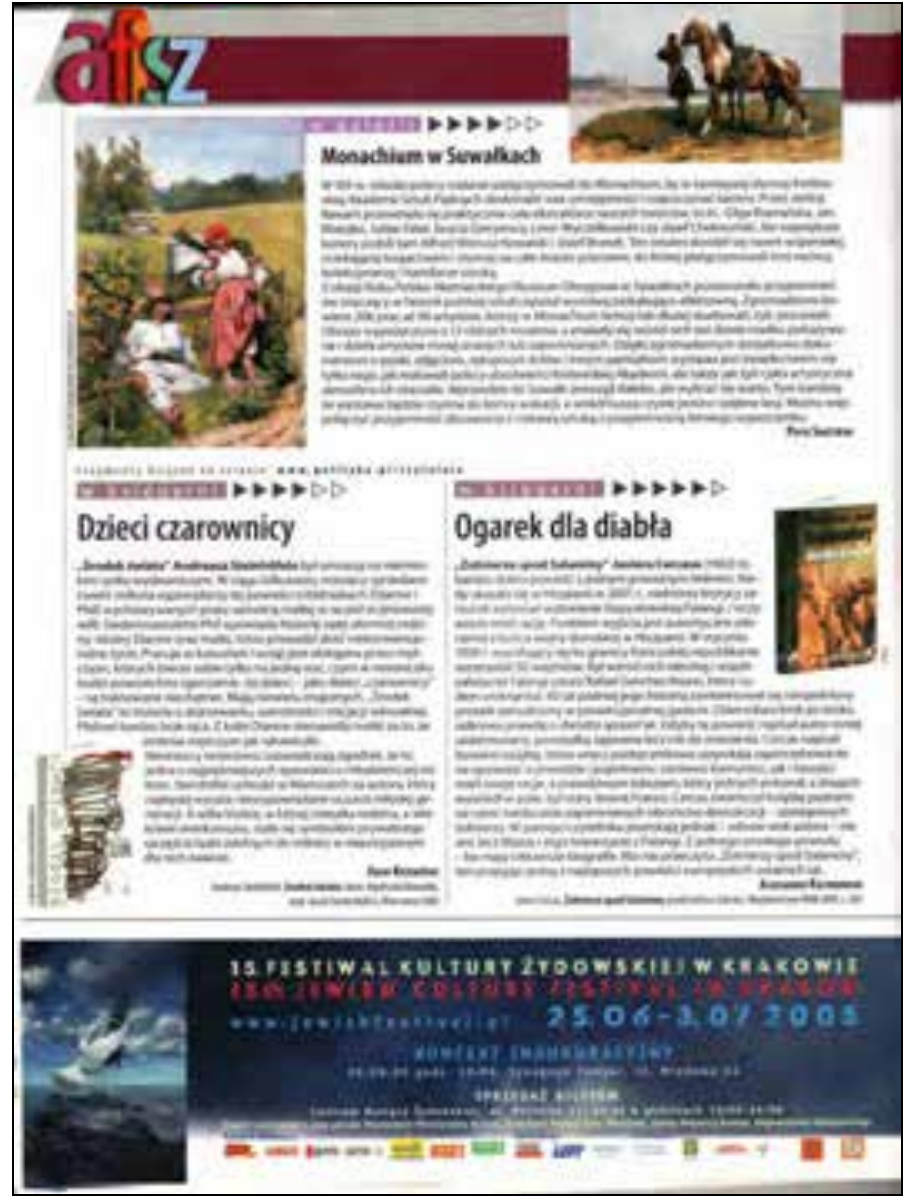

Zdjęcie 5. Strona recenzyjna na łamach „Polityki” „Polityka” 2005, nr 25, s. [68]

Objętościowe zmniejszenie omówień starano się zrekompensować w inny sposób. Obok standardowych prezentacji książek w ramach rubryki $W$ księgarni pojawił się kilkakrotnie dodatkowy element, za każdym razem inaczej tytułowany. Cechą charakterystyczną był tu temat, który łączył książki (zazwyczaj trzy tytuły), wybrane przez jednego lub dwóch recenzentów. I tak był to: Afisz: Czytadła na plażę ${ }^{67}$, Afisz: Czytadła podróżne ${ }^{68}$,

67 „Polityka” 2005, nr 29, s. 52 (3 książki, 1 recenzent, Mariusz Czubaj).

68 „Polityka” 2005, nr 30, s. 54; ibidem, nr 31, s. 54 (ta rubryka pojawiła się dwukrotnie w kolejno następujących po sobie numerach. W każdym znalazły się trzy tytuły książek, w pierwszym przypadku przedstawione przez jednego recenzenta: Aleksandra Kaczorowskiego, w drugim - przez dwoje: Katarzynę Janowską i Mariusza Czubaja). 
Książka na łamach wybranych czasopism w Polsce u progu XXI wieku

Afisz: Czytadła fantastyczne ${ }^{69}$, Afisz: Obrazki z PRL ${ }^{70}$, Afisz: Lektury podróżne ${ }^{71}$, Afisz: Lektury rocznicowe ${ }^{72}$, Afisz: Ostre czytadła73, Afisz: Zabójcze czytadła $^{74}$, Afisz: Czwarta władza75.

Recenzje zamieszczane w ramach tych rubryk miały formę niewielkich adnotacji treściowych, zacznie krótszych od zwyczajowych, choć i w tym przypadku podawano adres bibliograficzny proponowanej lektury, a obok recenzji książki znajdowała się kopia jej okładki. Całość miała objętość kolumny na jasnym tle.

Zdarzały się też recenzje okazjonalne, jak np. przed Świętami Bożego Narodzenia, kiedy redakcja proponowała czytelnikom listę prezentów książkowych pod choinkę ${ }^{76}$, a także na przykład przed majowym weekendem ${ }^{77}$. W takich przypadkach były to krótkie omówienia wybranych tytułów, zazwyczaj wzbogacone o podstawowe informacje bibliograficzne i kopie okładek proponowanych książek. Podobny charakter miały propozycje lekturowe na wakacje ${ }^{78}$.

Jak już wspomniano, recenzje znajdowały się również w innych działach i rubrykach pisma. W tabeli 4 zaprezentowano liczbę i lokalizację omówień lub form do nich zbliżonych.

69 „Polityka” 2005, nr 32, s. 58 (3 książki, 1 recenzent, Wojciech Krusiński).

70 „Polityka” 2005, nr 34, s. 56 (wyjątkowo 4 tytuły, zaproponowane przez Wiesława Władykę).

71 „Polityka” 2005, nr 35, s. 60 (3 recenzje 3 książek zrecenzowane przez Romana Kurkiewicza).

72 „Polityka” 2005, nr 36, s. 58 (3 tytuły omówione przez 2 recenzentów: Agnieszkę Celedę i Wiesława Władykę).

73 „Polityka” 2005, nr 37, s. 56 (3 książki przedstawione przez M. Czubaja. Zaproponował on kryminały i horrory).

74 „Polityka” 2005, nr 41, s. 60; ibidem, nr 43, s. 64 (propozycja w sumie 6 tytułów; w pierwszym z numerów recenzentem był W. Krusiński, w drugim - M. Czubaj).

75 „Polityka” 2005, nr 50, s. 62 (3 książki zaprezentowane w postaci 3 recenzji przez jedną recenzentkę, K. Lubelską).

76 (zp) i in., Goraczka grudniowej choinki, „Polityka” 2001, nr 49, s. 54-55.

77 J. Wróblewski, Między bestsellerem a arcydziełem, „Polityka” 2002, nr 18, s. 47.

78 J. Klimczyk, J. Wróblewski, Trzeba to wreszcie przeczytać, „Polityka” 2002, nr 27, s. 49-51; J. Wróblewski, Lektury na każdq pogodę, ibidem, 2001, nr 27, s. 43-45. Jedna z takich propozycji była szczególnie interesująca i rozbudowana, przybrała bowiem postać „przewodnika czytelniczego wokół Morza Śródziemnego, czyli po miejscach, które na zagraniczne wakacje Polacy wybierają najchętniej”. Zob. J. Podgórska, M. Strzałkowska, Do czytania na wakacjach, ibidem, 2003, nr 27, s. 52-54. 
Tabela 4. Recenzje drukowane poza rubryką recenzyjną na łamach „Polityki”

\begin{tabular}{|l|c|c|c|c|c|c|}
\hline \multicolumn{1}{|c|}{ Nazwa działu/rubryki } & 2001 & 2002 & 2003 & 2004 & 2005 & Razem \\
\hline Analiza & 1 & - & - & - & - & 1 \\
\hline Edukacja & 1 & - & - & - & - & 1 \\
\hline Fusy plusy i minusy & - & - & - & 3 & - & 3 \\
\hline Gospodarka & - & 1 & - & - & - & 1 \\
\hline Groński & 2 & 3 & - & 2 & 2 & 9 \\
\hline Historia & 5 & 5 & 4 & 10 & 3 & 27 \\
\hline Idee & - & - & - & 1 & - & 1 \\
\hline Komentarze: do i od redakcji & - & - & - & 3 & - & 3 \\
\hline Kraj & - & 1 & 2 & - & 1 & 4 \\
\hline Kultura & 26 & 23 & 15 & 16 & 45 & 125 \\
\hline Ludzie & - & - & - & 1 & - & 1 \\
\hline Ludzie i wydarzenia & - & 2 & 1 & 1 & - & 4 \\
\hline Nauka & 4 & 1 & - & 1 & 2 & 8 \\
\hline Perswazje i wycinki & 1 & 2 & - & - & - & 3 \\
\hline Pilch & 5 & 7 & 4 & 3 & 5 & 24 \\
\hline Polityka i obyczaje & - & 2 & 3 & 1 & 1 & 7 \\
\hline Społeczeństwo & - & 3 & 3 & 2 & 2 & 10 \\
\hline Sport & - & - & 1 & - & - & 1 \\
\hline Stomma & 2 & 1 & 5 & 2 & 2 & 12 \\
\hline Świat & - & 1 & 1 & 2 & 1 & 5 \\
\hline Za stołem & - & - & - & - & 1 & 1 \\
\hline $\begin{array}{l}\text { Ogółem liczba recenzji poza } \\
\text { specjalną rubryką, poświęconą } \\
\text { książce }\end{array}$ & 47 & 52 & 39 & 48 & 65 & 251 \\
\hline
\end{tabular}

Źródło: badania własne.

Jak widać, drugie miejsce, po rubryce recenzyjnej, pod względem liczby recenzji, omówień zajmuje dział Kultura, poza rubryką książkową (125 omówień), następnie Historia (27) oraz felieton J. Pilcha, w którym znany pisarz niejednokrotnie dzielił się wrażeniami z przeczytanej lektury. Podobną formę wybierał L. Stomma, który 12 razy skorzystał z tej możliwości kontaktu z czytelnikami, by podzielić się z nimi opiniami o poznanych książkach.

Poza wymienionymi wcześniej nazwiskami, autorami recenzji, rozmieszczonych $\mathrm{w}$ całym piśmie (włączając $\mathrm{w}$ to omówioną już częściowo rubrykę recenzyjną) w ciągu analizowanych 5 lat było jeszcze 122 innych dziennikarzy współpracujących z „Polityką” (zob. Aneks 1. Autorzy recenzji drukowanych na łamach „Polityki” w latach 2001-2005).

Najczęściej naturalnie pojawiały się nazwiska tych, którzy swoje omówienia zamieszczali w ramach działu Kultura i poprzedzającego go Afisza, co jest oczywistą konsekwencją faktu, że w tych właśnie miejscach drukowano najwięcej recenzji. Według Z. Pietrasika 
recenzenci dobierani byli do konkretnych książek. Jedni zajmowali się prozą, inni poezją, jeszcze inni śledzili literaturę popularną. Korzystaliśmy również z autorów zewnętrznych ${ }^{79}$.

Absolutnym rekordzistą, jeśli chodzi o liczbę prezentowanych $\mathrm{w}$ ten sposób tytułów, był M. Czubaj, który przedstawił aż 93 książki. Następny recenzent, Aleksander Kaczorowski, zaprezentował ich 43, kolejni „rekordowi" recenzenci to: Zdzisław Pietrasik Adam Szostkiewicz (obydwaj po 35 tytułów), Jarosław Klejnocki (28), Jerzy Pilch (27), Piotr Huniewicz (23), Piotr Sarzyński, Wojciech Krusiński, Jerzy Wróblewski (po 22), Andrzej Garlicki (19), Adam Krzemiński, Wiesław Władyka (po 18), Piotr Adamczewski, Edwin Bendyk (po 16), Mirosław Pęczak (15), Dariusz Nowacki (13), Ludwik Stomma (12) oraz Mariusz Cieślik, Ryszard M. Groński i Daniel Passent (po 11).

Ogółem zrecenzowano książki 585 różnych autorów ${ }^{80}$, w tym 324 pisarzy polskich i 261 obcych (zob. Aneks 2. Autorzy recenzowanych książek na łamach „Polityki” w latach 2001-2005). Jak twierdzi Z. Pietrasik: „Nie było żadnych ustaleń dotyczących wyboru recenzowanych książek", chociaż przewagę autorów rodzimych można tłumaczyć tym, iż starano się „w miarę możliwości nie pomijać książek krajowych autorów, zwłaszcza tych, z którymi wiązaliśmy największe nadzieje". Recenzenci kilkakrotnie prezentowali więcej niż jedną książkę tego samego autora. Było tak w 98 przypadkach: w odniesieniu do pisarzy polskich 56 razy, zaś w stosunku do twórców obcych 42-krotnie.

W tabeli 5 przedstawiono nazwiska pisarzy, których recenzenci omawiali najczęściej.

Tabela 5. Najczęściej recenzowani autorzy polscy na łamach „Polityki” w latach 2001-2005

\begin{tabular}{|c|c|l|}
\hline \multicolumn{1}{|c|}{ Dane twórcy } & Liczba recenzji & \multicolumn{1}{|c|}{ Tytuły recenzowanych książek } \\
\hline Dorota Masłowska & 5 & $\begin{array}{l}\text { Paw królowej (dwukrotnie) } \\
\text { Wojna polsko-ruska pod flaga biało-czerwona } \\
\text { (trzykrotnie) }\end{array}$ \\
\hline Stefan Chwin & 4 & $\begin{array}{l}\text { Kartki z dziennika } \\
\text { Wspólna kapiel } \\
\text { Złoty pelikan } \\
\text { Żona prezydenta }\end{array}$ \\
\hline Katarzyna Grochola & 4 & $\begin{array}{l}\text { Nigdy } \text { w życiu! (dwukrotnie) } \\
\text { Serce na temblaku } \\
\text { Upoważnienie do szczęścia }\end{array}$ \\
\hline
\end{tabular}

${ }^{79}$ Informacje uzyskane dzięki korespondencji ze Zdzisławem Pietrasikiem.

${ }^{80}$ Liczba ta obejmuje nazwiska autorów, które podane były w jakiejkolwiek formie przy recenzji, także np. w postaci okładki książki. W 54 przypadkach brakowało tej informacji. 


\begin{tabular}{|c|c|c|}
\hline Dane twórcy & Liczba recenzji & Tytuły recenzowanych książek \\
\hline Ewa Lipska & 4 & \begin{tabular}{|l} 
Gdzie indziej \\
Ja \\
Sklepy zoologiczne \\
Uwaga: stopień \\
\end{tabular} \\
\hline Tomasz Piątek & 4 & \begin{tabular}{|l} 
Bagno \\
Heroina \\
Kilka nocy poza domem \\
Przypadek Justyny \\
\end{tabular} \\
\hline Jerzy Sosnowski & 4 & $\begin{array}{l}\text { Apokryf Agłai } \\
\text { Linia nocna (Singles`collection) } \\
\text { Prąd zatokowy } \\
\text { Wielościan }\end{array}$ \\
\hline Anna Brzezińska & 3 & $\begin{array}{l}\text { Letni deszcz } \\
\text { Opowieści z Wilżyńskiej Doliny } \\
\text { Wody głębokie jak niebo }\end{array}$ \\
\hline Janusz Głowacki & 3 & $\begin{array}{l}\text { Ostatni cieć } \\
\text { Z głowy (dwukrotnie) }\end{array}$ \\
\hline $\begin{array}{l}\text { Ryszard Marek } \\
\text { Groński }\end{array}$ & 3 & $\begin{array}{l}\text { Kłębuszek snu } \\
\text { Suche oczy. Powieść brukowa } \\
\text { Jeż na kaktusie, wypisy z histerii najnowszej 1999- } \\
2002\end{array}$ \\
\hline Paweł Huelle & 3 & $\begin{array}{l}\text { Castorp } \\
\text { Mercedes-Benz. Z listów do Hrabala (dwukrotnie) }\end{array}$ \\
\hline $\begin{array}{l}\text { Jan Paweł II } \\
\text { Jan Paweł II, } \\
\text { Skawarnicki Marek }\end{array}$ & 3 & $\begin{array}{l}\text { Autobiografia } \\
\text { Wskazania na trzecie tysiąclecie } \\
\text { Listy prywatne papieża }\end{array}$ \\
\hline Hanna Krall & 3 & $\begin{array}{l}\text { Spokojne niedzielne popołudnie } \\
\text { To ty jesteś Daniel } \\
\text { Wyjątkowo długa lista }\end{array}$ \\
\hline Krystyna Lubelska & 3 & $\begin{array}{l}\text { Miłość w stanie wyższej konieczności (dwukrotnie) } \\
\text { Życie tam i z powrotem }\end{array}$ \\
\hline Jerzy Pilch & 3 & $\begin{array}{l}\text { Miasto utrapienia } \\
\text { Narty Ojca Świętego } \\
\text { Upadek człowieka pod Dworcem Centralnym } \\
\end{array}$ \\
\hline Andrzej Sapkowski & 3 & $\begin{array}{l}\text { Boży bojownicy } \\
\text { Narrenturm } \\
\text { Rękopis znaleziony w smoczej jaskini. Kompendium } \\
\text { wiedzy o literaturze fantasy }\end{array}$ \\
\hline Sławomir Shuty & 3 & $\begin{array}{l}\text { Cukier w normie z ekstrabonusem } \\
\text { Produkt polski (recycling) } \\
\text { Zwał }\end{array}$ \\
\hline
\end{tabular}


Tabela 5 (cd.)

\begin{tabular}{|l|c|l|}
\hline \multicolumn{1}{|c|}{ Dane twórcy } & Liczba recenzji & \multicolumn{1}{|c|}{ Tytuły recenzowanych książek } \\
\hline $\begin{array}{l}\text { Wisława Szymbor- } \\
\text { ska }\end{array}$ & 3 & $\begin{array}{l}\text { Chwila } \\
\text { Dwukropek } \\
\text { Rymowanki dla dużych dzieci }\end{array}$ \\
\hline Janusz L. Wiśniewski & $3^{a}$ & $\begin{array}{l}\text { Los powtórzony } \\
\text { Martyna } \\
\text { Samotność w sieci } \\
\text { Tryptyk } \\
\text { Zespoły napięć }\end{array}$ \\
\hline
\end{tabular}

${ }^{a}$ W jednej z recenzji zrecenzowano kilka tytułów. Zob. „Polityka” 2004, nr 7, s. 64. Źródło: badania własne.

W przypadku literatury polskiej widać, że recenzenci, sięgając kilkakrotnie po utwory tego samego twórcy, nierzadko wybierali także, obok autorów literatury popularnej (K. Grochola, D. Masłowska, A. Sapkowski), pisarzy znanych raczej węższemu kręgowi odbiorców (na przykład H. Krall, J. Sosnowski). Interesujący jest również fakt, że w przedstawionej w tabeli 5 grupie znalazły się trzy nazwiska poetów (Ewa Lipska, Wisława Szymborska, Marcin Świetlicki).

Warto zaznaczyć, że kilkakrotnie omówiono książki, których autorami byli współpracownicy pisma. Wśród nich (poza już wymienionymi) znaleźli się: E. Bendyk (Antymatrix. Człowiek w labiryncie sieci), Z. Kałużyński (Do czytania pod prysznicem), K. Koźniewski (I zawsze krzyż oksydowany...), L. Stomma (Słownik polskich wyzwisk, inwektyw i określeń pejoratywnych; Dzieje smaku), W. Władyka (Kartki z PRL. Ludzie, fakty, wydarzenia, t. 1, 1944-1970) i J. Żakowski (Trwoga i nadzieja).

Nieco odmienne wnioski nasuwają się $\mathrm{w}$ odniesieniu do zestawienia zawierającego nazwiska pisarzy obcych.

W większości tworzyli oni grupę twórców popularnych, których książki nierzadko gościły na listach bestsellerów (U. Eco, S. King). Jeśli przyjrzyjmy się pełnej liście nazwisk autorów książek prezentowanych na łamach pisma, zauważymy, że wnioski wypływające $\mathrm{z}$ analizy tabeli 6 są reprezentatywne dla całej grupy twórców. 
Tabela 6. Najczęściej recenzowani autorzy obcy na łamach „Polityki” w latach 2001-2005

\begin{tabular}{|c|c|c|}
\hline Autor & Liczba recenzji & Tytuły recenzowanych książek \\
\hline Paul Auster & 5 & $\begin{array}{l}\text { Księga złudzeń } \\
\text { Noc wyroczni } \\
\text { Szaleństwo Brooklynu } \\
\text { Timbuktu } \\
\text { Wiążąc koniec z końcem }\end{array}$ \\
\hline Harlan Coben & 5 & $\begin{array}{l}\text { Bez skrupułów } \\
\text { Bez śladu } \\
\text { Krótka piłka } \\
\text { Nie mów nikomu } \\
\text { Tylko jedno spojrzenie } \\
\end{array}$ \\
\hline Umberto Eco & 5 & $\begin{array}{l}\text { Baudolino } \\
\text { Historia piękna } \\
\text { O literaturze } \\
\text { Tajemniczy płomień królowej Loany (dwu- } \\
\text { krotnie) }\end{array}$ \\
\hline Amélie Nothomb & 5 & \begin{tabular}{|l} 
Antychrysta \\
Krasomówca \\
Metafizyka rur \\
Sabotaż miłosny \\
Z pokorq i uniżeniem \\
\end{tabular} \\
\hline Dan Brown & 4 & $\begin{array}{l}\text { Cyfrowa twierdza } \\
\text { Kod Leonarda da Vinci (trzykrotnie) }\end{array}$ \\
\hline John Grisham & 4 & $\begin{array}{l}\text { Król afer } \\
\text { Malowany dom } \\
\text { Wezwanie }\end{array}$ \\
\hline $\begin{array}{l}\text { Gabriel García } \\
\text { Márquez }\end{array}$ & 4 & $\begin{array}{l}\text { Na fałszywych papierach w Chile } \\
\text { Pamięć o moich smutnych dziwkach } \\
\text { Skandal stulecia i inne felietony } \\
\text { Życie jest opowieścia }\end{array}$ \\
\hline $\begin{array}{l}\text { Arturo Pérez- } \\
\text {-Reverte }\end{array}$ & 4 & \begin{tabular}{|l} 
Królowa Południa \\
Przygody kapitana Alatriste, t. 1 \\
Przygody kapitana Alatriste, t. 2 \\
Terytorium Komańczów \\
\end{tabular} \\
\hline John le Carré & 3 & $\begin{array}{l}\text { Miasteczko w Niemczech } \\
\text { Przyjaźń absolutna } \\
\text { Wierny ogrodnik }\end{array}$ \\
\hline Norman Davies & 3 & $\begin{array}{l}\text { Mikrokosmos: Portret miasta środkowoeuro- } \\
\text { pejskiego } \\
\text { Rising '44: The Battle for Warsaw } \\
\text { Wyspy. Historia }\end{array}$ \\
\hline
\end{tabular}


Tabela 6 (cd.)

\begin{tabular}{|l|c|l|}
\hline \multicolumn{1}{|c|}{ Autor } & Liczba recenzji & \multicolumn{1}{|c|}{ Tytuły recenzowanych książek } \\
\hline Michel Houellebecq & 3 & $\begin{array}{l}\text { Cząstki elementarne } \\
\text { Możliwość wsypy } \\
\text { Platforma }\end{array}$ \\
\hline Stephen King & 3 & $\begin{array}{l}\text { Buick 8 } \\
\text { Colorado Kid } \\
\text { Jak pisać. Pamiętnik rzemieślnika }\end{array}$ \\
\hline Philip Roth & 3 & $\begin{array}{l}\text { Amerykańska sielanka } \\
\text { Cień pisarza } \\
\text { Spisek przeciwko Ameryce }\end{array}$ \\
\hline José Carlos Somoza & 3 & $\begin{array}{l}\text { Dafne znikająca } \\
\text { Jaskinia filozofów } \\
\text { Listy od zabójcy bez znaczenia }\end{array}$ \\
\hline Robert Wilson & 3 & $\begin{array}{l}\text { Ślepiec z Sewilli } \\
\text { Śmierć } \text { w Lizbonie } \\
\text { Zaułek łgarza }\end{array}$ \\
\hline
\end{tabular}

Źródło: badania własne.

W przypadku autorów obcych nieco częściej niż w odniesieniu do twórców rodzimych prezentowane były dzieła znane (poza wymienionymi recenzenci proponowali np. książki Roberta Ludluma, Jonathana Carrolla, Johna M. Coetzee`a, Paula Coelho, Helen Fielding, Johna Irvinga, Deana Koontze`a, Davida Lodge`a, Terry'ego Pratchette`a, Salmana Rushdie, José Saramago). Przewaga ta, mimo że zauważalna, nie jest jednak na tyle duża, by można mówić o propagowaniu przez pismo literatury masowej. Typowe „czytadła” nie stanowiły tu szczególnie znaczącej grupy (wyjątkiem jest drukowana przez pewien czas opisana wcześniej sporadyczna rubryka różnie zatytułowana, na przykład Czytadła na plażę). Bardzo rzadko zdarzały się choćby recenzje romansów. Był to jednak naturalny efekt określenia przez pismo typu adresata. Potwierdzeniem tej tezy jest zestawienie prezentowanej $\mathrm{w}$ tygodniku literatury polskiej. W tym przypadku recenzenci omawiali częściej utwory pisarzy mniej znanych ${ }^{81}$. Nierzadko przedstawiana była również poezja. Obok już wymienionych pojawiły się nazwiska m.in. Zbigniewa Herberta, Czesława Miłosza, Kazimierza Orłosia i Tadeusza Różewicza.

${ }^{81}$ Zdarzały się wyjątki, np. w 2004 r. zrecenzowano książkę Adama Małysza, Moje życie, Wydawnictwo m, Kraków 2004. Zaznaczyć należy jednak, że był to okres przypadający na apogeum popularności tego skoczka narciarskiego. 
Można zatem powiedzieć, że książki proponowane czytelnikom „Polityki” tworzą grupę ambitnych lektur, które zainteresować mogą odbiorcę, kupującego wiodący w Polsce tygodnik opinii.

W badanym okresie recenzenci skorzystali z propozycji 189 wydawców (zob. Aneks 3. Wydawcy recenzowanych książek na łamach „Polityki” w latach 2001-2005), w tym 9 oficyn zagranicznych ${ }^{82}$. W tabeli 7 zaprezentowano tych edytorów, z oferty których dziennikarze „Polityki” korzystali najczęściej.

Tabela 7. Wydawcy najczęściej recenzowanych książek na łamach „Polityki” w latach 2001-2005

\begin{tabular}{|l|c|}
\hline \multicolumn{1}{|c|}{ Nazwa wydawcy } & Liczba recenzji \\
\hline Wydawnictwo W.A.B. & $87^{a}$ \\
\hline Wydawnictwo Prószyński i S-ka & 49 \\
\hline Społeczny Instytut Wydawniczy Znak & 36 \\
\hline Wydawnictwo Muza & 30 \\
\hline Wydawnictwo Literackie & 29 \\
\hline Świat Literacki & 23 \\
\hline $\begin{array}{l}\text { Dom Wydawniczy REBIS } \\
\text { Wydawnictwo Zysk }\end{array}$ & 20 \\
\hline Wydawnictwo Czarne & 19 \\
\hline Wydawnictwo Iskry & 18 \\
\hline $\begin{array}{l}\text { Wydawnictwo Sic! } \\
\text { Oficyna Literacka Noir sur Blanc } \\
\text { Wydawnictwo Amber }\end{array}$ & 16 \\
\hline
\end{tabular}

${ }^{a} \mathrm{~W}$ tym trzykrotnie z Wydawnictwem CiS oraz dwukrotnie z Wydawnictwem Małe.

Źródło: badania własne.

Najczęściej sięgano po książki znanych oficyn: Wydawnictwa W.A.B., Wydawnictwa Prószyński i S-ka czy Społecznego Instytutu Wydawniczego Znak, ale prezentowano również ofertę mało znanych edytorów, na przykład Domu Wydawniczego Errata, Grupy IMAGE, Oficyny Wydawniczej Fogra, Stentor, Wydawnictwa BASIL, Wydawnictwa Efor, Wydawnictwo Imagolibris, Wydawnictwa Post, Wydawnictwa Veda.

$82 \mathrm{~W} 112$ przypadkach nie podano nazwy wydawcy, jednak na potrzeby prezentowanej pracy jej autorka sprawdziła brakujące elementy. W 12 przypadkach nie ustalono wydawcy. Skorzystano z "Przewodnika Bibliograficznego” on line, dostępnego na stronie internetowej Biblioteki Narodowej: www.bn.org.pl oraz ze stron: http://czytelnia.onet.pl/, http://www. empik.com/. 


\subsection{Zakres i charakter recenzji - przykłady ${ }^{83}$}

Recenzje zamieszczane na łamach „Polityki” prezentowały zazwyczaj nowości wydawnicze, choć czasem sięgano także po książki wydane kilka lat lub miesięcy wcześniej ${ }^{84}$. Najmniej było zapowiedzi wydawniczych.

Objętość omówień wahała się od kilku lub kilkunastu zdań, aż do tekstów jedno-, a nawet czterostronicowych. Obszerniejsze recenzje odnaleźć można było głównie poza rubryką recenzyjną, chociaż i tu niekiedy pojawiały się dłuższe prezentacje (szczególnie w okresie, gdy strony poświęcone recenzjom nosiły tytuł Kultura/książki).

Najczęstszymi ich elementami było streszczenie proponowanej książki, niekiedy krótka charakterystyka jej autora i praktycznie niemal zawsze opinia na temat danego tytułu. W przypadku książek recenzowanych poza wspomnianą rubryką, częściej pojawiała się bardziej wnikliwa charakterystyka twórczości danego pisarza, odwołanie się do jego wcześniejszych utworów, a także bogatszy komentarz, uzasadniający ocenę omawianej książki. W tym miejscu czytelnik mógł spodziewać się także raczej ogólnego nakreślenia tła akcji proponowanego utworu.

Inaczej było w przypadku recenzji drukowanych na przeznaczonych do tego stronach. Tu streszczenie często nabierało pierwszoplanowego znaczenia i zazwyczaj było dokładniejsze. Recenzent dbał o przekazanie większej liczby szczegółów, odnoszących się nie tylko do zarysowania głównych wątków utworu, jego charakteru ${ }^{85}$, najważniejszych postaci, ale i nierzadko podawał informacje dotyczące miejsca i czasu, w którym opisane zostały losy bohaterów. Oto kilka wybranych przykładów:

Znajdujemy się na wysepce u wybrzeży Chile. Jest początek XX wieku, ale tu cywilizacja jeszcze nie dotarła. Życie bohaterów toczy się w rytmie zbiorów zboża i jabłek. Nie znają oni współczesnego pojęcia pracy, która nie jest dla nich jeszcze oddzielona od zabawy i religijnych obrzędów. Ta sielanka szybko się jednak kończy. Wyspiarze, którzy żyli w harmonii z naturą i tworzyli ścisłą wspólnotę, stykają się ze światem pieniądza ${ }^{86}$.

${ }^{83} \mathrm{~W}$ tym miejscu przedstawiono recenzje, zamieszczane w całym periodyku, starając się równocześnie uchwycić różnicę pomiędzy omówieniami drukowanymi w rubrykach recenzyjnych i poza nimi. Jednocześnie, jako że „Polityka” stanowi jedynie jeden z tytułów w prezentowanej pracy, niemożliwa jest, ze względów objętościowych, szczegółowa charakterystyka większej liczby recenzowanych na jej łamach książek. Dlatego też ograniczono się do przedstawienia wybranych, reprezentatywnych w odczuciu autorki, recenzji.

84 Zob. np. „Polityka” 2002, nr 42, s. 106: recenzja książki wyd. w 1926 r.: Księgarnia Polska Bernarda Połonieckiego.

85 Zob. np. Z. Pietrasik, Żywot Jakuba, „Polityka” 2003, nr 2, s. 47; H. Zaworska, Szalony Wienia, ibidem, 2002, nr 12, s. 56.

${ }^{86}$ K. Gajewski, W stylu wielkiego realizmu, „Polityka” 2001, nr 23, s. 57. 
Książka nazywa się „Ostatni cieć” i składa się z opowieści tytułowego bohatera, chłopa spod Włoszczowej, rzuconego w głąb Ameryki, a także wynurzeń postaci, z którymi się zetknął na tym dziwnym, zagrożonym zagładą kontynencie. Rzecz dzieje się w przyszłości, niezbyt jednak odległej, powiedzmy na początku XXI wieku, ale dalej niż dziśe7.

czy

Akcja powieści „Czwarte niebo” Mariusza Sieniewicza [...] toczy się w określonym miejscu i czasie. Jest to Olsztyn [...] główny bohater [...] Zygmunt Drzeźniak, dobiegający trzydziestki, nieudacznik z wyboru. Coś tam studiował, lecz bez sukcesów, teraz dorabia w uczelni jako portier, traktując zajęcie tymczasowo...88.

\section{Z innej recenzji czytelnik dowiadywał się, że:}

Trzecia powieść Marka Krajewskiego - rozgrywa się we Wrocławiu we wrześniu 1919 r. [...] Jej bohaterem jest znany czytelnikowi z wcześniejszych części zgorzkniały i cyniczny miłośnik klasycznej poezji łacińskiej, weteran I wojny światowej Eberhard Mock [...]. Tym razem wrocławski policjant próbuje rozwikłać tzw. sprawę czterech marynarzy ${ }^{89}$,

w kolejnej mógł przeczytać:

Autobiografia Gabriela Garcii Márqueza - „Życie jest opowieścią” - to barwna historia o pierwszych trzydziestu latach spędzonych przez przyszłego noblistę na wysłuchiwaniu rodzinnych przygód i nauce. Książka ta opisuje zarazem narodziny magicznej wyobraźni pisarza...90.

Jak wspomniano, kolejnym elementem recenzji była prezentacja autora proponowanej książki. W omówieniach zamieszczanych $\mathrm{w}$ specjalnie do tego przeznaczonych rubrykach ograniczała się ona nierzadko do krótkich informacji, jak na przykład: sce...91

Andrew Nagorski - wybitny publicysta, przez lata korespondent „Newsweeka” w Polczy

Amélie Nothomb jest piękna, bogata, sławna i utalentowana. Ma 35 lat, 10 książek na koncie i status literackiej gwiazdy w krajach francuskojęzycznych ${ }^{92}$.

87 Z. Pietrasik, Opowieści na koniec świata, „Polityka” 2001, nr 43, s. 54.

88 Z. Pietrasik, Giaur warmiński, „Polityka” 2004, nr 4, s. 49.

89 P. Huniewicz, Breslau po raz trzeci, „Polityka” 2005, nr 28, s. 54.

${ }^{90}$ J. Wróblewski, Márquez: narodziny magicznej wyobraźni, „Polityka” 2004, nr 15, s. 63.

91 J. Królak, Świat bez Hitlera, „Polityka” 2003, nr 22, s. 53.

92 M. Cieślik, Proza popowa, „Polityka” 2002, nr 15, s. 46. 
Niekiedy jednak recenzent starał się podać nieco więcej szczegółów dotyczących autora, i tak na przykład czytelnik dowiadywał się, że:

Simon Sebag Montefiore studiował historię w Cambridge. Talent pisarski rozwinął współpracując z takimi pismami, jak „New York Times”, „Spektator”, „Sunday Times”93,

a

Krzysztof Mroziewcz jak mało kto jest powołany do napisania takiej książki: weteran Ameryki Łacińskiej, wieloletni korespondent PAP w Indiach i w okolicy (Afganistan, Pakistan), ambasador RP w New Delhi, Sri Lance i Nepalu, laureat telewizyjnych Wiktorów, wieloletni publicysta „Polityki”, doradca ministra spraw zagranicznych, słowem - w polskim dziennikarstwie instytucja ${ }^{94}$,

zaś

Roy Jacobson uważany jest w Norwegii za jednego z najbardziej utalentowanych pisarzy współczesnych, co potwierdzają liczne przyznane mu nagrody literackie. Jest autorem kilkunastu tomów prozy i opowiadań, w Polsce ukazały się dwie jego książki...95.

\section{Z kolei Marcin Meller pisał o twórcy Terytorium Komanczów:}

W Polsce Pérez-Reverte to autor znany od niedawna ze świetnych erudycyjnych thrillerów osnutych wokół wielkiej sztuki, religii, okultyzmu, historii. Kochają go fani czarnego kryminału spod znaku Raymonda Chandlera i wielbiciele narracji Stendhala. Jednak dla Hiszpanów ten 50-letni dziś pisarz przede wszystkim był twarzą telewizyjną, korespondentem wojennym państwowej TVE, wcześniej jeszcze zasłynął jako reporter z afrykańskich wojen dziennika „Pueblo"...96.

Niekiedy przywoływano nagrody, które otrzymał autor proponowanej książki ${ }^{97}$.

Ostatnim najczęściej pojawiającym się elementem recenzji była ocena przedstawianej książki. W omówieniach drukowanych w rubrykach recenzyjnych pojawiała się ona w opisanych okresach w postaci symboli, ale poza tym czytelnik, niezależnie od nich mógł poznać osobiste odczucia recenzenta, który nie wahał się używać mniej lub bardziej rozbudowanych określeń, na podkreślenie własnej opinii. Odbiorca dowiadywał się zatem, że proponowana książka to „świetna lektura”, „niebywale sympatyczna, pogodna, ale i pouczająca”, „doskonale napisana”, „zaskakująco dobra”, „znakomita”,

\footnotetext{
93 A. Garlicki, Stalin, jego dworzanie i kobiety, „Polityka” 2004, nr 42, s. 60.

94 D. Passent, Przewodnik po globalnej wiosce, „Polityka” 2004, nr 22, s. 62.

95 W. Krusiński, Agent z przeszłościq, „Polityka” 2003, nr 48, s. 57.

96 M. Meller, Zmarnowana bomba, „Polityka” 2001, nr 17, s. 57.

97 Zob. np. „Polityka” 2003, nr 45, s. 67; ibidem, 2004, nr 12, s. 63;
} 
„intrygująca”, „sprawnie napisana”, „dobra literatura”. Tego typu określenia (o charakterze reklamowym) powtarzały się wielokrotnie, w różnych omówieniach, $\mathrm{w}$ odniesieniu do rozmaitych książek. Jakkolwiek przeważały oceny pozytywne, to nie szczędzono również krytyki. W rubrykach recenzyjnych prezentowano ją, poza wspomnianymi symbolami, również w postaci krótkich stwierdzeń, odnoszących się zazwyczaj bezpośrednio do autora (na przykład: „Manuela Gretkowska - największa skandalistka w polskiej współczesnej literaturze - napisała swoja najgorszą książkę"98, „Po autorze trzech książek i finaliście nagrody Nike można się spodziewać znacznie więcej”99), rzadziej do danej książki (jak choćby: „powieść sprawia wrażenie napisanej na chybcika, między kolejnymi felietonami, a płynący z niej morał - że nie tak miało być - nie wydaje się specjalnie frapujący"100). Niekiedy ocena negatywna był obszerniej wyjaśniana, jak na przykład w przypadku Popularnej encyklopedii mass mediów:

Brakuje spisu haseł, nie mówiąc już o indeksach osobowych i rzeczowych znacznie ułatwiających posługiwanie się taką publikacją. Nie wiadomo też, jakimi kryteriami kierowali się jej twórcy decydując się na biogram Marii Koterbskiej, a nie np. Kazika Staszewskiego101.

Nierzadko oceny negatywne pojawiały się również w omówieniach, zamieszczanych poza rubryką recenzyjną.

Co ciekawe, w niekorzystnym świetle przedstawiona została na przykład książka autorki, nagrodzonej Paszportem Polityki, Doroty Masłowskiej102, choć tygodnik najczęściej promował twórców - laureatów tegoż wyróżnienia poprzez wywiady z nimi lub skrzętne odnotowywanie ich kolejnych sukcesów. Nie wahano się negatywnie oceniać również dzieł znanych twórców zagranicznych. Tak było w przypadku nowej książki U. Eco: Baudolino. Recenzent stwierdził: „Umberto Eco napisał kolejne czytadło dla erudytów, niestety nudniejsze od poprzednich"103, ciekawie uzasadniając swoją opinię.

Niekiedy negatywne sądy zamieszczano w wiele mówiącej rubryce $\mathrm{Ni}$ skie loty ${ }^{104}$, w której w formie prześmiewczej podkreślano wady danego utworu. Czasem jednak (choć stosunkowo rzadko) krytyka dzieła była znacznie obszerniejsza i stawała się początkiem polemiki pomiędzy recen-

98 M. Czubaj, Gównojad i syssanka, „Polityka” 2003, nr 13, s. 57.

${ }^{99}$ A. Kaczorowski, Szklana lipa, „Polityka” 2005, nr 21, s. 70.

100 A. Kaczorowski, Pisarstwo, „Polityka” 2005, nr 36, s. 58.

101 M. Czubaj, Encyklopedia na wyrost, „Polityka” 2001, nr 3, s. 59.

102 L. Stomma, Paszport bez wizy, „Polityka” 2003, nr 6, s. 98, chociaż niecały rok wcześniej pojawiła się recenzja pozytywna tejże książki: J. Pilch, Monolog Silnego, ibidem, 2002, nr 37, s. 103.

103 M. Cieślik, Zmyślny kłamca Baudolino, „Polityka” 2001, nr 47, s. [56]-57.

104 P. Sarzyński, Wydawniczy glut, „Polityka” 2005, nr 2, s. 61. 
zentem a autorem. Tak było na przykład w numerze 11 (2004), w którym przedstawiona została książka Antoniego Dudka: Reglamentowana rewolucja. Rozkład dyktatury komunistycznej w Polsce 1988-1990105. Już sam początek wskazywał na charakter recenzji: „Spiskowa teoria dziejów to ulubiona teza niedouczonych polityków. Znacznie gorzej, gdy sięgają po nią zawodowi historycy"106. Dalej recenzent, A. Garlicki, wytknął kolejne błędy, jakie znalazł w książce, a także wskazał na autoplagiat, popełniony przez A. Dudka: „Zawiera też książka obszerne fragmenty żywcem przepisane z wcześniejszej pracy tegoż autora"107. Odbiorca mógł również dowiedzieć się, zanim jeszcze sam po nią sięgnął, że „Książka [...] jest wyjątkowo niechlujnie wydana, co jest winą wydawcy, a nie autora"108. Po dwóch tygodniach, kupując „Politykę”, jej czytelnik miał jednak możliwość poznać drugą stronę medalu, jako że w piśmie pojawiła się odpowiedź A. Dudka, zaczynająca się od słów:

Konkurencja między autorami, którzy w tym samym czasie wydali prace historyczne na podobny temat, może mieć charakter rzeczowej dyskusji, ale może też przybrać formę rozmaitych aluzji i uszczypliwości. Czytając polemikę prof. Garlickiego („Polityka” 11) z moją „Reglamentowaną rewolucją” trudno oprzeć się wrażeniu, że wybrał on ten drugi model ${ }^{109}$.

Na tej samej stronie znalazła się riposta A. Garlickiego.

Polemiką był też dwugłos w sprawie książki Andrzeja Krajewskiego: Między współpracq a oporem. Twórcy kultury wobec systemu politycznego PRL (1975-1980)110.

Nierzadko zresztą sięgano po tytuły omawiające okres PRL autorstwa osób dawniej bądź aktualnie związanych z „Polityką”. Na przykład w numerze 6 (2003) pojawiła się recenzja Dzienników politycznych 1976-1978 M. Rakowskiego ${ }^{111}$, a w numerze 23 (2005) Kartki z PRL pod red. W. Władyki (ten tytuł omówiony został nawet dwukrotnie) ${ }^{112}$.

Literatura wyższego obiegu recenzowana była zazwyczaj w ramach działów: Analiza, Historia, Nauka, natomiast na stronach Kultury prezentowano częściej książki popularne, zajmujące czołowe miejsca na listach

105 A. Garlicki, Opowieść z tezq, „Polityka” 2004, nr 11, s. 70.

106 Ibidem.

107 Ibidem.

108 Ibidem.

${ }^{109}$ A. Dudek, Dworsko czy spiskowo?, „Polityka” 2004, nr 13, s. 88.

110 A. Krajewski, Między współpracq a oporem. Twórcy kultury wobec systemu politycznego PRL (1975-1980), „Polityka” 2004, nr 28, s. 99: recenzja książki. Polemika z tą recenzją pojawiła się w numerze 22 (2004), s. 99, jej autorem był A. Krajewski.

111 D. Passent, Czy „Dzienniki” mogą kłamać?, „Polityka” 2003, nr 6, s. 73.

112 L. Stomma, Kartki z PRL, „Polityka” 2005, nr 11, s. 114; A. Szostkiewicz, Daty Polaków, ibidem, nr 19, s. 89. 
bestsellerów, adresowane do czytelników z różnych grup wiekowych. Jako że w badanym okresie bohaterem wielu takich zestawień był Harry Potter, rozważano przyczyny popularności książek o małym czarodzieju, informowano o kolejnych częściach cyklu, zarówno tomach książki, jak i ich ekranizacjach, obszernie je recenzując. Pisano również o akcjach, towarzyszących pojawieniu się na rynku następnej części ${ }^{113}$. Przytaczano także (w ramach prześmiewczo-szyderczej rubryki Polityka i obyczaje) opinie krytyczne wobec opowieści o Harrym Potterze, pojawiające się głównie na łamach „Naszego Dziennika”.

Naturalnie prezentowano nie tylko literaturę adresowaną do dzieci i młodzieży114.

Obszerne, ciekawe omówienie znalazło się na przykład w numerze 51 (2004), a dotyczyło nowej książki G. G. Márqueza. Zajęło niemal dwie strony, opatrzono je zdjęciem pisarza, którego życiorys zręcznie wpleciono w recenzję 115 . Pisano również o prozie R. Ludluma, oceniając jego ostatnią powieść: Klątwa Prometeusza116.

Jak już wspomniano, niejednokrotnie pojawiały się także omówienia prezentujące dwie książki różnych autorów jednocześnie. Na przykład w jednym z nich recenzent, A. Krzemiński, stwierdził:

„Lektor” Bernarda Schlinka to światowy bestseller, w którym jest zarówno pikantna akcja, jak i potężna dawka psychodramy. Uwiedzenie, miłość, ludobójstwo, zbrodnia i kara, a także klątwa dotykająca następnego pokolenia. Warto tę powieść czytać razem z „Madame” Antoniego Libery ${ }^{117}$.

Na łamach „Polityki” drukowano również zagraniczne korespondencje, przybliżające polskiemu czytelnikowi książki wydane za granicą, na przykład w Londynie ${ }^{118}$, Nowym Jorku ${ }^{119}$ czy w Paryżu ${ }^{120}$.

Czasem książka stawała się tylko pretekstem do dalszych rozważań. Zdarzało się tak przeważnie w przypadku felietonów J. Pilcha, R. Grońskiego

113 Zob. np. A. Niezgoda, Mugole do Wołomina, „Polityka” 2001, nr 40, s. 91; M. Cieślik, Harry bohater, ibidem, nr 42, s. [50]-51; A. Rogozińska-Wickers, Harry Potter Superstar, ibidem, nr 48, s. 58-[59]; Z. Kałużyński, Ja i Harry Potter, ibidem, 2002, nr 7, s. [46]-47; M. Czubaj, Globalny Harry, ibidem, 2003, nr 26. s. 88.

114 Warto zresztą zauważyć, że w recenzjach, zamieszczanych na łamach tygodnika „Polityka”, rzadko bywał określany adresat, zob. np. „Polityka” 2004, nr 43, s. 62; ibidem, 2005, nr 9, s. 60 .

115 K. Mroziewicz, Jego smutne dziwki, „Polityka” 2004, nr 51, s. 70-71 (rec. książka: G. G. Márquez, Pamięć o moich smutnych dziwkach). Brak adresu wydawniczego.

116 M. Czubaj, Potęga spisku, „Polityka” 2001, nr 12, s. [5]-51.

117 A. Krzemiński, Papierowe libido, „Polityka” 2001, nr 17, s. [49].

118 „Polityka” 2005, nr 28, s. 66-67.

119 K. Mroziewicz, Wywiad-rzeka, „Polityka” 2001, nr 24, s. 54

120 „Polityka” 2005, nr 35, s. 66-67. 
czy L. Stommy. Szczególnie autor Bezpowrotnie utraconej leworęczności sięgał po znaną sobie książkę lub przypominał sylwetkę pisarza, by dalej snuć rozważania na wybrany przez siebie temat. Niejednokrotnie pisał o literaturze i jej twórcach, w rozmaity zresztą sposób; czasem z atencją, czasem sarkastycznie lub krytycznie, zawsze jednak były to teksty interesujące, charakterystyczne dla stylu pisania tego autora, niekiedy zresztą dające początek polemice ${ }^{121}$.

Niestety, poza działem Kultura i Historia, w pozostałych miejscach rzadko zdarzało się, by recenzenci przestrzegali profesjonalnej zasady zamieszczania danych bibliograficznych dotyczących omawianej książki. Niektórzy (jak J. Pilch) podawali podstawowe informacje (autor, tytuł, wydawca, ale już bez roku wydania) w tekście, inni ograniczali się tylko do zasygnalizowania tytułu i/lub autora.

Częstokroć recenzje miały ciekawe, przyciągające wzrok tytuły. Oto kilka wybranych przykładów122: Bunt człowieka ometkowanego, Fajtłapa jest wszędzie, I ty jesteś barbarzyńca, Jaskinia pozorów, Konopnicka $w$ dresie, Paraliżująca siła wyobraźni, Piękna teoria niemożności, Winne jest życie, Wydawniczy glut, Życie jak powieść.

Reasumując, ta forma informacji o książce na łamach „Polityki” była bogato reprezentowana, zaś omawiane tytuły (w większości przypadków) dostosowywano do potencjalnych preferencji czytelniczych odbiorców pisma.

\subsubsection{Napiszę, jak się napatrzę ${ }^{123}$ : wywiady}

Jedną z form obecności literatury w prasie są rozmowy z jej twórcami. $\mathrm{Na}$ łamach prezentowanego tygodnika $\mathrm{z}$ takiej możliwości jej prezentacji skorzystano w ciągu badanych pięciu lat 97 razy (zob. Aneks 4. Nazwiska osób związanych z książką, z którymi przeprowadzono wywiad na łamach „Polityki” w latach 2001-2005). W tabeli 8 zaprezentowano liczbę wywiadów w poszczególnych latach.

W tej liczbie nie zawsze rozmówcami byli pisarze; często uwzględniano osoby tylko pośrednio związane $\mathrm{z}$ literaturą i kulturą ${ }^{124}$. Jak twierdzi

121 Zob. np. J. Pilch, Głupota Susan Sontag, „Polityka” 2002, nr 38, s. 95; M. Król, Nie lecę na Pilcha, ibidem, nr 41, s. 99; J. Pilch, Upadek Króla, ibidem, nr 42, s. 102.

122 Kolejno: „Polityka” 2004, nr 38, s. 54; 2001, nr 36, s. [54]; 2004, nr 43, s. 77-79; 2003 , nr 28, s. $45 ; 2005$, nr 10, s. 62; 2001, nr 35, s. 56; 2005, nr 20, s. $110 ; 2004$, nr 48, s. 62; 2005, nr 2, s. $61 ; 2001$, nr 30, s. 49.

123 „Polityka” 2001, nr 36, s. [54]. Słowa Tadeusza Konwickiego, z jego krótkiej wypowiedzi.

${ }^{124} \mathrm{~W}$ tej liczbie znaleźli się pisarze, językoznawcy, historycy, aktorzy, odtwarzający główne role $\mathrm{w}$ adaptacjach znanych dzieł. Pominięto tych, którzy związani byli z innymi dziedzinami życia, jak np. ekonomią czy polityką. 
Z. Pietrasik, wynikało to z faktu, że: „w Polsce jest mało pisarzy, z którymi warto robić wywiady. Z wszystkimi ważnymi autorami wywiady już zrobiliśmy (z niektórymi parę razy). Regularnie corocznie robimy wywiady z pisarzami młodymi - laureatami naszej nagrody Paszport $>$ Polityki<". Kryteria wyboru rozmówcy były proste: „ważne, >gorące< nazwisko, i pretekst - najlepiej nowe dzieło. Albo okrągła rocznica urodzin, ważna nagroda itp."125

Tabela 8. Wywiady zamieszczane na łamach „Polityki” w latach 2001-2005

\begin{tabular}{|c|c|}
\hline Rok & Liczba wywiadów \\
\hline 2001 & 26 \\
\hline 2002 & 16 \\
\hline 2003 & 17 \\
\hline 2004 & 16 \\
\hline 2005 & 22 \\
\hline Ogółem & 97 \\
\hline
\end{tabular}

Źródło: badania własne.

Wśród autorów, z którymi rozmawiano, znaleźli się m.in.: Boris Akunin, Paul Auster, John le Carré, Harlan Coben, Umberto Eco, Wiktor Jerofiejew (dwukrotnie), Ryszard Kapuściński, Krystyna Kofta, Tadeusz Konwicki (dwukrotnie), Ewa Lipska, Czesław Miłosz, Stanisław Lem, Wisława Szymborska, Adam Zagajewski. Wywiady przeprowadzano również z laureatami Paszportów Polityki w kategorii Literatura. O sobie i swej twórczości opowiedzieli: Paweł Huelle (dwukrotnie), Marzanna Bogumiła Kielar, Wojciech Kuczok, Dorota Masłowska, Jerzy Pilch oraz Sławomir Shuty.

Ten sposób prezentacji twórców czytelnicy mogli odnaleźć, podobnie jak recenzje, w rozmaitych działach pisma, m.in. w ramach Afisza, Historii, Kultury, Nauki, Świata, Wydarzeń. Kilkakrotnie stworzono specjalną rubrykę: Rozmowa Polityki. Wywiady miały różną objętość: poczynając od 2 kolumn, a kończąc na 4 stronach. Niemal zawsze zawierały w sobie te same elementy: obok krótkiej notki biograficznej pojawiało się zdjęcie rozmówcy, a na zakończenie nazwisko redaktora, przeprowadzającego wywiad.

Niekiedy była to wypowiedź twórcy w formie odpowiedzi na jedno tylko pytanie. Tę postać miniwywiadu wykorzystywano głównie w $2001 \mathrm{r}$.

125 Informacje uzyskane dzięki korespondencji ze Zdzisławem Pietrasikiem. 
Pojawiała się ona $w$ ramach rubryki recenzyjnej ${ }^{126}$. Wtedy zamieszczano również jako dodatkowy element odsyłacz do Czytelni On Line.

Wywiad z autorem drukowano czasami przy okazji recenzji127 bądź reklamy jego książki. Z. Pietrasik przyznaje, że „zbieżność z recenzją była absolutnie zamierzona, ale z reklamą - nie"128.

Stosunkowo rzadko pytano pisarzy o ich życie osobiste. Intymne, przejmujące wyznania stały się kanwą rozmowy z K. Koftą. Opowiedziała ona o swojej walce $\mathrm{z}$ chorobą nowotworową, o śmierci i nadziei.

Siedzimy tu teraz obie w jednym miejscu świata. Nie ma nas w miliardach innych miejsc. Nasza śmierć oznaczałaby tylko tyle, że nie będzie nas jeszcze w tym jednym.[...] Nigdy nie szukałam sensu życia. Wystarczy mi, że jem, chodzę, oddycham, kładę się spać i wstaję rano, piszę i kocham ${ }^{129}$.

W kolejnym wywiadzie, którego bohaterem był Cz. Miłosz, pojawiło się wiele refleksji, wspomnień autora Umysłu zniewolonego dotyczących sztuki, literatury, przyjaźni, miłości, domu i życia. Poeta stwierdził w rozmowie z Katarzyną Janowską:

Uważam się zresztą za igraszkę losu, za kogoś, czyje życie bardzo mało od niego zależało. [...] Czasami bardzo bym chciał popłakać nad sobą, ale zawsze powstrzymywało mnie uczucie przyzwoitości i poczucie formy ${ }^{130}$.

O swoim dzieciństwie i wczesnej młodości, a także pasjach, opowiedział W. Kuczok ${ }^{131}$.

W każdej z tych rozmów pojawiał się jednak w mniejszym lub większym stopniu wątek twórczości rozmówców. Wspomniany autor Opowieści przebranych wyznał:

Każde zdanie oglądam z nieufnością, staram się wykrzesać z niego jakieś iskry, choć czasem przydałoby się najprościej opisać przejście człowieka na drugą stronę ulicy ${ }^{132}$.

126 Zob. np. A. Z. Marszałek, Paweł Huelle w mercedesie, „Polityka” 2001, nr 37, s. 56; [notowała Agnieszka Wójcik], Napiszę, jak się napatrzę, ibidem, nr 36, s. [54]; Magia mediów, ibidem, nr 48, s. 56.

127 Zob. np.: „Polityka” 2005, nr 22, s. 70-71: E. E. Schmidt, Oskar i Pani Róża. Książka była nie tylko recenzowana, ale i reklamowana. Recenzja: ibidem 2004, nr 9, s. 71; reklama: ibidem, nr 46, s. 14/[15].

128 Informacje uzyskane dzięki korespondencji ze Zdzisławem Pietrasikiem.

129 Trzymam się prosto, rozm. B. Pietkiewicz, „Polityka” 2003, nr 8, s. 76.

130 Jestem igraszkq losu, rozm. K. Janowska, „Polityka” 2001, nr 26, s. [50], 51.

131 Jestem bardzo pokrzywiony, rozm. B. Pietkiewicz, „Polityka” 2004, nr 3, s. 58-59.

132 Ibidem. 
O własnych doświadczeniach, opisanych następnie w książce, opowiedzieli czytelnikom tygodnika m.in. T. Piątek, autor Heroiny133, i S. Shuty, autor powieści Zwał134.

Twórczość danego autora była najczęstszym przewodnim tematem rozmów. Pisarzy pytano nie tylko o ich książki, ale także o to, co chcą poprzez swoje utwory przekazać, jak sami postrzegają swoje pisarstwo, jaką funkcję mu przypisują. I tak na przykład P. Huelle stwierdził m.in., że

Najważniejsza jest chęć opowiedzenia historii, którą uważa się za ważną. Za tekstem powinno stać przeżycie i prawda egzystencjalna. Nie da się inaczej tworzyć. Pisanie na siłę, bez wewnętrznego przekonania, choćby po to tylko, żeby nie zapomniał o tobie kapryśny duch rynku, kończy się źle135.

Nierzadko bohater wywiadu opowiadał o swoim warsztacie pisarskim, odczuciach i emocjach, towarzyszących procesowi twórczemu. Czytelnicy dowiedzieli się na przykład, jak pracuje P. Auster:

Nigdy nie piszę w gorączce. Nie mam twórczych szałów. Jestem powolny, ostrożny, nieufny. [...] Zawsze piszę ręcznie. Najpierw próbuję ołówkiem. Bo można wycierać. Kiedy czuję się pewniej, sięgam po długopis. Dopiero kiedy mam gotowy kompletny akapit, piszę go na maszynie. Potem zaczynam na kartkach budować kolejny akapit. Kiedy się już nadaje, znów siadam do maszyny ...136.

\section{Z kolei D. Masłowska wyznała:}

Gdy pisałam książkę, czułam osobny świat, takie niesamowite wciągnięcie, takie podporządkowanie. Rzeczywistość przestaje wtedy męczyć, idzie się przez nią z nastawieniem, że zaraz coś się znajdzie, coś się stanie i można będzie to dołączyć do tego osobnego świata ${ }^{137}$.

\section{Natomiast E. Lipska opowiadając o swoich wierszach zaznaczyła:}

granicę mam instynktownie zapisaną w sobie. Żaden „przemyt” wydarzeń osobistych. To wcale nie znaczy, że nie korzystam ze swoich biograficznych przeżyć czy faktów, ale rzadko opisuję je wprost. Czasami zaszyfrowuję swoją rzeczywistość, przemalowuję obrazy, zniekształcam formy - ale właśnie na tym polega pewnie poetycka zabawa138,

zaś A. Nothomb dzieląc się z czytelnikami „Polityki” swoimi przemyśleniami, stwierdziła:

\footnotetext{
133 Heros na heroinie, rozm. B. Pietkiewicz „Polityka” 2002, nr 22, s. 90-91.

134 Zwiędły biust konsumpcji, rozm. M. Czubaj, „Polityka” 2005, nr 4, s. 68-69.

135 Bo sa góry, rozm. J. Wróblewski, „Polityka” 2002, nr 3, s. 48.

136 Piszę na papierze w kratkę, rozm. J. Żakowski, „Polityka” 2004, nr 19, s. 60.

137 Wszystko rzuca cień, rozm. B. Pietkiewicz, „Polityka” 2003, nr 4, s. 52.

138 Minęła piąta po południu, rozm. K. Janowska, „Polityka” 2003, nr 25, s. 66.
} 
Myślę, że tu należy szukać tajemnicy mojego sukcesu - jestem znikąd i nigdzie nie należę. Każdy się może we mnie rozpoznać. [...] Piszę, posługując się dwiema istniejącymi we mnie skłonnościami - romantyczną i destrukcyjną ${ }^{139}$.

Nierzadko padały pytania dotyczące kondycji współczesnej literatury. T. Konwicki stwierdził m.in.

takiej wiary w literaturę, jaką miało moje pokolenie i wcześniejsze, dziś już nie ma. [...] Dziś wysoko został awansowany rynek najniższy, literatura obyczajowo-rodzajowo-romansowa, która cieszy się i będzie się cieszyć powodzeniem u niezbyt wymagającego czytelnika140.

\section{Z kolei U. Eco ostrzegał:}

Ostatnio pojawiło się prawdziwe niebezpieczeństwo: Internet może zagrozić pojęciu skończonego dzieła i jego autora. [...] Tekst-archetyp przestaje istnieć, znika też fundamentalne poczucie bliskości, jakie staje się naszym udziałem w kontakcie z książką ${ }^{141}$.

I w tym przypadku warto zwrócić uwagę na tytuły tej formy prezentacji literatury. Oto kilka wybranych przykładów ${ }^{142}$ : Bo sq góry, Diagnoza ze skarpetek, Duszq, mózgiem, rękq, Heros na heroinie, Jestem igraszkq losu, Piękna teoria wszystkiego, Trzy paszporty mojego syna, Wszystko rzuca cień, Zbrodnia rozrywkowa.

Podsumowując, wywiady z pisarzami lub innymi przedstawicielami świata literackiego były z reguły obszerne, poruszano w nich tematy ważne i interesujące. Były rzetelnie przygotowywane, solidnie dopracowane; dzięki nim czytelnicy mieli możliwość poznać twórczość wybranego rozmówcy, a także, nierzadko, koleje jego zawodowego życia. Dziennikarz, prowadzący rozmowę, nie ograniczał się do zadawania suchych pytań, nierzadko komentował na bieżąco odpowiedź pisarza, wypowiadając własne sądy i opinie na temat omawianych spraw.

\subsubsection{Warto czytać $^{143}$ : reklamy książek}

Dużo miejsca na łamach pisma zajmowała reklama. Biorąc pod uwagę temat pracy, można wyróżnić trzy zasadnicze kategorie, będące przedmiotem anonsów, związanych z interesującą nas problematyką:

139 Wirus sukcesu, rozm. J. Orzechowska, „Polityka” 2002, nr 30, s. 51.

140 Kawka i papierosik, rozm. K. Janowska, „Polityka” 2005, nr 16, s. [73]

141 Ginekolodzy też się zakochuja, rozm. J. Orzechowska, „Polityka” 2004, nr 2, s. 59.

142 Kolejno: „Polityka” 2002, nr 3, s. 47-48; 2004, nr 44, s. 74, 76; 2001, nr 42, s. 17; 2002, nr 22, s. 90-91; 2001, nr 26, s. 48-51; 2002, nr 18, s. 76-68; 2003, nr 41, s. 58-60; nr 4, s. 52-53; 2002, nr 50, s. 66-[67].

143 Hasło reklamowe w jednym z anonsów. Zob. „Polityka” 2005, nr 47, s. 102. 
1) książki (w tym encyklopedie, leksykony, słowniki, podręczniki, poradniki, przewodniki, albumy, atlasy i zeszyty z ćwiczeniami),

2) akcje tygodnika związane z książką (konkursy, targi, spotkania) ${ }^{144}$,

3) prasa, w tym autoreklama ${ }^{145}$.

Tego typu reklam pojawiło się w piśmie ogółem 2021.

Ciekawą, choć wcale nie największą grupę, stanowią inseraty książkowe. W sumie znalazło się tu ich 696, w tym m.in. 91 dotyczyło encyklopedii, 50 odnosiło się do słowników, 22 reklamowało podręczniki ${ }^{146}$. W tabeli 9 zaprezentowano liczbę tego typu reklam w poszczególnych latach.

Tabela 9. Ogłoszenia wydawców książek na łamach „Polityki” w latach 2001-2005

\begin{tabular}{|c|c|}
\hline Rok & Liczba reklam \\
\hline 2001 & 268 \\
\hline 2002 & 144 \\
\hline 2003 & 64 \\
\hline 2004 & 138 \\
\hline 2005 & 82 \\
\hline Ogółem & 696 \\
\hline
\end{tabular}

Źródło: badania własne.

Trudno mówić o stałej tendencji w liczbie zamieszczanych każdego roku ogłoszeń. Największa była ona w pierwszym badanym roczniku, najniższa dwa lata później, w roku następnym ponownie wzrosła, by w ostatnich analizowanych 12 miesiącach powtórnie ulec wyraźnemu zmniejszeniu. Inseraty drukowane były w różnych miejscach pisma, nie zawsze jednak ich lokalizacja była wybrana trafnie. Nawet biorąc pod uwagę wcześniejsze planowane rozmieszczenie materiałów redakcyjnych, Biuro Reklamy powinno jednak starać się, by unikać gaf w postaci np. niefortunnie umieszczonej reklamy Wielkiej encyklopedii PWN. Anons pojawił się tuż pod działem: Fusy, plusy i minusy; dodatkowo, jak na ironię, reklama opatrzona była hasłem: Inwestuj $w$ rzeczy wielkie ${ }^{147}$. Na szczęście, takich wpadek było niewiele.

144 Akcje pisma ze względu na swą dwojaką postać (reklamę i komentarz tekstowy) zostaną omówione w dalszej części rozdziału.

145 Zagadnienie dotyczące informacji o prasie na łamach prezentowanego pisma zostanie dokładniej przedstawione w ostatniej części rozdziału.

146 Do podanej liczby inseratów nie wliczono ogłoszeń reklamujących wydawnictwa multimedialne (było ich w sumie 28, w tym 22 inseraty dotyczące podręczników oraz 6 anonsów promujących słowniki).

147 „Polityka” 2005, nr 45, s. [109]. 
Najczęściej reklamowano tytuły, nad którymi w „Polityce” obejmowano patronat medialny. Stosunkowo dużo było inseratów dotyczących książek, wydanych przez tygodnik (samodzielnie lub wspólnie z innym wydawnictwem). Ponadto dość często, podobnie jak w przypadku recenzji, zdarzały się reklamy książek, których autorami byli współpracownicy pisma.

Kwestią anonsów wydawniczych zajmowało się Biuro Reklamy. Starania w tym kierunku podejmowane były zarówno ze strony tygodnika, jak i samych wydawców. Mogli oni decydować o formie anonsu poprzez zaproponowanie własnego projektu lub też ograniczali się do akceptacji oferty biura w tym zakresie.

W badanym okresie $\mathrm{w}$ taki sposób do czytelnika dotarła informacja o 541 tytułach książek. W reklamach pojawiło się 253 różnych autorów ${ }^{148}$ (Aneks 5. Autorzy książek reklamowanych na łamach „Polityki” w latach 2001-2005), w tym 143 autorów polskich i 110 obcych. Czasem zdarzało się, że reklamowano książkę wcześniej zrecenzowaną na łamach pisma bądź odwrotnie: najpierw pojawiała się reklama, a później recenzowano dany tytuł. Tak było na przykład w przypadku książki Mariusza Maślanki: Bidul ${ }^{149}$, Amosa Oza: Czarownik swojego plemienia ${ }^{150}$, Jerzego Sosnowskiego: Prąd zatokowy ${ }^{151}$ czy T. Piątka: Bagno ${ }^{152}$.

Ogłoszenia wydawnicze w większości przypadków nie posiadały jednak zasadniczej cechy, decydującej o ich powodzeniu: zazwyczaj ich powtarzalność ograniczała się do dwukrotnego ${ }^{153}$, bardzo rzadko trzykrotnego ${ }^{154}$ pojawienia się danego tytułu. Wyjątkiem było Wydawnictwo Kurpisz SA oraz Wydawnictwo Naukowe PWN, które znacznie częściej zamieszczały reklamę tego samego tytułu.

Następnym wyjątkiem były książki wydane przez „Politykę” wspólnie z innym wydawnictwem bądź autorstwa współpracowników pisma. Jak wykazała jednak analiza anonsów, znaczna część edytorów niemal w każdym numerze zamieszczała swój inserat, zmieniała jego zawartość, za każdym razem proponując inny (bądź inne) tytuł (tytuły), choć forma

$148 \mathrm{~W}$ tej liczbie brak jest tych przypadków, kiedy autor był trudny do ustalenia, bądź reklamodawca go nie podawał, albo też książka wydana była przez zespół autorów. Na przykład dotyczyło to encyklopedii, słowników czy leksykonów.

149 „Polityka” 2004, nr 10, s. 21: reklama książki, recenzja: ibidem, s. 55.

150 „Polityka” 2004, nr 44, s. 106: reklama książki, jej recenzja: ibidem, nr 42, s. 59 (książka została zaprezentowana przez samego autora, który opowiedział o niej w ramach rubryki: Co ja tu robię?).

151 „Polityka” 2003, nr 38, s. 106: reklama książki, jej recenzja pojawiła się w tym samym numerze, na s. 70.

152 „Polityka” 2004, nr 8, s. 83: reklama książki, jej recenzja: zob. ibidem, nr 6, s. 57.

153 Tak stało się w przypadku 72 tytułów.

154 Tak zdarzyło się w przypadku 20 tytułów. 
ogłoszenia pozostawała ta sama. W ten sposób wydawcy reklamowali niejako samo swoje istnienie, nie zaś konkretne tytuły z własnej oferty, tworząc raczej tylko jej ogólny przegląd. Wykorzystując tę samą formę anonsu, ale niemal za każdym razem proponując inne tytuły, informowało o swym istnieniu i ofercie, na przykład Wydawnictwo W.A.B. i Wiedza Powszechna. Jednak zdarzało się, że propozycje powtarzały się, co obrazuje tabela 10.

Tabela 10. Najczęściej powtarzające się tytuły w reklamach wydawniczych na łamach „Polityki” w latach 2001-2005

\begin{tabular}{|c|c|c|}
\hline Tytuł reklamowanej pozycji & Wydawca & Liczba anonsów \\
\hline $\begin{array}{l}\text { Britannica - edycja polska } \\
\text { (pod red. W. Wolarskiego) }\end{array}$ & Wydawnictwo Kurpisz SA & 22 \\
\hline $\begin{array}{l}\text { Wielka encyklopedia geografii świata } \\
\text { (pod red. R. Przebitkowskiego) }\end{array}$ & Wydawnictwo Kurpisz SA & 22 \\
\hline $\begin{array}{l}\text { Wielka historia powszechna } \\
\text { (pod red. J. Dąbrowskiego) }\end{array}$ & Wydawnictwo Kurpisz SA & 20 \\
\hline Za stołem (P. Adamczewski) & $\begin{array}{l}\text { Wydawnictwo Sens, } \\
\text { „Polityka” } \\
\text { Spółdzielnia Pracy }\end{array}$ & 19 \\
\hline Nalewka na czereśniach (L. Stomma) & $\begin{array}{l}\text { Wydawnictwo Sens, } \\
\text { „Polityka” } \\
\text { Spółdzielnia Pracy }\end{array}$ & 14 \\
\hline Suche oczy (R. M. Groński) & $\begin{array}{l}\text { Wydawnictwo Sens } \\
\text { „Polityka” } \\
\text { Spółdzielnia Pracy }\end{array}$ & 13 \\
\hline Wielka encyklopedia powszechna PWN & $\begin{array}{l}\text { Wydawnictwo Naukowe } \\
\text { PWN }\end{array}$ & 11 \\
\hline Irytacje (A. Szczypiorski) & $\begin{array}{l}\text { AWR „Polityka”, Wydawni- } \\
\text { ctwo Sens }\end{array}$ & 9 \\
\hline Atlas Europa: 2002-2003 & dounpol - Pilot & 7 \\
\hline Świat i Polska 2004 & $\begin{array}{l}\text { AWR „Polityka”, The } \\
\text { Economist }\end{array}$ & 7 \\
\hline Encyklopedia zdrowia Gazety Wyborczej & Agora SA & 4 \\
\hline Kanon królewski (Z. Kałużyński) & $\begin{array}{l}\text { [Latarnik; „Polityka” } \\
\text { Spółdzielnia Pracy] }\end{array}$ & 4 \\
\hline
\end{tabular}

Źródło: badania własne.

Widać, że najczęściej proponowane tytuły to oferta wspomnianego wydawnictwa encyklopedycznego i książki autorów tygodnika. Tutaj także forma pozostawała bez zmian, łącznie jednak z tytułem, o którym wydawca wytrwale informował ok. 20 razy. 
Inni wydawcy nie byli już tak konsekwentni, przynajmniej w odniesieniu do jednego tytułu. Nieco inaczej bowiem przedstawiała się sytuacja w przypadku jednego autora i kilku jego dzieł. Ale i wtedy trudno jest mówić o systematycznej, wielokrotnej informacji. W ciągu analizowanych 5 lat w grupie pisarzy, których nazwisko zostało wspomniane przynajmniej czterokrotnie, i to przy okazji więcej niż jednej książki, znalazło się zaledwie ośmiu autorów (tabela 11).

Tabela 11. Autorzy książek reklamowanych przez wydawców (więcej niż 1 tytuł) na łamach „Polityki” w latach 2001-2005

\begin{tabular}{|c|c|c|c|}
\hline Nazwisko autora & Liczba inseratów & Liczba tytułów & Tytuły reklamowanych książek \\
\hline $\begin{array}{l}\text { Zygmunt Kałużyń- } \\
\text { ski }\end{array}$ & 7 & 2 & $\begin{array}{l}\text { Do czytania pod prysznicem } \\
\text { Kanon królewski }\end{array}$ \\
\hline Isaiah Berlin & 4 & 2 & $\begin{array}{l}\text { Pokrzywione drzewo człowieczeń- } \\
\text { stwa } \\
\text { Rosyjscy myśliciele }\end{array}$ \\
\hline John M. Coetzee & 4 & 4 & $\begin{array}{l}\text { Czekając na barbarzyńców } \\
\text { Hańba } \\
\text { W sercu kraju } \\
\text { Wiek żelaza }\end{array}$ \\
\hline Norman Davies & 4 & 4 & $\begin{array}{l}\text { Boże igrzysko. Historia Polski } \\
\text { Europa. Historia } \\
\text { Powstanie } 44 \\
\text { Smok wawelski nad Tamiza }\end{array}$ \\
\hline Robert Makłowicz & 4 & 4 & $\begin{array}{l}\text { CK Kuchnia } \\
\text { Czy wierzyć platynowym blondyn- } \\
\text { kom? Rzecz o restauracjach i nie } \\
\text { tylko } \\
\text { Kalendarz znaleziony w brytfannie } \\
2005 \\
\text { Zjeść Kraków. Przewodnik subiek- } \\
\text { tywny }\end{array}$ \\
\hline $\begin{array}{l}\text { Krzysztof Mrozie- } \\
\text { wicz }\end{array}$ & 4 & 4 & $\begin{array}{l}\text { Ćakra, czyli kołowa historia Indii } \\
\text { Dziennikarz w globalnej wiosce } \\
\text { Moc, niemoc i przemoc } \\
\text { Ucieczka do Indii }\end{array}$ \\
\hline Agnieszka Osiecka & 4 & 2 & $\begin{array}{l}\text { Galeria Potworów } \\
\text { W tańcu }\end{array}$ \\
\hline Jan Twardowski & 4 & $5+$ & \begin{tabular}{|l|} 
Niecodziennik cały \\
Przezroczystość. Wybór wierszy \\
Śmierć na śmierć nie umiera. Myśli \\
wybrane \\
Niebieskie okulary \\
Znaki ufności
\end{tabular} \\
\hline
\end{tabular}

Źródło: badania własne. 
Korzystnym skutkiem braku powtarzalności reklam tych samych tytułów i niewielkiej liczby powtarzanych reklamowanych autorów była bez wątpienia duża różnorodność książek proponowanych w ten sposób czytelnikowi. Miał on możliwość poznać ofertę 57 edytorów, bo tylu zdecydowało się użyć tej formy promocji. Jest to liczba znacznie niższa od danych dotyczących liczby oficyn, z których korzystali recenzenci „Polityki”. W tabeli 12 zaprezentowano wydawców, którzy najczęściej reklamowali swą ofertę na łamach pisma (pełen wykaz: zob. Aneks 6. Wydawcy, którzy zamieścili swe anonse na łamach „Polityki” w latach 2001-2005).

Tabela 12. Wydawcy najczęściej zamieszczający inseraty na łamach „Polityki” w latach 2001-2005

\begin{tabular}{|c|c|}
\hline Nazwa wydawcy & Liczba anonsów \\
\hline Dom Wydawniczy Bellona & 184 \\
\hline Społeczny Instytut Wydawniczy Znak & 82 \\
\hline Wydawnictwo Kurpisz SA & 73 \\
\hline $\begin{array}{l}\text { „Polityka” Spółdzielnia Pracy i „The } \\
\text { Economist” }\end{array}$ & $67^{a}$ \\
\hline WSiP & 44 \\
\hline Wydawnictwo W.A.B. & 35 \\
\hline Wiedza Powszechna & 33 \\
\hline Wydawnictwo Prószyński i S-ka & 31 \\
\hline Wydawnictwo Naukowe PWN & \multirow{2}{*}{24} \\
\hline Wydawnictwo Wiedza Powszechna & \\
\hline Wydawnictwo Wiedza i Życie & 12 \\
\hline
\end{tabular}

${ }^{a} \mathrm{~W}$ tym trzykrotnie jako samodzielne wydawnictwo, 11 wespół z „The Economist" i 53 razy we współpracy z Wydawnictwem Sens.

Źródło: badania własne.

Porównując tabelę 12 z analogiczną, odnoszącą się do wydawców najczęściej recenzowanych książek, zauważyć można, że w niewielkim stopniu oficyny te powtarzają się. Dom Wydawniczy Bellona, który reklamował 184 tytuły, w tabeli $7 \mathrm{w}$ ogóle się nie pojawia; podobnie jest w przypadku 7 innych wydawnictw. Wynika to m.in. z charakteru ich oferty. Na przykład Wydawnictwo Kurpisz SA czy Wydawnictwo Naukowe PWN specjalizuje się w edycji encyklopedii i słowników, nie recenzowanych na łamach pisma, natomiast WSiP proponuje podręczniki, także nie stanowiące przedmiotu recenzji. Powtarzającymi się edytorami byli: Społeczny Instytut Wydawniczy Znak, Wydawnictwo W.A.B. oraz Prószyński i S-ka. Znamienne było również zjawisko, że z łamów „Polityki” nie korzystali wydawcy literatury 
masowej, na przykład nie znajdziemy tu reklam proponujących kupno romansów, a w liczbie najczęstszych reklamodawców występowały oficyny, zajmujące się opracowaniem źródeł informacji typu encyklopedie czy podręczniki. Potwierdza to tezę, że charakter tygodnika i jego adresat determinował nie tylko jego zawartość merytoryczną, ale również rodzaj proponowanej literatury, także tej $\mathrm{w}$ formie reklam ${ }^{155}$. Jednocześnie pojawiały się tu również anonse mało znanych oficyn, jak na przykład Bonowo, ISA, Nadir, Wydawnictwo STO, Wydawnictwo SWPS Academica.

Warto jednak zaznaczyć, że Dom Wydawniczy Bellona zamieścił reklamę swej oferty czterokrotnie $\mathrm{w}$ formie niezwykle rozbudowanej. W dwóch przypadkach była to czterostronicowa wkładka do tygodnika, zszyta z nim, a zawierająca raz 73 tytuły 156 , a raz 64157 . Natomiast w dwóch pozostałych sytuacjach były to całostronicowe reklamy tego wydawnictwa, proponujące raz 21 tytułów ${ }^{158}$, a raz $20^{159}$. Były to ogłoszenia okazjonalne, trzy z nich pojawiły się przed Świętami Bożego Narodzenia, a jedno z okazji Wielkanocy. Wtedy też Wydawnictwo świętowało jubileusz 55-lecia swego istnienia, co zaowocowało niezwykle interesującą formą inseratu. Podobną formę anonsu (czterostronicową wkładkę) zastosował Społeczny Instytut Wydawniczy Znak, który w numerze 46 (2001) zamieścił w ten sposób informację o 51 tytułach ${ }^{160}$. Także $w$ tym przypadku był to pomysł związany ze zbliżającymi się Świętami. Nie zabrakło zresztą w ogłoszeniu świadczących o tym elementów. Obydwa przypadki obrazują zdjęcia 6 i 7 (s. 95).

W obydwu ogłoszeniach zamieszczono kopie okładek proponowanych książek. Jednocześnie $w$ anonsie pierwszym (zdjęcie 6) warto zwrócić uwagę na informacje, związane z jubileuszem oficyny (na przykład „Struktura tematyczna tytułów 2001” czy „Łączne przychody Bellony w latach 1992-2001"). Z kolei reklama drugiego wydawcy (zdjęcie 7) jest bardziej czytelna, dzięki mniejszej liczbie elementów. Jednak trzy lata później, w 2004 r., oficyna ta, ponownie zamieszczając swoją ofertę, zaproponowała już ponad dwukrotnie więcej książek (24 tytuły) ${ }^{161}$.

Zazwyczaj jednak ta postać obecności książki na łamach „Polityki” prezentowała się znacznie skromniej. Analiza inseratów pozwoliła wyróżnić dwa ich typy.

155 Tezę tę potwierdza również Z. Pietrasik: „zasada generalna jest taka, że możemy reklamować >towar< wysokiej marki, odpowiadający gustom i poziomowi naszego odbiorcy".

156 „Polityka” 2001, nr 49, pomiędzy s. $42 / 43$ i 66/67.

157 „Polityka” 2002, nr 46, pomiędzy s. 46/47 i 62/63.

158 „Polityka” 2002, nr 13, s. [65].

159 „Polityka” 2003, nr 47, s. [73].

160 „Polityka” 2001, nr 46, pomiędzy s. 46/47 i 70/71.

161 „Polityka” 2004, nr 46, pomiędzy s. 14/15 oraz 110/111. 


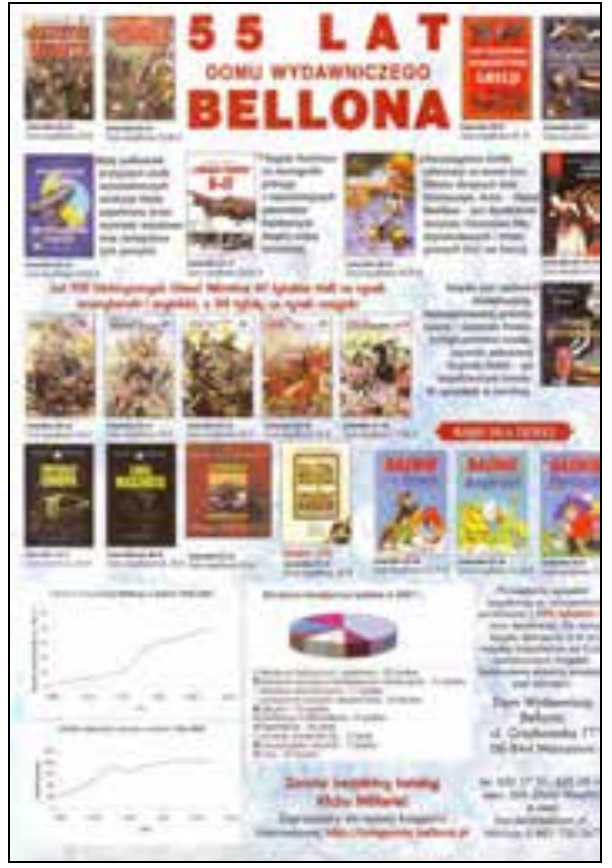

Zdjęcie 6. Wybrane ogłoszenie wydawnicze zamieszczone na łamach „Polityki” „Polityka” 2002, nr 13, s. [65]

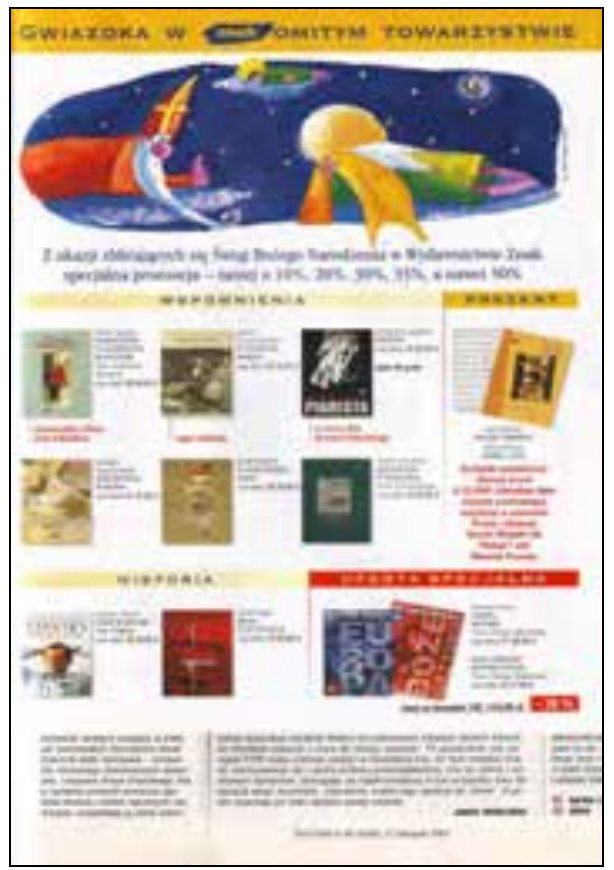

Zdjęcie 7. Wybrane ogłoszenie wydawnicze zamieszczone na łamach „Polityki” „Polityka” 2001, nr 46

Pierwszy, skromniejszy, ograniczał się do podania autora, tytułu reklamowanej książki wraz z nazwą wydawcy i formą kontaktu z nim (nierzadko był to jedynie adres strony internetowej danej oficyny). Niekiedy dodatkowym elementem bywała kopia okładki reklamowanej książki. Nie zapominano jednak o zaznaczeniu patronów medialnych czuwających nad wydaną książką.

Drugi typ reklamy zawierał dodatkowe informacje w postaci krótkiej adnotacji treściowej, dotyczącej polecanej książki i jej cenę. Poniżej zamieszczono wybrane przykłady tego typu anonsów (zdjęcia 8 i 9). 


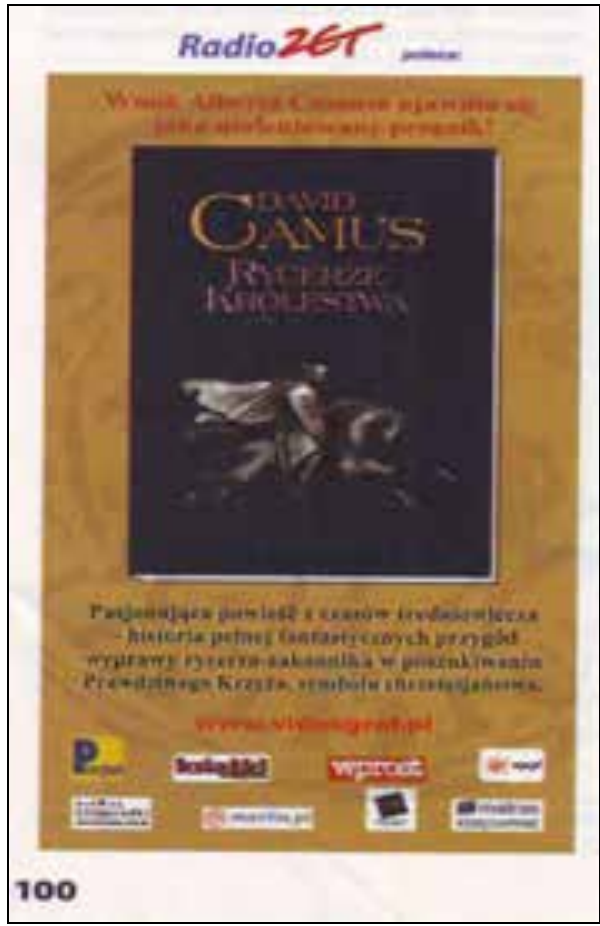

Zdjęcie 8. Wybrane ogłoszenie wydawnicze zamieszczone na łamach „Polityki” „Polityka” 2005, nr 45, s. 100

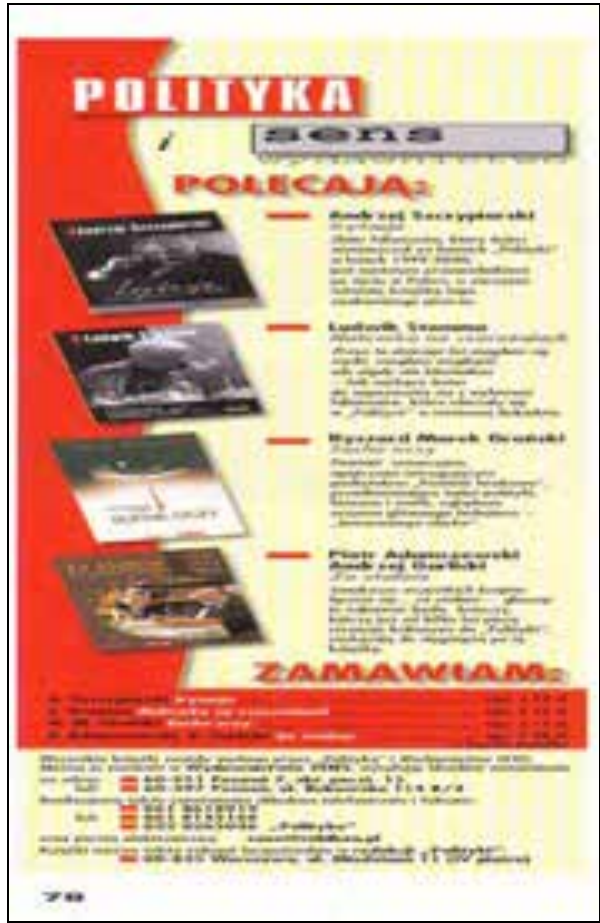

Zdjęcie 9. Wybrane ogłoszenie wydawnicze zamieszczone na łamach „Polityki” „Polityka” 2001, nr 11, s. 78

Czasem w inseracie pojawiała się opinia znanej osoby na temat prezentowanego tytułu162 i dodatkowo promujące go hasła reklamowe.

Częściej można było spotkać pierwszy typ ogłoszenia, chociaż wymienione elementy nierzadko mieszały się ze sobą. Reklamy bywały najczęściej kolorowe, przyjmowały postać raczej niedużych modułów, choć zdarzały się również wspomniane już ogłoszenia całostronicowe. Było ich jednak niewiele. Poza Domem Wydawniczym Bellona takie reklamy zamieszczało na przykład Wydawnictwo Naukowe PWN. Warto na chwilę zatrzymać się przy nim, jako że w tym przypadku inseraty były niezwykle starannie przygotowane, interesujące i bogate w elementy przykuwające wzrok (hasła) - zdjęcia 10 i 11. 


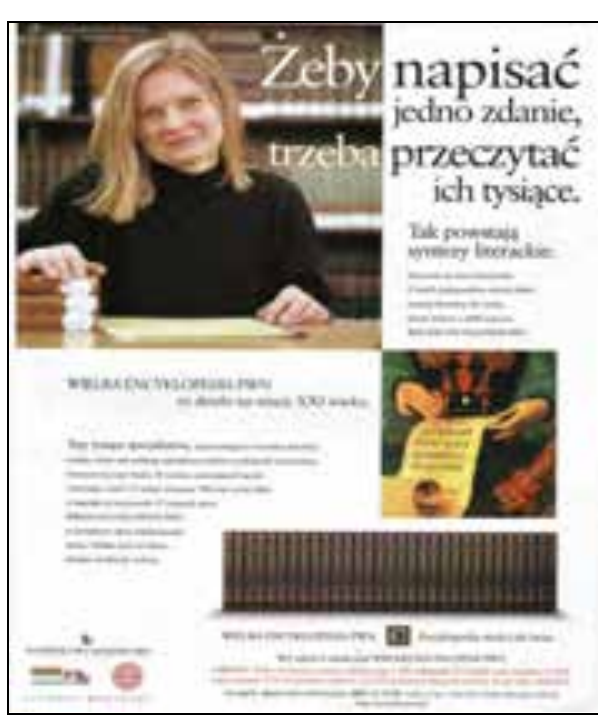

Zdjęcie 10. Wybrane ogłoszenie wydawnicze zamieszczone na łamach „Polityki” „Polityka” 2001, nr 12, s. [107]

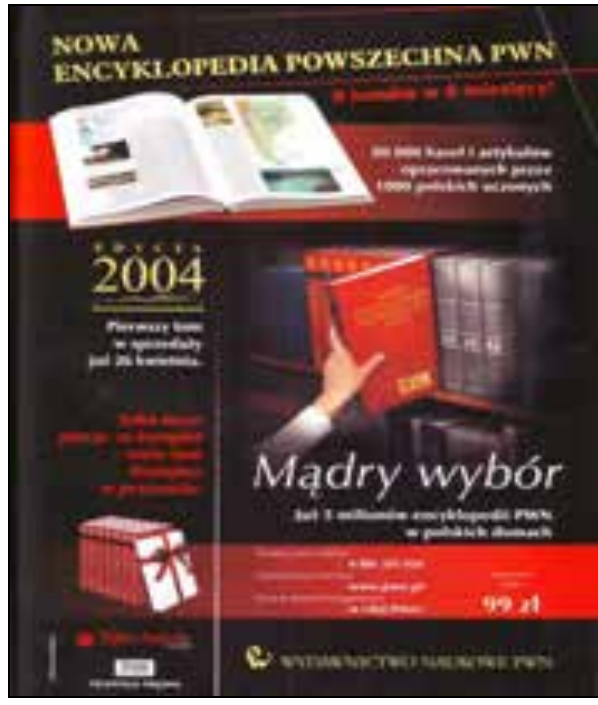

Zdjęcie 11. Wybrane ogłoszenie wydawnicze zamieszczone na łamach „Polityki” „Polityka” 2004, nr 18, s. [67]

Anonse reklamujące Wielkq encyklopedię powszechnq PWN różniły się zdjęciem jednego z jej autorów i hasłem reklamowym, na przykład obok zdjęcia Jerzego Szackiego pojawiły się takie oto słowa: „Życie społeczeństwa nie jest takim chaosem, jak się wydaje. Tyle wiem z socjologii..."163. Ogłoszenia tej oficyny zajmowały przeważnie całą stronę, chociaż zdarzały się też inseraty mniejsze objętościowo, zawierające w konsekwencji znacznie mniej elementów ${ }^{164}$.

Jak już wspomniano, w tygodniku przeważały reklamy niewielkie objętościowo. Wynikało to naturalnie w pierwszym rzędzie z możliwości i chęci wydawcy, objętość inseratu bowiem zależna była od ceny. Prawdopodobnie z tego powodu niektórzy edytorzy ograniczali się do krótkiej, acz treściwej informacji o wybranych tytułach, przy okazji starając się maksymalnie wykorzystać zakupione miejsce, informując czytelnika o swej ofercie. Tak było m.in. w przypadku Wydawnictwa Wiedza i Życie (zdjęcia 12 i 13). 


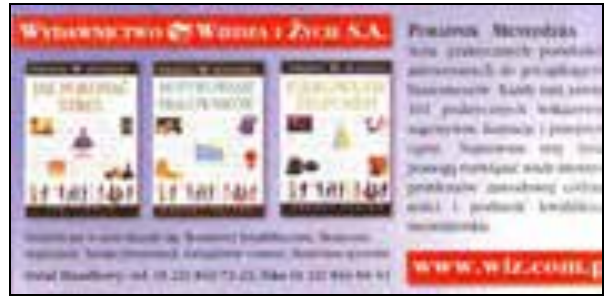

Zdjęcie 12. Wybrane ogłoszenie wydawnicze zamieszczone na łamach „Polityki” „Polityka” 2001, nr 5, s. 53

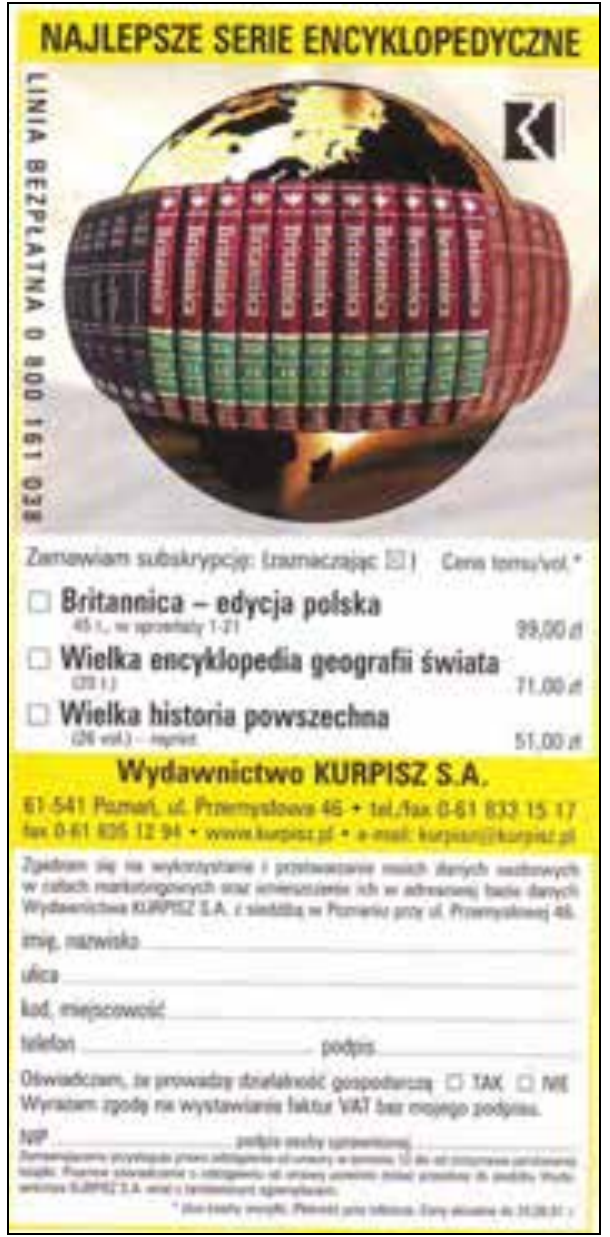

Zdjęcie 13. Wybrane ogłoszenie wydawnicze zamieszczone na łamach „Polityki” „Polityka” 2001, nr 20, s. 67

W pierwszym przypadku mamy do czynienia z reklamą, w której znajdują się wszystkie podstawowe elementy: wybrane $\mathrm{z}$ oferty wydawniczej trzy tytuły, przy okazji wspomniane także pozycje wcześniej wydane, a wszystkie wchodzące w skład omówionej obok serii. Podany jest kontakt z wydawcą zarówno telefoniczny, jak i e-mailowy. Przy ogłoszeniu drugim (zdjęcie 13) zwraca uwagę oryginalny pomysł pokazania grzbietów reklamowanych encyklopedii, oplatających kulę ziemską. Dodatkowym elementem jest również cena i gotowy kupon na subskrypcję proponowanych tytułów. 
Obok inseratów książkowych pojawiła się raz reklama innego edytora, $\mathrm{z}$ założenia promująca samo wydawnictwo, a nie konkretne tytuły z jego oferty, choć i one znalazły się w ogłoszeniu ${ }^{165}$. Uwagę czytelnika przyciągało w tym przypadku hasło reklamowe, ale jeśli ktoś chciałby przeczytać tytuły widoczne na ogłoszeniu, musiałby użyć do tego celu lupy. Nazwa wydawcy, w postaci jego exlibrisu, także nie oszałamiała wielkością. Nieco lepiej prezentowała się inna forma anonsu tego wydawcy. W tym przypadku podstawowym elementem był opis proponowanej serii podręczników; wzmocniony opinią jednego z nauczycieli, korzystających z proponowanych podręczników - zdjęcia 14 i 15.

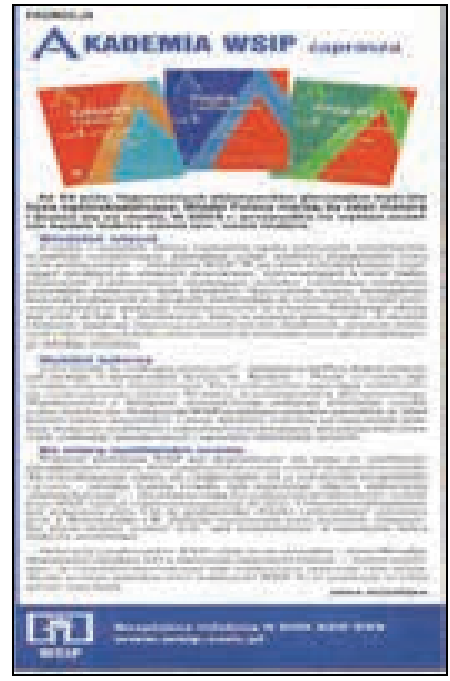

Zdjęcie 14. Wybrane ogłoszenie wydawnicze zamieszczone na łamach „Polityki” „Polityka” 2002, nr 35, s. [59]

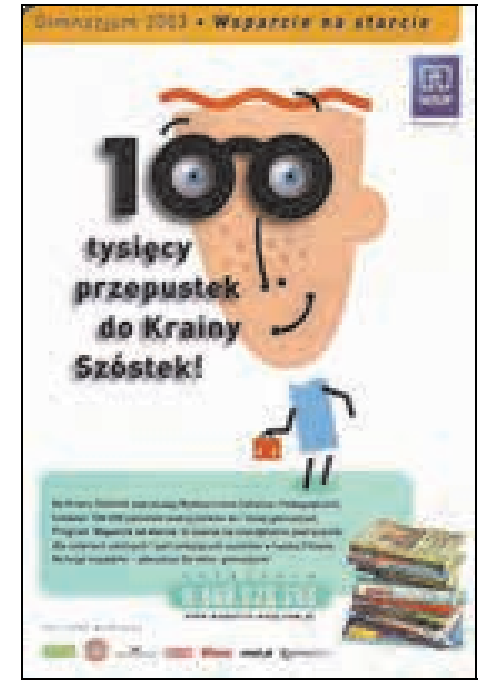

Zdjęcie 15. Wybrane ogłoszenie wydawnicze zamieszczone na łamach „Polityki” „Polityka” 2003, nr 24, s. [45]

Przedmiotem reklamy bywały również konkursy i rozmaitego rodzaju akcje, organizowane przez tygodnik oraz instytucje związane z książką. Stanowią one dodatkową formę obecności książki na jej łamach, będąc jednocześnie przykładem zaangażowania „Polityki” w sprawy kultury i literatury. Przyjmowały one dwojaką postać: anonsu i informacji tekstowej, dlatego zostaną omówione w oddzielnym, zamieszczonym poniżej podrozdziale. 


\subsubsection{4. Łańcuch książkowo-pokarmowy ${ }^{166}$ inne formy informacji o książce}

Tego typu informacji pojawiło się w badanym okresie 1084. Jak już częściowo wspomniano w tabeli 2 , złożyły się nań:

- sylwetki/portrety (113),

- artykuły, poświęcone sprawom książki lub rynku wydawniczo-księgarskiego (296),

- ekranizacje, adaptacje i inscenizacje znanych powieści (121),

- listy czytelników, nawiązujące do zamieszczonej informacji związanej z książką (58),

- konkursy i akcje, organizowane przez „Politykę” (49),

- inne ${ }^{167}$ (447).

Miały one różną objętość, poczynając od jednozdaniowych wzmianek poprzez kilkuzdaniowe informacje i komentarze, jednostronicowe artykuły, a kończąc na tekstach dłuższych, którym poświęcano więcej niż jedną stronę. Znajdowały się one, w zależności od tematu, w różnych działach i rubrykach, choć najczęściej czytelnik mógł je odnaleźć w ramach Kultury bądź Afisza.

Ze względu na ograniczone możliwości objętościowe pracy, niemożliwe jest pełne omówienie wszystkich tego typu informacji; bardziej szczegółowa ich prezentacja znalazła się w innych tekstach autorki ${ }^{168}$, poświęconych tygodnikowi. Tutaj zaprezentowane zostaną najciekawsze, a jednocześnie najbardziej reprezentatywne przykłady.

\subsection{Dojść do stosu, nie dalej:169: sylwetki/portrety}

Portrety twórców i wspomnienia z nimi związane pojawiły się na łamach tygodnika 113 razy. W ten sposób przybliżono sylwetki 94 prozaików, poetów oraz osób związanych ze środowiskiem dziennikarskim (głównie z tygodnikiem „Polityka”).

166 Tytuł artykułu, poświęconego rynkowi wydawniczo-księgarskiemu. Zob. „Polityka” 2004, nr 21, s. 70-[73].

$167 \mathrm{~W}$ tej kategorii uwzględniono wszelkiego rodzaju informacje, zazwyczaj w postaci krótkich notek, donoszących np. o nagrodach, otrzymanych przez ludzi związanych z książką, nadaniu imienia twórcy szkole, instytucji itd., jak również informujące o ich jubileuszach, także śmierci.

168 Zob. np. M. Przybysz-Stawska, Literatura w prasie polskiej na przykładzie tygodnika „Polityka”, [w:] Mistrzowie literatury czy dziennikarstwa?, red. naukowa K. Wolny-Zmorzyński, W. Furman, J. Snopek, Seria: Akademickie Warsztaty Dziennikarskie, Wydawnictwo POLTEXT, Warszawa 2011, s. [44]-57.

169 Felieton o Ilji Erenburgu. Zob. „Polityka” 2002, nr 17, s. 95. 
Tę formę obecności książki na łamach pisma zamieszczano nierzadko w związku z jubileuszem obchodzonym przez danego twórcę, nagrodą przezeń otrzymaną, jego odejściem (jak na przykład w przypadku Cz. Miłosza czy R. Ludluma) bądź rocznicą śmierci. Niekiedy (jak choćby w przypadku T. Pratchetta) pretekstem do napisania o znanym pisarzu była jego wizyta w Polsce.

Nie zawsze były to szczegółowe charakterystyki prezentowanej postaci, ale za każdym razem w pewnym stopniu ją przybliżały, na przykład poprzez analizę jej twórczości. Niekiedy drukowano je w ramach specjalnie tworzonych działów (Ludzie, Pożegnanie, Wspomnienie), sporadycznie w działach Kraj lub Ludzie i Wydarzenia, Świat. Częściej jednak odnaleźć je można było na stronach poświęconych kulturze. 0 znanych mistrzach pióra pisali czasem felietoniści „Polityki”, na przykład Jerzy Pilch, Jan Z. Słojewski czy Ludwik Stomma.

W ten sposób zaprezentowano m.in. sylwetkę Tadeusza Boya-Żeleńskiego, Karola Dickensa, Ilji Erenburga, Witolda Gombrowicza (dwukrotnie), Bohumila Hrabala, Tove Jansson, Ryszarda Kapuścińskiego, Władysława Kopalińskiego, Stanisława Mackiewicza, Czesława Miłosza (siedmiokrotnie), Andrzeja Frycza Modrzewskiego, Orhana Pamuka, George Sand (dwukrotnie), Sławomira Shuty, Wirginii Woolf, Andrzeja Zagajewskiego (dwukrotnie). (Pełen wykaz wszystkich twórców, których sylwetki omówiono na łamach pisma, zob. Aneks 7. Sylwetki twórców przedstawionych na łamach „Polityki” w latach 2001-2005).

Kilkakrotnie coroczna Nagroda Nobla w dziedzinie literatury stawała się pretekstem, by polskim czytelnikom zaprezentować postać jej laureata. Tak było na przykład w roku 2001, kiedy został nim Vidiadhar S. Naipaul, pisarz w Polsce mało znany, choć jego książki wydawano u nas już w latach 70.170 Podobnie było, kiedy tę prestiżową nagrodę odebrał Imre Kertész za Los utracony, choć w tym przypadku niemal dwustronicowy tekst mniej był portretem samego pisarza, co raczej opisywał ten fragment historii Węgier, który stał się motywem przewodnim nagrodzonej książki ${ }^{171}$. Mariusz Czubaj pisał o Johnie M. Coetzee - nobliście z roku 2003172, a bohaterką felietonu Jerzego Pilcha stała się Elfriede Jelinek (laureatka Nagrody Nobla

170 A. Szostkiewicz, Utracona przeszłość, „Polityka” 2001, nr 43, s. 48-49. Warto też zwrócić uwagę na krótki tekst, zamieszczony w rubryce Niskie loty, w tym samym numerze pisma, w którym zamieszczono niemal dwustronicowy artykuł poświęcony V. S. Naipaulowi, zob. Z. Pietrasik, Plama, s. 46. Zob. też: (jaw), Conrad z Trynidadu, ibidem, nr 42, s. 48.

171 T. Olszański, Rachunek za Nobla, „Polityka” 2003, nr 5, s. 63-64. Pomimo, że I. Kertesz otrzymał nagrodę w 2002 r., tekst na łamach „Polityki” pojawił się na początku $2003 \mathrm{r}$.

172 M. Czubaj, Afrykański chłód, „Polityka” 2003, nr 41, s. 106-[107]. Tekst był prezentacją twórczości J. M. Coetzee. 
z 2004 r.) 173. Informowano także o laureatach rodzimych wyróżnień, na przykład corocznej Nagrody Nike ${ }^{174}$ czy Paszportów Polityki.

Niekiedy czytelnik miał możliwość poznać bliżej sylwetkę twórcy niekoniecznie prezentowaną $\mathrm{w}$ formie laurki. Na przykład znana pisarka, Susan Sontag, stała się przedmiotem polemiki pomiędzy Jerzym Pilchem (który nie szczędził jej uwag krytycznych) i Markiem Królem (pełniącym w tej sytuacji rolę obrońcy autorki Miłośnika wulkanów) ${ }^{175}$, a wspomniany już Gabriela G. Márquez został, wspólnie ze swoim przyjacielem Fidelem Castro, bohaterem, a raczej antybohaterem artykułu Komunizm magiczny ${ }^{176}$. Zazwyczaj jednak postacie twórców kreślono z dużą dozą sympatii, jak choćby w przypadku portretu T. Różewicza ${ }^{177}$. Dwustronicowy tekst poświęcony poecie zakończono fragmentem wiersza, który według jego brata, Stanisława, stanowi klucz do autora Czasu który idzie („Tam jest wszystko, co myśli o rodzinie, domu, miłości, o tym wszystkim, czego dziś ze świata ubywa")178:

...w świetle lamp kopcących / człowiek był zadomowiony / mocniej w radości / głębiej $\mathrm{w}$ trosce / cienie rozchwiane / odchodziły wracały rosły / słowa były cieplejsze / nieśmiałe / dom kołysał się / odpływał z trumną i kołyską ${ }^{179}$.

Podobny w swej wymowie był portret Ryszarda Kapuścińskiego ${ }^{180}$ czy wspomnienie o Tove Jansson, autorce opowieści o Muminkach ${ }^{181}$.

Większość tekstów wzbogacały zdjęcia prezentowanych osób, czasem krótka notka biograficzna. Uwagę zwracały tytuły, na przykład182: Bez szans na sens, Fakt, to fikcja, Guru z górnej półki, Każdy jest, jaki jest, Kochaj

173 J. Pilch, Oblicze noblistki, „Polityka” 2004, nr 42, s. 113 . W tym przypadku autor skoncentrował się raczej na swoich wrażeniach ogólnych niż na szczegółowej charakterystyce pisarki i jej twórczości.

174 W tym przypadku informacje miały jednak zazwyczaj charakter krótkich notek, zob. np.: Nike dla Kuczoka, „Polityka” 2004, nr 41, s. 16; Nike dla Pilcha, ibidem, 2001, nr 42, s. 12; Nike dla Rymkiewicza, ibidem, 2003 nr 41, s. 12; Zaskakująca Nike, ibidem, 2002, nr 40, s. 13.

175 J. Pilch, Głupota Susan Sontag, „Polityka” 2002, nr 38, s. 95; M. Król, Nie lecę na Pilcha, ibidem, nr 41, s. 99; J. Pilch, Upadek Króla, ibidem, nr 42, s. 102.

176 K. Mroziewicz, Komunizm magiczny, „Polityka” 2004, nr 44, s. 59.

177 K. Janowska, Portret w świetle lamp, „Polityka” 2001, nr 40, s. 50-52.

178 Ibidem, s. 52.

179 Ibidem.

180 K. Mroziewicz, Ciągle w podróży, „Polityka” 2005, nr 41, s. 62-[63].

181 M. Strzałkowska, Każdy jest, jaki jest, „Polityka” 2001, nr 28, s. 50-51.

182 Kolejno: „Polityka” 2003, nr 14, s. 64, 66; 2004, nr 52/53, s. 132-135; 2001, nr 29, s. $52-53$; nr 28, s. 50-51; 2004, nr 35, s. 96; 2005, nr 48, s. 50, [52]; nr 39, s. 107; nr 15, s. $116 ; 2002$, nr 1 , s. $87 ; 2004$, nr 18, s. 64-66; 2005, nr 46, s. 72-74; 2003, nr 34, s. 83; nr 34, s. $85 ; 2004$, nr 51, s. [75]. 
dzikiego łabędzia, Krew zatruta nienawiściq, Listy do kobiety życia, Mistrz dygresji, Nie zdradził stylu, Nieznośna trudność bytu, Pustynia rzeczywistości, Siła duszy, U Kornela $w$ duszy niedziela, Waga pamięci.

Podsumowując, można stwierdzić, że ta forma informacji pośrednio związanej z literaturą, prezentowana na łamach omawianego tygodnika, jest zadowalająca. Należy przy tym zaznaczyć, że nierzadko przenikała się ona z tekstami, które w szerszym zakresie podejmowały interesującą nas problematykę. Omawiając wybrane gatunki literackie, autorzy pisma przywoływali reprezentatywnych dla nich twórców. Podobnie było, kiedy na łamach periodyku pojawiał się tekst, traktujący o kondycji współczesnej literatury zarówno rodzimej, jak i obcej; wówczas pisano również o jej przedstawicielach, niekiedy odwołując się do epizodów z ich życia, które wpłynęły na powstanie ich dzieł.

\subsection{Spotkanie z literaturq ${ }^{183}$ : teksty poświęcone książce i rynkowi wydawniczo-księgarskiemu}

Tego typu tekstów ukazało się w tygodniku w badanym okresie 296 (zob. Aneks 8. Wybór tekstów związanych z literaturą i rynkiem wydawniczo-księgarskim, zamieszczonych na łamach „Polityki” w latach 20012005). Ze względu na objętość można wyróżnić kilka ich rodzajów:

1) dłuższe, przynajmniej jednostronicowe artykuły;

2) komentarze, obejmujące zazwyczaj około pół strony;

3) jedno- lub kilkuzdaniowe wzmianki.

Drukowano je w całym tygodniku, chociaż najwięcej znajdowało się ich w ramach działu Kultura.

Pisano o literaturze różnych krajów, w tym m.in. amerykańskiej, czeskiej, hiszpańskiej, izraelskiej, portugalskiej, rosyjskiej szwajcarskiej i ukraińskiej.

Problematyka literacka prezentowana była z różnych punktów widzenia. I tak na przykład Mariusz Czubaj przedstawił twórczość trojga pisarzy europejskich: Maxa Cegielskiego, Iriny Dienieżkiny i Julii Zeh, dowodząc, że „pisarze z Polski, Niemiec i Rosji mówią często jednym głosem. Wspólnota problemów sięga poza granice Unii"184. Natomiast A. Krzemiński, opierając się na listach bestsellerów z Francji, Niemiec i Wielkiej Brytanii (zabrakło analogicznego zestawienia z Polski), stwierdził, że „każdy najchętniej czyta swoje. Czytamy najchętniej o sobie, porozumiewamy się zaś głównie dzięki 
Amerykanom”185 oraz, że: „Wciąż jesteśmy zamknięci we własnych kręgach językowych. I nasze literatury narodowe raczej nie układają się w naczynia połączone wspólnego obiegu literackiego"186. Zestawienia bestsellerów były także dowodem na to, że współczesny europejski czytelnik najchętniej sięga po mniej ambitną lekturę $\mathrm{w}$ postaci kryminałów, książek sensacyjnych i romansów.

Pojawiło się również wiele tekstów poświęconych literaturze polskiej, na przykład prozie współczesnej. M. Czubaj, pisząc o „powieści w czasach recesji”, krytykował bohaterów rodzimej prozy, którzy „są samotnikami z musu albo egoistami z wyboru, co ostatecznie na to samo wychodzi"187, podając za przykład utwory znanych pisarzy młodego pokolenia: M. Cegielskiego, D. Masłowskiej, T. Piątka. Portret wyłaniający się z tej charakterystyki nie wyglądał optymistycznie, ale jak stwierdził autor: „Można powiedzieć, że takich mamy literackich bohaterów, jakie mamy czasy, a obraz Polski współczesnej nie rysuje się budująco"188. Podobny w swej wymowie był tekst Pawła Dunin-Wąsowicza, który krytykował niski poziom merytoryczny współczesnej literatury, pisząc:

Nasi pisarze, zwłaszcza najmłodsi, za bardzo ufają swej pamięci, za rzadko natomiast zaglądają do archiwów i bibliotek. W rezultacie mają często problemy nie tylko z realiami historycznymi, ale i tymi jak najbardziej współczesnymi ${ }^{189}$.

Równocześnie jednak pocieszał odbiorców, że gafy przytrafiają się nie tylko autorom polskim, ale i znanym, zagranicznym twórcom, takim jak na przykład P. Coelho. Artykuł ten doczekał się odzewu ze strony czytelników pisma, którzy w swych listach wyrazili własne opinie na temat poruszony przez P. Dunin-Wąsowicza, wytykając mu jednocześnie jego własne potknięcia w tekście traktującym o błędach ${ }^{190}$.

Pisano także o tym, jak twórczość polska postrzegana jest na świecie ${ }^{191}$, w jaki sposób Polacy są w niej przedstawiani ${ }^{192}$ i na jakie języki jest ona przekładana ${ }^{193}$.

\footnotetext{
185 A. Krzemiński, Co czyta Europa?, „Polityka” 2005, nr 29, s. 54-56.

186 Ibidem, s. 54.

187 M. Czubaj, Powieść w czasach recesji, „Polityka” 2002, nr 49, s. 62.

188 Ibidem, s. [65].

189 P. Dunin-Wąsowicz, Książka gaf i pomyłek, „Polityka” 2005, nr 31, s. 62.

190 Zob. „Polityka” 2005, nr 41, s. 105.

191 M. Reich-Ranicki, Skopać wieszcza, „Polityka” 2001, nr 15, s. [57]-58.

192 J. Kurkiewicz, Jak nas piszq, „Polityka” 2004, nr 4, s. 52-[55].

193 Zob. np. „Polityka” 2005, nr 21, s. 72-75; nr 48, s. 66. Pisano także o tłumaczeniach na inne języki książek laureatów Paszportów Polityki (zob. np. ibidem, nr 19, s. 64) lub współpracowników pisma (zob. np. ibidem, nr 33, s. 24).
} 
Prezentowano różne typy literatury, m.in. biograficzną, ezoteryczną, fantastyczną, katolicką, komiksową ${ }^{194}$, kryminalną, kulinarną (w której, według słów autora, po roku 1989 dokonała się istna rewolucja), nacjonalistyczną, polityczną oraz sensacyjną.

Kilkakrotnie pisano o książkach adresowanych do młodzieży. Na przykład w 2002 r. pojawił się bardzo ciekawy, choć pesymistyczny tekst Piotra Sarzyńskiego, w którym autor stwierdził, że dawni bohaterowie bestsellerów wraz ze swymi twórcami (m.in. Arkadym Fiedlerem, Zbigniewem Nienackim, Edmundem Niziurskim) odchodzą w zapomnienie: „Wszyscy oni jeszcze żyją w społecznej świadomości, ale już bardziej we wdzięcznej pamięci rodziców lub dziadków aniżeli w umysłach ich dzieci i wnuków"195. Na szczęście jednak okazało się, że nie do końca jest to prawda. Młodzi czytelnicy „Polityki” zaprotestowali przeciwko tej, być może prowokacyjnej w założeniu konstatacji, przysyłając do redakcji tygodnika listy ${ }^{196}$.

Podobnie pesymistyczny był tekst A. Krzemińskiego: Sorry, Winnetou, dowodzący, że książki o Indianach trafiają powoli do lamusa, przegrywając z grami komputerowymi, m.in. dlatego, że „mit indiański został wyeksploatowany do końca. Z tej kopalni nie da się wydobyć nic nowego"197.

Idąc z duchem czasu, kilkakrotnie pisano o blogach jako „literaturze” nowego typu, przeważnie mało ambitnej, choć cieszącej się coraz większą popularnością ${ }^{198}$.

Zastanawiano się również nad tym, jak w przyszłości wyglądać będzie pisarstwo polskie, stawiano pytania o jego charakter i temat, analizowano jednocześnie jego stan teraźniejszy. I tak na przykład, według Marka Zaleskiego, literatura w przyszłości będzie

zalecała się do nas, natarczywie wystawiała przed oczy konterfekt autora, będzie uchylała się od eksperymentu, ale i wystawiała na próbę naszą potrzebę zanurzenia się $\mathrm{w}$ wartkiej, dobrze prowadzonej opowieści, mrugając przy tym porozumiewawczo: tu wszystko dzieje się między nami, literackimi wyjadaczami ${ }^{199}$.

Pisząc o teraźniejszości i przyszłości, nie zapominano o przeszłości, przypominając o rocznicach związanych z twórcami literatury. I tak na

1940 literaturze komiksowej pisano 10-krotnie, zob. m.in. M. Czubaj, Polska według Śledzia, „Polityka” 2002, nr 34, s. 56-[57]; M. Chaciński, Powieści z dymkiem, ibidem, 2003, nr 47, s. 64-67.

195 P. Sarzyński, Samochodzik jeździ dżipem, „Polityka” 2002, nr 34, s. 55.

196 A. Brożek, M. Pieńkowska [czytelnicy], Superksiążki, „Polityka” 2002, nr 36, s. 91.

197 S. Krzemiński, Sorry, Winnetou, „Polityka” 2002, nr 29, s. 46.

198 Zob. np. B. Mikołajewska, Cierpienia młodego Glogera, „Polityka” 2001, nr 49, s. 8385; M. Matuzik, Blogi i blagi, ibidem, 2004, nr 2, s. 78.

199 M. Zaleski, Prognoza prozy, „Polityka” 2005, nr 44, s. 62. 
przykład w 2005 r. z okazji 500 rocznicy urodzin Mikołaja Reja zamieszczono niemal czterostronicowy artykuł na temat piśmiennictwa staropolskiego: Poeci z naszej planety200, a z okazji Roku Gombrowiczowskiego pojawił się tekst pióra Agnieszki Celedy: Gombrowicz ze styropianu ${ }^{201}$.

Interesującym spostrzeżeniem wynikającym $\mathrm{z}$ analizy treści pisma jest fakt, że dużo miejsca poświęcano w nim również poezji. Znalazły się tu teksty krytyczne na jej temat, na przykład w numerze 18 (2002): Ciemni $w$ pełni, w którym autor przytaczał wiersze młodych poetów, zazwyczaj znanych w niewielkim kręgu odbiorców, opatrując je ironicznym komentarzem. Niekiedy pisano o niej z przymrużeniem oka, cytując (w ramach prześmiewczego w swym założeniu działu Polityka i obyczaje) wiersze drukowane na łamach „Naszego Dziennika”, a nawet zamieszczając tekst, poświęcony poezji pojawiającej się $\mathrm{w}$ tejże gazecie: Polska do rymu202. Jakkolwiek autor, Z. Pietrasik, zastrzegł, że prezentując „pokrótce główne nurty tej twórczości, nie [miał - M.P.S.] zamiaru kpić ani wyśmiewać”203, to jednak trudno oprzeć się wrażeniu, że taki właśnie cel mu przyświecał, kiedy pieczołowicie przytaczał fragmenty owej twórczości, opatrując je charakterystycznym komentarzem.

Prezentowano dorobek Czesława Miłosza, Juliana Przybosia, Ryszarda Krynickiego, Tomasza Różyckiego, Marka Rymkiewicza, Wisławy Szymborskiej. Pisano także o Krakowie, w którym:

Poezja upstrzyła trotuary, obłazi mury kamienic, wdziera się do pubów, kawiarni, alternatywnych piwnic. W zależności od dzielnicy miasto poezją oddycha lub dyszy. Z Krakowa poetycka powódź rozlewa się na inne miasta, a nawet kontynenty 204.

Wspominano o konkursach poetyckich organizowanych w tym mieście. Informowano o przyjeździe amerykańskich poetów do Krakowa ${ }^{205}$, o zorganizowanym przez Laurę Bush w Białym Domu sympozjum „Poezja i głos amerykański”206. Dwukrotnie pojawiła się rubryka, w ramach której drukowano nowe wiersze T. Różewicza ${ }^{207}$.

Poruszający tekst ukazał się w numerze 49 w 2001 r. (Pod gwiazdq rozpacznq), wspominający zmarłych tragicznie poetów i pisarzy, m.in.: Andrzeja Bursę, Stanisława Czycza, Marka Hłaskę, Edwarda Stachurę i Rafała

200 K. Janowska, Poeci z naszej planety, „Polityka” 2005, nr 50, s. 70-73.

201 A. Celeda, Gombrowicz ze styropianu, „Polityka” 2004, nr 43, s. 71.

202 Z. Pietrasik, Polska do rymu, „Polityka” 2001, nr 7, s. 46-[49].

203 Ibidem, s. [49].

${ }^{204}$ K. Janowska, W rynnie wierszem mówiq płynnie, „Polityka” 2004, nr 14, s. 64.

205 A. Szoszkiewicz, Miłość do Miłosza, „Polityka” 2002, nr 31, s. 56-57.

206 [br. aut.], Harold Pinter atakuje wierszem, „Polityka” 2003, nr 17, s. [15]. [informacja ukazała się w ramach działu Ludzie $i$ Wydarzenia. Świat].

207 „Polityka” 2005, nr 40, s. 61. 
Wojaczka208. M. Pęczak, przypominając losy owych „kaskaderów literatury”, zastanawiał się jednocześnie, dlaczego ich legendy bledną we współczesnym świecie, nie budząc emocji takich, jak dawniej i dlaczego dziś brak jest podobnych postaci. Częściową odpowiedzią na te pytania był tekst Marcina Kołodziejczyka. Dzisiejsi potencjalni bohaterowie, wywodzący się z „wrażliwych inteligentów uprawiających prozę lub poezję”, borykając się z zupełnie przyziemnymi problemami, nie mają raczej szans na to, by stać się żywą legendą na miarę M. Hłaski czy E. Stachury, bo

wolność dla kultury okazała się tragedią i objawiła się literatom we wzroście liczby niskonakładowych pism społeczno-kulturalnych zamieszczających wiersze i prozę. A także w nastawieniu czytelników, którzy tych pism masowo nie czytają oraz nie kupują tomików z poezją209.

Pisarze i poeci zmuszeni są często „podejmować zawody nietwórcze, często frustrujące, aby się utrzymać"210. M. Kołodziejczyk kreślił sylwetki i życiorysy współczesnych poetów, którzy „kiedyś pisaniem chcieli zbawić świat”, a teraz, kiedy „Wolność zamieniła książkę z dobra kultury w produkt rynkowy"211 chwytają się innych zajęć. Współczesny świat i kultura wykształciły zapotrzebowanie na zupełnie inny typ bohatera, niż było to dawniej. Niegdysiejszy zbuntowany i romantyczny - ustąpił miejsca przebojowemu idolowi z Big Brothera. Miejsce literatury zajęła telewizja i Internet. Dziś

Książki znikają z księgarń, a księgarnie coraz częściej znikają z ulic. [...] lektury kupuje się w supermarketach, korzysta ze sprzedaży wysyłkowej i Internetu. Od kilku tygodni można książki zamawiać przez telefon - jak pizze czy taksówkę212.

Tak w 2001 r. o sytuacji na rynku wydawniczo-księgarskim pisała na łamach „Polityki” Maja Wolny.

Zagadnienie rynku książki i jej odbioru niejednokrotnie było przedmiotem publikacji zamieszczanych na łamach tygodnika. W cytowanym artykule przywołano wyniki badań czytelnictwa za rok 2000, przeprowadzonych przez Instytut Książki i Czytelnictwa Biblioteki Narodowej, z których wynikało, że „78\% Polaków powyżej 15 roku życia w ogóle nie czyta książek lub też sięga po nie sporadycznie. Tylko $22 \%$ ma na swoim rocznym koncie 7 i więcej pozycji”213. 0 stanie czytelnictwa w Polsce pisano nieraz

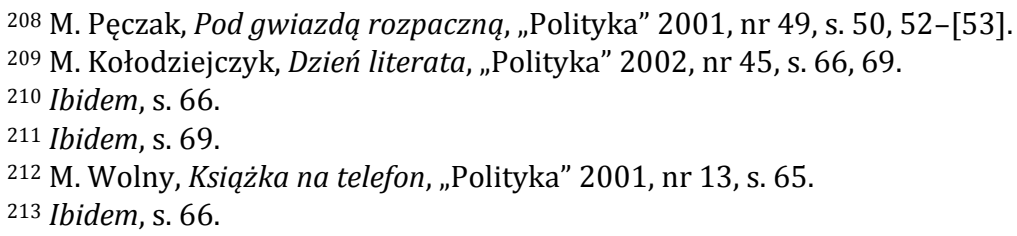


zarówno w formie krótkich informacji214, jak i obszerniejszych komentarzy (na przykład opinia Andrzeja Nowakowskiego, prezesa Polskiej Izby Książki215), zawsze ubolewając nad tym, że Polacy czytają mało i często niechętnie.

Jako jeden z powodów tej sytuacji wskazywano zbyt wysokie ceny książek, które powodują, że potencjalni czytelnicy kupują głównie podręczniki, bo na inne tytuły ich nie stać 216 . W kolejnym artykule dotyczącym tej kwestii podkreślano, że takiego stanu rzeczy nie poprawiają problemy z dystrybucją:

W drodze do czytelnika książka przechodzi przez wielu pośredników (przedstawiciel, lokalna hurtownia), a każdy dolicza sobie kilka złotych. Jeżeli któreś z ogniw tego łańcucha bankrutuje, a zdarza się to ostatnio często, pieniądze za książkę nie wracają do wydawcy. I musi on sobie odbić to na innych tytułach ${ }^{217}$.

W cytowanym tekście pojawiło się jednocześnie interesujące zestawienie liczbowe dotyczące rynku książki oraz elementy, które składają się na jej cenę. Wynikało z nich, że najmniej przeznacza się w Polsce na promocję tytułu, niewiele więcej otrzymuje autor, zaś największe zyski ze sprzedanej książki czerpią wydawcy ${ }^{218}$. Obok agentów literackich i dystrybutorów książek stali się oni bohaterami kolejnego tekstu, który wywołał żywy odzew wśród czytelników i wydawców: Łańcuch książkowo-pokarmowy219. Ponad rok później w piśmie pojawił się następny artykuł podejmujący to samo zagadnienie: Grupa trzymająca książkę220.

Omawiano również problemy wydawców, wynikające na przykład $\mathrm{z}$ istniejącego w Polsce zjawiska, określanego jako piractwo książkowe, które „wcale nie należy do gospodarczego podziemia. Proceder ten uprawiają oficjalnie wydawnictwa, a pirackie egzemplarze sprzedaje się w zwyczajnych księgarniach"221.

214 Zob. np. [br. aut.], Nie czytamy, „Polityka” 2001, nr 33, s. 12; Nie czytamy, ibidem, 2002, nr 21, s. 14.

215 A. Nowakowski, Harry Potter i analfabeci, „Polityka” 2002, nr 3, s. 15. Warto zaznaczyć, że komentarz ten spotkał się z odzewem czytelników „Polityki”, zob. np. M. Teresińska [czytelniczka], Co na to księgarze?, ibidem, nr 7, s. 68.

216 P. Stasiak, Kilo Coelho, „Polityka” 2003, nr 36, s. 36-38.

217 Ibidem, s. 37.

218 Ibidem, s. 38.

219 M. Czubaj, Łańcuch książkowo-pokarmowy, „Polityka” 2004, nr 21, s. 70-[73]. Listy czytelników, zob. np. ibidem, nr 26, s. [95].

220 M. Czubaj, Grupa trzymająca książkę, „Polityka” 2005, nr 43, s. 74-76.

221 J. Konikowski, Słowo na lewo, „Polityka” 2004, nr 29, s. 41-43. O pirackich wydaniach książek pisano także: [br. aut.], Piraci wydali papieża, ibidem, 2005, nr 19, s. 17. 
W 2003 r. czytelnicy „Polityki” mogli przeczytać także o prywatyzacji WSiP222 i późniejszych kłopotach tego wydawnictwa ${ }^{223}$ czy perypetiach archidiecezjalnego Wydawnictwa Stella Maris ${ }^{224}$.

Analiza zebranego materiału pozwala stwierdzić, że stosunkowo rzadko pisano o targach książki. Pojawiły się zaledwie cztery ogłoszenia, reklamujące to przedsięwzięcie związane z promocją literatury: dwukrotnie informowano w ten sposób o Międzynarodowych Targach Książki w Warszawie i dwukrotnie o Targach Książki w Krakowie. Relacje z tych imprez, jak również z targów, których organizatorzy nie reklamowali (na przykład Targów Książki Edukacyjnej), podobnie jak i inne teksty im poświęcone, miały charakter przeważnie krytyczny. Stwierdzano:

O tym, że rynek książki w Polsce drastycznie się kurczy, wiadomo było od dawna. Że czytelnictwo mamy jedno z najniższych w Europie, również jest pewne. Na największym krajowym kiermaszu, jakim są warszawskie Targi Książki, całą tę mizerię ruchu wydawniczego widać jak na dłoni. Na dwóch piętrach wokół Sali Kongresowej - niewielu uczestników, nowości jak na lekarstwo. Zabrakło czołowych wystawców [...]. Odwołano wizyty zagranicznych pisarzy 225 .

Antoni Libera zastanawiał się „Co targi książki mają wspólnego z literaturą i sztuką?", dochodząc do wniosku, że

To, czego jesteśmy świadkami obecnie, cały ten monstrualnie wielki świat zadrukowanego papieru, rozchodzącej się błyskawicznie informacji, nieustannie zmieniających się rankingów i list bestsellerów, niewiele ma wspólnego z kulturą w dawnym sensie tego słowa ${ }^{226}$.

Nie lepiej, zdaniem dziennikarzy „Polityki”, prezentowała się sytuacja Targów Książki we Frankfurcie. W 2001 r. oceniano, że były one „mniejsze i skromniejsze niż rok temu"227, choć w tym przypadku powodów dopatrywano się w katastrofie, spowodowanej atakiem terrorystów na World Trade Center w Nowym Jorku. Ale rok później nie było lepiej: „Na tegorocznych Targach Książki we Frankfurcie wydawcy robili dobrą minę do smętnej gry. Branżę dopadł kryzys, dostrzegalny po pustych miejscach w halach wystawowych"228, spowodowany złą kondycją książki we współczesnym świecie. Targi książki stawały się pretekstem do pisania o kryzysie

222 J. Solska, Sobie i Muzie, „Polityka” 2003, nr 6, s. 24-[27].

223 J. Solska, Kto ma akcje, ten ma rację, „Polityka” 2005, nr 32, s. 36-39. Artykuł ukazał się w dziale Gospodarka.

224 „Polityka” 2004, nr 8, s. 13; nr 13, s. [14]; nr 14, s. 14.

225 J. Wróblewski, Harry Potter i reszta, „Polityka” 2001, nr 39, s. 13.

${ }^{226}$ A. Libera, Seans uwielbienia, „Polityka” 2001, nr 16, s. [52].

227 M. Wolny, Talibowie w miękkiej oprawie, „Polityka” 2001, nr 43, s. 50.

228 A. Krzemiński, Grubsze lepsze, „Polityka” 2002, nr 43, s. [66]. 
literatury i czytelnictwa, a także, z drugiej strony, o bestsellerach i wydawcach, królujących, mimo wszystko, na rynku229.

Ze swej strony redakcja starała się jednak, by mimo kryzysu czytelnictwa, a może właśnie dlatego - książkę promować. Warto wspomnieć o ciekawej inicjatywie redakcji, która z okazji Dnia Dziecka zleciła Fundacji ABCXXI przeprowadzenie sondy wśród znanych osób życia publicznego (polityków, artystów, pisarzy, sportowców), na temat lektur ich dzieciństwa, a następnie wyniki badań zamieściła w jednym z numerów pisma ${ }^{230}$. Dzięki temu czytelnik mógł dowiedzieć się, że ulubioną książką z lat dziecięcych Leszka Balcerowicza był m.in. Ostatni Mohikanin (Jamesa F. Coopera) i Tajemnicza wyspa (Julesa Verne`a), Zbigniewa Bońka - Chłopcy z Placu Broni (Ferenca Molnára) i Do przerwy 0:1 (Adama Bahdaja), Hanny Krall - Ania z Zielonego Wzgórza (Lucy M. Montgomery), a Stanisława Lema - Księga dżungli (Rudyarda Kiplinga) i Trzej muszkieterowie (Aleksandra Dumas).

Poza wymienionymi formami obecności książki na łamach „Polityki” pojawiały się także informacje z nią związane w postaci zazwyczaj krótkich wzmianek. Dotyczyły one na przykład konkursu na czytanie i rozumienie tekstu (z udziałem młodych ludzi z 32 krajów, w tym z Polski) ${ }^{231}$, zwyczaju foliowania książek ${ }^{232}$ czy zdjęcia z anteny telewizyjnej programu Dobre książki233. Pisano również o likwidacji departamentu książki w Ministerstwie Kultury i powołaniu Instytutu Książki234.

Taką postać miały też informacje związane z bibliotekami. Pojawiło się ich stosunkowo niewiele (20). Informowano na przykład o powrocie do Polski XV-wiecznej Księgi praw miejskich Głubczyc ${ }^{235}$, przekazaniu Bibliotece Jagiellońskiej zbiorów z prywatnej biblioteki książąt Sanguszków ${ }^{236}$, o starodrukach książnicy Jagiellońskiej237, otwarciu nowej Biblioteki Aleksandryjskiej238, a także o liczbie zlikwidowanych po 1989 r. bibliotek ${ }^{239}$.

W ramach działu Tydzień w kraju oraz Działu kadr240 informowano czytelników o nagrodach, wyróżnieniach, nadawaniu tytułów, jubileuszach,

229 Zob. np. M. Czubaj, Ksiq̨żki z ekranu, „Polityka” 2002, nr 21, s. 61-[63].

230 Zob. [br. aut.], Nasze pierwsze lektury, „Polityka” 2002, nr 22, s. 50-53.

231 [br. aut.], Polak nie rozumie, „Polityka” 2001, nr 50, s. 12.

232 M. Czubaj, Ksiq̨żka zafoliowana, „Polityka” 2003, nr 15, s. 52.

233 [br. aut.], „Dobre ksiq̨żki” już niedobre, „Polityka” 2003, nr 8, s. 12.

234 [br. aut.], Instytut Książki, „Polityka” 2004, nr 3, s. 14. Ta informacja była nieco dłuższa.

235 [br. aut.], Staruszka z Głubczyc, „Polityka” 2002, nr 31, str. 12.

236 [br. aut.], Książęcy podarunek, „Polityka” 2002, nr 29, s. 12.

237 [br. aut.], Starodruki znów w Jagiellonce , „Polityka” 2002, nr 25, s. 12.

238 (AB), Cud świata z problemami, „Polityka” 2002, nr 43, s. 15.

239 Kraina bez ksiqzżek [opinia Michała Jagiełły], „Polityka” 2003, nr 15, s. 86.

240 W 2002 r. [od nr 40] dział zmienił nazwę na Kadry nominacje denominacje. 
rocznicach, a także o śmierci osób związanych ze światem kultury i literatury. Wzmianki te miały zazwyczaj postać jedno- lub kilkuzdaniowych notek, pozbawionych komentarza, czasem tylko opatrzonych odsyłaczem do artykułu - wspomnienia, poświęconego danej osobie, znajdującego się wewnątrz numeru.

Warto także wspomnieć o tekstach dotyczących adaptacji, ekranizacji oraz inscenizacji literatury. Informacji tego typu pojawiło się na łamach pisma 121. Komentowano na przykład kolejne próby przeniesienia na ekran zarówno klasyki polskiej, jak i światowej (Krzyżaków Henryka Sienkiewicza, Przedwiośnia Stefana Żeromskiego, Przygód Olivera Twista Karola Dickensa, Targowiska próżności Wiliama Makepeace`a), prozy popularnej (Nigdy w życiu! K. Grocholi, Jednorocznej wdowy Johna Irvinga) oraz fantastyki (Solaris Stanisława Lema i Raportu mniejszości Philipa K. Dicka). Pisano o kolejnych inscenizacjach dramatów Williama Szekspira, a także dzieł twórców rodzimych: Aleksandra Fredry, Witolda Gombrowicza i Sławomira Mrożka.

Przy omawianiu rozmaitych form obecności literatury, prezentowanych na łamach pisma nie można pominąć również licznych listów do redakcji, będących bądź odzewem na zamieszczony artykuł bądź też zwracających uwagę na określony problem, dotyczący rynku wydawniczego i książek. Przykładem może być list od rozgoryczonego 15-letniego czytelnika w sprawie niedostępności Biblioteki Narodowej dla zwykłego zjadacza chleba $^{241}$, głos czytelnika nawiązujący do artykułu Z. Kałużyńskiego o popularności Pamiętnika Bridget Jones ${ }^{242}$ czy opinia związana $\mathrm{z}$ artykułem o cenach książek ${ }^{243}$.

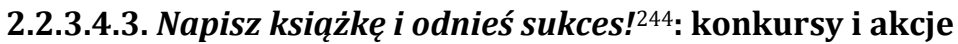

Kolejną formą obecności książki na łamach omawianego tygodnika były konkursy i akcje z nią związane. Można je podzielić na trzy grupy:

1) te, które pismo organizowało lub współinicjowało (cyklicznie bądź jednorazowo);

2) takie, którym patronowało;

3) inne przedsięwzięcia, o których redakcja jedynie informowała (przeważnie w formie ogłoszeń reklamowych).

Pierwszą grupę stanowiły konkursy ${ }^{245}$ zarówno organizowane regularnie (zazwyczaj w cyklu rocznym), jak i inicjatywy jednorazowe.

241 „Polityka” 2003, nr 23, s. 85.

242 „Polityka” 2001, nr 30, s. 35.

243 „Polityka” 2003, nr 45, s. 107.

244 „Polityka” 2002, nr 45, s. [85].

2450 potrzebnie konkursów pisano już w 2002 r. Zob. J. Biała, Marynistyczny epos o góralu, „Polityka” 2002, nr 35, s. 58. 
„Polityka” była organizatorem kilku takich przedsięwzięć. Jednym z najstarszych był wspominany wcześniej konkurs historyczny.

To najstarsza przyznawana w Polsce nagroda dla książki historycznej. Kiedy redakcja powoływała ją w 1959 r., podkreślała, że mają to być nagrody dla publikacji najnowszej historii Polski. W ciągu kilkudziesięciu lat funkcjonowania nagrody jej laureatami zostało ponad stu autorów ${ }^{246}$.

W badanym okresie nagrodzono w ten sposób 18 twórców. Najpierw na łamach pisma pojawiała się krótka notka, zatytułowana Nagrody historyczne, w której redakcja zwracała się do czytelników i wydawców z prośbą o zgłaszanie kandydatów, zasługujących na to wyróżnienie. Spośród nadesłanych tytułów jury wybierało prace, opublikowane w poprzednim roku, dotyczące najnowszej historii Polski, m.in. $\mathrm{z}$ następujących kategorii: pamiętniki i wspomnienia, prace naukowe i popularnonaukowe, wydawnictwo źródłowe. Nagradzano także debiut roku, za który autor otrzymywał nagrodę $w$ wysokości 4 tys. zł, pozostali - 5 tys. zł (tylko w 2001 r. nagroda ta wynosiła 6 tys. zł). Ogłoszenie listy laureatów wraz z podaniem tytułów nagrodzonych książek drukowano $\mathrm{w}$ listopadzie lub grudniu danego roku, w dziale Historia, $\mathrm{a} \mathrm{w}$ jednym $\mathrm{z}$ kolejnych numerów pisma omawiano uhonorowane $\mathrm{w}$ ten sposób książki. W tabeli 13 przedstawiono laureatów nagrody z lat 2001-2005.

Tabela 13. Laureaci Nagród Historycznych, przyznawanych przez „Politykę” w latach 2001-2005

\begin{tabular}{|c|l|l|l|}
\hline $\begin{array}{c}\text { Rok, w którym } \\
\text { przyznano nagrodę }\end{array}$ & \multicolumn{1}{|c|}{ Kategoria } & Nazwisko laureata & \multicolumn{1}{|c|}{$\begin{array}{c}\text { Tytuł nagrodzonej } \\
\text { publikacji }\end{array}$} \\
\hline \multirow{2}{*}{2001} & $\begin{array}{l}\text { Prace naukowe i po- } \\
\text { pularnonaukowe }\end{array}$ & Szarota Tomasz & $\begin{array}{l}\text { U progu zagłady } \\
\text { (Wydawnictwo Sic!) }\end{array}$ \\
\cline { 2 - 4 } & $\begin{array}{l}\text { Wydawnictwa } \\
\text { źródłowe }\end{array}$ & Czesław Osękowski & $\begin{array}{l}\text { Referendum 30 czerwca } \\
\text { (1946 roku w Polsce } \\
\text { (Wydawnictwo Sejmowe) } \\
\text { Wybory do Sejmu z 19 } \\
\text { stycznia 1947 roku w Polsce } \\
\text { (Wydawnictwo Poznańskie) }\end{array}$ \\
\hline \multirow{2}{*}{2001} & $\begin{array}{l}\text { Pamiętniki, } \\
\text { wspomnienia, } \\
\text { relacje }\end{array}$ & $\begin{array}{l}\text { Olena Batonowa } \\
\text { i Andrzej Friszke } \\
\text { (za przygotowanie } \\
\text { do druku) }\end{array}$ & $\begin{array}{l}\text { Listy 1946-1967 } \\
\text { (Instytut Studiów Politycz- } \\
\text { nych PAN) }\end{array}$ \\
\cline { 2 - 4 } & Debiut & $\begin{array}{l}\text { Repatriacja ludności polskiej } \\
\text { z ZSRR w latach 1955-59 } \\
\text { (Fundacja im. Ericha Brosta } \\
\text { przy Fundacji im. Friedricha } \\
\text { Eberta; Oficyna Wydawnicza } \\
\text { Wolumen) }\end{array}$ \\
\hline
\end{tabular}

${ }^{246}$ Folder wewnątrzredakcyjny „Polityki”, s. 17. 


\begin{tabular}{|c|c|c|c|}
\hline $\begin{array}{c}\text { Rok, w którym } \\
\text { przyznano nagrodę }\end{array}$ & Kategoria & Nazwisko laureata & $\begin{array}{c}\text { Tytuł nagrodzonej } \\
\text { publikacji }\end{array}$ \\
\hline \multirow{5}{*}{2002} & $\begin{array}{l}\text { Prace naukowe } \\
\text { i popularnonau- } \\
\text { kowe }\end{array}$ & Jerzy Kochanowski & $\begin{array}{l}\text { W polskiej niewoli. Niemiec- } \\
\text { cy jeńcy wojenni w Polsce } \\
\text { (1945-1950) } \\
\text { (Wydawnictwo Neriton) }\end{array}$ \\
\hline & $\begin{array}{l}\text { Wydawnictwa } \\
\text { źródłowe }\end{array}$ & $\begin{array}{l}\text { Wanda Krystyna } \\
\text { Roman }\end{array}$ & $\begin{array}{l}\text { Za Polskę do celi śmierci. } \\
\text { Śledztwo i proces Nikodema } \\
\text { Sulika } \\
\text { (Wydawnictwo Adam } \\
\text { Marszałek) }\end{array}$ \\
\hline & $\begin{array}{l}\text { Pamiętniki, } \\
\text { wspomnienia, } \\
\text { relacje }\end{array}$ & $\begin{array}{l}\text { Karolina Lancko- } \\
\text { rońska }\end{array}$ & $\begin{array}{l}\text { Wspomnienia wojenne } \\
\text { (Wydawnictwo Znak) }\end{array}$ \\
\hline & Debiut & Marcin Zaremba & $\begin{array}{l}\text { Komunizm, legitymizacja, } \\
\text { nacjonalizm } \\
\text { (Wydawnictwo Naukowe } \\
\text { Scholar) }\end{array}$ \\
\hline & Nagroda Specjalna & Maria Hirszowicz & $\begin{array}{l}\text { Pułapki zaangażowania. } \\
\text { Intelektualiści w służbie } \\
\text { komunizmu } \\
\text { (Wydawnictwo Naukowe } \\
\text { Scholar) }\end{array}$ \\
\hline \multirow{3}{*}{2003} & $\begin{array}{l}\text { Prace naukowe } \\
\text { i popularnonau- } \\
\text { kowe }\end{array}$ & Marian Łatyński & $\begin{array}{l}\text { Nie paść na kolana. Szkice } \\
\text { o polskiej polityce lat powo- } \\
\text { jennych } \\
\text { (Towarzystwo Przyjaciół } \\
\text { Ossolineum) }\end{array}$ \\
\hline & $\begin{array}{l}\text { Pamiętniki, } \\
\text { wspomnienia, } \\
\text { relacje }\end{array}$ & $\begin{array}{l}\text { Elżbieta Neyman } \\
\text { (za wyb., oprac. i } \\
\text { wprowadzenie do } \\
\text { książki) }\end{array}$ & $\begin{array}{l}\text { Intymny portret uczonych. } \\
\text { Korespondencja Marii } \\
\text { i Stanisława Ossowskich } \\
\text { (Wydawnictwo Sic!) }\end{array}$ \\
\hline & Debiut & Michał Maranda & $\begin{array}{l}\text { Nazistowskie obozy zagłady. } \\
\text { Opis i próba analizy zjawiska } \\
\text { (UW, Instytut Stosowanych } \\
\text { Nauk Społecznych) }\end{array}$ \\
\hline
\end{tabular}


Tabela 13 (cd.)

\begin{tabular}{|c|l|l|l|}
\hline $\begin{array}{c}\text { Rok, w którym } \\
\text { nadano nagrodę }\end{array}$ & \multicolumn{1}{|c|}{ Kategoria } & Nazwisko laureata & Tytuł nagrodzonej publikacji \\
\hline \multirow{5}{*}{2004} & $\begin{array}{l}\text { Prace naukowe i po- } \\
\text { pularnonaukowe }\end{array}$ & Leszek Olejnik & $\begin{array}{l}\text { Polityka narodowościowa } \\
\text { Polski w latach 1944-1960 } \\
\text { (Wydawnictwo Uniwersyte- } \\
\text { tu Łódzkiego) }\end{array}$ \\
\cline { 2 - 5 } & $\begin{array}{l}\text { Pamiętniki, wspom- } \\
\text { nienia, relacje }\end{array}$ & Edward Hałoń & $\begin{array}{l}\text { W cieniu Auschwitz } \\
\text { (Wydawnictwo Państwowe } \\
\text { Muzeum Auschwitz- } \\
\text {-Birkenau) }\end{array}$ \\
\cline { 2 - 5 } 2005 & Debiut & Jacek Piotrowski & $\begin{array}{l}\text { Piłsudczycy bez lidera } \\
\text { (Wydawnictwo Adam } \\
\text { Marszałek) }\end{array}$ \\
\hline & prace naukowe i po- \\
& pularnonaukowe & Henryk Słabek & $\begin{array}{l}\text { Obraz robotników polskich } \\
\text { w latach 1945-1989 } \\
\text { (Instytut Historii PAN, } \\
\text { Wyższa Szkoła Gospodarki } \\
\text { Krajowej w Kutnie) }\end{array}$ \\
\cline { 2 - 4 } & $\begin{array}{l}\text { Wydawnictwa } \\
\text { źródłowe }\end{array}$ & Anna Bikont & $\begin{array}{l}\text { Myz Jedwabnego } \\
\text { (Wydawnictwo Prószyński } \\
\text { i S-ka) }\end{array}$ \\
\hline
\end{tabular}

Źródło: „Polityka” 2001-2005.

Kolejne wyróżnienie, regularnie przyznawane przez tygodnik, to wspomniane wcześniej Paszporty Polityki. Po raz pierwszy wręczono je w 1993 r. W numerze 1 (2001) czytamy m.in.:

Artystów i twórców podzielić można na dwie grupy: tych, którzy zyskali już sławę, i tych, którzy dopiero o tym marzą. Naszymi, przyznawanymi już po raz ósmy, nagrodami Paszportów „Polityki” pragniemy zawsze uchwycić ów moment przechodzenia z jednej do drugiej kategorii. Próbujemy zwrócić uwagę naszych czytelników, mediów, organizatorów życia kulturalnego i wszystkich miłośników kultury na twórców, którzy zdali już świetnie pierwsze egzaminy z talentu, wyobraźni i oryginalności, ale ciągle jeszcze czekają na wielką sławę i ciągle jeszcze najwybitniejsze osiągnięcia zawodowe mają przed sobą ${ }^{247}$.

W kategorii Literatura w latach 2001-2005 laureatami zostali: P. Huelle (2001, Mercedes Benz), D. Masłowska (2002, Wojna polsko-ruska pod flaga biało-czerwonq), W. Kuczok (2003, Gnój), S. Shuty (2004, Zwał), M. Krajewski (2005, za cykl powieściowy zapoczątkowany książką Śmierć w Breslau).

W 2003 r. z okazji 10-lecia wręczenia Paszportów zorganizowano trwający miesiąc Festiwal Kulturalny „Polityki”, Paszporty do Europy. Odbyło się ponad 30 imprez z nim związanych: koncertów, wystaw, publicznych debat 
(m.in. „Pisarstwo - terapia, zawód, powołanie”), przeglądów filmowych i spektakli teatralnych. Uczestniczyli w nim laureaci z lat ubiegłych ${ }^{248}$.

Inna, cykliczna forma promocji kultury, w tym literatury, inicjowana przez tygodnik to Salony Polityki (organizowane na przykład w warszawskim Klubie Pod Jaszczurami). W ramach spotkań odbywały się tu m.in. Wieczory autorskie oraz Turniej Jednego Wiersza. Reklamowano je na łamach pisma ${ }^{249}$, ale niestety, nie zamieszczano relacji $\mathrm{z}$ ich przebiegu. W latach 2001-2005 zorganizowano spotkanie m.in. z Wojciechem Bonowiczem, Jackiem Podsiadło i Marcinem Świetlickim.

„Polityka” była także pomysłodawcą kilku jednorazowych konkursów literackich. Jednym z nich była Literacka zabawa z nagrodami (2001) promowana hasłem: Napisz powieść z Pilchem. Pomysł ten był anonsowany już na okładce tygodnika250. Moderator konkursu (J. Pilch) napisał początek powieści, natomiast zadaniem czytelników było dopisanie jej dalszego ciągu, o objętości maksymalnie pół strony maszynopisu. J. Pilch wybierał najciekawszy, jego zdaniem, fragment i dodawał go do opowieści. Autor otrzymywał nagrodę w wysokości 500 zł, zaś po zakończeniu konkursu wśród wszystkich jego uczestników rozlosowane zostały nagrody. Za każdym razem obok wybranego fragmentu pojawiał się komentarz Moderatora, który już na początku stwierdził:

Tak jest: piszemy rzecz, na którą czeka naród. Naród bowiem czeka na interesującą i dobrze opowiedzianą historię. Poza wszystkim jestem absolutnie pewien: na pewno nie dla licznych, ale dla nielicznych, może nawet dla bardzo nielicznych spośród Państwa ten pomysł „Polityki” jest po prostu wielką szansą251.

Od następnego numeru na okładce zamieszczano hasło, przypominające o konkursie: Napisz z Pilchem powieść, na którq czeka cały naród! Drukowano także kilka innych ciekawych, choć niewykorzystanych fragmentów, przysyłanych przez czytelników, prezentując jednocześnie dwa wątki powieści. Pomysł spotkał się z tak dużym zainteresowaniem, że we wrześniowym numerze redakcja przyznała:

Pisanie powieści z Pilchem miało być zabawą wakacyjną, jednak w związku z niesłabnącym zainteresowaniem Czytelników postanowiliśmy ją przedłużyć. Będzie trwała tak długo, jak długo zechcecie się państwo bawić252.

\footnotetext{
248 Relacja z Festiwalu, zob. P. Sarzyński, Paszporty do Europy, „Polityka” 2003, nr 8, s. 58.

249 Zob. np. „Polityka” 2001, nr 42, s. [50].

250 Zob. np. „Polityka” 2001, nr 26.

251 „Polityka” 2001, nr 26, s. 3.

252 „Polityka” 2001, nr 36, s. 84.
} 
Konkurs zakończono trzy tygodnie później, w numerze 39 (2001), choć jednocześnie zaproponowano czytelnikom jego kontynuację w Internecie.

Znany pisarz był także koordynatorem kolejnego konkursu literackiego, zainicjowanego przez redakcję w świątecznym numerze „Polityki” w grudniu 2003 r.253 Tym razem był to Ogólnonarodowy Konkurs na Opowiadanie: Pisz do Pilcha. Konkurs z jednej strony miał być

sprzeciwem wobec zaniku sztuki opowiadania, z drugiej strony [miał - przyp. M.P.S.] wzmóc i przyspieszyć rychłe odrodzenie tej sztuki. [...] dać interesujące świadectwo tego, o czym i jak Polacy dziś opowiadają 254 .

Pomysł, jak przyznał J. Pilch, wzorowany był na podobnym przedsięwzięciu zorganizowanym w Stanach Zjednoczonych przez P. Austera. Kanwą opowiadania powinno być prawdziwe zdarzenie, które przydarzyło się czytelnikowi lub osobie mu bliskiej albo historia tak dobrze opowiedziana, że można było w nią uwierzyć. Objętość tekstu ograniczono do 7 tys. znaków. Konkurs trwał do 9 kwietnia 2004 r., ale listę laureatów podano dopiero $\mathrm{w}$ ostatnim numerze $\mathrm{z}$ tego roku ${ }^{255}$. Wynikało to $\mathrm{z}$ faktu, że do redakcji wpłynęło ponad 3 tys. opowiadań. Na zakończenie jedyny juror, którym był J. Pilch, sformułował kilka tez, określających „polskie charaktery". Na podstawie przesłanych opowiadań stwierdził m.in., że:

nie da się z czystym sumieniem powiedzieć, że Polacy opowiadają, że lubią i potrafią opowiadać. Polacy raczej gadają i lubią gadać. Triumfuje rozlewność, brak konstrukcji i bezpuentowowść. [...]. Najciekawszy wniosek, jaki nasunął mi się w trakcie lektury opowiadań, jest chyba taki, że Polacy nie bardzo lubią i potrafią opowiadać o zdarzeniach, ale lubią i potrafią opowiadać o ludziach ${ }^{256}$.

Ostatecznie wybrano 52 opowiadania, które zgodnie z założeniami miały stanowić podstawę antologii, wydanej przez Świat Książki257.

Kolejnym konkursem był zabawny pomysł, polegający na napisaniu przez czytelników „Polityki” krótkiego grafomańskiego tekstu, w którym znalazłby się kolejno: opis przyrody, dialog miłosny i zakończenie, w którym bohaterowie wymyślonej historyjki... dochodzą na przystanek autobusowy. Warunkiem było również użycie w tekście podanych przez redakcję słów. Zasady zostały poprzedzone odpowiednim wprowadzeniem,

253 „Polityka” 2003, nr 51/52, s. 103.

254 J. Pilch, Ogłaszam, a „Polityka” czyni to wraz ze mna, Ogólnonarodowy Konkurs na Opowiadanie, „Polityka” 2003, nr 51/52, s. 103.

255 W międzyczasie ukazywały się, nierzadko krytyczne, komentarze J. Pilcha, dotyczące nadsyłanych tekstów. Zob. np. J. Pilch, Szkoła pisania, „Polityka” 2004, nr 2, s. 84.

256 J. Pilch, Polskie charaktery, „Polityka” 2004, nr 52/53, s. 160.

257 Pisz do Pilcha. Opowiadań współczesnych 30 i 3, Świat Książki, Warszawa 2005. 
rodzajem miniporadnika, w którym opisano podstawowe cechy grafomanii, posiłkując się cytatami z literatury polskiej258. Czytelnicy chętnie odpowiedzieli na ten rodzaj literackiej zabawy (I ty możesz zostać grafomanem), nadsyłając w sumie ok. 100 tekstów „próbujących się zmierzyć z nader subtelną materią złego pisania"259. Najzabawniejsze z nich zostały opublikowane w numerze 6 (2003) periodyku ${ }^{260}$.

Tygodnik był również współorganizatorem konkursu literackiego na pamiętniki polskich emigrantów. Partnerem tego projektu był „Nowy Dziennik” (wydawany w Nowym Jorku) i pismo „Świecie Nasz” (ukazujące się w Montrealu). Patronat medialny objęła TV Polonia i Radio Polonia. Informacja na temat tego przedsięwzięcia ukazała się w formie ogłoszenia w lutym 2005 r. Redakcja pisała:

Chcemy, aby emigranci opowiedzieli o sobie, o tym, dlaczego opuścili Polskę. Jak w nowym miejscu urządzili się, kto im pomógł, a kto się od nich odwrócił. Chcemy dowiedzieć się, czego nauczyło ich życie w innym kraju i w innej kulturze. Wreszcie - chcemy wiedzieć, na ile żywy jest odwieczny dylemat: wracać czy nie wracać?261

Na prace w formie wspomnień, komentarzy, refleksji, relacji i opisów czekano do końca czerwca 2005 r. Lista laureatów, wraz z komentarzem jury, ogłoszona została w grudniu tegoż roku262.

„Polityka” nie tylko była organizatorem bądź współinicjatorem tego typu przedsięwzięć, ale także o nich informowała. Komunikaty pojawiały się zazwyczaj w formie ogłoszeń reklamowych. Przykładem jest pomysł Instytutu Gospodarstwa Społecznego, który wraz z Krajowym Urzędem Pracy zorganizował konkurs na Pamiętniki bezrobotnych (2001)263. Przedsięwzięciu patronował minister pracy i polityki społecznej. Reguły konkursu, w którym przewidziano trzy nagrody główne (I miejsce - 5000 zł, II - 4000 zł, III - 3000 zł) i 10 wyróżnień (po 1000 zł), podane zostały w ogłoszeniu reklamowym zamieszczonym na łamach „Polityki”264.

Inną ciekawą inicjatywę promował na łamach pisma Empik. W roku 2001 i 2002 pojawiała się informacja o cyklicznej akcji (AS Empik-u). Jej pierwsza odsłona odbyła się w 1999 r. Jak pisali inicjatorzy pomysłu:

258 M. Czubaj, Trędowate metafory, „Polityka” 2002, nr 51/52, s. 104-108.

259 M. Czubaj, Wielka Trędowata, „Polityka” 2003, nr 6, s. 64.

260 Ibidem, s. 64-67.

261 „Polityka” 2005, nr 7, s. [85].

262 „Polityka” 2005, nr 49, s. [108]. Nagrody w konkursie: I miejsce - 2 tys. dolarów, II - 1,5 tys. dolarów, III - 1 tys. dolarów; 3 wyróżnienia po 500 dolarów.

263 Było to być może mimowolne nawiązanie do podobnych inicjatyw podejmowanych w II Rzeczypospolitej. Owocowały one wydaniem pamiętników bezrobotnych, chłopów, robotników.

264 „Polityka” 2001, nr 8, s. 56. Ponownie ogłoszenie to pojawiło się w grudniu: ibidem, nr 49, s. 90. 
EMPiK co kwartał zbiera opinie dyrektorów działów poszczególnych salonów, by pod koniec roku przedstawić Kapitule ASÓW Empik-u listę tytułów zasługujących na szczególną uwagę i wyróżnienie. Tak jak w latach poprzednich, miano WYDARZENIA ROKU otrzyma pozycja, która zdaniem Kapituły, wniosła nową jakość do polskiej kultury i wywarła największy wpływ na zachowania i gusty odbiorców, co wcale nie musi oznaczać sukcesu komercyjnego 265 .

Wśród nominowanych znajdowali się kandydaci z następujących kategorii: „książka polska”, „książka zagraniczna”, „płyta polska”, „płyta zagraniczna”, "film dvd”, „film vhs”, „multimedia edukacja”, „multimedia rozrywka". W każdej grupie znajdowało się pięciu kandydatów²66. W 2001 r. na decydującym etapie pojawiła się m.in. książka J. Pilcha: Pod Mocnym Aniołem.

Dwukrotnie (w 2001 i 2002 r.) wydrukowano ogłoszenie, w którym reklamodawca (Skarbnica Współczesnych Poetów) zwracał się do poetów, „piszących do szuflady”, by nadsyłali swe prace. Wybrane z nich miały być zamieszczone w przygotowywanej Antologii poezji ${ }^{267}$.

W tygodniku pojawiła się też informacja Klubu Świata Książki, który był organizatorem konkursu na powieść współczesną dla kobiet: Złote pióro 2002268. Nagrodą było wydanie wybranej powieści i honorarium autorskie. Przewidywano również trzy wyróżnienia (ich autorzy mieli otrzymać eleganckie pióra).

Pojawiały się także ogłoszenia dotyczące Konkursu Publicystycznego o Nagrodę im. Andrzeja Szczypiorskiego. W inseracie czytamy:

W tegorocznej edycji jury proponuje formułę „Porozumienie mimo podziałów”. Zachęca autorów, by wzorem Andrzeja Szczypiorskiego zechcieli skomentować dzisiejszą sytuację w Polsce, oceniając przeszkody, ale i szanse porozumienia między wieloma skonfliktowanymi ze sobą grupami społeczeństwa ${ }^{269}$.

Inicjatorem przedsięwzięcia było Wydawnictwo Sens, jednym z jurorów został W. Władyka. Przewidziano trzy nagrody finansowe (3000 zł, 1500 zł, 1000 zł). W ogłoszeniu podającym listę laureatów znalazła się informacja o tym, że wydana zostanie praca zbiorowa, w której znajdą się nagrodzone i wyróżnione teksty270.

265 „Polityka” 2002, nr 5, s. 55.

266 Książki polskie i zagraniczne, nominowane do tytułu w 2001 r., zob. „Polityka” 2001, nr 44, s. 50; nr 47, s. 61; nr 51/52, s. 85.

267 „Polityka” 2001, nr 9, s. 98; 2002, nr 19, s. 51.

268 „Polityka” 2002, nr 45, s. [85].

269 „Polityka” 2002, nr 6, s. 81. Przypomnienie o konkursie pojawiło się w następnym numerze pisma: ibidem, $\mathrm{nr} 7, \mathrm{~s} .78$.

270 „Polityka” 2002, nr 22, s. [101]. 
W 2004 r. pojawiło się również ogłoszenie o konkursie na tekst opowiadający o życiu gejów i lesbijek ${ }^{271}$.

Drugą grupę inicjatyw, podejmowanych przez „Politykę”, a związanych z książką, stanowią (obok konkursów) rozmaite akcje.

Najgłośniejszą i najdłużej trwającą było przedsięwzięcie Cała Polska czyta dzieciom. Po raz pierwszy informacja na ten temat pojawiła się na łamach pisma 2 czerwca 2001 r.:

Tak nazywa się akcja Fundacji ABCXXI - program Zdrowia Emocjonalnego, do której przyłącza się redakcja „Polityki”. Robimy to z okazji Dnia Dziecka 2001 r., ale ze znacznie istotniejszych powodów. Podzielamy przekonanie animatorów akcji, że czytanie jest sercem edukacji, więc najlepsze, co możemy zrobić dla dobrej przyszłości naszego dziecka, jest czytanie mu na głos 272 .

W następnym numerze znalazł się dłuższy, ponadstronicowy tekst Ireny Koźmińskiej (założycielki Fundacji): 20 minut273, w którym przekonywała ona o dobrodziejstwach, płynących z głośnego czytania książek dzieciom, i radziła, jak robić to najlepiej. W kolejnym numerze ponownie nawiązano do tej akcji. Magdalena Strzałkowska proponowała odpowiednie dla dzieci lektury, podając tytuły, które można wybrać z niezwykle bogatej oferty wydawniczej, „co zrobić, żeby dziecko nas w ogóle słuchało?” i „jak odróżnić książkę prawdziwą od książki - pułapki?"274. Akcja doczekała się odzewu ze strony czytelników, którzy w listach w pełni aprobowali pomysł przyzwyczajania dzieci do czytania od najmłodszych lat ${ }^{275}$. Od tego czasu przypominano o akcji, na przykład w postaci krótkich wzmianek lub poprzez dołączanie do tygodnika wkładki reklamującej to przedsięwzięcie. W ramach akcji zorganizowany został Ogólnopolski Tydzień Czytania, w którym udział wzięło ponad 150 miast. Przygotowane zostały w nich liczne imprezy z udziałem znanych pisarzy, aktorów i polityków, popierających tę formę promocji książki. Inicjatywa okazała się ogromnym sukcesem. W 2005 r. pojawiło się ogłoszenie, w którym organizatorzy akcji zwracali się do czytelników z prośbą o wsparcie Fundacji ABCXXI poprzez przekazanie na jej konto $1 \%$ swego podatku ${ }^{276}$.

271 „Polityka” 2004, nr 1, s. 106.

272 „Polityka” 2001, nr 22, s. 12.

273 I. Koźmińska, 20 minut, „Polityka” 2001, nr 23, s. 62, 64.

274 M. Strzałkowska, Uszatek wiecznie żywy, „Polityka” 2001, nr 24, s. 88-90.

275 Zob. np. „Polityka” 2001, nr 28, s. 82.

276 „Polityka” 2005, nr 12, s. 114. W 2007 r., a zatem w okresie, który nie obejmuje zakresu prezentowanej pracy, zapoczątkowano wydawanie Kolekcji książek „dla dzieci, rodziców i dziadków do wspólnego czytania”, będącej owocem akcji. Zob. np. „Polityka” 2007, nr 4, s. [92], M. Czubaj, Lotta i Emil, wspaniałe uparciuchy, ibidem, nr 48, s. 93. 
Warto także wspomnieć o pomniejszych pomysłach redakcji, realizowanych na łamach pisma. Jednym z nich był jednorazowy pomysł w $2001 \mathrm{r}$., polegający na propozycji wzięcia udziału w wakacyjnym kursie pisarstwa, prowadzonym (z przymrużeniem oka) przez Agnieszkę Glińską, Jerzego Pilcha i Tadeusza Słobodzianka. Kurs miał odbywać się w domu pracy twórczej nad Wigrami 277 .

Na łamach „Polityki” zamieszczano również liczne zaproszenia na spotkania z pisarzami, promującymi swe książki i relacje z tych imprez. Czytelnicy dowiedzieli się $\mathrm{w}$ ten sposób m.in. o spotkaniach z Normanem Daviesem, Arturem Domosławskim, Wojciechem Kuczokiem, Reesem Laurencem, Stanisławem Lemem, Dorotą Masłowską, Krzysztofem Mroziewiczem, Rudolfem von Thaddenem i Stanisławem Zawiślańskim.

Odnaleźć można także zaproszenia do wzięcia udziału w innych akcjach, związanych z literaturą. Propozycje te miały postać bądź krótkich wzmianek bądź ogłoszeń reklamowych. Przykładem może być zachęta do wzięcia udziału w publicznym czytaniu utworów Cz. Miłosza z okazji jego 90. urodzin czy w podobnej inicjatywie: publicznym czytaniu na głos przez 3 tys. wiernych przez 7 dni i nocy Pisma świętego. Ciekawą inicjatywę podjął Instytut Informacji Naukowej i Studiów Bibliologicznych Uniwersytetu Warszawskiego wespół z Fundacją „INFO XXI”. W dniach 7-10 kwietnia 2001 r. w Bibliotece Uniwersyteckiej miały się odbywać spotkania pod wspólnym tytułem Szał czytania. Pismo, będąc jednym z patronów medialnych tego przedsięwzięcia, kilkakrotnie zamieściło jego reklamę ${ }^{278}$.

\subsubsection{Kup gadżetę!279 Inne informacje: o prasie i środowisku dziennikarskim}

„Polityka” dużo miejsca poświęcała także sprawom rynku prasowego (zob. Aneks 9. Wybór tekstów poświęconych rynkowi prasowemu, drukowanych na łamach „Polityki” w latach 2001-2005). Pisano o zmianach zachodzących na rynku prasowym w Polsce ${ }^{280}$, o pojawieniu się na nim nowych periodyków: „Newsweek Polska” w 2001 r., „Faktu” dwa lata później czy w 2005 r. „Nowego Dnia”. Zamieszczano także obszerniejsze teksty poświęcone określonym rodzajom prasy, na przykład młodzieżo-

277 „Polityka” 2002, nr 30, s. 85.

278 Informacje na temat tej akcji pojawiły się także w innym badanym periodyku. Zostanie ona omówiona w dalszej części pracy.

279 [Pis. oryg.], „Polityka” 2003, nr 37, s. 40-42.

280 Zob. np. A. Rybak, Sezon krokodyli [o sytuacji na rynku prasy codziennej i konkurencji pomiędzy Wydawnictwem Agora i Axel Springer], „Polityka” 2005, nr 41, s. 24-26. 
wej281, lokalnej282, adresowanej do mężczyzn ${ }^{283}$. Pisano o konkretnych tytułach, na przykład „Przyjaciółce”284, „Tygodniku Powszechnym”285, „Trybunie”286, miesięczniku „Państwo i Prawo” (z okazji jubileuszu 55-lecia jego istnienia) ${ }^{287}$.

Przypominano pisma z okresu PRL (na przykład tygodnik „Rzeczywistość" ${ }^{288,}$ miesięcznik „Kontakt”289 czy „Robotnik”290). Kreślono sylwetki redaktorów i dziennikarzy (jak choćby Krystyny Kaszuby, pierwszej redaktor naczelnej „Twojego Stylu”291). W postaci krótkich wzmianek w ramach działu Kadry nominacje denominacje informowano o roszadach na stanowiskach redaktorów naczelnych w gazetach i czasopismach polskich oraz o zmianach właścicieli poszczególnych tytułów.

Rozważano także kwestię etyki dziennikarskiej i granic swobody wypowiedzi. Wielokrotnie zastanawiano się nad położeniem tradycyjnej prasy i sposobów, stosowanych przez większość wydawców gazet i czasopism, dzięki którym starali się oni zatrzymać czytelników przy danym tytule. Pisano zatem o gadżetach, dołączanych do prasy, o kolekcjach książek, przygotowywanych przez wydawców, a także o prasie w Internecie.

Jednocześnie „Polityka” przyłączyła się do przedsięwzięcia, zorganizowanego przez Wydawców Prasy w ramach akcji informacyjnej: „Bądź mądry - czytaj prasę". Na łamach tygodnika pojawiły się też reklamy, promujące czytelnictwo gazet i czasopism. Na zdjęciu 16 ukazano jeden z przykładów tego typu reklam ${ }^{292}$.

281 M. Pęczak, Ślizg we fluid, „Polityka” 2001, nr 28, s. 51-[52].

282 P. Pytlakowski, Cenzor wójt, „Polityka” 2002, nr 32, s. 29-31.

283 K. Lubelska, Męska przygoda, „Polityka” 2001, nr 33, s. [52]-[54].

284 B. Pietkiewicz, Babska przyjaźń, „Polityka” 2003, nr 13, s. 92-93.

285 A. Szostkiewicz, Życiorysy pod prąd, „Polityka” 2002, nr 28, s. 66-67.

286 M. Janicki, P. Pytlakowski, Podwójne życie organu, „Polityka” 2002, nr 50, s. 32-34.

287 [br. aut.], Jubileusze, „Polityka” 2001, nr 21, s. 12.

288 P. Pytlakowski, Betonowa „Rzeczywistość”, „Polityka” 2003, nr 2, s. 64-66.

289 R. Lewandowski, Jak wypalił się Kontakt, „Polityka” 2003, nr 20, s. 74-76.

290 I. T. Miecik, Kornik, „Polityka” 2001, nr 38, s. 72-74, 77.

291 K. Lubelska, Madame Redaktor, „Polityka” 2002, nr 14, s. 78-80.

292 Inny przykład reklamy z tego cyklu, zob. „Polityka” 2005, nr 29, s. [99]. 


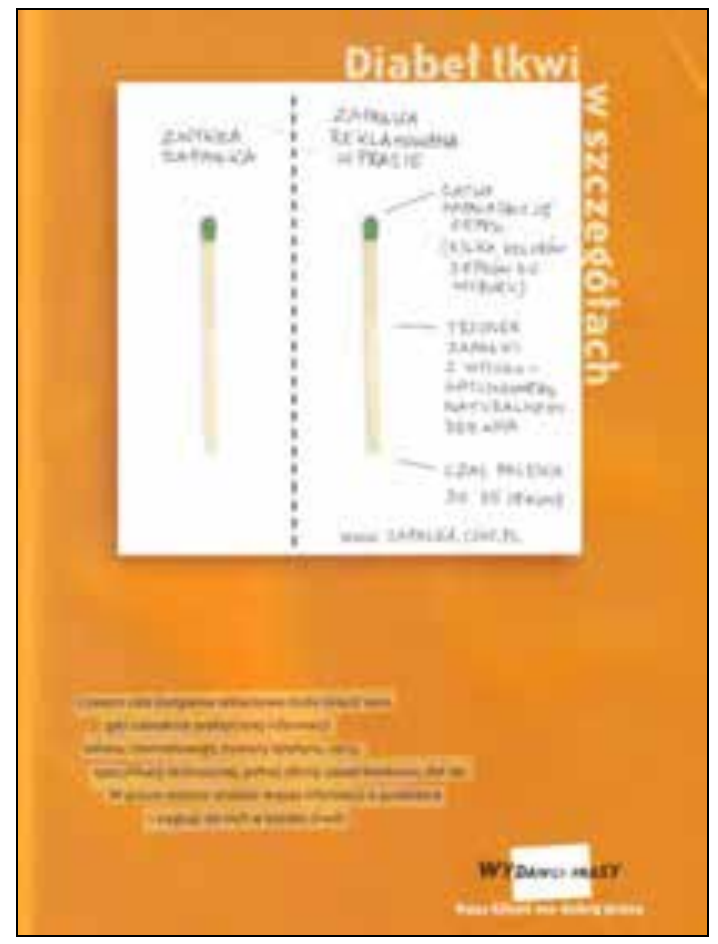

Zdjęcie 16. Reklama Wydawców Prasy „Polityka” 2003, nr 14, s. [81]

W 2005 r. na łamach pisma znalazł się protest Izby Wydawców Prasy przeciwko zwiększenia opodatkowania książek i prasy.

Innym elementem, wpisującym się w kampanię upowszechniania prasy, były bez wątpienia liczne reklamy zarówno poszczególnych periodyków, jak i promocja samej „Polityki” i tytułów wydawanych przez Spółdzielnię Pracy („Forum” i „Res Publiki Nowej”). Stanowią one temat na oddzielną pracę, ale warto $\mathrm{w}$ tym miejscu zaznaczyć, że zarówno ich liczba w badanym okresie (521 anonsów ${ }^{293}$, z czego 466 reklamujące czasopisma, 22 promujące gazety i 33 dodatki do nich), jak i forma są niezwykle imponujące w omawianym tygodniku. W sumie w postaci reklam pojawiła się informacja o 48 tytułach gazet i czasopism. Zamieszczono m.in. inseraty promujące "Cosmopolitan”, „Gazetę Prawną", „Gazetę Wyborczą", „Muratora”, „National Geographic”, „Panią Domu”, „Przyjaciółkę”, „Zwierciadło”, „Życie”. Najciekawiej w tej grupie prezentowały się reklamy "National Geographic”.

293 Ta liczba odnosi się do wszystkich tego typu inseratów, bez względu na powtarzalność reklamowanych w nich tytułów. 
Zajmowały one zazwyczaj całą stronę, były niezwykle barwne i za każdym razem zawierały inne elementy. Niemal w każdym anonsie pojawiała się okładka określonego numeru promowanego pisma, wzbogacona o hasła reklamowe (zdjęcie 17-19).

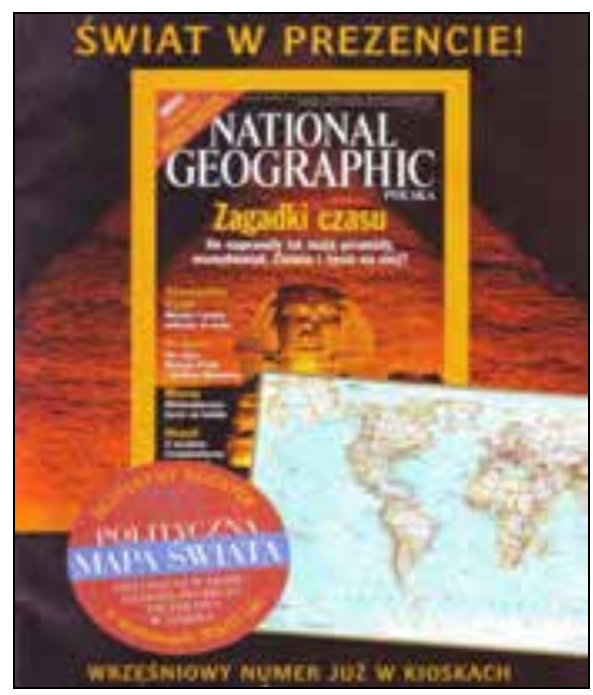

Zdjęcie 17. Wybrane ogłoszenie wydawnicze zamieszczone na łamach „Polityki” „Polityka” 2001, nr 35, s. [18]

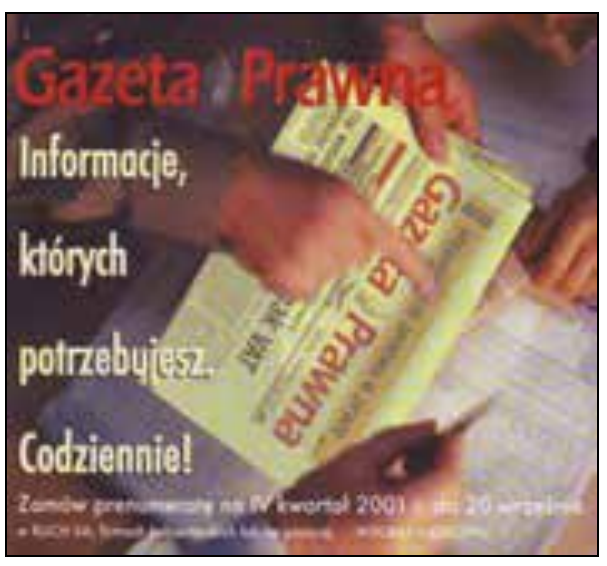

Zdjęcie 18. Wybrane ogłoszenie wydawnicze zamieszczone na łamach „Polityki” „Polityka” 2001, nr 36, s. [65]

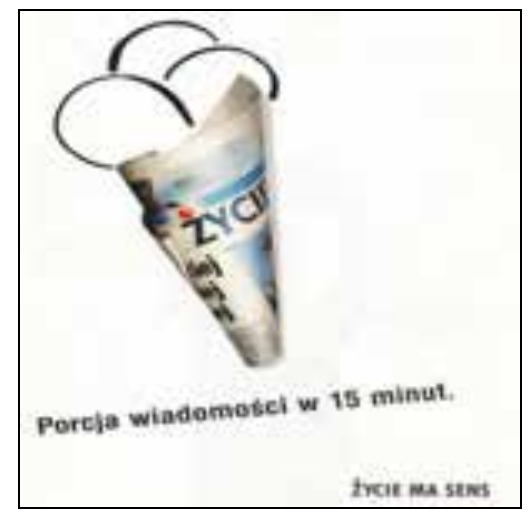

Zdjęcie 19. Wybrane ogłoszenie wydawnicze zamieszczone na łamach „Polityki”

„Polityka” 2001, nr 38, s. [91] 
W pierwszym ogłoszeniu elementem zachęcającym do kupna tytułu miał być bezpłatny dodatek w postaci Politycznej mapy świata, natomiast w dwóch kolejnych inseratach wzrok czytelnika przykuwały hasła reklamowe. Jednocześnie w ogłoszeniu promującym dziennik „Życie” temu celowi służył również element graficzny, ciekawie prezentujący proponowany tytuł294.

Jednak rekordy powtarzalności pojawiły się w przypadku autoreklamy pism wydawanych przez Spółdzielnię Pracy Polityka. Najwięcej, bo aż 265 razy, pojawił się inserat, promujący „Forum” (anonse zawierały z reguły podobne elementy), 35-krotnie ogłoszenie dotyczące „Res Publiki Nowej”, zaś sama "Polityka” reklamowana była zarówno w postaci tradycyjnej, jak i online. Informowano także o możliwości słuchania reportaży z tygodnika na falach wybranych rozgłośni radiowych. Niejednokrotnie zdarzało się, że cała strona poświęcona była autoreklamie pisma295.

Podsumowując publikacje dotyczące prasy, zamieszczane na łamach „Polityki”, można powiedzieć, że stanowiły one stosunkowo liczną grupę; starano się informować czytelników zarówno o pojawieniu się nowych tytułów, jak i o ogólnej kondycji wybranych rodzajów prasy. Biorąc pod uwagę charakter omawianego pisma, wydaje się, że liczba tego typu tekstów była wystarczająca; spełniały one głównie funkcję informacyjną.

Analiza zebranych danych pozwala stwierdzić, że problematyka związana z kulturą, literaturą zajmowała ważne miejsce w polityce redakcyjnej tygodnika.

Jednocześnie zaprezentowany powyżej materiał świadczy o bogactwie i różnorodności informacji o książce, zamieszczanych na łamach „Polityki”. Promując literaturę, wykorzystano rozmaite formy przekazu, poczynając od recenzji, poprzez reklamy, wywiady, portrety pisarzy, a kończąc na publikacjach ogólnych, związanych $\mathrm{z}$ interesującym nas zagadnieniem. Teksty miały różny charakter (informacyjny, komentujący, analityczny) i objętość (od półstronicowych, poprzez dwustronicowe, kończąc na obszerniejszych). $\mathrm{Z}$ reguły przygotowywane były profesjonalnie, a w przypadku dłuższych artykułów tekst opisowy wzbogacano trafnie dobranymi zdjęciami. Omawiano nie tylko literaturę rodzimą i jej kondycję we współczesnym świecie, ale sięgano również po piśmiennictwo zagraniczne, prezentując sylwetki wybranych pisarzy i ich twórczość.

294 Inne, ciekawe reklamy tytułów prasowych: zob. np. „Polityka” 2001, nr 6, s. 43 (inserat promujący „Przyjaciółkę”), podobny w formie anons proponujący „Panią domu”: ibidem, nr 11, s. 65; ibidem, nr 21, s. [67] (miesięcznik „Profit”), ibidem, 2003, nr 7, s. [69] („Pilot: dodatek telewizyjny”), ibidem, nr 31, s. [57] (reklama miesięcznika kobiecego „Zwierciadło”).

295 Od 2001 r. pojawiały się często całostronicowe reklamy Polityki On Line, zob. np. „Polityka” 2001, nr 15, s. [100]. Pamiętano także o promocji prenumeraty tygodnika; zazwyczaj przypominano o niej w grudniu danego roku, zob. np. ibidem, 2003, nr 49, s. [107]. 
Oceniając poziom i wartość prezentowanych informacji, można powiedzieć, że spełniały one swoją rolę, wynikającą z definicji prasy opinii. Jednocześnie (przynajmniej w pewnym stopniu) zdawały się wpisywać w cele redakcji, które Z. Pietrasik określił w następujący sposób:

Polityka tygodnika w tym względzie jest zdroworozsądkowa: oceniamy rzeczy zasługujące na uwagę naszą i naszych czytelników. Nie ulegamy naciskom i modom. Nie lansujemy, lecz przedstawiamy. Staramy się być „przewodnikiem po chaosie”, wybrać z ogromnej liczby ofert to, co cenne, odrzucić chłam wydawniczy ${ }^{296}$.

Tym samym udowadniano swą czołową pozycję lidera wśród pism opinii w Polsce, także pod względem zainteresowań problematyką kulturalną i literacką.

296 Informacje uzyskane dzięki korespondencji ze Zdzisławem Pietrasikiem. 


\section{3. „Wprost” górą! ${ }^{1}$}

\subsubsection{Z Poznania do Warszawy: historia czasopisma}

To jest gazeta, która zawsze dzień czy dwa dni przed jakimś istotnym wydarzeniem okazuje się najlepiej poinformowana ${ }^{2}$.

Numer zerowy „Wprost” z podtytułem „Tygodnik Społeczno-Polityczny" ukazał się 24 października 1982 r. w Poznaniu, w miejsce zlikwidowanego niemal rok wcześniej czasopisma „Tydzień”3. Redakcja, którą częściowo tworzyły osoby związane z poprzednim periodykiem, tak pisała o nowym tytule:

Od poprzednika [...] różni je i kształt zewnętrzny i charakter. Traci więc swoje pismo spora grupa zwolenników magazynów kolorowych, zyskują jednak czytelnicy oczekujący lektur związanych z trudnymi problemami współczesności. [...] krótki wyraz nie może oddać programu czasopisma, sygnalizuje jednak zamiar otwartego kontaktu z Czytelnikami i intencją publicystyki komunikatywnej. Tytuł ten wskazuje na publicystyczny i dyskusyjny charakter tygodnika, co stawia go w określonej rodzinie czasopism i orientuje Czytelnika w charakterze oferty 4 .

Dalej określone zostały cele, jakie stawiała przed sobą redakcja, wskazując na wagę i znaczenie spraw związanych z polityką, podkreślając, że nowy periodyk jest: „pismem politycznym przez swoją solidarność z linią i programem politycznym Polskiej Zjednoczonej Partii Robotniczej”, choć jednocześnie „otwartym, który udostępni swoje łamy każdemu, kto wobec spraw dnia zechce zająć własne stanowisko, bądź swoją wiedzą lub doświadczeniem służyć innym"6.

Sygnalny numer liczył 32 strony. Z założenia adresowany miał być przede wszystkim do odbiorców w Wielkopolsce, choć zamierzano również dotrzeć do innych regionów w kraju. Na następne wydanie „Wprost” czytelnicy musieli jednak zaczekać dłużej niż tydzień. Ponownie pojawiło

1 Tytuł informacji dotyczącej przyznania w 2004 r. tygodnikowi nagrody Wydawcy Roku przez pismo „Media \& Marketing”, „Wprost” 2004, nr 39, s. 6.

2 „Wprost” 2005, nr 11, s. 10 (słowa Aleksandra Kwaśniewskiego zamieszczone na łamach "Gazety Wyborczej" z 9 marca 2005 r.).

3 „Tydzień” - periodyk wydawany był w Poznaniu od 23 września 1973 r. do 13 grudnia 1981 r. W sumie ukazało się 50 numerów tego pisma. Jego redaktorem naczelnym był Mieczysław Skąpski.

4 „Wprost” 1982, nr 0, s. 2.

5 Ibidem.

${ }^{6}$ Ibidem, s. 3. 
się ono 5 grudnia 1982 r. Podobnie, jak poprzedni numer, również i ten, oficjalny pierwszy, wydany został przez RSW „Prasa-Książka-Ruch” i Wielkopolskie Wydawnictwo Prasowe. Redaktorem naczelnym został Janusz Przybysz, jego zastępcą Waldemar Kosiński, a sekretarzem redakcji Jerzy Matuszkiewicz. W skład zespołu weszli: Marcin Bajerowicz, Grażyna Banaszkiewicz, Zenon Bosacki, Andrzej Haegenbarth, Krystyna Lubiańska, Tomasz Mańkowski, Edward Pawlak, Anita Pudlik, Mariusz Stachowiak, Ewa Staniewicz, Tomasz Talarczyk i Tadeusz Wójcicki. Tym razem redakcja była bardziej powściągliwa w swych deklaracjach, ograniczając się do krótkiego stwierdzenia:

Nie chcemy gubić spraw ważnych i nam bliskich w powodzi słów, tym bardziej, że wiele słów pięknych i ważnych uległo dewaluacji. [...] Naszą postawę, nasze dążenia i ambicje, będzie dokumentował każdy kolejny numer pisma. Jedno możemy obiecać naszym Czytelnikom: może to nam się czasem nie udawać, ale zawsze będziemy się starać pisać w p r o s t

To wydanie również miało objętość 32 stron, kosztowało 15 zł ${ }^{8}$ Od numeru 7 (1983) redaktorem naczelnym został Waldemar Kosiński, pojawiły się również nowe nazwiska, na przykład Jana Biłosa, Piotra Gabryela, Eugeniusza Jarosika i Tadeusza Owczarzaka.

Do 1989 r. pismo miało zasięg regionalny, z siedzibą redakcji w Poznaniu.

Jak pisze Jan Załuski:

„Wprost” lat osiemdziesiątych należał do tych czasopism, które podejmowały - choć trudno powiedzieć, że preferowały - tematy określane jako „odważne”, niechętnie akceptowane przez politycznych decydentów. Z jednej strony ukazywano biedę milionów ludzi, społeczny margines, patologie, $\mathrm{z}$ drugiej upowszechniano przykłady osób, którym się powiodło, bo wzięły sprawy w swoje ręce i naśladowały drobnych kapitalistów z Zachodu9 .

Na łamach ówczesnego tygodnika dominowała problematyka społeczno-polityczna ${ }^{10}$, która jednak nie przysparzała mu popularności. Objętość numeru pozostawała niezmienna: nadal liczył 32 strony, nieznacznie, w przeciwieństwie do szaty graficznej periodyku, zmieniały się działy i rubryki. Do numeru 26 w 1984 r. czytelnicy kojarzyli „Wprost” z okładką

7 „Wprost” 1982, nr 1, s. 2.

${ }^{8} \mathrm{~W}$ numerze zerowym nie podano ceny; być może, jako egzemplarz pokazowy, rozdawany był za darmo.

9 J. Załuski, Zawiłe losy „Wprostu”, [w:] Prasa dawna i współczesna. Część piąta, red. B. Kosmanowa, Wydawnictwo Naukowe Instytutu Nauk Politycznych i Dziennikarstwa Uniwersytetu im. Adam Mickiewicza w Poznaniu, Poznań 2004, s. 88.

${ }^{10}$ Na przykład w 1983 r. tygodnik zaangażował się w upowszechnianie idei związanej z Patriotycznym Ruchem Odrodzenia Narodowego (PRON), współorganizując spotkania, na których prezentowano program tej organizacji. 
w charakterystycznej, żółtej ramce, z tytułem wydrukowanym czarną lub białą czcionką i kilkoma stronami wewnątrz numeru na żółtym tle. Ale w połowie tego roku kolor żółty zastąpiono różowym. Przetrwał on dwa lata. W tym czasie zdarzały się numery pisma, w których okładka, prawdopodobnie ze względów finansowych, przypominała jednak raczej kolor szary niż każdy inny.

Zawartość, i być może w pewnym stopniu także względy estetyczne, decydowały o tym, że aż do czasu prywatyzacji „Wprost” było tytułem deficytowym. Sytuacji nie zmieniał fakt, że do zespołu redakcyjnego dołączali w tych latach kolejni dziennikarze. Wśród nich znaleźli się m.in. Piotr Andrzejewski, Iwona Gajdzińska, Piotr Grochmalski, Przemysław Grociak, Marek Król11, Jerzy Matuszkiewicz (pełniący przez kilka miesięcy funkcję zastępcy redaktora naczelnego), Wacław Miziniak, Rafał Węgierkiewicz, Marek Zieleniewski i Piotr Zimny.

Rok 1989, podobnie jak dla całej prasy, tak i dla „Wprost” okazał się czasem zmian. Od numeru 11 (z 12 marca 1989 r.) redaktorem naczelnym pisma został M. Król12. Periodyk stał się pismem ogólnopolskim, choć nadal z siedzibą w Poznaniu i oddziałem w Warszawie, zatrudniającym miejscowych dziennikarzy. Nie wpłynęło to jednak w sposób wyraźny na zmianę jego zawartości czy szaty graficznej. Objętość numeru pozostawała niezmienna, działy i rubryki były podobne. Warto jednak zaznaczyć, że tygodnik otrzymał w tym czasie I nagrodę Klubu Redakcyjnego Stowarzyszenia Dziennikarzy Polskiej Rzeczypospolitej Ludowej za „zdobycie przebojem rynku czytelniczego i uznanie czytelników"13.

Rok 1990 to kolejne zmiany w piśmie. Ich zwiastunem stała się okładka numeru czerwcowego ${ }^{14}$ : wydrukowana na lepszym jakościowo papierze, w innej (niebieskiej) tonacji, symbolicznie nawiązywała do numeru zerowego „Wprost” z 1982 r. M. Król pisał:

oddając czytelnikom 394 numer naszego tygodnika z kolorową okładką i zmienionym układem wewnątrz, postanowiliśmy, bez zbędnych fanfar i manifestów, zakończyć okres szary w dziejach „Wprost”. Podjęliśmy próbę wydawania pisma, które poziomem edytorskim, a także redakcyjnym powinno sprostać oczekiwaniom naszych wymagających czytelników ${ }^{15}$.

11 Jego nazwisko po raz pierwszy pojawiło się w stopce redakcyjnej w numerze 6 (1984).

12 Pełnił on tę funkcję aż do 2006 r. Pomimo, że kolejne lata nie są objęte w ramy czasowe tej pracy, warto wiedzieć, że kolejnymi redaktorami pisma byli: P. Gabryel (20062007), St. Janecki (2007-2010), T. Lis (od 2010 r.).

13 Za: J. Załuski, Zawiłe losy..., s. 88.

14 Zob. „Wprost” 1990, nr 23.

15 M. Król, Zakaz zawracania, „Wprost” 1990, nr 23, s. 2. 
Od tego numeru na łamach periodyku zaczął pojawiać się m.in. cykl wywiadów ze Stefanem Kisielewskim, drukowany odtąd w rubryce Kisiel ${ }^{16}$. Ta forma dziennikarska była stałą pozycją każdego wydania, ale dopiero teraz zaczęła przyciągać w większym niż do tej pory stopniu zainteresowanie czytelników. A było ono periodykowi bardzo potrzebne, jako że właśnie $\mathrm{w}$ tym czasie zaczęły się jego problemy związane z prawem własności do tytułu.

W marcu 1990 r., zgodnie z uchwaloną wtedy ustawą, rozpoczęto likwidację RSW „Prasa-Książka-Ruch”, jednocześnie prywatyzując jej majątek. We wrześniu tego roku omawiany tytuł został tymczasowo wydzierżawiony Agencji Wydawniczo-Reklamowej „Wprost”, utworzonej przez Marka Króla i Lecha Kruszonę. Agencja wydawała tygodnik do lutego 1991 r., kiedy pismo zostało nieodpłatnie przekazane powstałej w redakcji Spółdzielni Pracy Dziennikarzy „Wprost” (jej prezesem był M. Król). Miała ona kontynuować wydawanie periodyku wspólnie z firmą Rok Corporation. Jednak następnego dnia po otrzymaniu praw do wydawania pisma spółdzielnia bezpłatnie przekazała to prawo AWR „Wprost”. Agencja podpisała ze Spółdzielnią umowę, w której znalazło się zapewnienie, że zarówno zyski, jak i straty, wynikające z wydawania tygodnika, obciążą wyłącznie konto AWR ${ }^{17}$.

Sama Spółdzielnia dziennikarska, mimo podpisanego z Likwidatorem RSW zobowiązania, nie podjęła działalności, przez niemal 2 lata nie zorganizowano także żadnego zebrania członków Spółdzielni. De facto zatem pismo wydawane było przez Rok Corporation i Agencję „Wprost”. Taka sytuacja trwała do kwietnia 1993 r. Przeprowadzona wówczas kontrola NIK wykazała nieprawidłowości własnościowe; wyniki zostały przedstawione Komisji Likwidacyjnej RSW. Jej szef, Tomasz Kwieciński, przekazał sprawę praw do tytułu na drogę sądową, a w mediach pojawiła się informacja, że tygodnik prawdopodobnie zostanie wystawiony na sprzedaż $w$ drodze przetargu.

Perturbacje sądowe trwały aż do 1999 roku i zakończyły się ugodą. AWR za prawo do posiadania tytułu wypłaciła Komisji milion dolarów ${ }^{18}$.

16 Wywiady ze S. Kisielewskim drukowane były do numeru 37 (1991). W następnym wydaniu pojawiła się informacja: „Kisiel: zawieszamy - na jakiś czas - rozmowy z panem Stefanem Kisielewskim z przyczyn zależnych od Pana Boga. Redakcja”. Zob. „Wprost” 1991, nr 38, s. 6.

17 Poza tym, w stopce redakcyjnej zjawiła się także inna zmiana; zamiast dotychczasowej informacji: „Wprost Tygodnik społeczno-polityczny RSW Prasa-Książka-Ruch”, Wielkopolskie Wydawnictwo Prasowe, pojawiła się zmiana nazwy wydawcy: Wielkopolskie Wydawnictwo Prasowe RSW „Prasa-Książka-Ruch”. Po raz pierwszy taka informacja znalazła się w numerze 20 (1989).

18 Za: T. Mielczarek, Monopol, pluralizm, koncentracja. Środki komunikowania masowego w Polsce w latach 1989-2006, Wydawnictwa Akademickie i Profesjonalne, Warszawa 2007, s. 154. W styczniu 2000 r. właścicielami AWR „Wprost” byli: M. Król (60\% udziałów), L. Kruszona (34\% udziałów), P. Gabryel, E. Jarosik i M. Zieleniewski (po 2\%). 
W tym okresie sytuacja tygodnika na rynku prasowym była już ustabilizowana pod względem finansowym. Posiadał on już także ukształtowaną grupę odbiorców. Przeprowadzona w tym samym roku ankieta wykazała, że w pierwszym rzędzie były to osoby z wykształceniem średnim, mieszkańcy dużych, powyżej 500 tys., miast, w wieku 35-54 lat, zwolennicy ówczesnej Unii Wolności ${ }^{19}$.

Jednocześnie z procesem wytoczonym przez Komisję Likwidacyjną RSW odbywały się inne sprawy sądowe przeciwko „Wprost”: dziennikarze pisma oskarżani byli wielokrotnie o naruszanie dóbr i zamieszczanie nieprawdziwych wiadomości ${ }^{20}$. W tym czasie tygodnik popadł także w poważny konflikt z Kościołem katolickim²1.

W 1997 r. Rok Corporation wniósł oskarżenie przeciwko „Wprost”, zarzucając pismu niedotrzymywanie umowy i oszustwa finansowe związane z podziałem zysków ze sprzedaży 22 . W połowie lat 90 . szerokim echem w mediach odbiła się też sprawa publikacji, zamieszczonych na łamach tygodnika „Nie”, „Dziennika Poznańskiego” i „Przeglądu Tygodniowego”, dotyczących M. Króla i jego domniemanych związków m.in. z dawną Służbą Bezpieczeństwa i UOP23.

Ostatnia dekada XX w. to z jednej strony okres dla pisma trudny, ale $\mathrm{z}$ drugiej były to dlań lata rozwoju. Zmieniał się wygląd zewnętrzny periodyku: we wspomnianym 1990 roku (od numeru 27) pojawił się kolejny pomysł związany grafiką pisma: okładka w czerwonej, charakterystycznej ramce stała się odtąd znakiem rozpoznawczym „Wprost”. W latach następnych wprowadzano coraz nowocześniejszą szatę graficzną. Wraz ze zwiększeniem objętości periodyku (z 32 do 96 stron w 1992 r.) zwiększał się również jego nakład: w 1992 r. wzrósł do 250 tys. egz. ${ }^{24}$ AWR stała się też (od 1995 r.) właścicielem czasopisma „Mój Pies” i miesięcznika „BusinessWeek/Polska" (od 2000 r.).

${ }^{19}$ Redakcja, Wprost od czytelników, „Wprost” 1999, nr 16, s. 27, 28.

20 Więcej, zob. m.in. J. Załuski, Zawiłe..., s. 92-94.

21 Przyczyną był artykuł opublikowany 21 maja 1995 r.: Kościół niezgody. Jego autor oskarżał w nim m.in. prymasa kard. J. Glempa o działania rzekomo szkodzące wizerunkowi Kościoła.

22 Zarzuty Rok Corporation doprowadziły do zatrzymania P. Gabryela, M. Króla i L. Kruszony. I ta sprawa odbiła się szerokim echem w mediach. Zob. m.in. odpowiedź tygodnika: St. Janecki, Zamach na „Wprost”, „Wprost” 1998, nr 1, s. 22-23.

${ }^{23}$ Zob. m.in. P. Dębski, Agent Marek Król, „Przegląd Tygodniowy” 1996, nr 4, s. 5; odpowiedź „Wprost”: zob. m.in. M. Cielemęcki, St. Janecki, współpraca J. S. Mac, Zemsta SLD, „Wprost” 1996, nr 49, s. 26-28; Z. Dąbrowska, Powiedzmy to wprost, „Przegląd Tygodniowy” 1998, nr 40, s. 8-9. Do sprawy powrócono w 2005 r., zob. m.in. T. Sygut, Kto stoi za „Wprost”, „Przegląd” 2005, nr 11, s. 10-[13].

24 Przypomnijmy, że na początku lat 90. XX w. nakład tygodnika „Polityka” wynosił tylko 130 tys. egz. 
Nie bez wpływu na rosnącą popularność tygodnika był fakt, że na jego łamach pojawiały się teksty, związane z głośnymi wówczas „aferami” politycznymi, jak choćby z tzw. sprawą Olina czy aferą InterAms. Jednocześnie w stopce redakcyjnej pisma zaczęły pojawiać się nowe nazwiska, m.in. Marioli Balickiej, Piotra Gajdzińskiego, Wiesława Kota, Aldony Łukomskiej, Bogusława Mazura. „Wprost” posiadało już w tym czasie swoich korespondentów zagranicznych, m.in.: Marka Brzezińskiego (informacje z Paryża), Piotra Cywińskiego (doniesienia z Bonn), Leszka Mazana (depesze z Pragi), Tomasza Wróblewskiego (relacje z Waszyngtonu).

Jednym z najskuteczniejszych sposobów na zwiększenie popularności pisma była odpowiedź na zmieniające się oczekiwania, szczególnie młodszych, czytelników. Jak redakcja sama przyznawała, „Internet otworzył przed > Wprost< nowe możliwości" 25. Na łamach periodyku w największym stopniu, w porównaniu z innymi tytułami z tej grupy, zaangażowano się w propagowanie nowoczesnych technologii. Dzięki temu tygodnik stał się jednym $\mathrm{z}$ pierwszych $\mathrm{w}$ Polsce tytułów prasowych dostępnych on-line. Pierwszy krok w tym kierunku uczyniono już w 1995 r., tworząc stronę www.wprost.pl. W kolejnych latach rozbudowywano ją o kolejne serwisy tematyczne, bazy danych i inne narzędzia interaktywne ${ }^{26}$.

$\mathrm{Z}$ szarego, prowincjonalnego pisma, zatrudniającego zaledwie kilku dziennikarzy, „Wprost” stawało się powoli nowoczesnym periodykiem, konkurującym o pierwsze miejsce z „Polityką” w grupie pism opinii.

Znaczącym momentem stał się dla periodyku rok 2000. W listopadzie tego roku redakcja przeniosła się z Poznania do Warszawy, do nowoczesnego budynku przy Al. Jerozolimskich 123. Agencja Wydawniczo-Reklamowa „Wprost” ulokowana została na 25. i 26. piętrze. Zmiana adresu oznaczała jednocześnie zmiany personalne w redakcji. Z ok. 100-osobowego składu redakcyjnego ponad 20 współpracowników zrezygnowało z przeprowadzki albo otrzymało wymówienia. Kilku dziennikarzy, pozostałych w Poznaniu, miało być korespondentami pisma27. Zmiana adresu nie pociągnęła za sobą zmian w wyglądzie tygodnika: zachowano stałe działy i rubryki oraz dotychczasową szatę graficzną wraz z objętością numeru (w tym czasie średnio już 130 stron).

Koniec wieku w periodyku żegnano interesującym plebiscytem, skierowanym do czytelników. Wraz z Programem 3 Polskiego Radia postano-

25 M. Karpiński, [br. tyt.], „Wprost” 2001, nr 36, s. 50.

26 Więcej o działaniach „Wprost” w tym w zakresie: zob. m.in. M. Przybysz-Stawska „Wprost” z Internetu. Budowanie nowego wizerunku prasy, [w:] Biblioteka Książka Internet 2010, red. Z. Osiński, Instytut Bibliotekoznawstwa i Informacji Naukowej UMCS w Lublinie, Lublin 2010, s. [125]-137; eadem, Tradycja i nowoczesność czwartej władzy (na przykładzie tygodników opinii: „Polityki”, „Wprost” $i$ „Newsweek Polska”) [w druku].

27 M. Chlabicz, „Wprost” do Warszawy, „Press” 2000, nr 11, s. 20. 
wiono wybrać zjawisko, które stanowiłoby symbol mijającego stulecia. Wśród propozycji znalazła się m.in. telewizja, samolot, kino, lodówka, ale także teoria względności i dziura ozonowa. Każdego dnia jedna z propozycji była prezentowana na antenie radiowej, zaś do czytelników i słuchaczy należał wybór tego, które uznają za najistotniejsze ${ }^{28}$. Wyniki zostały ogłoszone w lutowym numerze tygodnika w 2001 r. ${ }^{29}$

Dwa miesiące później, w kwietniu 2001 r., redakcja przedstawiła kolejną nowość: prenumeratę „Wprost” on-line, podkreślając, że tygodnik jest pierwszym w Polsce, w którym proponuje się odbiorcom takie ułatwienie ${ }^{30}$. $\mathrm{Na}$ chętnych czekały upusty i atrakcyjne nagrody. Od tej pory systematycznie ukazywało się w piśmie przypomnienie skorzystania z tej możliwości ${ }^{31}$.

W lipcu została uruchomiona następna usługa: czytelnicy tygodnika mogli założyć własne darmowe konto pocztowe, które miało funkcjonować w ramach serwisu Poczta Wprost ${ }^{32}$. Tworząc kolejne możliwości interaktywnego wykorzystania Internetu, redakcja pisała: „Wszystkie serwisy tworzymy w taki sposób, aby były czytelne dla kogoś, kto pierwszy raz w życiu korzysta z sieci, a jednocześnie oferowały zaawansowane produkty dla użytkowników ze stażem" ${ }^{33}$. W ten sposób proponowano następujące serwisy:

- www.wprost. pl. (zawierał aktualizowane na bieżąco informacje, analizy, komentarze i opinie),

- tygodnik.wprost.pl (było to internetowe wydanie pisma, w którym znalazła się baza danych zawierająca artykuły i felietony, zamieszczane w tygodniku),

- archiwum.wprost.pl. (dzięki wyszukiwarce czytelnik mógł w tym miejscu odnaleźć teksty zamieszczane w drukowanej wersji periodyku od lipca 1998 r., a także wiadomości z Wprost On-line),

- cafe.wprost.pl. (była to wirtualna kawiarenka, „miejsce spotkań” internautów, w której odbywały się cotygodniowe czaty z zaproszonymi politykami, przedstawicielami kultury i biznesu),

- kariera.wprost.pl. (poświęcono ją rynkowi pracy w Polsce. Zainteresowani mogli w tym miejscu odnaleźć propozycje pracodawców, kierowane zarówno do absolwentów szkół i uczelni, jak i do osób posiadających już staż w określonych zawodach. Pojawiły się tu oferty pracy dwóch największych internetowych serwisów pośrednictwa pracy: jobpilot.pl i jobaid.pl. Zamieszczano również porady dla poszukujących zatrudnienia, a w dziale

28 St. Janecki, Symbole XX wieku, „Wprost” 2000, nr 52/53, s. 26-[28], 30, 32, 34.

29 Pierwsze miejsce zajął komputer i Internet. Więcej, zob. St. Janecki, Znaki czasu, „Wprost” 2001, nr 2, s. 38-39.

30 [br. aut.], Złóż zamówienie on line, „Wprost” 2001, nr 15, s. [60].

31 „Wprost” 2001, nr 16, s. [55].

32 B. Leśniewski, E. Orłowski, Poczta.wprost.pl., „Wprost” 2001, nr 29, s. 48.

33 M. Karpiński, [br. tyt.], „Wprost” 2001, nr 36, s. 51. 
pomocy w zarządzaniu karierą znalazły się cenne wskazówki i rady. Dzięki pojawiającym się $\mathrm{w}$ tym serwisie wybranym artykułom drukowanym w tygodniku, rankingowi szkół wyższych i liście 100 najbogatszych Polaków witryna pozwalała poznać specyfikę rynku pracy w Polsce i rządzące nim prawa),

- forum.wprost.pl. (tu znajdowały się fora dyskusyjne „Wprost”, na których internauci mieli możliwość poruszyć każdy interesujący ich temat, wymienić poglądy i opinie),

- intermedia.wprost.pl. (było to internetowe wydanie działu Intermedia, zamieszczanego w drukowanej wersji tygodnika, urozmaicone o dodatkowe informacje z branży teleinformatycznej),

- www.sport.wprost.pl. (to serwis zawierający najnowsze informacje sportowe),

• kisiel.wprost.pl. (witryna poświęcona S. Kisielewskiemu oraz nagrodom jego imienia),

- Cr.wprost.pl (serwis związany z tytułem Człowieka Roku, przyznawanym przez tygodnik).

W latach następnych rozbudowywano stronę o kolejne serwisy, nie zaniedbując jednocześnie ich reklamy w wersji drukowanej pisma ${ }^{34}$.

Proponując czytelnikom rozwiązania w oparciu o możliwości, jakie dawało nowe medium, redakcja nie zapominała również o wersji tradycyjnej periodyku. Od numeru 50 (2001) zmieniono dzień wydawania pisma: odtąd miał się on pojawiać w kioskach w poniedziałki. Forma graficzna tygodnika uległa zmianie, pierwszy numer w kolejnym roku w historii pisma (2002) ukazał się w ulepszonej pod tym względem szacie, podobnie było w kwietniu tego roku. Pojawiały się nowe działy i rubryki 35 .

34 Zob. np. „Wprost” 2002, nr 11, s. 65. W ciągu następnych lat powstawały kolejne serwisy; niektóre z nich zostały przygotowane w okresie, nie objętym przez ramy czasowe tej pracy; warto jednak wspomnieć o kilku z nich: Gover.pl (pierwszy polski serwis typu „watch dog”, śledzący zachowania polskich polityków), Pitbul.pl (ironicznie komentujący polską scenę polityczną i dokonania jej reprezentantów), Blogbox.com.pl (zebrane z sieci najlepsze wpisy, składające się na swego rodzaju bibliotekę blogów); Nieruchomości.wprost.pl (najświeższe oferty kupna, sprzedaży i wynajmu mieszkań oraz domów); Motoryzacja.wprost.pl (oferty kupna i sprzedaży motocykli, samochodów osobowych i ciężarowych). Najciekawszy z nich to, jak się wydaje InfoTuba.pl, działający w sieci od 2008 r. serwis dziennikarstwa obywatelskiego, forum wymiany opinii i poglądów na tematy polityczne, ekonomiczne, społeczne, kulturalne i sportowe. Serwis ten został dokładniej omówiony w innym miejscu przez autorkę: M. Przybysz-Stawska: Nowe oblicze mediów, czyli dziennikarstwo obywatelskie, „Transformacje”. Pismo Interdyscyplinarne” 2012, nr 1-4, 289-304.

35 Np. Z życia koalicji/Z życia opozycji, zawierające krótkie, prześmiewcze wzmianki, komentujące polską scenę polityczną. Po raz pierwszy pojawiły się tygodniku w numerze 3 (2002), s. 10-11; Skaner - przegląd najważniejszych wydarzeń minionego tygodnia, wcześniej: Peryskop, zob. „Wprost” 2004, nr 6, s. 6-10. Zmiany dotyczące grafiki i zawartości pisma były szczególnie częste w 2002 r.; większość z nich była jednak niewielka, dlatego nie są one w tym miejscu szczegółowo opisywane. 
$\mathrm{Z}$ okazji 20-lecia istnienia pisma redakcja zleciła włoskiej firmie Marlen wykonanie pamiątkowej serii 200 wiecznych piór, zaś w 2002 r., świętując wydanie 1000. numeru „Wprost”, czytelnicy wzięli udział w konkursie związanym z najważniejszymi wydarzeniami ostatnich lat. Pierwszą nagrodą była dwuosobowa tygodniowa wycieczka do wybranego przez laureata miejsca na świecie ${ }^{36}$. Stabilna sytuacja finansowa pisma pozwoliła AWR na zakup kolejnych tytułów: w 2003 r. Agencja stała się właścicielem miesięcznika dla kobiet „Pani”37, a rok później czasopisma dla miłośników sportów wodnych „Rejs”38. W tym samym roku (2004) na łamach „Wprost” zaproponowano czytelnikom, mieszkającym na Mazowszu, dodatek kulturalny Warszawa i Kultura (WiK). Był to przewodnik repertuarowy kin, teatrów, wystaw, festiwali, koncertów, klubów, restauracji i pubów; znalazły się tu także informacje związane z literaturą39. W 2005 r. z okazji wakacji wydany został Wakacyjny Informator Kulturalny, tym razem o zasięgu ogólnopolskim ${ }^{40}$.

Zwieńczeniem starań redakcji w konkurencyjnej walce o czytelnika było otrzymanie przez AWR w 2004 r. prestiżowego tytułu Wydawcy Roku, przyznawanego przez pismo „Media \& Marketing”. We wrześniowym numerze „Wprost” pisano z dumą:

Zrobiliśmy wrażenie przede wszystkim rozmiarami naszych inwestycji - podczas gdy na rynku medialnym panuje bryndza, AWR „Wprost” jest wciąż w ofensywie! W ostatnim czasie przejęliśmy „Panią”, „Rejs” oraz „WiK. Warszawa i Kultura”. Wszystkie te tytuły odżyły, a stare wcale nie mają się gorzej. Warto podkreślić, że AWR „Wprost” to firma rdzennie polska, która doskonale daje sobie radę w konkurencji z zachodnimi potentatami medialnymi. Świadczą o tym zarówno jakość wydawanych pism, jak i zyski firmy ${ }^{41}$.

W tym czasie AWR wydawała już 6 tytułów prasowych, miała ustabilizowaną pozycję na rynku prasowym w Polsce i, co najważniejsze, grono wiernych czytelników.

Na popularność periodyku wpływ mieli również bez wątpienia jego współpracownicy. W badanym okresie (2001-2005) znaleźli się wśród nich

36 Więcej, zob. [br. aut.], 1000 prezentów na 1000 numer „Wprost” oraz podróż marzeń, „Wprost” 2002, nr 3, s. [28]-[29].

37 Periodyk zakupiony został od wydawnictwa Edipresse Polska, sprzedano go w 2005 r. Wydawnictwu Bauer.

38 Miesięcznik zakupiony w 2004 r., został zamknięty w 2005 r.

39 Pod tym tytułem ukazywał się najpierw jako samodzielne pismo; w postaci dodatku po raz pierwszy został dołączony w nr 18 (2004). Później zmienił tytuł na „Wprost i Kultura”. Przeważnie wydawany był w cyklu miesięcznym.

40 Tę edycję dołączono do numeru 27 (2005). Zapowiedź zob. WIK, czyli Wakacyjny Informator Kulturalny, „Wprost” 2005, nr 26, s. 102.

41 [br. aut.], Wprost górą! , „Wprost” 2004, nr 39, s. 6. 
nie tylko znani publicyści i dziennikarze, ale również politycy, historycy, pisarze, a nawet piosenkarze. Na łamach tygodnika pojawiały się teksty m.in.: Leszka Balcerowicza, Czesława Bieleckiego, Stefana Bratkowskiego, Olgierda Budrewicza, Sławomira Cenckiewicza, Małgorzaty Domagalik, Antoniego Dudka, Lecha Falandysza, Andrzeja Grajewskiego, Zygmunta Kałużyńskiego, Leszka Millera, Piotra Moszyńskiego, Tomasza Nałęcza, Piotra Nowiny-Konopki, Tomasza Raczka, Macieja Rybińskiego, Piotra Semki, Jana Stradowskiego, Pawła Śpiewaka, Stanisława Tyma, Lecha Wałęsy, Szewacha Weissa, Bronisława Wildsteina i Marcina Wolskiego. Taki dobór nazwisk gwarantował pismu popularność, mimo że musiano rywalizować z „Polityką”, a od września 2001 r. również z „Newsweek Polska”.

Dlatego też, podobnie jak w nich, tak i we „Wprost” wprowadzano kolejne przeobrażenia. I tak na przykład w numerze 20 (2005) redakcja informowała:

Zmieniliśmy wygląd. Tygodnik „Wprost” ma teraz wyraźnie oddzielone stałe rubryki od tekstów publicystycznych (różnią się kolorystyką i układem graficznym). W renomowanej amerykańskiej firmie kupiliśmy nowe czcionki ze starannie zaprojektowanym krojem liter. Nasz tygodnik stał się nowocześniejszy, łatwiej go czytać 42 .

Najczęstszym przeobrażeniom ulegała w analizowanym okresie rubryka Menu, drukowana w ramach działu Kultura. Ze względu jednak na temat pracy zmiany te zostaną przedstawione $\mathrm{w}$ dalszej jej części.

W ostatnim numerze w 2005 r. redakcja podała wyniki Instytutu Monitorowania Mediów, według których tygodnik „Wprost” był w październiku tego roku najbardziej opiniotwórczym pismem w Polsce, a liczba jego cytowań była niemal tak duża jak ich suma w przypadku dwóch największych konkurentów pisma („Polityki” i „Newsweek Polska”).

W 2007 r., podobnie jak w tygodniku „Polityka”, tak i na łamach „Wprost” świętowano swój jubileusz - w tym przypadku było to 25-lecie istnienia pisma. Z tej okazji wydany został okolicznościowy kalendarz z grafikami Rafała Olbińskiego; ukazało się też wydanie specjalne numeru.

M. Król tak podsumował historię pisma:

Cieszy nas szczególnie powtarzające się w opiniach sympatyków, ale także naszych zacnych krytyków, jedno spostrzeżenie - że pismo ma charakter. W czasach, kiedy nic tak nie poprawia wizerunku, jak brak poglądów, bycie pismem z charakterem to ogromny sukces i zasługa całego zespołu redakcyjnego tygodnika „Wprost”. Wątpiącym przypominam ostrzeżenie Cycerona, że pełzanie nie chroni przed upadkiem, a tygodnik to nie jest studolarówka, żeby się wszystkim podobał 43 .

42 [br. aut.], „Wprost” odświeżony, „Wprost” 2005, nr 20, s. 10.

43 M. Król, Instynkt „Wprost”, „Wprost” 2007, nr 49, s. [47]. 


\subsubsection{Zawartość, akcje i czytelnicy}

Zawartość pisma, mimo zmieniających się działów i rubryk, jest od lat podobna. Tak jak w przypadku większości tytułów z tej grupy, koncentrowała się w trzech blokach tematycznych, obejmujących zagadnienia związane z polityką, gospodarką i kulturą. W analizowanym okresie były one opisywane w następujących działach: Biznes-Ludzie-Pieniq̨dze, Intermedia, Kultura, Nauka i Zdrowie, Polska, Świat, Życie i Historia. Do stałych elementów pisma należały również felietony wspomnianych wcześniej współpracowników „Wprost”: Małgorzaty Domagalik, Zygmunta Kałużyńskiego, Tomasza Raczka, Piotra Moszyńskiego, Macieja Rybińskiego, Krzysztofa Skiby, Marka Skwarnickiego, Bronisława Wildsteina i Wacława Wilczyńskiego.

Jak już wcześniej zaznaczono, na łamach „Wprost” interesowano się w dużym stopniu rozwojem Internetu i nowościami technologicznymi. Stąd na jego zawartość składał się rozbudowany dział Intermedia ${ }^{44}$, w którym informowano czytelników o rozwoju nowych mediów i o tym, jakie dają one możliwości w odniesieniu m.in. do prasy ${ }^{45}$. W dziale pojawiały się rubryki o znamiennych tytułach, na przykład Innowacje, Intermożliwości, Przegląd intermediów. W ramach Wszechnicy wiedzy wszelakiej proponowano czytelnikom skorzystanie z interesujących stron internetowych, w sposób przystępny wyjaśniano zasady działania nowoczesnych urządzeń teleinformatycznych, opisywano najważniejsze, najbardziej popularne albo po prostu ciekawe portale i serwisy, recenzowano również pierwsze wydawnictwa multimedialne.

Stopniowo powstawało systematycznie rozbudowywane internetowe imperium „Wprost”. Takie działania wyraźnie wskazywały na to, że redakcja pragnie przyciągnąc młodsze pokolenie czytelników. Służyły temu na przykład wspomniane wcześniej spotkania w wirtualnym świecie Cafe Wprost. Wytyczonemu celowi sprzyjały liczne patronaty pisma nad imprezami i konkursami, związanymi z nowymi mediami. Od 2001 r. w tygodniku przyznawano Certyfikat Telekomunikacyjny Wprost. Była to, zainicjowana przy okazji targów Komputer Expo, nagroda za najciekawsze i najbardziej innowacyjne rozwiązania teleinformatyczne ${ }^{46}$. Redakcja wybierała grupę urządzeń, które jej zdaniem były najbardziej nowatorskie, a czytelnicy mieli

44 Od numeru 50 (2002) zmieniono jego nazwę na Życie i Intermedia. Od numeru 24 (2005) zrezygnowano z tej części pisma, ograniczając się odtąd do zamieszczania adresu witryny (www.wprost.pl).

45 Podkreślano np., że dzięki interaktywnym możliwościom Internetu tradycyjna gazeta może stanowić nie tylko źródło informacji, ale stać się może również ciekawą formą rozrywki.

46 Pierwsza informacja na ten temat pojawiła się w styczniu 2001 r. Zob. „Wprost” 2001, nr 3, s. 43. 
głosować na wybrane przez siebie, a wcześniej charakteryzowane w poszczególnych numerach tygodnika ${ }^{47}$, najciekawsze produkty.

Innym konkursem były Złote Strony Wprost. Czytelnicy i internauci wskazywali stronę, którą uznali za najciekawszą i SMS-em wysyłali jej adres na podany przez redakcję numer telefonu. Spośród zgłoszonych propozycji raz w tygodniu wybierana była przez dziennikarzy prowadzących Wprost On-line najlepsza strona, a jej adres wraz z kopią i krótką charakterystyką drukowany był w kolejnym numerze pisma, stanowiąc jej reklamę. Oceniana była zawartość treściowa zgłoszonej strony, jej walory użytkowe, poznawcze i edukacyjne. Nie bez znaczenia była jej estetyka, premiowano też oryginalną grafikę. Nagrody (możliwość zamieszczenia na nagrodzonej stronie logo Złotej Strony Wprost, a także prawo do bezpłatnego korzystania z danych serwisu stat24.pl.) przyznawane były także w cyklu miesięcznym i rocznym. Laureaci Złotej Strony Miesiaca mieli prawo do nagrody w postaci kwartalnej prenumeraty tygodnika „Wprost”, a zwycięzcy Rocznej Nagrody do półrocznej subskrypcji pisma.

Jednak warto przypomnieć, że w periodyku, poza nowatorskimi pomysłami, będącymi odpowiedzią na współczesne oczekiwania młodszych odbiorców, zachowano także tradycję swych wcześniejszych konkursów i nagród.

Do najstarszych należała zainicjowana w 1990 r. Nagroda Kisiela. Początkowo przyznawał ją sam S. Kisielewski „stawiając na ludzi >nienormalnych<, którzy na przekór warunkom odnieśli sukcesy w polityce, gospodarce lub publicystyce" 48 . Po jego śmierci zadanie to przejęła specjalna Kapituła, składająca się z wszystkich dotychczasowych laureatów i gościa honorowego, Jerzego Kisielewskiego oraz M. Króla. Jak pisała redakcja: „Nagrody Kisiela stały się strażnikiem higieny polskiego życia publicznego, w którym jest miejsce na więcej niż kilka jedynie słusznych wizji rzeczywistości"49. Zwycięzcami zostawały osoby, które zdaniem Kapituły mogły poszczycić się szczególnymi osiągnięciami $\mathrm{w}$ reprezentowanych przez siebie dziedzinach (polityce, publicystyce, biznesie) ${ }^{50}$. Pierwszymi laureatami byli m.in. Stefan Bratkowski, Józef Kuśmierek, Janusz Korwin-Mikke, Mieczysław Wilczek,

47 Zob. np. K. Król, Certyfikat Wprost 2001, „Wprost” 2001, nr 4, s. 48-49.

48 A. Filas, Realny kisielizm, „Wprost” 2001, nr 46, s. 24.

49 G. Pawelczyk, Triada Kisiela, „Wprost” 2002, nr 46, s. 22.

50 Jakkolwiek cezura czasowa pracy kończy się na 2005 r., warto jednak wiedzieć, że nagrody za rok 2007 i 2008 nie zostały przyznane. Powodem był sprzeciw 25 członków, wchodzących w skład Kapituły. Ich zdaniem poziom pewnych publikacji „Wprost” oraz zaangażowanie pisma nie pozwala na kontynuowanie idei Nagrody w jej dotychczasowej postaci. Część osób wysunęła propozycję powołania niezależnej fundacji. Została ona założona jako Fundacja Kisiela w 2008 r., a na jej czele stanął syn S. Kisielewskiego, J. Kisielewski. 
Wacław Wilczyński (lista laureatów, zob. Aneks 10. Laureaci Nagród Kisiela, lata 2001-2005).

Kolejnym wyróżnieniem, nadawanym w tygodniku był tytuł Człowieka Roku, przyznawany od 1991 r. ${ }^{51}$ osobie, która „w sposób pozytywny, godny powszechnego uwielbienia lub skrajnie negatywny, wręcz krwawy"52 odcisnęła swe piętno na otaczającej ją rzeczywistości. Pierwszym finalistą był L. Balcerowicz (lista laureatów - zob. Aneks 11. Człowiek Roku tygodnika „Wprost” w latach 2001-2005).

Przeciwieństwem dla tytułu Człowieka Roku stała się Nagroda Złamanego Grosza im. Hilarego Minca, przyznawana od 2001 r. Już sam wybór patrona nagrody wskazywał na jej charakter ${ }^{53}$. Otrzymywali ją ci, którzy, zdaniem jury, w największym stopniu zaszkodzili polskiej gospodarce, albo ci, którzy byli pomysłodawcami najbardziej paradoksalnych i szkodliwych inicjatyw w tej dziedzinie ${ }^{54}$. Pierwszymi laureatami tej niechlubnej nagrody zostali Marek Dyduch, Marian Krzaklewski oraz Leszek Miller55.

W 2004 r. „Wprost” wspólnie z dwutygodnikiem „BusinessWeek” przyznało Portfele Roku: bankom za najlepsze kredyty i firmom, które w danym roku rozwijały się najbardziej dynamicznie i zaskoczyły rynek nowymi inicjatywami. W roku następnym ponownie nadano te wyróżnienia.

Warto wspomnieć także o rankingach, przygotowywanych przez pismo. Najstarszym była Lista 100 najbogatszych Polaków, zaprezentowana po raz pierwszy na łamach „Wprost” w 1990 r. We wrześniowym numerze pojawiło się wówczas skromne zestawienie 25 najbogatszych Polaków ${ }^{56}$. Pełna lista dołączana była w postaci oddzielnej wkładki do głównego wydania tygodnika. Wzorując się na magazynach „EuroBusiness” i „Forbes” , przygotowujących podobne zestawienia, redakcja „Wprost”, szacując fortuny najbogatszych Polaków, zastosowała podobne metody. Do kandydatów Listy wysyłano kwestionariusze z prośbą o podanie informacji dotyczących posiadanych udziałów lub akcji oraz przychodów w danym roku. Majątek kandydata określano również według innych wskaźników, np. porównywano wartość przedsiębiorstw, które działały w tym samym sektorze gospo-

51 Pomysłodawcą tego wyróżnienia jest redakcja tygodnika „Time”, która nadaje ten tytuł od $1927 \mathrm{r}$.

52 M. Zieleniewski, Lęk wysokości, „Wprost” 2001, nr 1, s. 3.

53 Hilary Minc (1905-1974) - działacz komunistyczny, w pierwszych powojennych rządach minister przemysłu i handlu, w latach 1948-1954 przewodniczący Państwowej Komisji Planowania Gospodarczego; współodpowiedzialny za wprowadzenie modelu gospodarki, opartego na wzorach sowieckich.

54 Więcej, zob. M. Cielemęcki, M. Zieliński, współpraca K. Trębski, Nagroda Złamanego Grosza, „Wprost” 2001, nr 37, s. 34-37.

55 http://wprost.com.pl/ar/11228/Rynek-praca-wlasnosc/?I=984, wrzesień 2009.

56 Zob. P. Gabryel, 25 najbogatszych Polaków, „Wprost” 1990, nr 36, s. [7]. 
darczym i wybierano najwyższą, a wartość nieruchomości posiadanych przez daną osobę określano na podstawie średnich cen, obowiązujących w regionie ${ }^{57}$.

Kolejnym zestawieniem była zainicjowana cztery lata później (w 1994 roku) akcja Złote Indeksy. Przyznawane były one corocznie najlepszym polskim uczelniom, tworząc tym samym ich ranking, „najwszechstronniejszy, najbardziej obiektywny oraz najbardziej przydatny maturzystom i studentom”58, przewodnik „po dobrej edukacji”59.

Podobną tematykę prezentowano w kolejnym zestawieniu, przygotowywanym w tygodniku. Był to Ranking szkół wyższych, drukowany od 1994 r., również jako samoistny, bezpłatny dodatek do wybranego numeru pisma ${ }^{60}$. W zestawieniu brano pod uwagę zarówno szkoły publiczne, jak i niepaństwowe, charakteryzowano ich wydziały, kierunki, określano jakość kształcenia i rynkową wartość dyplomu każdej z nich.

W badanym okresie na łamach „Wprost” przygotowywano również ranking najlepszych szpitali w Polsce, prezentując placówki legitymujące się najlepszymi efektami w leczeniu określonych schorzeń oraz zapewniające jednocześnie najlepszą opiekę medyczną. Wybór szpitali następował na podstawie wyników ankiet, wypełnionych przez poszczególne placówki.

Interesującym pomysłem był także konkurs, współorganizowany przez tygodnik wraz z Ambasadą USA w Polsce, adresowany do młodych dziennikarzy. Po raz pierwszy został on zorganizowany w 1999 r. Odtąd corocznie prezentowano hasło przewodnie, będące jednocześnie tematem pracy konkursowej. Ze względu na kompozycję rozprawy inicjatywa ta zostanie omówiona w dalszej części rozdziału.

W październiku 2005 r. tygodnik przejął od „Polityki” rolę patrona medialnego w Klubie Pod Jaszczurami. Od tego czasu to właśnie „Wprost” stało się organizatorem tamtejszych spotkań z wybitnymi osobami życia publicznego. Jedną z pierwszych imprez tego typu była promocja książki Ukraina na zakręcie. Drogi i bezdroża pomarańczowej rewolucji (Jerzy Marek Nowakowski, Juliusz Urbanowicz, Agnieszka Korniejenko, Wydawnictwo Trio, Warszawa 2005). ${ }^{61}$

$\mathrm{W}$ analizowanym okresie $\mathrm{w}$ tygodniku organizowano bądź patronowano również innym, cyklicznie organizowanym akcjom, na przykład Piknikowi Naukowemu czy Konfrontacjom Naukowym. Współpracowano także z in-

57 Więcej, zob. M. Cielemęcki, Jak wycenialiśmy, „Wprost” 100 najbogatszych Polaków. Bezpłatny dodatek do numeru 25/2002, s. 4.

58 R. Kamiński, Złote indeksy, „Wprost” 2001, nr 21, s. 32.

59 W. Sumliński, Akademia konkurencji, „Wprost” 2004, nr 19, s. 36.

60 Zob. np. Ranking szkół wyższych. Bezpłatny dodatek do numeru 20 (2001).

61 [br. aut.], Rozdroża Ukrainy, „Wprost” 2005, nr 43, s. 98. 
nymi mediami: z Programem 3 Polskiego Radia, Programem 1 Polskiej Telewizji, Telewizją TVN.

Wszystkie te działania redakcji „Wprost” spowodowały, że (jak wskazywały wielokrotnie organizowane ankiety, a także ogólnopolskie badania czytelnictwa) docelowa grupa odbiorów pisma zbliżona jest do czytelników jego głównego konkurenta, „Polityki”, choć audytorium „Wprost” stanowią ludzie nieco młodsi (ponad połowa z nich nie przekroczyła jeszcze 45. roku życia), mieszkańcy dużych miast, o poglądach liberalnych i centroprawicowych.

Dowód na stabilną i uznaną pozycję tygodnika na rynku prasowym stanowią nagrody zarówno dla samego tytułu, jego wydawcy, dziennikarzy i współpracowników, jak i akcji, inicjowanych bądź wspieranych przez periodyk.

I tak na przykład, w 2002 r. Michał Zieliński otrzymał nagrodę Ostrego Pióra, rok później Aleksander Kwaśniewski wręczył redakcji dyplom za wspieranie akcji wyposażenia szkół w sprzęt komputerowy. W tym samym roku (2003) „Wprost” zostało nagrodzone w konkursie na Okładkę Roku w kategorii Czasopisma opinii, organizowanym przez Izbę Wydawców Prasy, w 2004 r. tygodnik otrzymał laur za wspieranie inicjatyw Stowarzyszenia Willa Decjusza. W 2005 r. B. Wildsteina, jako publicystę „Wprost”, wyróżniono nagrodą dziennikarską im. Mieczysława i Ksawerego Pruszyńskich.

Historia „Wprost” doprowadziła w 2005 r. tygodnik do czołowego miejsca w grupie polskich pism opinii. Jak stwierdził jego wieloletni redaktor naczelny:

Kondycja „Wprost”, mimo licznych ataków, jest wspaniała. Świadczą o tym nie tylko doskonałe wyniki ekonomiczne [...], ale wysoka, nieustannie wzrastająca sprzedaż pisma, które od kilku lat jest największym polskim tygodnikiem informacyjnym. [...] Nie warto żyć przeszłością, lecz warto żyć z przeszłością, także w przyszłości. Rok 1989, a zwłaszcza 1991, czyli lata upadku tzw. realnego socjalizmu w Polsce i rozpoczęcia reform wolnorynkowych pod przewodnictwem Leszka Balcerowicza, stworzyły tygodnikowi „Wprost” niepowtarzalną szansę, którą - jak sądzę - wykorzystaliśmy optymalnie ${ }^{62}$.

\subsubsection{Czytam, więc jestem ${ }^{63}$ : książka na łamach pisma}

Obok dominującej na łamach „Wprost” tematyki, związanej z polityką i gospodarką, w badanym okresie zamieszczano także informacje dotyczące szeroko pojętej kultury. Objętość tekstów z nią związanych wahała się od

62 M. Król, Reguła „Wprost”, „Wprost” 1998, nr 3, s. 3.

63 Tytuł publikacji Ł. Radwana i W. Chełminiaka, zob. „Wprost” 2003, nr 16, s. 112-[115]. 
kilkuzdaniowych wzmianek, poprzez nieco dłuższe doniesienia, a kończąc na całostronicowych komentarzach i refleksjach.

Informacje, dotyczące książki, teatru, kina oraz muzyki, drukowane były przede wszystkim na ostatnich stronach pisma i zawierały się w dziale Kultura, anonsowanym rubryką Menu. Obok recenzji książek pojawiały się tu omówienia filmów, spektakli, wystaw i koncertów. W tym miejscu czytelnik mógł odnaleźć również zapowiedzi imprez kulturalnych, premier zarówno książek, jak i płyt z muzyką czy filmem. Drukowano tu także krótkie relacje z już odbytych spotkań, listy bestsellerów, teksty komentujące kondycję literatury polskiej i obcej, sztuki współczesnej, teatru i kina.

Informacje związane z książką pojawiały się też na innych stronach pisma. Poza wspomnianą Kulturq, czytelnik mógł je odnaleźć również m.in. w następujących działach: Biznes-Ludzie-Pieniądze, Historia, Nauka i Zdrowie, Świat, Życie i Intermedia. Czasem przybierały one postać felietonów M. Domagalik (Druga płeć) czy T. Raczka (Ekran osobisty).

Analiza tygodnika pozwoliła wyodrębnić następujące formy obecności literatury i informacji o niej wraz z ich liczbą w poszczególnych latach ${ }^{64}$ (tabela 14).

Tabela 14. Formy obecności książki i informacji o niej na łamach „Wprost” w latach 2001-2005

\begin{tabular}{|l|c|}
\hline \multicolumn{1}{|c|}{ Rodzaj informacji } & Liczba ogółem \\
\hline Recenzje & 725 \\
\hline Wywiady & 46 \\
\hline Reklamy książek & 573 \\
\hline Sylwetki/portrety & 68 \\
\hline $\begin{array}{l}\text { Artykuły, poświęcone sprawom książki lub rynku wydawniczo-księ- } \\
\text { garskiego }\end{array}$ & 240 \\
\hline Ekranizacje, adaptacje, inscenizacje & 136 \\
\hline Konkursy i akcje & 35 \\
\hline Listy bestsellerów & 181 \\
\hline $\begin{array}{l}\text { Listy czytelników, nawiązujące do zamieszczonej informacji } \\
\text { związanej z książką }\end{array}$ & 51 \\
\hline Inne ${ }^{a}$ & 288 \\
\hline Ogółem & 2343 \\
\hline
\end{tabular}

${ }^{a} \mathrm{~W}$ tym przypadku uwzględniono krótkie zazwyczaj informacje, dotyczące wydarzeń i ludzi związanych ze światem książki (np. wzmianki o spotkaniach z autorami, notki o jubieleuszach twórców itd.)

Źródło: badania własne.

${ }^{64}$ Podobnie jak w przypadku tygodnika „Polityka” przyjęto kolejność podawania poszczególnych kategorii według kolejności ich omawiania. 
W sumie w badanym okresie pojawiło się na łamach „Wprost” 2343 informacji bezpośrednio lub pośrednio związanych z książką. Zwraca jednak uwagę niefrasobliwe, niekonsekwentne, by nie powiedzieć nieprofesjonalne, podejście do przygotowania ich od strony formalnej. Widoczna była niekonsekwencja w doborze elementów, składających się na daną informację. Często brak było podstawowych danych bibliograficznych, które powinny ją uzupełniać. I tak na przykład przy omawianiu książki nierzadko ograniczano się do podania jej autora i tytułu, z pominięciem nazwy wydawcy, miejsca i roku wydania. Teksty bywały anonimowe albo podpisane tylko inicjałami. Szczególnie widoczne było to w roczniku 2002, kiedy redakcja najwyraźniej nie mogła zdecydować się na formę graficzną periodyku. Brak nagłówków, nieprecyzyjne określenie rubryk wprowadzały chaos, który opanowano dopiero na przełomie 2003 i 2004 r.

\subsubsection{Celna lektura ${ }^{65}$ : miejsce recenzji w układzie pisma}

W latach 2001-2005 na łamach „Wprost” pojawiło się w sumie 725 recenzji książek ${ }^{66}$. W tabeli 15 zaprezentowano dokładną liczbę omówień w każdym roku.

Tabela 15. Recenzje zamieszczane na łamach „Wprost” w latach 2001-2005

\begin{tabular}{|c|c|}
\hline Rok & Liczba recenzji ogółem \\
\hline 2001 & 84 \\
\hline 2002 & 75 \\
\hline 2003 & 96 \\
\hline 2004 & 277 \\
\hline 2005 & 193 \\
\hline Ogółem & 725 \\
\hline
\end{tabular}

Źródło: badania własne.

Zauważamy tendencję rosnącą: najmniej recenzji znalazło się na początku badanego okresu w 2001 i 2002 r., ich apogeum nastąpiło w roku 2004, zaś rok zamykający analizę badawczą prezentowanej pracy charakteryzuje się ponownie mniejszą liczbą omówień.

65 Tytuł recenzji. Zob. „Wprost” 2004, nr 41, s. 12.

$66 \mathrm{~W}$ tej grupie znalazły się również: komiksy (24 razy), albumy (17-krotnie), encyklopedie (5 razy), słowniki (sześciokrotnie), atlasy (4 razy), przewodniki (2 razy) i poradnik (raz). Warto zaznaczyć, że obok największej grupy omówień, dotyczących książek, pojawiały się także adnotacje odnoszące się do wybranych numerów czasopism oraz wystaw fotografii znanych artystów czy filmów. Ze względu na temat pracy ograniczono się w niej do prezentacji recenzji książek, ich ekranizacji bądź inscenizacji znanych dramatów. 
Zamieszczano je w całym piśmie. Najwięcej znalazło się ich w dziale Kultura, chociaż, jak już wcześniej wspomniano, pojawiały się one także w innych miejscach periodyku67. W tabeli 16 przedstawiono ich liczbę wraz z lokalizacją w tygodniku.

Tabela 16. Recenzje w poszczególnych działach i rubrykach „Wprost” w latach 2001-2005

\begin{tabular}{|c|c|c|c|c|}
\hline Rok & Razem & $\begin{array}{c}\text { W specjalnych } \\
\text { rubrykach, poświęco- } \\
\text { nych na recenzję } \\
\text { książki }^{a}\end{array}$ & $\begin{array}{c}\text { W dziale Kultura, } \\
\text { poza specjalnymi } \\
\text { rubrykami, poświęcony- } \\
\text { mi książce }\end{array}$ & $\begin{array}{c}\text { W innych } \\
\text { miejscach } \\
\text { w piśmie }^{c}\end{array}$ \\
\hline 2001 & 84 & 38 & 25 & 21 \\
\hline 2002 & 75 & 57 & 9 & 9 \\
\hline 2003 & 96 & 73 & 16 & 7 \\
\hline 2004 & 277 & 211 & 38 & 28 \\
\hline 2005 & 193 & 149 & 22 & 22 \\
\hline Ogółem & 725 & 528 & 110 & 87 \\
\hline
\end{tabular}

${ }^{a}$ Czyli rubrykach recenzyjnych, specjalnie poświęconych omówieniu książek. W przypadku tygodnika „Wprost” były trzy takie rubryki: jedna (Od hitu do kitu) znajdowała się w dziale Biznes-Ludzie-Pieniądze i dwie, drukowane w dziale Kultura (Menu Książki oraz Sława i chała $\rightarrow$ Recenzje). W analizowanym okresie kilkakrotnie zmieniały one swoją formę, nie każda z nich była obecna przez cały badany okres. Zostaną one dokładnie przedstawione w dalszej części rozdziału. Należy jednak już w tym miejscu zaznaczyć, że w rubryce Sława i chała, obok omówień książek, pojawiały się również recenzje filmów, wystaw i spektakli.

${ }^{b}$ Do działu tego, ze względu na charakter zamieszczanych $\mathrm{w}$ nim informacji, zaliczono również poprzedzające go Menu, bez omówień znajdujących się w specjalnej rubryce.

${ }^{c}$ Szczegółowe określenie innych działów i rubryk, zob. tabela 17.

Źródło: badania własne.

Jak wynika z tabeli 16, najwięcej recenzji pojawiło się w ramach rubryk recenzyjnych, poświęconych omówieniom książek. Na drugim miejscu znalazły się pozostałe rubryki działu Kultura, chociaż warto zauważyć, że dwukrotnie liczba recenzji była taka sama tu, jak i poza tym działem (w 2002 i 2005 r.).

67 Należy zaznaczyć, że niezwykle trudno było zaklasyfikować zebrany materiał do jasno sprecyzowanych kategorii, a następnie określić prawidłowości związane z ich przynależnością do poszczególnych rubryk. Kolejną trudność stanowił problem dotyczący samych rubryk. Te bowiem, które można byłoby nazwać typowo recenzyjnymi, podlegały częstym przemianom: zmianie zaś ulegała nie tylko ich nazwa, ale sam fakt ich istnienia: pojawiały się nagle, bez żadnej zapowiedzi ze strony redakcji, drukowane były w kilku kolejnych numerach, a następnie, bez informacji o tym, znikały. Niestety, niefrasobliwe podejście redakcji do precyzyjnego określania charakteru zamieszczanych informacji, a także częste zmiany tytułów poszczególnych rubryk, powodowało, że trudno jest jednoznacznie zaklasyfikować daną wzmiankę do określonego rodzaju informacji. Stąd za typowo recenzyjne uznano te rubryki (lub strony w periodyku), które w tytule dokładnie określały swą zawartość. 
Niezależnie jednak od lokalizacji omówień, w przeważającej większości brakowało $\mathrm{w}$ nich podstawowych danych bibliograficznych. Jakby mimochodem podawano w treści recenzji autora i tytuł książki, ale zazwyczaj to było wszystko, na co mógł liczyć czytelnik. Być może redakcja doszła do wniosku, że wystarczy zamieścić obok recenzji kopię okładki prezentowanej książki, by zaspokoić ciekawość czytelnika w tym względzie. Jednak małe, nieostre zdjęcia, nie spełniały swego zadania. Z trudem można było z nich odczytać tytuł książki, nazwisko jej autora, zaś nazwy wydawcy odbiorca w najlepszym razie mógł się jedynie domyślić. Na 725 recenzji zaledwie w 362 przypadkach podano edytora, jedynie w 46 miejsce wydania, a tylko 147 razy rok ukazania się publikacji. W przypadku prezentacji książek autorów obcych ani razu nie przywołano nazwiska tłumacza.

Przez pierwsze badane lata recenzje bywały przeważnie anonimowe, choć wyjątek pod tym względem stanowiła rubryka Od hitu do kitu, którą drukowano w ramach działu Biznes-Ludzie-Pieniq̨dze, gdzie przedstawiano książki związane z tą właśnie problematyką. Ale i w tym przypadku recenzent skromnie ograniczał się do podania swoich inicjałów, sądząc (być może), że jest dostatecznie znany adresatowi „Wprost”, by ten bez trudu je rozszyfrował.

Warto zauważyć, że najgorzej pod tym względem prezentował się dział, który z założenia stanowił odpowiednie miejsce dla recenzji i gdzie pojawiało się ich najwięcej, czyli... Kultura. Jego forma graficzna zmieniała się często, co, być może, było efektem równie częstych zmian w grupie osób, które przygotowywały informacje kulturalne. Do numeru 7 w 2001 r. w stopce redakcyjnej pojawiały się nazwiska Wiesława Kota i Doroty Szwarcman, w kolejnych numerach odnaleźć można Jacka Borowskiego, Tomasza Cichonia, Justynę Kobus i Helenę Zaworską jako osoby odpowiedzialne za omawiany dział. W następnym roku pojawił się Wiesław Chełminiak, Jacek Melchior i Tomasz Raczek, a w kolejnych latach Łukasz Radwan, Jerzy Rzewuski, Marta Sawicka i Kamil Śmiałkowski. Dopiero od numeru 44 (2002) określony został kierownik działu, a był nim W. Chełminiak.

Tak częste zmiany wpływały prawdopodobnie na to, że dział, poza tym, że ewoluował wraz $\mathrm{z}$ całym tygodnikiem, zmieniał się dodatkowo przy okazji zmian personalnych.

Na początku badanego okresu, w 2001 r., strona, na której recenzowano książki, przedstawiała się bardzo skromnie. Stanowiła jeden z elementów Menu: jedno- lub dwustronicowego wprowadzenia w świat kultury, prezentowanej na łamach „Wprost”. Kilka, rzadziej kilkanaście, zdań, składających się na zwięzłe streszczenie prezentowanej lektury, znajdowało się w rubryce zatytułowanej Książka68. Obok pojawiały się podobne pod względem objętości informacje, dotyczące bądź to wydanej właśnie płyty, bądź

${ }^{68}$ W przypadku omówienia dwóch tytułów w ramach tej rubryki, nosiła ona tytuł Książki. 
organizowanej wystawy, bądź też premiery filmowej lub teatralnej, noszące adekwatne do treści tytuły. Na zdjęciach 20 i 21 przedstawiono wybrane przykłady interesującej nas rubryki.

Ta forma pojawiła się w 28 numerach roku 2001. Jedynym dodatkowym elementem recenzji była kopia okładki omawianej książki.

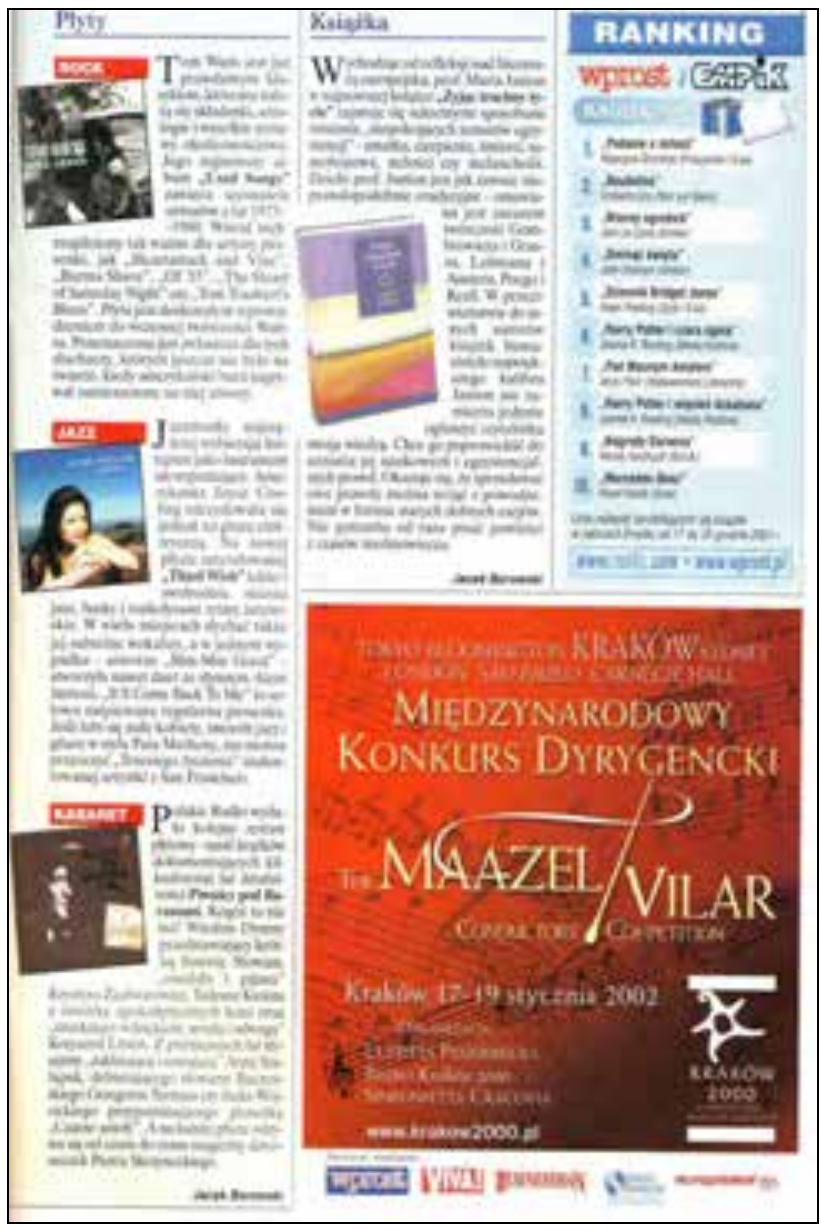

Zdjęcie 20. Strona recenzyjna na łamach "Wprost" „Wprost” 2001, nr 2, s. [103] 


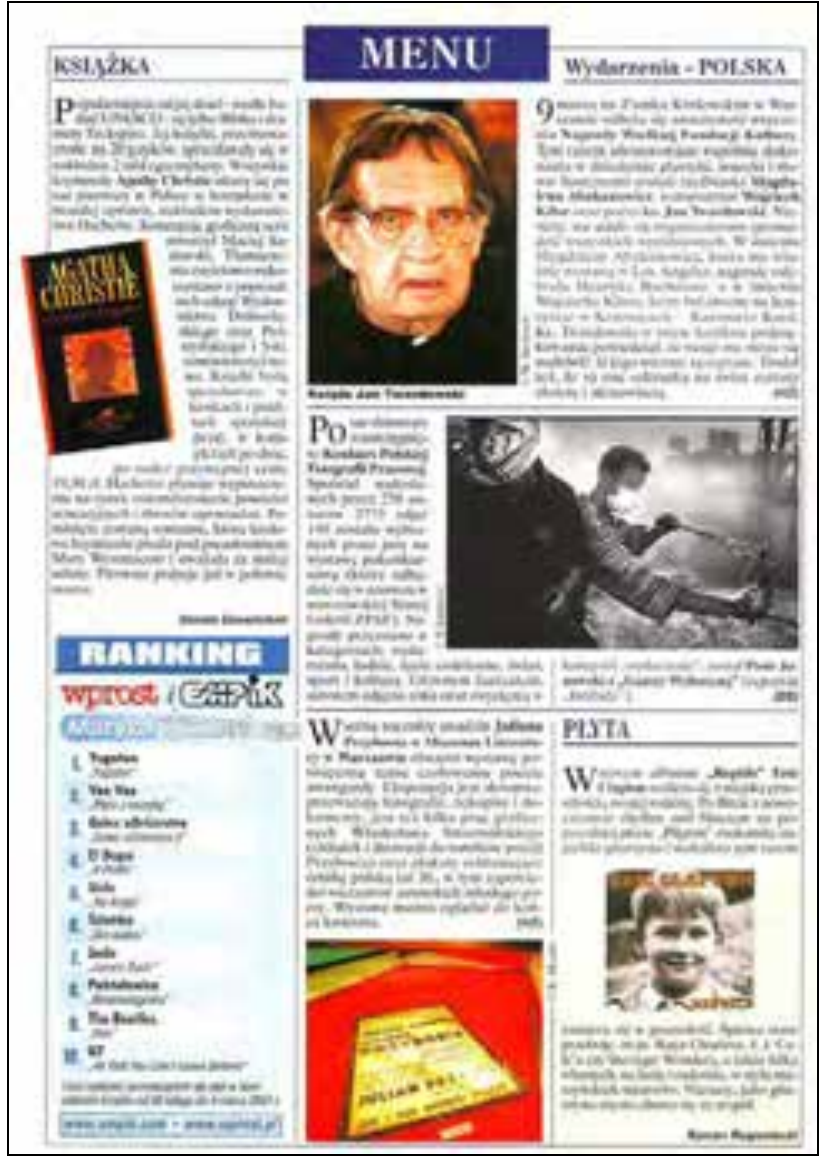

Zdjęcie 21. Strona recenzyjna na łamach „Wprost” „Wprost” 2001, nr 11, s. 108

Dwie kolejne zmiany, głównie o charakterze graficznym, nastąpiły kolejno: od numeru 15 (2002) i od 24 (2003) - zdjęcia 22-24.

Choć Menu zwiększyło swoją objętość: z 2 do 4 stron ${ }^{69}$, to jednak w odniesieniu do recenzji książek zmiany miały charakter jedynie graficzny. Omówienia nadal przyjmowały postać stosunkowo krótkich adnotacji treściowych, w większości nie podpisanych. Dane bibliograficzne w dalszym ciągu ograniczano do tytułu i autora książki, z kopią okładki jako jedynym elementem dodatkowym. Poza tym wydaje się, że w tym okresie prezentowana rubryka stała się mniej czytelna w porównaniu z wcześniej proponowaną.

${ }^{69}$ Była to jednak zmiana niekonsekwentna, nie przestrzegana w każdym numerze. 


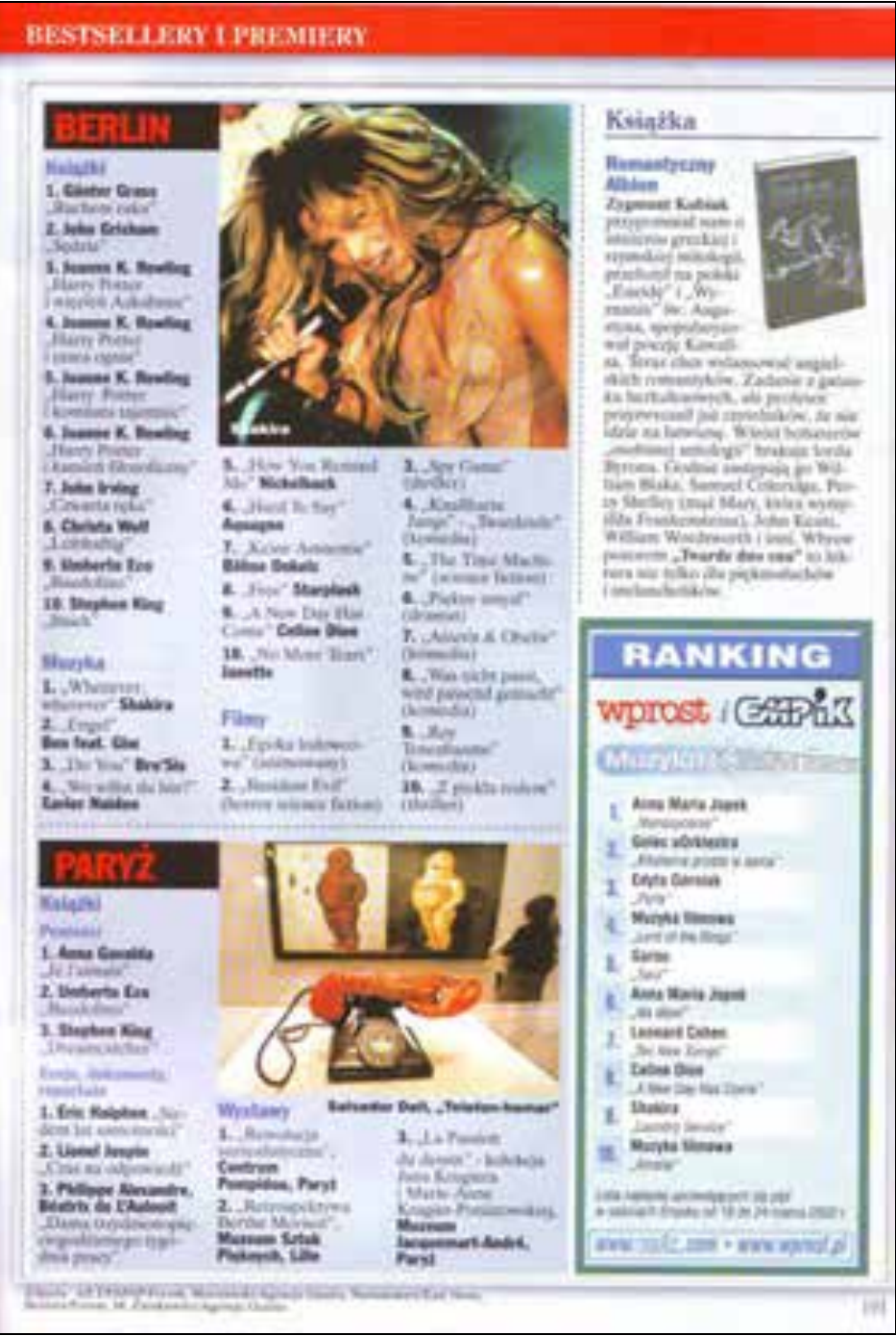

Zdjęcie 22. Strona recenzyjna na łamach „Wprost” „Wprost” 2002, nr 14, s. 101 


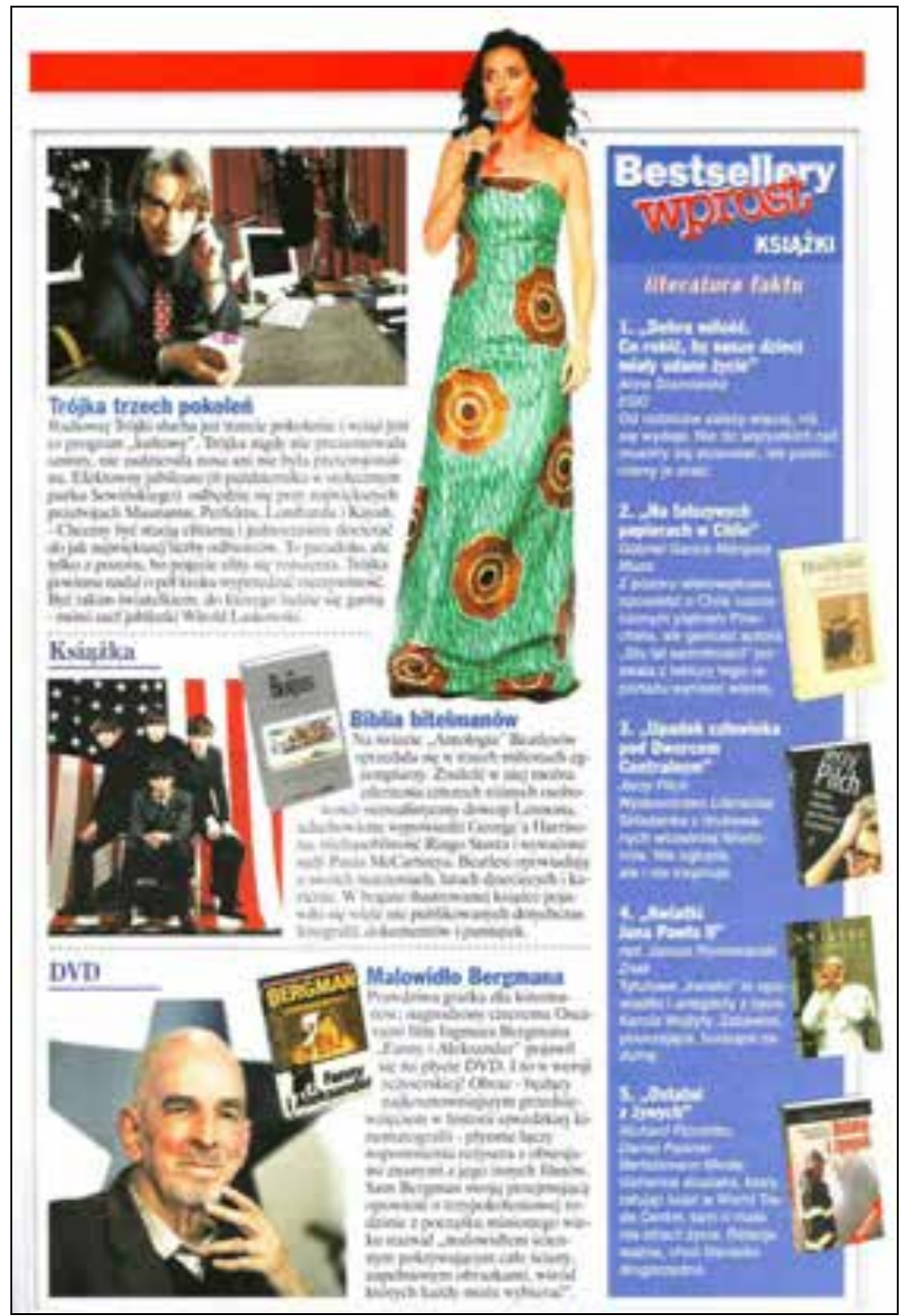

Zdjęcie 23. Strona recenzyjna na łamach „Wprost” „Wprost” 2002, nr 40, s. 113 


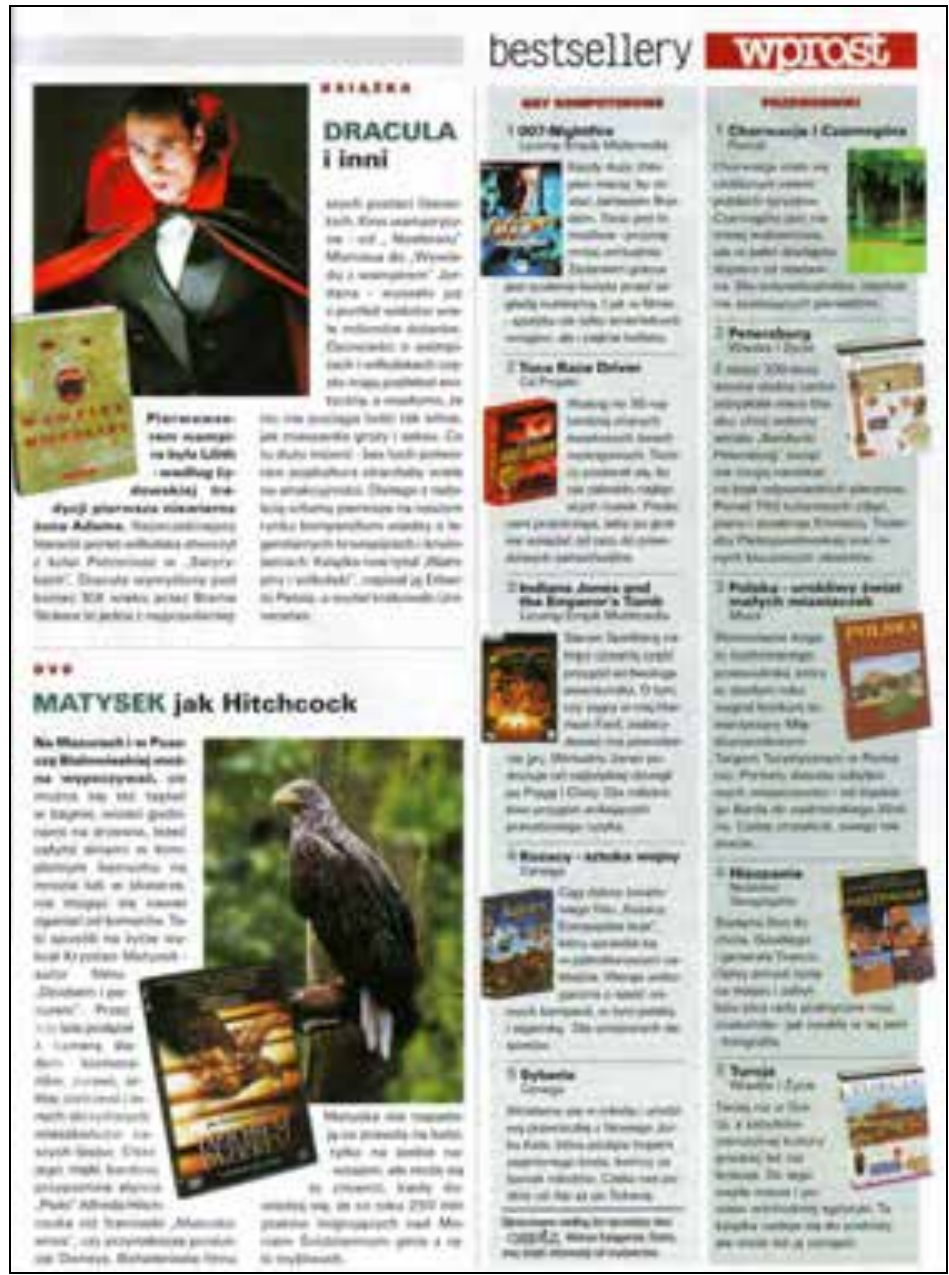

Zdjęcie 24. Strona recenzyjna na łamach „Wprost” „Wprost” 2003, nr 27, s. 97

Ważną zmianą w 2003 r. było dołączenie do samotnej dotąd rubryki (drukowanej w ramach Menu) Książka recenzji, która odtąd pojawiała się na kolejnych stronach pisma, choć nadal w tym samym dziale. Nowa propozycja otrzymała jednoznacznie brzmiący tytuł Sława i chała70. Po raz pierwszy znalazła się ona w numerze $44(2003)^{71}$. Na stronie jej poświęconej za-

${ }^{70}$ Można się domyślać, że była to świadoma parafraza tytułu jednej z książek J. Iwaszkiewicza.

${ }^{71}$ Czytelnicy zetknęli się już z podobnym pomysłem w 2001 r., ale wówczas rubryka ta odnosiła się do innych wydarzeń kulturalnych - w numerze 51/52 była to recenzja dwóch filmów. Zob. „Wprost” 2001, nr 51/52, s. 125. 
mieszczano krótkie opisy zarówno książek, jak i filmów, spektakli teatralnych i wystaw (z odpowiednimi podtytułami: Film, Ksiq̨żki, Teatr, Wystawa). Po raz pierwszy zaprezentowała się w taki sposób w numerze 44 (2003) - zdjęcie 25.

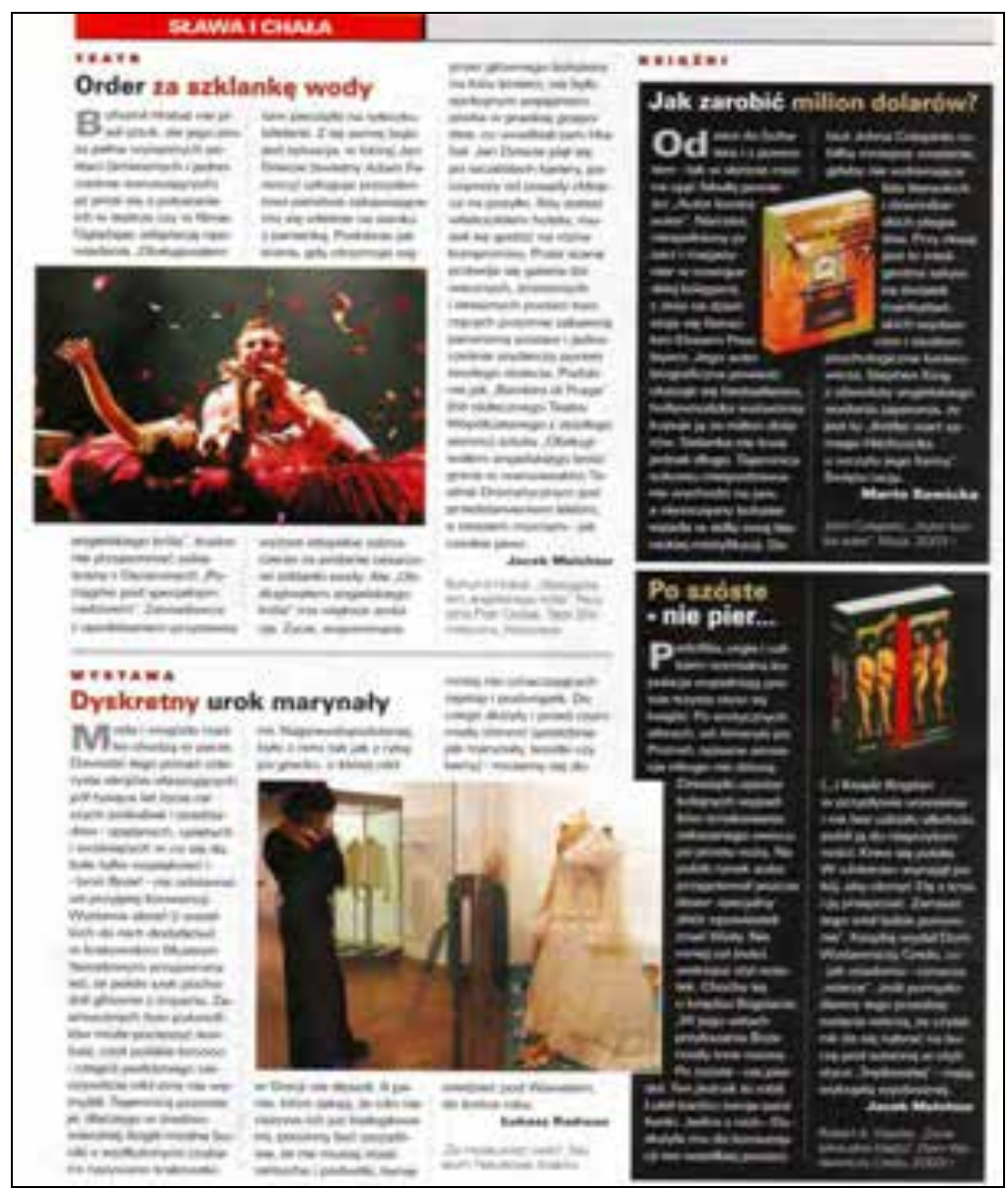

Zdjęcie 25. Strona recenzyjna na łamach „Wprost” „Wprost” 2003, nr 44, s. 114

Sława i chała miała zatem podobny charakter jak Menu, ale w przypadku nowej strony recenzyjnej omówienia były nieco dłuższe, podpisywane, a nawet (w większości) zawierały, umieszczone na końcu prezentacji określonego tytułu, dane bibliograficzne. Były one niepełne, ale przynajmniej recenzent dbał o to, by podać obok autora i tytułu także nazwę wydawcy i rok wydania przedstawianej książki. Strona, dzięki mniejszej liczbie informacji, była bardziej czytelna. 
Kolejne zmiany nastąpiły w 2004 r. i dotyczyły obydwu omawianych rubryk. Menu ponownie zmieniło szatę graficzną i od tej pory przeważnie ograniczało się do dwóch stron. Przykładowa rubryka recenzyjna, nadal o tym samym, nieskomplikowanym tytule, Ksiq̨żka, w odświeżonej formie wyglądała tak, jak na przykład na zdjęciu 26.

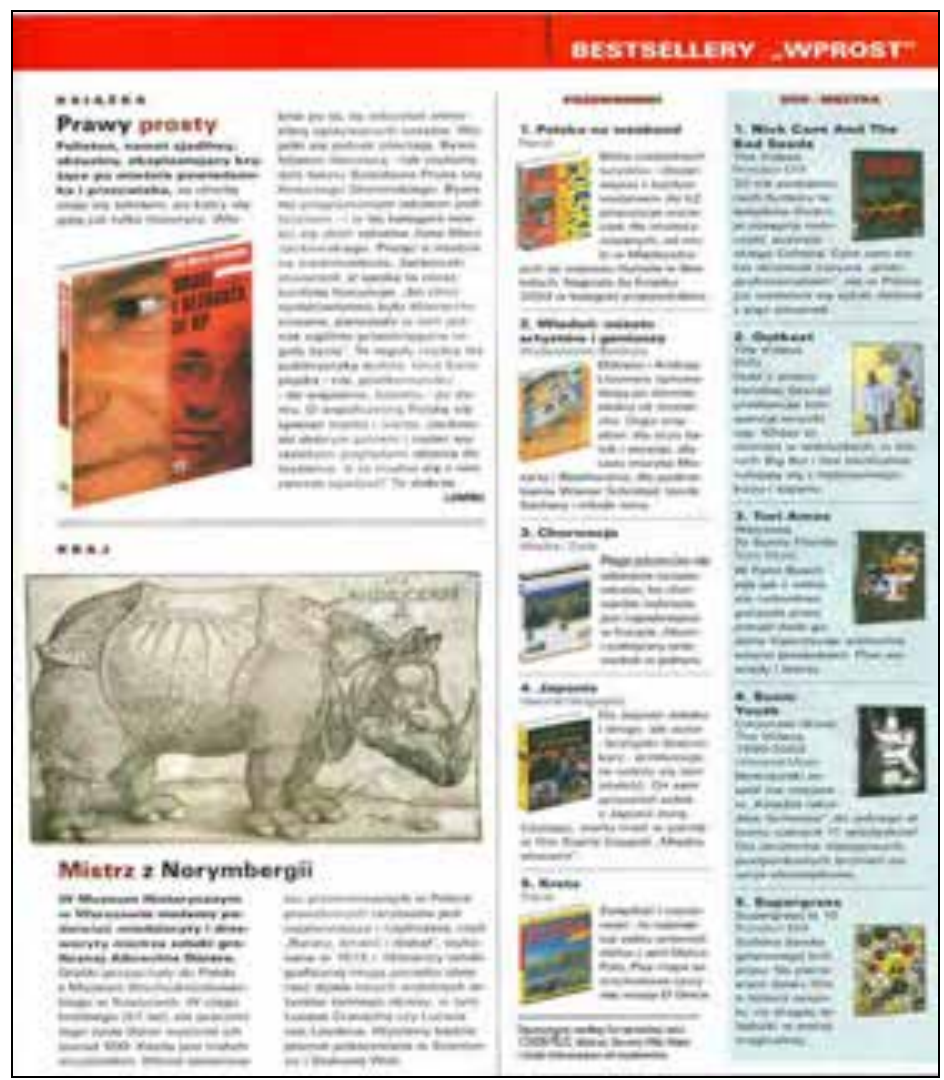

Zdjęcie 26. Strona recenzyjna na łamach „Wprost”

„Wprost” 2004, nr 29, s. 87

Natomiast druga z recenzyjnych propozycji, Sława i chała, została zastąpiona podobnymi w swej formie Recenzjami. Miały one podobnie jak w poprzednich przypadkach charakter swego rodzaju kroniki wydarzeń kulturalnych. Dodatkowym elementem stały się symbole graficzne, które w założeniu miały oddawać odczucia recenzenta, związane z opisywanym wydarzeniem. Jednak nie wyjaśniono ich znaczenia, wychodząc prawdopodobnie z założenia, że są one dla odbiorcy wystarczająco czytelne. Być może stwierdzono także, że nie warto zajmować się ich wyjaśnianiem w sytuacji, gdy nie sięgano po nie za każdym razem. Brak konsekwencji dawał się 
bowiem zauważyć i w tym przypadku, a czytelnik kupując kolejny numer pisma nie mógł być pewien, czy je odnajdzie. Niemniej jednak, jak można się było domyślać, pięć gwiazdek przy omawianej propozycji oznaczało, że przedstawiana książka, film, spektakl lub płyta zasługują na uwagę czytelnika, natomiast jedna, że nie warto im poświęcać czasu. Po raz pierwszy czytelnik poznał tę odświeżoną stronę w numerze 44 (2004) - zdjęcie 27.

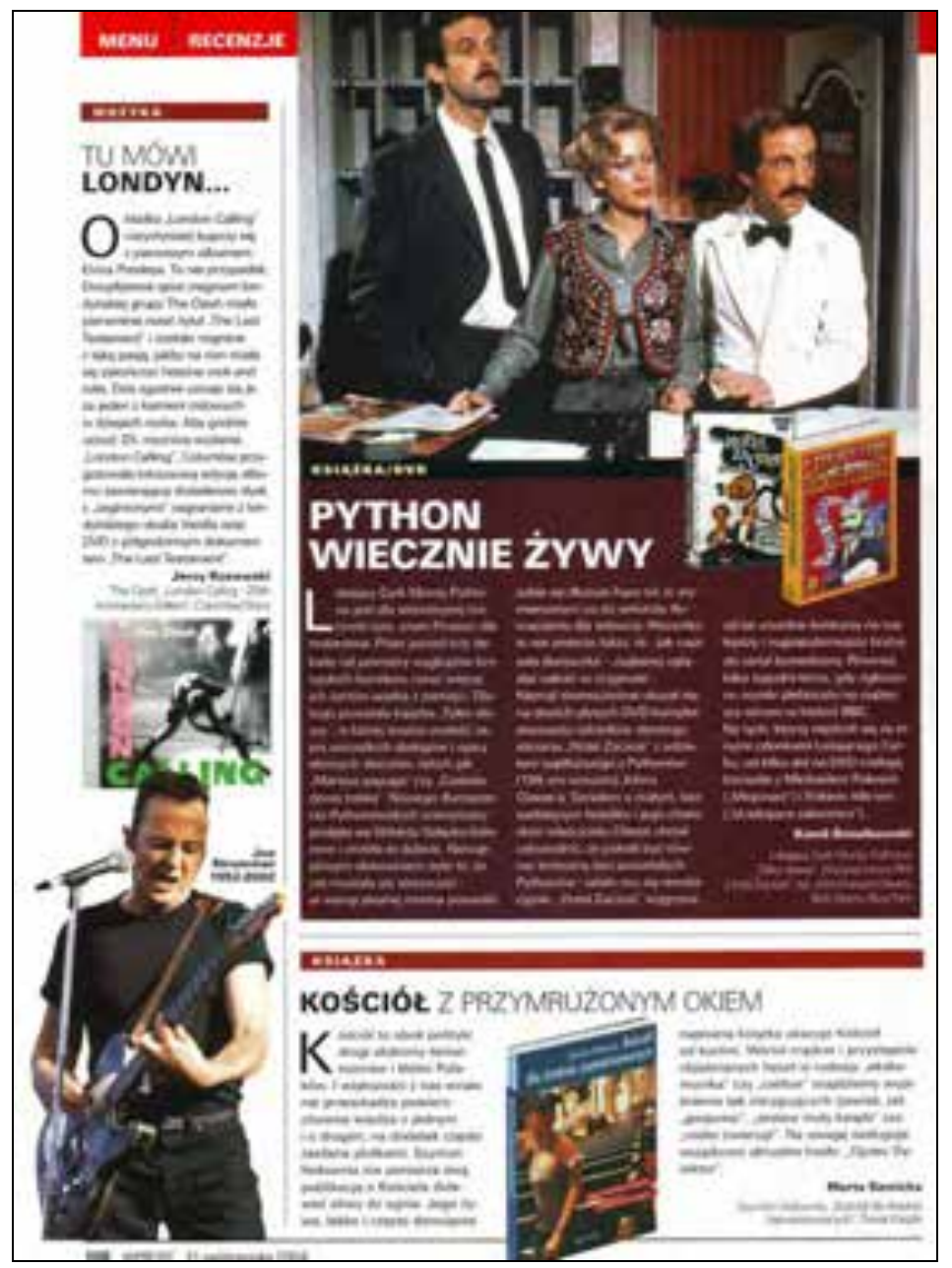

Zdjęcie 27. Strona recenzyjna na łamach „Wprost”

„Wprost” 2004, nr 44, s. 109.

Recenzje tu zamieszczane, szczególnie te odnoszące się do książek, były w porównaniu z dotychczasowymi nieco dłuższe, dane (dzięki wyraźniejszym i większym zdjęciom okładek prezentowanych książek) były bardziej 
czytelne, ale i w tych omówieniach nadal brak było pozostałych elementów składających się na pełny adres bibliograficzny.

Od numeru 20 (2005) zmieniła się częściowo grafika Menu, a od numeru 26 (2005) Recenzje stały się odrębną rubryką, choć nadal drukowaną w dziale Kultura. Do końca badanego okresu grafika obydwu rubryk wyglądała następująco - zdjęcia 28 i 29.

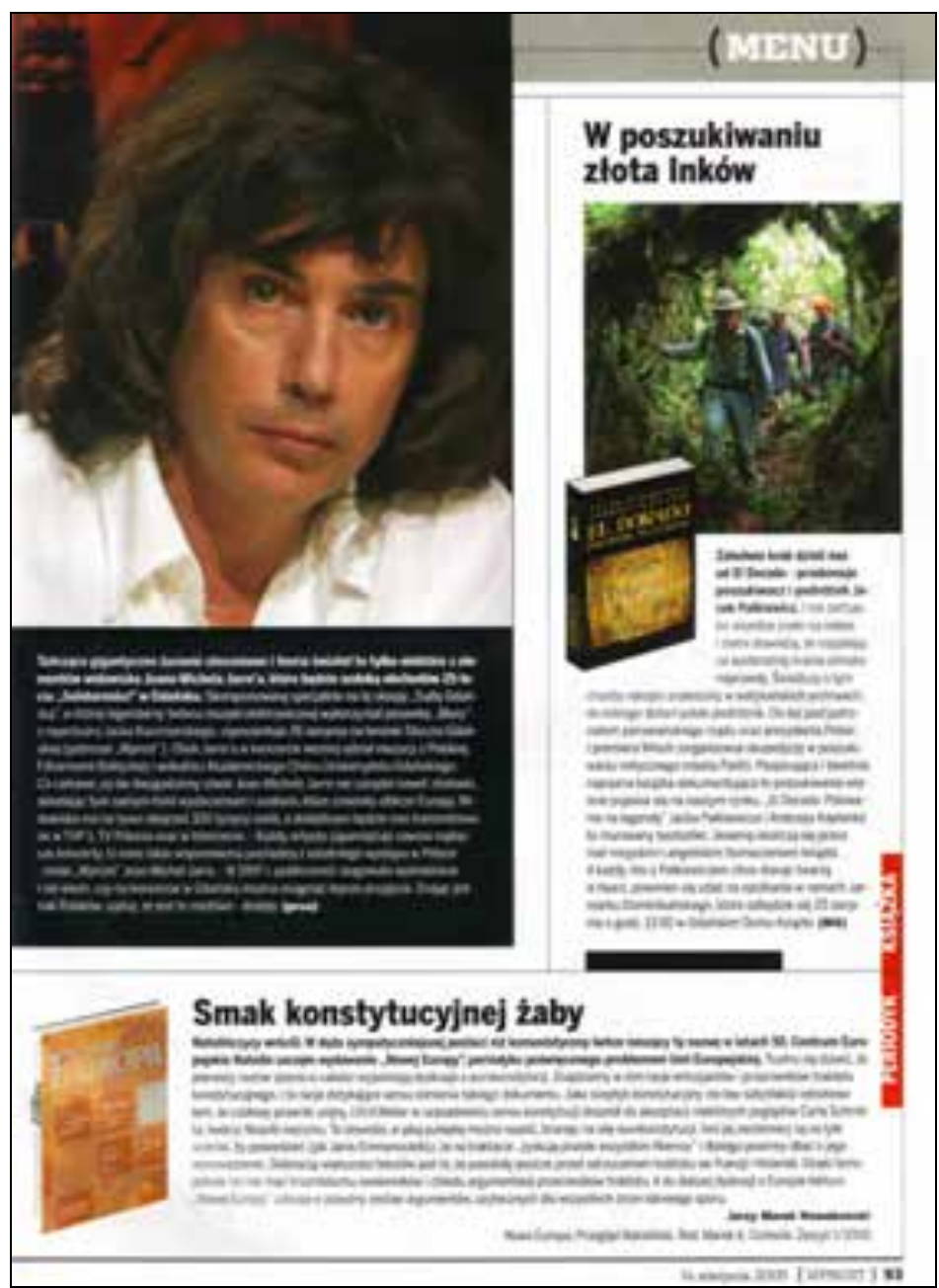

Zdjęcie 28. Strona recenzyjna na łamach „Wprost” „Wprost” 2005, nr 32, s. 93 


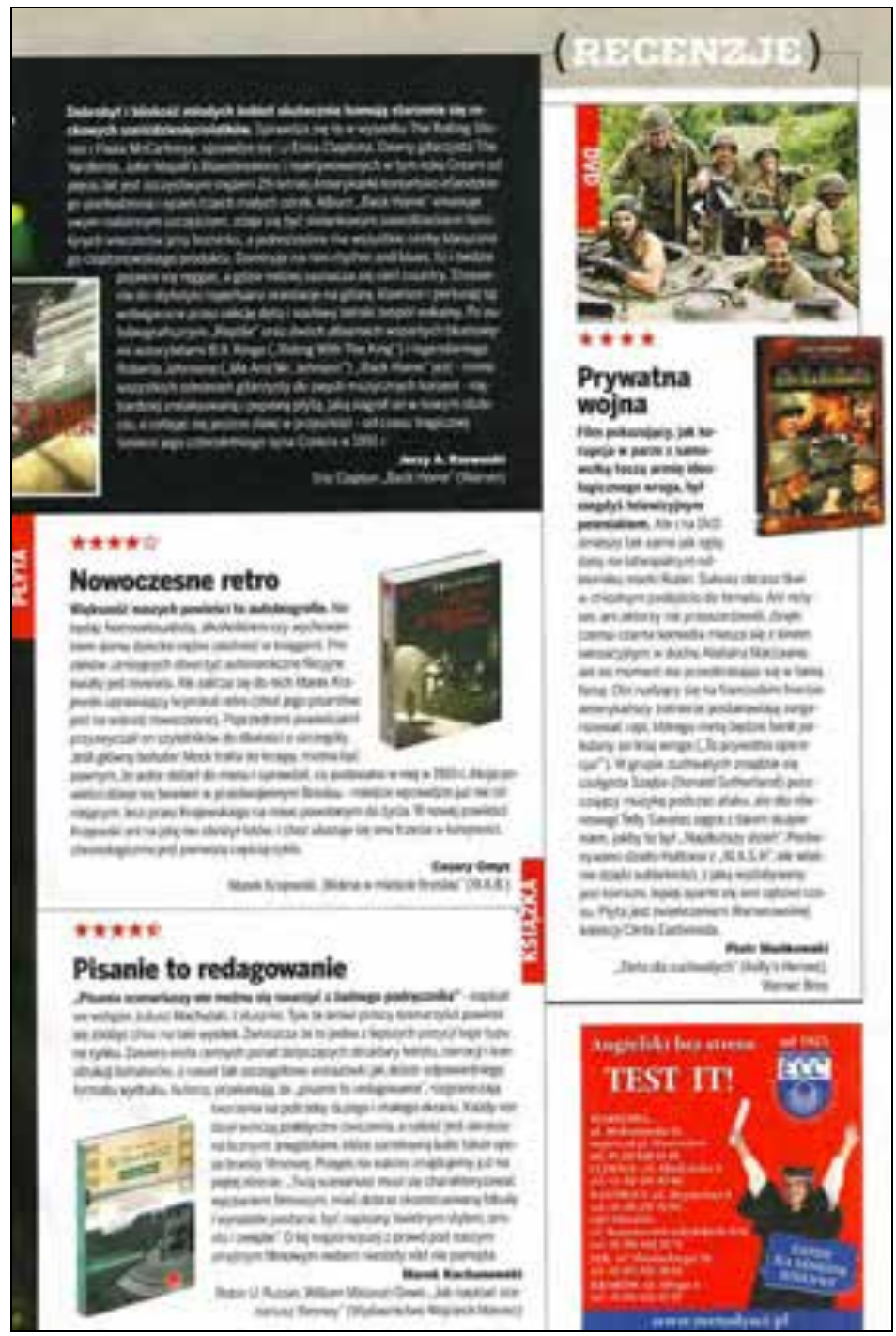

Zdjęcie 29. Strona recenzyjna na łamach „Wprost” „Wprost” 2005, nr 35, s. [89]

Zmiany miały charakter głównie graficzny, natomiast pod względem objętości omówień wybranych książek niewiele się zmieniło. Prezentacji wybranych tytułów towarzyszyły te same elementy, w podobny sposób wyeksponowana kopia okładki oraz dane bibliograficzne.

Jak wspomniano wcześniej, recenzje książek drukowano również poza działem Kultura. W tabeli 17 przedstawiono nazwy tych działów, w których systematycznie bądź sporadycznie pojawiały się omówienia książek. 
Tabela 17. Recenzje zamieszczane na łamach „Wprost” w poszczególnych działach i rubrykach innych niż typowa rubryka recenzyjna w latach 2001-2005

\begin{tabular}{|l|c|c|c|c|c|c|}
\hline \multicolumn{1}{|c|}{ Nazwa działu } & Razem & 2001 & 2002 & 2003 & 2004 & 2005 \\
\hline $\begin{array}{l}\text { Biznes-Ludzie-Pieniqdze: } \\
\text { Giełda: Od hitu do kitu }\end{array}$ & 150 & 5 & 1 & 39 & 52 & 53 \\
\hline Historia & 7 & - & - & 1 & 3 & 3 \\
\hline Kadry & 1 & & & - & 1 & - \\
\hline Kraj & 1 & & & - & 1 & - \\
\hline Kultura & 109 & 25 & 9 & 15 & 38 & 22 \\
\hline Nauka i zdrowie: Know-How & 21 & 9 & - & - & - & 12 \\
\hline Polska & 1 & & & - & 1 & - \\
\hline Skaner & 7 & - & - & - & 5 & 2 \\
\hline Świat & 16 & 4 & 2 & 1 & 7 & 2 \\
\hline Życie i intermedia ${ }^{d}$ & 6 & 1 & 1 & 1 & 3 & - \\
\hline Cytat dyplomatyczny [felieton] & 1 & & & 1 & - & - \\
\hline Druga płeć [felieton] & 17 & 4 & 5 & 2 & 4 & 2 \\
\hline 2x2 = 4 [felieton] & 1 & & & - & 1 & - \\
\hline Ekran osobisty [felieton] & 2 & & & - & 2 & - \\
\hline Nałęcz [felieton] & 2 & & 1 & 1 & - & - \\
\hline Okiem barbarzyńcy [felieton] & 1 & & & - & & 1 \\
\hline Perły do lamusa [felieton] & 1 & 1 & & - & - & - \\
\hline Piórem i pazurem [felieton] & 1 & 1 & & - & - & - \\
\hline Salonowiec [felieton] & 1 & 1 & & - & - & - \\
\hline
\end{tabular}

a Jakkolwiek rubryka ta została już uwzględniona w tabeli 16 , to jednak ze względu na fakt, że znajduje się poza działem Kultura, postanowiono ją wziąć pod uwagę także i w tym przypadku.

${ }^{b}$ Raz był to dział Życie i historia.

$c$ Poza drukowanym w tym miejscu niekiedy felietonem Nałęcz, wyodrębnionym w tabeli.

${ }^{d}$ Poza wyszczególnionymi w tabeli felietonami: Druga płeć, Ekran osobisty.

Źródło: badania własne.

Najwięcej recenzji poza działem Kultura pojawiło się na stronach poświęconych zagadnieniom ekonomicznym, w dziale: Biznes-Ludzie-Pieniq̨dze. Początkowo omówienia zajmowały średnio kolumnę tekstu, drukowane były niesystematycznie, nie posiadały odrębnego, stałego tytułu. Dopiero od numeru 10 w 2003 r. pojawiła się stała rubryka, zamieszczona na pierwszej stronie działu, obok podobnych objętościowo wzmianek, w telegraficznym skrócie informujących o tym, co dzieje się w świecie biznesu w Polsce i za granicą, opisujących zdarzenia zarówno ważne, jak i tylko kontrowersyjne, a czasem zabawne czy ciekawe. Mała rubryka, umieszczona na dole strony, zatytułowana Od hitu do kitu, drukowana była od tej pory systematycznie, a pierwszą przedstawioną tym miejscu książką było Komunikowanie $w$ kryzysie Anny Murdoch. Jednak i tu recenzent (podpisany inicjałami) nie podał wydawcy, miejsca wydania czy roku, 
w którym prezentowany tytuł pojawił się na rynku. Obok kilkuzdaniowej charakterystyki znajdowało się zdjęcie okładki prezentowanej książki, a opis kończyła krótka ocena: „Mimo zastrzeżeń - rzecz warta lektury”72. Większość omówień, znajdujących się w tej rubryce zawierała subiektywną ocenę prezentowanego tytułu, czasem nie pozostawiającą wątpliwości co do wrażeń, jakie książka wywarła na recenzencie. Warto w całości przytoczyć jedną z nich:

Ładnie zaprojektowana okładka, estetyczna czcionka i stylowe ryciny nawiązujące do chińskiej tradycji to jedyne zalety „Sztuki wojny w zarządzaniu projektami”. Gdyby wydawnictwo nie zadrukowało 135 stron tej książki przemyśleniami pana Seweryna Spałki, miałaby ona jeszcze jedną zaletę - mogłaby służyć za całkiem gustowny notes. Niestety, zamiast notesu za 39 zł dostajemy bezużyteczny przedmiot - książkę z dziesiątkami banalnych zasad dotyczących zarządzania projektami, inspirowanymi „Sztuką wojny” Sun Tzu. Dobrze, że ten chiński filozof nie dożył naszych czasów ${ }^{73}$.

Negatywna ocena książki ograniczała się jednak zazwyczaj do krótkiego, podsumowującego zdania, np. „Niestety, nawet przykłady z życia życia do tej książki nie wnoszą"74 czy jednoznacznego określenia: „Kit!”75

Podobny charakter miała rubryka, która, jak wynika z analizy, pojawiła się w kilku numerach pisma w roku 2001, by powrócić na jego łamy 4 lata później, w 2005 r. Dzięki Know-How, zamieszczanemu na stronach poświęconych nauce i zdrowiu, czytelnik miał możliwość dowiedzieć się o 18 książkach, związanych z zagadnieniami, poruszanymi w dziale. W 15 przypadkach pod omówieniem, zajmującym połowę lub całą kolumnę, znalazły się niemal pełne dane bibliograficzne, ale nadal bez nazwiska tłumacza w przypadku książek autorów obcych. Recenzent ograniczał się do podania swoich inicjałów, rekompensując czytelnikowi ten brak kopią okładki proponowanej książki i w 2001 roku zdjęciem, które w założeniu miało nawiązywać do treści lektury. Recenzja znajdowała się obok kilkunastozdaniowych ciekawostek związanych $\mathrm{z}$ nauką i zdrowiem, jak na przykład wzmianki o dobroczynnym działaniu żurawiny, przyczynach depresji czy sposobach porozumiewania się słoni. Można powiedzieć, że treść przedstawianych książek przystosowana była do tego typu informacji - pisano o książkach popularnonaukowych, na przykład Dlaczego czarne dziury nie sq czarne? Nierozwiązywalne problemy współczesnej nauki (Robert M. Hazen, Maxine Singer, Prószyński i S-ka, Warszawa 2001)76, DNA. Tajemnica życia

\footnotetext{
72 (MC), Wziać kryzys za rogi, „Wprost” 2003, nr 10, s. [38].

73 (SS), Sztuka wciskania kitu, „Wprost” 2005, nr 32, s. 40.

${ }^{74}$ SS, W pogoni za klientem, „Wprost” 2005, nr 26, s. 38.

75 (SS), Nie za szybcy, nie za mądrzy, „Wprost” 2004, nr 208, s. 38.

76 „Wprost” 2001, nr 30, s. 65.
} 
(James D. Watson, Andrew Berry, Cis, W.A.B., Warszawa 2005) ${ }^{77}$, Nanontechnologia. Narodziny nowej nauki, czyli świat cząsteczka po cząsteczce (Ed Regis, Prószyński i S-ka, Warszawa 2001)78, Przetrwaja najpiękniejsi. Wszystko, co nauka mówi o ludzkim pięknie (Nancy Etcoff, Cis i W.A.B., Warszawa 2000)79, Struktura kosmosu. Przestrzeń, czas i struktura rzeczywistości (Brian Greene, Prószyński i S-ka, Warszawa 2005) ${ }^{80}$.

$\mathrm{W}$ pozostałych przypadkach były to z reguły krótkie notki, luźno nawiązujące do książki, bądź wspominające o niej mimochodem. Wyjątkiem były recenzje, które pojawiały się sporadycznie w dziale Historia bądź też w stałych rubrykach w postaci felietonów (na przykład M. Domagalik).

Jak już wcześniej wspomniano, znaczna część recenzji, zamieszczanych na łamach „Wprost” nie była podpisana: na 725 tekstów - 167 było anonimowych, a 217 razy recenzent ograniczył się jedynie do podania swoich inicjałów. W grupie recenzji podpisanych nazwiskami znalazło się 181 nazwisk; rekordzistką była M. Sawicka (jej nazwisko pojawiło się 86-krotnie), następnie K. Śmiałkowski (33 razy proponował czytelnikom wybraną przez siebie książkę), Ł. Radwan (30-krotnie). Recenzentami byli również m.in.: M. Cieślik, J. Kobus, J. Melchior, B. Wildstein i H. Zaworska (zob. Aneks 12. Autorzy recenzji drukowanych na łamach „Wprost” w latach 2001-2005).

W sumie zrecenzowano książki 573 różnych autorów ${ }^{81}$. Wśród nich znalazło się 264 autorów polskich i 309 obcych. Tworzą oni bardzo zróżnicowaną grupę: znaleźli się w niej zarówno pisarze znani szerokiej publiczności, jak i ci, o których niewielu czytelników pisma mogło słyszeć (zob. Aneks 13. Autorzy książek recenzowanych na łamach „Wprost” w latach 2001-2005).

Zdarzało się, że recenzenci więcej niż raz omawiali ten sam tytuł lub proponowali więcej niż jedną książkę tego samego autora. Takich przypadków było 63: w większości jednak to samo nazwisko autora pojawiało się zaledwie dwukrotnie, przeważnie $\mathrm{w}$ odniesieniu do dwóch różnych książek, prezentowanych w odległym od siebie czasie. Był to zatem raczej przypadek, nie działanie planowane. Wśród autorów przywołanych dwukrotnie pojawili się: Anne Applebaum, Kenneth Blanchard, Bohdan Butenko, Bogusław Chrabota, Hillary Clinton, Paulo Coelho, Stephen R. Covey, Michael Crichton, Antonio R. Damasio, Umberto Eco, Helen Fielding, John Grisham, Aleksander Hall, Wojciech Haman, Christian Jacq, Jan Paweł II, Tadeusz A. Kisielewski, Feliks W. Kres, Antoni Kroh, Zygmunt Kubiak, Roma

77 „Wprost” 2005, nr 8, s. 71.

78 „Wprost” 2001, nr 13, s. 76.

79 „Wprost” 2001, nr 2, s. 73.

80 „Wprost” 2005, nr 46, s. 82.

81 Ta liczba zawiera nazwiska autorów, podane przez recenzentów. W 32 przypadkach zabrakło tej informacji. 
Ligocka, Maciej Łuczak, Iwona Majewska-Opiełka, Dorota Masłowska, Frank Miller, Jan Miodek, Danuta Młodzikowska, Vladimir Nabokov, Andrzej Nowak, Joyce C. Oates, Agnieszka Osiecka, Milorad Pavić, Beata Pawlikowska, Józef Penc, Tomasz Piątek, Richard Pipes, T. Raczek, Jeremy Rifkin, Maciej Rybiński, Eustachy Rylski, Joanna Siedlecka, Jerzy Surdykowski, Kazimiera Szczuka, Jan Tomkowski, Oscar Wilde, Bronisław Wildstein, Janusz L. Wiśniewski, Kama Zboralska i Andrzej Żuławski.

Znacznie mniejszą grupę stanowili twórcy, których książki omawiano przynajmniej trzykrotnie (tabela 18).

Tabela 18. Najczęściej recenzowani autorzy na łamach „Wprost” w latach 2001-2005

\begin{tabular}{|c|c|c|}
\hline Dane twórcy & Liczba recenzji & Tytuły recenzowanych książek \\
\hline Olgierd Budrewicz & 5 & $\begin{array}{l}\text { Byłem wszędzie (dwukrotnie) } \\
\text { Opowieść pachnąca czekolada } \\
\text { Polska dla poczq̨tkujących } \\
\text { Warszawa przedwczorajsza }\end{array}$ \\
\hline Dan Brown & 3 & $\begin{array}{l}\text { Cyfrowa twierdza } \\
\text { Kod Leonarda da Vinci (dwukrotnie) }\end{array}$ \\
\hline Norman Davies & 3 & $\begin{array}{l}\text { Jak powstało Powstanie '44 } \\
\text { Smok wawelski nad Tamiza. Eseje... } \\
\text { Wyspy }\end{array}$ \\
\hline Jan Maria Jackowski & 3 & $\begin{array}{l}\text { Drogi i bezdroża III RP } \\
\text { Polska w globalnej sieci } \\
\text { Usłyszeć głos ludzi }\end{array}$ \\
\hline Philip Kotler & 3 & $\begin{array}{l}\text { Dziesięć śmiertelnych grzechów marketingu } \\
\text { Marketing (dwukrotnie) }\end{array}$ \\
\hline Catherine Millet & 3 & Życie seksualne Catherine M. (trzykrotnie) \\
\hline Thomas Sowell & 3 & $\begin{array}{l}\text { Ekonomia dla każdego (dwukrotnie) } \\
\text { Ekonomia stosowana }\end{array}$ \\
\hline Wojciech Wencel & 3 & $\begin{array}{l}\text { Przepis na arcydzieło } \\
\text { Wiersze zebrane } \\
\text { Ziemia Święta }\end{array}$ \\
\hline $\begin{array}{l}\text { Stanisław Ignacy Witkie- } \\
\text { wicz }\end{array}$ & 3 & $\begin{array}{l}\text { Dramaty III } \\
\text { Listy do żony } \\
\text { Panna Tutli Putli }\end{array}$ \\
\hline Marcin Wolski & 3 & $\begin{array}{l}\text { Kabaret Nadredaktora } \\
\text { Rekonkwista } \\
\text { Zamach na Polskę }\end{array}$ \\
\hline
\end{tabular}

Źródło: badania własne. 
Warto zauważyć, że 0. Budrewicz, którego książki przedstawiono pięciokrotnie, był współpracownikiem pisma, a zatem recenzje w tym przypadku miały jednocześnie formę autopromocji tygodnika. Pojawiają się nazwiska autorów popularnych bestsellerów (D. Brown), chociaż nie brakuje również pisarzy mniej znanych (J. M. Jackowski, W. Wencel) czy kontrowersyjnych (C. Millet).

W przypadku prezentowania tych samych tytułów ich recenzentami były zazwyczaj inne osoby. Bestseller D. Browna: Kod Leonarda da Vinci najpierw w 2004 r. omówiony został przez K. Śmiałkowskiego ${ }^{82}$, a ponad rok później, w 2005 r., przedstawił go J. Rzewuski83. W pierwszym przypadku była to kilkunastozdaniowa adnotacja, w drugim - obszerna dwustronicowa recenzja.

Tabela 19. Wydawcy najczęściej recenzowanych książek na łamach „Wprost” w latach 2001-2005

\begin{tabular}{|l|c|}
\hline \multicolumn{1}{|c|}{ Nazwa wydawcy } & Liczba recenzji \\
\hline Wydawnictwo W.A.B. & $33^{a}$ \\
\hline Wydawnictwo Prószyński i S-ka & 33 \\
\hline Dom Wydawniczy REBIS & 26 \\
\hline $\begin{array}{l}\text { Społeczny Instytut Wydawniczy Znak } \\
\text { Wydawnictwo Świat Książki }\end{array}$ & 23 \\
\hline Wydawnictwo Muza & 21 \\
\hline Wydawnictwo Literackie & 19 \\
\hline Wydawnictwo Helion & 15 \\
\hline Wydawnictwo Egmont Polska & 13 \\
\hline Wydawnictwo Zysk i S-ka & $12^{b}$ \\
\hline
\end{tabular}

${ }^{a} \mathrm{~W}$ tym $\mathrm{w}$ pięciu przypadkach $\mathrm{w}$ kooperacji z innymi edytorami: czterokrotnie z Wydawnictwem CiS, raz z Wydawnictwem Zysk i S-ka.

${ }^{b} \mathrm{~W}$ tym raz z Wydawnictwem W.A.B.

Źródła: badania własne.

Jak już wcześniej zaznaczono, recenzenci „Wprost” w niewielkim stopniu dbali o podawanie danych bibliograficznych. Ten brak profesjonalizmu widać szczególnie w przypadku informacji związanej z wydawcą prezento-

82 K. Śmiałkowski, Ewangelia według Browna, „Wprost” 2004, nr 15, s. 118.

83 J. A. Rzewuski, Kod Dana Browna, „Wprost” 2005, nr 29, s. [102]-104. W tym przypadku recenzent przypominał również czytelnikowi inne książki D. Browna, nadając szersze tło swojemu omówieniu. 
wanych książek: nie podano jej w 362 przypadkach. Jednak na potrzeby pracy jej autorka ustaliła brakujące nazwy edytorów ${ }^{84}$, dzięki czemu w tabeli 19 zaprezentowano oficyny, z oferty których recenzenci tygodnika korzystali najczęściej (zob. Aneks 14. Wydawcy książek recenzowanych na łamach „Wprost” w latach 2001-2005).

Recenzenci pisma skorzystali w sumie z dorobku 213 wydawców. Najczęściej sięgano po tytuły Wydawnictwa W.A.B. i Wydawnictwa Prószyński i S-ka (po 33 razy). Interesujące jest spostrzeżenie, że ci sami edytorzy byli najchętniej wybierani również przez recenzentów tygodnika „Polityka” (analogicznie: 87 i 49 razy). Podobnie sytuacja wygląda w odniesieniu do trzeciego wydawcy, a jest nim w obydwu przypadkach Społeczny Instytut Wydawniczy Znak (tu: 23 razy, na łamach wcześniej omawianego periodyku: 36 razy). Jednak zaledwie w kilku przypadkach były to te same tytuły (na przykład Widmokrag Wojciecha Kuczoka czy Finimondo Piotra Siemiona, obydwa tytuły wydane przez W.A.B.). Świadczy to o bogatej i zróżnicowanej ofercie wydawców, a także o różnicach w wyborach, którymi kierowali się recenzenci obydwu pism.

\subsection{Zakres i charakter recenzji - przykłady 85}

Recenzje zamieszczane na łamach „Wprost” miały w badanym okresie różną objętość: od kilkuzdaniowych wzmianek, poprzez omówienia zajmujące stronę, kończąc na dwu-, a nawet trzystronicowych charakterystykach. Jednak w zdecydowanej większości składały się nań krótkie adnotacje, pobieżnie omawiające dany tytuł, w których dominowały elementy objaśniająco-sprawozdawcze. Najbardziej reprezentatywne dla pisma były omówienia zamieszczane w specjalnych, wcześniej przedstawionych rubrykach drukowanych $\mathrm{w}$ ramach działu poświęconego zagadnieniom kulturalnym lub w dziale Biznes-Ludzie-Pieniq̨dze.

Pozostałe recenzje, które czytelnik mógł odnaleźć w innych miejscach pisma, stanowiły niewielką część wszystkich omówień, chociaż zdecydowanie różniły się od nich objętością - były obszerniejsze. Wynikało to z faktu, że książka stawała się zazwyczaj $\mathrm{w}$ takim przypadku tematem stałego felietonu, zajmującego zwyczajowo jedną stronę tygodnika. Tę formę

${ }^{84} \mathrm{~W} 13$ przypadkach nie udało się ustalić wydawcy recenzowanej książki, na przykład dlatego, że nie podano jej roku wydania, a publikowana była przez różnych edytorów w różnych latach. Przy uzupełnianiu brakujących informacji skorzystano z „Przewodnika Bibliograficznego" w postaci bazy danych Biblioteki Narodowej: www.bn.org.pl oraz stron internetowych: http://czytelnia.onet.pl, http://www.empik.com.

85 Ze względów wspominanych wcześniej, ograniczono się do przedstawienia wybranych, reprezentatywnych recenzji. 
dziennikarską wykorzystywali szczególnie M. Domagalik ${ }^{86}$ czy B. Wildstein, ${ }^{87}$ którzy kilkakrotnie sięgnęli po przeczytaną przez siebie książkę, by podzielić się z czytelnikami „Wprost” swoimi wrażeniami po danej lekturze.

Zdarzały się także obszerne recenzje w dziale Historia: te omówienia były szczególnie wartościowe, zazwyczaj były też wyjątkami pod względem formalnym, gdyż pod recenzją jej autor zamieszczał dane bibliograficzne. Prezentowane $\mathrm{w}$ tym miejscu książki, chociaż było ich niewiele, zwracały uwagę nie tylko swą objętością, ale i doborem tytułów. Na przykład w październikowym numerze z 2003 r. Konrad Kołodziejski umiejętnie, rozbudzając ciekawość czytelnika, przedstawił książkę Józefa Hena Mój przyjaciel król. Opowieść o Stanisławie Auguście88, a w 2004 r. Andrzej Nowak omówił tytuł Richarda Pipesa Żyłem. Wspomnienia niezależnego ${ }^{89}$.

Omówienia pomieszczane w prezentowanym periodyku zawierały zazwyczaj, podobnie jak recenzje zamieszczane na łamach „Polityki”, streszczenie proponowanej książki. Miało ono różny charakter. Niekiedy było dość ogólne (jak na przykład: „To poetycka (choć oparta na prawdziwych zdarzeniach) opowieść o miłości z czasów turecko-greckiego konfliktu. [...] Poruszająca opowieść o dziewczynie imieniem Ferzan to również skarbnica wiedzy o historii, obyczajach i religii mieszkańców Cypru"90), częściej jednak recenzent starał się przekazać więcej informacji na temat treści danej książki. Oto kilka wybranych przykładów, w których element streszczenia odgrywał pierwszoplanową rolę:

Rzecz dzieje się współcześnie w Wenecji, gdzie para bohaterów przeżywa wielką, lecz beznadziejną miłośćc ${ }^{91}$. [...] Autor wcielił się w rolę detektywa i na podstawie wskazówek zawartych w dokumentach traktujących o twórcy Kaplicy Sykstyńskiej odtworzył historię jego życia. Opowiada o ludziach, którzy kształtowali niezwykłą osobowość [...], próbując jednocześnie rozwiązać zagadkę fenomenu jednego z największych geniuszy w historii ${ }^{92}$.

Cztery tygodnie na Farmie, amerykańskim ośrodku dla uzależnionych od alkoholu, trwa turnus, na który trafia polski pisarz W. - bohater powieści Wiktora Osiatyńskiego „Rebab”. Ta książka to brutalnie szczera, bezkompromisowa relacja z małego zamkniętego światka, w którym zdesperowani alkoholicy usiłują poradzić sobie z chorobą, która ich niszczy, a jeszcze bardziej ich najbliższych ${ }^{93}$.

86 Zob. np. M. Domagalik, Dziwna książka w słusznej sprawie, „Wprost” 2004, nr 33, s. 66. Tę samą książkę omówiła we wcześniejszym numerze pisma M. Sawicka: Lament barana, ibidem, nr 32, s. 96.

87 B. Widstein, Powaga myślenia, „Wprost” 2005, nr 41, s. 15.

88 K. Kołodziejski, Król nowej epoki, „Wprost” 2003, nr 43, s. [71].

${ }^{89}$ A. Nowak, Historia zwycięstwa, „Wprost” 2004, nr 44, s. 79.

90 [br. aut.], Ferzan, czyli miłość na Cyprze, „Wprost” 2003, nr 38, s. 96.

91 [br. aut.], Miłość i śmierć w Wenecji, „Wprost” 2002, nr 20, s. 107.

92 [br. aut.], [br. tyt.], „Wprost” 2001, nr 32, s. [86].

93 [br. aut.], Samotność alkoholika, „Wprost” 2003, nr 48, s. 105. 
Autor w intrygujący sposób opowiada historię romansu Żydówki z wysokim dygnitarzem z otoczenia Himmlera. Sklonowana w czasie wojny przez niemieckiego lekarza zajmującego się eksperymentami medycznymi, piękna kobieta okazuje się bohaterką niezwykłą. Autor [...] odmalował burzliwe losy jej oraz ludzi, z którymi się styka ${ }^{94}$.

Jednak prezentacja głównej fabuły proponowanej lektury stosunkowo rzadko w przypadku omawianego periodyku (w porównaniu z tygodnikiem "Polityka”) nabierała pierwszoplanowego znaczenia. Recenzenci „Wprost” częściej starali się zachęcić czytelników do sięgnięcia po proponowaną książkę poprzez opisanie jej autora. Były to zazwyczaj krótkie prezentacje o różnym charakterze. Niekiedy przedstawiano suche fakty, dotyczące twórcy (na przykład „Aleksander Klugman, dziennikarz urodzony w Łodzi, w Izraelu mieszkający od roku 1957, wieloletni korespondent >Rzeczpospolitej<..."95). Nierzadko jednak podkreślano jego zalety (na przykład: „Ostatni taki romantyk - mówią o nim koledzy po piórze, choć pozbawiony jest polskiej martyrologicznej rzewności i sentymentalizmu. Pisarz, scenarzysta i reżyser Tadeusz Konwicki, warszawiak rodem z Wileńszczyzny..."96) czy przypominano osiągnięcia („Autor-współtwórca sukcesu programu radiowego $>60$ minut na godzinę $<$ i cyklu telewizyjnego $>$ Polskie zoo $<-$ jest jedną $\mathrm{z}$ oryginalniejszych postaci polskiego życia literackiego. Ma też już bogaty dorobek prozatorski"97). W wielu przypadkach, gdy recenzent koncentrował się na przytoczeniu głównych wątków książki, nie zamieszczał swojego zdania na jej temat, ocenę pozostawiając czytelnikowi.

Jednak należy podkreślić, że komentarz oceniający był tym elementem, który w recenzjach drukowanych na łamach „Wprost” pojawiał się wyraźnie częściej, niż były to w przypadku omówień zamieszczanych w „Polityce”. Analiza zebranego materiału pozwala również stwierdzić, że oceny, które pojawiały się we „Wprost”, znacznie częściej, niż było to czynione na łamach wcześniej przedstawionego periodyku, były negatywne. Poza wspominaną już rubryką Od hitu do kitu, najwięcej tego typu opinii pojawiało się na opisanych już częściowo stronach zatytułowanych Sława i chała. Dosadnej krytyki nie szczędzono jednak również w podstawowej rubryce poświęconej recenzjom książek. Dziennikarze wyrażali swoje odczucia wprost (sic!), nie szczędząc słów krytyki zarówno twórcom, jak i ich dziełom. Oto wybrane przykłady, ilustrujące opinie recenzentów:

Najnowsze dzieło Waldemara Łysiaka miało być hołdem dla bibliofilstwa, czyli pasji zbierania książek. W rzeczywistości jest to kolejna książka o samym autorze. I to książka hołdownicza. To zbiory Łysiaka są największe, najwspanialsze i jedyne w swoim rodzaju. To

\footnotetext{
94 [br. aut.], [br. tyt.], „Wprost” 2001, nr 10, s. 100.

95 [br. aut], [br. tyt.], „Wprost” 2001, nr 33, s. 84.

96 [br. aut], [br. tyt.], „Wprost” 2001, nr 41, s. s. 118.

97 [br. aut], [br. tyt.], „Wprost” 2001, nr 48, s. 109.
} 
na jego cześć ukuto sformułowanie „książka w stanie Łysiakowym” (czytaj: idealnym). [...] nie mamy żadnych wątpliwości - Łysiak to największy współczesny polski samochwała ${ }^{98}$.

Nina Adrycz w drugim tomie biograficznych zapisków robi wszystko co może, by do ewentualnego trzeciego tomu nikt już nie chciał zajrzećc9.

Polityczne rozgrywki, intrygi - to świetny temat na pikantną, demaskatorską powieść z kluczem o publicznej telewizji. Zwłaszcza, jeśli sam autor spędził w gmachu na Woronicza osiem lat. Trzeba dużo wysiłku, by zmarnować tak obiecujący materiał. A jednak Monice Luft się to udało 100 .

Pojawiały się również oceny pozytywne, jak choćby pochlebny komentarz na temat książki Anne Fadiman:

Entuzjazm autorki może udzielić się nawet tym, którzy rzadko i niechętnie obcują ze słowem pisanym. Liczne anegdoty o pisarzach czy wydawcach oraz dodane do tekstu objaśnienia Jana Gondowicza nie pozwalają się zagubić wśród literackich historii. Po prostu radość czytania ${ }^{101 .}$

czy zachwyt nad Uniwersalnym słownikiem języka polskiego Wydawnictwa Naukowego PWN102. Niekiedy recenzent ograniczał się do krótkich stwierdzeń, określających książkę jako „wystrzałowy debiut”, lekturę „pasjonującą”, „pouczającą”, „,edytorski smakołyk nad smakołykami”, ale i zdarzały się tytuły , które w oczach recenzenta zasłużyły na stwierdzenie, że są „przerażająco nudne".

Stosunkowo rzadko określano adresata przedstawianej książki ${ }^{103}$.

Czasem omawiano lektury, które tematycznie nawiązywały do tekstu, znajdującego się obok. Tak było na przykład w przypadku Lwa Gumilowa: Od Rusi do Rosji. Charakterystyka tej pozycji pojawiła się pod tekstem opisującym wydarzenia w teatrze na Dubrowce w Moskwie ${ }^{104}$.

Nierzadko zdarzały się recenzje propozycji wcześniej reklamowanych na łamach periodyku bądź tytułów wydanych za granicą. Kilkakrotnie proponowano czytelnikom książki współpracowników pisma: P. Cywińskiego i Rogera Boyesa Sezon na Europę ${ }^{105}$, M. Cieślika Święto wniebowzię-

98 K. Śmiałkowski, Łysiak I Wielki, „Wprost” 2003, nr 47, s. 114.

99 J. Melchior, Królowa jest naga, „Wprost” 2003, nr 49, s. 114.

100 M. Sawicka, Śmiechu warte, „Wprost” 2004, nr 11, s. 116. Zob. też np. eadem, Wielki brak, ibidem, 2005, nr 34, s. [97]; eadem, Zakalec w słowniku, ibidem, 2004, nr 46, s. 100.

101 M. Sawicka, Zwariowani bibliofile, „Wprost” 2004, nr 11, s. 116.

102 [br. aut.], Wszystko o języku polskim..., „Wprost” 2003, nr 18, s. 98.

103 Zob. np. „Wprost” 2004, nr 2, s. 88; 2002, nr 38, s. 113.

104 Zob. „Wprost” 2002, nr 45, s. 100.

105 [br. aut.], Cywiński i Boyes za kurtynq, „Wprost” 2003, nr 21, 106. 
cia106, Z. Kałużyńskiego Pamiętnik orchidei107, M. Rybińskiego Jestem, więc piszę 2003-2005108, T. Raczka Karuzela z madonnami109, K. Skiby Skibq w mur ${ }^{110}$, B. Wildsteina Mistrz i Długi cień PRL... ${ }^{111}$, M. Wolskiego Zamach na Polskę 112.

W zestawieniu tytułów książek, które zostały zrecenzowane na łamach „Wprost”, trudno jednak doszukać się wyraźnego klucza, który stanowiłby kryterium doboru lektur proponowanych czytelnikom pisma. Była to zróżnicowana grupa rozmaitych książek, zazwyczaj omówionych pobieżnie, bez zwracania uwagi na podanie ważnych informacji, które w tym przypadku raczej sygnalizowały dany tytuł, niż solidnie go omawiały. Rzadko zdarzały się recenzje obszerne, dogłębnie analizujące prezentowaną książkę i opisujące jej autora, uzupełnione uzasadnioną oceną. Poza już wspomnianymi, takim wyjątkiem było omówienie książki D. Masłowskiej. Recenzentka nie szczędziła ostrych słów, stwierdzając dosadnie:

bożyszcze salonów puściło literackiego pawia [aluzja do tytułu książki: Paw królowej - przyp. M.P.S.]. [...] Tymczasem mizdrzący się do literatów krytycy mówią o sprawnie zrymowanym językowym eksperymencie jako o arcydziele. A najnowsza książka najgłośniejszej polskiej autorki młodego pokolenia jest niczym więcej jak środowiskowym bluzgiem. Jego zasięg w normalnych warunkach, czyli bez sztucznie pompowanej sławy literatki, ograniczyłby się do wąskiego kręgu odbiorców, zapewne znajomych. [...] kipi cynizmem, epatuje brzydotą i głupotą, zraża agresywnym językiem, brakiem spójnej fabuły ${ }^{113}$.

Innym przykładem obszerniejszego omówienia była jednostronicowa prezentacja książki Henryka Grynberga, uznanego przez recenzentkę za „świetnego kronikarza”, który „o swoich bohaterach pisze ciepło, z nutą melancholii”. Pod jego zręcznym piórem ożywają Uchodźcy: Marek Hłasko, Jerzy Kosiński, Leopold Tyrmand i wielu innych. Ich losy, opowiedziane barwnym językiem stały się kanwą ważnej i ciekawej książki, która wyraźnie spodobała się dziennikarce pisma ${ }^{114}$.

Jednak większość omówień ograniczała się do krótkiego streszczenia i ewentualnej zwięzłej oceny, sprawiając przy tym wrażenie, jakby recenzent przepisał notkę $\mathrm{z}$ okładki książki, zmieniając jedynie szyk wyrazów w zdaniu. Jedynym elementem, który zdawał się spełniać swoje funkcje, były

106 M. Sawicka, Kronika z czereśniami, „Wprost” 2005, nr 48, s. 110.

107 [br. aut.], Pamiętnik orchidei, „Wprost” 2003, nr 14, s. 96.

108 (Gmyz), Ryba od głowy, „Wprost” 2005, nr 41, s. [117].

109 [br. aut.], Madonny bez madonny, „Wprost” 2003, nr 49, s. 103.

110 (MN), Liberalny beret, „Wprost” 2005, nr 48, s. [111].

111 Ł. Radwan, Przynieś mi jego skalp, „Wprost” 2004, nr 48, s. 100; M. Dzierżanowski, Konsekwentny jak Wildstein, ibidem, 2005, nr 17, s. [113].

112 K. Śmiałkowski, Wolski kontra Al-Kaida, „Wprost” 2005, nr 26, s. 104.

113 M. Sawicka, Paw warszawski, „Wprost” 2005, nr 21, s. 110-[111].

114 M. Sawicka, Piękni siedemdziesięcioletni, „Wprost” 2005, nr 3, s. 103. 
tytuły recenzji. Jedne $\mathrm{z}$ nich były zabawne, inne przykuwały wzrok swą oryginalnością. Oto kilka przykładów ${ }^{115}$ : Arcydzieło bez arcydzieła, Geografia literatury, Kronika z czereśniami, Lektura na hamak, Literatura dla pokolenia MTV, Nie tylko dla kobiet, O tym, co ważne, Obława na pisarzy, Piórem i Mieczem, Siła słów, Skarbiec złotoustych, Słowo jak skalpel, Sprzedawca obietnic, Umrzeć dla literatury, $W$ poszukiwaniu natchnienia, $Z$ siebie się śmiejecie!, Zdumienie światem, Ziemia i chmury, Zwariowani bibliofile, Zysk uświęca środki.

Warto też wspomnieć o Rankingach i Bestsellerach „Wprost”. Były to zestawienia najlepiej sprzedających się książek, płyt dvd z filmami, muzyką, ale także listy wystaw, zamieszczane na początku działu Kultura, w ramach Меnu. W pierwszym badanym roczniku drukowano, w skromnej formie, wyłącznie Rankingi. Pojawiły się one w sumie w 41 numerach w roku 2001 i 2002, obejmowały za każdym razem 10 tytułów książek wraz z ich autorami i wydawcą. $\mathrm{W}$ drugim badanym roczniku zamieszczono Bestsellery Wprost, drukowane na zmianę bądź równolegle z Rankingami - zdjęcia 30 i 31.

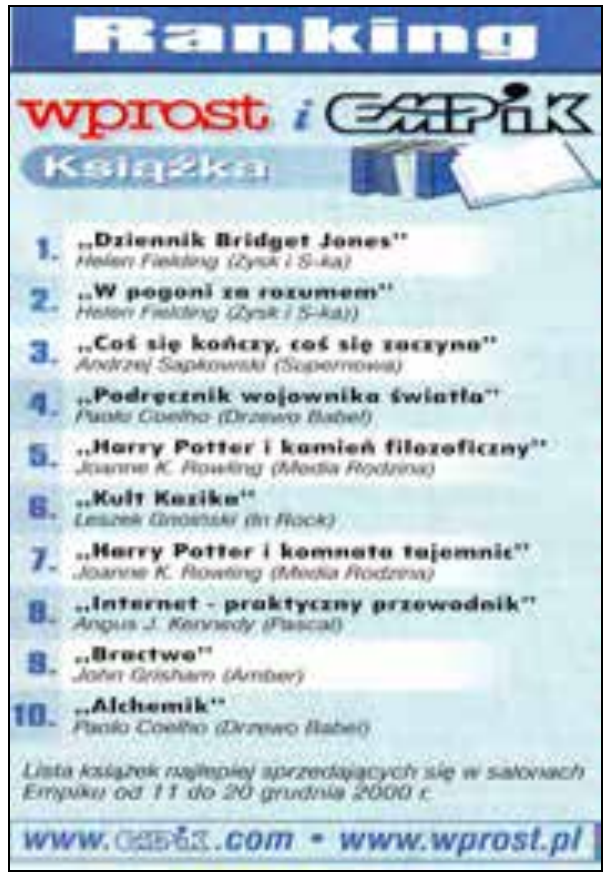

Zdjęcie 30. Ranking Wprost i Empiku „Wprost" 2001, nr 1, s. 100

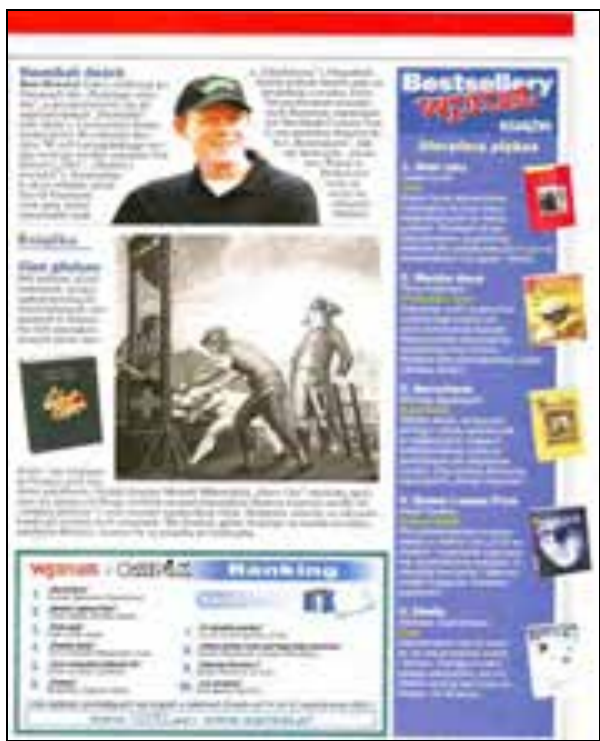

Zdjęcie 31. Bestsellery Wprost „Wprost” 2002, nr 45, s. 111

115 Kolejno: „Wprost” 2005, nr 5, s. [95]; 2003, nr 8, s. 97; 2005, nr 48, s. 110; 2003, nr 32, s. 89; 2004, nr 26, s. 112; 2005, nr 32, s. 95; nr 29, s. 40; nr 12, s. 100-102; 2003, nr 30, s. $89 ; 2005$, nr 4, s. $38 ; 2004$, nr 14, s. $120 ;$ nr 40, s. 118; 2003, nr 13, s. [50]; 2005, nr 16, s. [113]; 2004, nr 12, s. 41; nr 24, s. 111; 2001, nr 22, s. 89; 2002, nr 26, s. 108; 2004, nr 11, s. 116; 2003, nr 42, s. 39. W 50 przypadkach recenzje nie posiadały tytułów. 
Bestsellery Wprost były bardziej rozbudowane, przy tytułach książek ${ }^{116}$ znajdowały się krótkie adnotacje treściowe, poprzedzone skromnymi danymi bibliograficznymi, uzupełnionymi kopiami okładek prezentowanych w ten sposób tytułów. Znalazły się one w 100 numerach pisma. Te dwie formy informacji o najlepiej sprzedających się książkach korzystnie harmonizowały z innymi elementami omawianego tu działu.

W 2003 r. wraz ze zmianami graficznymi w całym piśmie zmieniła się też nieco forma Bestsellerów, choć zmiany te dotyczyły w zasadzie kolorystyki; częściej też zamieszczano obok siebie zestawienia dotyczące książek i na przykład filmów ${ }^{117}$. W następnym roku ponownie ulepszono grafikę, dzięki czemu zestawienia stały się bardziej czytelne, choć nadal miały tę samą objętość i zawierały te same elementy ${ }^{118}$. W numerze 43 (2004) po raz ostatni zestawienie zostało zamieszczone pod dotychczasowym tytułem. Od wydania następnego tygodnik, jak już wspomniano wcześniej, zmienił grafikę, co objęło również dział kulturalny. W numerze 45 (2004) na miejsce dotychczasowych bestsellerów pojawiły się podobne $\mathrm{w}$ swej formule, nieco krótsze zestawienia (liczące zazwyczaj cztery tytuły), zatytułowane „Wprost” poleca, jednak bez żadnego wyjaśnienia ze strony redakcji119.

$\mathrm{Na}$ zakończenie każdego roku prezentowano Bestsellery ostatnich 12 miesięcy. Zestawienia te obejmowały dwie lub cztery strony i sygnalizowały cieszące się największą popularnością książki, płyty z filmami oraz muzyką ${ }^{120}$. W 2001 r. (w odniesieniu do literatury) zestawienie było najuboższe, zawierało jedynie kopie okładek książek z podstawowymi danymi bibliograficznymi (autor, tytuł i wydawca), natomiast $w$ latach następnych pojawiły się dodatkowo krótkie adnotacje treściowe, zaś w 2002 r. także zdjęcia niektórych autorów ${ }^{121}$.

116 W większości przypadków było to 5 tytułów.

117 Zob. np. „Wprost” 2003, nr 47, s. 105.

118 Zob. np. „Wprost” 2004, nr 30, s. 87.

119 Zamieszczono je w 21 numerach w latach 2004-2005. Ze względu na lokalizację i niemal taką samą formę, jak Bestsellery, potraktowano je w pracy jako kontynuację poprzednich zestawień.

120 Zob. „Wprost” 2005, nr 51/52, s. 160-161.

121 „Wprost” 2001, nr 51/52, s. [132]-[133]; 2002, nr 51/52, s. 142-145; 2003, nr 51/52, s. $158-160 ; 2005$, nr $51 / 52$, s. $160-161$. 


\subsubsection{Dyskretny urok historyjek ${ }^{122:}$ wywiady}

Kolejna forma informacji, związana z książką, to wywiady z pisarzami. W badanym okresie na łamach „Wprost” było ich 46 . W tabeli 20 przedstawiono ich liczbę w każdym roku.

Tabela 20. Wywiady zamieszczone na łamach „Wprost” w latach 2001-2005

\begin{tabular}{|c|c|}
\hline Rok & Liczba wywiadów \\
\hline 2001 & 18 \\
\hline 2002 & 9 \\
\hline 2003 & 9 \\
\hline 2004 & 6 \\
\hline 2005 & 4 \\
\hline Ogółem & 46 \\
\hline
\end{tabular}

Źródło: badania własne.

Jak widać, najwięcej było ich w pierwszym analizowanym roku, później liczba ta malała, by w 2005 r. zamknąć się zaledwie w czterech wywiadach. Nadto tylko w 15 przypadkach bohaterami tej formy prezentacji twórców byli pisarze. Pozostałe rozmowy przeprowadzono z wybitnymi naukowcami, filozofami, jednocześnie będącymi autorami książek, a także z reżyserami, którzy przenieśli na ekran znane powieści i aktorami - odtwórcami ról w ekranizacjach książkowych (zob. Aneks 15. Osoby związane z książką, z którymi przeprowadzono wywiad na łamach „Wprost” w latach 2001-2005).

Wśród rozmówców znaleźli się następujący pisarze: Władimir Bukowski i Wiktor Suworow ${ }^{123}$, Norman Davies, Joachim Fest, David Forden, Katarzyna Grochola, Etgar Keret, Roma Ligocka, Jeremy Rifkin, Benjamin Weiser, Carlos Ruiz Zafón, a także poeta Czesław Miłosz, krytyk literacki Marcel Reich-Ranicki oraz Jan Nowak-Jeziorański, Françoise Sagan.

Wywiady nie miały swojego stałego miejsca w piśmie, drukowane były w różnych działach, zajmowały średnio dwie strony, na których pojawiało się zdjęcie rozmówcy zazwyczaj z dotyczącą go krótką notą biograficzną. Wydaje się, sądząc po liczbie tych publikacji, że redakcja „Wprost” przywiązywała niewielką wagę do tej formy promocji książki. Oceniając je pod względem przygotowania pytań, także należy podkreślić, że były one znacznie mniej interesujące od rozmów, drukowanych na łamach tygodnika „Polityka”.

122 Tytuł wywiadu z hiszpańskim pisarzem C R. Zafónem, „Wprost” 2005, nr 28, s. 109.

${ }^{123}$ Rozmowa przeprowadzona była z nimi obydwoma jednocześnie. Poza tym W. Suworow był bohaterem kolejnych dwóch wywiadów. 
Trzykrotnie przeprowadzono wywiad z W. Suworowem. Za każdym razem tematem rozmów była Rosja i ówczesna polityka państw byłego bloku wschodniego ${ }^{124}$. Do rozmowy zaproszono również Joachima Festa, autora biografii o Adolfie Hitlerze. Podzielił się on z czytelnikami „Wprost” m.in. własną opinią na temat historii Niemiec, stwierdzając:

Nie ma narodów sprawców. Zbrodnie zawsze są dziełem konkretnych jednostek. Wyrażenie „naród sprawców” powoduje, że rozmywa się osobistą odpowiedzialność. Z drugiej strony, Niemcy jako naród cudownie odgrywają rolę kozła ofiarnego. [...] Hitler był człowiekiem. Hitler tkwi w każdym z nas. Zło może zaistnieć w każdym człowieku. To prawda, która przy całym rozrachunku z przeszłością nam umyka ${ }^{125}$.

Na łamach pisma pojawił się również zapis rozmowy z Cz. Miłoszem. W tym przypadku czytelnicy tygodnika poznali m.in. opinię poety na temat współczesnej literatury i kultury ${ }^{126}$. Z kolei o swojej nowej książce opowiedziała R. Ligocka, podkreślając:

Moja historia opowiada o tym, w jaki sposób człowiekowi można wyrządzić wielką krzywdę przy użyciu zaledwie jednego słowa. Mówi o tym, jak niebezpieczne są pomówienia. Jak jedno zdanie może zrujnować całe życie ${ }^{127}$.

W porównaniu z „Polityką" w tygodniku „Wprost” w bardzo niewielkim stopniu wykorzystywano tę formę prezentacji twórców.

\subsubsection{Supersensacja ${ }^{128}$ : reklamy książek}

Na łamach „Wprost” pojawiały się również reklamy. Podobnie, jak w przypadku tygodnika „Polityka”, tak i tu można wyodrębnić trzy kategorie stanowiące przedmiot inseratów, związanych z problematyką określoną w temacie pracy:

1) książki (w tej grupie znalazły się także encyklopedie, leksykony, słowniki, podręczniki, poradniki, informatory, przewodniki, albumy oraz atlasy),

2) akcje tygodnika związane z książką (konkursy, targi, spotkania) ${ }^{129}$,

3) prasa, w tym autoreklama ${ }^{130}$.

124 „Wprost” 2001, nr 33, s. 75-77; 2001, nr 39, s. 57; 2003, nr 24, s. 75.

125 Kusząca postać zła, rozm. C. Gryz, współpr. H. Christ, „Wprost” 2005, nr 18, s. 68-[69].

126 Jestem antymodernista, rozm. J. Kobus, „Wprost” 2002, nr 9, s. 107.

127 Czułe słówka, rozm. M. Sawicka, „Wprost” 2004, nr 44, s. 117.

128 Hasło reklamowe w jednej z reklam wydawniczych. Zob. „Wprost” 2002, nr 34, s. 90.

${ }^{129}$ Przybierały one dwojaką postać (reklam i tekstów opisowych) i zostaną omówione w dalszej części rozdziału.

130 Ta kwestia zostanie dokładniej przedstawione w ostatniej części rozdziału. 
W latach 2001-2005 na łamach pisma pojawiło się w sumie 1667 tego typu inseratów. Reklamy książek stanowiły ok. 1/3 tej liczby: było ich 573 . $\mathrm{W}$ tabeli 21 przedstawiono ich liczbę w każdym z badanych roczników.

Tabela 21. Ogłoszenia wydawców książek w latach 2001-2005 na łamach „Wprost”

\begin{tabular}{|c|c|}
\hline Rok & Liczba inseratów książkowych \\
\hline 2001 & 89 \\
\hline 2002 & 124 \\
\hline 2003 & 84 \\
\hline 2004 & 89 \\
\hline 2005 & 187 \\
\hline Ogółem & 573 \\
\hline
\end{tabular}

Źródło: badania własne.

Liczba reklam jest nierówna, ale wyraźnie widać rosnący profesjonalizm Biura Reklamy tygodnika „Wprost” w ich przygotowaniu. O ile w $2001 \mathrm{r}$. były one stosunkowo skromne, mało pomysłowe, nierzadko niewyraźne bądź niezbyt trafnie umieszczane, o tyle $\mathrm{w}$ latach następnych ich forma uległa poprawie.

W ciągu 5 lat na łamach „Wprost” pojawiły się reklamy 328 tytułów książek. W inseratach znalazło się 196 nazwisk autorów ${ }^{131}$, w tym 70 pisarzy polskich i 126 autorów obcych (Aneks 16. Autorzy reklamowanych książek na łamach „Wprost” w latach 2001-2005).

Kilkakrotnie reklamowano książkę wcześniej zrecenzowaną na łamach pisma. Tak było w przypadku Tajemnic kodu: nieautoryzowanego przewodnika po sekretach Kodu Leonarda da Vinci Dana Bursteina ${ }^{132}$ czy Ja wam pokażę! K. Grocholi133 i Losu powtórzonego J. L. Wiśniewskiego ${ }^{134}$.

W większości przypadków reklamy proponowanych tytułów powtarzały się dwukrotnie (rzadziej trzykrotnie) w następujących po sobie numerach pisma. Zdarzały się jednak tytuły częściej reklamowane. Zobrazowano to $\mathrm{w}$ tabeli 22.

$131 \mathrm{~W}$ tej liczbie pominięto przypadki, gdy reklamodawca nie podawał autora, był on trudny do ustalenia albo kiedy książka wydana była przez zespół autorów. Ostatni przypadek dotyczył np. encyklopedii, leksykonów i słowników.

132 Reklama, zob. „Wprost” 2004, nr 38, s. 121; recenzja, zob. ibidem, 2004, nr 37, s. 119.

133 Reklama, zob. np. „Wprost” 2004, nr 15, s. [95]; recenzja, zob. ibidem, 2004, nr 14, s. 109.

134 Reklama, zob. „Wprost” 2004, nr 38, s. 121; recenzja, zob. ibidem, 2004, nr 38, s. 107. 
Tabela 22. Najczęściej powtarzające się tytuły w reklamach wydawniczych w latach 2001-2005 na łamach „Wprost”

\begin{tabular}{|c|c|c|}
\hline Tytuł reklamowanej pozycji & Wydawca & $\begin{array}{c}\text { Liczba } \\
\text { anonsów }\end{array}$ \\
\hline $\begin{array}{l}\text { Azyl Arkham } \\
\text { (David McKean ) }\end{array}$ & Egmont Polska & 8 \\
\hline $\begin{array}{l}\text { Feralny Major } \\
\text { (Moebius ) }\end{array}$ & Egmont Polska & 8 \\
\hline $\begin{array}{l}\text { Kingdom Come } \\
\text { (Alex Ross) }\end{array}$ & Egmont Polska & 8 \\
\hline $\begin{array}{l}\text { Legendy naszych czasów } \\
\text { (Enki Bilal) }\end{array}$ & Egmont Polska & 8 \\
\hline $\begin{array}{l}\text { Nigdy w życiu! } \\
\text { (Katarzyna Grochola) }\end{array}$ & \begin{tabular}{|l|} 
Wydawnictwo W.A.B. \\
Wydawnictwo Prószyński i S-ka
\end{tabular} & 7 \\
\hline $\begin{array}{l}\text { Nagrody Darwina. Ewolucja w działaniu } \\
\text { (Wendy Northcutt) }\end{array}$ & Wydawnictwo W.A.B. & 5 \\
\hline $\begin{array}{l}\text { Samotna misja. Pułkownik Kukliński i zimna } \\
\text { wojna } \\
\text { (Józef Szaniawski) }\end{array}$ & Ex Libris & 5 \\
\hline $\begin{array}{l}\text { Cosi fan tutti } \\
\text { (Michael Dibdin) }\end{array}$ & Dom Wydawniczy REBIS & 4 \\
\hline $\begin{array}{l}\text { Emocje. Naukowo o uczuciach } \\
\text { (Dylan Evans) }\end{array}$ & Dom Wydawniczy REBIS & 4 \\
\hline $\begin{array}{l}\text { Express Méditerranée } \\
\text { (Jacek Pałasiński) }\end{array}$ & Wydawnictwo Akade & 4 \\
\hline $\begin{array}{l}\text { Honor Prizzich } \\
\text { (Richard Condon ) }\end{array}$ & Dom Wydawniczy REBIS & 4 \\
\hline Informatory & [brak informacji o wydawcy] & 4 \\
\hline $\begin{array}{l}\text { Kabal } \\
\text { (Michael Dibdin) }\end{array}$ & Dom Wydawniczy REBIS & 4 \\
\hline $\begin{array}{l}\text { Karuzela z Madonnami } \\
\text { (Tomasz Raczek) }\end{array}$ & Instytut Wydawniczy Latarnik & 4 \\
\hline $\begin{array}{l}\text { Napoleon. Nieśmiertelny ze Świętej Heleny } \\
\text { (Max Gallo) }\end{array}$ & Dom Wydawniczy REBIS & 4 \\
\hline $\begin{array}{l}P L-B O Y \\
\text { (Marcin Szczygielski) }\end{array}$ & Instytut Wydawniczy Latarnik & 4 \\
\hline $\begin{array}{l}\text { Rodzina Prizzich } \\
\text { (Richard Condon) }\end{array}$ & Dom Wydawniczy REBIS & 4 \\
\hline $\begin{array}{l}\text { S@motność w sieci } \\
\text { (Janusz L. Wiśniewski) }\end{array}$ & Wydawnictwo Prószyński i S-ka & 4 \\
\hline $\begin{array}{l}\text { Sens dobra. Wprowadzenie do etyki } \\
\text { (Simon Blackburn) }\end{array}$ & Dom Wydawniczy REBIS & 4 \\
\hline $\begin{array}{l}\text { Serce na temblaku } \\
\text { (Katarzyna Grochola) }\end{array}$ & Wydawnictwo W.A.B. & 4 \\
\hline $\begin{array}{l}\text { Wprost z oblężonej świątyni } \\
\text { (Jacek Pałasiński) }\end{array}$ & Wydawnictwo Akade & 4 \\
\hline
\end{tabular}

Źródło: badania własne. 
Najczęściej reklamowane były komiksy: anons je promujący pojawił się osiem razy w 2005 r. Wydawca powtarzał ogłoszenie w dwóch następujących po sobie numerach „Wprost”, by następnie przypomnieć czytelnikom o proponowanych tytułach mniej więcej dwa miesiące później. Zwraca uwagę także fakt kilkakrotnej obecności Domu Wydawniczego REBIS, który promował siedem tytułów ze swej oferty.

Nierzadko zdarzało się również, że edytor rezygnował z powtarzania reklamy tego samego tytułu, a decydował się na prezentację kilku różnych książek tego samego twórcy $\mathrm{w}$ jednym lub kilku anonsach. W ciągu badanego okresu tylko nazwiska 16 autorów wymieniano w reklamach przynajmniej czterokrotnie - i to przy okazji więcej niż jednej książki. W tabeli 23 zaprezentowano nazwiska tych twórców, którzy pojawiali się w reklamach najczęściej:

Tabela 23. Autorzy książek reklamowanych przez wydawców (więcej niż 1 tytuł) na łamach „Wprost” w latach 2001-2005

\begin{tabular}{|c|c|c|c|}
\hline Nazwisko autora & Liczba inseratów & Liczba tytułów & Tytuły reklamowanych książek \\
\hline Katarzyna Grochola & 10 & $x_{2}$ & $\begin{array}{l}\text { Ja wam pokażę! (dwukrotnie]) } \\
\text { Nigdy w życiu! (siedmiokrotnie) } \\
\text { Osobowość ćmy (czterokrotnie) } \\
\text { Serce na temblaku (dwukrotnie) } \\
\text { Związki i rozwiązki miłosnea } \\
\text { (dwukrotnie) }\end{array}$ \\
\hline Janusz L. Wiśniewski & 10 & 4 & $\begin{array}{l}\text { Los powtórzony (dwukrotnie) } \\
\text { Martyna (dwukrotnie) } \\
\text { S@motność w sieci (czterokrotnie) } \\
\text { Zespoły napięć (dwukrotnie) }\end{array}$ \\
\hline Jacek Pałasiński & 8 & 2 & $\begin{array}{l}\text { Express Méditerranée (czterokrot- } \\
\text { nie) } \\
\text { Wprost z oblężonej świątyni } \\
\text { (czterokrotnie) }\end{array}$ \\
\hline Maciej Łuczak & 6 & 3 & $\begin{array}{l}\text { Miś, czyli rzecz o Stanisławie Barei } \\
\text { (dwukrotnie) } \\
\text { Rejs, dlaczego szczególnie nie chodzę } \\
\text { na filmy polskie (dwukrotnie) } \\
\text { Wniebowzięci, czyli jak to się robi } \\
\text { hydrozagadkę (dwukrotnie) }\end{array}$ \\
\hline Beata Pawlikowska & 5 & 3 & $\begin{array}{l}\text { Blondynka śpiewa w Ukajali } \\
\text { (dwukrotnie) } \\
\text { Blondynka Tao (dwukrotnie) } \\
\text { Blondynka u szamana }\end{array}$ \\
\hline Andrzej Pilipiuk & 5 & 4 & $\begin{array}{l}\text { Czarownik Iwanow } \\
\text { Kroniki Jakuba Wędrowycza } \\
\text { Kuzynki (dwukrotnie) } \\
\text { Weźmiesz czarno kure... }\end{array}$ \\
\hline
\end{tabular}


Tabela 23 (cd.)

\begin{tabular}{|c|c|c|c|}
\hline Nazwisko autora & Liczba inseratów & Liczba tytułów & Tytuły reklamowanych książek \\
\hline Simon Blackburn & 4 & 2 & $\begin{array}{l}\text { Myśl. Wprowadzenie do filozofii } \\
\text { Sens dobra: wprowadzenie do etyki }\end{array}$ \\
\hline Max Gallo & 4 & 4 & $\begin{array}{l}\text { Napoleon. Pieśń wymarszu (t. I) } \\
\text { Napoleon. Słońce w Austerlitz (t. II) } \\
\text { Napoleon. Cesarz królów (t. III) } \\
\text { Napoleon. Nieśmiertelny ze Świętej } \\
\text { Heleny (t. IV) }\end{array}$ \\
\hline Richard Condon & 4 & 2 & \begin{tabular}{|l|} 
Honor Prizzich (czterokrotnie) \\
Rodzina Prizzich (czterokrotnie)
\end{tabular} \\
\hline Michael Dibdin & 4 & 2 & $\begin{array}{l}\text { Cosi fan tutti (czterokrotnie) } \\
\text { Kabal (czterokrotnie) }\end{array}$ \\
\hline Tomasz Raczek & 4 & 2 & $\begin{array}{l}\text { Karuzela z herosami: męski świat } \\
\text { w } 57 \text { odsłonach (dwukrotnie) } \\
\text { Karuzela z Madonnami:57 bardzo } \\
\text { zakręconych kobiet (czterokrotnie) }\end{array}$ \\
\hline Roma Ligocka & 4 & 2 & \begin{tabular}{|l|} 
Kobieta w podróży (dwukrotnie) \\
Tylko ja sama (dwukrotnie) \\
\end{tabular} \\
\hline Izabela Sowa & 4 & 2 & \begin{tabular}{|l|} 
Cierpkość wiśni (dwukrotnie) \\
Smak świeżych malin (dwukrotnie) \\
\end{tabular} \\
\hline Marcin Szczygielski & 4 & 3 & $\begin{array}{l}\text { Kuchnia na ciężkie czasy } \\
\text { PL-BOY (czterokrotnie) } \\
\text { Wiosna PL-BOYA } \\
\end{array}$ \\
\hline Wit Szostak & 4 & 2 & $\begin{array}{l}\text { Ględźby Ropucha (dwukrotnie) } \\
\text { Poszarpane granice (dwukrotnie) }\end{array}$ \\
\hline Susanna Clarke & 3 & 3 & $\begin{array}{l}\text { Jonathan Strange i pan Norrel, t. } 1 \\
\text { Jonathan Strange i pan Norrel, t. } 2 \\
\text { Jonathan Strange i pan Norrel, t. } 3 \\
\end{array}$ \\
\hline David M. Buss & 2 & 2 & \begin{tabular}{|l|} 
Ewolucja pożądania \\
Zazdrość: niebezpieczna namiętność
\end{tabular} \\
\hline John Le Carré & 2 & 2 & \begin{tabular}{|l|} 
Przyjaźń absolutna \\
Wierny ogrodnik \\
\end{tabular} \\
\hline Maria Nurowska & 2 & 2 & $\begin{array}{l}\text { Imię twoje... } \\
\text { Powrót do Lwowa }\end{array}$ \\
\hline José Saramago & 2 & 3 & $\begin{array}{l}\text { Baltazar i Blimunda (dwukrotnie) } \\
\text { Podwojenie (dwukrotnie) } \\
\text { Wszystkie imiona (dwukrotnie) } \\
\end{array}$ \\
\hline
\end{tabular}

${ }^{a}$ Książka wspólnie napisana z A. Wiśniewskim.

Źródło: badania własne.

Obydwa zestawienia potwierdzają wniosek, który nasuwa się po przyjrzeniu się pełnej liście wszystkich tytułów i autorów reklamowanych w piśmie. Dzieła Cz. Miłosza sąsiadują z komiksami, książka popularnonaukowa $\mathrm{z}$ powieściowym bestsellerem. Podobnie, jak było to $\mathrm{w}$ przypadku recenzji, tak i tu brak jest wyraźnej polityki wydawniczej redakcji. Niekiedy zdarzały się reklamy, które pojawiły się na łamach pisma tylko raz, ale 
wydawca polecał w nich uwadze czytelników kilka tytułów tego samego autora. Tak było na przykład w przypadku powieści Moniki Szwai135.

Warto zwrócić uwagę na jeszcze jeden typ reklamy, w tym przypadku zachęcający do kupna trylogii Johna R. R. Tolkiena - zdjęcie 32.

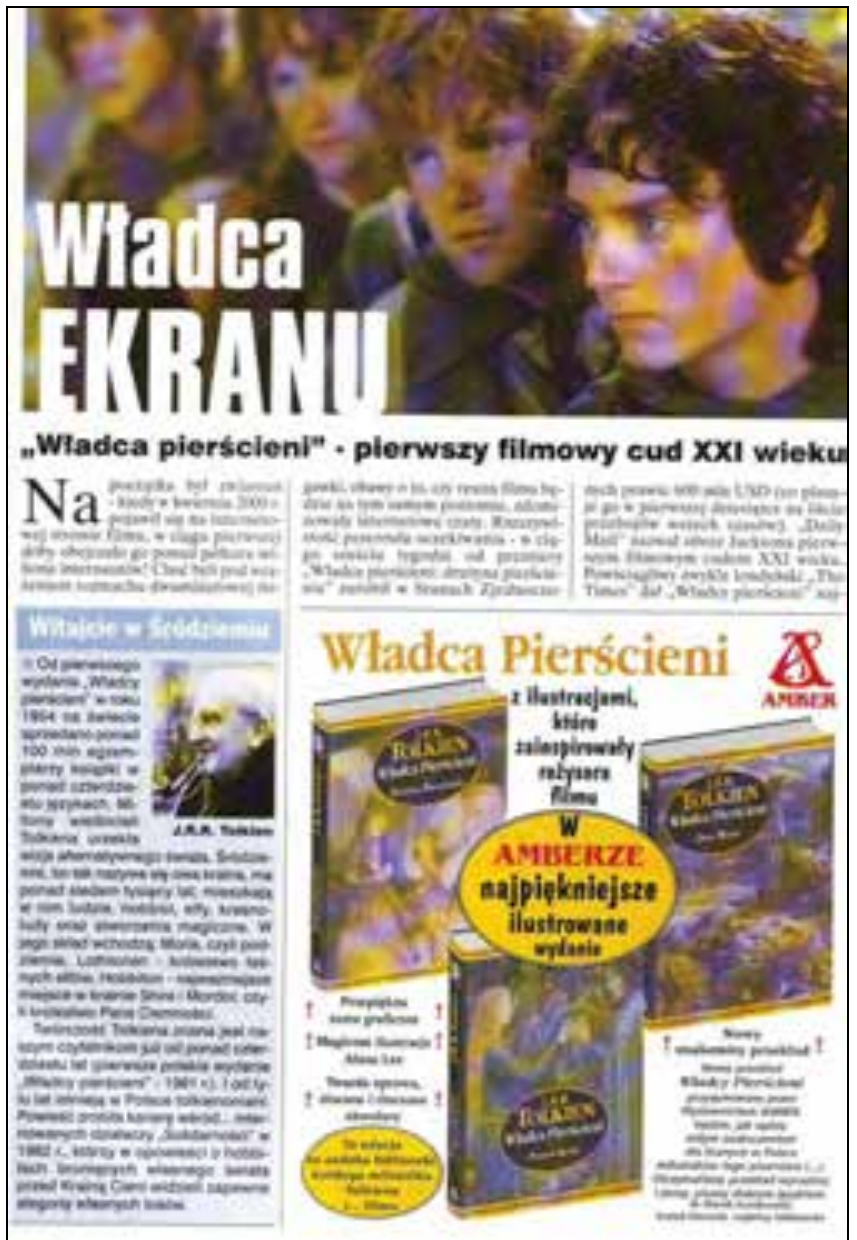

Zdjęcie 32. Wybrane ogłoszenie wydawnicze zamieszczone na łamach „Wprost”

„Wprost” 2002, nr 7, s. [101]

Reklamowane tytuły nawiązywały do tekstu znajdującego się obok. Był to dobry pomysł, by przy okazji omawiania ekranizacji znanej książki przypomnieć czytelnikom o jej wersji oryginalnej. Tak bywało jednak rzadko. 
Różnorodność reklamowanej oferty wynikała ze znacznej liczby wydawców, którzy zamieszczali swoje anonse na łamach pisma. W ciągu 5 lat $\mathrm{z}$ tej formy promocji skorzystało 75 edytorów ${ }^{136}$ (zob. Aneks 17 . Wydawcy, którzy zamieścili swe anonse na łamach „Wprost” w latach 2001-2005). W tabeli 24 przedstawiono te oficyny, które najczęściej reklamowały swoją ofertę na łamach „Wprost”.

Tabela 24. Wydawcy najczęściej zamieszczający inseraty na łamach „Wprost” w latach 2001-2005

\begin{tabular}{|l|c|}
\hline \multicolumn{1}{|c|}{ Nazwa wydawcy } & Liczba anonsów \\
\hline Dom Wydawniczy REBIS & 79 \\
\hline Wydawnictwo W.A.B. & 46 \\
\hline Wydawnictwo Prószyński i S-ka & 43 \\
\hline $\begin{array}{l}\text { Wydawnictwo Amber } \\
\text { Wydawnictwo Egmont Polska } \\
\text { Young Digital Poland. Wydawnictwo interaktywne }\end{array}$ & 32 \\
\hline Wydawnictwo Literackie & 25 \\
\hline Wydawnictwo Fabryka Słów & 15 \\
\hline Wydawnictwo Naukowe PWN & 13 \\
\hline Wydawnictwo Pascal & 12 \\
\hline $\begin{array}{l}\text { Wydawnictwo Arkady } \\
\text { Kluszczyński Wydawnictwo }\end{array}$ & 11 \\
\hline Wydawnictwo National Geographic & 10 \\
\hline
\end{tabular}

Źródło: badania własne.

Jak wynika z tabeli 24, w największym stopniu z tej formy promocji w pierwszym rzędzie skorzystały duże i znane wydawnictwa. Zrezygnowały one $\mathrm{z}$ kilkukrotnego promowania tych samych tytułów na rzecz reklamy szerszej oferty: do czytelnika trafiała w tym przypadku zazwyczaj tylko raz informacja o danym tytule, a w następnym anonsie pojawiały się kolejne propozycje $\mathrm{z}$ oferty danego edytora. $\mathrm{W}$ pamięci czytelnika utrwalała się zatem przede wszystkim nazwa wydawcy, czemu zresztą sprzyjała zbliżona zazwyczaj forma reklamy. W większości przypadków ogłoszenie było podobne graficznie, zmieniał się jedynie tytuł i autor proponowanej książki i naturalnie lokalizacja reklamy w piśmie (dotyczyło to przede wszystkim wydawców wymienionych w tabeli 24). W ten sposób czytelnik kojarzył po pewnym czasie moduł reklamowy z określonym wydawcą. Oto przykład inseratów wybranego wydawcy - zdjęcie 33 i 34.

136 W 10 przypadkach w anonsie brakowało nazwy wydawcy, zob. np. reklama książki J. L. Wiśniewskiego Los powtórzony, „Wprost” 2004, nr 36, s. [75]. 


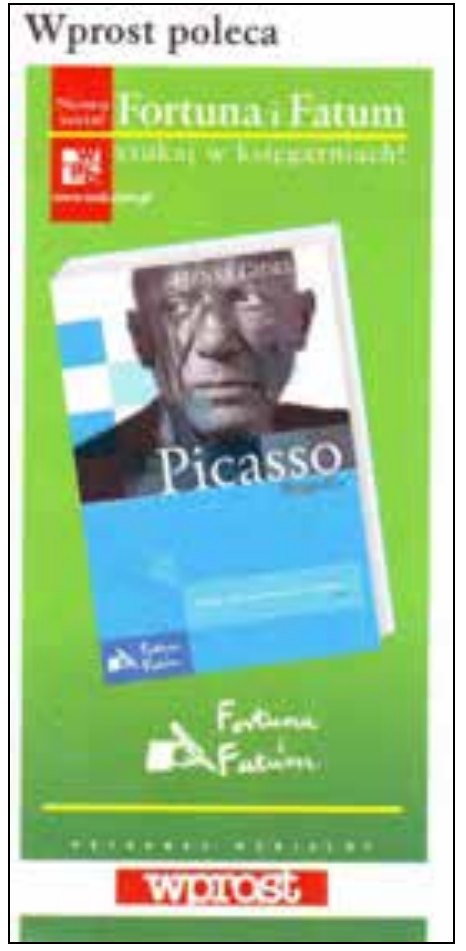

Zdjęcie 33. Wybrane ogłoszenie wydawnicze na łamach „Wprost” „Wprost” 2004, nr 29, s. [28]

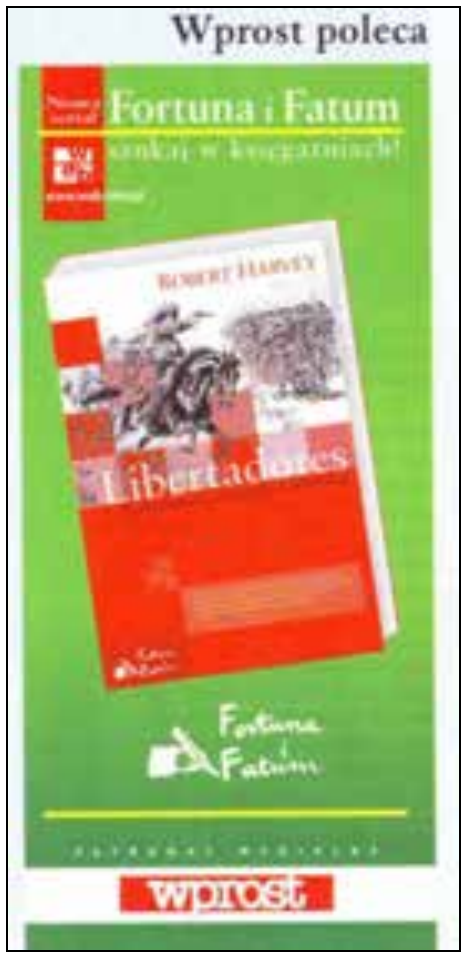

Zdjęcie 34. Wybrane ogłoszenie wydawnicze na łamach "Wprost" „Wprost” 2004, nr 31, s. [81]

Obydwa inseraty, zachowując tę samą formułę, proponowały inną książkę. Za każdym razem pojawiały się te same elementy, a nad obydwoma tytułami patronat medialny sprawował omawiany tygodnik.

Przez cały badany okres ogłoszenia wydawnicze rozmieszczane były w różnych miejscach pisma, miały różną objętość i zawierały rozmaite elementy. Najczęściej pojawiały się one na stronie w całości poświęconej reklamom: obok inseratów promujących książki drukowano ogłoszenia informujące o mających się odbyć wystawach, premierach filmowych, festiwalach i koncertach. Zdarzało się jednak, że obok anonsów książkowych znajdowała się reklama banku, klubu czy imprezy okazjonalnej (na przykład wakacyjnej). Wszystkie te reklamy (przeważnie zatytułowane Wprost poleca) były kolorowe, czasem jednak grafika zawodziła. Oto przykłady wybranych ogłoszeń - zdjęcia 35 i 36. 


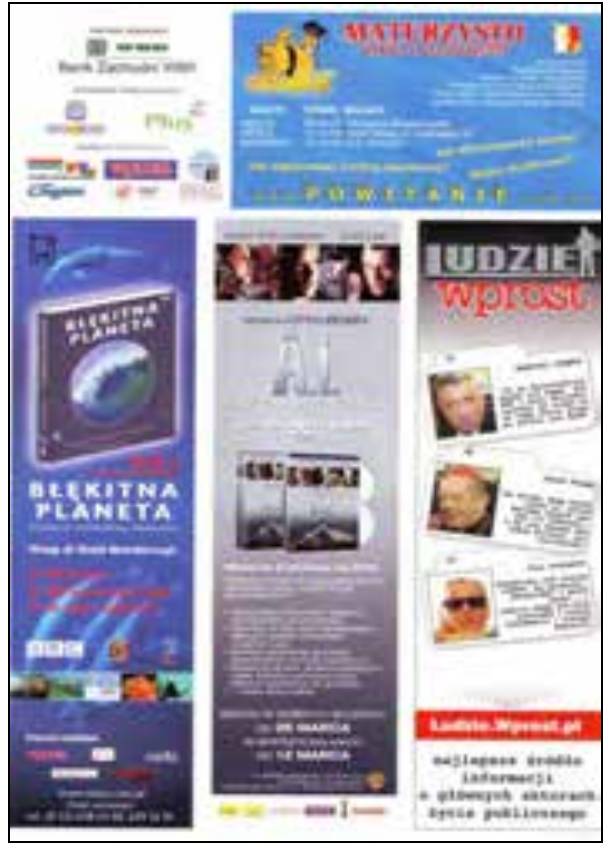

Zdjęcie 35. Wybrane ogłoszenie wydawnicze zamieszczone na łamach „Wprost” „Wprost” 2002, nr 14 , s. [105]

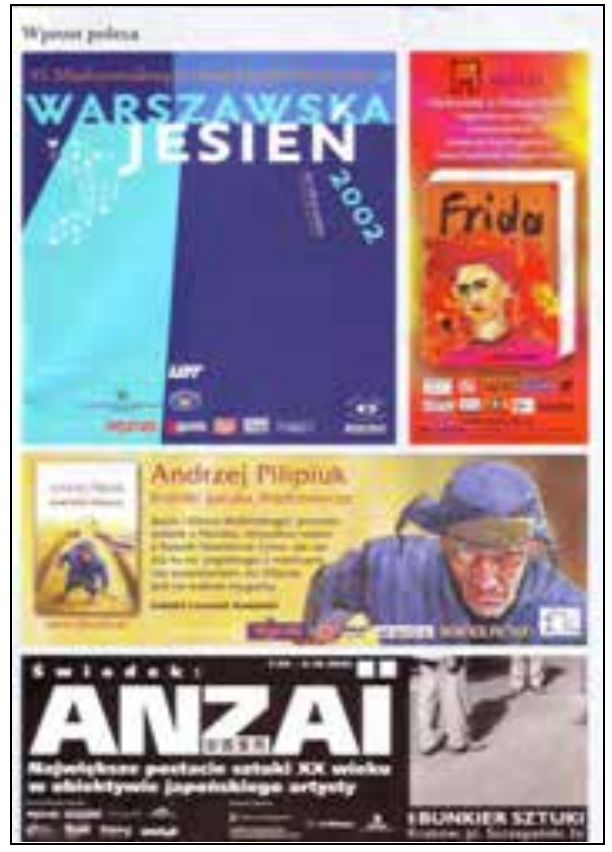

Zdjęcie 36. Wybrane ogłoszenie wydawnicze zamieszczone na łamach „Wprost”

„Wprost” 2002, nr 38, s. [125]

Zbyt duże nagromadzenie elementów w przytoczonych ogłoszeniach, brak wyraźnego ich oddzielenia, powodowały, że przekaz stawał się mało czytelny i zamiast zachęcić, mógł zniechęcić czytelnika. Szczególnie nieczytelna wydaje się być reklama wydawnicza zamieszczona w pierwszym z przywołanych przykładów (zdjęcie 35). W drugim przypadku charakterystyczna okładka drugiej z polecanych książek (A. Pilipiuka) zwracała uwagę odbiorcy.

Częściej jednak kolory dobrane były korzystniej. Każda z reklam na stronie wyróżniała się dostatecznie; niekiedy jeden $\mathrm{z}$ jej elementów był wystarczająco oryginalny, by w pierwszym rzędzie zwrócić uwagę czytelnika i aby ogłoszenie zdominowało pozostałe reklamy na danej stronie. Oto przykłady obrazujące takie rozwiązanie - zdjęcia 37 i 38. 


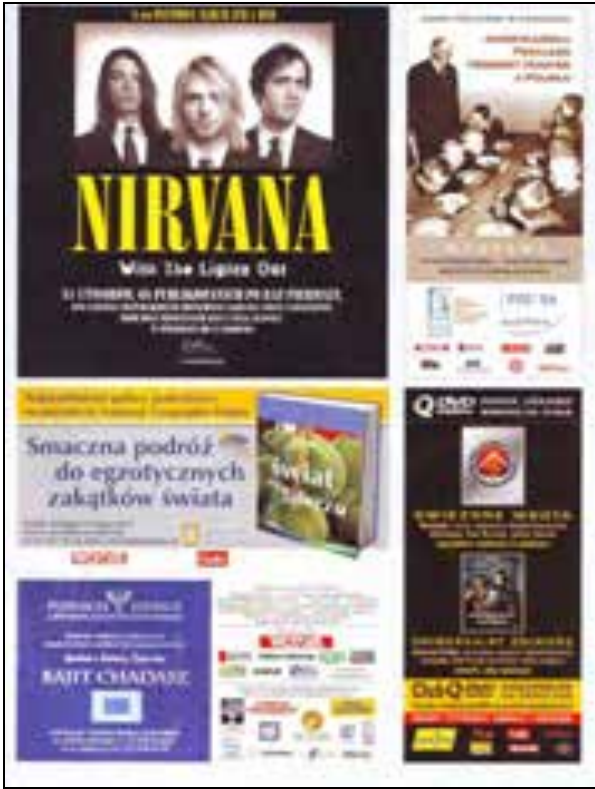

Zdjęcie 37. Wybrane ogłoszenie wydawnicze zamieszczone na łamach „Wprost” „Wprost” 2004, nr 48, s. [113]

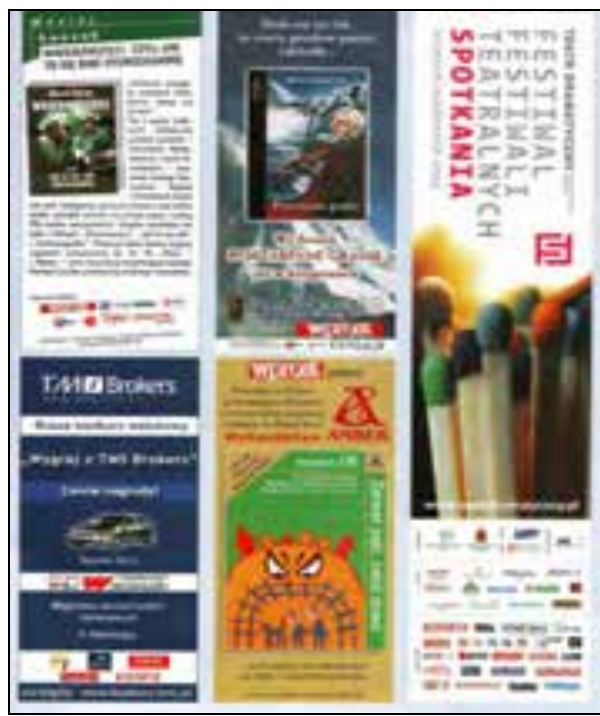

Zdjęcie 38. Wybrane ogłoszenie wydawnicze zamieszczone na łamach „Wprost”

„Wprost” 2004, nr 39, s. [101]

Pomimo iż w przywołanych przykładach reklamy zamieszczane na wybranej stronie nie były od siebie wyraźnie oddzielone, to jednak odpowiednio dobrana kolorystyka powodowała, że na pierwszy rzut oka widać, iż były to ogłoszenia osobne, chociaż dyskusyjny pozostaje fakt, czy odbiorca tygodnika zatrzymał się specjalnie na stronie w całości poświęconej reklamom, by analizować, co jest przedmiotem każdej z nich.

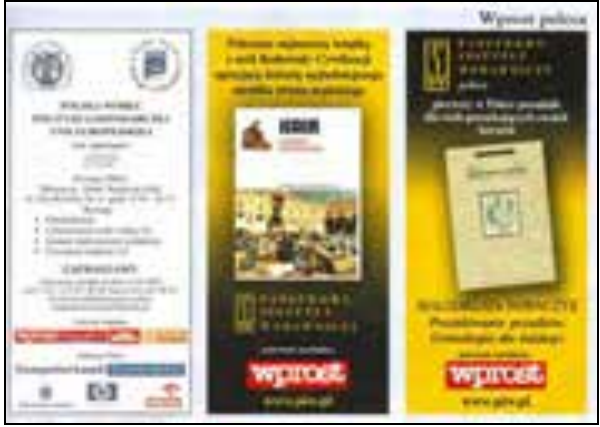

Zdjęcie 39. Wybrane ogłoszenie wydawnicze zamieszczone na łamach „Wprost” „Wprost” 2005, nr 19, s. [107]

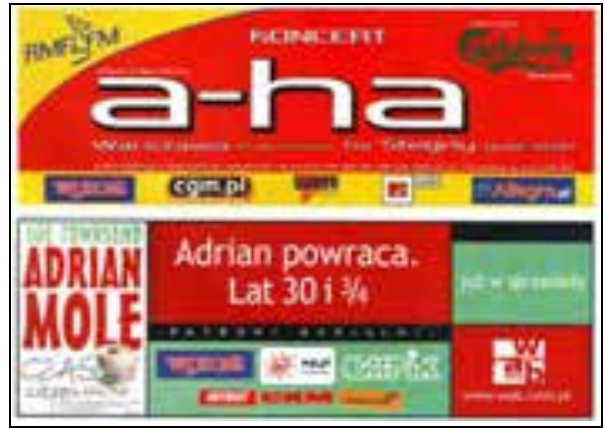

Zdjęcie 40. Wybrane ogłoszenie wydawnicze zamieszczone na łamach „Wprost” „Wprost” 2002, nr 35, s. [109] 
Niekiedy ogłoszenia wydawnicze drukowano u dołu strony, w postaci niewielkiego modułu. Te inseraty były z reguły dostatecznie wyróżnione, nawet wtedy, gdy pojawiało się ich kilka obok siebie - zdjęcia 39 i 40.

Rzadko pojawiały się pojedyncze anonse. Przeważnie obok znajdowała się jeszcze jedna lub dwie reklamy, promujące książkę albo ogłoszenia zupełnie nie związane z rynkiem wydawniczym. Każdy z inseratów był wyraźnie oddzielony od poprzedniego, dodatkowo wyróżniał się kolorystycznie. Przy promocji książki pojawiała się zazwyczaj kopia jej okładki, a także hasło reklamowe. W przypadku reklamy kolejnej części cyklu autorstwa Sue Townsend (zdjęcie 40) hasło to dla wielu wielbicieli bohatera - wiecznego nieudacznika - było wystarczającym bodźcem, by sięgnąć po kolejny tom opisujący jego losy. Czasem reklama zawierała zabawne elementy, które przykuwały uwagę czytelnika - zdjęcie 41 .

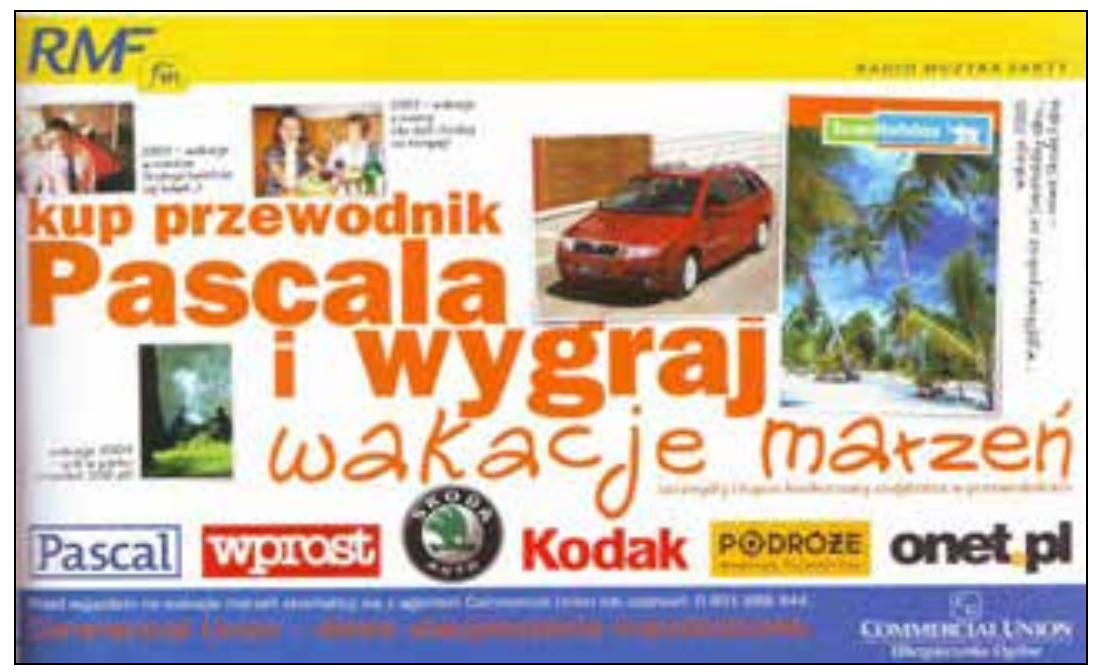

Zdjęcie 41. Wybrane ogłoszenie wydawnicze zamieszczone na łamach „Wprost” „Wprost” 2005, nr 25, s. [75]

Takich inseratów było jednak niewiele. W większości z nich zamieszczano podstawowe informacje, ewentualnie uzupełnione o hasło reklamowe, przeważnie mało oryginalne (typu: „kup!”, „przeczytaj!” „warto!”) lub odwołujące się do nazwiska autora oraz podkreślające, że jest to uznany pisarz ${ }^{137}$. Stosunkowo rzadko pojawiały się ogłoszenia bardziej urozmaicone, ciekawsze, w których potencjalny odbiorca mógł znaleźć obok adnotacji treściowej, danych bibliograficznych i haseł reklamowych także krótką 


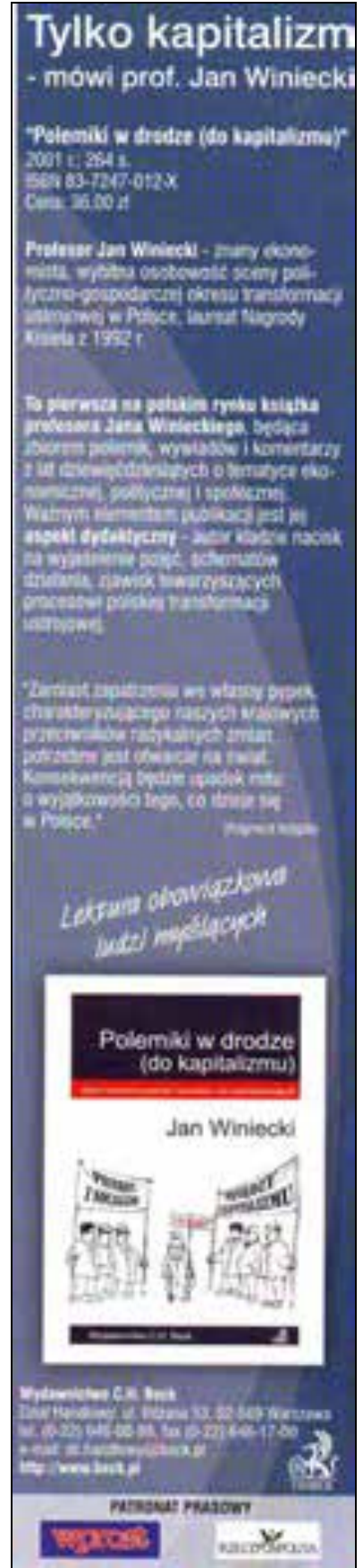

Zdjęcie 42. Wybrane ogłoszenie wydawnicze zamieszczone na łamach „Wprost” „Wprost” 2001, nr 25, s. 92

\section{Prószyniski i S-ka}

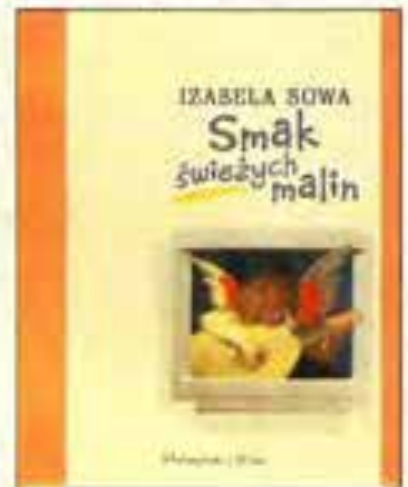

-8mak swiezych malin" to joden $z$ lombw

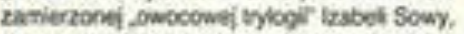
pradstaminiacol zycle nasaelatek, dwodsieslolatek I trzydriestolatek = tym pięinym kraju Europy Srodkcowoj, dajagy fyle motkwold abukcy/mym sytenom, obdarzonym przez Natury I dobwisdarente gumouym krepgostupem, shobra noborozca oraz lokpiami z hendowanej stal. Jok sama mówi o glownef bohatence: Malina nie jest koleyna rodzima podrobka Bridgot Jones cty. Ally Mcleal, tak ink -Pomndowy Dobremirn nie jest polska wersia animowana =McOwwera-, Jakub Dursh - stowiarska dolidor Queen, a Strok Wamolskj - keakowsika MoctaGodella, Maina to po prostu maina, a sie polska odmana owoou klw?. I tatca wtabivie jest glowna bohaleka. ze swoimi lekarti, exarzeriami

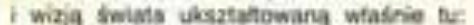
w krainie bigosu, zuriou / salmonelle.

\section{Patronat medialny: onet pl Gatis nicole Risers}

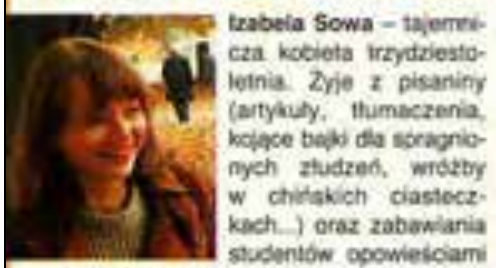
o magicznej mocy psychologil spoleczene. Typowe sowa: wiekstost deia presespo weryes $w$ krakewsikch biblotelach i cryelniach. Budzi silp potriym weczorem i whedy zaczina po-twoctye.

Zdjęcie 43. Wybrane ogłoszenie wydawnicze zamieszczone na łamach „Wprost” „Wprost” 2002, nr 6, s. 31 
notkę biograficzną dotyczącą autora. Wybrane przykłady tego typu anonsów - zob. zdjęcie 42 i 43 . W tych ogłoszeniach reklamodawca zamieścił adnotację treściową, dodatkowo uzupełniając reklamę krótką notką biograficzną dotyczącą autora oraz w przypadku pierwszego tytułu, Polemiki $w$ drodze (do kapitalizmu), także fragmentem proponowanej książki.

Szczególnie staranne reklamy zamieszczano z okazji zbliżających się Świąt Bożego Narodzenia. Wtedy obok zwykłych, standardowych elementów, pojawiały się tradycyjne symbole świąt, które urozmaicały i wzbogacały dane ogłoszenie. Wyjątkowo interesujące anonse proponowało Wydawnictwo Naukowe PWN. Również Dom Wydawniczy REBIS starał się przypomnieć czytelnikom swoją ofertę przed zbliżającymi się Świętami. Oto wybrane przykłady inseratów tych oficyn - zdjęcie 44 i 45.

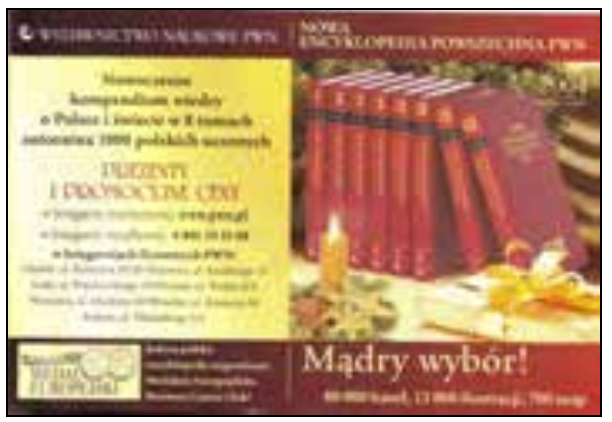

Zdjęcie 44. Wybrane ogłoszenie wydawnicze zamieszczone na łamach „Wprost” „Wprost” 2004, nr 51, s. [111]

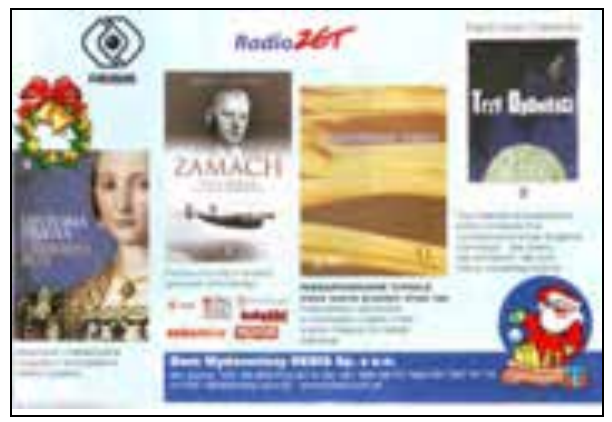

Zdjęcie 45. Wybrane ogłoszenie wydawnicze zamieszczone na łamach „Wprost” „Wprost” 2005, nr 51/52, s. [165]

Zaletą pierwszego ogłoszenia (zdjęcie 44) są jego ciepłe barwy, stwarzające nastrojowy, świąteczny klimat. W drugim inseracie (zdjęcie 45) proponowano kilka tytułów, ale dzięki wyrazistej grafice każdy z nich był doskonale widoczny, zaś elementy świąteczne dodawały tylko uroku, dzięki czemu całość przykuwała uwagę czytelnika.

Niektórzy edytorzy (na przykład Wydawnictwo Prószyński i S-ka, Wydawnictwo Amber, Arkady, Kluszczyński i S-ka oraz wspominane wcześniej Wydawnictwo Naukowe PWN) inwestowali w reklamę całostronicową, chociaż należała ona do wyjątków. Wydawcy wybierali wówczas rozmaite rozwiązania: albo poświęcali cały anons na promocję jednego tytułu, albo też starali się zamieścić w nim jak najwięcej propozycji ze swojej oferty. Zazwyczaj ograniczali się do najważniejszych elementów, z których wyeksponowane miejsce zajmowała kopia okładki (okładek) proponowanej książki (książek), chociaż niekiedy dodawali doń krótkie adnotacje treściowe ${ }^{138}$. 
Ciekawy pomysł pojawił się także w przypadku anonsu Wydawnictwa W.A.B. Elementem zachęcającym do kupna książki (Nigdy $w$ życiu! K. Grocholi) był konkurs, w którym czytelnik powinien wykazać się znajomością jej treści. Po przesłaniu prawidłowej odpowiedzi czytelnicy mieli szansę wygrać zestaw kosmetyków (chociaż może lepszym rozwiązaniem byłaby nagroda książkowa) ${ }^{139}$.

Jednak, co już wcześniej podkreślono, podobnie, jak było to w przypadku recenzji, tak i w odniesieniu do reklam trudno jest doszukać się wyraźnego, jednoznacznego klucza. Recenzenci kierowali się raczej własnym gustem, tym, czy książka jest znana, nowa, lub po prostu prezentowali tytuły, będące egzemplarzami recenzyjnymi. W odniesieniu do reklam można stwierdzić, że były to propozycje największych polskich oficyn, specjalizujących się w różnego rodzaju literaturze.

Poza ogłoszeniami wydawniczymi pojawiały się również inseraty informujące o konkursach i akcjach, organizowanych zarówno przez „Wprost”, jak i przez instytucje związane z książką. Zapowiedzi targów czy spotkań autorskich miały jednak postać nie tylko reklam, ale i komentarzy oraz relacji z odbytych już imprez. Stąd zostaną one omówione w kolejnym podrozdziale.

\subsubsection{Literatura dopisana ${ }^{140}$ : inne formy informacji o książce}

Na łamach „Wprost” w latach 2001-2005, poza recenzjami i reklamami, ukazało się 818 różnego typu informacji bezpośrednio bądź pośrednio związanych z książką. Jak już wcześniej wspomniano, w tej grupie pojawiły się rozmaite informacje, o różnej objętości, które miały postać notatek prasowych, zapowiedzi, relacji, komentarzy, dotyczących literatury, książki bądź rynku wydawniczo-księgarskiego itd. (Aneks 18. Wybór tekstów związanych z literaturą i rynkiem wydawniczo-księgarskim, zamieszczonych na łamach "Wprost” w latach 2001-2005.). Analiza zebranego materiału pozwoliła, podobnie jak w przypadku tygodnika „Polityka”, wyodrębnić kilka typów informacji. W badanych rocznikach znalazły się 141 :

- sylwetki / portrety (68);

- artykuły, poświęcone sprawom książki lub rynku wydawniczo-księgarskiego (240);

- ekranizacje, adaptacje i inscenizacje znanych utworów (136);

139 „Wprost” 2001, nr 13, s. 31.

140 Tytuł jednej z publikacji, zob. „Wprost” 2003, nr 13, s. 97.

141 Pominięto tu listy bestsellerów, które wymieniono w tabeli 14. Ta kategoria została wcześniej omówiona. 
- listy czytelników, nawiązujące do zamieszczonej wcześniej informacji związanej z książką (51);

- konkursy i akcje (35);

- inne $^{142}(288)$.

\subsection{Nie gasić światła ${ }^{143:}$ sylwetki/portrety}

Wspomnienia twórców pojawiają się w prasie po ich odejściu. Kreślona jest wówczas sylwetka pisarza, przypominane są jego dzieła, czasem pojawiają się opinie o nim, wypowiadane przez przyjaciół. W przypadku tygodnika „Wprost” tego typu portretów było 68. Wspominano nie tylko pisarzy, literatów, ale również dziennikarzy, publicystów, ludzi kultury i sztuki. Pojawiła się informacja o śmierci Marii Danilewicz-Zielińskiej, Jana Nowaka-Jeziorańskiego, Jana Józefa Szczepańskiego, krótkie wspomnienie o Richardzie Avedonie, Saulu Bellowie, Peterze F. Druckerze, Jerzym Dudzie-Graczu, Orianie Falllaci, Zofii Hertz, Zygmuncie Kałużyńskim, Szymonie Kobylińskim, Janie Kottcie, Zygmuncie Kubiaku, Macieju Łukaszewiczu, Krzysztofie Mętraku, Karolu Mikule, Czesławie Miłoszu, Janie Mirosławie Mossakowskim, Danielu Pearlu, Marku Polańskim, Stanisławie Stommie, Tomaszu Strzemboszu, Januszu Szpotańskim, ks. Stanisławie Tkoczu, Henryku Tomaszowskim i Bolesławie Wierzbiańskim.

W większości z tych przypadków były to jednak tylko kilku- lub kilkunastozdaniowe wzmianki, mające raczej charakter oficjalny, bez wyraźniejszego czy głębszego zaangażowania piszącego. Wyjątkiem było wspomnienie Cz. Miłosza ${ }^{144}$.

Przywołano również sylwetkę Susan Sontag, przypominając m.in., że

Była wielką polonofilką: w latach 80. kibicowała „Solidarności”, a swoją ostatnią, nagrodzoną National Book Award, powieść „W Ameryce” osnuła wokół historii Heleny Modrzejewskiej, legendy polskiej amerykańskiej sceny teatralnej XIX wieku. [...] Świetnym erudycyjnym wstępem opatrzyła amerykańskie wydania „Ferdydurke” Witolda Gombrowicza oraz wybór wierszy Adama Zagajewskiego...145.

$142 \mathrm{~W}$ tej grupie zostały uwzględnione, podobnie jak w przypadku tygodnika „Polityka”, rozmaitego rodzaju informacje, przeważnie w formie niewielkich objętościowo notek, donoszących na przykład o otrzymanych przez osoby związane z książką nagrodach, jubileuszach, ale i o śmierci znanych osób ze świata literatury.

143 Tytuł felietonu M. Domagalik, dotyczącego M. Wisłockiej, zob. „Wprost” 2005, nr 7, s. 71.

144 „Wprost” 2004, nr 34, s. 92-[93].

145 (MS), Śmierć polonofilki, „Wprost” 2005, nr 1, s. 100. 
O twórcach pisano nie tylko przy tak smutnej okazji. Czytelnik „Wprost” dowiadywał się o ich życiu i twórczości także przy innych okazjach, na przykład, gdy otrzymywali oni nagrody. I tak, noblista z 2001 r., Vidiadhar S. Naipaul, stał się bohaterem tekstu Kolizja kultur. J. Kobus, cytując opinie na temat przyznania nagrody autorowi Marionetek, przypomniała krótko jego życiorys, wydane w Polsce książki i przywołała charakterystykę jego twórczości, nakreśloną przez Marię Zborowską, polską tłumaczkę jego dzieł. Według niej pisarz „akcentuje nieprzekraczalność granic między odmiennymi cywilizacjami, opisuje konflikty społeczeństw żyjących na styku różnych kultur" 146.

Z kolei o Johnie M. Coetzee pisał w 2003 r. M. Cieślik, przypominając m.in. dwie jego książki ${ }^{147}$.

O innym (z 1978 r.) laureacie Nagrody Nobla opowiedziała czytelnikom tygodnika M. Sawicka. „Sztukmistrz z Warszawy”148, czyli I. B. Singer, wyłaniał się z tego tekstu jako pisarz, którego twórczość jest bardzo rozmaicie postrzegana: przez wielu krytykowany i jednocześnie przez innych uwielbiany, sam uważał, że „jest typowym Żydem z Krochmalnej”, twierdząc: „Na chwilę znalazłem się w pałacach sztokholmskich, ściskałem ręce książąt i królów, ale w duszy pozostałem biedakiem, jednym z małomiasteczkowych nędzarzy"149. Publikacja pojawiła się przy okazji organizowanego w 2004 r. Festiwalu Kultury Żydowskiej, który miał być odtąd inicjowany w kolejnych latach, $w$ rocznicę urodzin pisarza.

Bohaterem portretów, kreślonych na łamach pisma, byli również potencjalni laureaci najważniejszej nagrody literackiej, ci, których twórczość była kontrowersyjna, ciekawa, znana na świecie. Taką postacią był bez wątpienia w badanym okresie P. Coelho; jego kolejne książki zajmowały stałe miejsce na listach bestsellerów w różnych krajach. Ten twórca, nim został w wieku 38 lat pisarzem, prowadził niezwykle burzliwe życie. Czytelnicy tygodnika dowiedzieli się m.in., że

próbował tworzyć sztuki teatralne, które sam reżyserował. Pisał też scenariusze dla telewizji, był dziennikarzem telewizyjnym, autorem tekstów piosenek dla najpopularniejszych brazylijskich gwiazd muzyki pop i rocka, szefem dyskoteki. Jeszcze wcześniej był hippisem, narkomanem, należał do sekty satanistów. W dzieciństwie trzykrotnie rodzice oddawali go do zakładu poprawczego ${ }^{150}$.

146 J. Kobus, współpraca: M. Kukliński, Kolizja kultur, „Wprost” 2001, nr 42, s. [126].

147 M. Cieślik, Dostojewski z Afryki, „Wprost” 2003, nr 41, s. 110-[111].

148 Tytuł publikacji, której bohaterem jest I. B. Singer. Zob. „Wprost” 2004, nr 42, s. 114-[115].

149 Obydwa ostatnie cytaty: M. Sawicka, Sztukmistrz z Warszawy, „Wprost” 2004, nr 42, s. 114.

150 J. Melchior, Alchemik duszy, „Wprost” 2003, nr 11, s. [104]. 
Jak stwierdził J. Melchior, „Popularność Coelho to mądrość w pigułce. To także triumf znajomości sztuki marketingu. Jego książki zawierają na tyle ogólne recepty życiowe, żeby nikt na nich źle nie wyszedł i nie poczuł się oszukany"151. Kilka z owych aforyzmów, które autor Alchemika zawarł w swoich książkach, znalazło się w opisywanym tekście, na przykład: „Dopóki żyjemy, nie ma rzeczy niemożliwych, a w ostatecznym rozrachunku nawet w najgorszym z nas znajdzie się coś dobrego"152.

Pisano również m.in. o Milanie Kunderze, który „jako jedyny prozaik z naszej części Europy odniósł komercyjny sukces na Zachodzie"153, o S. Clarke, będącej w 2004 r. „literackim objawieniem sezonu”154. Nie zapomniano i o polskich twórcach, jak choćby o Andrzeju Sapkowskim, określonym mianem „Polski wojownik”155, czy o Katarzynie Grocholi, która m.in. powiedziała o sobie: „Jestem pierwszorzędnym pisarzem drugorzędnym"156. Ostatni przywołany cytat odnaleźć można było w publikacji poświęconej w dużej mierze polskiej powieści popularnej. Nierzadko zdarzało się, że sylwetki twórców pojawiały się także przy okazji komentarzy dotyczących zarówno kondycji polskiej i obcej literatury współczesnej, jak i rodzimego rynku książki.

\subsection{Arcydzieła nijakości ${ }^{157}$ : teksty, poświęcone książce i rynkowi wydawniczo-księgarskiemu}

Tego typu informacji znalazło się na łamach pisma 240. Interesujące jest przy tym spostrzeżenie, że częściej zamieszczano obszerne, wymagające solidnego przygotowania rozważania, dotyczące ogólnych zagadnień związanych $\mathrm{z}$ interesującym nas tematem (pojawiały się one przede wszystkim w dziale Kultura) niż krótkie informacje dotyczące chociażby imprez związanych z książką (te drukowano w całym tygodniku).

Jaki obraz kreowały owe komentarze czy choćby refleksje i rozważania? Na ich podstawie odbiorca "Wprost” mógł ukształtować sobie raczej pesymistyczny obraz, dotyczący współczesnej literatury, szczególnie rodzimej. Ponuremu wizerunkowi winni byli, jak wynikało z lektury tekstów tygodnika, wszyscy, poza czytelnikami.

\footnotetext{
151 Ibidem, s. [104]-[105].

152 Ibidem, s. [104].

153 M. Cieślik, Milan bez ziemi, „Wprost” 2003, nr 40, s. 112.

154 „Wprost” 2004, nr 43, s. 114-115.

155 Tytuł publikacji na temat A. Sapkowskiego, zob. „Wprost” 2004, nr 40, s. 116.

156 M. Sawicka, Grocholiada, „Wprost” 2004, nr 9, s. 96.

157 Tytuł jednej z publikacji, zob. „Wprost” 2003, nr 51/52, s. 166-167.
} 
Kwestie dotyczące literatury poruszane były nierzadko w szerszym aspekcie, przy okazji omawiania kondycji polskiej kultury współczesnej. Zastanawiano się na przykład nad efektami, płynącymi z dofinansowywania przez państwo produkcji filmowej, teatralnej i wydawniczej. Autorzy jednego z artykułów, cytując słowa Grzegorza Szczodrowskiego, ekonomisty z Centrum im. Adama Smitha, zgodnie konkludowali, że „Nikomu nie przyjdzie do głowy, że nie ma gorszej strategii w kulturze niż ułatwianie życia twórcom, bo to przepustka do tworzenia miernoty"158. Podobny problem pojawił się w tekście Plecami do widza, charakteryzującym współczesną polską kulturę, która „przypomina sierotę po PRL: tęskniącą za tatusiem, który chociaż bywał surowy i niesprawiedliwy, zapewniał jednak twórcom wikt i opierunek"159. Taka taktyka może być jednym z powodów niskiego poziomu czytelnictwa w Polsce.

Innych przyczyn szukali autorzy kolejnego interesującego tekstu: Czytam, więc jestem ${ }^{160}$. Zaczynając od pesymistycznego stwierdzenia Stanisława Lema, że „Nikt nic nie czyta, a jeśli czyta, to nic nie rozumie, a jeśli nawet rozumie, to nic nie pamięta", podawali dane dotyczące czytelnictwa w innych krajach, wskazywali na liczby określające nikłe zainteresowanie Polaków lekturą. Podkreślając ważną rolę instytucji wspierających bądź promujących czytanie, przywoływali przykłady imprez, konkursów i rozmaitych inicjatyw, mających zachęcić do sięgnięcia po książkę. Wskazywali na rolę bibliotek $\mathrm{w}$ tym względzie i jednocześnie przypominali o problemach finansowych, które przekładają się na funkcjonowanie tych placówek. Ciekawy tekst, którego celem było podkreślenie wagi kontaktów z książką i płynących z tego korzyści, kończył się niespodziewanie stwierdzeniem, które trudno powiązać z poprzednim akapitem, choć jednocześnie poruszona tu dyskusyjna kwestia mogłaby dać sumpt do dalszych rozważań. Wysunięta została mianowicie supozycja, że winę za taki, a nie inny stan rzeczy w Polsce ponoszą krytycy, ponieważ to właśnie oni kreują „zjawiska literackie, dzieła skończonych grafomanów, co tylko zraża oszukanych czytelników"161.

Podobna opinia pojawiła się w piśmie kilkakrotnie. Justyna Kobus i Tomasz Mackiewicz podzielając ten pogląd, pisali o „usłużnym wazeliniarstwie" zamiast rzetelnej krytyki, o tym, że współczesnym recenzentom zależy bardziej na zachowaniu przyjaźni twórców niż na opinii czytelników. Efektem takiego postępowania miał być brak lub znikoma liczba recenzji

\footnotetext{
158 J. Kobus, Ł. Radwan, Lenin w Polsce, „Wprost” 2003, nr 19, s. 108.

159 J. Kobus, Plecami do widza, „Wprost” 2003, nr 1, s. 102.

160 Ł. Radwan, W. Chełminiak, Czytam, więc jestem, „Wprost” 2003, nr 16, s. 112-115.

161 Ibidem, s. 115
} 
negatywnych, zastępowanych przez neutralne oceny ${ }^{162}$. A przecież, jak przypomnieli autorzy, w polskiej tradycji można odnaleźć prawdziwych krytyków, których opinii obawiali się współcześni im twórcy. Przywołano postać Tadeusza Boya-Żeleńskiego, Karola Irzykowskiego oraz Antoniego Słonimskiego i wyrażono żal, że w dzisiejszym świecie brakuje odważnych recenzentów, a jeśli już tacy się pojawią, natychmiast stają się obiektem napaści, szyderstw i zostają odsunięci na margines życia kulturalnego. Podobnego zdania był autor kolejnego tekstu, podnoszącego tę kwestię, K. Skiba, felietonista pisma. Pisząc o „krytyce ukumplowionej”, nie tylko zresztą literackiej, dowodził, że w Polsce niemal niemożliwa jest szczera negatywna ocena, a ci, którzy naruszają status quo, stają się pariasami w środowisku twórczym, są prześladowani, a w najlepszym razie ignorowani. Stwierdziwszy, że „krytyką sztuki zaczynają rządzić środowiskowe i korporacyjne układy”, podał przykłady lansowania „wybranych” książek wykazując, że taki sposób postępowania doprowadza do manipulowania opinią odbiorcy, a także skazuje na zagładę i niepamięć prawdziwie utalentowanego pisarza czy artystę, promując w najlepszym razie przeciętnego twórcę. Warto zacytować słowa autora, które można nazwać swego rodzaju przesłaniem do „słusznie oburzonych” autorytetów: „Nawet najbardziej krytyczna recenzja nie uwłacza żadnemu artyście, a zwłaszcza wybitnemu"163.

Jako rodzaj przeciwwagi wobec tych oskarżeń można potraktować wywiad $\mathrm{z}$ M. Reichem-Ranickim, znanym bezkompromisowym krytykiem literackim. Rozmowa zatytułowana Nie piszę zakłamanych recenzji164 nie miała jednak następstw $\mathrm{w}$ postaci tekstów równoważących surowy osąd wydany przez dziennikarzy „Wprost” polskim krytykom.

W stan oskarżenia postawieni zostali także ci, którzy literaturę tworzą, czyli pisarze. Większość z nich to, według redakcji, autorzy, którzy „nie potrafią zdobywać serc czytelników”165, tworząc „arcydzieła nijakości”166. Według J. Tomkowskiego wynika to z chęci dostosowania się współczesnych pisarzy do oczekiwań czytelników, którzy chętniej sięgną po lekturę łatwą, lekką i przyjemną niż poważną, wymagającą większej koncentracji. J. Tomkowski zwrócił również uwagę na zmedializowanie oraz inne w porównaniu z niegdysiejszym, traktowanie książki. Może ona zostać umiejętnie wypromowana, i wtedy, niezależnie od obiektywnej wartości,

162 J. Kobus, współpraca T. Mackiewicz, Zabić krytyków, „Wprost” 2003, nr 4, s. 100-103. Warto zwrócić uwagę na opinię, która pojawiła się $w$ tekście, a dotyczyła tygodnika „Polityka”.

163 K. Skiba, Krytyka ukumplowiona, „Wprost” 2005, nr 7, s. [111].

164 [rozm. M. Stauber], Nie piszę zakłamanych recenzji, „Wprost” 2002, nr 24, s. 122-124.

165 J. Zomkowski, Arcydzieła nijakości, „Wprost” 2003, nr 51/52, s. 166.

166 Ibidem. 
zostać bestsellerem, w przeciwieństwie do tytułu wartościowego, ale pominiętego przez media. Obok szeregu innych okoliczności, szum informacyjny, w jakim żyje dziś przeciętny człowiek, powoduje, że nie dowiaduje się on o cennych, ambitnych i ważnych książkach. Na ogół do księgarń trafiają bowiem źle skonstruowane powieści, ponieważ typowy współczesny polski pisarz to „przeintelektualizowany młynek mielący automatycznie wszystkie możliwe wariacje i perturbacje"167, zaś „brak pasjonujących fabuł i pełnokrwistych bohaterów to grzech powszedni polskiej literatury współczesnej"168, w której akcja toczy się nierzadko w narkotycznych oparach. Narkotyki, jak pisała recenzentka „Wprost”, zastąpiły we współczesnej polskiej literaturze popularnej niegdysiejszy alkohol, stały się modnym i nadużywanym tematem: ,,> Odlotowa < pisanina lansowana jest w mediach, nominowana do wszelakich nagród, a jej autorzy brylują na pierwszych stronach gazet"169.

Monotonia tematów, brak przemyślanej konstrukcji, dynamicznych bohaterów, artystycznego kunsztu, ciekawych fabuł, od których czytelnik nie mógłby się oderwać - to, według dziennikarzy „Wprost” - główne wady rodzimej literatury. Tania psychologia, epatowanie wszechobecnym pesymizmem, apatią, marazmem i fatalizmem - oto, co przede wszystkim serwują nam twórcy170. Taka literatura, jak dowiaduje się czytelnik tygodnika, cieszy się jednak popularnością. Może to być efekt tego, że przeciętny Polak „ma poczucie bezradności, więc narzeka. Dlatego łatwo identyfikuje się z literaturą czy kinem, będącymi zapisem tej bezradności"171. Ów fatalizm i beznadziejność stał się motywem przewodnim naszej literatury, co prowadzi, jak ostrzega M. Sawicka, jedynie do wzmocnienia stereotypu Polaka, ciągłego nieudacznika i malkontenta. A przecież można pisać inaczej: dowodem na to ma być literatura obca. W amerykańskich powieściach, które w przeważającej większości kończą się szczęśliwie, bohaterowie niemal zawsze wychodzą z opresji cało, z uśmiechem na twarzy. Nawet literatura skandynawska, pomimo tradycyjnej powagi potomków Wikingów, jest „pełna witalności i poczucia humoru”"172, bo jej twórcy piszą, „by rozświetlić mroki Północy, a nie dobijać czytelnika ponurymi historiami"173. Podobną rolę ma do spełnienia tzw. proza kampusowa, opisana w kolejnym tekście, wymownie zatytułowanym: Balanga w kampusie ${ }^{174 . ~ Z a b a w n e ~}$

167 M. Sawicka, Młynek do pisania, „Wprost” 2004, nr 41, s. 103.

168 Ibidem, s. 102-103.

169 M. Sawicka, Gandziolatki, „Wprost” 2003, nr 44, s. 113.

170 M. Sawicka, Cały ten gnój, „Wprost” 2004, nr 8, s. 96-99.

171 Ibidem, s. 97.

172 M. Sawicka, Weseli ponuracy, „Wprost” 2004, nr 31, s. 94.

173 Ibidem.

174 M. Sawicka, Balanga w kampusie, „Wprost” 2004, nr 2, s. 99. 
powieści, których głównym celem jest rozbawienie czytelnika, są niezwykle popularne na Zachodzie i, jak się okazuje, również u nas, co powinno dać do myślenia rodzimym twórcom. Najwyraźniej bowiem, jak przekonuje autor, Polacy lubią nie tylko jesienną melancholię, ale i lekką rozrywkę, czego dowodzić ma również rosnąca popularność literatury kobiecej, a nawet feministycznej. Kilkakrotną bohaterką publikacji pojawiających się na łamach „Wprost” była jej przedstawicielka: „polska Bridget Jones”, czyli K. Grochola. Jej powieści mogą, według autorów tygodnika, stać się lekarstwem na wspomnianą zapaść rodzimej twórczości, mogą rozjaśnić przygnębiający i ponury obraz, proponowany przez innych polskich pisarzy. „Polscy literaci już powinni zacząć się bać fali piszących pań” - ostrzegała M. Sawicka ${ }^{175}$, przypominając długą tradycję piszących kobiet w polskiej literaturze. Powieści Zofii Nałkowskiej, Elizy Orzeszkowej, Marii Rodziewiczówny czy Narcyzy Żmichowskiej dowiodły, że i w Polkach drzemie talent pisarski. Ich współczesne następczynie godnie je reprezentują, wypełniając z powodzeniem niszę rynkową i to pomimo pewnego lekceważenia, okazywanego przez krytyków. Czytelnicy „Wprost” mogli dowiedzieć się, na czym polega sukces tej literatury. Jej popularny charakter, opisywane $\mathrm{w}$ nich emocje, z którymi mogą utożsamiać się czytelniczki, oraz fakt, że dają ludziom chwilę radości, niosąc przy tym nadzieję, że i w życiu może zdarzyć się szczęśliwe zakończenie - to przepis na sukces nie tylko powieści Manueli Gretkowskiej, ale i Katarzyny Grocholi, Izabeli Sowy, Doroty Szczepańskiej, Olgi Tokarczuk czy szerzej: autorek popularnej literatury kobiecej na świecie ${ }^{176}$. Nie bez znaczenia pozostawał fakt, że, jak wskazywały ówczesne badania czytelnictwa, przeprowadzone przez Bibliotekę Narodową, wśród czytających książki przewagę zyskały kobiety.

Idąc z duchem czasu, redakcja pisała nie tylko o tym typie piśmiennictwa. Czytelnicy mogli poznać bliżej zarówno literaturę określaną mianem faction $^{177}$, jak i fantastykę ${ }^{178} .0$ zróżnicowanych zainteresowaniach redakcji świadczy również fakt, że pisano też o literaturze komiksowej, zarówno rodzimej, jak i obcej. W jednym z tekstów podkreślano, że „Komiks to idealny przekaz współczesnej kultury: najważniejszy jest obraz, który dopełniają krótkie informacje"179, w innym, przy okazji Warszawskich Spotkań Komiksowych, przypomniano o Grzegorzu Rosińskim, jednym

175 M. Sawicka, Kobiety do piór!, „Wprost” 2005, nr 15, s. 118-119.

176 Zob. m.in. M. Sawicka, Grocholiada, „Wprost” 2004, nr 9, s. 96-97; eadem, Proza oralnego niepokoju, ibidem, nr 17, s. 101-102.

177 M. Sawicka, Prawdziwa fikcja, „Wprost” 2005, nr 2, s. 108-[109].

178 Np. tekst o twórczości A. Sapkowskiego: K. Śmiałkowski, Polski wojownik, „Wprost” 2004, nr 40, s. 116-[117]. Z kolei T. Pratchett i D. Adams to bohaterowie innej publikacji, zob. D. Wojciechowski, Monty Python w kosmosie, „Wprost” 2002, nr 35, s. [106]-107.

179 W. Chełminiak, Komiksomania, „Wprost” 2002, nr 28, s. 113-115. 
z najpopularniejszych rysowników w Europie ${ }^{180}$. Ważne jest przy tym to, że nie ograniczano się $\mathrm{w}$ każdym $\mathrm{z}$ tych przypadków do pisania jedynie o krajowych przedstawicielach prezentowanego gatunku literackiego. Przywoływano w mniejszym lub większym stopniu autorów zagranicznych, porównując ich twórczość z tą, którą reprezentują pisarze polscy.

Dbałość o literacką wiedzę czytelników „Wprost” przejawiała się także w tekstach donoszących o stanie czytelnictwa i kondycji literatury obcej. I tak, kilkakrotnie pisano o książkach, które cieszyły się uznaniem w innych krajach. Poza wspomnianą literaturą kobiecą donoszono na przykład o preferencjach czytelniczych Amerykanów, opisując bestsellery książkowe połowy 2004 r. za oceanem, wspominając przy okazji o akcji wspierania czytelnictwa, którą prowadziła w ramach swego programu Oprah Winfrey ${ }^{181}$.

Jednak nie tylko literatura amerykańska była przedmiotem relacji „Wprost”. Na łamach tygodnika znalazł się również tekst, mówiący o twórcach żydowskich, a jego autor, Szewach Weiss, podkreślał ich polskie korzenie ${ }^{182}$. W innym numerze pisma pojawił się tekst o Isaacu B. Singerze i jego twórczości ${ }^{183}$, w kolejnym o Philipie Rothcie ${ }^{184}$. Przy okazji majowych Targów Książki w Warszawie pisano o rosyjskim rynku książki i „rosyjskim desancie literackim na Polskę”, wymieniając Siergieja Dowłatowa, Wiktora Jerofiejewa, Aleksandrę Marininę jako tych, których książki cieszą się w naszym kraju rosnącym powodzeniem ${ }^{185}$. Opisywano rosyjską literaturę kryminalną, przywołując postać Darii Doncowej, wzorującej się na powieściach Joanny Chmielewskiej ${ }^{186}$. Czytelnicy tygodnika mieli również możliwość poznać „pięć nowych gwiazd współczesnej literatury światowej"187. Jonathan S. Foer, Edward P. Jones, Marc Levy, Ingo Schulze, Zadie Smith to według autorek tekstu pisarze, którzy „albo sięgną kiedyś po Nobla, albo powtórzq sukces Dana Browna"188. Ale także twórcy o uznanej już pozycji na świecie byli bohaterami publikacji zamieszczanych na łamach tygodnika. „Sławny, bogaty, uwielbiany przez czytelników i szanowany przez krytykę literacką"189 John Irving, „jedyny pisarz z naszej

180 K. Śmiałkowski, Sława znaleziona w komiksie, „Wprost” 2004, nr 12, s. 118.

${ }^{181}$ K. Śmiałkowski, współpraca: K Sławińska: Rosół dla duszy, „Wprost” 2004, nr 20, s. 104-105.

182 Sz. Weiss, Pokolenie Zagłady, „Wprost” 2005, nr 34, s. 104.

183 M. Sawicka, Sztukmistrz z Warszawy, „Wprost” 2004, nr 42, s. 114-[115].

184 M. Sawicka, Wrzód palanta, „Wprost” 2004, nr 6, s. 95. Poniżej tekstu znalazł się wywiad z reżyserem, który podjął się ekranizacji jednej z powieści P. Rotha.

185 J. Melchior, M. Sawicka, Seks ze Stalinem, „Wprost” 2004, nr 21, s. 108-109.

186 M. Sawicka, Sherlock Holmsow [pis. oryg. - M.P.S.], „Wprost” 2004, nr 47, s. 110-[111].

187 M. Sawicka, współpraca M. Nadzieja, Piszę, bo czytam, „Wprost” 2005, nr 45, s. 113.

188 Ibidem, s. 112.

189 M. Sawicka: Zapaśnik literatury, „Wprost” 2005, nr 11, s. 108-[109]. 
części Europy, który wyszedł poza rodzime piekiełko"190 Milan Kundera, „wygnańcy literatury”191: Gabriel G. Márquez i Mario V. Llosa czy Haruki Murakami (będący „jednym z najbardziej znanych i cenionych współczesnych pisarzy na świecie"192) - to niektórzy z nich. Teksty im poświęcone zajmowały średnio 1,5 strony w tygodniku, opowiadały o ich życiu i krótko charakteryzowały twórczość. Obowiązkowym elementem było zdjęcie lub kilka zdjęć prezentowanego autora. W ten sposób przedstawiono również twórczość Agathy Christie193, Toma Clancy194, J. M. Coetzee195, Mario V. Llosy196, V. S. Naipaula197.

Pisząc o zagranicznych mistrzach pióra, nie zapominano również o polskich autorach. Zazwyczaj jednak pisano o dawnych, uznanych twórcach. Z okazji jubileuszu 45-lecia istnienia warszawskich Hybryd przypomniano czytelnikom nie tylko aktorów i piosenkarzy, ale i poetów oraz pisarzy związanych ze znanym klubem, wyrosłym na fali odwilży w 1956 r.: Mirona Białoszewskiego, Edwarda Stachurę i Leopolda Tyrmanda. Kontrowersyjna śmierć Jerzego Zawieyskiego, dramatopisarza, prozaika i eseisty ${ }^{198}$, opowieść o Julianie Tuwimie i towarzyszącej mu niesławie ${ }^{199}$ czy przypomnienie autora Zielonej Gęsi, Konstantego I. Gałczyńskiego 200 - to kilka następnych przykładów tekstów, poświęconych rodzimej literaturze i jej twórcom. Kilkakrotnie pisano o Cz. Miłoszu: raz z okazji jego zbliżających się 90. urodzin, kiedy indziej przy cytowaniu opinii znanych osób na temat Internetu. Przywołano również pogląd autora Zniewolonego umysłu na nowe medium $^{201}$, pisano o wierszach noblisty202, zamieszczono relację ze spotkania poświęconego twórczości poety ${ }^{203}$. Z kolei Jerzy Sosnowski, komentując wyniki zorganizowanego przez radiową Trójkę plebiscytu, pisał o „najważniejszej książce", zastanawiając się nad wyborem tej, która może wywrzeć największy wpływ na czytającego ${ }^{204}$.

\footnotetext{
190 M. Cieślik, Milan bez ziemi, „Wprost” 2003, nr 40, s. 112-[113].

191 C. M. Casas, Wygnańcy literatury, „Wprost” 2004, nr 3, s. 96-[97].

192 C. Ishida, Samotność w Tokio, „Wprost” 2005, nr 44, s. 118-[119].

193 „Wprost" 2001, nr 51/52, s. 130-131.

194 „Wprost" 2004, nr 20, s. 106-[107].

195 „Wprost” 2003, nr 41, s. 110-111.

196 „Wprost” 2003, nr 47, s. 110-111.

197 „Wprost” 2001, nr 42, s. 126-127.

198 D. Baliszewski, Upadek z wysokości, „Wprost” 2005, nr 26, s. 78-[79].

199 M. Sawicka, Klątwa Tuwima, „Wprost” 2004, nr 4, s. 98.

200 J. Kobus, Czarownik Gałczyński, „Wprost” 2003, nr 9, s. 104.

201 M. Karpiński, [br. tyt.], „Wprost” 2001, nr 51/52, s. 68-69.

202 M. Skwarnicki, Chwila radości, „Wprost” 2001, nr 28, s. 69.

203 (MS), Poetyckie Zaduszki, „Wprost” 2004, nr 45, s. 104.

204 J. Sosnowski, Wielka trójka książkowa, „Wprost” 2002, nr 49, s. [112].
} 
Odrębną grupę tekstów, obok poświęconych literaturze i jej twórcom, stanowiły publikacje związane z funkcjonowaniem współczesnego rynku wydawniczo-księgarskiego w Polsce. Publikowano zarówno dłuższe teksty okolicznościowe, dotyczące na przykład jubileuszu, obchodzonego przez danego wydawcę205, jak i krótsze wzmianki zamieszczane $\mathrm{z}$ podobnej okazji ${ }^{206}$ czy obszerniejsze rozważania, odnoszące się do problematyki, związanej z działalnością edytorską w Polsce.

Wojciech M. Darski, przywołując opinię największych polskich wydawców, którzy zgodnie stwierdzili, że „nie ma kryzysu wydawniczego w naszym kraju”, doszedł do wniosku, że „polski rynek książki rozkwita mimo dekoniunktury w gospodarce"207. Jest to zasługa, jak autor twierdził dalej, kilku największych edytorów, których przychody w 2001 r. nie były wcale bagatelne. Jednocześnie przyznał, że „lokomotywami polskich wydawców są popularni zachodni autorzy, z którymi udało się podpisać wieloletnie kontrakty”208, bo, poza kilkoma wyjątkami, „po prostu nie mamy własnych pierwszorzędnych drugorzędnych autorów"209.

Nie bez znaczenia pozostawała też kwestia finansowa, poruszana także na łamach wcześniej omawianego tygodnika „Polityka”. Również w przypadku „Wprost” czytelnik miał okazję poznać zaplecze rynku wydawniczego. Kilkakrotnie opisywano bowiem sprawę wynagrodzenia pisarzy i ich umów z wydawcami. Nawet najbardziej znani, ci, których książki od wielu lat zajmują pierwsze miejsca na listach bestsellerów (na przykład Joanna Chmielewska czy Małgorzata Musierowicz), nie mogą porównywać własnych dochodów z apanażami swych zagranicznych kolegów. Jak dowiadywał się czytelnik,

przeciętny nakład w Polsce nie przekracza 3 tys. egzemplarzy, a honorarium autorskie to zazwyczaj 10 proc. ceny uzyskiwanej przez wydawcę, co często oznacza 1-2 zł od egzemplarza. Na książce zatem autor zarabia najmniej210.

Jednym ze sposobów rozwiązania trudnej sytuacji twórców jest zakładanie przez nich własnych oficyn. Czytelnicy „Wprost” mogli dowiedzieć się, że tak zrobiła m.in. Joanna Chmielewska, Andrzej Stasiuk czy Olga To$\operatorname{karczuk}^{211}$.

205 Zob. np. tekst poświęcony wydawnictwu Znak: M. Sawicka, Krakowskie igrzysko, „Wprost” 2004, nr 47, s. 114-[115].

2060 15-leciu wyd. Amber, zob. [br. aut.], Fart Ambera, „Wprost” 2004, nr 10, s. 96.

207 W. M. Darski, Modna książka, „Wprost” 2002, nr 19, s. 110-111.

208 Ibidem, s. 111.

209 Ibidem.

210 M. Sawicka, Gwiezdne wojny wydawców, „Wprost” 2005, nr 20, s. [101].

211 W. M. Darski, Maszyny do pisania, „Wprost” 2002, nr 10, s. 106-[109]; M. Sawicka, Gwiezdne wojny wydawców, ibidem, 2005, nr 20, s. 100-[101]. 
Jednocześnie przedstawiono drugą stronę medalu: w jednym z numerów „Wprost” pojawił się tekst, opisujący problemy edytorów i panującą wśród nich nie zawsze uczciwą konkurencję oraz nielojalność samych autorów $^{212}$. Sytuacji nie poprawiał fakt, że, jak wskazywali autorzy tygodnika, książka, obok innych wytworów kultury, stała się „towarem”, kupowanym na wagę i wykorzystywanym jako produkt marketingowy. „Okazało się, że na rynku produkt kulturalny jest przede wszystkim dobrem konsumpcyjnym”213, jak pisali publicyści „Wprost”, i, co ciekawe, zdawali się, przynajmniej w pewnym sensie, pochwalać taki stan rzeczy. Powołując się na Andy Warhola, zgadzali się, że

kultura nie jest pojęciem czy zjawiskiem ekskluzywnym. Handluje się nią jak piwem czy jogurtem w wielopakach. I dzięki temu coraz więcej osób może z nią obcować. W końcu sensem produkcji kulturalnej nie jest autarkia i niszowy obieg, lecz masowość214.

Potwierdzeniem, przynajmniej do pewnego stopnia, cytowanej tezy o traktowaniu książki jako przede wszystkim produktu marketingowego, na którym można zarobić, był kolejny tekst, opisujący działania wydawców, firm muzycznych czy innych instytucji, zwyczajowo wiązanych z kulturą, wykorzystujących Walentynki jako okazję do zwiększenia swych zysków. K. Śmiałkowski przekonywał czytelników, że „najlepiej sprzedają się produkty [książki, płyty z filmem czy muzyką - przyp. M.P.S.] trafiające na rynek z konkretnej okazji” i ubolewał, że „Chyba tylko ociężałością naszych twórców filmowych można tłumaczyć to, że na święta Bożego Narodzenia nie doczekaliśmy się jeszcze sympatycznej komedii rodzinnej z Mikołajem w roli głównej. Kolejne zestawy kolęd to zbyt duża łatwizna"215. Tak pragmatyczne i kontrowersyjne podejście do kultury, w tym książki, było jednak rzadkością.

Warto wspomnieć, że redakcja „Wprost” starała się informować swych czytelników również o rozmaitych ciekawych nowinkach związanych $\mathrm{z}$ literaturą. Drukowane były one przeważnie w ramach Kultury, niekiedy w sporadycznie pojawiającej się rubryce Wydarzenie tygodnia, częściej obok recenzji lub na kolejnych stronach pisma. Przybierały rozmaitą postać: niektóre były obszernymi tekstami, zajmującymi stronę i więcej w danym numerze, inne miały charakter krótkich wzmianek, jeszcze inne pojawiały się jako kilkunastozdaniowe notki, wzbogacone zdjęciem lub rysunkiem. W jednej grupie znajdowały się te, które dotyczyły zarówno kwestii nie tylko ciekawych, ale jednocześnie poważnych. Do drugiej zaliczyć można

\footnotetext{
212 M. Sawicka, Gwiezdne wojny...

${ }^{213}$ M. Sawicka, Ł. Radwan, Hurtownia kultury, „Wprost” 2004, nr 49, s. 118.

214 Ibidem, s. [119].

215 K. Śmiałkowski, Kultura miłosnego niepokoju, „Wprost” 2005, nr 6, s. [105].
} 
takie, które traktowały interesującą nas tematykę z przymrużeniem oka, nierzadko opatrując podawaną informację zabawnym komentarzem.

W pierwszej znalazła się na przykład publikacja o badaniach nad słynnym manuskryptem Voynicha ${ }^{216}$, tekst o kontrowersjach narosłych wokół Biblii ${ }^{217}$ czy o współpracy polskich pisarzy i poetów z Sowietami ${ }^{218}$. Interesujący artykuł: Naród Księgi ukazał się w marcowym numerze w 2001 r., a dotyczył encyklopedii jako tej pozycji, którą Polacy uważają za niezbędną w swym domowym księgozbiorze. Autor przypominał największe polskie i obce encyklopedie, podkreślając znaczenie tego typu źródła informacji ${ }^{219}$. 0 reprincie Biblii Gutenberga informował Ł. Radwan ${ }^{220}$. W tekście opisującym wzrastającą liczbę ludzi chorujących na depresję i choroby nerwowe przywołano przykłady znanych artystów, twórców, m.in. Sylvii Plath, która „pisała najlepsze wiersze, cierpiąc z powodu bezsenności, gorączki i napadów furii”221 czy Virginii Woolf, która „przechodziła okresy klinicznej depresji, popadała również $\mathrm{w}$ nastroje maniakalne" 222 . W jednym z numerów pisma pojawił się krótki tekst opisujący modę na tworzenie kontynuacji uznanych dzieł223, w innym informowano o liczbie sprzedanych egzemplarzy nowej powieści A. Sapkowskiego (Narrentarum) i tłumaczeniu na język hiszpański innej jego książki ${ }^{224}$.

W grupie drugiej umieścić można na przykład doniesienie o „pisaniu” książki przez jednego z polityków, lidera Samoobrony, Andrzeja Leppera ${ }^{225}$, informację o ukazaniu się w księgarniach w Moskwie rzekomo nie publikowanej dotąd części Podróży Guliwera Jonathana Swifta226, wzmiankę o podaniu w encyklopedii „Gazety Wyborczej” błędnej informacji o śmierci żyjącego nadal Mariana Grześczaka, prezesa Stowarzyszenia Pisarzy Polskich 227.

216 P. Górecki, Rękopis znaleziony we Frascati, „Wprost” 2004, nr 38, s. 86-[87].

217 A. Baranowska, Najnowszy Testament, „Wprost” 2004, nr 15, s. 80. Z kolei zupełnie inny charakter miała krótka notka, dotycząca Nowego Testamentu, opublikowanego w postaci kolorowego pisma, adresowanego do nastolatek przez Wydawnictwo Transit Books; zob. (DŁ), Biblia w stylu pop, „Wprost” 2003, nr 38, s. [81].

218 K. Kołodziejski, Elita niewolników Stalina, „Wprost” 2003, nr 38, s. 68-70.

219 A. Szarlik, współpraca: M. Maciejewska: Naród księgi, „Wprost” 2001, nr 12, s. 78,80 .

220 七. Radwan, Gutenberg współczesny, „Wprost” 2002, nr 48, s. 122-123.

221 J. Michalak, Mózg na huśtawce, „Wprost” 2003, nr 2, s. [76]-77].

222 Ibidem.

223 J. Melchior, Literatura dopisana, „Wprost” 2003, nr 13, s. 97.

224 [br. aut.], El Brujo znaczy Wiedźmin, „Wprost” 2002, nr 46, s. 102.

225 (MS), Płodny Lepper, „Wprost” 2004, nr 14, s. 7.

226 (MS), Swawolne Liliputy, „Wprost” 2005, nr 33, s. 92.

227 (AB), Grześczak żyje!, „Wprost” 2005, nr 35, s. [11]. 
Zazwyczaj w kilku zdaniach informowano także o nagrodach ${ }^{228}$. I tak na przykład w numerze 42. w 2001 r. pojawiła się notka o Nagrodzie Nike dla Jerzego Pilcha za jego książkę Pod Mocnym Aniołem. W numerze 48 z 2003 r. informowano o Nagrodzie Pen Clubu dla Jana Krasińskiego, autora cyklu powieści, m.in. Na stracenie, Twarzq do ściany. Donoszono o wręczeniu Nagrody Wielkiej Fundacji Kultury m.in. dla poety ks. Jana Twardowskiego, o nagrodzie dla Idy Fink (autorki opowiadań i powieści o Holocauście), tworzącej w języku polskim, także wręczonej przez Pen Club.

Postać krótkich doniesień przybierały również zazwyczaj informacje dotyczące targów i innych imprez związanych z książką. Pisano m.in. o krakowskich targach książki ${ }^{29}$, VII Międzynarodowym Festiwalu Sztuki Książki w Warszawie ${ }^{230}$, 49. Międzynarodowych Targach Książki w Warszawie ${ }^{231}$. Przeważnie ograniczano się do zwięzłej notki:

483 wydawnictwa, w tym 177 polskich, wzięły udział w 47. Międzynarodowych Targach Książki w Warszawie. Gośćmi imprezy byli: Carlos Fuentes i Hari Kunzru (autor najdroższego debiutu w dziejach rynku wydawniczego, powieści „Impresjonista”, za którą zapłacono 1,8 mln dolarów). Tegoroczne targi to pierwszy krok do stworzenia festiwalu książki - nowej formuły imprezy wykorzystującej różne media (od plastyki po seanse filmowe) ${ }^{232}$.

Informowano o Międzynarodowych Targach Książki w Göteborgu, gdzie gościem honorowym miała być Polska ${ }^{233}$. Zaledwie kilkakrotnie doniesienia związane z tego typu wydarzeniami miały objętość nieco większą. Tak było przy omawianiu 5. Targów Książki w Warszawie, kiedy felietonista pisma, M. Skwarnicki, podzielił się z czytelnikami swymi wrażeniami z tejże imprezy ${ }^{234}$. Podobnie nieco obszerniejszy komentarz pojawił się dwa lata później, kiedy pisano o malejącej randze Międzynarodowych Targów Książki w Warszawie, zauważając, że w sytuacji, gdy „wszystkie okoliczne księgarnie kuszą tytułami ze światowych list bestsellerów, wiara, że czytelnik zapłaci za bilet tylko po to, by ujrzeć je na targowych stoiskach, prowadzi donikąd"235. Honorowi goście kolejnych targów, Rosjanie, byli bohaterami wspomnianego wcześniej tekstu Seks ze Stalinem ${ }^{236}$. W jednym z numerów pisma znalazła się krótka relacja z zakończonych niedawno Dni

228 Zob. np. tekst autorstwa M. Gretkowskiej, poświęcony polskim nagrodom literackim w 2001 r. i ich laureatom: M. Gretkowska, Nagroda bez głowy, „Wprost” 2001, nr 38, s. 116.

229 (MS), Kraków książki, „Wprost” 2005, nr 44, s. [109].

230 [br. aut.], Księgi jak rzeźby, „Wprost” 2003, nr 20, s. 113.

231 [br. aut.], Kochanka Gutenberga, „Wprost” 2004, nr 22, s. 98.

232 [br. aut.], Festiwal książki, „Wprost” 2002, nr 21, s. 106.

233 [br. aut.], Potop polski, „Wprost” 2003, nr 41, s. 105.

${ }^{234}$ M. Skwarnicki, Biblioteczka flisaka, „Wprost” 2001, nr 45, s. 83.

235 [br. aut.], Targi czyli kiermasz, „Wprost” 2003, nr 21, s. 104.

236 J. Melchior, M. Sawicka, Seks ze Stalinem, „Wprost” 2004, nr 21, s. 108-[109]. 
Tischnerowskich237. Donoszono także o obecności Biblioteki Narodowej na 14. Targach Książki w Warszawie238.

Na temat bibliotek pojawiło się na łamach pisma w badanym okresie zaledwie kilka informacji. Na przykład w 2003 r. czytelnicy mieli możliwość dowiedzieć się więcej o kontrowersyjnych planach polskiego rządu dotyczących przekazania Niemcom zbiorów tzw. Berlinki ${ }^{239}$. Przeważnie jednak informacje związane z bibliotekami miały postać kilku-, kilkunastozdaniowych wzmianek o charakterze czysto informacyjnym. Odnotowano fakt oddania do użytku nowego gmachu Biblioteki Jagiellońskiej przy okazji inauguracji 638. roku akademickiego ${ }^{240}$, donoszono o darach, przekazywanych Bibliotece Narodowej zarówno przez osoby prywatne, jak i organizacje $^{241}$, planach digitalizacji jej zbiorów ${ }^{242}$. Realizując politykę propagowania nowych mediów, redakcja pisała o bibliotekach wirtualnych ${ }^{243}$, proponowano skorzystanie z wortalu Historia Książki, zawierającego ciekawostki dotyczące książki i bibliotek ${ }^{244}$ czy donoszono o popularyzacji literatury przez Internet, w którym pojawia się coraz więcej poświęconych jej serwisów 245 .

Jakkolwiek na łamach „Wprost” liczba informacji związanych z książką i ich zróżnicowanie były mniejsze niż w przypadku „Polityki”, to jednak i tym razem niemożliwe jest zaprezentowanie ich wszystkich. Warto jednak wspomnieć jeszcze o recenzjach czy choćby krótkich doniesieniach dotyczących ekranizacji znanych powieści, nie tylko literatury klasycznej, ale i bestsellerów powieści współczesnych oraz inscenizacjach dramatów. Tego typu informacji ukazało się przez 5 lat na łamach „Wprost” 136 (99 informacji o ekranizacjach i 47 na temat inscenizacji). Miały one różną objętość i charakteryzowały się rozmaitym stopniem analizy prezentowanego materiału. Dzięki nim czytelnik tygodnika dowiedział się m.in. o kolejnej w historii ekranizacji Quo vadis Henryka Sienkiewicza, Ogniem i mieczem tegoż autora, Starej Baśni Józefa I. Kraszewskiego, kolejnych części cyklu o Harrym Potterze, romansu wszechczasów, czyli Przeminęło z wiatrem, przeniesieniu na srebrny ekran Wiedźmina A. Sapkowskiego, o kolejnej ekranizacji Solaris St. Lema. Recenzje planowanych bądź już zrealizowanych

237 (JK), [br. tyt.], zob. „Wprost” 2001, nr 23, s. 108.

238 [br. aut.], Narodowa na targach, „Wprost” 2003, nr 39, s. 96.

239 S. Sieradzki, Pruski targ, „Wprost” 2003, nr 39, s. 102-103.

240 P. Jasica, [br. tyt.], „Wprost” 2001, nr 41, s. 118.

241 Zob. np. J. Kobus, Żaglowiec pamięci narodowej, „Wprost” 2003, nr 10, s. 96; (JK), [br. tyt.] , ibidem, 2001, nr 27, s. 102; [br. aut.], Pielgrzym Gere, ibidem, 2002, nr 38, s. 7; (JK), [br. tyt.], 2001, nr 27, s. 102.

242 Zob. J. Kobus, Żaglowiec pamięci...

243 K. Wypustek, Globalna biblioteka, „Wprost” 2001, nr 6, s. 48-49.

244 [br. aut.], Akademia bibliofila, „Wprost” 2002, nr 24, s. 64.

245 [br. aut.], Biblioteczka internauty, „Wprost” 2001, nr 32, s. 52. W tej krótkiej notce znalazła się informacja o stronie, założonej przez licealistę. 
ekranizacji nie zawsze miały charakter pozytywny. Pisząc o polskiej kulturze, w tym literaturze i przeniesieniu jej klasyki na ekran, J. Melchior uznał, że: „Tylko 5 proc. polskiej produkcji kulturalnej ma szansę w konfrontacji z zachodnim importem"246. Pisząc o polskim i światowym kinie w 2001 r., J. Kobus stwierdziła z kolei:

niewiele jest nowych pomysłów, twórcy filmowi przede wszystkim dyskontują wcześniejsze sukcesy - własne lub cudze. Z ekranowej dominacji adaptacji i sequeli płynie smutny wniosek: kino zjada własny ogon. [...] polskie kino zachłysnęło się adaptacjami rodzimej literatury. Amerykańskie nadal faworyzuje sequele 247 .

Negatywnie odniesiono się do ekranizacji jednej z części wspomnianego cyklu o małym czarodzieju, autorstwa Joanne K. Rowling248. Z kolei pisząc o zastoju w polskim kinie familijnym, wspomniano o przeniesieniu na ekran kolejnej powieści H. Sienkiewicza: $W$ pustyni $i$ w puszczy ${ }^{249}$. W 2003 r. T. Raczek chociaż przyznał, że

największe sukcesy filmowe mijającego roku należały do sprawnych rzemieślników, realizujących precyzyjnie nakreślone plany marketingowe. Zwyciężali najwierniejsi ilustratorzy fabuł, które wcześniej zdobyły nasze serca dzięki książkom i komiksom,

to jednak równocześnie stwierdził, że

gdyby przyjrzeć się bliżej wartości artystycznej tych trzech liderów [mowa o ekranizacji książek o Harrym Potterze, Władcy pierścieni i komiksu Spider-Man - przyp. M.P.S.], trzeba by wyraźnie powiedzieć, że jest ona tylko zadowalająca. Raz lepsza, raz gorsza. Żaden z tych filmów na pewno nie stanie się przełomowym dziełem w dziejach kinematografii. Także ich reżyserzy [...] raczej nie dołączą do panteonu największych twórców ${ }^{250}$.

T. Raczek przypominał zatem, że fakt, iż książka jest bestsellerem, nie gwarantuje jeszcze sukcesu jej ekranizacji. Chociaż zdarzają się wyjątki, do których należy John Grisham - „prawdziwa maszynka do produkcji bestsellerów: książkowych i filmowych [...] kasowy pewniak"251, autor prawniczych dreszczowców, które stają się przebojami kinowymi.

Pisano nie tylko o znanych dziełach, przeniesionych na ekran. Wspominano również na przykład o ekranizacji książki Requiem dla snu Huberta Selby`ego ${ }^{252}$ czy Wyznań gejszy Arthura Guldena ${ }^{253}$.

246 J. Melchior, Kultura nic, „Wprost” 2003, nr 9, s. [98]-101.

247 J. Kobus, Quo vadis, Hannibalu?, „Wprost” 2001, nr 1, s. 102-103.

248 Z. Kałużyński, T. Raczek, Banał na miotle, „Wprost” 2002, nr 5, s. 106-107.

249 J. Kobus, Sienkiewicz politycznie poprawny, „Wprost” 2001, nr 12, s. 116-118.

250 T. Raczek, Ruchome ilustracje, „Wprost” 2003, nr 2, s. 67.

251 Ł. Radwan, Adwokat diabła, „Wprost” 2003, nr 43, s. 112-113.

252 [br. aut.], Prywatne piekło, „Wprost” 2003, nr 30, s. 89.

253 (PB), Co wy wiecie o gejszach, „Wprost” 2005, nr 49, s. 96. 
W przypadku informacji dotyczących inscenizacji, najczęstszym przedmiotem tych zazwyczaj kilkuzdaniowych wzmianek były dramaty Williama Szekspira. Informowano o VII Festiwalu Szekspirowskim w Gdańsku (również reklama tej imprezy pojawiała się kilkakrotnie na łamach pisma), a także o przedstawieniach festiwalu Malty, w trakcie którego planowano wystawić dramaty W. Szekspira. Czytelnik mógł też dowiedzieć się o udanej premierze Snu nocy letniej, Komedii omyłek, wystawieniu Makbeta i Hamleta. Raz pojawił się obszerniejszy tekst dotyczący różnych inscenizacji dzieł W. Szekspira. Wspomniano również o adaptacji Hanemanna Stefana Chwina, przeniesionego na scenę teatru Wybrzeże, o dziełach Sławomira Mrożka: Krawcu i Wielebnych oraz Weselu Stanisława Wyspiańskiego.

Niejako uzupełnieniem tego typu informacji były reklamy, rekomendujące kolejne ekranizacje, na przykład hasłem „Zmierz się z ciemnymi siłami Mordoru" zapraszano czytelników na Dwie wieże (I część Władcy pierścieni), a „Skradziono mu tożsamość. Teraz chce ją odzyskać” na Krucjatę Bourne'a.

W badanym okresie pojawiły się 34 reklamy ekranizacji znanych utworów, a najczęstszym ich przedmiotem były kolejne części trylogii J. R. R. Tolkiena ${ }^{254}$.

Wiele publikacji doczekało się odzewu ze strony czytelników. Listy od nich drukowano w rubryce Poczta albo Wprost od czytelników. Kilku z nich nawiązywało do recenzji wspomnianych ekranizacji książek J. R. R. Tolkiena, odpierając zarzuty stawiane przez dziennikarzy „Wprost”255. Odnoszono się także m.in. do nieudanej ekranizacji Quo vadis ${ }^{256}$. Pojawiały się również głosy w sprawie powieści o Harrym Potterze 257 .

Warto wspomnieć też o kolejnej formie promocji książki: drukowaniu na łamach pisma jej fragmentów. W przypadku omawianego periodyku były to z reguły zapowiedzi mających się dopiero ukazać propozycji wydawniczych. W ten sposób czytelnik „Wprost” mógł poznać 17 lektur, a wśród nich m.in. recenzowaną i reklamowaną na łamach tygodnika książkę Ukraina na zakręcie. Drogi i bezdroża pomarańczowej rewolucji258, książkę Anny Politkowskiej Rosja Putina ${ }^{259}$ czy fragment książki S. Bratkowskiego Nieco inna historia cywilizacji. Dzieje banków, bankierów i obrotu pieniężnego 260 albo Daniela Pipesa Wojujący islam sięga po Amerykę261, a także Ryszard Kukliń-

\footnotetext{
254 Zob. np. „Wprost” 2003, nr 36, s. [49]; 2004, nr 1, s. [77]; 2003, nr 35, s. [77].

255 „Wprost" 2002, nr 12, s. [16].

256 „Wprost” 2001, nr 42, s. 3; nr 36, s. 11.

257 „Wprost” 2002, nr 7, s. 17; nr 8, s. [16].

258 W tym przypadku był to przykład promocji prospektywnej: wydrukowano fragment książki, która dopiero miała się ukazać na rynku. Był to tytuł przygotowywany przez autorów pisma. Zob. „Wprost” 2005, nr 32, s. 86-88.

259 „Wprost" 2005, nr 35, s. [83]-[85].

260 „Wprost" 2003, nr 1, s. 68-70.

261 „Wprost” 2003, nr 32, s. 85-86.
} 
ski. Życie ściśle tajne Benjamina Weisera ${ }^{262}$. Wśród proponowanych $\mathrm{w}$ ten sposób tytułów pojawiły się również nieco łatwiejsze w odbiorze książki, na przykład Wniebowzięci, czyli jak to się robi... M. Łuczaka ${ }^{263}$ czy Polka M. Gretkowskiej264.

Na łamach pisma pojawiały się także okolicznościowe formy informacji o książce, związane ze zbliżającymi się świętami bądź wakacjami265. W $2004 \mathrm{r}$. czterokrotnie w Wakacyjnej czytelni znalazły się propozycje kilku tytułów: biografii, powieści przygodowych, zbioru opowiadań, młodzieżowej sagi fantasy, a także lektur związanych z rocznicą Powstania Warszawskiego, z krótkimi adnotacjami treściowymi, uzupełnionymi kopiami okładek polecanych książek ${ }^{266}$. Rok później redakcja poprosiła znanych krytyków i pisarzy o propozycje lektur na wakacje. Wśród rekomendujących znaleźli m.in. się Hanna Krall, Antoni Libera, Andrzej Pilipiuk, Izabela Sowa i Tomasz Łubieński. Ich propozycje, opatrzone dłuższym niż w poprzednim przypadku opisem, objęły 16 tytułów ${ }^{267}$. Również z okazji zbliżających się Świąt Bożego Narodzenia redakcja proponowała pod choinkę książki: w 2004 r. $\mathrm{w}$ dwustronicowym zestawieniu, obok płyt z filmami, znalazły się m.in. albumy, encyklopedie, a także propozycje dla dzieci; każdy z tytułów był krótko omówiony 268 . W 2005 r. redakcja zaproponowała już tylko trzy tytuły. Wraz z książkami polecano płyty dvd z muzyką269.

\subsection{Pionierzy nowej epoki ${ }^{270}$ : konkursy i akcje}

Ostatnią grupę informacji, związanych z książką, pojawiającą się na łamach pisma, stanowiły konkursy i akcje. W porównaniu z wcześniej omawianym tygodnikiem „Polityka”, „Wprost” nie może poszczycić się zbyt

262 „Wprost” 2005, nr 6, s. [72]-[75].

263 „Wprost” 2004, nr 38, s. 114-115.

264 „Wprost” 2001, nr 18, s. 96-97.

265 Warto przy tej okazji zwrócić uwagę na felieton K. Skiby: Lektury na chmury, w którym autor w specyficzny dla siebie sposób wyrażał własne zdanie na temat wakacyjnej lektury, w kontekście ogólnej sytuacji w kraju. Zob. K. Skiba, Lektury na chmury, „Wprost” 2005, nr 28, s. 114.

266 [br. aut.], Wakacyjna czytelnia, „Wprost” 2004, nr 29, s. 86 (w tym przypadku redakcja zaproponowała czytelnikom konkurs: w nagrodę za napisanie krótkiej recenzji jednego z proponowanych tytułów mieli oni otrzymać tę właśnie książkę); „Wprost” 2004, nr 31, s. 86; $\mathrm{nr} 32$, s. 88; nr 34, s. 86.

267 [br. aut.], Krzyżacki poker w cieniu wiatru, „Wprost” 2005, nr 26, s. 109-110.

268 [br. aut.], Wprost poleca pod choinkę, „Wprost” 2004, nr 49, s. 110-[111].

269 Były to: Anioły i demony (D. Browna), Anioł (H. Vorgrimlera i in.), Potrawy biblijne (J. Hutta i H. Kleina). Zob. [br. aut.], Wprost poleca pod choinke, „Wprost” 2005, nr 49, s. [111].

270 Tytuł relacji z rozwiązania 4. edycji konkursu dla młodych dziennikarzy. Zob. T. Wojciechowski, Pionierzy nowej epoki, „Wprost” 2001, nr 23, s. 34-35. 
wieloma tego typu przedsięwzięciami. Dorobek pisma w tym względzie przedstawia się bardzo skromnie: kilka jednorazowych inicjatyw, niewiele więcej pomysłów, w których „Wprost” był współorganizatorem i nieco więcej tych, o których $\mathrm{w}$ tygodniku informowano, przeważnie zresztą w postaci płatnego ogłoszenia.

Do pierwszej grupy zaliczyć można konkursy. Tego typu przedsięwzięć inicjowanych, czy raczej współorganizowanych przez tygodnik, było bardzo niewiele.

Przedsięwzięcia bezpośrednio związane z książką, które można zaliczyć do tej kategorii, pojawiły się dwukrotnie w 2004 r., w okresie wakacyjnym. Pierwszy raz redakcja zaprosiła czytelników do udziału w swego rodzaju konkursie 4 lipca (2004). Pod recenzjami trzech książek pojawiła się obietnica, że przedstawione tytuły otrzymają ci, którzy w najlepszy sposób uzasadnią swoją chęć ich posiadania271. Dwa tygodnie później, w podobnej formule, pojawiły się recenzje trzech innych książek. Tym razem tylko jeden $\mathrm{z}$ wymienionych tytułów stanowił nagrodę. Miał ją otrzymać ten, kto napisze najciekawszą recenzję tej książki272.

Do innej grupy inicjatyw pisma można zaliczyć wspomniany wcześniej, organizowany od roku 1998 przez tygodnik "Wprost” wraz z Ambasadą USA w Polsce, konkurs adresowany do młodych dziennikarzy Walcz o staż!. Za każdym razem proponowano zainteresowanym inny temat, który miał stać się podstawą ich konkursowej pracy. I tak, hasłem edycji w roku 2001 było: Pionierzy nowej epoki, w roku następnym: Nowe wyzwania nowego wieku, w 2003 r.: Euroameryka?, a następna edycja przebiegała pod hasłem Amerykanizacja kultury czy jednolita kultura globalna? W ostatnim analizowanym roku, 2005, uczestnicy mieli odpowiedzieć na pytanie: Czy możliwa jest demokracja $w$ krajach posttotalitarnych? Nadsyłane na konkurs prace oceniała specjalna komisja, w której zasiadali m.in. rzecznik prasowy ambasady amerykańskiej, prezes AWR „Wprost”, redaktor naczelny pisma i kilku wybranych dziennikarzy. Nagrodą główną był staż w The Missouri School of Journalism, na laureatów czekały także staże w redakcji tygodnika „Wprost”, zaproszenia na uroczystą galę wręczenia tytułów Człowieka Roku oraz liczne nagrody rzeczowe.

Podobny charakter miał inny konkurs, tym razem objęty patronatem medialnym przez „Wprost”: Reportaż na Staż. W 2004 r. organizatorem tego konkursu, adresowanego do studentów, było Studenckie Koło Naukowe

271 [br. aut.], Na deszczowe dni, „Wprost” 2004, nr 27, s. 92. Proponowano książki: Wiosna Pl-Boya. Życie seksualne oswojonych M. Szczygielskiego, Kuba Rozpruwacz. Portret zabójcy (P. Cornweel) oraz Między niebem a piekłem w oprac. B. Pawlikowskiej.

272 [br. aut.], Wakacyjna czytelnia, „Wprost” 2004, nr 29, s. 86. Tym razem były to następujące tytuły: Miłość i śmierć. Morderstwo Kurta Cobaina M. Wallace`a i I. Halperine`a, Liczy się każda sekunda L. Armstronga i S. Jenkins oraz Picasso. Biografia autorstwa H. Gidele`a. 
Językoznawców przy Wydziale Filologicznym Uniwersytetu Śląskiego 273. Nagrody przyznawano w kategoriach: radiowej, telewizyjnej i prasowej.

Innym konkursem była wspólna inicjatywa Muzeum Powstania Warszawskiego oraz tygodnika „Wprost”: Powstańcze blizny. W 2005 r. na łamach pisma pojawiło się ogłoszenie, w którym organizatorzy zapraszali czytelników do napisania eseju związanego ze wspomnieniami dotyczącymi Powstania 1944 r. ${ }^{274}$ Nagrodą główną była kwota 5 tys. zł oraz pióro, którego fundatorem był Lech Kaczyński, ówczesny prezydent stolicy. Kilka tygodni później ogłoszono listę zwycięzców275.

Warto wspomnieć również o jednej z najstarszych inicjatyw współorganizowanych przez redakcję tygodnika, którą był Konkurs im. Krzysztofa Mętraka, organizowany od $1995 \mathrm{r}$. Inicjatywa ta miała na celu promocję ludzi młodych (do 32. roku życia), piszących o filmie. Konkurs adresowany był do studentów, dziennikarzy i krytyków276.

Ważną grupę stanowiły konkursy, o których czytelnik dowiadywał się dzięki ogłoszeniom, zamieszczanym na łamach periodyku. W pierwszym rzędzie zaliczyć do nich można cykliczny Konkurs im. Józefa Mackiewicza. Po raz pierwszy informacja na ten temat pojawiła się w numerze 37. w 2001 r.277 Odtąd co roku we "Wprost” informowano najpierw o zasadach konkursu, a później zamieszczano krótką relację z wręczenia nagród laureatom. Zwycięzca otrzymywał medal z mottem, stanowiącym cytat słów autora Okien zatkanych szmatami: „Jedynie prawda jest ciekawa” oraz czek (na przykład w 2003 r. na 8 tys. dolarów), fundowany przez osoby prywatne (we wspomnianym 2003 r. byli nimi Jan M. Małek oraz Zbigniew Zarywski). Poza głównym laureatem wybierano wśród nominowanych autorów, którzy otrzymywali wyróżnienia; tych nagradzano od 2004 r. popiersiem J. Mackiewicza. Nagrodę przyznawano „za książki odznaczające się wybitnymi walorami literackimi oraz tematyką ważną kulturowo, społecznie lub politycznie"278. W tabeli 25 zaprezentowano listę zwycięzców wraz z tytułami książek, które zostały nagrodzone (po raz pierwszy nagrodę przyznano w 2002 r. $)^{279}$.

273 Informacje o wynikach konkursu w 2004 r., zob. [br. aut.], Konkurs na staż, „Wprost” 2004, nr 16, s. 92.

274 Zob. np. „Wprost” 2004, nr 4, s. 32, powtórzone m.in. ibidem, nr 7, s. 33.

275 „Wprost” 2004, nr 14, s. 6.

276 Np. w 2004 r. przewidziano trzy nagrody: I w wysokości 10 tys. zł oraz rzeźba autorstwa A. Myjaka, II - w wysokości 5 tys. zł, oraz III - 2,5 tys. zł.

277 [br. aut.], Nagroda im. Józefa Mackiewicza, „Wprost” 2001, nr 37, s. 11.

278 www.mackiewicz.pl, 10 października 2010.

279 Chociaż tygodnik nie był bezpośrednim organizatorem konkursu, warto wymienić jego laureatów, jako że była to ważna impreza kulturalna, która była przedmiotem publikacji na łamach omawianego periodyku. 
Tabela 25. Laureaci Nagrody Literackiej im. Józefa Mackiewicza

\begin{tabular}{|c|c|c|}
\hline $\begin{array}{c}\text { Rok, w którym } \\
\text { przyznano nagrode }\end{array}$ & Nazwisko laureata & Tytuł nagrodzonej publikacji \\
\hline \multirow{3}{*}{2002} & $\begin{array}{l}\text { Nagroda główna: } \\
\text { Władysław Siemaszko } \\
\text { Ewa Siemaszko }\end{array}$ & $\begin{array}{l}\text { Ludobójstwo dokonane przez nacjo- } \\
\text { nalistów ukraińskich na ludności } \\
\text { polskiej Wołynia 1939-1945 } \\
\text { (Wydawnictwo Von Borowiecky) }\end{array}$ \\
\hline & $\begin{array}{l}\text { Wyróżnienie: } \\
\text { Dawid Bieńkowski }\end{array}$ & $\begin{array}{l}\text { Jest } \\
\text { (Wydawnictwo Agawa) }\end{array}$ \\
\hline & $\begin{array}{l}\text { Wyróżnienie: } \\
\text { Wojciech Kleniec }\end{array}$ & $\begin{array}{l}\text { Proces pokazowy } \\
\text { (Wydawnictwo El-Ka) }\end{array}$ \\
\hline \multirow{3}{*}{2003} & $\begin{array}{l}\text { Nagroda główna: } \\
\text { Jan M. Chodakiewicz }\end{array}$ & $\begin{array}{l}\text { Ejszyszki. Kulisy zajść w Ejszyszkach, } \\
\text { epilog stosunków polsko-żydowskich } \\
\text { na Kresach 1944-1945 } \\
\text { (Wydawnictwo Fronda) }\end{array}$ \\
\hline & $\begin{array}{l}\text { Wyróżnienie: } \\
\text { Maciej Urbanowski }\end{array}$ & $\begin{array}{l}\text { Oczyszczenie. Szkice o literaturze } \\
\text { polskiej XX wieku } \\
\text { (Wydawnictwo Arcana) }\end{array}$ \\
\hline & $\begin{array}{l}\text { Wyróżnienie: } \\
\text { Cezary Michalski }\end{array}$ & $\begin{array}{l}\text { Siła odpychania } \\
\text { (Wydawnictwo W.A.M.) }\end{array}$ \\
\hline \multirow{3}{*}{2004} & $\begin{array}{l}\text { Nagroda główna: } \\
\text { Wojciech Albiński }\end{array}$ & $\begin{array}{l}\text { Kalahari } \\
\text { (Wydawnictwo Twój Styl) }\end{array}$ \\
\hline & $\begin{array}{l}\text { Wyróżnienie: } \\
\text { Anna Pawełczyńska }\end{array}$ & $\begin{array}{l}\text { Koniec kresowego świata } \\
\text { (Wydawnictwo Test) }\end{array}$ \\
\hline & $\begin{array}{l}\text { Wyróżnienie: } \\
\text { Wacław Holewiński }\end{array}$ & $\begin{array}{l}\text { Lament nad Babilonem } \\
\text { (Wydawnictwo Prószyński i S-ka) }\end{array}$ \\
\hline \multirow{3}{*}{2005} & $\begin{array}{l}\text { Nagroda główna: } \\
\text { Eustachy Rylski }\end{array}$ & $\begin{array}{l}\text { Człowiek w cieniu } \\
\text { (Wydawnictwo Świat Książki) }\end{array}$ \\
\hline & $\begin{array}{l}\text { Wyróżnienie: } \\
\text { Sławomir Cenckiewicz }\end{array}$ & $\begin{array}{l}\text { Oczami bezpieki. Szkice i materiały } \\
\text { z dziejów aparatu bezpieczeństwa } \\
P R L \\
\text { (Wydawnictwo Arcana) }\end{array}$ \\
\hline & $\begin{array}{l}\text { Wyróżnienie: } \\
\text { Aleksander Kopiński }\end{array}$ & $\begin{array}{l}\text { Ludzie z charakterem. O okupacyj- } \\
\text { nym sporze Czesława Miłosza } \\
\text { i Andrzeja Trzebińskiego } \\
\text { (Wydawnictwo Fronda) }\end{array}$ \\
\hline
\end{tabular}

Źródło: www.mackiewicz.pl oraz badania własne.

Na łamach periodyku informowano także o 2. edycji Nagród Asy Empiku (ta sama inicjatywa reklamowana była także na łamach „Polityki”). W anonsie pojawiła się lista 12 propozycji nominowanych do nagrody Wydarzenie Roku 2000 (wśród nich znalazły się obok tytułu filmu, płyt z muzyką też propozycje książkowe), a zadanie czytelnika polegało na zaznaczeniu wybranej przez siebie pozycji, wypełnieniu kuponu i wrzuceniu go do urn, wystawionych w salonach sieci Empik. Nagrodę otrzymać miały osoby, 
których wybór pokryłby się z werdyktem jury280. Kilka tygodni później pojawiła się informacja o laureatach. W kategorii książki polskiej została nagrodzona Joanna Chmielewska za tytuł Jak wytrzymać z mężczyznq, a w kategorii książki zagranicznej - Internet - praktyczny przewodnik (Angusa J. Kennedy`ego) ${ }^{281}$.

Innym konkursem była propozycja Świata Książki, nota bene reklamowana również na łamach tygodnika „Polityka”. Złote pióro był to konkurs na współczesną powieść dla kobiet - jego anons pojawił się w piśmie w roku 2002 i $2003^{282}$.

Niektóre informacje miały charakter zaproszenia na imprezy związane z książką: dzięki nim czytelnicy dowiedzieli się m.in. o spotkaniu z Suzanne Clarke, autorką m.in. powieści Jonathan Strange i pan Norrel283, Niną Terentiew (było to spotkanie promujące książkę Zwierzenia kontrolowane) ${ }^{284}$, a także o zorganizowanej w redakcji „Wprost” promocji książki Bronisława Wildsteina Długi cień $P R L-u . . .285$, spotkaniu autorskim z Tadeuszem Różewiczem z okazji wydania 1. tomu jego Utworów zebranych ${ }^{286}$ oraz z Leszkiem Szarugą ${ }^{287}$. Nie omieszkano poinformować czytelników także o niezwykle udanej imprezie z okazji wydania książki jednego ze współpracowników pisma. Redakcja „Wprost” zorganizowała w jednej z warszawskich księgarń spotkanie promocyjne z T. Raczkiem, autorem Karuzeli z herosami, czyli męskiego świata w 57 odsłonach ${ }^{288}$. W 2005 r. czytelnicy dowiedzieli się o pierwszej edycji imprezy w ramach całorocznego cyklu „4 pory książki”, organizowanego przez Instytut Książki289.

Informacje związane z przedsięwzięciami promującymi książkę przybierały także postać reklam. Tak było na przykład w odniesieniu do targów. W ciągu badanego okresu pojawiło się ich jednak niewiele (12), przy czym jedno z nich zostało zamieszczone nie przez organizatorów, a przez wydawcę. Świat Książki proponował czytelnikom spotkania z zaproszonymi przez siebie pisarzami (Nicci Frenchem, Carlosem Fuentesem i Katarzyną Pisarzewską). Dwukrotnie na łamach pisma znalazło się zaproszenie (także

280 Anons reklamowy, zob. „Wprost” 2001, nr 3, s. [18]. Warto wspomnieć, że na koniec 2001 r. EMPiK dołączył do grudniowego numeru tygodnika świąteczną kartę rabatową, upoważniającą do zniżki przy zakupach (w tym książkowych) w salonach sieci.

281 „Wprost” 2001, nr 7, s. 99.

${ }^{282}$ Konkurs ten został już wcześniej omówiony w rozdziale poświęconym tygodnikowi „Polityka”. Zob. s. 118.

283 (MS), Spotkanie z magia, „Wprost” 2004, nr 47, s. [107].

284 "Wprost" 2004, nr 23, s. 101.

285 "Wprost" 2005, nr 19, s. 10.

286 „Wprost” 2003, nr 50, s. 102.

287 „Wprost” 2002, nr 6, s. 100.

288 (ŁR), 57 herosów i jeden Raczek, „Wprost” 2004, nr 48, s. 98.

289 (EMP), Jesień prozy, „Wprost” 2005, nr 41, s. 116. 
w formie reklamy) do udziału w Dniach Tischnerowskich, a także na Święto Młodego Czytelnika, organizowane przez Progenia.

Jako podsumowanie tej części rozdziału warto przytoczyć kilka interesujących tytułów omawianych powyżej informacji290: Białe kruki, Braterstwo kultur, Co leży na wieży?, Dzieje Księgi, Festiwal książki, Naród księgi, Pamięć dziejów, Piszę, bo czytam, Wielkie czytanie, Zapach książki, Zapaśnik literatury.

Na zakończenie tych rozważań należy zwrócić uwagę na fakt, że redakcja tygodnika nie zorganizowała samodzielnie w badanym okresie żadnego konkursu, bezpośrednio związanego z książką, nie podjęła również żadnej innej inicjatywy, której celem byłaby promocja literatury.

\subsubsection{Gazeta $w$ niebezpieczeństwie ${ }^{291}$ : inne informacje: o prasie i środowisku dziennikarskim}

Na łamach „Wprost” w analizowanych 5 rocznikach ukazało się 1157 rozmaitego rodzaju informacji związanych bezpośrednio bądź pośrednio z prasą (498 publikacji tekstowych oraz 659 reklam). Można je podzielić na trzy grupy.

Największą stanowiły kilkuzdaniowe wzmianki, dotyczące zarówno faktów, jak i ludzi, związanych z „czwartą władzą”. Część z tych informacji, $\mathrm{w}$ formie krótkich notek, drukowano w rubryce $Z$ życia koalicji/Z życia opozycji. Tutaj pojawiały się prześmiewcze komentarze, dotyczące głównie sceny politycznej, ale nierzadko ich autorzy, Robert Mazurek i Igor Zalewski, jako przedmiot żartów wybierali gazety bądź czasopisma i zamieszczane w nich teksty oraz pracujących tam dziennikarzy. Najczęstszym celem ataków był konkurencyjny tygodnik „Polityka”, ale również „Gazeta Wyborcza” i „Rzeczpospolita”. Także w innych działach i rubrykach znajdowały się krótkie notki, informujące o zmianach na rynku prasowym. Czytelnicy dowiedzieli się na przykład o planach firmy dystrybucyjnej Kolporter, która zamierzała wziąć udział w prywatyzacji RUCH-u ${ }^{292}$, poszerzeniu przez firmę wydawniczą Agora asortymentu wydawanej prasy293, kupnie przez norweski koncern Orkla dziennika „Życie Warszawy”294, odejściu z redakcji „Twojego Stylu” dotychczasowej redaktor naczelnej Krystyny Kaszuby295. Krótko po wprowadzeniu na rynek „Faktu” pisano o wszczęciu postępowania antymonopolowego przeciwko jego wydawcy, koncernowi Axel Sprin-

290 Kolejno: „Wprost” 2002, nr 5, s. 48; 2005, nr 38, s. 101; 2003, nr 7, s. 17; 2001, nr 28, s. $52 ; 2002$, nr 21, s. 106 ; 2001, nr 12 , s. 78, 80; nr 17, s. 50; 2005, nr 45, s. 112-114; 2003, nr 14, s. 97; 2001, nr 9, s. 104-105; 2005, nr 11, s. 108-[109].

291 Tytuł jednego z felietonów M. Wolskiego, zob. „Wprost” 2003, nr 42, s. 116.

292 „Wprost” 2001, nr 50, s. 44-[45].

293 „Wprost” 2002, nr 18, s. [37].

294 „Wprost” 2004, nr 38, s. 10.

295 „Wprost” 2003, nr 44, s. 12. 
ger Polska, za ustalenie ceny gazety poniżej kosztów produkcji296. Przypominano także o jubileuszach, na przykład o 60-leciu istnienia „Przekroju”297 czy jubileuszu „Fantastyki”298. Informowano o nagrodach, przyznawanych przez poszczególne tytuły prasowe, na przykład o Nagrodzie im. Jerzego Giedroycia, wręczanej przez „Rzeczpospolitą"299, nagrodzie dziennikarskiej im. Mieczysława i Ksawerego Pruszyńskich ${ }^{300}$, nagrodzie miesięcznika „Nowe Książki”301, nagrodach im. Dariusza Fikusa302, także nagrodach wręczanych przez Stowarzyszenie Dziennikarzy Polskich ${ }^{303}$. Pisano o tytułach Ludzi Roku, nadawanych przez dziennik „Życie”304 czy o Nagrodzie Rady Etyki Mediów ${ }^{305}$.

Informowano również o zagranicznym rynku prasowym. I tak na przykład czytelnicy dowiedzieli się o bankructwie Leo Kircha, niemieckiego magnata medialnego ${ }^{306}$. Pojawiały się również ciekawostki, czasem zabawne, a czasem kontrowersyjne, jak na przykład doniesienie o tym, że poszukiwany terrorysta, Osama bin Laden, jest jednym z kandydatów do tytułu Człowieka Roku, przyznawanego przez tygodnik „Time”307. W jednym z numerów zamieszczono krótką listę, zawierającą wysokość nakładów dzienników w poszczególnych krajach, przypadającą na tysiąc mieszkańców ${ }^{308}$.

Kolejną grupę stanowiły dłuższe teksty, poświęcone współczesnemu rynkowi prasowemu zarówno w Polsce, jak i za granicą. Pojawiały się one w rozmaitych działach periodyku, a dotyczyły na przykład rosnącej popularności tabloidów ${ }^{309}$, regionalnych gazet internetowych ${ }^{310}$ czy internetowych czasopism kulturalnych ${ }^{311}$.

Przybliżano czytelnikom wizerunek Polaków, kreowany przez prasę zachodnią. Według niej Polacy są katolikami o poglądach antysemickich,

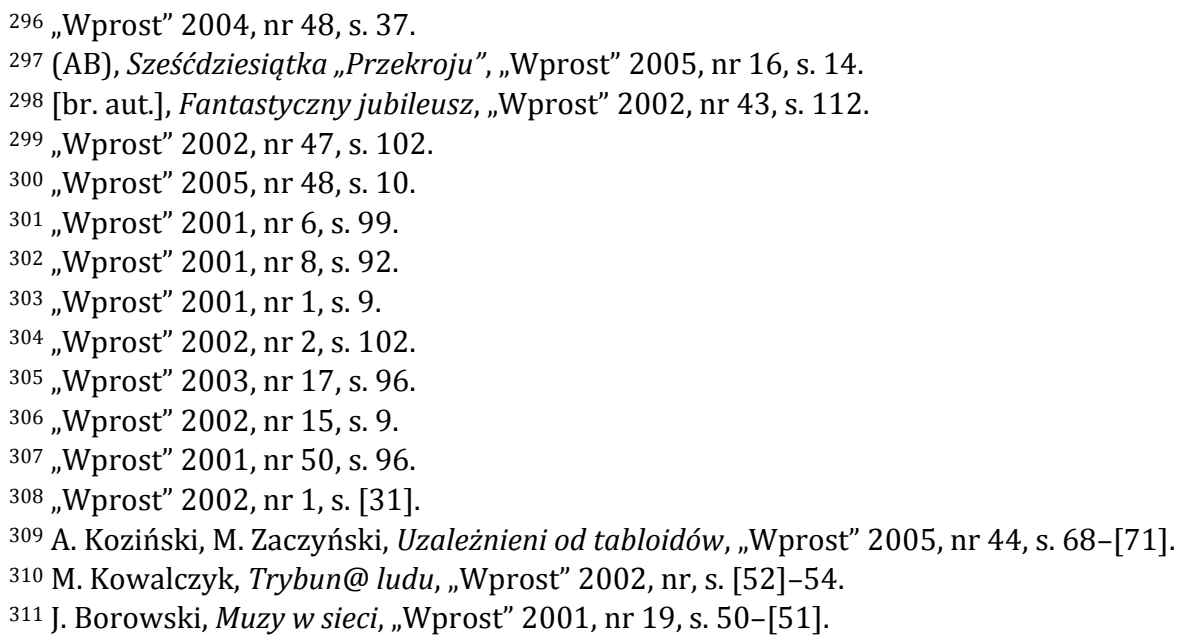


podatnymi na populistyczne hasła ${ }^{312}$. W jednym z numerów znalazł się tekst o prasie polskiej, która w efekcie rosnących udziałów kapitału niemieckiego w polskich mediach stała się „niemiecką kolonią medialną” 313 , w innym pisano o niemieckich brukowcach ${ }^{314}$, w kolejnym znalazł się tekst o najbardziej prestiżowym magazynie biznesowym na świecie „Forbes” 315 .

Wreszcie trzecią grupę stanowiła autopromocja „Wprost” oraz reklama innych periodyków, zarówno czasopism, jak i gazet.

Analiza zawartości tygodnika wykazała jego bardzo duże zaangażowanie w działalność promocyjną i dbałość o własny wizerunek. Systematycznie drukowano rankingi dotyczące czytelnictwa największych polskich tygodników informacyjnych oraz zestawienia podające liczbę cytowań tygodników opinii, gdzie „Wprost” było liderem. Skrupulatnie odnotowywano każdą nagrodę i wyróżnienie dla pisma i jego dziennikarzy. Zamieszczano listy pochwalne od czytelników na temat wydawanego periodyku. Regularnie pojawiały się różnego rodzaju reklamy, w których AWR

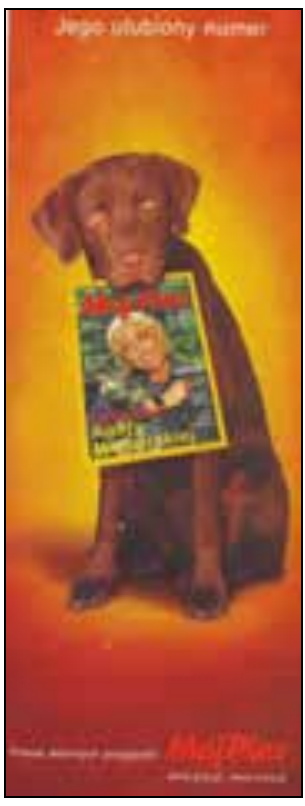

Zdjęcie 46. Wybrane ogłoszenie wydawnicze zamieszczone na łamach „Wprost” „Wprost” 2001, nr 30, s. [93]

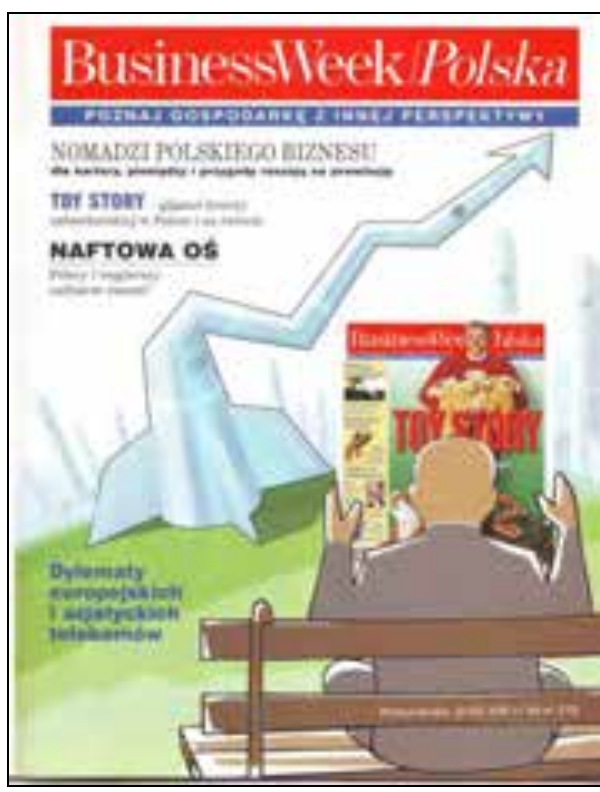

Zdjęcie 47. Wybrane ogłoszenie wydawnicze zamieszczone na łamach „Wprost” „Wprost” 2001, nr 2, s. [67]

312 P. Moszyński, Wyczucie, „Wprost” 2004, nr 20, s. 97.

313 S. Sieradzki, współpraca M. Rychter, P. Cywiński, Niemiecka prasa, „Wprost” 2003, nr 43, s. 22-24, 26.

314 P. Cywiński, Brukowce na bruku, „Wprost” 2001, nr 11, s. 77.

315 J. M. Fijor, Forbes wolności, „Wprost” 2002, nr 42, s. 54-56. 
promowała wydawane przez siebie tytuły (zdjęcie 46 i 47). Równie systematycznie zamieszczano informacje na temat stron internetowych, a w następnych latach wydań on-line pisma. Ciekawą formą promocji było drukowanie, w całości lub części, wybranego artykułu z „BusinessWeek Polska”, tytułu należącego do portfolio wydawcy, a obok zamieszczenie reklamy tegoż pisma.

Każda z autoreklam przykuwała uwagę jasnymi barwami. Przeważnie zamieszczano w nich kopie okładek proponowanych periodyków, czasem wzbogacając je o zachęcające hasła. Dodatkowo inseraty promujące periodyk „Mój Pies” posiadały zawsze ukazany humorystyczny akcent, nawiązujący do tytułu pisma (zdjęcie 46).

Dwa razy do roku przypominano czytelnikom o prenumeracie tytułów. Najbogatsze były ogłoszenia zachęcające do kupna i lektury „Wprost” 316 .

Na łamach pisma, poza promocją tytułów należących do AWR, pojawiały się, jak już wspomniano, także reklamy innych periodyków. W sumie w badanym okresie $\mathrm{w}$ anonsach znalazło się 29 tytułów zarówno dzienników, jak i czasopism. Wśród nich proponowano: „CHIP”, „Cogito”, „Dlaczego. Magazyn studencki”, „Dobre wnętrze”, „Gazetę Wyborczą” (i dodatki do niej: „Duży Format”, „Gazetę Praca”, „Nową Turystykę”), „Dziennik Chicagowski”, „Foyer”, „Gazetę Prawną”, „Look. Magazyn o Urodzie i Zdrowiu”, „M jak mieszkanie”, „Metropol”, „Mój Pies”, „Murator”, „Pani”, „Pani Domu”, „Podróże”, „Profit”, „Przyjaciółkę”, „Puls Biznesu”, „Rejs. Magazyn Żeglarzy i Motorowodniaków”, „Super Express”, „Twój Styl”, „Vita”, „Votre Beauté”, „Zdrowie” oraz „Życie”.

Reklamy tytułów były zazwyczaj całostronicowe, zwracały uwagę bogatą kolorystyką, choć przeważnie ograniczały się do kopii okładki reklamowanego numeru pisma i haseł, mających zachęcić odbiorców „Wprost” do sięgnięcia również po inne periodyki. Czytelnicy znajdowali te ogłoszenia $\mathrm{w}$ rozmaitych miejscach pisma. Oto kilka przykładów całostronicowych inseratów, jak również skromniejszych ogłoszeń, o objętości jednego lub dwóch modułów, zamieszczanych u dołu lub z boku strony (zdjęcia 48-51). 


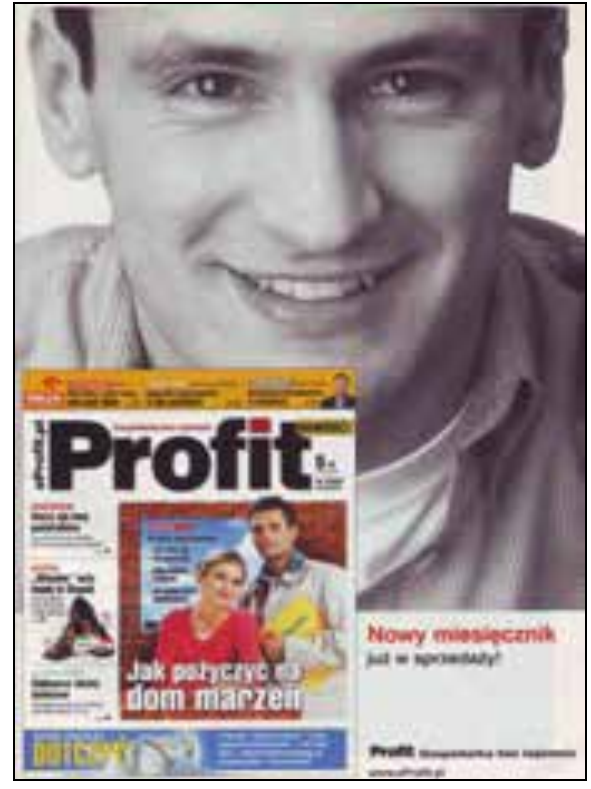

Zdjęcie 48. Wybrane ogłoszenie wydawnicze zamieszczone na łamach „Wprost” „Wprost” 2001, nr 35, s. [17]

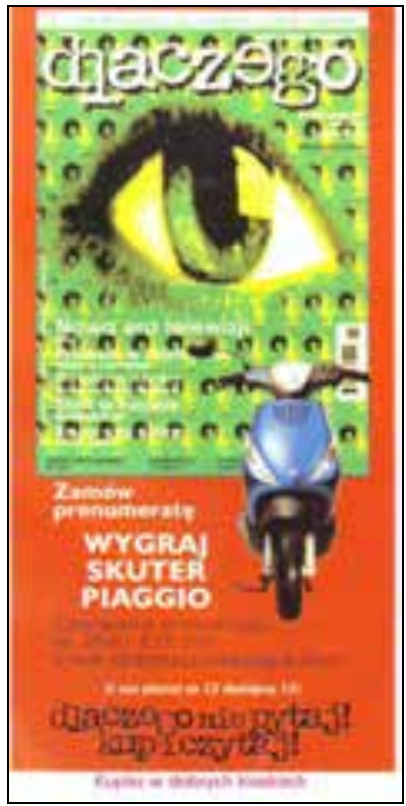

Zdjęcie 50. Wybrane ogłoszenie wydawnicze zamieszczone na łamach „Wprost” „Wprost” 2001, nr 14, s. 48

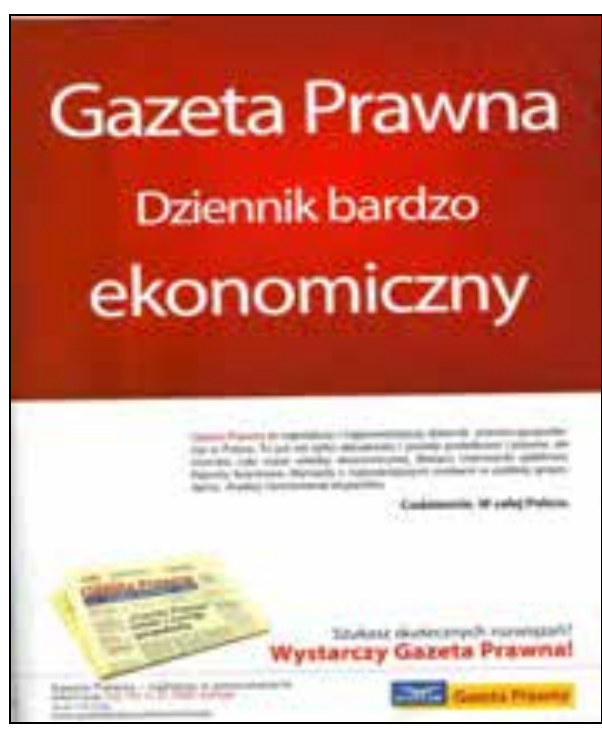

Zdjęcie 49. Wybrane ogłoszenie wydawnicze zamieszczone na łamach "Wprost” „Wprost” 2005, nr 38, s. [87]

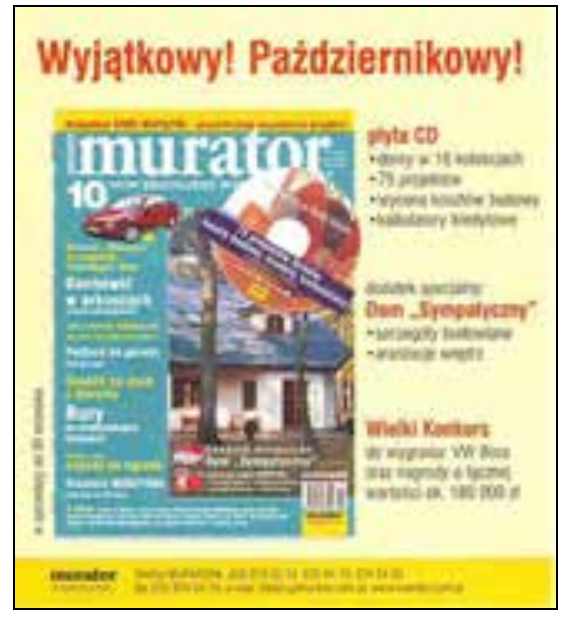

Zdjęcie 51. Wybrane ogłoszenie wydawnicze zamieszczone na łamach „Wprost”

„Wprost” 2002, nr 39, s. 72 
W każdym z przytoczonych przykładów uwagę czytelnika zwracał inny szczegół: w pierwszym ogłoszeniu było to zdjęcie potencjalnego czytelnika, w drugim hasła reklamowe, w trzecim kopia okładki kolejnego numeru proponowanego pisma oraz zdjęcie nagrody, którą można było wygrać w zamian za zamówienie prenumeraty. Ostatnie ogłoszenie jest najmniej czytelne, pomimo, że kolorystycznie wyróżnia się na tle strony. Umieszczone w tekście artykułu mogło być irytujące dla odbiorcy.

Warto wspomnieć, że w tygodniku „Wprost”, podobnie jak w „Polityce”, angażowano się $\mathrm{w}$ akcję przeciwko nowej ustawie VAT. W numerze 5 (2004) znalazła się krótka wzmianka na ten temat ${ }^{317}$, a w wydaniach następnych pojawiły się całostronicowe reklamy, stanowiące element akcji ${ }^{318}$.

Bardzo duża liczba informacji związanych z prasą, zamieszczanych na łamach „Wprost”, zasługuje z pewnością na odrębne opracowanie. Interesujące informacje, dotyczące „czwartej władzy”, były, w przypadku dłuższych tekstów, z reguły rzetelnie przygotowywane. Wyraźna była również troska wydawcy o autopromocję nie tylko flagowego tytułu, jakim był omawiany tygodnik, ale również pozostałych periodyków, uzupełniających portfolio AWR „Wprost”. Systematyczne przypominanie o nich, jak również częste propozycje kierujące czytelników na strony internetowe pisma, świadczą o dobrze przemyślanych działaniach marketingowych Biura Reklamy i Promocji omawianego periodyku.

Podsumowując zebrany materiał i przedstawione powyżej reprezentatywne dlań przykłady, można stwierdzić, że tygodnik „Wprost” pod względem liczby i zróżnicowania informacji związanych z książką w niewielkim stopniu ustępował $\mathrm{w}$ badanym okresie swemu największemu rywalowi.

Jednak wyraźna była różnica w sposobie prezentowania tekstów; porównanie wypadało zdecydowanie na korzyść „Polityki”. W przypadku „Wprost” często widać było opisywaną powyżej niedokładność, niedbałość i niekonsekwencję, szczególnie w odniesieniu do recenzji proponowanych lektur. Nadto częste zmiany tytułów i zawartości rubryk, brak informacji na ten temat powodowały $\mathrm{z}$ jednej strony chaos, a $\mathrm{z}$ drugiej niepewność czytelników. Był to błąd, którego można było uniknąć, a który wpływał niekorzystnie na odbiór treści proponowanych przez pismo. Treści skądinąd interesujących, przynajmniej w odniesieniu do zagadnień związanych

317 [br. aut.], Koalicja przeciw głupocie, „Wprost” 2004, nr 5, s. 33.

318 Zob. np. „Wprost” 2004, nr 5, s. [25]. 
z książką. Jakkolwiek obraz współczesnej literatury wyłaniający się z łamów periodyku miał charakter pesymistyczny, to jednak uwagę zwracały trafne spostrzeżenia i ciekawe wnioski (na przykład dotyczące monotonii tematów, poruszanych przez twórców rodzimych). Warto również podkreślić, że podobnie, jak było to w przypadku tygodnika „Polityka”, tak i tu odbiorca odnajdywał niemal wszystkie formy informacji związanej z książką. Były one wykorzystywane w różnym stopniu, co zostanie omówione $\mathrm{w}$ rozdziale podsumowującym prasę opinii. 


\section{4. „NEWSWEEK POLSKA” - najlepsze medium ${ }^{1}$}

\subsubsection{Historia pod tytułem „Newsweek"2}

Zajmowaliśmy cztery małe biurka w ogromnej sali, która za kilka miesięcy miała stać się newsroomem. Wkrótce przybyło biurek, krzeseł i pokoi na pierwszym piętrze biurowca w dzielnicy nowych biur i centrów handlowych na warszawskiej Ochocie. [...] mieliśmy tyle samo obaw, co nadziei. Amerykański tytuł, wprowadzany na polski rynek przez niemieckiego wydawcę, mógł odnieść sukces, ale też nasza robota mogła się równie dobrze skończyć klapą. Okazało się, że trafiliśmy3.

Najmłodszym z omawianych tytułów w grupie pism opinii jest tygodnik „Newsweek Polska”. Wydawany jest on na licencji amerykańskiej przez koncern Axel Springer Polska. Stanowi jedną z pięciu nieanglojęzycznych mutacji amerykańskiego periodyku, założonego w 1933 r. ${ }^{4}$ W $1961 \mathrm{r}$. The Washington Company wykupiła tytuł. Główna siedziba od początku istnienia wydania amerykańskiego mieści się w Nowym Jorku. Obecnie publikowane są trzy anglojęzyczne edycje: atlantycka (Wielka Brytania, Europa, Afryka i Bliski Wschód), azjatycka (kraje Azji i Pacyfiku) oraz latynoamerykańska (Meksyk, Karaiby, Ameryka Środkowa i Południowa). Wydawanych jest także pięć międzynarodowych edycji na zasadach licencji, z czego cztery obcojęzyczne.

Pojawienie się na rynku prasowym w Polsce tytułu, którego marka znana była wielu czytelnikom, poprzedzone zostało z jednej strony niemal dwuletnimi przygotowaniami wydawcy, z drugiej licznymi publikacjami, szczególnie $\mathrm{w}$ prasie branżowej ${ }^{5}$. Zastanawiano się, czy nowy periodyk znajdzie dla siebie miejsce wśród dwóch już istniejących, zakorzenionych i zdawałoby się, w pełni zaspokajających potrzeby czytelnicze, zainteresowanych tego typu prasą . Warto przypomnieć, że wcześniej podejmowane były próby wejścia na rynek trzeciego tytułu, który miał złamać duopol „Polityki” i „Wprost”. W 1993 r. wydawany przez francuskiego edytora tygodnik „Spotkania” upadł po trzech latach ukazywania się, podobnie było

1 Tytuł jednej z informacji, zob. [br. aut.], Najlepsze medium, „Newsweek Polska” 2002, nr 7, s. [111].

2 Tytuł wystawy, organizowanej przez omawiany tygodnik.

3 [br. aut.], Od kuchni [10 lat Newsweeka], „Newsweek Polska” 2011, nr 36, s. 21.

4 Pierwszy numer ukazał się na rynku 17 lutego $1933 \mathrm{r}$.

5 Zob. np. wybrane numery pism: „Media i Marketing Polska”, „Press”.

${ }^{6}$ Zob. np. T. Barański, Czekajq̨c na „Newsweeka”, „Press” 2001, nr 3, s. 46-47. 
z innym tytułem: w 1998 r. z rynku, po 13 tygodniach wydawania, zniknęły „Fakty”.

Być może m.in. dlatego redaktorzy naczelni konkurujących ze sobą tygodników („Polityki” i „Wprost”), Jerzy Baczyński i Marek Król, bez obaw oczekiwali debiutu nowego pisma, podkreślając, że nie boją się konfrontacji, co więcej, twierdząc, że konkurencja jest potrzebna, bo dzięki niej skorzystają nie tylko czytelnicy, ale i cały segment pism społeczno-politycznych?

Do podobnych wniosków doszedł niemiecki koncern medialny, Axel Springer. Nie obawiając się ryzyka, podjął wyzwanie, z którego zrezygnowało inne wydawnictwo, Edipresse Polska. Jego prezes, Zbigniew Napierała, był pomysłodawcą wydawania polskiej edycji amerykańskiego tytułu. Jej projektem, zaakceptowanym później przez Amerykanów, zajął się Tomasz Wróblewski ${ }^{8}$. Kiedy właściciele Edipresse Group w Szwajcarii wycofali się z projektu, T. Wróblewski, już z gotową koncepcją i nawiązanym kontaktem z Amerykanami, zwrócił się do koncernu niemieckiego, a konkretnie do prezesa polskiego przedstawiciela wydawcy, Axel Springer Polska, Wiesława Podkańskiego, który wspomina:

Rynek był podzielony między mocno upolitycznione „Politykę” i „Wprost”. Tomek zaproponował trzecią drogę - pismo, które nie zrezygnuje z polityki, ale dotrze do czytelników zainteresowanych obszarem tematów społecznych ${ }^{9}$.

Skoro Axel Springer poszukiwał w tym okresie pomysłu na opiniotwórczy tygodnik w Polsce, propozycja T. Wróblewskiego została szybko zaakceptowana. Wpisała się ona idealnie w strategię rozwojową firmy, która opierała się głównie na tzw. dywersyfikacji, czyli zaangażowaniu w nowe, różne segmenty rynku wydawniczego ${ }^{10}$. Jednocześnie wśród argumentów, które przemawiały na korzyść wprowadzenia w życie pomysłu wydawania tego akurat tygodnika, niebagatelną rolę odgrywała sama marka tytułu. Oryginalny „Newsweek” był doskonale rozpoznawalny jako jedno z nielicznych pism dostępnych w salonach Empik przed rokiem 1989, co przekładało się nie tylko na potencjalny sukces czytelniczy, ale również na dobry start w agencjach reklamowych. Nadto, dziennikarstwo amerykańskie postrzegane było przez polskie społeczeństwo jako profesjonalne, niezależne i obiektywne, dzięki czemu tytuł, który miał być wydawany na licencji

7 Ibidem, s. 46-47. Podobne opinie, zob. T. Wolski, Polski „Newsweek”, „Press” 2002, nr 35, s. 65.

8 W tamtym okresie S. Wróblewski pracował w redakcji tygodnika „Wprost”.

${ }^{9}$ A. Niziołek, Solista, „Press” 2007, nr 11, s. [45].

10 Więcej na ten temat, zob. J. Wilk, Wprowadzenie nowego produktu na rynek wydawniczy - studium przypadku „Newsweeka” $i$ „Faktu”, ,Zeszyty Naukowe Wyższej Szkoły Bankowej we Wrocławiu" 2008, nr 10, s. [209]-212. 
Amerykanów, zyskiwał tym samym od pierwszego numeru. Niemałe znaczenie miało również i to, że polscy dziennikarze, mający tworzyć tygodnik, posiadali szeroki dostęp do wspólnej dla wszystkich mutacji, bazy materiałów z różnych dziedzin.

Koncern niemiecki postanowił skorzystać z tak sprzyjających okoliczności, tym bardziej że swe doświadczenie, a także intuicję wydawniczą opierał na własnej ponad 50-letniej historii11 a w polski rynek wydawniczy inwestował od 1994 r. ${ }^{12}$ Profesjonalizm wydawcy sprawdził się na rynkach prasowych również w innych krajach, m.in. w Czechach, we Francji, Hiszpanii, Szwajcarii, i na Węgrzech, a także w działalności multimedialnej: Wydawnictwo Axel Springer posiadało w tamtym okresie udziały m.in. w kilku stacjach telewizyjnych (ProSieben, SAT1), radiowych (Radio Hamburg), firmach internetowych i teleinformatycznych. W latach 2001-2005 wydawało w Polsce kilkanaście czasopism, m.in. prasę adresowaną do kobiet („Cienie i Blaski”, „Oliwię”, „Panią Domu”, „Sekrety Serca”), dla młodzieży („Dziewczyna”, „Popcorn”), poświęconą problematyce komputerowej („Komputer Świat”, „Play”, „Wszystko Gra”), związaną z motoryzacją („Auto Bazar”, „Auto Sukces”, „Auto Świat”), dotyczącą urządzania i dekoracji wnętrz („Mieszkaj”) oraz prasę codzienną („Dziennik Polska. Europa. Świat”, „Fakt”) ${ }^{13}$. Ofertę koncernu wzbogacały także kolekcje książek.

Przygotowania do wydania pierwszego numeru pisma opiniotwórczego, które objęły również szczegółowe badania rynku, zajęły wydawcy niemal dwa lata. Zanim „Newsweek Polska” pojawił się w kioskach, T. Wróblewski wraz z zespołem, składającym się z byłych dziennikarzy m.in. redakcji „Gazety Wyborczej”, „Super Expressu”, „Wprost”, i „Życia” przygotował dziewięć numerów zerowych. W. Podkański podkreślał:

11 Koncern Axel Springer powstał w 1946 r., debiutując pismem „Nordwestdeutsche Hefte", wydawanym w Berlinie przez A. C. Springera. W ciągu swej wieloletniej historii koncern wydawał tytuły $\mathrm{z}$ prasy codziennej, czasopisma społeczno-polityczne, kobiece, motoryzacyjne i komputerowe. Jednym z najbardziej rozpoznawalnych tytułów koncernu jest tabloid „Bild”. Więcej, zob. O. Dąbrowska-Cendrowska, Niemieckie koncerny prasowe w Polsce w latach 1989-2008, Dom Wydawniczy Elipsa, Warszawa 2009, m.in. s. 52-58, $152-$ 158; 10-lecie Axel Springer Polska, dodatek reklamowy „Media i Marketing Polska. Raport Specjalny", wrzesień 2004.

12 Początkowo funkcjonowało na rynku polskim pod nazwą Europress Grupa Wydawnicza Sp. z o.o., po kilku miesiącach od zarejestrowania zmieniono nazwę na Axel Springer Polska Sp. z o.o. Jako pierwszy tytuł pojawił się periodyk dla kobiet „Pani Domu” (pierwszy numer ukazał się 31 sierpnia 1994 r.). Od początku działalności wydawnictwa w Polsce kierował nim prezes W. Podkański, zastąpiony później przez F. Felsa, dotychczasowego dyrektora generalnego polskiej spółki koncernu.

13 Więcej, zob. O. Dąbrowska-Cendrowska, Niemieckie koncerny... 
Na pewno nie będziemy szukać sensacji. Zaprezentujemy bardzo krytyczne podejście do aktualnych wydarzeń. [...] W tygodniku oprócz tematów społecznych i kulturalnych znajdzie się dużo artykułów z dziedziny nauki. Mniej będzie natomiast polityki [...] „Newsweek" nie będzie jednak unikał tych tematów, lecz dziennikarze będą obiektywni ${ }^{14}$.

Z kolei T. Wróblewski składał raczej ogólne obietnice:

Mamy nadzieję, że uda nam się stworzyć nową kategorię na rynku prasowym [...] Nie chcemy być postrzegani jako klasyczny komentujący tygodnik, ale magazyn, który szeroko traktuje społeczeństwo ${ }^{15}$.

Jednocześnie $w$ mediach rozpoczęła się szeroko zakrojona kampania reklamowa, na którą wydawca przeznaczył $12 \mathrm{mln}$ zł ${ }^{16}$. Te działania uaktywniły redakcje „Polityki” i „Wprost”: zwiększyły one koszty własnej promocji, poszukując równocześnie innych sposobów na powiększenie swych przychodów ${ }^{17}$.

Na początku 2001 r. przedstawiciel Axel Springer Polska złożył w sądzie wniosek o rejestrację tytułu. Wtedy okazało się, że od lat 80. XX w. należy on do koła ZSMP przy Wyższej Szkole Pedagogicznej w Piotrkowie Trybunalskim. Wyjaśnienie sprawy zajęło prawnikom wydawcy niemieckiego kilka miesięcy ${ }^{18}$. Jednak już w lipcu tegoż roku w krajach, w których wydawano magazyn, podano oficjalny komunikat o tym, że jesienią pojawi się kolejna edycja tygodnika, tym razem w Polsce. Umowa licencyjna podpisana została przez prezesa Newsweek International Inc. Petera J. Luffmana oraz prezesa Axel Springer Polska, W. Podkańskiego i Floriana Felsa (dyrektora zarządzającego wydawnictwem). Tytuł drukowany miał być w Radzyminie pod Warszawą. Cały, ponad 70-osobowy, zespół przeszedł wcześniej specjalne szkolenie. Nowego na gruncie polskim stylu pisania i redagowania tekstów, umiejętnego wykorzystania zdjęć uczyli dziennikarzy „Newsweek Polska” Amerykanie.

Pierwszy numer tak oczekiwanego pisma pojawił się z datą 9 września 2001 r., w poniedziałek (dwa konkurencyjne tygodniki trafiały do czytelnika w środę). Liczył 116 stron, kosztował 3 zł. Pierwszych kilkanaście numerów rozeszło się w wysokości ok. 325 tys. egz. ${ }^{19} \mathrm{~W}$ tym okresie jego najwięksi konkurenci sprzedawali średnio 253 tys. egz. („Polityka”)

14 T. Wolski, Polski..., s. 64.

15 K. Prewęcka, Będzie trio, „Media i Marketing Polska. Raport Specjalny. Magazyny” 2001, nr 16, s. 9.

${ }^{16}$ K. Prewęcka, Więcej opinii, „Media i Marketing Polska” 2001, nr 16, s. 9.

17 K. Prewęcka, Twórczy doping, „Media i Marketing Polska” 2001, nr 21, s. 26.

18 B. Drozdowska-Wolska, News na rynku, „Press” 2001, nr 8, s. 26.

19 Za: A. Niziołek, Solista, „Press” 2007, nr 11, s. [45]. 
i 224 tys. egz. („Wprost”) ${ }^{20}$. Siedziba redakcji przez cały badany okres mieściła się przy Alejach Jerozolimskich $181 \mathrm{w}$ Warszawie. Redaktorem naczelnym został T. Wróblewski. Obok niego, w stopce redakcyjnej, pojawiły się inne nazwiska: Andrzeja Dziurdzikowskiego, Barbary Harasimowicz-Waliszewskiej (sekretarz redakcji), Grzegorza Jankowskiego, Małgorzaty Kacprzak, Katarzyny Klejnockiej (zastępcy redaktorów prowadzących), Dariusza Rosickiego, Grzegorza Sommera (redaktorzy prowadzący), Ewy Wilcz-Grzędzińskiej, (zastępcy redaktora naczelnego). W rubryce Zamiast słów znalazło się zdjęcie całego zespołu redakcyjnego, w skład którego weszli m.in. Agnieszka Fedorczyk, Grzegorz Jankowski, Michał Karnowski, Wiesław Kot, Anna Mackiewicz, Wojciech Maziarski, Grażyna Musiałek, Piotr Osęka, Antoni Pawlak, Dorota Romanowska, Igor Ryciak, Dariusz Stasik, Anita Szarlik, Kamil Śmiałkowski i Dariusz Wilczak. Wśród komentatorów pisma pojawiły się nazwiska m.in. Stanisława Gomułki, Julii Pitery i Rafała A. Ziemkiewicza.

Richard M. Smith, redaktor naczelny „Newsweeka”, zwracając się do polskich czytelników, pisał:

Mierzymy wysoko, ale nasz cel jest prosty: dostarczyć Państwu możliwe najlepsze połączenie tego, co „Newsweek” pisze o świecie, z wysokiej jakości opisem wydarzeń, nowych trendów, kierunków rozwoju i postaci, które kształtują dzisiejsze oblicze Polski ${ }^{21}$.

\section{Natomiast T. Wróblewski obiecywał:}

Bezstronność, jaka stała się częścią amerykańskiej filozofii „Newsweeka”, pozwoli nam teraz, tu, w Polsce, bez obaw podejmować najciekawsze, a jednocześnie najtrudniejsze i politycznie niewygodne tematy. Powaga i prestiż pisma pozwolą też zajmować się najbardziej przyziemnymi tematami życia codziennego, bez rezygnowania jednocześnie z poważnych komentatorów i opiniotwórczych opracowań22,

równocześnie stwierdzając:

Dziś macie Państwo w rękach pismo hołdujące najwyższym światowym standardom dziennikarstwa. Tygodnik wykorzystujący najnowocześniejsze techniki prezentacji graficznej23.

Pomimo podobnych treści, które czytelnik odnajdował w periodyku, różnice pomiędzy nowym pismem a jego największymi konkurentami były widoczne na pierwszy rzut oka. Formuła tygodnika nie przeszkodziła

\footnotetext{
20 Źródło: ZKDP za I-VII 2001.

${ }^{21}$ R. M. Smith, Wiemy, że nie jest to łatwe wyzwanie, „Newsweek Polska” 2001, nr 1, s. 2.

22 T. Wróblewski, Musimy się jeszcze wiele nauczyć, „Newsweek Polska” 2001, nr 1, s. 2.

23 Ibidem.
} 
redakcji w realizacji celu, jakim była maksymalna aktualność: nie tylko komentowano i podsumowywano wydarzenia, ale także je zapowiadano i przewidywano. Duże znaczenie miała również szata graficzna i fotografia oraz specjalnie wyodrębniony dział infografiki ${ }^{24}$. Komunikatywne teksty, pisane przy wykorzystaniu techniki „od szczegółu do ogółu”, odpowiednie proporcje działów, ich przejrzystość i logika ${ }^{25}$ stały się istotnym atutem pisma, podobnie jak bezpretensjonalny język, który spodobał się szczególnie młodszym odbiorcom ${ }^{26}$. Każdy tekst budowano na wyrazistej, jasno sformułowanej tezie. Wynikało to pośrednio z faktu, że dziennikarze pisma korzystali z obszernego style booka, redakcyjnego podręcznika, opisującego technikę przygotowywania tekstów, wyjaśniającego, co każdy artykuł powinien zawierać, z jakich elementów winien się składać, tak by nie tylko przyciągnąć uwagę czytelnika, ale i zachęcić go do lektury całej publikacji. Każdy artykuł, zgodnie z regułami amerykańskimi, przechodził kilkustopniową korektę, co powodowało, że, jak twierdzili niektórzy dziennikarze, wszystkie teksty stawały się jednolite, bez wyraźnego charakteru piszących. Nie wpłynęło to jednak negatywnie, przynajmniej w początkowym okresie, na popularność tygodnika.

Jednocześnie warto zaznaczyć, że pismu sprzyjał także moment historyczny. Już w numerze 3 redakcja musiała zmierzyć się z tematem ataków terrorystycznych w Nowym Jorku (to wydanie osiągnęło rekordową sprzedaż 409 tys. egz.) ${ }^{27}$. Kolejny numer poświęcony był wyborom parlamentarnym w Polsce: „pokazaliśmy, jak będzie wyglądał przyszły Sejm, kto będzie premierem itd. Dziś wszyscy tak robią, ale wówczas to było coś niezwykłego"28 - wspomina T. Wróblewski.

W październiku świętowano wejście pisma na rynek w Polsce. W uroczystej gali udział wzięli m.in. Tadeusz Konwicki, Monika Richardson, Małgorzata Solorz-Żak i Andrzej Wajda.

Od pierwszych miesięcy na rynku „Newsweek Polska” zajął pozycję lidera wśród tygodników opinii. Po czterech miesiącach wydawca przestał

${ }^{24}$ Warto zwrócić uwagę, że infografika, łącząca w sobie liczby, rysunki, teksty i zdjęcia, przedstawiająca informację $\mathrm{w}$ formie łatwej nie tylko do przeczytania, ale i zrozumiałej, bywa nierzadko niedoceniana bądź błędnie przygotowywana. W przypadku „Newsweek Polska” niezwykle pomocne okazały się w tej sytuacji sprawdzone wzorce amerykańskie, które już na starcie nowego tygodnika odróżniły go korzystnie od pozostałych tytułów, szczególnie „Polityki” i „Wprost”.

25 [br. aut.], Strzał w dziesiątkę. „Newsweek Polska”, „Press” 2001, nr 9, s. 26.

26 Około 74\% odbiorców pisma nie przekroczyła 44. roku życia, dużą grupę stanowili studenci. Źródło: dane PBC General, okres X 2001-II 2002, za: K. Prewęcka, Opinie zawsze w cenie, „Media i Marketing Polska” 2002, nr 8, s. 17.

27 „Press” 2001, nr 10, s. 8.

28 A. Niziołek, Solista, s. 46. 
dopłacać do pisma, a po kolejnych pięciu zwróciły się koszty, przeznaczone na jego uruchomienie ${ }^{29}$.

Jednak w kolejnych miesiącach sytuacja zaczęła się zmieniać. Tempa i zasad, dotyczących pracy, narzuconych przez T. Wróblewskiego, nie wytrzymało wielu dziennikarzy. Jednocześnie coraz częściej narzekano na niemal całkowite uzależnienie od koncepcji redaktorów i brak samodzielności: „dostaliśmy przykaz, by każde pojęcie w tekście - poza wyrazami ojciec i matka - wyjaśniać. Burzyliśmy się, że tak się nie robi, że nas wyśmieją. Ale to na nic"30 - wspomina jeden ze współpracowników pisma, a inny dodaje: „W tej redakcji pożałowałem, że zostałem dziennikarzem”31. Duża rotacja piszących do tygodnika, także z czasem bardziej uderzająca jednostronność tekstów, a co za tym idzie, malejący obiektywizm, powodowały, że tytuł zaczął tracić czytelników. Konkurencyjne periodyki wprowadziły zmiany, a walor nowości, który towarzyszył „Newsweekowi”, spowszedniał, choć tygodnik nadal utrzymywał się w grupie najpoczytniejszych tytułów tej grupy. W takich okolicznościach wydawca podjął próby ratowania sytuacji. Jeszcze w 2001 r. zaproponowano czytelnikom dwa wydania specjalne: pierwsze, zatytułowane Ameryka $w$ ogniu, poświęcono wydarzeniom z 11 września 2001 r. Drugie (2001 - rok $w$ zdjęciach) zawierało fotografie, mające zilustrować najważniejsze wydarzenia mijającego roku. Pojawiły się fotografie związane z polityką, kulturą, religią i sportem. Od 2002 r. do wybranych numerów dołączano kilkunastostronicowe dodatki tematyczne: Jak szukać pracy za granica?, Mundial 2003 oraz Zapis klęski. Wydania specjalne i dodatki stały się od tej chwili tradycją pisma ${ }^{32}$. W tygodniku nawiązano również współpracę z wybranymi stacjami radiowymi i odtąd systematycznie na jego łamach pojawiało się zaproszenie do słuchania kilkuminutowych audycji, prowadzonych przez dziennikarzy periody$\mathrm{ku}^{33}$. Z czasem zwiększyła się liczba proponowanych programów, jak również liczba stacji radiowych ${ }^{34}$.

Jednocześnie nastąpiły niewielkie roszady w składzie redakcji ${ }^{35}$, a we wrześniu 2002 r. zmieniono makietę pisma. Wprowadzono inny krój czcionek, nowe kolory i nową siatkę graficzną, zwiększono liczbę zestawień

29 Ibidem.

30 T. Sygut, Newsweekowe roszady, „Przegląd” 2004, nr 38, s. 34.

31 A. Niziołek, Solista, s. 47.

32 Ich dokładniejsze omówienie znajdzie się w dalszej części rozdziału.

33 Czytelnikom proponowano albo spotkania z autorami wybranych artykułów danego numeru albo wydania radiowe „Newsweeka”. Zob. np. „Newsweek Polska” 2002, nr 39, s. [5].

${ }^{34}$ W 2005 r. Radio Newsweek funkcjonowało m.in. w Białymstoku, Gliwicach, Koninie, Lublinie, Łodzi, Olsztynie, Opolu, Ostrołęce, Radomiu i Tarnowie.

35 M.in. miejsce A. Dziurdzikowskiego i G. Sommera zajęła J. Zarembina, pojawiła się również nowa funkcja redaktora koordynatora, którą objęła M. Brason. 
statystycznych oraz infografiki, redakcja obiecywała więcej bardziej zaangażowanych emocjonalnie zdjęć. Przygotowano kampanię reklamową, która miała wzmocnić słabnącą pozycję pisma na rynku i jego wizerunek jako wiarygodnego i poważnego tytułu. Zmiany miały służyć także pozyskaniu młodych czytelników. Od 18 listopada 2002 r. można było przeczytać część informacji z aktualnego wydania "Newsweek Polska” na ekranie telefonu komórkowego, chociaż oferta dostępna była jedynie dla klientów jednej tylko sieci i ograniczała się do pełnych informacji z trzech działów: Jupiter, Laboratorium, Peryskop 36 .

Mimo podejmowanych działań, „Newsweek Polska” stawał się jednak powoli

tygodniowym tabloidem, w którym górę brało kredo [pis. oryg.]: towar ma być ładnie opakowany, środek ma drugoplanowe znaczenie, a wszystko razem wzięte musi się sprzedać. Do obiegu weszło nawet pojęcie „niusłikizacji”, co oznaczało nic innego, tylko banalny tekst $\mathrm{z}$ ładnym obrazkiem i chwytliwym tytułem ${ }^{37}$.

Z początkowych deklaracji pozostało niewiele. Sytuację ratowały w pewnym stopniu nazwiska, które pojawiały się na łamach pisma. W wydaniu świątecznym w 2002 r. zostały one wyeksponowane tak, że czytelnik już na dwóch pierwszych stronach mógł dowiedzieć się, że dla tygodnika piszą m.in. Tomasz Piątek, Jerzy Pomianowski, Dawid Warszawski, Jan Winiecki, jak również John Hulsman, Klaus Schab, George Soros czy Jurij Andruchowycz i Wiktor Jerofiejew. Podobny krok podjęto rok później, a wśród autorów pisma pojawili się m.in. Jan Krzysztof Bielecki, Piotr Bratkowski, Carlos Fuentes, Ryszard Kapuściński, Kazimierz Kutz i Ewa Łętowska. Biorąc pod uwagę temat pracy, warto również wymienić innych, poza podanymi wyżej, współpracowników tygodnika. Wśród nich znaleźli się także Krystyna Jagiełło, Tomasz Jastrun i Wojciech Kuczok.

Inną formą promocji periodyku stały się popularne $\mathrm{w}$ tamtym okresie, podejmowane również $\mathrm{w}$ innych redakcjach, spotkania internetowe, czyli czaty z dziennikarzami. Czytelnicy mieli w tym przypadku taką możliwość od 2002 r., a od roku 2003 na łamach pisma systematycznie przypominano o zaletach korzystania $\mathrm{z}$ jego strony internetowej38. Miała ona domenę o nazwie tożsamej $\mathrm{z}$ tytułem tygodnika $\mathrm{w}$ jego wersji tradycyjnej: www.newsweek.pl. Podzielono ją na wyraźnie wyodrębnione moduły: Archiwum, Działy, Online, Redakcja, Reklama Twój Głos, Wydania, Zakupy. Użytkownik mógł tu również odnaleźć odnośniki do głównych rubryk, adekwatnych z wydaniem tradycyjnym (m.in. Postać tygodnia, Społeczeń-

\footnotetext{
${ }^{36}$ [br. aut.], Newsweek $w$ telefonie, „Newsweek Polska” 2002, nr 47, s. [5].

37 T. Sygut, Newsweekowe..., s. 35.

38 [br. aut.], Sklepik on line, „Newsweek Polska” 2003, nr 17, s. 6.
} 
stwo, Świat) oraz do Radia Newsweek. O tym, że strona była starannie przygotowana i prowadzona, świadczyły listy czytelników. Jeden z nich pisał:

Ostatnio wszedłem na stronę internetową „Newsweeka”. Miłe zaskoczenie - macie jedną z lepszych stron, jakie znam. Choć wolę czytać was na papierze i kupuję każdy numer, możliwość korzystania z archiwum tekstów jest bardzo cenna ${ }^{39}$.

Inna opinia pozytywnie oceniająca stronę internetową periodyku znalazła swe odzwierciedlenie w 2004 r. w rankingu na najpopularniejsze portale: „Newsweek” znalazł się wśród 10 wybranych, cieszących się największym powodzeniem w Polsce ${ }^{40}$.

W tym czasie pochwały bardzo przydały się tygodnikowi, który w wyniku zamieszczenia dwóch kontrowersyjnych tekstów stracił wielu czytelników, a przede wszystkim opinię rzetelnego tytułu. Pierwszym był artykuł Bogacze na stos ${ }^{41}$, wraz z towarzyszącym mu rankingiem Dziesięciu najbardziej znienawidzonych Polaków. Publikacja, zaczynająca się od słów „Znienawidziliśmy polskich krezusów. Znienawidziliśmy polski kapitalizm. Znienawidziliśmy nasz kraj"42, wymieniająca m.in. Zbigniewa Niemczyka i Wandę Rapaczyńską wywołała z jednej strony niesmak wśród większości odbiorców, a z drugiej oburzenie i protesty środowiska dziennikarskiego ${ }^{43}$. Protestowali również sami zainteresowani, a jeden ze „znienawidzonych”, Aleksander Gudzowaty, zwrócił się do wydawcy „Newsweeka” w Nowym Jorku z pytaniem, czy tego typu teksty zgodne są ze standardami periodyku. T. Wróblewski przyznał się do błędu, ale to już nie pomogło w odzyskaniu części odbiorców.

Największe kontrowersje wzbudził jednak cykl artykułów, zamieszczony kilka tygodni później, anonsowany na okładce numeru hasłem Żydzi odbierają swoje 44 , a mówiący o Polakach, obawiających się restytucji mienia żydowskiego. Tekst spowodował odejście od pisma kolejnej grupy czytelników, zaś do redakcji, także do wydawcy, wysyłano listy protestacyjne, podpisane nie tylko przez naukowców, intelektualistów, ale również i samych dziennikarzy z innych pism ${ }^{45}$.

${ }^{39}$ A. Trybuła [czytelnik], Pożytki z Internetu, „Newsweek Polska” 2003, nr 33, s. 11.

40 [br. aut.], Newsweek z dobrej strony, „Newsweek Polska” 2004, nr 27, s. [7].

${ }^{41}$ St. Zunderlich, Bogacze na stos, „Newsweek Polska” 2004, nr 10, s. 44-46.

42 Ibidem, s. 44.

43 Więcej, zob. T. Sygut, Rzeczywistość według „Newsweeka”, „Przegląd” 2004, nr 20, s. [45]-[46].

${ }^{44}$ K. Olecki, współpr. M. Bogusz, M. Ananicz, Żydzi wracają po swoje, „Newsweek Polska" 2004, nr 14, s. 14-23.

45 A. Niziołek, Solista, s. 47. 
W maju 2004 r. podjęto próbę odzyskania zaufania odbiorców. Zwrócono się do nich z prośbą o wzięcie udziału w ankiecie na temat pisma: Zrób $z$ nami lepszy Newsweek ${ }^{46}$. Odpowiedziało na nią niemal 2 tys. czytelników ${ }^{47}$, a redakcja dziękując im za poświęcony czas, obiecywała, że uzyskane opinie pomogą jej w przygotowywaniu jeszcze lepszego pisma. Wydawca informował jednocześnie o kolejnych edycjach „Newsweeka” (na przykład w języku chińskim ${ }^{48}$ i rosyjskim ${ }^{49}$ ) czy choćby pojedynczych wydaniach specjalnych (jak wersja francuskojęzyczna jednego $\mathrm{z}$ takich wydań ${ }^{50}$ ), przypominając, że tytuł można czytać, poza językiem angielskim i polskim, także m.in. w języku hiszpańskim, japońskim i koreańskim.

Kolejne zmiany, poprzedzone kampanią reklamową w mediach, nastąpiły jesienią tego roku. Najważniejszą z nich było odejście ze stanowiska redaktora naczelnego T. Wróblewskiego (który został dyrektorem wydawniczym). Jednocześnie z pracy $\mathrm{w}$ redakcji zrezygnowała część dziennikarzy51. Tomasza Wróblewskiego zastąpił od numeru 41 (2004) Jarosław Sroka. Miał on, jak spekulowano w prasie, odbudować autorytet pisma. Zaczął od opracowania projektu zmian, które zamierzał wprowadzić $\mathrm{w}$ tygodniku. J. Sroka sprawował jednak funkcję naczelnego zaledwie 4 miesiące. Od numeru 5 (2005) redaktorem naczelnym został ponownie T. Wróblewski.

Rok 2005 nie przyniósł znaczących zmian w piśmie. Podobnie jak w innych periodykach, również w „Newsweek Polska” wprowadzono pewne innowacje, ale nie spowodowały one wyraźnego zwiększenia liczby odbiorców. Jednym z pomysłów było na przykład e-wydanie, do którego czytania redakcja zachęcała, pisząc:

Takie wydanie jest tańsze i można je pobrać z dowolnego miejsca na świecie na swój komputer. Ta wersja jest także bogatsza od papierowej o kilka dodatkowych opcji: wszystkie prezentowane w tekstach linki są aktywne, reklamy kierują od razu na stronę reklamowanego produktu, a niektóre teksty zostały wzbogacone o dźwiękowe wypowiedzi ich autorów. W prenumeracie e-wydanie tygodnika kosztuje tylko 1,50 zł52.

Przed podjęciem decyzji o prenumeracie czytelnik mógł bezpłatnie obejrzeć przykładowe e-wydania. Zamówienie wersji elektronicznej było

46 [br. aut.], Zrób z nami lepszy Newsweek, „Newsweek Polska” 2004, nr 21, s. 77-78.

47 [br. aut.], Zegarki dla czytelników, „Newsweek Polska” 2004, nr 25, s. [7].

48 [br. aut.], „Newsweek” po chińsku, „Newsweek Polska” 2003, nr 39, s. 8. Informowano, że „Newsweek” dociera do 25 mln osób, a dostępny jest w 190 krajach.

49 „Newsweek Polska” 2004, nr 21, s. 8. Wydawcą edycji rosyjskiej, drukowanej cyrylicą, miał być, podobnie jak w przypadku wydania polskiego, koncern niemiecki Axel Springer.

50 [br. aut.], Newsweek po francusku, „Newsweek Polska” 2004, nr 4, s. 9.

51 M.in. G. Induski, M. Kęskrawiec i D. Wilczak.

52 Numer pisma w wersji drukowanej kosztował wówczas 4,50 zł, zob. [br. aut.], Newsweek na ekranie, „Newsweek Polska” 2005, nr 44, s. 16. 
bardzo proste: wystarczyło wysłać sms na podany numer i aktywować otrzymany kod. Umożliwiono także odbiorcom zakupienie e-prenumeraty53. Przypominano czytelnikom również o innych, poza czatem i audycjami Radia Newsweek, formach spotkań z dziennikarzami pisma: blogi, prowadzone m.in. przez Piotra Bratkowskiego i Piotra Zarembę, cieszyły się, według redakcji, bardzo dużym zainteresowaniem internautów ${ }^{54}$.

Pomimo podejmowanych prób, tygodnikowi nie udało się jednak odzyskać utraconej w 2004 r. pozycji. W ostatnich badanych miesiącach nadal zajmował trzecie miejsce, w grupie pism opinii, po „Polityce” i „Wprost”55.

Niewątpliwie pojawienie się w 2001 r. nowego tytułu w tym segmencie prasowym w Polsce wpłynęło na poszerzenie rynku czytelniczego, zmusiło jednocześnie pozostałe tygodniki do walki o czytelnika i wprowadzenia zmian, które spowodowały urozmaicenie zarówno szaty graficznej, jak i zawartości każdego z tytułów.

\subsubsection{Zawartość, akcje i czytelnicy}

Typ pisma determinował jego zawartość, która sprowadzała się do zagadnień związanych z polityką, gospodarką, nauką i kulturą w Polsce oraz na świecie. Znajdowały one swe miejsce $\mathrm{w}$ działach i rubrykach, które w całym badanym okresie tylko w niewielkim stopniu modyfikowano.

Numer otwierała wspomniana już rubryka Zamiast słów, gdzie zamieszczano zdjęcia ilustrujące bądź wydarzenia ostatniego tygodnia, bądź też nawiązujące do zbliżających się Świąt. Następnie pojawiał się Peryskop. Nowy obraz tygodnia: trendy ludzkie, przypadki, świat polityki, w którym $\mathrm{w}$ formie zazwyczaj kilku- lub kilkunastozdaniowych not prezentowano wydarzenia określone w podtytule rubryki, wzbogacone trafnie wybranymi zdjęciami. Tutaj pojawiała się również rubryka, świadcząca o tym, że redakcja potrafiła zadbać o autopromocję: Newsroom. W tym tygodniu o nas. Czytelnik mógł w tym miejscu dowiedzieć się nie tylko o najnowszych inicjatywach pisma, ale i przypomnieć sobie o kontynuacji lub wznowieniu dawniejszych przedsięwzięć periodyku. Pisano tu także o otrzymanych przez dziennikarzy „Newsweeka” nagrodach bądź wyróżnieniach, o miejscu, jakie zajmował tygodnik w określonym czasie wśród pozostałych pism opinii. Na kolejnej stronie drukowano listy od czytelników, po których zaczynały się duże działy: Polska, Świat, Biznes, Nauka, Społeczeństwo,

53 Axel Springer stawia na Internet, http://wirtualnemedia.pl/document,,339229,Axel_ Springer_stawia_na_internet.html, 28 marca 2009.

54 Zob. np. [br.aut.], Blogerzy Newsweeka, „Newsweek Polska” 2005, nr 32, s. 8.

55 Średnie rozpowszechnianie płatne wyniosło w 2005 r.: 177,5 tys. egz. („Polityka”), 165, 5 tys. egz. („Wprost”), 165,4 tys. egz. („Newsweek Polska”). Źródło: ZDKP, cyt. za „Press” 2006, nr 3, s. 6 . 
Kultura, a w nich zazwyczaj dłuższe artykuły i komentarze. W ramach działów zamieszczano stałe rubryki, m.in. Postać tygodnia lub Laboratorium (tu drukowano ciekawostki z życia nauki). Numer zamykała stała rubryka Ostatnie słowo, gdzie swoje felietony drukowali m.in. Piotr Bratkowski, Andrzej Celiński, Ryszard Kalisz, Wojciech Maziarski, Antoni Pawlak, Jan Maria Rokita, Ernest Skalski, Jerzy Surdykowski, Maciej Wierzyński, Piotr Zaremba i Rafał A. Ziemkiewicz ${ }^{56}$.

Stałym zwyczajem pisma była edycja wspomnianych wcześniej dodatków tematycznych czy wydań specjalnych, drukowanych cyklicznie albo jednorazowo, związanych bądź to z wydarzeniami (na przykład Cel: Bagdad, Fala śmierci, Obrazy Roku), bądź o charakterze turystycznym (Dzika Polska, Kajakiem po Polsce, Polska na rowerze, Polska w siodle, $W$ górach Polski) lub kulinarnym (Ranking lokali Newsweeka, przedsięwzięcie realizowane z Radiem Zet). Poza wymienionymi, pismo proponowało swym czytelnikom również m.in.: Bibliotekę myśli (w jej ramach wydano na przykład Lektury współczesnego świata, które powinieneś mieć na półce czy 200 ksiq̨żek roku według Piotra Bratkowskiego, 79 postaci, które zmienity bieg dziejów), Encyklopedię zdrowia, Kwartalnik Studencki, Naukę.

Jednym z najbardziej rozpoznawalnych było cyklicznie pojawiające się wydanie specjalne, adresowane do młodszych odbiorców, zainteresowanych studiami za granicą ${ }^{57}$. Po raz pierwszy informacja na ten temat pojawiła się w numerze $40(2002)^{58}$. Miał to być 200 -stronicowy przewodnik na rok akademicki 2003/2004. Uwzględniono w nim ponad 700 uczelni w różnych krajach, m.in. w Australii, Francji, Niemczech, USA i Wielkiej Brytanii. Przedstawiono nie tylko dane związane z warunkami przyjęcia na prezentowane uczelnie, kosztami studiów czy wysokością stypendiów, ale także proponowano możliwości podjęcia sezonowej pracy i podawano kontakt do polskich wykładowców i studentów, którzy mogli służyć pomocą swym rodakom. W przewodniku zamieszczono również cenne wskazówki, dotyczące samego wyjazdu. Pomysł spotkał się z dużym zainteresowaniem, redakcja kontynuowała więc wydawanie przewodnika w latach kolejnych, drukując listy od wdzięcznych czytelników ${ }^{59}$.

Nie zapominano też o uczelniach rodzimych, poświęcając im jeden z rankingów pisma. W 2002 r. do numeru 13 dołączono 32-stronicowy dodatek (Ranking wyższych uczelni), w którym redaktor naczelny wyjaśniał:

56 W numerze 1 (2001) wydrukowano tekst A. Nagorskiego.

57 Wydanie specjalne „Newsweek Polska”: Studiować za granica 2003/2004 z datą 10 października 2002.

58 [br. aut.], Wydanie specjalne, „Newsweek Polska” 2002, nr 40, s. [4].

59 Zob. np. K. Golimowska [czytelniczka], Z „Newsweekiem” na studia, „Newsweek Polska" 2003, nr 47, s. 10; Zarząd Organizacji Studentów Polskich w Nowym Jorku, Studiować w USA, ibidem, 2004, nr 7, s. 11. 
Mają Państwo przed sobą pierwszy w Polsce praktyczny ranking wyższych uczelni. Przyjęliśmy tylko jeden, ale naszym zdaniem najbardziej miarodajny klucz oceny: po jakich studiach najłatwiej dziś zdobyć pracę, jakich absolwentów najbardziej poszukują pracodawcy?60

Obok wyników rankingu, przygotowanego na podstawie ankiety, scharakteryzowano również m.in. współczesny rynek pracy, omówiono staże studenckie i stypendia zagraniczne.

Adresowany do podobnej grupy docelowej był Kwartalnik Studencki. Po raz pierwszy wydano go w formie dodatku specjalnego do numeru 15, w 2003 r. Można było w nim znaleźć na przykład informacje dotyczące pracy w trakcie studiów, praktyk czy najkorzystniejszych kredytów studenckich. Przy okazji wydania drugiego, „Newsweek Polska” ogłosił konkurs internetowy Praktyka $z$ „Newsweeka”, w którym główną nagrodą miał być staż w Wielkiej Brytanii.

Kolejnym zestawieniem był Ranking szkół języka angielskiego. W 2002 r. redakcja pisała:

Szkoły językowe powstają jak grzyby po deszczu. Wiele z nich kusi niską ceną i lokalizacją na terenie osiedli. Blisko i tanio - to dla wielu argumenty wystarczające, by zdecydować się na tę, a nie inną szkołę. „Newsweek” postawił na ocenę ich jakości. Nasz ranking ma pomóc w wyborze najlepszych nauczycieli, programów i metod nauczania ${ }^{61}$.

Następnie wyjaśniano, w jaki sposób oceniano wybrane szkoły62. Na kolejnych stronach znajdował się ich wykaz wraz z adresami i z przypisanymi danej szkole punktami.

W akcję promującą naukę języka angielskiego wpisywała się również cykliczna akcja Let's Newsweek. Ta edukacyjna inicjatywa pisma polegała m.in. na wydaniu w 2004 r. zeszytu adresowanego do gimnazjów i szkół średnich, przeznaczonego do nauki języka angielskiego, w którym zamieszczono testy z anglojęzycznych wydań „Newsweeka” i komplety ćwiczeń. Podobne zestawy drukowane były systematycznie w wybranych numerach periodyku niemal od początku jego wydawania w Polsce.

Kolejnym rankingiem „Newsweek Polska” było zestawienie szpitali i związana z nim nagroda pisma "Wykrzyknik" dla najlepszej tego typu placówki w Polsce. Po raz pierwszy przyznano ją w 2002 r. Szpitalowi Wojewódzkiemu im. Jana Pawła II w Zamościu. Wybór poprzedzony był trwającą 6 miesięcy prezentacją szpitali i charakterystyką funkcjonujących w nich poszczególnych oddziałów. Natomiast w 2003 r. w tygodniku

60 T. Wróblewski, Szanowni Państwo, „Newsweek Polska” 2002, dodatek do numeru 13 Ranking uczelni.

${ }^{61}$ Ranking szkół językowych, „Newsweek Polska” 2002, nr 39, dodatek: Let’s Newsweek. Nasz ranking szkół języka angielskiego, s. VI.

62 Ibidem. 
zaproponowano czytelnikom ranking Bank przyjazny „Newsweeka”. Na zlecenie redakcji ankieterzy odwiedzili oddziały kilkunastu największych banków w Polsce, oceniając m.in. obsługę w oddziale, przez telefon i przez Internet, a wyniki tej inspekcji redakcja zamieściła w numerze 36 (2003) ${ }^{63}$. Inna inicjatywa tego typu zawierała się w rankingu 100 najcenniejszych firm w Polsce, obejmujących następujące branże: bankowość, energetyka, media, motoryzacja, paliwa, telekomunikacja, ubezpieczenia 64 . W tym samym roku redakcja zaproponowała wspomniany wcześniej Ranking lokali Newsweeka. Był to, w formie kilkunastostronicowej wkładki do podstawowego numeru, przewodnik po 100 najlepszych lokalach w sześciu największych miastach Polski, m.in. w Krakowie, Łodzi, Warszawie i Wrocławiu. Inne rankingi to: ranking najbogatszych prezydentów polskich miast, zestawienie najdroższych polskich firm, ranking najlepszych pracodawców 2003 r., a także I ogólnopolski ranking liceów ogólnokształcących, ranking najcenniejszych firm, raport o najdroższych i najbardziej snobistycznych ulicach siedmiu największych miast Polski.

Tygodnik był także organizatorem licznych imprez, spotkań i debat. Wśród nich znalazła się m.in. wystawa Historia pod tytułem „Newsweek”. Zorganizowano ją z okazji pierwszej rocznicy ukazywania się pisma na rynku w Polsce i 70. rocznicy „Newsweeka” amerykańskiego. Ekspozycję można było zwiedzać w kilkunastu miastach w Polsce, oglądając wydarzenia, zarejestrowane $\mathrm{w}$ formie zdjęć przez dziennikarzy i fotoreporterów pisma od ukazania się jego pierwszego numeru w 1933 r., a zamieszczonych na okładkach wydania amerykańskiego. Przedsięwzięciu towarzyszyły spotkania edukacyjne, m.in. cykl gawęd historycznych, nawiązujących do zdarzeń, prezentowanych na zdjęciach. Wydano również 132-stronicowy Katalog, zawierający 62 zdjęcia z wystawy 65 .

$\mathrm{Na}$ łamach tygodnika dbano również o promocję własnych dziennikarzy, organizując wystawy ich prac, jak choćby ekspozycję zdjęć Piotra Sadurskiego w budynku Biblioteki Uniwersytetu Warszawskiego, a przedstawiającą zdjęcia z Czeczenii i z obozów dla uchodźców w Inguszetii.

Redakcja „Newsweek Polska” organizowała także wiele spotkań cyklicznych. Jednym z nich był Antysalon, dyskusyjny klub tygodnika, działający od 2004 r. Pierwszymi gośćmi byli Tomasz Lis i Piotr Gaweł (członek zarządu TVP)66. Wśród kolejnych uczestników znaleźli się m.in. Roman Giertych i Donald Tusk, Jarosław Kaczyński, Jan M. Rokita. Spotkania odbywały się $\mathrm{w}$ różnych polskich miastach, na przykład w Warszawie

\footnotetext{
63 P. Włodarczyk, Przyjazny bank, „Newsweek Polska” 2003, nr 36, s. 49-57.

${ }^{64}$ Po raz pierwszy zaproponowano ten ranking w $2004 \mathrm{r}$.

65 Newsweek Polska. Katalog wystawy, wrzesień 2002 r.

66 [br. aut.], Antysalon, „Newsweek Polska” 2004, nr 15, s. [11].
} 
(w Klubie Selekcja lub Manhattan) i Olsztynie (w Miejskim Ośrodku Kultury). Zainicjowano również inny cykl spotkań (tym razem w warszawskim klubie Czuły Barbarzyńca) zatytułowany Rozmowy Piotra Bratkowskiego. Tematy spotkań były rozmaite, jak choćby: Zakaz palenia cygar czy Chrystus urodził się $w$ supermarkecie. Organizowano też sporadyczne spotkania, zatytułowane: Forum Newsweeka i Wyższej Szkoły Europejskiej im ks. J. Tischnera w Krakowie.

Ponadto organizowano rozmaite akcje i konkursy. Wśród nich znalazły się m.in. Program Edukacyjny Temat: „Newsweek Polska”, adresowany do nauczycieli i uczniów gimnazjów i liceów. Jak pisała redakcja, „Ma on pomóc nauczycielom, w przygotowaniu ciekawych zajęć na podstawie artykułów $\mathrm{z}>$ Newsweeka<"67. Szkoły, które zgłosiły się do programu, otrzymywały materiały (przewodnik, zeszyt ćwiczeń, testy oraz mapy). W ramach tego przedsięwzięcia zorganizowano na przykład (pod patronatem Narodowego Banku Polskiego) cykl zajęć Pomysł na biznes. W odstępach miesięcznych na stronie www.szkola.newsweek.pl zamieszczano zadania, których wykonanie miało złożyć się na kolejne rozdziały minibiznesu, przygotowywanego przez uczniów. Pomysł spotkał się z dużym odzewem, w drugim roku jego realizacji wzięło w nim udział ponad tysiąc szkół 68 .

Innym pomysłem był program-konkurs Junior Newsweek, który zaproponowano uczniom w 2003 r. Adresowany był on do „młodych dziennikarzy", wydających szkolne gazetki ${ }^{9}$. Redakcja przesłała do placówek, które zgłosiły swój akces w konkursie, dziennikarski podręcznik „Newsweeka”. Na laureatów czekało zaproszenie na kolegium redakcyjne pisma i udział w warsztatach dziennikarskich. W tym przypadku partnerami akcji była, obok Narodowego Banku Polskiego, Telekomunikacja Polska.

W tym samym roku, w marcu, wespół z programem 1 TVP oraz 17 regionalnymi rozgłośniami radiowymi zainicjowano konkurs Interiada 2003, przeznaczony dla młodzieży poniżej 18. roku życia. Miał on sprawdzić wiedzę uczestników na temat Polski i Unii Europejskiej, a jego zwieńczeniem było parareferendum, w którym uczestnicy mieli opowiedzieć się za lub przeciw naszemu wstąpieniu do Unii ${ }^{70}$.

Interesującym pomysłem był konkurs Newsreportaż. Po raz pierwszy zaproponowano go czytelnikom w 2002 r. Chętni mogli przysłać 6-8 zdjęć, które składałyby się na krótki fotoreportaż, odpowiadający tematem jednej $\mathrm{z}$ trzech kategorii: Wydarzenia, Ludzie, Życie codzienne ${ }^{71}$. W kolejnych

67 [br. aut.], Temat: „Newsweek Polska”, „Newsweek Polska” 2003, nr 21, s. 10.

68 [br. aut.], Temat: „Newsweek Polska”, „Newsweek Polska” 2004, nr 39, s. 9.

69 [br. aut.], Junior Newsweek, „Newsweek Polska” 2003, nr 46, s. [9].

70 [br. aut.], Europejski sondaż, „Newsweek Polska” 2003, nr 13, s. 4.

71 „Newsweek Polska” 2002, nr 24, s. 4. Rozwiązanie pierwszej edycji konkursu: [br. aut.], Newsreportaż: nagrodzeni, ibidem, nr 36, s. [5]. 
edycjach konkursu zaproponowano jeszcze jedną kategorię, mieszczącą się w temacie „kultura”.

Liczne inicjatywy były wielokrotnie doceniane i nagradzane, podobnie jak wydawnictwo i dziennikarze, tworzący polską edycję „Newsweeka”.

Już w 2001 r. Axel Springer Polska został wybrany Wydawcą Roku 2001 (według Raportu specjalnego Magazyny 2001 czasopisma branżowego „Media i Marketing Polska”). Z kolei w 2004 r. zdobył tytuł Wydawcy Roku w VIII edycji konkursu Partner Roku, organizowanego przez Ruch SA, m.in. za „partnerstwo, rzetelność i punktualność we współpracy”72.

Z kolei tygodnik „Newsweek Polska” otrzymał nagrodę w kategorii Medium reklamowe roku $2001 \mathrm{w}$ konkursie organizowanym przez miesięcznik „Impact”, a według Raportu specjalnego „Media i Marketing Polska” został Magazynem Roku 2002/2003. Pismo otrzymało również EFFIE 2002, srebrną statuetkę w kategorii „Media”, a także tytuł Debiut Roku w konkursie Media Trend, organizowanym przez Eskadrę. Szybki sukces wydawniczy pisma został nagrodzony Honorowym Medalem Europejskim, przyznawanym przez Urząd Komitetu Integracji Europejskiej oraz BCC, za efektowne wejście na rynek mediów. W 2003 r. „Newsweek Polska” otrzymał tytuł As Empiku w kategorii Tygodniki.

W latach 2001-2005 nagrody otrzymali bądź byli do nich nominowani m.in. Szymon Hołownia ${ }^{73}$, Karolina Jaroszewicz ${ }^{74}$, M. Kęskrawiec ${ }^{75}$, Stanisław Koczot76, Mira Suchodolska ${ }^{77}$, Piotr Zaremba ${ }^{78}$, Rafał A. Ziemkiewicz ${ }^{79}$.

Grupa docelowa odbiorców pisma zbliżona jest do czytelników dwóch wcześniej omawianych periodyków, chociaż po „Newsweek Polska” sięgają chętniej ludzie młodsi (w wieku od 15 do 24 lat), w tym studenci80.

72 [br. aut.], Wydawca Newsweeka nagrodzony, „Newsweek Polska” 2004, nr 49, s. 10.

73 Sz. Hołownia został nominowany do nagrody Ślad im. biskupa Jana Chrapka za „stworzenie nowatorskiej na polskim gruncie formuły pisania o sprawach religijnych w masowym piśmie świeckim”, Zob. [br. aut.], Nominowany do Śladu, „Newsweek Polska” 2004, nr 4, s. [9].

${ }^{74} \mathrm{~K}$. Jaroszewicz otrzymała nagrodę w konkursie im. Mieczysława Orłowicza za najlepsze materiały radiowe, telewizyjne i prasowe promujące polską turystykę krajową.

75 M. Kęskrawiec został nagrodzony Grand Press w kategorii dziennikarstwa specjalistycznego za artykuł Terror ekologiczny. Warto zaznaczyć, że nagrodę główną (tytuł Dziennikarza Roku) otrzymała J. Paradowska („Polityka”). M. Kęskrawiec został także m.in. laureatem (wraz z A. Tudyką z TVN) nagrody głównej w konkursie Tylko ryba nie bierze, zorganizowanym przez Fundację im Stefana Batorego. Także jeden z dziennikarzy tygodnika „Wprost” został nagrodzony w jednej z edycji tego konkursu.

76 St. Koczot został laureatem Ostrego Pióra 2002, nagrody przyznawanej przez Zarząd Business Centre Club i Radę Organizatorów.

77 M. Suchodolska otrzymała nagrodę Ostrego Pióra za propagowanie przedsiębiorczości, wspieranie idei wolnego rynku i szerzenie edukacji ekonomicznej.

78 Otrzymał nagrodę Dziennikarza Roku miesięcznika „Press”.

79 R. A. Ziemkiewicz był nominowany do Nagrody im A. Zajdla.

80 [br. aut.], Studenci za Newsweekiem, „Newsweek Polska” 2003, nr 14, s. [5]. 
W badanym okresie periodyk był również najchętniej czytanym tytułem $\mathrm{w}$ tej grupie pism przez menedżerów ${ }^{81}$.

Jakkolwiek tygodnikowi nie udało się zatrzymać na stałe pozycji lidera w grupie tygodników opinii, to jednak jego sukces czytelniczy na początku drogi, dotrzymanie kroku dwóm pozostałym konkurentom jest bezsprzecznie faktem. Z perspektywy czasu T. Wróblewski, założyciel i pierwszy redaktor naczelny pisma, stwierdził: „Polski >Newsweek< rozkwitł na przekór trendom prasowym na świecie. I swoją ciężką pracą, konsekwencją, dystansem do kolejnych wolt politycznych stał się symbolem swojej epoki"82.

\subsubsection{Fabrykanci bestsellerów ${ }^{83}$ : książka na łamach pisma}

Jak już wcześniej wspomniano, na zawartość pisma składały się również informacje związane z szeroko rozumianą kulturą, w tym z książką. Najwięcej znajdowało się ich w oddzielnym dziale, Kultura, zajmującym średnio ok. 14 ostatnich stron periodyku.

Do numeru 17 (2003) włącznie działem kierował Wiesław Kot ${ }^{84}$, zaś od następnego numeru zastąpiła go Grażyna Minkowska. Kolejnym szefem działu był Hubert Kropielnicki (od numeru 3/2004), następnie, od numeru 24 (2004) Józef Lubiński. Po nim Kultura kierował Tomasz Plata (od numeru 41/2004). Ostatnia zmiana na tym stanowisku w badanym okresie nastąpiła od numeru 23/2005, kiedy szefem działu został Mariusz Cieślik, jeden z dotychczasowych recenzentów tygodnika „Polityka”. Wraz z rotacją osób kierujących działem zmieniał się również skład osobowy dziennikarzy przygotowujących informacje kulturalne. W ciągu 5 lat byli to: Piotr Bratkowski, Joanna Jachmann, Agnieszka Kowalczewska, Monika Kucia, Lech Kurpiewski, Filip Łobodziński, Magdalena Łukaszewicz, Grzegorz Sobaszek, Kamil Śmiałkowski, Katarzyna Zalewska i Anita Zuchowa. Jakkolwiek skład zespołu zmieniał się, to jednak zazwyczaj pozostawał on średnio 5-osobowy. Najdłużej, bo ponad trzy lata, pracował w nim W. Kot ${ }^{85}$. Poza wymienionymi nazwiskami w dziale Kultura pojawiały się również teksty innych dziennikarzy lub współpracowników periodyku: Jakuba Chełmińskiego, Joanny Hayder, Joanny Kowalskiej, Wojciecha Kuczoka i Aleksandry

81 [br. aut.], Newsweek dla menedżerów, „Newsweek Polska” 2003, nr 43, s. [9].

82 T. Wróblewski, Dekada globalizacji, dekada „Newsweeka”, „Newsweek Polska” 2011, nr 36, s. 20.

83 Tytuł jednej z publikacji, zob. „Newsweek Polska” 2005, nr 28, s. 84.

${ }^{84}$ W. Kot nadal pozostawał w składzie osób, przygotowujących dział, mimo że już nim nie kierował. Jego nazwisko zniknęło ze stopki redakcyjnej dopiero w numerze 29 (2004).

85 Od numeru 1 (2001) do numeru 29 (2004). 
Więckiej. Warto również wymienić autorów zagranicznych, których publikacje drukowano najprawdopodobniej we wszystkich edycjach pisma. $\mathrm{W}$ ten sposób czytelnik polski mógł poznać opinie na tematy kulturalne m.in. Davida Ansena, Paulo Coelho, Normana Daviesa, Jeffa Gilesa, Wiktora Jerofiejewa, Johna Horna, Petera Plagensa.

Zmiany na stanowisku kierowników działu nie wpływały znacząco na jego strukturę. W jego pierwszej części drukowano dłuższe, liczące przynajmniej pół strony, teksty poprzedzane określającymi ich charakter nagłówkami: Architektura, Film, Kino, Ksiq̨żka, Muzyka, Sztuka, Teatr. Nie wszystkie były jednak systematycznie zamieszczane. Zdarzało się niejednokrotnie, że w kilku następujących po sobie numerach brakowało tekstu, który odnosiłby się do zagadnień związanych na przykład z architekturą czy teatrem. Jedyną, która pojawiała się w każdym wydaniu przez cały analizowany okres, była rubryka Książka. Elementem łączącym tę część działu z następną, była Sylwetka. W tym miejscu prezentowano postać zazwyczaj zagranicznego aktora lub piosenkarza, zawsze przy okazji premiery filmowej bądź muzycznej. Tylko raz przedstawiono tu pisarza, a był nim John Grisham $^{86}$. Dział zamykał Jupiter ${ }^{87}$. Był to (podobnie jak w przypadku Afisza w „Polityce” i Menu we „Wprost”) przegląd najważniejszych wydarzeń kulturalnych. Zajmował średnio 6 stron, podzielonych na pomniejsze rubryki, z których każda posiadała własny nagłówek, znów odnoszący się do przedmiotu kilku-, rzadziej kilkunastozdaniowej, notki, znajdującej się pod nim. W tym miejscu pojawiała się m.in. niewielka rubryka, zatytułowana Książka. W początkowym okresie drukowano tu również kolumnę, w której pojawiały się zaproszenia na imprezy organizowane w Pałacu Kultury i Nauki w Warszawie. Od numeru 37 w 2002 r. zamieszczano tu również (niesystematycznie) listę bestsellerów książkowych ostatniego miesiąca88, a od numeru 49 (2004) pojawiała się w tym miejscu (sporadycznie) rubryka W. Kuczoka, zatytułowana Dziennik zdziwień. Jak wykazano w analizie pisma, w latach 2001-2005 na jego łamach pojawiło się 1528 informacji, związanych z literaturą, w tym z książką. W tabeli 26 przedstawiono ich konkretne formy wraz z odpowiadającą im liczbą ${ }^{89}$.

86 „Newsweek Polska” 2001, nr 2, s. 107.

87 Rubryka zmieniała swą nazwę m.in. na: Kalendarz Polska, Kalendarz Europa, Na afiszu, Karnet. Więcej - zob. w dalszej części rozdziału.

88 Zostanie ona omówiona w dalszej części rozdziału.

${ }^{89}$ Analogicznie do porządku przyjętego w odniesieniu do dwóch poprzednich tygodników, tak i tu zachowano porządek podawania poszczególnych kategorii według kolejności ich prezentowania. 
Tabela 26. Formy obecności książki i informacji o niej na łamach „Newsweek Polska” w latach 2001-2005

\begin{tabular}{|l|c|}
\hline \multicolumn{1}{|c|}{ Rodzaj informacji } & Liczba publikacji \\
\hline Recenzje & 520 \\
\hline Wywiady & 26 \\
\hline Reklamy książek & 187 \\
\hline Portrety/sylwetki & 40 \\
\hline $\begin{array}{l}\text { Artykuły, poświęcone sprawom książki lub rynku wydawni- } \\
\text { czo-księgarskiego }\end{array}$ & 169 \\
\hline Ekranizacje, adaptacje, inscenizacje znanych dzieł & 162 \\
\hline Konkursy i akcje, organizowane przez „Newsweek Polska” & 92 \\
\hline Listy bestsellerów & 23 \\
\hline $\begin{array}{l}\text { Listy czytelników, nawiązujące do zamieszczonej informacji } \\
\text { związanej z książką }\end{array}$ & 174 \\
\hline Inne ${ }^{a}$ & 1528 \\
\hline Ogółem & 23 \\
\hline
\end{tabular}

${ }^{a} \mathrm{~W}$ tej kategorii uwzględniono wszelkiego rodzaju informacje, zazwyczaj w postaci krótkich notek, donoszących na przykład o nagrodach, otrzymanych przez ludzi związanych z książką, nadaniu imienia twórcy szkole, instytucji itd., ale także informujące o jubileuszach pisarzy czy ich śmierci.

Źródło: badania własne.

Ogólna liczba informacji bezpośrednio bądź pośrednio związanych z książką stawia badany tygodnik na 2. miejscu wśród omawianych w pracy pism opinii. Teksty, o różnej objętości i charakterze, pojawiały się stosunkowo rzadko poza Kulturą. Recenzje jako rodzaj publikacji mogły swą obecnością najbardziej zaskoczyć czytelnika w różnych działach pisma. Podobnie było w przypadku wywiadów i reklam książkowych. Ich stosunkowo niewielka liczba może niepokoić w piśmie, które wszak przez pewien czas zajmowało pozycję lidera w swej grupie, a później mieściło się wśród trzech najważniejszych polskich pism opinii.

Jakkolwiek obydwie formy zostaną scharakteryzowane poniżej, warto jednak już w tym miejscu zaznaczyć, że w skromnej grupie anonsów wydawniczych znaczącą liczbę stanowiły inseraty, reklamujące książki wydawnictwa Axel Springer Polska. 


\subsubsection{Muskając literaturę ${ }^{90}$ : miejsce recenzji w układzie pisma}

W badanym okresie na łamach pisma pojawiło się 520 recenzji ${ }^{91}$. W tabeli 27 zaprezentowano ich liczbę w każdym roku.

Tabela 27. Recenzje zamieszczane na łamach „Newsweek Polska” w latach 2001-2005

\begin{tabular}{|c|c|}
\hline Rok & Liczba recenzji ogółem \\
\hline 2001 & $34^{a}$ \\
\hline 2002 & 143 \\
\hline 2003 & 133 \\
\hline 2004 & 84 \\
\hline 2005 & 126 \\
\hline Ogółem & 520 \\
\hline
\end{tabular}

${ }^{a}$ Należy przypomnieć, że w 2001 r. do czytelnika trafiło jedynie 16 numerów tygodnika.

Źródło: badania własne.

Jak już wspomniano, większość recenzji drukowano w dziale Kultura. Mimo to, ponieważ sporadycznie pojawiały się one także $w$ innych miejscach pisma, warto przyjrzeć się bliżej ich lokalizacji. W tabeli 28 przedstawiono ich liczbę wraz z rozmieszczeniem.

Tabela 28. Recenzje w dziale Kultura oraz w innych miejscach w „Newsweek Polska” w latach 2001-2005

\begin{tabular}{|c|c|c|c|c|}
\hline Rok & Ogółem & $\begin{array}{c}\text { W specjalnych } \\
\text { rubrykach }^{a}\end{array}$ & $\begin{array}{c}\text { W dziale Kultura, } \\
\text { poza wyodrębnionymi } \\
\text { do tego celu rubrykami }\end{array}$ & $\begin{array}{c}\text { W innych miejscach } \\
\text { w piśmie }\end{array}$ \\
\hline 2001 & 34 & 23 & 11 & - \\
\hline 2002 & 143 & 115 & 14 & 14 \\
\hline 2003 & 133 & 115 & 14 & 7 \\
\hline 2004 & 84 & 62 & 15 & 9 \\
\hline 2005 & 126 & 100 & 17 & 34 \\
\hline Ogółem & 520 & 415 & 71 & 7 \\
\hline
\end{tabular}

${ }^{a}$ To znaczy w rubrykach poświęconych wyłącznie na recenzje książek. Rubryki te kilkakrotnie $\mathrm{w}$ badanym okresie zmieniały nazwę i formę: zostaną dokładnie omówione w dalszej części rozdziału.

Źródło: badania własne.

90 Tytuł recenzji. Zob. RZ, Muskając literaturę, „Newsweek Polska” 2005, nr 37, s. 102.

91 Ciekawą krytykę formy, jaką przybiera czasem współczesna recenzja, zamieścił J. Pilch w felietonie: Grucha nie kocha Gliny, „Polityka” 2003, nr 25, s. 100. 
Jak zatem widać, liczba recenzji, drukowanych poza działem poświęconym informacjom kulturalnym, była stosunkowo niewielka, a w pierwszym badanym roku takich omówień nie było w ogóle. Podobnie nieznaczną liczbę recenzji odnaleźć można było w omawianym dziale, ale poza specjalnie przeznaczoną na recenzje książek rubryką.

Książki prezentowane w działach innych niż Kultura w większości przypadków nawiązywały tematycznie do tekstów drukowanych na sąsiednich stronach. Na przykład obok artykułu dotyczącego granic, jakie są w stanie przekroczyć fotoreporterzy, by zdobyć ciekawe zdjęcie, pojawiła się recenzja książki opowiadającej o manipulacji w środkach masowego przekazu ${ }^{92}$. Obok tekstu, związanego z dniem Świętego Walentego, przedstawiono poemat Czesława Miłosza Orfeusz i Eurydyka, który poeta dedykował swej zmarłej żonie i w którym podkreślał, że w życiu najważniejsza jest miłość i wiara ${ }^{93}$. Obydwie recenzje znalazły się w dziale Społeczeństwo. Omówienia drukowano także na stronach poświęconych wydarzeniom na świecie (Świat) czy ciekawostkom naukowym (Nauka). Niekiedy książka stawała się przedmiotem felietonu. Tak było na przykład w tekście P. Bratkowskiego Dobra wiadomośćc4, w którym znalazła się recenzja książki Wygrać życie ${ }^{95}$. Ze względu na to, że liczba omówień książek, drukowanych poza specjalnie na to poświęconymi rubrykami była stosunkowo niewielka, szczególnie w przypadku tych recenzji, które znalazły się w innych, niż Kultura, działach (zaledwie 30), zrezygnowano z umieszczania dodatkowej tabeli, analogicznej do zaprezentowanych $\mathrm{w}$ odniesieniu do dwóch wcześniej omówionych periodyków.

Najbogatszy w recenzje był dział Kultura. Powyżej wspomniano już o rubrykach, w których tego typu promocja książki była systematycznie drukowana. Przyjrzyjmy się im bliżej.

Nieznacznie zmieniała się strona, poświęcana recenzjom, drukowana w pierwszej części działu, zatytułowana Książka bądź Książki. Zaledwie kilkakrotnie jej nazwa była inna, chociaż forma pozostawała niezmienna. Trzykrotnie trafiła do czytelników jako Recenzja ${ }^{96}$, zaś w siedmiu numerach tytułowano ją Literatura ${ }^{97}$, a w dwóch Premiery książki. Recenzje zajmowały

92 N. Kita, Problemy z prawdq „Newsweek Polska” 2004, nr 21, s. [85].

93 W. Kot, Powrót Orfeusza, „Newsweek Polska” 2003, nr 7, s. 83.

${ }_{94}$ Drukowanym w rubryce Ostatnie słowa.

95 P. Bratkowski, Dobra wiadomość, „Newsweek Polska” 2005, nr 50, s. 112, rec. książka: Wygrać życie, z Kamilem Durczokiem rozmawia Piotr Mucharski.

96 Tak było w numerach 36 (2003), 2, 3 (2004).

97 Tak było w następujących numerach w 2005 r.: 40, 42, 44, 45, 46, 48, 51/52. W tym przypadku pominięto jednak dane dotyczące autora recenzowanej książki, zamiast nich pojawił się rysunek. 
w niej przeważnie jedną stronę, zawsze zawierającą streszczenie proponowanego tytułu, poprzedzone krótką charakterystyką samego autora i niekiedy komentarzem recenzenta. Nadto drukowano w nich kopię okładki prezentowanej książki i jej (niemal pełne) dane bibliograficzne. W przypadku książki autora obcego nie zawsze pamiętano o podaniu nazwiska tłumacza, niekiedy pomijano również miejsce jej wydania. Rzadko informowano o roku, w którym pojawiła się na rynku, chociaż prawie nigdy nie zapominano o podaniu jej ceny. $W$ recenzji zamieszczano zdjęcie autora książki wraz z kilkoma informacjami na jego temat: 3-4 daty odnoszące się do ważnych wydarzeń z życia (niekiedy podawano wiek pisarza, ale także na przykład datę publikacji pierwszej książki bądź otrzymanej nagrody). Omówienie posiadało własny tytuł, było też podpisane pełnym nazwiskiem dziennikarza. Na zdjęciu 52 i 53 zamieszczono przykładowe strony recenzyje.

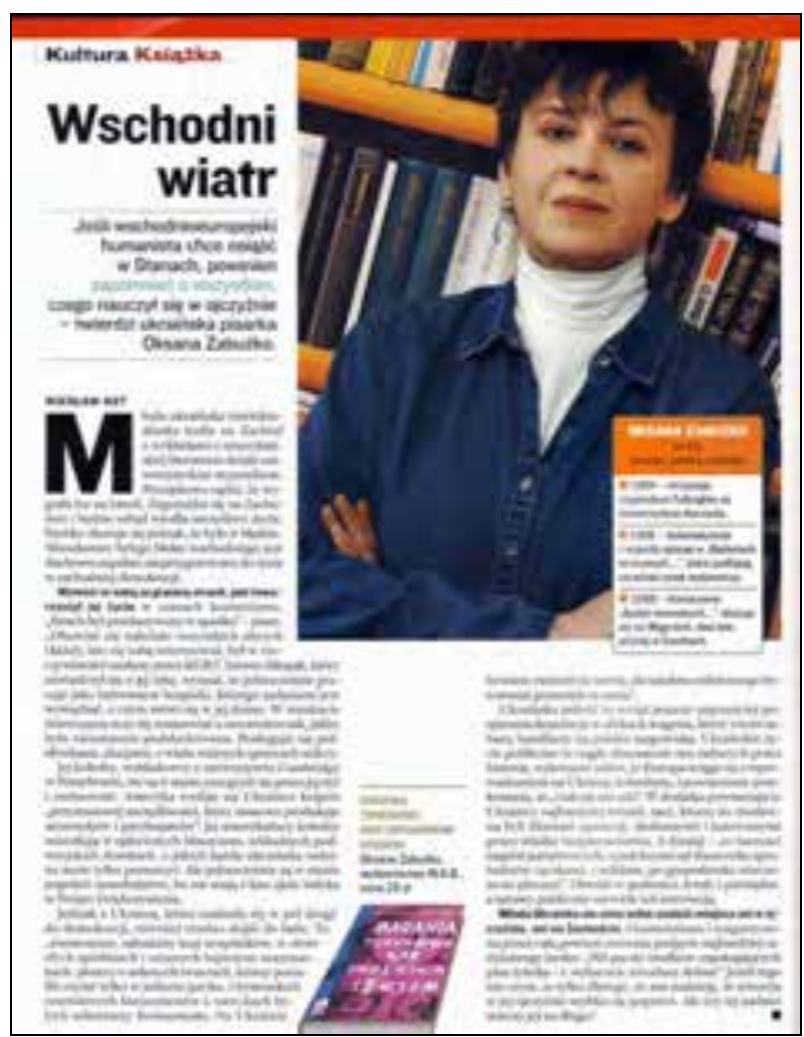

Zdjęcie 52. Przykładowa strona recenzyjna na łamach „Newsweek Polska” „Newsweek Polska” 2003, nr 8, s. 106 


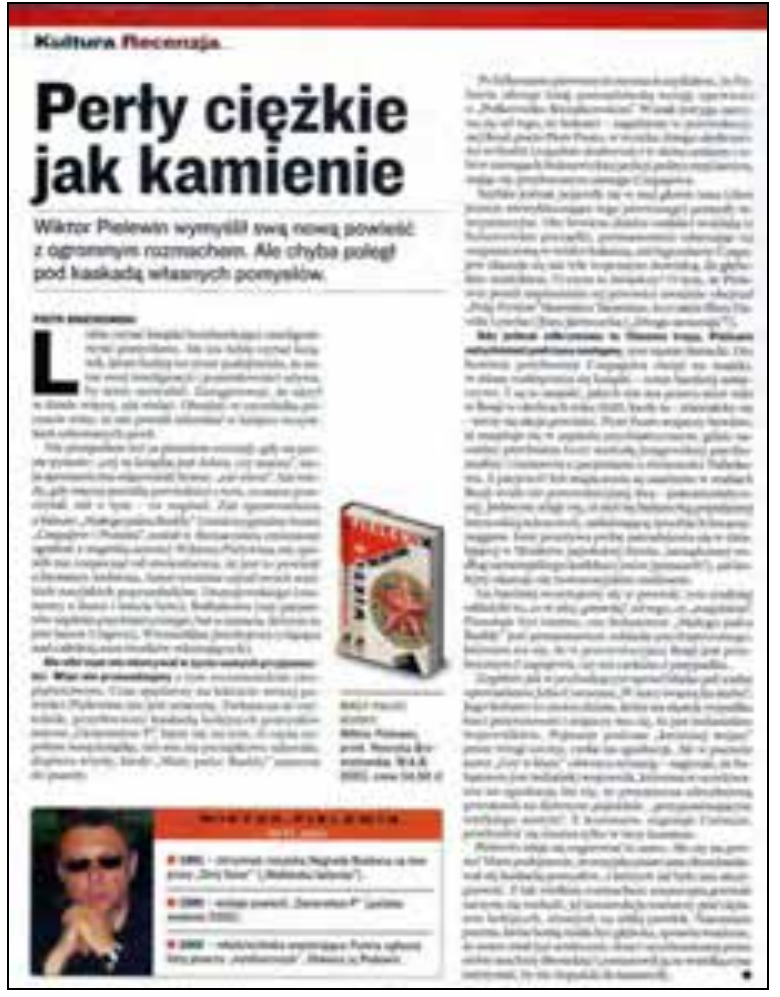

Zdjęcie 53. Przykładowa strona recenzyjna na łamach „Newsweek Polska” „Newsweek Polska” 2003, nr 36, s. 106

Od numeru 37 (2005) jako dodatkowy element pojawiła się ocena proponowanej książki, w postaci symboli przypominających sygnalizację świetlną: kolor zielony oznaczał, że lekturę warto przeczytać, żółty, że ewentualnie można się z nią zapoznać, zaś czerwony, że nie warto tracić na nią czasu ${ }^{98}$. Symbole oceny zmieniły się $\mathrm{w}$ numerze 47 (2005): pionowa lub pozioma kreska na czerwonym tle sugerowała, że książka według recenzenta jest słaba, kółko na żółtym polu wskazywało na ciekawy tytuł, zaś krzyżyk na zielonym tle oznaczał super-książkę.

W tych omówieniach prezentowano zazwyczaj jeden tytuł, chociaż zdarzały się również wyjątki, jak choćby w numerze 33 (2002), gdzie Aleksandra Boćkowska zaproponowała lekturę czterech książek: Manuela V. Montalbána Morderstwo w Komitecie Centralnym, Ptaki Bangkoku, Kwintet z Buenos Aires oraz Andrea Camilleri Psa z terakoty 99 albo kiedy Agata Passent proponowała czytelnikom pisma kilka wybranych przez siebie książek kucharskich ${ }^{100}$.

98 Zob. np. RZ, Muskając literature, „Newsweek Polska” 2005, nr 37, s. 102.

99 A. Boćkowska, Daleko od zbrodni, „Newsweek Polska” 2002, nr 33, s. 104-105.

100 A. Passent, Krajobraz po sałatce, „Newsweek Polska” 2005, nr 1, s. 99. 
Jednocześnie od wspomnianego 37 numeru w 2005 r., w ramach pierwszej części działu, zaczęto drukować kolumnę, w której znajdowały się trzy kilkuzdaniowe recenzje, każda $\mathrm{z}$ nich $\mathrm{z}$ własnym tytułem, podpisana inicjałami recenzenta i uzupełniona kopią okładki proponowanej książki oraz odnoszącymi się doń (niepełnymi) danymi bibliograficznymi i oceną. Po niecałych trzech miesiącach, od numeru 47 (2005) zmieniono zarówno nazwę, jak i w niewielkim stopniu formę tej rubryki na Premiery ksiq̨żki - tym razem recenzje nie były już anonimowe. Nowa propozycja wyglądała w taki oto sposób - zdjęcie 54 i 55.

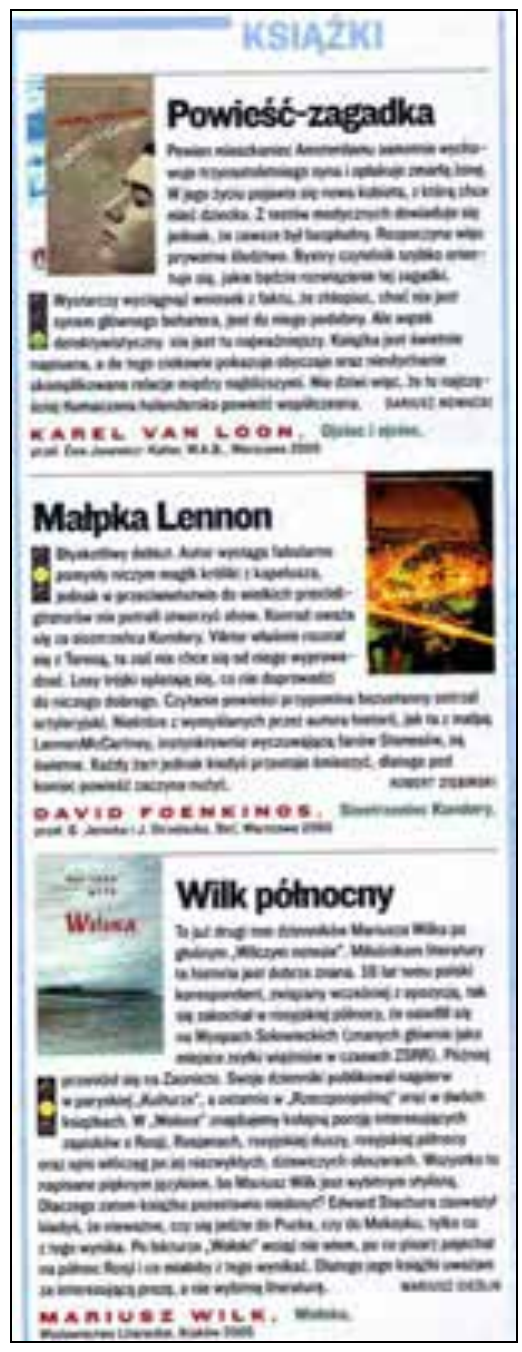

Zdjęcie 54. Przykładowa strona recenzyjna na łamach „Newsweek Polska” „Newsweek Polska” 2005, nr 38, s. 118

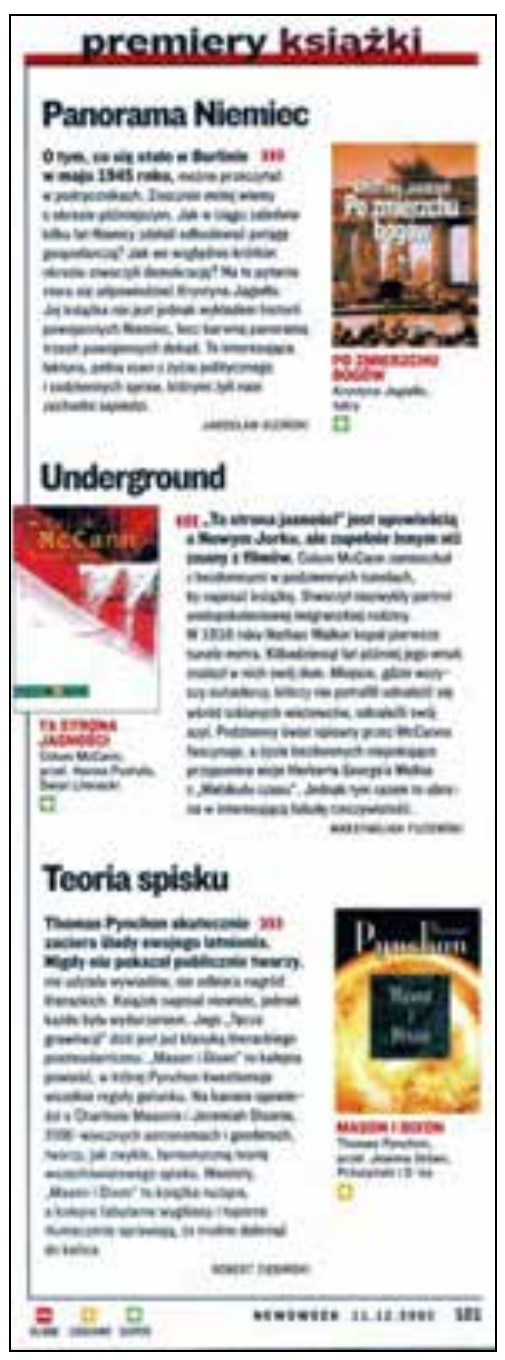

Zdjęcie 55. Przykładowa strona recenzyjna na łamach "Newsweek Polska” „Newsweek Polska” 2005, nr 49, s. 101 
Kolejną grupę omówień stanowiły informacje drukowane w drugiej części działu, w ramach stron, które przez większość badanego okresu nosiły tytuł Jupiter, od numeru 36 (2002) z podtytułem Tygodniowy raport Sztuka, Muzyka, Teatr, Wystawy, Film, Wideo, Ksiqzżka, Design. Od numeru 27 (2004) zmieniły one nazwę na Kalendarz Polska, Kalendarz Europa, a po kilku miesiącach $w$ jednym tylko numerze $(4 / 2005)$ czytelnik odnalazł je w postaci tytułu Na afiszu Tygodniowy raport Sztuka Muzyka Teatr Film Wideo/DVD Książka. Od kolejnego numeru widniała ona w piśmie jako Karnet Raport Sztuka Muzyka Teatr Film Wideo/DVD Książka.

$\mathrm{O}$ ile w początkowym okresie strony te pojawiały się systematycznie w każdym numerze tygodnika, o tyle w ostatnich badanych numerach proponowano je sporadycznie. Do numeru 4 (2005) w tym miejscu znajdowały się krótkie anonimowe omówienia, wyodrębnione nagłówkiem Ksiq̨żka, z niepełnymi danymi bibliograficznymi i kopią okładki proponowanego tytułu. Od numeru 5 (2005) wraz ze wspomnianą wcześniej zmianą nazwy rubryki, informacje związane z książką przyjmowały w tym miejscu postać sporadycznie zamieszczanych rankingów bądź równie sporadycznie drukowanej rubryki P. Bratkowskiego (zostanie ona omówiona w dalszej części rozdziału). Zaniechano wówczas drukowania na tych stronach choćby krótkich informacji związanych z książką.

Wcześniej jednak pojawiały się w tym miejscu krótkie omówienia. Miały one rozmaitą objętość, nie przekraczającą jednak pół strony, przeważnie zaś obejmowały zaledwie kilka zdań, sprowadzających się w większości przypadków do zwięzłego przedstawienia treści proponowanej książki.

Postać zamieszczanych $\mathrm{w}$ tym miejscu informacji o książce przypominała $\mathrm{w}$ większym stopniu adnotacje treściowe odnoszące się do prezentowanego tytułu niż faktyczną recenzję. Podstawową rubryką, poświęconą na obszerniejsze prezentowanie książek, była opisana wcześniej pierwsza część działu.

Należy także wspomnieć o rubryce zamieszczanej od numeru 4 (2005): Piotr Bratkowski poleca nowe ksiqzżki, najpierw w ramach $\mathrm{Na}$ afiszu, a następnie Karnetu. Miała ona postać modułu, zazwyczaj drukowanego u dołu strony, zawierającego krótkie adnotacje dotyczące trzech książek, z kopiami ich okładek obok. Dane bibliograficzne ograniczały się w tym przypadku do podania (w treści notki) autora i tytułu książki oraz na końcu jej wydawcy. Rubryka ta pojawiła się w siedmiu numerach pisma 101.

W jej obrębie znany recenzent prezentował krótko trzy wybrane przez siebie książki, ograniczając się zazwyczaj do krótkiego przedstawienia ich

101 „Newsweek Polska” 2005, nr 4, 5, 6, 7, 8, 9, 18, 35. Raz, z okazji rocznicy wybuchu Powstania Warszawskiego, pojawiła się podobna w swej formie rubryka: Powstanie Warszawskie. Nowe książki, zob. ibidem, nr 30, s. 102. 
treści i podania podstawowych danych bibliograficznych. Były to zatem krótkie adnotacje, nieco rozwinięte wzmianki informacyjne, wpisujące się w charakter tej rubryki.

W omawianym periodyku, w przeciwieństwie do dwóch poprzednich pism opinii, stosunkowo rzadko drukowano recenzje cykliczne, które redakcje zwykły zamieszczać z okazji Świąt Bożego Narodzenia, Wielkanocy czy chociażby zbliżających się wakacji102. Warto jednak $\mathrm{w}$ tym miejscu wspomnieć o jednej tego typu akcji pisma. Otóż w 2004 r. w jednym z numerów czerwcowych, pojawił się ośmiostronicowy przewodnik, w którym polecano różnego rodzaju lektury na lato: powieści, poradniki, komiksy, literaturę fantasy i science fiction, eseje, tytuły z literatury faktu. Krótkie opisy wybranych tytułów wzbogacono ich kolorowymi okładkami, pod którymi umieszczono podstawowe dane bibliograficzne (nazwisko autora, tytuł, nazwę wydawcy i cenę proponowanej książki) ${ }^{103}$.

Jakkolwiek inna akcja tygodnika nie przybrała formy typowej recenzji, to jednak, ze względu na założenia jej autorów, warto o niej wspomnieć. W 2002 r., w jednym z majowych numerów pojawił się przegląd 100 tytułów książek (po 10 propozycji przypisanych do wybranych gatunków literackich), wydanych od początku roku poprzedniego. Na pięciu stronach znalazły się kopie okładek wybranych książek z jednozdaniowymi adnotacjami oraz nazwiskiem autora i tytułem polecanej książki. Propozycje zgłoszone przez Witolda Beresia, Grzegorza Leszczyńskiego, Wacława Sadkowskiego, Joannę Siedlecką, Mariana Stalę, Jerzego Szyłaka, Jarosława Włodarczyka i R. Ziemkiewicza opracował K. Śmiałkowski, a ilustrował Dariusz Łabędzki. Były to różnorodne lektury, te, które wymienieni pisarze, dziennikarze, historycy, krytycy literatury uznali za wartościowe, takie, które warto mieć w swej domowej bibliotece. W zestawieniu znalazła się polska literatura piękna (m.in. Ty jesteś Daniel Hanny Krall, Zima Andrzeja Stasiuka) i obca (np. Makbet Williama Szekspira i Baudolino Umberto Eco), literatura popularna (wśród propozycji pojawił się Władca Pierścieni Johna R. R. Tolkiena, Opowieści o pilocie Pirxie Stanisława Lema). Pojawiły się również tytuły, zaliczone do literatury faktu (jak Prawda $w$ oczy nie kole Józefa Mackiewicza czy wspomnienia wojenne Karoliny Lanckorońskiej), poezji (m.in. Ewy Lipskiej Sklepy zoologiczne, Marcina Świetlickiego Czynny do odwołania). Zadbano także o miłośników komiksów, a wśród propono-

102 Zob. np. „Newsweek Polska” 2002, nr 22, s. 102-105; 2003 nr 21, s. 88-92. Pewną namiastką tej formy informacji o książce może być propozycja, jaka pojawiła się w $2002 \mathrm{r}$., tuż przed Świętami Bożego Narodzenia. Przypominała ona raczej reklamę wydawniczą niż ofertę odredakcyjną. Zob. Przepis na sukces, „Newsweek Polska” 2002, nr 48, s. 111.

103 [br. aut.], 70 ksiq̨żek, które warto przeczytać, „Newsweek Polska” 2004, nr 26, s. [97]-104. 
wanych tytułów znalazły się obok Tytusa, Romka i A'Tomka Henryka Chmielewskiego także m.in. Kajtek i Koko w kosmosie Janusza Christy 104.

W ciągu omawianych pięciu lat na łamach pisma pojawiło się 65 nazwisk recenzentów. Jest to liczba niepełna, jako że aż w 221 przypadkach omówienia książek były anonimowe. (zob. Aneks 19. Autorzy recenzji drukowanych na łamach „Newsweek Polska” w latach 2001-2005). Wśród podanych nazwisk, poza wcześniej wymienionymi, pojawili się również m.in. Agnieszka Fedorczyk, Maksymilian Fuzowski, Jarosław Giziński, Katarzyna Klejnocka, Janusz Majcherek, Andrew Nagorski, Dariusz Nowacki, Piotr Zaremba i Robert Ziębiński. Rekordzistą pod względem omówionych książek był W. Kot: przedstawił (głównie w obszernych recenzjach) 87 tytułów. Z kolei P. Bratkowski omówił 82 książki.

W sumie zrecenzowano książki 383 różnych autorów ${ }^{105}$, w tym 147 pisarzy polskich i 236 obcych (zob. Aneks 20. Autorzy recenzowanych książek na łamach „Newsweek Polska” w latach 2001-2005). Wyraźnie większa liczba nazwisk pisarzy obcych potwierdza politykę pisma, preferującego prezentację twórców zagranicznych, w mniejszym zaś stopniu polskich. Jak twierdzi W. Kot:

obecność wśród recenzowanych książek autorów obcych brała się z przekonania, że czytelnik „Newsweeka” jest osobą otwartą na świat i świata ciekawą. Na tym tle literatura polska była tylko skromnym wycinkiem tego szerokiego pasma rzeczy interesujących, które działy się na świecie. Poza tym trudno było co tydzień natknąć się na interesującą polską książkę. W dodatku w tłumaczeniach docierały do nas rzeczy wybitne, wyselekcjonowane już wcześniej przez światowe media i wydawców. Recenzowaliśmy więc często książki, o których dyskutował cały świat. Kryterium wyboru była opinia, jaką książka czy autor cieszył się na świecie. Informacje na ten temat pozyskiwaliśmy z zagranicznych witryn sprawdzając, jaką prasę ma dana pozycja. Jeżeli było wokół niej głośno, tym chętniej recenzowaliśmy ją $\mathrm{w}$ polskim tłumaczeniu. Było to zgodne z polityką informacyjną całego pisma ${ }^{106}$.

Zdarzało się, że kilkakrotnie recenzowano twórczość tego samego autora. Tak było w 61 przypadkach (21 razy w odniesieniu do autora polskiego i 40 razy wobec pisarza obcego). Największe zainteresowanie recenzentów wzbudziła twórczość Stephena Kinga i Harlana Cobena. Kilkakrotnie sięgnięto po książki Jana Pawła II. W tabeli 29 zaprezentowano nazwiska tych twórców, którzy najczęściej pojawiali się w recenzjach na łamach pisma ${ }^{107}$.

\footnotetext{
104 K. Śmiałkowski, Literatura XXI wieku, „Newsweek Polska” 2002, nr 18, s. 94-98.

$105 \mathrm{~W} 36$ przypadkach nie podano autora.

106 Informacje uzyskane dzięki korespondencji z W. Kotem.

107 Nie wprowadzono w tym przypadku dwóch tabel, oddzielnych dla pisarzy polskich i obcych, jako że cała grupa twórców była znacznie mniejsza niż w przypadku np. „Polityki”.
} 
Tabela 29. Najczęściej recenzowani autorzy polscy i obcy na łamach „Newsweek Polska” w latach 2001-2005

\begin{tabular}{|c|c|c|}
\hline Dane twórcy & Liczba recenzji & Tytuły recenzowanych książek \\
\hline Stephen King & 6 & $\begin{array}{l}\text { Danse Macabre } \\
\text { Colorado Kid } \\
\text { Miasteczko Salem } \\
\text { Powołanie Trójki } \\
\text { Roland } \\
\text { Wszystko jest względne }\end{array}$ \\
\hline Harlan Coben & 5 & $\begin{array}{l}\text { Bez pożegnania } \\
\text { Bez skrupułów } \\
\text { Bez śladu } \\
\text { Krótka piłka } \\
\text { Nie mów nikomu }\end{array}$ \\
\hline Jan Paweł II & 5 & $\begin{array}{l}\text { Pamięć i tożsamość (dwukrotnie) }{ }^{a} \\
\text { Pasterz i liberał } \\
\text { Pozdrawiam i błogosławię. Listy prywatne } \\
\text { papieża }^{b} \\
\text { Wstańcie, chodźmy! }\end{array}$ \\
\hline Norman Davies & 4 & $\begin{array}{l}\text { Microcosmos } \\
\text { Powstanie `44 (dwukrotnie) } \\
\text { Wyspy. Historia }\end{array}$ \\
\hline Katarzyna Grochola & 4 & $\begin{array}{l}\text { Ja wam pokażę! } \\
\text { Nigdy w życiu! } \\
\text { Podanie o miłość } \\
\text { Serce na temblaku }\end{array}$ \\
\hline Rafał A. Ziemkiewicz & 4 & $\begin{array}{l}\text { Cała kupa wielkich braci } \\
\text { Ciało obce } \\
\text { Polactwo } \\
\text { Viagra mać }\end{array}$ \\
\hline John M. Coetzee & 3 & $\begin{array}{l}\text { Elizabeth Costello } \\
\text { Slow Man } \\
\text { Godziny }\end{array}$ \\
\hline Michael Cunningham & 3 & $\begin{array}{l}\text { Dom na krańcu świata } \\
\text { Godziny } \\
\text { Z ciała i duszy }\end{array}$ \\
\hline Umberto Eco & 3 & $\begin{array}{l}\text { Baudolino } \\
\text { Historia jest piękna } \\
\text { Tajemniczy płomień królowej Loany }\end{array}$ \\
\hline Neil Gaiman & 3 & $\begin{array}{l}\text { Arlekin i walentynki } \\
\text { Dym i lustra } \\
\text { Morderstwa i tajemnice }\end{array}$ \\
\hline René Goscinny & 3 & $\begin{array}{l}\text { Lichotek i czarnoksiężnik } \\
\text { Nowe przygody Mikołajka } \\
\text { Wujek Puszkin, dobry niedźwiedź }\end{array}$ \\
\hline
\end{tabular}


Tabela 29 (cd.)

\begin{tabular}{|l|c|l|}
\hline \multicolumn{1}{|c|}{ Dane twórcy } & Liczba recenzji & \multicolumn{1}{|c|}{ Tytuły recenzowanych książek } \\
\hline Nick Hornby & 3 & $\begin{array}{l}\text { Długa droga } \text { w dół } \\
\text { Futbolowa gorqczza } \\
\text { Jak być dobrym }\end{array}$ \\
\hline Tomasz Lis & 3 & $\begin{array}{l}\text { Co z ta Polska? } \\
\text { Nie tylko fakty (dwukrotnie) }{ }^{c}\end{array}$ \\
\hline Robert Ludlum & 3 & $\begin{array}{l}\text { Opcja paryska } \\
\text { Protokół Sigmy } \\
\text { Zdrada Tristana }\end{array}$ \\
\hline Gabriel G. Márquez & 3 & $\begin{array}{l}\text { Memoria de mis putas tristes } \\
\text { Na fałszywych papierach } w \text { Chile } \\
\text { Skandal stulecia i inne felietony }\end{array}$ \\
\hline Czesław Miłosz & 3 & $\begin{array}{l}\text { Orfeusz i Eurydyka } \\
\text { Spiżarnia literacka } \\
\text { Wiersze, t. II }\end{array}$ \\
\hline Manuel V. Montalbán & 3 & $\begin{array}{l}\text { Kwintet z Buenos Aires } \\
\text { Morderstwo w Komitecie Centralnym } \\
\text { Ptaki Bangkoku }\end{array}$ \\
\hline
\end{tabular}

${ }^{a}$ W 2005 r. w numerze 6 pojawił się cały cykl tekstów, poświęconych nowej książce Jana Pawła II.

${ }^{b}$ W jednym przypadku była to książka napisana przy współpracy z M. Skwarnickim.

c Recenzja książki Nie tylko fakty pojawiła się w zaledwie odstępu 2 tygodni: „Newsweek Polska" 2004, nr 38, s. 80; nr 40, s. 106.

Źródło: badania własne.

Jak wynika z tabeli 29, grupę recenzowanych pisarzy stanowili w dużej mierze ci, którzy tworzyli literaturę popularną (jak choćby $H$. Coben, K. Grochola, S. King, R. Ludlum), z niewielkimi tylko wyjątkami (na przykład Jan Paweł II, Cz. Miłosz). Podobnie wyglądała sytuacja, jeśli przyjrzymy się nazwiskom, które pojawiły się przy okazji recenzji dwukrotnie. Wśród nich znaleźli się m.in. Stefan Chwin, Tom Clancy, Helen Fielding, Janusz Głowacki, John Grisham, Henryk Grynberg, John Irving, W. Kuczok, Stanisław Lem, Frank Miller, Joanne K. Rowling, Sławomir Shuty, Izabela Sowa, Andrzej Stasiuk, Olga Tokarczuk, William Wharton, Marcin Wolski. Niewielką grupę stanowili tacy autorzy, jak: Anne Applebaum, Bohumil Hrabal, Hanna Krall i Wiktor Pielewin. Zarówno w odniesieniu do literatury obcej, jak i polskiej, wybór był w większości ten sam: omawiano tytuły znane szerszej publiczności czytelniczej. Pełna lista nazwisk autorów książek recenzowanych w tym okresie na łamach pisma potwierdza ów wniosek. 
W ciągu 5 lat recenzenci tygodnika skorzystali z oferty 84 wydawców ${ }^{108}$ (zob. Aneks 21. Wydawcy recenzowanych książek na łamach „Newsweek Polska” w latach 2001-2005). W tabeli 30 przedstawiono te oficyny, z propozycji których redaktorzy pisma korzystali najczęściej.

Tabela 30. Wydawcy najczęściej recenzowanych książek na łamach „Newsweek Polska” w latach 2001-2005

\begin{tabular}{|l|c|}
\hline \multicolumn{1}{|c|}{ Nazwa wydawcy } & Liczba tytułów \\
\hline Dom Wydawniczy REBIS & 41 \\
\hline Wydawnictwo W.A.B. & 35 \\
\hline $\begin{array}{l}\text { Wydawnictwo Prószyński i S-ka } \\
\text { Społeczny Instytut Wydawniczy Znak }\end{array}$ & 33 \\
\hline Wydawnictwo Muza & $32^{a}$ \\
\hline Wydawnictwo Amber & 22 \\
\hline Wydawnictwo Literackie & 20 \\
\hline Świat Książki & 18 \\
\hline Wydawnictwo Albatros & $15^{b}$ \\
\hline Wydawnictwo Zysk i S-ka & 14 \\
\hline
\end{tabular}

a W jednym przypadku była to książka wydana wespół z Wydawnictwem Albatros.

${ }^{b}$ Raz była to książka wydana razem z Wydawnictwem Muza.

Źródło: badania własne.

Pełne zestawienie wydawców potwierdza wysuniętą powyżej tezę, że w tygodniku sięgano przede wszystkim po książki znanych edytorów, jak choćby Dom Wydawniczy REBIS, W.A.B. czy Wydawnictwo Prószyński i S-ka. Zaledwie kilkakrotnie przedstawiono ofertę mniej znanych oficyn, na przykład Wydawnictwa Gaudium, Werset albo Mag.

\subsection{Zakres i charakter recenzji - przykłady}

Większość recenzji prezentowała nowości wydawnicze. Niektóre z omówień miały charakter prospektywny. Tak było na przykład w przypadku książki Sándor Márai Wyznania patrycjusza,109, Davida Schicklera Pocałunki na Manhattanie ${ }^{110}$ czy Last stop Vienna Andrew Nagorsky`ego, szefa wydań obcojęzycznych „Newsweeka”111. Książki współpracowników pisma były kilkakrotnie przedmiotem recenzji. Proponowano m.in. Portrety

108 W 34 przypadkach nie podano nazwy wydawcy, z czego w 11 przypadkach książki opublikowane były prawdopodobnie za granicą (na podstawie: www.bn.org.pl).

109 [br aut.], Niepokorny patrycjusz, „Newsweek Polska” 2002, nr 10, s. [109].

110 [br aut.], Wielbiciel windy, „Newsweek Polska” 2003, nr 6, s. 110.

111 S. Meadows, Brunatne koszule, „Newsweek Polska” 2003, nr 3 , s. 110. 
sławnych Polaków dwudziestego wieku W. Kota112, Wiersze stare $i$ nowe P. Bratkowskiego ${ }^{113}$ i czterokrotnie książki R. A. Ziemkiewicza'114. Zachęcano również do sięgnięcia po tytuły wydane przez Axel Springer Polska w ramach kolekcji Literatura w spódnicy115. Kilkakrotnie przybliżano czytelnikom tytuły opublikowane za granicą116; niektóre z nich miały pojawić się w ciągu kilku miesięcy w Polsce.

W zależności od miejsca, w którym zamieszczano recenzje, miały one różną objętość: jeśli pojawiały się w pierwszej części działu Kultura lub poza nim, zajmowały zwyczajowo jedną stronę. Rzadko zdarzały się omówienia obszerniejsze. Wyjątkiem była pięciostronicowa prezentacja nowej książki Doroty Masłowskiej Paw królowej ${ }^{117}$ czy trzystronicowa recenzja Słynnych zdjęć $i$ ich historii Hansa-Michaela Koetzle ${ }^{118}$. Natomiast omówienia drukowane $\mathrm{w}$ ramach Jupitera przybierały postać raczej krótkich, kilkuzdaniowych notek, mających charakter wzmianek niźli typowych recenzji. Warto zaznaczyć, że większość recenzentów pisma dbała o podanie danych bibliograficznych. W przypadku omówień dokonywanych przez W. Kota były one najpełniejsze, choć i ten dziennikarz nie zawsze pamiętał o podawaniu nazwiska tłumacza proponowanej książki autora obcego czy miejscu jej wydania. Z reguły jednak również najkrótsze wzmianki o książkach posiadały elementy przynajmniej podstawowe, pozwalające zidentyfikować daną lekturę, jak choćby jej autor i tytuł. Zazwyczaj pod notką widniała również nazwa wydawcy i niemal zawsze cena proponowanego tytułu.

Prawie wszystkie recenzje, omówienia, czy choćby adnotacje, zawierały w sobie streszczenie głównych wątków proponowanej książki. Naturalnie, najbardziej rozbudowane pod tym względem były prezentacje lektur, pomieszczane w pierwszej części działu kulturalnego, chociaż i tu zdarzały się kilkuzdaniowe zaledwie streszczenia o różnym charakterze i rozmaitej formie. Oto kilka wybranych, typowych przykładów, ilustrujących tę cechę:

Rzecz o małym amerykańskim miasteczku, ale opisanym tak, jakby chodziło o ogromną gotycką katedrę. Bo losy tej zabitej dechami dziury ze stanu Maine ścielą się nie tylko główną nawą, ale mają też swoje kapliczki, krużganki i podcienie. Układa się z tego imponująca, 550-

112 [br aut.], Sto twarzy, „Newsweek Polska” 2001, nr 15, s. 110.

113 W. Kot, Drzazga buntu, „Newsweek Polska” 2003, nr 26, s. 106.

114 „Newsweek Polska” 2002, nr 11, s. 104; nr 49, s. 124; 2004, nr 32, s. 24-25; 2005, nr 33, s. 92.

115 Zob. np. [br. aut.], [br. tyt.], „Newsweek Polska” 2004, nr 43, s. [115].

116 „Newsweek Polska” 2003, nr 19, s. 106; nr 41, s. 113; 2002, nr 46, s. 106; 2004, nr 52/53, s. 108; 2005, nr 50, s.70-[71].

117 P. Bratkowski, M. Łukaszewicz, Ewangelia według McDoris, „Newsweek Polska” 2005, nr 20, s. [90]-96.

118 J. Bielinowicz, Zobaczmy to jeszcze raz, „Newsweek Polska” 2003, nr 19, s. 102-104. 
-stronicowa saga amerykańskiej prowincji. Możemy poczuć się jak u siebie, śledząc losy mieszkańców miasteczka, kiedyś tętniącego życiem i pewnego swych świetnych perspektyw, a dziś podupadającego ${ }^{119}$.

Mieszkający od lat w mieścinie Salthill rzeźbiarz Adam Berendt umiera w ponurych okolicznościach. Kulisy jego śmierci i życia odsłania czytelnikom zakochana w nim właścicielka księgarni Marina Troy. To właśnie ona odkrywa w domu Adama pudło z miłosnymi listami, które pisały do niego inne kobiety z miasta120.

Niekiedy recenzent ograniczał się do ogólnej charakterystyki treści danej książki, jak na przykład:

Tom zawiera łącznie ponad trzydzieści miniatur. W większości są to dowcipne obrazki z życia wzięte, choć nie brakuje też fantastycznych, zakręconych nowelek. [...] Bohaterami wszystkich opowiadań są zwyczajni, przeciętni obywatele, mieszkańcy bloków z wielkiej płyty lub wiosek, ulokowanych gdzieś na obrzeżach wielkich miast ${ }^{121}$.

Nie brakowało jednocześnie recenzji, które niemal w całości poświęcone były analizie głównej fabuły przedstawianej książki122.

Znacznie częściej, niż było to w przypadku dwóch wcześniej omówionych tygodników, w recenzjach zamieszczanych na łamach „Newsweek Polska", w pierwszej części działu kulturalnego, pojawiały się informacje związane $\mathrm{z}$ autorem proponowanej książki. Podawano je w rozmaitej formie. Przeważnie były to małe moduły, umieszczane przy zdjęciu twórcy, zawierające daty i przypisane im wydarzenia z jego życia, albo też tytuły jego najważniejszych książek. Poza jednak tymi encyklopedycznymi danymi, nierzadko w tekście recenzji odnaleźć można było rozszerzone informacje związane zwłaszcza z życiem zawodowym autora lub jego poglądami. I tak na przykład, czytelnicy przy okazji recenzji Niewdzięczności, dowiedzieli się, że jej autor, Alain Finkielkraut,

jest jednym z nielicznych dzisiaj intelektualistów, którym naprawdę zależy. Zależy przede wszystkim na tym, żeby zrozumieć świat. Ponadto zależy mu na tym, żeby rozumieć świat, $\mathrm{w}$ jakim żyjemy nie stawał się gorszy. [...] nie jest antyliberalny, ale obawia się tego, przed czym przestrzegał teoretyk liberalizmu Benjamin Constant, a mianowicie niebezpiecznej wolności od wspólnoty, od państwa, a wobec tego od tradycji i historii123.

\section{R. Ziębiński, proponując powieść S. Kinga Colorado Kid, przypomniał, że autor}

119 W. Kot, Rewers Ameryki, „Newsweek Polska” 2003, nr 30, s. 98.

120 R. Ziębiński, We władzy przypadku, „Newsweek Polska” 2005, nr 41, s. [121].

121 D. Nowacki, Kowalscy na surowo, „Newsweek Polska” 2005, nr 43, s. [117].

122 Zob. np. „Newsweek Polska” 2002, nr 46, s. 106; 2004, nr 36, s. 90-91; 2005, nr 10, s. 88.

123 M. Król, Świat bez pamięci, „Newsweek Polska” 2005, nr 47, s. 110. 
pokazał w czasie swojej wieloletniej kariery, że jest pisarzem sprawnym w każdym gatunku. Debiutował jako autor horrorów, pisał powieści obyczajowe, fantasy, wspomnienia, eseje ${ }^{124}$.

Z kolei Sz. Hołownia, pisząc o kontrowersyjnej książce Moralny rozrachunek, przypomina czytelnikom:

Kim jest Daniel Goldhagen? Dotąd wydawało się, że historykiem. Zasłynął, publikując w 1996 r. książkę „Gorliwi kaci Hitlera” (polskie wydanie: Prószyński i S-ka, 1999), gdzie na podstawie socjologicznej analizy kilku batalionów nazistowskiej policji dowodził, że tzw. normalni Niemcy są za Holocaust odpowiedzialni w tej samej mierze, co ich przywódcy. Za tę książkę otrzymał nawet w RFN Nagrodę Demokracji125.

\section{Czasami dany autor porównywany był z innymi twórcami, jak choćby:}

Russo jest świetnym kontynuatorem najlepszych badaczy amerykańskiej prowincji. Jak Sinclair Lewis (1885-1951), który z pasją i wyczuciem satyrycznym odtwarzał bogobojną i kapitalistyczną mentalność amerykańskiej klasy średniej jeszcze w latach 20., Russo idzie też śladem innego giganta współczesnej literatury Sherwooda Andersona (1876-1941) [...]. Blisko też Richardowi Russo do bardzo w Polsce lubianego Johna Irvinga126.

Niekiedy recenzent ograniczał się do krótkiego stwierdzenia, odnoszącego się do autora proponowanej książki, jak choćby:

Jeszcze rok temu Sławomir Shuty był pisarzem niszowym, autorem trzech tomów prozy, o których świat niewiele wiedział. Jego czwarta książka, nagrodzona Paszportem „Polityki” powieść „Zwał”, zmieniła wszystko: Shuty niemal z dnia na dzień stał się pisarzem trendy 127 .

Przeważająca liczba recenzji miała charakter pozytywny. I tak na przykład Piotr Kępiński chwalił wiersze Jarosława Mikołajewskiego:

Niezłe pióro ma ten poeta. Pisze jak jest. Nie zakręca i nie ściemnia. Jego zdania są proste i jednocześnie pełne treści. [...] poeta wytrawny, publicysta znakomity i autor kongenialnych tłumaczeń za nic ma napuszone metafory. [...] Dlatego polecam [...] Tak pisze Mikołajewski, który ma styl, że ho, ho. Wie też, jak opowiadać i nie nudzić przy okazji. Czego więcej trzeba?128

P. Bratkowski, przyznając się do swej młodzieńczej fascynacji twórczością E. Lipskiej, pisał o jej nowym tomiku wierszy, podkreślając, że jest w nim „jak dawniej inteligencja i ironia”, jednocześnie cytując jeden z nich

\footnotetext{
${ }^{124}$ R. Ziębiński, King pulp fiction, „Newsweek Polska” 2005, nr 39, s. 112.

125 Sz. Hołownia, Skandalista Goldhagen, „Newsweek Polska” 2002, nr 42, s. 88.

126 W. Kot, Rewers Ameryki, „Newsweek Polska” 2003, nr 30, s. 98.

127 D. Nowacki, Kowalscy na surowo, „Newsweek Polska” 2005, nr 43, s. [117].

128 P Kępiński, Opowieści o miłości i śmierci, „Newsweek Polska” 2005, nr 50, s. 112. Książka została oznaczona symbolem, oznaczającym tytuł „super”.
} 
(Dyskoteka) ${ }^{129}$. Przywoływanie jednego z utworów z proponowanych zbiorów wierszy było w przypadku prezentacji tego typu literatury częstym zwyczajem autorów tygodnika. Tak było również w przypadku wierszy Wisławy Szymborskiej (obok recenzji pojawił się wówczas przejmujący wiersz Wypadek drogowy, z tomu Dwukropek, w kolejnym omówieniu zbioru Chwila zamieszczono fragment wiersza $W$ zatrzęsieniu).

Recenzje poezji były jednak nieczęstym gościem na łamach pisma, przeważnie bowiem oceniano prozę. I tak na przykład, J. Giziński tak pisał o książce Krystyny Jagiełło, Po zmierzchu bogów: „To interesująca lektura, pełna scen z życia politycznego i codziennych spraw, którymi żyli nasi zachodni sąsiedzi"130 i przyznawał proponowanej książce najwyższą ocenę. Podobnie D. Nowacki uważał, że warto sięgnąć po książkę Karela van Loona Ojciec i ojciec, tak uzasadniając swoją opinię: „Książka jest świetnie napisana, a do tego ciekawie pokazuje obyczaje oraz niesłychanie skomplikowane relacje między najbliższymi. Nie dziwi więc, że to najczęściej tłumaczona holenderska powieść współczesna"131. Podobnie recenzja książki Nie mów nikomu zasłużyła w oczach $\mathrm{W}$. Kota, na pochwałę: „Precyzyjna intryga i odrażający bohaterowie - to recepta Harlana Cobena na mistrzowski kryminał. [...] czyta się jak dopracowany w najdrobniejszych szczegółach scenariusz inteligentnego thrillera" 132 .

Równie pozytywną opinię wystawił M. Cieślik Tajemniczemu płomieniowi królowej Loany U. Eco, twierdząc, że jest to najlepsza książka autora od czasów Imienia róży. Pomimo fabuły „zaskakująco wątłej”, podkreślał, że dla czytelnika płyną z lektury dwa ważne wnioski, z których jeden „ogranicza się do prostego stwierdzenia: mamy w życiu tylko dwie ważne sprawy: miłość i śmierć. Reszta to szpargały"133.

Pojawiały się jednak również recenzje negatywne, chociaż nie istniała specjalnie dla nich poświęcona rubryka, tak jak było to $\mathrm{w}$ przypadku tygodnika „Polityka”. Niepochlebne opinie drukowano na łamach „Newsweek Polska" w różnych działach i rubrykach pisma. Sz. Hołownia, omawiając wspomnianą już książkę D. J. Goldhagena, Moralny rozrachunek. Rola Kościoła katolickiego w holocauście, pisał:

Autor twierdzi, że Kościół jest odpowiedzialny za holocaust, a chrześcijaństwo legło u podstaw nazizmu. [...] znajdujemy zresztą całą gamę absurdów, treściowych i formalnych.

129 P. Bratkowski, Odjazd z dyskoteki, „Newsweek Polska” 2005, nr 5, s. 106.

130 J. Giziński, Panorama Niemiec, „Newsweek Polska” 2005, nr 49, s. 101.

131 D. Nowacki, Powieść-zagadka, „Newsweek Polska” 2005, nr 38, s. 118.

132 W. Kot, Kloaka klasy średniej, „Newsweek Polska” 2002, nr 37, s. 114. Zob. też np. ibidem, 2005, nr 40, s. 114; nr 41, s. [121]; nr 39, s. 112.

133 M. Cieślik, Profesor Eco i pan Umberto, „Newsweek Polska” 2005, nr 40, s. 112. 
Wiele rozdziałów zbudowanych jest w podobny, przypominający afektywne wyładowanie sposób ${ }^{134}$.

Również Młyn w piekarni nie znalazł uznania w oczach recenzenta periodyku. Czytelnik mógł się dowiedzieć, że

na blisko 400 stronicach książki [...] Jarosław Abramow-Newerly spisał codzienność polskich emigrantów, zarabiających na chleb w piekarni w Toronto. Zbędny wysiłek. Po pierwsze, przyjemniej czytałoby się powieść o połowę krótszą, zamiast brnąć przez fabułę, która wlecze się z odcinka na odcinek jak „Matysiakowie”. Po drugie, czy zbiorowy bohater książki, czyli emigracja, naprawdę wart jest powieści?135

Nieco delikatniejsza krytyka dotyczyła z kolei Wychowania dziewcząt $w$ Czechach, książki Michala Viewegha, który zdaniem M. Cieślika, jest czeskim „wcieleniem Jerzego Pilcha. Pisze z podobnym wdziękiem, tyle że ma zdecydowanie mniej do powiedzenia. [...] Czyta się z przyjemnością [...], ale i szybko się zapomina"136. R. Ziębiński nie obawiał się z kolei skrytykować znanego pisarza, U. Eco, przyznając, że bajki pióra autora Pięciu pism moralnych rozczarowują: „to naprędce sklecone, banalne historyjki, które sprawiają wrażenie niezamierzonej parodii >Małego księcia <. Wybitny humanista bez krzty wdzięku wykłada łopatologicznie, że warto być dobrym"137. Niekiedy pojawiały się komentarze, w których nie brakowało zarówno krytyki, jak i pochwały. Oto jeden z przykładów:

Najnowsza powieść autora „Trylogii nowojorskiej” nie zachwyca. Można darować pisarzowi, że się powtarza, ale nie można przemilczeć skutków przyjętej przez niego metody recyklingu. Mówiąc najdelikatniej, „Szaleństwa Brooklynu” to utwór nieco bałaganiarski, niezbyt spójny, miejscami kapryśny. [...]. Nie znaczy to jednak, że zszyte z dość przypadkowych kawałków „Szaleństwa Brooklynu” to zła książka. Gdzie tam! Paul Auster osiągnął taką biegłość w pisarskim rzemiośle, że nawet kiedy publikuje powieść, która niczego w obrazie jego twórczości nie zmienia, nie czujemy się nabrani. Może odrobinę zawiedzeni, ale to przecież nie to samo ${ }^{138}$.

W kilku przypadkach recenzowano książki, które w tym samym, we wcześniejszych lub $\mathrm{w}$ następnych numerach pisma były reklamowane. Niekiedy recenzja pojawiała się tuż obok reklamy tytułu, co wyraźnie osłabiało wymowę oceny recenzenta. I tak na przykład, reklama nowej książki Witolda Horwatha, zawierająca obszerny fragment powieści, znalazła

\footnotetext{
134 Sz. Hołownia, Skandalista Goldhagen, „Newsweek Polska” 2002, nr 42, s. 88.

135 W. Kot, Kanadyjski margines, „Newsweek Polska” 2002, nr 31, s. 100.

136 M. Cieślik, Czeski pop, „Newsweek Polska” 2005, nr 50, s. 112.

137 R. Ziębiński, Nie tylko dla dzieci, „Newsweek Polska” 2005, nr 50, s. 112.

138 D. Nowacki, Woody Allen literatury, „Newsweek Polska” 2005, nr 45, s. 116.
} 
się pod jej omówieniem ${ }^{139}$. Niekiedy recenzowano książkę autora, o którym pisano kilka stron wcześniej ${ }^{140 .}$

Bez wątpienia mocną stroną recenzji zamieszczanych na łamach tygodnika były ich tytuły. Oto kilka wybranych przykładów ${ }^{141}$ : Bolesna rozkosz kpiny, Co się dzieje, kiedy kobiety czytaja Biblię, Cywilizacja prowizorki, Diagnostyka uczuć, Dobra wiadomość, Drzazga buntu, Dyktatura własnego lęku, Honor czy ojczyzna?, Kpiący uśmiech mistrza, Kuglarz literatury, Mistrzowie ducha, Nieznośny ciężar myślenia, Poezja serca, Rubikon egzystencji, Rury i dusza, Struktura cudu, Sztuka perfidii, To życie dzieje się naprawdę, Woody Allen literatury, Życie tryb warunkowy.

\subsubsection{Tajny przepis na sukces ${ }^{142}$ : wywiady}

Na łamach „Newsweek Polska” znalazło się niewiele wywiadów przeprowadzonych z osobami bezpośrednio lub pośrednio związanymi z literaturą. W ciągu badanego okresu było ich zaledwie 26, i tylko w 8 przypadkach były to rozmowy z pisarzami. Wśród nich znaleźli się: Norman Davies (dwukrotnie), Janusz Głowacki, John Irving, Norman Mailer, Aaron Hotchner, Michael Ridpath, Zadie Smith (zob. Aneks 22. Nazwiska osób, związanych z książką, z którymi przeprowadzono wywiad na łamach „Newsweek Polska” w latach 2001-2005). Jak twierdzi W. Kot, niewielka liczba wywiadów z autorami wynikała z faktu

pojawiania się niewielu wybitnych, dyskusyjnych i głośnych książek polskich w skali roku. Poza tym, jeżeli mieliśmy do czynienia z wybitnym dziełem na przykład poetyckim czy eseistycznym, wychodziliśmy z założenia, że nasz przeciętny czytelnik i tak po nie nie sięgnie. Jest bowiem zainteresowany raczej kulturowym mainstreamem. Na wywiad nadawał się ktoś, czyja twórczość i osobowość wykraczałyby poza literaturę. Poza tym ten ktoś musiałby mieć coś do powiedzenia np. o sprawach społecznych czy politycznych, a takich autorów nie było wielu. Sam starałem się o pozyskanie T. Konwickiego i J. Głowackiego na stałych felietonistów pisma. Obaj jednak odmówili143.

139 „Newsweek Polska” 2005, nr 47, s. [111].

140 Zob. np. „Newsweek Polska” 2005, nr 16, s. 106-110. Recenzja dotyczyła książki Zb. Mentla: Wszystkie języki świata (Znak 2005): P. Bratkowski, Wszystkie języki świata, „Newsweek Polska” 2005, nr 16, s. 110. Sylwetkę pisarza przedstawiła na s. 106-109 M. Łukaszewicz w tekście Literacki spekulant.

141 Kolejno: „Newsweek Polska” 2003, nr 30, s. 97; 2004, nr 1, s. [94]-96; 2002, nr 25, s. $106 ; 2001, \mathrm{nr} 13$, s. $122 ; 2005$, nr 5, s. $112 ; 2003$, nr 26, s. 106; nr 49, s. $111 ; 2005$, nr 44, s. [107]; 2002, nr 43, s. 110; nr 4, s. 103; 2003, nr 2, s. 110; 2004, nr 44, s. 110; 2001, nr 11, s. $108 ; 2002$, nr 2, s. $108 ;$ nr 7, s. $109 ; 2003$, nr 37, s. $104 ; 2002$, nr 14, s. $108 ; 2005$, nr 36, s. 98; nr 45, s. 116; nr 46, s. 104.

142 „Newsweek Polska” 2003, nr 46, s. 6. Tytuł wywiadu z A. E. Hotchnerem, pisarzem i P. Newmanem, aktorem.

143 Informacje uzyskane dzięki korespondencji z W. Kotem. 
W tabeli 31 zaprezentowano liczbę wywiadów w poszczególnych latach.

Tabela 31. Wywiady zamieszczane na łamach

„Newsweek Polska” w latach 2001-2005

\begin{tabular}{|c|c|}
\hline Rok & Liczba wywiadów \\
\hline 2001 & 1 \\
\hline 2002 & 4 \\
\hline 2003 & 4 \\
\hline 2004 & 12 \\
\hline 2005 & 5 \\
\hline Ogółem & 26 \\
\hline
\end{tabular}

Źródło: badania własne.

W 13 przypadkach rozmowy pojawiły się w dziale Kultura, w pozostałych czytelnik odnalazł je w ramach informacji z Polski i ze świata, a także związanych z biznesem i nauką. Objętość wywiadów wahała się od pół do czterech stron. Nie wyróżniały się one jednak niczym szczególnym, można nawet stwierdzić, że w porównaniu z podobnymi formami promocji literatury zamieszczanymi na łamach tygodników „Polityka” i „Wprost” były ubogie w elementy dodatkowe. Jedynie, kiedy rozmawiano z N. Daviesem, głównie zresztą o sprawach związanych z polityką zagraniczną, w periody$\mathrm{ku}$ pod wydrukowaną rozmową znalazł się moduł z okładkami siedmiu książek tego eseisty i historyka, uzupełnionymi krótkimi adnotacjami i podstawowymi informacjami bibliograficznymi. W pozostałych przypadkach ograniczano się do zdjęcia rozmówcy i tylko kilkakrotnie do podania krótkich informacji o nim. Interesujący wywiad przeprowadzono z J. Irvingiem; rozmowa niemal w całości poświęcona była nowej książce autora Regulaminu tłoczni win. Nowy tytuł, Zanim cię znajdę, miał ukazać się na polskim rynku wydawniczym za kilka miesięcy. J. Irving uchylił rąbka tajemnicy, dotyczącej fabuły powieści, podkreślając jednocześnie, że jest powieściopisarzem komicznym ${ }^{144}$. Trzykrotnie wywiad pojawiał się obok recenzji książki, której autorem był rozmówca, co, jak twierdzi W. Kot, było

formą poszerzania publikacji na temat książki. Redakcja oceniała dzieło, a pisarz komentował je ze swej strony. Była to forma uhonorowania książki. Redakcja uznawała, że jest ona na tyle doniosła, że warto przy tej okazji dopytać autora. Był to zabieg zarezerwowany dla wydarzeń czytelniczych najwyższej rangi ${ }^{145}$.

144 Rozm. M. Jones, Chłopięcy świat, „Newsweek Polska” 2005, nr 29, s. 88-[89].

145 Informacje uzyskane dzięki korespondencji z W. Kotem. 


\subsubsection{Czas na dobrą książkę ${ }^{146}$ : reklamy książek}

W 221 numerach pisma pojawiły się 1192 reklamy, które odpowiadały tematowi pracy. Wśród nich można wyróżnić następujące grupy:

1) książki (także m.in. albumy, atlasy, encyklopedie, słowniki, podręczniki, poradniki, przewodniki),

2) akcje periodyku związane z książką (konkursy, targi, spotkania) ${ }^{147}$,

3) prasa, w tym autoreklama „Newsweek Polska” 148.

Ogłoszenia, bezpośrednio związane z książką, stanowiły niewielką część wszystkich reklam: tego typu anonsów było zaledwie 187, w tym zachęcających do kupna albumów pojawiło się 6, tyle samo było ogłoszeń promujących podręczniki. Encyklopedie reklamowano siedmiokrotnie, z kolei różnego rodzaju przewodniki stały się 25 razy przedmiotem reklam, słowniki czterokrotnie, tyleż samo razy komiksy, a multimedialne translatory tylko dwukrotnie, podobnie jak atlasy. Tylko raz proponowano $\mathrm{w}$ ten sposób poradnik i trzy razy katalogi. Panorama firm reklamowana była przez wydawcę czterokrotnie. $\mathrm{W}$ tabeli 32 zaprezentowano liczbę ogłoszeń wydawniczych w poszczególnych latach.

Tabela 32. Ogłoszenia wydawnicze zamieszczane na łamach „Newsweek Polska” w latach 2001-2005

\begin{tabular}{|c|c|}
\hline Rok & Liczba reklam w sumie \\
\hline 2001 & 9 \\
\hline 2002 & 23 \\
\hline 2003 & 16 \\
\hline 2004 & 44 \\
\hline 2005 & 96 \\
\hline Ogółem & 187 \\
\hline
\end{tabular}

Źródło: badania własne.

Zwraca uwagę niewielka liczba ogłoszeń w roku 2001. Nawet jeśli weźmie się pod uwagę fakt, że ukazało się wówczas zaledwie 16 numerów periodyku, to okazuje się, że średnio w $7 \mathrm{z}$ nich zabrakło takiej formy promocji książki. Dwa następne lata również nie są zbyt optymistyczne pod tym względem: do czytelników trafiało wiele numerów pozbawionych reklam wydawniczych. W ostatnich dwóch analizowanych rocznikach sytuacja pod tym względem wyglądała nieco lepiej, chociaż warto zaznaczyć, że w porów-

146 Hasło reklamowe w jednym z anonsów. Zob. „Newsweek Polska” 2005, nr 23, s. [105].

147 Ta grupa informacji, ze względu na swoją dwojaką postać (reklama i komentarz tekstowy) zostanie przedstawiona w dalszej części rozdziału (zob. inne formy informacji o książce).

148 Zagadnienie dotyczące informacji o prasie na łamach prezentowanego pisma zostanie dokładniej omówione w ostatniej części rozdziału. 
naniu z analogicznymi danymi w przypadku dwóch wcześniej przedstawionych pism, prezentowała się skromnie. Jak stwierdził W. Kot,

reklamy były dla wydawnictw za drogie i z kalkulacji wynikało, że nie przyniosą spodziewanego zainteresowania i zysków. Mogli sobie na nie pozwolić potentaci wydawniczy mający w dodatku do zaoferowania „pewny” tytuł. Ale to były albo bardzo rzadkie przypadki, albo nie było ich wcale ${ }^{149}$.

Inseraty drukowane były w całym piśmie, chociaż większość z nich znalazła się na stronach działu Kultura. Jak już wspomniano, niejednokrotnie pojawiały się one przy recenzjach książek lub przy okazji wywiadu z pisarzem. Warto również zaznaczyć, że wiele reklamowanych tytułów było wydanych przez Axel Springer Polska w ramach serii Literatura $w$ spódnicy. Nierzadko były to także tytuły, nad którymi wydawca lub tygodnik obejmował patronat medialny. Z drugiej strony, pomimo że chętnie omawiano książki współpracowników pisma, to jednak brakowało reklam tych tytułów.

Przez pięć lat do czytelników „Newsweek Polska” dotarła w ten sposób informacja o zaledwie 88 tytułach 39 autorów ${ }^{150}$, w tym 19 pisarzy polskich i 20 obcych (Aneks 23. Autorzy książek reklamowanych na łamach „Newsweek Polska" w latach 2001-2005). W tabeli 33 przedstawiono nazwiska tych twórców, którzy najczęściej pojawiali się w reklamach.

Tabela 33. Autorzy, których książki reklamowano najczęściej na łamach „Newsweek Polska” w latach 2001-2005

\begin{tabular}{|l|c|c|l|}
\hline \multicolumn{1}{|c|}{ Nazwisko autora } & Liczba inseratów & Liczba tytułów & Tytuły reklamowanych książek \\
\hline Helen Fielding & 6 & 2 & $\begin{array}{l}\text { Dziennik Bridget Jones } \\
\text { W pogoni za rozumem }\end{array}$ \\
\hline Jan Gawroński & 6 & 1 & Kolacja z Janem Pawłem II \\
\hline Maria Nurowska & 6 & 3 & $\begin{array}{l}\text { Imię twoje... } \\
\text { Powrót do Lwowa } \\
\text { Rosyjski kochanek }\end{array}$ \\
\hline Nicola Kraus & 5 & 1 & Niania w Nowym Jorku \\
\hline Tony Parsons & 5 & 2 & $\begin{array}{l}\text { Mężczyzna i chłopiec } \\
\text { Mężczyzna i żona }\end{array}$ \\
\hline Fannie Flagg & 4 & 1 & Smażone, zielone pomidory \\
\hline Jane Green & 4 & 1 & Prosto z mostu \\
\hline Lisa Jewell & 4 & 2 & $\begin{array}{l}\text { Impreza } \text { u Ralpha } \\
\text { Trzydziestka na karku }\end{array}$ \\
\hline Richard Picciotto & 4 & 1 & Ostatni z żywych \\
\hline Janusz L. Wiśniewski & 4 & 1 & S@motność w Sieci \\
\hline
\end{tabular}

Źródło: badania własne.

149 Informacje uzyskane dzięki korespondencji z W. Kotem.

150 W ośmiu przypadkach nie podano nazwiska autora reklamowanej książki. 
Ta zadziwiająca lista nazwisk wynika z faktu, że większość reklam odnosiła się do książek, wydanych przez Axel Springer w ramach wspomnianej wcześniej kolekcji, na którą składała się literatura popularna, adresowana do kobiet. Aż 8 z 10 nazwisk to autorzy książek wchodzących w skład tejże kolekcji. Nazwa koncernu pojawiła się w ogłoszeniach 55 razy. Poza nim tylko 13 edytorów skorzystało z możliwości reklamy swej oferty na łamach tygodnika. Ich pełne zestawienie zaprezentowano w tabeli 34 (także zob. Aneks 24. Wydawcy, którzy zamieścili swe anonse na łamach „Newsweek Polska” w latach 2001-2005).

Tabela 34. Wydawcy najczęściej zamieszczający inseraty na łamach „Newsweek Polska” w latach 2001-2005

\begin{tabular}{|l|c|}
\hline \multicolumn{1}{|c|}{ Nazwa wydawcy } & Liczba anonsów \\
\hline Wydawnictwo Pascal & 20 \\
\hline Świat Książki & 11 \\
\hline $\begin{array}{l}\text { ECTACO } \\
\text { Społeczny Instytut Wydawniczy } \\
\text { Znak }\end{array}$ & 8 \\
\hline Wydawnictwo W.A.B. & 7 \\
\hline Wydawnictwo Szkolne PWN & 6 \\
\hline $\begin{array}{l}\text { Polska Agencja Informacyjna S.A. } \\
\text { Wydawnictwo Naukowe PWN }\end{array}$ & 4 \\
\hline PWE & 3 \\
\hline INFOR & 2 \\
\hline ProDoKs & 1 \\
\hline Cross Media & \\
\hline Wydawnictwo Universitas & \\
\hline
\end{tabular}

Źródło: badania własne.

W powyższym zestawieniu brakuje kilku największych czy najbardziej popularnych wydawców tego okresu. Dom Wydawniczy Bellona, Wydawnictwo Prószyński i S-ka, WSiP nie były zainteresowane zamieszczeniem reklamy na łamach tego periodyku. 


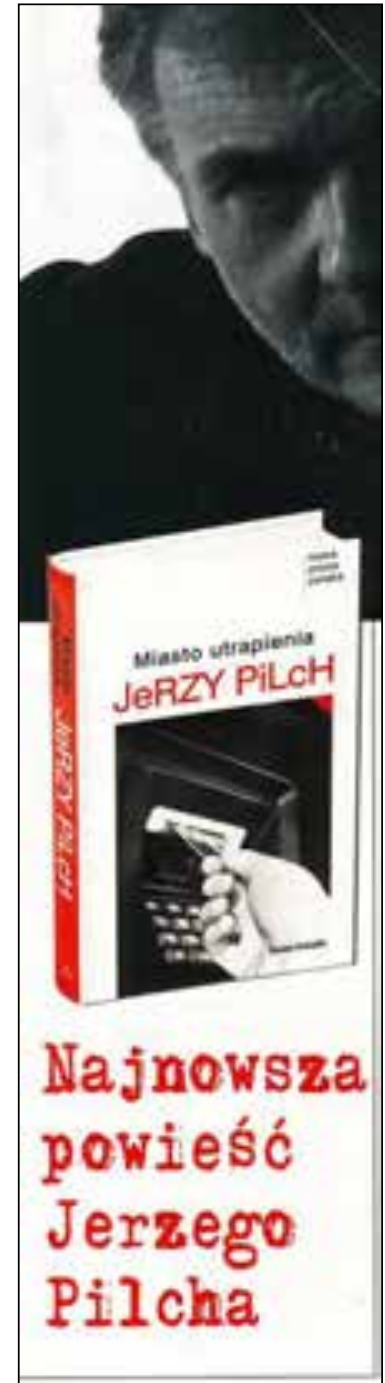

Pabron mediani:
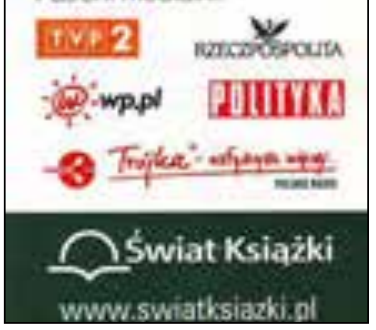

Ci, którzy z takiej możliwości skorzystali, prezentowali swą ofertę zazwyczaj $w$ formie niewielkich modułów, drukowanych u dołu strony, na całej jej szerokości lub też w postaci kolumny, przeważnie zamieszczanej z prawej strony. W 31 przypadkach były to całostronicowe reklamy, za każdym jednak razem czytelnik zachęcany był w ten sposób do kupna książki przez wydawcę „Newsweek Polska". Porównując analogiczne zestawienie w odniesieniu do recenzji, można zauważyć, że tylko dwa wydawnictwa powtórzyły się: były to Świat Książki i W.A.B.

Anonse wydawnicze pod względem graficznym nie były szczególnie atrakcyjne. Większość z nich miała skromną formę i zawierała niewiele elementów, chociaż przeważnie były one kolorowe. W wielu inseratach pojawiały się informacje o jednym tytule, niekiedy, szczególnie w odniesieniu do wspomnianej Literatury $w$ spódnicy oraz oferty podręczników, znajdowały się w nich dane o kilku książkach.

Interesującym pomysłem Wydawnictwa W.A.B. było zamieszczenie $\mathrm{w}$ anonsie fragmentu reklamowanej lektury. Tak było na przykład w przypadku książki Marka Krajewskiego Widma w mieście Breslau ${ }^{151}$ i Marcina Wolskiego Miejsce dla dwoj$g a^{152}$. Zazwyczaj w inseratach pojawiała się kopia okładki reklamowanej książki, hasło reklamowe odnoszące się przeważnie do podkreślenia waloru nowości proponowanego tytułu, podania patronów medialnych i nazwy wydawcy, czasem zdjęcie autora. Obok i poniżej przedstawiono przykładowe ogłoszenia zawierające wszystkie te elementy (zdjęcia 56-59).

$\triangleleft$ Zdjęcie 56. Przykładowe ogłoszenie wydawnicze zamieszczone na łamach „Newsweek Polska”

„Newsweek Polska” 2004, nr 5, s. 7

151 „Newsweek Polska” 2005, nr 35, s. [103].

152 „Newsweek Polska” 2005, nr 23, s. [105]. 
Nieodłącznym elementem każdego z przywołanych ogłoszeń była kopia okładki proponowanej książki, w rozmaity sposób eksponowana. Dodatkowo wzrok czytelnika przykuwała dobrze dobrana kolorystyka. Dwa pierwsze inseraty zawierały mało informacji, $\mathrm{w}$ dwóch następnych reklamodawca podkreślał walory polecanych tytułów, przy czym wartość „światowego bestsellera” opowiadającego o „dramacie, który rozegrał się na Antarktydzie" podnosił fakt, że była to historia prawdziwa.

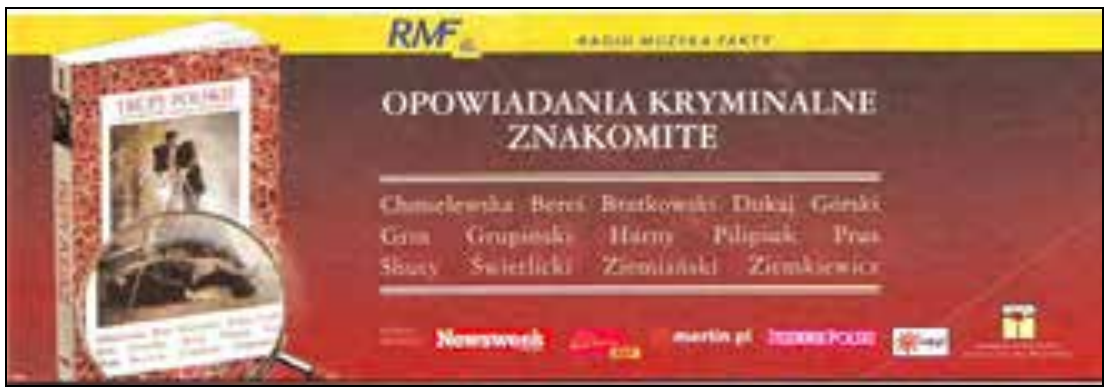

Zdjęcie 57. Przykładowe ogłoszenie wydawnicze zamieszczone na łamach „Newsweek Polska”

„Newsweek Polska” 2005, nr 46, s. [69]

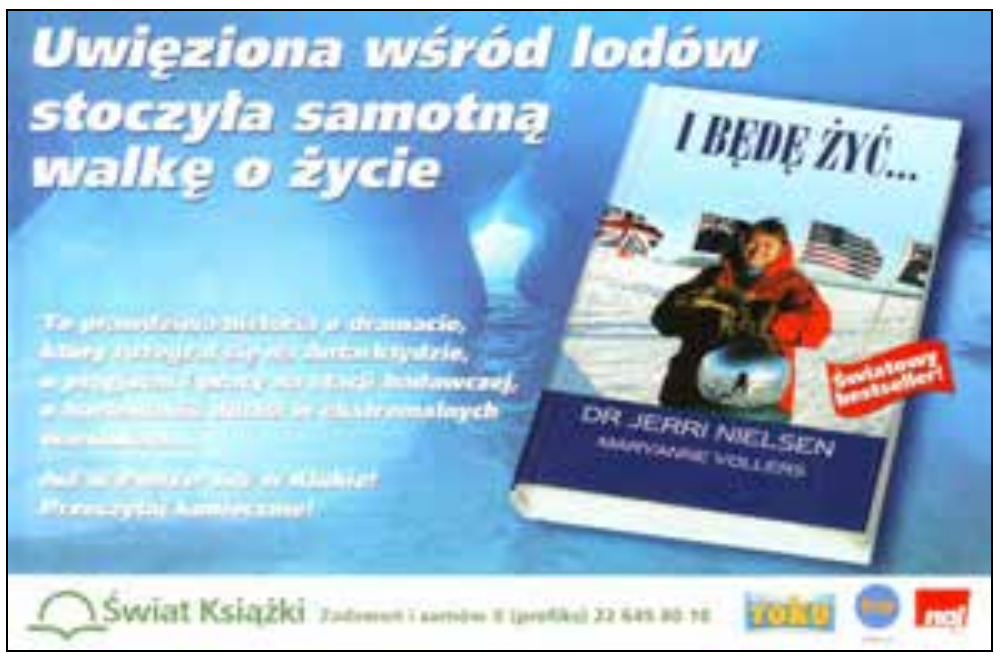

Zdjęcie 58. Przykładowe ogłoszenie wydawnicze zamieszczone na łamach „Newsweek Polska”

„Newsweek Polska” 2002, nr 2, s. 7 


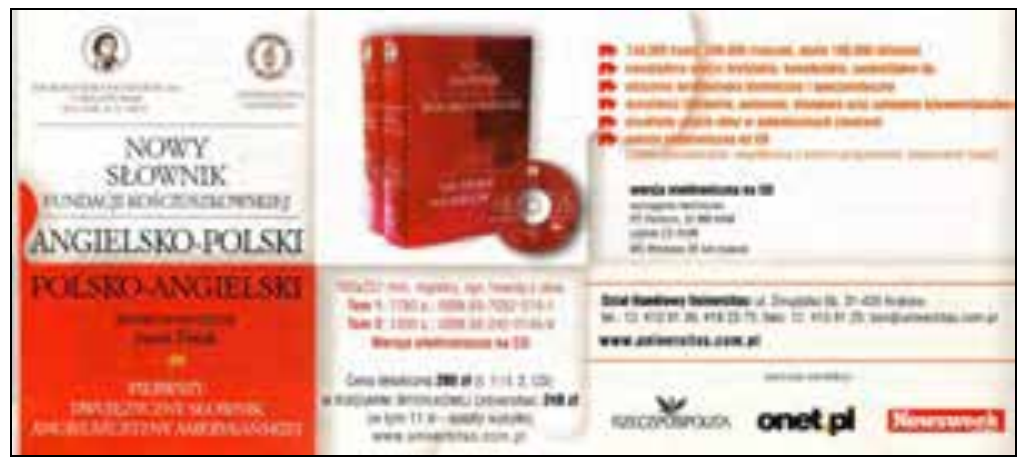

Zdjęcie 59. Przykładowe ogłoszenie wydawnicze zamieszczone na łamach „Newsweek Polska” „Newsweek Polska” 2003, nr 37, s. [40]

Ciekawie wyglądała również reklama książki $A B C$ dziennikarstwa, wydanej przez Axel Springer Polska. W tym przypadku czytelnik od razu zwracał uwagę na znane sobie twarze dziennikarzy, m.in. T. Lisa - zdjęcie 60.

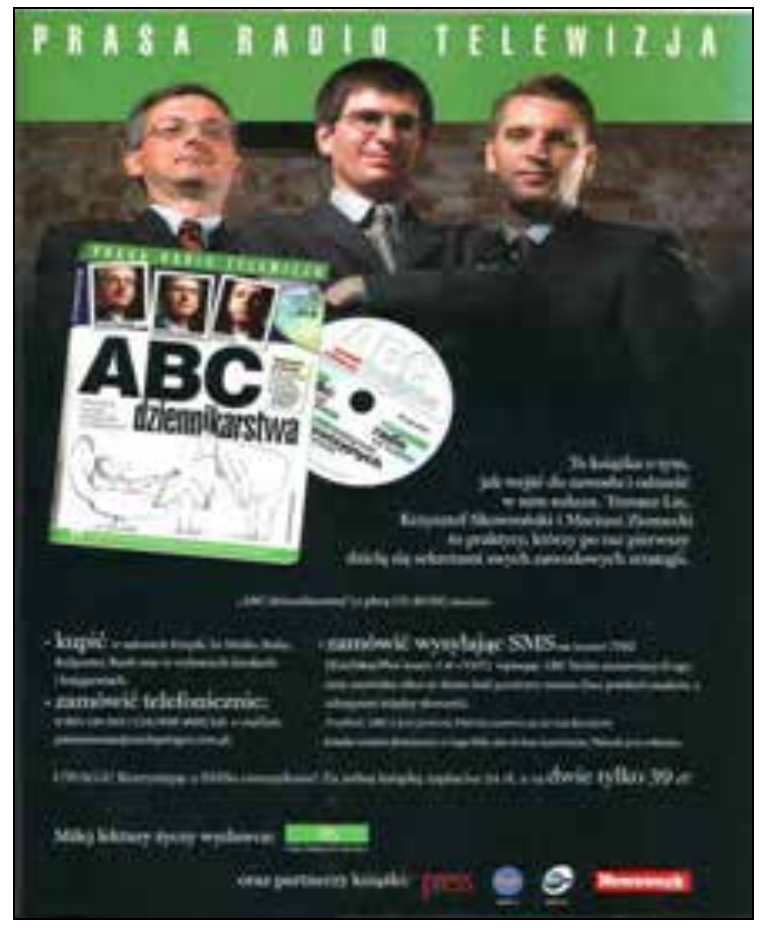

Zdjęcie 60. Przykładowe ogłoszenie wydawnicze zamieszczone na łamach „Newsweek Polska” „Newsweek Polska” 2002, nr 51-52, s. [175] 
W przypadku tego ogłoszenia elementem zwracającym uwagę odbiorcy miało być zapewne zdjęcie trzech dziennikarzy, których nazwiska znane były szerszej publiczności. Ich popularność miała w tym przypadku zagwarantować zainteresowanie czytelnika.

Podobnie, jak było to w przypadku dwóch wcześniej przedstawionych tygodników, tak i na łamach „Newsweek Polska” pojawiła się reklama Wydawnictwa Naukowego PWN, i tak jak czytelnicy dwóch konkurencyjnych tytułów, tak i odbiorcy omawianego tygodnika mogli podziwiać wyróżniającą się grafikę całostronicowego ogłoszenia tego edytora, choć zamieszczono je zaledwie dwukrotnie.

Zarówno w przypadku Słownika..., jak i Encyklopedii... wydawca podkreślał ich zalety; pomysłowe były również hasła reklamowe, które pojawiły się w obydwu przypadkach - zdjęcie 61 i 62.

Warto także przywołać najczęściej pojawiający się anons, autoreklamę wydawcy, przypominającego czytelnikom o proponowanej kolekcji zdjęcie 63.

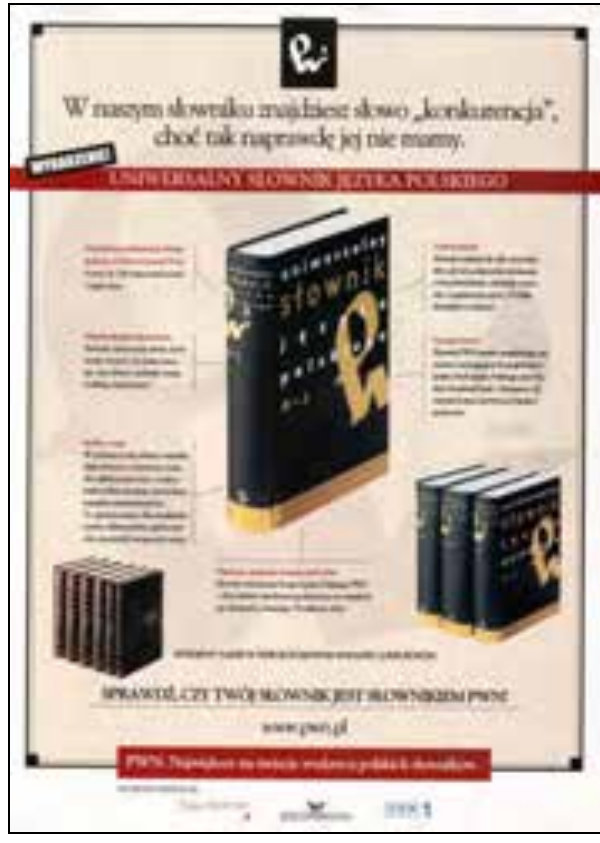

Zdjęcie 61. Przykładowe ogłoszenie wydawnicze zamieszczone na łamach „Newsweek Polska"

„Newsweek Polska” 2003, nr 16, s. [69]

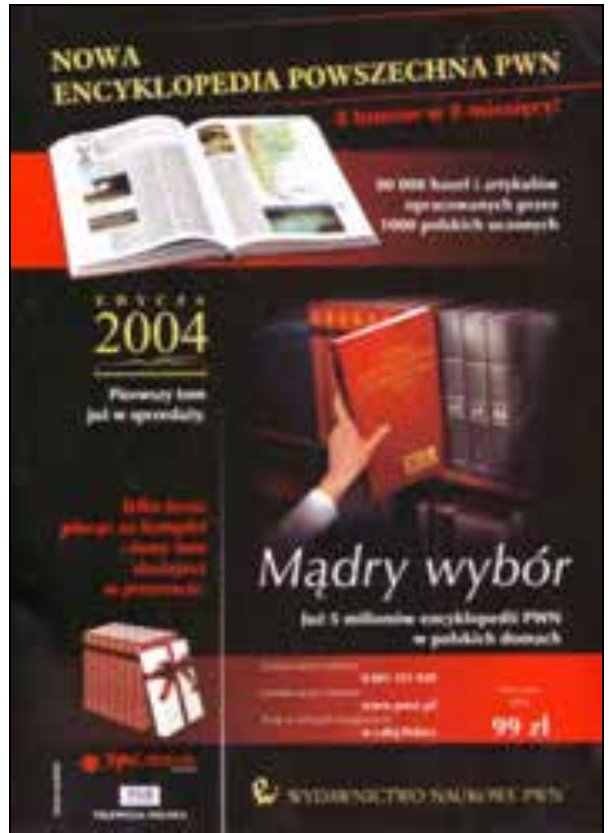

Zdjęcie 62. Przykładowe ogłoszenie wydawnicze zamieszczone na łamach „Newsweek Polska"

„Newsweek Polska” 2004, nr 19, s. [99] 


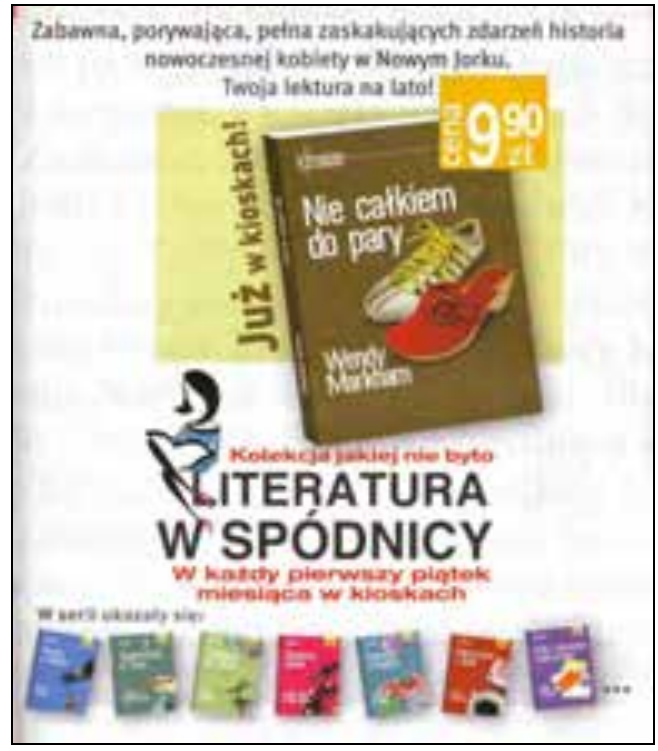

Zdjęcie 63. Przykładowe ogłoszenie wydawnicze zamieszczone na łamach „Newsweek Polska” „Newsweek Polska” 2005, nr 28, s. [89]

W reklamie tego cyklu zmieniały się jedynie tytuły, zaś pozostałe elementy za każdym niemal razem były takie same, dzięki czemu zakodowały się $\mathrm{w}$ umyśle odbiorcy, który sprawdzał jedynie, jaki kolejny tytuł został wydany w ramach znanej mu już serii.

W kontekście tematyki podejmowanej w pracy warto zaznaczyć, że poza książkami reklamowano również konkursy oraz akcje, których organizatorem był „Newsweek Polska”. Jako że miały one postać zarówno reklam, jak i tekstów opisowych, zostaną omówione w zamieszczonym poniżej podrozdziale.

Warto w tym miejscu wspomnieć o listach bestsellerów, drukowanych $\mathrm{w}$ periodyku. $\mathrm{W}$ badanym okresie pojawiły się one na łamach pisma 135 razy. Jak już wcześniej wspomniano, po raz pierwszy czytelnik odnalazł je w numerze 37 (2002), na stronach Jupitera ${ }^{153}$. Początkowo ta forma informacji o książce pojawiała się niesystematycznie. Pierwsze zestawienia nie są jednoznacznie określane jako typowe listy bestsellerów i tylko w niewielkim stopniu je przypominają. Ową niejednoznaczność podkreślał jeszcze

$153 \mathrm{~W}$ większości przypadków zestawienia te drukowano w tym miejscu periodyku, chociaż zdarzały się wyjątki, np. w numerze 51/51 (2003) czytelnik odnalazł je w ramach innej rubryki: Peryskop, na początku numeru. 
brak źródła, na podstawie którego były one przygotowane, jak również brak kryterium, według którego je wybierano. Kilkakrotnie zmieniały swą formę oraz tytuł, z czasem nie budzący już wątpliwości co do swego charakteru. I tak, Hity września ${ }^{154}$ zawierały pięć tytułów wraz z podstawowymi danymi bibliograficznymi, krótkimi adnotacjami treściowymi i kopiami okładek wybranych książek. Zbliżoną do nich formułę zachowały trzy kolejne zestawienia (Lektury na październik ${ }^{155}$, Ksiq̨żki w styczniu ${ }^{156}$ oraz Ksiq̨żki w zimie ${ }^{157}$ ). Ale już następne (Książki. Ranking ${ }^{158}$ ), które wydrukowano dopiero w numerze 11 (2003), zmieniło swą postać. Podzielone było na Literaturę obcq i Literaturę polska, w ramach których pojawiło się po pięć propozycji, a u dołu podano źródło, na podstawie którego zestawienie zostało przygotowane (sieć księgarni Matras) - zdjęcie 64 i 65.

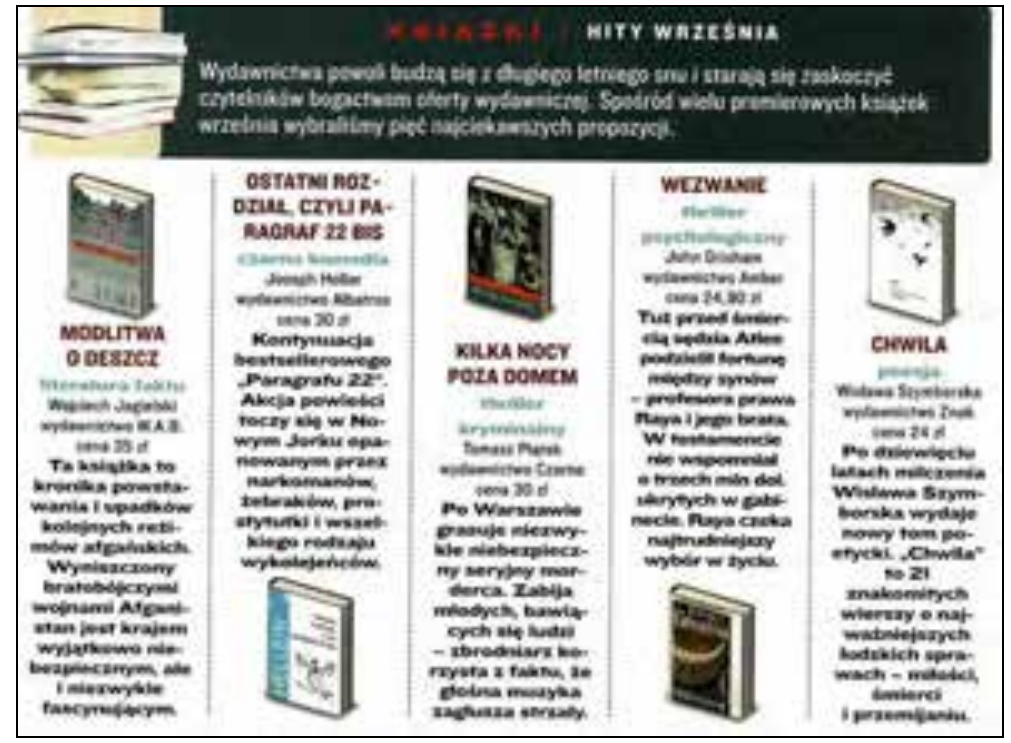

Zdjęcie 64. Hity września na łamach „Newsweek Polska” „Newsweek Polska” 2002, nr 37, s. 118

154 Hity września, „Newsweek Polska” 2002, nr 37, s. 118.

155 Lektury na październik, „Newsweek Polska” 2002, nr 41, s. 110.

156 Ksiq̨żki w styczniu, „Newsweek Polska” 2003, nr 4, s. 110.

157 Książki w zimie, „Newsweek Polska” 2003, nr 8, s. [110].

158 Ksiq̨żki. Ranking, „Newsweek Polska” 2003, nr 11, s. 103. 


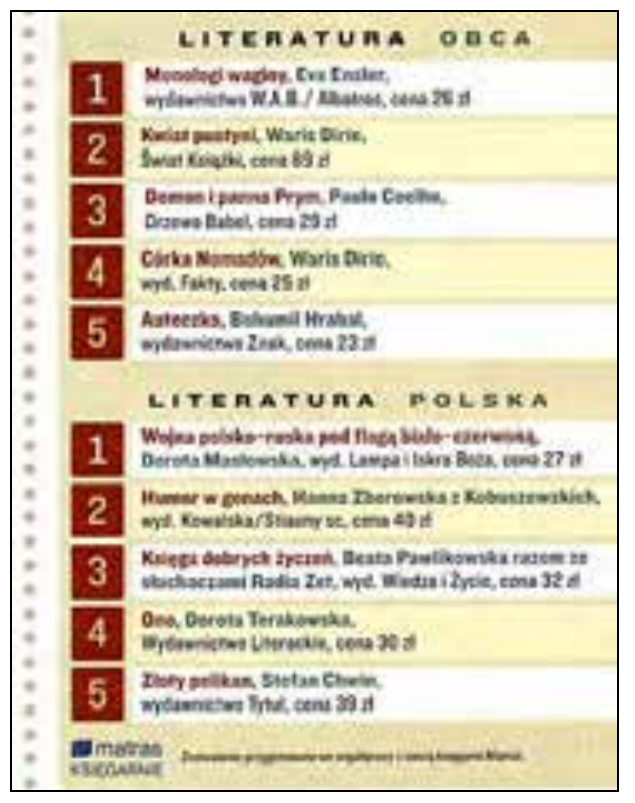

Zdjęcie 65. Ksiq̨żki. Ranking na łamach „Newsweek Polska”

„Newsweek Polska" 2003, nr 11, s. 103

Pod względem graficznym zestawienia te prezentowały się korzystnie, poszczególne elementy były od siebie wyraźnie oddzielone, dzięki czemu całość przekazu była czytelna. Pierwsza propozycja była $\mathrm{z}$ pewnością bardziej interesująca, ze względu na zamieszczenie przy każdej z pozycji krótkiej adnotacji treściowej oraz kopii okładek proponowanych książek. Natomiast wprowadzone zmiany przyniosły zmniejszenie informacji: ograniczono się do podawania danych bibliograficznych związanych z każdym tytułem i dwóch krótkich wzmianek dotyczących wybranych lektur.

W numerze 20 (2003) powrócono do poprzedniej formy, prezentując Komiks. Wiosenne hity, ale od numeru 22 (2003) ponownie ta forma informacji o książce uległa zmianie. Zatytułowano ją Ranking Newsweeka. Hity tygodnia. W trzech kolumnach (Książki, Muzyka, Kino) prezentowano 10 propozycji, opracowanych tym razem na podstawie danych uzyskanych od firmy ES-MEDIA (informacje o filmach) oraz sieci EMPiK (dane dotyczące płyt $\mathrm{z}$ muzyką oraz książek). W kolejnym zestawieniu dodano również oznaczenie, określające, czy dana propozycja jest nowością oraz czy zmieniła swoje miejsce w rankingu. Taką formę Ranking zachował do numeru 50 (2004), zmieniając jedynie niekiedy kolejność nagłówków poszczególnych kolumn. W 2005 r. w numerze 4 zamieszczono zestawienie w skromniejszej 


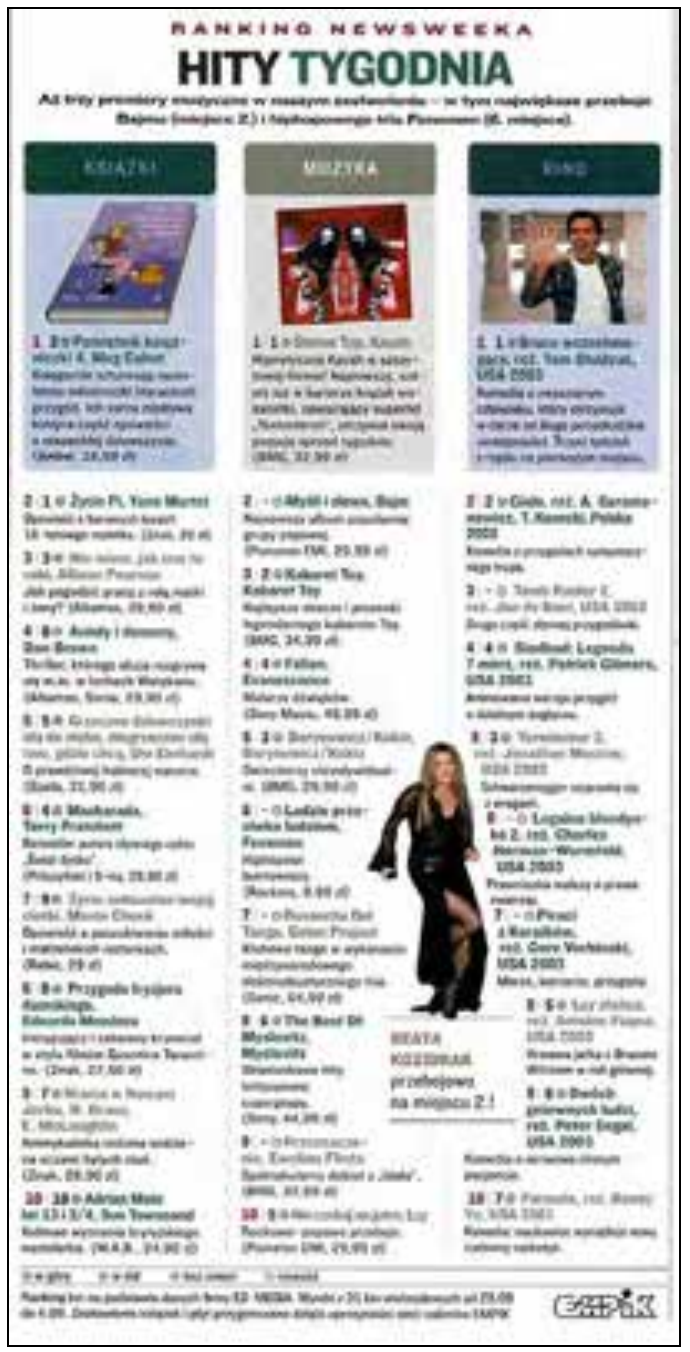

Zdjęcie 66. Ranking Newsweeka

„Newsweek Polska” 2003, nr 37, s. 110

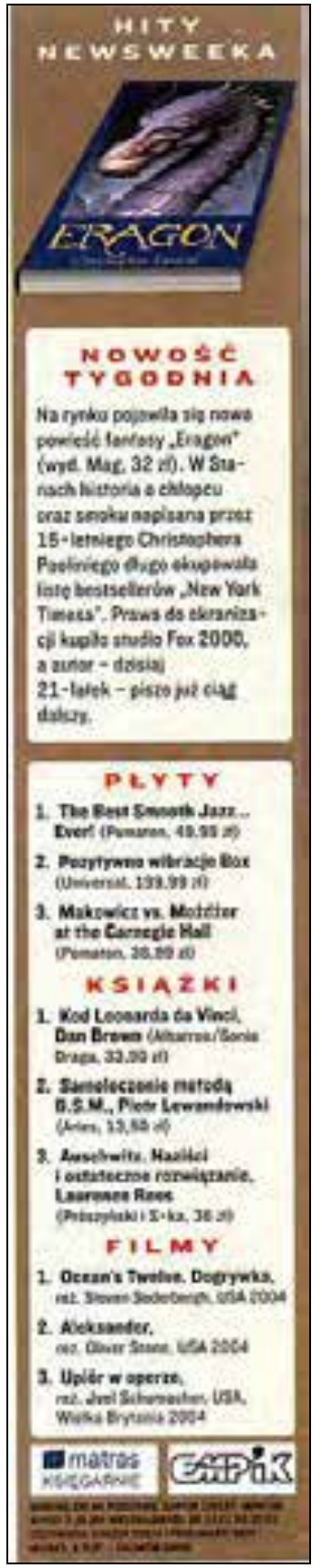

Zdjęcie 67. Hity Newsweeka „Newsweek Polska” 2005, nr 4, s. 107 
wersji. Przypomnijmy, w tymże numerze po raz pierwszy pojawiła się też zmieniona formuła dotychczasowej rubryki, teraz rozpoznawalna jako $\mathrm{Na}$ Afiszu Tygodniowy raport... W jego ramach czytelnik mógł obejrzeć Hity Newsweeka w postaci jednej kolumny, rozpoczynającej się od Nowości, Spadku bądź Skoku tygodnia. Drukowano tu trzy pozycje, odnoszące się do Płyt, Ksiq̨żek i Filmów. Obydwie formy zaprezentowano na zdjęciu 66 i 67.

Jakkolwiek źródło informacji pozostawało niezmienne, prezentacja samego zestawienia została zmodyfikowana. Najważniejszą zmianą było zgromadzenie w jednym wykazie informacji o „hitach” muzycznych, filmowych i książkowych. Poza pierwszym miejscem w każdej z kategorii, ograniczano się w przypadku pozostałych do jednozdaniowych informacji o charakterze bądź oceniających bądź też związanych z treścią, charakterem książki/przeboju muzycznego/filmu. W efekcie kolejnej modyfikacji do czytelnika trafiało skrócone zestawienie o charakterze czysto informacyjnym, pozbawione choćby krótkiej wzmianki odnoszącej się do treści czy oceny przedstawianych tytułów. Kolejną zmianę obrazuje zdjęcie 68.

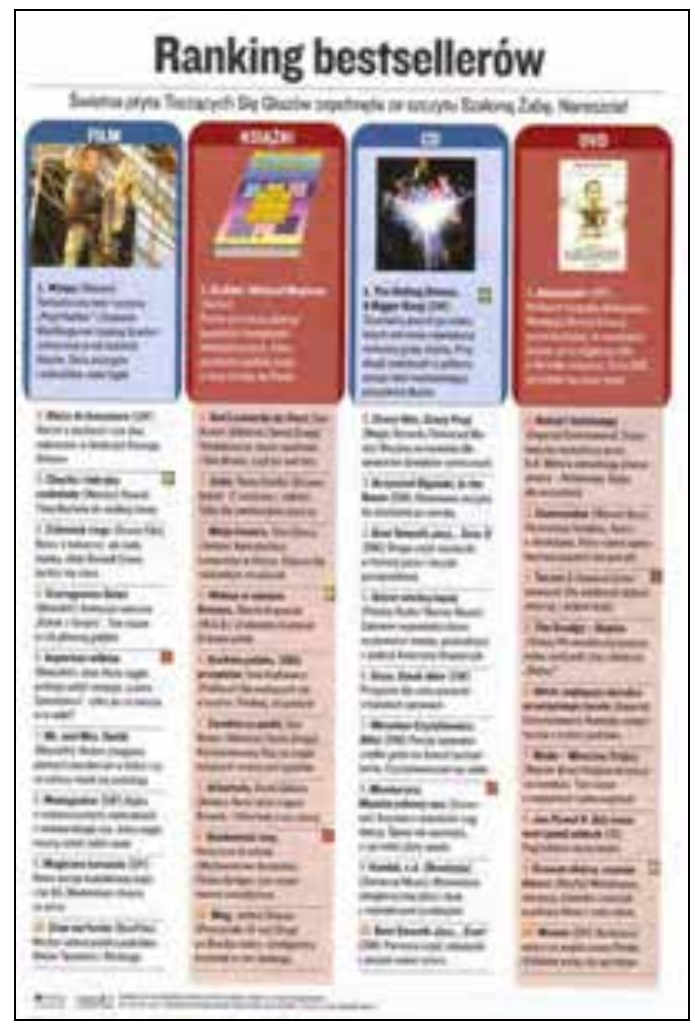

Zdjęcie 68. Ranking bestsellerów „Newsweek Polska” „Newsweek Polska” 2005, nr 38, s. 119 
Od numeru 37 (2005) po raz kolejny zmieniono formę zestawienia, powracając $\mathrm{w}$ pewnym stopniu do wersji wcześniejszej, bardziej rozbudowanej. Tym razem czytelnik miał do dyspozycji cztery kolumny (Film, Książki, $C D, D V D$ ), zawierające po 10 pozycji każda (zdjęcie 68).

Ranking zachował tę formę, tylko nieznacznie zmienioną, aż do numeru 50 (2005). Pozostawiono wspólne dla, tym razem już czterech kategorii, zestawienie, uzupełniając je jednak ponownie jednozdaniowymi informacjami oceniającymi lub dotyczącymi treści.

Należy zaznaczyć, że w kilku numerach pojawiły się zamiennie lub równolegle dwie formy omawianych zestawień: ta, która jako pierwsza gościła na łamach pisma, oraz jej późniejsza postać.

\subsubsection{Arcydzieła idq $w$ hurcie ${ }^{159}$ : inne formy informacji o książce}

Poza podstawowymi formami informacji o książkach, czyli recenzją i reklamą wydawniczą, na łamach tygodnika, podobnie jak w przypadku dwóch wcześniej przedstawionych periodyków, pojawiały się także inne jej postaci 160 :

- portrety, w tym wspomnienia (40);

- artykuły, poświęcone sprawom książki lub rynku wydawniczo-księgarskiego (169);

- ekranizacje, adaptacje i inscenizacje znanych dzieł (162);

- listy czytelników, nawiązujące do zamieszczonej informacji związanej książką (23);

- konkursy i akcje, organizowane przez „Newsweek Polska” (92)161;

- inne ${ }^{162}(174)$.

W sumie na łamach pisma w badanym okresie znalazło się 660 tego typu informacji. Najobszerniejsza pod względem liczby tekstów i, jak się zdaje, najbardziej interesująca była grupa publikacji związanych z literaturą, książką i rynkiem wydawniczo-księgarskim. Równocześnie zwraca uwagę szczególnie niewielka ( $\mathrm{w}$ porównaniu z poprzednimi pismami)

159 Tytuł artykułu, poświęconego rynkowi wydawniczo-księgarskiemu. Zob. „Newsweek Polska" 2002, nr 24, s. 104-[105].

160 Pominięto w tym miejscu listy bestsellerów, wymienione w tabeli 26 , jako że ta kategoria została już wcześniej omówiona.

$161 \mathrm{~W}$ tym przypadku dane w nawiasie oznaczają liczbę informacji związanych $\mathrm{z}$ tą kategorią, niezależnie od tego, czy była ona powtarzana; uwaga ta odnosi się szczególnie do wzmianek przypominających o konkursach lub akcjach organizowanych przez tygodnik.

$162 \mathrm{~W}$ tej kategorii uwzględniono, podobnie jak w przypadku dwóch wcześniej przedstawionych periodyków, informacje, zazwyczaj w postaci krótkich notek, donoszących o ludziach i wydarzeniach związanych bezpośrednio lub pośrednio z książką. 
liczba informacji mieszczących się w kategorii Inne. Wynika to w dużej mierze z faktu, że większość wzmianek, zawartych w ramach wspomnianego wcześniej Jupitera, odnosiła się w niewielkim tylko stopniu do informacji o książce w innej formie niż recenzja. Zaproszeń na spotkania z pisarzami, informacji o ich jubileuszach, nagrodach itd., było w tym miejscu, jedynym przeznaczonym przez redakcję na tego typu informacje, bardzo mało.

Podobnie skromną grupę stanowią teksty, poświęcone ludziom związanym ze światem książki.

Warto w tym miejscu zaznaczyć, że w porównaniu z wcześniej omówionymi tygodnikami na łamach „Newsweek Polska” znalazło się dużo tekstów, w których książka pojawiała się niejako „przy okazji”. Na przykład, pisząc o tym, jak ludzie poradzili sobie z traumatycznymi przeżyciami, proponowano jednocześnie czytelnikom kilka lektur, „które pomogą życie uczynić mądrzejszym i szczęśliwszym"163, opisując problem nieśmiałości, polecano lektury, które pomogą ludziom wstydliwym uporać się z takim problemem ${ }^{164}$. W takich przypadkach, poza podaniem potrzebnych do zidentyfikowania tytułu danych bibliograficznych, zazwyczaj zamieszczano obok nich i obok kopii okładki zalecanej książki krótką adnotację treściową.

Wszystkie te teksty, informacje oraz wzmianki, miały rozmaity charakter, formę i objętość. Wybrane przykłady, opisane poniżej, są reprezentatywne dla każdej z wymienionych kategorii.

\subsection{Mgnienie wieczności ${ }^{165}$ : sylwetki/portrety}

W ciągu niespełna 5 lat tego typu tekstów zamieszczono w piśmie 40 . $\mathrm{W}$ jednym $\mathrm{z}$ pierwszych numerów tygodnika ukazała się interesująca, a jednocześnie refleksyjna publikacja opowiadająca m.in. o barwnym życiu Sat Okh, Indianinie mieszkającym od ponad 50 lat w Polsce i piszącym książki o Indianach ${ }^{166}$. Tylko ten jeden raz czytelnicy pisma mieli okazję przeczytać o losach tak egzotycznego bohatera. W większości przypadków były to tradycyjne w swej formie portrety głównie żyjących pisarzy lub osób pośrednio związanych z książką. Trzykrotnie pojawił się tekst wspomnieniowy związany z odejściem, kolejno: Jacka Kaczmarskiego, Czesława Miłosza, Jana Nowaka-Jeziorańskiego.

$\mathrm{W}$ trzech przypadkach otrzymanie najbardziej prestiżowej nagrody literackiej, jaką jest Nagroda Literacka Nobla, było pretekstem do napisania

163 J. Kurzępa, Vademecum doliniarza, „Newsweek Polska” 2003, nr 16, s. 32, 34.

164 K. Romanowska, Odwaga na receptę, „Newsweek Polska” 2003, nr 40, s. [74]-80.

165 Tytuł tekstu poświęconego Cz. Miłoszowi. Zob. „Newsweek Polska” 2002, nr 5, s. 100-101.

166 J. Mielnik, Indiański biznes w Polsce, „Newsweek Polska” 2001, nr 4, s. 88. 
tekstu o jej laureatach. Poza standardową w takiej sytuacji charakterystyką pisarza i jego twórczości, redakcja wyrażała swoją opinię na temat słuszności przyznania nagrody temu akurat kandydatowi. W 2003 r. W. Kot stwierdził, że „świetnie się złożyło, że Coetzee dostał Nobla, bo wreszcie przestanie być przegapiany"167, uzasadniając szczegółowo swój pogląd i przywołując książki autora Mistrza $z$ Petersburga, wydane w Polsce. Dwa lata później, w 2005 r., pisano o twórczości ówczesnego laureata, Harolda Pintera:

jest tym dramatopisarzem, który wraz z Beckettem, Ionesco i Gonetem zrewolucjonizował teatr drugiej połowy XX wieku. To klasyk nowoczesności, którego twórczość przywodzi na myśl Czechowa i Kafkę. Można oczywiście nie zgadzać się z Haroldem Pinterem, jednak za wierność swoim poglądom i odwagę należy mu się szacunek. [...] Trzeba powiedzieć, że tegoroczna decyzja noblowskiego komitetu, choć niespodziewana, jest wyjątkowo trafna ${ }^{168}$.

Nieco kłopotu w ocenie decyzji szwedzkiego jury sprawiła rok wcześniej Elfriede Jelinek, o której z podobnej okazji pisał mniej więcej w tym samym czasie w tygodniku „Polityka” Jerzy Pilch. P. Bratkowski zauważał jedynie:

jeśli ktoś dotąd uważał, że literackie Nagrody Nobla przyznaje grono konserwatywnych kunktatorów starających się nikogo nie urazić, musi zmienić zdanie. Komitet noblowski, nagradzając w tym roku 58-letnią Austriaczkę Elfiede Jelinek, poszedł na całość i wykazał więcej młodzieńczej fantazji niż niejedno jury awangardowego konkursu literackiego, powstrzymując się od osobistej oceny kontrowersyjnej laureatki i jej twórczości ${ }^{169}$.

P. Kępiński przybliżył czytelnikom życiorys rosyjskiego poety Jewgienija Jewtuszenki, mówiącego o sobie, że jest „pisarzem duszy” ${ }^{170}$. Ciekawą formę przybrał portret R. Kapuścińskiego: tekst miał charakter nietypowego wywiadu, przy okazji zaś jego autor przedstawiał najnowszą książkę pisarza ${ }^{171}$. W jednym z tekstów poświęconych Cz. Miłoszowi pojawiło się kalendarium życia poety, ale dotyczące tylko lat 90. oraz jeden $\mathrm{z}$ jego wierszy (Druga przestrzeń z tomu o tym samym tytule) ${ }^{172}$.

Nie zawsze jednak były to portrety czy wspomnienia przedstawiające wybraną postać jedynie w korzystnym świetle. I tak czytelnik pisma mógł

167 W. Kot, Błyskotliwy samotnik, „Newsweek Polska” 2003, nr 41, s. 108-[109].

168 J. Majcherek, Klub czerwonego szampana, „Newsweek Polska” 2005, nr 42, s. 114.

169 P. Bratkowski, Nobel za kontrowersje, „Newsweek Polska” 2004, nr 42, s. 96.

170 P. Kępiński, Jewtuszenko wiecznie żywy, „Newsweek Polska” 2004, nr 2, s. 74.

171 P. Bratkowski, Reporter czasów postmodernizmu, „Newsweek Polska” 2003, nr 39, s. 88-89.

172 W. Kot, Mgnienie wieczności, „Newsweek Polska” 2002, nr 5, s. 100-101. 
też przyjrzeć się kontrowersyjnym faktom z życia dwóch innych postaci: Stanisława Mackiewicza'173 i Marcela Reich-Ranickiego ${ }^{174}$.

Kilkakrotną bohaterką tego typu tekstów była J. K. Rowling, systematycznie przypominana czytelnikom pisma przy okazji pojawienia się na rynku kolejnej części cyklu o Harrym Potterze. Kwestie biograficzne dotyczące autorki stanowiły jednak w takich przypadkach niewielką część publikacji, której autor koncentrował uwagę głównie na roztrząsaniu powodów popularności jej książek.

Poza wymienionymi twórcami, bohaterami tego typu tekstów byli również m.in.: Paulo Coelho (dwukrotnie), Mieczysław Czuma, Philip K. Dick, Tadeusz Dołęga-Mostowicz, John Grisham, Józef Flawiusz, Janusz Głowacki, René Goscinny, Cezary Harasimowicz, Paweł Huelle, David Rees, Grzegorz Rosiński, Salman Rushdie (zob. Aneks 25. Sylwetki twórców przedstawionych na łamach „Newsweek Polska” w latach 2001-2005). Portrety drukowano głównie w ramach Kultury, chociaż niekiedy odstępowano od tego zwyczaju i pojawiały się one na przykład na stronach poświęconych zagadnieniom związanym z Polską, światem i społeczeństwem. Zajmowały średnio jedną stronę, na której zamieszczano, obok tekstu, zdjęcie prezentowanego twórcy.

Warto również zaznaczyć i to, że pisarze byli wielokrotnie wspominani przy okazji publikacji, poruszających inne zagadnienia: powoływano się na ich opinie, sądy, przedstawiano epizody z ich życia, by zilustrować poruszany w publikacji temat. Na przykład D. Romanowska, pisząc o zbadanych i nazwanych formach inteligencji, przywołała postać m.in. Simone de Beauvoir, a Violetta Ozminkowski w zabawnym artykule o współczesnych relacjach pomiędzy kobietami i mężczyznami, w kilku zdaniach opisywała m.in. J. Pilcha i J. Głowackiego. Tematem przewodnim numeru 13 (2002) było pytanie dotyczące sensu życia: w tekście zacytowano opinie m.in. Tadeusza Konwickiego i ks. Jana Twardowskiego.

0 twórcach pisano także wtedy, gdy poruszano szersze zagadnienia, dotyczące kondycji współczesnej literatury zarówno polskiej, jak i obcej, a także, kiedy przedmiotem publikacji stawał się rynek wydawniczy.

173 K. Tarka, Powrót Cata, „Newsweek Polska” 2004, nr 25, s. 84-86.

174 G. Gnauck, Krytyk z bezpieki, „Newsweek Polska” 2002, nr 33, s. 32-33. 


\subsection{Lekarstwo dla duszy ${ }^{175}$ : teksty, poświęcone książce i rynkowi wydawniczo-księgarskiemu}

Na łamach „Newsweek Polska” ukazało się w badanym okresie 169 tego typu tekstów (zob. Aneks 26. Wybór tekstów związanych z literaturą i rynkiem wydawniczo-księgarskim zamieszczonych na łamach „Newsweeka” w latach 2001-2005). Biorąc pod uwagę ich treść oraz objętość, można wyróżnić wśród nich, podobnie jak w dwóch wcześniej omawianych przypadkach (tygodników „Polityka” i „Wprost”) następujące kategorie:

1) artykuły obejmujące przynajmniej stronę;

2) krótsze komentarze, zajmujące przeważnie ok. pół strony;

3) jedno- lub kilkuzdaniowe wzmianki.

Zamieszczano je w całym tygodniku, poczynając od rubryki otwierającej numer (Peryskop), poprzez strony, na których prezentowano wydarzenia z Polski i ze świata, działy związane z nauką, biznesem i kulturą.

Jaki obraz współczesnej literatury kształtował się w umyśle odbiorcy pisma? Teksty, poświęcone interesującej nas problematyce, nie dają na to pytanie jednoznacznej odpowiedzi.

$\mathrm{Z}$ jednej strony czytelnik odnajdował $\mathrm{w}$ nich potwierdzenie pesymistycznych, a wręcz apokaliptycznych wizji, które pojawiały się w innych mediach, z drugiej zaś z wielu publikacji wyłaniał się optymistyczny wizerunek kultury, w tym książki. Przyjrzyjmy się, na podstawie najciekawszych tekstów, obydwu obrazom.

Już w 2001 r. Andrzej Rosner podkreślał, że sytuacja na polskim rynku wydawniczym przedstawia się katastrofalnie, a kryzys widoczny jest dla każdego. Prorokował, że najbliższy rok nie zapowiada się lepiej, a nawet pod wieloma względami będzie gorszy. „Staniemy przed bolesną selekcją na rynku słowa drukowanego. [...] będzie to selekcja negatywna, eliminująca tytuły wartościowe, a promująca szmirę"176 - pisał m.in. Wskazał równocześnie sposoby, które miały zatrzymać ten bieg wydarzeń i skierować go na inne, korzystne tory. Zwiększenie nakładów finansowych na zakup książek dla bibliotek, wykorzystanie funduszy unijnych - to tylko niektóre pomysły, mające poprawić fatalną sytuację na rynku książki. Uprzedzając, że jest to proces długofalowy, na efekty którego trzeba czekać kilka lat, proponował skorzystać z doświadczeń Japonii, zamiast uczyć się (po raz kolejny) na własnych błędach. A błędy te doprowadziły do tego, że jak dowiadywał się czytelnik pisma, zaledwie 4\% Polaków interesuje się kulturą ${ }^{177}$, a $46 \%$ w ogóle nie czyta książek ${ }^{178}$. Nie czyta, bo nie lubi, czy

175 Napis nad wejściem do biblioteki w Tebach, za: J. Zarembina, Leczenie powieściq, „Newsweek Polska” 2005, nr 49, s. [71].

176 A. Rosner, Kultura na krawędzi, „Newsweek Polska” 2001, nr 16-17, s. 194.

177 „Newsweek Polska” 2002, nr 21, s. 8.

178 „Newsweek Polska” 2001, nr 1, s. 8. 
dlatego, że nie znajduje nic dla siebie? Pytanie nie jest bezzasadne, szczególnie w kontekście stwierdzenia Tomasza Jastruna:

szansę na sukces i karierę ma teraz dokładnie przeciętność. Przeciętność ma poparcie większości, trzeba więc tej większości dawać książki przeciętne, innych nie strawi ${ }^{179}$.

\section{Dalej ostrzegał:}

Czy jednak karmiąc przeciętność, nie tworzymy przy okazji potwora, który pożre wszystko, co nieprzeciętne? Z zewsząd widać i słychać, jak publicznie i bezwstydnie głupota zjada inteligencję. Straszny to widok ${ }^{180}$.

A przeciętność, jak wynikało z innego tekstu, ma dziś bardzo duże szanse na sukces: demokracja we wszystkich dziedzinach życia, w tym w kulturze, dała równość i wolność, a te spowodowały pospolitość - przynajmniej w odniesieniu do sztuki i literatury. Dziś każdy może zostać artystą, ułatwia mu to nie tylko owa równość, ale i nowoczesne technologie, media, które potrafią wykreować na bohatera zwycięzcę telewizyjnego talkshow. Nie prezentując żadnych talentów, staje się on gwiazdą kultury masowej, rozpoznawalną tak jak Czesław Miłosz czy Wisława Szymborska. „Demokracja równych szans dla wszystkich?” - pyta P. Bratkowski i odpowiada:

Wszędzie, ale przecież nie w sztuce, która przez całe wieki ludzkiej cywilizacji była sferą aktywności z samej swej natury niedemokratyczną i niesprawiedliwą, dopuszczającą nielicznych, wykluczającą większość. [...] paradoksalnie fundamentem sprawiedliwości w sztuce jest nierówność, gwarantująca zdolniejszym, bardziej pracowitym i pomysłowym wyższe miejsce w hierarchii ${ }^{181}$.

P. Bratkowski podkreślał, jak bardzo niezasłużona i niesprawiedliwa jest współczesna równość, która powoduje, że twory nieudolnych grafomanów funkcjonują na równych prawach z nielicznymi wytworami prawdziwej sztuki. Niesprawiedliwa, bo, jak konkludował, „niesprawiedliwe jest, gdy perły toną w śmieciach" 182 . Z kolei K. Śmiałkowski zadawał nostalgiczne pytanie: „Gdzie te czasy, gdy kultura była pojęciem ekskluzywnym... Dziś handluje się nią jak piwem i jogurtami - w wielopakach"183. Nastawieni przede wszystkim na zysk wydawcy książek, płyt z muzyką i filmami proponują klientom zestawy i kolekcje, które łączy nazwisko twórcy.

\footnotetext{
179 T. Jastrun, Moc truchleje, „Newsweek Polska” 2002, nr 10, s. 106.

180 Ibidem, s. 106.

181 P. Bratkowski, Równość, wolność, pospolitość, „Newsweek Polska” 2003, nr 51-52, s. 162.

182 Ibidem, s. [165].

183 K. Śmiałkowski, Arcydzieła idq w hurcie, „Newsweek Polska” 2002, nr 24, s. 104.
} 
Oszczędni odbiorcy chętnie korzystają z takiej formy i coraz częściej je kupują. Być może jest to sposób na promocję także literatury w sytuacji, gdy na zakup ekskluzywnego wydania książki ulubionego autora niewielu dziś stać. Niestety, kolejny tekst zdawał się rozwiewać te nadzieje. Pomimo, że przecież „literatura to przyprawa życia. Można się bez niej obejść, ale to ona nadaje naszej egzystencji smak i aromat”184, to jednak „coraz częściej rezygnujemy ze smaku w ogóle. [...] tak jak dawniej nie czytało [się] książek, bo [się] nie potrafiło - tak znów nie czyta [się] ich dziś, bo [się] nie musi"185.

Większość potencjalnych czytelników zastąpiła lekturę telewizją, Internetem i grami komputerowymi. Ci, którzy pozostali przy książce, oczekują od niej przede wszystkim rozrywki, w dodatku takiej, która będzie uwzględniała obejrzane przez nich wcześniej filmy i przeczytane dotąd książki, w ten sposób realizując aspiracje intelektualne odbiorcy. Stąd sukces literatury popularnej i jej obecność na listach bestsellerów. Na tych samych jednak listach, jak wynikało $\mathrm{z}$ innego tekstu, goszczą pozycje twórców literatury ambitniejszej. Czym można to wytłumaczyć? Czy może jednak Polaków nie zadowala przeciętność, nie zaspokajają ich gustów czytelniczych tylko lektury łatwe i przyjemne w odbiorze, nie wymagające większego wysiłku umysłowego? Może szukają czegoś więcej? Jeśli podobne złudzenia towarzyszyły czytelnikowi tygodnika, rychło zostały rozwiane. W tym samym tekście dowiadywał się on bowiem, że „sukcesy na listach bestsellerów nie mówią o naszych gustach literackich, lecz o naszym uzależnieniu od mediów"186. To dzięki mini-wykładom o filozofii, transmitowanym przez telewizję, Leszek Kołakowski stał się bardziej rozpoznawalny i wielu Polaków zapragnęło mieć jego książki na półce. To nimb noblistki przyciąga rodaków do poezji W. Szymborskiej. „Wypada” mieć choćby jeden tomik jej wierszy. Bo „chcielibyśmy być na tyle światowi, by czytać religijną poezję, nowatorską prozę i filozoficzne eseje. Ale najczęściej tego nie robimy"187. I w tym miejscu mediom przypada rola mentora, który (od czasu do czasu) uświadamia nam, że jednak powinniśmy zainteresować się kulturą wyższą. Wtedy, powodowani wyrzutami sumienia, kupujemy poważniejszą lekturę. I stawiamy ją na półce.

${ }_{184}$ P. Bratkowski, Bystrzy sprzedawcy słów, „Newsweek Polska” 2004, nr 26, s. 94.

185 Ibidem, s. 94-[95].

186 Ibidem, s. 96; P. Bratkowski, Równość..., s. 162.

186 P. Bratkowski, Równość..., s. [165].

186 K. Śmiałkowski, Arcydzieła..., s. 104.

186 P. Bratkowski, Bystrzy sprzedawcy..., s. 94.

186 Ibidem, s. 94, [95].

186 Ibidem, s. 96.

187 Ibidem. 
Ilu czytelników pisma odnalazło się w tym obrazie? Prawdopodobnie większość, choćby dlatego, że „dziś wydaje się oczywiste, że znaczną część literackiej produkcji stanowią książki pisane nie po to, by zmieniać świat, lecz by zapewnić czytelnikowi rozrywkę, a autorowi i wydawcy - godziwy zarobek"188. Co więcej, taką strategię wykorzystują już nie tylko twórcy literatury popularnej, ale również autorzy książek dotychczas ambitniejszych, mający aspiracje do przedstawiania świata w sposób bardziej złożony, niż taki, jaki jest prezentowany przez media. Tymczasem pisarze coraz częściej korzystają z tematów, pojawiających się na łamach tabloidów, jak przekonywał P. Bratkowski w tekście o jednoznacznie brzmiącym tytule Książki z gazet ${ }^{189}$ : „książka o >mocnym< temacie ma większe szanse na przebicie się do opinii publicznej. Pisarze o tym wiedzą; stąd nawet najsubtelniejsze rozważania starają się wpakować w fabułę, której nie powstydziłby się tabloid"190. Można zatem powiedzieć, że dzięki temu literatura nadal funkcjonuje we współczesnym świecie, co więcej, „ma się nieźle”191. Niestety, nie można tego powiedzieć o jej twórcach. Nie są już autorytetami, jak to dawniej bywało, „nie są już ani lekarzami sumień, ani bohaterami anegdot"192, nie istnieje kanon książek, które znają wszyscy. Brak jest zwartego, opiniotwórczego środowiska literatów, którzy byliby punktem odniesienia dla wielu czytelników. Nikt już dziś nie oczekuje od pisarza, że będzie przewodnikiem duchowym, wyrocznią w sprawach ważnych. Zresztą, czytając dalej tekst zamieszczony na łamach pisma, przekonujemy się, że „i sami pisarze niespecjalnie pchają się do tego, by uchodzić za kogoś więcej niż tylko specjalistów od pisania ciekawych, a czasem mądrych książek"193.

Podobna w swej wymowie była kolejna publikacja, określająca współczesnych twórców mianem „kronikarzy epoki”. Owszem, zgadzał się jej autor, pojawili się nowi pisarze i nowe tematy w literaturze. Ale zbierając fakty, czerpiąc pomysły z mediów, opisując je w formie lekkiej, takiej, która dostarczy czytelnikowi przede wszystkim rozrywki, nie tworzą oni jednolitej konfraterni z wszystkimi regułami rządzącymi dawniej środowiskami artystycznymi. Nawet twórczość tych, którzy (podobnie jak Andrzej Stasiuk, w którym na początku jego kariery literackiej niektórzy upatrywali nowego Marka Hłaski) zdawali się być nowymi autorytetami w literaturze, z czasem się zmieniła, dostosowała do powszechnie dziś panującej mody. A współcześnie, jak przekonuje A. Więcka, jednymi z najpopularniejszych postaci

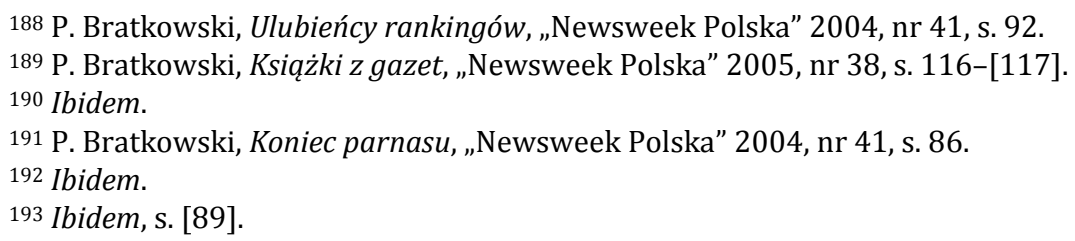


literatury są bohaterki książek adresowanych do nowej grupy czytelniczek: samotnych, młodych kobiet, które w kolejnych odsłonach losów Bridget Jones odnajdują siebie, swoje problemy, a przede wszystkim rozwiązanie własnych kłopotów. Literatura tego typu pełni terapeutyczną funkcję, krzepi swoje czytelniczki, pociesza je i bawi. Jednak nie tylko taki jest jej cel. Historie opisywane przez Candace Bushnell, Helen Fielding, Marian Keyes, Josie Lloyd, a w Polsce przez Katarzynę Grocholę, cieszą się tak dużym powodzeniem również dlatego, że ich

bohaterki w gruncie rzeczy tylko udają, że są niezaradne i głupie [...]. Kiedy stają przed nimi prawdziwe wyzwania, mobilizują się i zwalczają największe nawet przeciwności. By kobiety uwierzyły, że to możliwe, potrzeba właśnie takich powieści ${ }^{194}$.

Powieści, w których bohaterka jest na tyle przeciętna, że może się z nią utożsamiać jak najwięcej czytelniczek, a jednocześnie na tyle atrakcyjna, żeby każda z nich chciała być taka jak ona - stwierdza Joanna Jachmann, porównując te książki do łaskawego lustra, w którym kobiety chętnie się przeglądają ${ }^{195}$.

To jeden obraz, jaki wyłania się z przytoczonych powyżej tekstów, podejmujących interesującą nas problematykę. Z drugiej jednak strony autorzy tygodnika zdawali się dostrzegać także jaśniejsze punkty we współczesnym świecie literatury.

Oczywiście, jak przyznawał T. Piątek, „gry komputerowe i reklamy wdarły się do świata sztuki i zmieniły jego oblicze: film i książka muszą się do nich upodobnić"196, ale według niego nie musi to oznaczać katastrofy dla literatury. Wręcz przeciwnie, wszak na podstawie bestsellerów powstają gry komputerowe, realizowane są filmy - wszystko to może spowodować zainteresowanie widzów książką. Co więcej, pojawienie się owych gier jako rywali słowa drukowanego stawia przed książką nowe wyzwania. Pisarz będzie musiał zaoferować wytrawnemu graczowi komputerowemu (potencjalnemu czytelnikowi) nową strukturę powieści, przypominającą labirynt, po którym odbiorca będzie mógł wielokrotnie błądzić, za każdym razem odnajdując inną odpowiedź na swoje pytanie, inną interpretację głównych wątków książki. Stąd być może wynika dobra koniunktura dla powieściowych thrillerów, dla których, według autorów pisma, zapanowała „złota era". Borys Akunin, Michael Connelly, Jonathan Kellerman czy Aleksandra Marinina zapewniają wysoki poziom lektury w pisanych przez siebie powieściach. Polska literatura sensacyjna nie jest gorsza, co więcej „wyrastając z kultury popularnej i niby cały czas pozostając jej częścią, przeobra-

194 A. Więcka, Stalowe magnolie, „Newsweek Polska” 2001, nr 15, s. [105].

195 J. Jachmann, Książka jak lustro, „Newsweek Polska” 2004, nr 41, s. 97.

196 T. Piątek, Kultura wlezie wszędzie, „Newsweek Polska” 2002, nr 51-52, s. 196-[197]. 
ziła się w gatunek niszowy, dla koneserów"197. Pisana jest dla bardziej wymagającego czytelnika, który nie zadowoli się już tylko odpowiedzią na pytanie „kto zabił”, ani w jaki sposób prawda wyjdzie na jaw i rozumie, że „Współczesna powieść sensacyjna to więcej niż intryga”198.

Równie dobre wiadomości dla wszystkich miłośników literatury, obawiających się o jej przyszłość, niósł ze sobą inny tekst. W 2005 r. na łamach tygodnika P. Bratkowski pisał: „ukazało się tyle polskich powieści, że na nieprzyzwyczajonym do takiej obfitości rynku książki mogą się nawzajem zadeptać"199. Co więcej, są to, według niego, w znacznej mierze ambitne powieści zarówno uznanych autorów, jak i pisarzy nowego pokolenia. Nierzadko wśród nich znajdują się tytuły wartościowe, po które coraz częściej sięga czytelnik, chcący zrozumieć otaczający go świat. Media, przedstawiające uproszczony obraz rzeczywistości, przestają bowiem stopniowo wystarczać wymagającemu odbiorcy, nierzadko wracającemu do poważnych lektur, a przynajmniej sięgającemu po tytuły niszowe, nie zadowalającemu się już tylko lekturami łatwymi w odbiorze. Zapanowała swoista moda na kontrkulturę. Jak czytamy na łamach pisma:

sytuacja dojrzała do rewolucji, zdają się mniemać nasi wydawcy. Spod pras drukarskich jedna za drugą wychodzą książki wykpiwające konsumpcyjny styl życia kapitalistycznych społeczeństw. Kontestujące mieszczańską obyczajowość i system wartości. Kwestionujące nasze przyzwyczajenia co do istoty sztuki i jej społecznych funkcji200.

Nie jest to jednak zjawisko powszechne, bo jak przyznaje autor tekstu, niestety

w kulturze tak utowarowionej jak współczesna kultura masowa dla artystycznych buntowników, pragnących wyjść poza niszę, ale zarazem nie zamienić się w popkulturowy gadżet, pozostaje niezwykle wąska ścieżka ${ }^{201}$.

Pisano również o innych typach literatury, poza wymienionymi, chociaż takich tekstów było (w porównaniu z wcześniej omawianymi periodykami) wyraźnie mniej.

Najwięcej miejsca i uwagi dziennikarze „Newsweek Polska” poświęcali komiksowi ${ }^{202}$. Czytelnicy tygodnika mogli przeczytać, że jeśli chcą „się

197 P. Bratkowski, współpraca M. Łukaszewicz, Złota era thrillera, „Newsweek Polska” 2005, nr 6, s. 95-96.

198 Ibidem, s. 97.

199 P. Bratkowski, Książki wyniesione z powodzi, „Newsweek Polska” 2005, nr 21, s. 86.

200 P. Bratkowski, Recykling buntowników, „Newsweek Polska” 2005, nr 30, s. 88.

201 Ibidem, s. 90.

$202 \mathrm{~W}$ sumie w ciągu pięciu analizowanych lat pojawiły się na łamach pisma 24 teksty poświęcone komiksowi. 
czegoś dowiedzieć o wojnie, terroryzmie, zmianach obyczajowych itp. ważnych sprawach"203, powinni zainteresować się komiksami, jako że we współczesnym świecie jest to lektura obowiązkowa, nie tylko dla dzieci. Historie z dymkiem są zrozumiałe dla wszystkich, przekonywał autor artykułu, stanowią też swego rodzaju XXI-wieczny odpowiednik niegdysiejszych powieści Karola Dickensa. Czytelnik dowiadywał się również, że w ostatnich latach literatura rysunkowa rozwinęła się najprężniej ze wszystkich innych, co więcej, stała się częstym przedmiotem ekranizacji. Autorzy tekstu tłumaczyli, że doskonale wpisuje się ona we współczesną kulturę obrazkową, gdzie przeciętny odbiorca większość informacji o świecie czerpie przede wszystkim z telewizji czy Internetu. Przekonywano, że nie należy się wstydzić czytania komiksów, choćby dlatego, że „artyści komiksowi dołączają do twórców poważnej literatury [...], podejmują coraz poważniejsze tematy [...], najnowsze komiksy historyczne mają często wydźwięk polityczny" ${ }^{204}$. Pisano o renesansie popularności komiksu także w Polsce 205 , a przytaczane liczby (jak choćby fakt, że na rynek trafia rocznie 40 nowych tytułów, zaś nakład niektórych wydań sięga 70 tys. egz. ${ }^{206}$ ) świadczyły same za siebie. Recenzowano najbardziej popularne komiksy ostatnich lat: Maus (Arta Spiegelmana), Dalej z tq wojnq (Davida Reese`a), Morderstwa i tajemnice (Neila Gaigmana), ale i Solidarność. Nadzieja zwykłych ludzi (Macieja Jasińskiego) czy $Z$ Wadowic do Rzymu (rysunkowa biografia papieża Jana Pawła II). Nie zapomniano również o najpopularniejszych twórcach komiksu. W jednym z numerów pisma w 2005 r. przybliżono sylwetkę René Goscinnego, przypominając czytelnikom polskie korzenie twórcy przygód Mikołajka207. Raz pojawił się rodzaj rankingu ostatnio wydanych najpopularniejszych komiksów: znalazło się w nim pięć tytułów: Star Wars. Ostatni Rozkaz, Tytus Romek i A'Tomek; Thorgal. Królestwo pod piaskiem, Batman. Mroczny Rycerz kontratakuje 3 oraz 100 naboi. Cień drugiej szansy. Obok kopii ich okładek zamieszczono w tym miejscu podstawowe dane bibliograficzne i krótkie adnotacje treściowe ${ }^{208}$. 0 tym, że promocja komiksu spodobała się czytelnikom, świadczyły ich listy. Warto przytoczyć jeden z nich:

Wreszcie widzę światełko w tunelu w sprawie miejsca komiksu w naszej kulturze. Między innymi dzięki waszym publikacjom [...] pojawiła się szansa, by komiks wyszedł z getta

203 R. Foroohar, K. Śmiałkowski, Świat jak z obrazka, „Newsweek Polska” 2005, nr 36, s. [100].

204 B. Dehghanpisheh, Nie tylko dla dzieci, „Newsweek Polska” 2001, nr 6, s. 106.

205 K. M. Śmiałkowski, Renesans dymków, „Newsweek Polska” 2001, nr, s. 102-103.

206 W. Tkaczyk, Czas dorastania z dymkiem, „Newsweek Polska” 2003, nr 11, s. 91.

207 K. Śmiałkowski, Asteriks ponad podziałami, „Newsweek Polska” 2005, nr 42, s. 116.

208 Komiks w styczniu, „Newsweek Polska” 2003, nr 2, s. [111]. 
i przestał być domeną hermetycznego środowiska. Publikacje w tak opiniotwórczym tygodniku jak wasz, pokazują, że nie jest to banalna i marginalna rozrywka dla dzieci i nierozgarniętych dorosłych. Uświadamiacie, że komiks jest prawdziwą sztuką i elementem współczesnej kultury, którym trzeba się rzeczowo zajmować. Chwała wam za to!209

Znacznie rzadziej pisano o innych typach literatury. W ciągu badanego okresu tylko incydentalnie podnoszono kwestię literatury dla dzieci i młodzieży. Najczęściej przywoływano w tygodniku książki o Harrym Potterze, zazwyczaj przy okazji premiery kolejnej części cyklu. Wskazywano, że popularność opowieści o małym czarodzieju polega m.in. na tym, że „ich akcja rozgrywa się niby w czarodziejskiej krainie, a tak naprawdę niczym nie różni się od naszego świata"210, za każdym razem podkreślając, że „hegemonia najpopularniejszego czarodzieja wszech czasów pozostaje niezagrożona”211, a książki opowiadające jego losy „nie są zwykłą literaturą. To zjawisko rynkowe warte miliardy dolarów"212. Czytelnik pisma dowiadywał się, że kolejne tomy przygód Harry`ego zostały przetłumaczone na 55 języków, książkę sprzedano w 200 krajach całego świata, a na ekranizację kolejnych tomów czekają miliony fanów, wśród których są nie tylko dzieci, ale i dorośli. Bohater książki stał się "gwiazdą światowego biznesu”, jak napisała jedna z czytelniczek pisma ${ }^{213}$, jednocześnie zaś jego niewątpliwą zasługą dla całej współczesnej literatury dla dzieci i młodzieży był fakt, że „uruchomił proces > udoraślania< literatury dla dzieci”214. Autorzy prozy dla dzieci zrozumieli, że mali czytelnicy, podobnie jak dorośli, także „lubią się czasem bać”, a w książkach poszukują nie tylko „ugrzecznionych historii”, ale $\mathrm{i}$ „potwornych istot z zaświatów”215. Pisano również o tym, że w literaturze dla dzieci i młodzieży pojawiło się więcej „wyrazistych bohaterów i strasznych scen"216. Jednocześnie Justyna Święcicka (psycholog dziecięcy) tłumaczyła, że „Baśń powinna być metaforą życia. Dobro musi wygrywać ze złem sugestywnie, bo jeżeli na końcu baśni wszyscy się do siebie słodko uśmiechają, to nie ma w tym żadnej wartości wychowawczej"217. Zgadzał się z nią Grzegorz Leszczyński, badacz literatury dziecięcej, który uważał, że „baśń powinna być mentalnym amortyzatorem przed dorosłością. Oswoić

209 M. Puźniak [czytelnik pisma], Komiks to nie getto, „Newsweek Polska” 2003, nr 21, s. 14.

210 W. Kot, Demontaż iluzji, „Newsweek Polska” 2004, nr 4, s. 99.

211 [br. aur.], Potter zaczarował Paragona, „Newsweek Polska” 2004, nr 50, Biblioteka myśli dla dzieci i młodzieży, s. 22.

212 A. Matusiewicz, Harry w zakonie fortuny, „Newsweek Polska” 2003, nr 27, s. 42.

213 M. Salak [czytelniczka pisma], Potter gwiazdq biznesu, „Newsweek Polska” 2003, nr 29, s. 9.

${ }^{214}$ K. Zalewska, Puchatku, pora umierać, „Newsweek Polska” 2003, nr 48, s. 102.

215 Ibidem, s. 101-102.

216 Ibidem, s. 102.

217 Ibidem. 
dziecko z problemami prawdziwego świata"218. Podawano przykłady współczesnych książek, spełniających postulaty badaczy: Artemis Fowl (Eoina Colfera), Wiersze, że aż strach (Małgorzaty Strzałkowskiej), Zaklinacz cieni (Grahama P. Taylora).

W nawiązaniu do akcji Cała Polska czyta dzieciom zamieszczono tekst, prezentujący wybrane tytuły książek dla najmłodszych i tych nieco starszych czytelników. Znalazł się on we wspomnianej już propozycji lektur na lato. Wśród ośmiu proponowanych książek pojawił się m.in. Chłopiec lew Zizou Corder, Gwiazda Jerry`ego Spinelliego oraz oparty na filmie Shrek 2 Leona Jessego McCanna ${ }^{219}$. Rok później zamieszczono (w ramach wcześniej omawianej rubryki) Karnet dla dzieci, gdzie obok recenzji książki adresowanej do młodszych czytelników zaproponowano kilka nowych tytułów, które pojawiły się na rynku. W kolumnie znalazły się kopie okładek prezentowanych lektur wraz z krótkimi adnotacjami treściowymi. Na kolejnych stronach numeru proponowano przedstawienia teatralne, filmy na DVD, audiobooki dla dzieci oraz wystawę dla najmłodszych w stołecznej Królikarni. Przypominano rodzicom o Ogólnopolskim Tygodniu Czytania Dzieciom, a nawet polecano imprezy dla dzieci, odbywające się za granicą 220.

Poza kwestiami ogólnymi, związanymi z kondycją literatury współczesnej czy opisywaniem poszczególnych jej typów na łamach pisma, prezentowano także wybranych jej twórców, nie tylko w formie omówionych wcześniej portretów, ale również na szerszym tle, nierzadko na przykład przy okazji prezentacji nowej książki. Cytowano wówczas niekiedy opinię autora na temat roli twórców czy funkcji literatury w dzisiejszym zmedializowanym świecie. Przywołano na przykład słowa Adama Zagajewskiego, który uważał, że „pisarze powinni unikać inteligentnych żartów. Literatura ma olśniewać, budzić grozę i niepokój”221, zaś „od kultury należy oczekiwać nie sarkazmu, nie krytycznego dystansu [...], lecz wizji, ognia, płomienia, który towarzyszy duchowym odkryciom"222. Dariusz Baliszewski przypomniał receptę Tadeusza Dołęgi-Mostowicza na osiągnięcie sukcesu na polu literackim:

Weź skomplikowaną akcję, dodaj niebezpieczną przygodę, przypraw polityką, erotyką i obyczajowością i gotuj to w słowie prostym, dbając, by nie wykipiało niezrozumiałością, ale też bacz, by było to słowo ładne i w ładne zdania ułożone. Całość polej sosem dystansu i ironiii 223 .

218 Ibidem

219 K. Zalewska, Dla dzieci i młodzieży, „Newsweek Polska” 2004, nr 26, s. 102.

220 „Newsweek Polska” 2005, nr 22, s. 107-[109].

221 W. Kot, Dzisiejsza Europa grzęźnie w ironii, „Newsweek Polska” 2002, nr 41, s. [106].

222 Ibidem.

${ }^{223}$ D. Baliszewski, Niewygodna pamięć i czarna legenda, „Newsweek Polska” 2002, nr 39, s. 64. 
Jakkolwiek te wskazówki niezbyt pomogły samemu autorowi Kariery Nikodema Dyzmy, przynajmniej nie w oczach mu współczesnych („Odmawiano [mu] szacunku, lokując gdzieś na marginesie literatury"224], to jednak dziś taki sposób wydaje się gwarantować powodzenie. Innym środkiem, dzięki któremu na napisaniu książki można także zarobić, może być, według J. M. Coetzee, umiejętne sprzedanie przez pisarza posiadanych przezeń (zmiennych) poglądów „najlepiej w wielu kwestiach, każdy na osobną okazję"225. Czytelnik nie powinien oczekiwać głębi czy wskazania drogi w czytanych przez siebie książkach, bo „literatura, która kiedyś stanowiła dla ludzi obietnicę zbawienia, dziś sama o nie prosi w ponurym czyśćcu - jeśli oczekujecie czegoś więcej, porzućcie nadzieję"226.

W porównaniu z omawianymi wcześniej tygodnikami, na łamach „Newsweek Polska" pojawiało się niewiele tekstów komentujących kondycję współczesnej literatury obcej. Czytelnicy dowiedzieli się, że 40\% dorosłych Brytyjczyków nie czyta książek w ogóle i tak samo wygląda sytuacja w Rosji, gdzie dokładnie taki sam odsetek osób nie jest zainteresowanych literaturą. O trudnej sytuacji twórców w Rosji pisał W. Jerofiejew, podkreślając, że sam padł ofiarą „,wojny z pisarzami” 227. Z kolei na temat intensywnie rozwijającej się kultury, w tym literatury ukraińskiej, pisała Anna Sańczuk, przywołując sylwetki ukraińskich pisarzy młodego pokolenia ${ }^{228}$. 0 „prowokacyjnej” i odważnej literaturze indonezyjskiej, w której przewija się „romans z księdzem, homoseksualizm, prostytucja" donosili polskim czytelnikom Peter Janssen i Juliana Wilson ${ }^{229}$. M. Cieślik zamieścił krytyczny tekst o współczesnej literaturze francuskiej, reprezentowanej na polskim rynku przez Erica Emmanuela Schmidtta i Philippe Delerm, jednocześnie podkreślając małe wymagania polskich czytelników, których nietrudno jest „nabrać na pozory głębi”, serwowane przez autorów („strojących miny filozofów”), czytelników, którzy za to łatwo się wzruszają i kupują „produkt literaturopodobny”230. Mac Margolis, autor innej publikacji, zastanawiał się, „czy realizm magiczny umarł"231 i przypominając literaturę w stylu Gabriela G. Márqueza ostrzegał czytelników, że „nowe pokolenie iberoamerykańskich pisarzy jest wielkomiejskie, cwane i brutalne. Zapomnijcie o czarodziejach!"232

224 Ibidem, s. 65.

225 P. Bratkowski, Czy pisarz może być zbawiony?, „Newsweek Polska” 2005, nr 51-52, s. [157].

\footnotetext{
226 Ibidem.

227 W. Jerofiejew, Wojna z pisarzami, „Newsweek Polska” 2002, nr 50, s. 99.

228 A. Hańczuk, Kultura na pomarańczowo, „Newsweek Polska” 2005, nr 1, s. 56-[57].

229 P. Janssen, J. Wilson, Seks na stronie, „Newsweek Polska” 2003, nr 46, s. 113.

230 M. Cieślik, Trzy kolory: nudny, „Newsweek Polska” 2005, nr 31, s. 99.

231 M. Margolis, Czy realizm magiczny umarł?, „Newsweek Polska” 2002, nr 20, s. 104. 232 Ibidem.
} 
Oddzielną i ważną (chociaż niewielką) grupę stanowiły teksty, poświęcone rynkowi wydawniczo-księgarskiemu w Polsce. Brak wśród nich choćby jednego, który rzetelnie prezentowałby sytuację. Pojedyncze artykuły podejmowały oderwane, przede wszystkim „ciekawe” kwestie, jak na przykład sprawę „piractwa książkowego”. Pisząc o zagrożeniu dla książki, jakie niesie ze sobą Internet, wskazywano na bezkarność hakerów, którzy kopiują książki i rozprowadzają je w sieci. Ten proceder przynosi ogromne straty wydawcom, którzy czują się bezsilni, choćby dlatego, że mają niewielkie możliwości prawne, by ścigać „piratów”, rozpowszechniających nielegalne kopie praktycznie za darmo ${ }^{233}$. Jednym ze sposobów walki z nieuczciwą konkurencją miało być, jak dowiadywał się czytelnik, cyfrowe drukowanie książek przez wydawców. Otóż, wykorzystując nowoczesne metody, niektórzy edytorzy, naśladując firmy fonograficzne, postanowili sprzedawać zainteresowanym pojedyncze rozdziały publikowanych przez siebie książek w postaci cyfrowej. Wydawnictwa Szkolne i Pedagogiczne zdecydowały się na utworzenie bazy informatycznej, zawierającej wybrane tytuły z oferty własnej i innych wydawnictw, z której użytkownicy mogliby korzystać. Przed oczyma czytelnika pojawił się taki oto obraz:

w wybranych księgarniach staną komputerowe stoiska, w których będzie można zapoznać się z zasobami bazy i złożyć zamówienie, wypełniając elektroniczny formularz. Za pośrednictwem informatycznej sieci zamówienia spłyną do drukarni Sowa, gdzie książki będą automatycznie drukowane na jednej z trzech supernowoczesnych cyfrowych drukarek. Do odbiorców trafią za pośrednictwem poczty i firm kurierskich ${ }^{234}$.

Inną formą ratowania książki są, jak przekonywano na łamach „Newsweek Polska", jej e-wydania, coraz częściej proponowane czytelnikom. Stawiając pytanie, czy nagrane na kasetę lub płytę powieści stanowią „namiastkę kultury czy pełnowartościową ofertę dla miłośników książek” A. Więcka zdecydowanie podkreślała zalety audioliteratury. Ma ona być kierowana do ludzi, którym brak jest czasu na tradycyjne czytanie, a jej atrakcyjność gwarantują znani artyści, zatrudniani przez wydawcę. Pisano, że wśród najchętniej kupowanych audiobestsellerów znalazły się m.in. Quo vadis Henryka Sienkiewicza, Lalka Bolesława Prusa, ale także Dzienniki Bridget Jones H. Fielding235. Jednocześnie w innym tekście jego autorka podkreślała, że „literatura mówiona”, wydawana w takiej formie, jako efekt kolejnego etapu macdonaldyzacji kultury, niekoniecznie niesie za sobą tylko wartości pozytywne. Wygodne słuchanie literatury, nie zaś jej osobiste czytanie, powoduje według przywołanego w publikacji Wojciecha Maj-

233 I. Leszczyńska, Piraci zarzucają sieć, „Newsweek Polska” 2002, nr 49, s. 16-[17].

234 J. Olechowski, Ksiq̨żka na zamówienie, „Newsweek Polska” 2004, nr 38, s. 60.

235 A. Więcka, Literatura do słuchu, „Newsweek Polska” 2001, nr 7, s. [103]. 
chrzaka, zanik aktywności i intelektualnego zaangażowania czytelnika. Jednak ten głos był wyjątkiem; większość pytanych przez Mariannę Lutomską osób uważało, że jest to nie tylko trafne odczytanie potrzeb współczesnego czytelnika, ale jednocześnie bardzo dobra promocja literatury i że w Polsce obserwowane jest wciąż rosnące zainteresowanie audiobookami, podobnie jak czytanymi w radiu powieściami odcinkowymi ${ }^{236}$. Bardziej radykalną w swej wymowie opinię przedstawił Marcin Bójko, który wieszcząc koniec epoki książki tradycyjnej, wygłosił pochwalny tekst na temat e-druku, zwracając uwagę na fakt, że to nie forma książek zmieniała świat na przestrzeni wieków, ale ich treść. Jednocześnie poddawał pod rozwagę problemy, które wraz z rozpowszechnianiem się książki w wersji elektronicznej pojawią się przed wydawcami: trudności techniczne oraz problemy z ochroną praw autorskich. Osobom krytycznie nastawionym do rewolucji w słowie drukowanym radził, by spojrzały na nią

jak na usprawnienie starego wynalazku, które pociągnie za sobą zmiany w naszym życiu. Za pomocą Internetu uzyskamy dostęp do ogromnych księgozbiorów. Biblioteki przestaną być już tylko pomieszczeniami wypełnionymi od podłogi do sufitu półkami. Książki trafią do wnętrz komputerów ${ }^{237}$.

Póki co jednak, książki trafiają przede wszystkim do księgarń, wśród których także panuje konkurencja. P. Bratkowski zastanawiał się, czy współczesny czytelnik, poszukujący interesujących go książek, chętniej wybiera wielkie supermarkety, czy też lepiej czuje się w małych księgarniach, w których może zamówić kawę i czytać przy niej wybraną lekturę. Duże sieci handlowe, w których „wszystkiego jest za dużo” czy przytulne, niewielkie miejsca, gdzie „unosi się zapach dobrej kawy, a muzyka, jaką w niej słychać, nie ma nic wspólnego z notowaniami list przebojów"238? Nietrudno domyśleć się, który wariant wybrał P. Bratkowski. Proponował czytelnikom kilka miejsc, gdzie odnajdą spokój i w atmosferze, przesyconej zapachem książek, będą mogli oddać się przyjemności czytania. Pisząc o księgarni Czuły Barbarzyńca ${ }^{239}$ czy antykwariacie Massolit Books, opisywał również Traffic Club, przedsięwzięcie będące odpowiedzią na potrzeby tych, którzy wolą tradycyjny szelest przewracanych kartek w książce niż kliknięcia myszką w Internecie ${ }^{240}$.

236 M. Lutomska, Nie czytałeś, to posłuchaj, „Newsweek Polska” 2005, nr 3, s. [106]-107.

237 M. Bójko, E-książka do poduszki, „Newsweek Polska” 2004, nr 1, s. 57.

238 P. Bratkowski, Wojna słoni z myszkami, „Newsweek Polska” 2004, nr 1, s. [74]-77.

239 Przypomnijmy, że to właśnie w kluboksięgarni Czuły Barbarzyńca raz w miesiącu odbywały się wspomniane wcześniej spotkania, prowadzone przez P. Bratkowskiego, inspirowane współczesną kulturą.

240 P. Bratkowski, Wojna słoni..., s. 77. 
Temat księgarni pojawił się ponownie na łamach pisma rok później. W kilku następujących po sobie tekstach ich autorzy przedstawili zmiany, jakim uległy polskie księgarnie w ciągu ostatnich lat. P. Bratkowski przypomniał ich rolę szczególnie w okresie PRL i wysunął hipotezę, że dziś „wygrywają najwięksi i najmniejsi”. Pierwsi kuszą czytelników najszerszą ofertą i trwają na posterunku dzięki swej ekonomicznej sile. Najmniejsi, bo są na tyle oryginalni i pomysłowi, że przyciągają koneserów ${ }^{241}$. To właśnie w małych kluboksięgarniach „kupowanie książek jest czymś więcej niż tylko transakcją handlową”, a ich właścicieli „łączy potrzeba kreowania życia kulturalnego"242. M. Łukaszewicz przekonywała, że każdy, kto odwiedzi Czułego Barbarzyńcę, trafi na grupę ludzi, których łączy podobny pogląd na współczesny świat i kulturę. Czytelnicy dowiedzieli się również o hurtowni książek w podwarszawskim Skrzeszecie, urządzonej w dawnych budynkach gospodarczych, gdzie lektury „poukładane są w kilkumetrowe stosy na drewnianych paletach" 243 . W innym tekście w tym samym numerze pisma ta sama autorka pisała o książkach w supermarketach, w których stały się one "towarem tanim, szybkim oraz z założenia poradnikowo-familijnym"244, cytując słowa Marcina Baczyńskiego z firmy zaopatrującej super- i hipermarketowy rynek książki w Polsce, przerażonego faktem, że w tych miejscach największym powodzeniem cieszyła się pozycja Żylaki i hemoroidy (ponad 30 tys. sprzedanych egz.) ${ }^{245}$. Czytelnik pisma dowiadywał się, że w supermarketach w książki zaopatrują się przeważnie ludzie, którzy nie chodzą do księgarń, m.in. dlatego, że jest tam dla nich za drogo, a nierzadko zbyt kameralnie. Duża przestrzeń hipermarketu daje natomiast poczucie anonimowości, w której odnajduje się coraz więcej osób. Autorka artykułu wskazywała także na wyraźne zagrożenie, wypływające z faktu przejmowania funkcji księgarni przez centra handlowe, które mają swoje wyobrażenie o literaturze i lansują jej określony typ, dostosowany do masowego odbiorcy. Ostatni tekst traktował o księgarniach internetowych jako odpowiedzi na wszechobecny współcześnie brak czasu i pośpiech, które nie pozwalają na poszukiwania w tradycyjnych księgarniach czy antykwariatach. Liczba korzystających z usług portali księgarskich rośnie z roku na rok, co wynika, jak dowiadywał się czytelnik, w dużej mierze ze znacznie większej liczbowo oferty internetowych księgarń, a z drugiej z coraz szerszego dostępu do Internetu. Fakt bycia (znów) anonimowym również nie był $\mathrm{w}$ takim przypadku bez znaczenia ${ }^{246}$.

\footnotetext{
${ }^{241}$ P. Bratkowski, Więcej niż sklepy, „Newsweek Polska” 2005, nr 2, s. 94.

242 Ibidem, s. 95.

243 M. Łukaszewicz, Tomy w stodole , „Newsweek Polska” 2005, nr 2, s. 98.

244 P. Bratkowski, Więcej niż..., s. 95.

245 M. Łukaszewicz, Chleb i „Kod Leonarda”, „Newsweek Polska” 2005, nr 2, s. 96.

246 M. Łukaszewicz, Kup na stronie, „Newsweek Polska” 2005, nr 2, s. 97.
} 
W porównaniu z zaprezentowanymi wcześniej periodykami, na łamach „Newsweek Polska” znalazło się niewiele informacji dotyczących targów książki. Wśród zaledwie sześciu, jakie pojawiły się $\mathrm{w}$ ciągu badanego okresu, cztery miały postać krótkich wzmianek, jedna charakter ciekawostki, podającej liczbę osób, które odwiedziły Warszawskie Targi Książki, i tylko jedna była nieco dłuższym tekstem, zapowiadającym 50. Międzynarodowe Targi Książki w Warszawie. F. Łobodziński pisał o największych atrakcjach targów, wymieniając zarówno przewidywanych gości (m.in. mieli nimi być: Ken Follet, Henning Mankell i Amos Oz), jak i premiery książkowe (na przykład nowe powieści Daniela Odiji i Sławomira Shuty) ${ }^{247}$. Pięć informacji odnosiło się do rodzimych imprez, a tylko jedna donosiła o wygraniu na targach książki w Londynie konkursu na Młodego Wydawcę Roku przez polskie wydawnictwo Muchomor ${ }^{248}$.

Wśród innych tekstów, które można zaliczyć do omawianej grupy, warto wspomnieć o jeszcze kilku. Pierwszym z nich była publikacja poświęcona Media Rodzina, wydawcy wspomnianego w tekście cyklu o Harrym Potterze. Czytelnicy tygodnika poznali w tym przypadku postać założyciela oficyny, Amerykanina, Roberta Gamble ${ }^{249}$. Druga opowiadała o „książkach nie do poduszki", przygotowywanych przez koszalińskie Wydawnictwo Artystyczne oraz o podobnych edytorach, zajmujących się wydaniami bibliofilskimi 250 .

Z kolejnej publikacji czytelnik dowiadywał się o międzynarodowej serii Mity, interesującej inicjatywie szkockiego wydawcy Jamie Bynga, polegającej na tym, że do 2038 roku popularni pisarze z 33 krajów z całego świata (z Polski mieli to być Jacek Dukaj, Paweł Huelle i Olga Tokarczuk, zaś partnerem wydawniczym Znak) przygotują 100 książek, które będą nowymi, autorskimi wersjami starych mitów ${ }^{251}$. Bez wątpienia pomysł miał duży impet marketingowy i walor promocyjny, potrzebny w dobie kryzysu czytelniczego, choć na jego końcowy efekt będzie trzeba poczekać jeszcze kilka lat. W tygodniku wspomniano też o innym interesującym pomyśle, propagującym literaturę. Kluby książki, które powstają również w Polsce, w Stanach Zjednoczonych istnieją od dawna i cieszą się niesłabnącą popularnością, jak przekonywał czytelników pisma Malcolm Jones ${ }^{252}$. Ci, którym, leży na sercu dobro książki, mogą spać spokojnie, bo jak stwierdziła Pat Eiseman z wydawnictwa Scribner „jedyną rzeczą przyjemniejszą od czyta-

\footnotetext{
${ }^{247}$ F. Łobodziński, Zaczytani jak nigdy, „Newsweek Polska” 2005, nr 20, s. [97].

248 B. Kwiatek, Muchomor góra, „Newsweek Polska” 2005, nr 13, s. 4.

${ }^{249}$ E. Glapiak, Pastor z różdżkq, „Newsweek Polska” 2004, nr 8, s. 54-55.

250 M. R. Chehab, Książki nie do poduszki, „Newsweek Polska” 2003, nr 34, s. 92-93.

251 P. Bratkowski, Odyseja w globalnej wiosce, „Newsweek Polska” 2005, nr 41, s. 119-120.

252 M. Jones, Przeczytajcie, pogadajcie, „Newsweek Polska” 2002, nr 32, s. 104-105.
} 
nia jest rozmawianie o tym, co się właśnie przeczytało"253. Jednak lektura może być nie tylko przyjemnością, jak uzasadniała Jolanta Zarembina, pisząc o biblioterapii w tekście Leczenie powieścia, proponując jednocześnie kilka tytułów, które mogły okazać się pomocą w niełatwych chwilach w życiu ${ }^{254}$. Książki „w rękach terapeuty są narzędziem nie do przecenienia"255, o czym wiedzieli już starożytni Grecy, umieszczając nad wejściem do biblioteki napis: „Lekarstwo dla duszy”.

Jaka przyszłość czeka zatem książkę? Wydaje się, że dobrym podsumowaniem rozważań, zamieszczanych na łamach pisma (nierzadko, co trzeba przyznać, sprzecznych ze sobą), będą słowa autora tygodnika, który najczęściej wypowiadał się na temat literatury. Nie obawiał się on jej upadku czy końca, wszak wielokrotnie już w historii słowa drukowanego mówiono o końcu epoki Gutenberga. Kres miało położyć jej radio, później telewizja, dziś natomiast takim zagrożeniem ma być Internet. Tymczasem książka nadal istnieje. Zmienić się może forma literatury, ostrzegał P. Bratkowski. Być może będzie musiała ona być „literaturą fragmentu, rozpadu, by opowiedzieć prawdę w sposób zrozumiały dla człowieka, który w takim właśnie świecie żyje?"256 Zmienią się zapewne oczekiwania czytelników, którzy dziś będąc jeszcze dziećmi, kiedyś staną się nowymi odbiorcami literatury, z zupełnie innymi doświadczeniami.

Zanim ukształtują swój gust literacki, z całą pewnością zrobią trzy rzeczy, których nie robili w dzieciństwie ich rodzice. Obejrzą telenowelę. Zagrają w grę komputerową. Posurfują po Internecie. I te trzy czynności wpłyną na to, jakich książek będą szukać w księgarni257.

Prawdopodobnie częściej niż rodzice będą oglądać swoje ulubione powieści na srebrnym ekranie.

Na łamach pisma pojawiło się dużo tekstów poświęconych ekranizacji literatury, szczególnie zaś bestsellerów: kolejnych części książki o Harrym Potterze, a także Władcy Pierścieni. Pisano, że „Hollywood uwierzył w magię i na wyścigi ekranizuje powieści fantasy"258, zaś ekranizacja prozy J. R. R. Tolkiena „otwiera nowy rozdział w historii kina”259. Informowano także o ekranizacji Serii niefortunnych zdarzeń Daniela Handlera, Pachnidła Patricka Süskinda, dzieł Williama Szekspira. Równie często recenzowano rodzime produkcje, zazwyczaj jednak oceniając je negatywnie, jak choćby

253 Ibidem, s. 105.

254 J. Zarembina, Leczenie powieściq, „Newsweek Polska” 2005, nr 49, s. 70-[71].

255 Ibidem, s. [71].

256 P. Bratkowski, Klocki do czytania, „Newsweek Polska” 2004, nr 40, s. 94.

257 Ibidem, s. 92.

258 L. Kurpiowski, J. Giles, Czary-mary i dolary, „Newsweek Polska” 2005, nr 45, s. 96.

${ }^{259}$ K. Śmiałkowski, Władca efektów, „Newsweek Polska” 2002, nr 7, s. 99. 
Zemstę Aleksandra Fredry w reż. Andrzeja Wajdy²60. Ale czytelnicy mogli również poznać opinię dziennikarzy pisma na temat przeniesienia na srebrny ekran literatury popularnej (na przykład perypetii głównej bohaterki książkowego bestsellera K. Grocholi Nigdy w życiu), science fiction (jak choćby powieści St. Lema), klasyki polskiej (Qvo vadis czy Krzyżaków H. Sienkiewicza). Podobnie informowano o nowych inscenizacjach znanych dzieł, m.in. A. Mickiewicza (na przykład pisano o wystawieniu Dziadów w Teatrze im. Juliusza Słowackiego w Krakowie) czy W. Szekspira (wystawienie Makbeta w Narodowym Teatrze Starym w Krakowie). W tym przypadku jednak były to zazwyczaj krótkie wzmianki informacyjne, zamieszczane w ramach Jupitera czy później Karnetu, zawierające głównie dane organizacyjne, rzadziej krótki komentarz dotyczący anonsowanego wydarzenia.

Postać krótkich notek przybierały również informacje, zaliczone w pracy do kategorii Inne. Czasami informacja zawierała się w jednym tylko zdaniu (dotyczyło to głównie danych statystycznych) lub obejmowała kilka, rzadziej kilkanaście zdań. Taką postać przybierały przeważnie krótkie informacje ogólne, dotyczące na przykład czytelnictwa w Polsce i na świecie czy rozmaitych ciekawostek, związanych z książką (na przykład czytelnicy pisma dowiedzieli się, że podczas świątecznych zakupów 8,7\% Polaków kupuje pod choinkę książki). Zapraszano czytelników do odwiedzenia Muzeum Koziołka Matołka w Sochaczewie i Muzeum Najmniejszych Książek Świata w Katowicach. Informowano o tym, że Ministerstwo Kultury przygotowało wyprawki dla nowo narodzonych dzieci w postaci pięciu książek $\mathrm{z}$ bajkami. Podawano, na ile wyceniany jest majątek J. K. Rowling oraz liczbę sprzedanych na całym świecie egzemplarzy książki Harry Potter i Zakon Feniksa. W tej grupie znalazły się również informacje o imprezach kulturalnych, związanych z książką (jak na przykład o Ogólnopolskim Tygodniu Czytania Dzieciom czy o IV Głośnym Czytaniu Nocą, jako pomyśle spędzenia nocy świętojańskiej w kieleckim Antykwariacie Naukowym Andrzeja Metzgera, a także o 8. Festiwalu Literackim Warszawa Pisarzy, festiwalu poezji w Legnicy czy Poznańskim Slamie Poetyckim). Pisano także o spotkaniach z pisarzami (na przykład z Kirą Gałczyńską, Tadeuszem Różewiczem, 0. Tokarczuk, J. L. Wiśniewskim). Zazwyczaj w kilku zdaniach informowano również czytelników o nagrodach i wyróżnieniach, przyznanych twórcom, na przykład o nagrodzie dla J. Chmielewskiej za całokształt twórczości. Autorka Lesia odebrała to wyróżnienie na I Festiwalu Kryminału, który odbywał się w Krakowie.

Formę krótkich informacji przybierały również wzmianki, związane z bibliotekami. Począwszy od tego, że donoszono o wynalezieniu urządzenia, które w przyszłości może zastąpić tradycyjnego bibliotekarza, poprzez

260 W. Kot, Wydmuszka, „Newsweek Polska” 2002, nr 40, s. 94-96. 
informację o Bibliotece Internetowej, planowanej bibliotece więziennej w Piotrkowie Trybunalskim, która ma liczyć 5 tys. książek, przedstawienie pomysłu związanego z bibliobusami, a kończąc na zamierzeniach Michała Jagiełły (ówczesnego dyrektora Biblioteki Narodowej), pragnącego wykupić rękopis Quo vadis od Andrew de Janasza. Tygodnik proponował również rozmaite, niekonwencjonalne sposoby na to, by zachęcić Polaków do czytania (jak chociażby oryginalny pomysł zorganizowania biblioteki przez osoby prywatne, np. we własnej piwnicy czy na promie).

Analiza periodyku pozwoliła także wyodrębnić niewielką grupę tekstów, które donosiły o sprawach ciekawych lub oryginalnych, jak na przykład „odkrycie”, że wszystkie dzieła, dotąd przypisywane W. Szekspirowi, napisała kobieta, Mary Sidney Herbert ${ }^{261}$ czy publikacja poświęcona zwojom z Qumran ${ }^{262}$. Kilkakrotnie pisano o Biblii, np. informując o pierwszym (od ponad 100 lat) żydowskim tłumaczeniu jednej z jej ksiąg (Księgi Rodzaju) na język polski, podkreślając przy tym jego walory ${ }^{263}$. Być może, zainteresowanie autorów tygodnika Bibliq spowodowane było pojawieniem się sensacyjnej, a zarazem bestsellerowej powieści Dana Browna Kod Leonarda da Vinci - przy okazji recenzji tej książki sięgano do historii biblijnych. Pisano także o innej świętej księdze, Koranie ${ }^{264}$.

Warto również wspomnieć o listach od czytelników, którzy w ten sposób dzielili się swoimi uwagami dotyczącymi publikacji zamieszczanych na łamach pisma, a związanych z literaturą. Zazwyczaj opinie odbiorców tygodnika dotyczyły recenzowanych książek lub ich ekranizacji i w większości przypadków ich autorzy zgadzali się z oceną recenzentów pisma.

\subsection{Nasze skarby, nasze blizny ${ }^{265}$ : konkursy i akcje}

Podobnie, jak w przypadku dwóch wcześniej prezentowanych periodyków, tak i na łamach „Newsweek Polska” pojawiła się kolejna forma obecności książki, jaką są konkursy oraz akcje bezpośrednio lub pośrednio z nią związane. W porównaniu jednak z „Polityką" czy „Wprost” tego typu inicjatyw było niewiele, pomimo że bardzo często o nich informowano ${ }^{266}$.

261 A. Underwood, Szekspir też była kobieta, „Newsweek Polska” 2004, nr 27, s. 110.

262 A. Piotrowska, Zwoje z Qumran, „Newsweek Polska” 2001, nr 15, s. 72-75.

263 T. Korzeniowski, Dar z Synaju, „Newsweek Polska” 2001, nr 16, s. 196-197.

264 Zob. np. K. L. Woodward, Na poczatku była Księga, „Newsweek Polska” 2002, nr 7, s. 61-64; S. Theil, Koran inaczej, „Newsweek Polska” 2003, nr 32, s. 70.

265 Tytuł tekstu, w którym podano rozstrzygnięcie jednego z konkursów pisma. „Newsweek Polska" 2004, nr 22, s. 90-[93].

$266 \mathrm{~W}$ sumie na łamach tygodnika pojawiły się 92 informacje tekstowe na ich temat oraz 35 reklam, promujących tego typu przedsięwzięcia. W liczbie tej znajdują się również informacje dotyczące omówionego wcześniej konkursu na fotoreportaż (Newsreportaż), jak 
Biorąc pod uwagę temat pracy, najważniejszym jest konkurs literacki Podporiusz, organizowany przez omawiany tygodnik. Po raz pierwszy informacja na ten temat pojawiła się w numerze 4 (2003), w formie reklamy ${ }^{267}$. Od tej pory charakterystyczna postać siłacza, podpierającego rząd ustawionych na półce książek, stała się symbolem konkursu. Celem przedsięwzięcia miało być promowanie najlepszych tytułów minionego roku w dziedzinie literatury popularnonaukowej. Przewidziano trzy kategorie:

1. Wydarzenia. Zaliczono doń książki związane z dawną i współczesną historią, a także reportaże.

2. Ludzie. Tu planowano dokonywać wyboru wśród wspomnień, pamiętników, dzienników, listów oraz autobiografii i biografii.

3. Nauka. W tym przypadku postanowiono nagradzać literaturę popularnonaukową.

Przewidziano także nagrodę specjalną (Grand Prix), przeznaczoną dla autora książki, która otrzyma największą liczbę głosów. Dwa tygodnie później informowano czytelników, że w konkursie bierze udział 25 wydawców, którzy zgłosili 183 tytuły. Oceniane miały być one przez specjalne jury, w skład którego weszli przedstawiciele kultury i nauki. Każdy z nich miał zagłosować na wybrane przez siebie 5 z 73 książek reprezentujących kategorię Nauka, 5 z 49 w ramach kategorii Ludzie i 5 z 61 w kategorii Wydarzenia. Spośród $\mathrm{w}$ ten sposób nominowanych tytułów członkowie Akademii „Newsweeka” mieli wybrać jeden tytuł zwycięski dla każdej z kategorii. Redakcja wyrażała przy tym nadzieję, że „dzięki konkursowi polscy czytelnicy będą jeszcze chętniej sięgali po książki z najwyższej półki”268. $\mathrm{Z}$ wyłonionych $\mathrm{w}$ ten sposób 15 propozycji czytelnicy pisma mogli wybrać w plebiscycie jedną, którą uznali za najważniejsze wydarzenie w 2002 r. Listę nominowanych książek zamieszczono w numerze 15 (2003) ${ }^{269}$.

Prezentując pierwszych laureatów, redakcja pisała:

Uważamy, że tak, jak powstają listy pozycji literatury pięknej, których znajomość to dla wykształconego człowieka prawdziwy obowiązek, tak samo winniśmy tworzyć listę książek literatury faktu, które trzeba poznać 270 .

również wzmianki oraz notki informacyjne dotyczące spotkań, organizowanych przez „Newsweek Polska”, takich jak np. Antysalon czy Rozmowy Piotra Bratkowskiego (obydwie inicjatywy opisane zostały wcześniej).

267 „Newsweek Polska” 2003, nr 4, s. [67].

268 [br. aut]., Podporiusz, „Newsweek Polska” 2003, nr 5, s. 6.

269 [br. aut.], Podporiusz 2003, „Newsweek Polska” 2003, nr 15, s. 106-[107].

270 W. Kot, Fascynujace wciagające prawdziwe [pis. oryg.], „Newsweek Polska” 2003, nr 21, s. 84-87. 
Finalistom wręczano statuetki Podporiusza oraz nagrody pieniężne ufundowane przez wydawcę tygodnika, Axel Springer Polska. Zdobywca Grand Prix otrzymywał 40 tys. zł, zaś zwycięzcy w poszczególnych kategoriach po 20 tys. zł, natomiast zwycięstwo w plebiscycie czytelników miało charakter honorowy. W numerze, w którym ogłoszono zwycięzców 2. edycji konkursu271, zamieszczano także list Marka Belki, ówczesnego prezesa Rady Ministrów, który gratulował i jednocześnie chwalił inicjatywę pisma, podkreślając, że Podporiusz jest symbolem wysokiego poziomu nominowanych książek. W tabeli 35 zaprezentowano laureatów konkursu w latach 2003-2004272.

Tabela 35. Laureaci konkursu literackiego Podporiusz

\begin{tabular}{|c|c|c|c|}
\hline \begin{tabular}{|c|} 
Rok, w którym \\
przyznano nagrodę
\end{tabular} & Kategoria & Nazwisko laureata & Tytuł nagrodzonej publikacji \\
\hline \multirow{4}{*}{2003} & Wydarzenia & Ryszard Kapuściński & $\begin{array}{l}\text { Lapidarium V } \\
\text { (Czytelnik) }\end{array}$ \\
\hline & $\begin{array}{l}\text { Ludzie i jednocze- } \\
\text { śnie Grand Prix }\end{array}$ & Anna Sobolewska & $\begin{array}{l}\text { Cela. Odpowiedź na zespół } \\
\text { Downa } \\
\text { (Wydawnictwo W.A.B.) }\end{array}$ \\
\hline & Nauka & $\begin{array}{l}\text { Władysław Kopaliń- } \\
\text { ski }\end{array}$ & $\begin{array}{l}\text { Leksykon wątków miłosnych } \\
\text { (Muza SA) }\end{array}$ \\
\hline & \begin{tabular}{|l|} 
Nagroda Czytelni- \\
ków
\end{tabular} & Wojciech Jagielski & $\begin{array}{l}\text { Modlitwa o deszcz } \\
\text { (Wydawnictwo W.A.B.) }\end{array}$ \\
\hline \multirow{4}{*}{2004} & Wydarzenia & Andrzej Friszke & $\begin{array}{l}\text { Polska. Losy państwa i narodu } \\
\text { 1939-1989 } \\
\text { (Iskry) }\end{array}$ \\
\hline & Ludzie & Hanna Świda-Ziemba & $\begin{array}{l}\text { Urwany lot. Pokolenie inteli- } \\
\text { genckiej młodzieży powojen- } \\
\text { nej w świetle listów i pamięt- } \\
\text { ników z lat 1945-1948 } \\
\text { (Wydawnictwo Literackie) }\end{array}$ \\
\hline & $\begin{array}{l}\text { Nauka } \\
\text { i Grand Prix }\end{array}$ & Zygmunt Kubiak & $\begin{array}{l}\text { Piękno i gorycz Europy. Dzieje } \\
\text { Greków i Rzymian } \\
\text { (Świat Książki) }\end{array}$ \\
\hline & $\begin{array}{l}\text { Nagroda Czytelni- } \\
\text { ków }\end{array}$ & Ryszard Kapuściński & $\begin{array}{l}\text { Autoportret reportera }{ }^{a} \\
\text { (Społeczny Instytut Wydaw- } \\
\text { niczy Znak) }\end{array}$ \\
\hline
\end{tabular}

$a \mathrm{~W}$ tym przypadku autor odmówił przyjęcia nagrody, co było konsekwencją zamieszczenia w tygodniku wspomnianego wcześniej artykułu Żydzi odbierajq̨ swoje.

Źródło: „Newsweek Polska” 2003-2004.

271 P. Bratkowski, Nasze skarby, nasze blizny, „Newsweek Polska” 2004, nr 22, s. 90-[93].

272 W 2005 r. zabrakło informacji na ten temat. 
Niestety, pismo nie mogło poszczycić się innymi tego typu inicjatywami, związanymi z książką. Pozostałe propozycje były tylko pośrednio związane $\mathrm{z}$ literaturą, co więcej, miały charakter jednorazowy.

Jednym z pomysłów był trwający przez kilka miesięcy na przełomie 2004/2005 r. projekt, realizowany w ramach Programu Edukacyjnego, adresowany do gimnazjów i liceów, a zatytułowany Kto ty jesteś? Uczniowie mogli nadsyłać na adres periodyku swoje prace, w których w formie eseju, albumu lub prezentacji multimedialnej odpowiadaliby na pytanie, co oznacza dla nich bycie Polakiem. Do przygotowania konkursowej pracy mogły posłużyć, jak sugerowali organizatorzy, teksty, drukowane na łamach pisma, w bloku tematycznym Jacy jesteśmy - Polacy 2005. Odpowiedzią było ponad 100 prac, nadesłanych z różnych szkół z całej Polski. Autorzy najciekawszych zostali zaproszeni do redakcji pisma.

Warto wspomnieć o inicjatywie redakcji tygodnika, realizowanej w 2005 r. W lipcu tego roku rozpoczęto na łamach pisma druk cyklu opowiadań, jakich „jeszcze nie było”. Pomysł nazwano Wszystkie dni lata ${ }^{273}$. Redakcja zwróciła się do dziewięciorga wybranych pisarzy polskich, by ci napisali opowiadanie, którego akcja toczyłaby się w czasach współczesnych, na plaży, a bohaterami byłoby dwoje ludzi. Opowiadania, najpierw zamieszczane na łamach pisma $\mathrm{w}$ jego kolejnych dziewięciu numerach, zostały następnie wydane w postaci książki przez Wydawnictwo W.A.B. wspólnie z Axel Springer Polska. Zgodnie z zamierzeniem redakcji opowiadania miały być „panoramą współczesnej polskiej prozy miłosnej. I lekturą obowiązkową dla wszystkich, którzy kochają. Nie tylko literaturę"274. Cykl rozpoczął Wojciech Kuczok opowiadaniem Klapki (z zielonymi motylkami), następnie czytelnicy poznali kolejno opowiadania: Włodzimierza Kowalewskiego: Brzydki człowiek, Rafała A. Ziemkiewicza: Południca, Marii Nurowskiej: Długi letni dzień, Pawła Huelle275: Pierwsze lato, Izabeli Sowy: Wtorek, po sezonie, Stefana Chwina: Opowiadanie o miłości, Krystyny Kofty: Królowa fryzjerek, Sławomira Shuty: Stereotyp. Każde z opowiadań, drukowane w dziale Kultura, zajmowało zazwyczaj cztery strony. Na pierwszej z nich zamieszczano zdjęcie autora wraz z krótką notką na jego temat, całość uzupełniona była rysunkiem.

Warto jeszcze wspomnieć o interesującym pomyśle, jaki przedstawiono czytelnikom z okazji zbliżającego się Dnia św. Walentego w 2005 r. Zaproponowano nietypowy prezent dla osoby bliskiej: podróż szlakiem wybra-

273 Nawiązując tym samym częściowo do filmu T. Konwickiego Ostatni dzień lata.

274 [br. aut.], Wszystkie dni lata, „Newsweek Polska” 2005, nr 27, s. 95.

275 Temu opowiadaniu pomyłkowo przypisano numer czwarty, gdy faktycznie było piąte w kolejności. 
nych bohaterów romansów. Zachęcano do zwiedzenia Werony i domu Capulettich, Paryża i spaceru bulwarem Saint Germain des Prés. Czytelnikom prozy Milana Kundery proponowano podróż do Pragi, zaś tym, którzy poznali Kronikę wypadków miłosnych T. Konwickiego, wyprawę do Wilna. Miłośnikom Konstantego I. Gałczyńskiego wskazywano Leśniczówkę Pranie jako cel romantycznej wyprawy ${ }^{276}$.

O kilku przedsięwzięciach w tygodniku informowano czytelników bądź w formie krótkich notek, bądź też w postaci reklam. I tak na przykład, w 2002 r. pojawiło się ogłoszenie Stowarzyszenia Producentów i Dystrybutorów Sprzętu Medycznego, w którym organizatorzy ogłaszali konkurs na przedstawienie $\mathrm{w}$ formie pisemnej pracy na temat Jak zlikwidować lub zmniejszyć zadłużenie Zakładów Opieki Zdrowotnej? Nagrodą dla dwóch najciekawszych rozwiązań miały być nagrody finansowe w wysokości 8000 zł oraz przekazanie nagrodzonej pracy ministrowi zdrowia ${ }^{277}$.

W piśmie zamieszczano również, o czym wspomniano wyżej, zaproszenia bądź tylko informacje o spotkaniach $\mathrm{z}$ autorami, wystawach lub festiwalach, związanych z książką. Informowano na przykład o 5. zjeździe literatów, odbywającym się w ramach Festiwalu Literackiego „Warszawa pisarzy”, w Centrum Sztuki Współczesnej w Zamku Ujazdowskim w Warszawie czy o wystawie dla dzieci, inspirowanej książką Burnett F. Hodgson Tajemniczy ogród.

Warto przytoczyć kilka przykładów tytułów tekstów czy choćby tylko notek związanych z literaturą, jako że wiele z nich przyciągało wzrok czytelnika swą oryginalnością278: Chwila, w której otwiera się dłoń, Cywilizacja pamięci, Ksiqż̇ka jak lustro, Literacki spekulant, Mieć to coś, Nie czytałeś, to posłuchaj, Obnażanie Szekspira, Od pszczółki do komara, Piraci zarzucaja sieć, Pisarz objazdowy, Potter gwiazdq biznesu, Przyjaciel Matołka, Robot bibliotekarz, Szekspir też była kobieta, Tuwim zabroniony, Wielka komedia małych świństw, Witajcie w ciężkich czasach!, Wojna słoni z myszkami, Zaczytani jak nigdy, Zatargi i przyjemności, Zew pierścieni, Żeby zobaczyć pijawki.

276 [br. aut.], Walentynkowe pejzaże, „Newsweek Polska” 2005, nr 6, s. 6.

277 Zob. np. „Newsweek Polska” 2002, nr 15, s. [23].

278 Kolejno: „Newsweek Polska” 2005, nr 19, s. 100; 2001, nr 9, s. 92-93; 2004, nr 41, s. $41 ; 2005$, nr 16, s. 106-[109]; 2002, nr 28, s. [76]-83; 2005, nr 3, s. [106]-107; 2003, nr 31, s. $88-90 ; 2004$, nr 29, s. 64; 2002, nr 49, s. 16-[17]; 2005, nr 14, s. [111]; 2003, nr 29, s. 9; 2005, nr 17, s. [9]; 2004, nr 30, s. [77]; nr 27, s. $110 ; 2003$, nr 6, s. [95]; 2002, nr 7, s. 104$105 ; \mathrm{nr} 6$, s. 106; 2004, nr 1, s. [74]-77; 2005, nr 20, s. [97]; nr 22, s. 111; 2001, nr 15, s. [98]$101 ; 2005$, nr 3, s. 98-100. 


\subsubsection{Lepsza twarz mediów ${ }^{279}$. Inne informacje: o prasie i środowisku dziennikarskim}

Na łamach „Newsweek Polska” pojawiło się 207 informacji związanych z prasą i środowiskiem dziennikarskim. Miały one formę zarówno dłuższych artykułów, jak i krótszych komentarzy oraz wzmianek (zob. Aneks 27. Wybór tekstów poświęconych rynkowi prasowemu na łamach „Newsweek Polska" w latach 2001-2005).

Dłuższe (zajmujące średnio jedną stronę) teksty zamieszczano zazwyczaj w ramach działu Społeczeństwo, w sporadycznie pojawiającej się rubryce Media lub na stronach związanych z kwestiami biznesowymi. Natomiast krótkie notki, wzmianki o charakterze informacyjnym, pojawiały się zazwyczaj w ramach Peryskopu lub Jupitera.

Czytelnicy dowiedzieli się na przykład, że 15\% rodaków nie ma zaufania do prasy, 69\% Polaków uważa, że dziennikarze są dociekliwi, zaś niewiele mniej, bo $62 \%$ jest zdania, że dziennikarze są uczciwi. Bez wątpienia do ciekawostek zaliczyć można również informację, że największa na świecie reklama prasowa liczyła sobie 68 stron, a ukazała się w „New York Timesie". Jednak nie tylko tego typu informacje pojawiały się $w$ tygodniku.

W 2002 r. pisano o postępującej recesji w prasie, zwolnieniach dziennikarzy i bankructwie poszczególnych tytułów ${ }^{280}$, a rok później o planach rządu, zakładających nałożenie podatku na książki i prasę ${ }^{281}$. W tygodniku zamieszczono wówczas kilkunastozdaniową informację, w której przestrzegano przed takim posunięciem. Mogłoby ono bowiem, jak twierdzono, spowodować spadek sprzedaży prasy i książek i wpłynąć na obniżenie (i tak już niewielkiego) poziomu czytelnictwa. Na łamach periodyku włączono się również w akcję protestacyjną przeciwko tym planom, zamieszczając m.in. reklamy o określonej wymowie, znane także czytelnikom „Polityki” $i$ „Wprost”.

W ciągu badanych 5 lat na łamach tygodnika pojawiło się wiele tekstów, prezentujących wybrane typy prasy. Przedstawiono na przykład tzw. magazyny lifestylowe, w których „zakres tematyczny wyznaczają moda, sztuka i kultura”282, adresowane do „zblazowanych mieszczuchów”283. Pisano również o tabloidach zarówno $\mathrm{w}$ formie zapowiedzi nowego tytułu ${ }^{284}$, jak i zabawnej notki, opisującej „wojnę” pomiędzy „Super Expressem” a „Faktem”285. Czytelnik „Newsweek Polska” mógł dowiedzieć się także, jak

\footnotetext{
279 Tytuł jednej z publikacji, zob. „Newsweek Polska” 2002, nr 14, s. 94.

280 [br. aut.], Gazety na diecie, „Newsweek Polska” 2002, nr 50, s. 2.

281 D. Stasik, VAT-owanie czytelnika, „Newsweek Polska” 2003, nr 51/52, s. [7].

282 A. M. Kowalewska, Czy elita to czyta? „Newsweek Polska” 2003, nr 35, s. 65.

283 Ibidem.

284 J. Romanowicz, Fakt mówi za siebie, „Newsweek Polska” 2003, nr 42, s. 20-[21].

285 P. Szaniawski, Zabawa w ciepło-zimno, „Newsweek Polska” 2004, nr 39, s. 9.
} 
prezentuje się zarówno współczesna prasa kobieca ${ }^{286}$, młodzieżowa ${ }^{287}$, jak i sportowa ${ }^{288}$ czy wojskowa ${ }^{289}$. Pojawił się również tekst o pismach wirtualnych, istniejących wyłącznie w Internecie ${ }^{290}$, a także o nowym zjawisku na rynku, jakim stały się tygodniki telewizyjne, wydawane przez supermarkety291.

W kilku przypadkach prezentowano wybrane tytuły, zawsze w kontekście określonych wydarzeń z nimi związanych. I tak na przykład kilkakrotnie pisano o dzienniku „Rzeczpospolita”, przeważnie w aspekcie sporów, jakie toczyły się wówczas pomiędzy udziałowcami spółki Presspublica, wydającej tytuł292. Wspominano również o kłopotach innych pism, m.in. dziennika „Życie”293. W formie kilkuzdaniowych notek (czasem zabawnych lub ironicznych) pojawiały się informacje dotyczące takich czasopism jak na przykład „Machina"294, „Ozon”295, „Votre Beauté”296. Pisano też o wybranych dziennikarzach, na przykład o Adamie Michniku297 czy Bronisławie Wildsteinie 298 .

Na łamach pisma kilkakrotnie poruszano również kwestię zagranicznych mediów, na przykład irackich ${ }^{299}$ czy białoruskich $^{300}$.

Większość z tych informacji, niezależnie od formy, miała interesujące tytuły. Oto kilka wybranych przykładów ${ }^{301}$ : Chlapanie wielorybów, Ciężki kawałek prasy, Człowiek, co się Agorze nie kłaniał, Czwarta władza powiato-

286 A. Więcka, Reanimacja starszej pani, „Newsweek Polska” 2002, nr 8, s. 90-91.

287 A. Więcka, Test dla dziewicy, „Newsweek Polska” 2002, nr 30, s. 63; eadem, Poeci marketingu, ibidem, 2001, nr 13, s. 106-107; o prasie dziecięco-młodzieżowej: J. Romanowicz, Lep na małolata, ibidem, 2004, nr 44, s. 74.

288 J. Romanowicz, O sporcie bez sensacji, „Newsweek Polska” 2004, nr 17, s. 90-[91].

289 J. Mielnik, Czytaj fachowców, „Newsweek Polska” 2001, nr 8, s. 94.

290 A. Więcka, Czytelnik, czyli dziennikarz, „Newsweek Polska” 2002, nr 3, s. 94.

291 J. Romanowicz, Nagły atak zza węgła, „Newsweek Polska” 2003, nr 31, s. 83.

292 Zob. np. Z. Wojtkowska, Rzeczpospolita obojga wspólników, „Newsweek Polska” 2001, nr 13, s. 108.

293 Zob. np. M. Łukaszewicz, Szkoda „Życia”, „Newsweek Polska” 2002, nr 25, s. 96; [br. aut.], Łamy przeprosin, ibidem, 2003, nr 19, s. 8.

294 J. R., „Machina” w okopach, „Newsweek Polska” 2002, nr 3, s. 111.

295 PER, Jak trwoga, to do Boga, „Newsweek Polska” 2005, nr 37, s. [9].

296 Vio., Przerwa na urodę, „Newsweek Polska” 2002, nr 10, s. [111].

297 M. Karnowski, P. Zaremba, Koniec świata Redaktora, „Newsweek Polska” 2005, nr 17, s. 24-30.

298 P Zaremba, Człowiek, który się teczkom nie kłaniał, „Newsweek Polska” 2005, nr 5, s. 24-26.

299 W. Rogacin, Kamera nie kłamie, „Newsweek Polska” 2003, nr 33, s. 52-54.

300 M. Kacewicz, Kneblowanie prasy, „Newsweek Polska” 2002, nr 16, s. 74.

301 Kolejno: „Newsweek Polska” 2004, nr 22, s. 6; 2005, nr 41, s. 94-[95]; 2002, nr 33, s. 20-24; nr 26, s. $94-95$; nr 3, s. 94; nr 51/52, s. 181; 2003, nr 42, s. 20-[21]; 2002, nr 50, s. $2 ; 2003$, nr 19, s. 59; 2004, nr 44, s. 74; 2005, nr 33, s. 6; 2002, nr 7, s. [110]; 2001, nr 1, s. 88-89; 2004, nr 29, s. 36-[37]; 2002, nr 9, s. 92-93; 2003, nr 32, s. 84-85; nr 12, s. [43]; 2005, nr 26, s. 100 . 
wa, Czytelnik, czyli dziennikarz, Elektroniczny papier, Fakt mówi za siebie, Gazety na diecie, Kto ma sieć, ma wszystko, Lep na małolata, Łowcy tytułów, Moda i morświny, Nowe szaty naszych gazet, $O$ dwóch takich, co kupili gazetę, Prasa gra i śpiewa, Siła rażenia brukowców, Wojna na słowa, Żurnaliści i blogerzy.

Warto zaznaczyć, że (poza nielicznymi wyjątkami ${ }^{302}$ ) „Newsweek Polska" nie atakował na swoich łamach konkurentów, jak to czynił choćby tygodnik „Wprost” w stosunku przede wszystkim do „Polityki”.

Oddzielną grupę, o której trzeba wspomnieć, stanowiły reklamy i autoreklamy związane z prasą. W 567 ogłoszeniach pojawiło się 39 tytułów gazet i czasopism, wśród których najwięcej było pism wydawanych przez Axel Springer Polska. Zachęcano m.in. do kupna takich periodyków, jak „Auto Świat”, „Fakt”, „Komputer Świat”, „Na żywo” i „Oliwia”. Do czytelników trafiały również reklamy tytułów, znane z łamów „Polityki” czy „Wprost”, jak choćby anons reklamujący „Gazetę Prawną”, „Gazetę Wyborczą” oraz dodatki doń (m.in. „Duży Format” i „Turystykę”), „Puls Biznesu”, „Rzeczpospolitą". Kilkakrotnie pojawiły się reklamy periodyków dla kobiet: „Twojego Stylu”, „Vivy!” i „Zwierciadła”. Zamieszczano je w całym tygodni$\mathrm{ku}$, większość z nich miała postać niewielkich pod względem rozmiaru modułów, przeważnie umieszczanych u dołu strony, na całej jej szerokości. Rzadko zdarzały się tak interesujące pomysły na reklamę tytułu, jak w przypadku "Super Expressu”, gdzie anons zachęcający do sięgnięcia po tę gazetę pojawił się na trzech stronach, za każdym razem przykuwając wzrok odbiorcy ciekawym hasłem (zdjęcia 69-71).

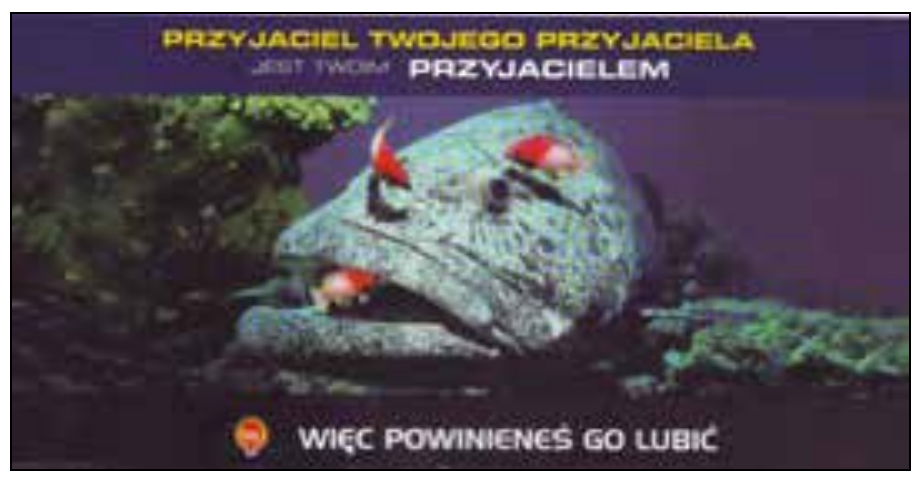

Zdjęcie 69. Przykładowe ogłoszenie zamieszczone na łamach „Newsweek Polska” „Newsweek Polska” 2003, nr 45, s. [59] 


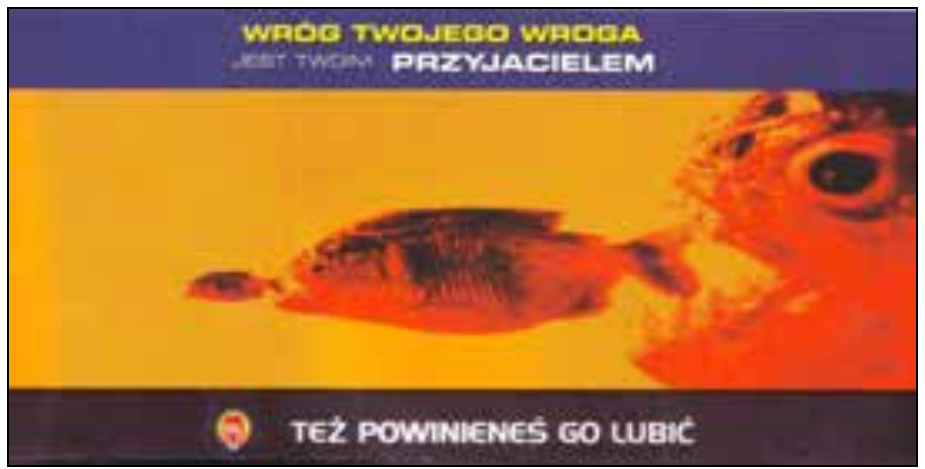

Zdjęcie 70. Przykładowe ogłoszenie zamieszczone na łamach „Newsweek Polska” „Newsweek Polska” 2003, nr 45, s. [61]

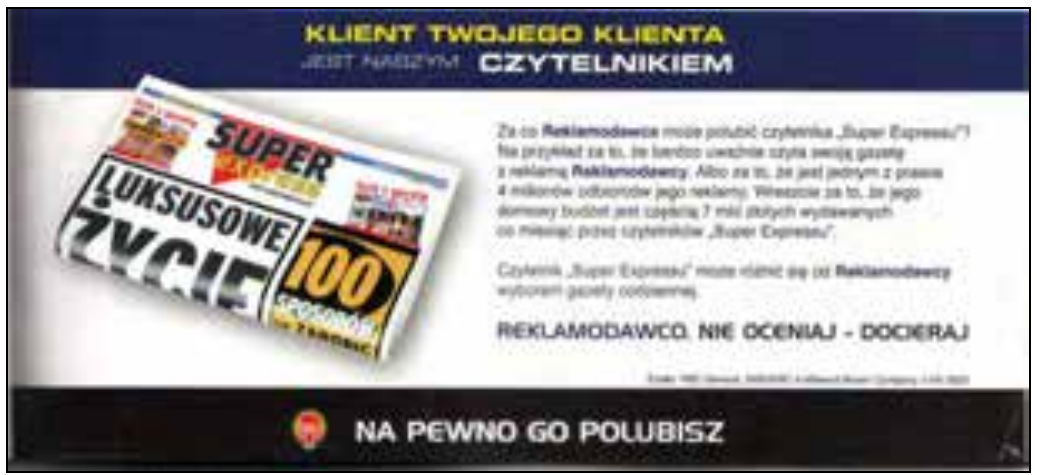

Zdjęcie 71. Przykładowe ogłoszenie zamieszczone na łamach „Newsweek Polska" „Newsweek Polska” 2003, nr 45, s. [63]

Czytelnik musiał chwilę zatrzymać się nad tymi ogłoszeniami, by zrozumieć sens pojawiających się $\mathrm{w}$ każdym $\mathrm{z}$ nich haseł reklamowych i odnieść je do zamieszczonych zdjęć.

W ostatnich miesiącach danego roku pojawiały się anonse, przypominające o zamówieniu prenumeraty na reklamowane tytuły. Wyraźne, a zarazem interesujące ogłoszenia zamieszczał wydawca dziennika „Rzeczpospolita"(zdjęcie 72). 


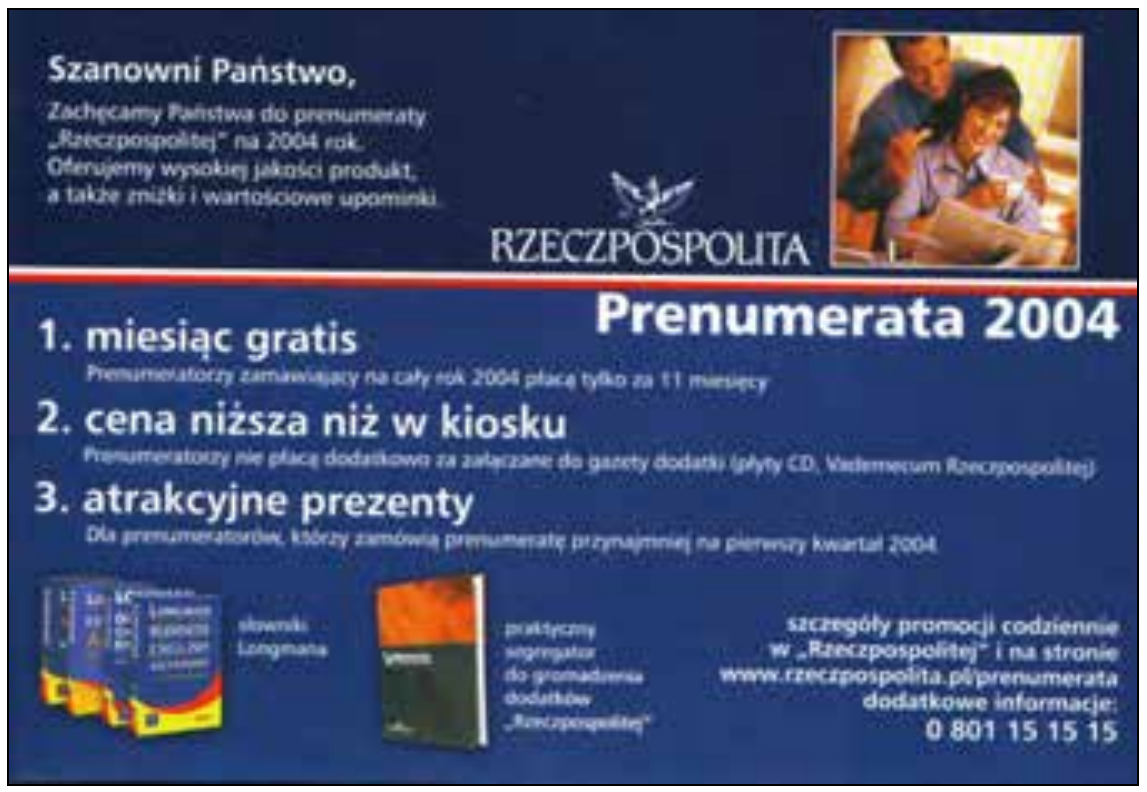

Zdjęcie 72. Przykładowe ogłoszenie zamieszczone na łamach „Newsweek Polska” „Newsweek Polska” 2003, nr 46, s. [87]

W tym przypadku uwagę czytelnika zwracał nie tylko bezpośredni zwrot („Szanowni Państwo”), ale możliwość rabatów i szansa na prezenty, jeśli tylko zdecyduje się on na zamówienie prenumeraty.

W „Newsweek Polska” nie zapominano o autopromocji. Nie szczędząc miejsca, zamieszczano na łamach tygodnika autoreklamę wszystkich tytułów należących do wydawcy Axel Springer Polska. Te anonse zajmowały zazwyczaj całą stronę, odznaczały się jaskrawymi kolorami i dopracowaną grafiką, zwieńczoną hasłami, zachęcającymi do kupna tytułu. Oto kilka przykładów - zdjęcia 73-75 (zob. s. 289).

Elementem zwracającym uwagę było za każdym razem mniej lub bardziej rozbudowane hasło, które wzbudzało zainteresowanie odbiorcy. Musiał on zatrzymać się na chwilę, żeby przeczytać zamieszczone przez wydawcę wyjaśnienie. W przypadku promocji dziennika, za każdym razem intrygujące stwierdzenie dotyczyło innego "faktu”: odbiorcy reklamowanej gazety nie zmywają naczyń, ponieważ posiadają zmywarkę, dzięki czemu stają się ważną grupą docelową dla potencjalnych reklamodawców. 


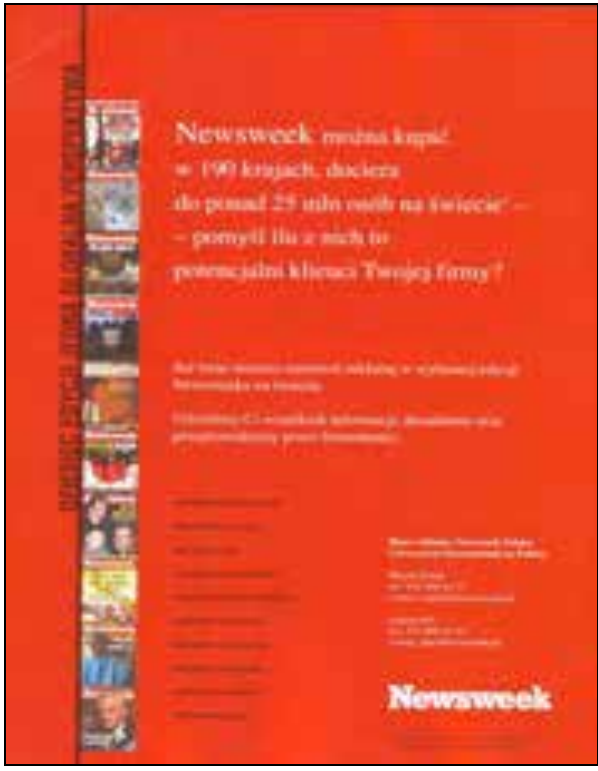

Zdjęcie 73. Przykładowe ogłoszenie zamieszczone na łamach „Newsweek Polska” „Newsweek Polska” 2003, nr 36, s. [44]

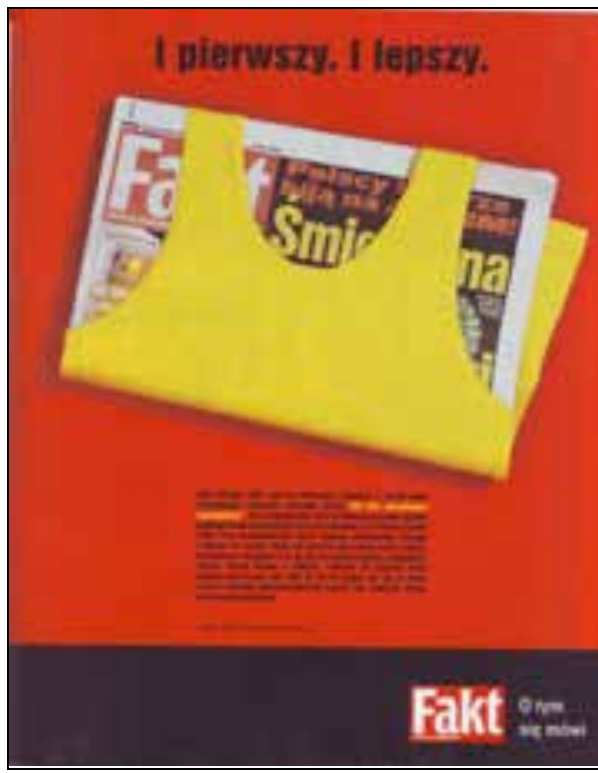

Zdjęcie 74. Przykładowe ogłoszenie zamieszczone na łamach „Newsweek Polska” „Newsweek Polska” 2004, nr 7, s. [85]

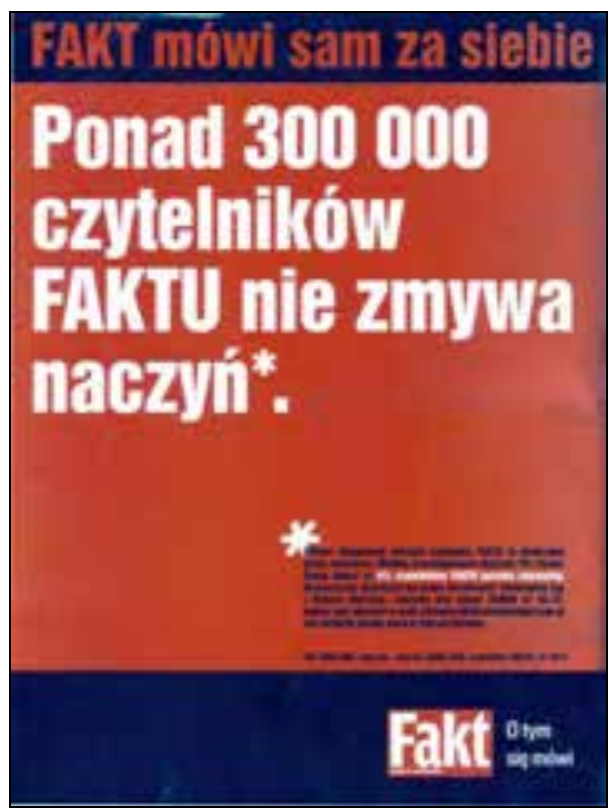

Zdjęcie75. Przykładowe ogłoszenie zamieszczone na łamach „Newsweek Polska” „Newsweek Polska” 2004, nr 32, s. [90] 
Niektóre z anonsów pojawiały się na łamach „Newsweek Polska” w takiej samej lub zbliżonej formie, w jakiej zamieszczano je w tygodnikach „Polityka” i „Wprost”. Tak było choćby w przypadku „Gazety Prawnej” czy dodatków do „Gazety Wyborczej” („Gazeta Praca”303 czy „Turystyka”304).

Podobnie było w odniesieniu do wspomnianej akcji, w której wydawcy prasy protestowali przeciwko nałożeniu podatku VAT na gazety i czasopisma. Anons protestacyjny przybrał i tu taką samą postać 305 .

Analiza niemal pięciu roczników „Newsweek Polska” pozwoliła na sformułowanie kilku interesujących wniosków. Pomimo deklarowanego od początku przez redakcję zainteresowania kulturą, informacji na jej temat na łamach pisma nie było dużo, szczególnie w porównaniu z dwoma największymi konkurentami periodyku: tygodnikami „Polityka” i „Wprost”. Szczególnie uderzająca była mała grupa ogłoszeń wydawniczych oraz wywiadów $\mathrm{z}$ twórcami. Poza wartościowym przedsięwzięciem w postaci opisanego konkursu Podporiusz, tygodnik nie inicjował innych tego typu akcji, nieszczególnie również wspierając podobne inicjatywy. Podobnie jak w przypadku Spółdzielni Pracy „Polityka” i AWR „Wprost”, Axel Springer wydawał własne książki i serie, nie były to jednak pozycje sygnowane tytułem „Newsweek Polska”. Zaprezentowane formy informacji o książce nierzadko przenikały się nawzajem. Analiza periodyku wykazała, że najczęściej było tak w przypadku recenzji, portretów osób związanych z literaturą i tekstów jej poświęconych. Omawiając i proponując czytelnikom pisma wybrany tytuł, recenzent nierzadko pisał o życiu i twórczości jego autora. I odwrotnie: opisując sylwetkę wybranego twórcy, zawsze sięgano do książek jego autorstwa, wspominając o nich choćby tylko jednym zdaniem. W. Kot stwierdził:

Zakładaliśmy, że nasz czytelnik jest konsumentem kultury w jej paśmie środkowym. Nie interesują go awangardy, ani kultura szczególnie wysoka, ale też lubi sytuować swoje zainteresowania powyżej kultury pop. Stąd wybory książek uznanych za wydarzenia literackie, ale nieszczególnie trudnych $\mathrm{w}$ odbiorze i skupionych raczej na problemach społecznych czy obyczajowych niż na kwestiach ściśle artystycznych. Poza tym sięgaliśmy często po książki ze świata, otwierając czytelnikowi oczy na zjawiska literackie, którymi interesowała się światowa publiczność, dając mu możliwość uczestniczenia w światowym dyskursie. Zasady te obowiązywały w całym piśmie i odnosiły się zarówno do kultury, jak i gospodarki ${ }^{306}$.

303 Zob. np. „Newsweek Polska” 2003, nr 38, s. [69].

304 Zob. np. „Newsweek Polska” 2003, nr 47, s. [83].

305 Zob. np. „Newsweek Polska” 2004, nr 5, s. [21].

306 Informacje uzyskane dzięki korespondencji z W. Kotem. 


\section{5. „Polityka”, „Wprost”, „Newsweek Polska”: więcej opinii ${ }^{1}$ - wnioski porównawcze}

Każdy z przedstawionych tytułów wyrósł na gruncie innej historii, która wpłynęła na jego dzisiejszy kształt i charakter. Największy pod tym względem bagaż zdaje się dźwigać tygodnik „Polityka”, przez szereg lat po 1989 r. (mimo starań redakcji, by to zmienić) nosząc na sobie piętno pisma postkomunistycznego. „Wprost” to z kolei przykład periodyku lokalnego, któremu udało się zaistnieć (i przetrwać) na arenie ogólnopolskiej. I wreszcie trzeci tytuł, „Newsweek Polska”, o znanej marce, który wniósł na rynek prasowy innowacyjne metody pracy redakcyjnej, oparte na doświadczeniach amerykańskich oraz nowy sposób redagowania tekstów. Jak pisała Karolina Prewęcka, pojawienie się tego pisma spowodowało w segmencie tygodników opinii „twórczy doping”2, szczególnie w odniesieniu do Spółdzielni Pracy „Polityka” oraz Agencji Wydawniczo-Reklamowej „Wprost”, które wprowadziły zmiany w wydawanych przez siebie tytułach i wyraźniej zaangażowały się $\mathrm{w}$ działania o charakterze autopromocyjnym.

Zawartość każdego z periodyków była w badanym okresie podobna, dotyczyła zagadnień związanych z polityką, gospodarką i kulturą w Polsce i na świecie. Tygodnik „Wprost” najbardziej spośród trzech przedstawionych tytułów zainteresowany był nowościami technologicznymi, promując różnorodne rozwiązania $\mathrm{w}$ tych dziedzinach, co bezpośrednio przekładało się na rozbudowany adekwatny dział w piśmie oraz wykorzystanie możliwości interaktywnych przy kształtowaniu wizerunku tytułu w Internecie.

Wyraźniejsze różnice pomiędzy przedstawionymi periodykami następowały na poziomie formy przekazu. Sposób prezentowania informacji w tygodniku „Newsweek Polska” był dostosowany do wymagań młodszego odbiorcy. Na łamach tego pisma zamieszczano wiele infografik, a prezentowane treści miały charakter bardziej (w porównaniu z dwoma pozostałymi tytułami) skondensowany.

Każdy z tygodników inicjował bądź wspierał w badanym okresie różnorodne przedsięwzięcia, organizował spotkania, wydawał dodatki specjalne i przygotowywał rankingi, przy czym niektóre z publikowanych zestawień miały zbliżony do siebie charakter (przykładem może tu być Ranking szkół wyższych czy Ranking szpitali). Każdy z periodyków nawiązał współpracę z innymi mediami (przeważnie wybranymi stacjami radiowymi i telewizyjnymi), z którymi przygotowywał programy lub współorganizował rozmaite akcje.

1 Tytuł publikacji, która ukazała się przed wydaniem pierwszego numeru tygodnika „Newsweek Polska”. Zob. K. Prewęcka, Więcej opinii, „Media i Marketing Polska” 2001, nr 16, s. 9.

2 K. Prewęcka, Twórczy doping, „Media i Marketing Polska” 2001, nr 21, s. 26. 
Każdy z tygodników był wielokrotnie nagradzany. Doceniano zarówno wydawców, jak i poszczególnych dziennikarzy. Warto zatrzymać się na chwilę przy kwestii współpracowników omawianych pism. Starano się pozyskać znane nazwiska; stąd na łamach „Polityki” pojawiały się felietony m.in. Zygmunta Kałużyńskiego, Jerzego Pilcha czy Krzysztofa Zanussiego. Na łamach „Wprost” drukowano teksty Małgorzaty Domagalik, Krzysztofa Skiby, Bronisława Wildsteina, a także Zygmunta Kałużyńskiego i Tomasza Raczka. Kiedy na rynku pojawił się „Newsweek Polska”, tajemnicą poliszynela stał się fakt, że wydawca tego tygodnika przejmuje dziennikarzy z innych redakcji ${ }^{3}$. W ten sposób do pisma przeszli m.in. Wiesław Kot i Kamil Śmiałkowski. Na łamach tego periodyku swoje felietony zamieszczał również Piotr Bratkowski, Wojciech Kuczok, Szymon Hołownia i Rafał A. Ziemkiewicz.

W ciągu 5 lat każdy z tytułów kilkakrotnie zmieniał swą formę graficzną, proponował nowe rubryki, a likwidował inne. Kwestie, związane z tematyką pracy, w każdym z nich odnajdywały swe miejsce w ramach działu, nazwanego w trzech przypadkach tak samo: Kultura. Dział ten na łamach „Polityki” drukowany był w środkowej części numeru, natomiast w przypadku dwóch kolejnych tytułów zamykał każde wydanie. Interesujące wydaje się podobieństwo, które można zaobserwować w strukturze działu: otóż w każdym z omawianych tytułów w ramach Kultury pojawiały się podobne w formie rubryki: Afisz („Polityka”), Menu („Wprost”) i Jupiter („Newsweek Polska”), będące tygodniowym przeglądem najważniejszych (według redakcji) wydarzeń związanych z literaturą, filmem, teatrem, kinem, sztuką i muzyką. 0 ile w pierwszym i trzecim przypadku anonsowały one cały dział, o tyle na łamach „Wprost” były elementem, który go zamykał. Pozostałą część działu stanowiły dłuższe teksty, komentujące lub tylko prezentujące wybrane wydarzenie bądź postać, związaną ze światem kultury.

Jak w kontekście zbliżonych funkcji, określonych w definicji tego typu pism, a także celów, jakie stawiała sobie każda redakcja, wyglądała informacja o książce na łamach każdego z badanych periodyków? Poniższa tabela przedstawia pierwsze różnice, wynikające $\mathrm{z}$ zebranych danych statystycznych:

3 Przypomnijmy, że sam redaktor naczelny „Newsweek Polska”, T. Wróblewski, był wcześniej współpracownikiem tygodnika „Wprost”. 
Tabela 36. Porównanie liczby informacji o książce na łamach tygodników „Polityka”, „Wprost” i „Newsweek Polska”

\begin{tabular}{|l|c|c|c|}
\hline \multicolumn{1}{|c|}{ Rodzaj informacji } & „Polityka” & „Wprost” & „Newsweek Polska” \\
\hline Recenzje & 792 & 725 & 520 \\
\hline Wywiady & 97 & 46 & 26 \\
\hline Reklamy książek & 696 & 573 & 187 \\
\hline Sylwetki/portrety & 113 & 68 & 135 \\
\hline Listy bestsellerów & 12 & 181 & 162 \\
\hline $\begin{array}{l}\text { Ekranizacje, adaptacje, insceni- } \\
\text { zacje }\end{array}$ & 121 & 136 & 92 \\
\hline Konkursy i akcje & 49 & 35 & 169 \\
\hline $\begin{array}{l}\text { Artykuły, poświęcone sprawom } \\
\text { książki }\end{array}$ & 296 & 240 & 23 \\
\hline Listy czytelników $^{\text {Inne }}{ }^{a}$ & 58 & 51 & 174 \\
\hline
\end{tabular}

${ }^{a} \mathrm{~W}$ tej grupie znalazły się informacje, zazwyczaj w postaci notek prasowych, informujących o wydarzeniach lub ludziach pośrednio bądź bezpośrednio związanych z książką.

Źródło: badania własne.

Dane statystyczne wskazują na wyraźną przewagę tygodnika „Polityka” w zamieszczaniu materiałów o książce. $W$ periodyku zrecenzowano największą liczbę książek, przeprowadzono najwięcej wywiadów, zaprezentowano też najwięcej sylwetek osób, związanych ze światem kultury, głównie literatury. Zorganizowano bądź patronowano największej liczbie konkursów i akcji, związanych z książką, a zainteresowanie kwestiami literatury i rynku wydawniczo-księgarskiego znalazło swój wyraz w największej w porównaniu z pozostałymi dwoma tytułami liczbie publikacji. Czytelnicy pisma okazali się najbardziej aktywni, jeśli chodzi o reakcję na czytane teksty, co znalazło swoje odzwierciedlenie w liczbie listów, komentujących wybrane artykuły, dotyczące interesującej nas problematyki. Także wydawcy książek uznali łamy „Polityki” za najbardziej korzystne do promocji swojej oferty. Czytelnicy pisma mieli jednak bardzo rzadko okazję ku temu, by poznać listy najlepiej sprzedających się książek. Podobnie nieczęsto (w porównaniu $\mathrm{z}$ dwoma pozostałymi tytułami) pojawiały się teksty dotyczące ekranizacji czy inscenizacji znanych utworów.

Drugi tygodnik, „Wprost”, w niewielkim stopniu ustępował swojemu rywalowi, przynajmniej w odniesieniu do omówień książek i tekstów komentujących kondycję współczesnego świata literatury. Najczęściej natomiast prezentował swoim czytelnikom listy bestsellerów.

Najsłabiej na tym tle wypadł ostatni z zaprezentowanych periodyków, „Newsweek Polska”. Fakt mniejszej liczby wszystkich analizowanych numerów tego pisma, wynikający z tego, że pojawił się on na rynku praso- 
wym dopiero we wrześniu 2001 r., nie powinien zasadniczo zmieniać stwierdzenia, że pismo to, pomimo deklarowanych założeń („Nie ma dziedziny życia, której nie podejmowałby >Newsweek<: od polityki przez ekonomię i trendy społeczne po szeroki zakres problematyki naukowej i wnikliwe analizy kulturalne"4), wypadło najgorzej w porównaniu z dwoma konkurentami. Potwierdziła to średnia tego typu publikacji, przypadająca na jeden numer, przedstawiona w tabeli 37 .

Tabela 37. Średnia liczby informacji, przypadająca na 1 numer $^{a}$

\begin{tabular}{|l|c|c|c|}
\hline \multicolumn{1}{|c|}{ Rodzaj informacji } & $\begin{array}{c}\text { "Polityka” } \\
\text { (256 numerów) }\end{array}$ & $\begin{array}{c}\text { "Wprost” } \\
\text { (256 numerów) }\end{array}$ & $\begin{array}{c}\text { "Newsweek Polska” } \\
\text { (220 numerów) }\end{array}$ \\
\hline Recenzje & 3,09 & 2,64 & 2,3 \\
\hline Wywiady & 0,37 & 0,17 & 0,11 \\
\hline Reklamy książek & 2,71 & 2,25 & 0,85 \\
\hline Artykuły & 1,8 & 1,55 & 1,8 \\
\hline Inne & 1,71 & 1,29 & 0,92 \\
\hline
\end{tabular}

${ }^{a}$ Pominięto pozostałe kategorie, jako że liczby w tych przypadkach były zbyt małe. Ponadto, bardziej szczegółowo omówiono różnice i podobieństwa w przypadku recenzji, wywiadów, ogłoszeń wydawniczych, reklam oraz publikacji dotyczących książki na łamach badanych tygodników.

Źródło: badania własne.

Jak wynika z obliczeń, średnio na jeden numer „Polityki” przypadały trzy recenzje, w przypadku „Wprost” i „Newsweek Polska” było ich dwie. Widać również różnicę w przygotowaniu omówień od strony formalnej. Jak wykazała analiza, największym profesjonalizmem w tym względzie mógł poszczycić się tygodnik „Polityka”, gdzie w większości przypadków pamiętano o potrzebnych do identyfikacji książki elementach, takich jak jej autor, tytuł, miejsce wydania, nazwa wydawcy i rok, w którym tytuł ukazał się na rynku. W przypadku książki autora obcego, podawano także (przeważnie) nazwisko tłumacza. Natomiast najbardziej niedbały okazał się pod tym względem tygodnik „Wprost”. Jak już pisano wcześniej, często przy recenzjach brakowało podstawowych informacji bibliograficznych, szczególnie przy tych, które drukowano w ramach Menu.

Czy recenzowane książki tworzyły spójny, zbieżny dla trzech tygodników kanon? Czy można wyodrębnić wspólny mianownik proponowanych lektur? Czy do odbiorcy zarówno „Polityki”, czytelnika „Wprost”, jak i adresata „Newsweek Polska” trafiały podobne książki? Czy ewentualne preferencje były takie same choćby dla dwóch z trzech omawianych periodyków? Którzy autorzy okazali się wspólni zarówno dla „Polityki”, „Wprost”

${ }^{4}$ www.newsweek.pl, 10 października 2011. 
i „Newsweeka”? Wśród tych, których książki recenzowano na łamach trzech tygodników, znalazło się 59 nazwisk (zob. Aneks 28. Wspólni dla tygodników „Polityka”, „Wprost”, „Newsweek Polska” autorzy recenzowanych książek w latach 2001-2005), m.in. byli to: Janusz Anderman, Anne Applebaum, Paul Auster, Dan Brown, Stefan Chwin, Harlan Coben, John M. Coetzee, Michael Cunningham, Norman Davies, Umberto Eco, Helen Fielding, Janusz Głowacki, Manuela Gretkowska, John Grisham, Katarzyna Grochola, Henryk Grynberg, Nick Hornby, Michel Houellebecq, Bohumil Hrabal, John Irving, Jan Paweł II, Imre Kertész, Stephen King, Marek Krajewski, Hanna Krall, Wojciech Kuczok, Milan Kundera, Stanisław Lem, Mario Vargas Llosa, Gabriel G. Márquez, Dorota Masłowska, Czesław Miłosz, Tomasz Piątek, Wiktor Pielewin, Joanne K. Rowling, Janusz L. Wiśniewski. W większości przypadków były to recenzje jednej tylko książki danego autora.

Wyraźną grupę wśród wymienionych nazwisk stanowią autorzy książek z list bestsellerów, twórcy literatury popularnej, chociaż nie brak i tych, których utwory stały się znane z innych powodów, jak choćby książki Anne Applebaum, Henryka Grynberga i Jana Pawła II. Wśród pisarzy znajdują się również laureaci nagród literackich, a także ci, którzy zostali uhonorowani w latach wcześniejszych (jak choćby nobliści: Cz. Miłosz, G. G. Márquez czy laureaci rodzimej Nagrody Nike: W. Kuczok). Wydaje się zatem, że w tym przypadku recenzenci każdego z periodyków kierowali się przede wszystkim kryterium popularności książek lub autorów.

Interesujące wydaje się ukazanie wspólnej płaszczyzny autorów recenzowanych książek na łamach tylko dwóch tygodników: dla „Polityki” i „Newsweek Polska” była to grupa 61 twórców, dla „Polityki” i „Wprost” 57 autorów, zaś dla „Wprost” i „Newsweek Polska” tylko 23.

Należy jednak zaznaczyć, że poza wspólnym dla trzech (lub tylko dwóch) periodyków zestawieniem nazwisk pisarzy daje się wyodrębnić inna jeszcze grupa recenzowanych książek, charakterystyczna dla każdego z pism, dotycząca aktualności omawianych książek. Recenzenci „Polityki” częściej niż ich koledzy z konkurencyjnych redakcji sięgali po tytuły wydane dawniej, z kolei odbiorcy „Newsweek Polska” mieli okazję nierzadko poznawać omówienia książek, które dopiero miały ukazać się na rynku. Natomiast na łamach „Wprost” gościły przede wszystkim prezentacje książek-nowości niedawno wydanych.

Na podstawie porównania dotyczącego wywiadów, przeprowadzanych na łamach trzech pism, można stwierdzić, że miały one podobną formę, nie wyróżniając się przy tym niczym szczególnym. W każdym z przypadków tekst wzbogacony był przeważnie zdjęciem rozmówcy i krótką notką biograficzną na jego temat (chociaż należy podkreślić, że tygodnik „Newsweek Polska" wydaje się w tym względzie prezentować najskromniej). Żaden z pisarzy nie był gościem wszystkich omawianych pism; tylko dwóch 
było bohaterami dwóch tygodników: z Cz. Miłoszem pojawił się wywiad na łamach „Polityki” i „Wprost”, zaś z N. Daviesem przeprowadzono rozmowę dla „Wprost” $i$ „Newsweek Polska”.

Kolejną kategorię informacji związanych z książką, którym warto bliżej się przyjrzeć, stanowią ogłoszenia wydawnicze. Jak już wcześniej zaznaczono, ich liczba była największa w przypadku tygodnika „Polityka” (696 reklam), a najmniejsza, jeśli chodzi o łamy „Newsweek Polska” (187 reklam) - różnica pomiędzy obydwoma tytułami jest niemal czterokrotna. W tym przypadku warto przyjrzeć się wydawcom, decydującym, który z trzech periodyków będzie najlepszy dla promocji ich oferty. W tabeli 38 zaprezentowano liczbę edytorów, którzy skorzystali $\mathrm{z}$ tej formy promocji w przypadku każdego z tygodników.

Tabela 38. Wydawcy, którzy zamieścili reklamy na łamach

„Polityki”, „Wprost” oraz „Newsweek Polska”

\begin{tabular}{|l|c|}
\hline \multicolumn{1}{|c|}{ Tytuł czasopisma } & Liczba wydawców \\
\hline „Polityka" & 57 \\
\hline „Wprost" & 75 \\
\hline „Newsweek Polska” & 14 \\
\hline
\end{tabular}

Źródło: badania własne.

Pierwsze spostrzeżenie dotyczy związku pomiędzy liczbą wydawców a liczbą zamieszczonych w każdym periodyku inseratów. „Wprost”, z łamów którego skorzystało najwięcej edytorów, znalazło się na drugim miejscu, jeśli chodzi o liczbę ogłoszeń wydawniczych. Uderzająca jest również dysproporcja pomiędzy tymi dwoma pierwszymi tygodnikami a trzecim z nich.

W analizie wykazano, że zaledwie pięciu edytorów skorzystało z gościny każdego z trzech pism. Były to wydawnictwa: Pascal, Świat Książki, Universitas, Wydawnictwo Naukowe PWN oraz Wydawnictwo W.A.B. Zatem to propozycja oficyn specjalizujących się w charakterystycznej ofercie (przewodników turystycznych, literatury naukowej i znanej z oferty encyklopedii i słowników) pojawiała się zazwyczaj na łamach trzech omawianych tytułów. Wyjątkiem w tej grupie jest Świat Książki i Wydawnictwo W.A.B., dwóch popularnych, prężnie działających w tym czasie edytorów (czyli mogących sobie pozwolić na inwestycję $w$ reklamę prasową), wydających w znacznej mierze literaturę popularną.

Jak natomiast wyglądał obraz współczesnej literatury, kreowany przez zaprezentowane tygodniki? Czy był on jednolity?

Na łamach każdego z pism ubolewano nad niskim poziomem czytelnictwa książek w Polsce. Ogólny ton publikacji był pesymistyczny, dominowały 
teksty krytykujące rodzimą literaturę współczesną. Wydawana obecnie proza polska jest monotonna, pozbawiona porywających fabuł i ciekawych postaci, przeważnie melancholijna bądź pesymistyczna („Wprost”). Prezentuje sobą niski poziom, nierzadko roi się w niej od błędów merytorycznych („Polityka”). Brak jest dziś „kaskaderów literatury” na miarę Marka Hłaski czy Edwarda Stachury („Polityka”, „Newsweek Polska”); triumfy święcą gwiazdy mediów, które przebojem zdobywają serca widzów. Winę za taki stan rzeczy ponoszą zarówno sami twórcy (którzy nie potrafią bądź nie chcą już pełnić roli autorytetów: „Polityka”, „Wprost”, „Newsweek Polska”), jak i krytycy („Wprost”: to oni kreują „dzieła skończonych grafomanów” i to im bardziej zależy na dobrych kontaktach z pisarzami niż na rzetelnej ocenie książki).

Pisarzy nierzadko zniechęcają dodatkowo problemy finansowe („Polityka”, „Newsweek Polska”), a także małe szanse na dotarcie do szerszego odbiorcy, który żyjąc w zmedializowanym świecie czyta, ogląda i słucha przede wszystkim to, co proponują mu środki masowego przekazu. A te zazwyczaj promują przeciętne talenty, tworzą warunki do „tworzenia miernoty” („Wprost”). Sytuacja nie poprawia się, gdyż coraz częściej kultura, w tym literatura, traktowane są jak dobra konsumpcyjne, którymi „handluje się w wielopakach” („Wprost”, „Newsweek Polska”), choć, być może, nie jest to najgorszy pomysł, bo dzięki temu książka znajduje więcej nabywców („Wprost”, „Newsweek Polska”).

Inne powody złej kondycji polskiej literatury to także i to, zdaniem omawianych pism opinii, że w naszym kraju przeznacza się znikome fundusze na upowszechnianie książek („Polityka”). Nie bez znaczenia są też problemy z dystrybucją oraz wydawcami („Polityka”, „Wprost”, „Newsweek Polska”). Ci jednak, chociaż osiągają największe zyski w „łańcuchu książkowo-pokarmowym", również borykają się z kłopotami, wśród których jednym z najważniejszych jest piractwo książkowe („Polityka”, „Newsweek Polska”). Jednak edytorzy znaleźli już sposób na walkę z nim: to cyfrowe drukowanie książek („Newsweek Polska”). Pewnym ratunkiem dla książki wydają się być także audiobooki, coraz bardziej popularne nie tylko w Polsce, ale i na świecie („Newsweek Polska”).

Obok narzekań na kondycję współczesnej literatury nie brakowało jednak tekstów optymistycznych. Wskazywano na te jej typy, które wbrew „recesji” radzą sobie całkiem dobrze na rynku czytelniczym, bo, jak się okazuje, Polacy lubią rozrywkę („Wprost”). Należy do niej popularna literatura kobieca, której funkcje terapeutyczne zgodnie podkreślały trzy pisma. Tak samo zgodnie prezentowano literaturę dla dzieci i młodzieży, w każdym z przypadków najczęściej pisząc o kolejnych tomach Harry Pottera - informacje o sukcesach kolejnych przygód małego czarodzieja zdominowały tę grupę tekstów. Nierzadko pisano także o komiksie, choć tu 
prym wiódł „Newsweek Polska”. Z kolei na łamach „Polityki” najczęściej (w porównaniu $\mathrm{z}$ dwoma rywalami) omawiano poezję.

Podsumowując, każdy z tygodników (w różnym stopniu) realizował przypisane mu z definicji funkcje. Poprzez wykorzystanie rozmaitych form prezentował wybrane przez siebie książki, przy czym już sam wybór tytułów kształtował w pewnym stopniu opinie czytelników, nawet jeśli wzmianka na temat danej lektury miała charakter czysto informacyjny. Najwyraźniejsza w tym względzie była (potwierdzona przez W. Kota) polityka redakcji „Newsweek Polska”, preferującej pisarzy obcych.

Wnioski te nabierają szczególnego znaczenia, zwłaszcza w kontekście wspomnianej wcześniej europeizacji czytelnictwa, o której pisał Ryszard Filas 5 .

Jednocześnie na podstawie zgromadzonego materiału można stwierdzić, że w każdym z przypadków kultura, w tym literatura, zajmowała niebagatelne miejsce $\mathrm{w}$ zawartości pism, przynajmniej pod względem ilościowym prezentując się na poziomie dostatecznym („Newsweek Polska”), dobrym („Wprost”), a nawet bardzo dobrym („Polityka”).

5 R. Filas, Dziesięć lat przemian mediów masowych w Polsce (1989-1999), „Zeszyty Prasoznawcze" 1999, nr 1-2, s. 55. 


\section{Rozdział 3}

\section{PRASA KOBIECA}

\subsection{Prasa kobieca. Krótka charakterystyka}

\section{Zgodnie z definicją Encyklopedii wiedzy o prasie, prasa kobieca to}

grupa czasopism, których profil kształtowany jest pod kątem potrzeb czytelniczych kobiet oraz ich aktualnego położenia społecznego. Oprócz więc artykułów publicystycznych, reportaży, felietonów, utworów literackich, a w niektórych czasopismach także ogólnoinformacyjnych materiałów prasowych, na ich treść składają się najczęściej działy i rubryki poświęcone sprawom mody, gospodarstwa domowego, wychowania dzieci, problematyce rodziny itp. Istotną cechą p.k. jest ustawiczna dążność do podnoszenia wiedzy (zwłaszcza praktycznej) i poziomu kulturalnego kobiet oraz stałego wzrostu ich udziału i pozycji w życiu społecznym i zawodowym. [...] Pod względem treści są to najczęściej wydawnictwa wielotematyczne, zbliżone do formuły magazynu¹.

Inną definicję podaje Zofia Sokół: czasopisma adresowane do płci pięknej to według niej

zespół wydawnictw periodycznych przeznaczonych dla kobiet, co zostało zaznaczone w tytule, podtytule, programie, treści, sposobie ujęcia tematów, strukturze oraz formie językowej. Prasa taka jest redagowana pod kątem zainteresowań kobiet w zależności od ich wieku, wykształcenia, zawodu, pochodzenia społecznego, środowiska życia i pracy, roli i miejsca w rodzinie i społeczeństwie².

Ten typ prasy był nierzadko przedmiotem publikacji. Jego długa historia $^{3}$ i specyfika interesowały wielu badaczy, jak na przykład Zuzannę

${ }^{1}$ Encyklopedia wiedzy o prasie, red. J. Maślanka, Zakład Narodowy im. Ossolińskich, Wrocław 1976, s. 172-173.

2 Z. Sokół, Prasa kobieca w Polsce w latach 1945-1995, Wydawnictwo Wyższej Szkoły Pedagogicznej, Rzeszów 1998, s. 8.

${ }^{3}$ Korzenie polskiej prasy kobiecej sięgają 1818 r., kiedy ukazały się dwa tytuły, pretendujące do miana pierwszego polskiego periodyku kobiecego. Według J. Maślanki był nim „Tygodnik Polski i Zagraniczny” (w 1820 r. zmienił on tytuł na „Wanda. Tygodnik Polski Płci Pięknej i Literaturze Poświęcony”), natomiast Z. Sokół za taki uważa „Miesięcznik Warszawski płci pięknej poświęcony”, zob. Z. Sokół, Prasa kobieca..., s. 29-30. 
Dąbrowską, Jerzego Franke, Zofię Lewartowską, Zofię Sokół, Władysława Tyrańskiego oraz Zofię Zaleską. W dziejach czasopiśmiennictwa kobiecego wyróżnić można kilka charakterystycznych etapów4. W każdym z tych okresów płeć słaba była inaczej postrzegana, przy czym prasa do niej adresowana propagowała adekwatne do czasów, w których się ukazywała, wzory osobowe kobiety, jej roli i miejsca w społeczeństwie, promując także określone modele małżeństwa i rodziny. Pomijając niezwykle interesujące, ale zbyt odległe od głównego wywodu pracy zagadnienia związane ze wspomnianymi przeobrażeniami ${ }^{5}$, należy jednak zaznaczyć, że zupełnie nowy etap historii rozpoczął się dla prasy kobiecej po zakończeniu drugiej wojny światowej. To wtedy nastąpiła wyraźna dynamika rozwoju tego typu czasopiśmiennictwa, aczkolwiek był to rozwój jednostronny, ograniczony panującym wtedy ustrojem, zgodnie z którym prasa podlegała określonym zasadom i celom polityki PZPR w dziedzinie komunikowania. Zmiany w prasie kobiecej, które wtedy nastąpiły, były efektem diametralnie nowej sytuacji, w jakiej znalazły się ówczesne kobiety; to do owych "nowych" czytelniczek kierowane były powstające wówczas pisma, m.in.: „Kobieta i Życie”, „Przyjaciółka”, „Ty i Ja”, „Uroda” czy przedstawione w prezentowanej książce „Zwierciadło”.

Tylko nieliczne z nich przetrwały transformację ustrojową w Polsce, która dla prasy kobiecej oznaczała bardzo duże zmiany, w znacznej mierze opisane we Wstępie i częściowo w pkt 1.2 Rynek prasy. Głównie tendencje rozwojowe. Część tytułów nie wytrzymała konkurencji i przestała się ukazywać, niektóre przeszły spektakularne zmiany zarówno pod względem graficznym, jak i w odniesieniu do zawartości oraz struktury organizacyjnowłasnościowej (niekiedy zakładając dziennikarskie spółdzielnie wydawnicze, a nierzadko szukając pomocy w postaci obcego kapitału). Dzięki temu gotowe były zmierzyć się z nowymi periodykami, często wydawanymi przez doświadczone, zagraniczne koncerny (m.in. Axel Springer, Heinrich Bauer, Burda, G+J). Przejmowanie prasy kobiecej przez kapitał zagraniczny w latach 1990-1995, ekspansja „kalek” zachodnich pism kobiecych stano-

${ }^{4}$ Dzieje prasy kobiecej obejmują następujące etapy: 1818-1860/1863, 1860/18631914, 1914-1918, dwudziestolecie międzywojenne, okres II wojny światowej, 1945-1949, 1950-1956, 1957-1970, 1971-1981, 1982-1989, 1989-do lat obejmujących zasięg chronologiczny pracy.

5 Pisali o nich m.in. J. Franke, Polska prasa kobieca w latach 1820-1918. W kręgu ofiary i poświęcenia, Wydawnictwo SBP, Warszawa 1999; Z. Sokół, Prasa kobieca..., a w odniesieniu do prasy kobiecej początków XXI w. m.in.: E. Sawa-Czajka, Wizerunki kobiet w prasie polskiej (po 1989 r.), [w:] Transformacje mediów (1989-1995): materiały pomocnicze do najnowszej historii dziennikarstwa, t. 26, red. A. Słomkowska, Warszawa 2004; B. Trzop, Typy kultury popularnej na łamach czasopism kobiecych, Oficyna Wydawnicza Uniwersytetu Zielonogórskiego, Zielona Góra 2005; D. Zaworska-Nikoniuk, Wzory kobiecości i męskości w polskiej prasie dla kobiet XXI wieku, Wydawnictwo Adam Marszałek, Toruń 2008. 
wiły jedne z najciekawszych, budzących nierzadko kontrowersje, zjawisk na rynku prasowym w Polsce $\mathrm{w}$ tym okresie i wpłynęły zasadniczo na gwałtowny rozwój czasopism adresowanych do pań.

Z drugiej strony, sytuacja polityczna, społeczna, ekonomiczna i kulturowa postawiły kobietę po raz kolejny w nowej sytuacji, a zaistniałe wtedy okoliczności wpłynęły na swoisty podział wśród kobiecego audytorium czytelniczego i zróżnicowanie typologii czasopism adresowanych do płci pięknej. Jak zauważyła Z. Sokół:

rozpoczął się proces różnicowania majątkowego i zarobkowego. Najmocniej odczuły to kobiety, które w pierwszej kolejności traciły pracę tworząc rzeszę bezrobotnych. Powstała grupa kobiet mających na utrzymaniu bezrobotnego męża; jednocześnie wyłoniła się inna, kobiet aktywnych, robiących karierę zawodową i finansową "bizneswomen”, „kobiet sukcesu”, „dam biznesu” i „menedżerek" 6 .

Kobiety, mimowolnie, zaczęły dzielić się na wyraźnie różniące się między sobą grupy: „bierne” (priorytetem w życiu była dla nich rodzina i wychowanie dzieci) oraz „dynamiczne” (energicznie dążące do zrobienia kariery, zdobycia niezależności finansowej i władzy). Istniała również trzecia, najliczniejsza grupa „kobiet pracujących”, które starały się połączyć obowiązki zawodowe z rodzinnymi, choć jednocześnie praca nie była dla nich pierwszoplanową wartością w życiu. Traktowały ją raczej jako konieczność, zapewniającą byt finansowy. Dla każdej z tych kategorii kobiet wydawane były periodyki, dostosowane do ich mentalności, zainteresowań i preferencji. Konsekwencją był wspomniany swoisty podział na trzy rodzaje pism kobiecych, które odwoływały się do opisanych powyżej trzech różnych typów odbiorczyń7:

1. Czasopisma popularne, „dla nas, ale nie o nas"8, przenoszące kobiety w krainę marzeń: wypełniały tzw. dolną półkę segmentu prasy kobiecej. Składały się na nie przeważnie „kalki” pism zachodnich. Były to tanie, ale bogato ilustrowane pisma, przeznaczone w większym stopniu do oglądania niż do czytania. Ich adresatkami miały być kobiety, które nie pracując zawodowo, realizowały się jako gospodynie domowe. Periodyki te utwierdzały swoje czytelniczki w wybranej przez nie (bądź narzuconej) drodze życiowej: praca zawodowa ukazana tu była jako zło konieczne, podkreślano jednocześnie, że prawdziwym powołaniem kobiety jest być dobrą żoną, matką, gospodynią i strażniczką domowego ogniska. Do tej grupy periody-

\footnotetext{
6 Z. Sokół, Prasa kobieca..., s. 355.

7 Typologia za: ibidem, s. 355-362.

${ }^{8}$ Określenie P. Sarzyńskiego. Zob. P. Sarzyński, Gazetowa Polka, „Polityka” 1992,
} nr 51, s. 8. 
ków zaliczyć można na przykład „Kobietę i Mężczyznę”, „Naj”, „Tinęe, „Z życia wzięte” czy „Życie na Gorąco”.

2. Pisma również popularne, jednak już nie tylko „dla nas”, ale i „o nas”, czyli periodyki dla „pań domu”: tytuły z tzw. półki środkowej. Przeznaczone one były dla kobiet pracujących, które nie mają większych ambicji zawodowych, a w kupowanych przez siebie czasopismach poszukują przede wszystkim porad, dotyczących rozwiązywania codziennych życiowych problemów, wskazówek, jak żyć niekoniecznie lepiej, ale chociaż wygodniej, jak połączyć pracę zawodową z życiem osobistym. Periodyki tego typu radziły, jak wypełniając codzienne obowiązki dobrej, zaradnej i praktycznej gospodyni, kobieta ma pozostać zadbana i zawsze uśmiechnięta, jak powinna zorganizować swój dzień, by mieć czas dla najbliższych. Wśród tytułów w tej grupie wymienić można m.in. „Chwilę dla Ciebie”, „Claudię”, „Przyjaciółkę”, „Świat Kobiety”.

3. Żurnale: ekskluzywne magazyny, z tzw. górnej półki, wydawane na dobrym jakościowo papierze, drogie (cena od 7 zł). Adresowane były do kobiet aktywnych (wspomnianych „bizneswomen”, „dam biznesu”, „kobiet sukcesu"), które niezależnie od wieku i okoliczności są zadbane i eleganckie. To kobiety, które wiedzą, jak należy pielęgnować swoje zdrowie i urodę, zwracają dużą uwagę na to, co jest aktualnie modne. Nie boją się stanąć do (wyrównanej) walki z mężczyzną, co więcej, nierzadko z nim wygrywają. Praca zawodowa dla adresatek tych pism to realizacja ambicji i jednocześnie sposób na to, aby zapewnić sobie niezależność finansową, która pozwoli na zakupy w firmowych sklepach, wakacyjny wyjazd za granicę czy systematyczne wizyty u dobrej kosmetyczki i fryzjera. Zazwyczaj kobietom tym udaje się łączyć życie zawodowe z prywatnym, co daje im pełnię szczęścia. Prasę traktują jako rodzaj rozrywki, której oddają się w czasie wolnym, poszukując w niej porad związanych z pielęgnacją urody, zdrowym trybem życia, modą, stylem bycia. Wzór adresatki tego typu periodyków określono na łamach „Zwierciadła” następująco: „Jest mądra, zaradna, otwarta. Nie załamują ją trudności, nie boi się podejmować decyzji i ryzyka. Jest ujmująca, zadbana, elegancka" ${ }^{\prime}$. Do czasopism tego rodzaju zalicza są m.in. „Elle”, „Kobietę i Życie”, „Pani”, „Twój Styl” oraz przywołane już „Zwierciadło”.

Wśród tytułów znajdujących się w ostatniej z wymienionych kategorii pojawiły się trzy magazyny, będące przedmiotem rozważań w następnym rozdziale. Jedną $\mathrm{z}$ ich cech powinna być, zgodnie $\mathrm{z}$ podaną wcześniej definicją, m.in. „ustawiczna dążność do podnoszenia [...] poziomu kulturalnego kobiet", mając zaś na uwadze cechy tej konkretnie kategorii adresatek (liderki w każdej dziedzinie życia, a więc także związanej z kulturą, w tym

${ }^{9}$ Za: Z. Sokół, Prasa kobieca..., s. 357. 
literaturą), zadanie to powinno stanowić szczególnie istotny punkt progra$\mathrm{mu}$, realizowanego przez redakcję.

Polki, jako „bastion czytelnictwa czasopism w Polsce”10, były jednocześnie ważną zbiorowością konsumentek, o którą zabiegać powinni, jak się zdaje, wydawcy, specjalizujący się w literaturze kobiecej. Jednocześnie na łamach ekskluzywnych magazynów, owych „żurnali”, nie powinno zabraknąc miejsca dla informacji o książce czy zróżnicowanych form jej promocji. Czy tak faktycznie było? W jakim stopniu redakcje „Zwierciadła”, „Twojego Stylu” i „Elle” kształtowały gust literacki swoich czytelniczek? Czy w program każdego z omówionych periodyków wpisana była na stałe kultura, a przede wszystkim, mieszczące się w niej „sprawy książki”?

10 Określenie Ryszarda Filasa. Zob. R. Filas, Dziesięć lat przemian mediów masowych w Polsce (1989-1999). Propozycja periodyzacji, „Zeszyty Prasoznawcze” 1999, nr 1-2, s. 51. 


\section{2. „Zwierciadło” w moim życiu ${ }^{1}$}

\subsubsection{Spójrz w siebie $^{2}$ : historia periodyku}

Staramy się pokazać rzeczywistość z niebanalnej perspektywy, chcemy pobudzić do myślenia, a jednocześnie dać Wam chwilę oddechu i rozrywki. Pragniemy być przyjaznym przystankiem w natłoku spraw ważnych i mniej ważnych. Wsparciem w odkrywaniu możliwości, poznawaniu emocji i rozumieniu relacji z innymi. Dużo uwagi poświęcamy aktualnościom kulturalnym, sztuce, bacznie obserwujemy styl, śledzimy trendy³.

Pierwszym z omawianych tytułów adresowanych do „kobiet sukcesu” jest „Zwierciadło”, jedno z najstarszych periodyków kobiecych, ukazujących się w Polsce. Pierwszy numer pisma, z podtytułem „Tygodnik Ilustrowany”, pojawił się 19 maja 1957 r., a zatem niecałe trzy miesiące po ukazaniu się przedstawionej wcześniej „Polityki”. Jak pisze Zofia Sokół,

Potrzebę nowego pisma społeczno-kulturalnego, obok wysokonakładowych pism, takich jak „Przyjaciółka” i „Kobieta i Życie”, motywowano potrzebą odrębnego pisma dla kobiet z wyższym wykształceniem. [...] Wydawania nowego pisma kobiecego domagały się inteligenckie środowiska kobiece. Wspomagał je tworzący się ruch inteligencki ${ }^{4}$.

\section{Wydawcą nowego tytułu był Zarząd Główny Ligi Kobiet5, który}

chciał mieć sojusznika w rozwiązywaniu trudnych problemów społecznych, a zarazem pismo atrakcyjne. Zdecydowano, że powinien być to tygodnik społeczno-kulturalny o charakterze

1 Tytuł jednego z konkursów, ogłoszonego prze omawiany periodyk. Zob. A. Nasiłowska, Zwierciadło w moim życiu, „Zwierciadło” 2002, nr 5, s. 62.

2 Hasło, reklamujące pismo.

${ }^{3}$ K. Montgomery, Dziękujemy!, „Zwierciadło” 2012, nr 5, s. 6.

${ }^{4}$ Z. Sokół, Prasa kobieca w Polsce w latach 1945-1995, Wydawnictwo Wyższej Szkoły Pedagogicznej, Rzeszów 1998, s. 145.

${ }^{5}$ Liga Kobiet - organizacja sięgająca swymi korzeniami 1913 r., kiedy I. Moszczeńska powołała w Królestwie Ligę Kobiet Pogotowia Wojennego. Organizacja o podobnym charakterze funkcjonowała także w Krakowie jako Liga Kobiet NKN Galicji i Śląska, kierowana przez Z. Oraczewską. Obie organizacje stawiały sobie za cel tworzenie zaplecza frontowego dla Legionów Polskich J. Piłsudskiego. W 1917 r. nastąpiło połączenie obu Lig, utworzono z nich Ligę Kobiet Polskich. W 1928 r. nastąpił rozłam, z którego wyłonił się Polski Związek Pracy Obywatelskiej i Liga Kobiet - wchodząca w skład Rady Narodowej Polek i w skład Unii Polskich Związków Obrończyń Ojczyzny. W czasie II wojny światowej członkinie Ligi Kobiet m.in. organizowały kolportaż tajnej prasy. W lutym 1945 r. Liga ujawniła się, ale nie otrzymała pozwolenia na prowadzenie jawnej działalności. Na początku 1950 r. powołano nową Ligę Kobiet, której wyznaczono m.in. rolę „pasa transmisyjnego uchwał i zaleceń PZPR 
magazynowym, możliwie bogato ilustrowany, o wyraźnym profilu społecznym i dużym ciężarze gatunkowym ${ }^{6}$.

Pomysłodawczynią tytułu nowego periodyku była Zofia Bystrzycka, która uważała, że jest on odpowiedni przede wszystkim dlatego, że będzie odzwierciedlać życie ${ }^{7}$. W ten sposób

w pięciopokojowym lokalu przy Elektoralnej [adres siedziby redakcji w Warszawie - przyp. M.P.S.] kręciły się chmary młodych, dobrze zapowiadających się i nieco starszych, bardziej znanych: Woroszylski, Osęka, Puchalski, Oberlaender, Flisak, Ewa Zieglar, Krystyna Usarek. [...] tak powstawało „Zwierciadło” pod okiem pierwszej naczelnej Aliny Rebane w atmosferze popaździernikowej odwilży ${ }^{8}$.

Zespół reakcyjny tworzyli ponadto: Marian Bielicki, wspomniana Zofia Bystrzycka, Krystyna Dąbrowska, Janina Janicka (sekretarz redakcji), Eryk Lipiński (kierownik graficzny), Nina Lilejko i Czesława Szymańska.

Pierwszy numer liczył 16 stron, wydano go w formacie 37 x $28 \mathrm{~cm}$, kosztował 2 zł. Brakowało w nim, zwyczajowej w takich sytuacjach, deklaracji odredakcyjnej, wskazania celów i zamierzeń, jakie stawiano przed nowym tytułem. Jednak odpowiedzią na pytanie, które (być może) zadawali sobie pierwsi czytelnicy „Zwierciadła”, była jego zawartość. Reportaż Zofii Posłysz Rodzice przed sq̨dem, tekst o pracy zawodowej kobiet, sylwetka Mai Berezowskiej, opowiadanie Françoise Millet-Joris, dział poświęcony modzie i urodzie (Jak Cię widzq, tak Cię piszq̨), rozrywka oraz zapowiedź krótkiego „kursu smukłej linii” w następnym numerze - były zwiastunami tematów, którym pismo pozostanie wierne przez następne lata. Problematyka społeczno-obyczajowa, tradycyjny reportaż, literatura, tendencje w modzie, porady, ,jak w latach burych tkanin, zerówek i nylonów zachować wdzięk i styl"9, a w późniejszym okresie także teksty poświęcone problemom wychowawczym wpisały się na stałe w ramy periodyku, wskazując jednocześnie jego charakter.

wśród mas kobiecych, domagając się jednocześnie podejmowania działań polityczno-propagandowych, społecznego aktywizowania kobiet". Po 1953 r. sytuacja uległa poprawie, ale wyraźne zmiany w odniesieniu do działalności Ligi Kobiet nastąpiły w 1955 r., kiedy powrócono do tradycji Społeczno-Obywatelskiej Ligi Kobiet z lat 1945-1948. Dwa lata później powołano omawiany periodyk, a LK stała się jego wydawcą. Więcej na temat działalności Ligi - zob. Z. Sokół, Prasa kobieca..., s. 135-142; eadem, Czasopisma organizacji kobiecych w Polsce (w latach 1989-1999), „Kieleckie Studia Bibliologiczne” 2000, nr 5, s. [127]-150.

6 „Zwierciadło” 1967, nr 21, s. [2].

7 Tekst jubileuszowy z okazji 10-lecia periodyku, zob. „Zwierciadło” 1967, nr 21, s. [2].

8 [br. aut.], Jak jubilat z jubilatem ..., „Zwierciadło” 1992, nr 5, s. [21].

${ }_{9}^{9}$ M. Jewiarz-Bartczak, Zwykłe kobiety też chcq być niezwykłe, „Zwierciadło” 2007, nr 8, s. [115]. 
Nowy tytuł spodobał się czytelniczkom, co potwierdzały listy, drukowane na jego łamach. W jednym z nich czytamy: „Miłe >Zwierciadło<. Przeczytałam >od deski do deski< Twój pierwszy numer, który z trudem dostałam podczas spaceru po Warszawie"10.

Od numeru 3 (1957) zniknęła z łamów stopka redakcyjna, co wynikało z faktu, że jeden ze współpracowników, M. Bielicki, nie był dobrze widziany przez ówczesne władze, stąd postanowiono zastosować taki właśnie wybieg, który pozwoliłby mu nadal pracować w redakcji. Starano się nie wchodzić w konflikt z władzą, wysiłki kierując na zdobywanie nowych czytelników. Periodyk stopniowo rozwijał się, dostosowując swój poziom do wymagań zmieniających się czytelniczek. W jego historii można wyodrębnić kilka charakterystycznych etapów, których granice wyznaczają zmiany właścicieli.

Pierwszy, obejmujący lata 1957-1960 to okres, gdy tytuł był organem Ligi Kobiet. W pierwszych latach istnienia pisma, w czasie odwilży popaździernikowej, niewiele było w nim propagandy politycznej, choć sporadycznie pojawiały się odezwy, jak na przykład z okazji 1 Maja, „święta postępu, pokoju, socjalizmu"11. Był to dla periodyku czas poszukiwań: obok zagadnień kulturalnych pojawiała się przeważnie problematyka społecznoobyczajowa. Zarówno forma, jak i treść przystosowana była do czytelnika o wyższych niż przeciętne aspiracjach intelektualnych i szerokich zainteresowaniach. W niemal każdym numerze tygodnika czytelnik odnajdował fragmenty literatury dotąd zakazanej: Erskine`a Caldwella, Alberta Camusa, Williama Faulknera czy Jeana Paula Sartre`a.

Drugi etap to lata 1961-1981, gdy tytuł wydawany był przez RSW „Prasa”, później RSW „Prasa-Książka-Ruch”. W tym czasie dwukrotnie nastąpiły roszady na stanowisku redaktora naczelnego: w 1972 r. został nim Józef Konecki (od 1967 r. zastępca A. Rebane), a w 1974 r. jego miejsce zajęła Krystyna Mojkowska. Tytuł zmienił swój charakter, stając się popularnym magazynem ilustrowanym dla wszystkich, z wyraźnie mniejszymi, niż na początku, ambicjami kulturalnymi. Na jego łamach drukowano artykuły na temat religii, etyki i moralności, nie brakowało także tekstów z zakresu socjologii, historii, a nawet polityki. Nie zapominano jednak o głównym adresacie pisma, stąd pojawiła się prowadzona przez Z. Bystrzycką rubryka Serce $w$ rozterce; „,walczyła [ona - przyp. M.P.S.] o kulturę współżycia, kulturę uczuć i godność kobiecą, która gdzieś się zagubiła w tym równouprawnieniu"12. Do dyspozycji czytelników oddawano także inne działy i rubryki, jak np. Album poezji miłosnej, Kuchnia i porady kulinarne, Plotki, notki, anegdotki. Z okazji jubileuszu dziesięciolecia tytułu

\footnotetext{
10 „Zwierciadło” 1957, nr 3, s. 2.

11 Za: T. Jastrun, Historia w numerach, „Zwierciadło” 2007, nr 5, s. 83.

12 H. Mieroszowa, „Zwierciadło” w moich oczach, „Prasa Polska” 1967, nr 7, s. 21-23.
} 
pojawiły się gratulacje i życzenia, m.in. od prezesa RSW „Prasa”, Tadeusza Galińskiego, który stwierdzał:

Poruszając żywotne problemy życia współczesnej kobiety i rodziny, zyskał sobie Wasz tygodnik w ciągu niewielu lat sympatię i uznanie szerokich rzesz czytelników, a bogata szata graficzna i interesująca treść stałych rubryk postawiły go w rzędzie jednego z bardziej poczytnych polskich magazynów kobiecych ${ }^{13}$.

Rok 1968 podobnie jak dla całej Polski, tak i dla „Zwierciadła” zapoczątkował trudne czasy. Redakcja podporządkowała się obowiązującej propagandzie. Po wydarzeniach marcowych z łamów tygodnika zniknęły znane nazwiska, stał się on szary i monotonny, pomimo starań dziennikarzy (m.in. kolorowych okładek, otwierających niemal każde wydanie).

Świętując piętnastolecie, zasięgnięto opinii czytelników na temat zawartości i poziomu pisma. Wśród jego sympatyków znaleźli się m.in. Hanka Bielicka, Irena Santor, Ewa Śnieżanka oraz Edyta Wojtczak. Pomimo pochlebnych ocen, nadal nie był to czas korzystny dla „Zwierciadła”. Nierzadko na jego łamach gościły odezwy i apele Ligi Kobiet oraz podobnych jej organizacji. Niejednokrotnie pojawiały się deklaracje, jak choćby w 1972 r.:

Życzymy sobie, by rok ten, pierwszy rok realizacji ambitnych zadań, określonych przez VI Zjazd partii, dzięki solidarnym naszym wysiłkom, rzetelnej pracy, dzięki naszemu zaangażowaniu i ofiarności - przyniósł krajowi, całemu społeczeństwu, wszystkim pełnię satysfakcji oraz widoczne postępy na drodze ku głównemu celowi socjalistycznego budownictwa - dobru człowieka pracy, wspólnemu dobru14.

Donoszono o wizytach przedstawicieli bratniego narodu15, relacjonowano przebieg spotkań sekretarzy partii, pisano o sukcesach władzy, kreślono sylwetki działaczek Ligi Kobiet i działaczy ORMO. Jednocześnie w ciągu tych i następnych lat zmieniała się szata graficzna pisma, tonację czarno-białą stopniowo zastępowano rosnącą liczbą kolorowych fotografii. Zmianie ulegał format, układ graficzny, zwiększono również objętość pojedynczego wydania do 32 stron.

W 1980 r. redakcja relacjonowała przebieg solidarnościowych strajków przy jednoczesnym drukowaniu tekstów propagandowych (np. Krystyna Kaszuba przeprowadzała wywiady z działaczami partyjnymi). Po wprowadzeniu stanu wojennego periodyk przestał się ukazywać, podzielając tym samym los innych pism. „Zwierciadło” reaktywowano w kwietniu 1982 r. ${ }^{16}$ ponownie jako organ Ligi Kobiet Polskich. Redakcja podkreślała, że

13 Tekst jubileuszowy z okazji 10-lecia periodyku, zob. „Zwierciadło” 1967, nr 21, s. [2].

${ }^{14}$ Krajowa Rada Kobiet Polskich przy Ogólnopolskim Komitecie Frontu Jedności Narodu, „Zwierciadło” 1972, nr 1, s. 2.

15 Zob. np. „Zwierciadło” 1977, nr 1, s. 2.

16 Przez kilka miesięcy w 1981 r. wydawane było przez Krajowe Wydawnictwo Czasopism. 
Największym bogactwem naszego kraju są ludzie, ich wiedza i mądrość. [...] Do budowy wspólnej, lepszej przyszłości musimy przystąpić wszyscy i to już teraz. „Nie ma Polaków lepszych i gorszych. Są tylko ci, którzy dla Ojczyzny pracują - i ci, którzy przeszkadzają” powiedział w Sejmie przewodniczący Wojskowej Rady Ocalenia Narodowego, gen. armii Wojciech Jaruzelski. [...] Polsce potrzebne są mądre i aktywne kobiety, na nie liczy partia przy odradzaniu swych szeregów, w tworzeniu wszelkich form samorządności, w odbudowie ruchu związkowego, w tworzeniu Obywatelskich Komitetów Odrodzenia Narodowego. Nasze pismo będzie Wam w tym pomagać. Pragniemy bowiem nadal kontynuować politykę porozumienia wszystkich patriotycznych sił stojących na gruncie ustroju socjalistycznego, politykę stałego dialogu władzy ze społeczeństwem ${ }^{17}$.

Obok deklaracji czytelnicy odnaleźli na łamach pisma dawne rubryki, także ulubione Serce $w$ rozterce, którym odtąd kierowała Zuzanna Celmer. Nowością stał się element dotąd nie spotykany w prasie tego typu: krzyżówka z premią. Jednocześnie zwiększono objętość, zmieniono format, a także wprowadzono kolor na środkowych kolumnach periodyku. Jak na ówczesne warunki, szata graficzna była atrakcyjna i wyróżniała tytuł na tle innych pism kobiecych tamtego okresu.

W 1991 r. tytuł został przejęty przez PZH „Uniwersal” S.A., firmowane przez spółkę „Uniproject”. W styczniu tegoż roku „Zwierciadło” zmieniło częstotliwość: z dotychczasowego tygodnika stało się miesięcznikiem. Jak pisze Tomasz Jastrun, pomimo że „W Polsce panuje już wolność, pismo jednak jest ciągle ubogie, chociaż ukazuje się więcej porad i psychologii"18. W 1992 r. w stopce redakcyjnej jako wydawca pojawił się „Uniproject” spółka z o.o. Periodykiem, liczącym średnio 80 stron, wydawanym w formacie 29 x $20 \mathrm{~cm}$ kierowała Danuta Wójcik. Magazyn zaczął stopniowo dostosowywać się do nowych warunków. Przy zachowaniu tradycyjnego zaangażowania w sprawy społeczne, coraz wyraźniejsze stawało się zainteresowanie psychologią i medycyną alternatywną. Periodyk posiadał już w tym czasie swoich stałych korespondentów zagranicznych, m.in. Ivo Jacobi (relacje ze Szwecji), Martę Klubowicz (doniesienia z Austrii), Zofię Łętkowską (korespondencje z USA), Magdalenę Rostron (informacje z Wielkiej Brytanii). Nastąpiła zmiana na stanowisku redaktor naczelnej, została nią Beata Dzięgielewska.

W 1998 r. miesięcznik stał się własnością holenderskiej firmy Imper Poland, zaś od numeru 2 (2002) właścicielem tytułu została Magdalena Jankiewicz, do której należało Wydawnictwo Zwierciadło Sp. z o.o. W 2003 r. magazynem zaczęła kierować Lucyna Olszewska.

Przez niemal 50 lat jego istnienia współpracowało z nim wielu znanych dziennikarzy, felietonistów i literatów. Wśród nich, poza wcześniej wymienionymi, pojawili się m.in. Olga Aszkenazy, Henryk Bereza, Andrzej Braun,

17 Zespół „Zwierciadła”, Drogie Czytelniczki!, „Zwierciadło” 1982, nr 1, s. 3.

18 T. Jastrun, Historia w numerach, „Zwierciadło” 2007, nr 5, s. 85. 
Michał Choromański, Józef Hen, Marek Hłasko, Jacek Klabiński, Leszek Kołakowski, Zbigniew Lew-Starowicz, Leszek Prorok, Arnold Słucki i Maciej Wierzyński. W zespole redakcyjnym pojawili się także m.in. Grzegorz Dydyński, Stefan Dźbikowski oraz Andrzej Gawłowski.

W latach 2001-2005 widoczne były częste roszady zarówno w zespole redakcyjnym, jak i wśród współpracowników pisma. Znaleźli się wśród nich m.in. Barbara Adamczewska, Renata Arendt-Dziurdzikowska, Lidia Butowska, Grażyna Dworak, Alina Gutek, Tomasz Jastrun, Małgorzata Kłeczek, Magdalena Oczachowska, Jolanta Otrębska i Joanna Szczepkowska. Do pozostałych współpracowników należeli m.in. Marek Berdadyn, Maria Bojarska, Magdalena Boratyńska-Komar, Tatiana Cichocka, Artur Cieślar, Paulo Coelho ${ }^{19}$, Jacek Dubois, Wojciech Eichelberger, Anna Gajos, Magda Mizuro, Jan Nowicki, Andrzej Poniedzielski, Magda Rybak, Sonia Raduńska, Krystyna Stachowicz, Stach Szabłowski, Edyta Szałek, Konrad Sztuka, Janusz Wróblewski oraz Katarzyna Zimmerer.

Redaktorzy, literaci i reporterzy tworzyli zawartość „Zwierciadła”, które, jak podkreślił J. Konecki, było „pismem nie tylko dla kobiet, ale i - skrótowo mówiąc - o kobietach"20.

\subsubsection{Zawartość, akcje, czytelnicy}

Na przestrzeni 50 lat historii periodyku zmieniała się jego zawartość, dostosowując się do przeobrażeń politycznych, kulturowych, a także mentalnych. Już w 1977 r., z okazji jubileuszu dwudziestolecia tytułu, K. Mojkowska zauważyła:

inna jest dzisiaj nasza czytelniczka. Wykształcona, znająca swój zawód i doceniająca swoją w nim wartość. Samodzielna, realizująca zasadę współpartnerstwa w rodzinie i rozumiejąca swoją rolę i miejsce w społeczeństwie ${ }^{21}$.

Inna była również adresatka pisma w roku 1989, inna u progu XXI w. Wtedy też wykształcił się stały charakter magazynu. Z pisma, interesującego się w pierwszych latach swego istnienia głównie problemami społeczno-obyczajowymi (często poruszane kwestie to alkoholizm, problemy rodzinne), wyrósł periodyk o charakterze przede wszystkim poradnikowym, z zacięciem psychologicznym, interesujący się psychoanalizą i psychotroniką, terapią, medycyną alternatywną oraz współczesnymi filozofiami.

19 Przez pewien czas był on felietonistą omawianego periodyku.

${ }^{20}$ J. Konecki, „Zwierciadlanych” uwag kilka, „Biuletyn Z.G. RSW>Prasa<” 1972, nr 153, s. 65.

${ }^{21}$ K. Mojkowska, Dwadzieścia lat, „Zwierciadło” 1977, nr 20, s. 2. 
„Zwierciadło" stało się swego rodzaju przewodnikiem duchowym dla swych czytelniczek, poszukującym nowych dróg i rozwiązań kłopotów związanych zarówno z życiem codziennym, jak i problemów egzystencjalnych, duchowych. Obok tych charakterystycznych zainteresowań, redakcja nie zapomniała, że przygotowuje każdy numer dla czytelniczek, które poszukują również porad związanych z modą, urodą i zdrowiem, a także chcą dowiedzieć się, jak inne kobiety poradziły sobie w trudnych życiowych sytuacjach. Pamiętano także, że potencjalni odbiorcy pisma interesują się też informacjami ze świata filmu, teatru, muzyki, literatury. Stąd w latach 2001-2005 można wyodrębnić cztery podstawowe grupy zagadnień, podejmowanych na łamach magazynu:

1) rozwój duchowy i emocjonalny kobiety, w tym jej relacje z mężczyzną;

2) rodzina i wychowanie;

3) kultura;

4) moda, uroda i zdrowie.

Powyższe kategorie zagadnień ujęto w struktury pisma w postaci zmieniających się (w niewielkim stopniu) $\mathrm{w}$ ciągu pięciu lat następujących działów i rubryk: Bliskość we dwoje, Co słychać, Dom, Felietony (m.in. T. Jastruna, W. Eichelbergera, A. Poniedzielskiego, przypowieści P. Coelho), Kuchnia, Moda, Moje niepokoje, Na szczęście, Naprawdę jaki jesteś [pis. oryg.], Polecamy (Film, Książki, Muzyka, Sztuka, Teatr), Przed lustrem, Psychologia, Relaks (horoskop, krzyżówka, konkursy), Spotkania (w ich ramach m.in. cykl Pytania do dwojga), Sztuka życia, Temat miesiąca, To nas dotyczy, To nas inspiruje, Twoje pieniądze, Uroda, Wspomnienia, Wydarzenia, Zdrowie. Każdy numer rozpoczynał aforyzm znanego pisarza, myśliciela bądź przewodnika duchowego (Na dobry początek).

Jednak nawet $\mathrm{w}$ typowych dla prasy kobiecej tekstach widoczny był bardzo często specyficzny duch pisma oraz jego poradnikowy charakter. Wyraźny był on na przykład w historiach opisywanych przez redakcję (Spotkania, Temat miesiaca), przeprowadzanych wywiadach (m.in. $\mathrm{Na}$ prawdę jaki jesteś) czy polecanych lekturach (Moje ksiq̨żki, Nowości wydawnicze). Jakkolwiek moda znajdowała swoje stałe miejsce na łamach pisma, to jednak nie była ona tematem priorytetowym. Dużo uwagi poświęcano natomiast problemom wychowawczym, a szczególnie wychowaniu dorastającej młodzieży.

Nie poprzestano na poradach, drukowanych na łamach pisma. Jednym z przejawów działalności, wpisujących się w program periodyku, był założony przezeń Instytut Psychospołeczny Zwierciadło (przekształcony w następnych latach w Pracownię Psychospołeczną Zwierciadło). Zapraszano czytelników do korzystania z porad zatrudnionych tam specjalistów: terapeutów oraz psychologów. W ramach określonych gabinetów proponowano pomoc $w$ trudnych sytuacjach życiowych, takich jak na przykład 
rozwód, przemoc fizyczna i emocjonalna, uzależnienia, depresje. Zachęcano do udziału w warsztatach i terapiach grupowych. W ofercie czytelnicy mieli do wyboru rozmaite programy, na przykład Ja i inni (rozwój umiejętności interpersonalnych), Poczucie własnej wartości, Warsztaty dla kobiet poszukujących dróg rozwoju, intuicji i siły. Instytut był systematycznie reklamowany na łamach pisma, przypominano o nim również przy okazji wybranych tekstów, poruszających problemy, wpisujące się w jego program.

Inną inicjatywą, realizującą idee „Zwierciadła”, było przedsięwzięcie, organizowane wspólnie z Dojrzewalniq Róż. Powstała ona „z potrzeby stworzenia przestrzeni, która sprzyja odkrywaniu i rozwijaniu kobiecości. Przestrzeni, która inspiruje, wspiera, umożliwia twórcze spotkania kobiet z kobietami”22. Jej misją było m.in. „Inspirowanie i wspieranie kobiet, które chcą żyć w zgodzie ze swoimi najgłębszymi pragnieniami, kroczyć własną drogą, mówić swoim głosem - pełnym głosem"23. W ramach tego pomysłu realizowano bądź wspierano rozmaite projekty, jak choćby Porozumienie bez Przemocy, PROGRESSteron Relacje czy Szkoła Trenerów.

Magazyn, propagując określone wartości, nagradzał tych, którzy je sobą prezentowali.

Tak powstał pomysł Kryształowych Zwierciadeł, nagrody, przyznawanej od 1995 r. wybitnym osobom lub zespołom, reprezentującym kulturę, sztukę, naukę i życie publiczne. Oceniano zarówno cechy charakteru kandydatów, jak i ich dokonania oraz postawę. Były to, jak pisano z okazji jubileuszu dziesięciolecia istnienia wyróżnień, „doroczne nagrody dla ludzi z pasją. Takich, którzy realizując siebie, przy okazji robią dużo dobrego dla innych" 24 . Kandydaci prezentowani byli na łamach magazynu, a następnie laureatów wyłaniała Kapituła, w skład której wchodzili m.in. finaliści edycji z ubiegłych lat oraz członkowie redakcji. Na przykład w 1995 r. nagrodzono m.in. Marię Wiernikowską za „szeroko rozumianą odwagę”, rok później za „szczególny talent i wytrwałość" nagrodę otrzymali m.in. Wisława Szymborska i Andrzej Seweryn, w 1998 r. za „niezależność” Kryształowym Zwierciadłem uhonorowano Igę Cembrzyńską oraz Olgę Tokarczuk. W 2002 r. nagrodę otrzymały m.in. Agnieszka Graff, Krystyna Janda, Barbara Labuda oraz Jagna Marczułajtis, wszystkie za „siłę kobiecości”25. W 2003 r. jednym z laureatów zostało Wydawnictwo Czarne za „nieuleganie wydawniczym modom". W 2005 r. zmieniono formułę nagrody, postanawiając przyznawać ją odtąd Ludziom Dialogu, „którzy łączą, a nie dzielą, którzy mają dar

${ }^{22}$ Dojrzewalnia Róż. Kobiecość w rozkwicie, http://www.dojrzewalnia.pl/o_nas/ o_dojrzewalni.html, kwiecień 2011.

23 Ibidem.

24 [br. aut.], Strzał w dziesiątkę, „Zwierciadło” 2005, nr 7, s. [8].

25 Wszyscy laureaci Kryształowych Zwierciadeł w latach 1995-2002, zob. „Zwierciadło” $2003 \mathrm{nr} 7$, s. 13. 
jednania różnych środowisk i niesienia pomocy"26. Kryształowymi Zwierciadłami mieli być odtąd honorowani kobieta i mężczyzna, bo ten właśnie rodzaj dialogu pomiędzy nimi magazyn starał się promować. Pierwszymi laureatami zreformowanego wyróżnienia zostali Hanna Polak (za stworzenie fundacji Aktywna Pomoc Dzieciom) i Paweł Althamer (za dokonania w sztuce) ${ }^{27}$.

Podobną inicjatywą, wpisującą się w ściśle określonego odbiorcę periodyku, było przyznawanie (od 1990 r.) tytułu Damy Biznesu. Celem tego przedsięwzięcia było promowanie tych kobiet, które wyróżniają się szczególnymi zdolnościami w dziedzinie zarządzania, a także „Żyją i pracują z pasją, z wewnętrznym poczuciem sensu i spełnienia. Potrafią troszczyć się nie tylko o wyniki ekonomiczne firmy, ale i o satysfakcję zespołu ludzi, którym kierują"28. Laureatkami poszczególnych edycji konkursu były m.in.: Grażyna Patulska (1998), Beata Pawłowska (2000), Hanna Gronkiewicz-Waltz (2004).

Pojawiały się także anonse, informujące o inicjatywach, organizowanych przez inne periodyki bądź instytucje, na przykład w 2003 r. zamieszczono informację o akcji Kobieta Bezpieczna, o której pisano również na łamach innego omawianego w pracy periodyku („Elle”).

„Zwierciadło” adresowane było do kobiet w wieku 20-44 lat, mających wykształcenie wyższe lub średnie, posiadających stałą pracę oraz wysokie dochody, mieszkających $\mathrm{w}$ miastach powyżej 100 tys. ${ }^{29}$ Jako periodyk zaliczany do magazynów ekskluzywnych, kierowany był do „kobiet sukcesu", o szerokich zainteresowaniach, które jednocześnie chcą poznać tajemnice własnej duszy, ale i nie stronią od nowinek, które pozwolą im zadbać o zdrowie, kondycję i urodę. Redakcja starała się pozyskać czytelników także wśród mężczyzn, stąd cyklicznie drukowano specjalną część dla panów, zatytułowaną Nowy mężczyzna (Po drugiej stronie). Drukowano ją w specjalnych, dwustronnych damsko-męskich numerach.

Zarówno periodyk, jak i jego dziennikarze byli kilkakrotnie nagradzani. Na przykład w 2001 r. trzecia nagroda w konkursie Polskiej Fotografii Prasowej w kategorii Ludzie przypadła Jackowi Piotrowskiemu, współpracującemu z magazynem. Anna Maria Nowakowska zdobyła w tym samym roku Grand Prix w konkursie zorganizowanym przez fundację Keep Walking na najciekawszy reportaż, zaś w 2002 r. B. Dzięgielewska została odznaczona Krzyżem Kawalerskim Orderu Odrodzenia Polski. Magazyn otrzymywał kilkakrotnie nagrodę w Konkursie Projektowania Prasowego

\footnotetext{
26 [br. aut.], Strzał..., s. [8].

27 Więcej, zob. ibidem, s. [8]-[9].

28 [br. aut.], Dama biznesu 2000, „Zwierciadło” 2001, nr 4, s. 54.

29 http://www.mediabuy.pl/prasa/Zwierciadlo/, kwiecień 2011.
} 
(kolejno w 2002, 2003, 2004 i 2005 r.). Doceniano m.in. typografię oraz okładki pisma.

„Zwierciadło” w ciągu swej długiej historii odegrało znaczącą rolę na polskim rynku prasowym. Było pismem kilku pokoleń kobiet, które sięgały po nie z różnych powodów: dla rozrywki, dla felietonów ulubionych autorów, ale także szukając rozwiązania własnych problemów. Jedna z czytelniczek wyznała:

„Zwierciadło” odkryłam przypadkiem i nie od razu zorientowałam się, jak wartościowym jest pismem. Czytałam o ludziach, którzy są szczęśliwi i potrafią znaleźć radość życia, choć stykają się z ogromem zła w sercach innych. Czytałam o ludziach, którzy robią z pasją to, co kochają, mimo że czasem im trudno. Czytałam wreszcie listy dotyczące wcześniejszych numerów, których nie widziałam na oczy, ale tematyka w nich zawarta dotyczyła bliskich mi spraw. Przeczytałam to wszystko i płakałam. [...] Uświadomiłam sobie, jak wiele straciłam nie pracując nad sobą, nie próbując zmienić tego, co złe, ale uciekając przed sobą, przed przeszłością, przed przeżyciami z domu rodzinnego. Dopiero teraz wiem, jak wiele zależy ode mnie ${ }^{30}$.

Ta laurka, wystawiona periodykowi, potwierdzała, że udało mu się zrealizować życzenie pierwszego zespołu redakcyjnego pisma: być zawsze blisko kobiet, być rzecznikiem ich spraw, pomagać im w rozwiązywaniu życiowych problemów. Świętując 50-lecie istnienia tytułu, T. Jastrun pisał:

Jeśli „Zwierciadło” dożyje stu lat, pozdrowimy was w roku 2057. Pochylcie się nad nami życzliwie. Mamy nadzieję, że przyznacie: na początku XXI stulecia to było zaskakująco dobre pismo. Chociaż prywatne, to z misją społeczną, unikające wszechobecnej komercji i stawiające na rozwój duchowy człowieka31.

Promowanie owego rozwoju duchowego widać wyraźnie także w wyborze literatury, proponowanej czytelnikom na łamach magazynu.

\subsubsection{Miłość, zazdrość, literatura ${ }^{32}$ : książka na łamach pisma}

Informacje o książce, zamieszczane na łamach „Zwierciadła”, stanowiły jego ważną część. Wyraźne było zainteresowanie redakcji sprawami bezpośrednio i pośrednio związanymi z literaturą, a także zaangażowanie w jej promowanie. Zwraca uwagę nie tylko liczba, ale również duże zróżnicowanie zastosowanych form tychże informacji. Część z nich pojawiła się, obok innych kwestii kulturalnych, w środkowej części periodyku, najpierw anonsowana w spisie treści zwrotem Polecamy, a następnie jako

30 „Zwierciadło” 2001, nr 3, s. 41.

31 T. Jastrun, Historia w numerach, „Zwierciadło” 2007, nr 5, s. 85.

32 Tytuł jednej z publikacji, związanej z interesującą nas tematyką, zob. „Zwierciadło” 2004, nr 5, s. [34]-[35]. Numer damsko-męski. 
część działu Kultura. Zajmował on średnio 10 stron, obejmując następujące rubryki: Sztuka, Ksiq̨żka ( $\leftarrow$ Nowości wydawnicze), Film, Teatr (od 2002 r. z tej rubryki zrezygnowano), Muzyka, sporadycznie Postać, a w późniejszym okresie Poezja rozbierana. Do numeru 11 (2003) w stopce redakcyjnej pojawiało się nazwisko J. Wróblewskiego jako szefa działu, natomiast później każda rubryka podpisywana była przez dziennikarza, który ją przygotowywał, bez wskazania na osobę odpowiedzialną za całość prezentowanego materiału. $\mathrm{W}$ ciągu analizowanego okresu pojawiły się na łamach pisma następujące nazwiska związane ze sprawami kulturalnymi: Magdalena Boratyńska-Komar, Manana Chyb, Tatiana Cichocka, Julia Daniszewska, Alina Gutek, Tomasz Jastrun, Joanna Klimczyk, Krystyna Kuczyńska, Jacek Melchior, Magda Mizuro, Magda Rybak, Stach Szabłowski, Mariola Wiktor, Iwona Zabielska-Stadnik, Honorata Zapaśnik.

Duża różnorodność form informacji o książce pozwoliła, podobnie jak w przypadku prasy opinii, wyodrębnić kilka ich kategorii. W tabeli 39 przedstawiono odnoszące się do nich dane statystyczne ${ }^{33}$.

Tabela 39. Formy obecności książki i informacji o niej na łamach „Zwierciadła” w latach 2001-2005

\begin{tabular}{|l|c|}
\hline \multicolumn{1}{|c|}{ Rodzaj informacji } & Liczba ogółem \\
\hline Recenzje & 407 \\
\hline Wywiady & 58 \\
\hline Reklamy książek & 150 \\
\hline Sylwetki/portrety & 70 \\
\hline $\begin{array}{l}\text { Artykuły, poświęcone sprawom książki lub rynku wydawniczo-księgar- } \\
\text { skiego }\end{array}$ & 37 \\
\hline Ekranizacje, adaptacje oraz inscenizacje znanych dzieł & 27 \\
\hline Konkursy i akcje & 157 \\
\hline Listy bestsellerów & - \\
\hline $\begin{array}{l}\text { Listy czytelników, nawiązujące do zamieszczonej informacji związanej } \\
\text { z książką }\end{array}$ & 14 \\
\hline Inne ${ }^{a}$ & 345 \\
\hline Ogółem & 1265 \\
\hline
\end{tabular}

${ }^{a} \mathrm{~W}$ tej kategorii uwzględniono felietony pisarzy, fragmenty powieści, opowiadania, krótkie informacje dotyczące książek, donoszące m.in. o jubileuszach pisarzy, ciekawostki, np. o stronach internetowych poświęconych literaturze, propozycje lektur związanych $\mathrm{z}$ literaturą, odnoszących się do tematu podjętego $\mathrm{w}$ danej publikacji itd.

Źródło: badania własne.

33 Wzorem poprzednich rozdziałów i w tym przyjęto kolejność podawania danych kategorii według kolejności ich prezentacji. 
Ogólna liczba wszystkich informacji związanych bezpośrednio lub pośrednio z literaturą i książką była stosunkowo duża, szczególnie, jeśli spojrzymy na nią w kontekście typu omawianego periodyku i wynikających zeń funkcji.

Największą grupę stanowiły recenzje. Ich liczba (407) oznacza, że $\mathrm{w}$ jednym numerze pisma drukowano ich średnio 6,7. Wynikało to $\mathrm{z}$ faktu, że rubryka recenzyjna była systematycznie rozbudowywana, a także stanowiło konsekwencję tego, że recenzje pojawiały się również poza działem poświęconym kulturze.

Drugie miejsce zajęła kategoria Inne (345). Znalazły się tu bardzo zróżnicowane informacje, także pod względem objętości; niektóre z nich miały postać jednozdaniowych wzmianek, inne zajmowały jedną stronę.

Zwraca również uwagę liczba konkursów i akcji związanych z książką (157). Były one regularnie organizowane przez cały badanych okres, przyjmując rozmaitą formę (ze względu na ich znaczenie zostaną jednak omówione $\mathrm{w}$ dalszej części rozdziału). Przy tak dużym zaangażowaniu pisma w upowszechnianie literatury może dziwić brak list bestsellerów.

Względnie dużą grupę stanowiły reklamy wydawnicze, aczkolwiek już w tym miejscu należy zasygnalizować, że podana liczba jest efektem zamieszczania przez edytorów obszernych anonsów, w których jednorazowo znajdowały się informacje o 20 i więcej tytułach.

Wymienione informacje o książce drukowano w różnych miejscach magazynu, przy czym tylko niektóre z nich miały swoje stałe miejsce w ramach działu kulturalnego. Jednym z jego niezmiennych elementów były recenzje.

\subsubsection{Nici światła między nami ${ }^{34}$ : miejsce recenzji w układzie pisma}

W latach 2001-2005 na łamach „Zwierciadła” ukazało się 407 recenzji książek $^{35}$. W tabeli 40 zaprezentowano ich liczbę w poszczególnych latach.

Tabela 40. Recenzje zamieszczane na łamach

„Zwierciadła” w latach 2001-2005

\begin{tabular}{|c|c|}
\hline Rok & Liczba recenzji \\
\hline 2001 & 69 \\
\hline 2002 & 80 \\
\hline 2003 & 89 \\
\hline 2004 & 78 \\
\hline 2005 & 91 \\
\hline Ogółem & 407 \\
\hline
\end{tabular}

Źródło: badania własne.

34 Tytuł jednej z recenzji. „Zwierciadło” 2004, nr 5, s. 60.

$35 \mathrm{~W}$ tej liczbie 380 recenzji pochodziło od redakcji. Pozostałe stanowią przykład m.in. zaangażowania czytelników w konkursy i akcje organizowane przez periodyk. 
Liczba recenzji w każdym z badanych roczników utrzymywała się na zbliżonym poziomie, zaś w 2005 r. osiągnęła pułap 91 omówień.

Warto zaznaczyć, że w przeciwieństwie do przedstawionych wcześniej periodyków z grupy pism opinii, gdzie recenzentów było kilku, a nawet kilkunastu, w tym przypadku wybrane książki omawiała jedna osoba, przypisana do rubryki recenzyjnej. W ciągu pięciu lat prezentacją wybranych lektur zajmowały się kolejno: M. Boratyńska-Komar (od pierwszego badanego numeru w 2001 r. do numeru 3 w 2003 r. włącznie, 124 recenzje), J. Klimczyk (4/2003-1/2005, 86 omówień) oraz M. Mizuro (2/2005$12 / 2005,43$ recenzje). Proponowały one wybrane tytuły w ramach rubryki Książki ( $\leftarrow$ Nowości wydawnicze), zamieszczanej w dziale kulturalnym. Od numeru 1 (2003) czytelnik pisma miał możliwość poznać także książki, przedstawiane przez R. Arendt-Dziurdzikowską w dziale Psychologia, najpierw w skromnej rubryce $\mathrm{Na}$ szczęście, gdzie pojawiały się również inne informacje, a później już na rozbudowanej, autorskiej stronie zatytułowanej Moje książki.

Poza wymienionymi recenzentkami, wybrane przez siebie książki proponowali (w innych, poza wspomnianymi, rubrykach pisma): Monika Krassowska-Kaszuba (4), Lucyna Olszewska (3), Maria Migdalska, Janusz Miliszkiewicz, Jan Nowicki, Anna Szokal, Iwona Zabielska-Stadnik (po jednej). W czterech przypadkach tego typu informacje nie były podpisane (zob. Aneks 29. Autorzy recenzji zamieszczanych książek na łamach „Zwierciadła" w latach 2001-2005).

W analizowanym okresie postać recenzji kilkakrotnie się zmieniała. Uwaga ta dotyczy szczególnie podstawowej rubryki, drukowanej w dziale kulturalnym.

Przez pierwszy analizowany rok pozostawała ona niezmienna (zob. zdjęcie 76). Jednak już na początku roku następnego pojawiły się pierwsze, nieznaczne na razie, modyfikacje. Dotyczyły one kroju czcionki w nazwie rubryki (1/2002) oraz dwukolorowego tytułu i innego kroju czcionki w tytule recenzji (3/2002). Ale już od kolejnego wydania (4/2002) nastąpiły wyraźniejsze zmiany: pojawił się inny układ recenzji na stronie oraz podkreślenie dwóch z nich. Przedstawiono wybrane przykłady, prezentujące kolejne pomysły redakcji $\mathrm{w}$ odniesieniu do interesującej nas strony recenzyjnej (zdjęcia 76-79). 


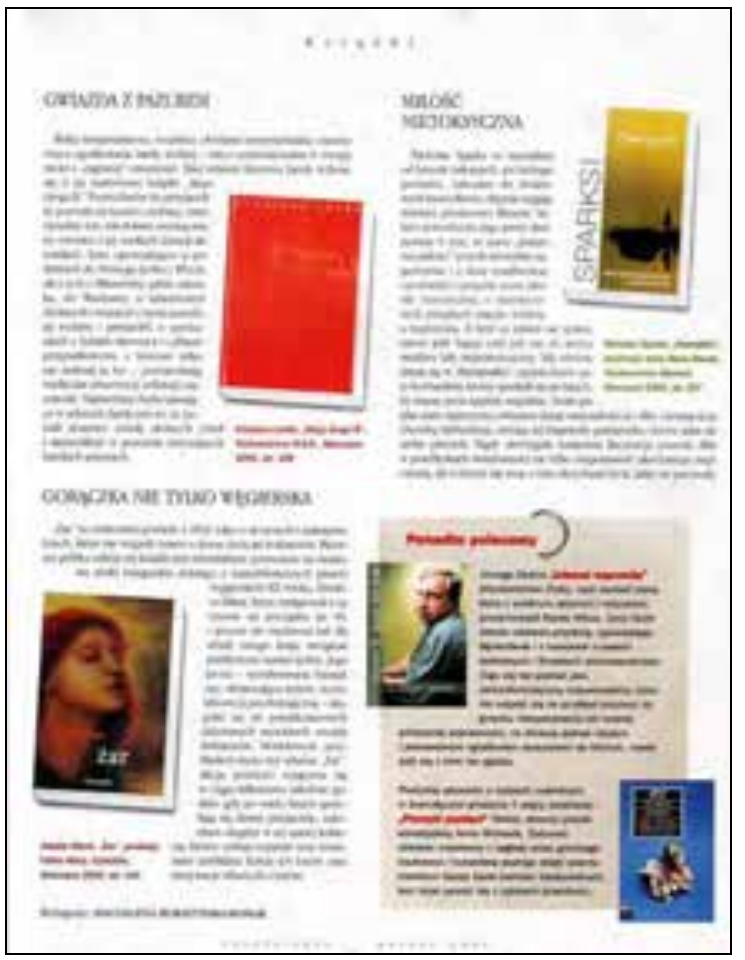

Zdjęcie 76. Przykładowa strona recenzyjna na łamach „Zwierciadła” „Zwierciadło” 2001, nr 3, s. 63

Zdjęcie 77. Przykładowa strona recenzyjna na łamach "Zwierciadła” „Zwierciadło” 2002, nr 2, s. 83

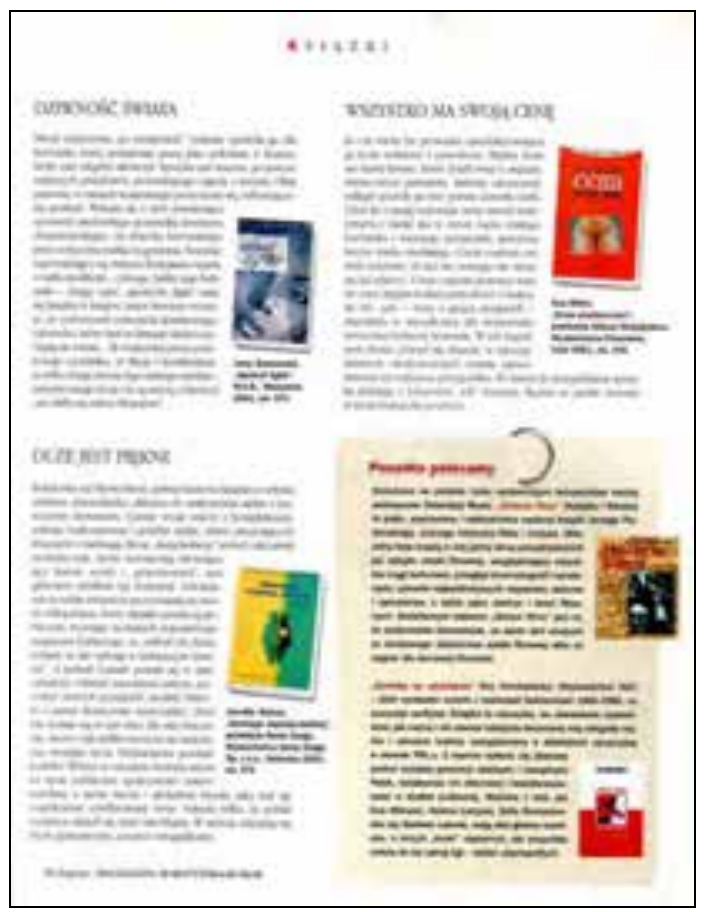




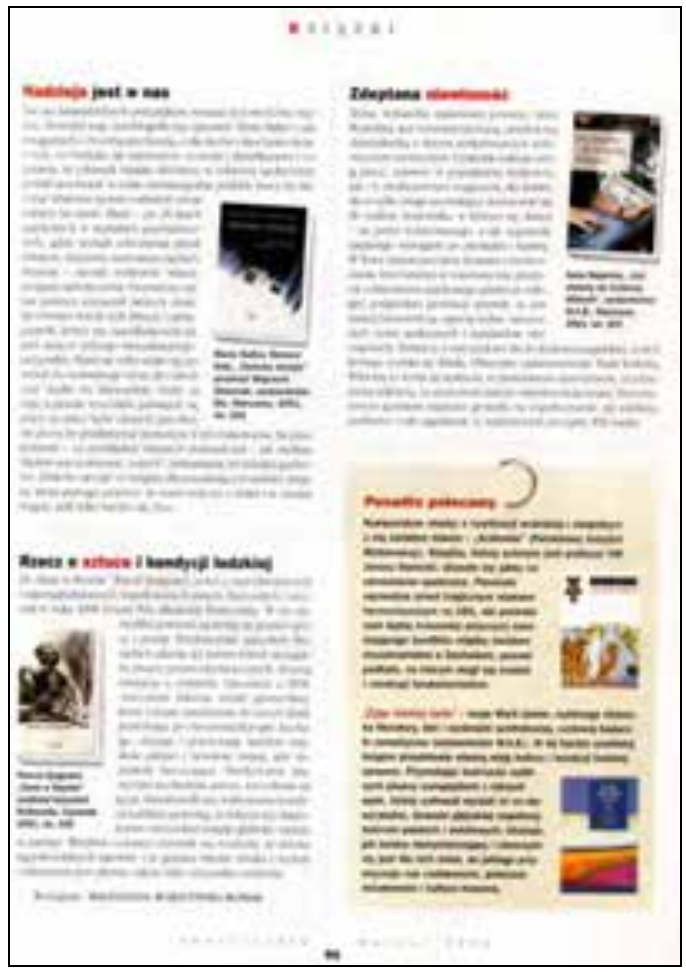

Zdjęcie 78. Przykładowa strona recenzyjna na łamach „Zwierciadła”

„Zwierciadło” 2002, nr 3, s. 95

Zdjęcie 79. Przykładowa strona recenzyjna na łamach „Zwierciadła” „Zwierciadło” 2002, nr 4, s. 79

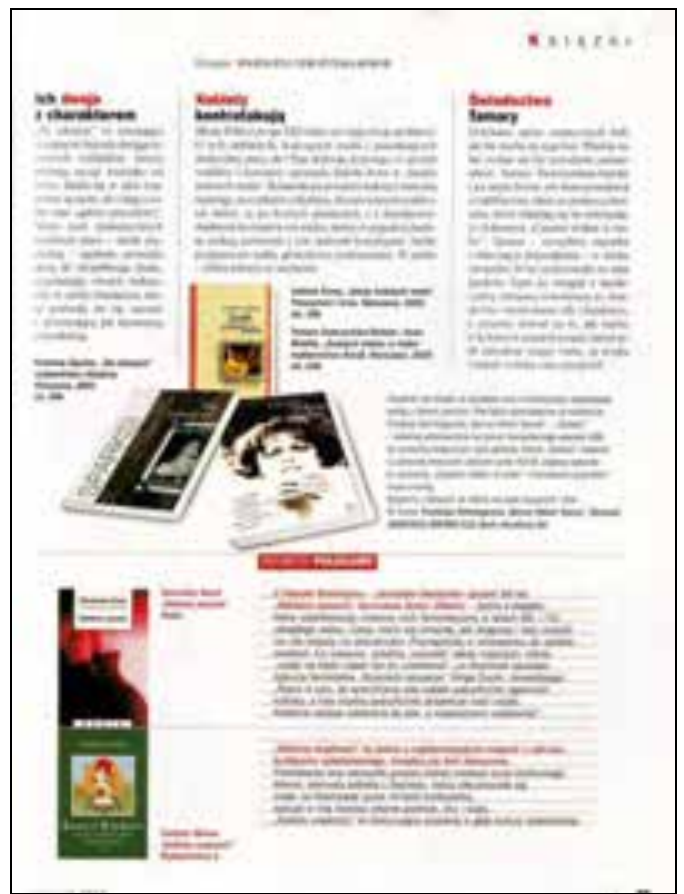


Wydaje się, że ostatnia z zaprezentowanych zmian nie była najlepszym rozwiązaniem: strona stała się mniej czytelna, przy czym podkreślenie dwóch recenzji, zamieszczonych w dolnej części strony, mogłoby sugerować, że proponowane książki są szczególnie polecane, ale przeczyłby temu nagłówek, zwłaszcza zaś określenie „ponadto”. Wydaje się, że był to raczej zabieg graficzny, niezbyt szczęśliwie dobrany.

Od numeru 5 (2002) nastąpiła kolejna kosmetyczna zmiana, tym razem dotycząca kroju czcionki w nazwie strony, poświęconej recenzjom. Aż do końca 2002 r. rubryka ta (obok innych informacji kulturalnych) zapowiadana była w spisie treści krótkim zaproszeniem: Ponadto polecamy, od numeru 10 (2002) ograniczonym do, może nieco deprecjonującego, Ponadto. Wraz z wydaniem pierwszym w następnym (2003) roku zastąpiono dotychczasowe Książki $\rightarrow$ Nowościami wydawniczymi, nadal w ten sam sposób anonsowanymi. Zrezygnowano z podkreśleń recenzji i z ich dotychczasowego nagłówka Ponadto polecamy, a od numeru lutowego po raz pierwszy pojawił się w rubryce dodatkowy element: dolną część strony przeznaczono na rekomendację wybranej książki przez znaną osobę: pisarza, kompozytora, aktora, reżysera, wydawcę. Dwa miesiące później (4/2003) zdecydowano się na wprowadzenie w spisie treści niewyszukanej, ale adekwatnej nazwy Kultura. Jednocześnie w jej ramach zwiększono miejsce przeznaczone na recenzje książek: z 1 do 2 stron. Recenzję pochodzącą od znanej osoby drukowano odtąd na ciemnoszarym tle. Tę ewolucję przedstawiają zdjęcia 80-83. 


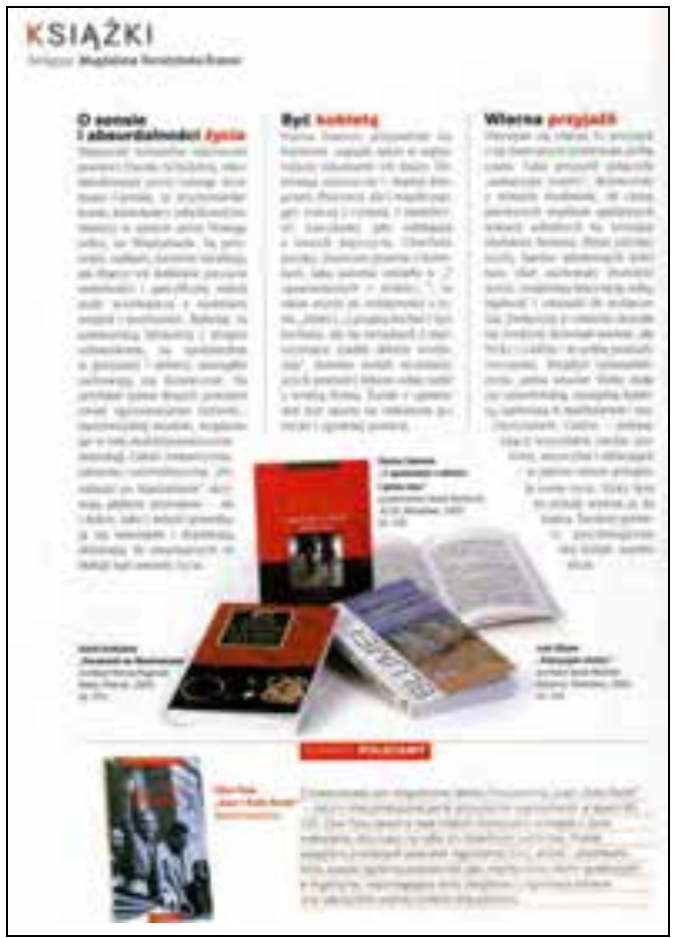

Zdjęcie 80. Przykładowa strona recenzyjna na łamach „Zwierciadła” „Zwierciadło” 2002, nr 5, s. 78

Zdjęcie 81. Przykładowa strona recenzyjna na łamach „Zwierciadła” „Zwierciadło” 2003, nr 1, s. 80

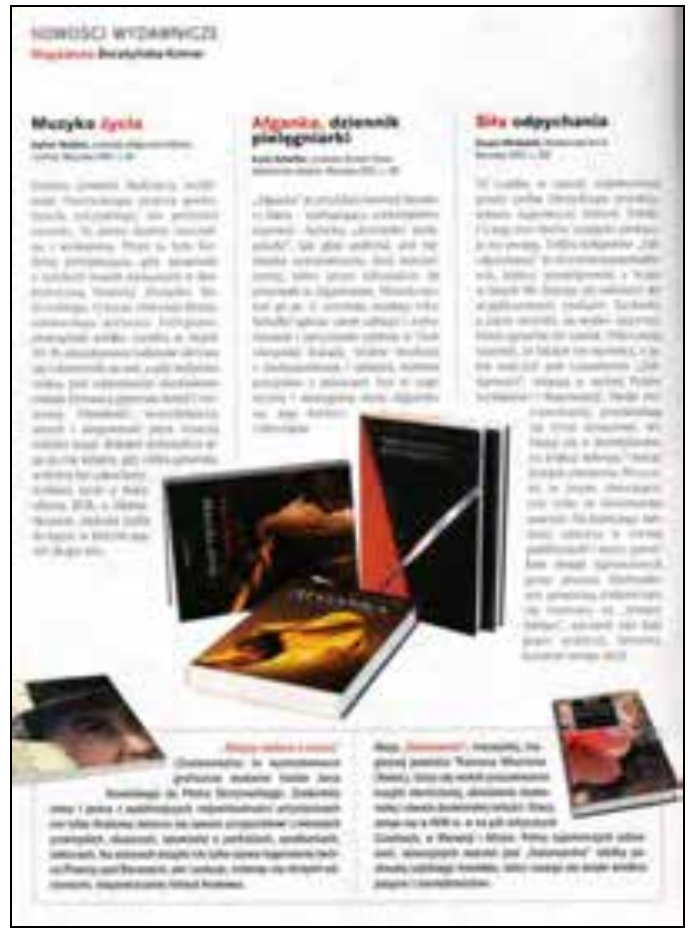




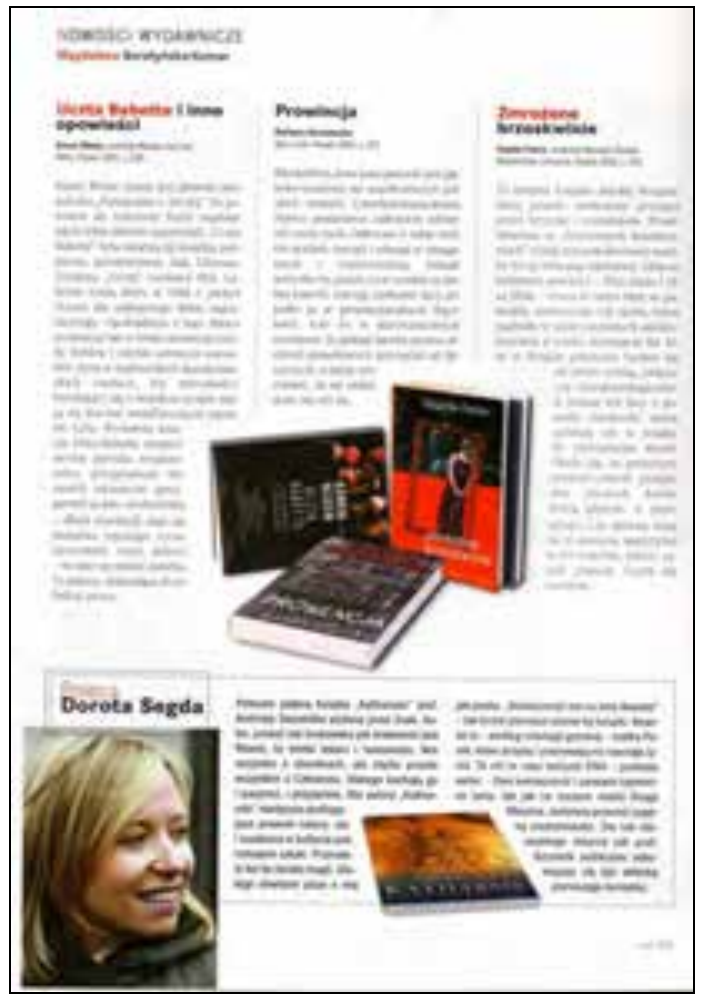

Zdjęcie 82. Przykładowa strona recenzyjna (jedna z dwóch) na łamach „Zwierciadła” „Zwierciadło” 2003, nr 2, s. [86]

Zdjęcie 83. Przykładowa strona recenzyjna (jedna z dwóch) na łamach „Zwierciadła” „Zwierciadło” 2003, nr 6, s. 98

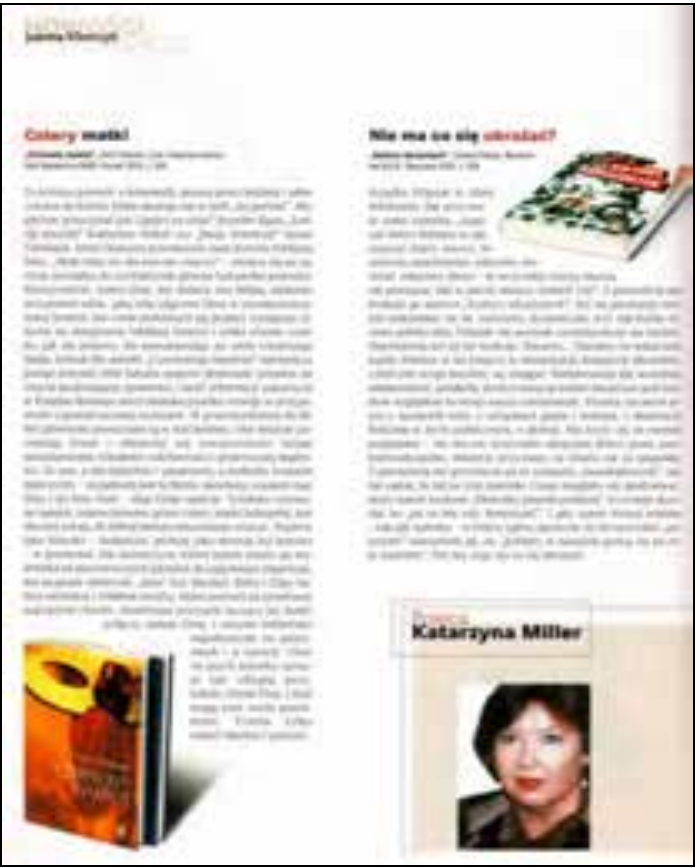


Zaproszenie znanych osób do podzielenia się z miłośnikami „Zwierciadła" wrażeniami po przeczytaniu danych lektur było z jednej strony interesującym pomysłem, o charakterze promocyjnym, a z drugiej wprowadzającym inne, poza redakcyjnym, spojrzenie na książkę. Podobnie powrót do umieszczania kopii okładek (które były najbardziej barwnymi elementami na stronie) prezentowanych książek przy odpowiadającym im recenzjom wydaje się trafnym rozwiązaniem. Zwiększenie miejsca przeznaczonego na prezentację książek pozwoliło jednocześnie na rozszerzenie objętości recenzji.

W numerze 9 (2003) zabrakło rekomendacji znanej osoby, ale w zamian pojawiła się propozycja konkursu na recenzję napisaną przez czytelników. Jakkolwiek miała się ona pojawić już od numeru październikowego, to jednak zamieszczono ją po raz pierwszy dopiero w wydaniu listopadowym $^{36}$. Najciekawsze recenzje przysyłane przez czytelników drukowano w pięciu kolejnych numerach, do marca następnego roku włącznie.

Od numeru pierwszego w 2004 r. ponownie zmienił się wygląd stron recenzyjnych: zdecydowano się na inne rozmieszczenie omówień i przypisanych doń opisów bibliograficznych. Całość recenzji drukowano odtąd na szarym tle, z dodatkowym wyróżnieniem propozycji pochodzącej od czytelnika, a od numeru 4 (kiedy konkurs na najciekawszą recenzję się skończył) prezentacji książki, polecanej przez znaną osobę. Od numeru kwietniowego zaczynając, cztery kolejne wydania to dowód na brak zdecydowania redakcji: obok stałych recenzji J. Klimczyk pojawiała się albo informacja o konkursie sms-owym związanym z książką, albo opinia znanej osoby, polecającej wybraną lekturę, albo wszystkie te elementy razem ${ }^{37}$. I dopiero od numeru 8 (2004) zdecydowano się na stałą formułę tej części działu, która odtąd, do września 2005 r. włącznie, składała się konsekwentnie (pomimo zmiany recenzentki w numerze lutowym) z trzech stałych części: czterech recenzji odredakcyjnych, tytułu proponowanego przez (zazwyczaj) celebrytę oraz konkursu sms-owego, przeważnie związanego z wybraną książką. W trzech ostatnich analizowanych numerach propozycje książkowe znanych osób zastąpiła niewielkich rozmiarów rubryka Nad czym pracuje... wybrany pisarz. Zdjęcia 84-89 przedstawiają wybrane przykłady odzwierciedlające trzy ostatnie zmiany $\mathrm{w}$ badanym okresie.

Dwa ostatnie rozwiązania zdają się być najkorzystniejsze z punktu widzenia czytelnika: zyskał on - dzięki przejrzystemu układowi stron, stonowanym kolorom, wyraźnym kopiom okładek, zachęcającym konkursom oraz interesującej informacji związanej z warsztatem pracy znanego pisarza - profesjonalnie i ciekawie przygotowaną stronę recenzyjną.

${ }^{36}$ Zrezygnowano z omawiania zmian w numerach 10-12 (2004) jako już zbyt szczegółowych i jednocześnie niewiele wnoszących do przedstawianych rozważań.

37 Zob. „Zwierciadło” 2004, nr 4, s. [70]-71; nr 5, s. 58-59; nr 6, s. 80-81; nr 7, s. 82-83. 


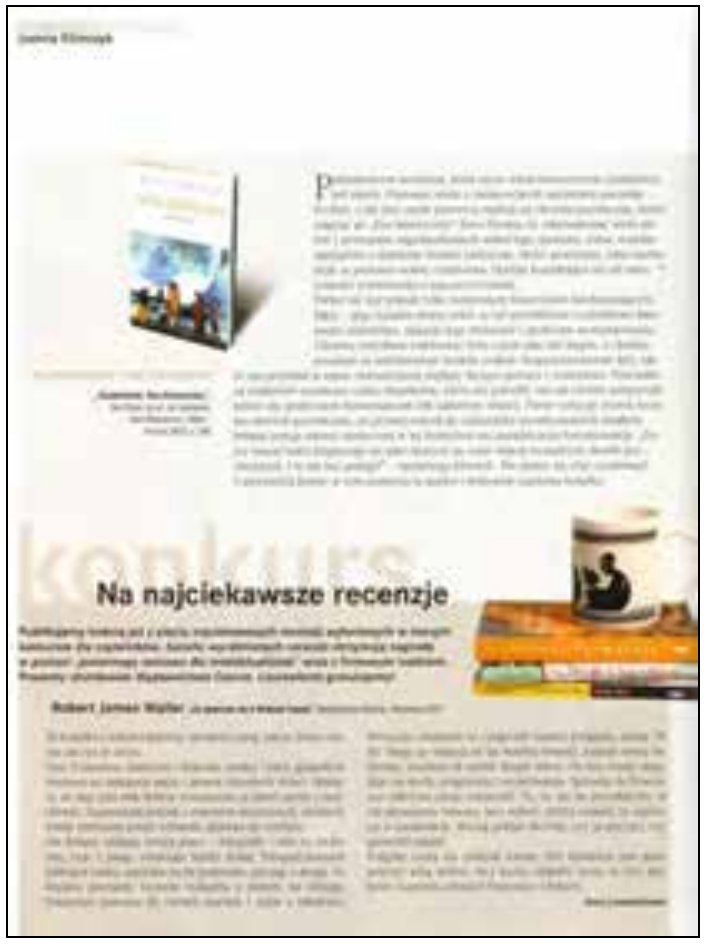

Zdjęcie 84. Przykładowa strona recenzyjna na łamach „Zwierciadła” „Zwierciadło” 2004, nr 1, s. 54

Zdjęcie 85. Przykładowa strona recenzyjna na łamach „Zwierciadła” „Zwierciadło” 2004, nr 1, s. 55

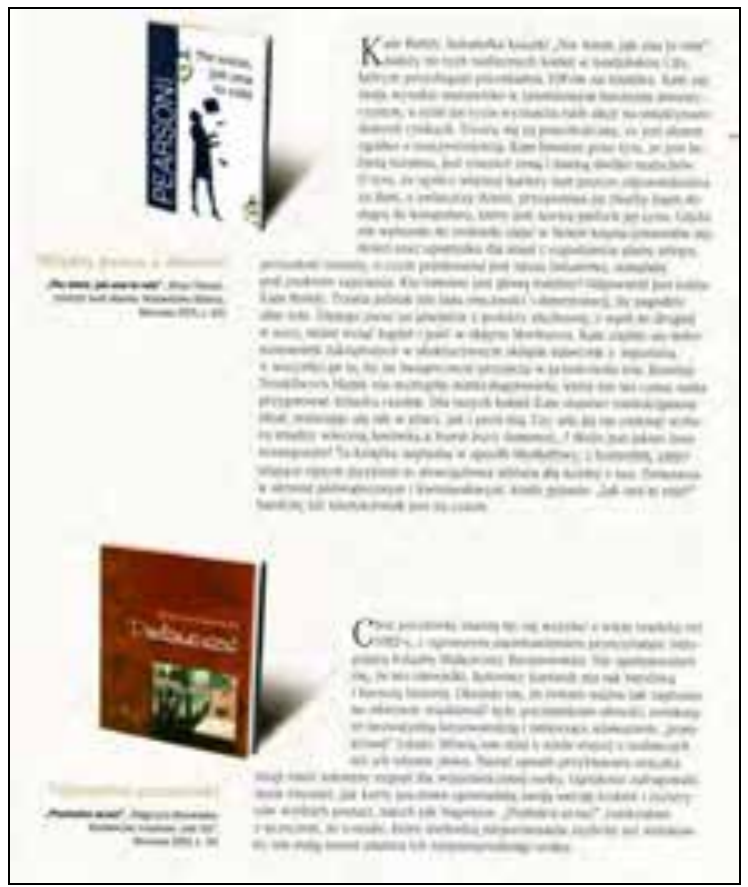




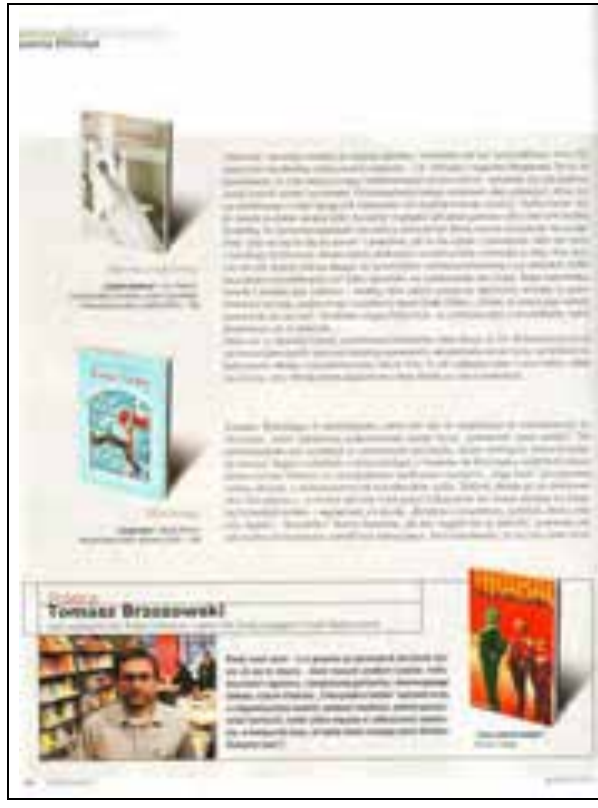

Zdjęcie 86. Przykładowa strona recenzyjna na łamach „Zwierciadła”

„Zwierciadło” 2004, nr 12, s. 78

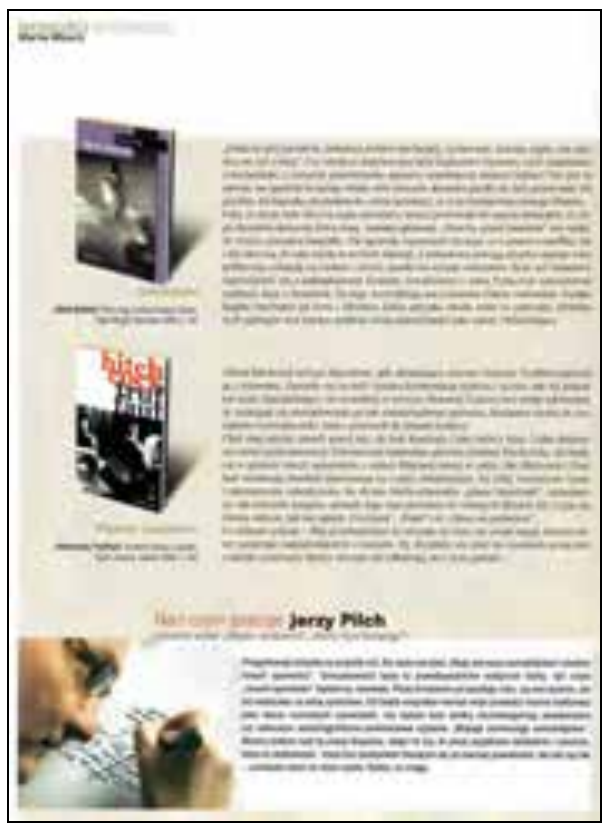

Zdjęcia 88. Przykładowa strona recenzyjna na łamach „Zwierciadła”

„Zwierciadło” 2005, nr 12, s. 92

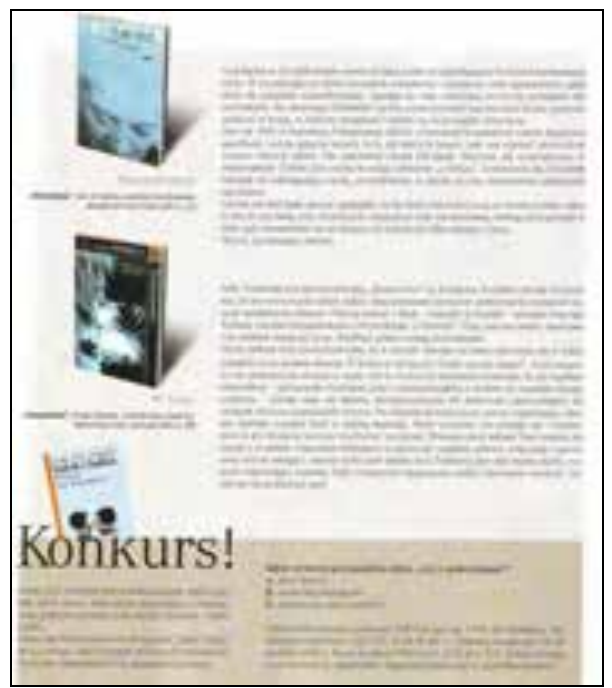

Zdjęcie 87. Przykładowa strona recenzyjna na łamach „Zwierciadła”

„Zwierciadło” 2004, nr 12, s. 79

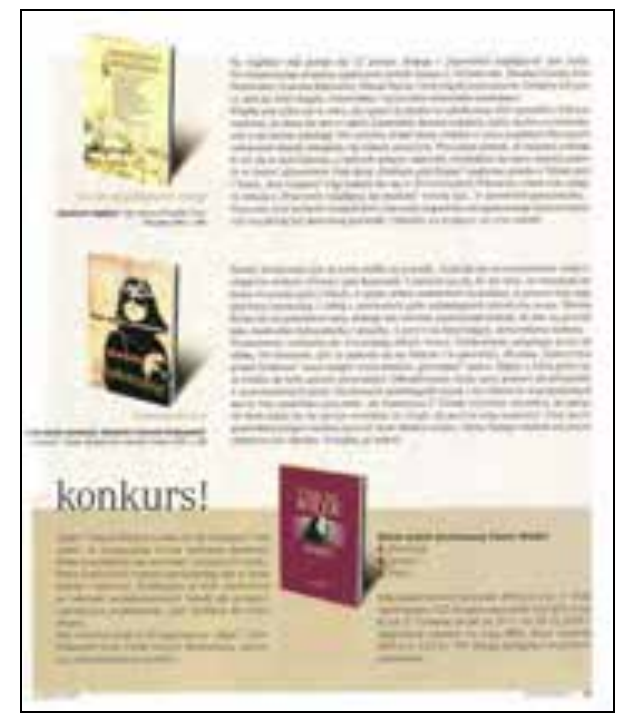

Zdjęcia 89. Przykładowa strona recenzyjna na łamach „Zwierciadła”

„Zwierciadło” 2005, nr 12, s. 93 
Interesującym spostrzeżeniem wydaje się fakt, że liczne modyfikacje, wprowadzane $\mathrm{w}$ tej części pisma, następowały niezależnie od zmian recenzentek. Podczas analizy zebranego materiału wykazano, że profil proponowanych lektur pozostał ten sam.

Jak wspomniano wcześniej, czytelnicy „Zwierciadła” mieli również możliwość poznać książki wybrane przez R. Arendt-Dziurdzikowską, zajmującą się $\mathrm{W}$ piśmie zagadnieniami $\mathrm{z}$ dziedziny psychologii. Tytuły przez nią proponowane drukowano zatem $\mathrm{w}$ odpowiadającym zainteresowaniom autorki dziale, co w sposób wyraźny determinowało charakter polecanych lektur. Początkowo omawiała ona krótko wybrane tytuły we wspomnianej wcześniej rubryce $\mathrm{Na}$ szczęście, obok ciekawostek m.in. z dziedziny psychologii.

Za każdym razem rubryka poprzedzana była swego rodzaju mottem, jednak nie zawsze do końca adekwatnym do znajdujących się poniżej informacji. Recenzowana książka zdawała się być jedną z ciekawostek pomieszczanych na stronie.

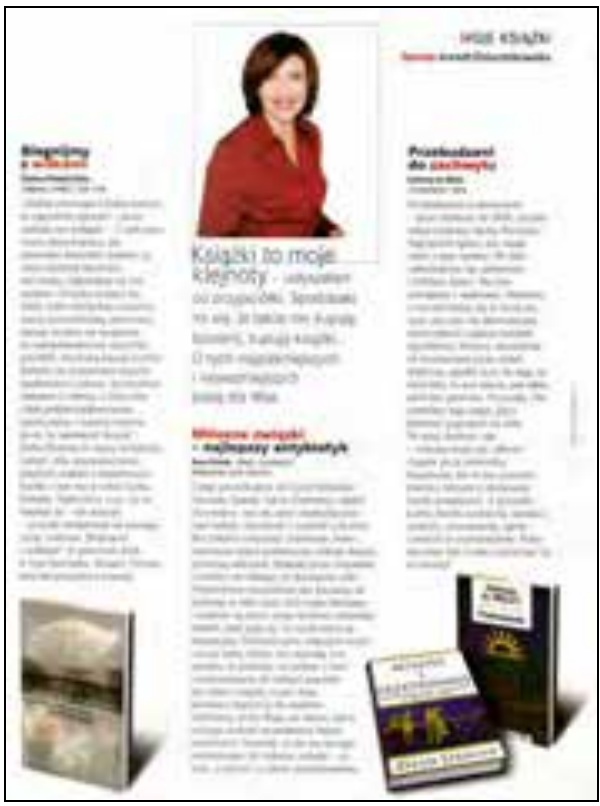

Zdjęcie 90. Przykładowa strona recenzyjna na łamach „Zwierciadła” „Zwierciadło” 2003, nr 1, s. 8

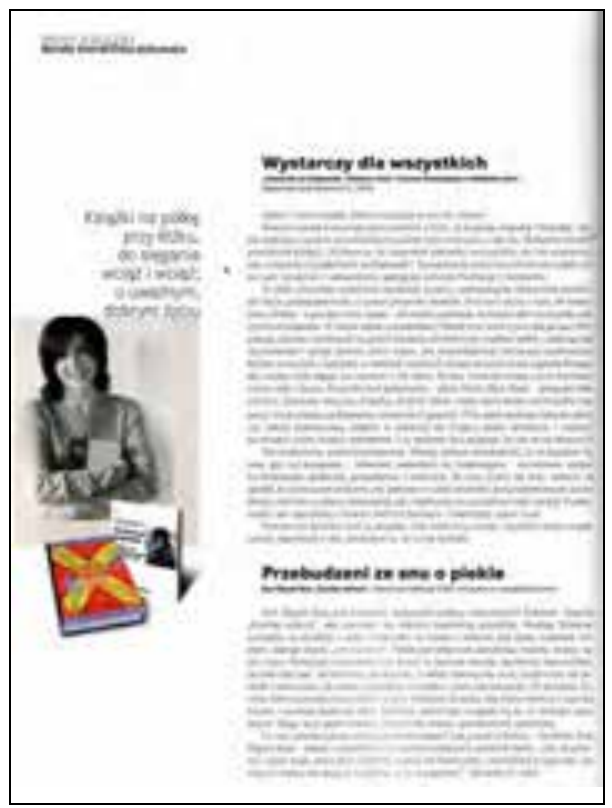

Zdjęcie 91. Przykładowa strona recenzyjna na łamach „Zwierciadła” „Zwierciadło” 2005, nr 4, s. 88

Od numeru 1 (2003) R. Arendt-Dziurdzikowska stała się jednak autorką samodzielnej rubryki, a jej indywidualny charakter podkreślony był przez nazwę: Moje książki. Pomysłodawczyni przyznawała: „nie kupuję biżuterii, 
kupuję książki. 0 tych najpiękniejszych i najważniejszych piszę dla Was"38. Odtąd, aż do ostatniego numeru w 2005 r., czytelnicy odnajdowali propozycje R. Arendt-Dziurdzikowskiej na stronie drukowanej przeważnie tuż przed Nowościami wydawniczymi. Do numeru 11 (2003) omówienia 2-3 książek miały postać odpowiadającym im 2-3 kolumnom na stronie, pojawiało się również zdjęcie recenzentki. Jedyna zmiana odnośnie tej strony nastąpiła od grudnia 2003 r.: recenzje wypoziomowano, zmieniono fotografię recenzentki. Wybrane przykłady, które ukazują opisane zmiany - zob. zdjęcia 90-91 (s. 325).

Strona sprawiała wrażenie surowej: pomimo zdjęcia recenzentki oraz kopii okładek proponowanych książek wyraźnie widać, że w tym przypadku ważniejsze było przedstawienie wybranej lektury niż nacisk na elementy, które dodatkowo miałyby zachęcić do jej przeczytania. Ważne było również krótkie wprowadzenie $\mathrm{w}$ tematykę proponowanych tytułów, nierzadko zawierające wydźwięk osobisty.

\subsection{Zakres i charakter recenzji - przykłady}

W ciągu pięciu lat na łamach „Zwierciadła” zrecenzowano w sumie książki 341 autorów, wśród których znalazło się 243 twórców obcych i 98 polskich (zob. Aneks 30. Autorzy książek recenzowanych na łamach „Zwierciadła" w latach 2001-2005). Biorąc pod uwagę adresata pisma, przeanalizowano zestawienie autorów recenzowanych książek pod względem płci: okazało się, że w 150 przypadkach były to kobiety, w pozostałych 191 mężczyźni. A zatem nie istniał wyraźny związek pomiędzy wspomnianymi czynnikami, nie starano się także w sposób zdecydowany promować kobietautorek. Zwracano jednak uwagę czytelników na książki napisane przez współpracowników pisma. Prezentowano na przykład Siedem boskich pomyłek W. Eichelbergera i R. Arendt-Dziurdzikowskiej, Gorący lód T. Jastruna czy Księgę początku i Czteroletniq filozofkę autorstwa Anny Nasiłowskiej.

Rzadko sięgano częściej niż raz po książkę tego samego autora.

Tendencję do prezentacji kilku tytułów tego samego twórcy widać szczególnie w przypadku Moich książek, gdzie R. Arendt-Dziurdzikowska zaproponowała czytelnikom w badanym okresie 103 tytuły 80 autorów ${ }^{39}$. Jednocześnie specyfika tej rubryki powodowała, że większość nazwisk, jaka się w tym miejscu pojawiała, nie należała do powszechnie znanych,

38 „Zwierciadło” 2003, nr 1, s. 83.

39 Ze względu na charakter tej strony, częściowo omówiono ją oddzielnie. Jednocześnie, ponieważ wyraźnie wpisywała się ona w przesłanie pisma, zdecydowano się scharakteryzować ją jako pierwszą, zaś rubrykę Książki $(\rightarrow$ Nowości wydawnicze) zaprezentowano w dalszej części rozdziału. 
a i wybór lektur podporządkowany był, co należy podkreślić, określonym kryteriom. Były to m.in. książki psychoterapeutów (6 tytułów Irvina Yaloma), psychoanalityków (Clarissa Pinkola Estés: 3 tytuły), psychologów (Kena Wilbera: 3 tytuły), filozofów i mistyków (Anthony'ego de Mello: 3 tytuły), nawiązujące do buddyzmu (Pema Cziedryna: 4 tytuły, Thicha Nhata Hanha: 2 tytuły), a także książki hinduskiego guru, Bhagwana Shree Rajneesha [Osho] (3 tytuły). Były to „Książki o przyjmowaniu wszystkich uczuć, o współczuciu i miłości” 40 , „Książki osobiste, gorące, przemyślane w każdym szczególe"41, o których R. Arendt-Dziurdzikowska pisała z dużym zaangażowaniem, dzieląc się z czytelnikami swoimi osobistymi odczuciami. Nierzadko przybliżała również krótko sylwetkę autora, przytaczała jedną $\mathrm{z}$ opowiedzianych przez niego $\mathrm{w}$ proponowanej książce historii. Z recenzji zamieszczanych $\mathrm{w}$ tym miejscu $\mathrm{w}$ magazynie wyłaniał się stosunkowo spójny obraz. Składały się nań lektury, których autorzy stawiali ważne i nierzadko trudne pytania, dotyczące życia, jego duchowego wymiaru, mówiące zarówno o harmonii, miłości i szczęściu, jak i o cierpieniu, rozpaczy, nietrwałości i zmienności bytu ludzkiego ${ }^{42}$, które wpisywały się w poradnikowo-społeczny charakter pisma. Były to także przeważnie recenzje książek traktujących o potrzebach ducha i ciała, mówiące o ludzkich słabościach i sile człowieka, o jego marzeniach i o tym, jak je realizować, pisane w sposób przystępny i według R. Arendt-Dziurdzikowskiej, ciekawy. Wśród proponowanych tytułów kilkakrotnie pojawiły się lektury, przypominające, że ludzkim życiem rządzi łańcuch przyczynowo-skutkowy i że warto zastanowić się nad kolejnym krokiem, zanim się go zrobi, nad słowem, które może spowodować trudne do przewidzenia skutki, bo „Wszystko jest połączone ze sobą niewidzialnymi nićmi światła”43. Warto za R. Arendt-Dziurdzikowską przytoczyć jedną z historii, opowiedzianych w proponowanej czytelnikom książce:

Pewnego dnia piękna i nieszczęśliwa Anshi gotowała ryż na rodzinny posiłek, kiedy teściowa wściekła się na nią bez istotnego powodu. Synowa wydawała się nie zwracać uwagi na jej przykre słowa, nagle jednak wyciągnęła z ognia kawałek drewna i gwałtownym ruchem wyrzuciła go przez okno: przez przypadek spadł na przechodzącego barana, którego runo zajęło się ogniem. Przerażony baran popędził prosto przed siebie i rzucił się na stóg siana, który też zaczął płonąć. Ponieważ tego dnia wiał silny wiatr, ogień dotarł do obór i stajni. Bydło i konie, uciekając, w zamęcie zniszczyły dom sąsiada. Ten, jako że z natury był człowiekiem

40 R. Arendt-Dziurdzikowska, Moje książki, „Zwierciadło” 2004, nr 12, s. 76.

${ }^{41}$ R. Arendt-Dziurdzikowska, Moje książki, „Zwierciadło” 2003, nr 5, s. 74.

42 Zob. np. R. Arendt-Dziurdzikowska, Zbudować zamek i narobić hałasu, „Zwierciadło” 2004, nr 7, s. 78; eadem, Uwolnić szczęście, ibidem, 2005, nr 12, s. 90; Miłość plus praca, ibidem, 2003, nr 9, s. 74; To lato też przeminie, ibidem, 2004, nr 9, s. 70.

43 R. Arendt-Dziurdzikowska, Nici światła między nami, „Zwierciadło” 2004, nr 5, s. 60. 
mściwym, poszukał zwady z właścicielem koni i tym sposobem, od sąsiada do sąsiada, od wioski do wioski, od prowincji do prowincji, rozprzestrzeniła się wojna, niczym pożar zarośli, i spustoszyła cały kraj. Oto, co może spowodować złość jednej jedynej teściowej44.

Polecany zestaw książek w rubryce, stanowiącej część działu Psychologia, służyć miał zapewne w założeniu poszerzaniu świadomości czytelników, pobudzaniu ich do zastanowienia się nad sprawami najważniejszymi, które, jak przyznawała recenzentka, mogą być czasem „Drażniące, bo wyrywają z błogiej drzemki” 45, ale które czytelnik „Zwierciadła” powinien poznać, ponieważ są to nierzadko „Książki przełomowe, bo przekraczają granicę, poszerzają świadomość” 46 . Czytelnicy mogli w nich znaleźć „Słowa, które uzdrawiają"47, często wtedy, gdy „życie nas przerasta”48. Należy zaznaczyć, że nie wszystkie przedstawiane w tym miejscu lektury były autorstwa psychologów, filozofów czy mistyków. Ale nawet recenzja bestsellera Katarzyny Grocholi niosła ze sobą wyraźne przesłanie: „Nigdy w życiu nie wolno się poddawać" 49 i korespondowała z charakterem innych omówień. Podobnie było w przypadku prezentacji Encyklopedii kompozycji ogrodowych: analogia pomiędzy pielęgnacją roślin a życiem człowieka posłużyła recenzentce do przekazania czytelnikom paru $\operatorname{rad}^{50}$. Zaledwie kilka książek adresowanych było wyraźnie do kobiet ${ }^{51}$; pozostałe propozycje mogły być w równym stopniu skierowane do czytelniczek, jak i do męskiej części odbiorców 52 .

Uwagę czytelników zwracały tytuły, zamieszczanych w omawianej rubryce recenzji. Oto kilka przykładów53: Biały człowiek szydzi, gardzi, pluje; Bogowie się śmiejq̨; Brama dla marzeń; Ciało zna odpowiedź; Czego dusza

${ }^{4}$ Ibidem.

45 Jakkolwiek uwaga ta pojawiła się w jednym z numerów przy recenzji dwóch wybranych książek, to można ją odnieść do większości proponowanych przez R. Arendt-Dziurdzikowską książek. R. Arendt-Dziurdzikowska, „Zwierciadło” 2005, nr 3, s. 84.

46 Zob. przyp. 45.

47 R. Arendt-Dziurdzikowska, Słowa, które uzdrawiaja, „Zwierciadło” 2001, nr 1, s. 83.

48 R. Arendt-Dziurdzikowska, Kiedy życie nas przerasta, „Zwierciadło” 2002, nr 2, s. 85.

${ }^{49}$ R. Arendt-Dziurdzikowska, Nigdy w życiu!, „Zwierciadło” 2001, nr 6, s. 93.

50 R. Arendt-Dziurdzikowska, Ogród jak dusza, „Zwierciadło” 2004, nr 5, s. 60.

51 Zob. np. R. Arendt-Dziurdzikowska, Żeglarzem, okrętem, a nawet oceanem „Zwierciadło” 2005, nr 9, s. 84; eadem: Święte kobiety kochają i cierpiq, ibidem, 2003, nr 12, s. 84.

52 To kolejna specyficzna cecha omawianego magazynu, wcześniej już wspomniana redakcja zamieszczanymi na łamach periodyku treściami, w tym związanymi z książką, starała się zainteresować mężczyzn.

53 Kolejno: „Zwierciadło” 2005, nr 11, s. 86; 2002, nr 4, s. 87; 2005, nr 1, s. 56; 2004, nr 4, s. 68; 2005, nr 7, s. 94; 2001, nr 3, s. 87; 2005, nr 2, s. 70; nr 7, s. 94; 2002, nr 3, s. 97; nr 1, s. 83; 2004, nr 12, s. 76; 2001, nr 7, s. 91; 2003, nr 6, s. 96; 2005, nr 5, s. 88; 2004, nr 5, s. $60 ; 2005$, nr 8, s. $66 ; 2003$, nr 12, s. $84 ; 2004$, nr 8, s. 74; 2001, nr 1, s. 83; 2003, nr 7, s. 100; 2004 , nr 2, s. 66; 2005, nr 6, s. 100-101. 
zapragnie; Czy jesteś wojownikiem światła?; Czy zdążyłam powiedzieć, że cię kocham?; Dusza spotyka... wielkq truskawkę; Fala jest morzem; JA jest złudzeniem; Marzyć, czyli zmieniać; Mieć czy być?; Miła albo zdrowa; Mój przyjaciel gepard, mój brat słoń; Nici światła między nami; Nieugięci pijq słodkq rosę; Odwaga to strach, który umie się modlić; Podq̨żý za zdarzonkiem; Słowa, które uzdrawiajq; Smakołyki dla ducha; $W$ świecie bez lęku; Złość to czerwono-żółty wesoły stworek.

Książki omówione przez R. Arendt-Dziurdzikowską pochodziły z oferty 44 edytorów. Najczęściej proponowała ona tytuły Agencji Wydawniczej Jacka Santorskiego, psychologa i psychoterapeuty (19) oraz Gdańskiego Wydawnictwa Psychologicznego (10 propozycji). Zwraca uwagę również liczba recenzowanych książek Wydawnictwa W.A.B. (9), które nie specjalizowało się bynajmniej w edycji preferowanych w rubryce tekstów. Takie propozycje oferował m.in. Buddyjski Dom Wydawniczy, Fundacja Centrum Kabbalah czy Związek Buddystów Zen „Bodhidharma” - książki przez nich wydane określały kierunek zainteresowań R. Arendt-Dziurdzikowskiej (zob. Aneks 31. Wydawcy książek recenzowanych na łamach „Zwierciadła” w latach 2001-2005. Strona recenzyjna: Moje książki).

Ta rubryka miała jednoznacznie określony charakter, a książki w niej prezentowane, co zostało już podkreślone, tworzyły jednolity obraz, niosący przesłanie, wpisujące się $\mathrm{w}$ ideologię pisma, widoczną także $\mathrm{w}$ innych tekstach, zamieszczanych na jego łamach.

Inny charakter miała podstawowa rubryka recenzyjna, jaką były Nowości wydawnicze (wcześniej znana czytelnikom jako Ksiq̨żki). Jak już wspomniano, początkowo zajmowała ona jedną stronę działu kulturalnego, później jej objętość zwiększono do dwóch stron. Do numeru lutowego w 2003 r. w tym miejscu pojawiały się wyłącznie recenzje odredakcyjne, później eksperymentowano z różnymi rozwiązaniami i propozycjami, jak choćby (przypomnijmy) z rekomendacjami pochodzącymi od znanych osób, które zgodziły się podzielić się z czytelnikami „Zwierciadła” opinią na temat swoich ulubionych lektur.

Recenzje odredakcyjne pochodzące najpierw od M. Boratyńskiej-Komar, później J. Klimczyk, a następnie M. Mizuro, obejmowały bardzo zróżnicowane lektury, aczkolwiek należy zaznaczyć, że owa różnorodność była niezależna od zmian na stanowisku recenzenta (-ek). W grupie książek, które pojawiły się $\mathrm{w}$ ciągu 5 lat $\mathrm{w}$ ramach tej rubryki, bardzo rzadko odnaleźć można było tytuły znane, a jeszcze rzadziej goszczące na listach bestsellerów. Świadczy o tym zarówno zestawienie nazwisk autorów, jak i fakt, że czytelnik rzadko poznawał więcej niż jeden tytuł tego samego twórcy. Tak zdarzyło się zaledwie w kilku przypadkach: dwukrotnie w omówieniach pojawili się pisarze zarówno znani szerszemu gronu odbiorców (m.in. Anna Bojarska, Paweł Huelle, Maria Janion, Roma Ligocka, 
Joyce C. Oates, Sue Townsend, Janusz L. Wiśniewski ${ }^{54}$ ), jak i tacy, o których większość czytelników słyszała zapewne po raz pierwszy (m.in. Elizabeth Abbott, Majgull Axellson, Cuca Canals, Sándor Márai) ${ }^{55}$. Tezę tę potwierdza pełne zestawienie nazwisk: obok m.in. Williama Whartona pojawiają się m.in. Tsultrim Allione, Alain Ayache, Quentin Bell, Matthias van Boxsel, Saint Bris Gonzaque, Suzanne Brøgger, Gibran Khalil Gibran, Jhumpa Lahiri, Ignacio Padilla, Pramoedya Ananta Toer, Banana Yoshimoto.

Nieco lepiej pod tym względem prezentował się przegląd nazwisk pisarzy polskich. Tu, pomimo różnego charakteru uprawianej przezeń twórczości, pojawiały się znacznie częściej nazwiska szerzej znane, choć, jak się zdaje, wynikało to raczej z faktu, że na polskim rynku wydawniczym trudno było młodym, nieznanym twórcom zadebiutować. Stąd pisano o książkach pisarzy już „sprawdzonych”, m.in. Małgorzaty Domagalik, Agnieszki Graff, Wojciecha Kuczoka, Andrzeja Stasiuka. Ale z drugiej strony, nie zapomniano jednak o Leniwych maskotkach, rekinach na smyczy, Tomasza Szlendaka czy Niejasnej sytuacji na kontynencie. Prywatnym przewodniku po różnych stronach świata Krzysztofa Środy, choć były to jednostkowe przypadki.

Przyglądając się książkom prezentowanym w tym miejscu, trudno jest (w przeciwieństwie do rubryki Moje książki) wskazać zdecydowane i jednolite kryteria, spajające całą grupę czy określić założenia, jakimi kierowały się recenzentki.

W wielu przypadkach polecano powieści, których bohaterowie uwikłani byli w trudne sytuacje życiowe bądź ich przeszłość naznaczona była piętnem, tajemnicą, cierpieniem, dramatem, z którym musieli zmierzyć się $\mathrm{w}$ dorosłym życiu. J. Klimczyk $\mathrm{w}$ odniesieniu do jednej $\mathrm{z}$ takich lektur napisała: „Nie sposób krótko streścić tej książki” 56 i wydaje się, że to stwierdzenie jest adekwatne do wielu proponowanych $\mathrm{w}$ tym miejscu tytułów. Spotykamy na przykład Cecylię, bohaterkę Daleko od Niflheimu (M. Axelsson), której spokojne z pozoru życie zakłóca „piekło wspomnień”. Zostaje zmuszona do bolesnego rozrachunku z przeszłością ${ }^{57}$. Poznajemy bezimienną postać z powieści Fleur Jaeggy (Proleterka), w życiu której „Echa historii rodziny - rozbitego małżeństwa rodziców, smutnego dzieciństwa w domu zaborczej i nieczułej babki, bankructwa ojca, wreszcie obyczajowego skandalu związanego z matką - nieustannie powracają"58. Spotkanie dwojga „naznaczonych”: Anelli (piętno pochodzenia żydowskiego, ciężar splątanych losów rodzinnych) i Vernora (kolor skóry, który na początku lat 60. XX w., w czasach, gdy toczy się akcja powieści, był wystarczającym

${ }^{54}$ W każdym z przypadków nazwisko pisarza znalazło się w rubryce dwukrotnie.

55 Poza pierwszą pisarką, której nazwisko pojawiło się w recenzjach trzykrotnie, w pozostałych przypadkach zdarzyło się tak dwukrotnie.

56 J. Klimczyk, Urok perwersji, „Zwierciadło” 2003, nr 10, s. 91.

57 J. Klimczyk, Piekło wspomnień, „Zwierciadło” 2003, nr 12, s. 86.

58 J. Klimczyk, Wyprawa w pamięć, „Zwierciadło” 2004, nr 2, s. 64. 
powodem, by skazać człowieka na ostracyzm), to tło kolejnej książki, proponowanej czytelnikom pisma ${ }^{59}$.

Wśród propozycji książkowych odnaleźć można także biografie (lub pretendujące do tego miana tytuły) znanych, nieprzeciętnych osób. Na przykład M. Boratyńska-Komar proponowała historię Juana i Evity Perón (Clive Foss) ${ }^{60}$, J. Klimczyk polecała biografię Virginii Woolf autorstwa Quentina Bella61. M. Mizuro zachęcała do sięgnięcia po Filozofię Andy'ego Warhola od A do B i z powrotem, pióra samego artysty62, a także do przeczytania książki o Dorocie Terakowskiej (K. T. Nowak) ${ }^{63}$.

Interesującą grupę książek stanowią propozycje powieści sensacyjnych z wątkiem kryminalnym (m.in. Ławka 102, Fred Vargas; Zniknięcie Patò, Andrea Camilleri; Kobieta ze śniegu, Leena Lehtolainen; Pierrot mon ami, Raymond Queneau), a także lektury wyraźnie adresowane do płci pięknej, choć o zgoła różnym charakterze, poczynając od klasyki feminizmu (Kobiecy eunuch Germaine Greer), poprzez Gender dla średnio zaawansowanych. Wykłady szczecińskie (Inga Iwasiów), Nasze ciała, nasze życie (oprac. B. Smoleń, E. Tomaszewicz), a kończąc na Siostrzanych uczuciach (M. Domagalik) czy książce, określonej jako „obowiązkowa lektura dla każdej z nas”64, czyli Nie wiem, jak ona to robi (Allison Pearson).

Kilkakrotnie polecano także albumy i książki z przepisami kucharskimi (np. Podróż po stołach Francji Ludwika Lewina). Czytelnicy mogli poznać również opinię recenzentek „Zwierciadła” na temat kilku wybranych wydań o charakterze encyklopedycznym, jak choćby Historię filmu Jerzego Płażewskiego czy Janusza Daneckiego kompendium wiedzy poświęcone Arabom, albo leksykon Grażyny Stachówny Polański od A do Z. Proponowano też m.in. literaturę faktu (Afganka, dziennik pielęgniarki Karli Scheffer), zbiory felietonów (Kultura obrażonych Izabeli Filipiak) i eseje (Żyjąc tracimy życie Marii Janion).

Powyższy przegląd lektur potwierdza postawioną wcześniej tezę: książki proponowane $\mathrm{w}$ tej rubryce stanowiły konglomerat różnych typów, jednocześnie zaś w dużej mierze były promocją autorów mniej znanych.

Od strony formalnej można jednak wyodrębnić kilka wspólnych dla tych omówień elementów. Są nimi: streszczenie głównych wątków prezentowanej książki (najobszerniejsze czytelnicy zawdzięczali J. Klimczyk), rzadziej kilka zdań na temat autora (głównie w kontekście jego dotychcza-

59 J. Klimczyk, Szukając samej siebie, „Zwierciadło” 2004, nr 5, s. 58.

60 M. Boratyńska-Komar, Ponadto polecamy, „Zwierciadło” 2002, nr 5, s. 78.

61 J. Klimczyk, Virginia i inni, „Zwierciadło” 2004, nr 7, s. 83.

62 M. Mizuro, A jednak geniusz?, „Zwierciadło” 2005, nr 9, s. 87.

63 M. Mizuro, Moja mama czarownica, „Zwierciadło” 2005, nr 12, s. 93.

${ }^{64}$ J. Klimczyk, Między praca a domem, „Zwierciadło” 2004, nr 1, s. 55. Powieść o kobiecie, której udaje się łączyć obowiązki zawodowe z macierzyństwem. 
sowych osiągnięć literackich, przywoływanie nagród, które zdobył) ocena (w niemal wszystkich przypadkach pozytywna, by nie powiedzieć, euforyczna, przy czym najbardziej osobistymi wrażeniami dzieliła się M. Komar-Boratyńska) i opis bibliograficzny, najpełniejszy, biorąc pod uwagę wszystkie recenzje, pomieszczane na różnych stronach periodyku. Poza autorem i tytułem recenzowanej książki pojawiało się tu miejsce wydania, nazwa wydawcy i rok wydania, a także nazwisko tłumacza w przypadku przekładu oraz liczba stron proponowanej lektury. Stałym elementem była także kopia okładki recenzowanej książki, zazwyczaj starannie wyeksponowana.

Poza trzema przypadkami omówienia zawierały oceny pozytywne, a nierzadko wręcz bardzo pochlebne. Czytelnik dowiadywał się, że polecana książka jest „interesująca”, „pasjonująca”, „poruszająca”, „świetna”, „warta naszego wysiłku”, „zabawna”, „znakomita”. Nierzadko okazywało się, że według recenzentki daną książkę „czyta się świetnie”65, kolejna „urzeka od pierwszej do ostatniej strony"66, a o jeszcze innej odbiorca mógł przeczytać, że „Pesymistyczna wymowa tej opowieści złagodzona została przez jej nieodpartą poetycką urodę, w której warto się zanurzyć" ${ }^{67}$. Natomiast Długa droga $w$ dół Nicka Hornby została określona przez M. Mizuro jako „antydepresyjna pigułka. Do zażycia natychmiast, choćby profilaktycznie"68.

Niektóre z tytułów recenzji zamieszczanych w tej rubryce były sygnałem dotyczącym treści proponowanej książki, inne przyciągały wzrok dzięki zabawnemu lub intrygującemu sformułowaniu. Oto kilka wybranych przykładów69: 80 dag treści; Być kobietą; Dogonić marzenia; Dźwięki i głosy; Europejka z kłami; Faceci na fastrygę; Kobiecość nabyta; Książka o Tobie; Książka dla wszystkich?; Mała czarna, duży kant; Miłość, wiatr i szachownica; O sensie i absurdalności życia; Po jakiej drabinie się wspinasz?; Pochwała kobiet; Wokulski evergreen; Wszystkie litery alfabetu; Żyję znaczy czytam [pis. oryg.].

Książki przedstawione $\mathrm{w}$ omawianej rubryce pochodziły $\mathrm{z}$ oferty 62 wydawców ${ }^{70}$ (zob. Aneks 32. Wydawcy książek recenzowanych na łamach „Zwierciadła” w latach 2001-2005. Strona recenzyjna: Książki $\rightarrow$ Nowości

65 M. Boratyńska-Komar, Zmrożone brzoskwinie, „Zwierciadło” 2003, nr 2, s. [86].

66 M. Mizuro, Nieuleczalny przypadek melancholii, „Zwierciadło” 2005, nr 7, s. 97.

67 M. Mizuro, Węgierski dryf, „Zwierciadło” 2005, nr 3, s. 87.

68 M. Mizuro, Byli sobie desperaci, „Zwierciadło” 2005, nr 6, s. 102.

${ }^{69}$ Kolejno: „Zwierciadło” 2005, nr 2, s. 72; 2002, nr 5, s. 78; 2001, nr 8, s. 73; 2004, nr 3, s. 91; 2005, nr 8, s. 69; 2003, nr 4, s. 78; nr 11, s. 93; nr 12, s. 86; 2005, nr 5, s. 91; nr 3, s. 87; 2003, nr 9, s. 76; 2002, nr 5, s. 78; nr 4, s. 30; nr 7, s. 84; 2003, nr 11, s. 94; 2004, nr 2, s. 64; 2003, nr 4, s. 78.

$70 \mathrm{~W} 17$ przypadkach nie podano nazwy wydawcy. Jednak na potrzeby pracy sprawdzono brakujące informacje, wykorzystując jedną z baz bibliograficznych Biblioteki Narodowej („Przewodnik Bibliograficzny”), www.bn.org.pl, kwiecień 2011. W jednym przypadku nie ustalono wydawcy. 
wydawnicze). W tabeli 41 przedstawiono tych edytorów, po ofertę których recenzentki Ksiq̨żek ( $\rightarrow$ Nowości wydawniczych) sięgały najczęściej.

Tabela 41. Wydawcy książek najczęściej recenzowanych na łamach „Zwierciadła” w latach 2001-2005

\begin{tabular}{|l|c|}
\hline \multicolumn{1}{|c|}{ Nazwa wydawcy } & Liczba tytułów \\
\hline Wydawnictwo W.A.B. & $33^{a}$ \\
\hline Dom Wydawniczy REBIS & 22 \\
\hline Społeczny Instytut Wydawniczy Znak & 20 \\
\hline Wydawnictwo Prószyński i S-ka & 19 \\
\hline Wydawnictwo Muza & 17 \\
\hline $\begin{array}{l}\text { Wydawnictwo Literackie } \\
\text { Czytelnik }\end{array}$ & 16 \\
\hline Wydawnictwo Albatros & $14^{b}$ \\
\hline Wydawnictwo Czarne & 12 \\
\hline Jacek Santorski \& CO Agencja Wydawnicza & 11 \\
\hline
\end{tabular}

${ }^{a}$ Jeden tytuł w koedycji z Wydawnictwem Albatros A. Kuryłowicz.

${ }^{b}$ Jeden tytuł w koedycji z Wydawnictwem W.A.B.

Źródło: badania własne.

Jak wynika z tabeli 41, 33 tytuły recenzowane w omawianej rubryce były propozycjami Wydawnictwa W.A.B., o 11 mniej pochodziło z oferty Domu Wydawniczego REBIS. Zatem czytelnik „Zwierciadła” mógł przekonać się, że obydwie oficyny wydawały nie tylko książki znanych i uznanych pisarzy, ale nie wahały się w nawiązaniu współpracy także z twórcami mało popularnymi, który nazwiska (przynajmniej w Polsce) nie były rozpoznawalne przez większość odbiorców.

Interesujące wydaje się spostrzeżenie, że w tabeli 41 znalazła się również Agencja Wydawnicza Jacek Santorski \& CO, przywołana także przy rubryce Moje książki. Z mniej znanych edytorów pojawiły się m.in. wydawnictwa: Anagram, Bis, Palabra, Poemat, Pogranicze, Solura, a także Fundacja Krakowska Alternatywa.

Należy jeszcze wspomnieć o recenzjach, drukowanych w innych, poza wspomnianymi dwoma, rubrykach.

I tak, w ramach rekomendacji w rubryce Poleca..., zamieszczanej na stronach Nowości wydawniczych pojawiło się w sumie 25 opinii na temat książek wybranych przez znane osoby. Wśród rekomendujących znaleźli się m.in. pisarze i poeci (Ewa Lipska, Izabela Sowa, Andrzej Stasiuk, Janusz L. Wiśniewski), wydawcy (Tomasz Brzozowski, Jacek Santorski), aktorzy (Dorota Segda, Joanna Szczepkowska), dziennikarz i krytyk filmowy (Tadeusz Sobolewski). Ich opinie obejmowały kilkanaście zdań, które uzupełniała kopia okładki proponowanej książki i niepełne w tym przypadku dane bibliograficzne (nierzadko na przykład zapominano o podaniu nazwiska 
tłumacza w przypadku przekładu) oraz zdjęcie osoby rekomendującej. Ta forma informacji pojawiała się na łamach pisma od numeru 2 (2003) do $\mathrm{nr} 9$ (2005).

Pięciokrotnie wydrukowano także recenzje pochodzące od czytelników. Stanowiły one wynik ogłoszonego przez pismo konkursu, dlatego zostaną bliżej scharakteryzowane $\mathrm{w}$ dalszej części rozdziału.

W 15 przypadkach pojawiła się również informacja o książce w ramach innych działów/rubryk: Co słychać?, Do zobaczenia, Krótko, Preteksty, Sztuka życia, Zdrowie. Poza słowem od redaktor naczelnej (Do zobaczenia) omówienia drukowane w tych miejscach miały postać krótkich notek, opatrzonych podstawowym opisem bibliograficznym i zazwyczaj kopią okładki proponowanej książki. Znaleźć tu można było na przykład wzmiankę o Słowniku ojczyzny-polszczyzny Jana Miodka czy Blondynce wśród łowców tęczy Beaty Pawlikowskiej.

Reasumując, najobszerniejsze omówienia drukowano w dwóch przeznaczonych na to miejscach: pierwsze znajdowało się w dziale Psychologia, drugie systematycznie odnaleźć można było obok innych informacji dotyczących kultury, na stronie zatytułowanej Książki ( $\rightarrow$ Nowości wydawnicze). W obydwu przypadkach wspólnymi elementami była wyraźnie wyeksponowana kopia okładki proponowanej książki oraz dane bibliograficzne, dokładniejsze jednak w przypadku Ksiq̨żek ( $\rightarrow$ Nowości wydawniczych). Dodatkowym elementem Moich ksiq̨żek było natomiast zdjęcie recenzentki, R. Arendt-Dziurdzikowskiej. Podobizna autora recenzji pojawiała się również w rubryce Poleca..., co było udanym pomysłem, przyciągającym uwagę czytelników.

Należy podkreślić staranność w przygotowaniu każdej z opisanych rubryk, zaś pewne niedociągnięcia (jak na przykład brak nazwiska tłumacza w przypadku większości tytułów proponowanych przez R. Arendt-Dziurdzikowską) rekompensowano w pewnym stopniu merytoryczną wartością samej recenzji. Omówienia książek stanowiły ważną część pisma, były starannie dopracowane, chociaż w przypadku podstawowej rubryki, jaką były Nowości wydawnicze, zabrakło wyraźnego kierunku czy wspólnego obrazu, który wyłaniałby się ze stron proponowanych książek.

\subsubsection{Czarownik swojego plemienia ${ }^{71}$ : wywiady}

Na łamach „Zwierciadła” w ciągu 5 lat pojawiło się 58 wywiadów z osobami bezpośrednio lub pośrednio związanymi z literaturą. Oto, jak przedstawiała się ich liczba w poszczególnych latach - tabela 42.

71 Tytuł wywiadu, zob. „Zwierciadło” 2005, nr 10, s. [46]-51. 
Tabela 42. Wywiady z osobami związanymi ze światem literatury, zamieszczane na łamach „Zwierciadła” w latach 2001-2005

\begin{tabular}{|c|c|}
\hline Rok & Liczba wywiadów \\
\hline 2001 & 6 \\
\hline 2002 & 8 \\
\hline 2003 & 10 \\
\hline 2004 & 11 \\
\hline 2005 & 23 \\
\hline Ogółem & 58 \\
\hline
\end{tabular}

Źródło: badania własne.

Wraz z każdym rokiem wzrastała liczba interesujących nas wywiadów, co wpisywało się $\mathrm{w}$ rosnące $\mathrm{z}$ upływem badanego czasu zainteresowanie redakcji sprawami książki, a szerzej: literatury.

Rozmowy drukowano przede wszystkim w ramach takich działów, jak: Naprawdę jaki jesteś, Pełnq Parq, Spotkania (w ich obrębie zamieszczano cykl Pytań do dwojga), rzadziej na stronach poświęconych Wychowaniu czy w sporadycznie pojawiającym się dziale Rozmowa. Wywiady przeprowadzali m.in.: Renata Arendt-Dziurdzikowska, Magdalena Banach, Tatiana Cichocka, Alina Gutek, niekiedy również Tomasz Jastrun oraz Jerzy Wróblewski.

Ta forma prezentacji twórców zajmowała zazwyczaj od dwóch do ośmiu stron, chociaż pojawił się (raz) również wywiad 10-stronicowy ${ }^{72}$. Obok wprowadzenia, stanowiącego zazwyczaj krótką charakterystykę danej osoby, w tekście zamieszczano także jej zdjęcia.

Redakcja wybierała głównie znanych twórców. Wśród nich znaleźli się m.in.: Marta Fox, Hanna Krall, Roma Ligocka, Amos Oz i Jerzy Pilch (zob. Aneks 33. Nazwiska osób związanych z książką, z którymi przeprowadzono wywiady na łamach „Zwierciadła” w latach 2001-2005). Tematem przewodnim była najczęściej twórczość danego autora, przy czym starano się dowiedzieć, $\mathrm{w}$ jakim stopniu stanowi ona odzwierciedlenie życia pisarza. Pytano także o inne, poza literackimi, zainteresowania. I tak na przykład, czytelnicy dowiedzieli się, jakie słabości ma i w co wierzy autor Pod Mocnym Anio$\nmid_{e m^{73}}$, a co na temat męskiej przyjaźni sądzi Mirosław Czyżykiewicz ${ }^{74}$.

72 Przeprowadzony był on z A. Bojarską i jej partnerem życiowym, Georgesem Rutowiczem, zob. „Zwierciadło” 2002, nr 7, s. 16-25.

73 „Zwierciadło" 2001, nr 1, s. 27.

74 „Zwierciadło” 2004, nr 1, s. [3]. Numer damsko-męski. 
O swych książkach opowiadali m.in. Marta Fox, Wojciech Tochman i Agata Tuszyńska.

Cechą, która zdawała się wpisywać w formułę pisma kobiecego, były podwójne wywiady, przeprowadzane na przykład ze znanym pisarzem i jego żoną/partnerką życiową. Bohaterami takich rozmów byli m.in. Jonathan i Beverly Carroll, Paulo Coelho i Christina Oiticica, Henryk i Ewa Sawkowie, William Wharton i Rosemary du Aime. W takich przypadkach pytano przeważnie o okoliczności, w jakich przyszła para się spotkała, co sprawiło, że zwrócili oni na siebie uwagę, jak wygląda ich codzienne życie, jak radzą sobie z problemami, a ponieważ bohaterami owych wywiadów były przeważnie pary mające za sobą wiele wspólnych lat, nieodmiennie pytano również o receptę udanego związku. J. Carroll wyznał:

Ludzie się zmieniają. Po 30 latach wspólnego życia my też jesteśmy trochę innymi osobami niż wtedy, gdy się poznawaliśmy. Wszystko polega na szczęściu. Jeśli się je ma, miłość nie gaśnie. Akceptujemy te zmiany, razem się uczymy, wciąż nawzajem się poznajemy. To ożywia związek ${ }^{75}$.

\section{Z kolei P. Coelho stwierdził:}

Jeśli ludzie naprawdę się kochają, nic nie jest w stanie zagrozić ich związkowi. Dobry związek wymaga czegoś więcej niż ciężkiej pracy. Trzeba umieć dawać sobie miłość76.

Poruszające wyznania czytelnicy odnaleźli $\mathrm{w}$ rozmowie $\mathrm{z}$ autorem $W$ księżycowa jasną noc i jego żoną. W obliczu choroby W. Whartona i zbliżającej się śmierci, jego żona mówiła:

I znów czekają mnie samotne podróże, bo on nigdy nie lubił się ruszać z domu. Ale przecież zawsze będziemy razem, tylko że Bert będzie gdzie indziej ${ }^{77}$.

Wymowa zamieszczanych wywiadów, szczególnie owych Pytań do dwojga, wpisywała się w poradnikowy, a z drugiej strony, optymistyczny charakter pisma. $\mathrm{W}$ obliczu problemów należy ze sobą rozmawiać, mówił bohater jednego z wywiadów. „Bez rodziny, bez tego spokoju ducha, jaki mam, bez komfortu psychicznego, jaki mi daje, nigdy bym tego [sukcesu - przyp. M.P.S.] nie osiągnął"78 stwierdził inny. Wartości, podkreślane przez periodyk widoczne były zatem także w tej formie informacji o książce.

75 Beverly i Jonathan Carroll w rozmowie z Januszem Wróblewskim, „Zwierciadło” 2003, nr 2, s. 23.

${ }^{76}$ Christina Oiticica, Paulo Coelho, rozm. B. Półtorak, „Zwierciadło” 2002, nr 5, s. 20.

77 Z Williamem Whartonem i jego żonq Rosemary du Aime rozmawia Renata Arendt-Dziurdzikowska, „Zwierciadło” 2002, nr 11, s. [37].

78 Pytania do dwojga. Henryk i Ewa Sawkowie, „Zwierciadło” 2002, nr 9, s. 19. 
I w tym przypadku widać zainteresowanie magazynu kwestiami związanymi z psychologią i wychowaniem. Z Anną M. Nowakowską, terapeutką znaną czytelnikom pisma $\mathrm{z}$ Pracowni Psychospołecznej Zwierciadło, autorką książki Przeklęte, rozmawiała Renata Arendt-Dziurdzikowska. Natomiast partnerem w innej rozmowie był Andrzej Samson. Pretekstem do spotkania było wznowienie w owym czasie jednej z jego książek: 20 tysięcy godzin w budzie. $O$ szkole, uczniowskim losie i paru innych sprawach ${ }^{79}$.

Z okazji zakończenia Roku Andersenowskiego (2005) do rozmowy zaproszono Bogusławę Sochańską, dyrektor Duńskiego Instytutu Kultury, autorkę nowego przekładu baśni autora Królowej Śniegu. Z jej opowieści wyłoniła się postać wielkiego pisarza, jednocześnie człowieka trudnego, egotycznego, który „padł ofiarą własnego talentu”" ${ }^{00}$, ale był też „bardzo piękny w swoim nieustannym zachwycie nad światem, począwszy od listka, skończywszy na bliźnim"81.

Innym przykładem, odzwierciedlającym zdecydowaną politykę pisma w zakresie promowania literatury i czytelnictwa, była dwukrotna rozmowa z Ireną Koźmińską, założycielką Fundacji „ABC XXI - Program Zdrowia Emocjonalnego", inicjatorką kampanii Cała Polska czyta dzieciom ${ }^{82}$, a także wywiad z Grzegorzem Leszczyńskim, literaturoznawcą, specjalistą od literatury dziecięcej ${ }^{33}$. Obydwoje podkreślali znaczenie książki w życiu dziecka, wskazując na rolę rodziców w rozbudzaniu i kształtowaniu jego potrzeb czytelniczych. Doradzali, jaka lektura jest dla niego najodpowiedniejsza i czym kierować powinni się rodzice w doborze zestawu tytułów dla swoich pociech. Autor Magicznej biblioteki: zbójeckich ksiąg młodego wieku stwierdził wręcz, że „Potrzeba czytania jest typowo ludzką potrzebą. Jeśli ktoś jej nie odczuwa, to znaczy, że nie jest człowiekiem. A jego dramat polega na tym, że nie zdaje sobie z tego sprawy"84. „Żeby zmieniły się dzieci, muszą zmienić się dorośli" - takim z kolei spostrzeżeniem podzieliła się z czytelnikami pisma I. Koźmińska ${ }^{85}$, opowiadając także o głównych założeniach realizowanej przez siebie akcji.

Magazyn zainicjował również cykl interesujących rozmów z poetami, drukowany w ramach rubryki Poezja rozbierana. Po raz pierwszy informacja na ten temat pojawiła się w majowym numerze w 2005 r. Redakcja pisała:

79 „Zwierciadło” 2004, nr 2, s. 84-87.

80 Baśń jego życia, rozm. T. Cichocka, „Zwierciadło” 2005, nr 12, s. 105.

81 Ibidem, s. 106.

82 Zacznijmy od czytania, rozm. A. Gutek, „Zwierciadło” 2001, nr 11, s. 44-47.

${ }^{83}$ Książka rozbudza człowieka w człowieku, rozm. A. Gutek, „Zwierciadło” 2003, nr 7, s. [110]-113. I. Koźmińska została laureatką Kryształowego Zwierciadła, nagrody przyznanej przez magazyn w $2004 \mathrm{r}$.

84 Ibidem, s. 111.

85 Zacznijmy od..., s. 45. 
Chcemy Was zachęcić do starej jak świat, choć nieco już zarzuconej aktywności - wspólnego czytania wierszy. [...] 0 jeden wybrany wiersz pytamy jego autora/autorkę. Pedantycznie przeglądamy strofę za strofą, rozbieramy wers z wersem, w poszukiwaniu rzeczywistych pierwowzorów osób, rzeczy, uczuć, sytuacji... Mamy nadzieję, że za każdym razem coś wspólnie odkryjemy ${ }^{86}$.

Pomysł kontynuowano do końca badanego okresu. 0 okolicznościach powstania danego utworu opowiedzieli czytelnikom „Zwierciadła”: Julia Hartwig, Ryszard Kapuściński, Ryszard Krynicki, Ewa Lipska, Jarosław Mikołajewski, Anna Piwkowska, Marcin Świetlicki i Adam Zagajewski.

Wywiady były formą chętnie używaną przez redakcję w celu przybliżania czytelnikom postaci związanych z książką, a trafnie dobrane pytania powodowały, że były to rozmowy, z którymi odbiorca zapoznawał się $\mathrm{z}$ dużym zainteresowaniem.

\subsubsection{Twoja książka, Twoja wiedza ${ }^{87}$ : reklamy książek}

Na łamach „Zwierciadła” odnaleźć można również ogłoszenia. W porównaniu z prezentowaną wcześniej prasą opinii ich liczba jest skromna: w ciągu 5 lat pojawiło się 287 reklam ${ }^{88}$, które nawiązywały do zagadnień, ujętych w tytule książki. Można wyróżnić następujące kategorie, które się doń kwalifikują:

1) książki,

2) akcje tygodnika związane z książką ${ }^{89}$,

3) prasa, w tym autoreklama ${ }^{90}$.

Spośród 287 reklam 150 stanowiły ogłoszenia wydawnicze, 76 miało charakter autopromocji związanych z inicjatywami periodyku, a 61 dotyczyło reklam innych czasopism oraz akcji odnoszących się do promocji prasy.

W tabeli 43 przedstawiono liczbę inseratów wydawniczych w każdym $\mathrm{z}$ badanych roczników.

86 [br. aut.], Po, „Zwierciadło” 2005, nr 5, s. 36.

87 Hasło reklamowe, zamieszczone w jednym z inseratów wydawniczych. Zob. „Zwierciadło" 2004, nr 8, s. 43.

88 Reklama, podobnie jak było to w odniesieniu do prasy opinii, jest w tym przypadku rozumiana jako tytuł, liczony także wówczas, jeśli pojawił się powtórnie.

89 Ta kategoria przyjmowała postać zarówno reklam, jak i tekstu komentującego, stąd zostanie omówiona w dalszej części rozdziału (Tę książkę warto znać: inne formy informacji o książce).

90 Zagadnienie dotyczące informacji o prasie na łamach prezentowanego pisma zostanie dokładniej przedstawione w ostatniej części rozdziału. 
Tabela 43. Reklamy wydawnicze zamieszczone na łamach „Zwierciadła” w latach 2001-2005

\begin{tabular}{|c|c|}
\hline Rok & Liczba inseratów książkowych \\
\hline 2001 & 58 \\
\hline 2002 & 57 \\
\hline 2003 & 23 \\
\hline 2004 & 10 \\
\hline 2005 & 2 \\
\hline Ogółem & 150 \\
\hline
\end{tabular}

Źródło: badania własne.

Od 2003 r. liczba reklam wyraźnie malała, by dwa lata później ograniczyć się do zaledwie dwóch inseratów, w dodatku promujących książki Wydawnictwa Zwierciadło.

W ogłoszeniach pojawiło się 90 nazwisk autorów, 110 tytułów, pochodzących $\mathrm{z}$ oferty 16 wydawców ${ }^{91}$. Najwięcej propozycji przedstawiło Gdańskie Wydawnictwo Psychologiczne (42) i Wydawnictwo Kurpisz SA (41), Wydawnictwo „Książka i Wiedza” (12) oraz Wydawnictwo Prószyński i S-ka (11). (Pełne zestawienie - zob. Aneks 34. Wydawcy reklamujący książki na łamach „Zwierciadła” w latach 2001-2005).

Bardzo rzadko tytuły powtarzały się: najwięcej, bo trzykrotnie, trafiła do czytelnika reklama proponująca sięgnięcie po Aniołka (Beaty Pawlak, Wydawnictwo Prószyńki i S-ka), Pana Tadeusza (dwukrotnie propozycję taką zamieściło Wydawnictwo Kurpisz SA i raz Wydawnictwo „Książka i Wiedza") oraz Wielkq encyklopedię PWN. Większość pozostałych edytorów ograniczała się do jednorazowego przedstawienia danego tytułu, rzadziej przywołując tę samą ofertę po raz drugi. Nieco inaczej przedstawiała się powtarzalność nazwisk autorów reklamowanych książek. W tabeli 44 zaprezentowano nazwiska tych twórców, których nazwiska pojawiały się najczęściej (zob. Aneks 35. Autorzy książek reklamowanych na łamach „Zwierciadła” w latach 2001-2005).

91 Wobec stosunkowo niewielkiej liczby edytorów zrezygnowano w tym przypadku z tabeli, prezentującej tych z nich, którzy najczęściej gościli na łamach pisma, ograniczając się do podania danych statystycznych w tekście opisowym. 
Tabela 44. Autorzy książek reklamowanych przez wydawców (więcej niż 1 tytuł) na łamach „Zwierciadła” w latach 2001-2005

\begin{tabular}{|l|c|c|l|}
\hline \multicolumn{1}{|c|}{ Nazwisko autora } & Liczba inseratów & Liczba tytułów & Tytuły reklamowanych książek \\
\hline Bolesław Prus & 2 & 2 & $\begin{array}{l}\text { Lalka } \\
\text { Chłopi }\end{array}$ \\
\hline Stefan Żeromski & 2 & 3 & $\begin{array}{l}\text { Ludzie bezdomni } \\
\text { Syzyfowe prace } \\
\text { Wierna rzeka }\end{array}$ \\
\hline $\begin{array}{l}\text { Tadeusz Dołęga- } \\
\text {-Mostowicz }\end{array}$ & 3 & 3 & $\begin{array}{l}\text { Kariera Nikodema Dyzmy } \\
\text { Profesor Wilczur } \\
\text { Znachor }\end{array}$ \\
\hline Beata Pawlak & 3 & 2 & $\begin{array}{l}\text { Aniołek } \\
\text { Piekło jest gdzie indziej }\end{array}$ \\
\hline Józef I. Kraszewski & 2 & 2 & $\begin{array}{l}\text { Hrabina Cosel } \\
\text { Stara Baśń }\end{array}$ \\
\hline Henryk Sienkiewicz & 2 & 2 & $\begin{array}{l}\text { Krzyżacy } \\
\text { Quo vadis }\end{array}$ \\
\hline Stanisław Wyspiański & 2 & 2 & $\begin{array}{l}\text { Warszawianka } \\
\text { Wesele }\end{array}$ \\
\hline Max Gallo & 1 & 4 & $\begin{array}{l}\text { Napoleon. Cesarz królów } \\
\text { Napoleon. Nieśmiertelny ze } \\
\text { Świętej Heleny } \\
\text { Napoleon. Pieśń wymarszu } \\
\text { Napoleon. Słońce Austerlitz }\end{array}$ \\
\hline Leslie Cameron-Bandler & 1 & 3 & $\begin{array}{l}\text { Know how } \\
\text { Ku harmonii w miłości } \\
\text { Wniewoli uczuć }\end{array}$ \\
\hline
\end{tabular}

Źródło: badania własne.

To zaskakujące zestawienie nazwisk, kojarzące się z listą szkolnych lektur, wynikało ze specyfiki oferty reklamodawców i charakteru zamieszczanych przez nich inseratów. Jeśli przyjrzymy się pełnemu zestawieniu proponowanych książek, nasunie się nam jeszcze jedno spostrzeżenie: obok klasyki i wydawnictw encyklopedycznych preferowane były poradniki psychologiczne, które odpowiadały profilowi pisma. Charakter proponowanych lektur wskazywał jednocześnie na typ odbiorcy: była nim wykształcona kobieta, ciekawa świata, która ceni literaturę piękną i chętnie poszerzy swoje horyzonty, zarówno dzięki kompendium wiedzy, jak i książkom, które odpowiedzą na nurtujące ją pytania egzystencjalne, a także pomogą $\mathrm{w}$ życiu codziennym, w utrzymaniu zgody i miłości w rodzinie (na przykład Pojedynek z nerwicq). Sporadycznie pojawiały się propozycje z kręgu literatury popularnej, jak np. Jestem nudziarq̨ M. Szwai czy Złodziejka Sarah Waters lub Martyna J. L. Wiśniewskiego.

Jak już zostało powyżej wspomniane, liderzy - jeśli chodzi o liczbę reklamowanych tytułów - wybierali całostronicowe reklamy z informacją dotyczącą 20 lub 30 tytułów jednorazowo. Oto wybrane przykłady - zdjęcia 92-94 (s. 341-342). 


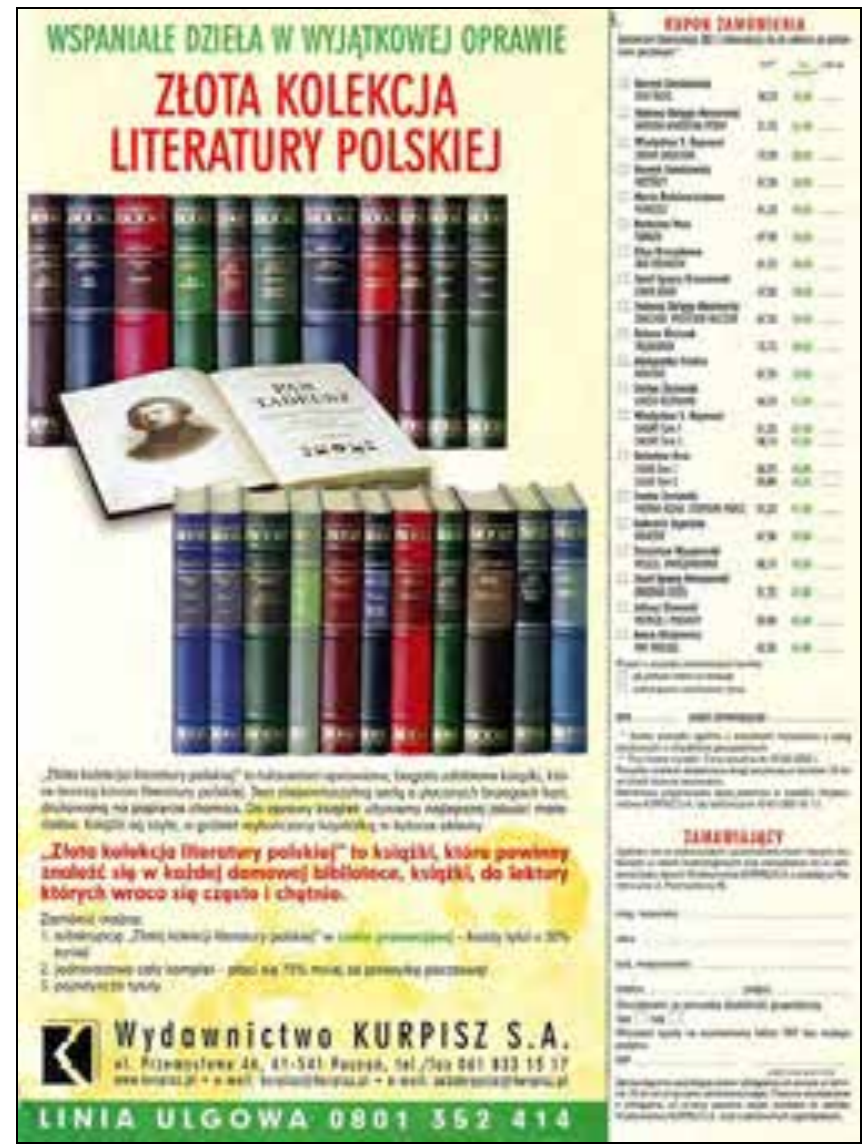

Zdjęcie 92. Wybrane ogłoszenie wydawnicze zamieszczone na łamach „Zwierciadła” „Zwierciadło” 2002, nr 1, s. [13]

W każdej z przedstawionych reklam widać maksymalne wykorzystanie miejsca: szczególnie $w$ dwóch pierwszych przypadkach $3 / 4$ powierzchni ogłoszenia zajmują kopie reklamowanych książek; jednak w drugim anonsie (s. 342) nie każda z nich jest dostatecznie czytelna. Uwagę odbiorcy przykuwają żywe kolory, zwłaszcza w pierwszym ogłoszeniu, gdzie wyraźnie wyeksponowane grzbiety książek są odzwierciedleniem hasła reklamowego, podkreślającego walor oprawy wybranych dzieł literatury pięknej. Interesującym pomysłem był aforyzm (wykorzystany w trzecim prezentowanym inseracie, s. 342) i nawiązujące doń tło reklamy, na którym umieszczono mniej (ale dzięki temu czytelniejszych) kopii okładek. 


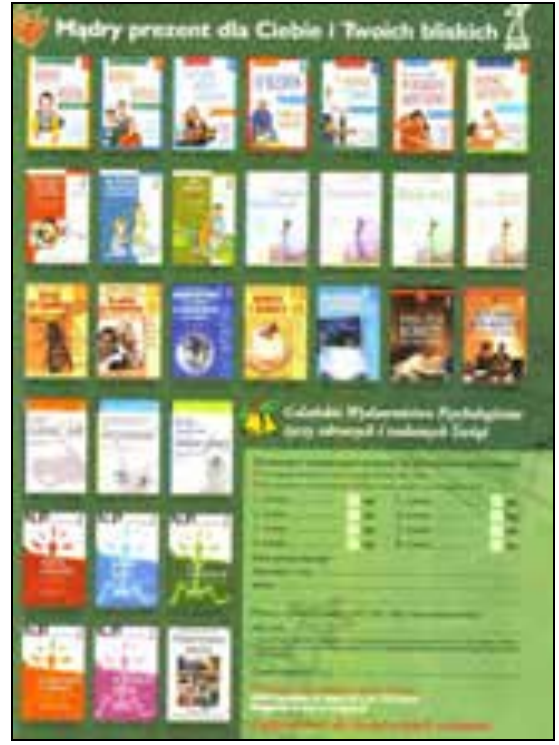

Zdjęcie 93. Wybrane ogłoszenie wydawnicze zamieszczone na łamach „Zwierciadła” „Zwierciadło” 2001, nr 12, s. [109]

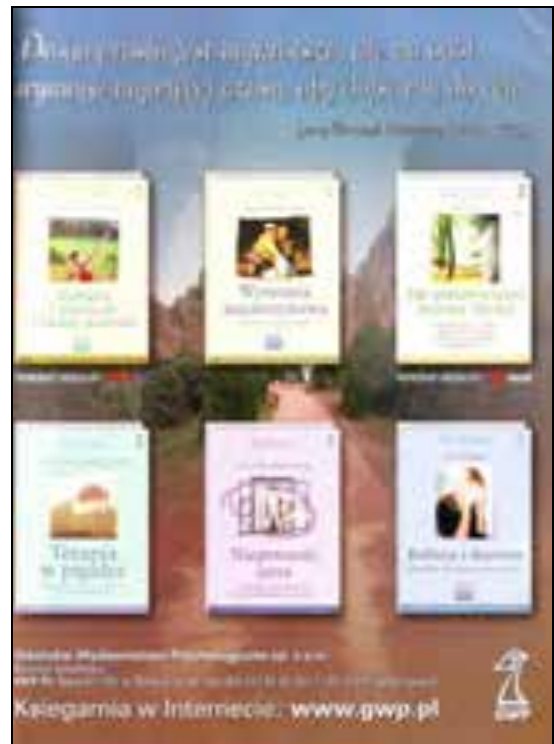

Zdjęcie 94. Wybrane ogłoszenie wydawnicze zamieszczone na łamach „Zwierciadła” „Zwierciadło” 2004, nr 2, s. [7]

Warto zwrócić uwagę także na inne reklamy. Dalej wybrano kilka przykładów - zdjęcia 95-96.

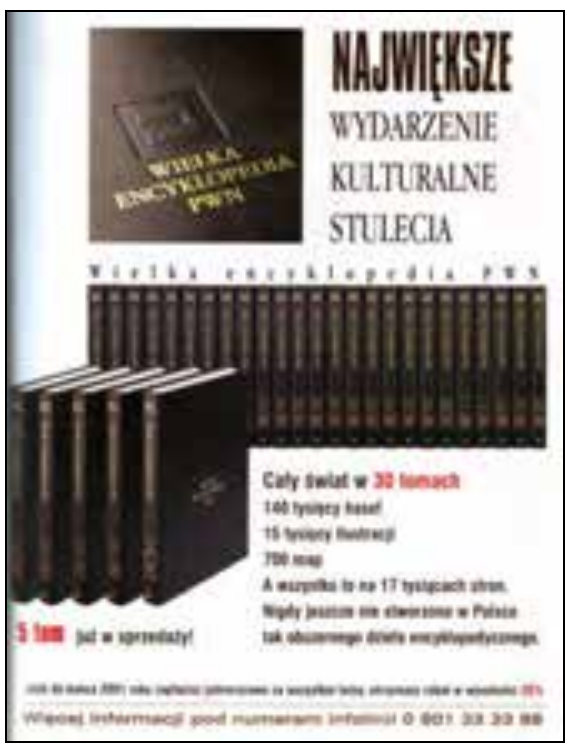

Zdjęcie 95. Wybrane ogłoszenie wydawnicze zamieszczone na łamach „Zwierciadła” „Zwierciadło” 2001, nr 10, s. [19]

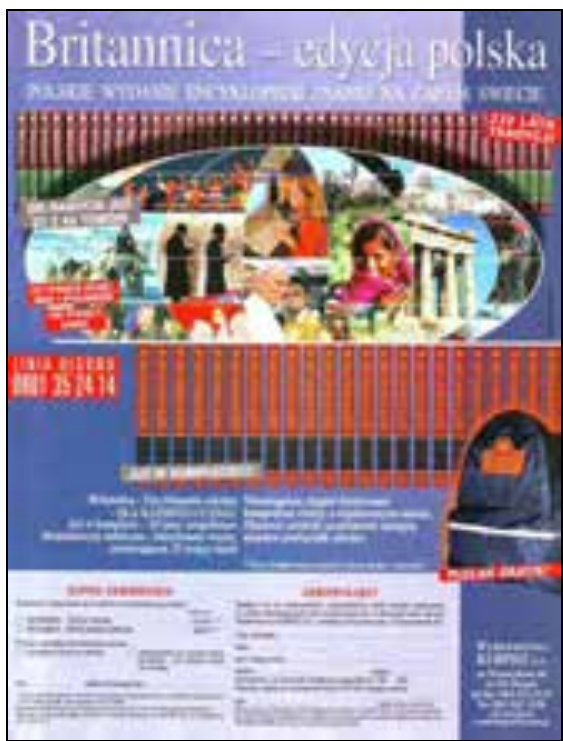

Zdjęcie 96. Wybrane ogłoszenie wydawnicze zamieszczone na łamach „Zwierciadła” „Zwierciadło” 2002, nr 5, s. [11] 
W każdym z prezentowanych przypadków reklamowano wydawnictwa źródłowe, przy czym w dwóch pierwszych ogłoszeniach (zdjęcia 95-96) uwzględniono pełne komplety encyklopedii, ułożone zachęcająco grzbietami do czytelnika, co zapewne zwiększać miało wrażenie przepychu. Także hasła odgrywały tu dużą rolę: „Cały świat w 30 tomach” - kusiło PWN; „Polskie wydanie encyklopedii znanej na całym świecie” - nie ustępowało kroku Wydawnictwo Kurpisz SA.

Jakkolwiek liczba reklam wydawniczych nie była zbyt duża, to jednak zwracała uwagę nie tylko staranność ich przygotowania pod względem graficznym (jak choćby w przytoczonych powyżej przykładach), ale także nierzadko pomysłowość ogłoszeniodawcy (zdjęcia 97-98).

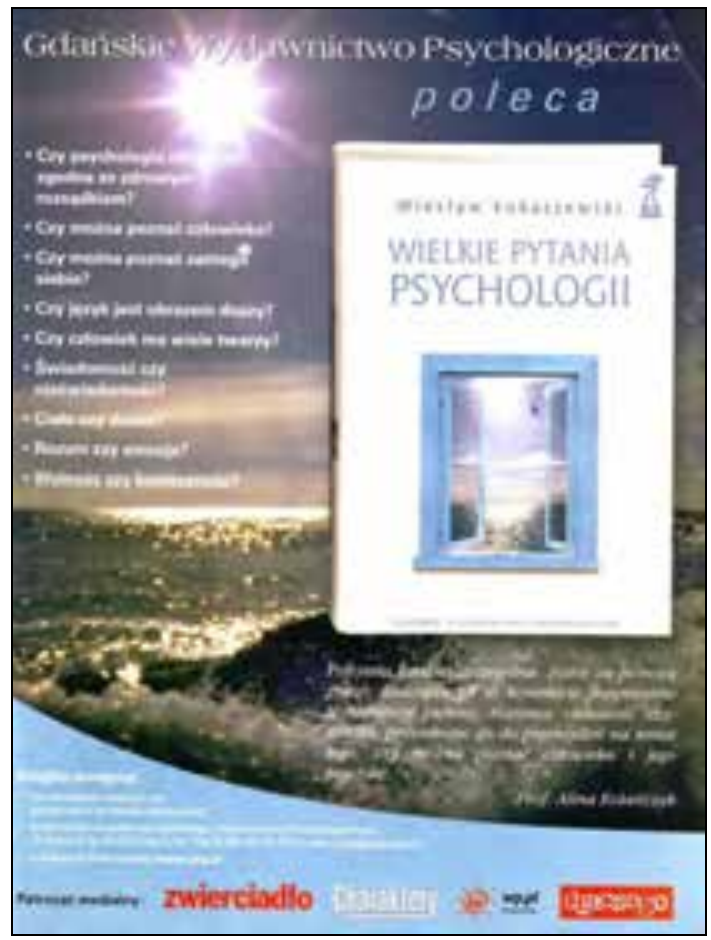

Zdjęcie 97. Wybrane ogłoszenie wydawnicze zamieszczone na łamach „Zwierciadła” „Zwierciadło” 2003, nr 3, s. [37]

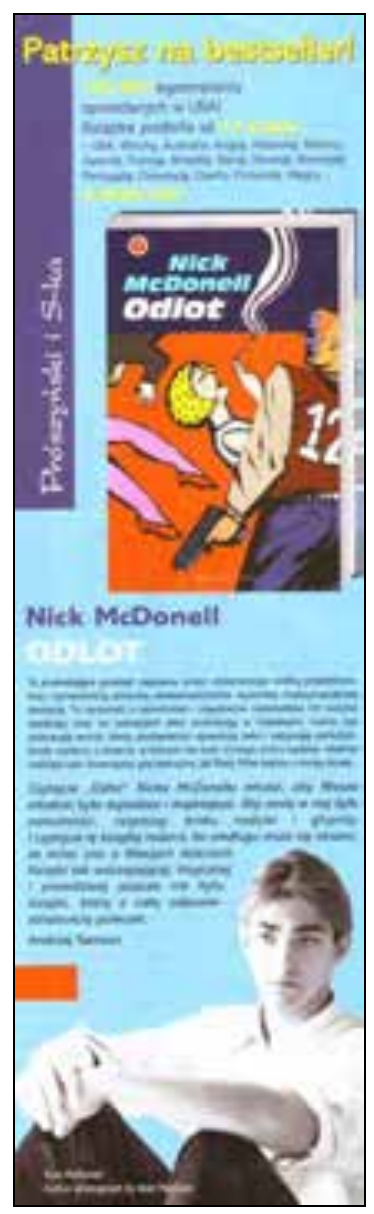

Zdjęcie 98. Wybrane ogłoszenie wydawnicze zamieszczone na łamach „Zwierciadła” „Zwierciadło” 2003, nr 11, s. [45] 
W pierwszym przypadku w odbiorcach starano się rozbudzić ciekawość poprzez stawianie im pytań, na które większość czytelników chciałaby znać odpowiedź: „Czy można poznać samego siebie? Czy w ogóle można poznać człowieka?" Kup proponowaną przez nas książkę, a znajdziesz odpowiedzi na te i inne jeszcze pytania, zdawał się kusić wydawca. I ponownie pojawiło się odpowiednio dobrane tło, które odpowiadało klimatowi reklamowanej lektury i z założenia miało nastawić czytelnika refleksyjnie. Inaczej było w przypadku drugiej reklamy. Tutaj niejako odbiorcy narzucano od razu ocenę: „Patrzysz na bestseller!” Czytelnik nie będzie raczej dyskutował z tym zdecydowanym oświadczeniem, a na wypadek, gdyby jednak obudziły się $\mathrm{w}$ nim wątpliwości, $\mathrm{w}$ następnym zdaniu zostały one rozwiane przez nieubłaganą matematykę: „135 tysięcy egzemplarzy w USA! Ta książka podbiła serca mieszkańców w 17 krajach!” A teraz "jest u nas"! Nie zwlekaj zatem, tylko ją kup. Na zachętę dodano opinię A. Samsona, będącego $\mathrm{z}$ pewnością wówczas autorytetem dla wielu czytelników „Zwierciadła”.

Ostatnia z prezentowanych reklam nie jest już tak ekspansywna, w porównaniu z poprzednią wydaje się nawet dość surowa, ale to zdaje się być jej atutem. Jednozdaniowe streszczenie, krótkie określenie gatunku i charakterystyczna grafika okładki książki wydawnictwa Noir sur Blanc z jego rozpoznawalnym exlibrisem oraz czarne tło nawzajem się dopełniały - zdjęcie 99.

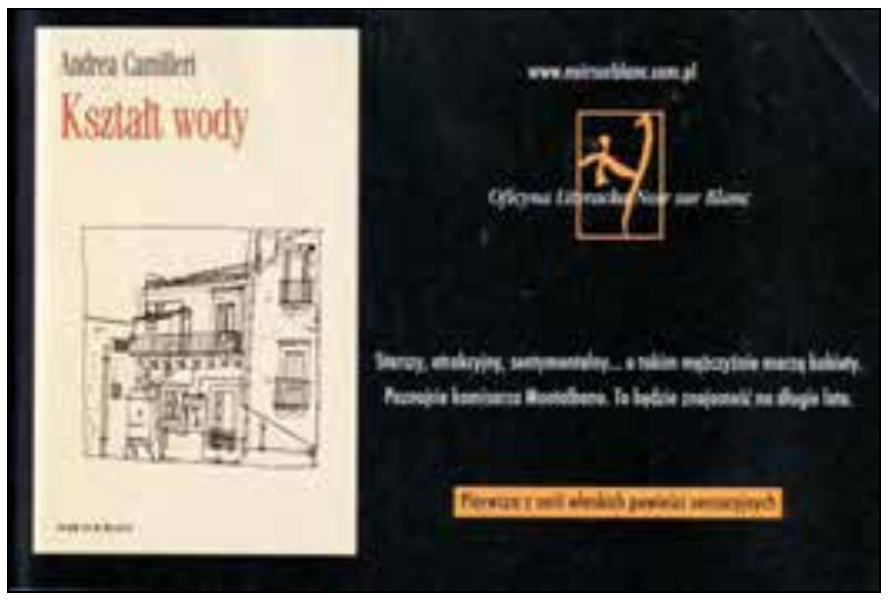

Zdjęcie 99. Wybrane ogłoszenie wydawnicze zamieszczone na łamach „Zwierciadła”

„Zwierciadło” 2002, nr 1, s. 95. 
Przytoczone przykłady są reprezentatywne dla ogłoszeń wydawniczych, zamieszczanych $\mathrm{w}$ piśmie. $\mathrm{Z}$ pewnością czytelnik nie mógł przejść obok nich obojętnie. Nawet jeśli tylko przeglądał dany numer, jego wzrok przyciągała albo grafika anonsu, albo hasło reklamowe, albo opinia autorytetu, albo wszystkie te elementy, tak jak było to w przypadku autoreklamy Wydawnictwa Zwierciadło (zdjęcie 100). Tu czytelnika osaczano zarówno za pomocą nasyconej barwy ogłoszenia, jak i hasła reklamowego oraz opinii cenionego przez czytelników współpracownika periodyku, W. Eichelbergera.

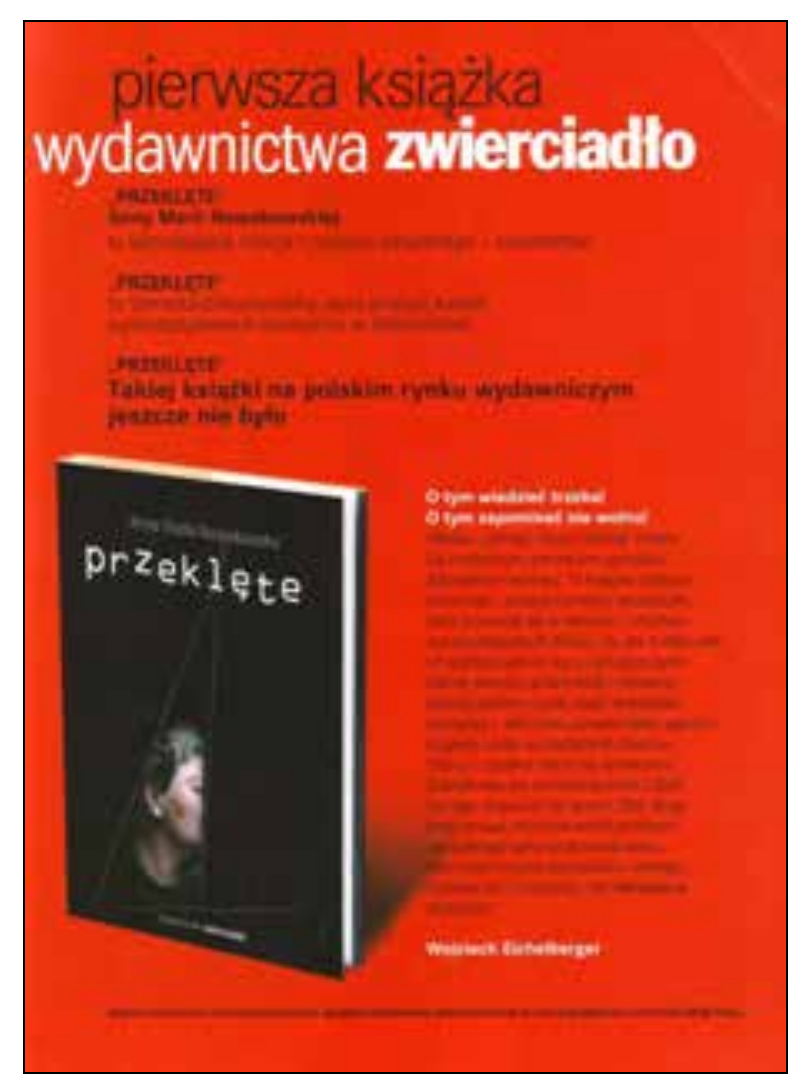

Zdjęcie 100. Wybrane ogłoszenie wydawnicze zamieszczone na łamach „Zwierciadła” „Zwierciadło” 2003, nr 1, s. [120]

Reasumując, także i ta forma informacji o książce, podobnie jak i recenzje, była starannie przygotowana, choć nie stanowiła stałego elementu w zawartości czasopisma. 


\subsubsection{Tę książkę warto znaćp ${ }^{92}$ inne formy informacji o książce}

W latach 2001-2005 na łamach „Zwierciadła” poza recenzjami, reklamami oraz wywiadami ukazało się 650 różnego typu informacji, które pośrednio lub bezpośrednio dotyczyły książki. Przyjmowały one różną objętość, miały różnoraki charakter, a czytelnik odnaleźć je mógł w całym magazynie (zob. Aneks 36. Wybór tekstów związanych z literaturą i rynkiem wydawniczo-księgarskim, zamieszczonych na łamach „Zwierciadła” w latach 2001-2005). Były one istotną częścią pisma, stanowiąc jednocześnie dowód zainteresowania redakcji problematyką kulturalną. Można wśród nich, wzorem poprzednich rozdziałów, wyodrębnić następujące kategorie:

- sylwetki/portrety (70),

- teksty, dotyczące rynku wydawniczo-księgarskiego (37),

- adaptacje, ekranizacje oraz inscenizacje znanych dzieł (27),

- listy czytelników (14),

- konkursy i akcje, organizowane przez tygodnik (157),

- inne $(345)^{93}$.

Poniżej scharakteryzowano każdą z kategorii, przedstawiając wybrane, reprezentatywne dla nich przykłady.

\subsection{On rysuje jej sny ${ }^{94}$ : sylwetki/portrety}

Portretów, wspomnień i historii dotyczących życia znanych osób, w tym przypadku związanych ze światem literatury, pojawiło się w ciągu pięciu lat na łamach pisma 70 .

Ze względu na typ odbiorcy periodyku specyficzna była grupa tekstów, w których kreślono portrety podwójne: ich bohaterowie prezentowani byli w charakterystycznych rubrykach: Jak kochali, Miłość, Pełnq parq. Opisano na przykład pełną wzlotów i rozstań miłość Antoine de Saint-Exupéry`ego i jego żony, Consueli. Z przedstawionego obrazu wyłaniała się postać autora Małego księcia: niezwykle emocjonalnego, gwałtownego i nieobliczalnego w uczuciach, który „Kochał ludzi, ale nie tracił czasu na objaśnianie uwagi i miłości, do jakich był zdolny”95, a jednocześnie był „Taki dziecinny, taki anielski, jakby spadł z nieba"96. Z kolei dzięki Remigiuszowi Grzeli czytelnicy poznali pierwszą miłość Ernesta Hemingwaya. O uczuciu do Agnes

92 Hasło, proponujące sięgnięcie po książkę, tematycznie związaną z problematyką wcześniej zamieszczonego na łamach magazynu tekstu, zob. „Zwierciadło” 2002, nr 7, s. 47.

93 Zob. Przypis a pod tabelą 39.

94 Tytuł jednego z portretów, zob. „Zwierciadło” 2005, nr 7, s. [50]-[55].

95 A. Lipiec-Wróblewska, Pamiętnik Róży, „Zwierciadło” 2002, nr 4, s. 70. Warto zaznaczyć, że pretekstem do przypomnienia autora Nocnego lotu stało się w tym przypadku wydanie Pamiętnika róży, C. de Saint-Exupéry.

96 Ibidem, s. 70. 
Hannie von Kurovsky pisał on w Pożegnaniu z broniq, zaś odbiorcy „Zwierciadła" mogli dowiedzieć się, w jakich okolicznościach pisarz poznał starszą od siebie o 7 lat pielęgniarkę, zakochał się w niej i dlaczego nie została ona jego żoną97. 0 trudnej miłości Jeana Paula Sartre`a i Simone de Beauvoir opowiedział natomiast A. Cieślar:

Ona - zagorzała feministka. On - jeden z głównych przedstawicieli egzystencjalizmu, laureat Nagrody Nobla, której nie przyjął. Najbardziej kontrowersyjna para kochanków XX wieku. Zakochani w swoich intelektach i potrzebie niezależności przez całe życie nie potrafili żyć bez siebie ${ }^{98}$.

Podobnie było w przypadku bohaterów innej historii: Katarzyny Kobro i Władysława Strzemińskiego, których „życie obrosło legendą”99 i których miłość zmieniła się w nienawiść. O uczuciu, które połączyło Zeldę i Francisa Fitzgeraldów, pisał z kolei Wacław Sadkowski, odkrywając na łamach pisma mało znane fakty na temat tej pary, „która dla Ameryki urzeczywistniała mit wielkiej i szczęśliwej miłości"100. Nie mogło zabraknąć także najbardziej znanego związku poetyckiego XX w.: Sylvii Plath i Teda Hughesa. Ich „taniec miłości i śmierci", w sposób przejmujący, opisała Katarzyna Reciak ${ }^{101}$.

Znaczna część opowiadanych na łamach magazynu historii przypominała romantyczne opowieści, w których miłość często bywała trudna, a rzadko szczęśliwa. Losy znanych w historii par, przedstawione w znamienny sposób (zwrócenie uwagi na wyjątkowo interesujące, a zazwyczaj mało znane szczegóły, wyeksponowanie określonych cech charakteru bohaterów) wpisywały się $\mathrm{w}$ realizowany przez periodyk program, gdzie prezentowano często również współczesne powikłane historie „z życia wzięte", udzielając porad, jak z nich wybrnąć. Jednocześnie, obok funkcji kulturowej czy rozrywkowej, przytoczone teksty zdawały się spełniać jeszcze jedną rolę: przybliżając postacie znanych twórców przypominano, że byli oni przede wszystkim ludźmi, którzy, podobnie jak czytelnicy pisma, nierzadko musieli radzić sobie z problemami, uczuciami i namiętnościami.

Nie zawsze jednak sięgano do historii dawnych i nieszczęśliwych. Bohaterami kilku obrazów byli także współcześni twórcy, jak choćby Andrzej Stasiuk i Monika Sznajderman ${ }^{102}$, Michał Zabłocki i Agnieszka Chrzanow-

97 R. Grzela, Dziewczyna Hemingwaya, „Zwierciadło” 2002, nr 7, s. 66-71.

98 A. Cieślar, Jean Paul Sartre i Simone de Beauvoir, „Zwierciadło” 2003, nr 2, s. 64.

${ }^{99}$ R. Grzela, Katarzyna Kobro i Władysław Strzemiński, „Zwierciadło” 2002, nr 8, s. 50.

100 W. Sadkowski, Mała Zelda i Wielki Gatsby, „Zwierciadło” 2003, nr 12, s. [93].

${ }^{101}$ K. Reciak, Sylvia Plath i Ted Hughes - taniec miłości i śmierci, „Zwierciadło” 2004, nr 6, s. [86].

102 A. Serafin, W centrum Europy, „Zwierciadło” 2003, nr 7, s. 34-[41]. 
ska103, Katarzyna Majewska i Andrzej Tylkowski (właściciele wydawnictwa Ilustris) ${ }^{104}$.

Drugą grupę tekstów, w których kreślono sylwetki znanych pisarzy, stanowiły pojedyncze portrety. Drukowano je w rubrykach: Naprawdę jaki jesteś [pis. oryg.], Portret, Postać, Skąd się wziq̨łem, Spotkania. I tu ich bohaterowie byli starannie wybierani. Na przykład o życiu Emily Brontë pisała Ewa Truszkiewicz ${ }^{105}$, natomiast Halinie Poświatowskiej poświęciła swój tekst Alina Gutek ${ }^{106}$.

Także i w tych obrazach pojawiały się sylwetki współczesnych literatów. Czytelnicy spotkać mogli na łamach pisma m.in. Henryka Chmielowskiego107, Pawła Huelle108, Marcina Świetlickiego109 czy Tomka Tryznę ${ }^{110}$. Pisano także o mniej znanych twórcach, jak choćby o autorkach powieści fantasy: Annie Brzezińskiej, Iwonie Surmik i Ewie Białołęckiej ${ }^{111}$. W numerze kwietniowym (2004) pojawiła się postać Diany Ławniczak, bohaterki stanowiącej znakomity przykład dla czytelniczek pisma:

Przez prawie 20 lat w urzędowych rubrykach wpisywała: „przy mężu”. Matka, żona, gospodyni domowa, emigrantka. Nie dała się szarzyźnie, rutynie, samotności. Napisała książkę marzeń, za którą pokochali ją Szwajcarzy. [...] Nad biurkiem powiesiła zdjęcie niewidomego śpiewaka Andrei Bocellego. Nie dlatego, że kocha operę. Lubi tylko, kiedy komuś w życiu wychodzi112.

Omówione powyżej teksty obejmowały zazwyczaj od 2 do 8 stron, ich autorzy urozmaicali je zdjęciami przedstawianych bohaterów, niekiedy publikację poprzedzało krótkie wprowadzenie. W niektórych przypadkach w tekście pojawiały się fragmenty wierszy lub powieści autorstwa tych twórców. Nierzadko na zakończenie czytelnicy mogli dowiedzieć się, na podstawie jakich książek powstał dany tekst.

Jeszcze jedną grupę, o której warto w tym miejscu wspomnieć, stanowią miniportrety, drukowane w ramach dwóch kolejnych rubryk: Najlepsze (w roku 2003) oraz Poznajcie ich (w latach 2004-2005). Przedstawiano tu (w kilku lub kilkunastu zdaniach) osoby, które osiągnęły w życiu sukces. Obok sportowców, artystów byli nimi także pisarze (jak na przykład Joanna Olczak-Ronikier, Dorota Terakowska) i poeci (Marzanna Kielar) oraz

\footnotetext{
103 A. Gutek, Równolegle „Zwierciadło” 2005, nr 5, s. 54-[59].

104 I. Czarnacka, On rysuje jej sny, „Zwierciadło” 2005, nr 7, s. [50]-[55].

105 E. Truszkiewicz, Emily z wrzosowisk, „Zwierciadło” 2004, nr 10, s. 80-84.

106 A. Gutek, Tak ładnie zaczynam dorastać, „Zwierciadło” 2002, nr 2, s. [36]-41.

107 H. Halek, Warszawa Papcia Chmiela, „Zwierciadło” 2005, nr 11, s. 63-67.

108 L. Butowska, Kwestia wewnętrznej prawdy, „Zwierciadło” 2002, nr 9, s. 54-56.

${ }^{109}$ K. Zimmerer, Marcin Świetlicki. Czynny do dowołania, „Zwierciadło” 2002, nr 11,

110 M. Terlecka-Reksnis, Debil \& filozof, „Zwierciadło” 2003, nr 6, s. [38]-42.

111 L. Butowska, Fantastki, „Zwierciadło” 2004, nr 2, s. [28]-33.

112 A. Filipowska, Ogród Diany, „Zwierciadło” 2004, nr 4, s. [50], 51.
} s. $62-67$. 
edytorzy (założycielki Wydawnictwa Muchomor), a także bibliotekarz (Krzysztof Kubaszek). I tutaj, obok tekstu, pojawiały się zdjęcia owych „najlepszych” i tych, których „należy poznać”. Poza zdjęciami, elementem, który przykuwał wzrok czytelnika, były tytuły. Oto kilka wybranych przykładów113: Bieg z przeszkodami, Dziewczyna Hemingwaya, Jak aksamit i jak stal, Kwestia wewnętrznej prawdy, Możesz być delfinem, Nie nadepnać krasnoludka, Pamiętnik Róży, Pod prąd, Równolegle, Skąd czerpać radość, Tak ładnie zaczynam dorastać, Życie w prezencie.

Podsumowując, ta forma informacji związana z literaturą była bogato reprezentowana na łamach pisma. Stanowiła interesującą jego część, odwołując się do tych spraw, które są dla kobiet ważne: z jednej strony była to sfera uczuć, z drugiej przypomnienie, że płeć słaba we współczesnym świecie nie musi być słabą faktycznie, bo pomimo przeciwności, a dzięki sile, nie zawsze do końca uświadamianej, kobieta może osiągnąć sukces.

\subsection{Warto było chciećc ${ }^{114}$ : teksty, poświęcone książce i rynkowi wydawni- czo-księgarskiemu}

Pomimo wyraźnego zainteresowania redakcji kwestiami związanymi z książką, na łamach miesięcznika pojawiło się stosunkowo niedużo publikacji, dotyczących współczesnego rynku wydawniczo-księgarskiego i jego przedstawicieli oraz kondycji współczesnej literatury. Publikacji, które można zaliczyć do tej grupy, było ogółem 37. Nie stanowiły one spójnego zbioru. Wydaje się, że były raczej przypadkowo dobrane, stanowiąc rodzaj rozwiniętej informacji na temat, który, z różnych względów, wydał się autorowi interesujący.

Niekiedy przybierały częściowo formy opisane powyżej. Tak było na przykład w przypadku opowieści o współczesnych bajkopisarzach. Anna Sańczuk nie tylko przedstawiła ich losy, ale także scharakteryzowała współczesne baśnie dla dzieci i najczęściej pojawiające się wątki w tym gatunku literackim, powołując się na doświadczenie bohaterów swej publikacji. Czytelnicy dowiedzieli się m.in., że „we współczesnej literaturze dziecięcej coraz silniejszy jest nurt >antypedagogiki<, którego początek można znaleźć już w postaci Pippi”115 i poznali współczesnych twórców baśni: Grzegorza Kasdepke, Katarzynę Kotowską, Małgorzatę Strzałkowską i Wojciecha Widłaka.

113 Kolejno: „Zwierciadło” 2004, nr 6, s. [40]-[47]; 2002, nr 7, s. 66-71; 2001, nr 5, s. 24-27; 2002, nr 9, s. 54-56; 2005, nr 4, s. [44]-[50]; 2001, nr 6, s. [28]-31; 2002, nr 4, s. 68-71; 2001, nr 3, s. 24-28; 2005, nr 5, s. 54-[59]; 2004, nr 7, s. [36]-[39]; 2002, nr 2, s. [36]-41; 2001, nr 11, s. 26-29.

114 Tytuł jednego z tekstów, zob. „Zwierciadło” 2003, nr 12, s. [60]-61.

115 A. Sańczuk, Bajki na nowy wiek, „Zwierciadło” 2003, nr 12, s. 35. 
Ciekawy tekst trafił do czytelników magazynu dzięki T. Jastrunowi. Podzielił się on z nimi wybranymi dedykacjami, wpisanymi przez autorów w książkach, znajdujących się w rodzinnym księgozbiorze. Wpisy opatrzone zostały krótkim komentarzem poety. Widzimy na przykład dedykację Jana Brzechwy z 1955 r., Wisławy Szymborskiej z 1993 r., osobiste życzenia od Juliana Tuwima dla „kochanego Tomcia”, który w 1951 r. miał zaledwie pół roku. Tym, którzy mogli oburzać się na "niszczenie” w ten sposób książek, T. Jastrun odpowiadał: „wpis znanego pisarza bywa po latach wzruszającą pamiątką, książka jest nadal żywa, nawet kiedy autor już odszedł na zawsze"116.

Nierzadko teksty zaliczone do opisywanej kategorii powiązane były pośrednio z kwestiami, podejmowanymi w innej formie na łamach periodyku. Stres, zmartwienia, kłopoty, problemy (także małżeńskie) i próby walki $\mathrm{z}$ nimi stały się pretekstem do przekazania kilku porad z zakresu terapii i psychologii, a wszystko to na podstawie cieszących się olbrzymim powodzeniem poradników terapeutów i psychologów znad Loary. Jak czerpać radość z życia? Jak cierpienie zmienić w szczęście? - pyta za Francuzami Joanna Orzechowska i cytuje rady specjalistów, przywołując jednocześnie tytuły ich bestsellerowych poradników. Czytelnicy „Zwierciadła” dowiedzieli się zatem, że „Nawet najbardziej nieszczęśliwa istota może ponownie narodzić się do życia”117, a także, że „Szczęście [...] może przybierać bardzo różnorodne formy w zależności od naszego wieku, etapu życia czy otoczenia"118. Pojawiła się również rada, cytowana za Jeanem-Luisem Servanem-Schreiberem: „Każdego ranka policz wszystko, co w życiu sprawia ci przyjemność [...]. Zadowolenie jest wynikiem regularnego treningu"119.

Niekiedy pojawiały się teksty, nawiązujące do literatury, w których stawała się ona pretekstem do poruszenia innych spraw, nierzadko z dziedziny interesującej „Zwierciadło”. Przykładem może być tekst Miłość, zazdrość i literatura. Literaturoznawca i filozof, Michał P. Markowski, tłumacząc, na czym polega zazdrość, jak się ona rodzi, odwoływał się do postaci znanych ze świata literatury: zazdrosnego Otella i podejrzliwego Swanna. Za pomocą wyrazistych przykładów, opisu konkretnych sytuacji, ubrał w słowa i zdefiniował uczucia, stanowiące temat, poruszany na łamach magazynu:

Zazdrość rodzi się sama z siebie i nie troszczy się o to, jak jest naprawdę. [...] człowiek zazdrosny zawsze wie lepiej i najdrobniejszy szczegół włączy w nurt swojej opowieści po to tylko, żeby się upewnić o swojej racji120,

\footnotetext{
116 Tytuł jednej z publikacji, zob. „Zwierciadło” 2001, nr 5, s. 50, 52.

117 J. Orzechowska, Francuski stres, „Zwierciadło” 2005, nr 4, s. 83.

118 Ibidem, s. 84.

119 Ibidem, s. [85].

120 M. P. Markowski, Miłość, zazdrość i literatura, „Zwierciadło” 2004, nr 5, s. 34.
} 
natomiast

Zakochany wszystko bierze za dobrą monetę. Zdarzenia z życia ukochanej osoby są dla niego tym, czym są, i nie wymagają żadnych dodatkowych wytłumaczeń. [...] Miłość wyklucza interpretacjęi21.

Tylko raz pojawił się tekst poświęcony oficynie wydawniczej. I w tym przypadku odnaleźć można charakterystyczne dla magazynu przesłania: „Stwórz pracę, którą kochasz [...] Żeby osiągnąć sukces, trzeba umieć znosić porażki. [...] Każde doświadczenie na coś się przydaje"122. Pisząc o wydawnictwie edukacyjnym Didasko, przywołano historię jego założycieli: Joanny i Piotra Białobrzeskich, którzy „nie mieli niczego, co dobrze jest mieć na starcie: mieszkania, znajomości i doświadczenia. Mieli natomiast nieprzepartą chęć działania i odwagę sięgania po to, co na pozór nieosiągalne"123. Dzięki temu udało im się założyć własne wydawnictwo, które stało się liderem wśród oficyn publikujących podręczniki.

Na podstawie analizy zebranego materiału można stwierdzić, że w magazynie $\mathrm{w}$ dużym stopniu interesowano się poezją. Jak już wspomniano, każdy numer rozpoczynał aforyzm znanego pisarza, poety, myśliciela bądź przewodnika duchowego. Nierzadko „na dobry początek” proponowano także fragment prozy bądź wiersz ${ }^{124}$. Również na dalszych stronach pisma odnaleźć można rozmaite formy związane $\mathrm{z}$ poezją. Jedną $\mathrm{z}$ nich były wspomniane powyżej wywiady z poetami w ramach rubryki Poezja rozbierana czy prezentacja sylwetki wybranego twórcy (jak choćby M. Kielar czy M. Świetlickiego). Innym pomysłem była pomieszczana w periodyku w latach 2001-2002 Multipoezja M. Zabłockiego ${ }^{125}$. Cykl wierszy, poświęconych współczesnym kobietom, pojawił się $\mathrm{w}$ piśmie po raz pierwszy w numerze 7 (2001). Bohaterkami jego utworów były m.in.: Ewa Demarczyk, Hanna Gronkiewicz-Waltz, Małgorzata Niemen, Janina Ochojska, Monika Olejnik, Irena Szewińska, Violetta Villas, Michalina Wisłocka i Edyta Wojtczak. Obok utworu pojawiało się zdjęcie jego bohaterki, a także fotografia autora wraz z krótką notą biograficzną, wyjaśnieniem celu projektu, jakim była Multipoezja oraz podaniem jej patronów. Oto jeden z przykładów:

121 M. P. Markowski, Miłość..., s. 34, [35].

122 A. Gutek, Warto było chcieć, „Zwierciadło” 2001, nr 5, s. 50, 52.

123 Ibidem, s. 51.

${ }^{124}$ Na przykład wiersz ks. J. Twardowskiego, zob. „Zwierciadło” 2002, nr 3, s. [3].

125 Multipoezja - był to autorski projekt M. Zabłockiego, którego celem było „poszukiwanie nowego sposobu istnienia poezji we współczesnym świecie” („Zwierciadło” 2001, nr 12, s. 22). Na łamach omawianego periodyku prezentowano wybrane wiersze „inspirowane życiem i dziełem współczesnych polskich kobiet" (ibidem). 


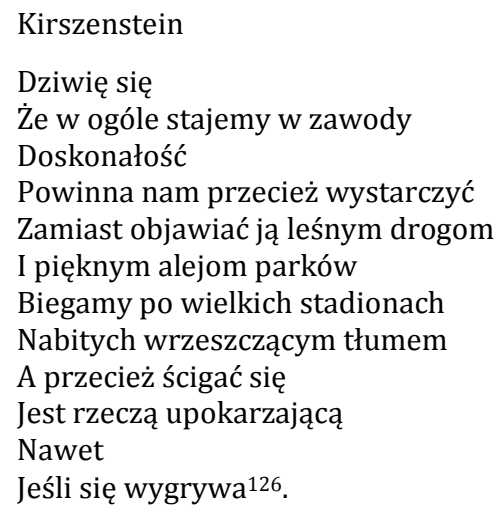

Interesującym i jednocześnie zabawnym pomysłem była parodia dzienników Bridget Jones. W odpowiedzi na duże zainteresowanie zarówno książką, jak i jej ekranizacją redakcja w kilku kolejnych numerach zamieszczała parodię znanych wielu czytelnikom na świecie zwierzeń młodej bohaterki, zatytułowaną Pamiętniki Brygidy Dąs.

Należy także wspomnieć o tekstach, mających zazwyczaj charakter recenzyjny, odnoszących się w większości do prezentacji ekranizacji bądź inscenizacji znanych dzieł. Najczęściej pojawiały się one w dziale kulturalnym, w rubryce Film lub Teatr. Zaledwie siedmiokrotnie znalazły się w innych miejscach periodyku, w ramach rubryk: Co słychać oraz Wydarzeń (przeglądu imprez kulturalnych danego miesiąca). Tego typu tekstów było w ciągu badanych pięciu lat 27 . Liczyły one kilkanaście zdań, obok których nierzadko pojawiały się zdjęcia z filmu lub sztuki, zaś pod prezentacją czytelnik odnajdował informacje dotyczące tytułu, nazwiska reżysera, odtwórców głównych ról, czasu pokazu filmu lub spektaklu. Donoszono na przykład o ekranizacji Zemsty Aleksandra Fredry ${ }^{127}$, pisano o filmie poświęconym Iris Murdoch ${ }^{128}$, ale także o adaptacji Idioty Fiodora Dostojewskiego ${ }^{129}$ czy wystawieniu Skąca Moliera w Teatrze Ateneum ${ }^{130}$. Odnotowywano również najpopularniejsze ówczesne premiery, jak choćby bestseller Andrzeja Sapkowskiego przeniesiony na srebrny ekran ${ }^{131}$ czy ekranizację I części trylogii Johna R. R. Tolkiena ${ }^{132}$. Nie zapomniano również o Pianiście

126 M. Zabłocki, Kirszenstein, „Zwierciadło” 2001, nr 8, s. 18. Kirszenstein to panieńskie nazwisko I. Szewińskiej, polskiej lekkoatletki.

127 „Zwierciadło” 2002, nr 10, s. 43.

128 „Zwierciadło” 2002, nr 6, s. 77.

129 "Zwierciadło" 2001, nr 1, s. 68.

130 „Zwierciadło” 2001, nr 5, s. 86.

131 „Zwierciadło” 2001, nr 11, s. 70.

132 „Zwierciadło” 2002, nr 2, s. 84. 
w reż. Romana Polańskiego ${ }^{133}$. Ograniczano się głównie do krótkiego streszczenia fabuły lub ewentualnego przypomnienia książki, na podstawie której powstał film. Owe niewielkie objętościowo omówienia nie przypominały bogatych prezentacji zamieszczanych w przedstawionych wcześniej tygodnikach opinii. Tu nie wyróżniały się niczym szczególnym, miały charakter krótkiej informacji, raczej pozbawionej osobistego zaangażowania piszącego. Od $2002 \mathrm{r}$. informacje na temat teatru praktycznie zniknęły z łamów periodyku, tylko sporadycznie pojawiała się wzmianka o premierze lub planach wystawienia spektaklu, przeważnie zresztą obok innych tego typu doniesień we wspomnianej rubryce poświęconej wydarzeniom kulturalnym danego miesiąca.

Czytelnicy potrafili docenić zainteresowanie pisma problematyką literacką, co przejawiało się w przysyłanych listach, skrzętnie odnotowywanych przez redakcję. W ciągu 5 lat pojawiło się 14 komentarzy od czytelników, nawiązujących bezpośrednio do spraw związanych z książką. Żywy odzew wzbudził wspomniany powyżej tekst, poświęcony H. Poświatowskiej. Redakcja zamieściła dwa listy od czytelniczek - miłośniczek poetki ${ }^{134}$. Dwie kolejne dzieliły się swoimi wrażeniami po lekturze wywiadu z W. Whartonem i jego żoną135. W 2005 r. redakcja wydrukowała obszerne podziękowanie innej jeszcze czytelniczki, która wyznawała m.in.: „Nareszcie doczekałam się tego, za czym tęskniłam od dłuższego czasu", czyli kącika z poezją ${ }^{136}$, jeszcze inna pisała o publikacji związanej ze współczesnymi autorami baśni 137 .

\subsection{Kolory $\operatorname{czasu}^{138}$ : konkursy i akcje}

Warto zatrzymać się przy inicjatywach redakcji „Zwierciadła”, które przybierały postać konkursów i akcji, związanych z książką. I tutaj (wzorem poprzednich rozdziałów) można wskazać (częściowo) na następujące ich rodzaje:

1) cykliczne konkursy o charakterze literackim i paraliterackim;

2) jednorazowe inicjatywy, których pomysłodawcą było „Zwierciadło”;

3) przedsięwzięcia realizowane wespół z innymi mediami, wydawnictwami oraz firmami (na przykład kosmetycznymi);

4) minikonkursy, w których nagrodą była książka.

133 „Zwierciadło” 2002, nr 9, s. 61.

134 „Zwierciadło” 2002, nr 4, s. 6.

135 „Zwierciadło” 2003, nr 1, s. 140.

136 „Zwierciadło" 2005, nr 6, s. 12.

137 "Zwierciadło” 2003, nr 12, s. 108.

138 Tytuł jednej z nagrodzonych prac w konkursie Mój czas; zob. [czytelniczka], Kolory czasu, „Zwierciadło” 2003, nr 9, s. 72. 
Informacje o wszystkich tego typu inicjatywach pojawiły się na łamach pisma 157 razy.

W pierwszej grupie znalazł się konkurs Dzień po dniu, który w badanym okresie odbył się dwukrotnie. Po raz pierwszy informacja na jego temat pojawiła się w numerze lipcowym (2004). Zachęcając do wzięcia w nim udziału, redakcja przedstawiała jednocześnie warunki, które dotyczyły przyszłych prac. Dziennik dotyczyć miał wydarzeń bieżących, nie powinien liczyć mniej niż 10 stron, ale nie więcej niż 50. Redakcja podkreślała: „Nie ma nieciekawego życia, każdy może być autorem dziennika, który zatrzyma czas"139. Na laureata czekał cenny długopis z limitowanej Edycji Pisarzy Charles Dickens, natomiast nagrodą dla dwóch wyróżnionych autorów były srebrne suszki do atramentu z ich inicjałami. Najciekawsze dzienniki miały być drukowane na łamach magazynu. Termin nadsyłania prac upływał 31 września (2004). W skład jury, które miało dokonać wyboru najlepszych dzienników, weszli: Tomasz Jastrun (przewodniczący), Alina Gutek oraz Jolanta Koral.

Interesującym pomysłem było pojawienie się obok zasad konkursu tekstu T. Jastruna, który przedstawił historię dzienników, przywołując przykłady najbardziej znanych, dzieląc się jednocześnie z czytelnikami swoimi uwagami na temat tego, jakie cechy powinny charakteryzować każdy podobny tekst. Zachęcał, by chwytać chwile i zatrzymywać je na papierze, jednocześnie przekonując, że „pisać może każdy, takie pisanie jest zdrowe, w naszych zagonionych czasach to szansa, by spotkać się ze sobą samym, zatrzymać się i zastanowić nad życiem i światem"140. Ale i w tym miejscu nie zabrakło uwagi, wpisującej się w program „Zwierciadła”: „Dziennik bywa więc autoterapią. Współczesny polski film i proza nie potrafią dać świadectwa trudnym latom przełomu wieków. Jestem pewien, że tę lukę wypełnią właśnie dzienniki. Te już napisane i te, które czekają na swoje pióro" 141 .

Jak się okazało, pomysł bardzo spodobał się czytelnikom pisma, czego dowodem był fakt, że redakcja otrzymała 280 dzienników, a ich poziom był bardzo wysoki ${ }^{142}$. Podsumowując prace jury, pisano m.in.:

Dzienniki, które od Was otrzymaliśmy, to dokument życia w Polsce roku 2004, gdzie wszyscy odwracają się ze wstrętem od polityki, narzekają na stan rzeczy, ale narzekają też na

139 T. Jastrun, Dzień po dniu, „Zwierciadło” 2004, nr 7, s. 88.

140 Ibidem, s. 89.

141 Ibidem.

142 [br. aut.], Dzień po dniu, „Zwierciadło” 2004, nr 12, s. 152. 
polskie narzekanie. To relacje z wakacji, ze szpitala, z sanatorium i z codzienności. Najważniejsze jednak są sprawy uczuciowe: szukanie partnera, walka o miłość, ból rozstania ${ }^{143}$.

Postanowiono do obiecanych wcześniej nagród i wyróżnień dołączyć Przepustki Literackie „Zwierciadła” (przyznano ich w sumie 35). Miały one stanowić zachętę do tego, by czytelnicy pisali dalej, bo „Tylko świat, który jest opisany, żyje dłużej niż chwilę"144. Główna laureatka została nową felietonistką pisma, zamieszczając odtąd swoje teksty w cyklu Miasteczko blisko morza. Komentarz do wyników konkursu i w tym przypadku stał się pretekstem, by określić typ czytelników magazynu:

Z dzienników wynika, że nasi czytelnicy, kobiety i mężczyźni, to nie jakaś przypadkowa grupa, łączy ich podobny rodzaj wrażliwości na świat, na jego barwy, zapachy, na zło i dobro. Dlatego chodzimy na takie same filmy, czytamy podobne książki, na to samo oburzamy się i tym samym zachwycamy. To jest rodzina ludzi wrażliwych i poszukujących w sferze ducha ${ }^{145}$.

Drugą edycję konkursu ogłoszono w październiku 2005 r. Tym razem poza pierwszą nagrodą (długopisem Montblanc z Limitowanej Edycji Pisarzy 2005 poświęconej Miguelowi Cervantesowi) zamierzano przyznać drugą i trzecią nagrodę (organizator Monblanc i kalendarz, obydwa z kolekcji „Diares \& Notes”). Liczbę wyróżnień planowano ustalić po zapoznaniu się z nadesłanymi pracami. Czytelnicy mogli przysyłać swoje pamiętniki do końca lutego 2006 r. Był to jednak jedyny przykład tego typu inicjatywy, powtarzanej w ciągu badanego okresu.

Kolejne pomysły, jakkolwiek równie interesujące i liczne, miały charakter jednorazowych przedsięwzięć o charakterze paraliterackim ${ }^{146}$. Do tej grupy zaliczyć można przede wszystkim wspomniany wcześniej konkurs na pochodzące od czytelników recenzje, dotyczące ich ulubionych lektur. Warunki konkursu przedstawiono w numerze wrześniowym w 2003 r. ${ }^{147}$, przeznaczając na omówienia książek, przysyłane przez czytelników, moduł u dołu strony, w rubryce Nowości wydawnicze. Autorzy pięciu najbardziej interesujących recenzji otrzymać mieli Jesienny zestaw dla intelektualistek, na który składały się trzy książki (Muzyka pop z Vittuli Mikaela Niemiego; Perwersja Jurija Andruchowycza i Stefcia Ćwiek w szponach życia Dubravki

143 T. Jastrun, Dzień po dniu, „Zwierciadło” 2005, nr 1, s. [58]. Numer damsko-męski. 144 [br. aut.], Konkurs na dziennik, „Zwierciadło” 2005, nr 1, s. 27. Numer damsko-męski.

145 T. Jastrun, Dzień po dniu, „Zwierciadło” 2005, nr 1, s. [59]. Numer damsko-męski.

146 Ze względu na ich liczbę, do dokładniejszej charakterystyki wybrano tylko niektóre $\mathrm{z}$ nich.

147 [br. aut.], Konkurs dla czytelników, „Zwierciadło” 2003, nr 9, s. 76. 
Ugrešić) oraz firmowy kubek. Fundatorem nagrody było wydawnictwo Czarne. Od numeru listopadowego (2003) do wydania w marcu (2004) drukowano nagrodzone recenzje. Liczyły one kilkanaście zdań, posiadały własny tytuł, uzupełnione były podstawowymi elementami opisu bibliograficznego (autor recenzowanej książki, jej tytuł, miejsce wydania, nazwa wydawcy i rok opublikowania tytułu). Obok pojawiało się zdjęcie zestawu nagród. Wśród zaprezentowanych $\mathrm{w}$ ten sposób lektur znalazły się: Co wydarzyło się $w$ Madison County (Roberta J. Wallera), Czerwony namiot (Anity Diamant), Lalka i perła (Olgi Tokarczuk), Tamara Łempicka (Laury Claridge) oraz Wylinka (Simony Popescu).

Innym pomysłem z tej grupy był konkurs na opowieść, którego hasłem przewodnim miało być „Zwierciadło” $w$ moim życiu. Ogłoszony został w wydaniu czerwcowym w 2001 r. ${ }^{148} \mathrm{~W}$ kolejnym numerze rozwinięto szerzej ideę pomysłu, pisząc:

Napiszcie nam, jakie jest Wasze zwierciadło - czy czasami przeglądacie się w zwierciadle swojego życia i pytacie siebie: czy tak chciałam żyć, czy tego pragnęłam? Jak widzicie siebie, jak siebie oceniacie? A może „Zwierciadło” pomogło Wam troszkę lepiej poznać i zrozumieć siebie? Czy bywało inspiracją? Czy pomagało w życiowych decyzjach? W jakich momentach Waszego życia zaprosiłyście je do siebie? Czego oczekujecie po Waszym „Zwierciadle”? Interesuje nas, jakie cele stawiacie sobie w życiu; jakim wartościom jesteście wierne; jak radzicie sobie z codziennością; jak wygląda Wasz dzień ${ }^{149}$.

Na prace, w formie dzienników, oczekiwano do końca września (2001). Wyniki konkursu ogłoszono w jubileuszowym numerze periodyku w maju 2002 r. Swoimi wrażeniami po lekturze nadesłanych prac (było ich 98) dzieliła się z czytelnikami A. Nasiłowska, przyznając, że niektóre z nich były wstrząsające, inne spokojne, pełne marzeń, ale pojawiły się i takie, które utrwalały chwile depresji i smutku. Oceniając je także pod względem językowym, podkreślała, że niektóre z czytanych przez nią prac świadczyły o talencie literackim, lekkości w posługiwaniu się piórem, dużej dozie poczucia humoru oraz ironii autorek ${ }^{150}$. Wyróżnione prace drukowano na łamach pisma do sierpnia tegoż roku.

Podobny pamiętnikarski charakter miał inny konkurs - Mój czas. Czytelnikom proponowano, by podzielili się własnymi przemyśleniami związanymi z tym, czym on jest dla nich, jak go postrzegają, by opisali, czy ich czas

148 [br. aut.], Konkurs dla czytelników!, „Zwierciadło” 2001, nr 6, s. 131. Konkurs wpisywał się w jubileusz 45-lecia magazynu, który przypadał na rok następny, choć jego wcześniejsze edycje odnaleźć można także we wcześniejszych rocznikach periodyku.

149 [br. aut.], Uwaga! Konkurs „Zwierciadło w moim życiu”, „Zwierciadło” 2001, nr 7, s. 55.

150 A. Nasiłowska, Zwierciadło w moim życiu, „Zwierciadło” 2002, nr 5, s. 62. 
jest „żelazny [...], jak jedna karta [...], jak kłębek wełny [...], jak wodospad [...], jak plaster miodu"151. Pięć najbardziej interesujących prac-opowieści, które nie powinny przekroczyć objętości 5 stron maszynopisu, obiecano opublikować na łamach magazynu, a ich autorów nagrodzić wytwornymi zegarkami. Podobnie jak $\mathrm{w}$ poprzednim przypadku tak i ten konkurs „przerósł oczekiwania” redakcji. Pojawił się m.in. „czas ciszy”, „czas pytań”, czas, który „goni i ucieka”, ale zdarzyły się i „kolory czasu”.

Czas był również przedmiotem kolejnego konkursu, a raczej oryginalnej zabawy literackiej $\mathrm{Na}$ czasie, obejmującej dwie kategorie: „jeszcze zdążę" i „już nie mam czasu”. Tym razem wyraźnie zaznaczono, że adresatami powinni być zarówno mężczyźni, jak i kobiety. Zasady były proste:

Spróbujcie napisać rymowany monolog osoby usiłującej skłonić swojego partnera do natychmiastowego wyjścia na bal lub jakąś inną imprezę [konkurs ogłoszono w okresie karnawału - przyp. M.P.S.], albo przeciwnie, do pozostania jeszcze trochę $\mathrm{w}$ domu, bo przecież „zdążymy” 152 .

Konkursowy monolog miał składać się z tylu zdań, ile godzin liczy dzień (12). Termin nadsyłania prac upływał 31 stycznia 2004 r., zaś na laureatów czekały ekskluzywne zegarki. Dostosowując się do żartobliwego charakteru konkursu, redakcja w formie rymowanej ogłosiła jego wyniki:

W pierwszej godzinie listy zbieramy. / W drugiej przez treść się ich przedzieramy./ W trzeciej tekst maili drukujemy. / W czwartej godzinie segregujemy / Prace na męskie i te od pań / (wszystkie w granicach dwunastu zdań). / W siódmej godzinie obejrzą wszyscy / niezwykłe, ręcznie zdobione listy. / Potem czytamy, jak na zegary / Patrzą autorów małżeńskie pary. / I po dwunastu godzinach pracy / zbiór finalistów macie na tacy153.

Następnie wydrukowano prace nagrodzone w dwóch kategoriach (dla czytelniczek i dla czytelników).

Podobnie satyryczny charakter miała inna jeszcze inicjatywa redakcji pisma, podjęta w 2003 r. ${ }^{154}$ Był to konkurs „z przymrużeniem oka”, w którym czytelnicy mieli ułożyć z 20 wybranych przez redakcję słów 20-zdaniowy utwór literacki (prozą lub wierszem). W każdym zdaniu powinien pojawić się jeden z podanych wyrazów: brodacz, chochla, czerstwy, deseń, eksperyment, goździk, karmnik, kontrola, lukier, łaźnia, mimika, narożnik, obyć się, okop, poczuć, rozlać, suknia, temat, wpływowy, żółw.

\footnotetext{
151 [br. aut.], Konkurs [:] mój czas, „Zwierciadło” 2003, nr 3, s. 58.

152 [br. aut.], Konkurs: Czas goni, czas ucieka, „Zwierciadło” 2004, nr 1, s. 81.

153 [br. aut.], Konkurs [:] Na czasie rozwiq̨zany [pis. oryg.], „Zwierciadło” 2004, nr 3, s. 147.

154 [br. aut.], Konkurs, „Zwierciadło” 2003, nr 4, s. 136.
} 
W tym przypadku nagrodą było 20 kompletów biżuterii. Na pomysły czekano do 15 kwietnia (2003), a wyniki (w równie zabawnej formie, jak w poprzednim przypadku) ogłoszono, pomimo wcześniejszej obietnicy, nie w numerze majowym, a w wydaniu czerwcowym. I tym razem czytelnicy stanęli na wysokości zadania. Redakcja przez kilka dni czuła się „jak w okopach z papieru"155, czytając teksty zarówno zabawne, a nawet frywolne, jak i refleksyjne i wspomnieniowe.

Warto również wspomnieć o konkursie poetyckim Snuć miłość. Ogłoszono go w numerze czerwcowym w 2005 r., proponując czytelnikom, by zmierzyli się z napisaniem wiersza lirycznego, erotyku albo fraszki miłosnej. Na konkurs należało przesłać minimum dwa utwory, ale nie więcej niż pięć. Nagrodą były firmowe kosmetyki. Na poezję czytelników czekano do 6 sierpnia 2005 r. Podobnie jak w czasie konkursu na napisanie pamiętnika Dzień po dniu, tak i w tym przypadku przewodniczącym jury został T. Jastrun, którego tekst o miłości pojawił się obok propozycji konkursu. Autor Deszczu, przyznając, że "nie ma recepty na pisanie wierszy miłosnych” 156 , dodawał, że „Każdy wiersz powinien być prawdziwy jak kolor oczu, uśmiech i odcisk palca"157. I wiele z nadesłanych na konkurs takimi właśnie było. Redakcja otrzymała prace ponad 1200 osób. Charakter nadesłanych wierszy omówiono kilka miesięcy później, w wydaniu listopadowym pisma. I tu przyznano Literackq Przepustkę „Zwierciadła”, a nagrodzone i wyróżnione utwory wydrukowano na Specjalnych stronach dla wiersza ${ }^{158}$.

Pojawiło się również kilka drobniejszych konkursów, w których proponowano czytelnikom określony temat do opisania, zaś wśród autorów najlepszych prac rozlosowano nagrody, nierzadko książkowe. Przykładem może być konkurs dla koneserów snów: należało opisać wybrany przez siebie, najbardziej interesujący, bądź najbardziej tajemniczy lub proroczy czy ważny z innych względów sen i przesłać ów opis na adres redakcji. Nagrodą była w tym przypadku książka Concerto d'amore Anny Boleckiej ${ }^{159}$, recenzowana na stronie obok.

Natomiast w grupie trzeciej (interesujących nas przedsięwzięć, w których pismo było jednym z inicjatorów) znalazł się m.in. konkurs na nazwę nowej serii, która zgodnie z założeniem obejmować miała światową współczesną prozę kobiecą, a wydawać ją miał Państwowy Instytut Wydawniczy,

155 [br. aut.], Konkurs. Rozwiq̨zanie, „Zwierciadło” 2003, nr 6, s. 106.

156 T. Jastrun, Snuć miłość, „Zwierciadło” 2005, nr 6, s. 99.

157 Ibidem.

158 T. Jastrun, Jeszcze poezja nie zginęła, „Zwierciadło” 2005, nr 11, s. 156-[159].

159 [br. aut.], Konkurs!, „Zwierciadło” 2004, nr 9, s. 72. 
natomiast „Zwierciadło” było patronem medialnym przedsięwzięcia. Nagrodą dla laureata miały być kolejne tytuły, które zamierzano wydać w planowanym cyklu'160.

Przykładem współpracy miesięcznika $\mathrm{z}$ innym wydawnictwem był konkurs na wskazanie postaci, która zdaniem czytelników powinna zostać bohaterem serii Biografie, realizowanej przez Wydawnictwo Książkowe Twój Styl161.

Magazyn nawiązał również współpracę m.in. ze Studiem Reportażu i Dokumentu Polskiego Radia SA, organizując wspólnie konkurs Okiem reportera. Zaproszenie do udziału w nim pojawiło się w sierpniu $2005 \mathrm{r}$. Interesujący był jeden z warunków, określających przyszłe prace. Organizatorzy spodziewali się prac, „które uwzględnią charakter miesięcznika $>$ Zwierciadło<"162. Pomocą miał służyć wywiad z H. Krall, a także przykładowe reportaże magazynu, zamieszczone na następnych stronach pisma. Pierwszą nagrodą było opublikowanie nagrodzonego tekstu na łamach periodyku, drugą - realizacja reportażu radiowego. Uhonorowaniem miejsca trzeciego była kolekcja 6 płyt CD, wydanych przez Polskie Radio SA: Antologia najwybitniejszych reportaży radiowych. Termin nadsyłania prac mijał 30 listopada 2005 r., a jego rozwiązanie pojawiło się w okresie nie obejmującym ram czasowych przyjętych w niniejszej książce.

Kolejnym przykładem współpracy „Zwierciadła” z innym medium był organizowany wspólnie z Programem 2 Polskiego Radia konkurs Napisz do słuchu. Przed chętnymi stanęło zadanie przygotowania scenariusza słuchowiska radiowego na dowolny temat, przy czym podobnie jak w przypadku wyżej opisanego konkursu, tak i tu jednym z warunków było uwzględnienie przez autorów m.in. specyfiki magazynu oraz dodatkowo charakteru Programu II Polskiego Radia163.

Miesięcznik nawiązywał współpracę również z innymi instytucjami i firmami, by inicjować i realizować konkursy, które nazwać można paraliterackimi. Jednym z pomysłów był konkurs Życie zaczyna się po czterdziestce, zaproponowany wspólnie z jedną z amerykańskich firm kosmetycznych w listopadowym numerze w 2004 r. Warto o nim wspomnieć, jako że, choć bardzo luźno można go zaliczyć do inicjatyw o charakterze także literackim, to w sposób wyraźny podkreślał typ odbiorczyń pisma. Czytelniczki poproszono o podzielenie się swoim podejściem do owej „magicznej granicy”

160 [br. aut.], Konkurs dla czytelników, „Zwierciadło” 2003, nr 10, s. 90. Zwyciężyła nazwa Spojrzenia.

161 „Zwierciadło” 2004, nr 4, s. 70.

162 [br. aut.], Okiem reportera, „Zwierciadło” 2005, nr 8, s. 124.

163 br. aut.], Napisz do słuchu, „Zwierciadło” 2005, nr 6, s. 109. 
wieku, o opisanie, co dla każdej z nich ona oznacza. Jednym z wymogów było dołączenie przez autorki listów własnego zdjęcia i podanie daty urodzenia. Na sześć laureatek najbardziej interesujących zwierzeń czekała kuracja „odnowy biologicznej”, przeprowadzana przez specjalistów: stylistów, kosmetologów i fryzjerów. Wyniki konkursu ogłoszono w kwietniu 2005 r., prezentując zdjęcia laureatek już po metamorfozie. Konkurs promował i w tym przypadku wzór kobiety, realizowany przez magazyn. Zwyciężczyniami były czytelniczki, dla których przekroczenie wieku 40 lat „to nie koniec świata. Wręcz przeciwnie!” ${ }^{164}$, a to dlatego, że są „otwarte na życie, pełne radości, wewnętrznego spokoju i ciekawe świata. Potrafią żyć tu i teraz. Potrafią żyć pełnią życia i wiedzą, że wszystko przed nimi" 165 .

Czwarta grupa konkursów okazała się najliczniejsza. Bardzo często książka była nagrodą, na przykład za prawidłowe rozwiązanie krzyżówki. W danym numerze czytelnik mógł otrzymać m.in. jeden z 20 lub 30 egzemplarzy wybranego przez redakcję lub ufundowanego przez wydawcę tytułu (na przykład Terapię Pauliny P. Ryszarda Sadaja, reklamowaną na łamach periodyku). Książka była także niekiedy nagrodą za najciekawszy list przysłany do redakcji. W 2004 r., a szczególnie 2005, zwiększyła się wyraźnie liczba konkursów sms-owych, w których należało wybrać jedną z (zazwyczaj trzech) odpowiedzi, nawiązujących do wybranej książki, stanowiącej jednocześnie nagrodę dla kilku (przeważnie 10 lub 20) osób, które przysłały prawidłowe rozwiązanie. Nie zapominano przy tej okazji o promocji własnych autorów. Na przykład z okazji niedawnej premiery książki T. Jastruna Rzeka podziemna zaproponowano czytelnikom udział w konkursie, w którym obiecywano rozlosować wśród poprawnych odpowiedzi 30 egzemplarzy tego tytułu 166 .

Jak wynika $\mathrm{z}$ analizy zebranego materiału, omawiany periodyk często i chętnie proponował rozmaitego rodzaju konkursy, inicjował ciekawe przedsięwzięcia, których celem było m.in. zacieśnienie kontaktów czytelników z pismem z jednej strony, a z drugiej, odkrywanie talentów literackich wśród jego odbiorców. Pomimo, że nie udało się wyłonić kolejnej Doroty Masłowskiej czy wspomóc debiutu następcy W. Kuczoka, to jednak niezaprzeczalną zaletą tych inicjatyw było rozwijanie zdolności pisarskich czytelników, a także warte podkreślenia promowanie (choćby niezamierzone) książek, będących nagrodą w licznych konkursach sms-owych.

\footnotetext{
164 [br. aut.], Życie zaczyna się po... czterdziestce, „Zwierciadło” 2005, nr 4, s. 124.

165 Ibidem.

166 „Zwierciadło” 2005, nr 4, s. 12.
} 
Zdecydowanie największą grupę stanowiły informacje nawiązujące do książki, zaliczone tu do kategorii Inne. Były one najbardziej zróżnicowane pod względem formy. Znaleźć wśród nich można zarówno dłuższe teksty, jak i krótkie wzmianki, notki i zapowiedzi.

Systematycznie drukowano felietony (w sumie było ich 192) znanych osób; wśród nich znajdował się stały cykl T. Jastruna Czułym okiem, Przypowieści P. Coelho, Kartki z białego zeszytu S. Raduńskiej oraz Felieton $z$ wierszem A. Poniedzielskiego. Kilkakrotnie pojawiły się Prawdy i zmyślenia M. Bojarskiej, zaś sporadycznie rubryka Punkt widzenia, a w jej obrębie felietony Agnieszki Graff, Krystyny Kofty i Piotra Pietuchy. Interesującym pomysłem była systematycznie drukowana rozmowa pomiędzy W. Eichelbergerem a T. Jastrunem (Mężczyzna wobec kobiet $\rightarrow$ Tajemnice mężczyzn $\rightarrow$ Jawa i sen), którzy poruszali tematy odpowiadające tytułowi cyklu. Kilkakrotnie do rozmowy zaproszono także P. Coelho. Redakcja bardzo ceniła sobie współpracę z autorem Alchemika, podkreślając, że pisane przez niego przypowieści przygotowywane są specjalnie dla „Zwierciadła”. Wzmocnieniu wymowy tej współpracy miał służyć nagłówek, używany także przy innych tego typu okazjach: Tylko u nas.

$\mathrm{Na}$ łamach pisma drukowano też fragmenty powieści (21). Wśród nich znalazły się m.in. Boyowie. Losy Zofii i Tadeusza Żeleńskich Barbary Winklowej, Jakbyś kamień jadła W. Tochmana, Jedenaście minut P. Coelho, Poczwarka D. Terakowskiej, Polka Manueli Gretkowskiej, Rozstania Magdy Dygat. Tytuły P. Coelho były kilkakrotnie przywoływane. Poza wspomnianymi, czytelnicy mogli poznać także fragmenty Demona i panny Prym oraz Zahira. Nie zapomniano również o promocji książek własnych autorów: pojawiły się na przykład urywki Alchemii alchemika autorstwa W. Eichelbergera i Wojciecha Szczawińskiego, a także książki składającej się z rozmów R. Arendt-Dziurdzikowskiej z W. Eichelbergerem, drukowanych na łamach pisma kilka lat wcześniej (Mężczyzna też człowiek). Zamieszczano również opowiadania (16), jak na przykład wspomniana parodia bestsellera Helen Fielding, w wykonaniu rodzimym występująca na łamach „Zwierciadła" jako Bridget Dąs czy cztery lata później, w 2005 r., opowiadanie Konrada T. Lewandowskiego, drukowane w pięciu odcinkach.

W magazynie pojawiały się również krótkie informacje związane z literaturą, zamieszczane w różnych działach i rubrykach, a donoszące $w$ kilku zdaniach bądź to o imprezach, związanych z książką, bądź dotyczące pisarzy. W latach 2004-2005 w ramach przygotowywanego przez K. Sztukę przeglądu najważniejszych z punktu widzenia redakcji wydarzeń kulturalnych danego miesiąca odnaleźć można było także informacje związane m.in. ze spotkaniami z książką (jak choćby dotyczące kolejnych targów książki, Wrocławskich Promocji Dobrych Książek, Festiwalu Książki „Bibliomania 
2004” i „Bajlandii - innym wymiarze bajki” czy o XIX Międzynarodowego Festiwalu Komiksu). Pojawiały się $w$ tym miejscu również informacje o spotkaniach z pisarzami (jak na przykład z autorkami książek z serii Europejki wyd. Czarne), wzmianki dotyczące imprez poetyckich (na przykład informacja o IX Ostrym Dyżurze Poetyckim w Teatrze Narodowym w Warszawie) czy dotyczące nagród literackich (m.in. wręczenie Nagrody Literackiej im. Józefa Mackiewicza). Informacje tego typu zajmowały kilkanaście zdań wśród innych tego rodzaju doniesień. Poza krótką charakterystyką czytelnik mógł liczyć na wskazówki organizacyjne: datę, miejsce i ewentualną cenę biletu na proponowaną imprezę.

Pisano także o rozmaitych ciekawostkach, związanych z książką (62). Wśród nich znalazła się m.in. informacja dotycząca programu, realizowanego w Szwecji: Czytam, wiem, tworzę, czy związana z rodzimą inicjatywą, Czytanie zbliża, stanowiącą część kampanii Cała Polska czyta dzieciom. Informowano, że tylko 4\% Polaków interesuje się kulturą, a także przytaczano dane statystyczne związane z czytelnictwem Polaków. Odbiorca „Zwierciadła” mógł również dowiedzieć się, jaki cel przyświeca Polskiemu Bractwu Kawalerów Gutenberga.

W latach 2003-2004 systematycznie przypominano o Kanonie książek dla dzieci i młodzieży, za każdym razem proponując inne tytuły (na przykład Baśnie Braci Grimm, Harry Potter i kamień filozoficzny Joanne J. Rowling, Akademia Pana Kleksa Jana Brzechwy, Opowieści z Narnii Clive'a S. Lewisa). Ta forma informacji miała charakter zbliżony do reklamy, zawsze zajmując niewielkich rozmiarów moduł, umieszczony zazwyczaj u dołu strony.

Periodyk adresowany był jednak przede wszystkim do publiczności dorosłej i jakkolwiek kwestie związane z dziećmi i młodzieżą były tu często podnoszone, to jednak oferta proponowanych w rozmaity sposób książek dostosowana była do dorosłego czytelnika. Wspomniany Kanon należał zatem do rzadkich przejawów zainteresowania magazynu promocją literatury dziecięcej czy młodzieżowej. Propozycje lektur adresowanych zarówno dla dorosłych, jak i dzieci odnaleźć można niekiedy przy okazji tekstów podejmujących kłopoty związane z wychowaniem. Wówczas na zakończenie wywodu pojawiał się krótki nagłówek: Polecamy, a pod nim tytuły kilku wybranych pozycji, po które powinien sięgnąć zarówno rodzic, jak i jego dziecko ${ }^{167}$. Częściej jednak proponowano wybrane książki rodzicom ${ }^{168}$.

167 Zob. np. „Zwierciadło” 2005, nr 8, s. [58]-[61].

168 Np. poradnik K. Czachowskiej i K. Małkowicz: Spokojnie, to tylko życie, zob. „Zwierciadło" 2002, nr 4, s. 86; książka L. Mieścickiej-Mellibrudy: Być matkq dorosłych dzieci, zob. „Zwierciadło” 2002, nr 2, s. 105. 
Ta forma, dzięki której czytelnicy dowiadywali się o książkach, po które warto sięgnąć, była wykorzystywana przez redakcję także przy innych tekstach, odnoszących się do rozmaitych kwestii. Na przykład pod publikacją, opisującą rozmaite uczulenia, pojawiła się sugestia, by sięgnąć po Poradnik medyczny. Alergie wydawnictwa Medium ${ }^{169}$. W innym przypadku proponowano książkę Homeopatia 101 praktycznych porad170, zaś pisząc o stanach depresyjnych zalecano lekturę Depresja - złośliwy smutek (Lewisa Wolperta) ${ }^{171}$.

Książka pojawiała się także jako źródło, z którego korzystali autorzy publikacji. Odnotowywali oni $\mathrm{w}$ takich przypadkach skrupulatnie dane bibliograficzne. Na wykorzystane książki powoływano się m.in. przy okazji tekstu na temat wspólnoty rodzinnej i tego, jak ją budować172 czy przy publikacji będącej tematem miesiąca: $W$ drodze do bliskości ${ }^{173}$.

\subsubsection{Dowód artystycznej osobowości ${ }^{174}$. Inne informacje: o prasie i środowisku dziennikarskim}

Na łamach „Zwierciadła” w niewielkim tylko stopniu interesowano się rynkiem prasowym. Informacji, które by doń nawiązywały, było bardzo mało (12). Poza trzema przypadkami były to krótkie, kilkunastozdaniowe wzmianki, na przykład informujące o jubileuszu pięciolecia czasopisma „Charaktery”, o nowym miesięczniku dla dzieci „Bajki-grajki” czy o odznaczeniu Barbary Toruńczyk (twórczyni „Zeszytów Literackich”) Krzyżem Oficerskim Orderu Odrodzenia Polski. Nieco dłuższy, jednostronicowy tekst pojawił się z okazji jubileuszu 60-lecia tygodnika „Przekrój”, przypominając jego współpracowników: Konstantego I. Gałczyńskiego, Jerzego Waldorffa, Melchiora Wańkowicza i innych.

169 „Zwierciadło” 2002, nr 4, s. 116.

170 „Zwierciadło” 2002, nr 4, s. 113.

171 „Zwierciadło” 2001, nr 10, s. 87.

172 „Zwierciadło” 2005, nr 12, s. 24-[29].

173 „Zwierciadło” 2005, nr 8, s. 28-[33].

174 Tytuł jednej z informacji, zob. S. Szabłowski, Dowód artystycznej osobowości, „Zwierciadło" 2003, nr 2, s. 82. 


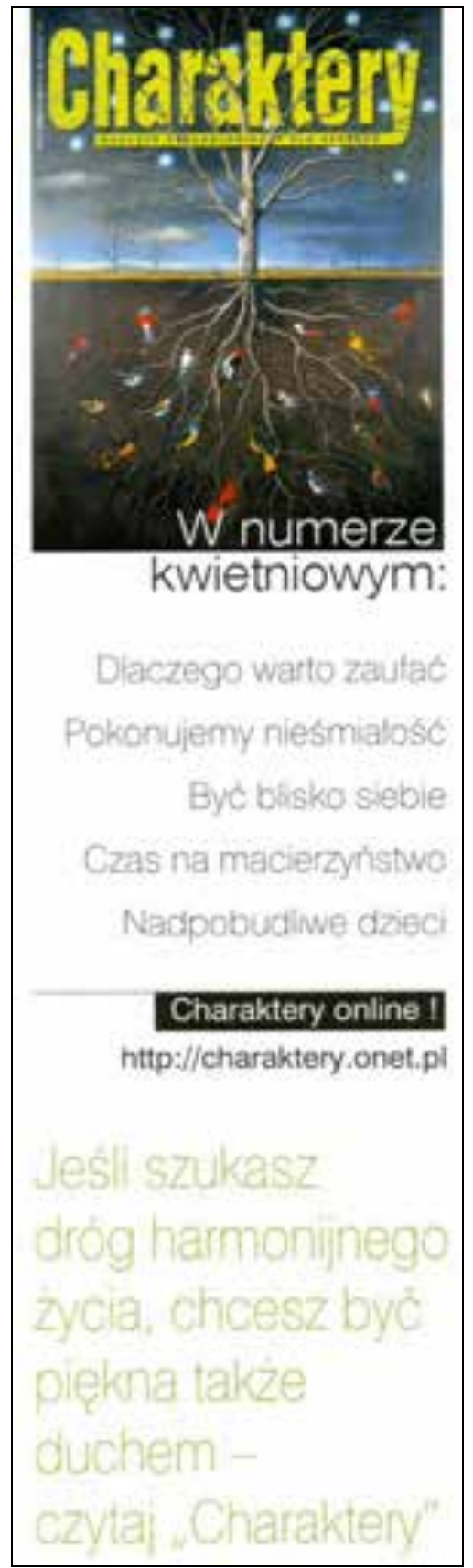

Zdjęcie 101. Wybrane ogłoszenie wydawnicze zamieszczone na łamach „Zwierciadła” „Zwierciadło” 2003, nr 4, s. [81]

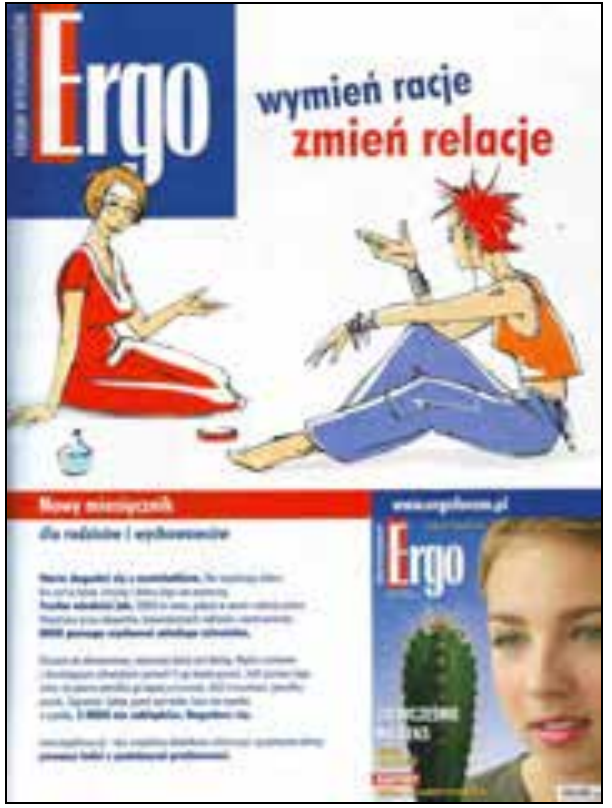

Zdjęcie 102. Wybrane ogłoszenie wydawnicze zamieszczone na łamach „Zwierciadła” „Zwierciadło” 2004, nr 9, [37]

Nieco częściej temat prasy pojawiał się dzięki reklamom; tych było $\mathrm{w}$ badanym okresie 60 . W sumie zaproponowano 23 różne periodyki. Wśród nich znalazły się m.in.: „Kuchnia. Magazyn dla smakoszy”; „M jak Mieszkanie”, „Ozon”; „Podróże”, „Polityka”, „Przekrój”, „Szósty Zmysł”. Warto zwrócić uwagę także na dwa inne tytuły, które wpisywały się $\mathrm{W}$ profil pisma i kilkakrotnie pojawiały się w na łamach „Zwierciadła” w formie reklamy: „Charaktery” oraz „Ergo: Forum Wychowawców". Oto wybrane przykłady - zdjęcie 101-103. 


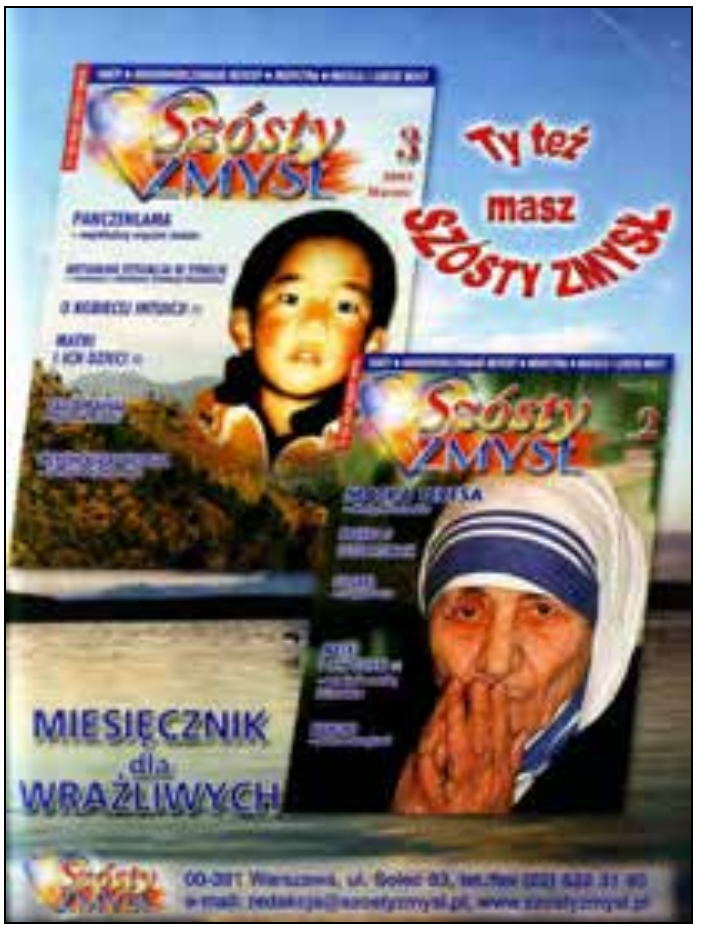

Zdjęcie 103. Wybrane ogłoszenie wydawnicze zamieszczone na łamach „Zwierciadła” „Zwierciadło” 2003, nr 3, s. [53]

W każdym z przywołanych powyżej ogłoszeń określony został adresat. "Charaktery” kierowano do osób, które „szukają dróg harmonijnego życia”, „Ergo...”, to „miesięcznik dla rodziców i wychowawców”, zaś „Szósty zmysł” to pismo „dla wrażliwych". W każdym anonsie zamieszczono także kopię okładki najbliższego numeru reklamowanego pisma, przy czym tylko $\mathrm{w}$ trzecim przypadku był to element najbardziej przykuwający wzrok. W ogłoszeniu pierwszym były nim zapowiedzi tematów najbliższego wydania, przy inseracie drugim to zadanie realizował rysunek, który w założeniu miał odzwierciedlać umieszczone powyżej hasło. Na nieco inne elementy zwrócili uwagę reklamodawcy proponujący sięgnąć po dwa inne pisma (zdjęcia 104-105). 


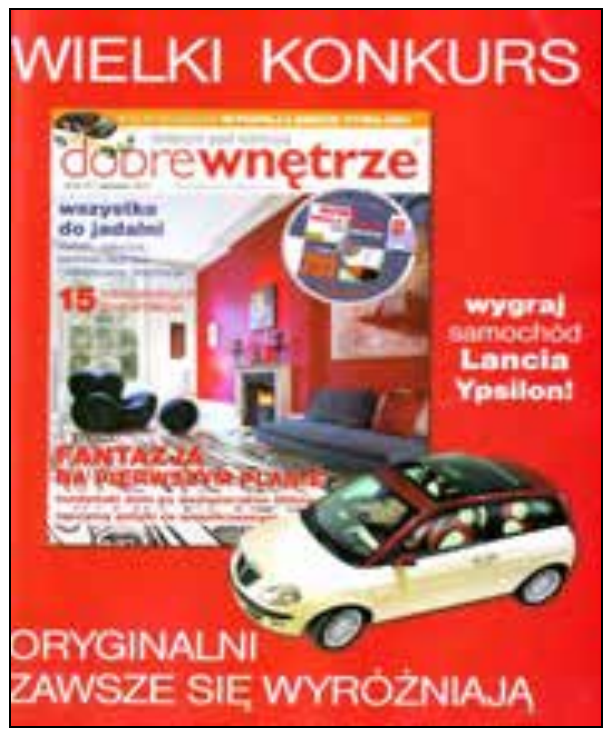

Zdjęcie 104. Wybrane ogłoszenie wydawnicze zamieszczone na łamach „Zwierciadła” „Zwierciadło” 2005, nr 3, s. [133]

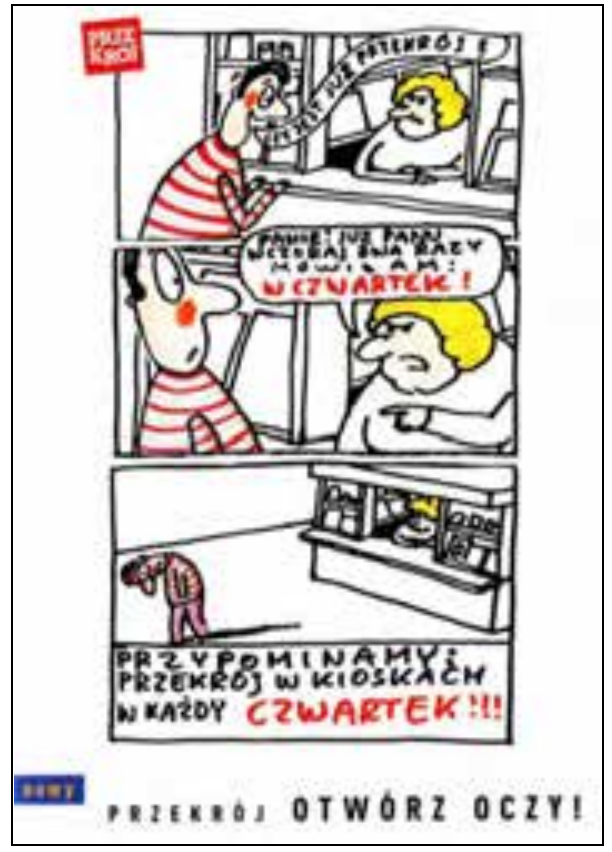

Zdjęcie 105. Wybrane ogłoszenie wydawnicze zamieszczone na łamach „Zwierciadła” „Zwierciadło” 2003, nr 6, s. [45]

W pierwszym przypadku (zdjęcie 104) czytelnika zachęcić miała możliwość wygranej w postaci samochodu, którego wizerunek pojawił się na pierwszym planie. Sugestywnie brzmiało hasło, które dawało do zrozumienia, że aby dołączyć do tych, którzy „zawsze się wyróżniają”, należy kupić proponowane czasopismo. Dzięki temu nie tylko będzie można oryginalnie urządzić swoje mieszkanie, ale także stać się właścicielem nietuzinkowego samochodu. W drugim ogłoszeniu (zdjęcie 105) postawiono na inny rodzaj oryginalności: w skądinąd znanej formie przypomniano czytelnikowi, kiedy ulubiony przez niego tytuł dostępny jest w sprzedaży.

„Zwierciadło” przyłączyło się do ogólnopolskiej kampanii (promocji prasy), w której udział brały także omówione wcześniej tygodniki opinii. Obok tych samych ogłoszeń, które pojawiały się na łamach „Polityki”, „Wprost” i „Newsweek Polska”, uwagę czytelnika zwracały też inne formy anonsu reklamującego prasę (zdjęcie 106).

Przewrotne hasło, a także tło utworzone z fragmentów artykułów, na którym pojawił się napis $\mathrm{z}$ liter wyciętych $\mathrm{z}$ gazet, niczym $\mathrm{w}$ anonimie, zwracały uwagę czytelnika, pomimo że ograniczono się do czarno-białej tonacji ogłoszenia. 


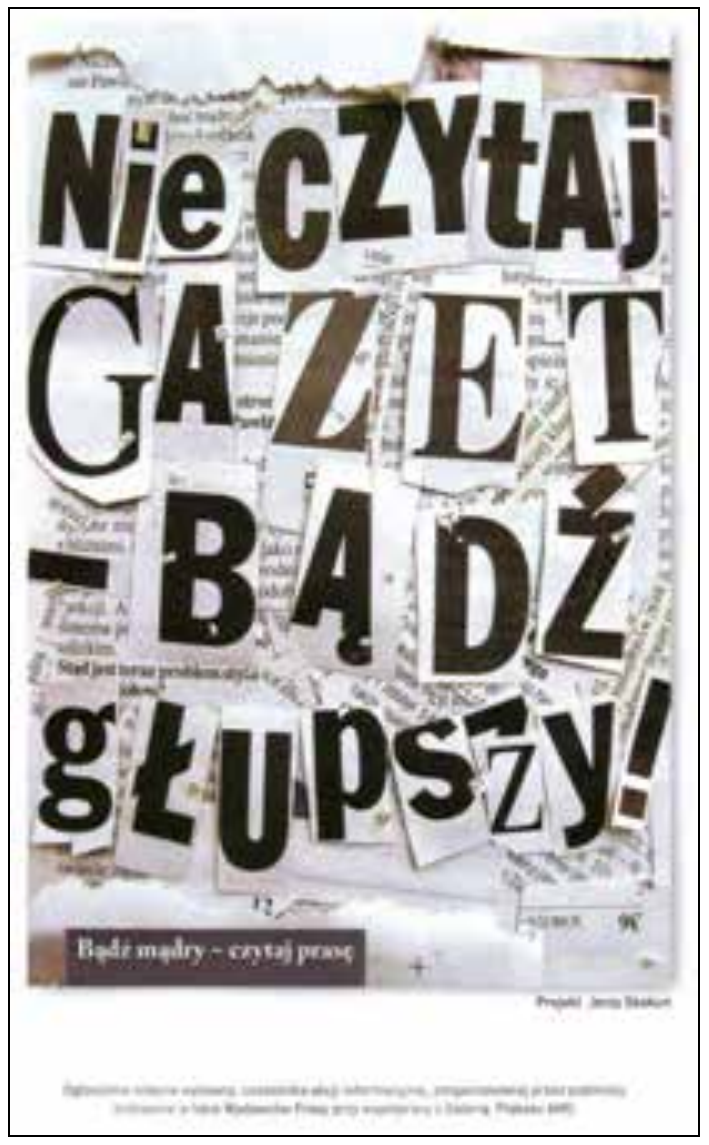

Zdjęcie 106. Wybrane ogłoszenie wydawnicze zamieszczone na łamach „Zwierciadła”

„Zwierciadło" 2005, nr 8, s. [53]

Inaczej wyglądała autopromocja „Zwierciadła”. Ogłoszeń tego typu było 76, co stanowiło razem 148 informacji związanych $\mathrm{z}$ prasą. Zarówno w większości anonsów przypominających o prenumeracie pisma, jak i reklamujących kolekcję periodyku czy podejmowane przezeń inicjatywy, sięgano najczęściej po nasycone kolory, które niekiedy współgrały z daną porą roku. Tak było choćby w reklamie zaprezentowanej na zdjęciu 107.

Uważny czytelnik zauważył w owym gąszczu jesiennych liści tytuł ulubionego przez siebie periodyku, umieszczony u góry strony. Ciepłe barwy miały w założeniu nastawić odbiorcę pozytywnie do czytanego magazynu, a bardziej dociekliwy adresat zaczął się, być może, zastanawiać nad głębią i przesłaniem, ukrytymi w owej reklamie. 


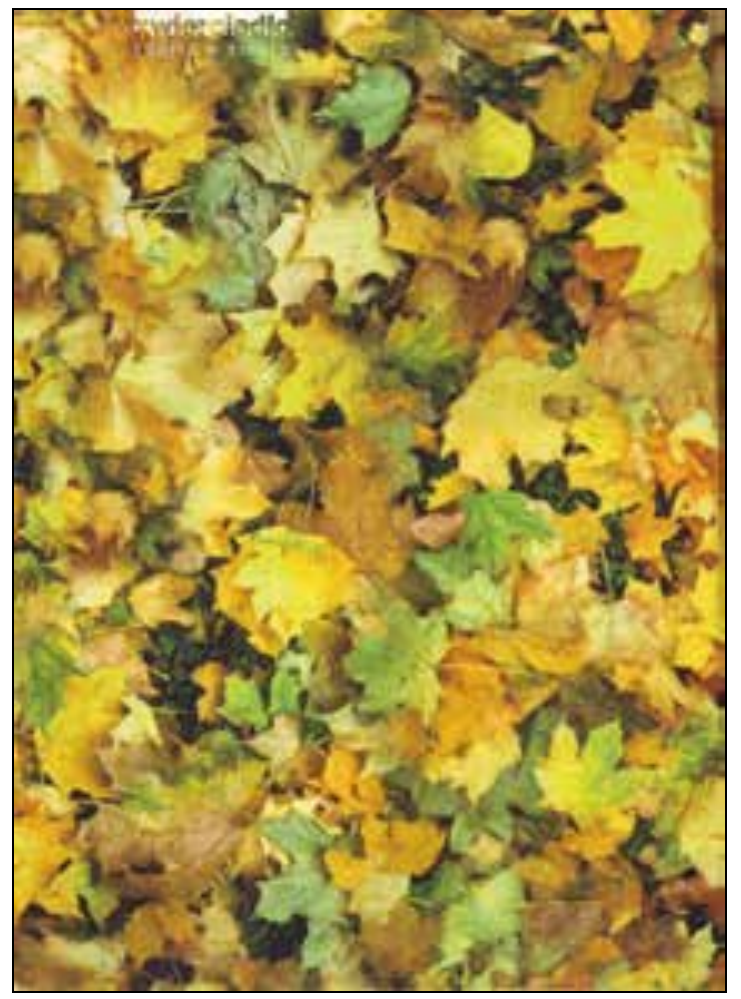

Zdjęcie 107. Wybrane ogłoszenie wydawnicze zamieszczone na łamach „Zwierciadła” „Zwierciadło” 2003, nr 10, s. [6]

Większość inseratów zarówno tych o charakterze autopromocyjnym, jak i reklamujących inne tytuły była całostronicowa. Zwiększało to czytelność przekazu, choć i w przypadku mniejszych ogłoszeń, zajmujących kolumnę lub (rzadziej) niewielki moduł, były one przejrzyste. Wynikało to również z faktu, że w pojedynczym ogłoszeniu reklamowano zazwyczaj jeden tytuł 175 .

Analiza zebranego materiału, a także przytoczone przykłady świadczą o dużym zainteresowaniu redakcji „Zwierciadła” książką. Najliczniej była ona reprezentowana w recenzjach i formach jej pokrewnych oraz w postaci proponowanych czytelnikom konkursów, szczególnie tych o charakterze miniquizów, wykorzystujących możliwości telefonii komórkowej.

175 Wyjątkiem był anons, w którym pojawiło się 8 tytułów czasopism, zob. „Zwierciadło” 2001, nr 3, s. [4]. 
Z wielu znajdujących się na łamach pisma form informacji o książce wyłaniał się obraz, który komponował się, co wielokrotnie podkreślano, z nadrzędną polityką pisma (ukierunkowanego na kreowanie określonego wzoru osobowego kobiety), przystosowanego jednocześnie do potencjalnych odbiorców. Konsekwencją była pewna jednostronność proponowanych lektur (w przypadku recenzji zamieszczanych w rubryce Moje ksiq̨żki) i zdeterminowany założonymi kryteriami wybór zarówno rozmówców do przeprowadzanych wywiadów, jak i bohaterów kreślonych sylwetek twórców. W wielu przypadkach pojawiało się przesłanie, które dałoby się zamknąc $\mathrm{w}$ słowach jednej z bohaterek historii, przytoczonej na łamach pisma: „Czas nie musi płynąć przeciwko nam. Nawet jeśli jest się kobietą. To nic, że ustawia nas naprzeciw lustra i każe liczyć kolejne zmarszczki. To nic pod warunkiem, że poza lustrzanym odbiciem mamy coś jeszcze"176.

${ }^{176}$ A. Filipowska, Ogród Diany, „Zwierciadło” 2004, nr 4, s. 54. 


\section{3. „Twój Styl”: luksus dostępny dla wszystkich ${ }^{1}$}

\subsubsection{Styl na lata2: historia periodyku}

Nigdzie lokalny tytuł nie wygrał konkurencji $\mathrm{z}$ wielkimi światowymi magazynami. W Polsce się to zdarzyło ${ }^{3}$.

Drugi z omawianych periodyków kobiecych, miesięcznik „Twój Styl”, pojawił się $\mathrm{w}$ Polsce $\mathrm{w}$ okresie najintensywniejszych przeobrażeń rynku prasowego, w 1990 r. Przypomnijmy: w tym czasie przystąpiono do likwidacji koncernu RSW Prasa-Książka-Ruch, wprowadzono w życie ustawę o zniesieniu cenzury, tworzono podstawy prawne umożliwiające zakładanie spółdzielni wydawniczych i spółek dziennikarskich. Były to jednocześnie miesiące, w których wydawcy borykali się z rosnącymi cenami usług poligraficznych i papieru oraz z problemami z kolportażem. Czynniki te $\mathrm{z}$ jednej strony wpłynęły m.in. na załamanie się czytelnictwa prasy, szczególnie $\mathrm{w}$ odniesieniu do wielu tzw. starych tytułów, z drugiej na tymczasowe zawieszenie lub zmniejszenie objętości dużej liczby periodyków. Jednocześnie pojawiły się zupełnie nowe pisma. Wśród nich pionierem w segmencie ekskluzywnych, tzw. lifestylowych czasopism kobiecych, stał się „Twój Styl”.

Jak twierdzi Krystyna Kaszuba, inicjatorka jego powstania, pomysł narodził się „Z zazdrości i mojej fascynacji pięknymi kolorowymi magazynami zachodnimi, które w PRL-u można było oglądać tylko w czytelni Empik-u na Ścianie Wschodniej"4. Z propozycją wydawania pisma, które zawartością miało przypominać zachodnie periodyki kobiece, K. Kaszuba zgłosiła się do Cezarego Windorbskiego, ówczesnego współwłaściciela spółki wydawniczej Interim. Przedsiębiorstwo powstało w 1988 r. jako Polska Grupa Interim, holding specjalizujący się w produkcji i dystrybucji luksusowych produktów. Rok później przekształciło się w Oficynę Wydawniczą. Sukces rynkowy i finansowy osiągnęło dzięki wydaniu bestsellerowego Abecadła Kisiela (Stefana Kisielewskiego). W czasie, kiedy Cezary Windorbski wraz z Grzegorzem Białeckim poszukiwali pomysłu na inwestycję zarobionego kapitału, pojawiła się $\mathrm{u}$ nich $\mathrm{K}$. Kaszuba $\mathrm{z}$ gotowym projektem prasowym. C. Windorbski przyznał: „Kiedy przejrzałem makiety, nie miałem wątpliwo-

\footnotetext{
${ }^{1}$ Część hasła, promującego periodyk: „Twój Styl” to luksus dostępny dla wszystkich.

2 Tytuł jubileuszowego artykułu, z okazji dziesięciolecia istnienia pisma. Zob. M. Jarco, współpraca: M. Mrozińska, Styl na lata, „Wprost” 2000, nr 41, s. 86, 88.

3 J. Pieńkowska, Po stronie kobiet, „Twój Styl” 2005, nr 12, s. 90.

${ }^{4}$ Ibidem.
} 
ści [...], że w tej propozycji tkwi wielki potencjał"5. Koncepcja periodyku oparta była na wzorach zachodnich takich pism, jak na przykład "Glamour” czy „Vogue”, co wyraźnie wskazywało na założenie wydawania magazynu wysokiej jakości, adresowanego do ściśle określonej grupy odbiorców.

Czasopismo miało nosić tytuł „Styl” (podobnie jak przedwojenny poznański periodyk), ale gdy zgłoszono tę propozycję do rejestracji, okazało się, że jest on już zarezerwowany przez innego wydawcę. Dodano wówczas zaimek „Twój”, co nadawało nazwie osobisty wydźwięk i okazało się korzystne dla dalszego rozwoju czasopisma. Wykorzystując w dużej mierze kontakty towarzyskie w celu pozyskania autorów, K. Kaszuba, wraz z niewielką grupą osób, przygotowała pierwszy numer, który był łączonym wydaniem wakacyjnym. Ukazał się on w nakładzie 100 tys. egzemplarzy w lipcu 1990 r. Liczył 64 strony, wydrukowany został w warszawskim Domu Słowa Polskiego. Na drugiej stronie pojawił się jasno sprecyzowany program, który redakcja zamierzała realizować:

Niezależnie od okoliczności trzeba wierzyć w siebie. Tylko czy każdy z nas wie, co jest jego wartością? Chcielibyśmy, by w odpowiedzi na to pytanie pomógł Państwu „TWÓJ STYL”. [...] Chcemy rozmawiać z Państwem o stosunkach międzyludzkich, o tym wszystkim, co ludzi zbliża, pozwala wzajemnie się zrozumieć, nawiązać nici uczuć i sympatii, chronić serdeczne związki i szanować osobowość drugiego człowieka. [...]. Miesięcznik [...], z którym wchodzimy na rynek, to właśnie styl Pani, to styl Pana, to Wasz styl. Styl życia, obyczaju, mody, stosunków wzajemnych nawiązujący do najlepszych tradycji przeszłości i wrażliwie otwarty na współczesność 6 .

Sukces pierwszego numeru, który rozszedł się niemal bez zwrotów, zaskoczył nawet wydawcę. Okazało się, że pomysł nowej na rynku prasowym w Polsce formuły periodyku wpisał się w oczekiwania czytelniczek, które do tej pory przyzwyczajone były do zupełnie innego typu prasy. Był odpowiedzią na ukryte pragnienia kobiet, a także rodzajem poradnika zarówno dla tych, które poszukiwały chwili zapomnienia i odskoczni od problemów codziennego życia, jak i dla tych, które próbowały odnaleźć się w nowej rzeczywistości, stawiającej przed nimi nowe wymagania. Był pierwszym polskim pismem, które lansowało styl nowoczesnej, eleganckiej, pewnej siebie kobiety, przedsiębiorczej, aktywnej zawodowo, słowem: kobiety sukcesu. „Twój Styl” stanowił

propozycję tworzenia własnego lepszego świata. Polki nie znały jeszcze słowa „asertywnośc” ani hasła „Jesteś tego warta”. Brak poczucia własnej wartości przeszkadzał im nie tylko

\footnotetext{
5 K. Lubelska, Madame Redaktor, „Polityka” 2002, nr 14, s. 80.

6 Zespół magazynu „Twój Styl”, Od redakcji, „Twój Styl” 1990, nr 1, s. 2.
} 
w rozwoju zawodowym, ale i w osiąganiu szczęścia. Pomagaliśmy kobietom odnaleźć siebie i czerpać z życia to, co najlepsze. Pokazywaliśmy, jak nie dać się ustawiać w roli tej gorszej7.

Jednocześnie kreował określony wizerunek kobiety i jej roli w społeczeństwie, wybrany model małżeństwa i rodziny. ${ }^{8}$

Po dwóch wakacyjnych miesiącach ukazał się numer drugi magazynu. Redakcja, dziękując za przychylne przyjęcie, apelowała, by czytelnicy dzielili się swoimi uwagami na temat kompozycji i zawartości periodyku. Prośba o udział w kształtowaniu jego postaci będzie odtąd systematycznie pojawiać się na łamach „Twojego Stylu” w rubryce Od redakcji.

Wraz z rosnącą popularnością tytułu sukcesywnie rósł także jego nakład, ale również i cena. Już w numerze 3 tłumaczono jej wzrost zwiększającymi się kosztami wydawniczymi, rekompensując czytelnikom ten fakt poprzez dołączenie do wydania w formie wkładki zestawu ćwiczeń callanetics i obiecując w zamian zwiększenie objętości periodyku (kolejny numer liczył już 76 stron).

Zreorganizowano status wydającej go spółki, którą w październiku zarejestrowano jako „Twój Styl” sp. z o.o.9 Oficyna Wydawnicza „Interim” zatrzymała $80 \%$ udziałów, pozostałe $20 \%$ podzielono po połowie pomiędzy osoby fizyczne, będące jej założycielami. Do spółki przystąpiła Krystyna Kaszuba, już oficjalnie jako redaktor naczelna, oraz Roman Wysocki, który miał pełnić funkcję wiceprezesa ds. wydawniczych. Stanowisko prezesa objął Cezary Windorbski, a dyrektorem naczelnym został Grzegorz Białecki.

Kolegium redakcyjne tworzyli Krystyna Kaszuba, Leokadia Kempska-Rylska i Roman Wysocki. Funkcję sekretarza redakcji sprawowała Anna Orlicka-Sapa, zaś wśród pierwszych współpracowników pisma znaleźli się: Ewa Bieszczadzka, Mariola Bojarska, Anna Grigo, Anna Humieja, Ilona Kondrat, Elżbieta Marianowska, Piotr Mitzner, Andrzej S. Nartowski, Edward Pietkiewicz, Joanna Rawik, Marzena Reich, Jacek Szmidt, Janusz

\footnotetext{
${ }^{7}$ J. Pieńkowska, Po stronie..., s. 92.

${ }^{8} \mathrm{Na}$ temat wzoru osobowego, modelu małżeństwa i rodziny, kształtowanego przez pisma kobiece tego okresu, w tym także przez „Twój Styl” pisała m.in. Z. Sokół, Prasa kobieca w Polsce w latach 1945-1995, Wydawnictwo Wyższej Szkoły Pedagogicznej w Rzeszowie, Rzeszów 1998. Zob. też: K. Wodniak, Miesięcznik „Twój Styl” w latach 1990-1995 jako nowy typ magazynu społeczno-kulturalnego, „Acta Univesritatis Wratislaviensis. Literatura i Kultura Popularna" 1998, nr VII, s. 259-260; M. Przybysz-Stawska, Między nowoczesnościa a tradycją? Rodzina $i$ wartości rodzinne prezentowane $w$ prasie kobiecej (na przykładzie czasopisma „Twój Styl” w latach 2006-2009), [w:] Wartości kulturowe w rodzinie: założenia, realia i egzemplifikacje, red. nauk. W. Muszyński, Wydawnictwo Adam Marszałek, Toruń 2010, s. [187]-203; eadem, Stylowa kobieta. Portret stylu życia współczesnej kobiety lansowany na łamach „Twojego Stylu” (w latach 2000-2003), [w:] „Nowy wspaniały świat?”. Moda, konsumpcja i rozrywka jako nowe style życia, red. naukowa W. Muszyński, Wydawnictwo Adam Marszałek, Toruń 2009, s. [50]-66.

${ }^{9}$ W skład spółki wchodziły dwa wydawnictwa: prasowe i książkowe.
} 
Szymański, Ewa Woydyłło oraz Mirosław Żuławski. Pierwszymi zagranicznymi korespondentami „Twojego Stylu” byli Blanka Farnik (Paryż), Janusz Szymański (Toronto) oraz Monika Teresińska (Boston). Siedziba redakcji znajdowała się w tym czasie przy ul. Świętojerskiej 5/7 w Warszawie.

Dzięki utrzymaniu wysokiego poziomu magazynu zarówno pod względem technicznym, jak i merytorycznym oraz konsekwentnemu propagowaniu założonego na początku wizerunku nowoczesnej kobiety, „Twój Styl” zyskał grono wiernych czytelników, którzy w drukowanych niejednokrotnie na łamach periodyku listach dawali wyraz swego przywiązania:

Ciekawe reportaże, felietony, moda, porady, eleganckie wydanie. Jest to coś, na co od dawna czekałam! Słowem prawie Zachód!10 [...] o tym, jak bardzo podobało mi się Wasze pismo niech świadczy fakt, że gdy kupiłam je, to czytałam jednym tchem aż do ostatniej strony i skończyłam o 24.00, pomimo, że nazajutrz rano szłam do pracy11.

Wraz z kolejnymi numerami tytuł stawał się coraz bardziej elegancki i luksusowy, jeśli chodzi o formę graficzną, a także ciekawszy pod względem treści. Rozszerzając zakres podejmowanych tematów, starając się dostosować do wzrastających wymogów odbiorców, korzystając z ich sugestii i porad, redakcja starała się jednocześnie zachować wierność nadrzędnej formule pisma, które miało pomagać czytelnikom w tworzeniu własnego stylu życia.

Ich liczba systematycznie rosła, rósł też jednorazowy nakład kolejnych wydań. W 1991 r. wyniósł on niemal 300 tys. egz.12 Przy przygotowaniu kolejnych numerów pracowało coraz więcej osób. Zwiększyła się liczba korespondentów zagranicznych: do polskich czytelników trafiały teksty pisane przez Jerzego Samborskiego (Londyn), Evę Zwierzyńską-Severi (Rzym). W tym czasie miesięcznik zainicjował konkurs Prababka w kolorze sepii. Czytelnicy przysyłali napisane przez siebie opowieści rodzinne, zainspirowane starymi fotografiami swoich przodków. Najciekawsze prace drukowano na łamach periodyku. Nagrodą główną był aparat fotograficzny, nadto na autorów wyróżnionych prac czekały inne, w tym książkowe, nagrody ${ }^{13}$.

W 1991 r. redakcja zwróciła się z prośbą do Ośrodka Badań Prasoznawczych Uniwersytetu Jagiellońskiego o zbadanie pozycji rynkowej „Twojego Stylu”. Na niemal 700 wydawanych wówczas czasopism w Polsce, tytuł uplasował się na 12. miejscu wśród 20 najbardziej popularnych

\footnotetext{
10 Zespół magazynu „Twój Styl”, Od redakcji, „Twój Styl” 1990, nr 4, s. 2.

11 Ibidem.

12 Zespół magazynu „Twój Styl”, Od redakcji, „Twój Styl” 1991, nr 7-8, s. 2.

${ }^{13}$ Konkurs rozstrzygnięto w numerze wakacyjnym 7-8 (1992). Jego rozwinięciem stała się seria, wydawana przez Wydawnictwo Książkowe Twój Styl, zatytułowana „W Kolorze Sepii" (zapoczątkowana w 1995 r.).
} 
periodyków w kraju ${ }^{14}$. Wraz z omówieniem wyników badań w numerze 11 (1991) pojawiła się również ankieta Co o nas myślicie? Jak nas oceniacie?, która miała pomóc $\mathrm{w}$ redagowaniu jeszcze ciekawszego, lepszego magazynu15. Jednocześnie spółka zaczęła wydawać cztery kolejne pisma: dwa z nich były to kwartalniki o charakterze specjalistycznych poradników: „Fryzury oraz „Sekrety Młodości i Urody”. Stanowiły one rozwinięcie analogicznych działów w piśmie macierzystym. Dwa następne to tygodnik dla młodych kobiet „To Ty” oraz miesięcznik „Czary”. Poza pierwszym wymienionym tytułem, pozostałe nie zdobyły dostatecznego uznania w oczach czytelników i po kilku numerach zostały zlikwidowane.

W 1992 r. wydawca wprowadził możliwość prenumeraty „Twojego Stylu". Tytuł osiągnął pułap 400 tys. egz., a numer 12 wydany w tym roku liczył już ponad 232 strony. W tym czasie ogłoszony został po raz pierwszy plebiscyt, w którym czytelnicy wybrać mieli Kobietę Roku16, zaś magazyn otrzymał prestiżową nagrodę, przyznaną przez Instytut Badania Opinii i Reklamy Pentor, „za najbardziej znaczące wydarzenie na rynku mediów”17. Pismo zmieniło się nieco pod względem graficznym, zyskując wyraźniejszą okładkę, drukowaną na sztywniejszym papierze, pojawiła się również bardziej czytelna stopka redakcyjna. Zmianie uległ także format: z dotychczasowego wynoszącego 20x29 cm osiągnął wielkość 23×29,5 cm. Redakcja wprowadziła wówczas po raz pierwszy zwyczaj grudniowego „numeru marzeń”, który miał być wydaniem „na zamówienie”, przygotowanym na podstawie życzeń czytelników. Propozycje tematów, jakie chcieliby oni znaleźć w świątecznym numerze magazynu, miały być wykorzystane przez redakcję i zaprezentowane na jego łamach. W tym samym roku utworzono mutację rosyjską i ukraińską „Twojego Stylu”, a kilka miesięcy później podjęto rozmowy ze stroną bułgarską ${ }^{18}$.

W tym czasie zespół tworzyła już znacznie większa grupa dziennikarzy niż na początku. Znaleźli się $\mathrm{w}$ niej m.in. Elżbieta Chęcińska, Renata Dziurdzikowska19, Adam Gutowski, Alina Niedzielska, Joanna Rawik, Liliana Śnieg-Czaplewska, zaś z Filadelfii korespondencję nadsyłała Aleksandra Ziółkowska-Boehm.

Lata następne przyniosły dalszy rozwój „Twojego Stylu”, zwiększenie jego nakładu i objętości. Jednocześnie rosnące wymagania zarówno rekla-

14 Zespół magazynu „Twój Styl”, Od redakcji, „Twój Styl” 1991, nr 11, s. 2.

15 [br. aut.], Od redakcji, „Twój Styl” 1991, nr 11, s. 144.

16 Wymienione akcje pisma zostaną omówione dokładniej w dalszej części rozdziału.

17 http://ftpsuperbrands.home.pl/SB1_pdf/Twoj_Styl.pdf, 2 lutego 2009.

18 Cyt. za: K. Wodniak, Współczesna prasa kobieca a sprawy książki, Wydawnictwo SBP, Warszawa 2004, s. 47.

19 Przeszła ona w późniejszym okresie do redakcji omawianego wcześniej miesięcznika „Zwierciadło”. 
modawców, jak i odbiorców, niewystarczająca baza poligraficzna w kraju spowodowały, że druk pisma przeniesiony został za granicę, do Donnelly Polish-American Painting Company (DPA).

Redakcja, świętując czwarte urodziny, pisała m.in.: „naszym celem jest pomoc w wyzwalaniu i utrwalaniu tych pozytywnych, ułatwiających życie emocji, pokazywanie barwnych stron życia, a nie szarzyzny, której tak wiele jest wokół"20. Do wydawcy miesięcznika zwrócił się w tym czasie francuski koncern Hachette Filipacchi Presse z propozycją współwydawania edycji polskiej wersji magazynu „Elle”. Ta propozycja potwierdzała pozycję „Twojego Stylu” na rynku prasowym jako pisma o wysokim poziomie edytorskim i merytorycznym oraz znaczącej grupie elitarnych czytelników. W październiku do sprzedaży trafił pierwszy numer nowego magazynu, wydawanego w koedycji z wydawcą „Twojego Stylu”.

W połowie lat 90 . XX w. omawiany miesięcznik liczył średnio 185 stron, drukowanych na coraz lepszej jakości papierze, ze zwiększającą się systematycznie liczbą zdjęć. W stopce redakcyjnej pojawiły się nazwiska osób, odpowiedzialnych za poszczególne działy, zaś redakcja inicjowała kolejne akcje, jak choćby przedsięwzięcie promowane hasłem Zdq̨żyć przed rakiem. Październik miesiq̨cem szansy czy konkurs Lekarz Przyjacielem Kobiety. Pomimo pojawienia się na rynku konkurencyjnych tytułów (m.in. „Cosmopolitan. Mocne Strony Kobiety” w 1998 r.), „Twój Styl” zachował pozycję lidera $\mathrm{w}$ tej grupie pism.

Kolejnym istotnym momentem w jego dziejach stał się rok 1995 . Wtedy to „Twój Styl” sp. z o.o. przekształcił się w Wydawnictwo Prasowe „Twój Styl” sp. z o.o. $\rightarrow$ WPTS (nadal wchodzące w skład Polskiej Grupy „Interim”), z którego wyodrębniło się Wydawnictwo Książkowe. Przewodniczącym Rady Nadzorczej WPTS został C. Windorbski, zaś Prezesem Zarządu G. Białecki. Z pismem współpracowali w tym czasie m.in. Krystyna Kofta, Olga Lipińska, Mira Michałowska, Irena Ostałowska i Kinga Wojtowicz. Ze Sztokholmu korespondencję nadsyłała Krystyna Hugosson-Bujwid, a z Waszyngtonu Kinga Rusin.

Periodyk jako jeden z pierwszych w Polsce uruchomił własną witrynę internetową (1996) pod adresem www.twojstyl.com.pl, zaś wydawca wprowadził na rynek kolejny tytuł: „XL” (magazyn muzyczny) ${ }^{21}$.

W 1997 r. połowę udziałów w spółce wydającej magazyn wykupiła amerykańska firma At Entertainment Inc. Inwestowała ona w Polsce w media elektroniczne (m.in. w 100\% kontrolując Polską Telewizję Kablową), co w odniesieniu do omawianego pisma przełożyło się na możliwość zaistnie-

20 K. Kaszuba, Od redakcji, „Twój Styl” 1994, nr 8, s. 6.

${ }^{21} \mathrm{Ze}$ względu na nikłe zainteresowanie tym periodykiem tytuł przeniesiono w $2000 \mathrm{r}$. do Internetu. 
nia tytułu w wersji programu telewizyjnego ${ }^{22}$. W tym czasie po raz pierwszy nagrodzono Dzienniki Polek w konkursie Miesiąc z życia kobiety. Wybrane prace zostały wydane w formie książki przez Wydawnictwo ${ }^{23}$.

Rok 1998 przyniósł kolejną zmianę: WPTS zmieniło nazwę na Dom Wydawniczy Twój Styl. Wtedy też wydawnictwo przeniosło swą siedzibę do nowego budynku przy ul. Okrzei $1 \mathrm{~A}$. W listopadzie wydano setny numer magazynu, liczący 328 stron. K. Kaszuba pisała:

Najbardziej cieszy mnie to, że nasze publikacje pomagają wielu osobom umocnić wiarę w siebie, we własne siły, dają poczucie własnej wartości, przeświadczenie, że można pokonać trudności, odbudować szczęście osobiste, żyć pełnią życia bynajmniej nie kosztem innych ${ }^{24}$.

Jakkolwiek była w tych stwierdzeniach pewna doza egzaltacji, prezentująca wyidealizowaną misję i wizję „Twojego Stylu”, to jednak pewne fakty były bezdyskusyjne: periodyk wydawano w nakładzie ok. 400 tys. egz. ${ }^{25}$, co zapewniało mu pozycję lidera w grupie pism lifestylowych. Tytuł wypracował rozpoznawalną na rynku markę, miał wierną grupę czytelników, z których wielu było jego odbiorcami od pierwszego numeru, a także grono znanych współpracowników, wśród których pojawiali się nie tylko dziennikarze, ale również specjaliści prezentujący rozmaite dziedziny (m.in. ekonomię, medycynę) i pisarze.

Ostatnie lata XX w. to kolejne inwestycje wydawcy „Twojego Stylu”. Do flagowego tytułu dołączono wydawane na licencji polskiej wersje: francuskiego miesięcznika poświęconego urodzie „Votre Beauté”, awangardowego miesięcznika dla mężczyzn włoskiej oficyny Rizzoli „Maks” oraz znaną kilku pokoleniom polskich dziewcząt „Filipinkę”.

$\mathrm{Z}$ okazji 10-lecia istnienia magazynu redakcja zaprosiła czytelniczki do siedziby pisma, a następnie w numerze jubileuszowym $(10 / 2000)^{26}$ przedstawiono relację z tego spotkania27.

W połowie $2001 \mathrm{r}$. wprowadzono zmiany w grafice pisma. Nie były one jednak zbyt głębokie, dotyczyły bardziej uatrakcyjnienia szaty periodyku

$22 \mathrm{Z}$ założenia miał on być utożsamiany ze swym prasowym odpowiednikiem. Po raz pierwszy wystartował 31 grudnia 1999 r. na antenie Wizji TV. Po kilku miesiącach emisji program zawieszono, ponownie pojawił się on w Programie 2 TVP. Zaczęto również wydawać magazyn abonentów Wizji TV, zatytułowany „Twoja Wizja”.

23 T. Jastrun, Historie prawdziwe. Współczesne dzienniki Polek, Wydawnictwo Książkowe „Twój Styl”, Warszawa 1999.

${ }^{24}$ K. Kaszuba, Od redakcji, „Twój Styl” 1998, nr 11, s. 30.

25 Ibidem.

26 Pomimo, że pierwszy numer „Twojego Stylu” ukazał się w lipcu, większość kolejnych rocznic świętowano w październiku, miesiącu zarejestrowania spółki „Twój Styl”.

27 A. Grigo, Dzień z życia redakcji, „Twój Styl” 2000, nr 10, s. 40-42, 44. 
niż jego zawartości czy zmian w tradycyjnym układzie działów i rubryk (miały raczej charakter prasowego liftingu). Poprawiono natomiast w sposób wyraźny wizerunek pisma w Internecie: strona „Twojego Stylu” stała się bardziej dynamiczna, zmieniono layout, wprowadzono elementy interaktywne, umożliwiające kontakt $\mathrm{z}$ czytelnikiem poprzez na przykład organizowanie spotkań w świecie wirtualnym w postaci tzw. czatów, ze znanymi osobami28. Zamieszczano także konkursy dla internautów, którzy wybrali tę formę kontaktu z tytułem.

W październiku tego samego roku Polska Grupa Interim odkupiła od spółki AtEntertainment (UPC) 50\% udziałów WPTS, stając się dzięki temu (ponownie) jego właścicielem. Nieznacznej modyfikacji uległa wówczas grafika pisma, co wyrażało się m.in. w zmienionej formie spisu treści oraz w zastosowaniu innego kroju czcionek przy tytułach działów i rubryk. Dzięki temu zawartość magazynu zyskała na przejrzystości. Zwiększyła się również liczba zamieszczanych w nim zdjęć.

Początek 2002 r. był dla pisma czasem zmian. Z redakcji odeszła jego założycielka, K. Kaszuba ${ }^{29}$. Wcześniej jednak, w efekcie konfliktu ${ }^{30}$ pomiędzy polskimi udziałowcami spółki (w której K. Kaszuba miała 5\% udziałów), doszło do przejęcia tytułu przez niemiecki koncern Heinricha Bauera ${ }^{31}$.

${ }^{28}$ A. Nalewajk, Sieć na kobiety, „Press” 2001, nr 2, s. 66.

${ }^{29}$ Po rezygnacji z pracy w redakcji „Twojego Stylu”, K. Kaszuba objęła stanowisko wiceprezesa w Wydawnictwie Edipresse Polska.

30 Przyczyną sporu były kwestie finansowe. K. Kaszuba domagała się zwiększenia nakładów na promocję pisma i jego ulepszanie. C. Windorbski (posiadający 43\% udziałów PGI) zarzucał jej, że jako główny udziałowiec nie ma żadnego wpływu na działalność spółki, szczególnie zaś na WPTS. Konflikt zaostrzył się jeszcze w październiku 2001 r. po wspomnianej powyżej transakcji. Wkrótce po jej dokonaniu wspólnicy PGI podjęli decyzję, że zarządzanie aktywami spółki przekażą firmie Trogon Asset Management (TAM), która weszła do zarządu PGI i WPTS. C. Windorbski nie zgadzał się z decyzjami TAM i 4 stycznia 2002 r. wystąpił do sądu o rozwiązanie PGI, informując o tym BRE Bank, w którym zaciągnięto kredyt na poczet wydawanych przez firmę pism. Konflikt pomiędzy wspólnikami PGI sprawił, że nie było możliwości ani sprawnego bieżącego funkcjonowania spółki, ani jej restrukturyzacji. W efekcie nad Grupą PGI zaciążyła groźba upadłości. Reakcja Banku była natychmiastowa: tego samego dnia, bez wcześniejszego ostrzeżenia, wypowiedział on wszystkie zawarte z grupą umowy kredytowe (ich łączna wartość wynosiła ok. 14 mln USD), żądając jednocześnie ich spłaty w ciągu 7 dni. W razie braku takiej spłaty, Bank zagroził, że niezwłocznie przejmie aktywa PGI, w tym również udziały WPTS, stanowiące zabezpieczenie kredytu. Potrzebne środki Grupa „Interim” zdobyła sprzedając Wydawnictwu Bauer swoje najcenniejsze aktywa: prawa do wydawania miesięczników „Twój Styl”, „Votre Beauté” oraz czasopisma „Filipinka”. Zob. http://www.wirtualnemedia.pl, A. Błaszczyk, U Bauera, ale w swoim stylu: „Twój Styl” ma nowego właściciela, 3 luty 2009.

31 Koncern Heinrich Bauer Verlag - jeden z największych wydawców czasopism w Europie. Jego historia sięga 1875 r., i założonej wówczas przez litografa, J. A. L. Bauera, drukarni biletów wizytowych. W 1903 r. firma zmieniła nazwę na J. A. L. Bauer und Sohne i zaczęła wydawać bezpłatną gazetę regionalną „Rotenburgsorter Zeitung”. Dynamiczny rozwój 
Nowy wydawca stworzył spółkę, która miała zająć się edycją wyłącznie pism luksusowych, stąd w styczniu 2002 r. powstało „Media Styl” (w grudniu 2002 r. włączone w struktury macierzystego koncernu). Od numeru 4 (2002) w stopce redakcyjnej pojawiła się nowa nazwa wydawcy. Na czele nowego Zarządu stanął Witold Woźniak (jako prezes), stanowisko dyrektora finansowego objął Andrzej Choynowski.

Początkowo wieloletnia redaktor naczelna odniosła się do tej zmiany optymistycznie, licząc na to, że finansowe możliwości nowego właściciela pozwolą zwiększyć przewagę „Twojego Stylu” nad konkurencją. Jednak szybko pojawiły się trudności we współpracy pomiędzy zarządem Wydawnictwa Bauer a K. Kaszubą. Jak wspomina jej następczyni: „Szefowa czuła się chyba trochę nieswojo, $\mathrm{z}$ boku [...]. Przychodziła, siedziała $\mathrm{w}$ gabinecie, robiliśmy pismo, ale ze strony wydawcy jakby nikt się nie interesował, co tu się dzieje"32. Nie godząc się na tę sytuację, zdecydowała się odejść. Jej miejsce zajęła Anna Achmatowicz-Schwendimann, pracująca w redakcji od 1993 r., a od roku 1997 pełniąca funkcję zastępcy redaktor naczelnej. Jej dotychczasowe stanowisko przejęli Ryszard Błaszkiewicz i Jolanta Chyłkiewicz.

Zmiany na tak ważnym dla periodyku stanowisku nie przyniosły jednak znaczących przeobrażeń w piśmie, bo, jak przyznawała redakcja, „chcemy, żeby dla naszych Czytelniczek TS pozostał tym, czym był zawsze: doradcą i przyjacielem"33. Miesięcznik zachował dotychczasową linię programową i ogólną strukturę każdego numeru, do której przywykli czytelnicy. Koncepcja magazynu pozostała niezmienna, podobnie jak zespół współpracowników, który tylko w niewielkim stopniu się zmienił (z K. Kaszubą odszedł na przykład Michał Piekarski, dotąd dyrektor artystyczny TS). Równocześnie jednak nowa redaktor naczelna podkreślała:

chcę utrzymać dotychczasowy charakter pisma i jednocześnie myślę o jego odświeżeniu. Nowy duch pojawi się w sposób naturalny. Jestem z innego pokolenia niż moja poprzedniczka. Wniosę swój temperament. Poza tym zmiany wymusza duch czasów. Piszemy o sprawach aktualnie interesujących kobiety ${ }^{34}$.

Tytuł otrzymał kilkumilionowy budżet promocyjny, który wykorzystano m.in. na kampanię reklamową, zainicjowaną już w maju 2002 r. Coraz częstszym elementem towarzyszącym kolejnym wydaniom był „prezent”,

przedsiębiorstwa przypadł na lata powojenne. Na polskim rynku prasowym koncern pojawił się w 1991 r., debiutując magazynem młodzieżowym „Bravo”. Więcej, zob. np. O. Dąbrowska-Cendrowska, Niemieckie koncerny prasowe w Polsce w latach 1989-2008, Dom Wydawniczy Elipsa, Warszawa 2009, s. 44-49, .

32 K. Lubelska, Madame..., s.78-[79].

33 A. Achmatowicz-Schwendimann, Od redakcji, „Twój Styl” 2002, nr 6, s. 12.

${ }^{34}$ K. Prewęcka, Wierny „,Twój Styl”, „Media i Marketing Polska” 2002, nr 12, s. 20. 
dołączany do pisma, w postaci na przykład kosmetyczki bądź torby. Dzięki m.in. tym staraniom „Twój Styl”, utrzymując średnią sprzedaż 295 tys. egz. i objętość ok. 227 stron, nadal zajmował pozycję lidera w grupie luksusowych pism adresowanych do kobiet 35 .

Jacek Szmidt, szef działu reportażu, wspominał:

Krystyny Kaszuby już w „Twoim Stylu” nie ma, a zespół i tak od kilku godzin myśli nad tytułem do jednego tekstu. Ona nas przekonała, że warto poświęcić pół dnia na znalezienie dobrego tytułu albo trzy razy poprawiać tekst ${ }^{36}$.

To, na co dotychczas wielu dziennikarzy narzekało ${ }^{37}$, wyznaczyło dalszą drogę rozwoju „Twojego Stylu”.

Tymczasem nowy wydawca poszerzał swoją ofertę pism luksusowych o kolejne tytuły, opierając się na sprawdzonej marce „Twojego Stylu”. Na rynku pojawił się „Twój Styl Trendy” (magazyn dotyczący aktualnych kierunków w modzie i stylu życia) oraz „Twój Styl Look” (pismo o zdrowiu i urodzie, które zastąpiło dotychczasowy tytuł „Votre Beauté”, ponieważ Spółka „Media Styl” nie posiadała zezwolenia na jego wydawanie z powodu braku odpowiedniego porozumienia z francuskim właścicielem praw do tytułu) ${ }^{38}$. Na początku 2003 r. redakcja zmieniła adres swojej siedziby, przenosząc się do budynku przy al. Stanów Zjednoczonych 61. Był to jednocześnie adres nowego właściciela. W stopce redakcyjnej jako wydawca pojawił się H. Bauer. W tym czasie objętość kolejnych numerów pisma wynosiła ok. 200 stron.

Kolejna zmiana na stanowisku redaktora naczelnego pisma nastąpiła od numeru 4 (2005). Annę Achmatowicz-Schwendimann zastąpiła Jolanta Pieńkowska, która dotąd pełniła funkcję dyrektora wydawniczego tytułu. Zwiastowało to kolejne, tym razem bardziej zdecydowane modyfikacje zarówno w szacie pisma, jak i jego zawartości merytorycznej. Kwietniowy numer „Twojego Stylu” ze zdjęciem Otylii Jędrzejczak na okładce i świeżą, wiosenną grafiką zapowiadał zmiany, których celem było pozyskanie młodszych czytelniczek.

Numer jubileuszowy, z okazji 15-lecia istnienia pisma na rynku, pojawił się w grudniu 2005 r. Miał objętość 304 stron, z czego część obejmowała specjalny, urodzinowy dodatek Stylowe lata. Na łamach magazynu pojawił

35 0. Dąbrowska-Cendrowska, Niemieckie koncerny..., s. 91.

36 http://www.wirtualnemedia.pl, A. Błaszczyk, U Bauera, ale w swoim stylu: „Twój Styl” ma nowego właściciela, luty 2009.

37 Przedmiotem narzekań były rządy K. Kaszuby jako redaktor naczelnej pisma. O stylu jej pracy krążyły w środowisku dziennikarskim legendy, kilku z jej początkowych współpracowników odeszło z redakcji, nie wytrzymując ostrego tempa i wymagań, które narzucała swojemu zespołowi. Zob. np. K. Lubelska, Madame..., s. 78-80.

38 http://www.wirtualne media.pl/index.twój.styl, luty 2009. 
się wywiad z K. Kaszubą, zaprezentowano także sylwetki kilku wybranych czytelniczek, które pod wpływem publikacji, zamieszczonych w piśmie, zdecydowały się zmienić swoje życie. Pojawiła się również zabawna w założeniu Kronika wypadków stylowych, czyli przykłady niezbyt udanych zdjęć lub innych potknięć, będących udziałem dziennikarzy TS39 i tego, jak z nich wybrnęli. W ciągu 15-letniej historii zmieniła się przede wszystkim forma graficzna „Twojego Stylu” i jego objętość, ale, jak stwierdziła J. Pieńkowska: „Jedno pozostało niezmienne: byliśmy, jesteśmy i mam nadzieję, że będziemy numerem jeden na polskim rynku wśród kobiecych magazynów" 40 .

\subsubsection{Zawartość, akcje, czytelnicy}

Charakter pisma, szczególnie zaś jasno określony odbiorca, determinowały zawartość periodyku. Poza cechami, specyficznymi dla prasy kobiecej, podejmowano $\mathrm{w}$ nim także problematykę, która zainteresować mogła współczesną „,kobietę sukcesu”, aktywną, przedsiębiorczą, niezależną finansowo. „Twój Styl”, jako pismo ekskluzywne, miał stać się rodzajem „poradnika z wyższej półki” dla „>kobiet nowej generacji<, > kobiet epoki Balcerowicza $<$, > kobiet naszych czasów<, odpowiedzialnych za siebie, troszczących się o swoje miejsce i pozycję w społeczeństwie"41. Zagadnienia, podejmowane na łamach pisma, dają się ująć w trzy podstawowe grupy:

1) praca, rodzina, inne wartości, które są ważne dla czytelniczek;

2) zdrowie, uroda i moda;

3) poradnictwo i rozrywka.

Tak określonym celom odpowiadała struktura magazynu. Interesującym spostrzeżeniem jest fakt, że od pierwszego wydania w 1990 r. do ostatniego badanego w roku 2005 nazwy działów (chociaż nie każdy z nich występował zawsze $\mathrm{w}$ tym samym miejscu $\mathrm{w}$ obrębie danego numeru) ulegały bardzo niewielkiej zmianie, a większość z nich pojawiała się przez cały badany okres. Należały do nich m.in.: Aktualności, Felieton, Kultura, Moda, Portrety, Relaks, Reportaż, Sekrety młodości i urody, Sztuka życia, Zdrowie. Niesystematycznie pojawiały się działy Dossier, Psychologia i seks, Stres.

${ }^{39}$ Jak na przykład jedna z nich, kiedy podczas ważnej sesji mody czekano na fotografa. Później okazało się, że wsiadł on do pociągu, by przejechać tylko jedną stację. Wybrał jednak nieopatrznie InterCity do Krakowa. Zaplanowaną sesję trzeba było wówczas przełożyć o dwa dni.

40 J. Pieńkowska, Od redakcji, „Twój Styl” 2005, nr 12, s. [10].

${ }^{41}$ Cyt. za: Z. Sokół, Prasa kobieca..., s. 336. 
W sposób najwyraźniejszy idee „Twojego Stylu” realizowały dwa z wymienionych działów, kształtując równocześnie określony wizerunek kobiety, propagowany przez periodyk.

I tak, w ramach przyjętego w obrębie Portretów cyklu (Jej/Jego Styl) prezentowano sylwetki znanych osób (zazwyczaj kobiet, rzadziej mężczyzn), które osiągnęły sukces w życiu. Wśród bohaterów owych tekstów znaleźli się m.in. Nina Andrycz, Hanna Bakuła, Joanna Chmielewska, Alain Delon, Jerzy Duda-Gracz, Anna Dymna, Janusz Gajos, Julia Hartwig, Joanna Pacuła, Grażyna Szapołowska, Beata Tyszkiewicz ${ }^{42}$, Maciej Zembaty. Niekiedy opisywano losy „zwykłych” kobiet, które dokonały (dzięki swej przedsiębiorczości, determinacji bądź silnej osobowości) czegoś wyjątkowego, o czym należało napisać. Taką postacią była choćby Zofia Zaleszczyk, bohaterka publikacji wydrukowanej w pierwszym numerze pisma.

Drugim działem, który wzmacniał ideologiczną wymowę pisma, była Sztuka życia. Przez kilka lat drukowano w tym miejscu teksty pióra Edwarda Pietkiewicza: Bon ton, w którym autor wprowadzał czytelników w tajniki savoir-vivre'u. Kolejnym cyklem była obecna od początku istnienia magazynu Alicja w krainie pieniądza (wcześniej Alicja w krainie banków) Andrzeja S. Nartowskiego. Udzielał on rad w zakresie finansów i mądrego nimi gospodarowania, prezentował wybrane placówki, tłumaczył zawiłości związane m.in. z kredytami bankowymi. W obrębie działu pojawiały się również innego rodzaju porady, na przykład jak przyjemnie spędzić weekend, jak przygotować udane przyjęcie czy „Co zmienić $\mathrm{w}$ domu, by być w zgodzie z tendencjami we wnętrzarstwie" 43 .

Warto również wspomnieć o Sekretach urody, dziale typowo poradniczym, w którym promowano zdrowy tryb życia, a jednocześnie prezentowano najnowsze kosmetyki, skuteczne diety oraz ćwiczenia. Tego typu wskazówki doskonale wpisywały się w ogólny program magazynu, propagującego wzór kobiety zadbanej, zdrowej i zorientowanej w „bestsellerach z perfumerii" 44 .

Dużo miejsca w periodyku zajmowała Moda, rozumiana tu jako rodzaj sztuki i biznesu, reprezentowana przez znanych projektantów i ich modelki. W tym miejscu drukowano, obok fotoreportaży, również sprawozdania z największych pokazów mody. W pierwszych numerach miesięcznika nierzadko pojawiały się przedruki z czasopism zagranicznych, na przykład „Brigitte”, „Marie-France” czy „Vogue”. Przez kilka lat do niemal każdego wydania dołączano wykroje sukni wieczorowych, spódnic lub bluzek.

\footnotetext{
42 Jej portret ukazał się w pierwszym numerze pisma.

43 K. Rzehak, Wojna luksusu z plastikiem, „Twój Styl” 2002, nr 1, s. 168-173.

44 To tytuł jednej z rubryk.
} 
W badanym okresie pojawiała się też rubryka Modne adresy, gdzie podawano nazwy sklepów, w których styliści pisma wybierali ubrania do sesji zdjęciowych.

$\mathrm{Na} ł a m a c h$ magazynu systematycznie poruszano kwestie związane $\mathrm{z}$ kulturą. Ze względu na temat pracy, odpowiadający im dział zostanie przedstawiony w dalszej części rozdziału.

Już na początku lat 90. XX w. na łamach pisma zaczęły pojawiać się reklamy. W miarę upływu czasu było ich coraz więcej, tak, że w niektórych numerach czytelnik musiał przebrnąć przez 20 i więcej stron, oddzielających poszczególne działy, a wypełnionych w całości kolorowymi ogłoszeniami. Redakcja niejednokrotnie tłumaczyła się z ich, często irytującej odbiorcę, wzrastającej liczby. Zazwyczaj argumentem obronnym było stwierdzenie, że dzięki temu stosunkowo rzadko podnoszona była cena periodyku. Wskazywano także na informacyjny charakter reklam, odwoływano się również do realiów wolnorynkowych, które narzucały konieczność udostępniania łamów pisma na potrzeby reklamodawców.

W jednym z pierwszych numerów, nawiązując do listów czytelników, dotyczących tej kwestii, a jednocześnie odwołując się do wielokrotnie zgłaszanych przez odbiorców sugestii, redakcja informowała o utworzeniu Centrum Badań Rynku-Fundacji „Twojego Stylu”. Jej celem miało być badanie jakości towarów. Pisano:

Chcemy wiedzieć sami - i doradzać Państwu - co warto, a czego nie warto kupować. [...] Fundacja [...] korzystając z usług i pomocy renomowanych laboratoriów i fachowców bada już różne produkty. Wyniki tych badań będziemy publikować w „Twoim Stylu” 45 .

Także z myślą o klientach, wydawca otworzył w 1991 r. pierwszy z sieci butików, oferując w sprzedaży wysyłkowej modne rzeczy, których zdjęcia publikowano wcześniej na łamach pisma.

Dbałość o czytelnika przejawiała się również we wspomnianych systematycznie drukowanych ankietach. W niemal każdym numerze zwracano się do odbiorców z pytaniem Jak nas oceniacie? i prośbą o szczere zdanie na temat aktualnego wydania. Elementem, który miał ostatecznie przekonać odbiorców, by poświęcili na to czas, były nagrody (na przykład torebki lub kosmetyki). Przypominano także, że redakcja czeka na bardziej osobiste opinie, wyrażane $\mathrm{w}$ formie listów. Najciekawsze $\mathrm{z}$ nich były następnie drukowane, a ich autorzy nagradzani. Systematycznie organizowano rodzaj konkursu na najciekawszą, zdaniem czytelników, okładkę minionego roku. Regularnie korzystano z usług profesjonalnych instytucji (jak na przykład Ośrodka Badań Prasoznawczych Uniwersytetu Jagiellońskiego) w celu poznania nie tylko pozycji rynkowej pisma, ale i samych odbiorców oraz ich oczekiwań wobec periodyku. Skrupulatnie odnotowywano również po-

45 Zespół magazynu „Twój Styl”, Od redakcji, „Twój Styl” 1993, nr 4, s. 8. 
wstawanie kolejnych klubów sympatyków pisma. Pierwsze z nich organizowano już w 1991 r., a przez kilka następnych lat tego rodzaju stowarzyszenia działały już $\mathrm{w}$ kilku miastach, m.in. w Krakowie, Łodzi i Radomiu.

Prezentowany tytuł najczęściej kojarzony był jednak z kilkoma innymi przedsięwzięciami.

Najbardziej znaną inicjatywą była społeczna kampania Zdążyć przed rakiem. Październik miesiacem szansy. Po raz pierwszy informacja na ten temat pojawiła się na łamach „Twojego Stylu” w październiku 1995 r. i odtąd co roku Stowarzyszenie Różowej Wstążki, powołane przez pismo, organizowało Marsz Różowej Wstążki ${ }^{4}$. Redakcja przypominała kobietom o konieczności badań profilaktycznych. Zamieszczano wywiady z lekarzami i znanymi osobami, które popierały to przedsięwzięcie oraz prezentowano sylwetki kobiet, które miały za sobą wygraną walkę z chorobą. Tłumaczono, jak samodzielnie przeprowadzić badanie, wyjaśniano specjalistyczne terminy medyczne ${ }^{47}$, współfinansowano badania genetyczne, dołączano do październikowych wydań kupony na bezpłatne prześwietlenia. K. Kaszuba pisała: „staramy się upublicznić problem, który wciąż wiele kobiet uważa za wstydliwy, a co gorsze, woli żyć w nieświadomości, nie zdając sobie sprawy, że skazuje się na śmierć, mając przecież ogromne szanse na wyleczenie" 48 . Redakcja „Twojego Stylu” była też współorganizatorem terapeutycznych warsztatów zdrowia dla kobiet ze zdiagnozowaną już chorobą.

Zainteresowanie na łamach magazynu zdrowiem kobiet znalazło swe odzwierciedlenie również w konkursie Lekarz przyjacielem kobiety, organizowanym od $1996 \mathrm{r}$. Zaproponowano, by czytelniczki przysyłały do redakcji nazwiska swoich kandydatów do tego tytułu, wpisywano ich na honorową Listę Przyjaciół Kobiet, a następnie nagradzano ${ }^{49}$.

Jedną z najstarszych inicjatyw pisma z kobietą w roli głównej był także plebiscyt organizowany od 1991 r., w którym nagrodą był Złoty Wawrzyn. Wręczano go Kobiecie Roku, wybranej spośród zgłoszonych przez czytelników kandydatek, które „wyróżniły się czymś szczególnym, zaimponowały swą postawą, działaniem, konsekwencją, mądrością, urodą, elegancją, wyjątkowością, zadziwiającym nas czynem" ${ }^{50}$. Poza nadsyłanymi propozycjami, redakcja prezentowała kandydatki zgłoszone zarówno przez laureatki z lat ubiegłych, jak i przez inne osoby publiczne, cieszące się autorytetem.

46 Pierwszy taki Marsz odbył się 23 czerwca 1996 r. Relacja, zob. [br. aut.], Pierwszy w Polsce Marsz Różowej Wstążki, „Twój Styl” 1996, nr 9, s. 26-27.

47 C. Szczylik, Szkoła badania piersi, „Twój Styl” 1996, nr 10, s. 168-169; [br. aut.], Słowniczek terminów medycznych, ibidem, s. 169.

${ }^{48}$ K. Kaszuba, Od redakcji, „Twój Styl” 1996, nr 9, s. 8.

49 Zob. Lekarz Przyjacielem Kobiety. Konkurs, „Twój Styl” 1996, nr 10, s. 169.

50 [br. aut.], Kobieta Roku 1992, „Twój Styl” 1992, nr 12, s. 22. 
Wśród uczestników plebiscytu rozlosowywano nagrody. Od 1991 r. tytuł ten zdobyły kolejno: Ewa Łętowska, Hanna Suchocka, Zofia Kuratowska, Janina Ochojska, Hanna Tosińska-Okrój, siostra Małgorzata Chmielewska, Jolanta Kwaśniewska, Hanna Gronkiewicz-Waltz, Monika Olejnik, Magdalena Abakanowicz, Katarzyna Maćkowska, Zyta Gilowska, Danuta Hübner, Otylia Jędrzejczak i Andżelika Borys.

Interesującym pomysłem, który także stał się znakiem rozpoznawczym pisma, był kolejny konkurs, tym razem związany z modą. Doskonałość Roku, czyli wyróżnienie wybranych przez specjalne jury kosmetyków, wręczano od 1995 r., natomiast Doskonałość Mody (Złote Guziki) dla najlepszej kolekcji ubrań, przyznawano od 1999 r. Zgodnie z regulaminem, zgłoszenia przysyłały adekwatne firmy i projektanci. Poza dyplomem, charakterystyczną statuetką oraz tytułem zwycięzcy uzyskiwali oni prawo do używania znaku towarowego Doskonałość Roku Twój Styl51.

Redakcja periodyku organizowała również inne, mniej znane akcje i konkursy, jak choćby przyznawane od 1993 r. nagrody (Alicje Andrzeja S. Nartowskiego) dla instytucji finansowych, głównie banków, za szczególnie przyjazny stosunek wobec klientów oraz najkorzystniejsze oferty dla budżetów gospodarstw domowych.

Ostatnią z inicjatyw, o której warto wspomnieć, a która wpisywała się, podobnie jak poprzednie, w formułę pisma, była zainicjowana w $2004 \mathrm{r}$. akcja Firma $w$ Twoim Stylu. A. Achmatowicz-Schwendimann wyjaśniała w ten sposób reguły projektu:

Szukamy miejsc pracy, gdzie równouprawnienie zadekretowane w ustawach wraz z naszym wejściem do Unii Europejskiej już się dokonało. Wierzę, że znajdziemy najlepsze przykłady, za którymi pójdą inni [...]. Za rok chcemy przyznać pierwsze tytuły Firmom w Twoim Stylu. [...] A jeśli Twoja firma już dziś zasługuje na wyróżnienie, napisz nam o niej [...]. Piszcie szczerze o tym, co Was boli, obiecuję, że niesolidnych pracodawców weźmiemy na spytki ${ }^{2}$.

Od tej pory na łamach pisma drukowano przysłane przez czytelników historie, które nierzadko przybierały postać opowiadań.

Tego typu akcje, o amatorskim charakterze paraliterackim, były kilkakrotnie podejmowane przez periodyk. Ze względu na tematykę pracy, zostaną omówione w dalszej części rozdziału.

Jak już wspomniano, „Twój Styl” był pionierem na polskim rynku ekskluzywnej prasy kobiecej, wzorowanym na magazynach zachodnich. Po-

${ }^{51}$ Regulamin obydwu konkursów, zob. np. „Twój Styl” 2001, nr 4, s. [234]-[235]. Rozwiązanie konkursu Złote Guziki, zob. ibidem, nr 10, s. [101], rozwiązanie konkursu Doskonałość Roku, zob. np. Doskonałość Roku '97. 12 najlepszych kosmetyków 1997 roku, dodatek bezpłatny, 1998, $\mathrm{nr} 1$.

52 A. Achmatowicz-Schwendimann, Od redakcji, „Twój Styl” 2004, nr 11, s. 12. 
czątkowo, pomimo wydawanych tytułów zaliczanych do tego samego segmentu na rynku (jak na przykład „Zwierciadło”), nie miał konkurencji. Także wtedy, kiedy pojawiły się nowe tytuły o zbliżonej formule, nierzadko wydawane na licencji, a omawiany periodyk musiał zmierzyć się z ich doświadczeniem, sprostać rosnącym wymaganiom czytelników - nadal utrzymywał pozycję lidera.

Od początku adresowany był do jasno określonego odbiorcy: przede wszystkim tworzono go dla kobiet, w wieku 20-50 lat, ambitnych, niezależnych w poglądach i działaniu, stawiających na osobisty rozwój, wykształconych, aktywnych zawodowo i niezależnych finansowo, mieszkanek dużych i średnich miast. W miarę upływu czasu wśród odbiorców przybywało również mężczyzn, o czym redakcja niejednokrotnie wspominała. Był to jeszcze jeden powód do dumy, podobnie jak fakt utrzymania się przez wiele lat na pierwszym miejscu $\mathrm{w}$ grupie luksusowych periodyków dla pań. Redakcja wielokrotnie podkreślała obydwa fakty, jak również skrupulatnie odnotowywała każdą nagrodę lub wyróżnienie zarówno dla wydawcy, jak i tytułu, dziennikarzy czy współpracowników pisma.

Kilkakrotnie nagradzana była jego twórczyni, K. Kaszuba. Na przykład w 1997 r. otrzymała Nagrodę Roku za Działalność Humanitarną od fundacji Człowiek-Człowiekowi. Organizacja dostrzegła starania redaktor naczelnej w propagowaniu wiedzy na temat raka piersi wśród kobiet. W $2001 \mathrm{r}$. otrzymała ona Krzyż Kawalerski Orderu Odrodzenia Polski.

Największą nagrodą dla pisma, co wielokrotnie podkreślano, było uznanie czytelników, a miarą sukcesu - liczba sprzedanych egzemplarzy. Znajdowało ono wyraz m.in. w licznie drukowanych na łamach magazynu listach, a także hasłach, które wpłynęły do redakcji w odpowiedzi na konkurs związany z promocją tytułu. To również dzięki wiernym czytelnikom „>Twój Styl< do dziś jest ewenementem w świecie wydawców"53.

\subsubsection{Róża jest różq̨ jest róża jest...54: książka na łamach pisma}

Problematyka książki na łamach omawianego periodyku była już w przeszłości przedmiotem publikacji. Na ten temat pisała Katarzyna Wodniak ${ }^{5}$, jednak zasięg chronologiczny jej pracy obejmował lata 19901999, a zatem poniższe rozważania można w pewnym stopniu traktować jako rodzaj kontynuacji analizy pisma w interesującym nas kontekście.

W latach 2001-2005 sprawy związane z kulturą, w tym upowszechnianiem czytelnictwa, jakkolwiek miały stałe miejsce $w$ magazynie, to jednak

\footnotetext{
53 J. Pieńkowska, Po stronie kobiet..., s. 90.

54 Tytuł portretu G. Stein, zob. „Twój Styl” 2002, nr 5, s. 140, 142, 144, 146.

55 K. Wodniak, Współczesna prasa kobieca...
} 
nie należały do priorytetowych. Uwaga ta odnosi się szczególnie do zagadnień dotyczących książki, które zajmowały stosunkowo niedużo miejsca na łamach magazynu, a prezentowane formy nie były zbyt zróżnicowane. Dominowały recenzje, omówienia, a także, co warto już w tym miejscu zaznaczyć, felietony osób bezpośrednio związanych z literaturą.

Informacje kulturalne drukowano w środkowej części pisma, po dziale związanym z modą ${ }^{56}$. Zajmowały one średnio 12 stron. W ramach najpierw Karnetu kulturalnego57, później Wydarzeń kulturalnych58, a następnie Kultury59 pojawiały się następujące stałe rubryki: Wydarzenie, Muzyka, Teatr ( $\rightarrow$ Karnet Teatralny), W kadrze, Galeria, Lektury. Sporadycznie występowały: Opera, Wystawy, Wywiad na wyłączność, zaś cyklicznie: $O$ nich jeszcze będzie głośno, Wielcy malarze, Wielkie festiwale. Dopiero w 2001 r. pojawiło się w stopce redakcyjnej nazwisko osoby, odpowiedzialnej za dział spraw kulturalnych. Była nią Aleksandra Szarłat. W numerze 9 (2005) połączono dział kulturalny z działem spraw zagranicznych. Odpowiedzialni zań byli Agnieszka Jastrzębska i Łukasz Modelski. W numerze 10 (2005) na miejscu Łukasza Modelskiego pojawiła się Magda Jaros jako redaktor kultury, natomiast Agnieszka Jastrzębska nadal sprawowała funkcję redaktor odpowiedzialnej.

Informacje dotyczące książki przyjmowały, jak już powyżej podkreślono, głównie postać recenzji, omówień i adnotacji, niemniej jednak pojawiło się również kilka innych kategorii, które treścią nawiązywały do literatury i osób z nią związanych. W tabeli 45 przedstawiono odnoszące się do nich dane statystyczne.

W sumie w analizowanych latach na łamach „Twojego Stylu” pojawiło się 900 informacji, bezpośrednio bądź pośrednio związanych z literaturą i książką. Widać zatem znaczącą różnicę liczbową w porównaniu z omawianymi wcześniej pismami opinii i to w odniesieniu do każdej z wymienionych kategorii. Jest to także mniej informacji, niż było ich na łamach prezentowanego wcześniej miesięcznika „Zwierciadło”. Największą liczbowo grupę stanowią recenzje, omówienia i adnotacje, a zaledwie dwukrotnie pojawiły się w piśmie listy bestsellerów, które zresztą miały specyficzny charakter ${ }^{60}$. Zwraca uwagę niewielka liczba ogłoszeń wydawniczych, przy czym większość z nich stanowiła ofertę Wydawnictwa Książkowego „Twój Styl”.

56 Należy jednak zaznaczyć, że w spisie treści dział kulturalny pojawiał się zazwyczaj po innych działach, np. po dziale Sztuka życia.

57 Taka nazwa działu kulturalnego funkcjonowała do numeru 10 (2004) włącznie.

58 Ten wspólny dla tekstów związanych z kulturą tytuł pojawił się zaledwie dwukrotnie: w numerach 11 i 12 (2004), chociaż w spisie treści nadal widniała poprzednia nazwa.

${ }^{59}$ Nazwa działu, stosowana od numeru 5 (2005), istniała do końca omawianego okresu.

60 Zostaną one omówione w dalszej części pracy. 
Tabela 45. Formy obecności książki i informacji o niej na łamach „Twojego Stylu” w latach 2001-2005

\begin{tabular}{|l|c|}
\hline \multicolumn{1}{|c|}{ Rodzaj informacji } & Liczba ogółem \\
\hline Recenzje, omówienia, adnotacje & 262 \\
\hline Wywiady & 73 \\
\hline Reklamy książek & 77 \\
\hline Sylwetki/portrety & 35 \\
\hline $\begin{array}{l}\text { Artykuły, poświęcone sprawom książki lub rynku wydawniczo- } \\
\text {-księgarskiego }\end{array}$ & 22 \\
\hline Ekranizacje i inscenizacje znanych dzieł & 45 \\
\hline Konkursy i akcje & 65 \\
\hline Listy bestsellerów & 2 \\
\hline $\begin{array}{l}\text { Listy czytelników, nawiązujące do zamieszczonej informacji związanej } \\
\text { z książką }\end{array}$ & 7 \\
\hline Inne ${ }^{a}$ & 312 \\
\hline Ogółem & 900 \\
\hline
\end{tabular}

${ }^{a} \mathrm{~W}$ tej kategorii, w dużej mierze podobnie, jak było to $\mathrm{w}$ odniesieniu do miesięcznika „Zwierciadło”, uwzględniono felietony pisarzy, fragmenty książek, krótkie wzmianki, dotyczące bezpośrednio lub pośrednio książek i autorów, notki polecające lekturę książki nawiązującej do zamieszczonej obok publikacji itd.

Źródło: badania własne.

Niemal wszystkie informacje (poza felietonami, tu zaliczonymi do kategorii „inne” oraz reklamami, które zazwyczaj drukowano w różnych miejscach pisma) znalazły się w dziale dotyczącym kwestii kulturalnych. Kilkakrotnie zmieniał on swój wygląd, chociaż modyfikacje dotyczyły przede wszystkim szaty graficznej.

\subsubsection{Eliksir pisania ${ }^{61}$ : miejsce recenzji w układzie pisma}

W latach 2001-2005 na łamach pisma ukazały się 262 recenzje, omówienia i adnotacje książek ${ }^{62}$, a zatem niemal o połowę mniej niż na łamach wcześniej omawianego miesięcznika. W tabeli 46 zaprezentowano ich liczbę w poszczególnych latach.

61 Tytuł jednej z recenzji, zob. „Twój Styl” 2002, nr 8, s. 122-[123].

62 W liczbie tej znajdują się wyłącznie recenzje odredakcyjne. 
Tabela 46. Recenzje, omówienia i adnotacje zamieszczone na łamach „Twojego Stylu” w latach 2001-2005

\begin{tabular}{|c|c|}
\hline Rok & $\begin{array}{c}\text { Liczba recenzji, } \\
\text { omówień i adnotacji }\end{array}$ \\
\hline 2001 & 35 \\
\hline 2002 & 30 \\
\hline 2003 & 61 \\
\hline 2004 & 85 \\
\hline 2005 & 51 \\
\hline Ogółem & 262 \\
\hline
\end{tabular}

Źródło: badania własne.

Jak wynika z tabeli 46, liczba recenzji, omówień i adnotacji była bardzo nierówna, trudno zatem mówić o jakiejkolwiek stałej tendencji. Zdarzały się numery, w których brakowało omówień książek, i takie, w których było ich więcej niż zazwyczaj. Wszystkie znalazły się w ramach działu kulturalnego, większość z nich na stronie (drukowanej w ostatniej części działu) zatytułowanej Lektury.

Podobnie jak było to w przypadku „Zwierciadła”, tak i tu wybrane książki omawiała jedna osoba. W analizowanym okresie kilkakrotnie następowały zmiany recenzenta, co zazwyczaj pociągało za sobą również korekty w wyglądzie interesującej nas rubryki. Jednak od początku zachowano pewien stały element, a był nim wspólny dla wszystkich omawianych książek tytuł główny, który wskazywał na temat przewodni prezentowanych lektur. Jednocześnie recenzja każdej lub kilku z nich otrzymywała dodatkowo swój własny tytuł. $\mathrm{Na}$ omówienia książek przez pięć lat poświęcano jedną stronę magazynu.

W pierwszym z omawianych roczników widać poszukiwania odpowiedniej formuły wspomnianej strony. W numerze 1 i 12 brak było typowych recenzji odredakcyjnych, w 2 i 3 pojawiły się one pod wspólnym tytułem: Książki zmieniaja świat. Podobną formę zachowała ona w numerze 4 (2001), chociaż zamieszczone tu recenzje nosiły tytuł Książka na wieczór. W numerze 2 i 3 proponowano czytelnikom cztery tytuły, w numerze 4 - pięć. Obok kopii okładki prezentowanej książki widniała kilkunastozdaniowa adnotacja treściowa, pod nią zaś dane bibliograficzne. W kolejnym wydaniu (nr 5/2001) znalazły się cztery recenzje, podpisane przez $T$. Jastruna. W następnych numerach $(6,8,9$, 10/2001 oraz 1,3/2002) pojawiła się Półka Tomasza Jastruna, w ramach której poeta prezentował wybrane przez siebie książki. W numerze 2/2002 zabrakło tego określenia, chociaż recenzent pozostawał ten sam.

I dopiero od numeru $4 \mathrm{w}$ roku następnym (2002) zdecydowano się na jedną, określoną formułę tej części działu oraz innego recenzenta. Odtąd, przez osiem numerów ${ }^{63}$ recenzje i omówienia wybranych tytułów druko-

${ }^{63} \mathrm{Z}$ wyjątkiem numeru 6 (2002), w którym zabrakło omawianej rubryki. 
wano na stronie zatytułowanej Izabela Filipiak o ksiq̨żkach. Stronę otwierało zdjęcie recenzentki wraz z krótką wzmianką biograficzną na jej temat. Pod wspólnym dla przedstawianych lektur tytułem i krótkim wprowadzeniem do tematyki prezentowanych książek pojawiały się trzy recenzje ${ }^{64}$, z których pierwsza zazwyczaj była dłuższa i dodatkowo wyróżniona pogrubioną czcionką. Omówienia miały przeważnie charakter dłuższych adnotacji treściowych, niekiedy z określeniem odbiorcy lub krótką informacją na temat autora. Obok recenzji drukowano kopię okładki danej książki, a pod adnotacją niemal pełne dane bibliograficzne, z podaniem nazwy wydawcy, roku wydania oraz nazwiska tłumacza w przypadku książki obcej. Nieznacznie zmieniała się konfiguracja recenzji na stronie, za każdym jednak razem widoczne było staranne przygotowanie rubryki i jej przejrzystość.

Od numeru 1 (2003) Izabelę Filipiak zastąpiła Anna Piwkowska. W niewielkim stopniu zmieniła się wówczas forma graficzna tej części działu i jej nazwa $(\rightarrow$ Lektury). Nadal znaleźć można było w tym miejscu trzy recenzje i te same elementy, które towarzyszyły poprzedniej formule. Różnice pomiędzy nimi były nieznaczne; obydwie prezentowały się zazwyczaj w następujący sposób (zdjęcie 108 i 109).

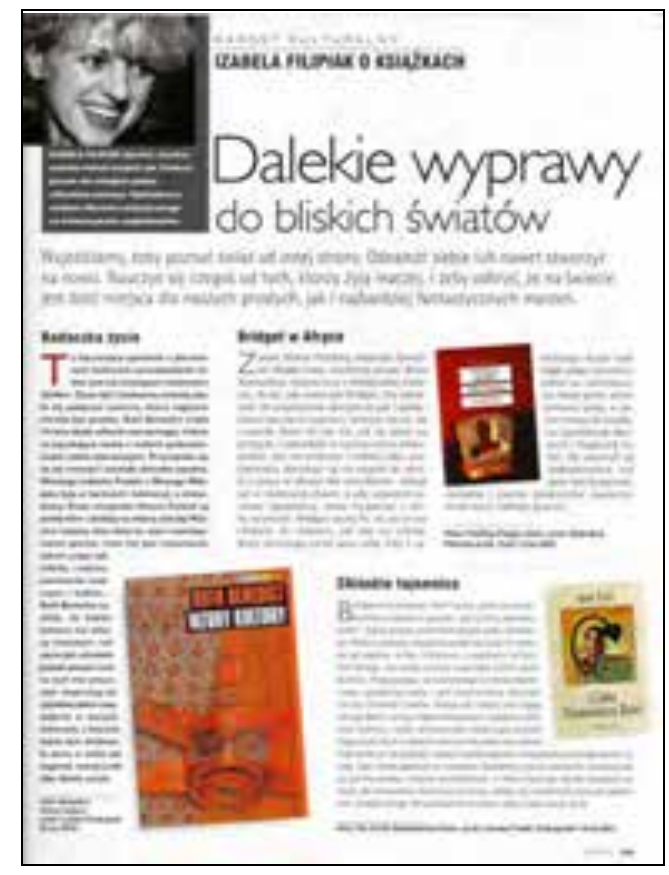

Zdjęcie 108. Przykładowa strona recenzyjna na łamach „Twojego Stylu” „Twój Styl” 2002, nr 8, s. 125

64 Wyjątkiem był numer 11 (2002), w którym znalazły się dwa typowe omówienia wybranych książek i obok wywiad z M. Kielar, nawiązujący do wydanego w tym czasie tomiku jej wierszy, którego kopia okładki wraz z odpowiednimi danymi bibliograficznymi znalazła się pod zamieszczonym wywiadem. 


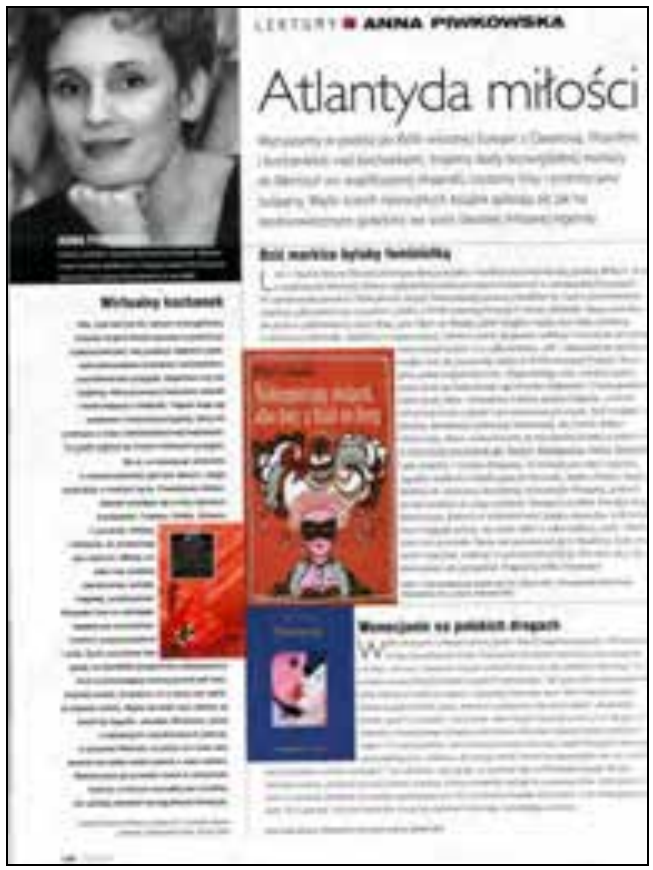

Zdjęcie 109. Przykładowa strona recenzyjna na łamach „Twojego Stylu” „Twój Styl” 2003, nr 6, s. 130

Od numeru 7 (2003) zwiększono liczbę omówień do dziewięciu, grafika działu uległa zmianie: recenzje wypoziomowano, podzielono je na trzy grupy (każda otrzymała własny tytuł), zawierające po trzy propozycje. Jednocześnie recenzja jednego tytułu zmniejszyła się do kilku (niekiedy trzech-czterech) zdań, co powodowało, że stawała się ona głównie adnotacją treściową. Taka formuła utrzymała się ponad rok, w niektórych wydaniach zmieniano tylko kolor czcionki we wspólnym dla wszystkich recenzji i omówień tytule.

W numerze 5 (2004) zmniejszono liczbę prezentowanych tytułów do sześciu, powracając $\mathrm{w}$ pewnym stopniu do wcześniejszej formy graficznej. W kolejnych numerach wprowadzano kosmetyczne zmiany, w postaci innego kroju i koloru czcionki w nazwie rubryki, nazwisku recenzentki oraz wspólnym tytule ( $\mathrm{nr} 6$ i 8/2004). Na zdjęciach 110-111 znajdują się wybrane przykłady, odzwierciedlające owe zmiany ${ }^{65}$.

65 Pominięto w przytoczonych zdjęciach zmianę w numerze 6/2004 jako już nazbyt szczegółową. 


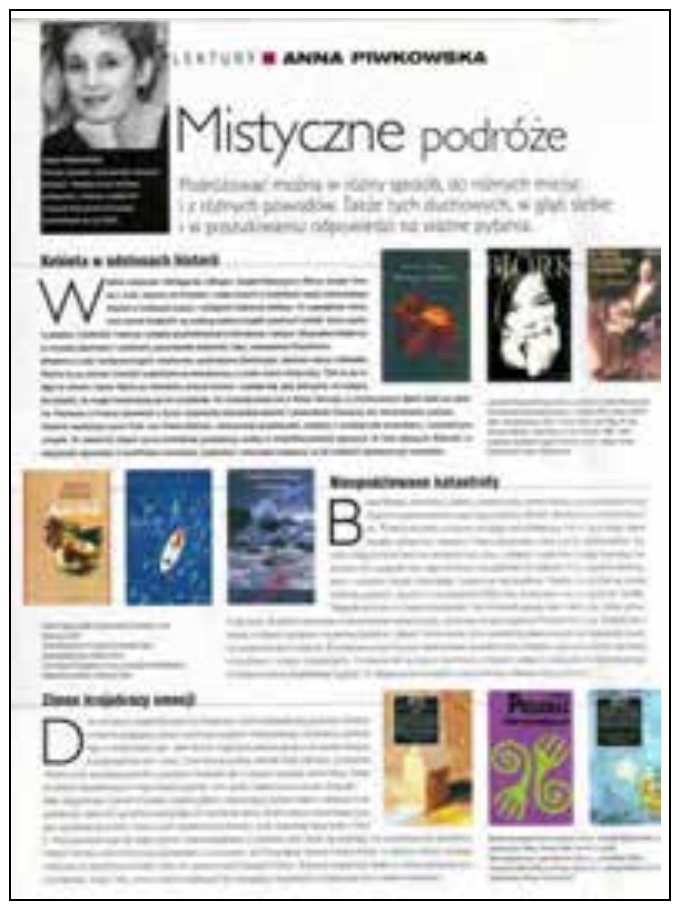

Zdjęcie 110. Przykładowa strona recenzyjna na łamach "Twojego Stylu” „Twój Styl” 2003, nr 9, s. 122

Zdjęcie 111. Przykładowa strona recenzyjna na łamach "Twojego Stylu” „Twój Styl” 2004, nr 5, s. 158

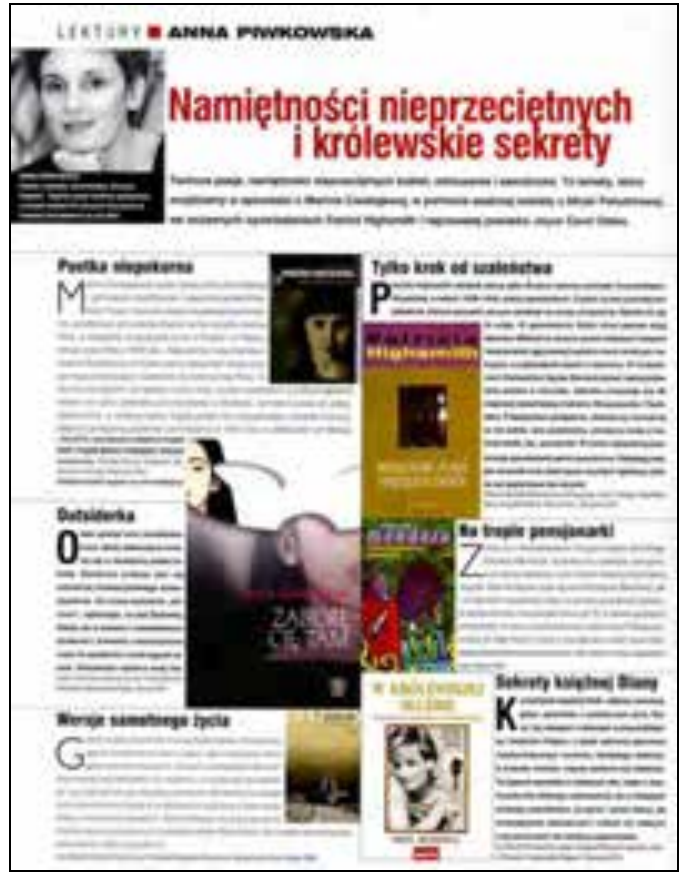


Wydaje się jednak, że poprzedni pomysł na wygląd strony poświęconej recenzjom książek był dla czytelnika korzystniejszy. W nowej wersji nachodzące na siebie kopie okładek zakłócały percepcję; można powiedzieć, że stały się elementem bardziej (w porównaniu z poprzednim wariantem), dominującym na stronie, przez co stała się ona mniej czytelna. Jednak najwyraźniej spodobała się redakcji, ponieważ w tej postaci utrzymała się przez następne 11 wydań. Kolejna zmiana nastąpiła w 2005 r. w numerze 4. Powrócono do wcześniejszego zwyczaju omawiania tylko trzech wybranych książek, zwiększono objętość adnotacji treściowych i układ strony. Dodano kolor, pozostając przy tej samej nazwie rubryki, zmieniono $\mathrm{w}$ niej krój i kolor czcionki, zaś nazwisko recenzentki zaczęto umieszczać u dołu strony. W kolejnym numerze zabrakło tradycyjnych recenzji; pojawiły się one ponownie $\mathrm{w}$ wydaniu następnym (6/2005). Przyniósł on ze sobą zmianę recenzenta. Został nim Leszek Bugajski, ale zanim czytelnicy zdążyli się do niego przyzwyczaić, zastąpił go Łukasz Modelski (od numeru 8/200566). Wtedy też nastąpiła kolejna zmiana w wyglądzie tej części działu. Pięć proponowanych tytułów, wyraźnie od siebie oddzielonych, to postać Lektur, jaka zachowała się do końca omawianego okresu. Zdjęcia 112-114 ilustrują te zmiany.

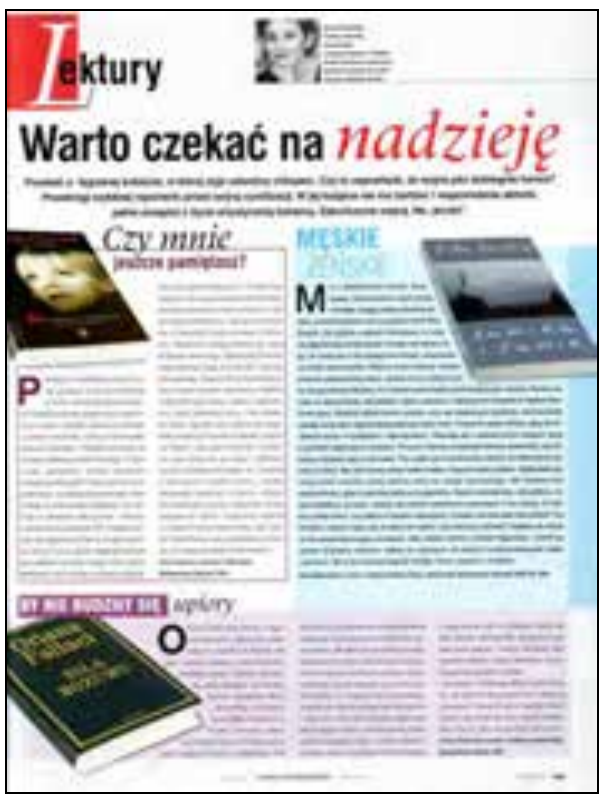

Zdjęcie 112. Przykładowa strona recenzyjna na łamach „Twojego Stylu” „Twój Styl” 2005, nr 4, s. 163

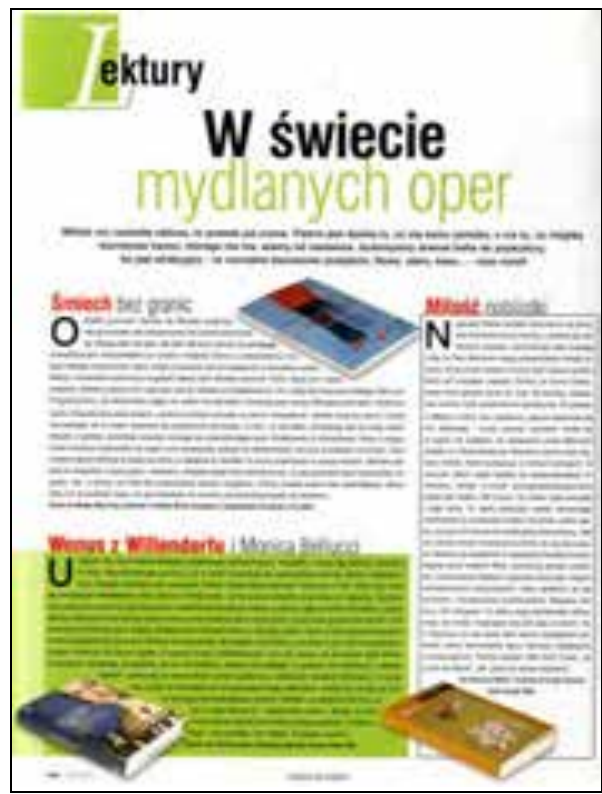

Zdjęcie 113. Przykładowa strona recenzyjna na łamach „Twojego Stylu” „Twój Styl” 2005, nr 6, s. 138

66 Wydanie lipcowe „Twojego Stylu” ponownie trafiło do czytelnika bez odredakcyjnych recenzji. 


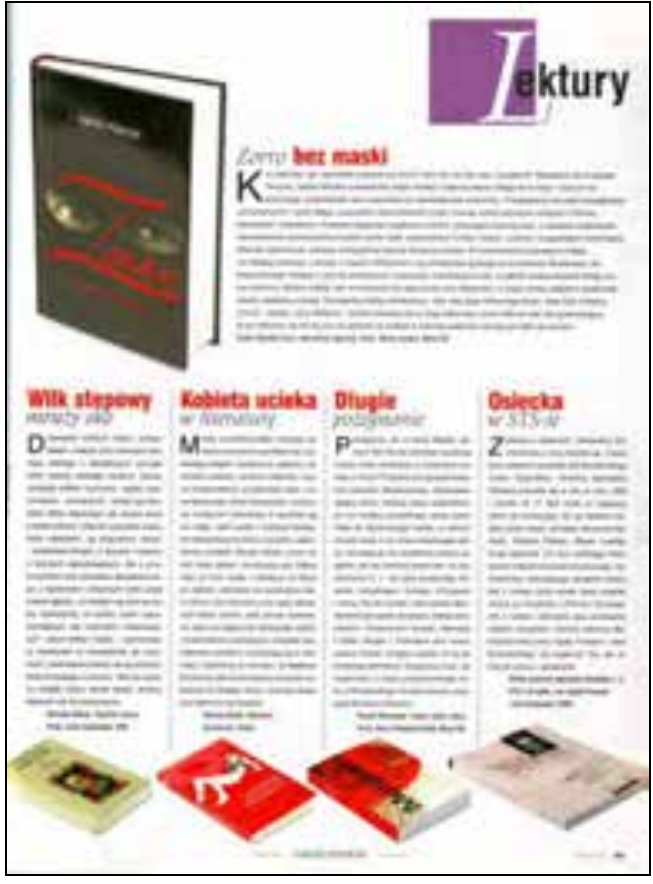

Zdjęcie nr 114. Przykładowa strona recenzyjna na łamach „Twojego Stylu” „Twój Styl”, 2005, nr 8, s. 99

Najbardziej znaczącą zmianą w odniesieniu do strony, poświęconej recenzjom, w ciągu pięciu analizowanych lat była zmieniająca się liczba prezentowanych w ten sposób książek: od dwóch do dziewięciu tytułów.

W każdym jednak przypadku strona ta była starannie opracowana, większość z omówień wyraźnie wyeksponowana, zaś zamieszczane barwne kopie okładek dzięki temu, że łatwo zapadały w pamięć, ułatwiały ewentualne poszukiwania danej książki w księgarni.

\subsection{Zakres i charakter recenzji - przykłady}

Ogółem zrecenzowano książki 226 autorów67, w tym 163 pisarzy obcych i zaledwie 63 twórców polskich (Aneks 37. Autorzy książek recenzowanych na łamach „Twojego Stylu” w latach 2001-2005).

Trzykrotnie sięgnięto po książki felietonistów pisma: dwa razy przedstawione zostały książki Agaty Passent i raz Krystyny Kofty.

Inaczej, niż było to w przypadku wcześniej omówionego „Zwierciadła”, tu, ze względu na adresata pisma, preferowano książki pisarzy-kobiet.

67 Brak zgodności liczby autorów z liczbą recenzji wynika także z faktu, że kilkakrotnie sięgnięto po więcej niż jedną książkę tego samego autora. 
Okazało się, że recenzji poddano książki 147 autorek i 80 autorów68. Co ciekawe, jednak mimo to najczęściej recenzowano książki pisarzy, m.in. Paula Austere`a. Trzykrotnie natomiast zaproponowano lekturę pióra Erici Jong.

W 17 przypadkach sięgnięto dwukrotnie po twórczość tego samego autora. W tej grupie znaleźli się: Isabel Allende, Grażyna Borkowska, John M. Coetzee, Michael Cunningham, Magda Dygat, Umberto Eco, Kathryn Harrison, Michel Houellebecq, Amélie Nothomb, Agata Passent, Shan Sa, Alice Sebold, José Carlos Somoza, Agata Tuszyńska, Robert James Waller, Virginia Woolf, Jerzy Żurek.

W grupie rekomendowanych w ten sposób przez redakcję książek wyraźnie przeważała beletrystyka, a w niej współczesne powieści. Wśród autorów, poza wymienionymi, pojawili się także m.in. Max Cegielski, Irina Dienieżkina, Małgorzata Domagalik, Helen Fielding, John Fowles, Janusz Głowacki, Paweł Huelle, Wojciech Kuczok, David Lodge, Tony Parsons, Jerzy Pilch, Dorota Terakowska i Olga Tokarczuk. Znamienne, iż zabrakło recenzji książek popularnej w tym czasie Katarzyny Grocholi69, a w przypadku innych, cieszących się powodzeniem autorek (jak H. Fielding czy O. Tokarczuk) pisano o ich mniej znanych książkach (Potęga sławy, Ostatnie historie).

Praktycznie, poza nielicznymi wyjątkami (na przykład Wiersze Wisławy Szymborskiej czy Umbra Marzanny Kielar), nie omawiano poezji, a zaledwie kilkakrotnie sięgnięto po opowiadania (na przykład Poparzone dzieci Ameryki, antologia opowiadań Zadie Smith czy Dama $w$ lustrze Virginii Woolf). Jednostkowymi przykładami były recenzje wspomnień (na przykład Sting: Niespokojna muzyka), biografii (na przykład A. Scott Berg, Kate, jakq pamiętam; wywiad z Katharine Hepburn), wydań encyklopedycznych (Władysław Kopaliński, Leksykon wątków miłosnych) czy wydawnictw albumowych (A. Passent, Pałac wiecznie żywy).

Jakkolwiek nie recenzowano książek, wyróżnionych Literacką Nagrodą Nobla, to jednak czytelnicy „Twojego Stylu” mogli poznać inne utwory noblistów (także tych z lat dawniejszych). I tak na przykład, A. Piwkowska pisała o Wieku żelaza oraz W sercu kraju J. M. Coetzee, a także o Skandalu stulecia $i$ innych opowiadaniach G. G. Márqueza.

Przyglądając się pełnej liście autorów omawianych książek i ich tytułom, trudno jednoznacznie odpowiedzieć na pytanie, czy wybór lektur do recenzji podyktowany był jednym kryterium, na przykład odbiorcą pisma, w którym w większości przypadków były czytelniczki, czy też kreowanym

${ }^{68} \mathrm{~W}$ dwóch przypadkach książka była dziełem dwóch autorów: raz byli to M. Piątkowska i L. K. Talko, a następnie N. Kraus i E. Mc Laughin.

${ }^{69}$ Przeprowadzono z nią jednak wywiad, zob. H. Samson [rozm.], Ona jest taka jak my: kobieca, wrażliwa i silna, „Twój Styl” 2003, nr 10, s. 58. 
przez „Twój Styl” wizerunkiem współczesnej kobiety, czyli takimi lekturami, w których bohaterki odpowiadałyby temu portretowi. Analizując wspólne dla kilku książek tytuły recenzji, można jednak na to pytanie przynajmniej częściowo odpowiedzieć pozytywnie. Oto kilka wybranych przykładów, które mogłyby potwierdzać taką tezę70: Atlantyda miłości, Dom twórczych kobiet, Jak kochajq artyści, Kobieta podejmuje grę, Kopciuszkom szczęście sprzyja, Namiętności nieprzeciętnych i królewskie sekrety, Noce królowej, O miłości magii i tajemnicy [pis. oryg.], O urodzie duszy i ciała, kobietach i grzechach codzienności, Odwaga mówienia o sobie, Opiekuńcze kobiety, Pasje życia, Romantyczne spełnienie, Spragnione miłości, Tęsknota za pięknem, $W$ kręgu silnych kobiet, $W$ świecie mydlanych oper, Warto czekać na nadzieję, Znane grzeszne i bezkompromisowe. Książkom, które recenzent umieszczał pod wybranymi przez siebie takimi właśnie tytułami, przewodziło kilka wątków, które z pewnością zainteresowałyby raczej kobiety niż mężczyzn: miłość, szczególnie romantyczna, nieprzeciętna, burzliwa i mistyczna, poszukiwana przez kobiety silne, bezkompromisowe, ale jednocześnie opiekuńcze, mądre, odważne i wrażliwe, pełne życiowych pasji, tęskniące za pięknem i wierzące w nadzieję.

Niejednokrotnie zachęcano do sięgnięcia po takie właśnie książki, w których bohaterki były kobietami odważnymi, radzącymi sobie z trudnościami życia (jak na przykład Samira i Samir Siby Shakib czy Jehannette Izabeli Szolc), bądź też sama autorka była znaną z siły i waleczności kobietą (Oriana Fallaci). Jednak rzadko „aspekt kobiecości” był wyeksponowany tak jak w przypadku wstępu do recenzji w wakacyjnym numerze pisma w 2003 r., kiedy A. Piwkowska pisała: „Wakacyjna literatura dla kobiet i o kobietach porywa w świat emocji, sensacji, tajemniczych egzotycznych podróży i przygody"71.

Recenzowane książki pochodziły z oferty 61 wydawców ${ }^{72}$ (zob. Aneks 38. Wydawcy książek recenzowanych na łamach „Twojego Stylu” w latach 2001-2005). W tabeli 47 zaprezentowano tych, po książki których recenzenci pisma sięgali najczęściej:

70 Kolejno: „Twój Styl” 2003, nr 6, s. 130; 2004, nr 10, s. 147; nr 4 , s. 152; 2003, nr 4, s. $142 ; 2002$, nr 7, s. $130 ; 2004$, nr 5, s. $158 ; 2002$, nr 8, s. $122 ; 2004$, nr 2, s. $132 ; 2001$, nr 4, s. [146]; nr 9, s. $121 ; 2002$, nr 9, s. $140 ; 2004$, nr 3, s. 130; 2003, nr 7, s. 124; 2001, nr 8, s. 86; 2003, nr 11, s. 138; 2004, nr 8, s. 115; 2005, nr 6, s. 138; nr 4, s. 163; 2004, nr 6, s. 138.

${ }^{71}$ A. Piwkowska, Romantyczne spełnienia, „Twój Styl” 2003, nr 7, s. 124.

$72 \mathrm{~W} 10$ przypadkach nie podano nazwy wydawcy; poza jednym wyjątkiem ustalono jednak na potrzeby pracy brakujące dane, korzystając z „Przewodnika Bibliograficznego”, dostępnego na: www.bn.org.pl, kwiecień 2012. 
Tabela 47. Wydawcy najczęściej recenzowanych na łamach „Twojego Stylu” książek w latach 2001-2005

\begin{tabular}{|l|c|}
\hline \multicolumn{1}{|c|}{ Nazwa wydawcy } & Liczba tytułów \\
\hline Dom Wydawniczy REBIS & 33 \\
\hline Wydawnictwo W.A.B. & $22^{a}$ \\
\hline $\begin{array}{l}\text { Wydawnictwo Muza S.A. } \\
\text { Wydawnictwo Prószyński i S-ka }\end{array}$ & 21 \\
\hline Wydawnictwo Literackie & 18 \\
\hline Świat Książki & 16 \\
\hline $\begin{array}{l}\text { Wydawnictwo Książkowe Twój Styl } \\
\text { Oficyna Literacka Noir sur Blanc } \\
\text { Wydawnictwo Zysk i S-ka }\end{array}$ & 12 \\
\hline $\begin{array}{l}\text { Wydawnictwo Albatros } \\
\text { Społeczny Instytut Wydawniczy Znak }\end{array}$ & 11 \\
\hline
\end{tabular}

${ }^{a} \mathrm{~W}$ tym raz była to książka wydana w koedycji z Wydawnictwem Cis.

Źródło: badania własne.

Jak zatem widać, dominowały oficyny o ugruntowanej na rynku pozycji, kilka z nich (jak na przykład Dom Wydawniczy REBIS czy Wydawnictwo W.A.B.) należało $\mathrm{w}$ owym czasie do czołówki największych edytorów w Polsce. Oferta większości tych wydawców doczekała się również recenzji ze strony tygodników opiniotwórczych, choć nie były to te same tytuły, zaś autorzy powtórzyli się zaledwie w kilku przypadkach, o czym szerzej będzie traktował podsumowujący rozdział książki. Recenzenci „Twojego Stylu” sięgali także po ofertę własnego wydawnictwa, jak również po książki mniej znanych edytorów, jak choćby Wydawnictwa Jeden Świat, Wydawnictwa Niebieska Studnia, Wydawnictwa Oskar, Wydawnictwa SZAFA czy Wydawnictwa TOtamTO.

Recenzje, omówienia i krótsze formy w postaci adnotacji treściowych były najbardziej rozbudowaną i najliczniejszą kategorią informacji o książce na łamach „Twojego Stylu”. Jak już wspomniano, pomimo zmieniających się recenzentów i wyglądu stron, poświęconych omówieniom wybranych lektur, zachowały one ten sam charakter. Były to krótsze lub dłuższe streszczenia głównego wątku proponowanej książki, niekiedy z informacją na temat jej autora, lub okoliczności, towarzyszących powstaniu danego utworu. Niekiedy starano się zarazem określić dodatkowo, kim będzie odbiorca prezentowanej książki. Wyraźna była jednak pewna prawidłowość w owych omówieniach: recenzenci zakładali, że mają do czynienia z wykształconym czytelnikiem, posiadającym określony poziom wiedzy ogólnej i literackiej. Stąd pojawiały się niekiedy odwołania do wcześniejszej twór- 
czości danego pisarza, porównania opisywanej fabuły do wykorzystanej w innej książce, przez innego autora. Przykładem jest choćby recenzja Grobowca dla Borysa (Danilo Kiš): „Narracja Sołżenicyna, melancholia Schulza i piękny tragizm Babla. Wielka literatura"73.

Adnotacje wzbogacano za każdym razem kopią okładki proponowanej książki (zdjęcia były wyraźne, najczęściej można było swobodnie odczytać $\mathrm{z}$ nich nie tylko tytuł, ale i nazwisko autora). Poza tym, nierzadko wzrok przyciągały tytuły recenzji, odnoszące się już tylko do wybranej książki lub jednej z grup tytułów, znajdujących się $\mathrm{w}$ ramach rubryki ${ }^{74}$. Oto kilka przykładów75: 21 punktów widzenia, Boskie pomyłki ludzkie grzechy [pis. org.], Ciekawsze od fikcji, Dzban nie do rozbicia, Eliksir pisania, Historia uczuć, Kiedy dwóch kocha jednq, Kobieta ucieka w literaturę, Kwiat na dnie studni, Literatura kobiet według kobiet, Malowanie życia, Mroczne sekrety osobowości, Na balu życia, Nasi ukochani, Nasza codzienna apokalipsa, Nie ma jak rodzina, Pięknie o pięknie, Piszę do ciebie, Prawdziwe życie puka do drzwi, Sandał żony Lota i słowicza podłoga, Satyra gorzka i przewrotna, Szalona powieść, Szukaj mnie pod tysiącem imion, Twórca i niszczyciel, Tylko krok do szaleństwa, Uczucia kontrolowane, W poszukiwaniu przeznaczenia, Wersje samotnego życia, Z kogo się śmiejecie?, Zimne krajobrazy emocji, Życie ciekawsze niż wyobraźnia, Życie i duchy, Życie jak sensacyjna powieść. Tytuły wyróżniały się nie tylko treścią, ale również wytłuszczoną bądź kolorową czcionką.

Przez cały poddany analizie okres podawano większość podstawowych danych bibliograficznych, które zawsze umieszczano na końcu recenzji. Najczęstszym brakującym elementem było miejsce wydania (w 106 recenzjach). Niekiedy, chociaż znacznie rzadziej, brakowało nazwy wydawcy (17 razy) czy roku publikacji (16 przypadków). Jednak w 13 przypadkach zapomniano o podaniu jednej $\mathrm{z}$ najważniejszych informacji, jaką jest nazwisko autora proponowanej książki. Zrezygnowano zarówno z określenia objętości książki, jak i podawania jej ceny. Nie zamieszczano też żadnej skali ocen, chociaż niemal wszystkie recenzowane książki uzyskiwały pozytywną opinię, ale jednak brakowało wyraźnej gradacji tychże not. Niekiedy recenzent, zachwycony przeczytaną książką dawał upust swoim

73 Ł. Modelski, Dzieci rewolucji, „Twój Styl” 2005, nr 9, s. 113.

${ }^{74}$ Jednak, na co trzeba zwrócić uwagę, to wyraźna niechęć zmieniających się recenzentów i korektora pisma wobec znaków przestankowych, szczególnie zaś przecinków. Dla zobrazowania tego spostrzeżenia zachowano w tym przypadku oryginalną pisownię tytułów.

75 Zob. kolejno: „Twój Styl” 2005, nr 12, s. 205; 2001, nr 4, s. [146]; 2005, nr 1, s. 117; 2003 , nr 8, s. 114; 2002, nr 8, s. 122-[123]; 2004, nr 7, s. 126; nr 7, s. 126; 2005, nr 8, s. 99; 2001, nr 6, s. 128; nr 4, s. [146]; nr 3, s. 94; 2004, nr 2, s. 132; nr 9, s. 119; nr 11, s. 149; 2005, nr 2, s. $129 ; 2003$, nr 10, s. $142 ; 2001$, nr 4, s. [146]; 2004, nr 8, s. $115 ; 2003$, nr 11, s. 138 ; nr 11, s. 138; nr 7, s. 124; 2001, nr 7, s. [114]; 2003, nr 4, s. 142; 2004, nr 9, s. 119; nr 5, s. $158 ; 2002$, nr 7, s. $130 ; 2004$, nr 1 , s. $113 ;$ nr 5, s. $158 ;$ nr 12, s. $153 ; 2003$, nr 9, s. 122; 2001, nr 2, s. 92; 2002, nr 1, s. [117]; 2004, nr 3, s. 130. 
uczuciom, używając krótkich, acz treściwych określeń, jak na przykład: „książka oniryczna, duszna, zaskakująca. Rewelacja”76, „książka świetna”77, lub nie szczędząc pochwał pod adresem autora: „Nagrodę Nobla dostała dwanaście lat temu, jest doświadczoną pisarką, a jednak jej najnowsza powieść promieniuje taką energią i siłą, że Toni Morrison mogą pozazdrościć młodzi pisarze”78 czy „Kilka godzin świetnej lektury holenderskiej kandydatki do literackiego Nobla"79 lub o Księdze złudzeń P. Austere`a „Ta książka przywraca wiarę w sens czytania długich powieści"80.

Objętość większości omówień drukowanych w ramach rubryki Lektury obejmowała kilkanaście zdań. Wyjątkowo zdarzały się prezentacje obszerniejsze, wychodzące poza standardowy opis wybranego tytułu. Tak było na przykład przy okazji nowej książki Sue Townsend: Numer 10. Obok tradycyjnej kilkuzdaniowej wzmianki na temat tego tytułu pojawiła się obszerniejsza charakterystyka twórczyni Adriana Mole’a wraz z jej zdjęciem oraz minikonkurs. Dla czytelników „Twojego Stylu” przewidziano 10 egzemplarzy opisywanej książki, jeśli poprawnie odpowiedzą na krótkie pytanie. Dla ułatwienia podano trzy podpowiedzisi.

Inaczej było $\mathrm{w}$ odniesieniu do recenzji, zamieszczanych poza rubryką recenzyjną. Tak było jedynie w ośmiu przypadkach ${ }^{82}$. Większość omówień miała charakter bieżący: zazwyczaj wybrane książki doczekały się prezentacji jeszcze w roku swego wydania ${ }^{83}$.

Niekiedy obok recenzji pojawiał się wywiad z pisarzem, nawiązujący do nowo wydanej przezeń książki, której kopia okładki zamieszczona była na początku rozmowy, a odnoszące się doń dane bibliograficzne na końcu.

\subsubsection{Lagodnieję z biegiem lat ${ }^{84}$ : wywiady}

Wywiady stanowiły bardzo ważny element polityki pisma. Gros z nich były to jednak rozmowy z żonami sławnych mężów: aktorów, piosenkarzy, czy polityków.

76 Ł. Modelski, Miłość po prostu, „Twój Styl” 2005, nr 10, s. 137.

77 L. Bugajski, Wenus z Willendorfu, „Twój Styl” 2005, nr 6, s. 138.

78 L. Bugajski, Miłość noblistki, „Twój Styl” 2005, nr 6, s. 138.

79 A. Piwkowska, Ciekawsze od fikcji, „Twój Styl” 2005, nr 1, s. 117.

${ }^{80}$ A. Piwkowska, Komik, który zniknąt, „Twój Styl” 2004, nr 7, s. 126.

81 „Twój Styl” 2005, nr 9, s. 112.

82 Zob. np. „Twój Styl” 2002, nr 1, s. 117; 2002, nr 8, s. 122-[123]; nr 11, s. 164; 2003, nr 8, s. [103].

${ }^{83}$ Chociaż zdarzały się także tytuły, proponowane w pierwszych numerach magazynu w danym roku. Wtedy przedstawiano książki, wydane kilka miesięcy wcześniej, a nawet w wydaniach wakacyjnych, gdzie recenzenci zachęcali do przeczytania książek, które trafiły na rynek rok wcześniej.

84 Tytuł wywiadu, zob. „Twój Styl” 2001, nr 12, s. [84]-87. 
Na podstawie analizy zawartości periodyku można było wyłonić 73 wywiady z osobami, które pośrednio bądź bezpośrednio związane były z literaturą (zob. Aneks 39. Nazwiska osób związanych z książką, z którymi przeprowadzono wywiad na łamach „Twojego Stylu” w latach 2001-2005). W tej grupie znalazło się 22 pisarzy, wśród nich m.in. pojawili się: Isabel Allende, Stefan Chwin, Carlos Fuentes, Janusz Głowacki, Agnieszka Graff, Manuela Gretkowska85, Katarzyna Grochola, Roma Ligocka, Ewa Lipska, A. Nothomb, Jerzy Pilch, Jośe Saramago, Z. Smith, William Wharton, Janusz L. Wiśniewski. Rozmówcami pisma byli także jego felietoniści: Krystyna Kofta, Agata Passent oraz Andrzej Żuławski. Najczęściej przeprowadzali je: Magda Jaros-Kropidłowska, Katarzyna Nowak, Dorota Sikora-Pouivet, A. Szarłat i Anna Tomiak. Rozmowy drukowano zazwyczaj w dziale Kultura (kilkakrotnie, jak wspomniano wyżej, obok recenzji, w ramach rubryki Lektury), w obrębie Mieszanki stylowej, Portretów, Psychologii, Zdrowia bądź $\mathrm{w}$ sporadycznie pojawiającym się Wywiadzie na wyłączność. Ta forma informacji o twórcy zajmowała od połowy do niemal pięciu stron. Zawierała prawie zawsze te same elementy: zdjęcie lub kilka zdjęć rozmówcy (nierzadko w jego domu, z osobą bliską u boku), krótką notkę na jego temat, niekiedy zastępowaną rodzajem wprowadzenia, w którym obok jednegodwóch zdań o bohaterze wywiadu znajdował się również sygnał dotyczący tematu przewodniego rozmowy. Jeśli pretekstem do niej była nowa książka pisarza, wówczas zamieszczano kopię jej okładki i dane bibliograficzne dotyczące nowego tytułu. Czasem pojawiało się również zaproszenie do udziału w konkursie (umieszczano je na końcu rozmowy), w którym nagrodą były książki ${ }^{86}$. Pierwszą zachętą do przeczytania wywiadu były tytuły, które miały zwrócić uwagę czytelnika, tak, by zainteresował się wybranym bohaterem. Oto kilka przykładów ${ }^{87}$ : Chciałabym pogodzić świat, Co jeszcze nam się zdarzy?, Donna Kiszocica, Dziewczynka w czerwonym płaszczyku to ja, Historia z niemorałem, Jestem przechodniem, Krzesany z życiem, Mam się z czego cieszyć, Nie śpię więc piszę [pis. oryg], O szczęście trzeba dbać, Przetrwam bo piszę [pis. oryg.], Ryzyko życia, Skandalistka z zasadami, Skazy na duszy, W pułapce przeznaczenia, $Z$ wiatrem i pod wiatr.

85 Był to podwójny wywiad, przeprowadzony także z P. Pietruchą, z okazji wydania wspólnej z M. Gretkowską książki: Sceny z życia pozamałżeńskiego.

86 Konkursy zostaną omówione w dalszej części rozdziału.

87 Zob. kolejno: „Twój Styl” 2001, nr 3, s. [58]-[61]; 2004, nr 4, s. [82]-[84]; 2002, nr 1, s. $116 ; 2001$, nr 6, s. 122-[124], 126; 2003, nr 4, s. 144-145; nr 6, s. 120-[121]; 2002, nr 8, s. $114-116 ; 2005$, nr 4, s. $160-162 ; 2003$, nr 8 , s. 112-113; nr 12, s. 72; nr 3, s. 118; 2002, nr 11, s. 156; nr 2, s. 174-[176]; 2003, nr 11, s. 130; 2001, nr 10, s. 128; 2003, nr 7, s. [118], [120], [122]. 
Niekiedy, jak wspomniano powyżej, wywiad z pisarzem drukowano obok rubryki recenzyjnej, a przedmiotem rozmowy stawała się nowo wydana książka. Tak było na przykład w czerwcowym numerze z 2001 r., kiedy K. Nowak pytała D. Terakowską o Poczwarkę, wydaną przez Wydawnictwo Literackie88. Książka wpisywała się w tytuły zaprezentowane obok przez T. Jastruna, których treść lub przesłanie określił on jako Wyprawy w głąb życia.

Ciekawym spostrzeżeniem wydaje się fakt, że na owe 73 wywiady, 54 przeprowadzono z kobietami, które osiągnęły w życiu sukces, czyli takimi, które odpowiadały wizerunkowi, preferowanemu przez pismo ${ }^{89}$. I tak na przykład, już początek rozmowy z Isabel Allende potwierdzał tę tezę: Agnieszka Meyer stwierdziła: „Kiedy musiała Pani opuścić Chile, miała Pani 40 lat, chorego męża i dwoje dzieci na utrzymaniu. Wiele kobiet by się w tej sytuacji załamało. A Pani odniosła wielki sukces literacki"90. Po tak intrygującym początku, czytelnicy dowiedzieli się m.in., jak autorka Domu duchów poradziła sobie z przeciwnościami losu, jak, łamiąc konwenanse, oświadczyła się swemu drugiemu mężowi, ale również i o tym, czym jest dla niej pisanie, prawdziwa i przybrana ojczyzna oraz jakie jest jej podejście do życia.

Inna bohaterka wywiadu, Joanna Olczak-Ronikier, to kolejna silna kobieta, wywodząca się z rodziny, gdzie „prababka Julia, babka Janina i [...] matka Hanna, wszystkie miały mocny charakter i dominującą osobowość"1, które to cechy ujawniały się w obliczu trudów życia i pozwoliły im przetrwać w niełatwych okolicznościach. Z kolei z portretu, wyłaniającego się z wywiadu z A. Graff, powstał obraz, w którym okazało się, że z niej „Feministka nie taka straszna", jak się wydaje, chociaż jest kobietą niezależną, jej związek opiera się na wolności, i która „realizuje własny projekt na życie, a nie ten narzucony przez tradycję i konwenanse" ${ }^{92}$. Jackie Collins, autorka bestsellerów, w których „zawsze wygrywają silne i niezależne kobiety”93, K. Kofta, która wierzy, że „jednak kobieta może być wolna, niezależna” 94 , E. Lipska, wyznająca, że

88 K. T. Nowak [rozm.], Motyl uwięziony, „Twój Styl” 2001, nr 6, s. 128.

89 Wywiady, których nie uwzględniono w tej liczbie, czyli takie, których bohaterami, częściej bohaterkami, byli ludzie nie związani ze światem literatury, także potwierdzają tę tezę. To osoby, które mogą poszczycić się osiągnięciami, powodzeniem i sławą, lub takie, które są związane $\mathrm{z}$ „ludźmi sukcesu” (w takim przypadku bywały to np. żony sławnych mężów: aktorów, piosenkarzy, sportowców, polityków, ambasadorów).

90 A. Meyer (rozm.), Żyj zgodnie z przeznaczeniem, „Twój Styl” 2001, nr 10, s. 77.

91 K. T. Nowak (rozm.), Łagodnieję z biegiem lat, „Twój Styl” 2001, nr 12, s. 85.

92 K. T. Nowak (rozm.), Feministka nie taka straszna, „Twój Styl” 2002, nr 3, s. 46.

93 A. Tomiak (rozm.), Skandalistka z zasadami, „Twój Styl” 2002, nr 2, s. 174.

94 I. Filipiak (rozm.), Między nami czarownicami, „Twój Styl” 2002, nr 11, s. 165. 
To od nas zależy, jak będziemy się starzeć. Ważna jest pogoda ducha, trochę przyjaciół, z którymi można pomilczeć. [...] To nieprawda, że wraz z czterdziestoma czy pięćdziesięcioma urodzinami wszystko w życiu kobiety się kończy. Zmarszczki mogą być piękne!95

czy Z. Smith, przyznająca, że według niej „kobietom jest trudniej”96 - to bohaterki, których życie ma być potwierdzeniem wartości propagowanych przez „Twój Styl”. Są tymi, którym, nierzadko mimo przeszkód, udało się osiągnąć sukces, spokój ducha, szczęście, a przynajmniej zadowolenie z życia, podobnie jak fikcyjnej bohaterce stworzonej przez K. Grocholę. Przy okazji ekranizacji Nigdy $w$ życiu! pojawiły się cztery wywiady, wydrukowane w tym samym numerze pisma: z autorką bestsellera, aktorką, odtwarzającą główną rolę w filmie, socjologiem z Uniwersytetu Warszawskiego oraz $\mathrm{z}$ autorką scenariusza. Każda z nich przedstawiła swoją opinię na temat popularności Judyty, bohaterki książki. Czytamy:

Kobiety, bez względu na charakter, kolor włosów, wiek, identyfikują się z nią. Bo ona jest esencją kobiety. Zmienna, inteligentna, dzielna, dobra. Ciepła, silna, wrażliwa. Niezależna. Chwilami ubezwłasnowolniona. Cudnie różnorodna97.

I w tym przypadku bohaterka (co prawda, fikcyjna) wpisywała się w określony wizerunek kobiety, kreowany przez pismo. Tezę tę potwierdzały słowa I. Łepkowskiej:

Tak układają się dziś losy kobiet. To my musimy zmagać się z olbrzymimi trudnościami. Lepiej radzimy sobie niż mężczyźni. Nie tracimy w tych zmaganiach kobiecości, dowcipu, urody. Jesteśmy mocniejsze moim zdaniem ${ }^{98}$.

Większość wywiadów niosła ze sobą takie właśnie przesłanie lub rodzaj morału.

\subsubsection{Przeczytaj koniecznie! ${ }^{99}$ : reklamy książek}

Na łamach „Twojego Stylu” pojawiały się również reklamy. Należy zaznaczyć, że jakkolwiek zajmowały one bardzo dużą część periodyku, to jednak w przeważającej większości ich przedmiotem były kosmetyki, ubrania czy artykuły higieniczne, a tylko nieznaczna ich cześć związana była

95 K. T. Nowak (rozm.), Pomilczmy z przyjaciółmi, „Twój Styl” 2003, nr 11, s. [137].

96 A. Cholewa-Selo (rozm.), Miłosne listy kobiet, „,Twój Styl” 2004, nr 5, s. 150.

97 A. Grigo [wysłuchała], Jest esencją kobiety, „Twój Styl” 2003, nr 10, s. 59.

98 A. Grigo (wysłuchała), Zachwyca swoja przemiana, „,Twój Styl” 2003, nr 10, s. 60.

99 Hasło reklamowe w jednym z anonsów wydawniczych. Zob. „Twój Styl” 2003, nr 4, s. [113]. 
$\mathrm{z}$ problematyką, określoną $\mathrm{w}$ temacie pracy. Pomimo skromnej liczby można wyróżnić następujące kategorie, które się w niej zawierają:

1) książki,

2) akcje tygodnika związane z książką 100 ,

3) prasa, w tym autoreklama ${ }^{101 .}$

W latach 2001-2005 ukazało się w sumie 415 reklam odpowiadających powyższym kategoriom, z czego zaledwie 77 stanowiły anonse wydawnicze. W 127 przypadkach przedmiotem ogłoszenia były czasopisma, a w 211 rozmaite akcje, organizowane przez periodyk. W tabeli 48 przedstawiono liczbę inseratów wydawniczych w każdym z badanych roczników.

Tabela 48. Ogłoszenia wydawnicze zamieszczane na łamach „Twojego Stylu” w latach 2001-2005

\begin{tabular}{|c|c|}
\hline Rok & Liczba inseratów książkowych \\
\hline 2001 & 57 \\
\hline 2002 & 10 \\
\hline 2003 & 1 \\
\hline 2004 & 9 \\
\hline 2005 & - \\
\hline Ogółem & 77 \\
\hline
\end{tabular}

Źródło: badania własne.

Największa liczba ogłoszeń pojawiła się w pierwszym badanym roczni$\mathrm{ku}$; wynikało to przede wszystkim z faktu, że w tamtym czasie Wydawnictwo Prasowe Twój Styl połączone było z Wydawnictwem Książkowym, które wykorzystywało łamy periodyku do autopromocji swej oferty. Zaskakująca, a zarazem zastanawiająca jest tak niewielka liczba reklam wydawniczych $\mathrm{w}$ piśmie, podobnie jak ich całkowity brak w ostatnim badanym roczniku.

W tej liczbie anonsów aż 61 stanowią ogłoszenia Wydawnictwa Książkowego Twój Styl, 9 - Wydawnictwa Migut Media S.A., 3 - Wydawnictwa Naukowego PWN, 3 - Wydawnictwa Świat Książki i 1 - Wydawnictwa Quelle (Aneks 40. Wydawcy, którzy zamieścili swe ogłoszenia na łamach „Twojego Stylu” w latach 2001-2005). W ogłoszeniach, niemal zmonopolizowanych przez wydawcę periodyku, pojawiła się informacja o 52 różnych tytułach. W inseratach znalazło się 35 nazwisk autorów, w tym 25 pisarzy polskich i 10 autorów obcych (Aneks 41. Autorzy książek reklamowanych

100 Ten typ informacji z uwagi na swoją dwojaką postać (komentarz tekstowy oraz reklama) zostanie przedstawiony w dalszej części rozdziału, zatytułowanej: Kto kupi buty dla noblistki?: inne formy informacji o książce.

101 Te zagadnienia zostaną omówione w ostatniej części rozdziału. 
na łamach „Twojego Stylu” w latach 2001-2005). W tabeli 49 zaprezentowano najczęściej reklamowane tytuły.

Tabela 49. Najczęściej powtarzające się tytuły w reklamach wydawniczych w latach 2001-2005 na łamach „Twojego Stylu”

\begin{tabular}{|l|l|c|}
\hline \multicolumn{1}{|c|}{ Tytuł reklamowanej pozycji } & \multicolumn{1}{|c|}{ Wydawca } & Liczba anonsów \\
\hline Oblicza polskiego dworu [album] & Wydawnictwo Migut Media S.A. & 9 \\
\cline { 1 - 2 } Wielka encyklopedia PWN & Wydawnictwo Naukowe PWN & \multirow{2}{*}{3} \\
\cline { 1 - 2 } $\begin{array}{l}\text { I będę żyć... (Jerri Nielsen, } \\
\text { Maryanne Vollers) }\end{array}$ & Wydawnictwo Świat Książki & \\
\cline { 1 - 2 } Empire (Marek Nowakowski) & Wydawnictwo Książkowe Twój Styl & \\
\hline
\end{tabular}

Źródło: badania własne.

W kilku przypadkach ten sam tytuł stał się dwukrotnie przedmiotem reklamy. Tak było na przykład w przypadku książek: Gęstwina (Bogusławy Latawiec), Kroniki czasów Mitanni (Bogusława Chraboty), Rondo de Gaulle'a (Olgi Stanisławskiej), Zasypie wszystko, zawieje... (Włodzimierza Odojewskiego); wszystkie propozycje pochodziły z ofert Wydawnictwa Książkowego Twój Styl. Podobnie niewielka powtarzalność pojawiała się w odniesieniu do autorów reklamowanych lektur - tabela 50.

Tabela 50. Autorzy książek reklamowanych przez wydawców (więcej niż 1 tytuł) na łamach „Twojego Stylu” w latach 2001-2005

\begin{tabular}{|l|c|c|l|}
\hline \multicolumn{1}{|c|}{ Nazwisko autora } & $\begin{array}{c}\text { Liczba } \\
\text { inseratów }\end{array}$ & $\begin{array}{c}\text { Liczba } \\
\text { tytułów }\end{array}$ & \multicolumn{1}{|c|}{ Tytuły reklamowanych książek } \\
\hline Zygmunt Kałużyński & 4 & 2 & $\begin{array}{l}\text { Perłowa ruletka. Leksykon filmowy }{ }^{a} \\
\text { Wampir salonowiec }\end{array}$ \\
\hline Marek Nowakowski & 4 & 2 & $\begin{array}{l}\text { Empire } \\
\text { Rajski ptak }\end{array}$ \\
\hline Josef Škvoreckỳ & 4 & 2 & $\begin{array}{l}\text { Dwa morderstwa w moim dwoistym życiu } \\
\text { Fajny sezon }\end{array}$ \\
\hline $\begin{array}{l}\text { Jarosław Abramow- } \\
\text {-Newerly }\end{array}$ & 3 & 2 & $\begin{array}{l}\text { Granica sokoła } \\
\text { Lwy mojego podwórka }\end{array}$ \\
\hline
\end{tabular}

${ }^{a}$ Książka napisana wspólnie z T. Raczkiem.

Źródło: badania własne.

Zaledwie w trzech przypadkach pojawiło się to samo nazwisko autora w recenzji i reklamie. Były to książki B. Chraboty, K. Kofty oraz J. Škvorecky`ego, a tylko $\mathrm{w}$ odniesieniu do ostatniego pisarza była to ta sama książka (Dwa morderstwa w moim dwoistym życiu). 
W trzech pierwszych numerach „Twojego Stylu” w 2001 r. znalazł się anons Wydawnictwa Naukowego PWN. Podobnie jak w przypadku innych przedstawianych w pracy periodyków zajmował całą stronę, przykuwał wzrok odbiorcy starannością przygotowania i ciekawym pomysłem (zdjęcie 115).

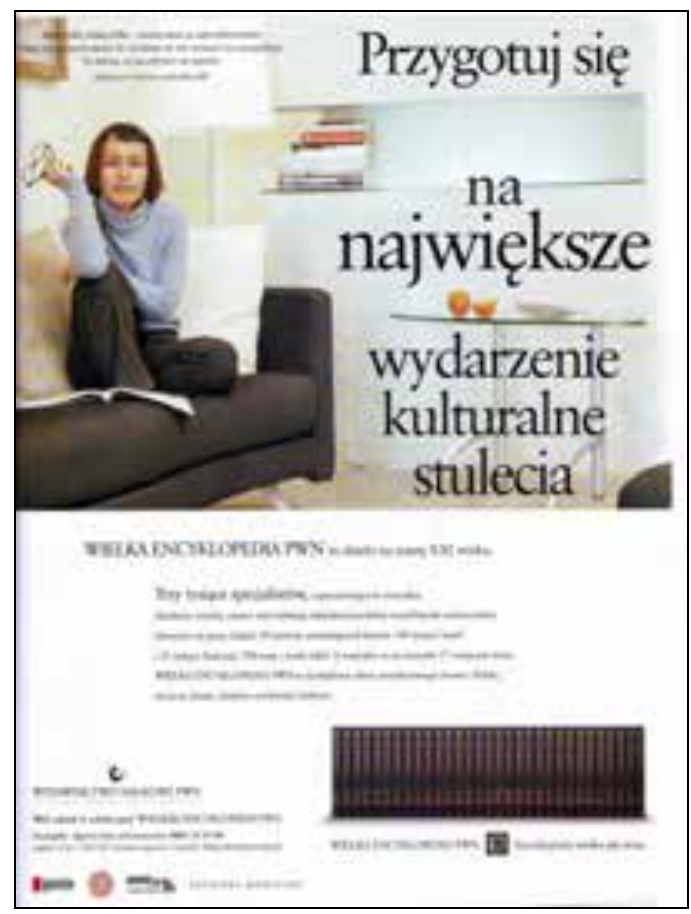

Zdjęcie 115. Przykładowe ogłoszenie wydawnicze zamieszczone na łamach „Twojego Stylu” „Twój Styl” 2001, nr 2, s. [93]

Podobnie od pierwszego omawianego numeru pojawiały się reklamy Wydawnictwa Książkowego Twój Styl. Miały one za każdym razem podobną formułę, zajmowały zazwyczaj całą stronę, chociaż kilkakrotnie ograniczono się do prezentacji tytułów w postaci mniejszego modułu, umieszczonego z boku strony. Czytelnik odnajdował je w środkowej lub ostatniej części periodyku, na stronach poświęconych sprawom kultury bądź w ramach działu Relaks lub Zdrowie. Anonse miały najczęściej postać zbliżoną do formuły rubryki recenzyjnej: $w$ inseracie pojawiał się tytuł wiodący, wspólny dla wszystkich (w tym przypadku reklamowanych) książek oraz podtytuły dla poszczególnych propozycji, wyraźne kopie okładek oferowanych lektur, adnotacje treściowe, dane bibliograficzne, uzupełnione o cenę książki oraz nierzadko hasło reklamowe i kupon zamówienia. W jednym ogłoszeniu pojawiało się zazwyczaj sześć tytułów (zdjęcie 116 i 117). 


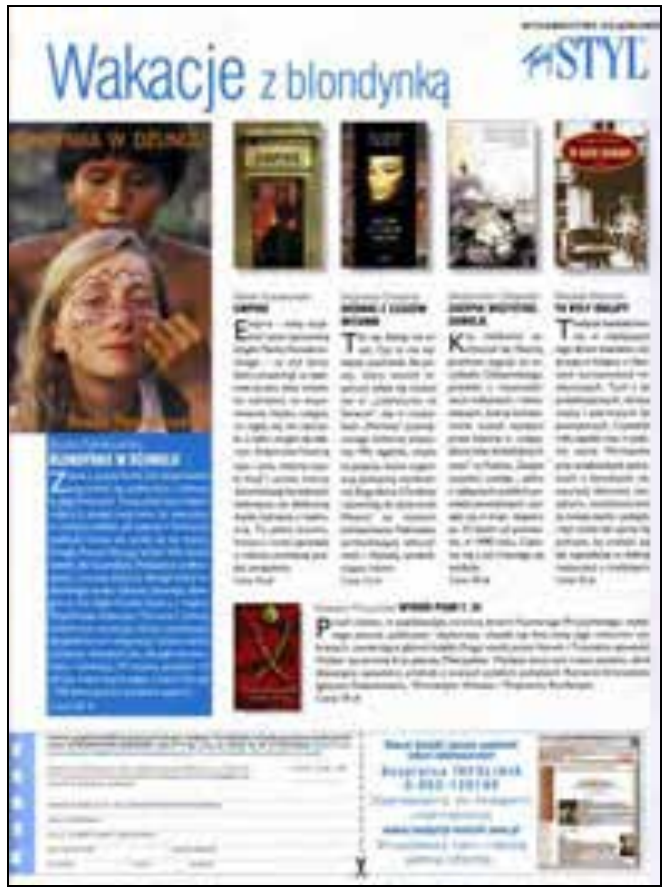

Zdjęcie nr 116. Przykładowe ogłoszenie wydawnicze zamieszczone na łamach "Twojego Stylu" „Twój Styl” 2001, nr 7, s. [186]

Zdjęcie nr 117. Przykładowe ogłoszenie wydawnicze zamieszczone na łamach „Twojego Stylu”

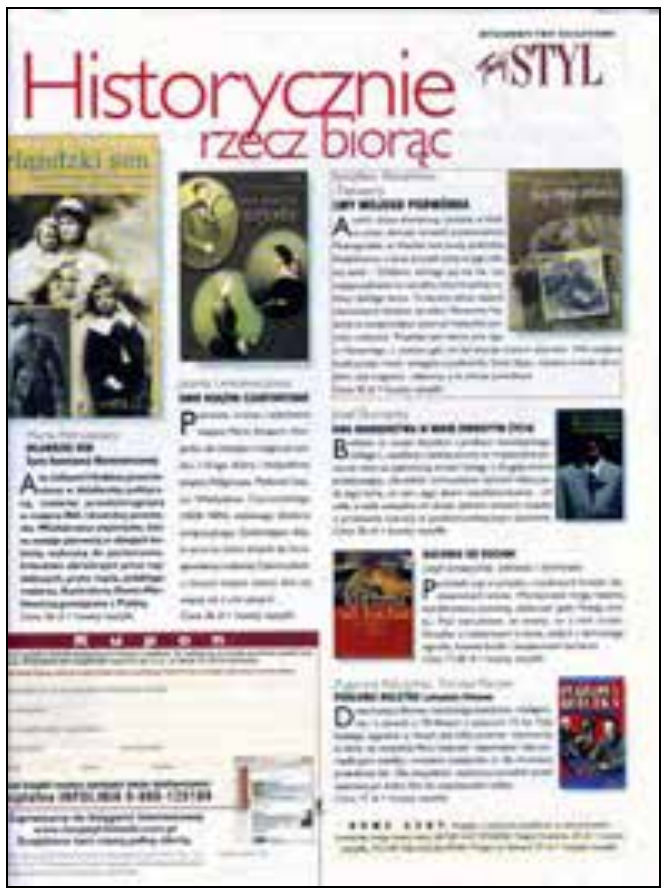


Kiedy na początku 2002 r. Wydawnictwo Książkowe Twój Styl przestało wykorzystywać łamy pisma do promocji swojej oferty, wówczas jedynym ogłoszeniem wydawniczym, trafiającym do czytelników magazynu, była propozycja oficyny Migut Media S.A., proponującej album Oblicza polskiego dworu. W większości przypadków anons miał tę samą formułę, która prezentowała się tak, jak zaprezentowano to na zdjęciu 118.

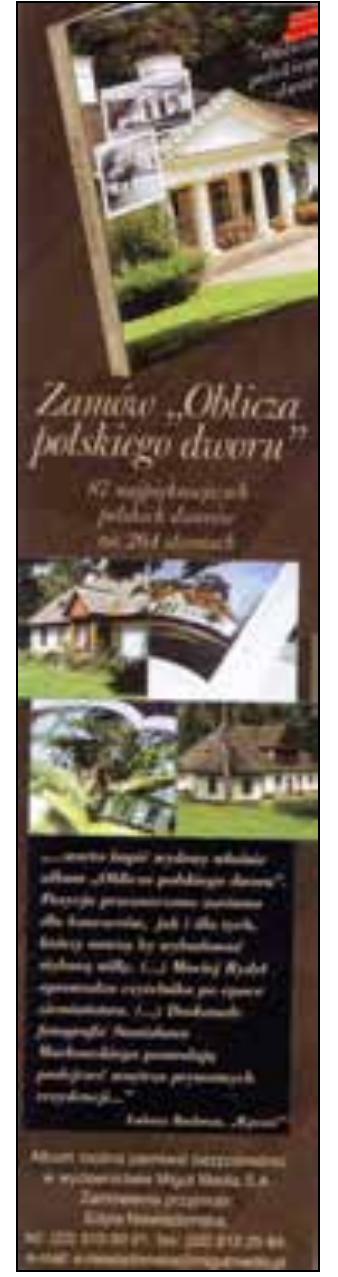

Zdjęcie nr 118. Przykładowe ogłoszenie wydawnicze zamieszczone na łamach „Twojego Stylu” „Twój Styl” 2004, nr 10, s. [222]

Warto zwrócić uwagę na cytowaną opinię: jej autorem był dziennikarz tygodnika „Wprost”. Funkcję zachęcającą spełniać miały również wybrane $\mathrm{z}$ albumu zdjęcia.

Jak zatem widać, ta postać informacji o książce na łamach periodyku była bardzo skromnie prezentowana zarówno pod względem liczby ogłoszeń, jak i zróżnicowania formy. Znacznie częściej pojawiające się reklamy z innych branż miały staranniej dopracowaną grafikę, były bardziej pomysłowe. Podobnie było $\mathrm{w}$ przypadku autoreklamy pisma. Zostanie ona omówiona w dalszej części rozdziału.

\subsubsection{Kto kupi buty dla noblistki? ${ }^{102}$ : inne formy informacji o książce}

Na łamach „Twojego Stylu” w latach 20012005, poza recenzjami i reklamami, ukazało się 486 różnego typu tekstów, które pośrednio lub bezpośrednio dotyczyły książki poprzez przedmiot informacji, jej bohatera lub osobę, która była jej autorem. Miały one rozmaitą objętość i charakter, rozmieszczone były w całym piśmie zarówno na stronach poświęconych kulturze, jak i w obrębie działów Moda, Psychologia, Relaks, Sztuka życia, Zdrowie (zob. Aneks 42. Wybór tekstów związanych z literaturą i rynkiem wydawniczo-księgarskim, zamieszczonych na łamach „Twojego Stylu” w latach 2001-2005). Zebrany materiał pozwolił, podobnie jak w przypadku poprzednich periodyków, na wyodrębnienie kilku kategorii tekstów/informacji, uwzględnionych wcześniej $\mathrm{w}$ tabeli 45 . W ten sposób można wyróżnić:

102 K. T. Nowak, Kto kupi buty dla noblistki?, „,Twój Styl” 2001, nr 6, s. 32-34, 36, 38. 
- sylwetki/portrety (35);

- artykuły, poświęcone sprawom książki lub rynku wydawniczo-księgarskiego (22);

- ekranizacje, adaptacje i inscenizacje znanych dzieł (45);

- listy czytelników, nawiązujące do informacji związanej książką (7);

- konkursy i akcje, organizowane przez tygodnik (65);

- inne (312).

Poniżej scharakteryzowano każdą z kategorii, prezentując wybrane, reprezentatywne dla niej przykłady.

\subsection{Książę i róża ${ }^{103:}$ sylwetki/portrety}

Portrety były jednym z działów pisma od początku jego istnienia. Jak już wspomniano wcześniej, zamieszczane tu cykle (jak choćby Jej Styl) wpisywały się $\mathrm{w}$ formułę periodyku, realizując propagowany przezeń określony wizerunek kobiety. Nierzadko zdarzało się, że teksty tego typu, opisujące życie wybranej osoby, jej osiągnięcia, poglądy, drukowano także w innych miejscach magazynu.

Bohaterami tych tekstów byli niekiedy pisarze bądź osoby pośrednio związane z literaturą. W analizowanym okresie takich przypadków było 35. Pojawiały się one w całym periodyku, chociaż zaledwie sześć z nich znalazło się w ramach Portretów. Inne czytelnicy odnajdowali na przykład w rubryce Hihg life story bądź w dziale Kultura, zaś dwa z nich miały formę reportażu. Większość zajmowała od czterech do pięciu stron. Poza wprowadzeniem (zazwyczaj intrygującym), w tekście znajdowały się liczne zdjęcia. Wśród prezentowanych pisarzy znaleźli się na przykład Manuela Gretkowska, Katarzyna Grochola, Wojciech Kuczok, Iris Murdoch, Ruth Rendell, Andrzej Stasiuk, Gertruda Stein i Virginia Woolf.

W kilku przypadkach kreślono sylwetkę nie tylko danego twórcy, ale i bliskiej mu osoby. Interesującym przykładem (podobnie jak w przypadku miesięcznika „Zwierciadło”) był tekst poświęcony autorowi Małego księcia. Anna Bojarska odsłaniała przed czytelnikami mało znane fakty nie tylko z życia Antoine`a de Saint-Exupéry`ego, ale również odkrywała tajemnice powstania książki, która uważana jest przez wielu za autobiografię pisarza104. W kolejnym tekście także pojawił się podwójny portret: W. Kuczoka i jego żony, Kariny. Joanna Laprus-Mikulska skoncentrowała swoją opowieść na życiu osobistym autora Widmokrągu, zaś odwołań do sukcesów zawodowych było niewiele ${ }^{105}$.

103 Tytuł jednego z tekstów, zob. „Twój Styl” 2001, nr 5, s. 128-130, [132]-[133].

104 A. Bojarska, Ksiq̨żę i róża, „Twój Styl” 2001, nr 5, s. 128-130, [132]-[133].

105 J. Laprus-Mikulska, Wreszcie trafiłem do domu, „Twój Styl” 2005, nr 3, s. 44-47. 
Inaczej było w przypadku tych portretów, gdzie bohaterami stawali się ludzie, znani nie tylko dzięki swym sukcesom, ale również ci, których losy były powikłane, życie naznaczone tragizmem, a poglądy kontrowersyjne. I tak na przykład, w 2001 r., przed pojawieniem się ekranach kin filmu Godziny, dzięki Elżbiecie Królikowskiej-Avis czytelnicy „Twojego Stylu” poznali sylwetkę Virginii Woolf. Starannie dobrane zdjęcia domu, w którym mieszkała wraz z mężem, dopełniały przejmujący tekst Nie zatrzymał mnie nikt ${ }^{106}$.

Z kolei o Sylvii Plath, jej życiu i wydanych po raz pierwszy bez cenzury dziennikach można było dowiedzieć się z tekstu pod wiele mówiącym tytułem: Udręczona dusza. Już wstęp do czterostronicowego portretu autorki Szklanego klosza przyciągał wzrok:

Kultowa poetka dwóch pokoleń: dzieci kwiatów i ich dzieci. [...] Jej poezja wciąż niepokoi, inspiruje, magnetyzuje. Wielki talent, niezwykła osobowość, światowa sława oraz tragiczna śmierć Sylvii Plath od niemal 40 lat przyciągają uwagę i wzbudzają kontrowersje ${ }^{107}$,

dalej czytelnik dowiadywał się, jak wyglądało jej życie z Tedem Hughesem, o tym, jak z pozycji „wybranki bogów” znalazła się na dnie rozpaczy, w depresji, która doprowadziła ją do śmierci. Natomiast przedmiotem kolejnego portretu stało się burzliwe życie Françoise Sagan: jej wzloty i upadki z werwą opisała korespondentka pisma z Paryża, D. Sikora-Pouivet ${ }^{108}$.

W niektórych przypadkach pod tekstem pojawiała się propozycja wzięcia udziału w konkursie, w którym nagrodą były książki autorstwa opisywanego pisarza/pisarki ${ }^{109}$.

Reasumując, portrety wydają się być najciekawszą formą informacji, związanej z książką, zamieszczanych na łamach magazynu. Nietuzinkowy bohater, pieczołowicie wybrane te wątki z jego życia, które mogły zainteresować czytelnika „Twojego Stylu”, umiejętnie rozbudzana ciekawość, sprawiały, że historie te czytać można jak fragment dobrze napisanej książki, nabierając chęci, by jeszcze bliżej poznać daną postać, choćby poprzez jej twórczość.

106 E. Królikowska-Avis, Nie zatrzymał mnie nikt, „Twój Styl” 2001, nr 11, s. [142]-146.

107 E. Królikowska-Avis, Udręczona dusza, „Twój Styl” 2001, nr 4, s. 139.

108 D. Sikora-Pouivet, Witajcie smutki, „Twój Styl” 2002, nr 8, s. 188-192.

109 Zob. np. „Twój Styl” 2004, nr 10, [16]-20. Więcej na temat konkursów - w dalszej części rozdziału. 


\subsection{Bez pouczania ${ }^{110}$ : teksty, poświęcone książce i rynkowi wydawniczo- księgarskiemu}

Formuła i charakter pisma decydowały o tym, że brak w nim było tekstów, analizujących kondycję współczesnej literatury czy sytuację na rynku wydawniczo-księgarskim tak, jak było to w przypadku prasy opinii. Obszerniejszych publikacji, traktujących bezpośrednio o sprawach, określonych w tytule pracy, było tu niewiele, zaledwie $22 \mathrm{w}$ ciągu 5 lat. Liczniejszą grupę stanowiły krótsze teksty, które należałoby nazwać raczej notkami, w poprzednich rozdziałach zaliczanymi do kategorii „inne”, a także, o czym wcześniej wspomniano, felietony, których autorzy byli pisarzami. Oddzielną grupę stanowiły propozycje książek, drukowane w sporadycznie pojawiającej się rubryce Co Państwo czytaja i polecają? Warto także wspomnieć o stosunkowo często zamieszczanych na łamach pisma fragmentach książek - nowościach bądź takich, które dopiero miały się ukazać. Ale i w tych przejawach zainteresowania literaturą widać wyraźnie realizowaną przez pismo ideologię i kontekst programowy periodyku.

Przyznając, że „Książki to żywioł. Mogą pochłonąć dom, wcisnąć się w kąty, zarosnąć każde wolne miejsce. Do zestawu podstawowego, który zabieramy z rodzinnego domu, dodajemy przez lata własne. Bo żyć bez książek nie sposób"111, proponowano (w formie zdjęć) sposoby na to, „Jak przechowywać książki w domu, żeby najpotrzebniejsze zawsze były pod ręką? Co zrobić, aby zdobiły wnętrze, zamiast je przytłaczać?"112. Inne teksty miały charakter przede wszystkim ciekawostek, które mogły zainteresować odbiorcę magazynu. Pisano na przykład o nowym nurcie w literaturze, znanym jako „mommy lit” („literatura dla mam”), zapoczątkowanym przez książkę Allison Pearson Nie wiem, jak ona to robi, a kontynuowanym przez przedstawiony przez pismo bestseller Babyville (Jane Green). Czytelnicy byli przekonywani, że to „Pełne humoru, inteligentnie napisane powieści”, które „podobają się milionom kobiet”113.

Z kolei Wojciech Bońkowski pisał o innych jeszcze książkach, które zaciekawić mogły przede wszystkim płeć piękną, sam zresztą na początku stwierdzając, że „Książki kucharskie są ulubioną lekturą kobiet”114 zarówno „mistrzyń rondla”, jak i tych, które „o prawdziwym gotowaniu nie wiedzą już prawie nic"115. Wszystkie zaś łączy jedno: są zabiegane, mają coraz mniej czasu na przygotowanie rodzinnego obiadu. Stąd rady, po które książki

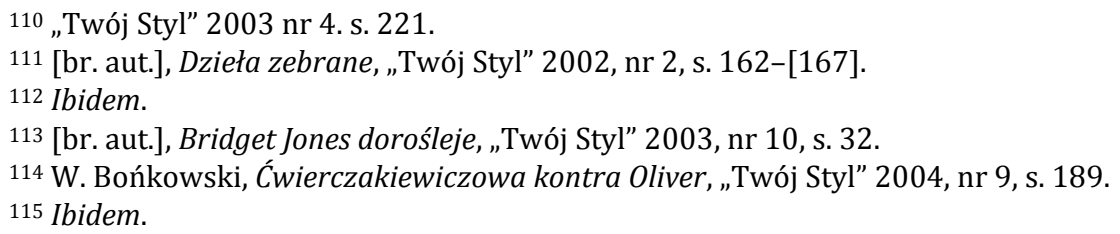


sięgnąć, które z licznie oferowanych tytułów mogą się najbardziej przydać: reprint 365 obiadów Lucyny Ćwierczakiewiczowej czy Oliver w kuchni Jamie`go Olivera. Dopełnieniem owego „przewodnika” były propozycje znanych (sic!) kobiet dotyczące ich ulubionych książek kucharskich oraz kuszące kopie okładek tychże lektur, a na sąsiedniej stronie m.in. przepis na lody w sosie malinowo-różanym i zaproszenie do jednej z warszawskich restauracji.

Kolejny tekst również wpisywał się w kategorię ciekawostek, które mogły zainteresować czytelniczki „Twojego Stylu”. Była to historia o tym, jak kobiety, sławne dzięki osiągniętym przez siebie sukcesom, wspólnie napisały dla swoich dzieci krótkie historyjki, wydane następnie w formie książki Bajki gwiazd. I tak,

Małgorzata Foremniak uczy, jak wyrosnąć na dobrego człowieka, a Monika Jaruzelska, jak zachwycić się rozmaitością świata. Jolanta Raszyńska i Jagna Marczułajtis opowiadają o dziecięcych smutkach i czują, jakby mówiły sobie i innym matkom o potrzebie macierzyńskiej miłości. Bo to są bajki dla dzieci i dorosłych. Prawdziwe jak życie ${ }^{116}$.

Tekst niósł ze sobą przesłanie (zawierające się w programie periodyku) o tym, jak ważne w życiu kobiety jest macierzyństwo, obok (niekoniecznie zamiast) kariery zawodowej.

O książkach i kobietach traktował także kolejny tekst: Sonia Draga, Iza Kowalczyk oraz Basia Stępień założyły własne wydawnictwa i osiągnęły sukces: o tym, o ich wcześniejszych losach, zanim książki zmieniły ich życie, opowiadała Agnieszka Litorowicz-Siegert ${ }^{117}$.

Warto także wspomnieć jeszcze o dwóch publikacjach, wpisujących się $\mathrm{w}$ tematykę pracy. W pierwszej z nich wyjątkowo opisani zostali nie tylko sławni ludzie, ale także ich „pierwsi sekretarze”. O pracy asystentów Stanisława Lema, Czesława Miłosza i Wisławy Szymborskiej, typowych i oryginalnych zleceniach, o ochronie prywatności twórców, a także o organizowaniu spotkań i wywiadów pisała K. Nowak w cyklu Twórcy i życie ${ }^{118 .}$ $\mathrm{W}$ tym interesującym tekście nie zabrakło również ciekawostek z życia codziennego „Wielkiej Trójki” oraz anegdot, opowiedzianych przez ich sekretarzy.

Równie interesujący był inny jeszcze reportaż, opowiadający o paryskiej księgarni Shakespeare\&Company, gdzie „W ciągu dnia zaglądają [...] turyści, wieczorami szukają noclegu zagubieni poeci, pisarze i artyści"119

\footnotetext{
116 J. Laprus-Mikulska, Na dobranoc i na całe życie, „Twój Styl” 2005, nr 6, s. 32.

117 A. Litorowicz-Siegert, W kobiecym wydaniu, „Twój Styl” 2005, nr 12, s. [64]-69.

118 K. T. Nowak, Kto kupi..., s. 32-34, 36, 38.

119 M. Wendołowska, Przystań poetów, „Twój Styl” 2005, nr 3, s. 72.
} 
i gdzie obowiązuje zasada: „Możesz tu zostać, jeśli czytasz jedną książkę dziennie" 120 .

Z kolei o bookcrossingu pisała Agnieszka Chądzyńska, tłumacząc, że nie jest to jedynie wymiana książek: „To również dyskusje o modnych autorach, przyjaźnie zawierane przez internet"121. U dołu tekstu znalazł się adres strony poświęconej tej inicjatywie, a także mini-konkurs z nagrodą w postaci 10 egzemplarzy powieści K. Grocholi Osobowość ćmy. Odpowiedź na pytanie konkursowe znajdowała się w tekście.

Przytoczone publikacje, każda kilkustronicowa, miały charakter relacji z wyraźnym dążeniem ich autorów do uwypuklenia najciekawszych wątków, wyeksponowania tych elementów opowiadanych historii, które wciągną czytelnika jak dobra książka. A dobre książki proponowano nie tylko $\mathrm{w}$ formie zaprezentowanej już rubryki recenzyjnej, ale również w postaci (jak w „Zwierciadle”) rekomendowanych przez znane osoby tytułów, tu zamieszczanych w sporadycznie pojawiającej się, wspomnianej już rubryce Co Państwo czytają i polecają?, drukowanej w dziale poświęconym sprawom kulturalnym. Taka forma promocji książki pojawiła się w ciągu pięciu lat siedmiokrotnie ${ }^{122}$. Poza jednym wyjątkiem, o swojej ulubionej lekturze opowiadały cztery wybrane osoby. Ich zdjęcia umieszczone były nad kilkunastozdaniowym opisem danej książki, tytułem opinii, adnotacji treściowej, podstawowymi danymi bibliograficznymi i kopią okładki proponowanej książki. O rekomendację poproszono m.in. wybranych aktorów (na przykład Piotra Adamczyka, Waldemara Goszcza i Magdalenę Stużyńską), dziennikarzy (Roberta Makłowicza, Joannę Racewicz i Andrzeja Sołtysika), muzyków (Grzegorza Turnaua, Wojciecha Waglewskiego) i literatów (Manuelę Gretkowską). Pomysł, by zapytać samych twórców o ich ulubione książki, pojawił się raz, w pierwszym analizowanym numerze w rubryce Co czytaja pisarze? Również w tym przypadku były to cztery osoby (Marek Bieńczyk, Anna Nasiłowska, Piotr Siemion, Olga Tokarczuk). Grafika rubryki zmieniła się trzykrotnie, co wiązało się z wcześniej omówionymi przemianami całego periodyku.

Uwagę zwracała wielość elementów, składających się na przedstawioną stronę: kopie okładek książek, zdjęcia osób opowiadających o wybranych lekturach, dane bibliograficzne - to wspólne części składowe, rozmaicie rozmieszczone i zaprezentowane w różnej tonacji kolorystycznej.

120 Ibidem, s. 74.

121 A. Chądzyńska, Uwolnić Grocholę, „Twój Styl” 2005, nr 6, s. [137].

122 „Twój Styl” 2001, nr 12, s. [138]; 2002, nr 2, s. [120]; nr 7, s. [131]; nr 11, s. [169]; 2003, nr 3, s. 126; 2005, nr 5, s. [126]; nr 7, s. [110]. 
Znalazły się tu bardzo zróżnicowane tytuły: obok Szachownicy flamandzkiej (Artura Pérez-Reverte) pojawiły się Drogi człowieka mistycznego (Jana A. Kłoczowskiego), obok Mitów i symboli starożytnego Egiptu (Andrzeja Niwińskiego), Białe jabłka (Jonathana Carrolla). Wyraźne, kolorowe zdjęcia kopii okładek proponowanych książek były elementem przykuwającym wzrok czytelnika, zaś opinie znanych osób miały mniej lub bardziej pogłębiony charakter. Niektóre ograniczały się do zasygnalizowania lub streszczenia głównych wątków proponowanej lektury, w innych pojawiała się jednoznaczna ocena (jak choćby w przypadku książki Zjeść Kraków. Przewodnik subiektywny Roberta Makłowicza i Stanisława Mancewicza: „Ta książka jest smaczna jak dobre, aromatyczne danie"123) czy intrygujące zakończenie („Zaskakujący finał wyjątkowej książki”) ${ }^{124}$.

Opiniami na temat przeczytanych książek mogli się również podzielić sami czytelnicy pisma w organizowanym w 2002 r. konkursie na internetową recenzję ${ }^{125}$. Ulubione tytuły odbiorców „Twojego Stylu” znalazły także swoje odbicie $\mathrm{w}$ formie nietypowej listy Bestsellery $z$ Internetu. Informacja na ten temat (wraz z zestawieniem 10 najczęściej czytanych przez odbiorców magazynu książek) pojawiła się jednak zaledwie dwukrotnie w dwóch pierwszych numerach periodyku w 2002 r. ${ }^{126}$

Znacznie częściej sięgano po inną jeszcze formę zachęty i promocji literatury. W ciągu 5 lat na łamach pisma 22 razy drukowano fragmenty wybranych książek. Przeważnie można było je odnaleźć w dziale kulturalnym, ale odbiorca mógł się na nie natknąć także przy czytaniu tekstów, poświęconych zdrowiu czy psychologii. Zajmowały od jednej do niemal sześciu stron, miały swój odrębny tytuł, określający do pewnego stopnia temat proponowanej książki, a w przypadku zapowiedzi wydawniczej na zakończenie podawano informacje bibliograficzne wraz $\mathrm{z}$ określeniem zbliżonej daty ukazania się danej lektury. Nierzadko proponowano czytelnikom udział w konkursie, w którym nagrodą była cytowana lektura. Sięgnięto w ten sposób m.in. po książkę $A B C$ dobrych manier Macieja B. Brzozowskiego i Romana Wysockiego, Afrykańskq odyseję Karen Blixen, Artemizję Alexandry Lapierre, Gdyby zamilkły kobiety Krystyny Kofty, Rozbuchanq wyobraźnię Olivii Joules H. Fielding oraz Siostrzane uczucia Małgorzaty Domagalik. Niekiedy przytaczany fragment urozmaicano rysunkami grafików pisma, czasem zamieszczano kopię okładki polecanej w ten sposób książki.

W 2001 r. pojawiła się lista propozycji lektur na wakacje (pomysł znany z łamów pism opinii, niewykorzystany przez miesięcznik „Zwierciadło”).

\footnotetext{
123 E. Lutczyn, Smaczna prawda o Krakowie, „Twój Styl” 2001, nr 12, s. [138].

${ }^{124}$ R. Dancewicz, Pelagia na tropie, „Twój Styl” 2005, nr 7, s. [110].

125 Zostanie on bliżej scharakteryzowany w dalszej części rozdziału.

126 „Twój Styl” 2002, nr 1, s. [117]; nr 2, s. [121].
} 
T. Jastrun zaproponował cztery książki, których kolorowe kopie okładek zwracały uwage czytelnika. Z charakterystycznym dla siebie poczuciem humoru oraz ironią poeta zachęcał do sięgnięcia m.in. po Kwiaty śliwy w złotym wazonie: „erotyczne nieprzyzwoitości, które kiedyś tak bulwersowały czytelnika, zbladły wobec bezwstydu naszych czasów. Fascynująca jest za to nadal obyczajowa warstwa powieści"127. Obok oferty Tomasza Jastruna znalazły się także propozycje trzech znanych osób (Magdaleny Cieleckiej, Andrzeja Chyry oraz Kamila Durczoka) wybranych przez nich lektur na urlop. Pod każdą z siedmiu pozycji znalazły się dane bibliograficzne dotyczące określonego tytułu.

Podobną okolicznościową formułę miały propozycje lektur-prezentów pod choinkę. Czterokrotnie 128 w „Twoim Stylu” prezentowano wybrane tytuły. W tych przypadkach nad tekstem przeważały zdjęcia. Barwne kopie okładek, zdjęcia otwartych książek i krótkie, kilkuzdaniowe (w 2005 r. nieco dłuższe) notki treściowe uzupełnione danymi bibliograficznymi miały zachęcić czytelników do obdarowania bliskich albumami, a także powieściami - m.in., jak pisano w jednym z numerów - „dla koneserów, smakoszy, wielbicieli sztuki i podróży"129.

Kilkakrotnie tytuł książki pojawiał się w kontekście publikacji, związanej z dowolnym zagadnieniem, innym niż literackie czy nawet kulturalne, a wpisującym się w tematykę „Twojego Stylu”, podobnie jak nazwisko pisarza, którego opinię cytowano przy okazji poruszania określonych zagadnień. Na przykład w tekście poświęconym kuchni i gotowaniu cytowano słowa M. Domagalik, która „uważa, że przygotowanie jednego ciepłego posiłku dziennie to obowiązek każdej kochającej żony"130. Opisano jednocześnie wystrój kuchni autorki m.in. feministycznych felietonów. Pojawiały się także, chociaż niezwykle rzadko, teksty, w których książka stawała się pretekstem do zajęcia się innym tematem Na przykład odnosząc się do bestsellera Cień wiatru Carlosa R. Zafóna, proponowano czytelnikom podróż śladami jego bohaterów ${ }^{131}$. Jednocześnie przy okazji pojawił się konkurs z prostym pytaniem, w którym nagrodą była ta właśnie książka. $\mathrm{W}$ innym numerze zamieszczono tekst o Nowej Zelandii, proponowanej przez biura podróży miłośnikom Władcy Pierścieni ${ }^{132}$.

127 T. Jastrun, Chiński Dekameron, „Twój Styl” 2001, nr 7, s. [114].

128 Kolejno w 2001, 2003, 2004 i 2005 r.

129 [br. aut.], Znajdź album pod choinkq, „Twój Styl” 2002, nr 12, s. [164].

130 M Smarzyńska-Karbownik, Kucharek sześć, „Twój Styl” 2002, nr 4, s. 34.

131 [br. aut.], Miasto zaczytane, „Twój Styl” 2005, nr 5, s. 88-89.

132 E. Sarnacka-Mahoney, Tranzytem przez Śródziemie, „Twój Styl” 2004, nr 2, s. 70-73. Należy jednak zaznaczyć, że tu odwoływano się raczej do ekranizacji powieści J. R. R. Tolkiena, nie zaś do wersji oryginalnej w postaci książki. 
Odrębną grupę publikacji wartych odnotowania, stanowiły wspomniane wcześniej felietony, których autorami byli pisarze. Każdy z nich drukował swoje teksty $\mathrm{w}$ stałych cyklach. W tabeli 51 zaprezentowano ich nazwiska wraz z tytułem cyklu felietonów oraz okresem, $\mathrm{w}$ jakim pojawiał się on w periodyku.

Tabela 51. Pisarze zamieszczający felietony na łamach „Twojego Stylu” w latach 2001-2005

\begin{tabular}{|l|l|c|}
\hline \multicolumn{1}{|c|}{$\begin{array}{c}\text { Nazwisko } \\
\text { felietonisty }\end{array}$} & \multicolumn{1}{|c|}{ Nazwa cyklu } & $\begin{array}{c}\text { Okres ukazywania się } \\
\text { danego cyklu }\end{array}$ \\
\hline A. Bojarska & Montparnasse 2001 & 2001 \\
\hline M. Gretkowska & Szkice na jedwabiu & $2002-2003$ \\
\hline T. Jastrun & Notatnik erotyczny & $2001-2003$ \\
\hline K. Kofta & Intercity $\rightarrow$ Rewizja osobista $\rightarrow$ Być z nim czy nie być & $2001-2005$ \\
\hline A. Passent & Krakowskie Przedmieście & $2001-2005$ \\
\hline A. Żuławski & Bilet miesięczny $\rightarrow$ Inaczej & $2001-2005$ \\
\hline
\end{tabular}

Źródło: badania własne.

Każdy z felietonów (ogółem było ich 229133) zajmował jedną stronę magazynu, u góry każdej kolumny zamieszczano zdjęcie danego felietonisty. Nie podejmowali oni raczej, jak można byłoby się spodziewać, tematów literackich, rzadko też sięgali po przeczytaną książkę, by dzielić się z czytelnikami periodyku wrażeniami po jej lekturze. Zazwyczaj felietony miały charakter luźnych rozważań, gdzie punktem wyjścia stawało się wydarzenie, w którym autor brał udział, obserwacje zachowań ludzkich (w przypadku felietonistek bardzo często był to komentarz do postaw współczesnych mężczyzn w określonych sytuacjach) lub rozważania związane z uczuciami, szczególnie z miłością i relacjami (nierzadko konfliktami) damsko-męskimi. Niektóre z felietonów miały bardzo sugestywne tytuły, jak na przykład134: Ciche dni, Cogutto się żeni, Cytrusek Chytrusek, Faceci i kury, Idealne sadomaso, Makbetowa, Mąż z billboardu, Żona z żelaza. Warto zwrócić uwagę na to, że teksty pisane przez znanych autorów miały najciekawsze tytuły, biorąc pod uwagę pozostałe formy informacji o książce. Poza wymienionymi, czytelnicy prawdopodobnie zwrócili uwagę także na takie, jak choćby135: Ancymon, Gwóźdź wbity w sedno, Ja cię wiercę, Ja to ktoś

133 Do tej grupy nie zaliczono trzech felietonów pióra J. Kaczmarskiego.

134 Kolejno: „Twój Styl” 2002, nr 7, s. 136; nr 2, s. 122; nr 10, s. 140; 2004, nr 8, s. 121; 2001, nr 11, s. [150]; 2005, nr 8, s. 100; nr 7, s. 111; 2001, nr 1, s. 114.

135 Kolejno: „Twój Styl” 2005, nr 4, s. 84; 2002, nr 1, s. 120; 2005, nr 7, s. 52; 2002, nr 10, s. 155; 2003, nr 10, s. 72; 2005, nr 3, s. 127; 2002, nr 12, s. 74; 2005, nr 6, s. 86; 2001, nr 10, s. [152]; 2004, nr 12, s. 68; 2005, nr 4, s. 165; 2003, nr 4, s. 76; 2003, nr 4, s. 146. 
inny, Kartki z zawistnika, Królestwo za kontakt!, Maszyna do życia, Pan Lolitek, Pani Curetta, Ściśle fajne, Twardy dysk duszy, Wypromuj się, Zmory pamięci.

Inny charakter miały krótkie notki, dotyczące interesujących nas zagadnień. W ciągu 5 lat pojawiło się 48 takich kilkuzdaniowych informacji. Zamieszczane były przeważnie $w$ ramach dwóch towarzysko-sensacyjnych rubryk: Mieszanki stylowej oraz High life 'u. Obok doniesień z życia gwiazd estrady i ekranu pojawiały się wzmianki dotyczące książek i pisarzy, przy czym notki te miały także nierzadko posmak sensacji, a przynajmniej niebanalnej ciekawostki. I tak na przykład, informowano o wydaniu przez Uniwersytet Qinghua książki, w której znalazły się wiersze i listy pisane w chińskim języku nushu, używanym tylko przez kobiety136, o ukazaniu się humorystycznego poradnika Corinne Maier Witaj lenistwo, czyli sztuka i konieczność wkładania jak najmniejszego wysiłku w pracę przedsiębiorstwa ${ }^{137}$. Czytelniczki pisma dowiedziały się również o ukazaniu się encyklopedii najlepiej ubranych kobiet świata ${ }^{138}$ oraz o dwóch nowych edycjach Wydawnictwa Arkady: Historii mody Françoise Bouchera i Tysiq̨ca ubiorów w Polsce Anny Sieradzkiej139. Pisano także o książce Doris Kopf-Shroeder, tłumaczącej dzieciom zawiłości polityki ${ }^{140}$. Zastanawiano się, czy mężem norweskiej księżniczki Marthy Luisy zostanie pisarz-skandalista Ari Behn ${ }^{141}$, a wszystkim zainteresowanym polecano internetową księgarnię feministyczną ${ }^{142}$. Uznano również, że odbiorców magazynu zainteresuje fakt, że Casual Oksana Robsky wydała w Rosji książkę o życiu tamtejszych milionerów ${ }^{143}$, a książę Henryk, mąż królowej Danii, Małgorzaty, opublikował tomik wierszy ${ }^{144}$. Skrupulatnie odnotowano także, co znani pisarze mówią o kobietach i małżeństwie; dzięki „cytatowi miesiąca” czytelnicy dowiedzieli się, że J. Carroll uważa, iż „Kobiety są bardziej interesujące od mężczyzn. Są prawdziwym skarbcem. Szkoda, że większość facetów nie potrafi znaleźć do nich klucza”145, a T. Parsons radził: „Gdy na widok mężczyzny serce nie przyspiesza, czas odejść, przekonać się, ile jest warte życie bez niego. Czasem miłość każe nam wrócić"146.

\footnotetext{
136 [br aut.], Jak kobieta z kobietą, „Twój Styl” 2004, nr 12, s. [24].

137 [br aut.], Przez lenistwo do kariery, „Twój Styl” 2004, nr 10, 26.

138 [br aut.], Wyrocznia przemówiła, „Twój Styl” 2004, nr 11, s. 22.

139 [br aut.], Suknie mówiq̨, „Twój Styl” 2003, nr 9, s. 107.

140 [br aut.], Kanclerzowa pisarka, „Twój Styl” 2001, nr 12, s. 32.

141 [br aut.], Księżniczka i pisarz, „Twój Styl” 2001, nr 6, s. [214].

142 [br aut.], Z nami znajdziecie w Internecie, „Twój Styl” 2002, nr 9, s. 20.

143 [br aut.], Nowe rosyjskie księżniczki, „Twój Styl” 2005, nr 5, s. 18.

144 [br aut.], Muza księcia Henryka, „Twój Styl” 2001, nr 2, s. 146.

145 „Twój Styl” 2001, nr 8, s. [18].

146 „Twój Styl” 2004, nr 4, s. 22.
} 
Pojawiały się też inne informacje. Na przykład, cytując dane Instytutu Książki i Czytelnictwa Biblioteki Narodowej z 2000 r., podawano „Fakty i liczby" dotyczące kontaktów Polek z książką. Największy (45) procent dotyczył kobiet, które przez ostatni rok nie miały w ręku książki, a wśród tych, które czytają, 20\% stanowiły miłośniczki romansów i powieści obyczajowych ${ }^{147}$. Być może po to, by skierować zainteresowania płci pięknej na szersze tory, poszerzyć jej horyzonty poza typową dlań lekturę, informowano o stronie internetowej, na której czytelniczki mogły odnaleźć słownik wyrazów obcych i zwrotów obcojęzycznych W. Kopalińskiego, będący częścią encyklopedii multimedialnej148 czy o ukazaniu się atlasu Drogi Europy ${ }^{149}$.

Formę krótkich notek przybierały także zazwyczaj informacje dotyczące ekranizacji czy inscenizacji znanych dzieł. Takich kilkuzdaniowych wzmianek, przeważnie o charakterze czysto informacyjnym, było w piśmie 45. Poza dwoma wyjątkami, wszystkie zamieszczono $w$ ramach działu kulturalnego, przeważnie w obrębie kolumny $W$ kadrze. Co się kręci? bądź Karnetu teatralnego. Pełniły one istotną funkcję przewodnika po bieżących lub mających się dopiero odbyć wydarzeniach kulturalnych. Czytelnicy dowiadywali się na przykład o adaptacji takich powieści, jak Solaris St. Lema, Afrodyty I. Allende, Bridget Jones H. Fielding, o premierze Starej baśni według Józefa I. Kraszewskiego, ale i o radiowej wersji Operetki Witolda Gombrowicza, inscenizacji Ślubów panieńskich Aleksandra Fredry, wystawieniu Matki Joanny od Aniołów na podstawie opowiadania Jarosława Iwaszkiewicza czy nietypowym, bo „lalkowym” przedstawieniu Makbeta na VI Festiwalu Szekspirowskim w Gdańsku. W większości przypadków na końcu wzmianki podawano informacje organizacyjne dotyczące danej imprezy. Pomimo że niewielkie objętościowo, niemal w każdym przypadku, posiadały swoje odrębne tytuły, których celem miało być zwrócenie uwagi czytelnika na tę właśnie informację. Niektóre zdawały się realizować to założenie z powodzeniem, na przykład 150: Aniołek z temperamentem, Anioły i demony w błocie, Dziewczynka patrzy na dorosłych, Nie widzę ciebie, Ofelio, Tam Raj twój, gdzie Ewa twoja, Trzy wcielenia kobiety.

Niestety, brakowało analogicznych informacji dotyczących na przykład spotkań autorskich czy targów książki lub innych imprez związanych z książką. A nie były to kwestie obojętne dla czytelników: o tym, że interesowała ich kultura, literatura, świadczyły listy do redakcji. Co prawda,

147 [br aut.], Fakty i liczby, „Twój Styl” 2001, nr 10, s. 42.

148 [br aut.], www.slownik-online.pl, „Twój Styl” 2002, nr 12, s. 28.

149 [br aut.], Z atlasem po drodze, „Twój Styl” 2002, nr 11, s. 229.

150 Kolejno: „Twój Styl” 2004, nr 9, s. 115; 2002, nr 9, s. [131]; 2003, nr 9, s. 116; 2004, nr 4, s. [149]; 2003, nr 9, s. 116; 2001, nr 1, s. [88]. 
reakcji dotyczących tekstów związanych z książką było niewiele, szczególnie $\mathrm{w}$ porównaniu $\mathrm{z}$ oddźwiękiem odbiorców na publikacje związane choćby ze zdrowiem czy urodą, niemniej jednak istniały. Przykładem może być list czytelnika odnoszącego się do tekstu opowiadającego o V. Woolf151. Żywe reakcje budziły także teksty M. Gretkowskiej ${ }^{152}$.

Kontakt z czytelnikami był niezwykle istotny dla redakcji „Twojego Stylu". Ich przywiązanie do pisma miały również wzmocnić liczne konkursy, organizowane systematycznie bądź cyklicznie.

\subsection{Książka w prezencie! ${ }^{153}$ Konkursy i akcje}

Magazyn był organizatorem wielu akcji i przedsięwzięć, ale niewiele z nich było związanych z krzewieniem literatury czy promocją książki154. Największe przedsięwzięcia, inicjowane przez redakcję pisma dotyczyły kwestii, kojarzonych na ogół przede wszystkim z publicznością kobiecą, na przykład wspomniany plebiscyt m.in. na Doskonałość Roku Twojego Stylu. Cenna i ważna była także opisana powyżej akcja Zdqż̇yć przed rakiem. Październik miesiącem szansy lub Lekarz Przyjacielem Kobiety.

Akcje, które można łączyć z problematyką książki, dają się ująć w trzy kategorie:

1) jednorazowe pomysły lub takie, w których periodyk był współorganizatorem albo jedynie pośrednikiem;

2) cykliczne paraliterackie konkursy;

3) minikonkursy, nawiązujące do przeczytanego tekstu, gdzie nagrodą były książki.

W grupie pierwszej znalazł się pomysł dopisania dalszego ciągu do książki K. Grocholi155. Na autorki najciekawszych tekstów czekało 20 egzemplarzy tytułu Ja wam pokażę! Innym pomysłem ${ }^{156}$ był konkurs na opowiadanie: Moje życie z Małym Fiatem. Czytelnicy mieli opisać najzabawniejszą przygodę, w której rolę bohatera odgrywał samochód tej marki, zaś

151 D. Radwańska, Czego się bała Virginia Woolf, „Twój Styl” 2002, nr 1, s. [16].

152 Zob. np. Anna C., Czytam o sobie, „Twój Styl” 2002, nr 3, s. [10]; K. Paluchowicz, Urok zmęczonej skandalistki, „Twój Styl” 2002, nr 3, s. [10].

153 „Twój Styl” 2001, nr 8, s. [107].

154 Warto przypomnieć, że w 1992 r. „Twój Styl” ustanowił Literacką Nagrodę Safony. Jury, złożone z profesjonalnych krytyków, miało (po uwzględnieniu głosów czytelników, zaproszonych do udziału w plebiscycie) corocznie wyłaniać utwór literacki, autorstwa współczesnej polskiej pisarki. Laureatką nagrody za rok 1992 została I. Krzywicka za książkę Wyznania gorszycielki. Konkurs ten miał tylko jedną edycję.

155 [br. aut.], Miłość czy zdrada?, „Twój Styl” 2004, nr 4, s. [156].

156 Realizowanym wspólnie z Firmą Fiat. 
nagrodą był nowy model Fiata Punto oraz publikacja najlepszego tekstu w jednym z numerów periodyku157.

Kolejnym pomysłem, który miał pobudzić czytelników magazynu do twórczości literackiej, była propozycja opisania swojej podróży marzeń. „Twój Styl”, wraz z British Airways wybrał osiem najciekawszych prac, a ich autorki spędziły w nagrodę weekend w Londynie. Relacja z pobytu, uzupełniona zdjęciami, znalazła się w jednym z numerów miesięcznika ${ }^{158}$.

Natomiast wraz z firmą kosmetyczną Dove zaproponowano czytelnikom napisanie opowiadania, minieseju bądź listu, który odpowiadałby na pytanie: Kiedy współczesna kobieta najbardziej czuje się kobietą?159. Nagrodą dla trzech najlepszych autorek był tygodniowy pobyt w spa, pozostałe 100 osób otrzymało zestawy kosmetyków, ufundowane przez sponsora.

Podobny charakter miał konkurs organizowany przez „Twój Styl” i firmę Avon. Czytelnicy magazynu mieli za zadanie opowiedzieć o swojej pierwszej dojrzałej miłości; nagrodą był wyjazd dla dwóch osób do Paryża ${ }^{160}$ oraz 20 nagród pocieszenia w postaci wód perfumowanych od sponsora.

Periodyk był jednym z patronów medialnych następnego ciekawego pomysłu: na pierwszą nowelę internetową, tworzoną wspólnie z czytelnikami ${ }^{161}$. Na łamach pisma znalazła się również informacja o konkursie Towarzystwa Ubezpieczeniowego na tekst z użyciem słowa „życie”162.

W drugiej grupie znalazły się takie inicjatywy, jak na przykład konkurs poetycki na wiersz o miłości. Po raz pierwszy został zorganizowany w $1998 \mathrm{r}$. W odpowiedzi na trzecią edycję ogłoszoną wespół z firmą Lancôme redakcja otrzymała 9 tys. wierszy ${ }^{163}$. Podsumowaniem trzech edycji było wydanie nakładem „Twojego Stylu” i Lancôme tomu poezji Kochaj wierszem, stanowiącego antologię wybranych utworów czytelniczek pisma.

Od 1998 r. organizowano konkurs na dziennik Miesiąc z życia kobiety. Druga edycja odbyła się po przerwie, w 2000 r. Obydwie spotkały się z żywym odzewem czytelniczek, ukazując „rozmaitość naszej codzienności, wielkie zmiany i wielkie nadzieje. $\mathrm{W}$ intymnych zapiskach zawarła się

157 A. Gaj, Rozstrzygamy konkurs Moje życie z Małym Fiatem, „Twój Styl” 2001, nr 4, s. 212.

158 A. Tomiak, Herbatka w Harrodsie, „Twój Styl” 2001, nr 11, s. [242]-[243].

159 [br. aut.], Oblicza kobiecości, „Twój Styl” 2001, nr 9, s. [186].

160 Tekst nagrodzonego opowiadania, zob. np. [br. aut.], „Twój Styl” 2005, nr 4, s. [144]. Na sąsiedniej stronie pojawiła się jednocześnie zachęta do udziału w kolejnym konkursie, organizowanym przez „Twój Styl” i firmę Avon - tym razem na napisanie (w dowolnej formie literackiej) wyznania miłości. Zob. „Twój Styl” 2005, nr 4, s. [145].

161 [br. aut.], Co zrobi Martyna?, „Twój Styl” 2002, nr 11, s. 254.

162 [br. aut.], Życie po fińsku, „Twój Styl” 2002, nr 11, s. [36].

163 [br. aut.], Kocham wierszem, „Twój Styl” 2001, nr 3, s. [96]. 
prawda czasu, ale również subiektywna prawda kobiecych przeżyć i odczuć"164. Rozpoczynając dwa lata później kolejną odsłonę, redakcja pytała „Jakie jesteśmy dziś, u progu XXI wieku? Co przynosi nam dzień za dniem? Jak patrzymy na własne duże i małe dramaty? W czym odnajdujemy przyjemność i szczęście?”, przekonując jednocześnie, że „nie ma rzeczy nieciekawych, a wszystko, co szczere ukazuje uciekający czas, może stać się bezcennym dokumentem"165. Za każdym razem przyznawano nagrodę główną (na przykład w 2002 r. był nią laptop) i wyróżnienia. Teksty laureatek drukowano w kilku następnych numerach magazynu166. Dzienniki, opisujące osobiste przeżycia, radości i smutki, sukcesy i porażki, stanowiły jednocześnie dowód na to, jak w przeciągu kilku lat zmieniła się sytuacja i wizerunek kobiety w Polsce, postrzeganie jej roli w małżeństwie, charakter jej priorytetów i wyborów.

W 2005 r. magazyn zaproponował swoim czytelnikom kolejny konkurs, połączony z akcją, której celem było promowanie równych praw dla kobiet w pracy. Miały one zgłaszać swoje kandydatury do wspomnianego już tytułu Firmy w Twoim Stylu. Jednocześnie niezadowoleni ze swoich pracodawców mogli o nich napisać do miesięcznika. Akcji towarzyszyły wywiady ze specjalistami oraz zarówno z zadowolonymi, jak i ze zniechęconymi „kobietami pracującymi”, drukowane obok wyróżnionych historii, przysyłanych przez czytelniczki, opisujące swoją pracę.

Trzecia grupa akcji była najliczniejsza. Często pod tekstem wywiadu, reportażu, portretu lub innej publikacji pojawiała się propozycja, kierowana do czytelników. Miała ona dwojaki charakter. Zachęcano ich do napisania tekstu (listu, minieseju, krótkiego opowiadania), nawiązującego do poruszanej tematyki, na przykład będącego odpowiedzią na pytanie: Jak pokochać teściową?167, Czy w domu bez mężczyzn można nauczyć się miłości? ${ }^{168}$, Czym jest dla Ciebie feminizm? ${ }^{169}$. Zazwyczaj nagrodami dla najciekawszych prac były książki, przeważnie ufundowane przez dane wydawnictwo, nierzadko $\mathrm{z}$ autografem autora.

164 [br. aut.], Ogłaszamy konkurs na dziennik Miesiąc z życia kobiety, „Twój Styl” 2002, nr 2, s. [121].

165 Ibidem.

$166 \mathrm{Na}$ przykład $\mathrm{w}$ jednym $\mathrm{z}$ numerów dołączono 16 dodatkowych stron, przeznaczonych wyłącznie na prezentację pięciu wybranych prac. Zob. „Twój Styl” 2001, nr 1, s. [97]-112.

167 Tekst nagrodzonej pracy, zob. „Twój Styl” 2001, nr 4, s. [236].

168 Nagrodą dla 10 czytelniczek była książka J. Olczak-Ronikier, W ogrodzie pamięci, „Twój Styl” 2001, nr 12 s. 87.

169 Także w tym przypadku nagrodą była książka, tym razem od Wydawnictwa W.A.B.:

A. Graff: Świat bez kobiet, z dedykacją autorki, zob. „Twój Styl” 2002, nr 3, s. 48. 
Drugim wariantem była prośba o udzielenie krótkiej odpowiedzi na pytanie, również dotyczące przeczytanej publikacji, zaś nagrodą było kilka (zazwyczaj 10) egzemplarzy książek. Były one także jedną z nagród za prawidłowe rozwiązanie krzyżówki, zamieszczanej na jednej z ostatnich stron pisma.

Warto wspomnieć o tym, że „Twój Styl” był współorganizatorem Nagrody im. Barbary Łopieńskiej za najlepszy wywiad prasowy ${ }^{170}$.

Niektóre z konkursów miały charakter podobnych do organizowanych przez miesięcznik „Zwierciadło”. W każdym z przypadków rozwijały potencjalne zdolności literackie u czytelników oraz zacieśniały ich więzi z wybranym periodykiem.

\subsubsection{Jadę tam, gdzie wojna ${ }^{171}$. Inne informacje: o prasie i środowisku dziennikarskim}

Podobnie, jak było to w przypadku „Zwierciadła”, tak i na łamach „Twojego Stylu" w ciągu 5 lat pojawiło się niewiele publikacji, związanych z rynkiem prasowym. W omawianym magazynie znalazło się ich zaledwie 9. Zamieszczano natomiast znacznie więcej reklam i autoreklam innych czasopism. W 127 anonsach pojawiło się 25 tytułów różnych periodyków, przy czym najczęściej promowano nowe tytuły Wydawnictwa Twój Styl. Wśród czasopism polecanych czytelnikom znalazły się m.in.: „Businessman Magazine” (5 razy), „Filipinka” (18), „Mam dziecko” (wcześniej jako „Mama i dziecko”, 9), „Newsweek Polska” (5), „Polityka” (13), „Świat kobiety” (5), „Votre Beauté” (14), „Wprost” (1). W większości przypadków były to jednostronicowe reklamy, prezentujące okładkę wybranego numeru, niekiedy uzupełnione hasłem reklamowym. Jednym $\mathrm{z}$ wyjątków były reklamy tygodnika „Polityka”. Niewielka liczba elementów, ale zwracające uwagę wyrazisty kolor i hasło przykuwały wzrok - zdjęcia 119-121.

170 [br. aut], Nagroda od Basi, „Twój Styl” 2004, nr 12, s. [24].

171 R. Cook, tłum. A. Szokal, Jadę tam, gdzie wojna, „Twój Styl” 2002, nr 2, s. [62]-67. 


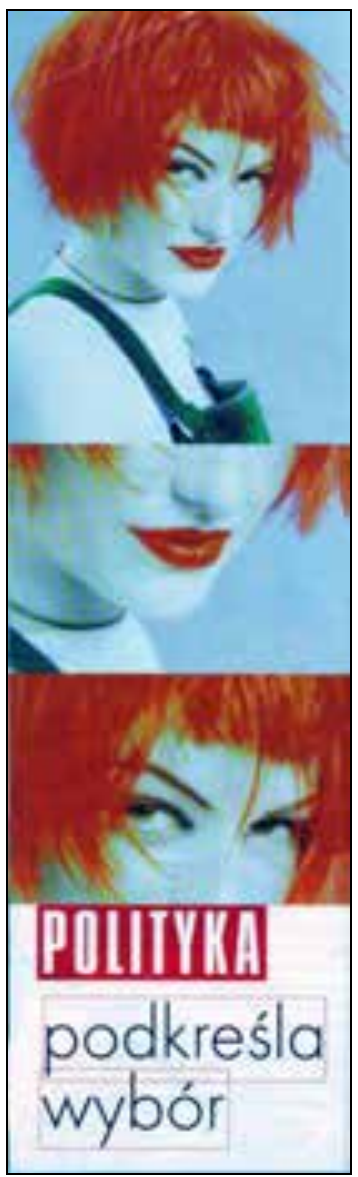

Zdjęcie 119. Przykładowe ogłoszenie wydawnicze zamieszczone na łamach „Twojego Stylu”

„Twój Styl” 2005, nr 11, s. [251]

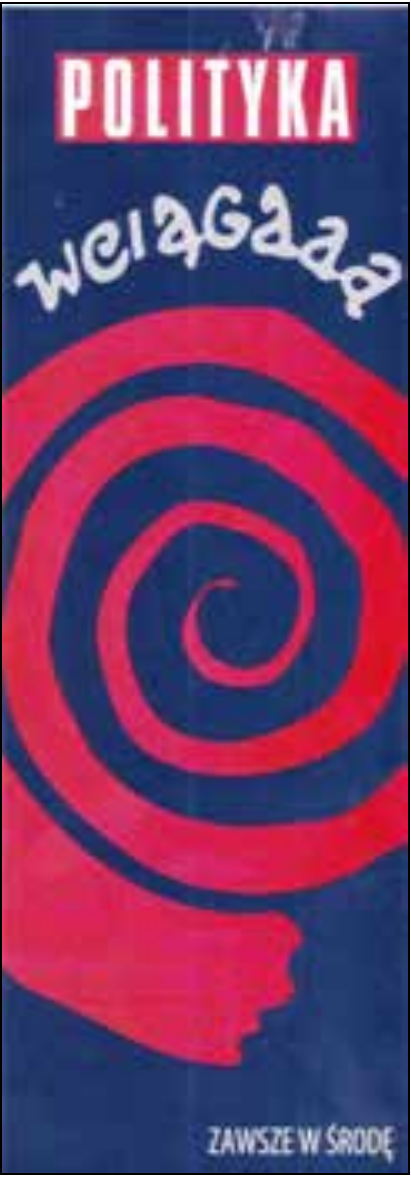

Zdjęcie 120. Przykładowe ogłoszenie wydawnicze zamieszczone na łamach „Twojego Stylu” „Twój Styl” 2002, nr 9, s. [138]

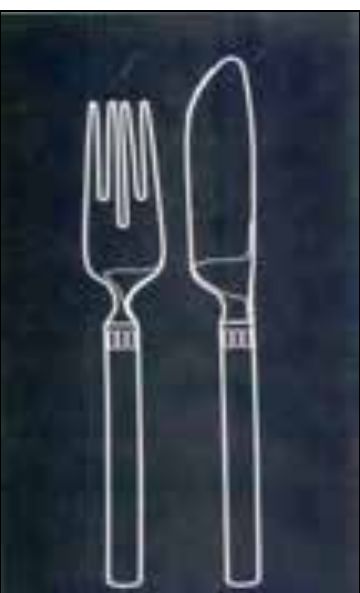

Jak zabracsię do politycanego pasztetu? wines licile romenang to utchin.

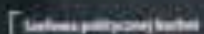

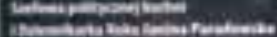

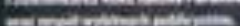

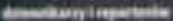

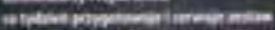

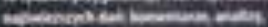

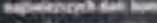

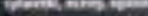

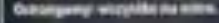

\section{POLITYKA}

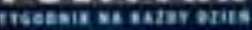

Zdjęcie 121. Przykładowe ogłoszenie wydawnicze zamieszczone na łamach „Twojego Stylu”

„Twój Styl” 2003, nr 4, s. [135]

Uwagę zwracała nasycona barwa anonsów, które zajmowały z reguły kolumnę, rzadziej całą stronę magazynu oraz hasła reklamowe (w przypadku trzeciego anonsu).

Na łamach „Twojego Stylu” znalazły się również reklamy rywali tygodnika „Polityka”: „Wprost” oraz „Newsweek Polska” - zdjęcia 122 i 123. 


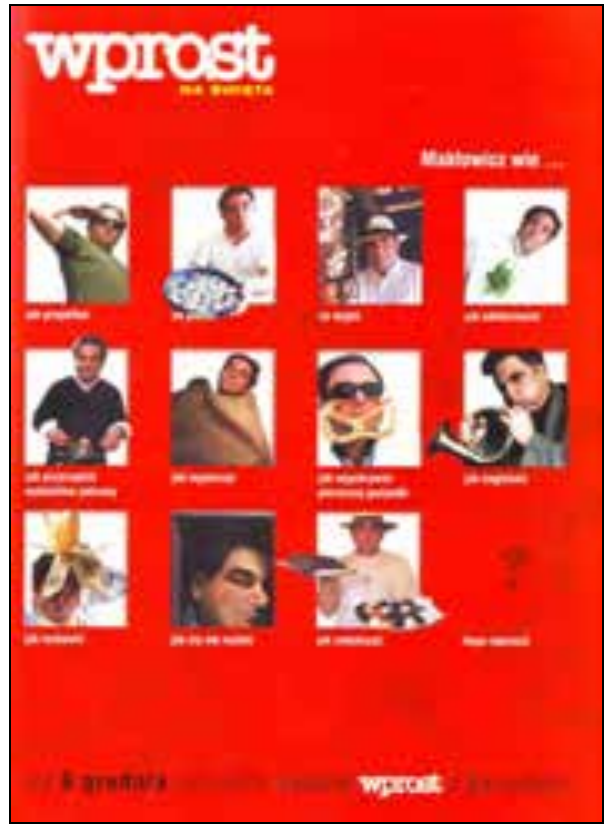

Zdjęcie 122. Przykładowe ogłoszenie wydawnicze zamieszczone łamach „Twojego Stylu"

„Twój Styl” 2003, nr 12, s. [235]

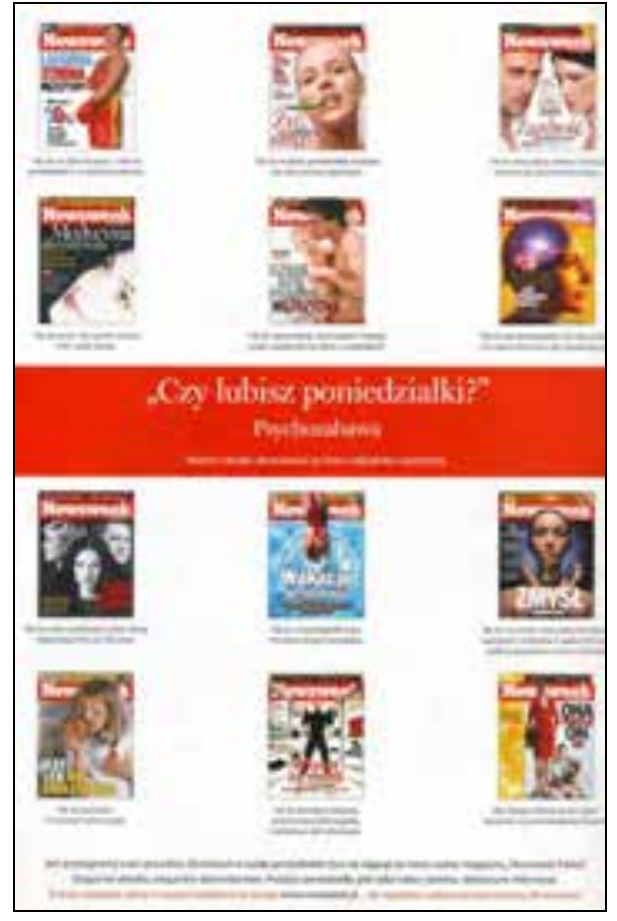

Zdjęcie 123. Przykładowe ogłoszenie wydawnicze zamieszczone łamach "Twojego Stylu” „Twój Styl” 2003, nr 8, s. [102]

W obydwu reklamach znalazły się zdjęcia: w przypadku pierwszej ich bohaterem był dziennikarz „Wprost”, Robert Makłowicz, w drugiej zachętą miały być okładki wybranych numerów periodyku. Za każdym razem ich uzupełnieniem było hasło reklamowe. Interesującą formę promocji zastosował wydawca "Newsweek Polska” w innym numerze „Twojego Stylu”. Zaproponowano czytelnikowi fragment ciekawego wywiadu, przerwanego w połowie zdania, a u dołu strony znalazła się informacja, że jego dokończenie odnaleźć można na łamach „Newsweeka” 172 .

Nierzadko pojawiały się również reklamy całostronicowe. Tak było w przypadku pisma „Mama i Dziecko” (zdjęcie 124).

$\mathrm{Z}$ reguły głównym elementem ogłoszenia była okładka zapowiadanego numeru pisma, $\mathrm{z}$ anonsującą jego treść adnotacją. 


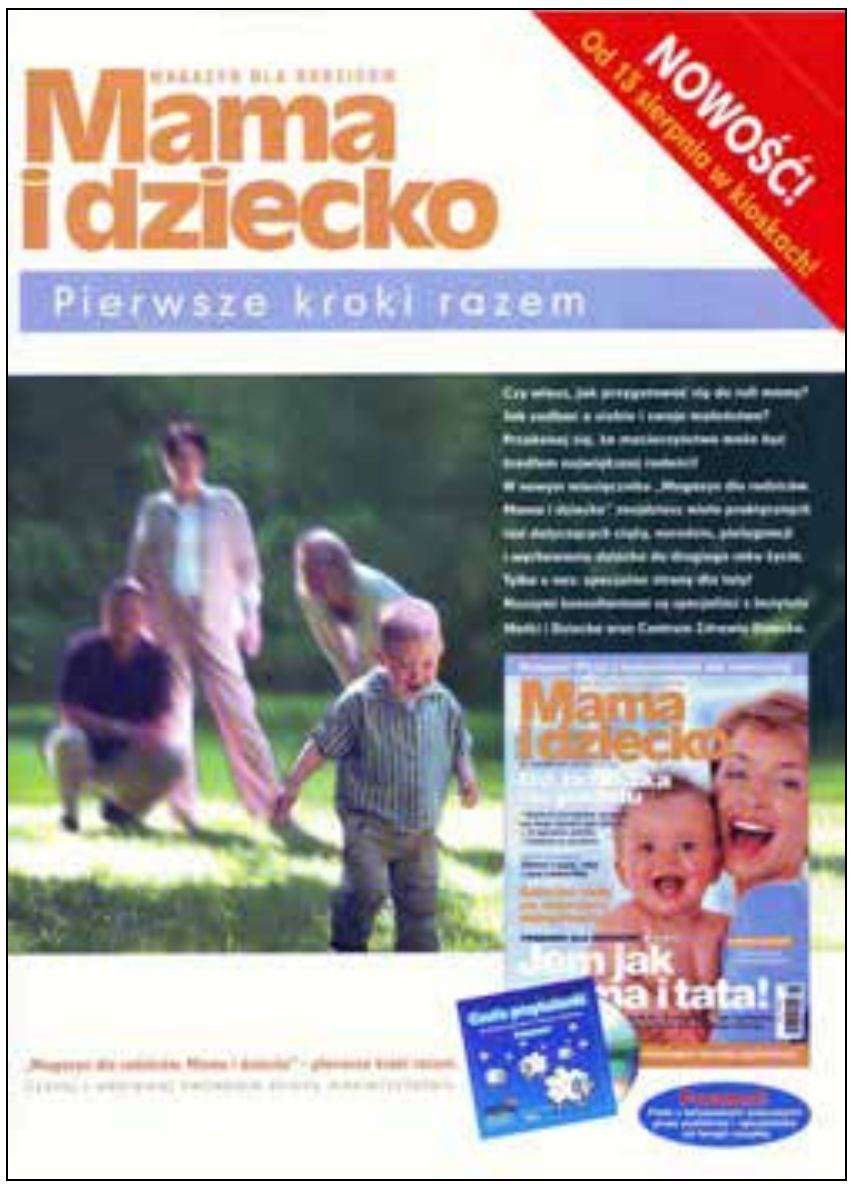

Zdjęcie 124. Przykładowe ogłoszenia wydawnicze zamieszczone na łamach „Twojego Stylu” „Twój Styl” 2002, nr 9, s. [203]

Na łamach „Twojego Stylu” znalazły się także reklamy czasopism, promowanych w przedstawionych wcześniej pismach opinii. I tak na przykład pojawiły się tytuły, adresowane do ściśle określonego odbiorcy, takie jak „BusinessWeek”. Były to zazwyczaj całostronicowe reklamy, skromne, jeśli chodzi o liczbę zawartych w nich elementów - zdjęcie 125 i 126. 


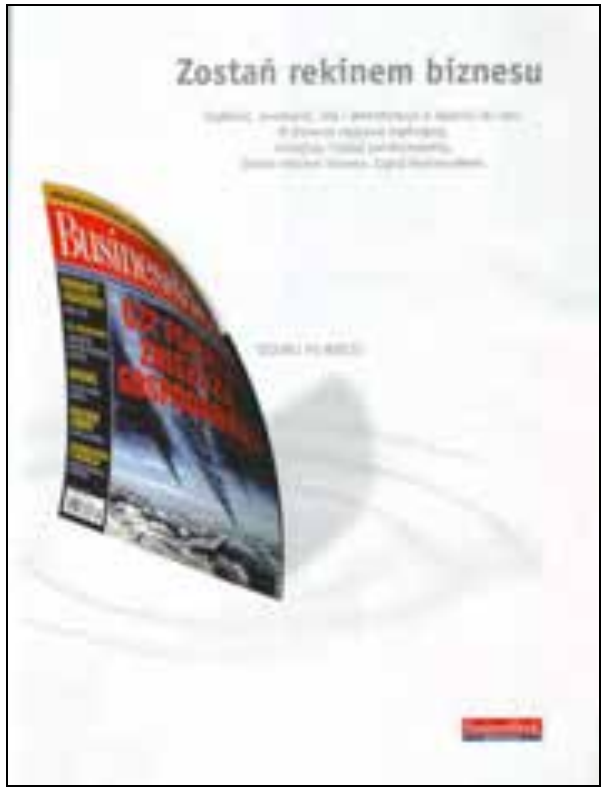

Zdjęcie 125. Przykładowe ogłoszenie wydawnicze zamieszczone na łamach „Twojego Stylu”

„Twój Styl” 2003, nr 4, s. [133]

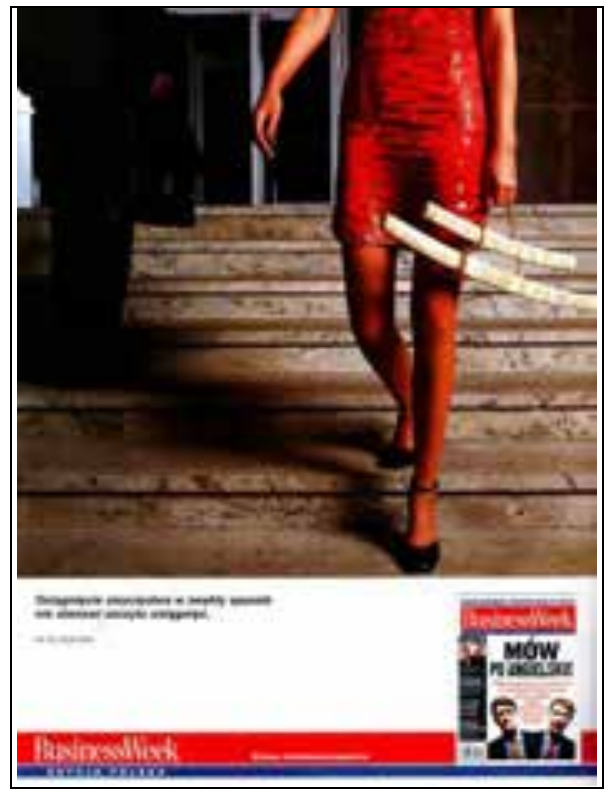

Zdjęcie 126. Przykładowe ogłoszenie wydawnicze zamieszczone na łamach „Twojego Stylu”

„Twój Styl” 2001, nr 11, s. [223]

W obydwu przypadkach uwagę odbiorcy zwracały hasła reklamowe: "Zostań rekinem biznesu” czy prowokujące "Osiągnięcie zwycięstwa w zwykły sposób nie stanowi szczytu osiągnięć". Tytuł proponowanego periodyku nie był tu głównym punktem reklamy, pojawiał się niejako „przy okazji", przy czym w drugim przypadku uwagę odbiorcy przykuwało zdjęcie kobiety, jej elegancja i nietypowa torebka, sugerujące, że czytelniczki „Twojego Stylu” łatwiej osiągną sukces, jeśli zaopatrzą się wcześniej w promowany periodyk.

Podobnie skromne, ale jednocześnie sugestywne były przywoływane we wcześniejszych rozdziałach pracy reklamy pisma adresowanego do miłośników zwierząt oraz bogatsze w elementy ogłoszenia, promujące znany miesięcznik, adresowany do dziewcząt (zdjęcie 127 i 128).

I w tych reklamach, podobnie jak w poprzednich, tytuł polecanego czasopisma nie był najważniejszym elementem; stanowił raczej dopełnienie treści dominujących $w$ inseracie: $w$ pierwszym przypadku były nim postacie zwierząt, w drugim sylwetka potencjalnej adresatki pisma. Hasło reklamujące „Filipinkę” było jednocześnie znakiem dla czytelniczek, za którym kryła się informacja o zmianie wydawcy pisma (stał się nim H. Bauer). Była to zatem forma autopromocji nowego wydawcy „Twojego Stylu”. 


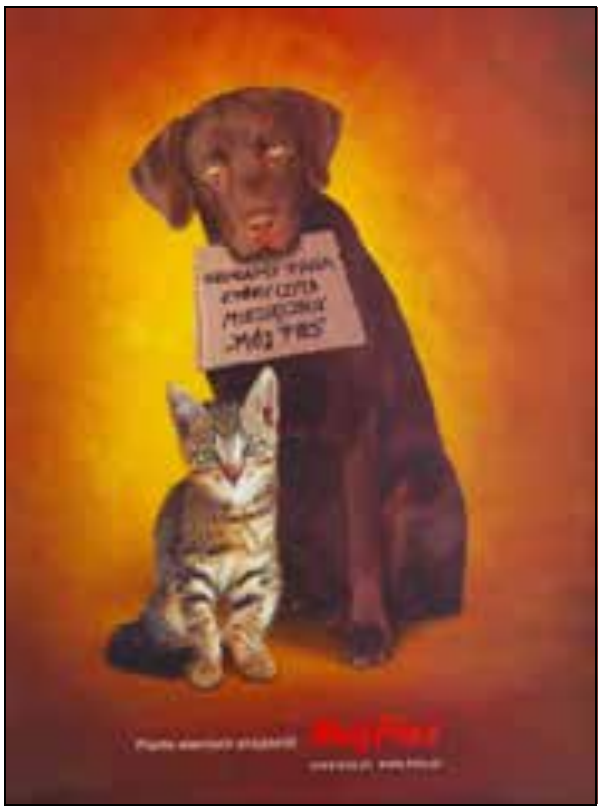

Zdjęcie 127. Przykładowe ogłoszenie wydawnicze zamieszczone na łamach „Twojego Stylu”

„Twój Styl”, 2001, nr 11, [235]

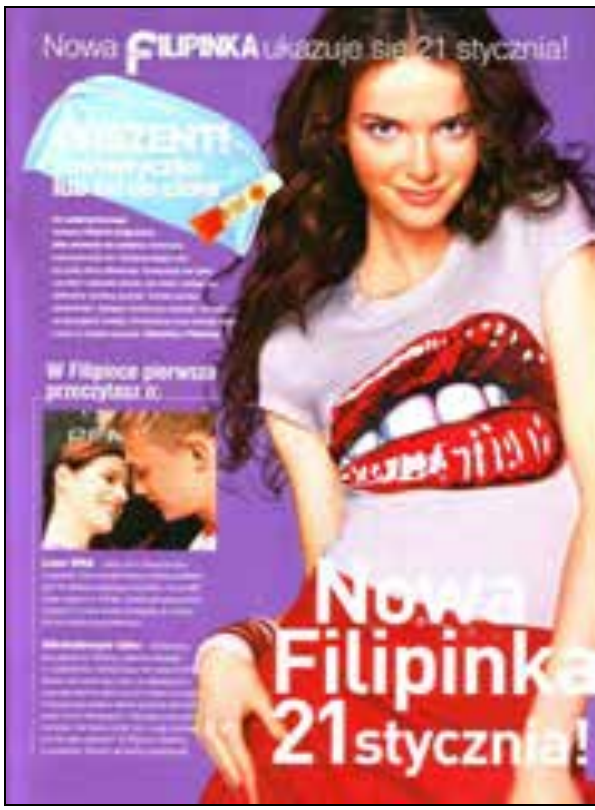

Zdjęcie 128. Przykładowe ogłoszenie wydawnicze zamieszczone na łamach „Twojego Stylu” „Twój Styl”, 2004 II, s. [80]

Warto zwrócić uwagę na fakt, że przez cały badany okres, niezależnie od tego, kto był właścicielem omawianego magazynu, na jego łamach pojawiała się systematycznie informacja o innych tytułach, znajdujących się w ofercie wydawcy. Najciekawsze pod względem grafiki były anonse proponujące magazyn „Look. Magazyn o Zdrowiu i Urodzie”173.

Systematycznie przypominano o prenumeracie „Twojego Stylu”; autoreklama zajmowała w takim przypadku zazwyczaj dwie strony w ostatniej części magazynu, była bardzo szczegółowa, dokładnie podawano w niej na przykład warunki prenumeraty.

Podsumowując, książka na łamach pisma prezentowana była w badanym okresie, w porównaniu z wcześniej omawianym periodykiem, jakim było „Zwierciadło”, stosunkowo skromnie.

Jednocześnie w każdej z omówionych na łamach „Twojego Stylu” form związanej z literaturą wyraźnie widać preferowane przez magazyn wartości, a przede wszystkim określony wzór osobowy kobiety. Nie ma tu miejsca na tragedie i smutki, są one rzadko wspominane, a jeśli się pojawiają, to

173 „Twój Styl” 2002, nr 12, s. [217]. 
jako romantyczne historie z tragicznymi bohaterkami w rolach głównych, przeżywającymi nieszczęśliwą miłość.

Badania wykazały jednocześnie brak nie tylko głębszych analiz (widocznych na łamach przedstawionej wcześniej prasy opinii), ale także ogólnych informacji o wydarzeniach literackich, takich jak np. targi książki, spotkania autorskie itd.

Zarówno sylwetki twórców, jak i wzmianki dotyczące książek zdaje się łączyć jedno kryterium: element nietuzinkowości, coś, co zaintryguje czytelnika, zatrzyma jego uwagę na dłużej. Bohaterowie portretów to osoby nieprzeciętne, nierzadko niepospolite, często są nimi silne kobiety. Notki informacyjne to także wzmianki o czymś niezwyczajnym, można powiedzieć, takie, które powinny pojawić się w zestawieniach największych ciekawostek roku, stanowiące dopełnienie plotek ze świata filmu, mody i urody. Brakowało rzetelnych informacji, żywszej reakcji czytelników na kwestie związane z literaturą, choć jednocześnie pojawiały się listy komentujące innego typu publikacje, pojawiające się na łamach pisma.

Jednocześnie w tekstach nas interesujących brakowało niejednokrotnie znaków interpunkcyjnych, wyraźna jest szczególnie niechęć autorów „Twojego Stylu" do przecinków i znaków zapytania.

Można odnieść wrażenie, że informacje o książce spełniać miały rolę dobrze dobranej broszki bądź kolorowego kwiatka do wytwornej sukni eleganckiej kobiety, jaką z założenia redakcji była czytelniczka „Twojego Stylu". 


\title{
3.4. „Elle”. Rzeczywistość lukrowana ${ }^{1}$
}

\subsubsection{Mój wybór, moje „Elle”: historia periodyku}

\begin{abstract}
„Elle” zdaje się pismem najbardziej oderwanym od rzeczywistości. Można odnieść wrażenie, że magazyn ten pisany jest w konwencji romansu: wszyscy wiemy, że fabuła jest nieprawdopodobna, ale umówiliśmy się, że wierzymy, bo to jest ładne ${ }^{3}$.
\end{abstract}

Trzeci periodyk adresowany do kobiet, stanowiący przedmiot rozważań w tym rozdziale, jest najmłodszym z omawianych pism prezentowanej grupy. Podobnie jak „Newsweek Polska” stanowi przykład tytułu znanego wcześniej na świecie, w Polsce zaś wydawanego na licencji. Należy do grupy ekskluzywnych periodyków dla kobiet, choć jego charakter, w porównaniu z wcześniej omawianymi czasopismami, jest nieco inny, bardziej jednostronny. Nie doczekał się zbyt wielu opracowań czy komentarzy, zaś pojawiające się wzmianki (szczególnie w prasie branżowej) dotyczyły zazwyczaj wydawcy, nie zaś samego pisma. Brak w historii magazynu spektakularnych zwrotów czy efektownych epizodów: określony wraz z pierwszym numerem wzorzec, raz sprawdzony, zdawał się pozostawać niemal niezmienny, podobnie jak kierunek polityki redakcyjnej.

„Elle” (w języku polskim oznacza „ona”), bo o nim mowa, to polska edycja francuskiego pisma, wydawanego od 21 listopada $1945 \mathrm{r}$. Założone ono zostało przez Pierre`a Lazareffa i jego żonę Hélène Gordon. W pierwszym numerze znalazły się informacje dotyczące bieżących wydarzeń, przybliżono czytelnikom trendy ówczesnej mody oraz przedstawiono sylwetki znanych osób. Magazyn, odtąd kojarzony przede wszystkim z modą, szybko odniósł olbrzymi sukces, najpierw we Francji, a później, dzięki kolejnym wydaniom, także w innych krajach. Pierwsza zagraniczna edycja ukazała się w USA, w 1985 r.

Na rynku prasowym w Polsce pierwszy numer magazynu (o objętości 146 stron) ukazał się w październiku 1994 r. Na okładce znalazło się zdjęcie światowej sławy modelki, Barbary Milewicz. Wydawcą została spółka EllePolska, w której jedną połowę udziałów posiadało Wydawnictwo Prasowe

1 Tytuł jednej z publikacji. Zob. B. Zubowicz, Rzeczywistość lukrowana, „Rzeczpospolita” 1997, nr 182, s. 4.

2 Tytuł listu jednej z czytelniczek, wydrukowany z okazji jubileuszowego wydania magazynu. Zob. „Elle” 2009, nr 11, s. 12.

${ }^{3}$ B. Zubowicz, Rzeczywistość..., s. 4. 
Twój Styl4, a drugą francuska firma Hachette Filipacchi Polska, znajdująca się $\mathrm{w}$ strukturach holdingu Lagardère ${ }^{5}$. Prezesem spółki został Roman Wysocki. Siedziba redakcji oraz wydawcy znajdowała się w Warszawie, przy ulicy Świętojerskiej 5/7 (podobnie jak miesięcznika „Twój Styl”). Pierwszą redaktor naczelną została Maria Majdanowicz-Pijanowska, a jej zastępcą Marzena Wilkanowicz-Devoud. Funkcję sekretarza redakcji pełniła Krystyna Stankiewicz, zaś dział kulturalny tworzyć miały Manuela Gretkowska oraz Agnieszka Różycka. Zabrakło, tradycyjnego w takich sytuacjach, „słowa od redakcji”.

Trzecie wydanie trafiło do czytelników w objętości 162 stron. W tym czasie koncern wprowadził już kolejne edycje magazynu w innych krajach: „Elle” włoska, brytyjska i niemiecka dowodziły rozległych zamierzeń francuskiego właściciela.

Kolejne numery wydania polskiego cieszyły się coraz większą popularnością, o czym świadczył nie tylko wzrastający nakład, ale także drukowane na łamach pisma listy:

To wspaniałe, że można kupić polskie wydanie miesięcznika „Elle”. Jestem z tego powodu bardzo szczęśliwa, ponieważ moje zainteresowania związane są z modą i kosmetykami. Uważam, że jesteście naprawdę wspaniałym pismem - ciekawym i pięknie wydawanym6 ${ }^{6}$.

Mam duże uznanie dla „Elle”. W czasie mojego rocznego pobytu we Francji czytywałam „Elle”. Byłam bardzo szczęśliwa, gdy zobaczyłam „Elle” w wersji polskiej. Ma ono ten charakterystyczny dla kultury francuskiej element lekkości, pewnej frywolności oraz wyrafinowania i szlachetnej subtelności ${ }^{7}$.

Jakby dla równowagi zamieszczano także uwagi krytyczne, nadsyłane przez czytelniczki:

${ }^{4}$ Zob. rozdz. 3.3, s. 375.

5 Koncern Lagardère CSA (Lagardère Groupe) - francuski holding (założony w 1980 r. przez Jeana Luca Lagardère`a), na który składają się: koncern medialny Lagardère Media oraz 15\% udziałów w EADS - europejskiej agencji kosmicznej i lotniczej. W ramach Lagardère Media funkcjonuje francuska grupa medialna Hachette, której najbardziej znaną częścią jest Wydawnictwo Hachette Livre, ponadto w skład grupy wchodzą: Hachette Filipacchi Mèdias (wcześniej Hachette Filipacchi Presse), wydające czasopisma oraz Hachette Distribution Services (HDS), zajmujące się dystrybucją. Częścią międzynarodowej grupy wydawniczej Hachette (skupiającej wydawnictwa m.in. z Francji, Hiszpanii, Włoch, Japonii) jest Wydawnictwo Hachette Polska sp. z o.o. Powstało ono w 2000 r. w efekcie zakupu przez Groupe Hachette Livre polskiego wydawnictwa Wiedza i Życie.

6 „Elle” 1995, nr 1, s. [6].

7 Ibidem. 
Jakże jestem rozczarowana pierwszym polskim wydaniem „Elle”. Spodziewałam się, że będziecie prawdziwym pismem dla kobiet w Polsce. Chyba nie ma sensu używanie tytułu, który w oryginale zawiera tyle treści ${ }^{8}$.

Takich głosów było jednak znacznie mniej, a przynajmniej znacznie rzadziej drukowano je na łamach magazynu.

Objętość kolejnych numerów pozostawała niezmienna, w przeciwieństwie do składu redakcji. Od numeru 4 w 1995 r. zamiast nazwiska Marii Majdanowicz-Pijanowskiej w stopce redakcyjnej pojawiła się informacja, że dyrektorem wydania jest Krystyna Kaszuba9 ${ }^{9}$ zaś zastępcą, nieistniejącego przez kilka miesięcy stanowiska redaktor naczelnej nadal pozostawała Marzena Wilkanowicz-Devoud, ale wraz z nią ciężar odpowiedzialności miał odtąd spoczywać na Manueli Gretkowskiej. Kolejne roszady personalne nastąpiły $\mathrm{w}$ numerze listopadowym $\mathrm{w}$ tym samym roku, kiedy wydawca zdecydował się nominować M. Wilkanowicz-Devoud na stanowisko redaktor naczelnej. Kierowała ona magazynem przez następne 13 lat. Natomiast M. Gretkowska pełniła dotychczasową funkcję do końca 1996 r., kiedy została dyrektorem literackim magazynu, a jej obowiązki przejęła Katarzyna Dolińska.

W październiku $1996 \mathrm{r}$. francuski koncern odkupił od polskiego udziałowca 50\% udziałów, stając się pełnym właścicielem magazynu. Odtąd jego wydawcą był Hachette Filipacchi Polska. Prezesem nowej spółki został Pierre Todorov, zaś dyrektorem generalnym Jan Dybczyński. Od stycznia 1997 r. zmienił się także adres redakcji i wydawcy; nowa siedziba mieściła się odtąd przy ulicy Pruszkowskiej $1 \mathrm{w}$ Warszawie. Wraz ze zmianą właściciela zwiększyła się średnia objętość numeru pisma: do końca lat 90. XX w. wynosiła ona 169 stron. Do miesięcznika zaczęto dołączać dodatki specjalne, na przykład w numerze 3 (1997) były to Światowe kolekcje wiosna-lato 1997, w wydaniu sierpniowym tegoż roku do czytelników trafił dodatek Gry i testy na plażę. W 1997 r. po raz pierwszy do numeru dołączono damską torbę z logo tytułu. Być może dzięki tym posunięciom sprzedaż magazynu systematycznie rosła ${ }^{10}$. W $1997 \mathrm{r}$. wydawca wprowadził na rynek kolejny tytuł: „Samo Zdrowie”, periodyk o charakterze poradnikowym.

W lutym 1998 r. dotychczasowego prezesa Hachette Filipacchi Presse zastąpił Gérald de Roquemaurel. Od numeru październikowego w 1998 r. Katarzynę Dolińską zmieniła na stanowisku zastępcy redaktora naczelnego Anna Moczulska. W tym czasie magazyn obecny był już także m.in. w Hiszpanii, Rosji, Singapurze, Szwajcarii i Szwecji. Z kolei z edycją polską współpracowało coraz więcej osób. Idąc w ślady pism o podobnej formule,

\footnotetext{
8 Ibidem.

9 Współpracująca wcześniej zarówno z miesięcznikiem „Zwierciadło”, jak i „Twój Styl”.

10 W latach 1996-1997 wzrosła o 34\%. Zob. „Media Polska” 1998, nr 6, s. [25].
} 
redakcja zaczęła drukować stałą rubrykę: $W$ tym numerze piszą, gdzie krótko prezentowała sylwetki autorów periodyku: niektórzy z nich nawiązywali stałą współpracę z magazynem, nazwiska innych pojawiały się na łamach miesięcznika sporadycznie lub jednorazowo. Wśród współpracowników magazynu znaleźli się m.in.: Bohdan Bielski, Tessa Capponi-Borawska, Agnieszka Chylińska, Zygmunt Kałużyński, Jarosław Kret, Maciej Kuroń, Izabella Kurzajewska, Wojciech Mann, Maria Nurowska, Maria Pakulnis, Ludwik Stomma, Teresa Torańska i Maciej Zembaty. W tym czasie poszerzył się zespół dziennikarzy, tworzących dział kulturalny: jego szefem nadal pozostawała A. Różycka, pomagali jej m.in. Maria Barcz, Bogusław Deptuła, Piotr Gruszczyński, Jan Hryniewicz, Małgorzata Saramonowicz i Artur Żmijewski.

W 1998 r. Hachette Filipacchi Polska stał się właścicielem kolejnego czasopisma: tym razem był to magazyn „Film”. Natomiast czytelnicy „Elle” zaczęli przyzwyczajać się do specjalnego, bogato ilustrowanego dodatku „Elle Deco", z którego w 2000 r. stworzono odrębny periodyk. Był to bardzo korzystny, choć jednocześnie trudny dla magazynu rok. Na rynku pojawiły się konkurencyjne pisma: „Marie Claire”, „Oliwia” i „Votre Beauté”. Mimo to J. Dybczyński podsumowywał: „w konkurencji odnotowaliśmy dobre wyniki. Istotne jest też, że udało się nam zmienić wizerunek $>$ Elle $<$. Uświadomiliśmy czytelniczkom, że jesteśmy wypełnieni treścią, a nie błahymi ciekawostkami"11. Zainteresowanie odbiorców znalazło swoje odzwierciedlenie także w dynamicznym wzroście przychodów z reklam ${ }^{12}$.

$\mathrm{Z}$ okazji pięciolecia pisma wydawca zorganizował urodzinową imprezę, połączoną z rozdaniem nagród „Elle”. W jubileuszowym felietonie W. Mann pisał o magazynie: „Lubię go dlatego, że istnieje na naszym rynku w sposób niehałaśliwy, bez umizgów wobec czytelników. Nie epatuje tanią sensacją, uczy, krótko mówiąc, elegancji"13.

W tym też roku (1999) magazyn zaistniał $\mathrm{w}$ Internecie, a redakcja przekonywała czytelników:

To świetna zabawa - zamiast przewracać kartki, klikasz w klawiaturę i od razu znajdujesz tekst, który Cię interesuje. Wszystkie nowinki ze świata „Elle” mogą przychodzić do Ciebie pocztą elektroniczną. Wystarczy je zaprenumerować, podając $w$ odpowiednim okienku swój e-mail. Dzięki odsyłaczowi World Wide Elle porównasz różne wersje narodowe naszego pisma. A jeśli zechcesz, możesz tu założyć własną stronę internetową, a nawet zrobić zakupy w naszym wirtualnym butiku14.

\footnotetext{
11 K. Prewęcka, Kadr po kadrze, „Media Polska” 1998, nr 12, s. 36.

12 P. Walicki, Beczka z piątą klepka, „Media Polska” 1998, nr 5, s. 22.

13 W. Mann, Plan pięcioletni wykonany, „Elle” 1999, nr 10, s. 58.

14 [br. aut.], Elle w sieci, „Elle” 1999, nr 6, s. 44.
} 
W 2000 r. nastąpiły kolejne roszady personalne w redakcji: M. Moczulską zastąpiły Ewa Siemieńska i Ewa Sypniewska. W tym samym roku w ofercie wydawnictwa znalazł się nowy periodyk, dotąd częściowo znany czytelnikom „Elle” jako dodatek: „Elle Decoration”, teraz jako ekskluzywny dwumiesięcznik poświęcony wnętrzom.

W 2001 r. na rynku pojawił się kolejny tytuł wydawcy „Elle”. Tym razem był to ekskluzywny miesięcznik adresowany do mężczyzn: „Maxim” (zawieszony w 2003 r.). Redakcja nie omieszkała także poinformować swoich czytelników, że w sierpniu ukaże się we Francji nowe pismo dla nastolatek „Elle Girl”15. Przygotowano wówczas po raz pierwszy kolekcję ubrań, na sezon jesienno-zimowy 2001, sygnowaną logo „Elle” i otwarto pierwszy butik, gdzie wybrane rzeczy można było nabyć.

Natomiast kolejny, 2002 r., nie był korzystny dla „Elle”, co wynikało z faktu, że sytuacja finansowa całej spółki była zła (pomimo że reaktywowała ona „Marie Claire”). Straty sięgnęły ponad $5 \mathrm{mln}$ zł'16. Wydawca, Hachette Filipacchi Polska, podjął decyzję o zmianie dyrektora generalnego: w 2003 r. J. Dybczyńskiego zastąpił Guillaume Devoud, mąż redaktor naczelnej pisma. Jakkolwiek tendencja spadkowa została częściowo zahamowana, to jednak w roku następnym (2004) „Elle” straciło zajmowane dotąd trzecie miejsce wśród luksusowych miesięczników kobiecych, jego miejsce zajął inny magazyn („Glamour”). Utrata prestiżowej pozycji wynikała w dużym stopniu według specjalistów z faktu, że „Wydawnictwo dumnie nie przyłączyło się do wojny gadżetowej, nie prowadziło też szerokich kompanii promocyjnej swoich tytułów"17 (wyjątek stanowiły torby z logo pisma lub sporadycznie dołączane doń próbki kosmetyków). Nowy dyrektor generalny przedstawił własny plan strategii przedsiębiorstwa, zaakceptowanej przez wydawcę, który przeznaczył na reklamę swoich tytułów kwotę $10 \mathrm{mln} z \mathrm{z}^{18}$. Miały one przynieść $\mathrm{w}$ perspektywie poprawę sytuacji wydawnictwa na rynku oraz wpłynąć na wzrost sprzedaży poszczególnych tytułów. Jednak plany nie przyniosły oczekiwanych rezultatów: w grudniu 2005 r. G. Devoud na zebraniu w siedzibie firmy ogłosił, że „Marie Claire” przestaje się ukazywać. Czas pokazał, że był to wstęp do większych zmian, które objęły także stanowisko dyrektora generalnego. Hachette Fillipacchi rozpoczęło rozmowy z Wydawnictwem Burda Polska ${ }^{19}$ i w 2006 r. utworzono spółkę, w której wydawca znanego miesięcznika z wykrojami miał większościowy, 51\% udział, ale francuska centrala Hachette zachowała meryto-

15 [br. aut.], Młodsza siostra, „Elle” 2001, nr 9, s. [49].

16 A. Nalewajk, Zadyszka, „Press” 2004, nr 5, s. 40.

17 Ibidem.

18 Ibidem, s. 42.

19 Warto zwrócić uwagę, że w wydawnictwie Burda funkcję doradcy Zarządu ds. edytorskich pełniła w tym czasie K. Kaszuba, była redaktor naczelna „Twojego Stylu”. 
ryczną kontrolę nad swoimi tytułami. Flagowy tytuł, „Elle” zajmował w tym czasie czwarte miejsce pod względem sprzedaży w segmencie pism kobiecych „z górnej półki” (za „Twoim Stylem”, „Glamour” i „Cosmopolitan”) i drugą pozycję pod względem przychodów z reklam ${ }^{20}$.

Lepiej radziły sobie edycje magazynu w innych krajach. Na koniec $2005 \mathrm{r}$. takich wydań było 38, a periodyk czytało 21 mln odbiorców na pięciu kontynentach ${ }^{21}$. Jednak, jak przyznał Zbigniew Napierała, prezes Edipresse Polska SA, „W Polsce, po tylu latach, >Elle< także powinna mieć lepszą pozycję"22, a sytuacja periodyku „to efekt nie tyle polityki redakcyjnej, co relatywnie małego rynku reklam dla takich magazynów" 23 . W tym czasie z miesięcznikiem współpracowali, poza już wymienionymi, także m.in. Max Cegielski, Henryk J. Chmielewski, Krzysztof Dubiel, Katarzyna Kolenda-Zalewska, Mikołaj Komar, Filip Łobodziński, Barbara Pietkiewicz (reporterka „Polityki”), Krystyna Romanowska, Marcin Tyszka, Ewa Winnicka. Znane nazwiska niewątpliwie wpływały na zainteresowanie czytelników pismem, o którym, pomimo kłopotów, na koniec 2005 r., z okazji jubileuszu 20-lecia „Elle” na świecie, M. Wilkanowicz-Devoud mogła powiedzieć:

Miksujemy radość życia. Fantazję z klasą. Ryzyko z zabawą. Optymizm to nasz twardy narkotyk! [...] Dzięki wam wszystkim jesteśmy największym pismem mody na świecie i numerem jeden pod względem ekspansji marki24.

\subsubsection{Zawartość, akcje, czytelnicy}

Częste zmiany personalne w redakcji 25 nie pociągały za sobą wyraźniejszych zmian w zawartości czy formie graficznej pisma. Wraz z upływem lat zwiększała się jedynie w sposób zauważalny liczba reklam oraz liczba zdjęć poświęconych modzie, zamieszczanych na jego łamach. Średnia objętość periodyku nieznacznie wzrosła i w latach 2001-2005 wynosiła 178 stron. Jego zawartość, jako magazynu poświęconego z założenia przede wszystkim modzie, w dużym stopniu podporządkowana była promocji ówczesnych trendów w różnych dziedzinach życia. W latach 2001-2005 tematykę pisma można przyporządkować trzem podstawowym grupom zagadnieniowym:

20 M. Lemańska, Elle u Anny, „Press” 2006, nr 2, s. [39].

${ }^{21}$ M. Wilkanowicz-Devoud, 20 lat Elle na świecie, „Elle” 2005, nr 11, s. 25.

22 M. Lemańska, Elle..., s. [39]-40.

23 Ibidem.

24 M. Wilkanowicz-Devoud, 20 lat Elle na świecie, „Elle” 2005, nr 11, s. 25.

25 Częste roszady następowały zwłaszcza na stanowiskach sekretarzy redakcji. Zmiany te nie są przedmiotem niniejszego opracowania, nie miały również wpływu na kształt periodyku, stąd nie zostały w tym miejscu szczegółowo omówione. 
1) moda,

2) zdrowie i uroda,

3) relacje damsko-męskie.

W obrębie tych grup znajdowały się następujące działy i rubryki26: Apteka, Co nowego?, Czy chciałabyś z nim być? $\left(\rightarrow\right.$ Notes Elle) ${ }^{27}$, Deco, Felieton, Kuchnia (zazwyczaj w tym miejscu pojawiała się autorska rubryka T. Capponi-Borawskiej: Deliketessy - pis. oryg.), Moda, Moja historia, Nowinki, Ona i On, Praca, Psychologia, Reportaż, Seks, Styl życia, Trendy, Uroda, Wywiad, Zdrowie, Życie codzienne (tu drukowano m.in. horoskop, a także podawano adresy sklepów, w których można było kupić polecane przez pismo modne kreacje). Systematycznie pojawiały się felietony W. Manna. Sporadycznie na łamach pisma drukowano Dom Elle, Kod dostępu (postać, przeważnie aktora), Raport Elle, Spotkania Elle i Sylwetki. Zawartość działów i rubryk składała się na obraz określonego stylu życia, preferowanego przez magazyn, adresowanego do kobiet, które są "ciekawe świata”, chcą „wiedzieć więcej”, „zmieniać świat” i „się rozwijać”28. Filozofia „Elle” została streszczona w numerze październikowym w 2004 r. Wówczas, z okazji 10-lecia magazynu w Polsce jego redaktor naczelna określiła dekalog, swego rodzaju credo „Elle”, które, być może, powinno był pojawić się numerze 1, a którego wówczas zabrakło. Po 10 latach program pisma, a jednocześnie jego odbiorca zostały określone w 10 punktach, które warto przytoczyć:

Tak jak Ty... 1. Poszukujemy: W miłości - równego tempa i podobnych oczekiwań. W przyjaźni - harcerskich ideałów. W modzie - fantazji i klasy. 2. Kochamy: Mężczyzn, którzy są kochankami i przyjaciółmi zarazem. Kobiety, które są wierne sobie. I tych, co nas inspirują do lepszego życia. 3. Walczymy: Z macho. Matką Polką. Stresem. Brakiem wiary w siebie. [...] 4. Kusimy: Zakręconą duszą, poczuciem humoru, zmysłową modą, pikantnymi smakami... 5. Ulegamy: Impulsom i intuicji. Pomysłom wielkich projektantów. Przedmiotom, które budują atmosferę. Niektórym mężczyznom też, oczywiście... 6. Bawimy się: Dobrze. Skojarzeniami. Historiami. Z przyjaciółmi. Czasem przesadzamy. 7. Miksujemy: Radość życia z odwagą. Ryzyko z zabawą. Szpilki ze skarpetkami, wystawiając na próbę męskie pożądanie i cierpliwość poprawnych koleżanek... 8. Prowokujemy: Bo chcemy zmieniać świat! 9. Marzymy: Żebyś się z nami czuła sobą. 10 . Nie poddajemy się! Jutro zaczynamy od nowa...29.

Stąd także określony styl przekazu treści, zawartych na łamach pisma. Dominowała w nim lekka forma, a wywiady przeprowadzane w piśmie,

${ }^{26}$ Nazwy działów i rubryk podano w porządku alfabetycznym. Uwzględniono przede wszystkim te, które w miarę systematycznie pojawiały się na łamach pisma, pominięto zaś te, który drukowano sporadycznie.

27 Był to dział kulturalny, który ze względu na temat pracy zostanie omówiony w dalszej części rozdziału.

28M. Wilkanowicz-Devoud, 20 lat Elle..., s. 25.

${ }^{29}$ M. Wilkanowicz-Devoud, 10 lat Elle, „Elle” 2004, nr 10, s. 15. 
podobnie jak prezentacja sylwetek wybranych osób, miały bezkonfliktowy, optymistyczny wydźwięk. Podejmowane niekiedy problemy (szczególnie w rubryce Ona i On lub Psychologia) dawały się zawsze rozwiązać. Tylko raz, w 2003 r., uwaga pisma skoncentrowała się na kwestiach politycznych, co związane było z przystąpieniem Polski do Unii Europejskiej. Po ogłoszeniu sondażu (udział w nim był nagradzany) wśród czytelniczek „Elle” na temat ich opinii związanej z wejściem Polski do wspólnoty europejskiej, ogłoszonego $\mathrm{w}$ numerze grudniowym w 2002 r.30, przedstawiono jego wyniki: okazało się, że $96 \%$ czytelniczek opowiedziało się za przystąpieniem naszego kraju w struktury UE ${ }^{31}$. Poważniejsze zainteresowania redakcji magazynu znalazły także swój wyraz w dwóch organizowanych przezeń akcjach. Zostaną one omówione w dalszej części rozdziału.

W porównaniu z wcześniej przedstawionymi dwoma magazynami, redakcja „Elle” kładła znacznie większy nacisk na kwestie dotyczące mody (co, jak już wcześniej podkreślono, było zgodne z założeniem periodyku), ale również na sprawy związane $\mathrm{z}$ urodą. $\mathrm{W}$ numerach przedwakacyjnych pojawiały się systematycznie porady dotyczące odchudzania (na przykład: Pokaż nogi: Wyszczuplanie i modelowanie. Ćwiczenia, zabiegi $w$ domu i gabinecie kosmetycznym, Akcja odchudzanie: Zapomnij o diecie, prawdy i mity o odchudzaniu, Brazylijki, jak one to robia, Trzy kilo mniej tam, gdzie chcesz, Tyjesz, bo..., 5 kilo w 15 dni), rady związane z pielęgnacją włosów (Wszystko o pięknych włosach: 20 sprawdzonych sposobów, Znajdź swój kolor: Wszystko o farbowaniu włosów $w$ domu $i$ w salonie) czy nowinki kosmetyczne (na przykład Kremy dla zestresowanych i zabiegi modelujące sylwetkę).

Niektóre numery miesięcznika można porównać do ekskluzywnych katalogów mody i urody bądź magazynów poświęconych urządzaniu domu. Niezwykle staranna grafika, dostęp do międzynarodowej sieci znanych fotografów i stylistów gwarantowały wysoki poziom edytorski i zasłużoną sławę w świecie mody. Magazyn znany był głównie z tych powodów. Nie miał za sobą długiej historii na polskim rynku prasowym, jak „Zwierciadło”, nie przeprowadzał równie spektakularnych akcji, jak „Twój Styl”, nie zasłynął z cyklicznych inicjatyw, które kojarzone byłyby nie tylko przez czytelników tytułu czy profesjonalistów z branży. Warto jednak wspomnieć o kilku przedsięwzięciach, zorganizowanych przez redakcję pisma.

Od 1998 r. systematycznie organizowano plebiscyt na Trofea Elle. Przyznawane były one najbardziej stylowym przedstawicielom świata polityki, show-bizneu oraz kultury. Czytelnicy wybierali, z kandydatów przedstawianych przez redakcję, najbardziej stylowe osobowości, gwiazdy i miejsca.

30 [br. aut.], Czytelleniczka z Uniq czy bez? [pis. oryg.], „Elle” 2002, nr 12, s. [129].

31 [br. aut.], 96\% czytelniczek jest za, „Elle” 2003, nr 1, s. 132. 
Wybór możliwy był w ośmiu kategoriach 32 : Aktor, Modelka, Muzyk, Osoba publiczna, Osobowość TV, Projektant, Stylowe miejsce oraz interesująca kategoria: Kogo kocha „Elle”? Czytelnicy mogli również zgłosić własnego kandydata, nie uwzględnionego przez redakcję. Znamienne, że brakowało tu przedstawicieli ze świata literatury, chociaż w kategorii Stylowe miejsce w 2001 r. pojawił się warszawski Café Antykwariat oraz Biblioteka Uniwersytetu Warszawskiego, a dwa lata później księgarnia Czuły Barbarzyńca. Po dokonaniu wyboru, organizowano uroczystą galę wręczenia nagród, z której zamieszczano fotoreportaż.

Dwie kolejne inicjatywy miały inny charakter. Pierwsza z nich, zapoczątkowana została w 2002 r. Była to Ogólnopolska Akcja Prewencyjna „Kobieta Bezpieczna”, której patronował magazyn (a informowało o niej także „Zwierciadło”). Wyjaśnienie zasad programu zajęć, adresowanych do kobiet, znalazło się w lutowym numerze „Elle” wraz z kuponem zgłoszeniowym na bezpłatne kursy samoobrony33. Przewidziano także zajęcia teoretyczne, przygotowane i prowadzone przez specjalistów, m.in. prawników i psychologów. W roku następnym akcję powtórzono, a informacja wraz z kuponem znalazła się kilkakrotnie na łamach pisma ${ }^{34}$.

Cel drugiej inicjatywy (Dzieci ulicy) przedstawiła w 2002 r. M. Wilkanowicz-Devoud:

Organizujemy akcję pomocy dzieciom ulicy. Nie jest to pomoc doraźna. Nie będziemy zbierać pieniędzy na jedzenie ani ubranie. Chcemy wraz z Fundacją dla Polski wesprzeć finansowo tych, którzy w różnych miejscach Polski poprzez swoje organizacje i stowarzyszenia nawiązują kontakt z dziećmi [...]. Namawiają do powrotu do szkoły, odrabiają z nimi lekcje, grają w piłkę. Potrafią zdobyć ich zaufanie i wiedzą też, w jaki sposób rozmawiać z ich rodzicami ${ }^{35}$.

Jednocześnie czytelnikom pisma zaproponowano limitowaną edycję damskich T-shirtów, z hasłem akcji: Ulica nie jest dla dzieci, którą można było otrzymać po wpłaceniu minimum 50 zł na podane przez redakcję konto. Przedsięwzięcie poparli znani aktorzy, sportowcy i piosenkarze. W 2004 i 2005 r. ponowiono akcję, a na łamach magazynu odnaleźć można było podobne jak w pierwszej edycji kupony, umożliwiające wsparcie inicjatywy ${ }^{36}$.

32 W ciągu analizowanego okresu określenie poszczególnych kategorii nieznacznie się zmieniało, np. zamiast Osobowość TV pojawiło się określenie Gwiazda TV, zob. „Elle” 2004, nr 8, s. [44].

33 [br. aut.], Broń się!, „Elle” 2002, nr 2, s. [63].

${ }^{34}$ Zob. np. „Elle” 2003, nr 6, s. [157].

35 M. Wilkanowicz-Devoud, Akcja Elle, „Elle” 2002, nr 5, s. 21.

36 Więcej, zob. np. M. Wilkanowicz-Devoud, Ulica nie jest dla dzieci, „Elle” 2005, nr 10, s. 15. 
Inne przedsięwzięcia, realizowane przez omawiany periodyk, wpisywały się w większym stopniu w politykę pisma (jak choćby Metamorfozy37). Zorganizowano również konkurs dla przyszłych projektantów, w którym główną nagrodą był miesięczny staż w dziale mody „Elle” lub dziale stylizacji Galerii Centrum. Innym pomysłem był konkurs Igła z nitkq, zorganizowany przez magazyn wspólnie z Fundacją dla Polski ${ }^{38}$.

W jubileuszowym, 100. numerze priodyku (1/2003) ukazała się informacja o rozpoczęciu akcji Polska jest trendy. Przedsięwzięcie miało przekonać o tym, że można w sposób nowoczesny i zarazem modny afirmować wartości patriotyczne. W kolejnych numerach pisma zaprezentowano sylwetki "młodych talentów” ze świata mediów, mody, designu i sztuki, a także przybliżono wyjątkowe miejsca w Polsce, kultowe filmy, książki i płyty oraz kreacje najlepszych polskich projektantów. Czytelnikom zaproponowano udział w konkursie, w którym mieli odpowiedzieć na pytanie: Dlaczego dla was Polska jest trendy?, a dla 100 najciekawszych autorów przewidziano T-shirty z limitowanej serii Polska jest trendy.

W magazynie opracowywano także cykliczne rankingi (na przykład Najlepiej i najgorzej ubranych posłów i posłanek) oraz raporty (jak choćby Kobieta 2002). Znajdowały one uznanie w oczach czytelników, czego dowodem jest choćby jeden z listów pochwalający 4. edycję rankingu „Elle”39. Miesięcznik wydawał również płyty „Z muzyką miejsc”, a także systematycznie kierował do swych czytelników ankiety (na przykład międzynarodowy sondaż „Elle”40).

Grupę docelową magazynu stanowią młode, poszukujące inspiracji kobiety, ,liderki opinii”, „estetki”41.

Periodyk, podobnie jak i jego współpracownicy, był stosunkowo rzadko nagradzany. Tym bardziej o każdej nagrodzie skwapliwie informowano. I tak na przykład, pisano o Kulinarnym Oscarze dla T. Capponi-Borawskiej, tworzącej autorską rubrykę na łamach "Elle”, informowano również o nagrodzie dla tej samej autorki za książkę Kuchnia pachnąca bazylią. Donoszono o prestiżowej nagrodzie dla francuskiego fotografa magazynu Gillesa Bernsimona, przyznawanej przez Stowarzyszenie Amerykańskich Projektantów Mody-CFDA.

37 „Elle“ 2002, nr 6, s. 138.

38 Zob. „Elle” 2004, nr 8, s. 42.

39 „Elle” 2001, nr 1, s. 14.

40 Redakcja polskiego wydania magazynu zaproponowała odbiorcom udział w sondażu, w którym czytelniczki „Elle” z 35 krajów miały odpowiedzieć na te same pytania, dotyczące m.in. stylu życia, poglądów, marzeń współczesnej kobiety. Wyniki ankiety zamierzano porównać z danymi, uzyskanymi w podobnej akcji, przeprowadzonej w 1998 r. Na uczestniczki ankiety czekały nagrody. Zob. [br. aut.], Nowe granice kobiecości..., „Elle” 2003, nr 2, s. 48.

41 http://www.mediabuy.pl/prasa/Elle/, kwiecień 2011. 
Jednym z dowodów uznania dla magazynu były słowa czytelniczki, która z okazji jubileuszu 15-lecia „Elle” w Polsce pisała: „Dziękuję, że jesteście i pomagacie mi dokonywać ważnych wyborów i podejmować świetne decyzje. Dzięki Wam zyskuję poczucie niesamowitej radości. Przekonuję się o tym za każdym razem, otwierając i czytając $>$ Elle<!" 42 .

\subsubsection{Przeczytaj ${ }^{43}$ : książka na łamach pisma}

Informacje dotyczące książki drukowano na łamach miesięcznika „Elle”, podobnie jak w przypadku wcześniej omawianych periodyków, w dziale kulturalnym. W badanym okresie zmieniał on trzykrotnie swoją nazwę. I tak od pierwszego badanego numeru w 2001 r. do kwietnia 2002 r. włącznie nosił tytuł Co nowego? Kino, moda, teatr, muzyka, sztuka, książki, od numeru $5 \mathrm{w}$ tymże roku zmieniono go na Notes Elle, zachowując przy tym ten sam podtytuł. Ta forma przetrwała aż do numeru marcowego w 2005 r. włącznie. Od kolejnego wydania (w kwietniu) ponownie zmieniono tytuł działu na Kultura Elle, dodając w podtytule obok pozostałych, rubrykę poświęconą fotografii.

Niezależnie jednak od nazwy, dział ten zajmował średnio 7 stron w pierwszej części pisma. Informacje dotyczące wydarzeń teatralnych, filmowych, muzycznych oraz związanych z książką drukowane były w rubrykach im poświęconych, przy czym książka reprezentowana była przede wszystkim $\mathrm{w}$ formie recenzji, krótkich omówień i adnotacji. Dział, a wraz z nim rubryka Książki, kilkakrotnie zmieniał swą formę, aczkolwiek przeobrażenia te miały charakter głównie graficzny.

Niemal przez cały analizowany okres za sprawy kulturalne w periodyku odpowiedzialna była Agnieszka Różycka, zastąpiona od numeru 2 (2004) przez Marię Barcz. Jej nazwisko widniało w stopce redakcyjnej przez cały badany okres; pozostałe osoby, przygotowujące dział kulturalny, zmieniały się tak, że w ciągu pięciu lat zespół tworzyli także Grzegorz Brzozowicz (odpowiedzialny za informacje muzyczne), Dobrochna Grott (nowinki multimedialne), Piotr Gruszczyński (recenzje teatralne), Monika Kuc (informacje z galerii sztuki), Roman Praszyński, Jarosław Lipszyc (omówienia książek), Aleksandra Rembowska (teatr) oraz Beata Nowicka. Poczynając od 2002 r., liczba osób, przygotowujących informacje kulturalne, była coraz mniejsza, tak że w ostatnim badanym roczniku były to już tylko dwie osoby: M. Barcz i B. Nowicka oraz dwóch współpracowników: J. Lipszyc i A. Rembowska.

42 Tatiana [czytelniczka], Mój wybór, moje Elle, „Elle” 2009, nr 11, s. 12.

43 Tytuł notki, zalecającej przeczytanie książki, zob. „Elle” 2001, nr 6, s. [67]. 
Jakkolwiek dominującą formę informacji o książce stanowiły recenzje, omówienia i streszczenia, to jednak analiza zebranego materiału pozwoliła wyodrębnić kilka innych kategorii związanych z interesującą nas problematyką. W tabeli 52 przedstawiono odnoszące się do nich dane statystyczne.

Tabela 52. Formy obecności książki i informacji o niej na łamach „Elle” w latach 2001-2005

\begin{tabular}{|l|c|}
\hline \multicolumn{1}{|c|}{ Rodzaj informacji } & Liczba ogółem \\
\hline Recenzje, omówienia, streszczenia & 444 \\
\hline Wywiady & 75 \\
\hline Reklamy książek & 26 \\
\hline Portrety/sylwetki & 8 \\
\hline $\begin{array}{l}\text { Artykuły, poświęcone sprawom książki lub rynku wydawniczo- } \\
\text {-księgarskiego }\end{array}$ & 4 \\
\hline Ekranizacje, adaptacje, inscenizacje znanych dzieł & 32 \\
\hline Konkursy i akcje & 14 \\
\hline Listy bestsellerów & - \\
\hline $\begin{array}{l}\text { Listy czytelników, nawiązujące do zamieszczonej informacji związanej } \\
\text { z książką }\end{array}$ & 2 \\
\hline Inne ${ }^{a}$ & 77 \\
\hline Ogółem & 682 \\
\hline
\end{tabular}

$a$ W tej kategorii, w dużej mierze podobnie, jak było to w przypadku dwóch wcześniej przedstawionych magazynów, uwzględniono felietony pisarzy, fragmenty książek, niewielkie objętościowo notki, związane pośrednio lub bezpośrednio z książkami, polecające daną lekturę, nawiązujące do wydrukowanej obok publikacji itd.

Źródło: badania własne.

W porównaniu z magazynami „Zwierciadło” i „Twój Styl” ogólna liczba informacji związanych bezpośrednio lub pośrednio z książką była wyraźnie mniejsza. Dla redakcji „Elle” kwestie związane z literaturą, w tym z książką, z pewnością nie należały do priorytetowych. Co więcej, jak wynika z analizy, były one ( $\mathrm{w}$ porównaniu $\mathrm{z}$ analogicznymi informacjami na łamach wcześniej prezentowanych miesięczników) bardziej powierzchowne, brak w nich też wyraźnego kierunku, który w odniesieniu do „Twojego Stylu” zarysowywał się w każdej z omawianych kategorii, a na łamach „Zwierciadła" widoczny były w wybranych formach informacji o książce.

Zwraca uwagę bardzo mała liczba anonsów wydawniczych i brak zestawienia bestsellerów. Pomimo że redakcja systematycznie w każdym numerze pisma drukowała listy od czytelników, to tylko zaledwie w dwóch przypadkach odnosiły się one bezpośrednio do spraw związanych z książką.

Jedyną większą liczbowo kategorią, w porównaniu z analogicznymi danymi dotyczącymi poprzednio omawianego magazynu, były recenzje, omówienia i streszczenia. 


\subsubsection{Do czytania, i oglądania ${ }^{44}$ : miejsce recenzji w układzie pisma}

W latach 2001-2005 na łamach pisma ukazały się 444 recenzje książek ${ }^{45}$. W tabeli 53 zaprezentowano ich liczbę w poszczególnych latach.

Tabela 53. Recenzje, omówienia, streszczenia na łamach „Elle” w latach 2001-2005

\begin{tabular}{|c|c|}
\hline Rok & $\begin{array}{c}\text { Liczba recenzji, } \\
\text { omówień, streszczeń }\end{array}$ \\
\hline 2001 & 110 \\
\hline 2002 & 98 \\
\hline 2003 & 78 \\
\hline 2004 & 73 \\
\hline 2005 & 85 \\
\hline Ogółem & 444 \\
\hline
\end{tabular}

Źródło: badania własne.

Wydaje się, że i w tym przypadku trudno mówić o stałej czy zamierzonej tendencji, pomimo że w latach 2002-2004 liczba recenzji nieznacznie się zmniejszała, by w 2005 r. znów nieco wzrosnąć. W pewnym stopniu wynikało to prawdopodobnie bardziej z faktu zmian, jakim rubryka recenzyjna podlegała na przestrzeni owych pięciu lat niż ze świadomej polityki redakcji magazynu. Podobnie, jak było to w przypadku „Zwierciadła” i „Twojego Stylu”, tak i tu książki recenzowała jedna osoba ${ }^{46}$. Najpierw był to R. Praszyński (od roku $2001^{47}$ do numeru 2 cztery lata później, w 2005 r.). W sumie przedstawił on 242 książki. W 2005 r. zastąpił go J. Lipszyc, który zrecenzował 60 tytułów. Prezentowali oni książki w specjalnie do tego przygotowywanej rubryce recenzyjnej. Poza nią znalazło się kilka krótkich wzmianek o książkach, które (ze względu na występujące w nich elementy) także zaliczono do grupy recenzji. W takich przypadkach wybrane tytuły proponowali: Ewa Awdziejczyk (raz), M. Barcz (raz), T. Capponi-Borawska, (pięciokrotnie), Agnieszka Kowalska (dwukrotnie), Iza Mazur-Poniatowska

44 Tytuł jednej z recenzji, zob. „Elle” 2003, nr 8, s. 42.

$45 \mathrm{~W}$ tej liczbie znajdują się wyłącznie recenzje redakcyjne.

${ }^{46}$ W 98 przypadkach omówienia książek nie były podpisane; poza kilkoma wyjątkami były to recenzje, omówienia i streszczenia zamieszczane na łamach pisma w 2001 r.; porównując zebrany materiał, można jednak przypuszczać, że ich autorem był R. Praszyński, szczególnie że (jak wynika z analizy wcześniejszych roczników pisma), jego nazwisko pojawiło się na stronie poświęconej książkom już w numerze 10 (1998). Jednak, ponieważ brak formalnego uzasadnienia, podane w tekście dane odnoszą się wyłącznie do podpisanych recenzji, omówień i streszczeń.

47 W 2001 r. tylko w numerze 11 znalazł się podpis R. Praszyńskiego, a w numerze 12 przy recenzjach książek pojawiły się jego inicjały. Zob. uwaga powyżej. 
(trzykrotnie), Alina Niedzielska, (siedmiokrotnie), M. R. [Małgorzata Rogala?] (raz), A. R[óżycka] (raz) i Agnieszka M. Wasieczko (ośmiokrotnie)48.

Znacznie częściej, niż stałych recenzentów, zmieniano formę i objętość rubryki poświęconej książkom. W ciągu dwóch pierwszych badanych lat obejmowała ona zaledwie skromną kolumnę z kilkoma krótkimi omówieniami wybranych tytułów, drukowaną obok innych wzmianek związanych z kulturą, natomiast od 2003 r. czytelnik odnajdował już bardziej zróżnicowane informacje o książce, którym poświęcano całą stronę, zaś w $2005 \mathrm{r}$. redakcja w kilku numerach pisma sprawom książki poświęcała dwie strony. Zmieniała się również objętość samych omówień (od 1-2-zdaniowych, które $\mathrm{w}$ zasadzie miały niewiele wspólnego $\mathrm{z}$ recenzją, poprzez nieco dłuższe, choć nadal bardzo powierzchowne, aż do obszerniejszych, zawierających ocenę proponowanego tytułu oraz nierzadko komentarz) i elementy, które się nań składały (tytuły recenzji, nazwisko recenzenta, podstawowe dane bibliograficzne dotyczące omawianej książki, kopie okładek książek, zdjęcia autorów). Nie uzasadniano wprowadzanych zmian, nie anonsowano ich nawet, tak że czytelnik kupując kolejny numer „Elle” nie wiedział, czy taka postać rubryki, do której przywykł, nie została zastąpiona innym pomysłem. Rubryka ewaluowała, stawała się bogatsza, głębsza, chociaż nie każda zmiana była dowodem profesjonalizmu redakcji, co widoczne było szczególnie w odniesieniu do podawania danych bibliograficznych dotyczących proponowanych książek.

Od pierwszego uwzględnionego w pracy numeru przez kolejne 13 wydań nosiła ona tytuł Książki, drukowana była w dziale Co nowego... Miała postać kolumny, w której proponowano czytelnikom od 7 do 9 tytułów. Owe omówienia, bardzo skromne pod względem merytorycznym, nie posiadały własnych tytułów. Każdą z nich poprzedzały niepełne dane bibliograficzne, na które składały się: nazwisko autora i tytuł jego książki, nazwa wydawcy, rzadziej miejsce i rok wydania. Nie podawano nazwiska tłumacza w przypadku przekładu, objętości proponowanej pozycji ani też jej ceny. Poza pierwszym poddanym analizie numerem ${ }^{49}$, u dołu kolumny, pod wszystkimi notkami, zamieszczano zdjęcie proponowanych książek, ułożonych jedna na drugiej, tak by czytelnik widział przede wszystkim ich grzbiety. Kolumna wyróżniała się na stronie kolorowym tłem: jasnożółtym lub jasnofioletowym. Był to dobry pomysł, jako że zazwyczaj stanowiła jedną z wielu innych informacji kulturalnych, zamieszczanych na danej stronie, a wprowadzenie tła o innym niż cała strona kolorze, na którym drukowano recenzje, zwiększało jej czytelność.

${ }^{48} \mathrm{~W}$ ośmiu przypadkach zabrakło nazwiska recenzenta.

49 W nr 1 (2001) w kolumnie recenzyjnej znalazło się 5 kopii okładek proponowanych książek (w sumie polecanych książek było 7), rozmieszczonych przy omówieniach. 
Od numeru 2 (2001) do numeru 1 (2002) włącznie obok kolumny recenzyjnej pojawiała się dodatkowa wzmianka o książce, zazwyczaj 1- lub 2-zdaniowa, niekiedy oceniająca, zawierająca podstawowe dane bibliograficzne oraz zdjęcie otwartej książki - w ten sposób redakcja chciała, jak się zdaje, dodatkowo zachęcić czytelników do lektury.

Wybrane poniżej przykłady stanowią odzwierciedlenie owych zmian (zdjęcie 129 i 130)

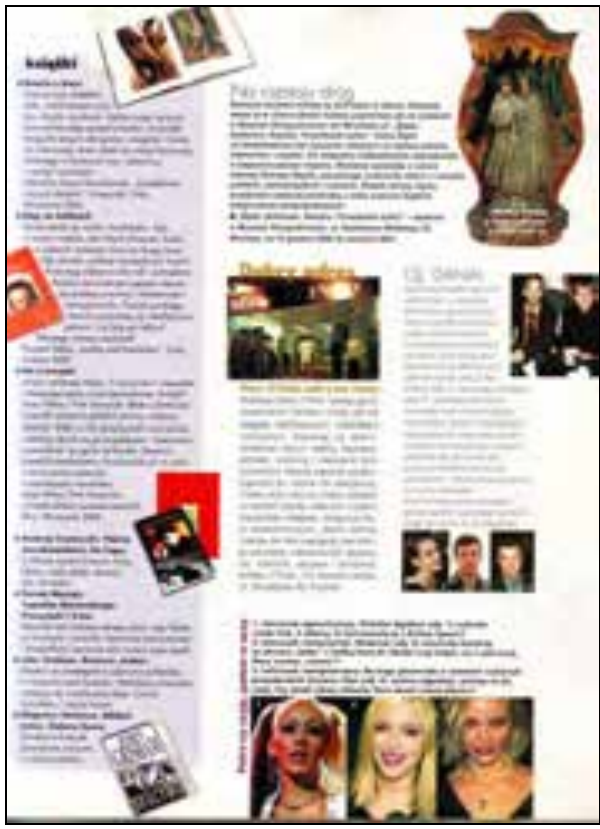

Zdjęcie 129. Rubryka poświęcona książce na łamach „Elle” „Elle” 2001, nr 1, s. [31]

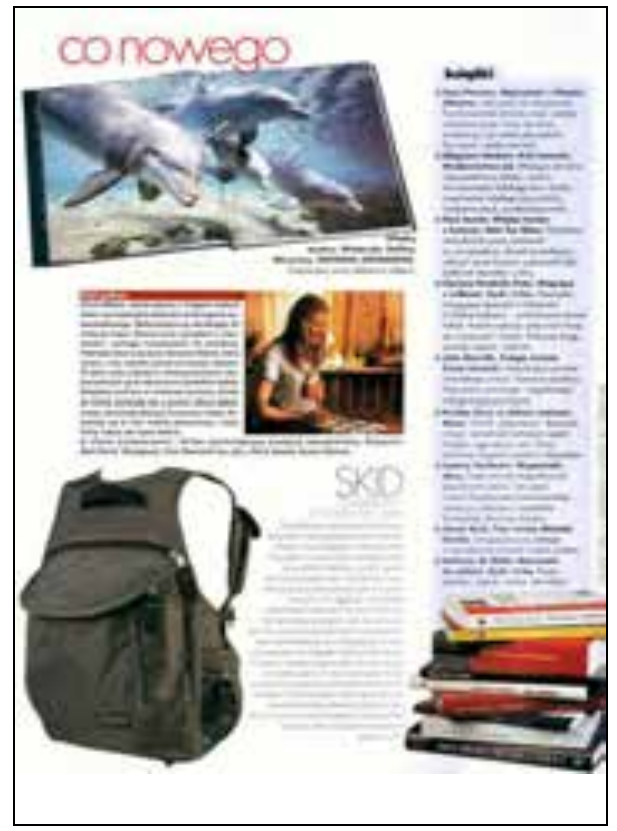

Zdjęcie 130. Rubryka poświęcona książce na łamach „Elle” „Elle” 2001, nr 9, s. [49]

Omówienia i streszczenia książek, krótkie i bardzo pobieżne, drukowano obok ciekawostek muzycznych, niewielkich objętościowo informacji o premierach filmowych lub nowinek ze świata mody. Równorzędne potraktowanie wszystkich tych informacji, składających się na szeroko rozumianą kulturę, nie wydaje się być dobrym rozwiązaniem, choć jednocześnie stanowi pewien dowód na to, $\mathrm{w}$ jaki sposób redakcja podchodziła do spraw związanych z tą dziedziną życia. Miały one być przede wszystkim rodzajem rozrywki, lekkiej i przyjemnej, by nie powiedzieć, powierzchownej, nie wymagającej większego wysiłku czy głębszego namysłu. 
Od numeru 2 (2002) zrezygnowano z dodatkowej wzmianki, dotyczącej książki, zamieszczanej dotąd obok kolumny recenzyjnej. Ona sama nie uległa jednak modyfikacji. Od numeru 5 (2002), jak wspomniano powyżej, zmieniono tytuł działu; odtąd czytelnicy interesujący się wydarzeniami kulturalnymi informacje o nich odnajdowali w ramach Notesu Elle..., zaś omówienia książek nadal pojawiały się w obrębie rubryki Książki. Jej forma pozostała niezmienna do numeru $3 \mathrm{w} 2003 \mathrm{r}$. włącznie.

Od kolejnego wydania (4/2003) sprawom związanym z książką poświęcano już całą stronę, a nazwę rubryki zmieniono na Elle Notes Książki. Dodatkowo w dwóch numerach w tymże roku (kwietniowym i majowym) rubryka poświęcona recenzjom anonsowana była tytułem Elle poleca. Zmniejszono liczbę prezentowanych książek do trzech (niekiedy czterech), za to przedstawiano je dokładniej: omówienia zajmowały już kilkanaście zdań (ok. 1/3 kolumny jedna). Przy niemal każdej recenzji pojawiała się kopia okładki proponowanej książki, chociaż omówienia nadal nie posiadały swych tytułów. Obok kolumny zamieszczano odtąd zazwyczaj jedną lub dwie dodatkowe recenzje, obszerniejsze, $\mathrm{z}$ odpowiednio większym zdjęciem okładki i wyróżnionym innym kolorem tytułem recenzji. Pojawiła się również interesująca forma informacji o książce, zatytułowana Uwaga, reklama ${ }^{50}$.

Wyraźniejsza zmiana nastąpiła od numeru 6 (2003). Nadal informacje o książce obejmowały całą stronę, ale modyfikacji uległa kolumna, w której zamieszczano część recenzji. U góry strony pojawiło się zdjęcie recenzenta i pochodzący od niego jednozdaniowy komentarz, obejmujący wszystkie proponowane $\mathrm{w}$ danej kolumnie książki lub odnoszące się tylko do jednego wybranego tytułu. Recenzje zyskały odrębne tytuły, a dane bibliograficzne, obejmujące te same elementy, co w poprzednich przypadkach, przeniesiono na koniec każdej z nich. Niekiedy obok kolumn zamieszczano wywiad, w którym pisarz opowiadał o wydanej niedawno książce. Taką formę rubryki utrzymano przez rok, do numeru 6 w 2004 r. włącznie. Zdjęcia 131 i 132 obrazują scharakteryzowane zmiany.

50 Zostanie ona omówiona w dalszej części rozdziału. 


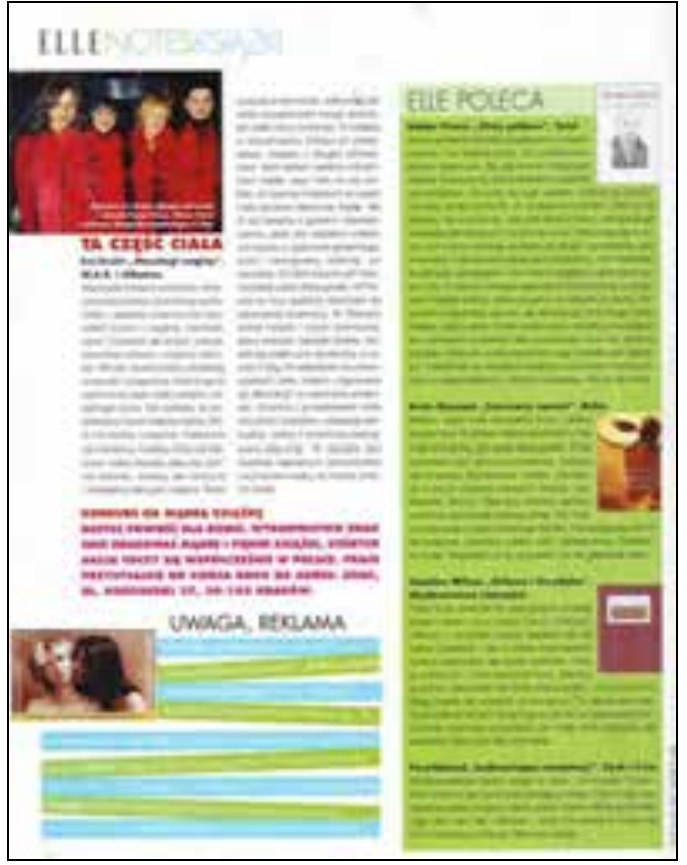

Zdjęcie 131. Strona recenzyjna na łamach „Elle”

„Elle” 2003, nr 5, s. 22

Zdjęcie 132. Strona recenzyjna na łamach „Elle” „Elle” 2004, nr 6, s. 50

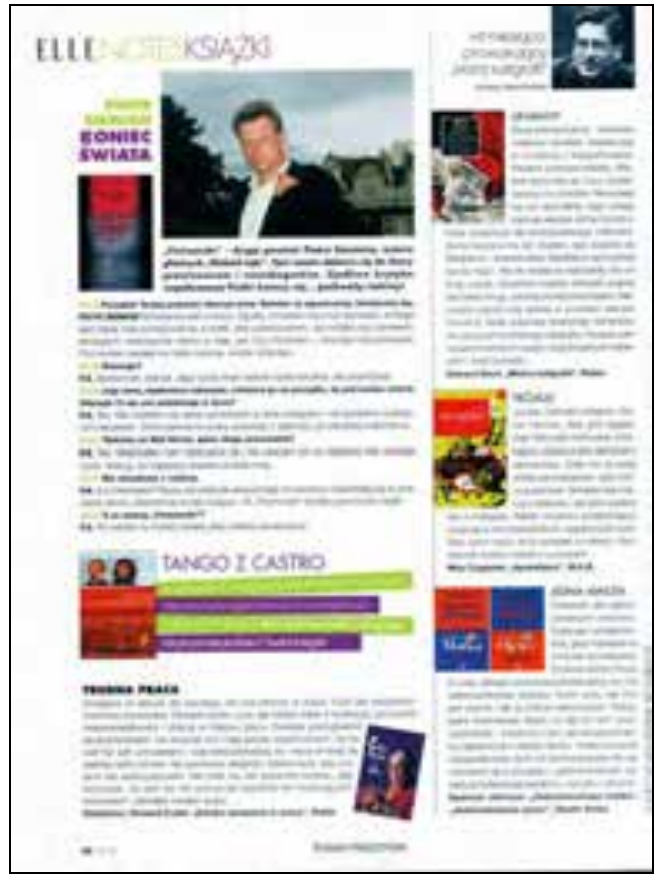


Dwa kolejne wydania (lipcowe i sierpniowe) w 2004 r. to nowa propozycja redakcji, związana ze stroną recenzyjną. Zmianie uległo rozmieszczenie omówień, jednocześnie zabrakło niektórych dotąd uwzględnianych elementów opisu bibliograficznego. Ograniczono się teraz do podawania autora, tytułu i wydawcy proponowanej książki. Zrezygnowano również ze zdjęcia recenzenta.

W numerze wrześniowym jednorazowo powrócono do poprzedniej formuły, zaś od numeru październikowego zaproponowano nowy układ strony, poświęconej książkom. Część recenzji drukowano odtąd u jej dołu, na kolorowym tle, z niewyraźnym wzorem okładki jednej z prezentowanych książek. Przeniesiono także informacje bibliograficzne dotyczące recenzowanej pozycji: czasem czytelnik odnajdował je pod tytułem recenzji, czasem na jej zakończenie. Obok krótkiej adnotacji drukowano niewielkich rozmiarów kopie okładek omawianych książek. U góry strony zamieszczano jedną lub dwie recenzje, przy których pojawiały się większe zdjęcia: autorów proponowanych lektur lub ich okładek. Liczba recenzji wahała się od 5 do 8 (zdjęcia 133 i 134).

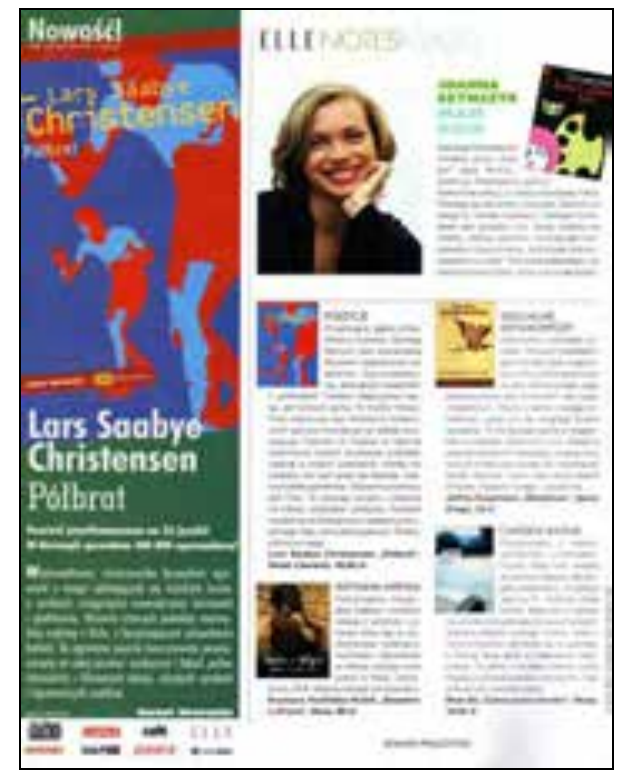

Zdjęcie 133. Strona recenzyjna na łamach „Elle” „Elle” 2004, nr 8, s. [40]

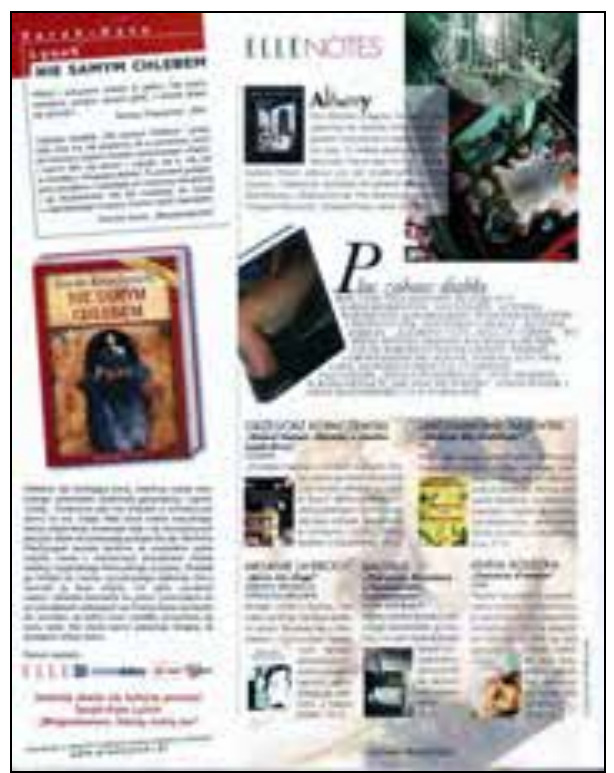

Zdjęcie 134. Strona recenzyjna na łamach „Elle”

„Elle” 2004, nr 10, s. [64]

Jak wcześniej wspomniano, od numeru 3 w 2005 r. R. Praszyńskiego zastąpił J. Lipszyc, a od kolejnego wydania (4/2005) zmieniono nazwę działu na Elle kultura. Kino, muzyka, książki, sztuka, fotografia, moda, zaś nazwę rubryki książkowej na Elle kultura książki. Informacje o książkach zaczęły pojawiać się na dwóch stronach pisma. Część recenzji (od dwóch do 
czterech) drukowano w kolumnie; przy nich pojawiły się symbole gwiazdek, określające ocenę proponowanej książki oraz jej cenę. Poza tymi omówieniami przedstawiano dodatkowo od jednego do czterech tytułów, z których wybrany prezentowano obszerniej. Każda z recenzji posiadała odrębny tytuł, zaś informacje bibliograficzne odnaleźć można było na zakończenie prezentacji danej książki. Dwukrotnie pojawił się $\mathrm{w}$ tym miejscu wywiad z pisarzem i także dwukrotnie zaprezentowano sylwetki wybranych twórców ${ }^{51}$. Poniżej przedstawiono przykłady 2-stronicowej rubryki książkowej z tego okresu (zdjęcia 135 i 136).

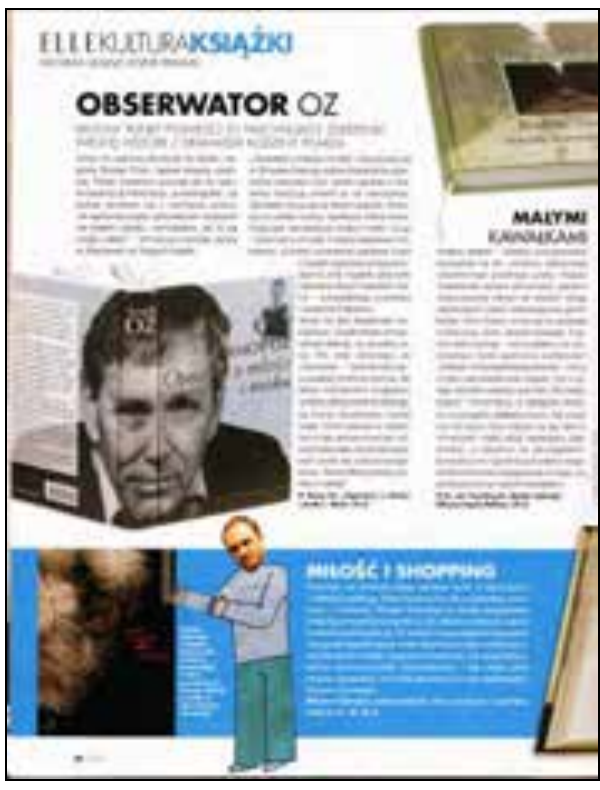

Zdjęcie 135. Strona recenzyjna (jedna z dwóch) na łamach „Elle” „Elle” 2005, nr 8, s. 38

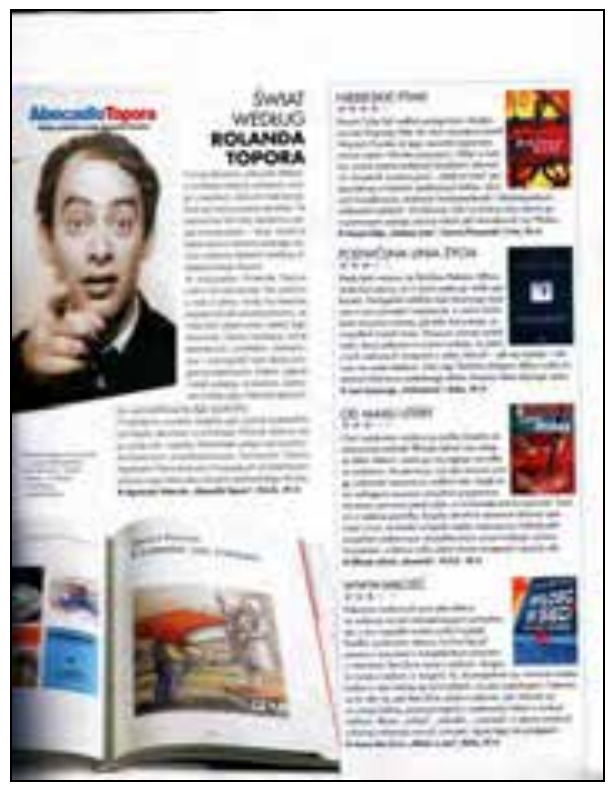

Zdjęcie 136. Strona recenzyjna (jedna z dwóch) na łamach „Elle” „Elle” 2005, nr 8, s. [39]

W dwóch ostatnich analizowanych numerach (11 i 12/2005) powrócono do skromniejszej wersji rubryki, związanej z prezentacją informacji związanych z książką, ponownie przeznaczając nań jedną stronę pisma i zmniejszając liczbę recenzji do $4(11 / 2005)$ i $5(12 / 2005)$ - zob. zdjęcie 137. 


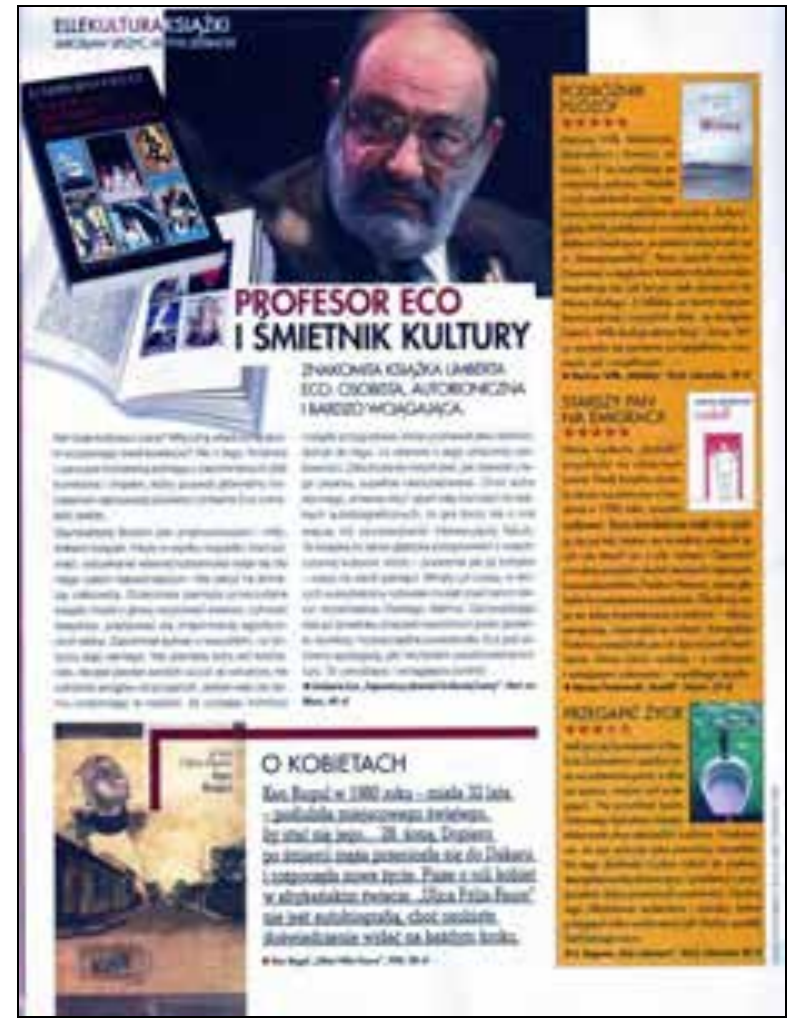

Zdjęcie 137. Rubryka poświęcona książce na łamach „Elle” „Elle” 2005, nr 12, s. [44]

Należy podkreślić, że zmiana recenzenta wpłynęła na poprawę zarówno formy prezentowanych informacji o książce, jak i jej wartości merytorycznej.

\subsection{Zakres i charakter recenzji - przykłady}

W ciągu pięciu lat zrecenzowano 442 książki (2 tytuły omówiono dwukrotnie) 360 autorów, w tym 123 pisarzy polskich i 237 obcych $^{52}$. W tej grupie znalazły się książki 154 kobiet, a zatem w tym przypadku nie można mówić o wyraźnej preferencji co do płci pisarza.

Recenzenci kilkakrotnie sięgali po książki tego samego autora. W tabeli 54 przedstawiono ich nazwiska wraz z tytułami wybranymi do omówienia przez recenzentów „Elle”.

52 W 29 przypadkach nie podano nazwiska autora prezentowanej książki. 
Tabela 54. Najczęściej recenzowani autorzy na łamach „Elle” w latach 2001-2005

\begin{tabular}{|c|c|c|}
\hline Dane twórcy & Liczba recenzji & Tytuły recenzowanych książek \\
\hline Katarzyna Grochola & 4 & $\begin{array}{l}\text { Osobowość ćmy } \\
\text { Podanie o miłość } \\
\text { Serce na temblaku } \\
\text { Zwiq̨zki i rozwiq̨zki miłosne }{ }^{a}\end{array}$ \\
\hline Julian Tuwim & 4 & $\begin{array}{l}\text { Dyzio marzyciel } \\
\text { Ptasie plotki } \\
\text { Spóźniony słowik } \\
\text { Taniec }\end{array}$ \\
\hline Paul Auster & 3 & $\begin{array}{l}\text { Księga złudzeń } \\
\text { Timbuktu } \\
\text { Wiążąc koniec z końcem }\end{array}$ \\
\hline Paulo Coelho & 3 & $\begin{array}{l}\text { Demon i panna Prym } \\
\text { Podręcznik wojownika światła } \\
\text { Zair }\end{array}$ \\
\hline John M. Coetzee & 3 & $\begin{array}{l}\text { Hańba } \\
\text { Mistrz z Petersburga } \\
\text { Wiek żelaza }\end{array}$ \\
\hline Nick Hornby & 3 & $\begin{array}{l}\text { Był sobie chłopiec } \\
\text { Długa droga } w \text { dół } \\
\text { Jak być dobrym }\end{array}$ \\
\hline
\end{tabular}

${ }^{a}$ Książka napisana wspólnie z A. Wiśniewskim.

Źródło: badania własne.

To, być może, zaskakujące zestawienie (K. Grochola obok J. Tuwima, J. M. Coetzee obok N. Hornby) potwierdza po raz kolejny postawioną wcześniej tezę, dotyczącą polityki redakcji pisma wobec kwestii związanych z książką 53. Można wysunąć hipotezę, że kryterium wyboru tytułów do recenzji stanowiła moda na określony tytuł lub popularność wybranego pisarza. Teoria ta znajduje swoje potwierdzenie, gdy przyjrzymy się pełnej liście nazwisk pisarzy, których utwory stały się przedmiotem recenzji (zob. Aneks 43. Autorzy książek recenzowanych na łamach „Elle” w latach 20012005). W przypadku, gdy pisarz był szczególnie popularny, nie wahano się sięgnąć po inną jego książkę. Jak wynika z tabeli 54, tylko w sześciu przypadkach byli to twórcy, których nazwiska pojawiły się w recenzjach przynajmniej trzykrotnie. Warto jednak wspomnieć o tym, że aż w 33 przypadkach po książki tego samego autora sięgano dwukrotnie, przy czym

53 Wyjątkiem jest J. Tuwim, którego wiersze dla dzieci znalazły się jednorazowo jako przedmiot recenzji, zamieszczonej obok tradycyjnej kolumny. W magazynie kilkakrotnie pojawiły się recenzje książek dla dzieci, były to jednak sporadyczne próby promocji lektur dla najmłodszych czytelników, pojawiające się obok zwyczajowych omówień. 
w większości były to różne tytuły. I tak pojawiły się omówienia dwóch książek m.in. Anne Bankroft, Jonathana Carrolle`a, Harlana Cobena, Umberto Eco, Helen Fielding, Aleksandry Marininy, Tony`ego Parsonsa, Terry`ego Pratchetta, Jeanette Winterson. Recenzenci proponowali również książki mniej znanych autorów, jak choćby Banerjee Chitra Divakaruni czy Charlotte Fiell lub Huang Po. Nie zaniedbano także promocji książek, napisanych przez współpracowników magazynu. Informowano o książce T. CapponiBorawskiej (dwukrotnie) oraz Beaty Pawłowicz. Proponowano również książkę recenzentki „Twojego Stylu”, Izabeli Filipiak, a także autorów „Polityki”, Mai Wolny i Piotra Sarzyńskiego.

Jednocześnie warto zwrócić uwagę na fakt, że pomimo uwzględnienia powieści K. Grocholi, autorki powieści dla kobiet, a zatem, głównych adresatek „Elle”, nie omawiano najbardziej znanych tytułów pióra tej autorki: Nigdy w życiu czy Ja wam pokażę!

W recenzjach przeważała literatura popularna. Czytelnikom pisma proponowano przede wszystkim powieści, ale, co warto zaznaczyć, w porównaniu z magazynem „Twój Styl”, na łamach „Elle” częściej prezentowano opowiadania (na przykład Jonathana Carrola Cylinder Heidelberga, Jerzego Sosnowskiego Linia nocna) i wierszy (m.in. Krystyny Gucewicz Z miłości, Ireny Conti Di Mauro Miłość - Czułość - Dobroć, Włodzimierza Kowalewskiego Światło i lęk, Marcina Świetlickiego Nieczynny, Wisławy Szymborskiej Chwila). Kilkakrotnie przedstawiano wybrane poradniki (na przykład Wojciecha Kruczyńskiego i Pawła Droździka Zawsze bezpieczna. Psychologiczne aspekty samoobrony kobiet czy Spencera Johnsona Jednominutowa matka i Jednominutowy ojciec).

Omówienia i streszczenia, drukowane na łamach pisma (szczególnie w ciągu pierwszego badanego roku), były zazwyczaj bardzo krótkie, nierzadko 1-3-zdaniowe. Wydaje się, że celem R. Praszyńskiego było zamieszczenie informacji o jak największej liczbie tytułów w danym numerze periodyku, bez głębszej analizy czy choćby szerszego zarysowania treści lub sylwetek bohaterów proponowanych lektur. Omówienia te przypominały raczej streszczenie kolejnego odcinka telenoweli, nie zaś solidną recenzję. Oto kilka wybranych przykładów: „Interesująco o ewolucji” (o książce Iana Tattersalla I stał się człowiek) ${ }^{54}$, „0 ojcu, Stanisławie Dygacie, szczerze, a więc smutno. Dobry artysta, kiepski człowiek" (o Rozstaniach Magdy Dygat)55, „Droga polskiego aktora do francuskiego sukcesu” (na temat biografii Andrzeja Seweryna pióra Teresy Wilniewczyc) ${ }^{56}$, „0 straceńcach

\footnotetext{
54 „Elle” 2001, nr 8, s. [34].

55 Ibidem.

56,"Elle” 2001, nr 10, s. [58].
} 
i maniakach wspinaczki" (na temat Wielkich górskich przygód Stefano Ardito) ${ }^{57}$. Nierzadko były to zdania jednoznacznie oceniające: „Proste, głębokie, piękne i trudne. Jak miłość" (o Wezwaniu do miłości Anthony`ego de Mello) ${ }^{58}$, „Ekscytująca opowieść o Marilyn Monroe, jej rozkoszy i cierpieniu" (o Blondynce J. C. Oates) lub mające zaintrygować lub choćby zaciekawić czytelnika „Elle”: „Nie wiedziałem, że poetkę łączyły tak mocne intymne związki z matką" (podsumowanie wrażeń po lekturze Nierozważnej i nieromantycznej. O Halinie Poświatowskiej, autorstwa Grażyny Borkowskiej) ${ }^{59}$.

0 ile $\mathrm{w}$ początkowym analizowanym okresie przeważały tak zwięzłe wzmianki, przy których jednak pojawiały się (niepełne, o czym wspomniano wcześniej) dane bibliograficzne, o tyle w miarę upływu czasu zwiększyła się liczba nieco dłuższych omówień, choć i one nie imponowały głębszą analizą treści czy choćby rzetelnym komentarzem dotyczącym proponowanego tytułu. Jednak coraz częściej łączyły już w sobie streszczenie prezentowanej książki oraz jej ocenę, nierzadko bardzo osobistą. Oto przykłady: „O dziennikarce w ciąży, którą zostawia narzeczony. Zabawna i wzruszająca historia. Duże wrażenie zrobił na mnie wiarygodny obraz kobiety, odrzuconej przez ojca" (odczucia R. Praszyńskiego po lekturze książki Jennifer Weiner Kochając większa kobietę $\left.{ }^{60}\right)$; „Cień właśnie wychodzi z amerykańskiego więzienia. Niestety, jego ukochana żona ginie w wypadku samochodowym. Ale nie do końca. Opuszcza cmentarz i chce, aby przywrócił ją do życia. Cień przyjmuje pracę u osobnika, który podaje się za skandynawskiego boga Odyna. Wplątuje się $\mathrm{w}$ wojnę między starymi bogami $\mathrm{z}$ wielu mitologii a nowymi bogami komputerów i kart kredytowych. Niezwykle sprawnie napisana powieść. Błyskotliwa i dynamiczna jak komiks" (o Amerykańskich bogach Neila Gaimana) ${ }^{61}$.

W 2003 r. zmniejszono liczbę recenzji, drukowanych w kolumnie, ale dzięki temu stały się one obszerniejsze. Związane to było ze wspomnianym już zwiększeniem miejsca w piśmie, przeznaczonego na informacje o książce. Od numeru 4 (2003) była to cała strona. Obok dotychczasowej kolumny drukowano jedną obszerniejszą recenzję lub trzy nieco skromniejsze pod względem objętości. Jednocześnie od numeru 5 (2003) pojawiła się specyficzna forma informacji o książce, zatytułowana Uwaga, reklama, drukowana obok kolumny recenzyjnej; zostanie ona omówiona w dalszej części rozdziału. Niekiedy recenzję zastępował wywiad z pisarzem.

\footnotetext{
57 „Elle” 2002, nr 3, s. 53.

58 „Elle” 2001, nr 9, s. [48].

59 „Elle” 2002, nr 2, s. 33.

60 „Elle” 2002, nr 3, s. 53.

61 „Elle” 2002, nr 8, s. 49.
} 
Wraz ze zmianą w 2005 r. recenzenta książek zmieniła się postać omówień. Niektóre z nich były już obszerniejszymi komentarzami na temat proponowanych książek, nierzadko zawierającymi również krótką charakterystykę ich autora62. Było to możliwe dzięki kolejnemu zwiększeniu miejsca przeznaczonego na informację o książce do wspomnianych dwóch stron. Jednocześnie przy części omówień (drukowanych w tradycyjnej kolumnie) znalazła się skala ocen od 1 do 5 gwiazdek. Zarówno w tych przypadkach, jak i w recenzjach zamieszczanych obok nadal pojawiały się jednoznaczne oceny proponowanej lektury, pochodzące od recenzentów: „Znakomita książka Umberta Eco. Osobista, autoironiczna i bardzo wciągająca” (o Tajemniczym płomieniu królowej Loany) ${ }^{63}$, „Genialna humoreska napisana z cudownym językowym wyczuciem" (o książce Tamary Bołdak-Janowskiej: Kto to jest ten Jan Olik?) ${ }^{64}$.

Większość recenzji była pozytywna. Poza cytowanymi powyżej ocenami, warto przytoczyć kilka jeszcze przykładów, stanowiących wyraz odczuć, zarówno R. Praszkowskiego, jak i J. Lipszyca, po przeczytaniu danej książki. Poczynając od osobistych zwierzeń: „Przyznam się - piszę tę notę, nie doczytawszy książki do końca. To 500 stron lektury, którą należy smakować powoli. Na dodatek o prawo do czytania >Cienia wiatru< muszę walczyć z własną żoną...”65, a kończąc na zwięzłych stwierdzeniach: „Proste, wstrząsające, ważne" (ocena Dziewczynki w czerwonym płaszczyku Romy Ligockiej)66, „Najbardziej niezwykły kryminał, jaki czytałem” (Eliot Pattison Mantra czaszki) ${ }^{67}$, „Trzymający w napięciu, ambitny thriller” (o Jaskini Tima Krabbé68). Nierzadko pojawiały się również oceny negatywne, przy czym było ich wyraźnie więcej niż w przypadku omówień, zamieszczanych na łamach „Zwierciadła” czy „Twojego Stylu”. Poza krótkimi stwierdzeniami: „Naiwna bajka” (o książce Amélie Nothomb Rtęć) ${ }^{69}$, niekiedy recenzent uzasadniał negatywną opinię, jak na przykład przy ocenie wierszy M. Świetlickiego: „Męczy mnie gęba poety. Jego ostatni tomik to raptem atrakcyjne zapiski frustrata. [...] U poety czterdziestoletniego szukam mądrości. A rozpacz nie jest mądrością"70 czy prezentując książkę I. Filipiak (Alma):

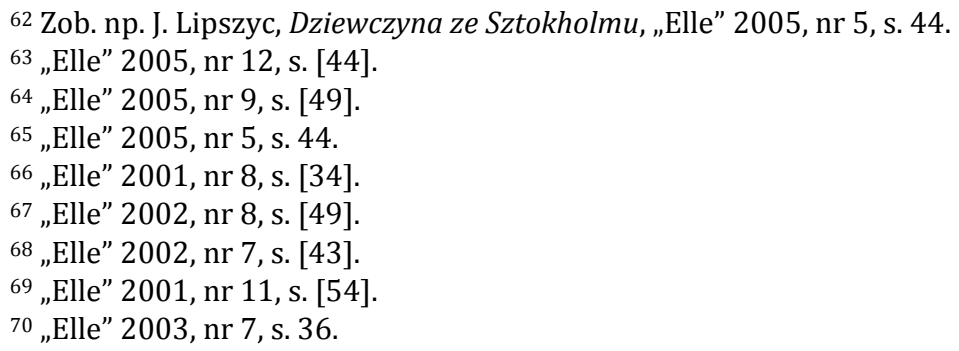


Poetyka koszmarnego złego snu jest absolutnie nieprzystępna. Nieokreślona kobieta wędruje podziemnymi korytarzami w poszukiwaniu swego dziecka, które jest potworem. Korytarze raz są cyrkiem, a raz burdelem. Ciemna, duszna atmosfera. Do tego zdania natrętnie metaforyczne. Żadnej litości dla biednego czytelnika71.

W porównaniu z recenzjami, zamieszczanymi na łamach „Twojego Stylu”, omówienia adresowane do czytelników „Elle” raczej nie odwoływały się do ich wiedzy czy znajomości świata literackiego. Bardzo rzadko pojawiało się porównanie proponowanej książki lub pisarza do innego dzieła czy twórcy. Brak było również, o czym wspomniano powyżej, wyraźnego kryterium doboru lektur, które kreowałyby określony wizerunek kobiety, jej roli we współczesnym świecie, tak jak to było w przypadku poprzedniego pisma. Tytuły recenzji, jakkolwiek niekiedy trafnie sformułowane, zabawne czy interesujące, także nie stanowiły żadnej wskazówki co do preferencji recenzentów „Elle”, nie składały się na jednolity czy choćby zarysowany ogólnie obraz. Oto kilka przykładów ${ }^{72}$ : Celny strzał, Dla miłości zginq tysiq̨ce, Duch miłości, Każdy z nas jest wyjątkowy!, Mądry szaleniec, Melancholijna małpa, Mistrz akapitu, Mistrz o mistrzu, Niebiańska udręka, Od ananasa do żyta, Plac zabaw diabła, Podwójna linia życia, Poruszające godziny, Profesor Eco i śmietnik kultury, Profesorskie zabawy, Przegapić życie, Sfrustrowani, Siła gwiazdy, Siostry Boga, Spokój i melancholia, Sprawy najważniejsze, Trochę kultury!, Zapach słońca, Złość na zdrowie.

Poza recenzjami, omówieniami i streszczeniami, zamieszczanymi w rubryce książkowej, pojawiały się również krótkie notki, informujące o szczególnie interesujących tytułach, drukowane w innych miejscach magazynu. Proponowane tu lektury związane były z rubryką lub działem, w którym je zamieszczano. Czytelnik odnajdował je zatem na przykład w ramach takich rubryk, jak Fotografia, Moda, Sztuka, Teatr, ale także i poza działem kulturalnym, na stronie zatytułowanej Elle Delikatesy czy Elle Apteka. Osoby odpowiedzialne za te rubryki zwracały uwagę czytelników na tytuły, które zazwyczaj stanowiły uzupełnienie innych informacji, znajdujących się w tym miejscu. I tak A. Wasieczko zachęcała do sięgnięcia po album The Polaroid Book, I. Mazur-Poniatowska proponowała Lady. Kobietę elegancka. A. Różycka wskazywała na Ojcobójców. Młodszych, zdolniejszych $w$ teatrze polskim jako lekturę, na którą warto poświęcić czas. Z kolei T. Capponi-

71 „Elle” 2004, nr 1, s. 34.

72 Zob. kolejno: „Elle” 2003, nr 10, s. 40; 2004, nr 5, s. 48; s. 52; 2003, nr 1, s. 60; nr 10, s. 40; 2005, nr 2, s. [42]; nr 9, s. 48; nr 7, s. 36-[37]; 2004, nr 1, s. 34; 2002, nr 9, s. 158; 2004, nr 10, s. [64]; 2005, nr 8, s. [39]; 2003, nr 4, s. 28; 2005, nr 12, s. [44]; nr 4, s. [42]; nr 12, s. [44]; 2004, nr 2, s. 40; 2001, nr 3, s. [45]; 2004, nr 2, s. 40; nr 7, s. [44]; 2003, nr 6, s. 26; 2004, nr 5, s. 52; 2005, nr 2, s. [42]; 2003, nr 7, s. 36. 
-Borawska zachęcała do sięgnięcia m.in. po książkę Kuchnia polska - potrawy regionalne i Wina Europy, zaś A. Niedzielska proponowała lekturę tytułu Zdrowo jeść: żywność i substancje lecznicze od A do Z. Omówienia te miały rozmaitą objętość: od kilku do kilkunastu zdań. Uzupełniały je kopie okładek danych książek i podstawowe informacje bibliograficzne na ich temat.

Prezentowane książki pochodziły z oferty 80 wydawców ${ }^{73}$. W tabeli 55 przedstawiono instytucje edytorskie, których dorobek wykorzystywano najczęściej w recenzjach pisma.

Tabela 55. Wydawcy najczęściej recenzowanych książek na łamach „Elle” w latach 2001-2005

\begin{tabular}{|l|c|}
\hline \multicolumn{1}{|c|}{ Nazwa wydawcy } & Liczba tytułów \\
\hline Wydawnictwo W.A.B. & $38^{a}$ \\
\hline Wydawnictwo REBIS & $34^{b}$ \\
\hline Wydawnictwo Muza & 34 \\
\hline Wydawnictwo Zysk i S-ka & 31 \\
\hline $\begin{array}{l}\text { Społeczny Instytut Wydawniczy } \\
\text { Znak }\end{array}$ & 24 \\
\hline Wydawnictwo Prószyński i S-ka & 21 \\
\hline Wydawnictwo Albatros & $20^{c}$ \\
\hline Wydawnictwo Literackie & 19 \\
\cline { 1 - 1 } Oficyna Literacka Noir sur Blanc & 11 \\
\hline Wydawnictwo Santorski \& S-ka & \\
\hline
\end{tabular}

$a$ W tym raz w koedycji z Wyd. Albatrosem.

${ }^{b}$ Raz w koedycji z BBC Books.

$c$ W jednym przypadku w koedycji z W.A.B.

Źródło: badania własne.

W tej grupie znaleźli się wydawcy znani na rynku (dwie pierwsze pozycje zajęli jedni $\mathrm{z}$ największych edytorów w tamtym okresie). Jednak poza znanymi oficynami, recenzenci sięgali także po propozycje pochodzące z oferty mniej znanych wydawców, takich jak na przykład Wydawnictwo Bonobo, Graffiti BC, Greybull Press, Wydawnictwo Mudra czy Kallisto, Pokolenie, Via Nova.

73 W 10 przypadkach nie podano nazwy wydawcy. Jednak na potrzeby pracy uzupełniono (poza dwoma wyjątkami) brakujące informacje na podstawie „Przewodnika Bibliograficznego" w wersji online, www.bnorg.pl/cgi-bin/makwww.exe?BM=23, kwiecień 2011. 


\subsubsection{Gonię kanarka na dachu ${ }^{74}$ : wywiady}

Podobnie, jak było to w przypadku magazynu „Twój Styl”, tak i na łamach „Elle” wywiady stanowiły istotną część pisma. Ale i tu bohaterami rozmów byli przeważnie aktorzy, modelki/modele albo żony polityków, biznesmenów, a znacznie rzadziej osoby związane z literaturą. Jednak w ciągu pięciu lat na łamach pisma pojawiły się także rozmowy z pisarzami. Było ich 75 . W tabeli 56 zaprezentowano ich liczbę w poszczególnych latach.

Tabela 56. Wywiady zamieszczone na łamach „Elle” w latach 2001-2005

\begin{tabular}{|c|c|}
\hline Rok & Liczba wywiadów \\
\hline 2001 & 27 \\
\hline 2002 & 11 \\
\hline 2003 & 11 \\
\hline 2004 & 15 \\
\hline 2005 & 11 \\
\hline Ogółem & 75 \\
\hline
\end{tabular}

Źródło: badania własne.

Wśród literatów, goszczących na łamach „Elle”, znaleźli się m.in.: Anna Bojarska, Anna Brzezińska, M. Cegielski, Stefan Chwin, Magdalena Dygat, Manuela Gretkowska, Katarzyna Grochola (dwukrotnie), Wojciech Kuczok, Zbigniew Mentzel, Tomasz Piątek, Małgorzata Saramonowicz, Izabela Sowa, Dorota Terakowska i Michał Witkowski. W kilku przypadkach rozmówcami byli także twórcy zagraniczni: Paulo Coelho, Etgar Keret, Eric Emmanuel Schmitt, Nicholas Sparks (zob. Aneks 44. Nazwiska osób związanych z książką, z którymi przeprowadzono wywiad na łamach „Elle” w latach 2001-2005).

Interesującym pomysłem redakcji był wybór osób, związanych ze znanymi pisarzami. I tak na przykład na łamach pisma pojawił się wywiad z Maurycym Gomulickim (prawnukiem Wiktora Gomulickiego, autora Wspomnień niebieskiego mundurka), Anne Goscinny (córką współtwórcy Mikołajka), podwójny wywiad z Carol Miłosz (drugą żoną Czesława Miłosza) oraz Erin Gilbert (jego wnuczką), Krystyną Krynicką (żoną Ryszarda Krynickiego), Mattchew Pritchardem (wnukiem Agathy Christie) oraz Willy Whartonem (synem autora $W$ księżycowq jasna noc). Czterokrotnie przeprowadzono wywiady ze współpracownikami magazynu: M. Cegielskim, B. Pawłowicz, R. Praszyńskim i D. Terakowską.

W większości przypadków rozmowy przeprowadzał R. Praszyński. Poza nim o sprawy interesujące czytelników „Elle” wypytywali pisarzy m.in.

${ }^{74}$ Tytuł wywiadu, zob. „Elle” 2005, nr 8, s. [72]-73. 
M. Barcz, Marek Cieszewski, Magdalena Jankowska, J. Lipszyc, Dominika Latałowska, B. Nowicka i B. Pawłowicz.

Ta forma informacji o świecie literackim zajmowała od kilkunastu zdań do czterech stron. W każdej znalazło się wprowadzenie, obejmujące charakterystykę rozmówcy, niekiedy także ogólny zarys tematów podejmowanych podczas wywiadu. W większości przypadków było ono kilkuzdaniowe, ale zdarzały się również całostronicowe prezentacje, będące swego rodzaju portretem rozmówcy, kreślonym z dużą dozą sympatii. Tak było na przykład w przypadku rozmowy z Jerzym Pilchem ${ }^{75}$. Poprzedzający ją obraz autora Pod Mocnym Aniołem to umiejętnie wybrane epizody z jego życia, potwierdzające jego wizerunek „miłośnika kobiet i trunków”, a jednocześnie ukazujące go jako człowieka, który „Wydaje się, że wszystko przeżył, wszystko wie, wszystko czytał. Zna się na ludziach i umie słuchać", choć jednocześnie „płaci dużą cenę za swoją przenikliwość. Jest egocentrykiem. Uwielbia czytać własne teksty"76. W następującej później rozmowie czytelnik poznawał członków rodziny J. Pilcha, którzy wywarli największy wpływ na jego życie, w mniejszym stopniu poruszane są w niej sprawy związane z pisarstwem. Podobnie było w przypadku wywiadu z W. Kuczokiem, gdzie R. Praszyński pytał przede wszystkim o sprawy związane z życiem osobistym pisarza, który m.in. wyznał: „Marzę o domu na wsi, w którym mógłbym zamieszkać z kobietą i dzieckiem”77 i przyznał: „Nie potrafię odnaleźć się $\mathrm{w}$ pewnych wymiarach codzienności. [...] Etatowa praca, dyspozycyjność, absurdalnie krótkie urlopy - to nie dla mnie"78. W tekście zamieszczono kopię okładki powieści Gnój, ale pojawiło się tylko jedno pytanie jej dotyczące.

Niemal w każdym przypadku na początku wywiadu znajdował się powszechnie stosowany „chwyt”: kilka zdań na temat rozmówcy, które miały przykuć uwagę czytelnika, rozbudzić jego ciekawość i spowodować, że przeczyta zamieszczony poniżej zapis rozmowy. O T. Piątku informowano:

Napisał wstrząsającą powieść „Heroina”. O młodych warszawiakach biorących narkotyki. 0 świecie, w którym nie ma miłości, moralności, prawdy. Poznał go doskonale. Sam brał79,

\section{o I. Sowie:}

Blondynka o niebieskich oczach. Bała się śmierci, więc poszła na terapię. Nie chciała mieć szefa, więc została pisarką. Jej powieści są bestsellerami 80 .

\footnotetext{
75 R. Praszyński, Chłopiec z kuszq, „Elle” 2001, nr 1, s. [60]-65.

76 Ibidem, s. 63.

77 R. Praszyński, Mózg mam normalny, „Elle” 2003, nr 7, s. 29.

78 Ibidem.

${ }^{79}$ R. Praszyński, Ja i heroina, „Elle” 2002, nr 6, s. 111.

80 R. Praszyński, Już mi lżej ze sobq, „Elle” 2003, nr 6, s. [88].
} 
O bohaterce kolejnego wywiadu, M. Dygat:

Przyjacielska. Ale złośliwa i humorzasta. W Ameryce i Polsce ma trzy domy. Nigdy nie pracowała. Zyskała rozgłos książką o ojcu. Właśnie wydaje drugą powieść81,

o A. Bojarskiej:

Orgia seksualna w domu amerykańskiego dziennikarza w Warszawie z udziałem polityków i aktorek. Niemieccy policjanci katują więźniów. Kto jest zły: policja czy terroryści? Żeby awansować, dziennikarka śpi z szefową lesbijką. To tematy powieści Anny Bojarskiej, pisarki nazywanej skandalistką. A jak wygląda jej prywatne życie? Czy zna terrorystów? Z kim romansowała? Czy jest podobna do Toski, bohaterki swojej powieści? ${ }^{82}$

Wywiady urozmaicane były zdjęciami, niekiedy także kopią okładki najnowszej książki pisarza i podstawowymi danymi bibliograficznymi na jego temat.

Założenie owych rozmów było podobne jak w przypadku „Zwierciadła” czy „Twojego Stylu”: starano się uwypuklić te wątki z życia rozmówców, które mogły zainteresować odbiorcę ekskluzywnego pisma kobiecego, jakim było „Elle”. Przyciągnięciu uwagi odbiorcy służyć miały również tytuły. Wśród najciekawszych znalazły się m.in.83: Chłopiec z kuszq, Człowiek z klanu, Dość biadolenia, Gonię kanarka na dachu, Jakaś moja prawda, Już mi lżej ze soba, Narzeczona Winnetou, Nie zostawię mamy, Piszę książki, których mi brakuje, Przychodzę ostatni, Skandalistka Anna B., Smoki, anioły i dzieci, Szczęście ma kształt serca, Zakochany po końce włosów, Zaprogramowana na szczęście.

Spełniały one z powodzeniem funkcję, jaką pełnią zazwyczaj hasła reklamowe w anonsach wydawniczych. Tych jednak na łamach omawianego magazynu było bardzo mało. Warto jednak przyjrzeć się tym, które trafiły do czytelników ciągu pięciu lat.

\subsubsection{Książka potrzebna czytelnikom ${ }^{84}$ : reklamy książek}

Podobnie, jak było to w przypadku „Twojego Stylu”, tak i na łamach „Elle” znalazło się bardzo dużo ogłoszeń. Wiekszość z nich dotyczyła jednak ubrań, kosmetyków, a także artykułów higienicznych. Bardzo niewielka

81 R. Praszyński, Wybaczyłam ojcu, „Elle” 2003, nr 5, s. [64].

82 B. Pawłowicz, Skandalistka Anna B., „Elle” 2002, nr 7, s. [74].

83 Zob. kolejno: „Elle” 2001, nr 1, s. 64-65; 2004, nr 7, s. [48]; nr 5, s. 52; 2005, nr 8, s. [72]-73; 2001, nr 10, s. [62]; 2003, nr 6, s. 88-89; 2001, nr 4, s. [46]; 2004, nr 3, s. 40-41; 2005 , nr 11, s. 56; 2003, nr 2, s. 66-69; 2002, nr 7, s. [74]-78; 2005, nr 10, s. [43]; 2004, nr 6, s. [78]-[79]; 2002, nr 4, s. [90]-92, 94; 2004, nr 3, s. [50].

${ }^{84}$ Hasło reklamowe jednego z anonsów, zob. „Elle” 2003, nr 6, s. [77]. 
część związana była z problematyką, ujętą w temacie tej pracy. Zaledwie 17 zaliczyć można do typowych inseratów wydawniczych ${ }^{85}$. Dodać do nich należy jednak dziewięć „ogłoszeń”, mających specyficzną formę, którą można umiejscowić na pograniczu recenzji i reklamy. Nieco większą grupę stanowiły ogłoszenia, reklamujące akcje, inicjowane bądź współorganizowane przez magazyn. Najliczniej reprezentowana była promocja innych czasopism, w tym również wydawanych przez Hachette Filipacchi.

Jakkolwiek liczba anonsów wydawniczych była niewielka, to jednak warto przytoczyć dane dotyczące każdego z badanych roczników pisma ${ }^{86}$ (tabela 57).

Tabela 57. Ogłoszenia wydawnicze zamieszczane na łamach „Elle” w latach 2001-2005

\begin{tabular}{|c|c|}
\hline Rok & Liczba inseratów książkowych \\
\hline 2001 & - \\
\hline 2002 & - \\
\hline 2003 & $13^{a}$ \\
\hline 2004 & 8 \\
\hline 2005 & 5 \\
\hline Ogółem & 26 \\
\hline
\end{tabular}

${ }^{a} \mathrm{~W}$ tej liczbie znalazło się dziewięć wspomnianych wcześniej, charakterystycznych reklam, które zostaną omówione w dalszej części podrozdziału.

Źródło: badania własne.

Większość reklam znalazła się w ramach działu kulturalnego, a tylko siedmiokrotnie pojawiły się one $w$ innych miejscach pisma. $W$ pięciu przypadkach w anonsie znalazł się więcej niż jeden tytuł książki. Raz były to dwie propozycje, a czterokrotnie trzy tytuły.

Czytelnikom „Elle” zaproponowano książki 19 autorów, w tym 11 polskich i 8 obcych. Trzykrotnie zachęcano do kupna książki współpracowników periodyku: dwukrotnie były to powieści D. Terakowskiej: Dobry adres to człowiek [pis. oryg.] oraz Ono, raz Dziennik Toskański T. Capponi-Borawskiej.

Reklamy obejmowały ofertę ośmiu wydawców. Byli to: Jacek Santorski \& Co, Lampa i Iskra Boża, POST, Wydawnictwo Prószyński i S-ka (ośmiokrotnie), Rosner \& Wspólnicy, Świat Literacki (dwukrotnie), Wydawnictwo

85 Niezależnie od powtarzalności reklamy danego tytułu.

${ }^{86}$ Ze względu na niewielką liczbę ogłoszeń wydawniczych zrezygnowano w tym przypadku z dwóch tabel, które zamieszczono w poprzednich rozdziałach, a które odwzorowywały tytuły najczęściej reklamowane na łamach danego pisma. 
Amber oraz Wydawnictwo Literackie. W ośmiu przypadkach nie podano nazwy wydawcy, ale dotyczyło to wspomnianej wcześniej charakterystycznej formy reklamy.

Większość z anonsów była niewielka objętościowo: obejmowała kolumnę na stronie. Jednak każda $\mathrm{z}$ nich była starannie przygotowana pod względem graficznym. Oto przykład - zdjęcia 138 i 139.

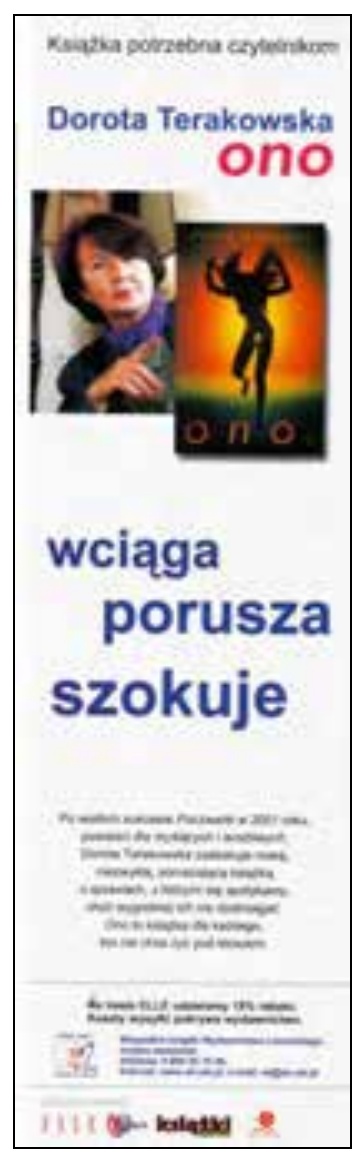

Zdjęcie 138. Wybrane ogłoszenie wydawnicze zamieszczone na łamach „Elle” „Elle” 2003, nr 6, s. [77]

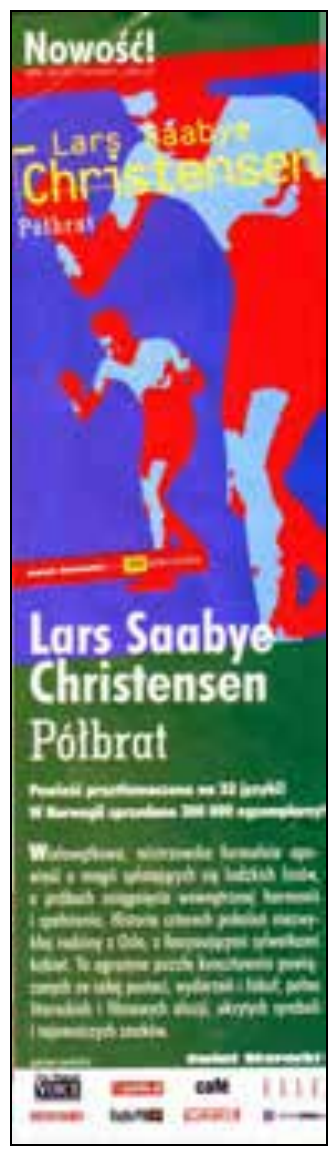

Zdjęcie 139. Wybrane ogłoszenie wydawnicze zamieszczone na łamach „Elle” „Elle” 2005, nr 1, s. [42]

W pierwszym przypadku reklamodawca przypominał odbiorcom poprzednią książkę autorki, powieść, która osiągnęła sukces. W określeniu potencjalnego adresata krył się rodzaj wyzwania, bo któż z czytelników „Elle” chciałby „żyć pod kloszem”? Hasła reklamowe były krótkie, ale to one zdawały się najbardziej zwracać uwagę i sygnalizować, że książka budzi 
silne emocje, nie tylko bowiem „wciąga”, ale i „porusza”, a nawet „szokuje”. Drugi anons przyciągał wzrok intensywnym czerwonym kolorem, wyraźnie odcinającym się od niebieskiego tła. Tu elementami, które miały przekonać czytelnika, stały się dwa fakty: tytuł został przetłumaczony na 33 języki, a liczba sprzedanych egzemplarzy osiągnęła pułap $3 \mathrm{mln}$.

Inaczej prezentowały się reklamy, w których proponowano jednocześnie kilka tytułów - zdjęcia 140-142.

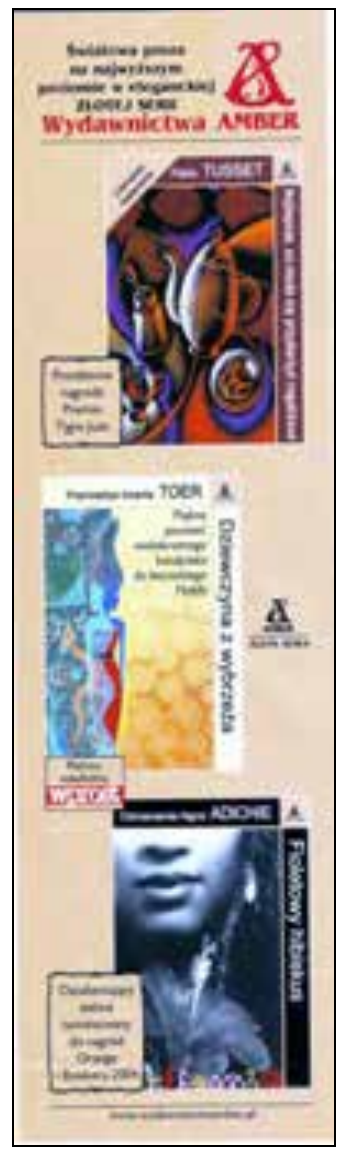

Zdjęcie 140. Wybrane ogłoszenie wydawnicze zamieszczone na łamach „Elle”

„Elle” 2004, nr 10, s. [64]

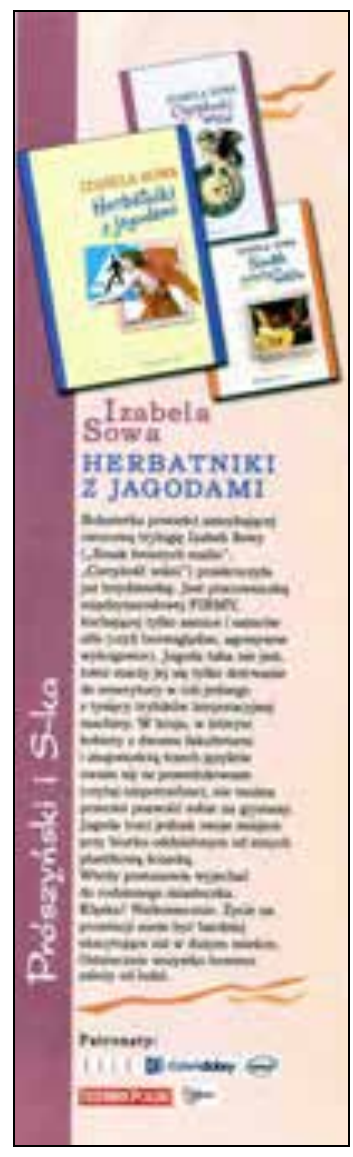

Zdjęcie 141. Wybrane ogłoszenie wydawnicze zamieszczone na łamach „Elle”

„Elle” 2003, nr 7, s. [97]

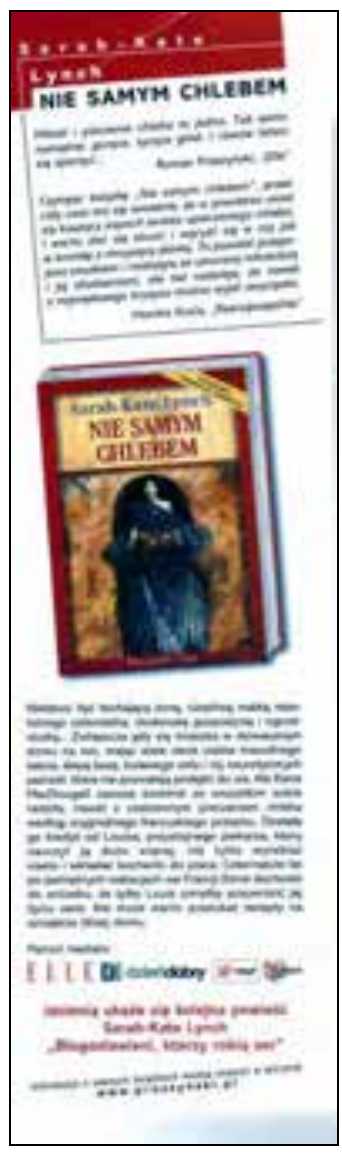

Zdjęcie 142. Wybrane ogłoszenie wydawnicze zamieszczone na łamach „Elle”

„Elle” 2004, nr 8, s. [40] 
W pierwszym inseracie zamieszczono kopie okładek proponowanych książek, przy których pojawiła się jednozdaniowa adnotacja: raz informująca o zdobytej przez książkę nagrodzie, następnie podkreślająca rangę autora, kilkakrotnego kandydata do Nagrody Nobla, i wreszcie mówiąca o nominacji do prestiżowych nagród literackich.

W drugiej reklamie pojawiły się kopie trzech okładek, ale nacisk położony został na jedną z książek, która zamykała trylogię; dalsze losy bohaterki dwóch wcześniejszych powieści zostały krótko naszkicowane, sugerując jednocześnie optymistyczne zakończenie.

W trzecim ogłoszeniu pojawił się nowy element: reklamodawca zacytował opinie dwóch recenzentów, przy czym jedną z nich było omówienie, drukowane na łamach „Elle”. I tu znalazła się krótka adnotacja, przybliżająca treść powieści. Zamieszczona została również zapowiedź kolejnej książki tej samej autorki. Elementem, łączącym wszystkie te reklamy, są kopie okładek proponowanych książek, a także wyrazista grafika anonsów.

Inną postać przybrała wspomniana powyżej ciekawa forma informacji o książce, która pojawiła się na łamach magazynu po raz pierwszy w numerze 4 w 2003 r. Drukowano ją w rubryce poświęconej książkom obok kolumny recenzyjnej w formie kilku zdań, zatytułowanych Uwaga, reklama! Po raz ostatni znalazła się ona w numerze 12 (2003). Niemal w każdym przypadku cytowano opinię autora o prezentowanej $\mathrm{w}$ ten sposób książce. Oto przykłady wybranych ogłoszeń - zdjęcia 143 i 144.

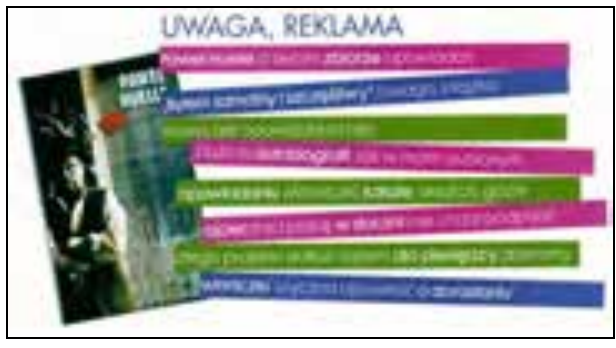

Zdjęcie 143. Wybrane ogłoszenie wydawnicze zamieszczone na łamach „Elle” „Elle” 2003, nr 4, s. 22

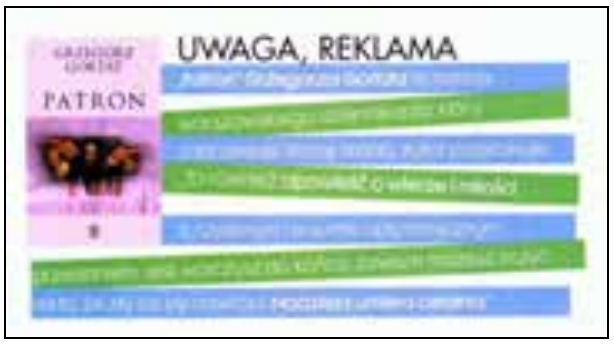

Zdjęcie 144. Wybrane ogłoszenie wydawnicze zamieszczone na łamach „Elle” „Elle” 2003, nr 7, s. 36

Stałym elementem była tu kopia okładki tak proponowanej książki, a także ciekawie rozmieszczone zdania. Charakterystyczny był fakt, że nie podawano nazwy wydawcy, choć na niektórych kopiach okładek była ona widoczna. Dzięki temu do czytelnika pisma dotarła informacja o dziewięciu tytułach dziewięciu różnych autorów (ośmiu rodzimych i jednym obcym). 
Pomimo pewnej oryginalności w tego rodzaju przekazie reklama wydawnicza była bardzo skromnie reprezentowana na łamach magazynu. Niewielka liczba proponowanych w ten sposób tytułów uniemożliwia głębszą analizę.

\subsubsection{Poezja dnia codziennego ${ }^{87}$ : inne formy informacji o książce}

Książka była obecna na łamach „Elle” przede wszystkim poprzez zamieszczane tu recenzje, omówienia, streszczenia i wywiady oraz w niewielkim stopniu reklamy. Poza tymi formami informacji o świecie literatury, sporadycznie pojawiały się także inne, chociaż ich liczba była niewielka (135). Wzorem wcześniej omawianych periodyków, zamieszczono poniżej wyodrębnione kategorie informacji, które można zaliczyć do grupy bezpośrednio lub pośrednio związanych z książką:

- portrety/sylwetki (8);

- artykuły, poświęcone sprawom książki lub rynku wydawniczo-księgarskiego, w tym teksty okolicznościowe (4);

- ekranizacje, adaptacje oraz inscenizacje znanych utworów (32);

- konkursy i akcje (14);

- inne (77).

Zwraca uwagę niewielka, w porównaniu z wcześniej omawianymi pismami liczba odpowiadająca każdej z kategorii. Nadto, poza ostatnią z wymienionych („inne”), są one bardzo skromnie prezentowane pod względem merytorycznym.

Jakkolwiek często przedstawiano sylwetki wybranych osób, to jednak bohaterami tego typu tekstów byli (podobnie jak w przypadku wywiadów) przede wszystkim aktorzy, piosenkarze, modele lub żony sławnych mężów, reprezentujących inne, poza kulturą, sfery życia. W ciągu analizowanych 5 lat zaledwie w 8 przypadkach przedstawiono postacie związane bezpośrednio lub pośrednio z literaturą. Byli to: Leszek Kołakowski, Toni Morrison, Krystyna Łubieńska ${ }^{88}$, R. Praszyński, Krzysztof Siwczyk, Wit Szostak, rodzina Szumowskich i D. Terakowska ${ }^{89}$.

Pamiętać jednak należy, że, jak wspomniano wcześniej, wiele wywiadów poprzedzonych było portretami rozmówców.

Druga kategoria tekstów była równie skromnie reprezentowana: zaledwie w czterech numerach pojawiły się publikacje, które podnosiły obszerniej kwestie związaną z książką. W numerze 3 (2002) pojawił się tekst

87 „Elle” 2003, nr 2, s. [146].

${ }^{88}$ Była ona wnuczką sportretowanej w Przedwiośniu przyjaciółki S. Żeromskiego.

${ }^{89} \mathrm{Z}$ powodu skromnej liczby portretów, a przede wszystkim ze względu na fakt, że ich bohaterowie byli (poza jednym wyjątkiem) tylko pośrednio związani z literaturą, nie opisywano szerzej tej kategorii, podobnie jak publikacji związanych z rynkiem książki. 
dotyczący komiksu. W numerze 6 (2001) opisywano rynek poradników seksualnych w Polsce, a w numerze 8 (2003) pisano o blogach jako o nowym rodzaju literatury. W numerze 2 (2001) pojawił się tekst o drugiej części książki H. Fielding i o ludziach, którzy identyfikują się z Bridget Jones.

Częściej pisano o ekranizacjach znanych dzieł lub ich inscenizacjach (32). Informacje te drukowano przede wszystkim w dziale kulturalnym, w różnych jego rubrykach, głównie tych poświęconych kinu lub teatrowi. Dwukrotnie znalazły się one w ramach odpowiednio Portretu Elle i Reportażu Elle. Zazwyczaj przybierały postać kilku lub kilkunastozdaniowych notek, choć w pięciu przypadkach zajęły odpowiednio: trzykrotnie cztery strony, raz dwie strony i raz jedną stronę w magazynie. Dzięki nim czytelnicy dowiedzieli się m.in. o ekranizacji Wiedźmina, ekranizacji powieści Ismaila Kadaré, ekranizacji Pornografii w reżyserii Jana J. Kolskiego, Pawła Huelle Weisera Dawidka, inscenizacji Mistrza i Małgorzaty Michaiła Bułhakowa czy o najbardziej kontrowersyjnym spektaklu Oczyszczeni Sarah Kann w reżyserii Krzysztofa Warlikowskiego.

Pisano także o IX Międzynarodowym Festiwalu Szekspirowskim w Trójmieście, o 14. edycji Międzynarodowego Festiwalu Teatralnym Malta w Poznaniu oraz przedstawiono relację (głównie zdjęciową) z XXIX Festiwalu Filmów Polskich.

Były to jednak przeważnie krótkie, powierzchowne informacje.

\subsection{Konkursy i akcje}

Także i ta forma promocji książki na łamach „Elle” była bardzo skromnie reprezentowana. Zaledwie 14 razy pojawiła się informacja związana z konkursami lub akcjami, nawiązującymi do zagadnień nas interesujących, przy czym tylko raz zamieszczono ją w formie reklamy.

Najważniejszą inicjatywą związaną z książką był konkurs o Złote Pióro na współczesną powieść dla kobiet, organizowany wspólnie z Klubem Świat Książki od 2001 r. Najlepszą nadesłaną pracę wybrać miało jury w składzie: K. Grochola, przedstawiciele „Elle” (E. Awdziejczyk, R. Praszyński) oraz reprezentanci Klubu (Bogdan Dąbrowski, Iwona Janas, Barbara Miecznicka) i sekretarz konkursu: Malwina Głowacka ${ }^{90}$. Główną nagrodą było wydanie i dystrybucja wybranej powieści, nadto na jej twórcę czekało wynagrodzenie autorskie. Poza nagrodą główną trzech uczestników otrzymywało wyróżnienia w postaci wiecznych piór (każde o wartości 2400 zł) ${ }^{91}$. Inicjatywa ta była promowana również w innych czasopismach, na przykład na

$90 \mathrm{~W}$ kolejnych edycjach zmieniał się nieznacznie skład jury, np. w 2002 r. pojawiła się w nim m.in. J. Kobus, kierująca działem kulturalnym w tygodniku „Wprost”.

91 [br. aut.], Konkurs o Złote pióro!, „Elle” 2001, nr 8, s. [39]. 
łamach tygodnika „Wprost”. Laureatami kolejnych edycji byli: Katarzyna Pisarzewska (Halo, Wikta!, 2002), Agnieszka Stefańska (Extra Vergine, 2003), Sławomir Górzyński (Babol, 2005) ${ }^{92}$. Z autorami nagrodzonych książek przeprowadzano wywiady, a w przypadku pierwszej edycji redakcja zaproponowała również konkurs, nawiązujący do wydanej książki-laureatki. Wystarczyło odpowiedzieć na dwa pytania i wziąć udział w losowaniu nagrody, którą była nagrodzona książka.

W ciągu pięciu lat była to jednak tylko jedna inicjatywa, którą można zaliczyć do konkursów literackich organizowanych przez magazyn. Raz pojawiło się także ogłoszenie dotyczące konkursu wydawnictwa Znak na książkę dla dzieci93. Sporadycznie znaleźć można również ogłoszenia, które pośrednio i w sposób luźny nawiązywały do książki, lub takie, w których była ona nagrodą. Na przykład w jednym z numerów pojawiło się pytanie, wymagające znajomości powieści Dziennik Bridget Jones lub jej ekranizacji $^{94}$. Inny konkurs polegał na przedstawieniu własnej deklaracji miłosnej w formie sms-owej, w kolejnym zaproponowano „Zadanie polegające na ułożeniu hasła reklamującego SPA jako nową filozofię pielęgnacji ciała"95. Jeśli proponowano czytelnikom „Elle” tego rodzaju wysiłek intelektualny, to były to głównie takie próby.

Ostatnią grupę informacji związanych z książką stanowi kategoria, określona mianem Inne (77). Wśród nich można wyróżnić dodatkowo kilka mniejszych grup.

Pierwsza z nich, najobszerniejsza, obejmuje krótkie (zazwyczaj kilkuzdaniowe) wzmianki, zapowiadające ukazanie się nowej książki na rynku, odnoszące się do wybranego, aktualnego epizodu z życia pisarza lub dotyczące innego faktu, zdarzenia czy miejsca, uznanego przez redakcję za wystarczająco ciekawe, by wzbudzić zainteresowanie czytelnika. Można tu wymienić informację o internetowej wypożyczalni książek, o stronach internetowych, poświęconych Małemu Księciu, ale i o wyjściu za mąż i urodzeniu dziecka przez H. Fielding, a także notkę o kapelach Pidżama Porno i Strachy na Lachy, które nagrały m.in. płytę z krakowskim poetą, M. Świetlickim, o poetyckim czacie www.multipoezja.onet.pl, gdzie zgromadzeni raz $\mathrm{w}$ tygodniu piszą wspólnie wiersz na wcześniej ustalony temat i gdzie każdy może wysłać propozycję własnej linijki. W tej grupie znalazła się też informacja na temat blogów w USA i Polsce, a wśród nich o jednym, którego autorka wydała swe zwierzenia drukiem, a książka stała się best-

\footnotetext{
92 W 2004 r. jury postanowiło nie przyznawać głównej nagrody.

93 „Elle” 2003, nr 5, s. 22.

94 „Elle” 2001, nr 10, s. [62].

95 [br. aut.], Wyniki konkursu, „Elle” 2001, nr 11, s. [18].
} 
sellerem. Czytelnicy magazynu dowiedzieli się także o pojawieniu się w sprzedaży m.in. takich książek, jak: Ładna kuchnia $w$ weekend oraz Teren prywatny (Barbary Kosmowskiej). Znaleźli również zapowiedzi wydawnicze: nowego tomiku poezji Beaty Pawłowicz Nad duszność wyjść rzeczy oraz ekskluzywnego wydania wszystkich kryminałów A. Christie. W formie krótkich notek polecano czytelnikom magazynu także sięgnięcie po wybrane książki, na przykład H. Fielding Przewodnik po życiu według Bridget Jones czy K. Grocholi Nigdy w życiu!.

Drugą z grup, mieszczących się w kategorii „inne” stanowią teksty, w których książka pojawiała się niejako „przy okazji”. I tak na przykład, A. Niedzielska pisząc o odchudzaniu, podawała informację, z jakich lektur korzystała (Michel Montignac: Jeść, aby schudnać i Dieta dla biznesmena). Na końcu publikacji dotyczącej małżeńskich konfliktów pojawiła się propozycja Poczytaj sobie i dane dotyczące dwóch książek (E.-E. Schmitt: Małe zbrodnie małżeńskie; R. Skynner, J. Cleese, Żyć w rodzinie i przetrwać) ${ }^{96}$.

Także niejako „przy okazji”, w tekstach poświęconych innym zagadnieniom, pojawiała się osoba pisarza (lub innego przedstawiciela świata książki) albo też jego opinia na dany temat. Na przykład w tekście stanowiącym rodzaj zbiorowego portretu współczesnych znanych trzydziestolatków zaprezentowano sylwetkę W. Kuczoka. W swego rodzaju sondzie na temat tego, co podoba się najbogatszym Polakom, pojawiły się zwierzenia Wiesława Uchańskiego, prezesa Wydawnictwa Iskry. W innej publikacji o kobietach opowiadał m.in. Piotr Diehl, także edytor.

W porównaniu z magazynami „Zwierciadło” czy „Twój Styl”, z „Elle” współpracowało niewielu pisarzy ${ }^{97}$. W badanym okresie jedynie D. Terakowska zamieszczała swoje felietony w stałym cyklu Elle opinie $\rightarrow$ Elle moim zdaniem (w latach 2003-2004). Inny autor, M. Cegielski, przygotowywał rubrykę muzyczną.

Trzykrotnie zamieszczono na łamach pisma fragmenty wybranych książek. Były to kolejno: komiks Tomek, Romek i A`Tomek ${ }^{98}$; pamiętnik Latify: Ukradziona twarz ${ }^{99}$, powieść K. Pisarzewskiej Halo, Wikta100.

96 „Elle” 2005, nr 12, s. 72.

97 Ich teksty także zaliczono do kategorii Inne, podobnie jak fragmenty powieści, drukowane na łamach pisma.

98 „Elle” 2001, nr 8, s. 40.

99 "Elle" 2002, nr 2, s. 76.

100 „Elle” 2002, nr 5, s. 106. 


\subsubsection{Gazeta jak rolls-royce ${ }^{101}$. Inne informacje: o prasie i środowisku dziennikarskim}

Informacje związane z prasą pojawiały się na łamach magazynu w dwojakiej formie: jako dłuższe teksty lub krótkie wzmianki oraz w postaci reklam.

W pierwszej grupie wyodrębniono 37 pozycji. Część z nich znaleźć można było $\mathrm{w}$ dziale kulturalnym, inne pojawiały się $\mathrm{w}$ ramach rubryk: Adresy Elle, Elle demaskuje, Flesz Elle, Koneksje, Ranking Elle, Reportaż Elle. Niemal połowa $\mathrm{z}$ nich zajmowała przynajmniej stronę $\mathrm{w}$ piśmie, pozostałe miały objętość kilkunastu zdań.

W numerze lipcowym w 2005 r. ukazał się reportaż, związany z jubileuszem 60-lecia „Tygodnika Powszechnego”102. B. Nowicka przypomniała historię pisma, jego współpracowników, przytaczając jednocześnie ich wspomnienia związane z pracą w redakcji.

Był to jednak jedyny przykład tego typu tekstu; pozostałe wydają się znacznie bardziej wpisywać w politykę pisma. I tak Aneta Kołaszewska pisała o dziennikarzach śledczych ${ }^{103}$, a M. Barcz o paparazzich ${ }^{104}$. Kilkakrotnie pojawiły się również relacje, głównie zdjęciowe, z rozmaitych imprez prasowych, na przykład z wręczenia Paszportów „Polityki”105, a także Złotych Kaczek, nagród magazynu „Film”106 czy z Balu Dziennikarzy ${ }^{107}$.

Kupujący „Elle” mogli dowiedzieć się także m.in. o tym, jakie są różnice w czytaniu gazet przez kobiety i mężczyzn, i o tym, że brytyjski magazyn „Tatler” ogłosił listę osób najchętniej zapraszanych na przyjęcia. Na łamach periodyku znalazła się również notka o pojawieniu się nowego magazynu $A 4$, poświęconego „modzie, kulturze i stylowi życia”, o gazecie australijskiej „Not is Magazine”, o formacie 1,5 m na $2 \mathrm{~m}$ czy o specyficznym wydaniu magazynu „Visionaire”, wypalonym laserem.

Drugą grupę informacji związanych z prasą stanowiły reklamy. Były to przede wszystkim ogłoszenia promujące inne periodyki. Takich anonsów było w ciągu 5 lat 183. Pojawiły się w nich rozmaite tytuły różnych periodyków, a wśród nich m.in.: „Aktivist”, „Avanti”, „Cztery kąty”, „Logo”, „Marie Claire”, „Kobieta” [magazyn interaktywny], „Maxim”. Najczęściej jednak powtarzały się reklamy promujące tytuły wydawnictwa Hachette Filipacchi: „Elle Decoration” (38 razy), „Film” (47 razy) i „Samo Zdrowie” (42 razy). Oto wybrane przykłady ogłoszeń (zdjęcia 145 i 146):

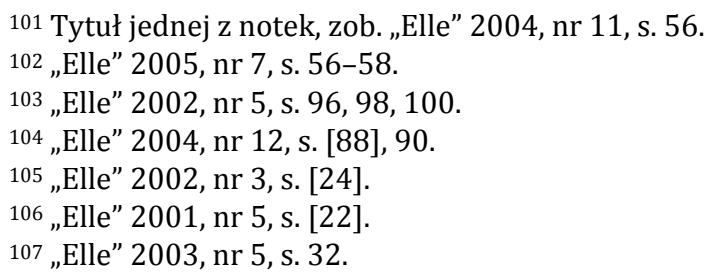




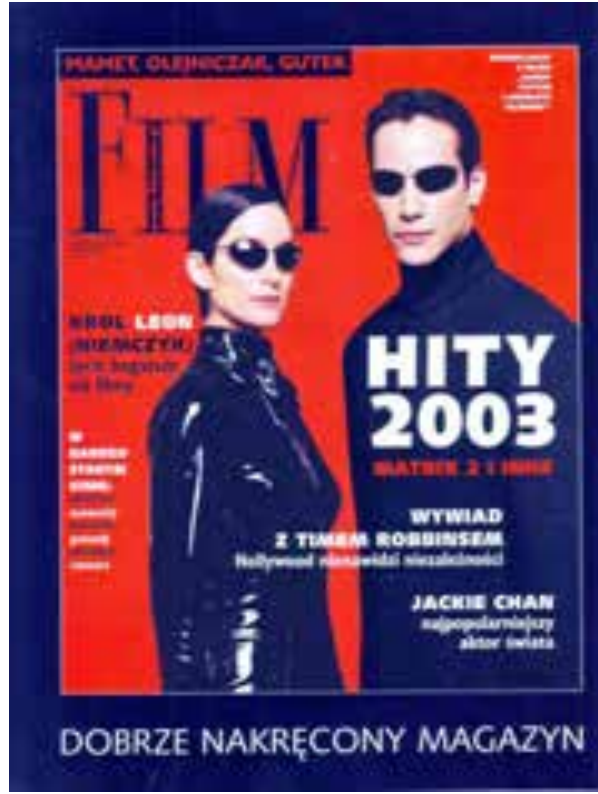

Zdjęcie 145. Wybrane ogłoszenie wydawnicze zamieszczone na łamach „Elle” „Elle” 2003, nr 1, s. [54]

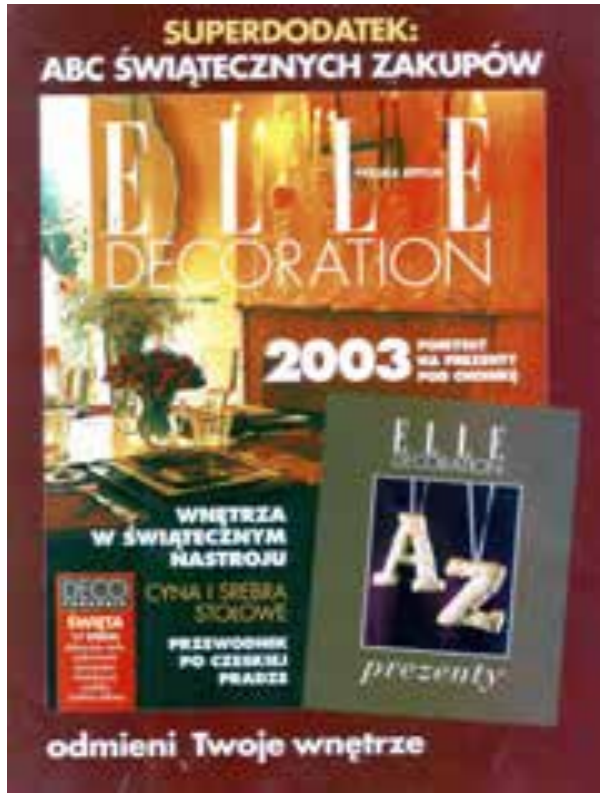

Zdjęcie 146. Wybrane ogłoszenie wydawnicze zamieszczone na łamach „Elle” „Elle” 2003, nr 1, s. [36]

Uwagę czytelników zwracały ciekawie dobrane kolory. Jednocześnie każda z reklam składała się z tych samych elementów: kopii okładki polecanego periodyku i hasła reklamowego, oddające charakter danego pisma.

Znaczną grupę stanowiły reklamy promujące „Elle”: ich przedmiotem była prenumerata magazynu, zapowiedź następnego numeru, nierzadko $\mathrm{z}$ „prezentem” w postaci torby, kosmetyczki lub filmu na płycie dvd. Poza czasopismami reklamowano także Charytatywny Bal Dziennikarzy i samą prasę. I w tym przypadku, podobnie jak było to we wcześniej omawianych periodykach, ogłoszenia te miały oryginalny wygląd (zdjęcie 147). 


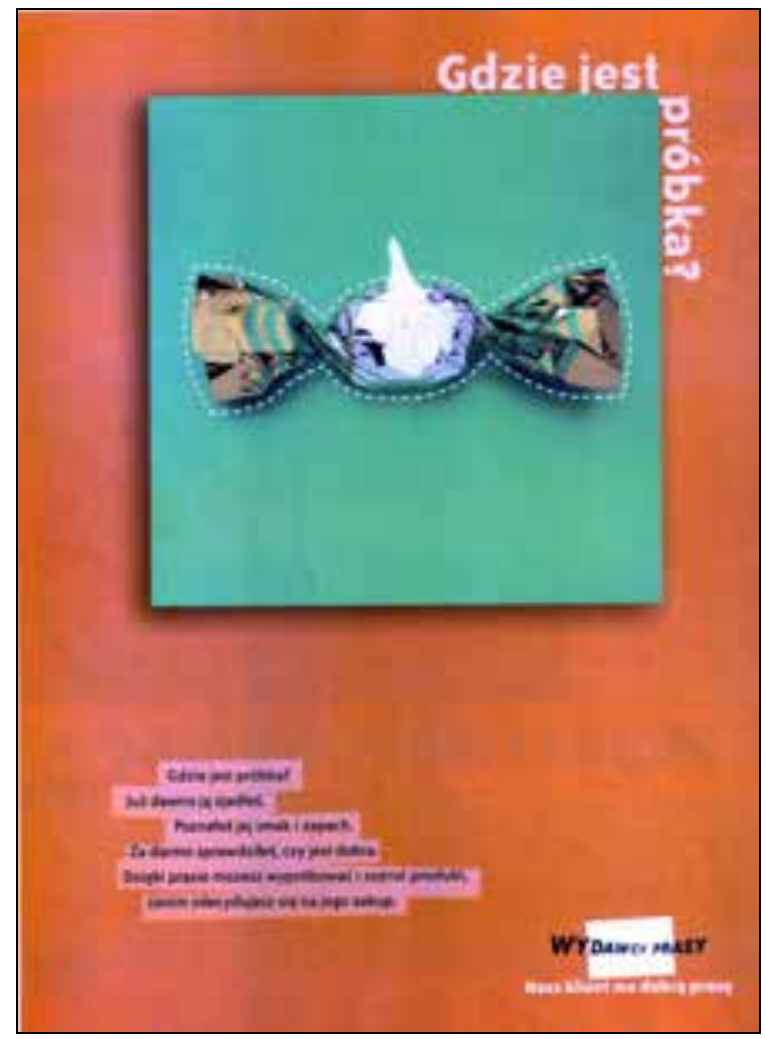

Zdjęcie 147. Wybrane ogłoszenie wydawnicze zamieszczone na łamach „Elle” „Elle” 2003, nr 5, s. [78]

Pomimo niewielkiej liczby elementów, składających się na powyższe reklamy, zwracały one uwagę odbiorcy swoją oryginalnością.

Podsumowując, magazyn „Elle”, jak wykazała analiza, okazał się najmniej otwarty na sprawy związane z książką. Recenzje, zamieszczane w badanym okresie, w większości przypadków były powierzchowne, bliżej im było do wzmianek niż do rzetelnego omówienia. Reklam wydawniczych pojawiało się bardzo mało, podobnie tekstów poruszających kwestie związane $\mathrm{z}$ literaturą, $\mathrm{w}$ tym książką. Jakkolwiek pismo uznawano za typowy tytuł poświęcony modzie, to jednak samo kwalifikowało się do periodyków z tzw. wyższej półki, aspirując do miana ekskluzywnego magazynu dla kobiet. Jednak nie do końca spełniało założenia związane $\mathrm{z}$ tego typu pismem. Pomimo, że zagadnieniom kultury poświęcano kilka stron, a nawet przeznaczono nań oddzielny dział, to kwestie dotyczące 
książki były $\mathrm{w}$ nim traktowane marginalnie. Dobór lektur był jeśli nie przypadkowy, to oparty na trudnym do uchwycenia jednoznacznym kryterium. W przypadku innych form informacji o książce takim czynnikiem, co warto powtórzyć, zdawała się być moda. Zaletą działu i zamieszczonej w nim rubryki książkowej, podobnie jak całego magazynu, była grafika. Można chyba pokusić się o stwierdzenie, że w przypadku tego tytułu, i w odniesieniu do interesujących nas zagadnień przeważnie forma brała górę nad treścią. 


\subsection{Po stronie kobiet ${ }^{1}$ : „Zwierciadło”, „Twój Styl”, „Elle” a książka - wnioski porównawcze}

Jak już stwierdzono, prasa kobieca po 1989 r. rozwijała się najprężniej; to właśnie w tej grupie pojawiło się najwięcej nowych czasopism o zasięgu ogólnopolskim. Niewielu tytułom zakorzenionym na rynku udało się przetrwać walkę o czytelnika (należało do nich „Zwierciadło”), inne zaś wzorowały się na periodykach zachodnich (jak na przykład „Twój Styl”) bądź stanowiły polską edycję pism zagranicznych (m.in. „Elle”) lub były ich kalkami (znaczna część pism z tzw. dolnej półki).

Poddane analizie tytuły należały do tego samego segmentu prasy: ekskluzywnych magazynów, adresowanych do „kobiet sukcesu”. Miały zatem do spełnienia zbliżone cele, pełniły podobne funkcje, a ich zawartość koncentrowała się wokół tych samych bloków tematycznych (praca i rodzina, zdrowie, moda i uroda, rozwój emocjonalny i duchowy kobiety, kultura/rozrywka).

Jednak każdy z analizowanych tytułów miał swoją wyraźną specyfikę, odróżniającą go od pozostałych.

Jakkolwiek tematyka wszystkich trzech była zbliżona (co wynikało z ich definicji), to już na tym poziomie można wyodrębnić pewne różnice pomiędzy nimi. Na łamach „Zwierciadła” widać największe (w porównaniu $\mathrm{z}$ „Twoim Stylem” i „Elle”) zainteresowanie zagadnieniami dotyczącymi wychowania i równie duże, charakterystyczne dla tego miesięcznika, zaangażowanie $\mathrm{w}$ kwestie związane $\mathrm{z}$ psychologią, psychoanalizą i nowoczesnymi technikami terapeutycznymi.

Natomiast „Twój Styl” zdawał się najbardziej wpisywać w formułę ekskluzywnego magazynu kobiecego. W dużym stopniu podporządkowywał on zawartość swej naczelnej idei: promocji działań, dzięki którym kobieta osiągnie w każdej dziedzinie sukces, pogodzi życie zawodowe z prywatnym, zachowując przy tym urodę, a wszystko to zawdzięczając sile, którą rozwinie $\mathrm{w}$ sobie m.in. dzięki poradom, zawartym w czytanym przez siebie piśmie.

Z kolei „Elle” w największym spośród opisanych tytułów stopniu zajmował się modą i jak już zostało podkreślone, było pismem „modowym”, podporządkowanym trendom $w$ różnych dziedzinach życia, poczynając od prezentacji kolekcji ubrań, poprzez nowoczesne urządzenie domu, a kończąc na nowinkach ze świata kultury, nierzadko ocierających się o plotkę i sensację. Było pismem w pewnym sensie po prostu snobistycznym.

1 J. Pieńkowska, Po stronie kobiet, „Twój Styl” 2005, nr 12, s. 90. 
O ile forma przekazu była podobna w przypadku dwóch pierwszych miesięczników, o tyle na łamach trzeciego z nich czytelnik odnajdował treści podane w lżejszej, ale jednocześnie nierzadko powierzchownej formie.

Z deklaracji redakcyjnych wynikało, że „Zwierciadło” i „Twój Styl” adresowano do kobiet $\mathrm{w}$ niemal tym samym przedziale wiekowym (analogicznie: 20-44 lata, 20-50 lat), jednak zawartość obydwu periodyków zdawała się wskazywać, że dane te należałoby odwrócić: pierwszy z tytułów mógłby zainteresować starsze od czytelników „Twojego Stylu” audytorium. Natomiast „Elle” wyraźnie skierowane było do kobiet, które nie przekroczyły 40 lat. Przypominało niekiedy bardziej periodyk adresowany do starszych dziewcząt niż dojrzałych kobiet.

Interesujące spostrzeżenie wynika z porównania konkursów i akcji związanych z książką, przeprowadzanych szczególnie przez dwa pierwsze tytuły, które były pomysłodawcami licznych przedsięwzięć tego typu. Zarówno na łamach jednego, jak i drugiego, pojawiła się propozycja pisania dzienników przez czytelników: konkurs Dzień po dniu to pomysł, który odnaleźć można w „Zwierciadle” (po raz pierwszy zaproponowano go w 2004 r.), a Miesiq̨c z życia kobiety to inicjatywa „Twojego Stylu” (po raz pierwszy zorganizowana w 1998 r.). Kolejny podobny projekt to konkurs poetycki o tematyce miłosnej („Zwierciadło”: Snuć miłość; „Twój Styl”: wiersz o miłości). Nadto zwyczajem obydwu periodyków było przedstawienie określonego tematu, na który czytelnicy napisać mieli opowiadanie lub esej, zaś autorzy najlepszych prac otrzymywali nagrody, niejednokrotnie książkowe. Jednym z przykładów był konkurs adresowany tylko do kobiet: Życie zaczyna się po czterdziestce, to temat zaproponowany przez „Zwierciadło”. Z kolei „Twój Styl” zadał swym czytelniczkom pytanie: Kiedy współczesna kobieta czuje się kobietą? Już choćby w tym przypadku widoczny był charakter obydwu miesięczników: pierwszy stawiał na praktyczną stronę życia, zaś w podtekście proponowanego tematu pojawiał się z jednej strony optymizm („zaczyna się...”), z drugiej - gotowość do pocieszenia tych, dla których granica 40 lat życia jest trudną do przejścia barierą. Natomiast w temacie zaproponowanym przez „Twój Styl” pojawił się pewien rodzaj intymności, podkreślenie kobiecości, a więc tych kwestii, które często były podnoszone przez magazyn („Urodziłam się kobietą - więc chcę żyć jak kobieta, korzystać z atrybutów swojej kobiecości i mieć świadomość, że nie jestem ani mniej, ani więcej od mężczyzny warta; jestem po prostu inna"2). Tradycją stały się również konkursy sms-owe, obecne na łamach dwóch pierwszych tytułów. Natomiast $\mathrm{w}$ przypadku trzeciego $\mathrm{z}$ omawianych

${ }^{2}$ Fragment jednej z nadesłanych na konkurs prac. [br. aut.], Oblicza kobiecości, „Twój Styl" 2001, nr 9, s. [186]. 
magazynów, „Elle”, ta forma informacji o książce była niezwykle skromnie prezentowana. Jedyną tego typu inicjatywą był bowiem, przypomnijmy, konkurs o Złote Pióro, zorganizowany wspólnie z Klubem Świat Książki, w którym proponowano czytelnikom, by spróbowali swych sił jako autorzy współczesnej powieści dla kobiet.

Podobnie periodyk ten nie zapisał się w owym czasie w ogólnej świadomości odbiorców mediów szczególnie spektakularnymi akcjami, plebiscytami czy rankingami o charakterze ogólnym, już nie związanymi z książką. Trofea Elle kojarzone były przede wszystkim przez celebrytów i osoby zainteresowane modą. Z kolei dwie inne akcje: Kobieta Bezpieczna oraz Dzieci ulicy, jakkolwiek potrzebne, ważne i wartościowe, nie były jednak na tyle szeroko rozpropagowane, by dotrzeć do szerokiego odbiorcy. Nieco lepiej przedstawiała się w tym względzie sytuacja „Zwierciadła”, aczkolwiek i w tym przypadku organizowane przezeń akcje miały przeważnie stosunkowo wąskie grono odbiorców, ograniczone w znacznej mierze do czytelników pisma. To oni przede wszystkim wiedzieli o istnieniu Instytutu Psychospołecznego Zwierciadło, choć jednocześnie Kryształowe Zwierciadła znało już więcej osób (choćby słuchacze radia).

Inaczej było w przypadku akcji, organizowanych przez „Twój Styl”. Hasło Doskonałość Roku kojarzone było przez wiele kobiet, nie tylko czytelniczek magazynu. Jednak jego niewątpliwą zasługą, o zupełnie innym charakterze, było zwrócenie uwagi na problem związany z chorobą raka piersi i systematyczne organizowanie nawiązującej doń kampanii: Zdq̨żyć przed rakiem. Październik miesiq̨cem szansy.

I to właśnie ten miesięcznik był najczęściej nagradzany, podobnie jak jego współpracownicy. Zarówno „Zwierciadło”, jak i „Elle”, jakkolwiek także uhonorowane kilkoma tytułami czy wyróżnieniami, pozostawało w tym względzie rzadziej dostrzegane.

Każdy z periodyków kilkakrotnie zmieniał szatę graficzną, chociaż w okresie objętym tematem pracy owe modyfikacje były nieduże. Zbliżona była również objętość pojedynczych numerów każdego z magazynów: „Zwierciadło” obejmowało średnio 180 stron, „Twój Styl” liczył ich 200, a „Elle” trafiało do czytelników w objętości ok. 178 stron.

Najwięcej miejsca na informacje kulturalne, w które wpisywały się materiały związane z książką, poświęcał „Twój Styl” (12 stron, środkowa część magazynu), drugie miejsce zajmowało „Zwierciadło” (10 stron, także środkowa część pisma), ostatnie przypadło „Elle” (7 stron, w pierwszej części danego wydania). Jednak największe zainteresowanie problematyką dotyczącą literatury przejawiał najstarszy z badanych periodyków. W tabeli 58 zaprezentowano dane statystyczne obrazujące stopień zaangażowania każdego z miesięczników w promowanie literatury, w tym książki. 
Tabela 58. Porównanie liczby informacji o książce na łamach magazynów: „Zwierciadło”, „Twój Styl”, Elle” w latach 2001-2005

\begin{tabular}{|l|c|c|c|}
\hline \multicolumn{1}{|c|}{ Wyszczególnienie } & „Zwierciadło” & „Twój Styl” & „Elle” \\
\hline Recenzje, omówienia, streszczenia & 407 & 262 & 444 \\
\hline Wywiady & 58 & 73 & 75 \\
\hline Reklamy książek & 150 & 77 & 26 \\
\hline Portrety/sylwetki & 70 & 35 & 8 \\
\hline $\begin{array}{l}\text { Artykuły, poświęcone sprawom książki } \\
\text { lub rynkowi wydawniczo-księgarskiemu }\end{array}$ & 37 & 22 & 4 \\
\hline Ekranizacje, adaptacje, inscenizacje & 27 & 45 & 32 \\
\hline Konkursy i akcje & 157 & 65 & 14 \\
\hline Listy bestsellerów & - & 2 & - \\
\hline $\begin{array}{l}\text { Listy czytelników, nawiązujące do zamie- } \\
\text { szczonej informacji związanej z książką }\end{array}$ & 14 & 7 & 2 \\
\hline Inne & 345 & 312 & 77 \\
\hline Ogółem & 1265 & 900 & 682 \\
\hline
\end{tabular}

Źródło: badania własne.

Pomimo, że przewaga liczbowa „Zwierciadła” nad dwoma pozostałymi tytułami nie jest tak duża jak w przypadku „Polityki”, dystansującej swych rywali $\mathrm{w}$ tym względzie, to jednak porównując te dane $\mathrm{z}$ analogicznymi przypadającymi w udziale „Elle”, zauważamy, że (pomimo niektórych kategorii), jest ona niemal dwukrotnie większa. Jednocześnie, jak dowiedziono tego $\mathrm{w}$ analizie, każdy $\mathrm{z}$ rodzajów informacji, uwzględnionych w tabeli 58, a zamieszczonych na łamach „Zwierciadła”, cechował się większą rzetelnością, dokładnością, a w przypadku reklam - starannością przygotowania. Największe dysproporcje wystąpiły w przypadku „Zwierciadła” i „Elle”. Liczba inseratów wydawniczych, jaka pojawiła się na łamach polskiej edycji francuskiego magazynu, stanowi zaledwie ok. piątą część wszystkich ogłoszeń tego typu, którą odnaleźć mógł czytelnik „Zwierciadła”. Liczba portretów osób, związanych ze światem literackim, drukowanych w obydwu periodykach, także zwraca uwagę: 70 („Zwierciadło”), 8 („Elle”).

„Twój Styl”, w kontekście danych statystycznych, plasuje się na miejscu drugim, jednocześnie pod względem sposobu przygotowania publikacji zdecydowanie zbliżając się do „Zwierciadła”.

Warto przyjrzeć się, jak wyglądała średnia tego typu publikacji, przypadającą na jeden numer, przedstawiona w tabeli 59. 
Tabela 59. Średnia liczby informacji, przypadająca na 1 numer $^{a}$

\begin{tabular}{|l|c|c|c|}
\hline \multicolumn{1}{|c|}{ Wyszzczególnienie } & $\begin{array}{c}\text { „Zwierciadło” } \\
\text { (60 numerów) }\end{array}$ & $\begin{array}{c}\text { „Twój Styl” } \\
\text { (60 numerów) }\end{array}$ & $\begin{array}{c}\text { „Elle” } \\
\text { (60 numerów) }\end{array}$ \\
\hline $\begin{array}{l}\text { Recenzje, omówienia } \\
\text { i streszczenia }\end{array}$ & 6,7 & 4,36 & 7,4 \\
\hline Wywiady & 0,8 & 1,21 & 1,25 \\
\hline Reklamy książek & 2,5 & 1,28 & 0,43 \\
\hline Konkursyb & 2,61 & 1,08 & 0,23 \\
\hline $\begin{array}{l}\text { Artykuły, poświęcone } \\
\text { sprawom książki lub } \\
\text { rynkowi wydawniczo- } \\
\text {-księgarskiemu }\end{array}$ & 0,6 & 0,36 & 0,06 \\
\hline Innec & & & 1,28 \\
\hline
\end{tabular}

a Pominięto pozostałe kategorie, podane w tabeli 58, ponieważ liczby w tych przypadkach były zbyt małe lub nie wnosiły nic dostatecznie charakterystycznego do każdego z porównywanych pism. W dalszej części rozdziału bardziej szczegółowo omówiono różnice i podobieństwa dotyczące 1) recenzji, 2) reklam oraz 3) wywiadów, jako że te formy informacji o książce w najbardziej charakterystyczny sposób wskazywały na przesłanie każdego z periodyków.

${ }^{b}$ Wprowadzono dodatkową kategorię, w porównaniu z analogiczną tabelą, zamieszczoną $\mathrm{w}$ rozdziale porównującym prasę opinii, ponieważ uznano, że w przypadku czasopism kobiecych konkursy czy akcje przez nie organizowane są ważnym przyczynkiem do dalszych porównań.

${ }^{c} \mathrm{~W}$ tej kategorii znalazły się m.in. felietony pisarzy, fragmenty powieści, opowiadania, a także krótkie wzmianki, związane z książką, nierzadko o charakterze ciekawostek.

Źródło: badania własne.

W obydwu przypadkach zwraca uwagę przewaga recenzji, omówień i streszczeń w przypadku miesięcznika „Elle”. Jednak ich analiza (o czym dokładniej pisano w rozdz. 3.4) utwierdzić może w przekonaniu, że ilość $\mathrm{w}$ tym przypadku nie idzie $\mathrm{w}$ parze $\mathrm{z}$ jakością i pozwala jednocześnie rozwiać złudzenia, że do czytelników trafiała rzetelna informacja o książce, jaką powinna być recenzja, drukowana w periodyku, mieniącym się pismem adresowanym do wykształconych i ambitnych kobiet, „liderek opinii”3.

Drugą kategorią, w której magazyn ten miał liczbową przewagę nad swymi konkurentami, były wywiady. Te z kolei stanowiły zaletę pisma. Trzecia grupa informacji, która zostanie dokładniej omówiona (reklamy książek) w żadnym z przypadków nie prezentowała się zbyt okazale.

W „Zwierciadle” i „Elle” dominującą formą informacji o książce były recenzje, omówienia i streszczenia, natomiast w „Twoim Stylu” najliczniejszą grupę stanowiła kategoria Inne.

${ }^{3}$ http://www.mediabuy.pl/prasa/Elle/, kwiecień 2011. 
Strony recenzyjne w ciągu badanego okresu kilkakrotnie ulegały zmianom, opisanym w poszczególnych rozdziałach, ale porównując każdą z propozycji, należy podkreślić, że w sposób najbardziej profesjonalny przygotowywane były na łamach „Zwierciadła”. Spostrzeżenie to dotyczy w równym stopniu formy omówień, informacji bibliograficznych (wśród których znalazły się takie elementy, jak: autor, tytuł, nazwa wydawcy, miejsce i rok wydania, przeważnie także nazwisko tłumacza w przypadku przekładu), jak i wartości merytorycznej recenzji. Natomiast „Elle” oferowało swoim czytelnikom przez część analizowanego okresu bardzo krótkie, 1-2-zdaniowe wzmianki lub nieco tylko dłuższe adnotacje treściowe. Początkowo zajmowały one jedynie kolumnę (w jednym numerze drukowano kilka takich informacji), obok innych informacji, a raczej ciekawostek kulturalnych, dopiero w 2003 r. poświęcono im całą stronę, jednak i wtedy w większości przypadków były one pobieżne.

Od strony graficznej wskazać można kilka cech wspólnych omówień zamieszczanych na łamach trzech charakteryzowanych magazynów: w każdym dużą rolę odgrywały kopie okładek proponowanych książek, w różny sposób eksponowane. $\mathrm{W}$ rozmaitym czasie elementem dodatkowym stawało się zdjęcie recenzenta, przy czym w przypadku specyficznej dla „Zwierciadła” drugiej rubryki recenzyjnej (Moje książki Renaty ArendtDziurdzikowskiej) było ono obecne przez cały badany okres.

Pomijając tę charakterystyczną dla „Zwierciadła” rubrykę, najbardziej wyrazisty obraz wyłaniał się z omówień, zamieszczanych na łamach „Twojego Stylu”. Czytelnikom proponowano książki, które poruszały tematy, mogące zainteresować w większym stopniu kobiety niż męską część odbiorców periodyku. Wśród nich miłość była bardzo często głównym wątkiem, a bohaterka nierzadko posiadała cechy i osobowość, preferowane przez magazyn: była silną, ale opiekuńczą, wrażliwą, ale odważną, pełną życiowych pasji, ale skrycie tęskniącą za pięknem i romantyzmem kobietą.

Natomiast w przypadku „Zwierciadła” w podstawowej rubryce recenzyjnej tego magazynu pojawiały się książki, które tworzyły bogaty konglomerat różnych wątków, choć i tu bohaterkami nierzadko były kobiety uwikłane w rozmaite problemy, tragedie i zdarzenia, ciążące na ich życiu.

Z kolei na łamach „Elle”, zgodnie ze zwyczajem, wpisującym się w ideologię pisma, proponowano książki przede wszystkim „modne” lub przynajmniej te, których autorzy byli w danym czasie popularni.

W każdym z przypadków większość książek stanowiły nowości wydawnicze, przy czym wiele z nich otrzymywało od recenzenta pozytywną ocenę (najwięcej uwag krytycznych odnaleźć można na łamach „Elle”, choć ograniczano się tu do krótkich, kąśliwych spostrzeżeń, rzadko uzasadnianych). 
Pomijając rubrykę Moje książki, znajdującą się na łamach „Zwierciadła”, zbadano, czy książki, proponowane przez recenzentów trzech magazynów spotykały się we wspólnym punkcie, tworząc rodzaj kanonu lektur adresowanych do kobiet.

W grupie pisarzy, których książki omawiano na łamach każdego z trzech charakteryzowanych magazynów, znalazły się 34 nazwiska. Przeważali pisarze znani, choć zróżnicowani pod względem typu uprawianej literatury, jak na przykład John M. Coetzee, Umberto Eco, Helen Fielding, Janusz Głowacki, John Irving, Wojciech Kuczok, Arturo Pérez-Reverte, Olga Tokarczuk. Pojawili się wśród nich także autorzy znani węższemu kręgowi odbiorców, m.in. Hella Haasse czy Mary Morrissy.

Najbardziej zaskakujące okazało się zestawienie autorów wspólnych dla „Zwierciadła” i „Elle”. W tej grupie pojawiło się bowiem najwięcej nazwisk (57). Dwa różniące się od siebie w dość dużym stopniu periodyki, niespodziewanie wykazały największą zbieżną płaszczyznę zainteresowań. Wśród „wspólnych” pisarzy znaleźli się Jonathan Carroll, Paulo Coelho, Agnieszka Graff, Katarzyna Grochola, ale także Roma Ligocka, Hanna Samson i Wisława Szymborska. W dużej części byli to zatem autorzy książek bądź ambitniejszych (odpowiadających tym samym aspiracjom „Zwierciadła”), bądź „modnych” w tamtych latach (czyli spełniających kryteria „Elle”).

Najskromniejszą liczbowo grupę stanowiły nazwiska pisarzy wspólnych dla „Zwierciadła” i „Twojego Stylu” (24), co prowadzi do konkluzji, że magazyny te, jakkolwiek zbliżone do siebie m.in. sposobem prezentacji proponowanych tematów, starały się jednak wyróżnić, nadając sobie indywidualny charakter. W obydwu redakcjach pamiętano jednak o głównym adresacie, jakim były kobiety, stąd i w tym przypadku można było wyodrębnić wspólną listę autorów recenzowanych książek. Wśród pisarzy znajdujących się w tej grupie pojawili się m.in. Jurij Andruchowycz, Karen Blixen, Michael Cunningham, Magda Dygat, Paweł Huelle, José C. Somoza, Virginia Woolf. Pełna lista potwierdza w znacznej mierze wniosek, który nasuwa się, gdy spojrzymy choćby tylko na wymienione powyżej nazwiska: są to $\mathrm{w}$ dużej części pisarze, których książki odpowiadają programom obydwu pism.

Wyraźna różnica pomiędzy trzema magazynami pojawiła się w odniesieniu do ogłoszeń wydawniczych. Jedyną wspólną ich cechą jest ich niewielka liczba. Tylko Wydawnictwo Naukowe PWN skorzystało z takiej możliwości promocji, prezentując Wielkq encyklopedię PWN w każdym z prezentowanych miesięczników. Zaskakujący jest fakt, że edytorzy, specjalizujący się w wydawaniu literatury kobiecej, w tak niewielkim stopniu reklamowali swoją ofertę na łamach omawianych periodyków. 
„Zwierciadło” i „Elle” okazało się w tym samym stopniu atrakcyjne dla dwóch oficyn, Wydawnictwa Literackiego oraz Wydawnictwa Prószyński i S-ka, którzy uznali, że czytelnicy tych magazynów zainteresują się ich ofertą.

Każdy z magazynów miał swojego lidera-reklamodawcę w odniesieniu do ogłoszeń wydawniczych. W przypadku „Zwierciadła” było to Gdańskie Wydawnictwo Psychologiczne (42 tytuły) oraz Wydawnictwo Kurpisz (41 propozycji). Za pośrednictwem „Twojego Stylu” swoją ofertę proponowało wydawnictwo tego pisma (60-krotnie). Z kolei czytelnicy „Elle” najczęściej spotykali się z propozycjami książek wydanymi przez Jacka Santorskiego \& Co, Lampę i Iskrę Bożą, POST oraz Prószyńskiego i S-kę (ośmiokrotnie).

W przypadku „Zwierciadła” i „Twojego Stylu” inseraty prezentowały się najbardziej okazale. Zazwyczaj były całostronicowe, barwne i czytelne. Inaczej było $\mathrm{z}$ anonsami na łamach „Elle”. Większość z nich miała postać niewielkich modułów, reklamujących przeważnie jeden, rzadziej kilka tytułów. Ale i tu uwagę zwracała ciekawa grafika ogłoszeń oraz hasła reklamowe.

Należy podkreślić, że łamy każdego z magazynów były niezwykle gościnne dla reklam innego typu: oferujących na przykład kosmetyki i artykuły higieniczne. Czyżby potencjalni reklamodawcy - wydawcy, uważali, że kobietę interesują przede wszystkim tego rodzaju produkty i że w związku z tym „nie opłaca” się zamieszczać na łamach omawianych pism reklam książek...?

Interesujące spostrzeżenia wynikają z analizy wywiadów, zamieszczanych $\mathrm{w}$ badanych periodykach. Stanowiły one istotny element każdego z nich, aczkolwiek rozmowy z literatami stanowiły niewielką tylko część wszystkich rozmów, drukowanych na łamach tych pism. Najczęstszymi ich bohaterami byli bowiem przedstawiciele innego, niż literacki, świata: piosenkarze, aktorzy, a w przypadku „Twojego Stylu” nierzadko żony znanych polityków lub biznesmenów. Jednak do rozmów zapraszano niekiedy również pisarzy lub osoby pośrednio związane z książką. Najwięcej takich spotkań odbyło się na łamach „Elle”, najmniej zorganizowało ich "Zwierciadło". Rekompensatą dla czytelników tego magazynu była objętość przeprowadzanych wywiadów, największa, w porównaniu $\mathrm{z}$ dwoma rywalami (2-8 stron). Najskromniejsze pod względem objętości drukowanych wywiadów okazało się „Elle” (kilkanaście zdań - 4 strony). Redakcja każdego $\mathrm{z}$ magazynów chętnie urozmaicała ten typ informacji zdjęciami swych rozmówców, nierzadko prezentując ich w otoczeniu rodziny lub przyjaciół. Zgodnie dbano również o przedstawienie bohaterów wywiadów: każdą rozmowę otwierała krótka charakterystyka twórcy, przy czym starano się już w tym miejscu zasygnalizować przewodni wątek rozmowy. 
W przypadku „Zwierciadła” i „Twojego Stylu” była to twórczość danego autora, natomiast czytelnicy „Elle” mieli większą szansę poznać prywatne życie pisarza, bowiem tu w wyraźnie mniejszym stopniu poruszano sprawy związane z jego twórczością, koncentrując się na tych faktach z jego życia, które były kontrowersyjne lub przynajmniej budziły ambiwalentne uczucia otoczenia. W ten charakterystyczny klimat „Elle” wpisywały się również wywiady z osobami związanymi ze znanymi twórcami: dziećmi, wnukami, współmałżonkami. Pytano wówczas nierzadko o przyzwyczajenia, nawyki znanego pisarza lub poety, wspólne z nim wspomnienia. Z takich rozmów wyłaniały się dzięki temu portrety mniej oficjalne, rodzinne, przedstawiające daną postać oczyma bliskich osób. Tego typu rozmowy sporadycznie pojawiały się również na łamach dwóch pozostałych pism, chociaż „Zwierciadło" wybrało nieco inną formę przybliżenia znanej czytelnikom postaci. Przeprowadzano bowiem rozmowy jednocześnie z pisarzem i jego żoną/partnerką życiową, zadając obojgu podobne pytania (w takich przypadkach temat tych rozmów zbliżony był do wątków podejmowanych na łamach „Elle”).

Inny zazwyczaj charakter miały wywiady, drukowane na łamach „Twojego Stylu": wydaje się, że służyły one nie tylko rozrywce czy zaspokojeniu ciekawości czytelników (jak było to w dużej mierze w przypadku dwóch poprzednich pism), ale miały nieść ze sobą wyraźne przesłanie, zgodne $\mathrm{z}$ programem magazynu. Ich bohaterkami były bowiem $\mathrm{w}$ większości kobiety, i to takie, które osiągnęły w życiu sukces, pokonując niejednokrotnie przeszkody, bariery, problemy i trudności, okazując się nierzadko silniejszymi do mężczyzn.

Zaledwie trzech twórców gościło na łamach każdego z trzech miesięczników: Anna Bojarska (na łamach „Zwierciadła” wspólnie z Grzegorzem Rutowiczem), Jerzy Pilch oraz Andrzej Samson.

Oddzielną kategorią, stanowiącą rodzaj kontynuacji wywiadów, były portrety znanych pisarzy. Najpełniej występowały one na łamach „Zwierciadła” oraz „Twojego Stylu”, najskromniej w najmłodszym z omawianych periodyków. W dwóch pierwszych magazynach były to zajmujące historie ze starannie wybranym bohaterem, które odbiorca czytał z dużym zainteresowaniem, jak dobrze napisane opowiadanie. I w tym przypadku życie wybranych osób, ich zmagania z trudnościami, przeżyte tragedie, nieszczęśliwe miłości, wpisywały się w program każdego z magazynów, stanowiąc jego stały element.

Powyższe porównania, ograniczone do najbardziej reprezentatywnych dla każdego z periodyków form informacji o książce, prowadzą do interesujących wniosków. 
Charakter każdego z magazynów był wynikiem założonego na początku przez redakcję programu. Jedynie „Zwierciadło” miało za sobą długą historię i podobnie jak „Polityka”, wyrosło w warunkach, w jakich funkcjonowała prasa w okresie PRL. Jednak w jego przypadku pozostał po tamtym okresie inny ciężar. Problematyka społeczna, poruszana w szerokim zakresie w latach Polski Ludowej przez periodyk, została w pewnym stopniu zastąpiona przez kwestie wychowawcze, ale obydwa zagadnienia traktowane były z takim samym zaangażowaniem, by nie powiedzieć, namaszczeniem. „Twój Styl” narodził się już po transformacji ustrojowej w Polsce, od początku dostosowując się do nowych okoliczności, wzorując na przykładach zachodnich magazynów, wolny był tym samym od brzemienia przeszłości i owego „namaszczonego”, dydaktycznego stylu, nie zawsze łatwego w odbiorze. Z kolei „Elle”, będąc polską edycją pisma francuskiego, miało niejako gotową makietę i założenia programowe, które redakcja starała się jedynie przystosować do polskich realiów.

Ciągły rozwój, będący w dużym stopniu efektem nieustającej walki o czytelnika, doprowadził do ukształtowania charakteru każdego z tytułów, badanych w latach 2001-2005. Pomimo że każdy z nich zaliczony został do tej samej grupy magazynów ekskluzywnych, adresowanych do tej samej kategorii czytelników, to jednak analiza każdego z nich, przynajmniej w interesującym nas kontekście, uwidoczniła wyraźne różnice pomiędzy nimi i to zarówno w formie, jak i treści. Największe różnice zdają się dzielić „Zwierciadło” i „Elle”. Pierwsze z nich zachowując poważny, czasem nawet nazbyt egzaltowany ton, pozostało pismem o charakterze poradnikowym, analizującym głęboko niemal każdą poruszaną kwestię, także tę związaną z książką. Drugie oferowało czytelnikom dużą dawkę informacji, podanych jednak w sposób lekki, nierzadko niezobowiązujący, autorytatywny ton zachowując głównie dla spraw związanych z modą, pozostając tym samym wierne modelowi pisma rozrywkowego, co przekładało się także na formę materiałów związanych z literaturą.

Natomiast „Twój Styl” starał się, jak się wydaje, wypośrodkować ciężar swych zainteresowań, proporcjonalnie dzieląc go pomiędzy rozmaite kwestie (poczynając od spraw zawodowych i rodzinnych, w których kobieta odgrywa główną rolę, poprzez zdrowie i urodę, a na zagadnieniach kulturalnych kończąc), kładąc mniej więcej równy nacisk na każdy z poruszanych tematów, książkę traktując jednak jako jeden z mniej istotnych elementów, z pewnością nie należących do priorytetowych.

„Zwierciadło” i „Twój Styl” nierzadko wykorzystywały informacje związane z książką do przekazania naczelnego przesłania, przyświecającego każdemu z nich; materiały dotyczące literatury były często swego rodzaju „pasem transmisyjnym”, służącym redakcji do promowania określonych wartości, bliskich każdemu z nich. 
Powyższe spostrzeżenia oznaczają, że definicja tego typu prasy (pism kobiecych, zaliczanych do grupy ekskluzywnych magazynów) jest bardzo pojemna: mieszczą się $\mathrm{w}$ niej zarówno periodyki, podejmujące szerokie spektrum zagadnień, jak i te, które uwagę swoją koncentrują w dużej mierze na kwestiach z pewnością ważnych dla kobiet (moda, uroda), ale jednocześnie inne sprawy traktowane są tu jako drugorzędne, podawane w lekkiej formie, nierzadko powierzchownie. Uwagi te, dotyczące przede wszystkim poruszanych przez owe magazyny zagadnień związanych z książką, są jednocześnie odpowiedzią na pytania, postawione w rozdziale otwierającym rozważania dotyczące wybranych czasopism kobiecych. 


\section{Rozdział 4}

\section{PRASA MŁODZIEŻoWA}

\subsection{Prasa młodzieżowa. Krótka charakterystyka}

[...] to rynek bardzo trudny, wymagający ciągłego zabiegania o czytelników, którzy ze swoich pism szybko - w ciągu zaledwie dwóchtrzech lat - wyrastają ${ }^{1}$.

Prasa młodzieżowa według Juliana Maślanki, to

ogół gazet i czasopism, adresowanych do młodych odbiorców w wieku od 14 do 25 lat [...], preferujących treści mogące zainteresować ten krąg odbiorców (rozrywkowe; popularnonaukowe, problemowe, omawiające kwestie młodzieżowe; poradnictwo) ${ }^{2}$.

W czasopiśmiennictwie tego typu nie tylko opisuje się, ale i z założenia kreuje określoną rzeczywistość, propaguje pewien styl życia i myślenia, kształtuje postawy młodych czytelników wobec otaczającego ich świata ${ }^{3}$. Tym samym periodyki zaliczane do tej grupy pełnią funkcję wychowawczą, niejednokrotnie także edukacyjną. Prasa młodzieżowa, nierzadko w literaturze omawiana jest wspólnie z czasopiśmiennictwem dla dzieci (jako prasa dziecięco-młodzieżowa), stanowiąc przedmiot wielu opracowań4.

W Europie została ona zainicjowana w połowie XVIII w. przez takie tytuły, jak „The Lilipution Magazyn” (Londyn 1751), „Der Kinderfreund”

${ }^{1}$ A. Olbrot, $W$ sieci, „Press” 2008, nr 7, s. 54.

${ }^{2}$ Encyklopedia wiedzy o prasie, red. J. Maślanka, Zakład Narodowy im. Ossolińskich, Ośrodek Badań Prasoznawczych „Prasa-Książka-Ruch”, Wrocław i in. 1976, s. 175.

3 J. Jarowiecki, Prasa dla dzieci i młodzieży (nurty, tendencje, zmiany), „Zeszyty Wszechnicy Świętokrzyskiej" 1996, nr 3, s. 70.

4 Wśród badaczy tego typu czasopiśmiennictwa należy wymienić m.in. J. Jarowieckiego, J. Kumiegę, G. Leszczyńskiego, J. Papuzińską, J. Szockiego. Warto również zwrócić uwagę na opracowania autorstwa M. Adamczyka, M. Glogiera, S. Frycie, K. Heskiej-Kwaśniewicz, M. Rogoża, Z. Sokół, D. Żebrowskiej. 
(Berlin 1775-1784) i „Dietskoje Czitienije dla Sierdca i Rozuma” (Petersburg 1785-1789)5. Na gruncie polskim zapoczątkowała ją na początku XIX w. Klementyna $\mathrm{z}$ Tańskich Hoffmanowa, aczkolwiek ta inicjatywa kierowana była przede wszystkim do dzieci („Rozrywki dla Dzieci” 18241828). W latach 1854-1855 Ewaryst Estkowski redagował „Szkółkę dla Młodzieży” (jako kontynuację „Szkółki dla Dzieci”). W drugiej połowie XIX w. nastąpił rozwój tego czasopiśmiennictwa (na przykład „Rozrywki dla Młodocianego Wieku” 1857-1860 czy „Rozrywki Obrazowo-Opisowe” 1835-1860)6 , ale jego rozkwit przypadł na dwudziestolecie międzywojenne. W dużej mierze było to wynikiem działalności Związku Nauczycielstwa Polskiego (ZNP), który stworzył trzystopniowy system prasy dziecięcej i młodzieżowej, przystosowany do poszczególnych faz rozwoju dziecka, a następnie nastolatka (odpowiadały mu czasopisma: „Mały Płomyczek”, „Płomyczek" i „Płomyk”). W okresie II wojny światowej tego typu pisma także były wydawane, choć $\mathrm{w}$ grupie konspiracyjnych tytułów stanowiły niewielką część. Wśród nich powstał na przykład „Brzask”, „Bądź Gotów” czy „Źródło”.

Okres Polski Ludowej to intensywny rozwój wydawnictw periodycznych, kierowanych do tej grupy odbiorców ${ }^{8}$. Wydawane wtedy tytuły nadal uwzględniały kategorie wiekowe, odpowiadające poszczególnym etapom rozwojowym dzieci i młodzieży („Miś”, „Świerszczyk”, „Płomyczek” oraz „Płomyk”). Ich wydawcą był, obok RSW, Instytut Wydawniczy „Nasza Księgarnia”. Obydwie „nie tylko dbały o właściwy poziom edytorski swoich tytułów, ale też synchronizowały go z programem dydaktycznym realizowanym w szkołach podstawowych"9. Poza nimi, czasopisma młodzieżowe wydawała również wchodząca w skład RSW, Młodzieżowa Agencja Wydawnicza (MAW). Jej periodyki były szczególnie przesycone treściami ideologicznymi, nierzadko politycznymi (m.in. „Nowa Wieś”, „Walka Młodych"). Trzecią grupę pism, nie tyle adresowaną do młodzieży, co w znacznym stopniu m.in. przez nią czytaną, stanowiły tytuły o tematyce przyrodniczej, sportowej lub technicznej.

5 Słownik literatury dziecięcej i młodzieżowej, red. B. Tylicka, G. Leszczyński, Zakład Narodowy im. Ossolińskich, Wrocław 2002, s. 72.

${ }^{6}$ D. Żebrowska, Czasopisma dziecięce w III Rzeczypospolitej - rekonesans i próba charakterystyki, [w]: Biblioteka i informacja $w$ demokratycznym systemie edukacji dorosłych, red. H. Hovenberg i in., Linköpings Universitet, Państwowy Ośrodek Kształcenia Bibliotekarzy im. Joachima Lelewela, Linköping, Jarocin 1996, s. 157.

7 S. Frycie, Literatura dla dzieci i młodzieży w latach 1945-1970: zarys monograficzny, materiały, Wydawnictwa Szkolne i Pedagogiczne, Warszawa 1988, s. 34.

${ }^{8}$ Już 1 maja 1945 r. ukazał się w Łodzi pierwszy numer „Świerszczyka”.

${ }_{9}^{9}$ T. Mielczarek, Monopol, pluralizm, koncentracja. Środki komunikowania masowego $w$ Polsce w latach 1989-2006, Wydawnictwa Akademickie i Profesjonalne, Warszawa 2007, s. 197. 
Po 1989 r. zmiany, które objęły cały rynek prasowy w Polsce, nie ominęły także i tego segmentu czasopism. Wraz z likwidacją RSW upadła również MAW i większość wydawanych przez nią tytułów, inne zaś zmieniły swoją formułę, wyraźnie zbliżając się do prasy rodzinno-kobiecej. Przeobrażenia dotknęły również „Naszą Księgarnię”, przekształcając ją $\mathrm{w}$ spółkę z o.o. Jednocześnie powstało szereg nowych wydawnictw, na rynek wkroczyły obce koncerny, wprowadzając „kalki” zachodnich magazynów młodzieżowych. Zaczęły również pojawiać się m.in. czasopisma konfesyjne dla dzieci i młodzieży (na przykład „Fletnia Pana”) oraz periodyki wydawane przez harcerstwo (jak choćby „Czuwaj”) ${ }^{10}$. Tym samym liczba tytułów prasowych adresowanych do młodzieży wyraźnie wzrosła, co szczególnie widoczne było w latach 1989-199511. W drugiej połowie lat 90. XX w. ta wzrostowa tendencja uległa najpierw zahamowaniu, a następnie stała się wyraźnie malejąca. W 2005 r. wydawano ogółem 124 periodyki o różnej częstotliwości i zawartości.

Inną, niezwykle istotną zmianą, jaka dotknęła interesującą nas grupę czasopism, było załamanie dotychczasowego, wspomnianego wyżej modelu, opierającego się na podziale na poziomy, odpowiadające poszczególnym etapom rozwoju osobowego dzieci i młodzieży. Wydawcy nadal wprawdzie kierowali swoją ofertę do czytelników w konkretnym przedziale wiekowym, ale równocześnie zróżnicowana tematyka poszczególnych periodyków, proponowane formy przekazu, powodowały, iż „młodzi czytelnicy, mając dostęp do rozrywki starszych, sami wybierali to, co ich interesowało, jedynym bowiem ograniczeniem $\mathrm{w}$ dokonywaniu wyborów czytelniczych stała się współcześnie umiejętność czytania"12. Wielu badaczy ${ }^{13}$ przyjęło nowy model podziału tej grupy pism, oparty na kryterium zawartości, stosowanych form wypowiedzi oraz charakteru i typu odbiorców. W ten sposób wyróżniono m.in.14:

1) czasopisma kulturalno-kształcące ${ }^{15}$. Mają one charakter magazynów, ich zawartość opiera się na treściach kulturalno-kształcąco-rozrywkowych,

10 Z. Sokół, Czasopisma dla młodzieży szkolnej (1990-1995), „Poradnik Bibliotekarza” 1996, nr 11, s. [11].

110 ile w 1989 r. w tej grupie pism odnotowano ogółem 79 tytułów, o tyle w 1993 r. było ich już 131, rok później 153, zaś w 1995 r. najmłodsi i nastoletni czytelnicy mieli do wyboru 160 tytułów. Zob. „Ruch Wydawniczy w Liczbach 2005”.

12 B. Niesporek-Szamburska, Czasopisma dla dzieci i młodzieży, [w:] Literatura dla dzieci i młodzieży (po roku 1980), t. 2, red. K. Heska-Kwaśniewicz, Wydawnictwo UŚ, Katowice 2009 , s. 35.

13 M.in. J. Papuzińska, A. Przecławska, Z. Sokół, J. Szocki. Por. J. Jarowiecki, Studia nad prasq polskq XIX i XX wieku, Wydawnictwo Naukowe WSP, Kraków 1997, s. 223.

${ }^{14}$ Więcej zob. B. Niesporek-Szamburska, Czasopisma dla dzieci..., s. 35-40.

15 Chodzi tu o periodyki adresowane wyłącznie do dzieci i młodzieży, nie zaś o pisma społeczno-kulturalne przeznaczone dla wszystkich odbiorców. 
tekstach literackich, takich jak wiersze i opowiadania, ciekawostkach dotyczących różnych dziedzin życia. Proponują czytelnikom także konkursy, zagadki, mini-komiksy (na przykład „Świerszczyk”);

2) periodyki rozrywkowo-zabawowe (m.in. „Uśmiech Numeru”, „Zgaduj-Zgadula");

3) czasopisma komiksowe (jak choćby „Kubuś Puchatek”, „Muminki”);

4) pisma edukacyjne („Angielski jest Super”, „Cogito”, ,Victor Gimnazjalista");

5) tytuły medialne. Są związane z edukacyjnymi programami telewizyjnymi (na przykład „Disney i Ja”);

6) periodyki techniczne (m.in. „ABC Techniki”, „Horyzonty Techniki”);

7) pisma hobbystyczne („Magazyn Muzyczny”, „Tylko Rock”);

8) czasopisma wyznaniowe (katolickie i mniejszości religijnych - „Beniamin”, „Miłujcie się!”);

8) periodyki szkolne.

Dużą grupę liczących się na rynku czasopism młodzieżowych tworzyły w badanym okresie tytuły, które, ze względu na swą zawartość (w dużym stopniu nawiązującą do prasy adresowanej do dorosłego odbiorcy ${ }^{16}$ ), nie dały się zamknąć w obrębie wymienionych wyżej grup lub kwalifikowały się jednocześnie do różnych rodzajów. Znalazły się wśród nich ${ }^{17}$ :

1) magazyny kulturalno-rozrywkowe (takie jak na przykład „Bravo”, „Dziewczyna”, „Filipinka”, „Popcorn”, „Twist”),

2) czasopisma społeczno-kulturalne (m.in. „Carpe Diem”, „Cogito”, „Filipinka"),

3) periodyki społeczno-polityczne („Atak”, „Lider Przyszłości”).

Niezwykle zróżnicowaną ofertę prasy młodzieżowej uzupełniały liczne czasopisma adresowane do wyraźnie wyodrębnionej grupy młodych odbiorców, na przykład studentów, ale również pisma kierowane do kinomanów, czy tytuły, które mogły zainteresować przedstawicieli subkultur młodzieżowych. A zatem w miejsce dotychczasowego podziału tej grupy czasopism na poziomy czytelniczo-wiekowe pojawił się podział według kryterium specjalistyczno-rodzajowego. Jednocześnie wraz ze wzrostem ilościowym, przeobrażeniom uległa szata graficzna tych periodyków (można pokusić się o stwierdzenie, że pisma tego typu wiodły w tym względzie prym na rynku prasowym). Wszystkie tytuły adresowane do nastoletnich czytelników stały się kolorowe, większość zaczęto drukować na błyszczącym papierze, z lakierowaną okładką. Równocześnie jednak wiele

\footnotetext{
16 J. Jarowiecki czasopisma kierowane do czytelników 12-20-letnich klasyfikuje oddzielnie, por. J. Jarowiecki, Studia..., s. 229.

${ }^{17}$ Niektóre z tytułów, ze względu na ich charakter, można umieścić jednocześnie w dwóch grupach.
} 
z periodyków, szczególnie tych kopiujących zachodnie magazyny lub naśladujące periodyki kobiece, budziło zastrzeżenia, jako że „Krzykliwość i agresywność form plastycznych, kompozycyjny chaos, natłok monotematycznych zdjęć, schematyzm, sprawiają, że wspomniane czasopisma nie należą do edytorsko udanych" 18 .

Wady, dostrzeżone przez badaczy, nie przeszkadzały młodym czytelnikom; wręcz przeciwnie, popularność tego typu tytułów bardzo szybko rosła, co więcej, większość pozostałych, dotąd ambitniejszych pism (jak na przykład „Filipinka”), chcąc utrzymać się na rynku, dostosowywała do nich swą formę. Ale nie tylko szata graficzna ówczesnych magazynów młodzieżowych budziła kontrowersje. Ich zawartośćc ${ }^{19}$ zwróciła uwagę nie tylko prasoznawców, ale również pedagogów, wychowawców i samych rodziców. Zaczęło bowiem ukazywać się coraz więcej magazynów o charakterze rozrywkowo-poradniczym, przy czym, jak zauważył Jerzy Jarowiecki,

ich „obrazkowość”, „komiksowość” często zastąpiła dotychczasowe wartościowe treści poznawcze. Konkurencja rynkowa sprawiła, że w tych czasopismach [...] dominuje forma nad treścią, co jest wyrazem walki o młodego czytelnika, w której - niestety - przewagę osiągają wysokonakładowe tytuły, najczęściej stanowiące polskie mutacje zachodnio-europejskich magazynów z ich wątpliwymi wartościami i wzorami zachowań. Dominuje w nich sensacja, problematyka seksualna, muzyka, rozrywka. Obrazy w nich zawarte oderwane są od problemów przeciętnych ludzi, jak praca, kształcenie się czy szeroko pojęte życie rodzinne. W wynurzeniach wielu idolów tej prasy [...] nie spotyka się głębszej refleksji nad życiem czy prawdziwymi uczuciami ${ }^{20}$.

Zmiana roli tego typu prasy, która dotąd pełniła głównie funkcję wychowawczą, nierzadko edukacyjną, budziła liczne zastrzeżenia, podobnie jak i język, styl przekazu, obecny na łamach większości periodyków. Programowe wręcz posługiwanie się gwarą młodzieżową (na przykład liczne anglicyzmy, neologizmy oraz wyraźny infantylizm językowy, przejawiający się w szczególnym upodobaniu do stosowania zdrobnień lub zgrubień wyrazów) stało się szybko cechą charakterystyczną wielu pism młodzieżowych $^{21}$. Warto również zwrócić uwagę w tym miejscu na stosowane na ich łamach gatunki dziennikarskie. Jakkolwiek Zofia Sokół zauważyła, że w wielu

18 B. Olszewska, Edytorstwo współczesnych czasopism dla dzieci i młodzieży. Zarys problematyki, [w:] Książka dziecięca 1990-2005, red. G. Leszczyński i in., Wydawnictwo Stowarzyszenia Bibliotekarzy Polskich, Warszawa 2006, s. 176.

19 Przede wszystkich dotyczyło to tytułów znajdujących się ofercie niemieckich koncernów.

20 J. Jarowiecki, Prasa dla dzieci..., s. 70.

${ }^{21}$ Język tej prasy stał się przedmiotem opracowań autorstwa m.in. W. Kajtocha, zob. np. W. Kajtoch, Odlotowe bez dwóch zdań!: kultura języka, stylu, perswazji w czasopismach dla młodzieży, „Zeszyty Prasoznawcze” 1999, nr 3/4, s. 79-102; idem, O stylu popularnych pism młodzieżowych, „Polonistyka” 2002, nr 9, s. 531-536. 
magazynach pojawiły się wówczas m.in. felietony, reportaże i wywiady22, to jednak należy podkreślić, że znaczna ich część w niewielkim tylko stopniu odpowiadała swym klasycznym definicjom. Redakcje pism młodzieżowych starały się konstruować przygotowywany materiał w ten sposób, by przede wszystkim odpowiadał on na sześć podstawowych pytań (kto?, co?, gdzie?, kiedy?, jak? i dlaczego? ${ }^{23}$ ), rzadziej dbając o przekazanie informacji w formie bardziej rozbudowanej, charakterystycznej dla gatunków publicystycznych. Drukowano recenzje, ale nawet i ta jedna $\mathrm{z}$ najstarszych i najbardziej rozpowszechnionych form, zajmująca, jak pisze Zbigniew Bauer, „miejsce pośrednie między obszarem informacji i publicystyki” ${ }^{24}$, na łamach pism młodzieżowych tego okresu pojawiała się w postaci nierzadko wyraźnie odbiegającej od wzorcowej25. Dominowały informacyjne gatunki dziennikarskie, wśród nich wzmianka, zapowiedź oraz notatka prasowa, rzadziej wywiad, czasem reportaż. Jednym z przykładów pism, które odpowiadały powyższej charakterystyce, był magazyn „Dziewczyna”, polska edycja periodyku szwajcarskiego, która w epoce obrazkowego postrzegania rzeczywistości doskonale wpisała się w gusta nastolatków, stosując opisane metody.

Przedstawione zmiany stały się widocznym znakiem ówczesnych czasów, w których także wydawcy prasy młodzieżowej przystąpili do walki o „pokolenie Internetu”, podejmując rozmaite zabiegi, jak na przykład obecność tytułu w sieci, dołączanie „prezentów” do kolejnych numerów pisma, specjalne wkładki i dodatki do wybranych wydań itd. Komercjalizacja całej prasy, spadek czytelnictwa gazet i czasopism ${ }^{26}$, zmiana stylu życia, także nastolatków, upowszechnienie Internetu - wszystkie te czynniki wpłynęły na taki właśnie kształt znacznej części periodyków młodzieżowych. Ta część rynku prasowego zdominowana została przez koncerny niemieckie (szczególnie koncern Axel Springer oraz wydawnictwo Heinricha Bauera), nadające ton niemal całemu czasopiśmiennictwu młodzieżowemu. Wśród wydawanych wtedy tytułów odnaleźć jednak można było także ambitniejsze periodyki, zaliczane do pism społeczno-kulturalnych o poważniejszym charakterze, starające się dbać o rozwój intelektualny

22 Z. Sokół, Transformacja prasy dziecięco-młodzieżowej w latach 1990-1991, „Poradnik Bibliotekarza" 1996, nr 7/8, s. 7.

$23 \mathrm{~W}$ ten sposób scharakteryzował podstawową strukturę gatunków informacyjnych Z. Bauer, zob. Dziennikarstwo i świat mediów, red. Z. Bauer, E. Chudziński, Universitas, Kraków 2004, s. 151.

24 Ibidem, s.161.

25 Zob. Wstęp, przyp. 34.

${ }^{26} \mathrm{~W}$ przypadku prasy dla dzieci i młodzieży spowodowany także $\mathrm{w}$ dużym stopniu względami demograficznymi: na przełomie XX i XXI w. odnotowano niski przyrost naturalny, w związku z czym potencjalna grupa odbiorców tego typu prasy wyraźnie zmalała. 
swych czytelników (m.in. dwutygodnik „Cogito”). Należały one jednak do mniejszości, stanowiąc wyraźny wyjątek.

W jakim stopniu wobec tego tak odmieniona prasa młodzieżowa informowała swych nastoletnich czytelników o książkach? Czy, kierując określone treści do młodego odbiorcy, oddziałując na niego w wieku, kiedy człowiek jest szczególnie podatny na wpływy z zewnątrz, kształtowała jego gust literacki, wychowując przyszłego czytelnika, interesującego się książką? Przybliżona powyżej krótka charakterystyka pism tego typu zdaje się sugerować negatywną odpowiedź na tak postawione pytania. Specyfika większości tytułów wydaje się nie budzić zbytnich nadziei na to, by ich redakcje dbały o edukację literacką swych „podopiecznych”.

Czy wobec tego czytelnicy czasopism młodzieżowych z lat 2001-2005 nie odnajdowali na łamach kupowanych przez siebie periodyków żadnych informacji związanych z książką? A może było wręcz przeciwnie: w dobie kultury masowej, nastawionej przede wszystkim na rozrywkę, dostrzeżono w książce walory, które odpowiadałyby popularnemu charakterowi większości pism?

Aby odpowiedzieć na te pytania, analizie poddano trzy specyficzne w swej formie i treści pisma. Pierwszy z nich to „Filipinka”, tytuł z długoletnią historią i tradycją, który wychował kilka pokoleń czytelniczek, starając się spełniać ambitną rolę doradcy i przewodnika w życiu dorastających dziewcząt. Drugi periodyk to „Dziewczyna”, magazyn, preferujący głównie treści rozrywkowo-poradnikowe, który stał się w latach 90. XX w. przykładem sukcesu wydawanej w Polsce na licencji kopii magazynu zachodniego. Trzecim pismem stał się dwutygodnik „Cogito”, jedno z nielicznych czasopism młodzieżowych, o wyższych aspiracjach, edukacyjnym charakterze, adresowane do ambitniejszej grupy docelowej, niż dwa poprzednie tytuły.

Wybierając te periodyki, postanowiono zbadać, w jakim stopniu czasopisma o tak różnej historii, specyfice, polityce redakcyjnej, zawartości, a przecież kierowane do podobnej grupy wiekowej nastoletnich odbiorców, informowały swych czytelników o sprawach, związanych z książką. W obliczu przytoczonej wcześniej charakterystyki postawiono tezę, że o ile dwa z wybranych tytułów („Filipinka” i „Cogito”) starały się, choć kierowane nieco odmiennymi pobudkami, przekazywać na swych łamach treści związane z literaturą za pomocą m.in. recenzji i wywiadów, o tyle w przypadku trzeciego $\mathrm{z}$ periodyków analogicznych informacji zamieszczano mniej. Jednocześnie postawiono pytanie, czy w obliczu zakładanych podobieństw pojawi się wspólna dla wymienionych dwóch pism („Filipinki” i „Cogito”) płaszczyzna recenzowanych książek? Interesujące wydaje się również zbadanie, $\mathrm{w}$ jakim stopniu wybrane periodyki były ważne dla wydawców, jako miejsce potencjalnej reklamy ich oferty. Czy do czytelników każdego $\mathrm{z}$ pism trafiała informacja o książkach $\mathrm{w}$ postaci inseratów 
wydawniczych? Czy edytorzy rezygnowali częściej z łamów miesięcznika „Dziewczyna”, postrzegając ten magazyn jako „zbyt rozrywkowy”, koncentrując raczej swoją uwagę na dwutygodniku "Cogito”, doceniając jego edukacyjną rolę?

I wreszcie, czy redakcje tych pism, zdając sobie sprawę z wagi spoczywającej na nich odpowiedzialności, potrafiły przyjąć na siebie rolę nie tylko doradcy w rozwiązywaniu ważnych dla nastolatków problemów, ale i funkcję przewodnika, może nawet nauczyciela, po świecie kultury, literatury, książki? Czy przekaz wizualny, tak charakterystyczny dla większości pism młodzieżowych, zastąpił całkowicie wagę i znaczenie przekazu słownego?

Wyniki analizy zawartości wybranych periodyków w kontekście problematyki określonej w tytule książki pozwoliły w znacznym stopniu odpowiedzieć na postawione pytania. 


\section{2. „Filipinka”: Tylko dla dziewcząt ${ }^{1}$}

\subsubsection{Była sobie Filipinka²: historia czasopisma}

Czytała ją w podstawówce, w liceum, czytała ona sama, jej mama, babcia, czasem nawet tata przeglądał. I każdy znajdował dla siebie coś ciekawego... ${ }^{3}$

Jak już wspomniano, w okresie odwilży popaździernikowej w $1957 \mathrm{r}$. powstało wiele nowych periodyków, $\mathrm{w}$ tym m.in. 30 tytułów adresowanych do kobiet ${ }^{4}$. Jednocześnie w ramach RSW „Prasa” powołano Krajowe Wydawnictwo Czasopism, które przejęło wydawanie najbardziej popularnych pism kobiecych, m.in. „Kobietę i Życie”. Na łamach tego właśnie pisma pojawiła się zapowiedź nowego magazynu, skierowanego do dziewcząt. Była to odpowiedź redakcji na liczne listy od czytelniczek zarówno starszych, jak i młodszych, domagających się oddzielnego pisma adresowanego do „młodzieży żeńskiej”. Rozpisany został konkurs na tytuł nowego periodyku. Dla autorek najlepszych propozycji czekały nagrody: „kupon materiału na letnią sukienkę" (I miejsce), „kupon wełny na spódnicę” (II miejsce) oraz torebka (III miejsce) ${ }^{6}$. Po ok. dwóch miesiącach, 15 maja 1957 r., pojawiła się „Filipinka”, pierwsze i przez wiele następnych lat jedyne czasopismo w Polsce, adresowane do dziewcząt. Jego nakład wyniósł 100 tys. egz., objętość 16 stron, a format zbliżony był do gazetowego $(35 \times 24,5 \mathrm{~cm})$. Pierwszym wydawcą periodyku było Warszawskie Wydawnictwo Prasowe7, będące jednym z przedsiębiorstw RSW „Prasa”. Siedziba redakcji mieściła się, podobnie jak było to w przypadku tygodnika „Polityka", w Pałacu Kultury i Nauki w Warszawie, zajmując pokoje na XVII piętrze. Redaktor naczelną dwutygodnika (taką częstotliwość przyjął nowy tytuł) została Felicja Strumińska, sprawująca tę funkcję do 1969 r. „Filipinka”, jako

1 Tytuł tekstu zapowiadającego ukazanie się nowego pisma dla dziewcząt, „Filipinki”, zob. „Kobieta i Życie” 1957, nr 11, s. 2.

2 Tytuł jednej z publikacji, zob. A. Drwal, Była sobie Filipinka, http://www.pinezka.pl/ content/view/2153/209, kwiecień 2011.

3 K. Kromka, F jak Filipinka, http://www.pinezka.pl/content/view/2153/209, kwiecień 2011.

4 Z. Sokół, Prasa kobieca w Polsce w latach 1945-1995, Wydawnictwo WSP, Rzeszów 1998, s. 50.

5 Warto zaznaczyć, że obok tego typu próśb pojawiały się również głosy, sprzeciwiające się wydawaniu oddzielnego magazynu dla dziewcząt, zob. „Filipinka” 1992, nr 20, s. 3-5.

6 [br. aut.], Tylko dla dziewcząt, „Kobieta i Życie” 1957, nr 11, s. 2.

7 Później Krajowe Wydawnictwo Czasopism RSW „Prasa-Książka-Ruch”.

8 Od 1973 r. jako „Prasa-Książka-Ruch”. 
„młodsze dziecko” „Kobiety i Życia”, przez kilka kolejnych lat redagowana była przez ten sam zespół. W stopce redakcyjnej odnaleźć można informację, że przygotowaniem każdego numeru zajmowało się kolegium redakcyjne, dopiero $\mathrm{w}$ następnych latach zaczęły pojawiać się $\mathrm{w}$ tym miejscu nazwiska współpracowników pisma.

W artykule wstępnym czytamy:

Podejmujemy dziś trudną próbę uwolnienia Ciebie od ciężaru konfliktów i trosk, dopomożenia Ci w trudnych sprawach Twego życia. [...] pamiętaj, że postaramy się zrozumieć każdą z Twych myśli. [...] Zapomnij o tym, że ktoś kto w Redakcji czyta Twój list - jest starszy od Ciebie. [...] Pamiętaj tylko o tym, że jest to ktoś - kto wychodzi Ci naprzeciw, kto chce zrozumieć Ciebie i może... potrafi to zrobić 9 .

Deklaracje te odpowiadały oczekiwaniom czytelniczek, z których jedna pisała:

Chciałabym, aby „Filipinka” stała się dla mnie i dla każdej z nas przyjaciółką, która umie poradzić, pocieszyć i podtrzymać na duchu. [...] Poza tym, niech w „Filipince” będzie wszystko, co łączy się z codziennym życiem i niech każda z nas coś dla siebie znajdzie ${ }^{10}$.

Nowe czasopismo od pierwszego numeru stało się bardzo popularne wśród nastolatek. Nakład szybko wzrastał (do 265-300 tys. egz.), a mimo to nie pokrywał zapotrzebowania społecznego (brak papieru uniemożliwiał zwiększenie liczby drukowanych egzemplarzy). Na pytania czytelniczek odpowiadało współpracujące z periodykiem grono specjalistów: pedagogów, psychologów, socjologów i lekarzy. Unikając moralizatorskiego, sztywnego tonu, redakcja dostosowywała formę publikacji do języka i stylu ówczesnych dziewcząt, stawiając na relację partnerską.

od pierwszego numeru F. była po stronie swojej czytelniczki. Wychowując ją, często pouczając, stopując jej nierozsądne pomysły, ale mówiąc: lubimy cię, jesteśmy z tobą, rozumiemy, że to trudny dla ciebie czas. Nie wyśmiewamy się, wspieramy, pokazujemy ci, że nie jesteś sama ${ }^{11}$.

Zaproponowana formuła spodobała się dziewczętom, a o popularności czasopisma świadczył m.in. fakt upowszechnienia nazwy „Filipinka”: tak nazywano sklepy, kawiarnie, ciastka i torty, istniał nawet zespół Filipinki. Powstawały Kluby Filipinek, gdzie spotykały się czytelniczki, wymieniając się m.in. opiniami na tematy poruszane $\mathrm{w}$ piśmie. $\mathrm{W}$ latach następnych periodyk kolportowany był również $w$ innych krajach, trafił także na kontynent amerykański, rozprowadzany wśród tamtejszej Polonii.

\footnotetext{
9 [br. aut.], Od Anny do Zuzanny, „Filipinka” 1957, nr 1, s. 2.

10 [czytelniczka], Zwierzenia, „Filipinka” 1957, nr 1, s. 3.

11 A. Drwal, Była sobie...
} 
Wraz z upływem lat zmieniała się grafika periodyku, jego objętość, format i zawartość, choć ta w niewielkim tylko stopniu: poszerzano poruszane zagadnienia, tworząc dodatkowe działy i rubryki, pozostając jednocześnie wiernym naczelnej zasadzie: radzić, pokazywać, ale i zmuszać do myślenia ${ }^{12}$. Następowały również zmiany na stanowisku redaktor naczelnej: w 1969 r. F. Strumińską zastąpiła Irena Tarlowska, która funkcję tę sprawowała do 1975 r. Jej miejsce zajęła wtedy Maria Dańkowska-Majke (kierowała ona pismem w latach 1976-1982).

Pod koniec lat 70. w „Filipince” pojawiło się więcej kolorowych, lepszych pod względem jakości, fotografii. Pastelowe, stonowane barwy na okładce zastąpiono żywszymi kolorami. Nakład pisma osiągnął wtedy pułap 550-700 tys. egz. ${ }^{13} \mathrm{~W}$ latach 80 . zmieniła się wyraźnie okładka magazynu, nabierając charakteru bardziej artystycznego, rzadziej pojawiały się na niej tradycyjne dotąd zdjęcia czytelniczek, częściej za to drukowano w tym miejscu abstrakcyjne fotografie. Jednak ograniczenia związane z papierem dotknęły również „Filipinkę". Kilka numerów z 1981 r. zostało wydanych w mniejszym formacie. Mimo to większość czytelniczek mogła podpisać się pod jednym z listów, wydrukowanych na łamach periodyku:

Czytałam „Filipinkę” z wielką radością. Chociaż F. była czarno-biała, była pisana bombowym językiem! Czytelnicy wiedzieli, że redakcja myśli tak jak oni sami: w szarym komunistycznym świecie „Filipinka” była powiewem wolnego, barwnego świata14.

Stan wojenny nie ominął również i tego tytułu, który podzielił los ówczesnej prasy. Numer z datą 13 grudnia 1981 r. nie dotarł już do kiosków. Następny trafił do czytelników 30 maja 1982 r., anonsowany wcześniej na łamach „Kobiety i Życia”15. „Nowa” „Filipinka” powróciła do dawnego formatu i objętości 16 stron ze względów, jak pisano, „technicznych”. Redaktor naczelną została Barbara Sidorczyk (w 1986 r. zastąpiona przez Hannę Jaworowską-Błońską), zaś wśród współpracowników pisma znaleźli się m.in. Anna Frankowska, Kalina Gawęcka, Zuzanna Jastrzębska, Witold Kuliński, Joanna Młynarczyk, Anna Okulicz, Anna Osiewska, Irena Ostałowska oraz Bożena Winch. Pomimo że czasopismo było skromne, by nie powiedzieć, zgrzebne $\mathrm{w}$ swej formie, nadal cieszyło się popularnością

12 Dokładna analiza owych zmian nie stanowi jednak przedmiotu niniejszej książki, stąd przedstawiona zostanie tylko ogólnie.

13 Za: J. Kałużna, Współczesne pisma dla dziewcząt na przykładzie „Filipinki” i „Dziewczyny”, Praca magisterska, Uniwersytet Łódzki, Katedra Bibliotekoznawstwa i Informacji Naukowej, promotor: H. Tadeusiewicz, Łódź 2004.

14 [czytelniczka], Fanka Filipinki, „Filipinka” 2001, nr 1, s. [10].

15 [br. aut.], Za tydzień będzie „Filipinka”, „Kobieta i Życie” 1982, nr 7, s. 11. 
wśród nastolatek, czego dowodem był nakład, pod koniec lat 80. osiągający poziom ok. 550 tys. egzemplarzy ${ }^{16}$.

Największe zmiany $\mathrm{w}$ periodyku nastąpiły wraz $\mathrm{z}$ transformacją ustrojową w Polsce w 1989 r. Wynikające stąd konsekwencje, w bardzo wyraźny sposób odbiły się także na „Filipince”. Od tego czasu przy jednoczesnym podnoszeniu poziomu graficznego, w sposób widoczny zdążała ona $\mathrm{w}$ stronę komercyjnej zawartości, obniżając poziom merytoryczny, udowadniając m.in., że zmiany własnościowe pociągają za sobą zazwyczaj poważne zmiany także $\mathrm{w}$ formie i treści danego tytułu.

Zapoczątkowała je prywatyzacja majątku RSW „Prasa-Książka-Ruch”. Jak pisano wcześniej, wraz z nią pojawiło się wiele koncepcji dotyczących wydawania prasy dla kobiet. Niektóre redakcje pism kobiecych zakładały spółdzielnie dziennikarskie, inne szukały oparcia w kapitale zagranicznym. Do pierwszej grupy należał omawiany tytuł. Złożona z 13 członków Dziennikarska Spółdzielnia Pracy „Filipinka” powstała 2 maja 1990 r. Początkowo szukała porozumienia z DSW „Kobieta i Życie” oraz DSP „Magazyn Rodzinny”: planowano utworzyć wspólny minikoncern prasy kobiecej, „Federację Prasy Kobiecej i Rodzinnej". Jednak plany Komisji Likwidacyjnej wobec „Filipinki” były inne: miała ona przystąpić do Warszawskiej Grupy Prasowej. W tym czasie periodyk pod względem graficznym niewiele się zmienił. Jego objętość nadal wynosiła 16 stron, drukowanych na nieco tylko lepszym jakościowo papierze.

W kwietniu 1991 r. przestało jednak istnieć Warszawskie Wydawnictwo Prasowe. W tym samym roku DSP „Filipinka” podpisała umowę wydawniczą z wydawcą magazynu „Twój Styl”, tworząc Porozumienie Wydawniczo-Dziennikarskie Spółdzielni Pracy „Filipinka” oraz „Twój Styl” spółka z o. o. Spółka ta wydawała omawiany dwutygodnik od listopada 1991 do czerwca 1992 r. W tym okresie wraz z rosnącą liczbą konkurencyjnych pism adresowanych do młodzieży rozpoczęła się metamorfoza „Filipinki”. Zrezygnowano z dotychczasowego, gazetowego formatu, pojawił się lepszy jakościowo papier, wprowadzono kolor na większą liczbę kolumn pisma. Jednak wtórna transformacja rynku prasowego nie ominęła również i tego periodyku. W lipcu 1992 r. redakcja „Filipinki” odeszła z dotychczasowej spółki i wraz z Domem Wydawniczym BBiP (który uzyskał większość udziałów: 87,5\%) utworzyła Dom Wydawniczy „Filipinka” - spółkę z o.o. Nowo powstała spółka miała administrować, redagować i kolportować tytuł. Zmieniono jego format, zwiększono liczbę stron średnio do 30, później 40. Zmianie uległa również grafika czasopisma. Wyraźnie wyodrębniono w nim poszczególne działy i rubryki, dzięki czemu jego zawartość stała się bardziej przejrzysta. Nakład pisma wynosił w tym czasie ok. 200 tys.

16 Z. Sokół, Prasa kobieca..., s. 123. 
egzemplarzy. W 1994 r. niemal połowę udziałów w firmie BBiP (44\%) wykupił norweski koncern prasowy Orkla Media ${ }^{17}$. Jednak nowy udziałowiec w nikłym tylko stopniu interesował się działalnością nowo nabytego tytułu, nie wnikając również w jego zawartość. Pomimo starań redakcji, ponownego zwiększenia objętości periodyku (do 46 stron), rozmaitych dodatków dołączanych do wydania głównego ${ }^{18}$, „Filipinka” stopniowo traciła czytelników. W latach 1994-1997 jej nakład spadł do poziomu wyjściowego z 1957 r. i wynosił 100 tys. egzemplarzy. W 1996 r. nową redaktor naczelną pisma została Anna Mazurkiewicz, jednak nie zmieniło to złej sytuacji periodyku. W 1997 r. zwroty osiągnęły 40\% ${ }^{19}$. Trudności finansowe doprowadziły w 1998 r. do sprzedania tytułu Wydawnictwu Prasowemu „Twój Styl”. Od tego momentu zaczął się nowy etap w historii „Filipinki”. Stopniowo nowy wydawca pożegnał się ze wszystkimi członkami dawnej redakcji. Nową redaktor naczelną została Liliana Fabisińska. Zawartość periodyku ponownie uległa zmianie. Pierwszy numer „nowej Filipinki" trafił do czytelniczek we wrześniu 1998 r. Lepszy jakościowo papier, nowy format i szata graficzna (do złudzenia przypominająca formułę „Twojego Stylu”), zwiększona (do średnio 98 stron) objętość, więcej kolorowych zdjęć - miały przyciągnąć nowe czytelniczki i zatrzymać dawne adresatki „Filipinki”. Temu samemu celowi służyły kolejne zabiegi: zmodyfikowana okładka, nowe działy i rubryki, zwiększona liczba tekstów o charakterze poradnikowym, wywiadów ze znanymi osobami, zdjęć z sesji modowych. Zabiegi te sprawiły, że pismo, nad całością którego czuwała Krystyna Kaszuba (redaktor naczelna „Twojego Stylu”), zaczęło coraz bardziej przypominać zachodnie magazyny.

W 1999 r. zmieniono częstotliwość wydawania tytułu, z dwutygodnika stał się on miesięcznikiem, liczącym średnio 80 stron, traktowanym coraz częściej przez czytelniczki jako luksusowy magazyn dla dziewcząt. Zmiany te, jakkolwiek rozmaicie przyjmowane, przyniosły jednak oczekiwane przez wydawcę efekty: sytuacja finansowa pisma poprawiła się, podobnie jak jego nakład. Ponownie zmieniła się redaktor naczelna. Została nią Joanna Dowgiałło-Tyszka. W tym czasie powstała internetowa strona magazynu (www.filipinka.pl), na której obok publikacji analogicznych do zamieszczanych na łamach wersji drukowanej zaproponowano czytelniczkom także Forum i Czat. Dzięki temu mogły one komunikować się między sobą,

17 Orkla Media - koncern norweski, w Polsce od 1990 r., zaistniał jako większościowy udziałowiec dziennika „Rzeczpospolita”, „Życia Warszawy” oraz właściciel lub współwłaściciel dziesięciu dzienników regionalnych i lokalnych. Więcej, zob. np. KL, Orkla buduje swoja potęgę, „Press” 1996, nr 5, s. 5; K. Rosiński, Orkla Media. 10 lat w Polsce, Orkla Press Polska, Warszawa 2004.

18 Jak choćby Filipinka Plus (do numeru 17/1996), Jesień (do numeru 22/1996), Snowboard (do numeru 3/1997).

19 A. Piwowarska, Trzy oblicza Filipinki, „Zeszyty Prasoznawcze” 2003, nr 3-4, s. 128. 
wymieniając uwagi i dyskutując na proponowane nierzadko przez redakcję tematy. Zgodnie ze schematem tego typu stron, także i na tej zamieszczano rozmaite gry on line, „tapety” oraz e-kartki okolicznościowe. Strona stała się również miejscem, gdzie ogłaszano liczne konkursy (na przykład pisanie własnego dziennika).

Nowy wiek „Filipinka” powitała w nowej szacie graficznej i zmienionej zawartości. W 2001 r. średni sprzedawany nakład pisma wynosił już 130,2 tys. egzemplarzy, a sam tytuł przedstawiany był jako jeden z przykładów sukcesu na rynku prasowym ${ }^{20}$.

W tym czasie zespół redakcyjny tworzyli: Monika Bielkiewicz, Inga Kazana, Piotr Kozub (sekretarz redakcji), Agnieszka Maciejak, Ewa Mierzejewska (zastępca redaktor naczelnej), Sylwia Orłowska, Katarzyna Troszczyńska, Joanna Wrześniowska oraz Iwona Zgliczyńska. Wśród stałych współpracowników znaleźli się m.in. Piotr Baran, Olga Butkiewicz, Zbigniew Lew-Starowicz, Katarzyna Nosowska, Zuzanna Śliwa i Natalia Usenko.

$\mathrm{W}$ badanym okresie, wraz z kolejnymi zmianami zachodzącymi w piśmie, pojawiły się jeszcze inne nazwiska. Kolejne wydania pisma przygotowywali m.in. Joanna Bachanek, Michał Chmielewski, Wanda Czech, Agnieszka Jeleniewska, Marta Kacprzyk-Sobieraj, Magdalena Kawczyńska, Monika Kucia, Kaja Popoff-Szczepańska, Bartek Rączkowski i Barbara Tuleja. Wśród współpracowników znaleźli się na przykład Monika Dąbrowska, Andrzej Depko, Agnieszka Gardyszewska, Monika Jaroszewska, Ewa KaniewskaLenarczyk, Bartek Koziczyński, Tomasz Kłys, Justyna Masella, Mirosław Nahacz, Fiolka Najdenowicz, Anita Roston, Bartek Sapota, Marzena Sendler, Marta Szafrańska, Alicja Wysocka, a także Kuba Wojewódzki.

W styczniu 2002 r. nastąpiły kolejne zmiany własnościowe. H. Bauera Koncern kupił od spółki Polska Grupa Interim (właściciela WPTS) prawa do wydawania m.in. „Filipinki”21. Wydawnictwo Prasowe „Twój Styl” przekształcono w Spółkę Media Styl, która należała do Grupy Wydawniczej Bauer. W omawianym periodyku zmniejszono format, wprowadzono nowe rubryki, zmieniono nieco szatę graficzną. Redaktor naczelna, J. Dowgiałło-Tyszka, pisała do czytelniczek:

Chcemy, żeby Filipinka szła z duchem czasów, żeby Was zaskakiwała i była nowoczesna [...] Duch Waszego magazynu nie zmienia się. Zmienia się trochę forma. Mamy jednak nadzieję, że tak jak my w redakcji, uznacie, że jest to krok naprzód ${ }^{22}$.

20 R. Filas, Aktywność czytelnicza Polaków przełomu wieków, „Zeszyty Prasoznawcze” 2001, nr 3-4, s. 21-26, 28.

21 Sprawa przejęcia przez niemiecki koncern Wydawnictwa Prasowego „Twój Styl” została już omówiona w rozdziale 3.3.1, poświęconym miesięcznikowi „Twój Styl”. Zob. s. 377-378.

22 J. Dowgiałło-Tyszka, Cześć dziewczyny! [pis. oryg.], „Filipinka” 2002, nr 5, s. [2]. 
Jednak zarówno zmiana właściciela, jak i formy oraz (w pewnym stopniu) zawartości pisma nie wyszła tytułowi na dobre. Jeszcze w tym samym (2002) roku średnia wysokość sprzedaży miesięcznika zmniejszyła się do ok. 93 tys. egzemplarzy 23. Pod koniec tego roku Spółkę Media Styl włączono w struktury Wydawnictwa Bauer ${ }^{24}$. Numer styczniowy (2003) trafił do czytelniczek w zmienionej postaci. „Nowa Filipinka na Nowy Rok” miała inny od dotychczasowego format, nowe nazwy rubryk i inną zawartość. Redakcja w liście do czytelniczek przyznawała:

Rewolucję w „Filipince” zrobiliśmy z Wami. Zmieniło się wszystko. Teraz znajdziecie w swoim piśmie więcej tematów, więcej gwiazd, chłopaków, porad, ciekawych tekstów. [...] $\mathrm{Z}$ waszych listów wiemy, że od swojego magazynu wymagacie wiele. Wielokrotnie podkreślacie, że „Filipinka” ma swojego ducha. Ma to „coś”, co wyróżnia ją spośród innych pism. Wprowadzając zmiany, staraliśmy się tego „czegoś” nie stracić25.

Początkowo wydawało się, że zmiany te wpłynęły pozytywnie na kondycję tego najdłużej ukazującego się periodyku dla dziewcząt w Polsce. Nastąpił wzrost jego sprzedaży do 109 tys. egz. ${ }^{26}$, choć należy podkreślić, że do pierwszych numerów pisma w tymże roku dołączone były gadżety, co mogło mieć wpływ na wskaźniki jego sprzedaży.

W tym czasie (styczeń 2003) z redakcji odeszła J. Dowgiałło-Tyszka. Zastąpiła ją Anna Damięcka, kierująca dotąd innym periodykiem młodzieżowym, „Bravo Girl!”. Zmiana ta wskazywała na kierunek działań wydawcy. Z ambitnego, wartościowego pisma dla dziewcząt „Filipinka” zmierzała coraz wyraźniej w stronę pop-kulturowych pism młodzieżowych, które można było porównać do takich tytułów niemieckiego koncernu jak „Bravo” czy „Twist”. Pojawiło się więcej krótkich reportaży, rozbudowano dział poświęcony modzie i kosmetykom, zawartość magazynu podzielono na bloki tematyczne, z których każdy otrzymał własny kolor. Jak przyznała ówczesna redaktor naczelna: „chcemy wychować przyszłe czytelniczki $>$ Twojego Stylu<"27.

Kolejne zmiany objęły „Filipinkę” w 2004 r. Zmniejszony został jej format, pojawił się nowy projekt okładki, zwiększono objętość pojedynczego wydania z 88 do 124 stron (wynikało to m.in. z wprowadzenia obszernego działu Filipinka Plus, dotyczącego tematyki edukacyjnej, w ramach którego omawiano m.in. lektury szkolne). Nową redaktor naczelną (od numeru 6)

23 Dane Związku Kontroli Dystrybucji Prasy.

${ }^{24}$ Nazwa tego koncernu zaczęła pojawiać się w stopce redakcyjnej „Filipinki” od wydania marcowego w $2003 \mathrm{r}$.

25 J. Dowgiałło-Tyszka, Witajcie w nowej Filipince, „Filipinka” 2003, nr 1, s. 6.

26 Dane Związku Kontroli Dystrybucji Prasy.

27 „Press” 2002, nr 12, s. 12. 
została Dorota Górnicka-Urban (zastąpiona w 2005 r. przez p.o. redaktor naczelnej Martę Dziubalską, a następnie od nr 12 przez Iwonę Kwiecień). Pomimo zmian, w kwietniu 2006 r. wydawca zdecydował o zamknięciu „Filipinki”, motywując decyzję zbyt dużą konkurencją w tej grupie pism i zbyt małymi przychodami z reklam, osiąganymi w przypadku omawianego tytułu28. W ten sposób $\mathrm{z}$ rynku prasowego zniknął zasłużony i ważny periodyk, który wychował kilka pokoleń dziewcząt. Przeobrażenia, jakim został poddany po 1989 r., jakkolwiek prawdopodobnie konieczne, zmieniły go w bardzo dużym stopniu. Z dawnej „Filipinki”, która „radziła, pokazywała, ale też robiła coś, czego współczesna prasa nie robi - zachęcała do myślenia" ${ }^{29}$ po latach zostało niewiele. Jak pisała o swoich wrażeniach jedna z jego dawnych czytelniczek, która:

kupiła kiedyś tę nową, barwną, wydaną na pięknym papierze Filipinkę, aby zarazić bakcylem swoją dorastającą córkę. Po zapoznaniu się z zawartością wpadła jednak w przerażenie. Kosmetyki, moda, seks, horoskop, mało śmieszny humor... To już wszystko? Dlaczego w miejsce mądrych porad psyche\&soma pojawiły się pseudopsychologiczne teksty? Co się stało z recenzjami książek, sztuk teatralnych, pełnymi ciekawostek artykułami popularnonaukowymi, niebanalnymi opowiadaniami? Co czytać $\mathrm{w}$ gazecie, w większości z obrazków złożonej? Czy z tak kochanej przez nią Filipinki, która ją wychowywała, kształtowała i bawiła, pozostał już tylko tytuł?30

Jednocześnie stawiała pytanie, które zadawały sobie, być może, inne dawne czytelniczki pisma:

A właściwie dlaczego tak się stać musiało? Czy faktycznie w dzisiejszych czasach mądre, przyjazne, skierowane do młodzieży pismo nie ma szans się sprzedać? Czy tego typu prasa nie jest już potrzebna? A może Filipinka „skończyła się” właśnie dlatego, że odeszła od swojej linii programowej, stając się kolejną barwną gazetką o niczym?31

\subsubsection{Zawartość, czytelnicy, akcje}

Zawartość „Filipinki” była przedmiotem kilku opracowań32. Wielokrotnie podkreślano jej edukacyjny i wychowawczy, a także społecznokulturalny charakter. Jednak, jak sygnalizowano to wcześniej, określenia te odpowiadały w znacznej mierze dawnej formule periodyku, zaś w niewielkim tylko stopniu odnieść je można było do „Filipinki” wydawanej na początku XXI w.

${ }^{28}$ K. Jasionek, Młodzi wiedzq lepiej, „Press. Magazyn Ekstra” 2006, nr 7, s. 13.

${ }^{29}$ K. Kromka, F jak Filipinka, http://www.pinezka.pl/content/view/2153/209, kwiecień 2011.

30 Ibidem.

31 Ibidem.

32 Pisały o niej m.in. A. Piwowarska, K. Prewęcka, M. Siwko, Z. Sokół. 
Jak pisała Zofia Sokół, zawartość omawianego czasopisma oparto

na psychologicznej zasadzie poszukiwania odpowiedzi na pytania zadawane w wieku 15-16 lat: „kim jestem?”, „kim będę?”, „kim powinnam być?”. „Jakie jest moje miejsce w społeczeństwie, w rodzinie, w grupie rówieśniczej, w szkole? Jak widzą mnie koleżanki i koledzy, nauczyciele i rodzice, krewni i znajomi?33

Tak sprecyzowanym pytaniom odpowiadały zagadnienia, poruszane na łamach pisma, szczególnie do 1990 r.: dom i rodzina, szkoła i nauka, relacje z rówieśnikami (w tym przyjaźnie, pierwsze miłości oraz rozstania), zdrowie i uroda, kultura, obyczajowość (na przykład normy postępowania w określonych sytuacjach), edukacja (przygotowanie do matury, prezentacja najmodniejszych kierunków studiów, wybór przyszłego zawodu). Po owym znamiennym, także dla „Filipinki” 1990 r., proporcje tekstów, nawiązujących do wymienionych kwestii, były stopniowo zmieniane; większy nacisk położono na nowinki dotyczące pielęgnacji urody oraz kontaktów z rówieśnikami (szczególnie z męskimi ich przedstawicielami), więcej miejsca zaczęto również poświęcać modzie i plotkom ze świata filmu i muzyki. Wcześniejszych bohaterów reprezentujących literaturę zastąpili idole muzyczni i filmowi. Recenzje książek zmniejszono do minimum na rzecz omówień premier filmowych i nowych przebojów muzycznych ${ }^{34}$. W piśmie zaczęło brakować głębszych refleksji i analiz, oddających specyfikę „dawnej” „Filipinki”, zawartość periodyku zaczęła nabierać przede wszystkim charakteru informacyjno-reklamowego. Wyraźnemu zmniejszeniu uległy gatunki publicystyczne (na przykład artykuły czy felietony), ustępując miejsca gatunkom informacyjnym (wzmiankom, notatkom, rozmaitym sprawozdaniom i kronikom wydarzeń).

Porównywanie często zmieniających się nazw działów i rubryk nie jest tematem niniejszego opracowania, można jednak wyodrębnić kilka stałych elementów, składających się na zawartość magazynu. Na początku badanego okresu były to: Antrakt (m.in. Film, Nowe płyty, Wideo), Goracy temat, Ładna i zdrowa, Między nami, Odpocznij (m.in. Cześć poeci i poetki, Filip z Piwnymi Oczami, krzyżówka, psychotest), Szafa, Szkolne boje. Rok 2003, wraz ze wspomnianymi wcześniej zmianami, przynosił częste modyfikacje w strukturze pisma, na którą składały się teraz inne nazwy działów (i rubryk): Deser (Dekoder snów, horoskop, krzyżówka, opowiadanie, Poezja, Twój pokój), Lusterko (Bazar, Gabinet, Kosmetyczka, Lekcja urody, Trzymaj forme, Wasze sprawy), Rozrusznik (Kariera, Kasa, Licznik gwiazd, Postaw na swoim, Szkoła), Scena $\rightarrow$ Notes kulturalny (Filmowe hity, Idol, Ksiq̨żki, Moja

33 Z. Sokół, Prasa kobieca..., s. 123-124.

34 Porównanie zawartości „Filipinki” na przykładzie wybranych numerów z poszczególnych lat przeprowadziła A. Piwowarska, zob. A. Piwowarska, Trzy oblicza Filipinki, „Zeszyty Prasoznawcze" 2003, nr 3-4, s. [127]-146. 
piosenka, Prosto z planu, Teatr, $W$ dwa ognie) oraz zachowane wcześniejsze elementy pisma, jak np. Czarna Strona (dawniej Filip z Piwnymi Oczami), Goracy temat, Komiks, Listy do F. W połowie 2003 r. ponownie pojawiły się zmiany; czytelniczki miały do wyboru m.in. takie działy jak Kultura, Psychologia (później jako Psyche $\rightarrow$ Psychologia i seks), Uroda ( $\rightarrow$ Moda i uroda), Qchnia, Zawsze w F. Następne numery przynosiły kolejne nowe rubryki, jak na przykład Ciało i dusza, Dossier, Dzieje się, Filipinka plus, Ja plus..., Kurs na karierę, School na full. Pobieżne choćby spojrzenie na zmiany zachodzące w nazwach działów i rubryk potwierdza wcześniejsze spostrzeżenia: w miarę upływu czasu „Filipinka” stawała się coraz bardziej „modna”, język i styl publikacji zbliżał się wyraźnie do ówczesnego slangu młodzieżowego, zawartość miała charakter bardziej komercyjny, niemal bliźniaczo podobny do innych pism młodzieżowych, popularnych, wysokonakładowych, które łączyły te same uniwersalne sformułowania, co sprawiało wrażenie kolejnych kalek tego samego tytułu, odbierając „Filipince” jej indywidualny, specyficzny charakter. Z pisma społeczno-kulturalnego stała się periodykiem poradnikowo-rozrywkowym oraz informacyjno-reklamowym. Wyraźne było w tym okresie zwiększenie liczby zdjęć oraz porad dotyczących zdrowia i pielęgnacji urody. Tendencja ta widoczna była do końca badanego okresu.

W 2005 r. ponownie zmieniono format magazynu. W latach 2001-2005 jego objętość wynosiła średnio 86 stron. Jednocześnie zmieniał się jego adresat. 0 ile bowiem „Filipinka” sprzed 1990 r. kierowana była do starszych (16-20 lat), ambitnych dziewcząt, o tyle w jej kolejnych wydaniach w latach następnych widać wyraźnie starania redakcji, by tytułem zainteresować młodsze (głównie w wieku gimnazjalnym, 11-14 lat) czytelniczki, o znacznie mniejszych (zbliżonych do przeciętnych) wymaganiach ${ }^{35}$. Podobnie jak przeważająca część prasy młodzieżowej w tamtym okresie, „nowa” „Filipinka” wychowywać miała swoje czytelniczki „na wzorowe konsumentki: towarów, reklamowanych za pomocą porad, masowej kultury, opisywanej za pomocą >rozrywkowych porad<"36, przyszłe adresatki magazynów kobiecych: „Twojego Stylu” lub „Elle”.

Do przeszłości należały ambitne akcje typu Latająca Biblioteka ${ }^{37}$. W analizowanym okresie redakcja organizowała przedsięwzięcia o innym

35 Obniżenie wieku czytelniczek zaczęło się wyraźnie w chwili wykupienia pisma przez WPTS, w kolejnych latach następowało dalsze odmładzanie adresatek periodyku.

36 A. Piwowarska, Gatunki dziennikarskie na łamach trzech wcieleń „Filipinki” - podobieństwa i różnice, „Zeszyty Prasoznawcze” 2005, nr 1, s. 68.

37 Latająca Biblioteka - inicjatywa, adresowana do mieszkanek wsi i małych miast, w których książki w tamtych latach były trudno dostępne. Akcja polegała na wymianie książek pomiędzy czytelniczkami: „Dziewczęta zostają podzielone na kilkuosobowe kółka. Każda uczestniczka otrzymuje z redakcji trzy książki, które po przeczytaniu przesyła (wedle ustalonej kolejności) koleżance ze swojego kółka” („Filipinka” 1965, nr 19, s. 11). 
charakterze, na przykład Dziewczyna Filipinki (w postaci krótkiej notatki prezentowano czytelniczki, które podejmują ciekawe, nierzadko niekonwencjonalne działania, zachęcając jednocześnie pozostałe dziewczęta do przysyłania zgłoszeń ${ }^{38}$ ), Superhit $F$. (comiesięczny wybór przez czytelniczki najlepszego kosmetyku) czy Zacznij karierę z Filipinkq³9. Należy wspomnieć również o konkursie Nauczyciel na 6: czytelniczki przysyłały propozycje własnych kandydatów na najlepszych, ich zdaniem, pedagogów, którym później przyznawano nagrody i wpisywano ich na honorową listę „Filipinki”.

Cyklicznie organizowanym, o wieloletniej tradycji był Konkurs Literacki Filipinki. Ze względu na charakter pracy zostanie on omówiony w dalszej jej części.

$\mathrm{Na}$ łamach periodyku pojawiały się także ogłoszenia o konkursach, organizowanych m.in. przez instytucje, firmy lub szkoły (na przykład konkurs Międzynarodowej Szkoły Charakteryzacji Marii Ewy Dziewulskiej: Zgadnij, kto to jest? $\left.{ }^{40}\right)$.

\subsubsection{Ile w Tobie z Bridget Jones? ${ }^{21}$ : książka na łamach pisma}

Jakkolwiek do 1990 r. literatura była chętnie reprezentowana na łamach „Filipinki”, o tyle w latach następnych wyraźna stała się tendencja do zmniejszania $\mathrm{w}$ periodyku miejsca poświęconego książce. $\mathrm{W}$ badanym okresie szeroko rozumiana kultura reprezentowana była przede wszystkim poprzez informacje dotyczące filmu i muzyki, natomiast interesujące nas zagadnienia związane $\mathrm{z}$ literaturą poruszano $\mathrm{w}$ znacznie mniejszym stopniu, systematycznie je marginalizując.

W latach 2001-2005 dział, w którym pojawiały się strony lub rubryki poświęcone kulturze, wielokrotnie zmieniał swą nazwę oraz formę. Częste zmiany ${ }^{42}$ zdają się odzwierciedlać nie tylko przeobrażenia, jakie obejmowały periodyk $\mathrm{w}$ badanym okresie, ale również dają wyraz niezdecydowaniu redakcji, poszukiwaniom, które (być może) miały na celu utrafić w gust współczesnych dziewcząt. W efekcie jednak w strukturze działu kulturalnego, a w jego ramach w interesującej nas rubryce, panował niemal nieustanny chaos.

38 Zob. np. „Filipinka” 2004, nr 7, s. [5].

39 „Filipinka” 2003, nr 4, s. [28]-[29].

40 Zob. np. „Filipinka” 2004, nr 4, s. [5].

41 Tytuł, zob. „Filipinka” 2001, nr 8, s. [53].

$42 \mathrm{~W}$ trakcie analizowanych 5 lat pięciokrotnie zmieniono nazwę działu kulturalnego (Antrakt $\rightarrow$ Scena $\rightarrow$ Notes kulturalny $\rightarrow$ Dzieje się $\rightarrow$ F. teraz) i aż 12 razy zmianie ulegała nazwa strony, w ramach której odnaleźć można było informacje dotyczące książek (kilkakrotnie powracano do raz zarzuconej nazwy). Ze względu na tak częste modyfikacje zdecydowano się je omówić w tym miejscu, nie zaś w podrozdziale poświęconym recenzjom książek, unikając $w$ ten sposób niezbędnego w takim przypadku powtarzania informacji. 
Przez pierwsze dwa lata był to wyodrębniony w spisie treści Antrakt, który wewnątrz numeru odnaleźć można było na przypisanych mu stronach jako Segregator ${ }^{43}$. W jego obrębie, zazwyczaj w środkowej części numeru, drukowano (systematycznie lub sporadycznie) następujące rubryki: Film, Idol Książki, Muzyka, Wideo, Zjawiska. Zajmowały one średnio 8 stron zawartości pisma, przy czym najbardziej interesująca nas rubryka nie pojawiała się w każdym numerze ${ }^{44}$. Książce poświęcano przeważnie całą stronę, choć w kwietniowym i grudniowym wydaniu w $2001 \mathrm{r}$. była to tylko kolumna.

Od numeru 1 (2003) wraz z opisanymi wcześniej przeobrażeniami, zachodzącymi w magazynie, nastąpiła również zmiana nazwy działu kulturalnego. Dotychczasowy Antrakt zastąpiła w spisie treści (a także analogicznie wewnątrz numeru) Scena, zaś w jej ramach obok większości dotychczasowych rubryk ${ }^{45}$, pojawiła się dodatkowo Sztuka (na stronie jej poświęconej drukowano m.in. informacje związane z książką). Zanim jednak czytelniczki zdążyły przyzwyczaić się do nowej formuły, od wydania kwietniowego (2003) nastąpiła kolejna zmiana: zamiast Sceny zaproponowano Notes kulturalny, a w jego obrębie, obok podobnych do poprzednich rubryk, dodano dwie nowe: Multimedia, Prześwietlenie, oraz jednorazowo (w wydaniu majowym) część zatytułowaną Kultura. Od numeru czerwcowego (2003) wyodrębniono oddzielną stronę, zatytułowaną Ksiq̨żki, którą poza jednym wyjątkiem ${ }^{46}$ drukowano do numeru 9 (2003) włącznie. W numerze 10 (2003) ponownie zmieniono jej nazwę. Odtąd czytelniczki zainteresowane książką mogły znaleźć informacje z nią związane w ramach Literatury. Nowa nazwa nie utrzymała się długo, bo tylko do następnego, listopadowego numeru. Natomiast w wydaniu świątecznym, grudniowym, oraz noworocznym, otwierającym rok 2004, zabrakło rubryki poświęconej książce.

Od numeru 2 w 2004 r., nadal w ramach Notesu Kulturalnego powrócono do wcześniejszej nazwy rubryki, jaką były Książki. Po czterech numerach redakcja uznała za stosowne dodać jeszcze określenie To warto czytać. Kolejne trzy wydania (czerwcowe, lipcowe i sierpniowe) to rubryka zatytułowana Literatura. Numer wrześniowy powitał czytelniczki znaną nazwą: Książki.

Październik 2004 r. to kolejne zmiany. Tym razem strona, na której odnaleźć można m.in. informacje związane z książką, otrzymała tytuł Przebojnik.

${ }^{43}$ Inna nazwa działu, pojawiająca się w spisie treści i inna wewnątrz numeru była częstą praktyką redakcji.

44 Pominięto ją w następujących numerach w 2001 r.: 1, 2, 5, 6, 7, 11 oraz w roku 2002 w numerach: $4,5,8$.

45 Poza wyodrębnionymi dotychczas Książkami.

46 W numerze lipcowym (2003). 
Od numeru $1 \mathrm{w} 2005$ r., zachowując powyższą nazwę interesującej nas strony, zmieniono nazwę działu kulturalnego, który odtąd nosił tytuł Dzieje się. Jednorazowo, w wydaniu kwietniowym, pojawiła się nowa nazwa: Warto obejrzeć.

Ostatnia w badanym okresie zmiana nastąpiła od numeru majowego pisma. Informacje kulturalne przeniesiono do działu $F$. teraz. W jego obrębie wyszczególniono rubrykę Obejrzyj i przeczytaj, skróconą od numeru 9 (2005) do propozycji/polecenia Przeczytaj ${ }^{47}$.

Przeważająca liczba informacji kulturalnych zamieszczana była w przywołanym powyżej dziale, zmieniającym na przestrzeni 5 lat swą nazwę. Jednak wzmianki związane $\mathrm{z}$ problematyką kulturalną pojawiały się niekiedy także na innych stronach periodyku. Zostaną one omówione w dalszej części rozdziału.

Do numeru 5 (2002) włącznie za sprawy kultury odpowiadała w piśmie Inga Kazana, w dwóch kolejnych numerach w stopce redakcyjnej pojawiło się nazwisko Bartka Rączkowskiego jako osoby czuwającej nad przygotowaniem informacji kulturalnych. Od numeru sierpniowego tegoż roku został on mianowany na stanowisko p.o. redaktora naczelnego, natomiast w numerze 9 nową redaktor odpowiedzialną za dział kulturalny została Monika Kucia, pełniąca tę funkcje do numeru 2 (2003) włącznie. W następnych siedmiu numerach pisma brakuje informacji dotyczącej osoby odpowiedzialnej za tenże dział i dopiero w wydaniu październikowym (2003) znalazło się w stopce redakcyjnej nazwisko Moniki Dąbrowskiej. Wraz z kolejnymi zmianami w piśmie, które nastąpiły w 2004 r., ze stopki redakcyjnej zniknęło jej nazwisko i aż do końca badanego okresu brak oficjalnie zastępującej jej osoby. Charakterystyczne jest również spostrzeżenie, że przeważająca liczba informacji kulturalnych nie była podpisywana, zatem trudno jest podać w tym miejscu inne jeszcze nazwiska osób, które przygotowywały $\mathrm{w}$ analizowanym okresie teksty składające się na interesujący nas dział.

Dominującą formą informacji o książce na łamach prezentowanego pisma w badanym okresie były recenzje, aczkolwiek, jak już został to powiedziane w części wstępnej do rozdziału opisującego wybrane pisma młodzieżowe, nie w pełni odpowiadały one definicji gatunku publicystycznego, do którego są zaliczane. Przypomnijmy, że ich postać częściej przypominała notatkę prasową, adnotację treściową, omówienie lub krótkie streszczenie, pozbawione rozbudowanych elementów, charakterystycznych dla wzorcowej recenzji. Sporadycznie pojawiały się jednak również inne formy dzien-

$47 \mathrm{~W}$ ostatnim badanym numerze $(12 / 2005)$ nazwa ta nie pojawiła się, aczkolwiek rubryka zachowała swą wcześniejszą formę. 
nikarskie, a jakkolwiek było ich niewiele, to można jednak wyodrębnić, wzorem poprzednich rozdziałów, następujące kategorie i odpowiadające im dane statystyczne ${ }^{48}$ (tabela 60).

Tabela 60. Formy obecności książki i informacji o niej na łamach na łamach „Filipinki” w latach 2001-2005

\begin{tabular}{|l|c|}
\hline \multicolumn{1}{|c|}{ Rodzaj informacji } & Liczba ogółem \\
\hline Recenzje, omówienia, streszczenia & 179 \\
\hline Wywiady & 19 \\
\hline Reklamy książek & 159 \\
\hline Sylwetki/portrety & 10 \\
\hline Artykuły, poświęcone książce i rynkowi wydawniczo-księgarskiemu & 15 \\
\hline Ekranizacje, adaptacje, inscenizacje znanych dzieł & 49 \\
\hline Konkursy i akcje & 60 \\
\hline Listy bestsellerów & 8 \\
\hline $\begin{array}{l}\text { Listy czytelników, nawiązujące do zamieszczonej informacji } \\
\text { związanej z książką }\end{array}$ & 3 \\
\hline Inne & \\
\hline Ogółem & 177 \\
\hline
\end{tabular}

${ }^{a}$ Ze względu na specyfikę i charakter zamieszczanych w omawianym periodyku informacji związanych z książką do kategorii Inne zaliczono w tym przypadku teksty, których autorem był pisarz, fragmenty powieści, komiks i opowiadania drukowane w odcinkach na łamach pisma, rubrykę poetycką, kilkakrotnie zamieszczoną rubrykę Co czyta...? oraz wzmianki i notatki prasowe, donoszące o wydarzeniach związanych z literaturą.

Źródło: badania własne.

Jak już wspomniano powyżej, przeważającą kategorią związaną z informacją o książce na łamach omawianego pisma były Recenzje, omówienia i streszczenia (179). Pozostałe, poza grupą Inne, Reklamy książek oraz Konkursy i akcje, prezentowane były pod względem liczbowym bardzo skromnie. Zwraca szczególnie uwagę znikoma niemal liczba listów czytelniczek, w których odnosiłyby się one do prezentowanych na łamach miesięcznika książek, szczególnie że odzew kupujących „Filipinkę” na inne tematy poruszane w piśmie był duży.

Jak wynika $\mathrm{z}$ analizy zebranego materiału, dominującą formą dziennikarską, którą można odnaleźć w periodyku, były gatunki informacyjne, takie jak wywiad, sylwetki/portrety, listy czytelników, inne, wśród których przeważały wzmianki, notki prasowe, $\mathrm{w}$ tym informacje poszerzone i pełne. Poza recenzjami, omówieniami i streszczeniami sporadycznie pojawiały się inne formy publicystyczne, jak na przykład felietony i artykuły, bardzo

48 Podobnie jak w poprzednich rozdziałach, tak i tu przyjęto porządek podawania określonych kategorii zgodnie z kolejnością ich omawiania w dalszej części pracy. 
rzadko zaś spotkać można było na łamach o opisywanego miesięcznika komentarze.

Większość wymienionych w tabeli 60 informacji drukowana była w ramach działu zawierającego doniesienia kulturalne. Wśród nich znalazły się także recenzje.

\subsubsection{Czytasz i w lot chwytasz ${ }^{49}$ : miejsce recenzji w układzie pisma}

W latach 2001-2005 na łamach „Filipinki” pojawiło się w sumie 179 recenzji, omówień i streszczeń książek ${ }^{50}$. W tabeli 61 zaprezentowano ich liczbę w poszczególnych latach.

Tabela 61. Recenzje i omówienia książek zamieszczane na łamach „Filipinki”w latach 2001-2005

\begin{tabular}{|c|c|}
\hline Rok & Liczba recenzji, omówień i streszczeń \\
\hline 2001 & 17 \\
\hline 2002 & 52 \\
\hline 2003 & 27 \\
\hline 2004 & 44 \\
\hline 2005 & 39 \\
\hline Ogółem & 179 \\
\hline
\end{tabular}

Źródło: badania własne.

Liczba recenzji, omówień i streszczeń była bardzo nierówna; trudno mówić o jakichkolwiek tendencjach; różnica pomiędzy ich najmniejszą a największą liczbą jest ponad trzykrotna, co wynikało z przytoczonych powyżej częstych zmian związanych z rubryką, w której drukowano także omówienia książek, jak również z faktu, że (szczególnie w początkowym okresie) recenzje nie należały do systematycznie zamieszczanych w magazynie materiałów. W 2001 r., pomimo że strona związana z książką znalazła swe miejsce $\mathrm{w}$ sześciu wydaniach, to recenzje pojawiły się $\mathrm{w}$ pięciu $\mathrm{z}$ nich, przy czym ich rozmieszczenie za każdym razem było nieco inne. W następnym, 2002 r., interesująca nas strona pojawiła się w dziewięciu wydaniach, ale recenzje zamieszczono tylko w siedmiu z nich, od numeru czerwcowego anonsując część omówień tytułem Filipinka poleca. Oto wybrane przykłady obrazujące tę formę informacji o książce, wykorzystywaną na łamach prezentowanego pisma (zdjęcia 148-150) ${ }^{51}$.

49 Tytuł jednej z recenzji, „Filipinka” 2001, nr 4, s. [43].

$50 \mathrm{~W}$ tej liczbie znalazły się wyłącznie recenzje odredakcyjne.

51 Ze względu na częste zmiany, zachodzące na omawianych stronach, podane przykłady odzwierciedlają tylko najważniejsze z nich. 


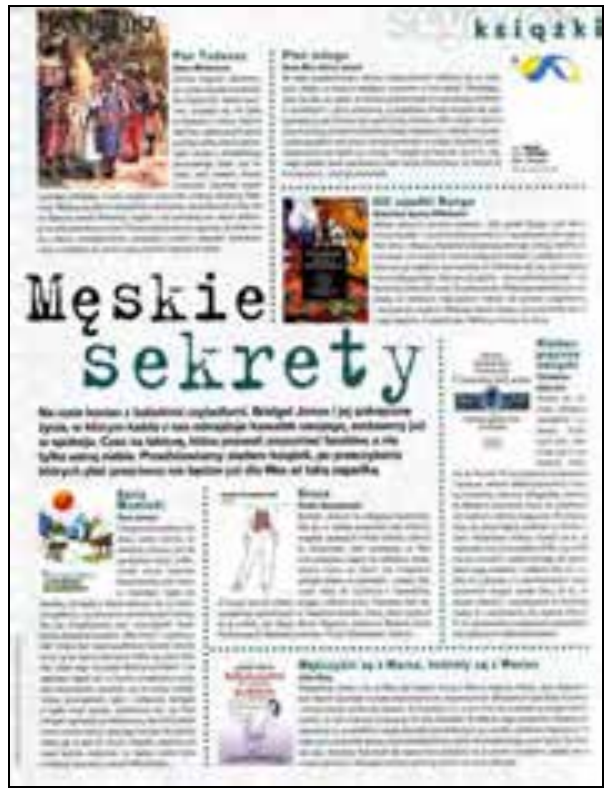

Zdjęcie 148. Strona recenzyjna na łamach „Filipinki”

„Filipinka” 2001, nr 10, s. 48

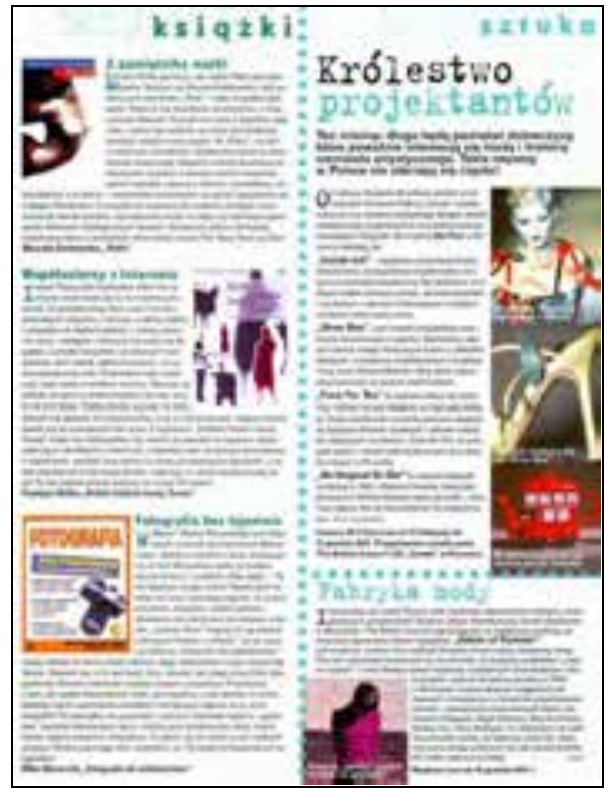

Zdjęcie 149. Strona recenzyjna na łamach "Filipinki"

„Filipinka” 2001, nr 12, s. [59]

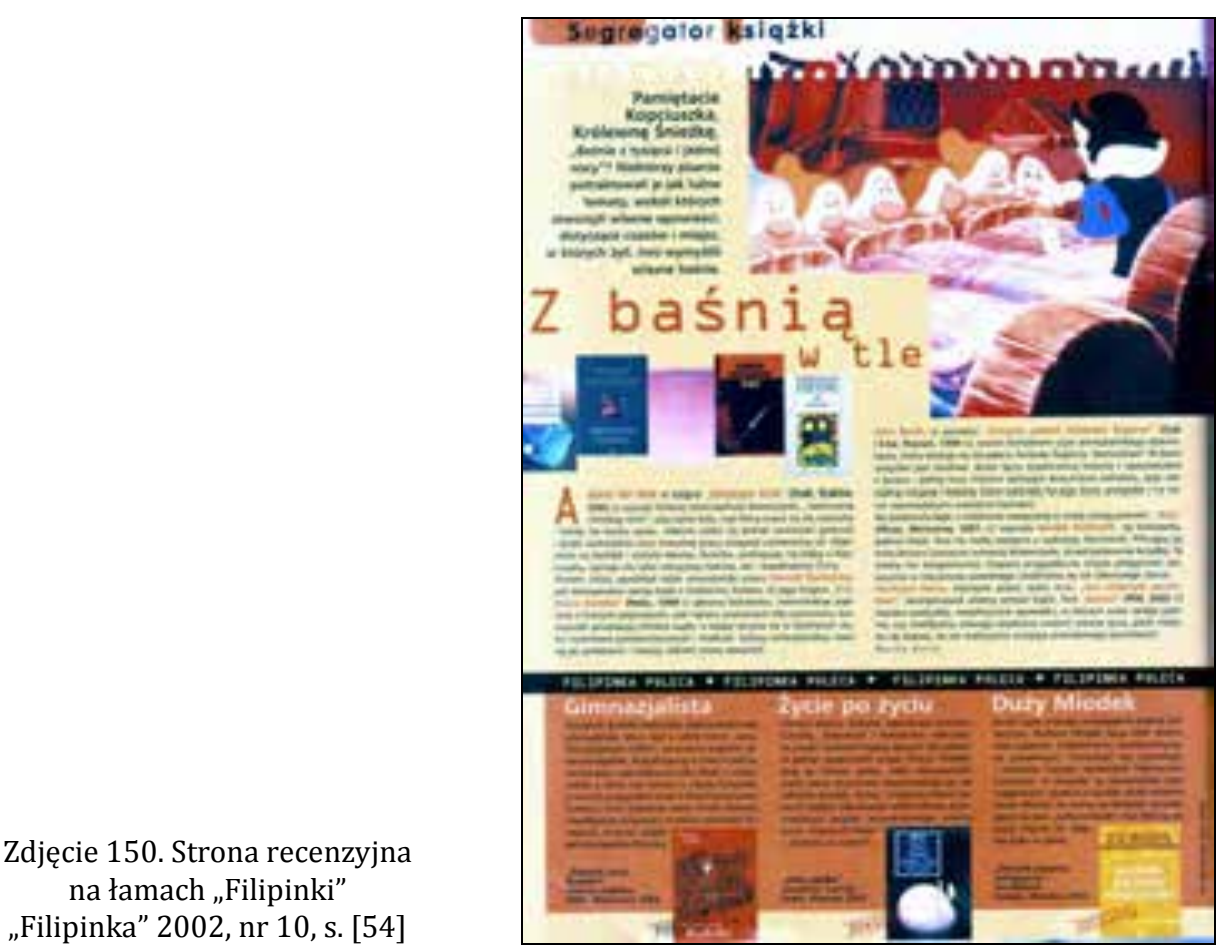


W każdym z prezentowanych przypadków recenzje rozmieszczone były na stronie w inny sposób, ale wydaje się, że za każdym razem panował na niej pewien chaos. Zbyt duże nagromadzenie elementów, niewyraźne ich oddzielenie powodowało szum informacyjny, szczególnie w dwóch pierwszych przykładach. Czytelnik mógł odnieść wrażenie, że redakcji zależało przede wszystkim na maksymalnym wykorzystaniu miejsca, bez zwracania szczególnej uwagi na stopień komunikatywności przekazu. W pięciu numerach w 2002 r. niektóre omówienia wyodrębnione były hasłem Filipinka poleca, i drukowane u dołu strony (na przykład zdjęcie 150).

W 2003 r. recenzje, omówienia i streszczenia zamieszczono w siedmiu numerach pisma, chociaż strona związana z książką pojawiła się w 10 wydaniach pismach ${ }^{52}, \mathrm{w}$ dwóch zaś ją pominięto ${ }^{53}$. Także $\mathrm{w}$ ramach tego roku jej nazwa i forma ulegały zmianom. Eksperymentowano z rozmaitym rozmieszczeniem omówień na wybranej dla nich stronie, przy czym nie w każdym przypadku przeznaczano dla nich tyle samo miejsca. Poniżej wybrano przykłady ilustrujące owe modyfikacje (zdjęcie 151-153).

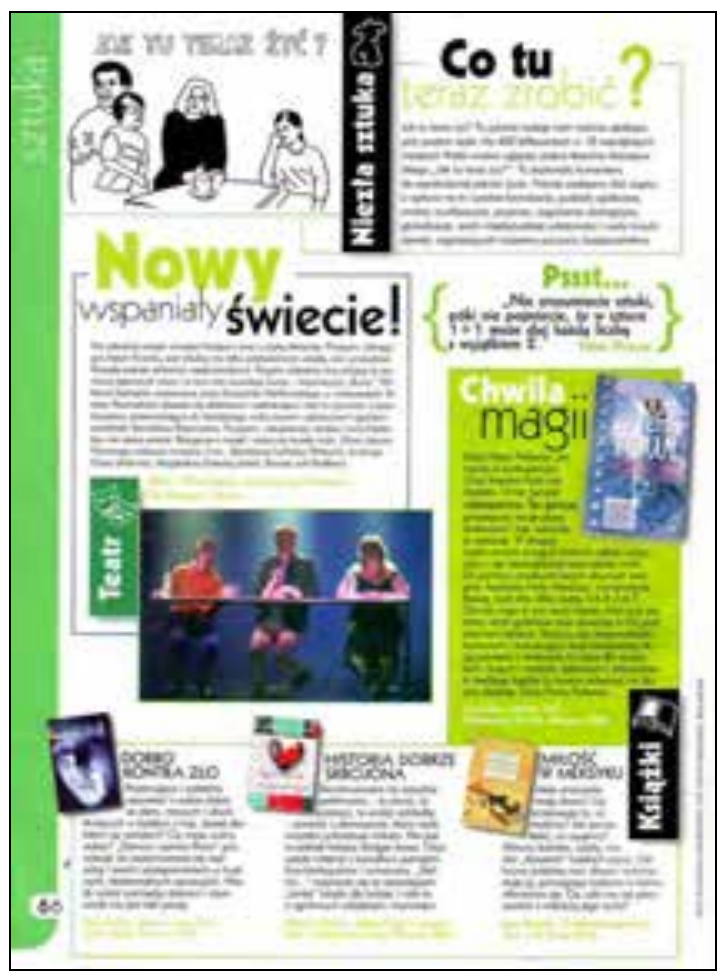

Zdjęcie 151. Strona recenzyjna na łamach „Filipinki” „Filipinka” 2003, nr 3, s. 66

$52 \mathrm{~W}$ trzech pozostałych wydrukowano fragmenty wybranych powieści.

53 W numerach 1 i 12 (2003) . 
Zdjęcie 152. Strona recenzyjna na łamach „Filipinki” „Filipinka” 2003, nr 6, s. [67]

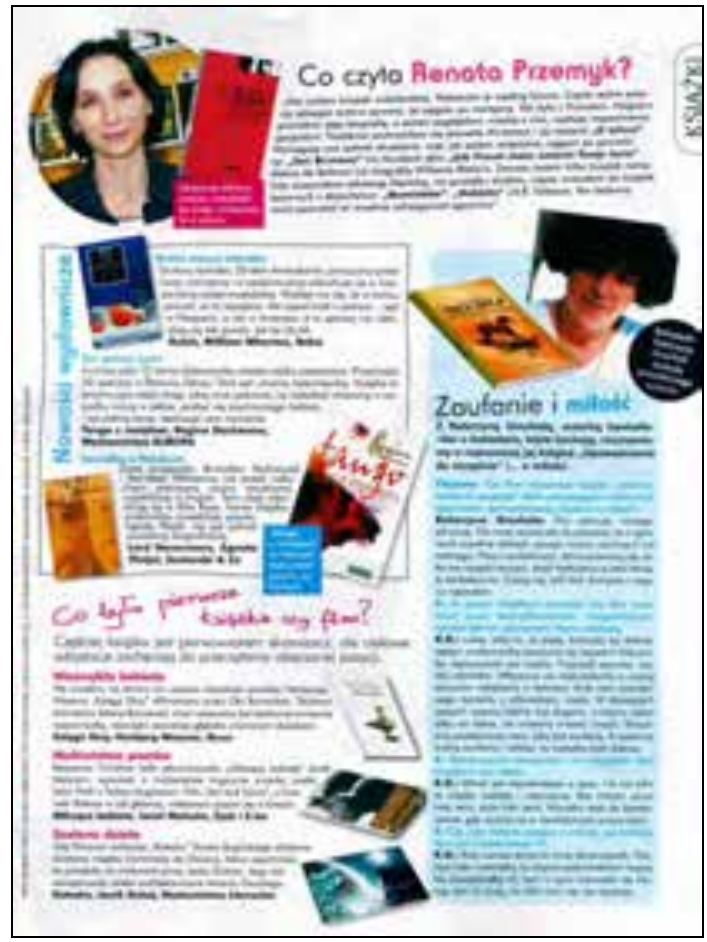

Za każdym razem grafika strony była inna, jednak nadal pozostawała mało przejrzysta, choć bardzo kolorowa, co odpowiadało całej zawartości periodyku. W dwóch pierwszych przykładach najliczniejszymi stałymi elementami były kopie okładek prezentowanych książek, w większości jednak zbyt małe, by stanowić czytelne źródło informacji. Równie zmienna była liczba omówień: od jednego (w lipcu/2003), poprzez trzy (m.in. w wydaniu marcowym), a kończąc na pięciu (numer sierpniowy). Wahaniom ulegała również ich objętość. 


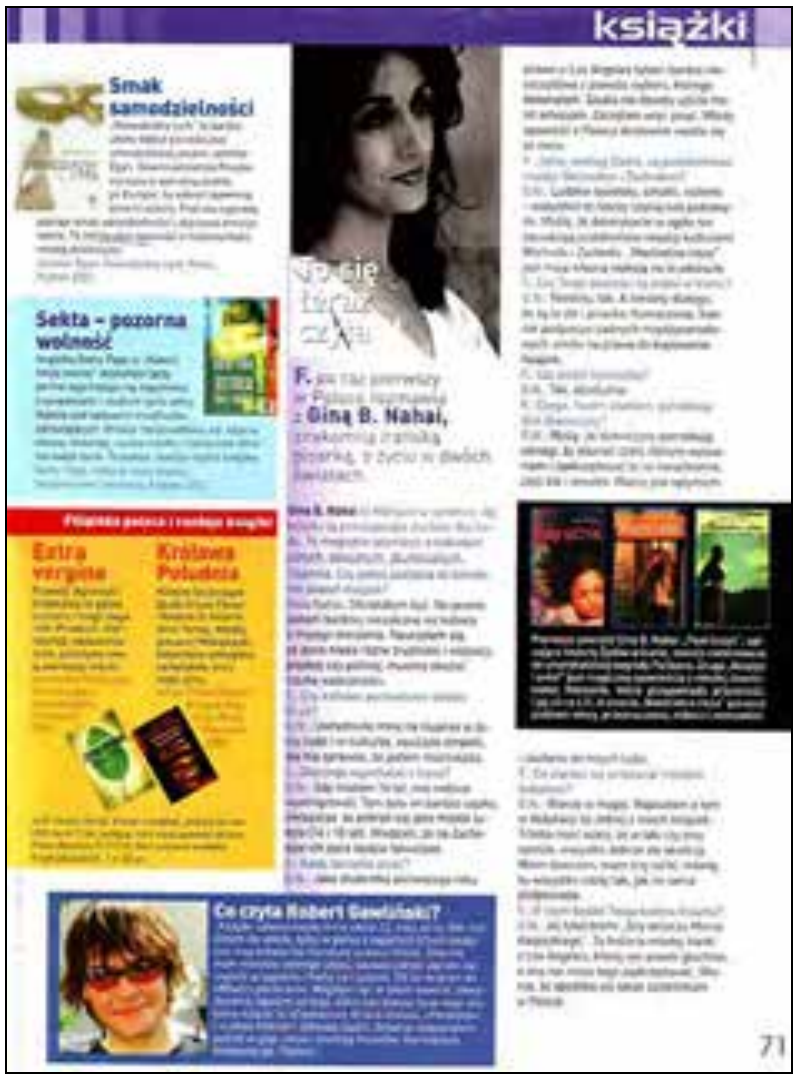

Zdjęcie 153. Strona recenzyjna na łamach „Filipinki”

„Filipinka” 2003, nr 8, s. 71

Kolejne modyfikacje nastąpiły w 2004 r. Wraz z opisanymi wcześniej zmianami tytułu strony recenzyjnej, czytelniczkom kilkakrotnie (niemal w każdym kolejnym numerze) proponowano inny jej wygląd. W ciągu 12 miesięcy recenzji książek zabrakło tylko raz, w wydaniu styczniowym, natomiast $\mathrm{w}$ numerze 2 na sprawy związane $\mathrm{z}$ książką, $\mathrm{w}$ tym omówienia wybranych tytułów, przeznaczono dwie strony. Próby redakcji, zmierzające do znalezienia najlepszego rozwiązania dla prezentacji interesujących nas informacji, przedstawiono na zdjęciu 154.

Zmiany wprowadzano bardzo często, w 2004 r. praktycznie niemal w każdym numerze (zdjęcia 155-158). 


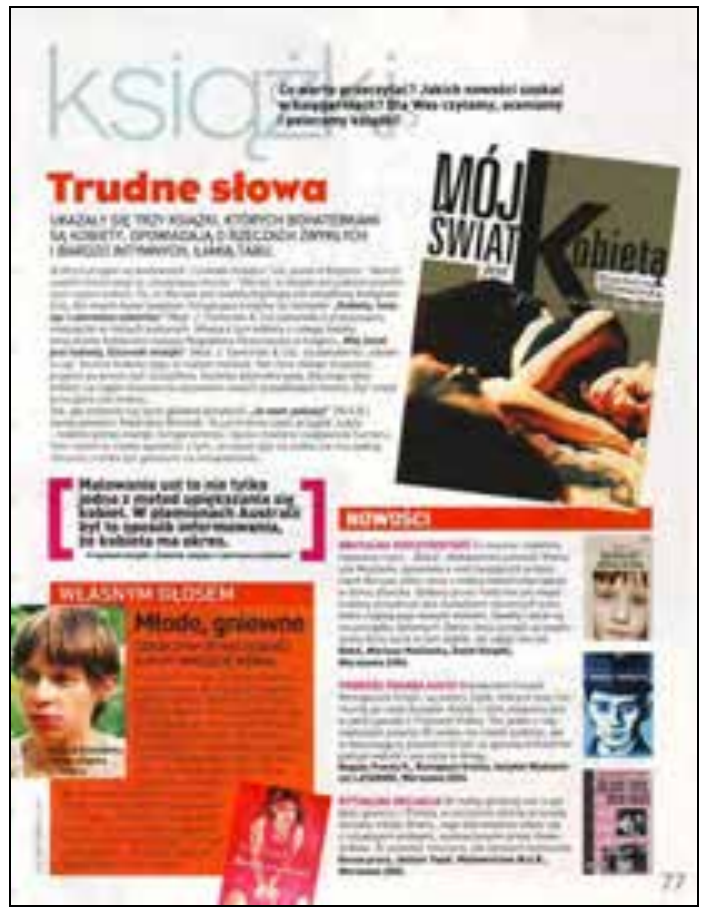

Zdjęcie 154. Strona recenzyjna na łamach „Filipinki”

„Filipinka” 2004, nr 3, s. 77

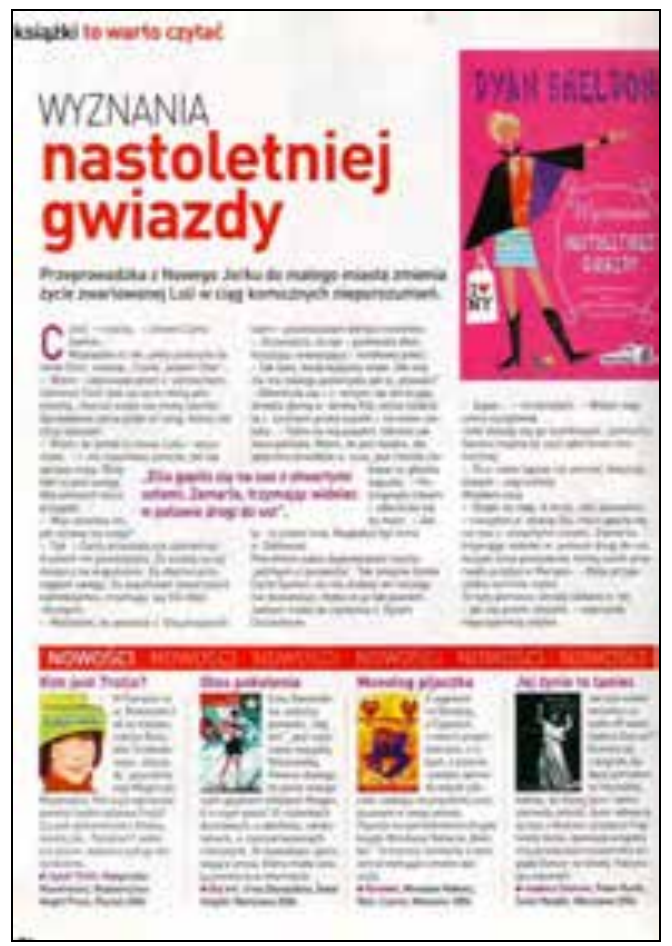

Zdjęcie 155. Strona recenzyjna na łamach „Filipinki” „Filipinka” 2004, nr 5, s. 74 


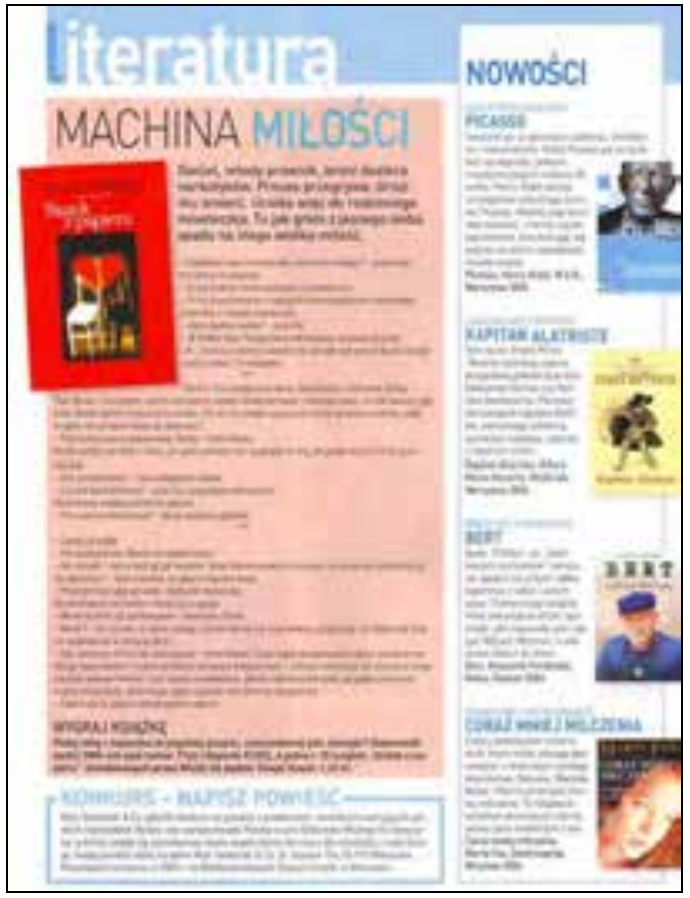

Zdjęcie 156. Strona recenzyjna na łamach „Filipinki” „Filipinka” 2004, nr 7, s. 76

Zdjęcie 157. Strona recenzyjna na łamach „Filipinki” „Filipinka” 2004, nr 9, s. [69]

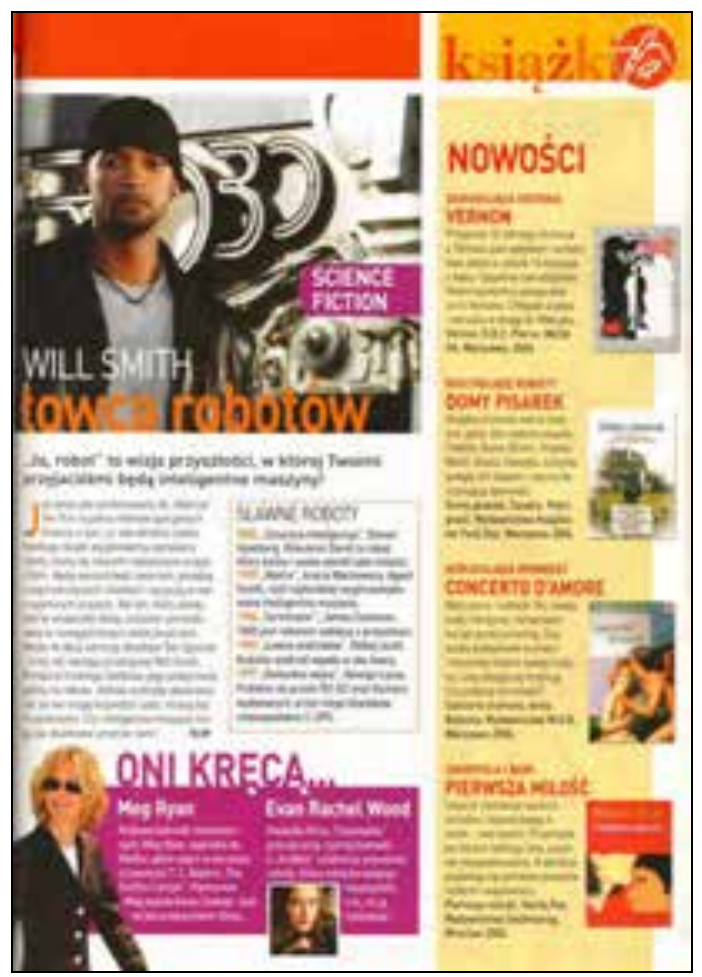




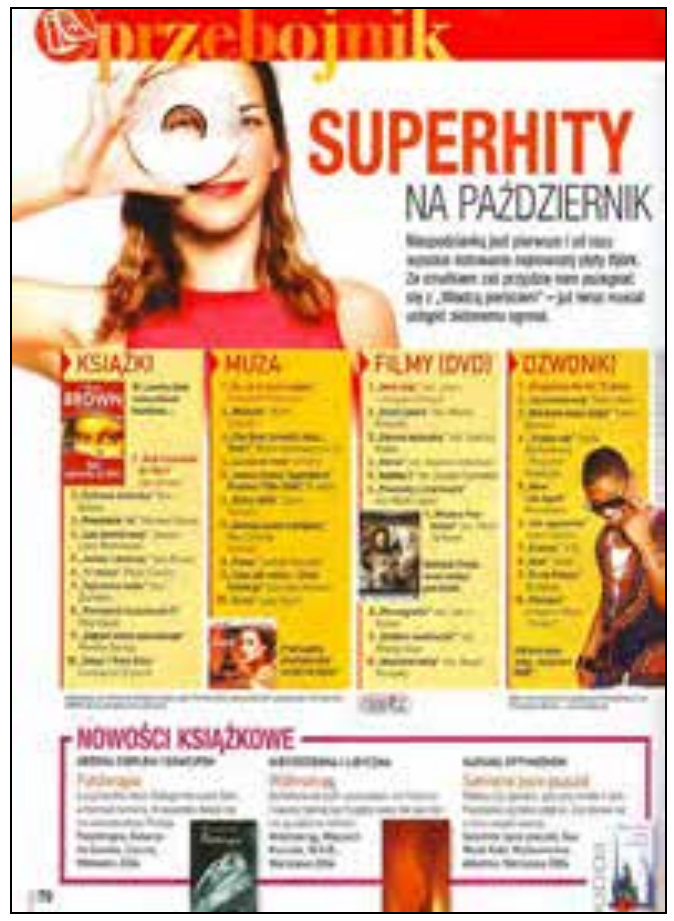

Zdjęcie 158. Strona recenzyjna na łamach „Filipinki”

Filipinka” 2004, nr 10, s. 70

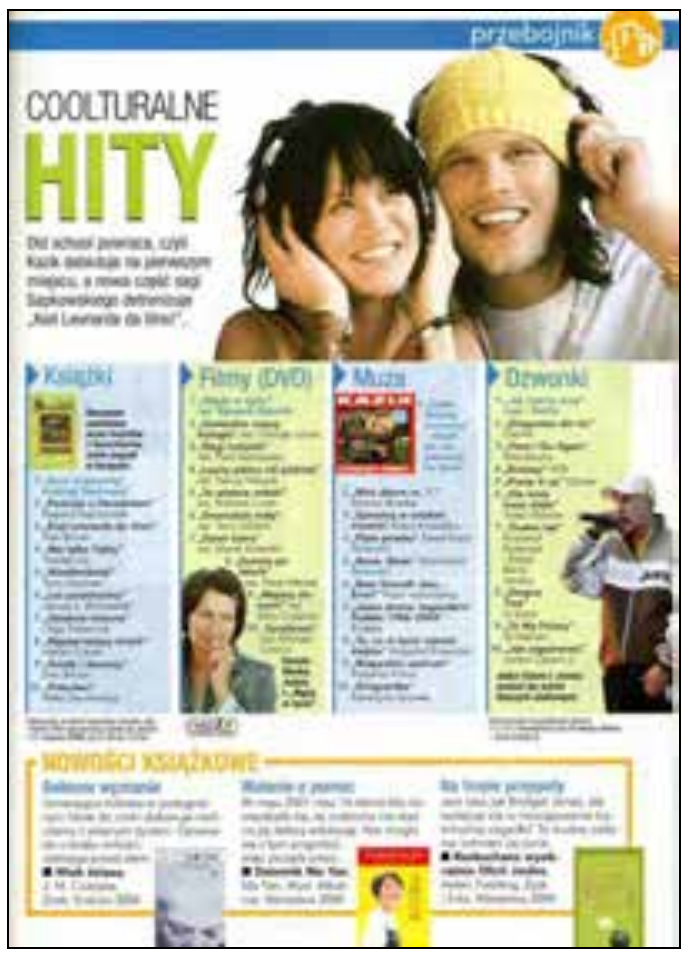

Zdjęcie 159. Strona recenzyjna na łamach „Filipinki”

„Filipinka” 2004, nr 11, s. [73] 
Eksperymentowano nie tylko z różnym rozmieszczeniem elementów na stronie i zmianą jej tytułu, ale również $\mathrm{z}$ wprowadzaniem $\mathrm{w}$ tym miejscu różnych kolorów (obok różowego i czerwonego, pojawiał się także niebieski, zielony i żółty) - zdjęcie 159.

Ostatnie przytoczone przykłady obrazują zmiany zachodzące w obrębie interesującej nas strony $\mathrm{w}$ okresie zaledwie jednego roku. Do wydania sierpniowego widać największe zróżnicowanie informacji o książce zamieszczanych w tym miejscu pod względem formy. Zazwyczaj obok omówień (3-4), umieszczonych w postaci kolumny lub modułu u dołu strony, drukowano fragment wybranej powieści, niekiedy także proponowano konkurs sms-owy, w którym nagrodą były książki (zdjęcia 154-156). Obok owych omówień, coraz krótszych pod względem objętości, coraz bardziej przypominających wzmianki niż prawdziwe recenzje umieszczano kopie okładek prezentowanych książek, a także odnoszące się do nich podstawowe dane bibliograficzne. W numerach marcowym i kwietniowym (2004) pojawiło się wprowadzenie anonsujące zawartość rubryki: „Co warto przeczytać? Jakich nowości szukać w księgarniach? Dla Was czytamy, oceniamy i polecamy książki!", sugerujące specjalne starania redakcji. (zdjęcie 154), zarzucone jednak w kolejnych wydaniach pisma.

Jednak już od numeru sierpniowego widać stopniowe redukowanie miejsca przeznaczonego na omówienia. Najpierw była to tylko kolumna, obok innych informacji, związanych na przykład z filmem lub muzyką (zdjęcie 157), później objętość omówień zmniejszono do 1-3-zdaniowych adnotacji treściowych, drukowanych $\mathrm{w}$ formie modułu u dołu strony, pod listą bestsellerów, wśród których znalazły się także książki (zdjęcie 158159). Wzmianki te, jakkolwiek traktowane jako jeden z ostatnich elementów zamieszczanych na stronie (szczególnie od numeru październikowego), stały się bardziej wyraźne, głównie dzięki wprowadzeniu bardziej stonowanych kolorów. Stałym ich składnikiem pozostała kopia okładki proponowanej książki (także bardziej czytelna) i określające ją podstawowe dane bibliograficzne. Taką formę recenzji zachowano do numeru 4 (2005). Od numeru 6 pojawiły się kolejne modyfikacje, związane z lokalizacją omówień na danej stronie, choć nie były one już zbyt rewolucyjne. Ostatni badany rok (2005) przyniósł kolejne zmiany, które widoczne są w wybranych poniżej przykładach (zdjęcia 160-161). 
Zdjęcie 160. Strona recenzyjna na łamach „Filipinki”

„Filipinka” 2005, nr 6, s. 14
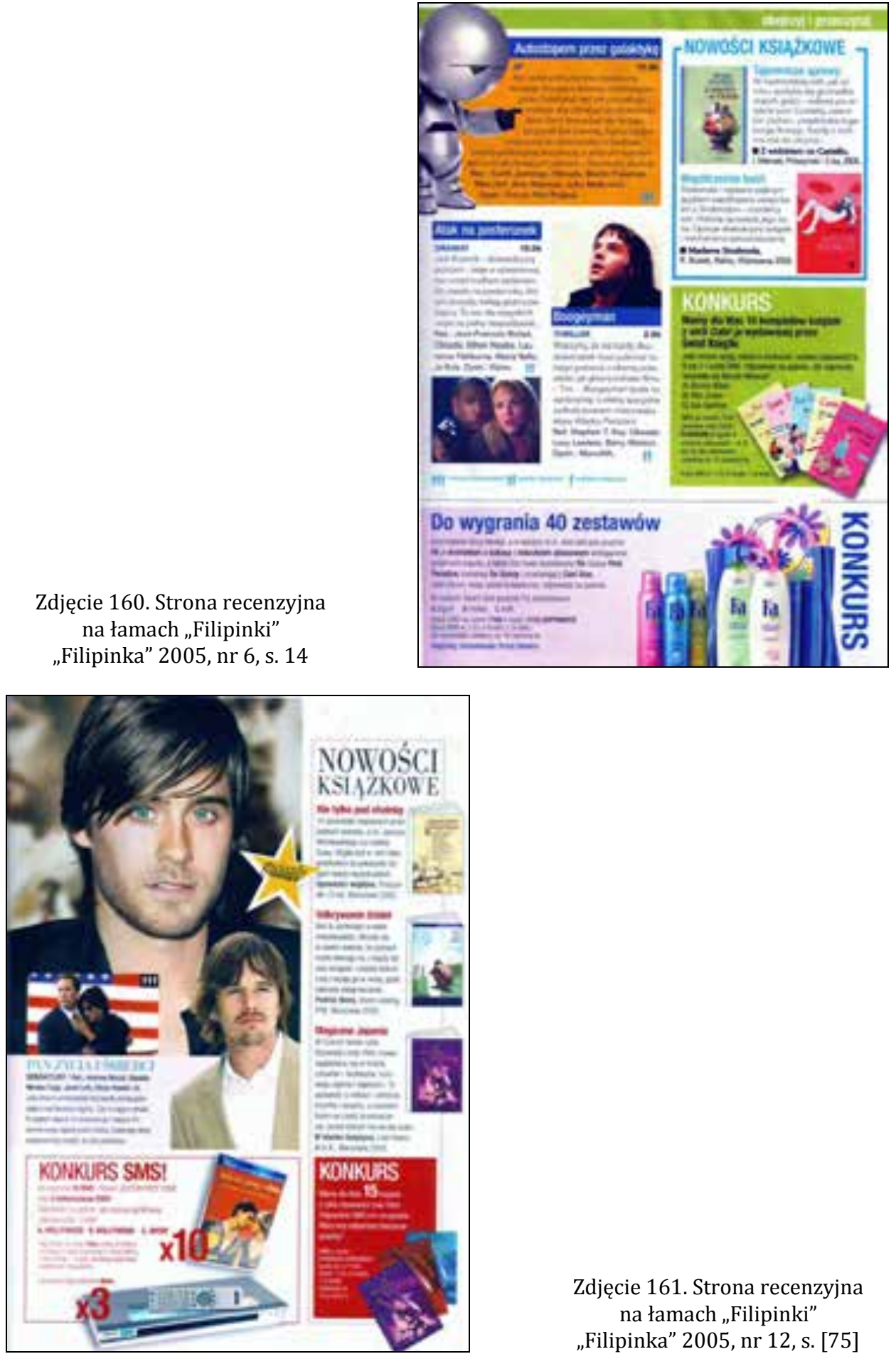

Zdjęcie 161. Strona recenzyjna na łamach „Filipinki”

„Filipinka” 2005, nr 12, s. [75] 
Prezentowane wyżej zmiany miały głównie charakter graficzny. Jednocześnie nadal utrzymywała się tendencja, polegająca na ograniczeniu objętości omówień, poświęconych książkom. Miały one w tym czasie wciąż postać zwięzłych adnotacji treściowych, notatek prasowych o charakterze czysto informacyjnym, które $\mathrm{z}$ faktyczną recenzją miały już niewiele wspólnego. Patrząc na te strony, czytelnik mógł odnieść wrażenie, że przegląda kolorowy komiks. Znalazły się tu krótkie teksty, przedzielone kontrastowymi pod względem koloru tytułami lub tłem, na którym drukowano daną informację. Czytelnicy mieli do dyspozycji najpierw niewielki objętościowo moduł, wtłoczony pomiędzy inne informacje, zaliczone przez redakcję do kategorii kulturalnych, później jego zwiększenie i przeniesienie na dół strony. Od numeru sierpniowego (2005) powrócono do kolumny, zawierającej 3-4 omówienia. Ich forma odpowiadała charakterowi całego periodyku, który, jak już podkreślano, coraz wyraźniej upodobniał się do innych magazynów młodzieżowych Wydawnictwa Bauer. W efekcie wprowadzanych zmian strona poświęcona sprawom kulturalnym zyskiwała pod względem graficznym na przejrzystości, ale jednocześnie wyraźnie traciła pod względem merytorycznym.

\subsection{Zakres i charakter recenzji - przykłady}

W latach 2001-2005 na łamach „Filipinki” przedstawiono w formie recenzji, omówień i streszczeń książki 156 autorów, w tym 58 pisarzy polskich i 98 twórców obcych (zob. Aneks 45. Autorzy książek recenzowanych na łamach „Filipinki” w latach 2001-2005).

Rzadko proponowano więcej niż jedną książkę tego samego autora. Zaledwie trzykrotnie omówiono trzy tytuły tego samego twórcy (tak było w przypadku książek Katarzyny Grocholi, Joanne Harris, Amélie Nothomb). Natomiast dwie książki tego samego autora przedstawiono 12-krotnie. Wśród wyróżnionych w ten sposób pisarzy znaleźli się: Isabel Allende, Paulo Coelho, Joanna Fabicka, Helen Fielding, Marta Fox, Yann Martel, Małgorzata Musierowicz, Wendy Northcutt, Arturo Pérez-Reverte, Krystyna Siesicka, Janusz. L. Wiśniewski oraz Stanisław I. Witkiewicz. Nazwiska autorów recenzowanych książek wskazują na drogę, jaką przeszła „Filipinka" w trakcie badanego okresu. Obok bowiem autorów książek adresowanych do starszych czytelników, w tym także adresatek 18-20-letnich, pojawiły się propozycje literatury typowo młodzieżowej, $\mathrm{w}$ tym również lektur dla uczniów w wieku gimnazjalnym. Poza wymienionymi, proponowano też sięgnięcie po twórczość takich autorów, jak na przykład John M. Coetzee, Jonthan Carroll, Magda Dygat, Fiodor Dostojewski, Etgar Keret, Jaeggy Fleur, Manuela Gretkowska, Hari Kunzru, Gabriel G. Márquez, 
Czesław Miłosz, Andrzej Stasiuk, a zatem tych twórców, których odnajdziemy także wśród recenzji zamieszczanych zarówno na łamach tygodników opinii, jak i periodyków kobiecych. Jednocześnie czytelniczki „Filipinki” mogły poznać zdanie redakcji pisma na temat książek takich autorów jak choćby Marta Dzido, Victor Bockris, Regina Dachówna, ale także i Tove Jansson, Lucy M. Montgomery, Mirosław Nahacz czy Sue Townsend.

Cechą łączącą nazwiska autorów recenzowanych w periodyku książek zdaje się być ich popularność: większość bowiem twórców znana była szerszej publiczności. Inny klucz jest trudny do uchwycenia, jako że, zgodnie z tym, co już stwierdzono, książki polecane czytelniczkom pisma nie należały wyłącznie do kanonu lektur typowo młodzieżowych bądź tylko literatury „dorosłej”.

Najczęściej recenzowano powieści, rzadziej opowiadania (na przykład Wszystko jest względne. 14 mrocznych opowieści Stephena Kinga), zaledwie w kilku przypadkach proponowano tomiki wierszy (m.in. Co słychać w lustrach? Anny Kowalskiej), poradniki (na przykład Seane`a Coveya 7 nawyków skutecznego nastolatka) lub słowniki (jak choćby Słownik ojczyzny polszczyzny Jana Miodka).

Na przestrzeni pięciu lat kilkakrotnie zmieniała się objętość omówień, jednak przez przeważającą część czasu nie przekraczała ona kilku zdań. Najobszerniejsze $\mathrm{z}$ nich drukowano $\mathrm{w}$ latach 2001-2002, najkrótsze w ostatnim $\mathrm{z}$ badanych roczników.

Niekiedy wybrane tytuły podporządkowane były określonemu tematowi, na przykład $\mathrm{w}$ jednym $\mathrm{z}$ numerów zaproponowano czytelniczkom książki, których męscy bohaterowie (według redakcji) odpowiadali także typom współczesnych mężczyzn. Zachęcano do sięgnięcia po te właśnie lektury, bo odkrywać miały one prawa, rządzące męską naturą, a po ich przeczytaniu, jak przekonywano czytelniczki, „płeć przeciwna nie będzie już dla Was aż taką zagadką"54. Uważna lektura Pana Tadeusza miała jasno wskazywać na to, że mężczyźni „nie są z natury monogamistami, zdradzają z nudów i pobudek intelektualnych, a niektórzy po prostu wolą partnerki starsze od siebie"55. Z kolei poznanie Gracza Fiodora Dostojewskiego ostrzegać miało nastolatki przed typowymi hazardzistami, a Niebezpieczne związki Pierre'a A. F. Ch. de Laclose'a niosły ze sobą potwierdzenie tezy postawionej przez recenzenta, że „mężczyźni (czy to ze stulecia XVIII, czy XXI) nie są normalni i nawet kochając do szaleństwa mogą zdradzać i zadawać ból" 56 .

\footnotetext{
54 [br. aut.], Męskie sekrety, „Filipinka” 2001, nr 1, s. [49].

55 Ibidem.

56 Ibidem.
} 


\section{Innym razem proponowane książki łączył wątek matki i córki:}

Są jednym ciałem przez dziewięć miesięcy. Te dwie kobiety łączy szczególna więź. Nic dziwnego, że relacje między nimi to temat częsty w literaturze. Czasem są sobie bliskie przez całe życie, a czasem nie odnajdują drogi porozumienia. Matka pokazuje córce świat kobiety. Przeczytajcie dobre książki o matkach i córkach ${ }^{57}$

- zachęcano. W jednym omówieniu proponowano pięć tytułów: Córkę Nastawiacza Kości (Amy Tan), Kwietniowa czarownice (Majggull Axelsson), Niesfornq duszę (Anne Lamott), Paulę (I. Allende), Pięć ćwiartek pomarańczy (Joanne Harris). Wytypowane książki przedstawiono w postaci jednej recenzji, która zajęła niemal 3/4 strony. 0 ile jednak w poprzednim przypadku w recenzjach pojawił się obok streszczenia fabuły książki pewien element analizy i porównania, o tyle tu ograniczono się do nakreślenia głównych wątków każdej z proponowanych książek i krótkich odniesień do ich autorek. Podobną formułę zachowało omówienie czterech lektur, zaproponowanych $\mathrm{w}$ następnym, październikowym numerze pisma (2002) ${ }^{58}$. Polecano w nim Ostatnia podróż Sindbada Żeglarza (Johna Bartha), Królewnę Śnieżkę (Donalda Barthelme), Rtęć (A. Nothomb) oraz Baśnie (H. Hesse). I w tym przypadku recenzentka, M. Kucia, ograniczyła się do zwięzłego przedstawienia treści każdej z książek.

Te dwa zabiegi recenzyjne (streszczenie i ewentualne odniesienia do osoby autora) były najczęstszymi elementami, pojawiającymi się w pozostałych omówieniach książek. W 2001 i 2002 r., gdy na recenzje poświęcano więcej miejsca, streszczenia były niekiedy bardziej szczegółowe, czasem wzbogacone o ciekawostkę dotyczącą autora bądź historii powstania książki. Warto przytoczyć jeden z odpowiadających temu opisowi charakterystycznych przykładów:

Iwona Tramp jest nastolatką, która nie zamierza zmarnować życia na rodzimej prowincji. Za wszelką cenę chce uciec i od sfrustrowanych rodziców, i od braci z piekła rodem, i amantów od siedmiu boleści, i szkoły, której nie znosi, i kolegów, z którymi nie może się dogadać, a przede wszystkim od własnych kompleksów. Jest młoda, zdeterminowana, ma jasno wyznaczone cele. Postanawia więc rozpocząć nowe życie w wielkim mieście. Okazuje się jednak, że życie w wielkomiejskiej dżungli wcale nie jest łatwe. Trzeba bardzo uważać na ludzi, których spotyka się na swojej drodze, aby w niej przetrwać, należy przystosować się do panujących tam praw. Z wydaniem „Krótkiej historii Iwony Tramp” wiąże się ciekawostka. Czy wiecie, że powieść ta najpierw ukazała się w odcinkach w Internecie, a bywalcy sieci na

57 [br. aut.], Matka i córka, „Filipinka” 2002, nr 9, s. [44].

58 M. Kucia, $Z$ baśniq $w$ tle, „Filipinka” 2002, nr 10, s. [54]. Należy zaznaczyć, że w obydwu przedstawionych przypadkach nie były to jedyne tego typu informacje na stronie; pod omówionymi tytułami zamieszczono moduł, zatytułowany Filipinka poleca, pod którym znalazły się trzy opisy kolejnych książek. 
bieżąco komentowali wydarzenia, wyrażali swą opinię na temat postępowania bohaterki, a nawet włączali się w tok pracy pisarki, ingerując w rozwój powieściowej akcji? To się nazywa proces twórczy na miarę XXI wieku!59

Wraz ze zmniejszaniem objętości recenzji, streszczenia proponowanych książek stały się znacznie bardziej zwięzłe, przypominając nierzadko bardziej adnotację reklamową, niż zabieg recenzyjny. Oto kilka ilustrujących to stwierdzenie przykładów:

Mado, bohaterka książki „Świat w ziarnku piasku” po latach powraca do rodzinnego domu. Tam spotyka tajemniczego mężczyznę. Nie tylko ratuje wioskę przed zagładą, ale także znajduje miłość życia60.

Powieść Agnieszki Stefańskiej to pełna humoru i magii saga rodu Pruskich. Narratorka, nastoletnia Julia, przeżywa swoją pierwszą miłość61.

Łucja kocha Jose, Galago ma wiele fobii, Konrad romans. A wszystko dzieje się na warszawskiej Pradze62.

W 2005 r. były to już w zasadzie przeważnie tylko krótkie hasła, sygnalizujące temat, poruszany w proponowanej książce.

Młody dziennikarz chce napisać kompromitujący artykuł. Jego plany komplikuje nagłe uczucie63.

Fascynująca opowieść o Francuzce, która w przebraniu pielgrzyma dociera do niedostępnych dla cudzoziemców miejsc ${ }^{64}$.

Historia ambitnej dziewczyny, która samotnie przyjeżdża do Warszawy. W stolicy poznaje niezwykłych ludzi, którzy wpłyną na jej los ${ }^{65}$.

Wesoła i ironiczna opowieść o tym, jak być kobietą i wytrzymać ze sobą. Młoda bohaterka książki, Natasza, boryka się z wieloma niedogodnościami, ale mimo wszystko potrafi być szczęśliwa i cieszyć się życiem ${ }^{66}$.

Niekiedy dodatkowym elementem omówień była, jak w ostatnim przytoczonym powyżej przykładzie, ocena proponowanego tytułu, wyrażona za pomocą przymiotników. Pojawiały się m.in. stwierdzenia, że dana książka jest „fascynująca”, „piękna”, „bardzo mądra”, „dowcipna”, „mroczna, ale zarazem komiczna”, „żywiołowa i porywająca”. W 2004 i w kilku przypad-

59 [br. aut.], Współautorzy z Internetu, „Filipinka” 2001, nr 12, s. [59].

60 [br. aut.], Morska opowieść, „Filipinka” 2003, nr 2, s. 66.

61 [br. aut.], Extra vergine, „Filipinka” 2003, nr 8, s. 71.

62 [br. aut.], Urzeka ciepłem i dowcipem, „Filipinka” 2004, nr 10, s. 70.

63 [br. aut.], Sensacja i miłość, „Filipinka” 2005, nr 2, s. 109.

64 [br. aut.], Europejka w Tybecie, „Filipinka” 2005, nr 4, s. [15].

65 [br. aut.], Mądra i zabawna, „Filipinka” 2005, nr 7, s. 14.

66 [br. aut.], Codzienność z dawkq humoru, „Filipinka” 2005, nr 11, s. 83. 
kach w 2005 r. niektóre omówienia otrzymywały podwójny tytuł, z których pierwszy zawierał $\mathrm{w}$ sobie ocenę proponowanej książki. Na przykład Niewolnicę Mende Nazer określono jako „egzotyczną i wzruszającą”, Antychryst A. Nothomb, jak obiecywano, „rozproszy smutki”. Z kolei Pierwsza miłość M. Fox „uskrzydla i bawi”, zaś Sekretne życie pszczół Sue Monk Kidd „napawa optymizmem”.

Pomimo, że zaledwie w 19 przypadkach recenzje były podpisane ${ }^{67}$, to jednak równocześnie dbano o to, by każda z nich opatrzona była tytułem, a niektóre, jak wspomniano powyżej, posiadały ich dwa. Nie wszystkie spełniały cel, jakim było zwrócenie uwagi czytelnika; część z nich nie wyróżniała się niczym szczególnym, ale pojawiło się wśród nich kilka wyjątków, które warto przytoczyć68: Czuję, więc jestem; Dla tych, których nie ma; Eksperyment ze strachem; Garou i poziomki; Historia dobrze skrojona; Jej życie to taniec; Marzenia kontra rzeczywistość; Odkrywanie źródeł; Okruchy życia; Rozmowy z windą; Trudne słowa; Wołanie o pomoc; Żyć pełniq życia.

Poza tytułem, stałym elementem recenzji, omówień i streszczeń były kopie okładek proponowanych książek, a także podstawowe dane bibliograficzne, do których zazwyczaj należały: autor i tytuł recenzowanej książki, czasem miejsce i rok jej wydania, nazwa wydawcy. W 18 przypadkach w 2002 r. podano cenę proponowanego tytułu. Najczęściej pomijanym elementem było miejsce wydania (78 przypadków), następnie rok wydania (55 razy). Nie uwzględniano nazwiska tłumacza w przypadku przekładu, a także nie podawano liczby stron polecanej książki. Niekiedy przy recenzji pojawiał się konkurs sms-owy, nawiązujący bezpośrednio bądź do opisywanej książki, bądź do twórczości jej autora69.

Tylko raz, w 2002 r., rubryka recenzyjna przybrała formę, dostosowaną do zbliżających się Świąt. W tym przypadku były to Lektury od św. Mikołaja. Radzono czytelniczkom książki, dobrane do potencjalnych upodobań przyszłych obdarowywanych. Były zatem propozycje dla „miłośników dalekich podróży”, „,zekających na wielką miłość”, „spragnionych miodu na serce”, „amatorów zagadek”, „lubiących gotować”, i dla „chcących być na czasie"70. Zaproponowano sześć krótko omówionych książek, opatrzonych kopią ich okładek, podstawowymi danymi bibliograficznymi oraz ceną. Pod

67 W 2001 i 2002 r., 18 razy recenzentką była M. Kucia, raz omówienie podpisane było inicjałami „ik”, zaś pozostałe prezentacje były anonimowe.

68 Kolejno: „Filipinka” 2003, nr 2, s. 66; nr 2, s. 66; 2004, nr 4, s. 76; nr 4, s. 76; 2003, nr 3, s. 66; 2004, nr 5, s. 74; 2003, nr 5, s. 68; 2005, nr 12, s. [75]; nr 7, s. $14 ; 2002$, nr 6, s. [56]; 2004, nr 3, s. 77; nr 11, s. [73]; 2003, nr 6, s. [67].

${ }^{69}$ Zob. np. „Filipinka” 2003, nr 8, s. 71. W tym przypadku jedną z recenzowanych książek była Królowa Południa A. Pérez-Reverte, zaś w sms-owym konkursie proszono o podanie tytułu innej powieści tego autora.

70 „Filipinka” 2002, nr 12, s. [46]. 
każdą z tych krótkich informacji polecano jeszcze dwa lub trzy pokrewne im tytuły. Taka inicjatywa pojawiła się jednorazowo

Prezentowane książki pochodziły z oferty $\mathbf{3 7}$ edytorów ${ }^{71}$ (zob. Aneks 46. Wydawcy książek recenzowanych na łamach „Filipinki” w latach 20012005). W tabeli 62 zaprezentowano tych wydawców, po książki których sięgano najczęściej.

Tabela 62. Wydawcy najczęściej recenzowanych książek na łamach „Filipinki” w latach 2001-2005

\begin{tabular}{|l|c|}
\hline \multicolumn{1}{|c|}{ Nazwa wydawcy } & Liczba tytułów \\
\hline Wydawnictwo W.A.B. & 25 \\
\hline Muza S.A. & 15 \\
\hline Wydawnictwo Prószyński i S-ka & 13 \\
\hline Dom Wydawniczy REBIS & 12 \\
\hline Społeczny Instytut Wydawniczy Znak & 9 \\
\hline Świat Książki & 8 \\
\hline $\begin{array}{l}\text { Wydawnictwo Literackie } \\
\text { Wydawnictwo Jacek Santorski S-ka }\end{array}$ & 7 \\
\hline
\end{tabular}

Źródło: badania własne.

W grupie edytorów znalazły się znane oficyny, które dbały o promocję swej oferty także $\mathrm{w}$ pozostałych omówionych wcześniej periodykach. Recenzenci „Filipinki” sięgali przede wszystkim po książki znanych wydawców, co znajduje swoje potwierdzenie w ich pełnym zestawieniu. Poza wymienionymi omawiano ofertę takich wydawców, jak na przykład Akapit Press, Noir sur Blanc, PIW czy Zysk i S-ka.

Należy jeszcze wspomnieć o minirecenzjach, drukowanych poza działem kulturalnym. Takich przypadków było zaledwie pięć, wszystkie pojawiły w Niezbędniku, zamieszczanym w 2001 r., w dziale Między nami. Przedstawiano tu 10 rzeczy, „które warto znać mieć i przeżyć" [pis. oryg.] w danym miesiącu: czerwcu, lipcu, wrześniu, październiku i listopadzie. Obok nowego błyszczyku do ust, soku owocowego czy przenośnego odtwarzacza CD pojawiały się krótkie omówienia, informujące o nowej książce. Kolejno były to: Dziennik Bridget Jones H. Fielding, Blondynka Joyce C. Oates, Kalamburka M. Musierowicz, Rozstania M. Dygat oraz Coś się kończy, coś zaczyna Andrzeja Sapkowskiego. W kilku zdaniach prezentowano główny wątek proponowanej książki, zachęcając do jej przeczytania. Na końcu podawano jej cenę, ale pomijano pozostałe dane bibliograficzne, drukując za to kopię jej okładki.

71 W 23 przypadkach zabrakło tej informacji. Na potrzeby pracy uzupełniono brakujące dane, korzystając z „Przewodnika Bibliograficznego”, www.bn.org.pl, luty 2010. 
Należy podkreślić, że część z zamieszczanych na łamach pisma recenzji przynajmniej w pewnym stopniu spełniała podstawowe dla tego gatunku dziennikarskiego warunki: zawierała elementy informacyjne, znalazło się w niej miejsce na krótkie przedstawienie treści proponowanej książki, a niekiedy nawet odnaleźć tu można było pewien element analizy krytycznej $\mathrm{w}$ postaci oceny danego tytułu i jej uzasadnienia. Jednakże $\mathrm{w}$ miarę upływu czasu wraz ze zmniejszaniem objętości recenzji, tych elementów coraz częściej brakowało, aż zredukowano tę formę informacji o książce do krótkiej adnotacji treściowej. Jednocześnie trzeba zaznaczyć, że forma recenzji, omówieni i streszczeń, pomimo że na przestrzeni pięciu lat często ulegała przeobrażeniom, nie wpływała na zmianę podejścia redakcji do tego rodzaju informacji o książce. Traktowano je jako jeden $\mathrm{z}$ wielu (można odnieść wrażenie, że najmniej istotny) elementów działu. Znacznie więcej uwagi poświęcano informacjom muzycznym i filmowym, zaś recenzje książek zdawały się być z jednej strony okrojoną pozostałością po „dawnych czasach" periodyku, a z drugiej dowodziły pretensji wydawcy do udowodnienia, że nowa „Filipinka” jest, mimo wszystko, nadal tytułem ambitnym, bo w miarę systematycznie na jej łamach pojawiają się omówienia książek, o których jednak pisano „Krótko, coraz krócej”72.

\subsubsection{Jagodowa tajemnica ${ }^{73}$ : wywiady}

Jakkolwiek wywiady były chętnie używaną przez dziennikarzy „Filipinki” formą prezentacji wybranych twórców, to jednak najczęściej na rozmówców wybierano aktorów, piosenkarzy i innych celebrytów, znacznie zaś rzadziej pisarzy. W latach 2001-2005 pojawiło się zaledwie 19 wywiadów z osobami bezpośrednio lub pośrednio związanymi z literaturą (tabela 63).

Tabela 63. Wywiady z osobami związanymi ze światem

literatury, zamieszczane na łamach „Filipinki” w latach 2001-2005

\begin{tabular}{|c|c|}
\hline Rok & Liczba wywiadów \\
\hline 2001 & 1 \\
\hline 2002 & - \\
\hline 2003 & 14 \\
\hline 2004 & 4 \\
\hline 2005 & - \\
\hline Ogółem & 19 \\
\hline
\end{tabular}

Źródło: badania własne.

72 Tytuł jednej z recenzji, w której omówiono pięć książek, zob. „Filipinka” 2002, nr 11, s. [55].

73 Tytuł wywiadu, zob. „Filipinka” 2003, nr 4, s. [67]. 
Liczby odzwierciedlają niewielkie zainteresowanie miesięcznika tą formą popularyzacji osób związanych z literaturą. Zabrakło jej w 2002 i 2005 r., najwięcej (14) rozmów pojawiło się z przedstawicielami świata książki w 2003 r., w okresie, kiedy najczęściej eksperymentowano ze stronami recenzyjnymi. W 11 przypadkach wywiady znalazły się w ramach działu kulturalnego, w trzech w dziale Psychologia, dwukrotnie w ramach Tematu numeru, raz w obrębie działów: Na czasie, Prześwietlenie i raz jako Spotkanie w F.

Wywiady, podobnie jak i recenzje, w przeważającej liczbie przypadków nie były podpisywane; zaledwie pod dwoma z nich pojawiły się nazwiska osób, które je przeprowadziły (raz były to czytelniczki pisma, raz Anna Niewiadomska). Dziesięciokrotnie bohaterami wywiadów byli pisarze. Wśród nich znaleźli się: Jonathan Carroll, Irina Dieniżkina, Katarzyna Grochola, Joanne Harris, Heidi Hassenmüller, Mirosław Nahacz, Gina B. Nahai, Zadie Smith, Izabela Sowa oraz Andrzej Stasiuk.

W 2003 r. pojawił się cykl rozmów z autorkami polskiej edycji książki Nasze ciała, nasze życie: książka napisana przez kobiety dla kobiet (Stowarzyszenie Wschodnio-Zachodnia Sieć Współpracy Kobiet, NEWW-Polska we współpracy z Fundacją Rodzić po Ludzku) ${ }^{74}$. Książka ta, nazwana przez redakcję „Biblią nastolatek”, była intensywnie promowana na łamach periodyku. Na jej temat rozmawiano z jedną z redaktorek, Beatą Kołodziejczyk, oraz (kilkakrotnie) z autorką jednego z rozdziałów, Aleksandrą Solik. Jednocześnie proponowano czytelniczkom, by pisały do redakcji o swoich intymnych problemach, wątpliwościach, zdrowiu i lekarzach, z porad których korzystają. W ten sposób mogły stać się współautorkami książki.

Problem związany ze zdrowiem pojawił się także w innej, tym razem bardzo krótkiej, rozmowie, przeprowadzonej z autorką książki $W$ sidłach anoreksji ${ }^{75}$. Zwięzłe odpowiedzi na zadawane pytania nie wnosiły zbyt wielu nowych informacji dotyczących poruszanego problemu, stanowiły raczej rodzaj uzupełnienia związanego z zamieszczonym powyżej artykułem dotyczącym opisanej choroby.

Obszerniejsze i ciekawsze były wywiady z wymienionymi wcześniej pisarzami. Interesującym pomysłem stało się zaproszenie czytelniczek do przeprowadzenia rozmowy z J. Carrollem. Był to efekt akcji I Ty możesz porozmawiać z gwiazdą! Na adres redakcji należało przesłać pięć pytań do proponowanej przez periodyk znanej osoby: pisarza, piosenkarza lub aktora, a następnie czekać na odpowiedź i ewentualne spotkanie. W przywołanym przypadku Daria Gosek i Karolina Makuch zadawały pytania

74 Zob. np. „Filipinka” 2003, nr 5, s. 58; nr 9, s. 65.

75 Zob. „Filipinka” 2004, nr 2, s. [42]. Fragment tej książki drukowano na łamach pisma niemal rok wcześniej, w numerze lipcowym. 
swemu ulubionemu twórcy. Dzięki temu czytelniczki pisma dowiedziały się m.in., że autor Białych jabłek został pisarzem przypadkowo, a kiedy zaczyna pisać nową powieść, sam nie wie jeszcze, jak się ona zakończy. Poznały też jego motto życiowe: „nie przestawaj dążyć, nie przestawaj marzyć”76.

Z kolei dzięki kolejnej rozmowie, tym razem z Giną B. Nahai, czytelniczki poznały cele, które przyświecają jej twórczości: irańska pisarka w swych książkach stara się przekonać, że należy postępować tak, jak podpowiada serce, mieć zaufanie do innych i wierzyć w dobre zakończenie podejmowanych działań77. Z kolei o swych książek opowiedziało trzech kolejnych rozmówców: I. Dieniżkina, M. Nahacz oraz I. Sowa. Wywiad z autorem Osiem cztery był najobszerniejszy (wraz z dodatkowymi, uzupełniającymi go elementami znajdował się na dwóch stronach pisma) i, jak się zdaje, najlepiej wpisywał się $\mathrm{w}$ niegdysiejsze ambicje periodyku, odpowiadając także najpełniej definicji tego gatunku dziennikarskiego. Poniżej wywiadu znalazł się fragment książki oraz opinia na temat talentu młodego pisarza, wygłoszona przez A. Stasiuka, wydawcę tej powieści. Przyznał on, że „To dużej klasy literatura. Nosi znamiona rozwoju, wrażliwości i empatii do świata"78. Starannie wybrany fragment prawdopodobnie spodobał się większości czytelniczek pisma, oddawał bowiem charakter pokolenia, z którym utożsamiała się część adresatek:

Wiedzieliśmy, że i tak kiedyś to się kończy żoną, rodziną, domem i uporządkowanymi duperelowatymi błędnymi kołami. Chyba że ktoś z nas wpadnie w syf, ale raczej nie. Wiedzieliśmy, że inaczej udaje się tylko nielicznym, że o tych nielicznych potem się opowiada, że to są legendy. Wiedzieliśmy też, że mimo wszystko jesteśmy tak samo głupi jak wszyscy, jak całe nasze rozpieszczone pokolenie, że samym gadaniem się nie wygra. Ale nie można przecież wygrywać, bo nie ma się o co bić. Zresztą to i lepiej, bo teraz nikomu by się nie chciało ${ }^{79}$.

Zacytowany fragment książki obiecywał interesującą lekturę, z której zdawała się przebijać tęsknota współczesnej młodzieży za wartościami, którym można się było poświęcić, za które można było walczyć. Tak dopracowany wywiad pojawił się na łamach miesięcznika w trakcie badanego okresu tylko raz, przynajmniej w odniesieniu do rozmowy z osobą związaną $\mathrm{z}$ literaturą ${ }^{80}$. Pozostałe były nie tylko znacznie krótsze (średnio kolumna tekstu), ale także skromne pod względem zawartości (krótkie pytania dotyczące twórczości i równie zwięzłe odpowiedzi). W niemal każdym

76 Bulterier z różdżkq, rozm. D. Gosek, K. Makuch, „Filipinka” 2003, nr 1, s. 63.

77 [br. aut.], To się teraz czyta, „Filipinka” 2003, nr 8, s. 71.

78 „Filipinka” 2003, nr 7, s. [67].

${ }^{79}$ Ibidem.

80 Warto zauważyć, że M. Nahacz, który jako jedyny został obszerniej zaprezentowany, został później stałym felietonistą pisma. 
wywiadzie pojawiało się zdjęcie rozmówcy, ale brakowało choćby szerszej prezentacji jego twórczości i wprowadzenia w tematykę wywiadu.

Rozmowy z pisarzami, podobnie jak recenzje, traktowane były przez redakcję jako jeden z mniej ważnych elementów pisma, przy czym o ile omówienia drukowano na jego łamach $w$ miarę systematycznie, o tyle druga $\mathrm{z}$ prezentowanych $\mathrm{w}$ rozdziale form informacji o książce pojawiała się rzadko i poza przedstawionym powyżej wyjątkiem nie prezentowała się zbyt okazale.

\subsubsection{Super książka! ${ }^{81}$ : reklamy książek}

Przeważającą liczbę reklam, zamieszczanych na łamach „Filipinki”, stanowiły ogłoszenia proponujące zakup kosmetyków, środków chemicznych lub bielizny. Część reklam stanowiły anonse, których przedmiot związany był z problematyką, zawartą $\mathrm{w}$ tytule niniejszej książki. Wzorem poprzednich rozdziałów można wyodrębnić trzy kategorie, które mieściły się w jej obrębie, stosując kryterium przedmiotu danego ogłoszenia:

1) książki (159),

2) akcje tygodnika związane z książką (2) ${ }^{82}$,

3) prasa w tym autoreklama (115) ${ }^{83}$,

W grupie ogłoszeń wydawniczych znalazło się 159 reklam, 2 miały charakter promocji akcji periodyku, związanych z książką, a 115 dotyczyło reklam czasopism. W tabeli 64 przedstawiono liczbę inseratów wydawniczych w poszczególnych latach.

Tabela 64. Ogłoszenia wydawnicze zamieszczane na łamach „Filipinki” w latach 2001-2005

\begin{tabular}{|c|c|}
\hline Rok & Liczba inseratów książkowych \\
\hline 2001 & 44 \\
\hline 2002 & 71 \\
\hline 2003 & 3 \\
\hline 2004 & 25 \\
\hline 2005 & 16 \\
\hline Ogółem & 159 \\
\hline
\end{tabular}

Źródło: badania własne.

81 Hasło reklamowe w jednym z inseratów, zob. „Filipinka” 2004, nr 12, s. [30].

82 Ta kategoria przyjmowała postać zarówno reklam, jak i tekstu komentującego, stąd zostanie omówiona w dalszej części rozdziału (4.2.3.4.3).

83 Zagadnienie związane $\mathrm{z}$ informacją o prasie na łamach omawianego pisma zostanie dokładniej przedstawione w ostatniej części rozdziału. 
Najwięcej ogłoszeń wydawniczych ukazało się w 2002 r., najmniej rok później, przy czym różnica $\mathrm{w}$ tym przypadku jest ponad 23-krotna. W anonsach pojawiło się w sumie 44 autorów, w tym 21 pisarzy polskich i 23 obcych (zob. Aneks 47. Autorzy książek reklamowanych na łamach „Filipinki” w latach 2001-2005) ${ }^{84}$. Najczęściej powtarzanymi nazwiskami autorów reklamowanych książek byli85: M. Musierowicz (19-krotnie), Krystyna Siesicka (12-krotnie) oraz Lucyna Legut (10-krotnie). Wynikało to $\mathrm{z}$ faktu, że w jednym anonsie niejednokrotnie proponowano kilka tytułów tego samego autora. W ten sposób wydawcy starali się maksymalnie wykorzystać zakupioną przez siebie powierzchnię reklamową w czasopiśmie. Zaledwie dwukrotnie pojawiło się ogłoszenie, w którym proponowano jeden tytuł: była to książki Justyny Tomańskiej, raz Polka $w$ Londynie i raz Polka w Madrycie. Reklamowane książki były propozycjami 9 edytorów ${ }^{86}$. W 2001 r. głównym ogłoszeniodawcą było Wydawnictwo Akapit Press, specjalizujące się w publikowaniu literatury młodzieżowej, w roku następnym pojawili się dwaj kolejni edytorzy: Wydawnictwo Amber oraz Wydawnictwo GREG, które proponowało czytelniczkom „Filipinki” lektury szkolne. Było ono też jedynym wydawcą, które zamieściło swój anons na łamach tego pisma w 2003 r. W następnym roku łamy periodyku gościły, obok Wydawnictwa GREG, także oficynę Egmont i Wydawnictwa Szkolne i Pedagogiczne oraz dwukrotnie Wydawnictwo W.A.B. Raz zaproponowano książkę wydaną przez koncern Bauera. Ostatni badany rok to anonse czterech edytorów: DDB, W.A.B., Egmont oraz Prószyński i S-ka. W ciągu 5 lat najwięcej propozycji przedstawiło krakowskie Wydawnictwo GREG (53 tytuły) oraz łódzkie Akapit Press (34 tytuły). (Pełne zestawienie zob. Aneks 48. Wydawcy reklamujący książki na łamach „Filipinki” w latach 20012005). Książki tych edytorów w pełni odpowiadały profilowi czytelniczemu pisma. Obydwa wydawnictwa kilkakrotnie powtarzały swoją ofertę, przy czym za każdym razem forma anonsu była podobna (zdjęcia 162-163).

${ }^{84}$ Ze względu na niewielką liczbę autorów oraz równie niewielką liczbę powtarzających się nazwisk i tytułów książek zdecydowano się zrezygnować $\mathrm{w}$ tym rozdziale $\mathrm{z}$ tabeli prezentującej nazwiska tych twórców, których nazwisko pojawiło się w ogłoszeniach najwięcej razy.

85 Do statystyki zaliczano tylko nazwiska pierwszych podanych autorów.

$86 \mathrm{~W} 16$ przypadkach nazwa wydawcy była trudna do odczytania, na przykład ze względu na zasłaniającą ją kopię okładki proponowanej książki. 


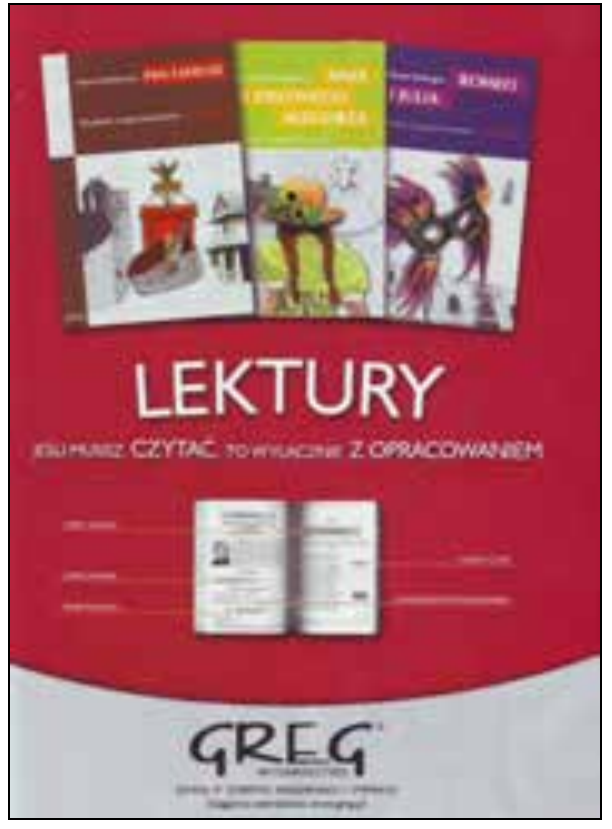

Zdjęcie 162. Wybrane ogłoszenie wydawnicze zamieszczone na łamach „Filipinki” „Filipinka” 2001, nr 11, s. [71]

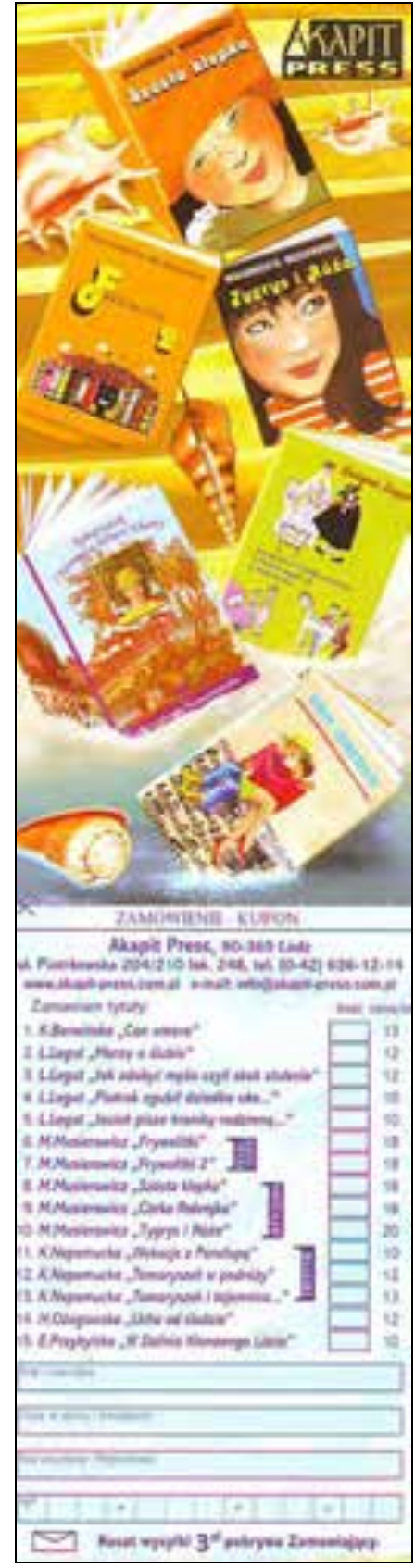

Zdjęcie 163. Wybrane ogłoszenie wydawnicze zamieszczone na łamach „Filipinki „Filipinka” 2001, nr 6, s. [63] 
Ogłoszenia Wydawnictwa GREG za każdym razem były całostronicowe, zawierały od 3 do 33 propozycji: poza lekturami z ich omówieniem czytelniczki mogły poznać także inne opracowania szkolne (z matematyki, języka angielskiego) oraz streszczenia lektur. Za każdym razem inseraty zwracały uwagę nasyconymi barwami, czytelną grafiką i wyraźnie wyeksponowaną nazwą wydawcy. Niekiedy (tak jak w przywołanym powyżej przykładzie) za pomocą haseł wskazywano na zawartość danej pozycji: w przypadku lektury, poza jej treścią, znajdowały się tu takie elementy, jak omówienie jej problematyki, charakterystyka bohaterów oraz wybrany cytat, który przyszły maturzysta mógł wykorzystać w swojej pracy. Z kolei wszystkie ogłoszenia Wydawnictwa Akapit Press zajmowały mniejszą powierzchnię, obejmując w każdym przypadku niecałą stronę periodyku. Jednorazowo proponowano od 11 do 15 tytułów. Uwagę przyciągały kopie okładek reklamowanych książek, pod którymi zamieszczano kupon zamówienia, zawierający nazwisko autora i tytuł danej pozycji oraz jej cenę. W przypadku lidera w ofercie tego edytora, czyli większości książek M. Musierowicz, pojawiała się informacja, że dany tytuł należy do znanego cyklu Jeżycjada. Od strony formalnej inseraty te były starannie przygotowywane i, pomimo że mniejsze objętościowo od anonsów Wydawnictwa GREG, były czytelne, aczkolwiek brakowało $\mathrm{w}$ nich krótkich choćby informacji o polecanych tytułach. Być może jednak wydawca zakładał, że autorzy polecanych książek są wystarczająco znani czytelniczkom pisma. Propozycje innych oficyn wyglądały podobnie. Były równie kolorowe, zajmowały kolumnę, a reklamodawcy przedstawiali od 1 do 33 tytułów w ogłoszeniu (zdjęcie 164-167). 


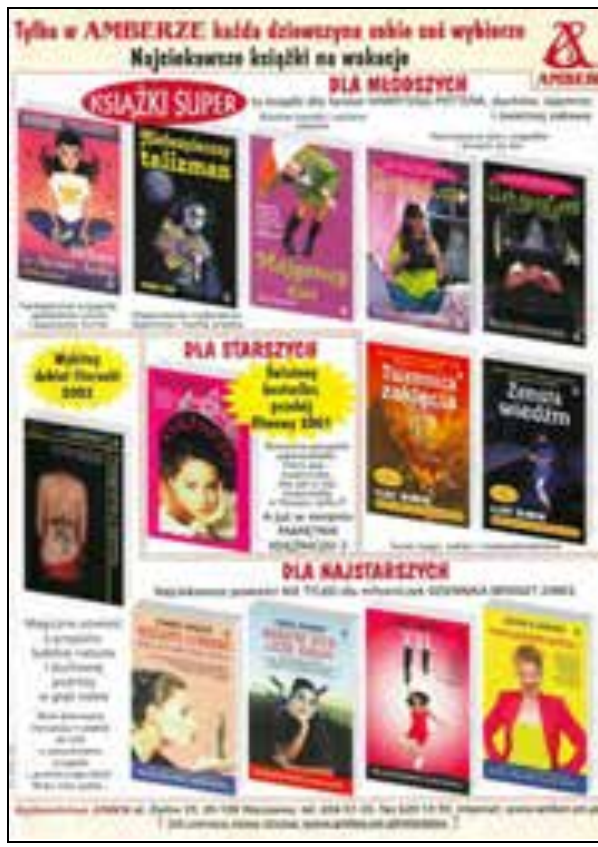

Zdjęcie 164. Wybrane ogłoszenie wydawnicze zamieszczone na łamach „Filipinki” „Filipinka” 2002, nr 7 [trzecia strona okładki]

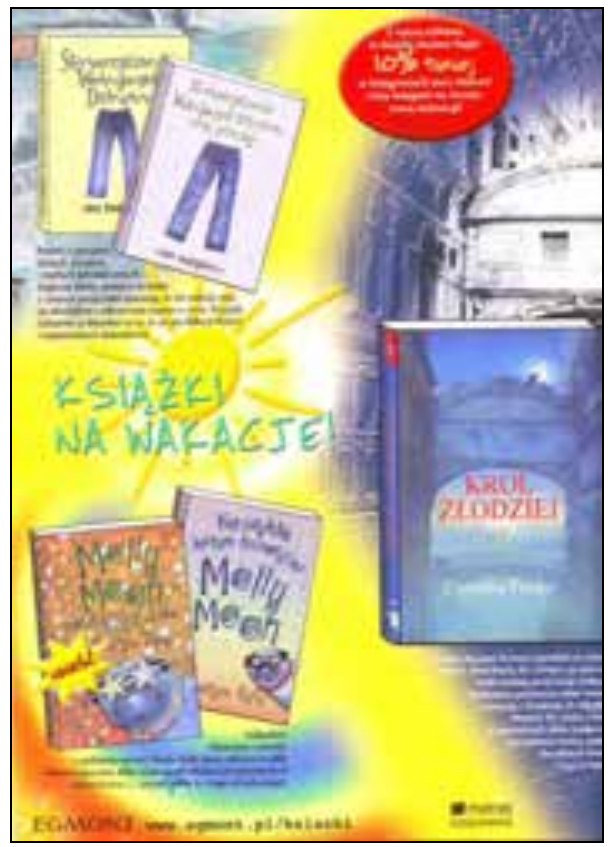

Zdjęcie 165. Wybrane ogłoszenie wydawnicze zamieszczone na łamach „Filipinki” „Filipinka” 2004, nr 6, s. [8]

W każdym z przywołanych przykładów ogłoszenia są wielobarwne, dominują w nich jaskrawe kolory (poza ostatnim przykładem). Zazwyczaj wydawcy starali się reklamować w jednym anonsie kilka, a nawet kilkanaście tytułów. Wspólnym dla wszystkich inseratów elementem były kopie okładek proponowanych książek, niekiedy $\mathrm{z}$ dokładnym określeniem adresata (zdjęcie 164) bądź streszczeniem danej lektury (trzy z przywołanych przykładów). Rzadko pojawiały się dodatkowe hasła reklamowe, często obecne $\mathrm{w}$ anonsach, zamieszczanych $\mathrm{w}$ prezentowanych pismach opinii. Pomimo tego ta forma informacji, goszcząca na łamach „Filipinki” była starannie, ciekawie przygotowana, w wielu przypadkach umieszczana w obrębie działu kulturalnego, chociaż ogłoszenia tego typu pojawiały się również poza nim, na przykład w dziale Między nami lub na wewnętrznej stronie tylnej okładki. 


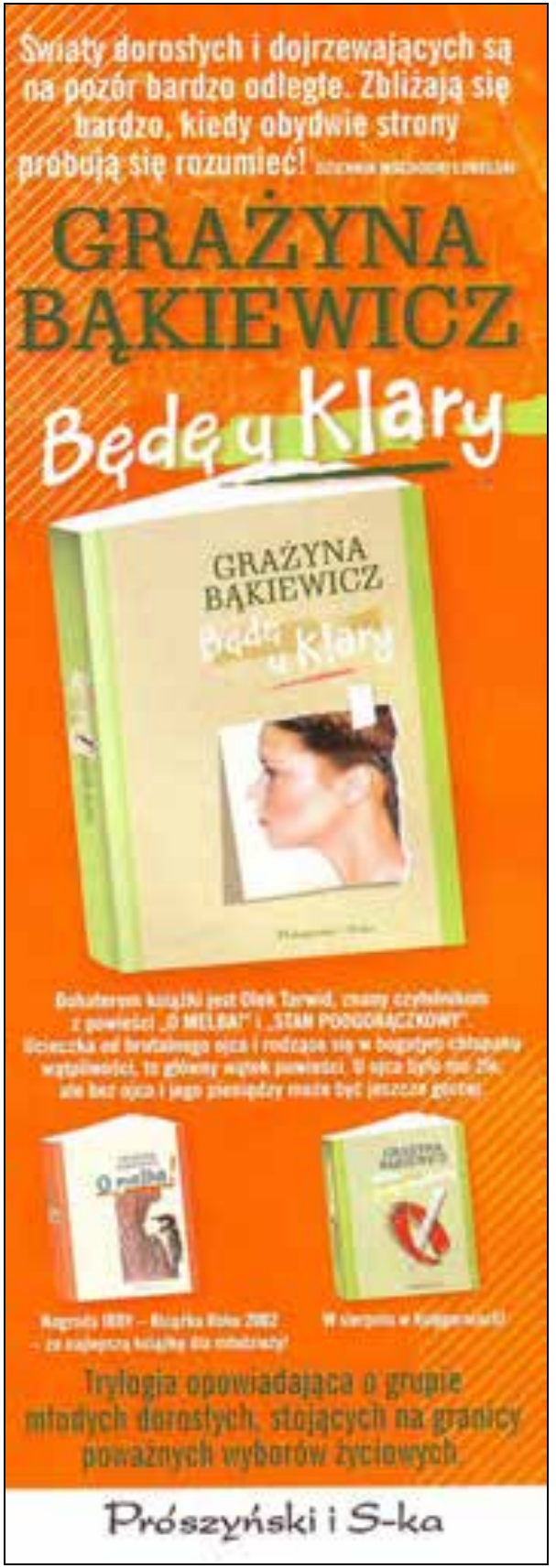

Zdjęcie 166. Wybrane ogłoszenie wydawnicze zamieszczone na łamach „Filipinki” „Filipinka” 2004, nr 12, s. [71]

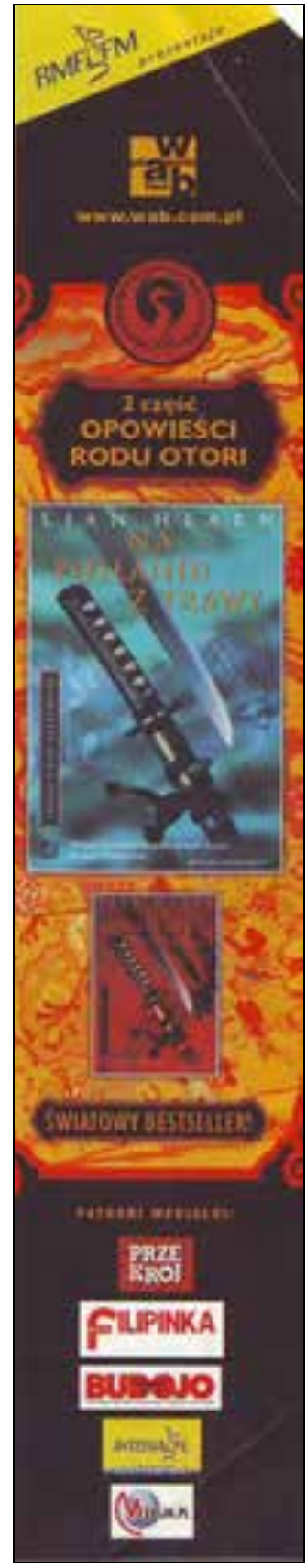

Zdjęcie 167. Wybrane ogłoszenie wydawnicze zamieszczone na łamach „Filipinki” „Filipinka” 2005, nr 7, s. [61] 


\subsubsection{Czego uczysz się od Harry'ego Pottera?: inne formy informacji o książce}

W latach 2001-2005 poza recenzjami, wywiadami oraz ogłoszeniami wydawniczymi na łamach „Filipinki” pojawiały się (chociaż w wyraźnie mniejszej liczbie niż przed 1989 r.) również inne formy informacji, związane bezpośrednio lub pośrednio $\mathrm{z}$ książką. $\mathrm{W}$ badanym okresie było ich w sumie 312 (zob. Aneks 49. Wybór tekstów związanych z literaturą i rynkiem wydawniczo-księgarskim, zamieszczonych na łamach „Filipinki” w latach 2001-2005). Przyjmowały one różną postać, niekiedy kilkuzdaniowych wzmianek, czasem miały nieco większą objętość. Wszystkie te informacje, podobnie jak w przypadku poprzednich rozdziałów, można podzielić na następujące kategorie:

- sylwetki/portrety (10);

- artykuły, nawiązujące do rynku wydawniczo-księgarskiego (15);

- adaptacje, ekranizacje oraz inscenizacje znanych dzieł (49);

- konkursy i akcje związane z książką, organizowane, współinicjowane przez tygodnik lub takie, o których periodyk tylko informował (60);

- listy czytelników (3);

- inne (177) ${ }^{87}$.

Najliczniej, podobnie jak było to w przypadku omówionych wcześniej pism z innych grup, reprezentowana była kategoria Inne. Na drugim miejscu znalazły się konkursy i akcje nawiązujące do książki lub takie, w których stanowiła ona nagrodę. Należy jednak zaznaczyć, że tylko nieliczne z nich miały charakter poważniejszych przedsięwzięć o charakterze cyklicznym, przeważająca zaś liczba były to inicjatywy jednorazowe.

Pozostałe grupy informacji były już wyraźnie skromniejsze pod względem ilościowym, w większości nie stanowiły stałego elementu pisma, pojawiając się w nim rzadko, w zasadzie tylko przy okazji znaczącego wydarzenia kulturalnego lub omawianego na łamach periodyku faktu. Dla zilustrowania postaci i charakteru tych informacji wybrano kilka reprezentatywnych dla każdej z kategorii przykładów.

\subsection{Pani z Bullerbyn ${ }^{88}$ : sylwetki/portrety}

„Należała do tych autorów książek dla dzieci, którzy nigdy nie próbowali mrugać porozumiewawczo do dorosłych ponad głowami swoich czytelników"89. Tak zaczynała się publikacja poświęcona Astrid Lindgren, jedna

${ }^{87}$ Zob. przypis a pod tabelą 60.

88 Tytuł jednej z publikacji, w tym przypadku prezentującej sylwetkę A. Lindgren, zob. „Filipinka” 2002, nr 4, s. [47].

${ }^{89}$ H. Bertz, Pani z Bullerbyn, „Filipinka” 2002, nr 4, s. [47]. 
z 10 opisanych sylwetek związanych bezpośrednio lub pośrednio z literaturą, jakie pojawiły się w badanym okresie na łamach „Filipinki”. Całostronicowy tekst opowiadający o twórczyni Pippi Langstrumpf, pisany z dużą sympatią, pojawił się w piśmie trzy miesiące po śmierci autorki. Przedstawiono w nim krótko losy pisarki i przypomniano bohaterów jej książek.

Inna publikacja o charakterze wspomnieniowym poświęcona była autorowi trylogii Władca Pierścieni. W dużym stopniu bodźcem do napisania tekstu była popularność ekranizacji kolejnych części powieści. Stąd obok faktów z życia twórcy Śródziemia pojawiły się Fakty i akty dotyczące przeniesienia powieści na srebrny ekran. W obydwu przypadkach skoncentrowano się w znacznej mierze na informacjach o charakterze ciekawostek. Czytelniczki dowiedziały się na przykład o tym, że John R. R. Tolkien opanował 13 języków obcych, w tym język polski, a początki popularnej trylogii miały postać bajki napisanej w 1936 r. przez niego dla własnych dzieci. Przekonały się, że ekranizacja Władcy Pierścieni stała się największym przedsięwzięciem w historii światowej kinematografii, a reżyserem filmu został Peter Jackson, mieszkający w Nowej Zelandii, specjalizujący się w horrorach ${ }^{90}$.

Wydarzenie, jakim była ekranizacja powieści, stało się pretekstem do przybliżenia czytelniczkom miesięcznika sylwetek aktorów, grających w filmie. Dwaj z nich: Elijah Wood i Orlando Bloom, pojawili się na łamach periodyku odpowiednio w 2002 i 2003 r. 0 ile charakterystyka odtwórcy Frodo Bagginsa była dość szczegółowa (autor przeprowadził czytelnika przez początki kariery aktora, poprzez kolejne grane przez niego role, opisał też jego ulubione zajęcia ${ }^{91}$ ), o tyle postać aktora grającego Legolasa przedstawiona została już bardziej powierzchownie. Znacznie krótsza forma, niewielkich rozmiarów akapity przedzielone tytułami i zawierające głównie ciekawostki (jak na przykład ta, że 0. Bloom „złamał już sobie w życiu prawie wszystko: od zęba i palca, przez nadgarstek, po obie nogi. Na planie $>$ Władcy< Orlando spadł z konia i połamał sobie żebra"92), odpowiadała zmienionej, charakterystycznej formule pisma.

Z kolei inne wydarzenie, jakim było wydanie Dzienników Kurta Cobaina, dało bodziec do przypomnienia jego sylwetki. Opisując początki legendarnego zespołu Nirvana, problemy „lidera ostatniej jak dotąd wielkiej muzycznej rewolucji" ${ }^{93}$ z narkotykami, podkreślano, że z jego pamiętników

\footnotetext{
90 [br. aut.], Profesor od hobbitów, „Filipinka” 2002, nr 3, s. [53].

${ }^{91}$ M. Chmielewski, Władca talentu, „Filipinka” 2002, nr 3, s. 56-[57].

92 K. M. Śmiałkowski, Zalotny elf, „Filipinka” 2003, nr 2, s. [67].

93 B. Kopiczyński, „Nie czytaj tego jak mnie nie ma”, „Filipinka” 2003, nr 10, s. 69.
} 
„Wyłania się [...] portret skłóconego ze światem nadwrażliwca”94. Cytowano fragmenty pamiętników, w których muzyk przyznawał, że każdy, kto sięgnie po tego typu używki, stanie się ich niewolnikiem ${ }^{95}$. Tym samym redakcja zdawała się przestrzegać czytelniczki przed nałogiem, wskazując jednocześnie do naśladowania inne wzory, jak choćby autorki młodego pokolenia. Im, pomimo wieku, udało się osiągnąć sukces literacki. Pierwszą z nich była Izabela Zych, która „Ucząc się do matury, napisała >Podziemny świat<. Zła, że nikt nie chce wydać jej książki, założyła własne wydawnictwo”96. Krótka charakterystyka nastolatki, która „Uwierzyła w siebie”97 pojawiła się rubryce Odkryj $w$ sobie talent. Bohaterką następnej publikacji była Irina Dienieżkina: „Beznadziejna romantyczka”98 pojawiła się obok m.in. angielskiej aktorki Keiry Knightley i tancerza, Kamila Czarneckiego, w tekście poświęconym karierom nastolatek, zamieszczonym w rubryce Im się udało.

W sześciu przypadkach teksty opisujące wybrane osoby drukowano w ramach działu kulturalnego, w pozostałych czterech zamieszczono je w działach i rubrykach nie mających nic wspólnego z tą dziedziną życia (na przykład we wspomnianych rubrykach Im się udało czy Odkryj $w$ sobie talent). Za każdym razem obejmowały one stronę lub dwie w piśmie, urozmaicano je zdjęciami bohaterów i krótkim wprowadzeniem. Pomimo pewnej staranności widocznej w przygotowaniu omawianych publikacji, nie można stwierdzić, by stanowiły one istotny, stały element pisma. Ich niewielka liczba w ciągu badanego okresu wskazuje raczej na przypadek, pojawienie się niezależnych okoliczności (śmierć pisarza, wydanie książki, podsumowanie wydarzeń roku, filmowa premiera), które stały się pretekstem do przypomnienia danej postaci.

Podobnie było w przypadku ogólnych publikacji poświęconych literaturze. W trakcie analizowanych 5 lat pojawiło się ich na łamach „Filipinki” 15, z czego 8 nawiązywało do popularnych w tamtym okresie książek.

94 Ibidem, s. 68. Tekst wzbudził odzew wśród czytelników: na łamach periodyku wydrukowano list oburzonej czytelniczki, której nie podobała się decyzja żony muzyka dotycząca wydania, wbrew jego woli, opisywanych Dzienników.

${ }_{95}$ Aby otrzymać omawianą książkę, należało odpowiedzieć na pytanie dotyczące tytułu drugiego albumu zespołu Nirvana.

96 J. Masella, Na przekór czarnowidzom, „Filipinka” 2003, nr 8, s. 38.

97 Ibidem.

98 [br. aut.], Debiuty 2003 - pięć minut do sławy, „Filipinka” 2003, nr 12, s. 22. 


\subsection{Teraz manga ${ }^{99}$ : teksty poświęcone książce}

Zjawisko Potteromanii, które osiągnęło apogeum w 2001 i 2002 r., było przedmiotem rozważań Izy Mazurkiewicz. Zastanawiając się, co jest powodem tak dużej popularności sagi o Harrym Potterze, stwierdziła ona, że pomimo powszechnie znanego schematu, spotykanego w niejednej książce, jego przygody

są po trosze baśnią, po trosze powieścią psychologiczną, są książką o dojrzewaniu i fabułą sensacyjną. Nie brak tu elementów thrillera i horroru jednocześnie [...], powieści przygodowej i detektywistycznej [...]. A wszystko to napisane lekkim, potocznym językiem, pełnym humoru i znanym tylko potterologom określeń ${ }^{100 .}$

Przesadny nieco w swej wymowie tekst był jednak także dość ogólny i niewolny od błędów (jeden z bohaterów powieści, Draco Malfoy, za sprawą magii?, pojawił się tu jako Darco). Wydaje się, że autorka zakładała, iż czytelniczki należą do fanek cyklu Joanne K. Rowling, stąd ograniczyła się do ogólnej charakterystyki zjawiska, podkreślając głównie jego ciekawsze aspekty, towarzyszące na przykład pojawieniu się kolejnych tomów powieści (jak choćby podpisanie przez osoby związane z publikacją książki zobowiązania o zachowaniu $\mathrm{w}$ tajemnicy zarówno tytułu, jak i fabuły kolejnej części, czy przechowywanie rękopisu powieści $\mathrm{w}$ bankowym sejfie). Jednocześnie pojawił się tu element, z którym czytelniczki „Filipinki” będą się spotykać w swoim dorosłym życiu bardzo często. „Kto do tej pory nie słyszał o Harrym Potterze, przekonuje się, że ominęło go coś, czym interesują się wszyscy!"101 - za tym stwierdzeniem kryła się sugestia, by ci nieszczęśliwcy, którzy nie poznali dotąd powszechnie znanego bestsellera, czym prędzej dołączyli do „wszystkich”, bo inaczej znajdą się poza kręgiem wtajemniczonych i będą się wśród nich negatywnie wyróżniać. Dla tych, którzy traktowaliby cykl opowieści o rezolutnym czarodzieju wyłącznie w kategoriach bajki, przeznaczony był natomiast kolejny tekst: Czego uczysz się od Harry'ego Pottera? Anna Dąbrowska przekonywała m.in., że „We wszystkim jest jakiś sens”, „Każda z nas jest czarodziejką”, „Śmiech pokona strach”, a niedowiarkowie (dzięki lekturze) powinni uwierzyć, że „Magia jest wszędzie"102. Ta publikacja nosiła w sobie echa "dawnej >Filipinki<", tytułu ambitnego, który nierzadko podkreślał aspekty wychowawcze w przywoływanych i omawianych przez siebie książkach. Pozostałe teksty, mieszczące się w omawianej grupie, nie posiadały jednak już tych cech. Nadal

\footnotetext{
99 Tytuł jednej z publikacji, zob. „Filipinka” 2003, nr 8, s. [22].

100 I. Mazurkiewicz, Potteromania, „Filipinka” 2001, nr 3, s. 45.

101 Ibidem.

102 A. Dąbrowska, Czego uczysz się od Harry`ego Pottera?, „Filipinka” 2001, nr 9, s. [55].
} 
odnosząc się do popularnych powieści czy gatunków literackich, zawierały w sobie najczęściej głównie element rozrywkowy lub informacyjny.

Na fali popularności bestsellerów H. Fielding zastanawiano się na przykład nad tym, Za co kochamy Bridget Jones. Podobnie jak w prasie opinii i czasopismach kobiecych, tak i tu odpowiedź sformułowana była podobnie: „Za to, że w jej problemach bardzo łatwo znaleźć swoje”103. Obok tych rozważań pojawiły się komentarze trzech czytelniczek, które starały się ustosunkować do pytania zawartego w tekście. Jednocześnie dla tych, które nie potrafiły zdecydować się, w jakim stopniu opisywana bohaterka odpowiada ich własnemu wizerunkowi, zamieszczono poniżej rodzaj podpowiedzi, który miał im ułatwić zadanie. Zacytowano kilka „złotych myśli” panny Jones, a jej miłośniczkom zaproponowano rodzimą wersję popularnego pamiętnika w postaci książki K. Grocholi (Nigdy w życiu!).

Nie zapominano również o popularnym cyklu Jeżycjada pióra M. Musierowicz. Pierwsza wzmianka wymagała od czytelniczek dobrej znajomości jednej z książek serii. W tekście dotyczącym przyjaźni pomiędzy dziewczętami, jednym z jej opisanych modeli była relacja pomiędzy bohaterkami Opium w rosole: Gabrysią i Kreską ${ }^{104}$. Ciekawy tekst związany z powieściami M. Musierowicz pojawił się także w numerze kwietniowym w 2002 r. ${ }^{105}$ Autorka wyruszyła śladem rodziny Borejków, odwiedzając znaną miłośniczkom powieści poznańską ulicę Roosvelta 5 i teatr, w którym gwiazdą sceny była Aniela Kowalik. Tekst z pewnością mógł zainteresować wielbicielki sagi, ale jednocześnie bezlitośnie rozwiewał ich złudzenia związane z rzeczywistym istnieniem najsłynniejszej (w kręgach czytającej młodzieży) współczesnej rodziny Poznania.

Poza publikacjami, nawiązującymi do określonych powieści, pojawiły się również teksty odnoszące się do popularnego gatunku literackiego, jakim stał się na początku XXI w. komiks. Trzykrotnie poświęcono mu miejsce $\mathrm{w}$ periodyku. Podobnie, jak było to w przypadku prasy opinii, tak i tu znalazło się podobne stwierdzenie, że ten typ literatury „jest w Polsce niedoceniany. Traktuje się go jak książeczkę dla dzieci. Tymczasem w Ameryce osiąga milionowe nakłady i jest czytany przez dorosłych"106. Opisując historię komiksu, przywołując postaci tych, którzy są przyszłością jego rodzimej wersji, zaznaczono, że może być on adresowany do różnych grup wiekowych: zainteresowane nim są bowiem zarówno dzieci, młodzież, jak i dorośli. I tu, podobnie jak w innych typach literatury, pojawiać się może komiks „z górnej półki”, jak i obrazkowy „fast-food” - czytelniczki „Filipinki”

\footnotetext{
103 [br. aut.], Za co kochamy Bridget Jones?, „Filipinka” 2001, nr 8, s. [53].

104 [br. aut.], Na dobre i na złe, „Filipinka” 2001, nr 8, s. 76.

105 K. Popoff-Szczepańska, Prawdziwy adres Borejków, „Filipinka” 2002, nr 4, s. [68].

106 [br. aut.], Herosi w akcji, „Filipinka” 2001, nr 11, s. [56].
} 
powinny nauczyć się je odróżniać i być może, pójść w ślady swych koleżanek, bohaterek kolejnej publikacji, które rysują komiksy107. Jego japońska odmiana (szczególnie popularna wśród nastolatek w kraju kwitnącej wiśni) stała się przedmiotem kolejnego tekstu. Dotyczył on jednak głównie efektów mody na mangę: skrupulatnie opisano cechy, wyróżniające nastolatki - wielbicielki japońskich komiksów i zamieszczono zdjęcia kilku gadżetów z nimi związanych ${ }^{108}$. Potraktowanie tematu w tak różny sposób w ciągu zaledwie kilku miesięcy, umieszczenie go w dziale poświęconym modzie było charakterystyczne dla pisma w tym okresie. $Z$ jednej strony podkreślano znaczenia komiksu, traktując jego tworzenie jako rodzaj sztuki, $\mathrm{z}$ drugiej pisano o jednej $\mathrm{z}$ jego odmian $\mathrm{z}$ pewnym przymrużeniem oka, koncentrując się przede wszystkim na jego popularnych aspektach.

W tym kontekście interesujący, a może nawet dwuznaczny, wydaje się być komentarz uzupełniający tekst poświęcony pauperyzacji kultury, w tym także sztuki, która

straciła aureolę, nie jest już święta. Mechaniczna reprodukcja sprawia, że obraz w zmultiplikowanej formie jest obecny wszędzie. Kiedyś pojedyncze, wyjątkowe dzieła można było obejrzeć jedynie w muzeum. Teraz żyjemy w kulturze kopii, powielacza. Przybliżanie sztuki, które możliwe jest dzięki jej kopiowaniu, powoduje estetyzację życia. Różne przedmioty stają się bardziej dekoracyjne niż użytkowe. Dzieła dawnych mistrzów zostały wciągnięte w biznes, w przemysł artystyczny ${ }^{109}$.

Także arcydzieła literackie, jak zauważyła autorka, „były upraszczane i przerabiane na komiksy, musicale i scenariusze kreskówek"110. Ciekawe było również kolejne stwierdzenie:

Wszelkie imprezy towarzyszące wystawom są także manipulacją dziełem sztuki. Prezentacja obrazów, rzeźb zostaje nagięta do potrzeb odbiorcy, przykrojona do jego możliwości percepcji. To sztuka ma się nagiąć do odbiorcy, a nie odbiorca do sztuki111.

Czyżby w tych słowach, napisanych przez autorkę w grudniu 2002 r., krył się przeczuwany przez nią los „Filipinki” ...?

107 M. Korczyka, O. Szaczkus, Komiks w rękach dziewczyn, „Filipinka” 2003, nr 12, s. [44]-45.

108 [br. aut.], Teraz manga, „Filipinka” 2003, nr 8, s. [22].

109 A. Budak, Kultura powielacza, „Filipinka” 2002, nr 12, s. [49]. Był to komentarz uzupełniający zamieszczony wcześniej tekst, zob. M. Kucia, Picasso $w$ łazience, ibidem, s. [48]-[49].

110 M. Kucia, Picasso..., s. [49].

111 Ibidem, s. [48]-[49]. 
Skłonności magazynu skierowane ku popularyzacji kultury obrazkowej, popularnej, widoczne były w wyraźnym upodobaniu redakcji do zamieszczania informacji związanych $\mathrm{z}$ filmem. Przejawiało się to $\mathrm{w}$ prezentacji wybranych aktorów i wywiadach z nimi, ale również w licznych wzmiankach dotyczących premier filmowych. Wśród nich pojawiały się także informacje poszerzone oraz niewielkie objętościowo recenzje dotyczące ekranizacji oraz inscenizacji znanych utworów. Nierzadko zamieszczano informacje, ocierające się o plotkę. W ciągu 5 lat na łamach pisma znalazło się 49 omówień rozmaitych ekranizacji oraz inscenizacji. Większość z nich pojawiła się w ramach działu kulturalnego, w rubrykach: Film, Kino, Wideo rzadziej Teatr. Pisano np. o ekranizacji takich powieści jak Dziennik Bridget Jones, Gnój, Nigdy w życiu!, również o cyklu o Harrym Potterze oraz o trylogii J. R. R. Tolkiena, ale także o Pornografii czy $W$ pustyni i w puszczy, przeniesionych na ekran przez znanych polskich reżyserów.

Informacje te miały przeważnie objętość kilku lub kilkunastu zdań, uzupełnionych danymi organizacyjnymi, zdjęciami aktorów bądź kadrami z filmu. Stanowiły element rozbudowanych rubryk związanych z X Muzą. Niekiedy czytelniczki miały możliwość wygrania płyty dvd $\mathrm{z}$ omawianym filmem, biorąc udział w konkursach sms-wych, będących (w miarę upływu czasu) coraz częstszym dodatkowym elementem przy tego typu informacjach.

\subsection{Wygraj książkę ${ }^{112}$ : konkursy i akcje}

Jakkolwiek na łamach „Filipinki” często pojawiały się rozmaitego rodzaju konkursy i akcje zarówno organizowane przez periodyk, jak i te, o których w piśmie tylko informowano, na przykład z racji patronatu medialnego, to jednak tego typu przedsięwzięcia związane z książką należały do rzadkości. W większości były to akcje o charakterze opisanym w pierwszej części rozdziału. Natomiast w grupie inicjatyw, które można zaliczyć do kategorii bezpośrednio lub pośrednio dotyczącej interesującej nas problematyki, pojawiały się:

1) systematycznie organizowane konkursy o charakterze literackim i paraliterackim,

2) jednorazowe przedsięwzięcia,

3) minikonkursy, w których nagrodą była wybrana lektura.

112 Tytuł notki, zapraszającej do wzięcia udziału w konkursie sms-owym, w którym nagrodą była książka. „Filipinka” 2004, nr 7, s. 76. 
Do pierwszej grupy należy zaliczyć Konkurs Literacki Filipinki, organizowany od 1995 r. Czytelniczkom proponowano napisanie opowiadania o dowolnej tematyce, o objętości do 5 stron maszynopisu, podpisanego wymyślonym przez jego autorkę pseudonimem. Najlepsze prace miały być drukowane na łamach miesięcznika, nadto na ich autorki czekały nagrody (na przykład komplety książek, plecaki i pióra) ${ }^{113}$. W 2004 r., w 10. edycji konkursu, określono temat opowiadania, którym był Przepis na świat doskonały. Izabela Filipiak radziła czytelniczkom:

Zanim zaczniesz pisać, pomyśl, co chciałabyś zmienić? Pisz tak, jakbyś mogła stworzyć lepszy świat. Myśl o szczegółach - jak wyglądają rodziny, czym jest miłość i przyjaźń? Rola pieniędzy? Czy władza stanowi problem? Co z chorobami, przemocą?114

Pierwotnie termin nadsyłania prac wyznaczono na koniec kwietnia, jednak później przedłużono go o kolejne 4 miesiące.

Innym cyklicznym przedsięwzięciem tego typu był konkurs na najlepszy pamiętnik, po raz pierwszy zainicjowany w 2000 r., kontynuowany w latach następnych. Czytelniczkom proponowano pisanie dziennika, a następnie przesłanie jego fragmentów do redakcji. Wśród prac (o objętości maksymalnie 5 stron) jury wybierało najciekawsze, które drukowano w „Filipince", a ich autorki otrzymywały nagrody (na przykład torby) ${ }^{115}$.

Na łamach periodyku nie analizowano przysyłanych prac (jak było to na przykład w przypadku prasy kobiecej, gdzie komentowano najczęściej poruszane przez czytelniczki tematy w pisanych przez nie pracach konkursowych), informując jedynie o laureatach i ograniczając się ewentualnie do stwierdzeń, że redakcja otrzymała bardzo dużo opowiadań lub „mnóstwo różnych, fantastycznych zapisków"116. W kolejnych numerach zamieszczano nagrodzone prace, w przypadku pamiętników anonsując je zaproszeniem do kolejnej edycji konkursu hasłem: „Ty też możesz być pisarką! Weź udział w konkursie na dziennik".

W badanym okresie były to najważniejsze systematycznie pojawiające się inicjatywy, związane z rozwijaniem zdolności literackich czytelniczek. Więcej tego typu przedsięwzięć znalazło się $\mathrm{w}$ drugiej $\mathrm{z}$ wymienionych grup.

Warto w tym miejscu przywołać interesujący konkurs na opowiadanie z czasów młodości babć czytelniczek pisma. W numerze czerwcowym (2001) wydrukowano nagrodzone opowiadanie Przetańczyć cała noc, a jego

113 Zob. np. „Filipinka” 2001, nr 2, s. [72]; 2002, nr 1, s. [41]. Jedna z nagrodzonych prac: ibidem, 2001, nr 9, s. [73].

114 I. Filipiak, Napisz opowiadanie, „Filipinka” 2004, nr 2, s. [66].

115 Zob. np. „Filipinka” 2001, nr 10, s. [75]; jedna z nagrodzonych prac: nr 8, s. 70-[71].

116 „Filipinka” 2001, nr 10, s. [71]. 
pointa oddawała nieco dydaktyczny charakter „dawnej” „Filipinki” i przypominała klimat wielu tekstów, zamieszczanych na łamach pisma przed 1995 r.:

kiedy będziesz miała tyle lat, co ja (chociaż pewnie wydaje ci się to niemożliwe!) i weźmiesz aktualny numer Filipinki do ręki, wtedy powiesz: „Za moich czasów to dopiero było wspaniale!”. Bo cóż to są te „moje czasy”? Po prostu czasy młodości, której z niczym porównać się nie da i powrócić do niej nie sposób...117.

Pomysł, jakkolwiek wartościowy, nie został powtórzony. Pozostałe konkursy nie wymagały już od czytelniczek większego zaangażowania. Znalazły się tu zarówno propozycje napisania krótkich tekstów na zadany przez redakcję temat, jak i takie, które nawiązywały do znanych książek i ich bohaterów. Jedną z nich był „magiczny konkurs” związany z Harrym Potterem. Proponowano, by czytelniczki wymyśliły oryginalny, czarodziejski przedmiot, narysowały go i opisały. Natchnienia można było szukać w kolejnych tomach powieści, w których obok latających mioteł pojawiały się świstokliki, zegary, przypominające o czynnościach, które należało wykonać w ciągu dnia, czy ruchome fotografie i fałszoskopy. Na autorki najciekawszych pomysłów czekały „czarodziejskie” nagrody (na przykład „20 cudownych teczek") ${ }^{118}$.

Warto również wspomnieć o pomniejszych konkursach, które w pewnym stopniu rozwijały zdolności twórcze czytelniczek „Filipinki”. Na przykład, przy okazji przywołanego wcześniej tekstu na temat komiksu, zaproponowano im narysowanie własnej obrazkowej historyjki z dymkiem i przesłanie jej do oceny redakcji. Najlepsze prace obiecywano wydrukować na łamach pisma119. Inny pomysł pojawił się w 2004 r., w numerze majowym, w którym proponowano czytelniczkom opisanie (w ramach konkursu Jak wchodziłam do Europy) własnych odczuć związanych z wstąpieniem Polski w struktury Unii Europejskiej. Wrażenia mogły być opisane w formie felietonu, opowiadania lub reportażu, a ich objętość nie powinna przekraczać 5000 znaków. Najlepsze prace obiecywano opublikować, zaś na autorkę jednej z nich czekał komplet eurokoszulek oraz Encyklopedia Unii Europejskiej120.

Kolejnym pomysłem była propozycja napisania historyjki, w której „istotną rolę” odgrywać miała... torba ${ }^{121}$, inny polegał na opisaniu przez czytelniczki najskuteczniejszego (ich zdaniem) sposobu na naukę języka obcego. W opisie znaleźć miały się podane przez redakcję słowa („klik”, „mysz" i „poliglota”) ${ }^{122}$.

\footnotetext{
117 J. Chojnacka [czytelniczka], Przetańczyć całą noc, „Filipinka” 2001, nr 6, s. [76].

118 „Filipinka” 2002, nr 2, s. [42].

119 „Filipinka” 2001, nr 11, s. [56].

120 „Filipinka” 2004, nr 5, s. 26.

121 „Filipinka” 2002, nr 5, s. [27].

122 „Filipinka” 2002, nr 7, s. [70].
} 
Kilkakrotnie nawiązywano pytaniem do opisywanej w magazynie książki, jej fragmentu, drukowanego w danym numerze lub zamieszczonego w nim wywiadu z pisarzem. Tak było na przykład przy okazji zamieszczenia fragmentu powieści Nicka McDonella Odlot, rozmowy z J. Harris czy recenzji powieści A. Pérez-Reverte. W takim przypadku nagrodą bywała zazwyczaj książka danego twórcy.

Od 2004 r. wyraźnie wzrosła liczba konkursów sms-owych, dotyczących różnych zagadnień, w tym takich, w których przedmiotem pytania lub nagrodą za poprawną odpowiedź była książka. Czytelniczki miały możliwość wygrać na przykład jeden z kompletów Opowieści rodu Otori, jeden z zestawów trylogii Enkiego Bilala, jeden z 15 egzemplarzy powieści Gnój Wojciecha Kuczoka czy jedną z powieści o Adrianie Mole`u (Sue Townsend). Książki bywały również niekiedy jedną z nagród za poprawne rozwiązanie krzyżówki. W większości przypadków fundatorami były oficyny wydawnicze. To, że książka traktowana była w tym przypadku na równi z zestawem kosmetyków do kąpieli lub kremu do rąk, mogło grozić tym, że w efekcie postępującej wokół komercjalizacji sztuki i literatury czytelniczki miały „szansę ją zrozumieć, ale jednocześnie [...] [mogły - przyp. M.P.S.] stracić dla niej szacunek"123.

O konkursie na napisanie powieści czytelniczki dowiedziały się z numeru lipcowego w 2004 r. Wydawnictwo Santorski \& Co proponowało opisanie życia współczesnych nastolatków, ich problemów, zmartwień i konfliktów. Nagrodzona powieść miała reprezentować Polskę w planowanej serii „Biblioteka Młodego Europejczyka”. Znaleźć się w niej miały najbardziej interesujące dzieła literatury adresowanej do młodzieży124.

Jednak tego typu informacja na łamach pisma należała do wyjątków; nie donosiło ono o podobnych inicjatywach innych wydawnictw czy instytucji, chociaż chętnie współpracowało na przykład z firmami kosmetycznymi, z którymi organizowało wspólne przedsięwzięcia.

Należy jednak wspomnieć o tekście opisującym wybrane przedsięwzięcia związane $\mathrm{z}$ promowaniem poezji, podejmowane $\mathrm{w}$ Internecie ${ }^{125}$. Obok projektu Michała Zabłockiego Multipoezja ${ }^{126}$ przedstawiono także Legnickie Biuro Literackie, serwisy www.wiersze.com. oraz www.republika.pl/bohman/ wierszok/.

Jakkolwiek konkursy paraliterackie pojawiały się w periodyku, a książka znajdowała swoje miejsce także w projektach organizowanych przez „Filipinkę", to jednak, poza opisanymi dwoma cyklicznymi pomysłami, nie

123 A. Budak, Kultura powielacza, „Filipinka” 2002, nr 12, s. [49].

124 „Filipinka” 2004, nr 7, s. 76.

125 M. Kucia, Poezja schwytana w sieci, „Filipinka”, 2002, nr 9, s. [48]-[49].

126 Projekt ten był już wspomniany w rozdziale poświęconym magazynowi kobiecemu „Zwierciadło” (3.2.3.4.2.) oraz krótko opisany w rozdziale dotyczącym miesięcznika „Elle” (zob. rozdz. 3.4.3.4.1.). 
stanowiły one szczególnie istotnego punktu w polityce redakcyjnej pisma. Wrażenie to pogłębia także, wspomniany wcześniej, brak należytego dopracowania tego typu pomysłów. Informowano o nich, podawano ogólne zasady udziału w nich, ale nie komentowano zbyt szeroko ich wyników, ograniczając się do podania danych osobowych laureatów i ewentualnego druku nagrodzonych prac.

Należy jednak docenić istnienie tego typu inicjatyw, podejmowanie prób zaangażowania czytelniczek w próby pisarskie, nawet jeśli były to próby ograniczone do pisania krótkich historyjek na proponowany przez periodyk temat. Ponadto, jak w przypadku konkursów sms-owych, organizowanych na łamach prasy kobiecej, te z nich, gdzie nagrodą była książka, stanowiły formę promocji (może nieświadomej) danego tytułu.

Podobnie było $\mathrm{w}$ wielu przypadkach, odnoszących się do informacji, zaliczonych do kategorii Inne. Była to, podobnie jak w prasie opinii czy czasopismach kobiecych, najbardziej rozbudowana grupa. Znalazły się w niej, jak już wspomniano, przede wszystkim wzmianki, notatki prasowe mniej lub bardziej rozbudowane oraz zapowiedzi, ale sporadycznie drukowano także nieco większe objętościowo wiadomości, a nawet reprezentatywne dla publicystycznych gatunków dziennikarskich formy.

Do zajmujących w piśmie stronę i więcej zaliczyć należy felietony. Ich autorami byli jednak przeważnie piosenkarze (na przykład Kasia Kowalska) lub celebryci (jak choćby Kuba Wojewódzki). Dopiero od numeru 6 (2004) pojawił się ten typ publikacji autorstwa M. Nahacza, bohatera jednego z wywiadów, autora powieści Osiem cztery i Bombel [pis. oryg.]. Odtąd teksty jego pióra można było znaleźć w rubryce zatytułowanej krótko Jego felieton, zajmującej stronę, opatrzoną dodatkowo zdjęciem autora i rysunkami odpowiadającymi treści aktualnego tekstu.

Stronę lub dwie poświęcano również na drukowanie fragmentów wybranych powieści. W ciągu 5 lat pojawiło się ich na łamach „Filipinki” 11. W ten sposób zachęcano do sięgnięcia po następujące tytuły: 20 tysięcy godzin w budzie (Andrzej Samson), Iwona czy Agnieszka? (Grażyna Katner), Odlot (Nick McDonell) Osobowość (Andrew O'Hagan), Oszaleć ze strachu (Jana Frey), Spalona żywcem (Souad), Sabotaż miłosny (Amélie Nothomb), Stan podgorączkowy (Grażyna Bąkiewicz), Statek z papieru (Scott Spencer), $W$ ciemności (Jana Frey), Wyznania nastoletniej gwiazdy (Dyan Sheldon). Obok cytowanego fragmentu zamieszczano zdjęcie autora, jego biogram, czasem przeprowadzano z nim krótki wywiad, niekiedy również proponowano czytelniczkom udział w konkursie sms-owym, nawiązującym zazwyczaj do twórczości danego pisarza.

Od numeru 6 (2001) na łamach miesięcznika drukowano także komiks w odcinkach, zatytułowany: Kfiatuszki [pis. oryg.]. Jego autorami byli 
Dennis Wojda oraz Tomasz Leśniak. Historia obrazkowa, drukowana do połowy 2004 r., opisywała przygody Baśki i jej przyjaciółek: Natki oraz Adeli. Czytelniczki przez niemal 3 lata mogły śledzić perypetie bohaterek, opisane w zabawny sposób, ich szkolne i prywatne życie oraz problemy z płcią przeciwną. W latach 2002-2003 pojawiało się w piśmie opowiadanie Jagody Gardy Szkoła Specjalnej Troski, zajmujące niemal dwie strony.

Stałym elementem w zawartości pisma była rubryka poetycka Cześć poeci i poetki [pis. oryg.] ${ }^{127}$, w której drukowano wiersze przysyłane przez czytelniczki, oceniane i komentowane przez pisarkę i poetkę, Natalię Usenko. Początkowo wiersze zajmowały dwie strony, później jednak ograniczano się do jednej strony w piśmie. Obok komentarza znajdowało się zdjęcie poetki, a wiersze czytelniczek przedzielone były rysunkami odpowiadającymi danemu motywowi, pojawiającemu się w wydrukowanych utworach. Niekiedy zamieszczano też krótkie odpowiedzi N. Usenko na listy czytelniczek.

Warto również przywołać kilkakrotnie zamieszczoną rubrykę, w której znane osoby dzieliły się z czytelniczkami tytułami swoich ulubionych książek. Dwukrotnie w 2002 r. zapytano znane aktorki (Magdalenę Stużyńską i Kaję Paschalską) o ich ulubione lektury. Filmowa Marcysia z serialu Złotopolscy przyznała, że niezapomnianą lekturą jej dzieciństwa był cykl powieści L. M. Montgomery oraz powieść Dzieci z Bullerbyn. W 2003 r. o swoich książkach opowiedzieli popularni piosenkarze: Robert Gawliński, Kasia Kowalska i Renata Przemyk oraz aktorka, Joanna Brodzik. Wokalista zespołu „Wilki” wyznał m.in.:

Książki zafascynowały mnie około 13. roku życia. Nie chodziłem do szkoły, tylko w parku z zapartym tchem śledziłem losy bohaterów literatury science fiction. Obecnie mam niewiele wolnego czasu, zawsze jednak staram się znaleźć w tygodniu chwilę na czytanie. Od lat wracam do „Władcy Pierścieni”128.

Natomiast K. Kowalska przyznała, że jako nastolatka czytała komiksy ze znanej serii Kajko i Kokosz, a także Wakacje z duchami Adama Bahdaja. Z kolei R. Przemyk wyznała, że lubi poznawać całą twórczość jednego, wybranego przez siebie autora. W ten sposób spędza czas m.in. z Marcelem Proustem. W dzieciństwie zaś przywiązana była do cyklu o Muminkach i Hobbita. Z kolei Tęsknota silnej kobiety za silnym mężczyznq (Mai Storch) okazała się ostatnio przeczytaną książką przez J. Brodzik.

Dużą grupę w kategorii określonej jako Inne stanowiły krótkie, kilkuzdaniowe informacje, które określić można jako wzmianki, a część z nich

127 W 2003 r. kilkakrotnie pojawiła się inna nazwa tej rubryki: Poezja.

128 [br. aut.], Co czyta Robert Gawliński?, „Filipinka” 2003, nr 8, s. 71. 
zaliczyć można do notatek prasowych. Było ich w sumie w ciągu pięciu lat 51. Pojawiały się zazwyczaj w dziale kulturalnym, ale kilka z nich znalazło się również w obrębie innych działów i rubryk, na przykład Między nami, Moda czy Nauka i kariera lub Niezbędnik. Niemal połowa z owych notek nie posiadała własnego tytułu, i tylko dwie z nich były podpisane. Informowano na przykład o istnieniu wirtualnej biblioteki ${ }^{129}$, portalach edukacyjnych ze słownikami130, o nowej serii Wydawnictwa Czarne ${ }^{131}$, ukazaniu się pierwszej części Opowieści rodu Otori: Po słowiczej podłodze ${ }^{132}$, polecano wybrane książki, jak choćby Mapę twoich myśli (Tony Buzan, Barry Buzan)133, Tomasza Piątka Przypadek Justyny134. Pisano o VII Międzynarodowym Festiwalu Sztuki Książki 2003 „Wędrówka”135 i o Festiwalu Poezji w Poznaniu136. Niekiedy informacje te miały charakter ciekawostek, jak choćby wzmianka o tym, że W. Wharton zamierza zamieszkać z żoną i synem w Białowieży ${ }^{137}$.

Tylko w kilku przypadkach książka była polecona przy okazji poruszenia wybranego przez dziennikarza tematu ${ }^{138}$.

Na koniec należy wspomnieć o listach bestsellerów. Pojawiły się one na łamach pisma zaledwie ośmiokrotnie: w 2001 (3 razy), 2004 (dwukrotnie) oraz 2005 r. (ponownie 3 razy). Najpierw był to EMPiK TOP 10, następnie Ksiq̨żki, a w 2005 r.: Ranking Filipinki. Za każdym razem zestawienie obejmowało 10 pozycji, zawierających nazwisko i imię autora książki, jej tytuł oraz nazwę wydawcy.

Prezentowana grupa informacji, zaliczona do kategorii Inne była najbardziej zróżnicowana. Część z nich, szczególnie te obszerniejsze, znajdowały się na pograniczu wcześniej omówionych form, jak choćby recenzji.

Wśród czytelniczek pisma sprawy książki nie znajdowały dużego oddźwięku, a przynajmniej zainteresowanie to nie przekładało się na listy, wysyłane do periodyku. Zaledwie trzykrotnie pojawiły się listy nawiązujące do publikacji dotyczącej książki. W 2001 r. Bina pisała:

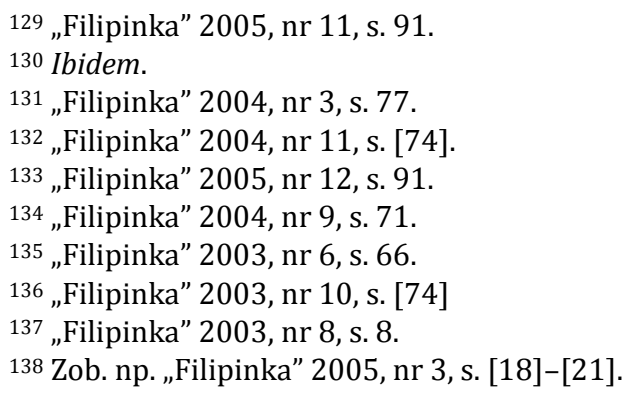


Niewielu moich znajomych czyta książki, bo wydaje im się, że to takie staroświeckie i niemodne. [...] Dziwi mnie fakt, że można obawiać się wyśmiania z powodu fascynacji światem lektur, książek czy poezji. [...] Zapewniam, że warto sięgnąć pod dobrą książkę i odpuścić sobie kolejny, tandetny film na wideo ${ }^{139}$.

Głos był bez wątpienia słuszny, redakcja przyznała rację czytelniczce, szkoda jednak, że opinii tej nie zastosowała do własnej polityki związanej z książką.

\subsubsection{Gazety na medal ${ }^{140}$. Inne informacje: o prasie i środowisku dziennikarskim}

W omawianym periodyku znalazły się jedynie dwie tekstowe informacje dotyczące prasy: pierwszą było ogłoszenie wyników VII Ogólnopolskiego Konkursu na Gazetę Szkolną „Nasza Gazeta”, drugą stała się niewielkich rozmiarów wzmianka o czasopiśmie „Świat Młodych”, w którym drukowano komiks Kajko i Kokosz ${ }^{141}$.

Natomiast nieco większą grupę stanowiła reklama czasopism i autopromocja innych periodyków, należących do wydawcy „Filipinki”. W sumie w ogłoszeniach tego typu pojawiło się dziewięć tytułów: „Bravo Girl!”, „Fun”, „Look. Magazyn o Urodzie i Zdrowiu”, „Rewia”, „Świat Porad”, „Świat Seriali”, „Twist”, „Twój Styl”, „Votre Beauté”. Ponadto reklamowano Pakiet Maturalny „Filipinki”, sześciokrotnie wydanie specjalne samego magazynu. Reklamy zamieszczano w całym periodyku, zajmowały moduł lub stronę. Dwudziestokrotnie pojawiła się autoreklama „Filipinki” on line, 63 razy przypomniano o prenumeracie periodyku - zob. zdjęcia 168 i 169.

139 Bina [czytelniczka], Ksiq̨żki górq̨, „Filipinka” 2001, nr 9, s. [3].

140 Tytuł informacji dotyczącej VII Ogólnopolskiego Konkursu na Gazetę Szkolną „Nasza Gazeta”. Zob. „Filipinka” 2001, nr 11, s. [63].

141 „Filipinka” 2001, nr 9, s. [6]. 


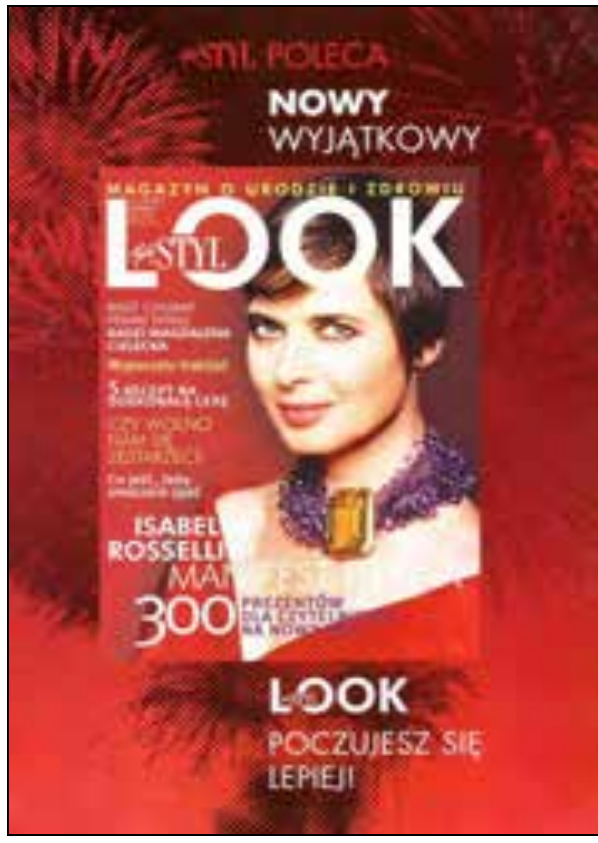

Zdjęcie 168. Wybrane ogłoszenie wydawnicze zamieszczone na łamach „Filipinki” „Filipinka” 2004, nr 5, s. [99]

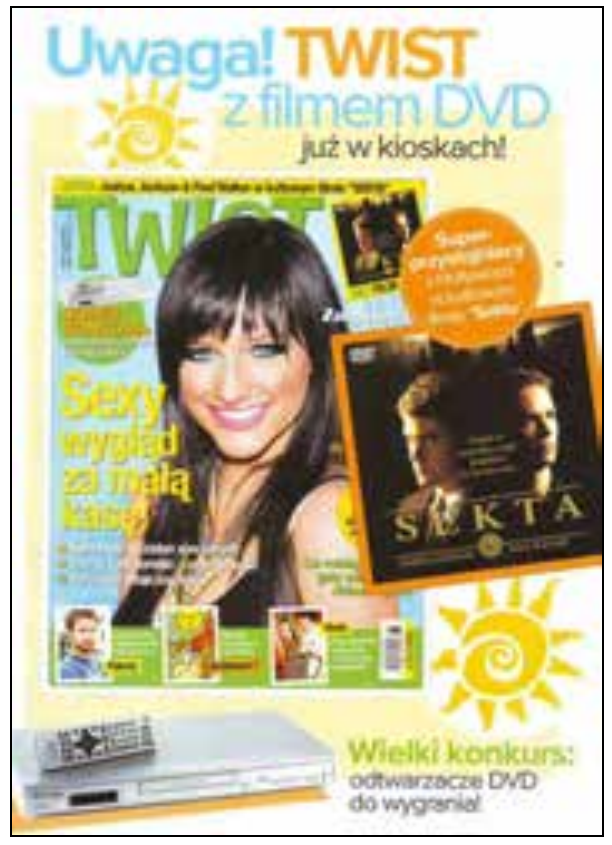

Zdjęcie 169. Wybrane ogłoszenie wydawnicze zamieszczone na łamach „Filipinki” „Filipinka” 2003, nr 2, s. [65]

Pomimo, że reklam proponujących inne periodyki było stosunkowo niewiele, to jednak zwracały uwagę czytelniczek żywymi barwami oraz sugestywnymi hasłami, na przykład „Look. Poczujesz się lepiej” (zdjęcie 168).

Jakkolwiek informacje na temat literatury znajdowały swoje miejsce w piśmie, to, jak już zaznaczono przy okazji omawiania poszczególnych ich form, nie stanowiły istotnego elementu w treści periodyku. Jego zawartość, wraz z kolejnymi latami, stawała się coraz bardziej oddalona o tej, do której przywykły wcześniejsze pokolenia czytelniczek pisma. Przeważać zaczęły krótkie teksty, przedmiotem publikacji stały się przede wszystkim modne fakty, książki i osoby z nimi związane. Dłuższe, tzn. jednostronicowe teksty, budowane były na podstawie ciekawostek, dotyczących danego tematu. 


\section{3. „Dziewczyna”: Jest wspaniała! ${ }^{1}$}

\subsubsection{Dziewczyna taka jak Ty2: historia czasopisma}

...lansuje pewien ideał dziewczyny: dba ona o cerę, troszczy się o włosy, pielęgnuje paznokcie, konserwuje dekolt, depiluje łydki [...]. Celem tego wszystkiego jest zdobycie chłopaka [...]. Następnie trzeba dowiedzieć się, jaki jest jego znak zodiaku ${ }^{3}$.

Zupełnie odmienny od przedstawionego $\mathrm{w}$ poprzednim rozdziale miesięcznika charakter miało kolejne czasopismo młodzieżowe, które stało się przedmiotem niniejszego opracowania.

Magazyn „Dziewczyna” był, podobnie jak tygodnik „Newsweek Polska”, przykładem polskiej edycji pisma zachodniego. Na polski rynek prasowy wprowadzony został przez wrocławską firmę Phoenix Intermedia ${ }^{4}$ jako polskojęzyczna wersja niemieckiego periodyku młodzieżowego „Mädchen”5. Phoenix Intermedia na mocy umowy otrzymał licencję m.in. na ten tytuł od szwajcarskiego wydawcy J. Marquarda.

Pierwszy numer pisma, które od początku przyjęło częstotliwość miesięcznika, ukazał się w maju 1991 r. Jego nakład liczył 200 tys. egz., wydany został w formacie 28,5 x 20,5, w objętości 72 stron. Redaktor naczelną

1 Opinia jednej z czytelniczek, zob. M. Watny [czytelniczka], Jest wspaniała!, „Dziewczyna" 1991, nr 3, s. 19.

2 Hasło reklamowe towarzyszące omawianemu periodykowi.

3 J. Szocki, Prasa dla dzieci i młodzieży. Czytelnictwo i funkcja, „Zeszyty Prasoznawcze” 1996, nr 3-4, s. 121.

${ }^{4}$ Phoenix Intermedia $\rightarrow$ Phoenix Press-Media - należało w latach 90. XX w. do największych wydawnictw w Europie. Była to spółka rodzinna, specjalizująca się w przekładaniu na język polski periodyków z niemieckiego kręgu językowego. Warto w tym miejscu podkreślić, że zawierane przez firmę umowy licencyjne zastrzegały wierność kopii z pierwowzorem, jednocześnie ograniczając liczbę tekstów polskich do zaledwie kilku w jednym numerze danego pisma. Praca redakcji ograniczała się głównie do tłumaczeń gotowych tekstów, co niekorzystnie wpływało na zawartość i charakter czasopisma, wydawanego wszak dla polskiego czytelnika. Phoenix Intermedia zaistniało na rynku polskim w 1990 r., dzięki dwóm miesięcznikom o charakterze poradnikowym („Trick und Schick” oraz „Nowe Pramo. Praktyczna Moda - Własne Wykonanie”). W 1991 r. firma rozpoczęła edycję dwóch kolejnych tytułów na licencji niemieckiej: „Popcorn” i „Dziewczyna”. Olbrzymi sukces obydwu magazynów sprawił, że właściciele PI, Elżbieta i Mirosław Poniżnikowie trafili w 1993 r. na listę 100 najbogatszych Polaków tygodnika „Wprost” (zajęli 70. miejsce).

${ }^{5}$ Było to pismo europejskie, którego wersje w językach narodowych wydawano również, poza Niemcami, w Czechach i na Słowacji. Właścicielem tytułu było szwajcarskie wydawnictwo Brisas, później wydawnictwo ZAG Zeitschriften-Verlag AG. 
wydania polskiego była Danuta Bukowska-Lechki, a jej zastępcą Jolanta Barlińska. Pod ich kierownictwem zespół tłumaczy przygotowywał teksty do kolejnych numerów nowego magazynu. Dzięki swej (niespotykanej dotąd na gruncie polskim) zawartości, periodyk wypełnił lukę w segmencie prasy dla młodzieży i zdobył szybko popularność. Z założenia miał to być tytuł „bogato ilustrowany, na >europejskim poziomie graficznym<, poruszający problemy młodzieży szkolnej"6, w którym znaleźć się miały materiały kulturalne (poświęcone sztuce, filmowi, muzyce), związane z modą i urodą, ale również reportaże opowiadające o życiu współczesnej młodzieży, jej problemach, pierwszej miłości. Czytelniczki odnaleźć miały na łamach nowego pisma liczne porady dotyczące, najogólniej mówiąc, „sztuki uwodzenia", zaś całość zdobić miały liczne zdjęciami ówczesnych idoli oraz fotokomiksy o miłości. Nowa dla polskich odbiorców obrazkowo-kolorowa formuła magazynu, podobnie jak niespotykany dotąd sposób pisania o sprawach intymnych, wpłynęły na olbrzymie zainteresowanie tytułem. Jego nakład szybko wzrastał, tak, że na koniec $1991 \mathrm{r}$. osiągnął pułap 400 tys. egz. Już w trzecim numerze pojawiły się pełne zachwytu listy od czytelników obojga płci:

Hej! „Dziewczyna” jest NAJLEPSZĄ gazetą, jaką kiedykolwiek czytałam. Jest wspaniała!7.

Mimo że jestem chłopcem, magazyn „Dziewczyna” bardzo mi się podoba. Mam zamiar kupować ten magazyn i chciałbym zapytać, czy w przyszłości będzie prenumerata?8.

Nareszcie mamy własne pismo na poziomie. Myślę, że my - dziewczyny nie będziemy zazdrościły już mamom ich gazety - „Pani”9.

W 1992 r. redaktor naczelna magazynu w jednym z wywiadów podkreśliła: „za najważniejszą cechę >Dziewczyny< uważam jej otwartość, szczerość, zgodność z oczekiwaniami tych czytelników, dla których jest przygotowywana"10. Opinia D. Bukowskiej-Lechki nie była jednak podzielana przez wszystkich. Jawność, wręcz ekshibicjonizm w przedstawianiu najbardziej intymnych spraw na łamach periodyku, przesadna otwartość na kwestie związane ze sprawami alkowy szokowały nie tylko recenzentów czy krytyków, ale również wychowawców i rodziców nastolatków. W prasie pojawiły się głosy oburzenia i protestu.

6 Z. Sokół, Czasopisma dla dziewcząt w Polsce w latach 1990-2004, „Studia Bibliologiczne" 2008, t. 17, s. 188.

7 M. Watny [czytelniczka], Jest..., s. 19.

8 T. Strożek [czytelnik], Mimo że..., „Dziewczyna” 1991, nr 3, s. 19.

${ }^{9}$ A. Martysiuk [czytelniczka], Nareszcie, „Dziewczyna” 1991, nr 3, s. 19.

10 D. Bukowska-Lechki, Rozmowa z redaktor naczelnq „Dziewczyny”. Rozm. przeprowadziła E. Gil-Kołakowska, „Ela” 1992, nr 4, s. 2. 
Dziewczyna w „Dziewczynie” [...] nie tyle „ma ciało” (i jeszcze coś oprócz tego), ile sama jest ciałem ${ }^{11}$. [Tego typu - przyp. M.P.S.] czasopisma nie tylko opisują, ale też kreują określoną rzeczywistość, lansują pewien styl życia i myślenia, kształtują postawy wobec świata i ludzi. Niestety, kierują one uwagę i oddziałują głównie na sferę emocjonalną, z pomijaniem intelektualnej, co może budzić obawy o rezultaty ich czytania ${ }^{12}$.

Periodyk dwukrotnie stał się tematem poruszanym na forum sejmowym. Określony został jako „pismo z pogranicza pornografii”; proponowano nawet, by wprowadzić wobec niego rodzaj cenzury. Jednak krytyka ta nie wpłynęła negatywnie na odbiór miesięcznika, a można wręcz stwierdzić, że stało się odwrotnie. W 1993 r. zwiększyła się jego objętość (do średnio 82 stron) oraz nakład (do 500 tys. egz.). Jednocześnie funkcję zastępcy redaktor naczelnej przejęła Ewa Szumowska-Lempart, zaś w stopce redakcyjnej pisma pojawiły się nazwiska osób, tworzących zespół redakcyjny. Wśród nich znalazły się w latach 90. XX w. m.in.: Joanna Dowgiałło ${ }^{13}$, Magdalena Dziemidek, Dagmara Fall, Dominika Gruczek, Beata Łukasiewicz, Katarzyna Lisiecka, Ewa Mierzejewska, Urszula Ososko, Jolanta Rogalska, Danuta Tauer oraz Magdalena Zając. W rok po ukazaniu się pierwszego numeru redakcja pisała:

Kochani, jesteście sensem naszej pracy, dla Was robimy „Dziewczynę”, staramy się, by była coraz ciekawsza, piękniejsza, mądrzejsza, bardziej Wam pomocna w dużych i małych problemach $^{14}$.

Czytelniczki nie pozostawały dłużne:

„Dziewczyna” to marka prawdziwej kobiety - mało tego, to nowy styl życia, to symbol jakości. [...] Jest rewelacyjna! Zachodnia jakość - krajowa cena. Podarowałam sobie odrobinę luksusu ${ }^{15}$.

Zachwyt, jaki wzbudzał magazyn, wypływał być może z intensywnej działalności redakcji: zwiększono liczbę porad, zainicjowano kilka konkursów i akcji (na przykład „Chłopak na plakat”, „Dziewczyna na okładkę”), utworzono „Klub dziewczyny”, a także zaczęto pisać również o polskiej muzyce i drukować materiały związane ściślej z problemami polskich nastolatków. Od początku bardzo istotne dla redakcji były relacje z czytelnikami. Stąd w każdym numerze zamieszczano liczne listy, w których pisali

11 K. Krzysztofek, Erotyzm bez duszy, „Przegląd Tygodniowy” 1993, nr 20, s. 10.

12 J. Szocki, Prasa dla dzieci..., s. 121. Zob. też np. D. Pilot: Bravo Tina, Gut Dziewczyna, „Gazeta Wyborcza” 1993, nr 39, s. 16; [br. aut.], Demoralizacja, ibidem, 1995, nr 139, s. 23.

13 W listopadzie 1998 r. została redaktor naczelną „Filipinki”.

14 „Dziewczyna” 1993, nr 5, s. 56.

${ }^{15}$ K. Mikołajczyk, D. Kozłowska [czytelniczki], Superreklama, „Dziewczyna” 1993, nr 5, s. 56. 
oni o swoich problemach, pytając o rady, chwaląc miesięcznik, komentując teksty, zamieszczone we wcześniejszych jego wydaniach. Redakcja do większości głosów starała się ustosunkować, jednocześnie zachęcając do kontaktów z periodykiem. Autor najciekawszego listu otrzymywał $50 \mathrm{zł}$, a pozostałe wydrukowane głosy nagradzano honorarium $w$ wysokości $10 \mathrm{zł}$.

W 1994 r. firma JMG Marquard ${ }^{16}$, która utworzyła w Polsce filię (JMG Publishing Poland), cofnęła (bez zachowania ustalonego terminu wypowiedzenia) licencję na wydawanie magazynu i przeniosła go do Warszawy. W lipcu obie firmy: Phoenix Intermedia oraz JMG Publishing Poland wydały „Dziewczynę”- pierwsi w stolicy, drudzy we Wrocławiu. Konflikt znalazł swe rozwiązanie w sądzie, gdzie firma Marquarda przegrała proces i jej nakłady tego wydania przejął Phoenix Intermedia.

Jednak ostatecznie Marquard odzyskał własną licencję na tytuł od Phoenix Intermedia ${ }^{17}$. W stopce redakcyjnej jako wydawca pojawił się JMG Magazine Publishing Company, zaś jako właściciel tytułu widniał ZAG Zeitschriften Verlag-AG Zug, Verlagsruppe Jürg Marquard.

Perturbacje własnościowe nie wpłynęły na wysokość nakładu, który nadal utrzymywał się na wysokości 500 tys. egzemplarzy. Podobnie niezmienna pozostawała zawartość każdego numeru (,jak zwykle, kolorowo i zajmująco. Sporo reportaży, trochę astrologii [...], coś dla urody, porady sercowe, wiersze i przystojni chłopcy na plakat"18) i jego objętość, choć forma coraz bardziej upodabniała się do innego popularnego, taniego, wysokonakładowego pisma, jakim był w tamtym okresie „Popcorn”. Od 1995 r. zatrudniono w redakcji „Dziewczyny” dyrektora artystycznego oraz osoby odpowiedzialne za layout pisma: stało się ono jeszcze bardziej kolorowe, zwiększono również liczbę zdjęć. Jednocześnie jego autopromocja osiągnęła apogeum. W jednym z numerów wydrukowano list zachwyconej czytelniczki. Warto go zacytować:

Dzisiaj, jak co dzień, w drodze do szkoły przechodziłam koło kiosku. Wśród stosu kolorowych gazet ujrzałam „Dziewczynę”. Kupiłam ją bez namysłu. Pierwszy miałam język polski i... klasówkę. Tematem wypracowania był: „Wpływ mojego ulubionego czasopisma na mój rozwój intelektualny”. Oczywiście, napisałam o „Dziewczynie”. Trochę z niej ściągałam, ale dostałam piątkę! Poza tym moja praca przekonała do czytania nawet profesorkę! Jesteście super!19

16 Verlagsgruppe Jürg Marquard był w tym czasie wydawcą licznych periodyków w wielu krajach, m.in. „Cosmopolitan”, „Metal Hammer”, „Pop/Rocky” w Niemczech, Szwajcarii i Austrii, a także "Chica Hoy” w Hiszpanii. W Polsce wydawał, poza „Dziewczyną”, także „Narty”, „Nowe Echo”, „Panoramę”, „Popcorn”, dzienniki: „Express Wieczorny”, ,,Sport”.

17 K. Prewęcka, Zmiana wizerunku, „Media i Marketing Polska” 1999, nr 21, s. 19.

18 „Dziewczyna” 1994, nr 11, s. [1]. Tak opisaną zawartość jednego z wydań można odnieść do każdego kolejnego numeru opisywanego miesięcznika.

19 Monika ze Sławkowa [czytelniczka], Superdziewczyna , „Dziewczyna” 1995, nr 2, s. 12. 
Była w tym wyraźna przesada, a nawet pewne zakłamanie, ponieważ na średnio 76 stronach drukowano głównie porady dotyczące uczesania, ubioru, makijażu, mody oraz relacji damsko-męskich. Trudno w nim odnaleźć treści kulturalne, które rozwijałyby intelektualnie czytelniczki, chyba że za taki element uzna się poszerzanie wiedzy dotyczącej działania rumianku lub tego, jak sprawdzić „prawdziwe zamiary” potencjalnego wielbiciela.

Sporadycznie pojawiały się również głosy delikatnie krytyczne, które jednak znajdowały się w zdecydowanej mniejszości, a krytyka w nich zawarta wystawiała nie najlepsze świadectwo bardziej autorce listu niźli periodykowi ${ }^{20}$. Kilkakrotnie pojawiły się oburzone głosy czytelniczek, niezadowolonych ze wzrastającej liczby reklam zamieszczanych w piśmie $^{21}$.

Od 1997 r. nastąpiła zmiana na stanowisku redaktor naczelnej: miesięcznikiem zaczęła kierować Agnieszka Lesiak, którą od numeru 7 w 1997 r. zastąpiła Monika Baran (później jako M. Baran-Finotello).

Kolejne lata to nieznaczne zmiany w strukturze pisma, przy równoczesnym, systematycznym podnoszeniu jego poziomu graficznego. Jednocześnie, obok coraz większej liczby reklam, pojawiały się lepsze pod względem jakości zdjęcia, coraz częściej przedstawiające gwiazdy z rodzimej półki, zwiększono też liczbę konkursów oraz akcji, mających na celu przyciągnąć nowe audytorium i jeszcze bardziej przywiązać do pisma wierne czytelniczki. Systematycznie drukowano ankiety, które miały pomóc redakcji w przygotowaniu magazynu, dostosowując go do oczekiwań odbiorców. Redakcja chwaliła się, że periodyk jest najpopularniejszym tytułem wśród dziewcząt w wieku 15-19 lat22 i jednocześnie przyznawała:

Chcemy pomagać, doradzać, ale nie wymądrzać się. Chcemy, by nasza „Dziewczyna” była taka, jak nasze Czytelniczki. By stała się ich najlepszą przyjaciółką23.

Pomimo niezaprzeczalnej popularności, jaką się cieszył, jednak i ten magazyn odczuł kryzys, który w drugiej połowie lat 90. XX w. dotknął segment prasy młodzieżowej: w 1998 r. po pismo sięgało 5,1\% badanych, w 1999 r. liczba ta zmniejszyła się do 2,8\%24.

Na początku 1999 r. redaktor naczelną została Monika Piasecka. Pod koniec tegoż roku koncern J. Marquarda sprzedał tytuł niemieckiemu wydawcy. Od stycznia 2000 r. „Dziewczyna” zadebiutowała pod szyldem

20 Zob. np. Mysza z Gdyni [czytelniczka], Znudzona, „Dziewczyna” 1995, nr 1, s. 14. Naturalnie należy dopuścić tu możliwość, iż takie działania były manipulacją redakcji.

21 Zob. np. „Dziewczyna” 1995, nr 9, s. 76; nr 11, s. [49].

${ }^{22}$ Reklama magazynu: „Media Polska” 1998, nr 2, s. [21].

23 Ibidem.

24 Za: K. Prewęcka, Zmiana wizerunku, „Media i Marketing Polska” 1999, nr 21, s. 19. 
nowego właściciela, którym został Axel Springer Polska, choć jego nazwa pojawiła się w stopce redakcyjnej od wydania lutowego. Redakcja magazynu przeniosła się do nowej siedziby (Al. Jerozolimskie 181).

Na początku nowego wieku sytuacja miesięcznika była ustabilizowana, nadal był jednym z najpopularniejszych periodyków młodzieżowych, choć jego nakład i sprzedaż nie były już tak wysokie jak na początku: w I kwartale 2001 r. średnia sprzedaż wynosiła 179110 egzemplarzy25. W tym czasie powstał pierwszy fanklub „Dziewczyny”, założony przez czytelniczki z Gdańska, które spotykały się raz w tygodniu, w środę, i rozmawiały na tematy poruszane na łamach magazynu ${ }^{26}$.

Wydawca inwestował $\mathrm{w}$ rozwój miesięcznika. I tak na przykład w połowie stycznia 2002 r. uruchomiono stronę internetową pisma (www. dziewczyna.pl). W serwisie pojawiło się m.in. forum dla czytelniczek, kącik informacyjny dotyczący życia gwiazd, sondy oraz liczne konkursy. Od wydania lutowego w 2002 r. „Dziewczyna” zmieniła zawartość merytoryczną, a także zmodyfikowała układ graficzny i zaproponowała czytelnikom nowe logo magazynu. Wprowadzono bardziej stonowaną kolorystykę, nowe rubryki (na przykład Fitness, Odżywianie), zwiększono powierzchnię, przeznaczoną na listy, porady, a także nowinki kulinarne, rozszerzono również rubryki zawierające informacje kulturalne. Redaktor naczelna przyznała, że zmiany spowodowała rosnąca konkurencja w segmencie pism młodzieżowych, „Musimy więc być czujni i stale uatrakcyjniać pismo, by zatrzymać regularne i przyciągać nowe czytelniczki"27. Temu celowi służyły też coraz częściej dołączane do magazynu gadżety. Na przykład do wydania październikowego i listopadowego w 2002 r. zaproponowano czytelnikom, przygotowane wspólnie z reklamodawcami, małe, kolorowe książeczki o urodzie. Dzięki tym zabiegom magazyn nadal był niezwykle popularny wśród nastolatek. Zawdzięczał to $\mathrm{w}$ dużej mierze nowoczesnej szacie graficznej, tematyce odpowiadającej gustom ówczesnych dziewcząt, cyklicznym konkursom, a także wydawanym w tym czasie dodatkom specjalnym (jak choćby letnie wydanie Lato \& Luz czy Dziewczyna poleca). Dużą popularnością cieszyły się również płyty CD z muzyką „Dziewczyny”. Nakład pisma, jakkolwiek niższy, utrzymywał się na stałym poziomie (w latach 2002-2004 jego średnia sprzedaż wynosiła ok. 131 tys. egzemplarzy $\left.{ }^{28}\right)$.

Pod koniec 2002 r. redaktor naczelną magazynu została (pełniąca dotychczas funkcję zastępcy) Donata Cieślik. Kolejne zmiany w formule

25 „Press” 2001, nr 7, s. 68.

26 Warto zauważyć zbieżność z podobną inicjatywą, związaną z wcześniej omawianym czasopismem, „Filipinką”.

27 [br. aut.], Dziewczyna chce zmian, „Media i Marketing Polska” 2002, nr 3, s. 22.

28 Źródło: Związek Kontroli Dystrybucji Prasy. 
periodyku wprowadzono od numeru 4 (2004): ponownie zmodyfikowano jego układ i grafikę. Jakkolwiek zawartość pisma w dalszym ciągu wzbudzała kontrowersje, to jednak były one mniejsze niż na początku. Wynikało to w znacznej mierze z faktu, że to, co szokowało w latach 90. XX w., przestało gorszyć kilka lat później. Jednocześnie wzrosła liczba periodyków młodzieżowych, które w swej formie i zawartości były bardzo podobne do „Dziewczyny", tworząc wraz z nią grupę popularnych, wysokonakładowych, kolorowych magazynów, w których zdjęcia i rysunek przeważały nad treścią, a i ta była powierzchowna, niosąc ze sobą głównie informacje nierzadko ocierające się o sensację, związane z życiem gwiazd i celebrytów, oferując porady z dziedzin, które, według redakcji, najbardziej interesowały współczesną młodzież. W ostatnim badanym roku nakład pisma wzrósł, wynosząc 212 tys. egzemplarzy, z czego sprzedawano ok. 150 tys. ${ }^{29} \mathrm{~W}$ tym czasie sukces wydawniczy miesięcznika był w dużej mierze efektem polityki wydawniczej, realizującego ją zespołu redakcyjnego oraz stałych współpracowników. W czasie objętym analizą znaleźli się wśród nich m.in.: Barbara Bartel, Sławomir Belina, Joanna Chatizow, Iwona Chodorowska-Zadros, Piotr Czerwiński, Joanna Germak, Magdalena Impert, Beata Łukasiewicz, Ewa Mościcka, Sylwia Orłowska, Milena Pawlak, Beata Przybyszewska-Kujawa, Anna Rędzio, Ola Rudzińska, Diana Rymuza, Maciej Śnieżek, Magdalena Więch, Paulina Wieczorek i Małgorzata Żebrowska-Piotrak.

\subsubsection{Zawartość, czytelnicy, akcje}

Na początku lat 90. młodzieżowe magazyny na niemieckich licencjach szokowały. Rodzice byli przyzwyczajeni do modelu prasy adresowanej do czterech poziomów rozwojowych uzależnionych od wieku dzieci. „Miś”, „Świerszczyk”, „Płomyczek” i „Płomyk” korespondowały z programem nauczania w szkołach. Kiedy więc zamiast tego pojawiły się magazyny o gwiazdach, z opowieściami o randkowaniu, makijażu i ciuchach, bez najmniejszego elementu edukacyjnego - chyba że z dziedziny erotyki - musiały wywoływać ogromne kontrowersje. [...] Ośrodek Badań Prasoznawczych Uniwersytetu Jagiellońskiego nazwał je kalkami (kopiami) i miał wiele racji w takiej ocenie. Praktycznie w całości były to po prostu polskie tłumaczenia niemieckich oryginałów, co najwyżej spolszczano imiona i miejsca zamieszkania bohaterów fotostory czy listów do redakcji. Dopiero po jakimś czasie doszła polska muzyka i filmy. Mimo to nastolatki uwielbiały magazyny dla młodzieży30.

W przytoczoną charakterystykę wpisywał się w pełni magazyn „Dziewczyna"; można zaryzykować stwierdzenie, że był on jednym z pierwszych, które wprowadziły modę na kolorowe młodzieżowe pisma „obrazkowe”.

${ }^{29}$ Za: T. Mielczarek, Monopol, pluralizm, koncentracja. Środki komunikowania masowego w Polsce w latach 1989-2006, Wydawnictwa Akademickie i Profesjonalne, Warszawa 2007, s. 198-199.

${ }^{30}$ www.prasa.reproterzy.pl, październik 2010. 
Zawartość pierwszego numeru wskazywała na charakter przyszłego periodyku, na którą składały się m.in. następujące działy, i poruszane w nich tematy: Baw się razem z nami (film, plakat, fotostory, nowelka), Eros i Psyche (Twój sposób na niego), Fakty i fakciki (Plotki o gwiazdach, Pop news, Posłuchajcie dziewczyny), Kontakty (Zapytaj Gabi), Moda (Nocny styl, Miłość do dżinsu), Uroda (Makijaż: słodkie kolory, Nowe fryzury prosto z Hollywood). Dużą popularnością cieszyła się rubryka Posłuchajcie dziewczyny, w której drukowano wybrane historie czytelników. Redakcja zachęcała, by opisywali oni zdarzenie, które im się przytrafiło, a które wywarło wpływ na ich życie; drukowane historie często opowiadały o miłości: szczęśliwej, i tej, która złamała serce bohatera. Autor wybranego tekstu otrzymywał honorarium wysokości 70 zł. Już w pierwszym numerze pojawiła się opowieść Sandry Erdmann z Bielefeld31; lead dobrze spełnił swą funkcję: „Miałam dopiero 15 lat, on 21 lat. Mimo wszelkich oporów kochaliśmy się - i zamieszkaliśmy razem. Czy naprawdę podjęliśmy słuszną decyzję?"32. Rubryka budziła wiele emocji, ale pojawiały się również głosy krytyczne. $\mathrm{W}$ jednym z listów poddano $\mathrm{w}$ wątpliwość prawdziwość przysyłanych historii: „Z pewnością dostajecie dużo opowiadań do >Posłuchajcie dziewczyny<, nic dziwnego - 70 zł! Oszaleliście! Większość ludzi je zmyśla i wysyła dla kasy. Wiemy to na własnym przykładzie"33.

Dużą popularnością cieszyła się również rubryka porad, w różnym czasie rozmaicie tytułowana, np. Zapytaj Gabi, Zapytaj Gośkę... W 1998 r. pojawiła się Półka z książkami. W tym czasie proporcje pomiędzy informacjami na temat gwiazd polskich i zagranicznych były już niemal równe: donoszono zarówno o tym, co słychać u Alici Silverstone, jakie są sposoby na blondynki według Gwyneth Paltrow, jak i przeprowadzano wywiady na przykład z Robertem Gawlińskim, Edytą Górniak czy Kasią Kowalską. Zwiększono liczbę tekstów, dotyczących relacji damsko-męskich, pojawiało się coraz więcej porad, dotyczących „udanego związku”, na przykład „Jak się z nim kłócić... ale nadal lubić?”, opisano „Dekalog Wielkiej Kusicielki”, radzono „Zanim się z nim umówisz... sprawdź czy warto!” [pis. oryg.].

Od numeru styczniowego w 1999 r. zmieniła się formuła periodyku, a wraz z nią nazwy działów i rubryk, choć tematyka poruszana na jego łamach pozostała niemal nie zmieniona. Teraz czytelnicy mieli do dyspozycji takie działy, jak: Baw się z nami!, Dziewczyna i chłopak, Dziewczyny takie

31 W tym czasie, o czym wcześniej wspomniano, zawartość periodyku składała się niemal w całości z przedruków tekstów, zawartych w niemieckiej wersji pisma. Znamienne jest to, że w stopce redakcyjnej magazynu w tym okresie poza nazwiskami redaktor naczelnej, jej zastępcy oraz danymi dotyczącymi redaktora technicznego pojawiał się zespół redakcyjny, który był w znacznym stopniu zespołem tłumaczy.

32 „Dziewczyna” 1991, nr 1, s. [72].

33 „Dziewczyna” 1995, nr 9, s. 76. 
jak ty, Idole, gwiazdy, hity, Moda, Temat miesiąca, Uroda, a niekiedy drukowano również reportaż. Elementem uzupełniającym zawartość pisma były plakaty z popularnymi gwiazdami ze świata filmu i muzyki, a także przedstawiające modeli.

Ponowne zmiany w strukturze magazynu pojawiły się, jak już wcześniej wspomniano, w drugim badanym roczniku: od numeru drugiego (2002) redakcja pisała:

Oddajemy w Wasze ręce nową, świeżutką, odmienioną „Dziewczynę”. Wychodząc naprzeciw Waszym oczekiwaniom poszerzyliśmy ją o kilka odjazdowych rubryk. Jesteśmy podekscytowane, bo „Dziewczyna” wygląda tak...inaczej! Nówka sztuka! [...] Mamy nadzieję, że się Wam spodobają rewolucje w gazecie i „Dziewczyna” pozostanie Waszą bardzo dobrą przyjaciółką ${ }^{34}$.

Owe „odjazdowe rubryki” zmieniły swoje nazwy, czytelnicy mogli wybierać pomiędzy: Beaty \& co (pielęgnacja, na przykład tłusta cera - twoja zmora?), Chwila dla Ciebie (m.in. wróżby, fotostory), Emocje (poruszano w tym miejscu tematy tabu, na przykład pisano o homoseksualizmie) Ona i on, Taka jak ty [pis,. oryg] (pytania intymne), To się nosi oraz Wielki świat (plotki, na topie). Struktura działów pozostawała w takiej formie do końca badanego okresu, modyfikowano jedynie wybrane rubryki, w tym poświęconą sprawom książki. Od numeru 3 w 2004 r. zmieniono nieco formę graficzną periodyku. Odtąd niemal każdy numer w 2005 r. otwierał aforyzm, przeważnie związany z miłością (na przykład „Kropla miłości znaczy więcej niż ocean rozumu”, Blaise Pascal; „Kobieta jest najsłabsza, gdy kocha, a najsilniejsza, gdy jest kochana", Gabriela Zapolska).

Do większości wydań dołączano „prezenty”, głównie kosmetyki lub biżuterię. Systematycznie rozbudowywano stronę internetową pisma, na której pojawił się m.in. spis zawartości numerów archiwalnych magazynu z lat 2001-2004, konkursy, a także linki, odsyłające do wybranych przez redakcję stron.

W porównaniu z wcześniej omówionym periodykiem, „Filipinką”, „Dziewczyna” nie zmieniała tak często swej formy, jednocześnie przez cały czas pozostając $\mathrm{w}$ zasadzie wierna tym samym założeniom. Magazyn, wydawany na licencji, sprawdzony w wielu innych krajach, praktycznie nie wymagał transformacji, co było konsekwencją faktu, że to właśnie do takich magazynów-„,kalek”, jak „Dziewczyna”, pozostałe pisma młodzieżowe w Polsce musiały się dostosować, a nie na odwrót.

W magazynie, w każdym okresie jego historii odnaleźć można było „pomysły na odlotowe fryzury”, „miks kolorowych ciuchów”, „wielki świat”,

34 „Dziewczyna” 2002, nr 2, s. [3]. 
odpowiedzi na „pytania intymne” i rady, jak wygrać „wojnę płci”. Jednocześnie redakcja obiecywała: „robić wszystko, by >Dziewczyna< była coraz ładniejsza i coraz ciekawsza. Chcemy, żeby każdy numer był przez Was oczekiwany z niecierpliwością!"35

Temu celowi służyły także liczne konkursy i akcje, inicjowane przez miesięcznik. Większość z nich miała podobny charakter, wpisując się $\mathrm{w}$ formułę pisma, nawiązywała bowiem przeważnie do spraw związanych $\mathrm{z}$ modą i urodą.

Jednym z pierwszych był konkurs Dziewczyna na okładkę, organizowany od 1991 r. Jego sponsorem była agencja modelek „Mega Models” z Hamburga. Czytelniczki zapraszano do wypełnienia załączonego do danego numeru magazynu kuponu, a następnie wybrane zapraszano na sesję zdjęciową, w czasie której wyłaniano finalistki. Dla laureatki przewidywano stypendium oraz pobyt $\mathrm{w}$ Hamburgu wraz z sesją zdjęciową ${ }^{36}$. Podobny charakter miał konkurs Dziewczyna „Dziewczyny”, organizowany wraz $\mathrm{z}$ jedną z agencji modelek (w poszczególnych latach byli to różni partnerzy), w którym spośród przysłanych przez czytelniczki zdjęć, jury wybierało Dziewczynę Miesiąca. I tu nagrodą dla laureatki była m.in. profesjonalna sesja zdjęciowa, sprzęt muzyczny oraz kosmetyki. Konkurs trwał przez 12 miesięcy, po których wybierano Dziewczynę Roku ${ }^{37}$. Kolejna inicjatywa, tym razem organizowana wespół z jednym z producentów kosmetyków, opierała się na podobnych zasadach: wypełnienie załączonego kuponu, dołączenie doń swojego zdjęcia, etapy (krajowy i zagraniczny), finał w Niemczech, nagroda - kontrakt z firmą sponsorującą konkurs. Organizowano również (wspólnie z Bankiem Twarzy) akcję Serialowa Dziewczyna, w której zadaniem czytelniczek było napisanie dalszego ciągu telewizyjnego serialu M jak miłość. Spośród wszystkich nadesłanych „scenariuszy” jury przyznawało nagrody, wśród których pierwszą był udział w jednym z epizodów w filmie, drugą - przygotowanie przez profesjonalistów portfolio; przewidziano także liczne nagrody pocieszenia.

Innym pomysłem był konkurs Bazarek Dziewczyny, w ramach którego proponowano różnorakie konkursy, na przykład zadaniem czytelniczek było zaprojektowanie wymarzonej, oryginalnej, a zarazem odważnej kreacji, zgodnej z aktualnymi trendami ${ }^{38}$, opisanie pomysłu na ciekawą imprezę, zorganizowaną na świeżym powietrzu ${ }^{39}$.

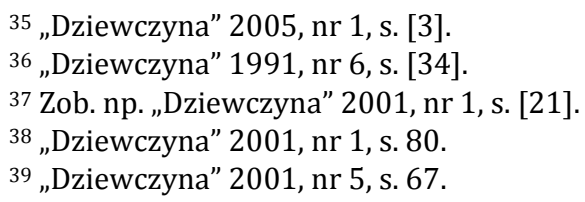


Inicjowano również rozmaite akcje jak na przykład Chłopak od Serca. Chętni czytelnicy, prezentujący silniejszą płeć, przysyłali do redakcji swoje zgłoszenia: zdjęcie wraz z krótką charakterystyką (znak zodiaku, hobby, odpowiedź na pytanie: co mi się podoba u dziewcząt?, ewentualnie wykonywany zawód) oraz adresem do korespondencji. Redakcja miała nadzieję, że „akcja serduszko” pomoże nawiązać pomiędzy czytelnikami przyjaźń, a może i miłość ${ }^{40}$. Przedsięwzięcie, zainicjowane w pierwszym numerze w 1993 r., kontynuowano w kolejnych wydaniach, proponując przysyłanie zgłoszeń także czytelniczkom. Innym pomysłem była akcja Chłopak na plakat. Spośród prezentowanych na łamach magazynu mężczyzn, czytelniczki wybierały jednego i oddawały nań swój głos na załączonym do danego numeru kuponie. Wybraniec zapraszany był na sesję zdjęciową, stając się jednocześnie bohaterem plakatu, zamieszczanego w piśmie ${ }^{41}$.

Miesięcznik wydawał również wspomnianą już płytę CD (wcześniej także kasetę magnetofonową) z muzyką disco i pop, zatytułowaną Mega pop-dance Dziewczyna. Kolejne edycje ukazywały się w okresie letnim, zawierały składankę popularnych przebojów.

Te oraz inne konkursy i akcje, systematyczne i jednorazowe, wpisywały się w charakter omawianego magazynu, co więcej, odpowiadały gustom czytelników pisma, adresowanego do nieco starszej grupy odbiorców niż „Filipinka”. „Dziewczyna” kierowana była do młodzieży szkolnej w wieku 15-19 lat. Propagowała określony wizerunek nowoczesnych nastolatek, $\mathrm{w}$ pewnym sensie rządząc ich gustami ${ }^{42}$. Zawartość tytułu w pełni odpowiadała „prasie obrazkowej” tamtego okresu. Jak pisał Jerzy Jarowiecki, „pismom tym [...] zarzuca się dominację formy nad treścią, lansowanie wątków erotycznych, brak refleksji nad prawdziwymi uczuciami"43. Periodyki tego typu przemawiały przede wszystkim przekazem wizualnym, nie zaś słownym. Brakowało w nich elementów edukacyjnych, widocznych chociażby na łamach „Filipinki”. Jak stwierdził jeden z autorów tygodnika "Polityka": „>Dziewczyna< nic nie daje, tylko schlebia i przytakuje"44.

Miesięcznik ten starał się, choć w szczątkowej formie, prezentować także informacje związane z szeroko pojętą kulturą. W większości dotyczyły one świata muzyki i filmu, jednak wyodrębniono również oddzielną rubrykę poświęconą książce.

40 Zob. np. „Dziewczyna” 1993, nr 1, s. 16.

41 Zob. np. „Dziewczyna” 1994, nr 12, s. [8].

42 Zob. np. P. T. Nowakowski, Modele człowieka propagowane $w$ wybranych czasopismach młodzieżowych. Analiza antropologiczno-etyczna, Maternus Media, Tychy 2002, s. 166-168; D. Pauluk, A. Sojka, Wizerunek nowoczesnej dziewczyny na łamach czasopism młodzieżowych wobec chrześcijańskiego ideału kobiety, Wydawnictwo Uniwersytetu Jagiellońskiego, Kraków 2009, s. 188-196.

43 J. Jarowiecki, za: http://wkajt.republika.pl/anapi/roz1.htm, październik 2010.

44 „Polityka” 1995, nr 9, s. 28. 
Należy jednak już w tym miejscu zasygnalizować, że podstawowa forma informacji o literaturze, czyli recenzja wybranych lektur, prezentowana była w dużej części w charakterystyczny dla periodyku sposób: zwięzły i powierzchowny. Lapidarne $\mathrm{w}$ swej formie wzmianki miały niewiele wspólnego z definicją recenzji, w której powinny pojawić się trzy podstawowe elementy: informacja, komentarz i ocena. Lakoniczne opisy treści proponowanej książki, jednowyrazowa ocena i brak jej uzasadnienia oraz rzetelnej analizy danego tytułu to dominujące cechy owych omówień. Pojawiały się jednak także prezentacje książek, które zasługiwały na miano recenzji, stąd, podobnie jak było to w przypadku miesięcznika „Filipinka”, i tu zdecydowano się przedstawić je w jednej grupie, jako recenzje, omówienia i streszczenia, zaliczając do tej grupy także zbliżone do recenzji formy prezentacji książki.

\subsubsection{Batman zamiast Sienkiewicza ${ }^{45}$ : książka na łamach pisma}

Opisany powyżej charakter periodyku wpływał także na stopień zainteresowania redakcji tematykę literacką. Był on niewielki, szczególnie w kontekście liczby informacji związanych z innymi zagadnieniami, składającymi się na problematykę kulturalną, poruszaną w magazynie. Kwestie związane z muzyką i filmem jakkolwiek były, podobnie jak te dotyczące książki, prezentowane $\mathrm{w}$ postaci minimalnych informacji prasowych, zapowiedzi, niewielkich objętościowo recenzji, to jednak znacznie przewyższały pod względem ilościowym podobne formy nawiązujące do spraw dotyczących literatury.

Dział kulturalny zajmował przez cały badany okres średnio 4 strony w ostatniej części pisma ${ }^{46}$. Od numeru 1 (2001) do wydania styczniowego włącznie w roku następnym nosił tytuł Idole, gwiazdy, hity, zaś rubrykę, w której zamieszczano także informacje związane z książką, nazwano $\mathrm{Na}$ topie: muzyka, kino, wideo, ksiq̨żkit7. Drukowano w niej, obok informacji dotyczących filmu, także omówienia (od 1 do $3^{48}$ ). Jedna z nich anonsowana była w trzech pierwszych numerach jako Fajna lekturka. W kolejnych wydaniach zrezygnowano z tej zapowiedzi, drukując recenzje książek obok

45 Tytuł jednej z publikacji, zob. „Dziewczyna” 2002, nr 6, s. [22]-[23].

46 Jakkolwiek nazwa działu i jego forma nie ulegały tak częstym zmianom, jak było to w przypadku „Filipinki”, postanowiono jednak, zachowując konsekwencję w obrębie opisywanej prasy młodzieżowej, omówić w tym miejscu modyfikacje związane z tą częścią periodyku. W podrozdziale zdecydowano się na zamieszczenie bardziej szczegółowych informacji, w oparciu o przywołane przykłady.

47 Nazwa działu pojawiała się w podanej formie w spisie treści, natomiast wewnątrz numeru ograniczano się do podania częściowej nazwy rubryki (Na topie).

48 Dane odnoszą się do recenzji odredakcyjnych. 
omówień filmów (pojawiających się w obrębie oddzielnego modułu jako Kino $w$ domu).

W numerze 2 (2002) nazwę działu zmieniono na Wielki świat, pozostawiając wcześniejszą nazwę rubryki ${ }^{49}$, modyfikując jednak jej formę graficzną. Obok informacji związanych z filmem, pojawiły się recenzje (od 5 do 7): cztery z nich anonsowano pytaniem: Co czytaja dorośli?, jedną drukowano bez wprowadzającej zapowiedzi. Do numeru 5 (2002) włącznie dodatkowo pojawiała się krótka opinia znanej osoby na temat wybranej przez nią lektury (Do poduchy). Od wydania czerwcowego zarzucono jednak tę formę promocji, i odtąd aż do numeru $3 \mathrm{w} 2004$ r., poza niewielkimi modyfikacjami ${ }^{50}$, strona poświęcona m.in. prezentacji książek pozostawała niezmienna.

W wydaniu marcowym (2004), pozostawiając tę samą nazwę działu51, zmodyfikowano formę prezentacji jego zawartości. Pod tytułem zapowiadającym informacje dotyczące filmu i książki jednorazowo pojawiło się hasło Musisz to mieć!, w odniesieniu do jednej z proponowanych książek, natomiast pozostałe cztery omówienia wydrukowano tym razem bez dotychczasowego wskazania na to, Co czytaja dorośli? W jego miejsce, od kolejnego, kwietniowego numeru, pojawił się tytuł $Z$ górnej półki. Zamieszczano tu nadal cztery recenzje, obok których pojawiało się dodatkowo jeszcze jedno omówienie. Taka postać interesującej nas rubryki utrzymała się do wydania styczniowego w 2005 r. Numer lutowy przyniósł ostatnią w badanym okresie zmianę. Informacje kulturalne $\mathrm{w}$ dalszym ciągu zamieszczano w dziale Wielki świat, w rubryce Na topie: Filmy, książki [nazwy, które pojawiały się w spisie treści], wewnątrz numeru występujące pod tytułem Na topie: Kino \& DVD \& Ksiqzżki, ale recenzje otrzymały dodatkowy podtytuł: prezentowano je odtąd jako Nowości książkowe. Nadal przedstawiano pięć książek.

Podobnie, jak wiele innych informacji drukowanych na łamach pisma, także i te odnoszące się do książek nie były bezpośrednio podpisywane. Jednak na stronie pojawiała się informacja dotycząca osoby, która je przygotowała. W 2001 r. można odnaleźć inicjały („em”), w następnym roczniku obok nich pojawiało się sporadycznie imię "Aśka” [Joanna Chati-

${ }^{49} \mathrm{~W}$ spisie treści rubryka widniała pod nazwą: Na topie: Kino, wideo, ksiqż̇ki, niekiedy oddzielnie pojawiało się Na topie: Muzyka. Wewnątrz numeru strona, na której drukowano recenzje książek, nosiła tytuł Wideo, książki.

50 Modyfikacje polegały na częściowej zmianie (od numeru grudniowego w 2002 r.) nazwy rubryki wewnątrz numeru. Pojawił się tytuł: DVD, książki, natomiast ze spisu treści zniknęła zapowiedź dotycząca książek. Zmieniało się również rozmieszczenie omówień na stronie.

$51 \mathrm{~W}$ spisie treści powróciła zapowiedź książek, anonsowana wspólnie z filmem ( $\mathrm{Na}$ topie: Filmy, książki), natomiast wewnątrz numeru strona rozpoznawalna była jako Na topie DVD \& książki. Od numeru 5 w 2004 r. nazwę rubryki poszerzono, i odtąd brzmiała ona: $N a$ topie: Kino \& DVD\& Książki. 
zow] lub samodzielnie „Dona” [Donata Cieślik] i „Sylwia” [Sylwia Tukendorf-Ceglarska], od numeru 10 (2002) dołączyła do nich „Magda” [Magdalena Więch?, Magdalena Wilmann?], która do numeru wrześniowego w 2003 r. podpisywała się już jako jedna osoba, przygotowująca dane informacje. W kolejnych wydaniach zastąpili ją „Maciek”52 (październik 2003 r., 12 następnych numerów w 2004 r. oraz numery 1-12 w 2005 r.) [Maciej Śnieżek] oraz „Arturio” (grudzień 2003 r.), „arti” (numer 13 w 2004 r.).

Podobnie, jak było to w przypadku „Filipinki”, tak i tu przeważającą formą informacji o książce były ich omówienia. Jednakże poza nimi odnaleźć można także inne kategorie obejmujące interesującą nas problematykę. Ich liczbę zaprezentowano w tabeli 65.

Tabela 65. Formy obecności książki i informacji o niej na łamach „Dziewczyny” w latach 2001-2005

\begin{tabular}{|l|c|}
\hline \multicolumn{1}{|c|}{ Rodzaj informacji } & Liczba ogółem \\
\hline Recenzje, omówienia, streszczenia & $268^{a}$ \\
\hline Wywiady & brak \\
\hline Reklamy książek & 173 \\
\hline Sylwetki/portrety & 7 \\
\hline Artykuły, poświęcone sprawom książki & 3 \\
\hline Ekranizacje, adaptacje, inscenizacje znanych dzieł & 35 \\
\hline Konkursy i akcje & 22 \\
\hline Listy bestsellerów & 11 \\
\hline Listy czytelników, nawiązujące do informacji związanej z książką & 4 \\
\hline Inne $b$ & 166 \\
\hline Ogółem & 689 \\
\hline
\end{tabular}

${ }^{a} \mathrm{~W}$ tej liczbie podano wyłącznie recenzje odredakcyjne. Poza nimi, na łamach pisma pojawiły się kilkakrotnie opinie znanych osób na temat wybranych przez nich książek, zamieszczane w ramach sporadycznie pojawiającego się cyklu Co czytaja gwiazdy? (np. 2001, nr 1), lub podobnego w swej formule cyklu Do poduchy (np. 2002, nr 5, s. [75]), Co czyta... (np. 2003, nr 1). Zostały one przedstawione w dalszej części rozdziału (podrozdz. Wiedźmin czy Winicjusz? Inne formy informacji o książce).

${ }^{b}$ Do kategorii Inne zaliczono $\mathrm{w}$ tym przypadku aforyzmy, opowiadanie, minikomiks oraz fotostory, drukowane na łamach magazynu, a także kilkuzdaniowe wzmianki, nawiązujące do problematyki, dotyczącej spraw książki.

Źródło: badania własne.

Najbardziej zaskakujący wydaje się być brak wywiadów z pisarzami lub innymi osobami, związanymi chociażby pośrednio z literaturą. Interesujące są także dane dotyczące liczby portretów twórców i tekstów, poświęconych

52 Od wydania majowego w 2005 r. zaczęto zamieszczać jego zdjęcie, ujawniając przy okazji nazwisko (Śnieżek). Odtąd czytelniczki pisma swoje uwagi na temat rubryki mogły kierować bezpośrednio do niego, na podany adres e-mailowy. 
problematyce literackiej lub wydawniczej. W pierwszym przypadku w trakcie 5 lat zaledwie siedmiokrotnie zaprezentowano sylwetkę osoby związanej (zresztą w sposób pośredni) z książką. Natomiast tylko trzykrotnie pojawiła się publikacja, którą można zaliczyć do grupy tekstów nawiązujących do zawartego w tytule książki tematu.

Liczby te stają się szczególnie znamienne w kontekście znacznie ich przewyższających pod względem ilości analogicznych publikacji, prezentujących inne zagadnienia, zaliczane przez redakcję do kulturalnych. Bohaterami wielu portretów byli aktorzy i piosenkarze, zaś kwestie związane z modą, relacjami damsko-męskimi zdominowały większość artykułów, drukowanych na łamach opisywanego periodyku.

W takim świetle stosunkowo duża liczba recenzji, omówień i streszczeń książek wydaje się nabierać szczególnego znaczenia, aczkolwiek należy pamiętać o podanym wcześniej zastrzeżeniu dotyczącym tej formy informacji.

\subsubsection{Proste życie ${ }^{53}$ : miejsce recenzji w układzie pisma}

W badanym okresie na łamach „Dziewczyny” ukazało się 268 recenzji, omówień i streszczeń książek. W tabeli 66 przedstawiono ich liczbę w poszczególnych latach.

Tabela 66. Recenzje, omówienia i streszczenia książek zamieszczane na łamach „Dziewczyny” w latach 2001-2005

\begin{tabular}{|c|c|}
\hline Rok & $\begin{array}{c}\text { Liczba recenzji, omówień } \\
\text { i streszczeń }\end{array}$ \\
\hline 2001 & 17 \\
\hline 2002 & 64 \\
\hline 2003 & 62 \\
\hline 2004 & 65 \\
\hline 2005 & 60 \\
\hline Ogółem & 268 \\
\hline
\end{tabular}

Źródło: badania własne.

Największa dysproporcja w liczbie omówień książek wystąpiła pomiędzy pierwszym a pozostałymi badanymi rocznikami. W 2001 r. liczba recenzji była niemal czterokrotnie mniejsza niż w roku następnym. Fakt ten wiązał się przede wszystkim ze zwiększeniem systematyczności zamieszczania tej formy informacji o książce $\mathrm{w}$ roku następnym. Zmiana postaci rubryki recenzyjnej wpłynęła wyraźnie na wzrost liczby prezentowanej $\mathrm{w}$ niej lektur. Pierwsze zmiany $\mathrm{w}$ tym zakresie prezentują wybrane przykłady (zdjęcie 170-173).

53 Tytuł jednej z recenzji, zob. „Dziewczyna” 2004, nr 6, s. [83]. 


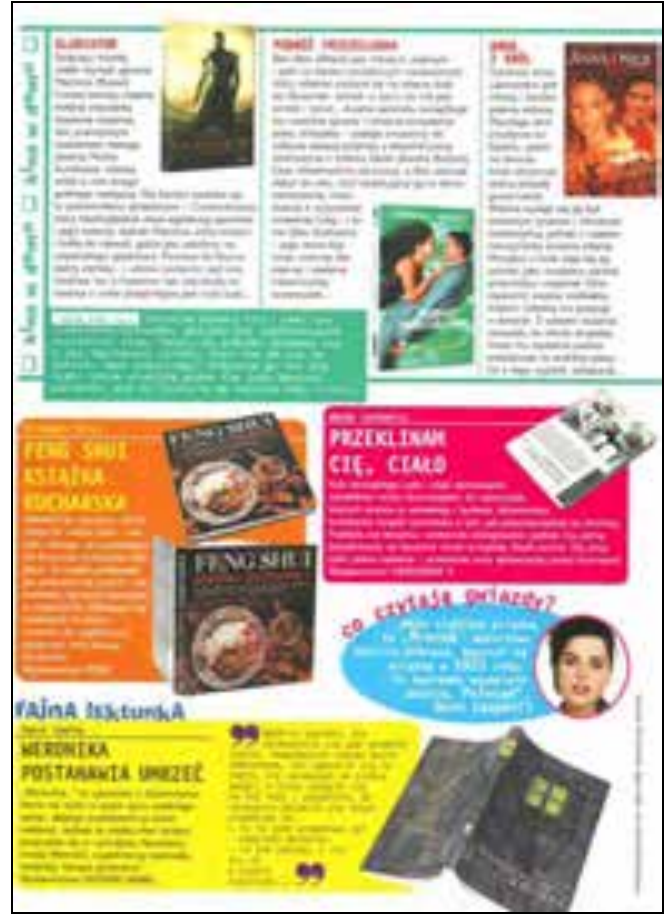

Zdjęcie 170. Przykładowa strona recenzyjna na łamach "Dziewczyny” „Dziewczyna” 2001, nr 2, s. [69]

Zdjęcie 171. Przykładowa strona recenzyjna na łamach „Dziewczyny” „Dziewczyna” 2001, nr 8, s. [69]

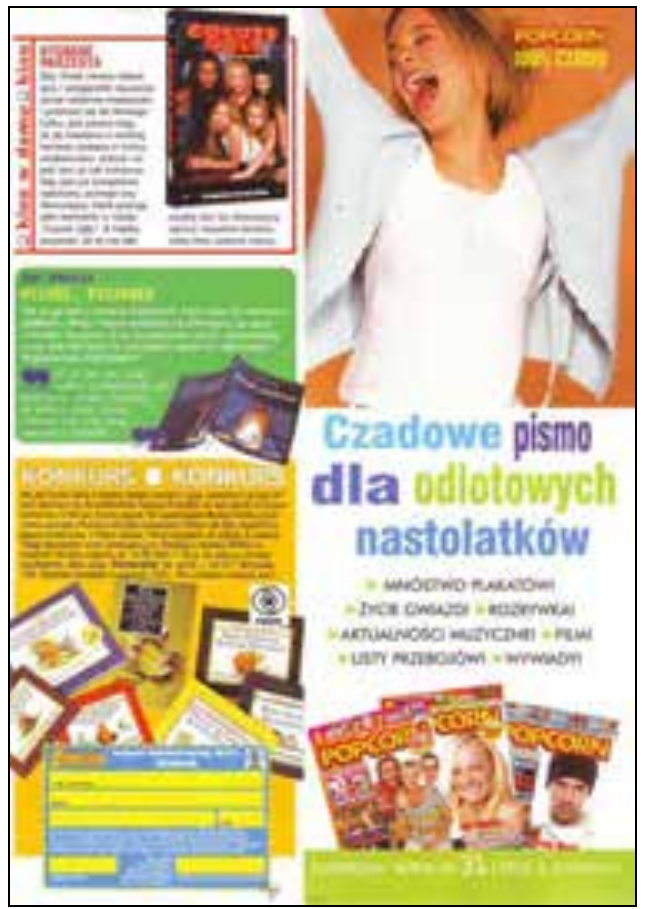




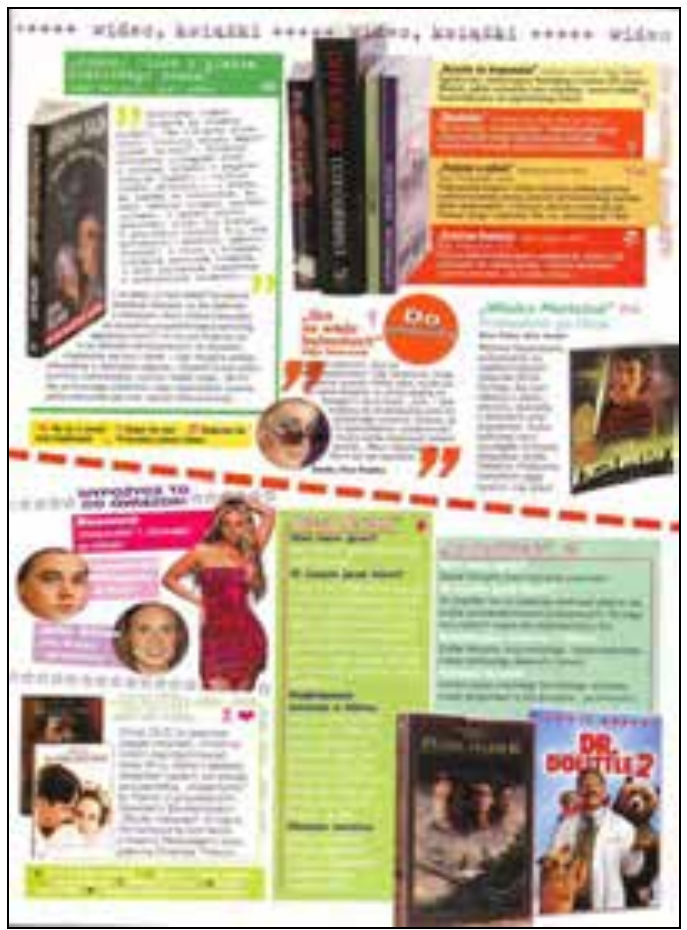

Zdjęcie 172. Przykładowa strona recenzyjna na łamach „Dziewczyny”

„Dziewczyna” 2002, nr 3, s. [77]

Zdjęcie 173. Przykładowa strona recenzyjna na łamach „Dziewczyny” „Dziewczyna” 2003, nr 11, s. 83

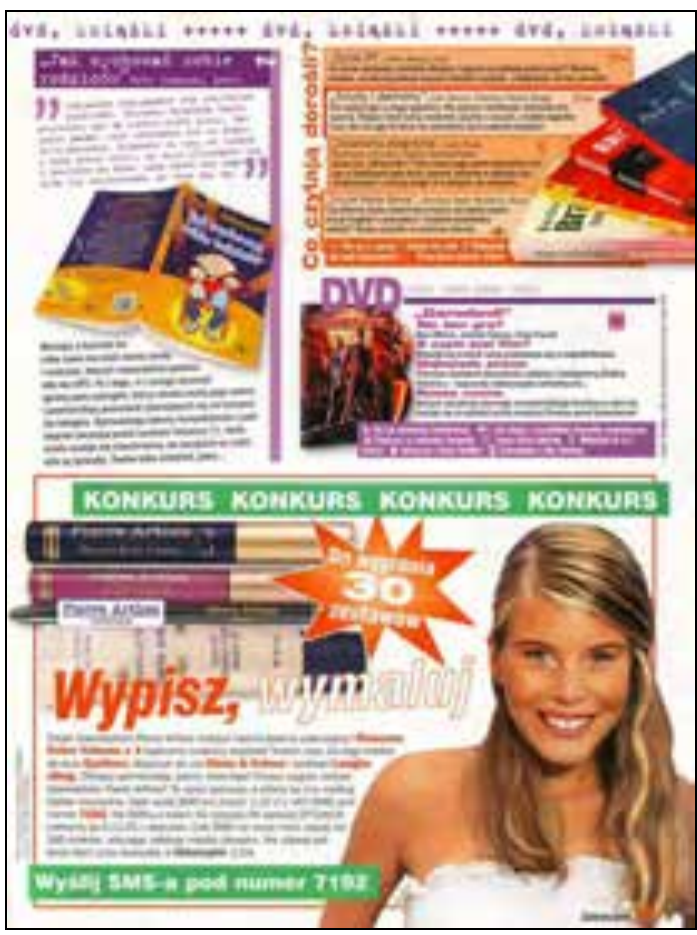


Niezależnie od wprowadzanych zmian, strona, na której zamieszczano także omówienia książek, pozostawała niezwykle barwna. Poza względami estetycznymi kolor pozwalał wyodrębnić poszczególne informacje, wyraźniej je od siebie oddzielając. Interesujące wydaje się spostrzeżenie, że przez cały badany okres recenzje książek dzieliły stronę z prezentacją filmów. Niekiedy zresztą informacje te $\mathrm{w}$ pewnym stopniu pokrywały się, gdy na przykład omawiana była ekranizacja znanej powieści. W 2002 r. pojawiły się symbole, oznaczające ocenę proponowanych lektur i oddzielne dla opinii na temat przedstawianych filmów. Podobnie, jak było to na łamach „Filipinki”, także i tu czytelnik mógł odnieść wrażenie, że redakcji zależy przede wszystkim na maksymalnym wykorzystaniu wolnego miejsca $\mathrm{w}$ piśmie. Pomiędzy poszczególnymi modułami pozostawiono niewiele światła, co wzmagało wrażenie wielości zamieszczonych informacji, a kolorowe kopie okładek, zdjęcia aktorów, kadry z filmów, nierzadko zamieszczane w tym miejscu reklamy sprawiały, że prezentowane strony do złudzenia przypominały komiks lub książkę z kolorowymi obrazkami i niewielką ilością tekstu. Jednocześnie były one (mimo wszystko) bardziej czytelne w odbiorze niż analogiczne strony „Filipinki”. Komponowały się z całą zawartością omawianego magazynu, widać było także większy profesjonalizm w ich przygotowaniu. Przejawiało się to na przykład w różnej prezentacji kopii okładek proponowanych lektur: niekiedy zdjęcie przedstawiało książkę ustawioną grzbietem do czytelnika, innym razem była to książka otwarta albo leżąca grzbietem do góry, zdarzało się, że obok recenzji umieszczano zdjęcie kilku tomów położonych obok siebie, okładkami w stronę czytelnika - te zabiegi urozmaicały odbiór prezentowanych treści, wprowadzały element różnorodności, ale nie przesytu, jak było to w przypadku wcześniej prezentowanego pisma.

Zmiana, która nastąpiła w 2002 r., ułatwiła odnalezienie omówień książkowych: informacje zostały uporządkowane, przydzielone do poszczególnych grup i kategorii.

Czytelnicy przez kilka miesięcy przyzwyczajali się do takiej formy opisywanej strony, jednak od numeru 3 (2004) zaproponowano im jej zmodyfikowaną postać. Przeobrażenia te nie miały rewolucyjnego charakteru, zmieniały głównie rozmieszczenie informacji na stronie i nazwę jednej z rubryk (Co czytajq dorośli $\rightarrow Z$ górnej półki). Idea pozostała jednak ta sama: nadal omawiano cztery książki w jednej grupie, jeden z tytułów zaś prezentowano oddzielnie. Większe zmiany wprowadzono, jak już wyżej wspomniano, od numeru $2 \mathrm{w} 2005$ r. Informacje odnoszące się do filmu i książki, w dalszym ciągu pozostające na tej samej stronie, ujęto w wyraźnie oddzielone od siebie szpalty, aczkolwiek założonego porządku nie udało się utrzymać zbyt długo. Przywołane zmiany przedstawiają przykłady - zob. zdjęcia 174-176. 


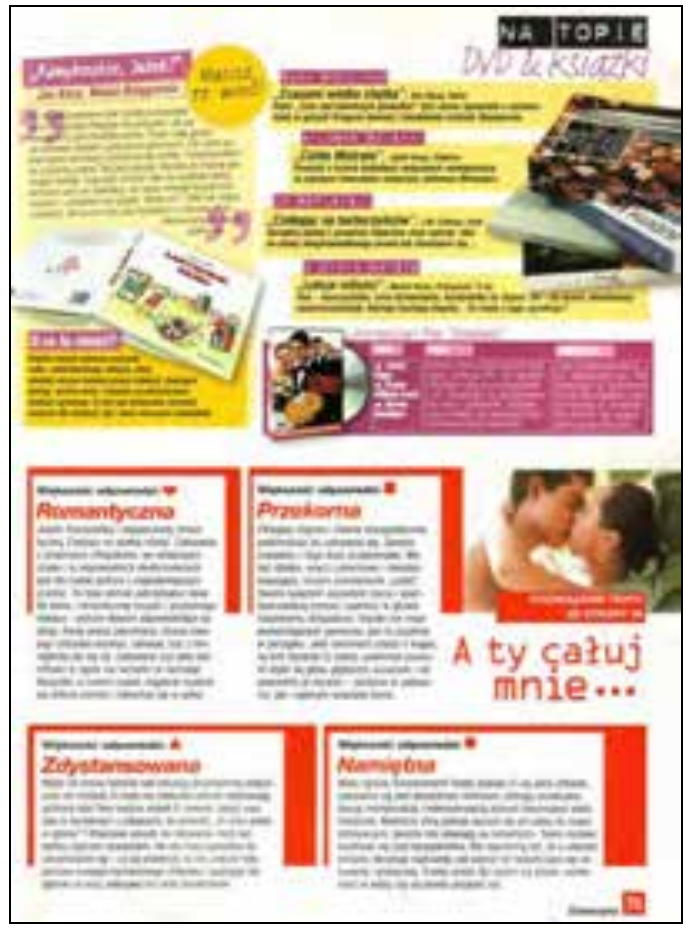

Zdjęcie 174. Przykładowa strona recenzyjna na łamach "Dziewczyny" „Dziewczyna” 2004, nr 3, s. 75

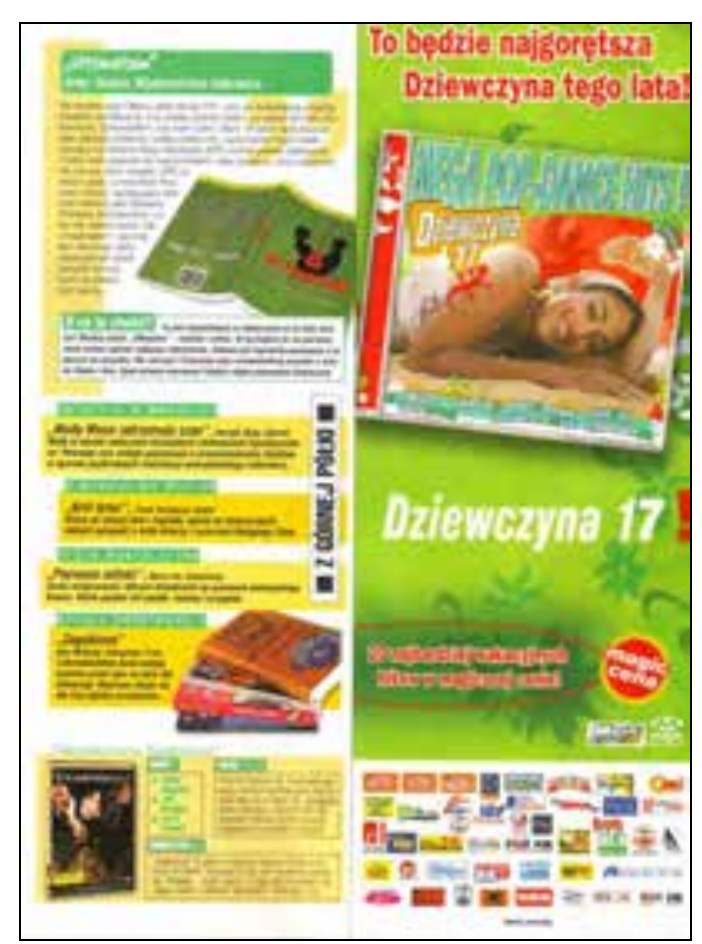

Zdjęcie 175. Przykładowa strona recenzyjna na łamach „Dziewczyny” „Dziewczyna” 2004, nr 10, s. [77] 


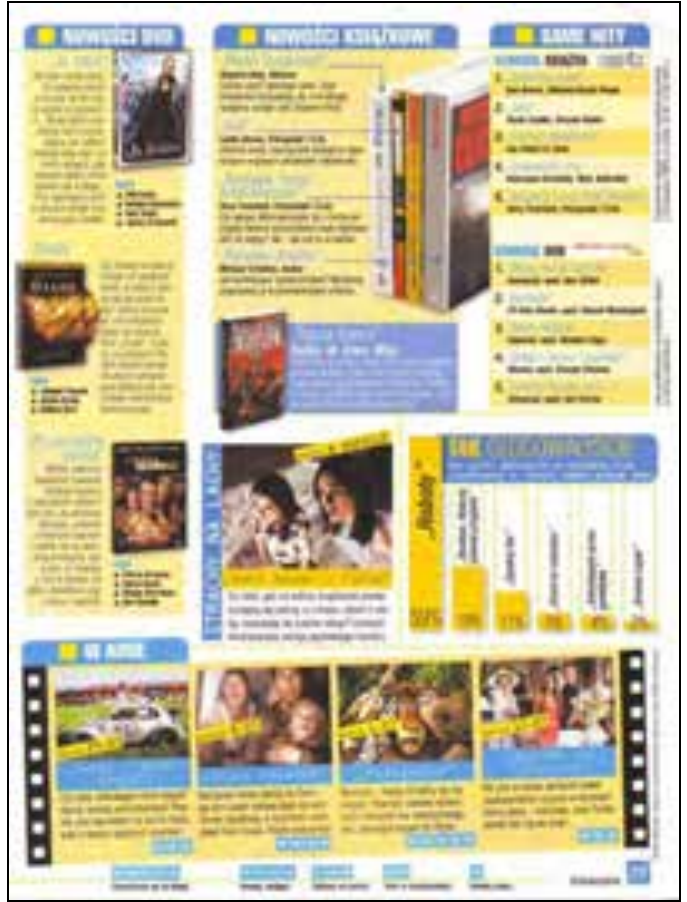

Zdjęcie 176. Przykładowa strona recenzyjna na łamach "Dziewczyny” „Dziewczyna” 2005, nr 7, s. 77

Wydaje się, że w miarę wprowadzanych zmian wspomniana wcześniej czytelność strony ulegała zmniejszeniu. Chociaż od numeru 2 (2005) podjęto próbę uporządkowania informacji, to została ona jednak szybko zastąpiona przez tendencję do nagromadzenia w jednym miejscu wielu informacji, jak widać to na zdjęciu 176. Dzięki jednak wyraźnemu zaznaczeniu tytułów poszczególnych kategorii (Nowości DVD, Nowości książkowe, Same hity) do pewnego stopnia udało się redakcji uniknąć męczącego dla czytelnika chaosu. Jednocześnie prezentacja książki została zminimalizowana do dwóch zdań, przyjmując tym samym charakter wzmianki, jeszcze bardziej odległej od recenzji, niż było to w przypadku wcześniej omawianego periodyku, „Filipinki”. Sygnalizowano jedynie istnienie danego tytułu, poprzez dwuzdaniowe streszczenie, pozbawione innych cech, charakterystycznych dla tak ambitnej formy informacji, jaką jest recenzja.

Pojawiła się wówczas po raz pierwszy (od wydania lutowego) swego rodzaju lista bestsellerów, czyli Ranking książek i Ranking $d v d$. Towarzyszył on tej rubryce do końca badanego okresu. Przez cały czas interesujące nas zestawienie obejmowało pięć pozycji, przygotowanych na podstawie wyników sprzedaży w salonach Empik. W wykazie znajdowały się takie elementy, jak: imię i nazwisko autora, tytuł książki oraz jej wydawca.

Niezależnie od zmian, rubryka oddawała charakter periodyków młodzieżowych wydawanych w tym czasie przez zagraniczne koncerny. Były 
one niemal wiernymi kopiami magazynów zachodnich, a „Dziewczyna”, jako polska wersja niemieckiego pisma, nie odbiegała od tych standardów. Zaletą tego faktu pozostawał wspomniany wyżej widoczny od strony graficznej profesjonalizm, który zapobiegał szumowi informacyjnemu, wyraźnemu w przypadku analogicznej rubryki, drukowanej na łamach „Filipinki”, szczególnie $\mathrm{w}$ okresie, gdy jej właścicielem pozostawało Wydawnictwo Prasowe „Twój Styl”. Wadą zaś było prezentowanie wybranych lektur w sposób powierzchowny, informacyjno-reklamowy, zdecydowanie bliższy krótkim, telegraficznym wzmiankom niźli ambitnym recenzjom, zawierającym rzetelną informację, głębszą analizę i uzasadnioną ocenę. Na przykładzie omawianego miesięcznika widać wyraźnie zmianę podejścia redakcji do tej formy informacji o książce, degrengoladę znaczenia recenzji, jej funkcji, którą powinna spełniać. Zastąpiona przez pospieszną, pobieżną informację wpisywała się jednak w politykę pisma, jego zawartość i, jak się zdaje, oczekiwania (nierzadko nawet nie uświadomione) młodego odbiorcy.

\subsection{Zakres i charakter recenzji - przykłady ${ }^{54}$}

W ciągu 5 lat w zamieszczanych na łamach pisma omówieniach pojawiło się 227 nazwisk pisarzy, w tym 161 autorów obcych i zaledwie 66 polskich $^{55}$ (zob. Aneks 50. Autorzy książek recenzowanych na łamach „Dziewczyny” w latach 2001-2005). Kilkakrotnie sięgnięto po książkę tego samego autora. W tabeli 67 zaprezentowano nazwiska tych twórców, którzy gościli w recenzjach minimum trzy razy.

Tabela 67. Nazwiska pisarzy, którzy pojawili się w recenzjach książek przynajmniej trzykrotnie na łamach „Dziewczyny” w latach 2001-2005

\begin{tabular}{|c|c|l|}
\hline Dane twórcy & Liczba recenzji & \multicolumn{1}{|c|}{ Tytuły recenzowanych książek } \\
\hline Terry Pratchett & 6 & $\begin{array}{l}\text { Bogowie, honor, Ankh-Morpork } \\
\text { Kapelusz pełen nieba } \\
\text { Ostatni bohater } \\
\text { Wiedźmikołaj } \\
\text { Wolni ciutludzie } \\
\text { Wyprawa czarownic }\end{array}$ \\
\hline Stephen King & \multirow{4}{*}{4} & $\begin{array}{l}\text { Mroczna wieża I: Roland } \\
\text { Pieśń Susannah } \\
\text { Rok wilkołaka } \\
\text { Wszystko jest względne }\end{array}$ \\
\hline
\end{tabular}

${ }^{54}$ Podrozdział obejmuje wszystkie recenzje odredakcyjne, zamieszczone w periodyku, bez względu na ich lokalizację.

$55 \mathrm{~W}$ trzech przypadkach zabrakło nazwiska autora. 
Tabela 67 (cd.)

\begin{tabular}{|l|c|l|}
\hline \multicolumn{1}{|c|}{ Dane twórcy } & Liczba recenzji & \multicolumn{1}{|c|}{ Tytuły recenzowanych książek } \\
\hline Meg Cabot & 3 & $\begin{array}{l}\text { Kiedy chłopak poznaje dziewczynę } \\
\text { Pamiętnik księżniczki (x2) }\end{array}$ \\
\hline Paulo Coelho & 3 & $\begin{array}{l}\text { Demon i panna Prym } \\
\text { Jedenaście minut } \\
\text { Weronika postanawia umrzé́ }\end{array}$ \\
\hline John Grisham & 3 & $\begin{array}{l}\text { Król afer } \\
\text { Ostatni sędzia } \\
\text { Wezwanie }\end{array}$ \\
\hline Yann Martel & 3 & $\begin{array}{l}\text { Historia rodziny Roccamatio } \\
\text { Ja } \\
\text { Życie Pi }\end{array}$ \\
\hline Eric Emmanuel Schmitt & 3 & $\begin{array}{l}\text { Dziecko Noego } \\
\text { Oskar i pani Róża } \\
\text { Pan Ibrahim i kwiaty Koranu }\end{array}$ \\
\hline Krystyna Siesicka & 3 & $\begin{array}{l}\text { Gorzkie słodkie pocałunki } \\
\text {... Nie ma } \text { z kim tańczyć... } \\
\text { Wróć, Aleksandrze! }\end{array}$ \\
\hline Alexander McCall Smith & 3 & $\begin{array}{l}\text { Kobieca Agencja Detektywistyczna Nr 1 } \\
\text { Moralność dla pięknych dziewcząt (x2) }\end{array}$ \\
\hline Izabela Sowa & 3 & $\begin{array}{l}\text { Cierpkość wiśni } \\
\text { Herbatniki z jagodami } \\
\text { Smak świeżych malin }\end{array}$ \\
\hline
\end{tabular}

Źródło: badania własne.

Większość nazwisk, które pojawiły się w powyższym zestawieniu, znana była z list bestsellerów. Byli to autorzy, tworzący literaturę popularną, chociaż nie zawsze tylko dla młodzieży, jednocześnie reprezentujący różne gatunki: T. Pratchett, twórca znanego Świata Dysku, S. King, „król horroru”, a z drugiej strony: K. Siesicka, autorka znana wielu pokoleniom dziewcząt, I. Sowa, przedstawicielka „młodego pokolenia” - tworzą kalejdoskop twórców, których książki proponowano czytelniczkom „Dziewczyny”.

Tezę tę w znacznej mierze potwierdza również zestawienie autorów, których nazwiska pojawiły się $\mathrm{w}$ omówieniach dwukrotnie. Wśród nich znaleźli się m.in. Grażyna Bąkiewicz, Maria Budzyńska, Agatha Christie, Marta Fox, Katarzyna Grochola, John Irving, Irena Matuszkiewicz Hanna Ożogowska, Joanne K. Rowling, Andrzej Sapkowski, William Wharton. Kryminały, powieści o miłości, książki o perypetiach bohaterów, będących w wieku czytelniczek pisma, ale i jednocześnie powieści fantasy, bestsellery na miarę Harry Pottera czy Ptaśka składały się na zróżnicowaną ofertę, w większości odpowiadającą wiekowo adresatowi periodyku.

Recenzenci pisma częściej, niż było to w przypadku „Filipinki”, sięgali kilkakrotnie po książki tego samego autora, nadto znaczna część tytułów 
odpowiadała w tym przypadku młodemu odbiorcy, jakim były czytelniczki pisma.

Gros prezentowanych książek stanowiły powieści, wśród których nie brakowało horrorów, kryminałów, książek sensacyjnych, także z gatunku fantasy. Jednakże większość proponowanych tytułów stanowiły powieści o życiu nastolatków, ich problemach, pierwszej miłości. Zaledwie kilka razy sięgnięto po opowiadania (na przykład Uczta Babette i inne opowieści... Karen Blixen, Upoważnienie do szczęścia Katarzyny Grocholi) i tylko raz zaproponowano poezję (Zebrane z powietrza Krzysztofa Pieczyńskiego).

Recenzje, streszczenia i omówienia zajmowały od jednego, poprzez kilka, do (najrzadziej) kilkunastu zdań. Krótsze omówienia znajdowały się w module zatytułowanym najpierw Co czytajq dorośli?, a następnie anonsowanym jako książki $Z$ górnej półki. Nieco dłuższymi omówieniami na stronie były zazwyczaj te, które pojawiały się poza tą grupą. Wszystkie uzupełnione były kopiami okładek proponowanych książek i podstawowymi danymi bibliograficznymi (autor, tytuł, wydawca). W wielu przypadkach tytuł książki był jednocześnie tytułem recenzji. Nie były one podpisywane; jak już wspomniano, w większości na stronie, na której obok informacji o książkach zamieszczano także opisy filmów, pojawiało się imię osoby, która je przygotowała (na przykład Magda, Maciek). Jak odnotowano wcześniej, dopiero od numeru majowego w 2005 r. zdecydowano się ujawnić nieco więcej szczegółów, i tak czytelniczki dowiedziały, się, że daną stronę przygotowywał Maciek Śnieżek.

Omówienia składały się zazwyczaj ze zwięzłego streszczenia głównego wątku proponowanej książki (od numeru 4 w 2004 r. do wydania styczniowego rok później włącznie przy informacji o książce, znajdującej się poza wspomnianą grupą pojawiało się przy tej okazji pytanie: $O$ co tu chodzi?). Oto kilka przykładów:

Kit Watson właśnie przeprowadził się do Stoneygate. Kit niezbyt dobrze czuje się w nowym miejscu. Pewnego dnia w szkole zaczepia go John Askew. Opowiada mu niezrozumiałe historie i oferuje udział w niebezpiecznej grze związanej z pewną katastrofą, która to miała miejsce wiele lat temu...56.

Chiny. Rządy Mao i rewolucja kulturalna. Na tym tle rozgrywa się dramatyczna, zakończona samobójstwem, historia pięknej dziewczyny...57

lub w sposób jeszcze bardziej lapidarny:

Życie maturzystki Maliny jest poplątane. Dziewczyna marzy o odrobinie spokoju, ale nie pozwalają jej na to odkryte przez nią rodzinne tajemnice... ${ }^{58}$.

\footnotetext{
56 „Dziewczyna” 2001, nr 3, s. [69].

57 „Dziewczyna” 2002, nr 9, s. [79].

58 „Dziewczyna” 2002, nr 11, s. [83].
} 
Major Paul Brenner z wydziału śledczego armii USA, prowadzi dochodzenie w sprawie zabójstwa pięknej kapitan Anne Campbell 59

czy podobnie lakonicznie:

Dziewczyna $\mathrm{z}$ małego miasteczka zdobywa posadę $\mathrm{w}$ redakcji prestiżowego pisma o modzie...60.

Niekiedy pomijano ten zabieg, zastępując go pytaniami, na które odpowiedź miała dać proponowana książka. Tego typu zachęcający chwyt zastosowano na przykład przy przywołaniu książki Roberta Ludluma: „Dlaczego kolega głównego bohatera książki, Bena Hartmana, spotkany przypadkowo (?) na ulicy w Zurychu zaczyna do niego strzelać? Kto dybie na bankiera? Co to jest Sigma? Odpowiedzi w książce!"61 albo proponując sięgnięcie po Trzeci cud Richarda Vetere`a: „Czy zdarzają się jeszcze cuda? A może te najważniejsze dzieją się w nas samych? Wątpiący i poszukujący - to książka dla Was!"62, lub przywołując Ptaka, który zwiastował trzęsienie ziemi S. Jones: „Żyjąca w Japonii Angielka podejrzana jest o zamordowanie przyjaciółki. Czy mogła to zrobić?"63.

Czasem łączono obydwa elementy, jak w przypadku Czerwonych liści P. Simons:

W lesie zostają znalezione zwłoki studentki, Cristiny... Brzmi nieźle? Czytajcie dalej. Ciało przeleżało w śniegu 9 dni. Robi się straszniej? Żaden z kolegów nie zgłosił jej zniknięcia... I co, przeczytacie?64

czy Inków Antoine`a B. Daniela:

Anamaya, duchowa strażniczka imperium i hiszpański szlachcic Gabriel, który przybył podbić Peru, zakochują się w sobie. Co zwycięży: miłość czy polityka?65

Podobnie było w odniesieniu do wielu innych książek, na przykład powieści M. Budzyńskiej Chłopakom, których kiedyś kochałam...:

Dominika została ofiarą Michała - zabójczo przystojnego blondasa, który ma...same zalety. Według niej, oczywiście. A w końcu to ta pierwsza, najprawdziwsza miłość w życiu bohaterki. Ale czy dziewczyna też podoba się Michałowi?66

\footnotetext{
59 „Dziewczyna” 2004, nr 5, s. [83].

60 „Dziewczyna” 2004, nr 7, s. [75].

61 „Dziewczyna” 2002, nr 7, s. [77].

62 „Dziewczyna” 2003, nr 1, s. [77].

63 „Dziewczyna” 2004, nr 11, s. [81].

64 „Dziewczyna” 2002, nr 6, s. [77].

65 „Dziewczyna” 2002, nr 11, s. [83].
} 
Nierzadko (szczególnie w przypadku omówień spoza grupy reprezentującej tytuły $Z$ górnej półki, a wcześniej określane pytaniem Co czytajq dorośli?) jako zachętę, która miała służyć sięgnięciu po proponowany tytuł, zamieszczano fragment polecanej książki. Jak już wspomniano, w tych recenzjach streszczenia fabuły bywały nieco dłuższe, ale nawet wtedy nie przekraczały kilku, rzadziej kilkunastu zdań:

Główny bohater to 16-letni Michał, skate lubujący się w potyczkach słownych. Pasjonuje się sportem i grami komputerowymi, więc rodzice przepowiadają mu rychłą karierę ochroniarza. Kumple go uwielbiają, a nauczyciele przeciwnie. To pełna błyskotliwych dialogów powieść o poszukiwaniu swojego miejsca w świecie ${ }^{67}$.

Buba jest nastolatką, która ma w życiu wielkiego farta. Jej rodzina jest jakby żywcem wzięta z kina familijnego: kochający rodzice, zakręcony dziadek i gosposia tworzą wraz z Bubą (i psem) zgrany zespół. W sprawach sercowych dziewczynie także dopisuje szczęście - stara się o nią aż dwóch kandydatów...Taką książkę dobrze jest od czasu do czasu przeczytać po to, by uwierzyć, że świat nie jest wcale taki zły. 'Buba` to dobry sposób na największą nawet chandręe8.

Podobnie jak w przykładzie podanym powyżej, ocena proponowanego tytułu pojawiała się niekiedy w samym jego omówieniu, zaś od wydania lutowego w 2002 r. wprowadzono na stałe symbole oddające odczucia recenzenta po przeczytaniu polecanej książki, umieszczane obok recenzji. Odtąd, do numeru 2 w 2004 r. włącznie, proponowane tytuły zaliczano do jednej z czterech kategorii: pojawiała się zatem książka, którą „Przeczytasz jednym tchem” (symbol „kciuka”)69, tytuł, przed którym ostrzegano czytelniczki, „Nie da ci zasnąć” (komentarz odzwierciedlał symbol oka), książka, której „Głupio nie znać” (temu stwierdzeniu odpowiadał symbol lupy) oraz lektura "Wyłącznie dla moli książkowych" (oznaczona małym stosem książek). W 127 recenzjach, które pojawiły się w tym czasie i przy których umieszczono jeden z umownych znaków, najczęściej proponowano książki, na które (według recenzenta) nie szkoda było czasu: w 57 przypadkach obiecywano „Przeczytasz jednym tchem”, w 42 książka miała „Nie dać ci zasnąć" i tylko w 9 pojawiała się delikatna krytyka, wyrażona określeniem „Wyłącznie dla moli książkowych”. Tak oceniono na przykład Syndrom

66 „Dziewczyna” 2001, nr 9, s. [69].

67 „Dziewczyna” 2003, nr 2, s. [75].

68 „Dziewczyna” 2003, nr 3, s. [75].

${ }^{69}$ Recenzje filmów, pomieszczane na tej samej stronie, na której drukowano omówienia książek, otrzymały swoje własne symbole-komentarze, inne od tych przypisanych lekturom. Niekiedy recenzenci książek korzystali dodatkowo z tych symboli, na przykład proponując Księgę wiedzy czarodziejskiej posłużyli się rysunkiem, określającym przeważnie charakter polecanego filmu, który w tym przypadku oznaczał, że czytelniczki będą miały do czynienia z „Czarownicami i elfami/ fantasy”, zob. „Dziewczyna” 2002, nr 7, s. [77]. 
Anastazji (Mary Higgins Clark), Wezwanie (Johna Grishama) oraz Przyjaciółki od serca (Patricii Gaffney). Wieloznaczne stwierdzenie „Głupio nie znać" odniesiono do 19 tytułów (m.in. do Blondynki Joyce C. Oates, Gry na wielu bębenkach Olgi Tokarczuk i Baudolino Umberto Eco).

Najbardziej pochlebne opinie pojawiły się m.in. przy takich książkach, jak Anioły $i$ demony (D. Browna), Życie Pi (Y. Martela), Gorzkie słodkie pocałunki (K. Siesickiej) oraz Demon i panna Prym (Paulo Coelho). Przy prezentacji tych książek znalazł się symbol „kciuka”. Natomiast rysunek oka pojawił się m.in. przy takich tytułach: Spójrz na mnie (Jennifer Egan), Nad Afganistanem Bóg już tylko płacze (S. Shakiby), Wszystko jest względne (S. Kinga) oraz Harry Potter i Kamień filozoficzny (J. K. Rowling).

Niezależnie od tych elementów, w samych omówieniach, jak już wspomniano powyżej, niejednokrotnie pojawiały się jednoznaczne oceny proponowanych książek. Podobnie, jak było to w przypadku tytułów polecanych na łamach „Filipinki”, tak i tu czytelniczki „Dziewczyny” dowiadywały się, że mają do czynienia z książką, określaną jako: „super!”, „fascynująca”, „zabawna”, ale również „wzruszająca”, „lekka, łatwa i przyjemna”. Proponowano i taką, którą „Bardzo (!!!) dobrze się czyta” albo „Czyta się ją jednym tchem”, taką, która „Naprawdę wciąga...”, od której „trudno się oderwać...”, przy której „Dobra zabawa gwarantowana”. Ocena ograniczała się jednak w tym przypadku do podanych określeń, których nie uzasadniano.

Najskromniejsze (zarówno pod względem formy, jak i treści) omówienia odnaleźć można w magazynie w 2005 r., od momentu wprowadzenia ostatnich w badanym okresie zmian dotyczących strony, na której pojawiały się informacje związane z książką i filmem. Dane dotyczące książek były w tym czasie, w porównaniu z wcześniejszymi latami, najkrótsze, zaniechano również drukowania fragmentu proponowanej lektury, elementu, który przez dłuższy czas towarzyszył jednemu z omówień, zamieszczanych w przedstawianej rubryce oraz wspomnianych symbolicznych ocen. Tytuł danej prezentacji stał się ponownie jednocześnie tytułem proponowanej książki. Do tego elementu, nierzadko wyróżniającego informację o książce, zamieszczanego w periodykach o różnym charakterze, redakcja „Dziewczyny" podchodziła bardzo niekonsekwentnie. Tylko w ok. 1/5 przypadków omówienia zyskały odrębny tytuł, nie wyróżniający się zresztą niczym szczególnym. Oto kilka wybranych przykładów70: Bajki o życiu, Dla dużych dzieci, Dla romantyków, Do refleksji, Miłosne ścieżki, Mrozi krew, Na tropach tajemnicy, Obserwując świat, Oda do jedzenia, Proste życie, Szpieg w spódnicy, Ścieżki miłości, Światy równoległe, Z życia wzięte, Życie nastolatków.

70 Kolejno: „Dziewczyna” 2005, nr 1, s. 73; 2004, nr 8, s. [75]; nr 6, s. [83]; nr 3, s. 75; nr 4, s. [75]; nr 5, s. [83]; nr 4, s. [75]; nr 6, s. [83]; 2003, nr 9, s. [7]; 2004, nr 6, s. [83]; nr 12, s. [73]; nr 7, s. [75]; nr 11, s. [81]; nr 3, s. 75; nr 10, s. [75]. 
Zaledwie w siedmiu przypadkach pojawiła się adnotacja treściowa, dotycząca książki, zamieszczona poza rubryką odpowiadającą tego typu informacjom, choć jednocześnie tylko dwie notki pojawiły się poza działem kulturalnym. Dotyczyły Niezwykłej księgi hipnotyzmu Molly Moon oraz Party z fantazją. Dwie kilkuzdaniowe wzmianki na ich temat pojawiły się w dziale To się nosi!, w rubryce To jest trendy!

Pięć książek zaproponowano w miejscu, zwyczajowo poświęconemu nowinkom muzycznym. Za każdym razem omówienie otrzymało ten sam tytuł: Czytanie jak z nut i pojawiło się w 2005 r. Zachęcano do sięgnięcia po książki Wydawnictwa In Rock: Encyklopedię polskiego rocka (Leszka Gnoińskiego), Jennifer Lopez (Tracy Kathleen), Kult Kazika (L. Gnoińskiego), o krowach, świniach, robakach oraz wszystkich utworach Pink Floyd (Wiesława Weissa) i Parabolę [o grupie Tool] (Bartka Koziczyńskiego). Były to w zasadzie jedynie krótkie wzmianki na temat wybranych tytułów, przy których zamieszczano kopię okładki danej książki.

Książki, omawiane na łamach „Dziewczyny”, pochodziły z oferty 43 wydawców ${ }^{71}$ (Aneks 51. Wydawcy książek recenzowanych na łamach „Dziewczyny” w latach 2001-2005). Jest to liczba większa niż w przypadku „Filipinki”. W tabeli 68 zaprezentowano edytorów, po książki których recenzenci „Dziewczyny” sięgali najczęściej.

Tabela 68. Wydawcy najczęściej recenzowanych książek na łamach „Dziewczyny” w latach 2001-2005

\begin{tabular}{|l|c|}
\hline \multicolumn{1}{|c|}{ Nazwa wydawcy } & Liczba tytułów \\
\hline Wydawnictwo Prószyński i S-ka & 58 \\
\hline Wydawnictwo Amber & $32^{a}$ \\
Dom Wydawniczy REBIS & $32^{b}$ \\
\hline Wydawnictwo Albatros & $29^{c}$ \\
\hline Społeczny Instytut Wydawniczy Znak & 14 \\
\hline Wydawnictwo Świat Książki & 13 \\
\hline Wydawnictwo Egmont & \\
Wydawnictwo Muza SA & 8 \\
Wydawnictwo Literackie & \\
\hline Wydawnictwo Akapit Press & 7 \\
\hline
\end{tabular}

${ }^{a}$ W tym raz do spółki z Domem Wydawniczym REBIS.

${ }^{b} \mathrm{~W}$ tym raz do spółki z Wydawnictwem Amber.

${ }^{c} \mathrm{~W}$ tym w jednym przypadku była to książka wydana w koedycji z Wydawnictwem Sonia Draga.

Źródło: badania własne

${ }^{71}$ W 6 przypadkach zabrakło informacji na temat wydawcy. Podobnie, jak było w analogicznych przypadkach w poprzednich rozdziałach, tak i tu uzupełniono brakujące dane na podstawie „Przewodnika Bibliograficznego” w wersji on line: www.bn.org.pl, kwiecień 2011. 
Na 10 oficyn wydawniczych, które pojawiły się w tabeli 68, z dorobku 6 korzystali zarówno recenzenci magazynu „Dziewczyna”, jak i „Filipinki”. Należały do tej grupy największe wydawnictwa tego okresu, m.in. Wydawnictwo Prószyński i S-ka oraz Dom Wydawniczy REBIS. Zabrakło jednak w powyższym zestawieniu Wydawnictwa W.A.B., które było liderem w przypadku książek recenzowanych na łamach „Filipinki”. Jeśli chodzi o „Dziewczynę", niekwestionowanym zwycięzcą w tym względzie okazało się Wydawnictwo Prószyński i S-ka.

Recenzenci sięgali głównie po książki znanych edytorów. Tylko w siedmiu przypadkach pojawiły się oficyny mało znane na rynku: Anagram, Kakadu, Panteon, Replika, Stapia, Wydawnictwo Interwers oraz Zibi.

Jak już wspomniano, omówienia zamieszczane na łamach prezentowanego periodyku, jakkolwiek (poza pierwszym rocznikiem) drukowane systematycznie, miały charakter krótkich, powierzchownych omówien. Wiele z nich przyjmowało postać zwięzłych wzmianek, ograniczających się do zasygnalizowania treści proponowanej książki, i, jak już zaznaczono wcześniej, uzupełnianych niekiedy jej fragmentem. Ta, można powiedzieć, ekspresowa forma podania informacji korespondowała z całą zawartością kolorowego magazynu, służącego bardziej do oglądania niż czytania. Od strony formalnej ograniczano się do podania najbardziej niezbędnych danych: autora, tytułu i nazwy wydawcy. W żadnym $\mathrm{z}$ omówień nie pojawiło się miejsce i rok wydania polecanej książki czy jej objętość. Tylko nieliczne tytuły owych omówień oddawały charakter proponowanych książek. Można jednak sądzić, że redakcja magazynu uznawała owe informacje za recenzje. Należy także pamiętać, iż jakkolwiek w mniejszym niż w przypadku „Filipinki” stopniu, to jednak i tu odnaleźć można wspominane już podstawowe elementy, składające się na recenzję, choć były one wykorzystane nierzadko w minimalnym stopniu. Jednocześnie zwraca szczególnie uwagę element konkretnie wyrażonej oceny.

Dobór proponowanych lektur, jakkolwiek nie tworzy kanonu tytułów szczególnie ambitnych, to jednak wydaje się być dostosowany do poziomu, oczekiwań i wieku czytelniczek pisma. W większości były to ${ }^{72}$ „bajki o życiu, dla dużych dzieci”, rzadziej „dla romantyków” czy tych, którzy „obserwując świat”, w czytanych książkach szukają tematu „do refleksji”. Chętnie przemierzają z bohaterami polecanych lektur "miłosne ścieżki”, ale sięgają także z ochotą po książki, których treść „mrozi krew”, lubią czasem znaleźć się na „tropach tajemnicy”, na których pojawia się „szpieg [najlepiej] w spódnicy”. Najchętniej jednak czytają te powieści, w których opisane jest „proste życie,

72 Określenia w dalszej części wywodu podane w cudzysłowie pochodzą z wybranych recenzji, omówień i streszczeń, zamieszczanych na łamach opisywanego magazynu. 
życie nastolatków”, historie „z życia wzięte”, takie, które mogą przytrafić się także im - czytelniczkom pisma, reklamującego się hasłem „Dziewczyna taka jak Ty!”.

\subsubsection{Tylko dla niegrzecznych...73: reklamy książek}

Większość reklam, zamieszczanych na łamach miesięcznika „Dziewczyna", promowała ubrania, kosmetyki oraz akcje, organizowane przez periodyk. Jednakże pewna część ogłoszeń odnosiła się do zagadnień, związanych $\mathrm{z}$ tematem niniejszej książki. Podobnie, jak było to w odniesieniu do wcześniej zaprezentowanych czasopism, również $\mathrm{w}$ tym przypadku można wyodrębnić trzy kategorie, które staną się przedmiotem dalszych rozważań:

1) książki,

2) akcje tygodnika związane z książką ${ }^{74}$,

3) prasa, w tym autoreklama ${ }^{75}$.

Podczas analizy zawartości pisma wykazano obecność 173 ogłoszeń, proponujących książki, 2 informowały o akcjach periodyku, z nią związanych, a 115 dotyczyło reklam czasopism. W tabeli 69 przedstawiono liczbę inseratów wydawniczych w poszczególnych latach.

Tabela 69. Ogłoszenia wydawnicze zamieszczane na łamach „Dziewczyny” w latach 2001-2005

\begin{tabular}{|c|c|}
\hline Rok & Liczba reklam książkowych \\
\hline 2001 & 3 \\
\hline 2002 & 16 \\
\hline 2003 & 52 \\
\hline 2004 & 35 \\
\hline 2005 & 67 \\
\hline Ogółem & 173 \\
\hline
\end{tabular}

Źródło: badania własne.

Podobnie, jak było to w przypadku omówień, tak i w odniesieniu do reklam najmniejsza ich liczba pojawiła się w 2001 r. ${ }^{76}$ Najwięcej ukazało się ich $\mathrm{w}$ ostatnim badanym roczniku, przy czym fakt ten związany był $\mathrm{z}$ autopromocją serii Literatura w spódnicy, stanowiącej ofertę Wydawnic-

73 Hasło reklamowe jednego z anonsów, zob. „Dziewczyna” 2005, nr 8, s. [31].

${ }_{74}$ Ta kategoria przyjmowała postać zarówno reklam, jak i tekstu komentującego, stąd zostanie omówiona w dalszej części rozdziału (4.3.3.3).

75 Problematyka związana z prasą, prezentowana na łamach omawianego periodyku, pojawiająca się w nim zarówno w postaci reklam, jak i tekstów, zostanie przedstawiona w ostatniej części rozdziału.

76 W numerze 10 (2001) ukazał się jeden inserat, w którym reklamowano trzy tytuły. 
twa Axel Springer. W jednym ogłoszeniu pojawiała się informacja zazwyczaj o 8 lub 9 tytułach, powtarzanych w różnej konfiguracji w następnych wydaniach pisma. Poza niemieckim koncernem, jedynymi oficynami, które zainteresowane były w badanym okresie zamieszczeniem reklamy własnej oferty na łamach omawianego periodyku, były: Wydawnictwo GREG, Wydawnictwo Prószyński i S-ka, Wydawnictwo Wilga, Wydawnictwo Znak. Ogłoszenia wydawnicze zostały zmonopolizowane przez znaną już z łamów „Filipinki” oficynę GREG, specjalizującą się w publikacji lektur szkolnych oraz wspomniane Wydawnictwo Axel Springer Polska.

W takim przypadku trudno mówić o większej lub szczególnie zróżnicowanej grupie pisarzy czy o powtarzalności ich nazwisk, jednak gwoli porządku należy odnotować, iż w zamieszczonych anonsach pojawiło się 25 nazwisk $^{77}$, w tym 7 autorów polskich i 18 obcych. Nazwiska, które kilkakrotnie się powtórzyły, należały bądź do autorów książek, proponowanych w ramach wspomnianej serii, bądź autorów lektur szkolnych. W pierwszej grupie znaleźli się m.in.: Tony Parsons (dziewięciokrotnie), Helen Fielding (7 razy), Nicola Kraus, Maria Nurowska, Janusz L. Wiśniewski (każde $\mathrm{z}$ nich pięciokrotnie), Joanna Chmielewska, Lisa Jewell, Wendy Markham (w każdym przypadku nazwisko powtórzyło się czterokrotnie), Candace Bushnell, Nick Hornby, Josie Lloyd (trzykrotnie). Natomiast w grupie drugiej trzykrotnie pojawiło się w ogłoszeniach nazwisko Adama Mickiewicza oraz Bolesława Prusa. W większości przypadków reklamowano te same tytuły.

Wydawnictwo GREG, obok lektur szkolnych, proponowało również ich streszczenia, natomiast wydawca magazynu zachęcał do kupna popularnej literatury kobiecej. W pierwszym przypadku ogłoszenia były całostronicowe, w drugim nierzadko obejmowały dwie strony w periodyku. Inseraty Wydawnictwa Prószyński i S-ka oraz oficyny Wilga były skromniejsze pod względem objętości, zajmując analogicznie: moduł z boku strony, u jej dołu, oraz kolumnę na wyróżniającym się tle. Ostatni z edytorów, Wydawnictwo Znak, na swoją jednorazową reklamę przeznaczyło całą stronę. Dalej zaprezentowano wybrane ogłoszenia każdego z wydawców (zdjęcia 177-180).

Każde z przywołanych ogłoszeń było czytelne, przejrzyste i kolorowe. W każdym widoczna była kopia okładki proponowanej książki, w dwóch pojawiło się hasło reklamowe (zdjęcie, 177, 180), zaś w ostatnim z zaprezentowanych anonsów zamieszczono dodatkowo dłuższe streszczenie proponowanej książki.

77 W 83 przypadkach nazwisko autora było niemożliwe do ustalenia, jako że reklama dotyczyła streszczeń lektur, okładki proponowanych tekstów były zasłonięte, tak, że nie udało się również odczytać w całości danego tytułu. W przypadku dwóch pozostałych ogłoszeń, w których reklamowano książki popularne, ustalono brakujące nazwiska. Do statystyki zaliczano tylko nazwiska pierwszych podanych autorów. 


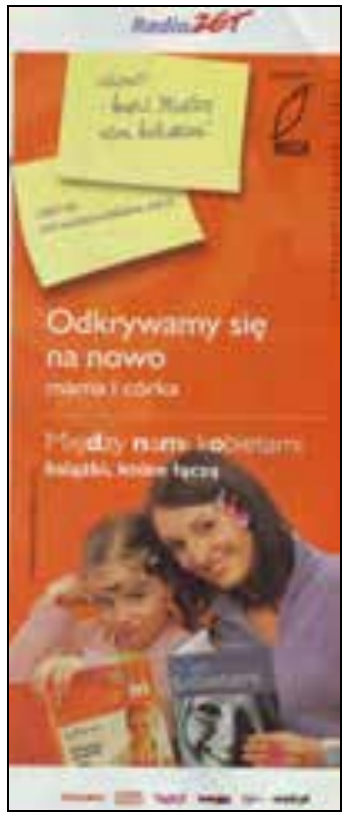

Zdjęcie 177. Wybrane ogłoszenie wydawnicze zamieszczone na łamach „Dziewczyny” „Dziewczyna” 2004, nr 7, s. [75]

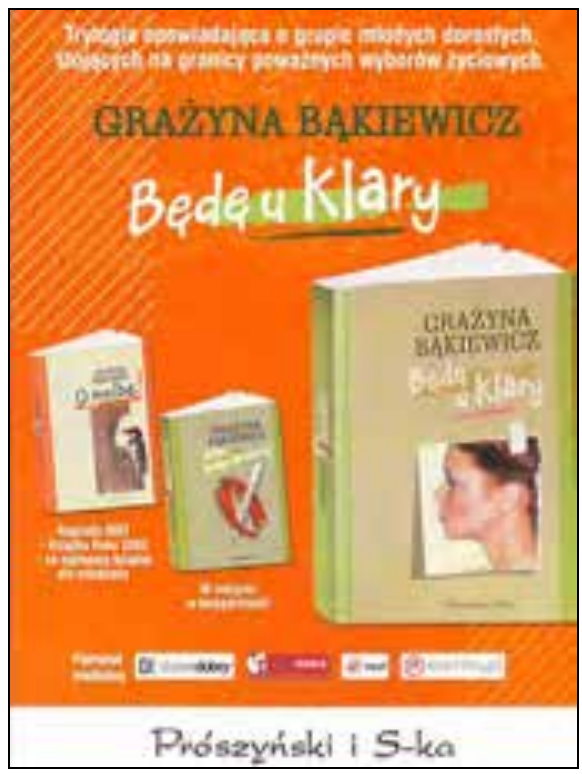

Zdjęcie 179. Wybrane ogłoszenie wydawnicze zamieszczone na łamach „Dziewczyny”

„Dziewczyna” 2005, nr 7, s. [29]

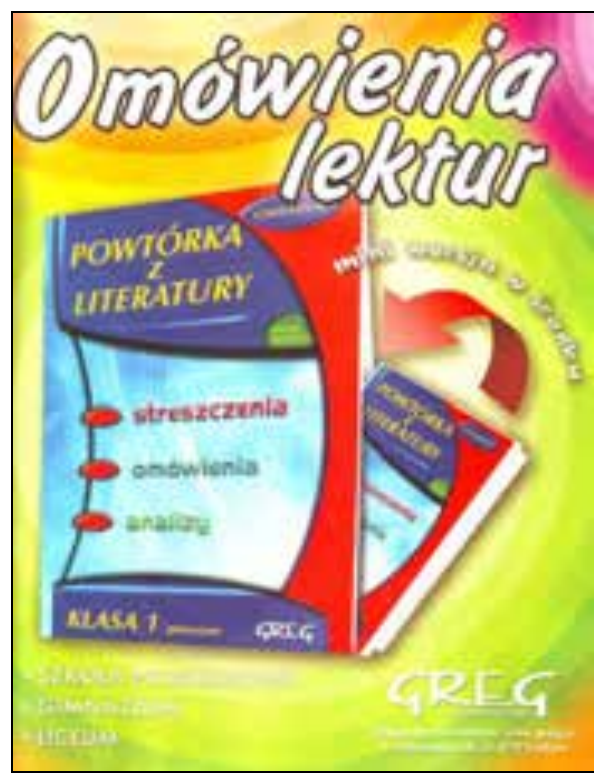

Zdjęcie 178. Wybrane ogłoszenie wydawnicze zamieszczone na łamach „Dziewczyny” „Dziewczyna” 2004, nr 10, s. [17]

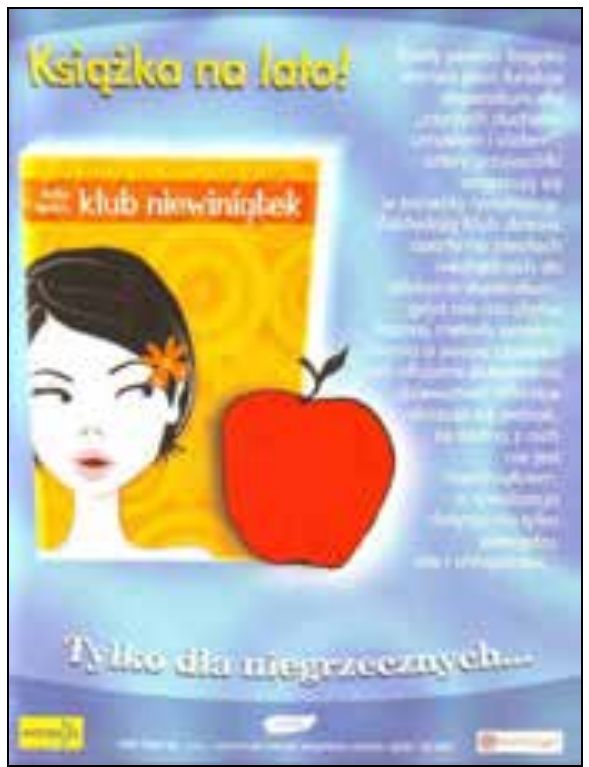

Zdjęcie 180. Wybrane ogłoszenie wydawnicze zamieszczone na łamach „Dziewczyny”

„Dziewczyna” 2005, nr 8, s. [31] 
Ta forma informacji o książce była starannie przygotowywana, zaś jasne kolory przykuwały uwagę czytelnika. Należy tylko żałować, że tak niewielu wydawców zdecydowało się zainwestować w promocję swej oferty na łamach opisywanego magazynu. Prawdopodobnie jednak nie tylko cena reklamy była w tym przypadku powodem. Należy się domyślać, że edytorzy kierowali się również charakterem periodyku oraz typem odbiorcy, do którego był on adresowany.

\subsubsection{Wiedźmin czy Winicjusz?"18: inne formy informacji o książce}

Omówienia książek i ich reklamy były podstawowymi formami informacji o książce na łamach prezentowanego periodyku. $\mathrm{W}$ bardzo niewielkim stopniu wykorzystano inne sposoby, by promować literaturę czy osoby z nią związane (zob. Aneks 52. Wybór tekstów związanych z literaturą i rynkiem wydawniczo-księgarskim zamieszczonych na łamach „Dziewczyny” w latach 2001-2005). Analiza zebranego w tym zakresie materiału pozwoliła, podobnie jak w odniesieniu do poprzednich periodyków, wyodrębnić następujące kategorie, przypisując im określone (w tym przypadku znacznie skromniejsze) dane liczbowe:

- portrety/sylwetki (7);

- publikacje, nawiązujące do rynku wydawniczo-księgarskiego (3);

- adaptacje, ekranizacje, oraz inscenizacje znanych dzieł (35);

- listy czytelników (4);

- konkursy i akcje związane z książką, organizowane, współinicjowane przez tygodnik lub takie, o których periodyk tylko informował (22);

- inne (166).

Zebrane dane statystyczne, odpowiadające każdej z kategorii, potwierdziły wcześniejsze spostrzeżenia. Skromna liczba portretów, zaledwie trzy teksty, odpowiadające problematyce literackiej, niewielki odzew czytelników na informacje z nią związane (efekt czy przyczyna niewielkiego stopnia zainteresowania periodyku sprawami książki?) ukazują, jakie miejsce zajmowały w magazynie kwestie dotyczące literatury. Informacje o ekranizacjach czy adaptacjach znanych dzieł nawiązywały do często zamieszczanych wzmianek donoszących o nowinkach ze świata filmu. Natomiast najliczniej reprezentowana grupa, określona jako „inne”, zawierała w sobie przede wszystkim opowiadania, fotostory oraz minikomiksy, drukowane na łamach miesięcznika, obejmując tylko $\mathrm{w}$ niewielkim stopniu wzmianki związane z książką.

Należy zaznaczyć, że niektóre z publikacji zostały włączone do danych kategorii, choć tylko w bardzo pośredni sposób im odpowiadały. Zdecydo-

78 Tytuł jednej z publikacji, „Dziewczyna” 2001, nr 12, s. 36. 
wano się jednak na zaliczenie ich do poszczególnych grup ze względu na to, ze stanowiły (mimo, że odległe) jedyne odzwierciedlenie zainteresowania periodyku w tym zakresie, a także dlatego, że ukazywały charakterystyczny sposób podejścia redakcji do spraw kultury, w tym literatury.

\subsection{Nasi herosi ${ }^{79}$ : sylwetki/portrety}

W trakcie badanego okresu ani razu nie pojawił się dłuższy tekst poświęcony pisarzowi. Jedynymi publikacjami, które, w odległy zresztą sposób, odpowiadałyby zaznaczonej kategorii, były te, w których opisywano aktorów, grających główne role w ekranizacjach bestsellerów w latach 2001-2005: trylogii Johna R. R. Tolkiena, cyklu o Harrym Potterze oraz Wiedźminie.

Dwukrotnie przedmiotem zainteresowania redakcji była sylwetka Elijaha Wooda. Po raz pierwszy pojawił się on na łamach pisma w marcu 2002 r., jako „Przystojny, skromny, z oczami koloru oceanu...”80 ulubieniec nastolatek. Ukazany został w różnych kontekstach (praca i kariera, rodzina, miłość, opinie innych aktorów na jego temat), przy czym i ten tekst, ogólny, z jednozdaniowym odniesieniem do książkowego pierwowzoru („zapoznał się $\mathrm{z}$ twórczością autora >Władcy Pierścieni< już w dzieciństwie, a nie tuż przed castingiem do roli Frodo..."81), kładł nacisk na sprawy, które (według redakcji) przede wszystkim mogły zainteresować czytelniczki pisma. $\mathrm{Na}$ koniec czekała na nie nie lada gratka: adres idola, do którego mogły wysłać list, a także propozycja redakcji, by podzieliły się swoimi wrażeniami na temat filmowego hobbisty Frodo: „Dziewczyny, czy urzekł Was Elijah? A może sądzicie, że to typ grzeczniutkiego chłopca?"82. Po raz drugi występował on w towarzystwie innych "najsłodszych chłopców Hollywood”83. Ich zdjęcia, z krótkimi notkami (znak zodiaku, stan cywilny, przypomnienie, z jakich filmów są znani, a także wyjaśnienie, „Za co [ich - przyp. M. P. S.] kochamy?") stanowiły treść obszernego (jak na zwyczaje periodyku), bo niemal 4-stronicowego tekstu.

Innym przykładem znamiennego podejścia pisma do interesujących nas zagadnień była kolejna publikacja. I tym razem ekranizacja Władcy pierście$n i$ bynajmniej nie stała się pretekstem do analizy filmu w kontekście książki, ale posłużyła do zasięgnięcia opinii czytelników pisma na temat preferencji współczesnych dziewcząt (czytaj: adresatek magazynu) w odniesieniu do dwóch różnych męskich typów, których cechy utożsamiali (według redak-

\footnotetext{
79 Tytuł jednej z publikacji, zob. „Dziewczyna” 2005, nr 8, s. 14-[15].

80 „Aśka”, Jestem Elijah. Elijah Wood, „Dziewczyna” 2002, nr 3, s. [21].

81 Ibidem.

82 Ibidem.

83 „Dziewczyna” 2003, nr 3, s. 18-[21].
} 
cji) bohaterowie filmu: Legolas i Aragorn. Zasięgnięto nawet zdania psychologa, Jana Michalskiego, w tej sprawie, który autorytatywnie stwierdził, że „Nie można jednoznacznie określić, jaki typ bardziej podoba się dziewczętom - twardziel czy elf... Każda ma swój ideał chłopaka"84.

Być może stał się nim, po przeczytaniu tekstu Nie tylko Czary-Harry, jeden z czterech aktorów, grających w ekranizacji powieści J. K. Rowling. W tym przypadku wskazać można kilka znamiennych cech, które podkreślają typowe dla periodyku prezentowanie danej kwestii. Do opisania postaci „asz” wybrała jedynie męskich odtwórców bohaterów cyklu, pomimo że jedną z głównych bohaterek jest przyjaciółka Harry Pottera, Hermiona Granger, grana przez Emmę Watson. Zostaje ona wspomniana jedynie mimochodem jako potencjalna sympatia Daniela Radcliffe'a. On sam, podobnie jak pozostali aktorzy, opisani zostali według pięciu kluczy: Tak się zaczęło, Bilet do Hogwartu zdobył.., Jego kinowy [sic!] bohater..., Czym Cię zaczaruje? oraz Kto go oczarował? Kilkuzdaniowe odpowiedzi, uzupełnione zdjęciami aktorów, i określeniami charakterystycznymi dla pisma (jak choćby „serducho”) niewolne były jednak od błędów (na przykład dla autorki tekstu Draco Malfoy stał się „mistrzem quidditcha”, choć czytelnicy powieści wiedzą, że do mistrzostwa w tym „magicznym sporcie” było mu daleko). „asz” zapomniała również o choćby jednozdaniowym napomknięciu o twórczyni postaci, w role których wcielili się „Most Wanted”85.

Wydaje się, że podane przykłady w pełni oddają nastawienie periodyku do interesujących nas zagadnień. Redakcja uznała, że czytelniczki pisma nie będą zainteresowane bliższym poznaniem na jego łamach znanych pisarzy (choćby J. K. Rowling czy A. Sapkowskiego). Być może obawiano się, że nie będą one wiedziały, kim oni są (świadczy o tym na przykład wyjaśnienie redakcji, pojawiające się choćby w jednym z przytoczonych tekstów, gdzie informowano, kto jest autorem powieści David Copperfield), i napotkawszy ich nazwiska, nie zatrzymają się dłużej przy proponowanym tekście. Jednocześnie brak odwołań do pierwowzorów literackich, krótkich choćby wzmianek dotyczących autorów zekranizowanych powieści świadczy z jednej strony o lekceważącym podejściu i deprecjonowaniu słowa pisanego, z drugiej o braku profesjonalizmu (wydaje się, że pisząc o adaptacji znanej powieści należałoby wspomnieć o jej twórcy...), a także, być może, o określonej ocenie poziomu wiedzy czytelniczek magazynu oraz zakresu ich zainteresowań.

Kolejnym dowodem potwierdzającym powyższe uwagi, a być może także prostą konsekwencją traktowania przez periodyk spraw związanych z książką, jest minimalne poświęcenie jej uwagi poprzez zamieszczanie

84 „Bat” (wysłuchała), Dwie wieże „Dziewczyna” 2003, nr 5, s. 28.

85 Tytuł rubryki, w której zamieszczono opisany tekst. 
dłuższych niż kilkuzdaniowe informacji czy komentarzy, odnoszących się do szeroko rozumianej literatury. Zaledwie trzykrotnie $\mathrm{w}$ ciągu pięciu lat czytelniczkom miesięcznika zaproponowano lekturę związaną z tą problematyką. Dwukrotnie zamieszczono tekst, poświęcony komiksowi. Jeden $\mathrm{z}$ nich pojawił się pod znamiennym tytułem Batman zamiast Sienkiewicza ${ }^{86}$. W drugim przyznawano, że „bohaterów komiksów można spotkać już nie tylko w książkach. Tego lata zdobią nasze ubrania i gadżety..." ${ }^{87 .}$

Ostatnia publikacja, związana z książką, dotyczyła cyklu o Harrym Potterze ${ }^{88}$. Autorka, Anna Gortatowicz, nakreśliła ogólną fabułę powieści, przypomniała jej początki, nie omieszkała zaproponować „Dobrych stron Harry`ego po polsku, po angielsku i po niemiecku”, czyli witryn internetowych, związanych ze znanym bohaterem. Zadała także pytanie („Czemu Harry Potter jest the best?"), ale nie podzieliła się z czytelniczkami swoim zdaniem na ten temat, odwołując się do opinii internautów. Czytelnicy mogli również sprawdzić, czy zapadli już na „Potteromanię”, korzystając z „Potterotestu”, zamieszczonego obok publikacji, którą uzupełniło również przypomnienie o przeniesieniu na srebrny ekran powieści.

Częste odwoływanie się do informacji związanych z filmem było charakterystyczne dla omawianego pisma $w$ tym okresie (tego typu wzmianek było $\mathrm{w}$ sumie 35). Poza przywołanymi wcześniej przykładami, nierzadko zamieszczano na jego łamach omówienie kolejnej ekranizacji. Niemal wszystkie tego typu informacje pojawiły się w ramach działu kulturalnego, w zmieniającej swą nazwę rubryce: $d v d$, kino, wideo. Obejmowały kilka lub kilkanaście zdań, uzupełnionych danymi związanymi z filmem (podawano zazwyczaj nazwisko reżysera, aktorów, grających główne role, rok produkcji, niekiedy ocenę), nierzadko urozmaiconych zdjęciem z planu filmowego lub kadrem z filmu. Pisano na przykład o ekranizacji kolejnych tomów Harry Pottera, trylogii J. R. R. Tolkiena, Dziennika Bridget Jones, ale również o Wiedźminie, W 80 dni dookoła świata czy Autostopem przez Galaktykę. Omówiono również ekranizację lektur szkolnych: W pustyni i w puszczy oraz Zemsty.

\subsection{Pod kolor ${ }^{89}$ : konkursy i akcje}

Podobnie, jak w przypadku wcześniej opisanych form informacji o książce, tak i w odniesieniu do konkursów, inicjatywy, które zaliczono do tej kategorii, były bardzo luźno związane z interesującą nas problematyką.

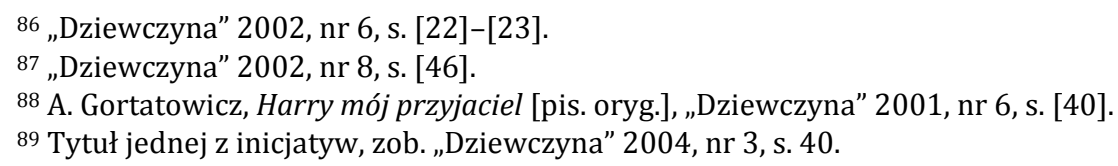


Magazyn nie mógł poszczycić się cyklicznie organizowanymi przedsięwzięciami o charakterze literackim ani nawet sporadycznymi przedsięwzięciami, które można zaliczyć do projektów, ściśle związanych z książką, wykorzystujących na przykład znajomość wybranych tytułów bądź rozwijających zdolności pisarskie czytelników. Stąd wprowadzenie w tym miejscu podziału, proponowanego $\mathrm{w}$ analogicznym częściach wcześniejszych rozdziałów, w tym przypadku jest niemożliwe.

Wśród kilku inicjatyw, które odwoływały się w pewnym stopniu do umiejętności prozatorskich adresatek pisma, można wymienić na przykład konkurs Ale obciach!, polegający na opisaniu przez czytelniczki historii, w której stały się one bohaterkami niezręcznej sytuacji. Najzabawniejsze opisy tego typu przygód drukowano na łamach magazynu, a ich autorki otrzymywały nagrody (m.in. maskotki, plecaki, kosmetyki) ${ }^{90}$. Ze szkołą związany był kolejny „superkonkurs”: należało wymyślić i opisać najskuteczniejszy sposób uczenia się do klasówek i sprawdzianów, metodę, która byłaby nie tylko efektywna, ale i łatwa oraz przyjemna. Nagrodą dla najbardziej pomysłowych był jeden z 12 zestawów multimedialnych podręczników szkolnych ${ }^{91}$.

Oryginalną inicjatywą była propozycja, by czytelniczki opisały swoją wizję świata na Ziemi za 100 lat. Ale i w tym przypadku nie zapominano, co przede wszystkim interesuje adresatki magazynu, prosząc, by opisały one, jak według nich „może wyglądać życie młodych dziewcząt za 100 lat. Jak będą dbały o urodę, jakie to makijaże będą wtedy modne, a może ktoś już wynajdzie niesamowity kosmetyk typu $6 \mathrm{w}$ jednym?"92.

Kilkakrotnie zachęcano, by nastolatki wykazały się zdolnościami „poetyckimi”, na przykład wymyślając krótką, rymowaną sentencję, zawierającą słowo MTV (konkurs zorganizowany z okazji pierwszych urodzin polskiej edycji programu MTV) ${ }^{93}$. Nagrodą dla 10 najoryginalniejszych i najzabawniejszych pomysłów były modne gadżety. Innym pomysłem była propozycja ułożenia wierszowanego wyznania miłości ${ }^{94}$.

Drugą grupę tego typu inicjatyw stanowiły konkursy, w których książka była nagrodą, zazwyczaj jedną z kilku, na przykład za prawidłowe rozwiązanie krzyżówki lub najciekawszy list. W ten sposób czytelniczki mogły wzbogacić swoją domową biblioteczkę o na przykład polecaną na łamach

90 Zob. np. „Dziewczyna” 2004, nr 12, s. 66. Ten konkurs był kontynuowany w kilku kolejnych numerach.

91 „Dziewczyna” 2001, nr 11, s. [65].

92 „Dziewczyna” 2001, nr 11, [73].

93 „Dziewczyna” 2001, nr 9, s. [11].

94 „Dziewczyna” 2004, nr 3, s. 40. 
miesięcznika książkę Między nami kobietami, 7 nawyków skutecznego nastolatka czy Wszystko OK.? Psychologia dla nastolatków. Nagrodą za najbardziej interesujący list przysłany do redakcji, był także, obok jego wydrukowania, niekiedy zestaw książek (na przykład powieści Grażyny Bąkiewicz lub Manueli Kalickiej). Raz multimedialne podręczniki stały się nagrodą za najbardziej oryginalny pomysł ułatwiający „wkuwanie bez stresu”, przysłany przez czytelniczki.

Pomimo, że adresatki miesięcznika często komentowały tematy, poruszane na jego łamach, przysyłając swoje opinie, to $\mathrm{w}$ odniesieniu do informacji o książce zaledwie czterokrotnie pojawił się głos, nawiązujący do książki, który redakcja wydrukowała wśród innych listów. Jedna z czytelniczek dziękowała za zamieszczenie artykułu o Harrym Potterze, przyznając: „Zachęciliście mnie do przeczytania książki, choć wcale nie zamierzałam po nią sięgać, bo sądziłam, że mi się nie spodoba" 95 , przy okazji zaś proponowała innym dziewczętom, by sięgnęły po jej własne „ostatnie superodkrycie” w postaci Buszującego w zbożu Jerome`a D. Salingera. Z kolei w odpowiedzi na kolejny list redakcja wyjaśniała, na czym polega zjawisko bookcrossingu.

Na koniec warto zatrzymać się przy ostatniej z wymienionych kategorii, określonej mianem Inne.

Systematycznie na łamach pisma drukowano dwie formy, spotykane zazwyczaj na łamach periodyków młodzieżowych. Pierwszą były opowiadania. Zamieszczano je do numeru 2 w 2004 r. włącznie, zajmowały one dwie strony, zazwyczaj w drugiej części pisma, w ramach działu Ona i on. Nazwa ta wskazywała wyraźnie na temat umieszczanych tu opowiadań. Krótkie wprowadzenia oddawały ich klimat:

Joanna po rozstaniu z Pawłem nie może wcale dojść do siebie. Nawet nie chce bawić się w sylwestrową nocy, woli sama zostać w domu. Na szczęście nagle pojawia się... niespodziewany gośćc6.

Wakacje to... straszne nudy! Bo co ma robić dziewczyna, której paczka wyjechała w siną dal, chłopak ją rzucił przed miesiącem i nic się wokół niej nie dzieje? Wejść na czat!97

Pech chciał, że siostry - Aśka i Magda zakochały się w tym samym chłopaku. Czy ta miłość je rozdzieli? Jakie znajdą wyjście z sytuacji? No i którą z nich wybierze Marcin? ${ }^{98}$

\footnotetext{
95 Dominika [czytelniczka], Kocham Harry’ego, „Dziewczyna” 2001, nr 10, s. [73].

96 „Dziewczyna” 2001, nr 1, s. 50.

97 „Dziewczyna” 2002, nr 8, s. 62.

98 „Dziewczyna” 2003, nr 5, s. 60.
} 
Czy zmiana wyglądu będzie dla Baśki powodem upadku, czy wręcz przeciwnie - dzięki niej przeżyje nareszcie prawdziwe miłosne uniesienia? ${ }^{99}$

Przykłady, reprezentatywne dla wszystkich opowiadań, drukowanych w periodyku, wskazują na główne wątki, opisywane przez autorów tych historii: (M. Kowalską, B. Łukasiewicz oraz Magdę i Betę). Rozstanie z chłopakiem, nieszczęśliwa miłość, niespodziewane, a pomyślne rozwiązanie problemów... oto, co stanowiło przedmiot opisywanych historii. Znamienne były rady, które dawano czytelniczkom na wypadek, gdyby znalazły się w podobnych do opisywanych sytuacjach: na przykład, znakomitym lekarstwem na nudę będzie nie książka, ale czat, który równie skutecznie (a nawet bardziej) jak zajmująca lektura oderwie myśli znudzonej nastolatki od niewesołych refleksji. Czytając, może co najwyżej przenieść się w wymyślony świat i poznać nie istniejących bohaterów, a Internet stwarza nieograniczone wręcz możliwości poznawania nowych ludzi, w tym i tego wymarzonego księcia, który ukoi żal za byłym chłopakiem.

Proste, niemal banalne historie, zawsze kończące się szczęśliwie, nie niosły ze sobą głębszych wartości ani nie odwoływały się do żadnych wzorów kulturowych, w tym wątków czy bohaterów literackich. A przecież w literaturze nie brak historii wielkich miłości, do których można byłoby się odnieść, poszerzając tym samym horyzonty poznawcze czytelniczek „Dziewczyny”. Jednakże, ponieważ pismo nastawione było przede wszystkim na rozrywkę, nie korzystano z takich wzorów, które wymagałyby większego wysiłku umysłowego, a (co gorsza) mogłyby się negatywnie kojarzyć większości adresatek pisma, dla których książki, jak się zdaje, wiązały się głównie z nudną lekturą obowiązkową w szkole.

Podobny do opowiadań charakter miały fotostory, drukowane (poza kilkoma numerami) na łamach pisma przez cały badany okres. Odnaleźć je można było $\mathrm{w}$ dziale Chwila dla Ciebie, zajmowały średnio 4 strony w drugiej części magazynu. I tu przedstawiano sytuacje potencjalnie możliwe, w których wątek konfliktu na tle miłosnym pojawiał się niemal w każdej historii:

Kiedy Laura poznaje Dawida, tak jej wpada w oko, że nie zamierza dzielić się nim z siostrą... Jednak sprytna Lucyna bardzo dba o to, by chłopak nieświadomie spotykał się zarówno z jedną, jak i drugą siostrą... ${ }^{100}$.

Ania chciałaby zdobyć serce Tomka. Bajkowa sceneria wydaje się do tego celu idealna. Tylko czy chłopak będzie zdecydowany?101

99 „Dziewczyna” 2004, nr 2, s. 58.

100 „Dziewczyna” 2002, nr 2, s. 44. 
Manuela w ogóle nie myśli o chłopakach, tylko o tym, by zostać sławną DJ-ką. Czy spotka kogoś, kto odmieni jej pogląd na tę sprawę?102

Podobnie jak w przypadku opowiadań, także i tu opisywane perypetie miłosne zawsze kończyły się happy endem.

Obydwie formy zastępowały fragmenty książek, drukowane w „Filipince", których, co znamienne, zabrakło w omawianym magazynie.

W 2002 r., od numeru 3 pojawił się na łamach pisma minikomiks Zuza. Były to krótkie, zabawne historyjki, drukowane na początku bądź w drugiej części pisma.

Jednak, podobnie jak w przypadku czasopisma „Filipinka”, tak i na łamach „Dziewczyny” pojawiały się sporadycznie zamieszczane wzmianki o charakterze ciekawostek, związanych z książką. Ale i te, nieliczne zresztą informacje, miały swoisty dla magazynu charakter. Na przykład, informowano czytelniczki o tym, że muzycy, Mary J. Blige, Ice-T, Busta Rhymes oraz Qeen Latifah, postanowili, korzystając z pomocy pisarki, Denise McIver, napisać książkę, w której zamierzali ostrzec młodych ludzi „przed zagrożeniami oraz pokusami życia"103. Pisano o panującej modzie na komiksy i ekranizacji Tytusa, Romka i A'Tomka, pojawieniu się kolejnego tomu o Harrym Potterze. Zapowiadano również książkę Willa Smitha, który uważając się za przykładnego tatę, postanowił wydać poradnik dla przyszłych ojców. Tego typu wzmianek, choć pośrednio nawiązujących do książki, było niewiele. Nieco częściej polecano dany tytuł przy okazji poruszania określonego problemu. Na przykład, pisząc o tym, jak pokonać nieśmiałość, zalecano przy okazji lekturę Carlson Dale i Carlson Hannah Wszystko OK.? Psychologia dla nastolatków, opisując problem społeczny, jakim jest hazard, odsyłano do książki Marka Griffithsa Gry i hazard. Uzależnienia dzieci $w$ okresie dorastania. Wybrane lektury proponowano również w rubryce Nie z tej ziemi, gdzie pisano na przykład o klątwach (wtedy radzono sięgnąć po książkę Anny Engelking Klątwa. Rzecz o ludowej magii słowa), czarownicach (żeby poszerzyć swoją wiedzę na ich temat, należało przeczytać dodatkowo Czarownice Erici Jong), potworach (tu radzono Yeti. Legendę i rzeczywistość Reinholda Messnera).

Znając słabość czytelniczek pisma do celebrytów, redakcja podjęła inicjatywę, polegającą na zasięganiu opinii znanych osób na temat wybranych przez nie książek. W roku 2001 (w wydaniu lutowym) na łamach miesięcznika gościła Neve Campbell, która wyznała, że jej ulubioną książką jest

\footnotetext{
101 „Dziewczyna” 2005, nr 12, s. 70-73.

102 „Dziewczyna” 2003, nr 4, s. [56]-59.

103 „Dziewczyna” 2002, nr 5, s. 10.
} 
Prorok Khalila Gibrana. Natomiast w 2002 r. w czterech kolejnych wydaniach (numery 2-5) lektury „do poduchy”104 polecali: „Karola z MTV” (proponowała Kościarza Luke Rhineharta), „Gosia, Viva Polska” (polecała Grę na wielu bębenkach O. Tokarczuk), „Natasha z Atomic Kitten” (była oczarowana pierwszą częścią cyklu o Harrym Potterze), „Tim z B3” (jego ulubioną książką okazał się Wywiad z wampirem Anne Rice). W wydaniu marcowym rok później (2003) zapytano Maćka Rocka o jego ulubione lektury. I on przyznał, że „pochłonął” serię o małym czarodzieju, ale sięga również chętnie po prozę Johna Grishama i Stephena Kinga.

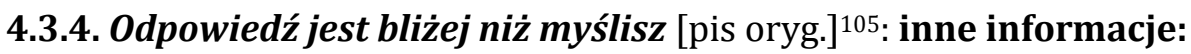 o prasie i środowisku dziennikarskim}

Na łamach „Dziewczyny” w badanym okresie zabrakło tekstów ściśle dotyczących prasy; sporadycznie drukowano wzmianki o znanym aktorze lub piosenkarzu, którzy oskarżali dany periodyk o zamieszczenie niepochlebnej na ich temat opinii ${ }^{106}$. Natomiast znaczną grupę związaną z prasą stanowiły reklamy, proponujące inne czasopisma, w znacznej mierze znajdujące się w portfolio wydawcy omawianego magazynu.

Ogółem w tego typu ogłoszeniach pojawiło się dziewięć tytułów czasopism. Najczęściej reklamowano inny miesięcznik młodzieżowy: „Popcorn” (44 razy), następnie "Oliwię” (28-krotnie), „Popcorn Stars” (21 razy). Pozostałe tytuły to: „Fakt”, „Komputer Świat”, „Komputer Świat. Gry”, „Na żywo”, „Pani Domu”, „Sekrety Serca”.

Bardzo rozwinięta była również autopromocja omawianego magazynu oraz inicjatyw przezeń podejmowanych. W każdym numerze reklamowano następne wydanie "Dziewczyny”, informowano także o specjalnych wydaniach pisma (na przykład „Dziewczyna. Lato \& Luz” czy „Dziewczyna. Nastolatki \& Miłość"). Ogłoszenia zajmowały zazwyczaj całą stronę lub średniej wielkości moduł, umieszczany u dołu lub z boku strony. Drukowano je w całym magazynie, bez przypisanych im stałych miejsc. Poniżej przedstawiono kilka przykładowych ogłoszeń (zdjęcia 181-185).

104 Tak tytułowano tę formę informacji.

105 Hasło reklamowe jednego z ogłoszeń promujących czasopismo „Komputer Świat”, „Dziewczyna” 2004, nr 2, s. [51].

106 Zob. np. „Dziewczyna” 2004, nr 5, s. [14]. 


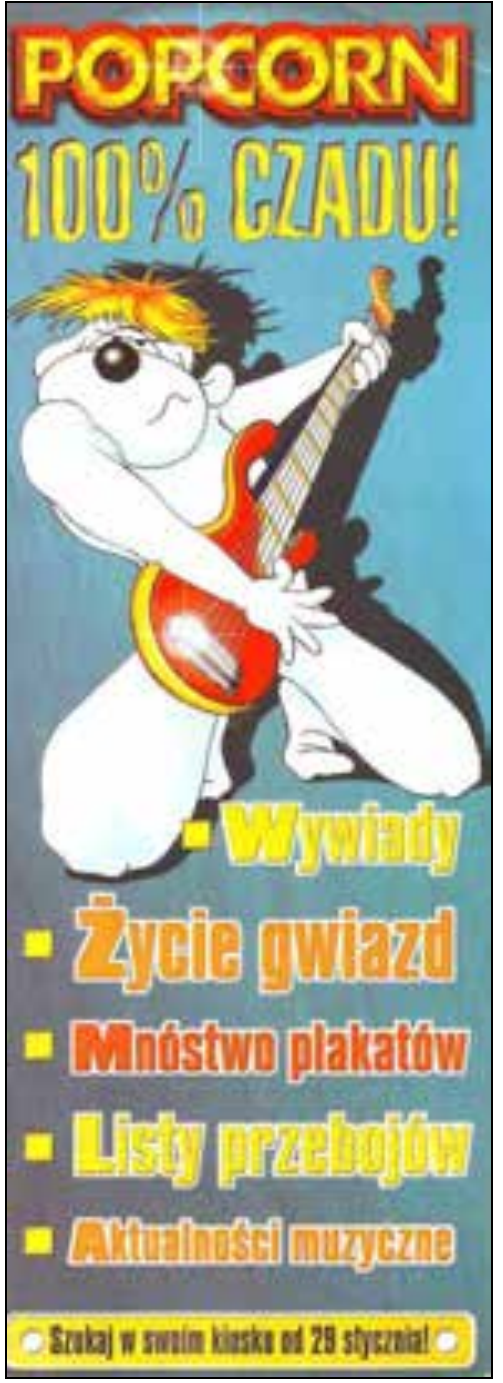

Zdjęcie 181. Wybrane ogłoszenie wydawnicze zamieszczone na łamach „Dziewczyny” „Dziewczyna” 2002, nr 2, [69]

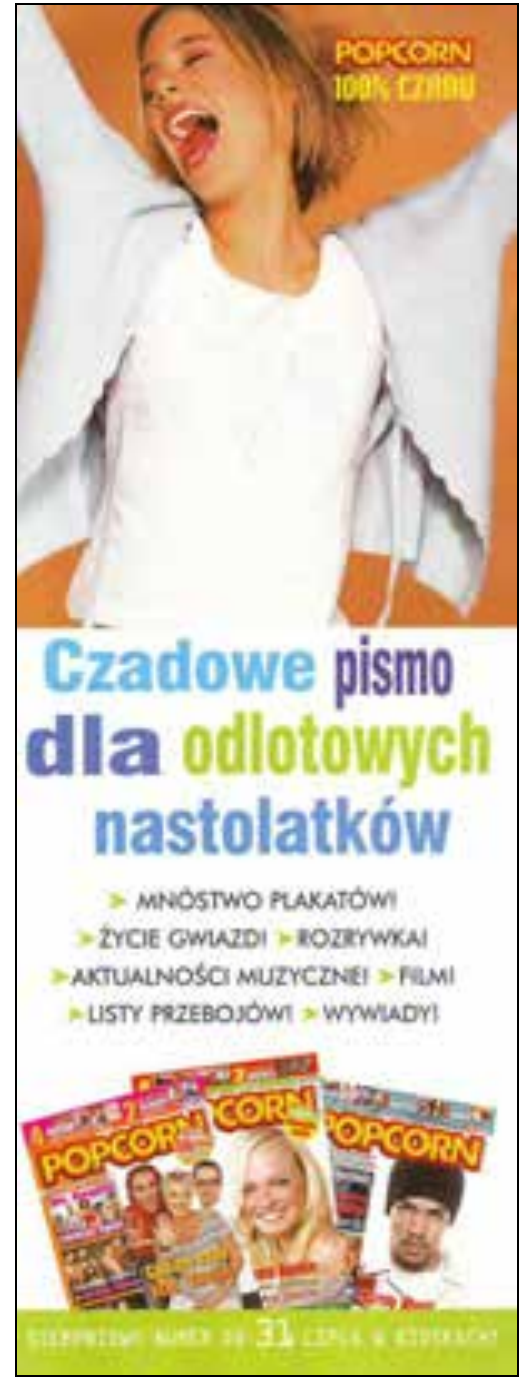

Zdjęcie 182. Wybrane ogłoszenie wydawnicze zamieszczone na łamach „Dziewczyny” „Dziewczyna” 2001, nr 8, s. 71 


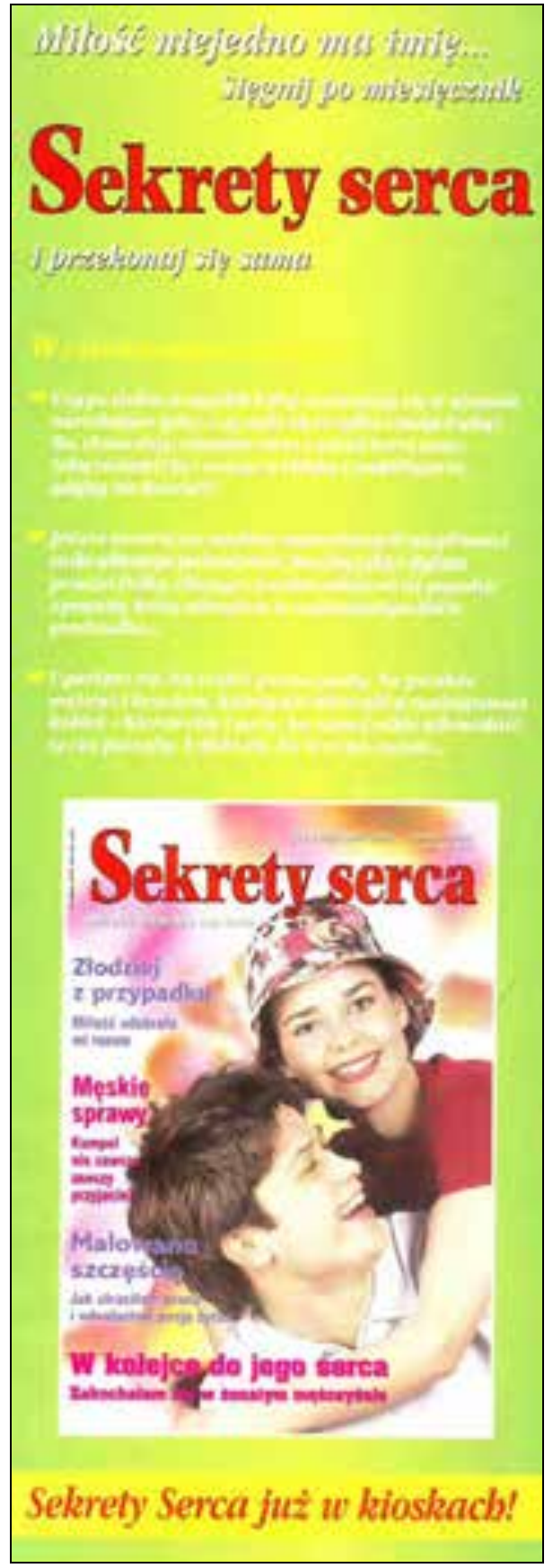

Zdjęcie 183. Wybrane ogłoszenie wydawnicze zamieszczone na łamach „Dziewczyny” „Dziewczyna” 2001, nr 7, s. [61] 


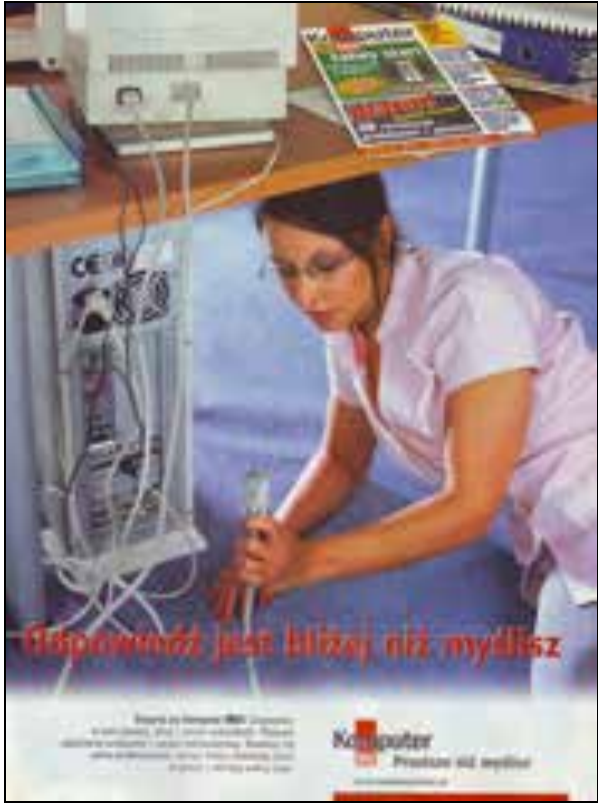

Zdjęcie 184. Wybrane ogłoszenie wydawnicze zamieszczone na łamach „Dziewczyny” „Dziewczyna” 2004, nr 2, s. [51]

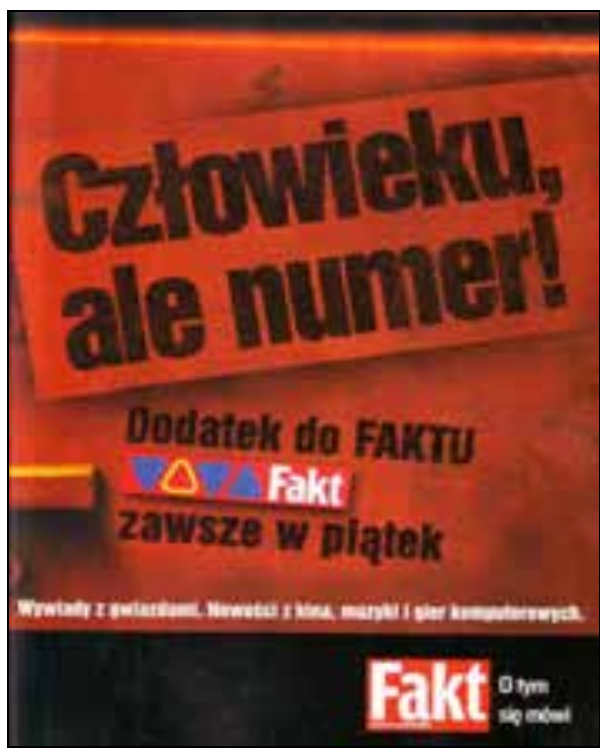

Zdjęcie 185. Wybrane ogłoszenie wydawnicze” zamieszczone na łamach „Dziewczyny” „Dziewczyna” 2004, nr 10, s. [33]

Podobnie, jak cała zawartość magazynu, tak i reklamy były bardzo kolorowe, przy czym w niemal każdej z przytoczonych powyżej dodatkowo uwagę zwracały hasła. W niektórych przypadkach określały one adresata: „dla odlotowych nastolatków” (zdjęcie 182), w innych podkreślały zawartość proponowanego periodyku: „wywiady, życie gwiazd, mnóstwo plakatów..." (zdjęcie 181), w jeszcze innych odnosiły się do przedstawionej sytuacji (zdjęcie 184) lub prezentowały sobą grę słów (zdjęcie 185).

Równie kolorowo prezentowały się ogłoszenia o charakterze autopromocyjnym (zdjęcie 186).

W przypadku reklam, zapowiadających wydania specjalne magazynu, na przykład z okazji zbliżających się wakacji, pamiętano zawsze o zaprezentowaniu nie tylko okładki danego tytułu, ale również wybranych stron i wypunktowaniu tematów, które można było znaleźć wewnątrz polecanego numeru. Natomiast proponując kolejne edycje najpierw kasety, a następnie płyty CD z wybranymi przebojami, podawano zazwyczaj, obok kopii okładki, także datę ukazania się w sklepach danego krążka. 


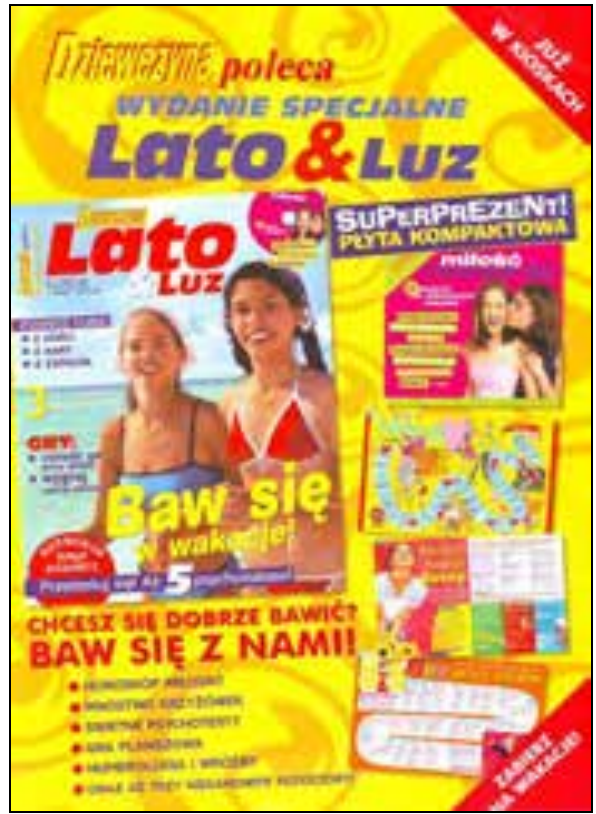

Zdjęcie 186. Wybrane ogłoszenie wydawnicze zamieszczone na łamach „Dziewczyny” „Dziewczyna” 2001, nr 9, [23]

Porównując ogłoszenia reklamujące czasopisma czy promujące akcje, inicjowane przez magazyn, $\mathrm{z}$ inseratami dotyczącymi książek, należy powiedzieć, że pierwsze $\mathrm{z}$ nich były nie tylko liczniejsze, ale i barwniejsze, bardziej pomysłowe, zwracały też większą uwagę choćby dzięki swej powtarzalności.

Analizując zawartość miesięcznika „Dziewczyna” można wysunąć konkluzję, iż życie współczesnych nastolatek obraca się wokół mody, kosmetyków i potencjalnych wielbicieli, których należy (za wszelką cenę) mieć jak najwięcej. Porady, jak dbać o siebie, by podobać się płci przeciwnej, rady, jak zdobyć chłopaka, a następnie urozmaicić związek, by zainteresowanie wymarzonego adoratora nie przeniosło się na najlepszą przyjaciółkę, zajmowały znaczną część pisma. W omawianym magazynie koncentrowano uwagę przede wszystkim na tematyce towarzyskiej, sensacyjnej, erotycznej, a także do pewnego stopnia astrologicznej (wyraźne upodobanie do horoskopów, omawianie cech charakteru odpowiadających poszczególnym znakom zodiaku, analizowanie zachowań pod ich kątem, częste psychotesty). Natomiast kwestie kulturalne, związane zresztą przede wszystkim $\mathrm{z}$ elementami kultury masowej, traktowane były jako rodzaj urozmaicenia zawartości pisma, jeden ze składników rubryk, poświęconych „wielkiemu światu”, gdzie pisano o życiu prywatnym gwiazd, szczególnie idoli zagranicznych.

Należy przy tym zwrócić uwagę na dwa fakty opisane wcześniej: jedną sprawą był dobór tematyki, także tej związanej z książką, poruszanej na łamach pisma, drugą - forma jej prezentacji. 


\title{
4.4. „Cogito. Szkoła. Matura. Studia. Życie”
}

\subsubsection{Pomyśleli, zaistnieli ${ }^{1}$ : historia czasopisma}

\begin{abstract}
Nie wchodzimy w tematykę innych pism. Nie piszemy o urodzie, modzie czy sporcie. [...] Pod względem merytorycznym nie mamy konkurencji. Nasi autorzy to ludzie młodzi, w większości studenci. Doskonale wiedzą, co chcą czytać ich koledzy².
\end{abstract}

Ostatnie z omawianych pism, zupełnie odmienne pod względem merytorycznym w porównaniu z dwoma wcześniej przedstawionymi czasopismami, adresowanymi do młodzieży, to przykład udanej realizacji ciekawego pomysłu dwojga amatorów, nie mających doświadczenia w branży wydawniczej i jednocześnie dowód na to, że w latach 90. XX w. możliwe było zaistnienie na polskim rynku prasowym wartościowego periodyku, nie poprzedzone większą kampanią reklamową czy badaniami marketingowymi.

Pismem tym jest „Cogito” z określającym jego zawartość podtytułem „Szkoła. Matura. Studia. Życie”. Dzieje tego periodyku toczyły się, w przeciwieństwie do historii wcześniej omawianych czasopism (zwłaszcza pierwszego z nich), bez szczególnych zawirowań. Od pierwszego numeru (w 1994 r.) do ostatniego badanego w 2005 r. właścicielem tytułu pozostawał ten sam wydawca, nie zmienił się również jego redaktor naczelny. Formuła pisma, jakkolwiek w ciągu 11 lat ulegała nieznacznym zmianom, pozostawała wierna pierwotnym celom, założonym przez jego inicjatorów. Periodyk nie był przedmiotem zbyt wielu opracowańn ${ }^{3}$, a jego (nieregularna) reklama ograniczała się głównie do wybranych czasopism kobiecych. Pomimo, że nie był nagradzany tak często jak inne pisma, zyskał jednak dużą popularność wśród młodzieży, osiągnął stałą pozycję na rynku, a w badanym okresie nie posiadał pod względem proponowanych treści konkurencji.

Pierwszy numer „Cogito” ukazał się 14 lutego 1994 r. Założycielami periodyku było małżeństwo nauczycieli: Katarzyna i Zbigniew Drodzy.

1 Tytuł publikacji poświęconej dwutygodnikowi „Cogito”, zob. „Press” 1998, nr 11, s. 62.

2 „Press” 1998, nr 11, s. 62.

${ }^{3}$ Kwerenda pozwoliła ustalić, że poza drobnymi publikacjami lub wzmiankami w prasie głównie branżowej lub krótkimi odwołaniami w tekstach poświęconych czasopismom młodzieżowym, pojawiły się trzy dłuższe omówienia wybranego tytułu, z których dwa poświęcono w znacznej mierze jego wydawcom. Zob. D. Binkiewicz, Pomyśleli, zaistnieli, „Press” 1998, nr 11, s. 62; A. Paciorek, Pięciolatek „Cogito” $i$ jego młodszy brat, „Rzeczpospolita" 1999, nr 35, s. 4-5; A. Uljasz, Prasa popularnonaukowa we współczesnej Polsce a edukacja humanistyczna i kulturalna młodzieży. Czasopisma „Cogito”, „Rocznik BibliologicznoPrasoznawczy" 2012, nr 4/15, s. 141-155 
Ucząc w liceum, poznałam zainteresowania i potrzeby młodych ludzi. Na rynku nie było wówczas pisma o szkole, przygotowywaniu się do matury i zdawaniu na studia. Postanowiliśmy więc z mężem wypełnić tę lukę 4 .

- wspomina pomysłodawczyni, K. Droga, dodając:

Wymyśliłam tytuł Cogito na zasadzie skojarzenia [...] bo było pismo „Jestem”, może więc być też „Myślę”. I ma ładny kontekst - Herbert, Kartezjusz ${ }^{5}$.

W ten sposób na rynku pojawiło się nowe czasopismo, o odmiennym charakterze od dotychczas dostępnych, adresowane do młodzieży w wieku 15-19 lat. Pierwszy numer liczył 40 stron, a jego nakład wynosił 40 tys. egz. W Słowie do czytelnika pisano:

Wierzymy, że kluczem do rozwiązania zagadki życia jest... myślenie. Stara ludzka przypadłość, przepraszam, stara ludzka umiejętność człowieka. [...] Myślę - wątpię - pytam szukam. To obliguje twórców pisma "Cogito” do wspomagania tych działań, zbierania informacji, podpowiadania różnych możliwości ${ }^{6}$.

Zaprezentowano obszernie również potencjalnego adresata nowego periodyku:

to młody człowiek, który należy do myślących i ambitnych. Stojąc u progu dorosłego żywota, nasz Ktoś (dziewczyna lub chłopak) rozgląda się i pyta o pracę, naukę, turystykę, rozrywkę, itd. Nie ukrywam, że nasz Ktoś to „człowiek uczący się" - czyli szkoła i plany edukacyjne zajmują w jego życiu ważne miejsce, a zatem w naszym piśmie też. I jeszcze - nasz Ktoś lubi wiedzieć - wiele wiedzieć o dziedzictwie kulturowym człowieka, lubi pofilozofować, włączyć się do dyskusji, lubi czasem pomyśleć indywidualnie7.

W pierwszym numerze wydrukowano także rodzaj motta: „Żaden zegar nie da ci wskazówek do życia" (S. Lec).

K. i Zb. Drodzy byli w tym czasie właścicielami Wydawnictwa AgaPress, założonego przez nich w 1991 r. Przez niemal rok, do momentu wydrukowania pierwszego numeru "Cogito”, wydawali poradniki polonistyczne i repetytoria maturalne, teraz zajęli się również przygotowaniem periodyku, określając od początku jego częstotliwość jako dwutygodnik. Przez pierwszych kilka miesięcy nieformalna redakcja składała się głównie z zaprzyjaźnionych z założycielami pisma nauczycielami. Nowy tytuł zdobył czytelników pomimo oferowania treści odmiennych od drukowanych na łamach omawianych wcześniej miesięczników: „Filipinki” i „Dziewczyny”

\footnotetext{
${ }^{4}$ A. Paciorek, Pięciolatek..., s. 4.

5 Ibidem.

6 „Cogito" 1994, nr 1, s. [1].

${ }^{7}$ Ibidem.
} 
oraz mimo dość ubogiej formy. Przetrwał pierwszy rok, wypełniając istniejącą wówczas niszę rynkową, a jego sprzedaż zaczęła przynosić zyski właścicielom. W 1995 r., w numerze jubileuszowym, K. Droga pisała:

przez minionych dwanaście miesięcy udało nam się skupić wokół tego pisemka wyznawców kultu głowy i zwolenników korzystania z rozumu. [...] Udało nam się pomóc przynajmniej części z Was w ważnych życiowych chwilach ${ }^{8}$.

Już wtedy wprowadzano pierwsze zmiany w wyglądzie pisma i jego zawartości, drukując nowe rubryki, kierując się przy tym opiniami czytelników, zawartymi zarówno w licznych listach, jak i ankietach dotyczących dwutygodnika.

Ambitny periodyk spodobał się wielu nastolatkom, którzy nie szczędzili pochwał pod jego adresem:

Gazeta jest wspaniała taka, jaka jest i niech się nie zmienia [...] Jestem siedemnastolatkiem, więc problemów z maturą jeszcze nie mam [...], ale Waszą gazetę czytam dlatego, że jest fajna 9 .

Rzadko pojawiały się głosy krytyczne, ale i te drukowano na łamach pisma: „Zadziwia to, co dzieje się $\mathrm{w}>$ Cogito<, zadziwia uparte forsowanie uniwersalno-nijakiej formuły pisma..." 10 .

Jednak potwierdzeniem popularności nowego tytułu stał się rosnący nakład kolejnych wydań, który w 1998 r. wyniósł 170 tys. egz., przy sprzedaży ok. 70-80\%11. Zwiększała się również objętość pojedynczego numeru: w 1995 r. wynosiła ona średnio 60 stron, wtedy też, jak wspomniano powyżej, wprowadzono pierwsze zmiany $\mathrm{w}$ formie graficznej periodyku, dzięki czemu stał się on bardziej przejrzysty. Kolejne drobne modyfikacje zaproponowano czytelnikom rok później, ulepszając także nieco papier, na którym czasopismo było drukowane. Po dwóch kolejnych latach jego objętość ponownie zwiększono (do ok. 70 stron), a w 1998 r. do czytelników trafiały treści zamieszczane na średnio 90 stronach. Warto zaznaczyć, że od 1997 r. zapoczątkowano dołączanie do wydania głównego dodatków specjalnych. Pierwszym z nich była Powtórka z epok (część 1 w 1997 r., część 2 - rok później), w roku następnym pojawił się dodatek Zapytaj o lekturę.

8 K. Droga, Słowo do Czytelnika, „Cogito” 1995, nr 3, s. 2.

9 Tomasz Ż. [czytelnik], Jacy jesteście, jak nas widzicie, „Cogito” 1996, nr 14, s. 50.

10 Damian [czytelnik], Ja i moi znajomi przestaniemy kupować „Cogito”, „Cogito” 1996, nr 1-4, s. 50.

11 „Press” 1998, nr 11, s. 62. 
Po czterech latach istnienia wyraźnie poprawiła się szata graficzna dwutygodnika oraz papier, na którym był drukowany. W 1998 r. „Cogito” zdystansowało pod względem liczby czytelników dwa inne pisma młodzieżowe: „Filipinkę” i „Bravo Sport”12. W ciągu pierwszych siedmiu lat systematycznie zwiększał się również zespół redakcyjny i grupa współpracowników pisma. Wśród nich znaleźli się m.in.: Beata Banaszuk, Ewa Barciszewska, Monika Bartnik, Jolanta Berent, Teresa Chwalińska, Anna Cimoch, Michał Jarnecki, Cezary Korzeniecki, Agnieszka Krasnodębska, Renata Kreczmar, Ludwik Janion, Marcin Łakomski, Joanna Malinowska, Ewa Nowak, Marta Olbryś, Małgorzata K. Piekarska, Dorota Próchniewicz, Jarosław Ruszczak, Ola Siewko, Agnieszka Trojan, Piotr Zakrzewski i Roman Zubczyński.

Powodzenie pisma pozwoliło wydawcy na wprowadzenie we wrześniu 1998 r. na rynek prasowy nowego periodyku. Był to dwutygodnik dla ośmioklasistów „Victor”. Jego formuła zbliżona była do „Cogito”: podstawowy trzon informacji związany był ze szkołą i egzaminami wstępnymi, w tym przypadku do szkół średnich. Jak przyznawał Z. Droga,

To było przemyślane posunięcie [...]. Przez „Victora” wychowujemy sobie czytelnika "Cogito”, nawet szata graficzna obu pism jest podobna. Myślimy, że czytelnicy przejdą naturalnym tokiem do „Cogito”13.

Jednocześnie sukces czytelniczy i finansowy związany z „Cogito” umożliwił zmianę siedziby redakcji: $\mathrm{z}$ niewielkiego, dwupokojowego pomieszczenia przy al. Stanów Zjednoczonych $51 \mathrm{w}$ Warszawie przeniesiono się do budynku przy ul Smulikowskiego 4. Wydawca zainwestował we własne studio graficzne, zwiększył również grono współpracowników. Na początku 1999 r. redakcja po raz kolejny zmieniła swą siedzibę. Tym razem wynajęto lokal przy ul. Grochowskiej 316/320. Jednak już w numerze 13 w stopce redakcyjnej ponownie pojawił się dawny adres redakcji, mieszczącej się przy al. Stanów Zjednoczonych. W tym samym numerze redaktor naczelna zapowiedziała zmiany w piśmie, anonsując nowe rubryki oraz ciekawszą szatę graficzną. Periodyk dostosowywał się do wymagającego odbiorcy, który nie był już tak skory do pochwał, jak na początku; obok pochlebnych dla redakcji listów pojawiały się częściej głosy krytykujące zawartość pisma. Warto zacytować jeden z nich:

Od pewnego czasu stwierdzam, że "Cogito" zamieszcza coraz mniej naprawdę ciekawych artykułów. Zastanawiam się, jaki cel Wy jako redakcja sobie stawiacie (oczywiście nie mam tutaj na myśli kwestii maturalno-edukacyjnej). Odnoszę wrażenie, że nic twórczego,

\footnotetext{
12 Ibidem.

13 A. Paciorek, Pięciolatek..., s. 4.
} 
interesującego [...]. Żal mi Was, jeśli naprawdę sądzicie, że istnieje jeden wymiar rzeczywistości. Jak tak dalej pójdzie, zginiecie w powodzi innych tego typu czasopism, tak samo jednolitych, wiernych "rzeczywistej prawdzie” i nudnych ${ }^{14}$.

Redakcja dokładała starań, by ten niekorzystny wizerunek zmienić. Od numeru 13 (1999) pojawiły się nowe rubryki, zaś od następnego wydania zaczęto dołączać do pisma dodatek specjalny Epoka, w którym omawiano wybraną epokę literacką. Od numeru 15 wyraźnie zmieniła się makieta dwutygodnika, dzięki czemu stało się ono bardziej kolorowe, wyraziste i nowoczesne. W tym czasie tytuł zaistniał w Internecie: w numerze 14 (1999) w stopce redakcyjnej pojawił się adres e-mailowy redakcji: cogito@cogito.com.pl. Poczynione zmiany znalazły uznanie w oczach czytelników ${ }^{15}$, pomimo że jednocześnie cena periodyku wzrosła.

W tym samym roku (1999), we wrześniu wydawca wprowadził na rynek nowy tytuł: miesięcznik „Lider Przyszłości”. W zamierzeniu wydawcy był on adresowany do tych czytelników, którzy swoją zawodową przyszłość wiązali z polityką, prawem, biznesem lub mediami. Na zawartość nowego pisma składać się miały m.in. informacje, dotyczące określonych kierunków studiów, prezentacja wybranych partii politycznych, a także wywiady z politykami.

Jednocześnie systematycznie zwiększała się objętość „Cogito”: w 1999 r. wynosiła średnio 100 stron, rok później ok. 110. W okresie objętym badaniem periodyk liczył średnio 98 stron, jego format był kilkakrotnie zmieniany ${ }^{16}$. W ciągu pięciu lat dwutygodnik kilkakrotnie zmieniał również szatę graficzną oraz nazwy działów i rubryk. Modyfikacje w jego układzie i formie nie są tematem niniejszej książki, należy jednak zauważyć, że polegały one głównie na wprowadzeniu lepszego jakościowo papieru17, zmianie kroju i koloru czcionki w nazwach działów, rubryk i tytułów publikacji. Zmiany przeprowadzano kilkakrotnie w każdym z badanych roczników ${ }^{18}$. K. Droga pisała w związku z tym:

14 Anka z Olsztyńskiego [czytelniczka], Wypadamy beznadziejnie, „Cogito” 1999, nr 12, s. [111]. Obok cytowanego listu zamieszczono inny, którego autorka dziękowała redakcji za poszerzanie horyzontów i zrozumienie, okazywane nastolatkom.

15 Zob. np. „Cogito” 1999, nr 16, s. 2.

16 Na początku badanego okresu wydawany był w formacie $21 \times 29,5 \mathrm{~cm}$, od numeru 13 (2001) zwiększonym do 23 x 29,5, i ponownie od numeru 12 (2002) zmniejszonym do 22 x $28 \mathrm{~cm}$, od numeru 14 (2003) do formatu 21,5 x $28 \mathrm{~cm}$ i od numeru 1 (2005) zmniejszyć go jeszcze do formatu $20,5 \times 27,5 \mathrm{~cm}$. Niekiedy numery wakacyjne wydawane były w nieznacznie mniejszym formacie.

17 Na przykład od numeru 3 w $2002 \mathrm{r}$.

18 Jak choćby od numeru 12, następnie 13 (2001), w 2002 r. od wydania 11, 12, 18, w 2003 r. od numeru 1, w 2004 r. od wydania 14 i w 2005 r. np. od numeru 1 i 15. 
Myślę, więc... szukam! Szukam - więc zmieniam świat, znajduję skarby jeszcze nieodkryte. Lubię zmiany, lubię ludzi. Jestem z grupy „Cogito” [...]. Ciekawe - jak ocenicie zmiany w „Cogito”? Ja powiem o nich tak: to nie ostatnie! Będziemy się zmieniać. Będziemy poszukiwać19.

Zazwyczaj owe zmiany polegały na ulepszaniu szaty graficznej pisma, ale niekiedy modyfikowano również jego strukturę, wprowadzając doń nowe rubryki, podejmujące lżejsze tematy. Redakcja zdawała się dostrzegać w większym niż wcześniej stopniu fakt, że większość odbiorców pisma stanowią dziewczęta, zainteresowane nie tylko spektakularnym zdaniem matury i pozytywnym wynikiem egzaminu na studia, ale również zajmują je sprawy związane z wyglądem czy relacjami z płcią przeciwną. Stąd pojawił się na przykład Kuferek, rubryka, o której pisano: „pomoże odnaleźć się w świecie urody. Prezentujemy, polecamy sprawdzone kosmetyki. Dzięki nim myślący Kogitowiec ładnie wygląda" 20 .

Wskazane częste zmiany formatu periodyku dowodziły częściowo prób dostosowania się do ówczesnych trendów, panujących wśród pism młodzieżowych, lansujących modę na mniejszy, a zatem bardziej poręczny, wygodny format. Temu celowi służyła także błyszcząca okładka i wprowadzenie żywszych kolorów, również na strony wewnątrz numeru. Stopniowo zwiększał się zespół osób, odpowiedzialnych za formę graficzną pisma.

Jak już wspomniano, przez cały analizowany okres redaktor naczelną pozostawała inicjatorka pisma, K. Droga, jego wydawcą zaś Agencja Wydawnicza Aga-Press S.C, $\rightarrow$ Spółka Jawna, z siedzibą w Warszawie, przy al. Stanów Zjednoczonych 51. Z dawnego zespołu reakcyjnego pozostały trzy osoby: B. Banaszuk, A. Krasnodębska oraz O. Siewko. W trakcie lat objętych badaniem dołączyli do nich m.in: Krzysztof Boczek, Agnieszka Boruszkowska, Monika Cieślik, Joanna Ćwiek, Artur Grabarczyk, Mira Ignatowicz, Magda Kuźnik, Renata Mazurowska, Dorota Nosowska, Małgorzata Olejniczak, Lily Paszkowska, Piotr Piegat, Agnieszka Pietrzykowska, Katarzyna Sobieraj, Eliza Świderska, Joanna Szeligowska, Krzysztof Zadros, Iza Zasłona i Beata Zielińska. Wśród współpracowników pisma, poza wymienionymi wcześniej, znaleźli się m.in. Urszula Bogdalska, Paweł Felis, Paweł Hebda, Lilka Poncyliusz, Jacek Przybylski, Izabela Redlińska, Dariusz Sarzyński, Małgorzata Sobieraj, Beata Stadryniak-Saracyn, Alicja Szewczyk, Ewa Wojtyna, Joanna Wysłowska i Edyta Woźnica.

K. Droga podkreślała, że zawartość dwutygodnika przygotowywana była przez ludzi młodych, znających potrzeby nastoletnich czytelników, z których wybrani po kilku latach stawali się współpracownikami periodyku. Jednocześnie rozbudowywane dodatki specjalne, a także opracowanie rubryk, przygotowujących do matury wymagało nawiązania kontaktów ze specjalistami, głównie nauczycielami szkół średnich.

${ }^{19}$ K. Droga, Słowo do czytelnika, „Cogito” 2005, nr 1, s. [3].

20 „Cogito" 2002, nr 8, s. 106. 


\subsubsection{Zawartość, czytelnicy, akcje}

Jak już zaznaczono, zawartość omawianego pisma różniła się zasadniczo od tej, którą nastoletniemu odbiorcy oferowały inne periodyki młodzieżowe, wydawane w badanym okresie.

Przytoczony na początku rozdziału podtytuł „Cogito” („Szkoła. Matura. Studia. Życie”) określał zarazem jego treść, która w przeważającej części podporządkowana była tematom związanym z edukacją młodzieży szkół średnich i studentów pierwszych lat. Głównym odbiorcą pisma byli jednak maturzyści. Stąd podstawowy trzon informacji związany był ze szkołą i egzaminami: dojrzałości i wstępnymi na wybrane uczelnie. Na łamach periodyku drukowano zatem obszerne powtórki materiału, wymaganego na egzaminach maturalnych. W dwutygodniku przeważała zdecydowanie humanistyka, bo jak przyznawała redaktor naczelna, co prawda „są też chętni do pisania o matematyce, ale żaden humanista zatrudniony w redakcji nie chce podjąć się sprawdzenia zadań"21. Do czytelników trafiały na przykład charakterystyki poszczególnych epok literackich, zasady pisania prac z języka polskiego, wskazówki dotyczące egzaminów ustnych, przygotowywania prezentacji, omówienia zasad nowej matury, gramatyka języków obcych.

Zamieszczano również teksty podejmujące tematy pozaszkolne, związane na przykład $\mathrm{z}$ relacjami pomiędzy nastolatkami a ich rodzicami, pierwszymi miłościami czy odnoszące się do problemów społecznych: narkotyków, alkoholizmu. Jednak zagadnienia, które w innych periodykach młodzieżowych stanowiły trzon ich zawartości, w tym przypadku były raczej uzupełnieniem podstawowych treści.

Tak pomyślanym założeniom odpowiadała struktura dwutygodnika. Należy powiedzieć, że składała się ona raczej z mniejszych rubryk niźli obszerniejszych w swym założeniu działów. Już w pierwszych rocznikach periodyku wyraźne było ukierunkowanie zainteresowań redakcji w stronę funkcji przede wszystkim edukacyjnej, a dopiero później (w znacznie mniejszym stopniu) rozrywkowej. Jakkolwiek rubryki i działy zmieniały kilkakrotnie swoje nazwy, to jednak zawartość merytoryczna pisma tylko w niewielkim stopniu ulegała zmianie. W latach 1994-2000 czytelnicy mieli $\mathrm{z}$ jednej strony do wyboru takie rubryki, jak na przykład22: Analizy $i$ interpretacje, Bank informacji, Blok polonistyczny, Notes humanisty, Proroctwa przed matura, Sprawdź, czy zdałbyś na..., Studia w..., Sztuka zdawania egzaminów, Zapytaj o lekturę, Zawód, Zrozumieć poezję, z drugiej zaś

${ }^{21}$ A. Paciorek, Pięciolatek..., s. 4.

22 Wyboru charakterystycznych rubryk dokonano na podstawie roczników 1994-2000 "Cogito". 
proponowano młodemu odbiorcy treści pomieszczane w takich rubrykach jak choćby: Co słychać, Czas na debiut, Film, Horoskop, Krok w rock, Krzyżówka, Reportaż, Seks i my, Śladami zamczysk, Top-temat, Trzeba odetchnać.

Kilka z wymienionych rubryk nadał było obecnych w latach 20012005. Należały doń m.in. Czas na debiut, Reportaż oraz Trzeba odetchnać. Poza nimi w analizowanym okresie można wyodrębnić także inne (zmieniające się) działy i rubryki. Wśród tych, które podkreślały edukacyjny charakter pisma, znalazły się m.in.: Edukacja, Kalejdoskop kierunkowy, Klub Cogito, Licealny żywot, Pakiet możliwości $\rightarrow$ Pakiet kierunków, Paszport $w$ przyszłość, Problem polonistyczny..., Serwis, Syllabusy, Studia za granica, Test na wstępne, Wieści z liceum, Zapiski erudyty.

Edukacyjny charakter periodyku wzmacniały również, stopniowo dodawane, liczne dodatki specjalne do głównego tytułu. Jakkolwiek w pierwszych latach istnienia periodyku było ich stosunkowo niewiele, o tyle w badanym okresie ich liczba znacznie wzrosła, podobnie jak i ich reklama na łamach dwutygodnika. Wśród najczęściej powtarzających się pojawiły się m.in.: Jak odpowiadać z polskiego, Jak pisać wypracowania, Liceum i matura, Matura pisemna, Motywy literackie, Lektury do nowej matury, Stara matura pisemna i ustna.

W miarę upływu czasu wzrastała jednak liczba rubryk, w których zamieszczano tematy nie związane ze szkołą. Wśród nich proponowano na przykład: Active-style, Art-obrazki, Cogito, Dymki, Galeria mody, Gorqcy temat, Internet, Jak żyja inni, Kawiarenka, Miszmasz informacyjny, Moda, Mówisz i masz, Muza, Obserwacje, Pasje, Prowokacje, Psycholog $\rightarrow$ Psyche, Rozmowa, Szkoła uczuć, Szkoła życia, Uroda, Variétés $\rightarrow$ Top Kultura, Wasz dj dziś gra..., Wzrockowisko, Zaproś jq do kina, Zdrowie. Już choćby pobieżne przyjrzenie się zmieniającym się nazwom wskazuje na przyjęty przez redakcję kierunek w ewolucji pisma, które musiało sprostać problemom, dotykającym w tym czasie segment prasy młodzieżowej, a spowodowanym m.in. rosnącą popularnością Internetu. Stąd odstąpienie redakcji od sztywnej dotąd formuły periodyku, poświęcenie większej liczby stron na sprawy interesujące przeciętnego nastolatka.

Od numeru 15 (2005) wprowadzono wyraźny podział na bloki tematyczne, podejmowane w piśmie, które reprezentowane były przez: Akademię „Cogito”, Magazyn „Cogito”, Studia, Życie i dodatkowe rubryki, mieszczące się pod wspólnym tytułem $A$ ponadto... (materiały powtórzeniowe do matury: Arkusze maturalne, Lektury do klas..., Sztuka prezentacji). Jednocześnie "Cogito” coraz bardziej zaczęło przypominać kolorowy magazyn, szczególnie pod względem szaty graficznej, chociaż nadal gros jego zawartości stanowiły teksty o charakterze edukacyjnym. 
Znaczna część akcji, podejmowanych przez omawiany periodyk również miała taki właśnie charakter. Nie organizowano raczej przedsięwzięć wpisujących się w działania innych tytułów młodzieżowych tego okresu. Inicjatywy, realizowane przez „Cogito”, których efektem były wspomniane wcześniej liczne dodatki specjalne (wydawane zarówno oddzielnie, w formie miesięczników, jak i dołączane do wydania głównego w postaci oddzielnie numerowanych arkuszy bądź kilkustronicowych wkładek tematycznych) korespondowały z edukacyjnymi działaniami redakcji. Nadto informowała ona skrupulatnie o rozmaitych targach językowych, edukacyjnych, zawodowych, konkursach, w których nagrodą było zdobycie indeksu na wybraną uczelnię wyższą. Proponowano również czytelnikom udział w Akademii Cogito, a w jej ramach uczestnictwo w warsztatach dziennikarskich. Zachęcano czytelników do udziału w licznych konkursach literackich (ze względu na temat niniejszej książki zostaną one szerzej omówione w dalszej części rozdziału).

Innych inicjatyw, niż wspomniane powyżej, było niewiele. Można do nich zaliczyć m.in. realizowaną w roku szkolnym 2001/2002 r. akcję Portret Pokolenia. Czytelnikom zaproponowano wspólne stworzenie obrazu młodzieży z przełomu wieków. Służyć temu miały zamieszczane na okładkach kolejnych wydań dwutygodnika zdjęcia współczesnych nastolatków. Redakcja pisała: „Spróbujemy zgadnąć, jacy jesteście - jacy bywacie. [...] pokażemy: odlotowców, artystyczne dusze, kujonów i olewaczy. Wielbicieli rocka albo poezji" 23 . Należało przysłać fotografię własną lub wybranej przez siebie osoby, „która ma w sobie >TO COŚ<”. W numerze wakacyjnym w roku następnym zaprezentowano 19 okładek, przedstawiających współczesnych nastolatków, w tym samym wydaniu znalazł się również raport dotyczący młodzieży z 2002 roku$^{24}$.

Z kolei w 2004 r. zaproponowano czytelnikom inny konkurs, także odbiegający od dotychczasowych inicjatyw, podejmowanych przez pismo. Wiązał się on $\mathrm{z}$ unowocześnieniem jego formuły. Zostań modelkq było przedsięwzięciem, organizowanym wspólnie z agencją modelek Ekstern Models $^{25}$ i stanowiło jedną z nielicznych akcji tego typu, bo, pomimo pewnego złagodzenia sztywnych ram periodyku, obejmującego opisane powyżej kwestie, „Cogito” pozostawało wiernej swej pierwotnej idei, kierując ją do tego samego typu odbiorcy, do którego zwracano się w 1995 r., przyznając:

Wychodzimy z założenia, że nasz Czytelnik - Kogitowiec, to wciąż i zawsze ten, który inwestuje w swoją przyszłość, zainteresowania określone i najczęściej humanistyczne ma i pragnie je poszerzać, a bardzo często sam próbuje tworzyć. Poza tym interesuje go

23 [br. aut.], Okładki Cogito: portret pokolenia, „Cogito” 2001, nr 14, s. [2].

24 I. Redlińska, Młodzież 2002, „Cogito” 2002, nr 11, s. 6-8, 10-[11].

25 [br. aut.], Konkurs: Zostań modelką!!!, „Cogito” 2004, nr 7, s. [7]. 
współczesny świat, „gorące” tematy i możliwość wyrobienia sobie własnego zdania w tej i owej sprawie. [...] sądzimy, że czyta nas przyszła inteligencja - przynajmniej o tym marzymy i takie właśnie potrzeby chcemy spełnić. Wszystko co powyżej, plus oczywiście odpowiednia dawka rozrywki, bo przecież są to właśnie zrównoważone sfery życia normalnego, myślącego, nowoczesnego człowieka26.

\subsubsection{Jak wydać powieść? ?27: książka na łamach pisma}

Biorąc pod uwagę powyższą charakterystykę periodyku, wydawać by się mogło, że książka odgrywała na jego łamach bardzo ważną rolę. Jednakże analiza zawartości periodyku zdaje się nie do końca potwierdzać taką tezę. Naturalnie literatura była przedmiotem wspomnianych wcześniej opracowań, przygotowujących czytelników do egzaminów maturalnych i wstępnych, niemniej jednak, jak już to zostało zaznaczone we Wstępie, badaniu poddano treści, pomieszczane w wydaniu głównym każdego z omawianych czasopism, zaś w przypadku „Cogito” pominięto również materiały o charakterze stricte edukacyjnym, a zatem wszelkiego rodzaju dodatki wydawane łącznie z pismem, jak na przykład Edukacja w liceum, czyli korepetycje z polskiego, przykładowe Arkusze maturalne czy Zeszyty licealisty. Zawierały one omówienia lektur szkolnych, prezentowały sylwetki wybranych pisarzy, podpowiadały, jak poprawnie napisać wypracowanie z języka polskiego, przygotować ciekawą prezentację na egzamin maturalny, przywoływały konteksty literackie, słowem, stanowiły rodzaj materiałów powtórzeniowych, ściśle edukacyjnych, i ze względu na swój charakter nie zostały włączone do przedstawionej statystyki. Jednak analiza zebranych danych, odpowiadających wyznaczonym w pracy kryteriom, pozwoliła wyodrębnić, wzorem poprzednich pism, następujące kategorie informacji związanych z książką oraz podać przypadającą na każdą z nich liczbę28.

Tabela 70. Formy obecności książki i informacji o niej na łamach „Cogito” w latach 2001-2005

\begin{tabular}{|l|c|}
\hline \multicolumn{1}{|c|}{ Rodzaj informacji } & Liczba ogółem \\
\hline Recenzje, omówienia, streszczenia & 200 \\
\hline Wywiady & 38 \\
\hline Reklamy książek & 807 \\
\hline Sylwetki/portrety ${ }^{a}$ & 3 \\
\hline $\begin{array}{l}\text { Artykuły, poświęcone książce i rynkowi wydawniczo-księ- } \\
\text { garskiemu }\end{array}$ & 32 \\
\hline Ekranizacje, adaptacje, inscenizacje znanych dzieł & 27 \\
\hline
\end{tabular}

26 K. Droga, Słowo do Czytelnika, „Cogito” 1995, nr 14, s. 3.

27 Tytuł jednej z publikacji: „Cogito” 2004, nr 17, s. 60.

${ }^{28}$ I w tym miejscu zachowano kolejność jak w analogicznych przypadkach w poprzednich rozdziałach, adekwatną do kolejności opisywanych kategorii. 


\begin{tabular}{|l|c|}
\hline \multicolumn{1}{|c|}{ Rodzaj informacji } & Liczba ogółem \\
\hline Konkursy i akcje & 60 \\
\hline Listy bestsellerów & 6 \\
\hline $\begin{array}{l}\text { Listy czytelników, nawiązujące do zamieszczonej na łamach } \\
\text { pisma informacji związanej z książką }\end{array}$ & brak \\
\hline Inne $^{b}$ & 211 \\
\hline Ogółem & 1384 \\
\hline
\end{tabular}

a Ze względu na nikłą liczbę, składającą się na tę kategorię, nie wyodrębniono jej w oddzielnym podrozdziale.

${ }^{b} \mathrm{~W}$ tym przypadku do kategorii Inne zaliczono: Klub Cogito, opowiadania, fragmenty powieści, komiks, rubrykę Czas na debiut oraz wzmianki, informujące o wydarzeniach związanych z książką.

Źródło: badania własne.

Ogółem liczba informacji związanych z książką (1384), w porównaniu z dwoma wcześniej omówionymi periodykami młodzieżowymi, jest imponująca. Przypomnijmy: w przypadku „Filipinki” było ich 679, na łamach „Dziewczyny” odnaleziono ich 689. Jednak w odniesieniu do „Cogito” należy pamiętać o dwukrotnie większej częstotliwości pisma (dwa poprzednie tytuły były miesięcznikami), stąd porównanie liczbowe trzech prezentowanych czasopism należy traktować w określony sposób. Nadto, już w tym miejscu trzeba zaznaczyć, że zaszczytne pierwsze miejsce $\mathrm{w}$ tym względzie "Cogito" zawdzięcza dwóm rubrykom, tu zaliczonym do kategorii Inne: Czas na debiut oraz Klub Cogito. Pierwsza z nich towarzyszyła pismu od początku jego istnienia, zamieszczano ją również przez cały badany okres. Natomiast Klub Cogito drukowano na łamach dwutygodnika z krótkimi przerwami, ale był jednym z najczęściej pojawiających się elementów.

Biorąc pod uwagę szczególnie pierwszy z wymienionych czynników, zwraca jednak uwagę większa (w porównaniu z dwoma rywalami) liczba ogłoszeń wydawniczych (807). Jak wykazano w analizie, oferta wydawców była jednakże $w$ dużym stopniu monotematyczna, uwzględniała przede wszystkim charakter periodyku, co dokładniej zostanie wykazane w dalszej części rozdziału. Warta podkreślenia jest duża liczba konkursów, proponowanych przez „Cogito”. Większość z nich miała, o czym już wspominano, charakter paraliteracki, ukierunkowane one były często na kształtowanie umiejętności poprawnego pisania, rozwijanie wyobraźni, sprawdzenie wiedzy, także tej przekazywanej w periodyku.

Trzecią pod względem wielkości kategorią jest grupa określona mianem „inne”, której znaczna część (podobnie jak w przypadku „Filipinki” 
i „Dziewczyny”) stanowiły, reprezentujące najważniejsze informacyjne gatunki dziennikarskie ${ }^{29}$, wzmianki i notatki prasowe.

Jakkolwiek na łamach "Cogito” odnaleźć można również zaliczane do ambitniejszych gatunków dziennikarskich felietony czy dyskusje, to jednak nie podejmowały one tematów, które zostały określone w tytule książki. Z kolei recenzje, zaliczane do tej właśnie grupy, nie do końca odpowiadały swej definicji, jako że podobnie jak było to w przypadku dwóch wcześniejszych miesięczników, zbliżały się niebezpiecznie do obszaru charakterystycznego dla gatunków informacyjnych, a ich publicystyczny charakter $\mathrm{w}$ wielu przypadkach był wątpliwy. Jednak, podobnie jak w odniesieniu do dwóch wcześniejszych pism, tak i tu, zaliczono je do kategorii recenzji. Jednocześnie, zajmując miejsce pośrednie pomiędzy obszarem informacji a publicystyki, wydają się bardziej, niż tego typu informacje pomieszczane na łamach „Filipinki” i „Dziewczyny”, spełniać wymogi stawiane tej formie informacji o książce.

Wymienione $\mathrm{w}$ tabeli 70 materiały odnaleźć można było $\mathrm{w}$ całym niemal periodyku, a tylko niektóre $\mathrm{z}$ nich zamieszczano na stronach, poświęconych wydarzeniom kulturalnym. Charakterystyczne dla pisma jest to, że poświęcony im dział jedynie w 2003 r. nosił nazwę adekwatną do drukowanych w nim treści (Top kultura). W pozostałych rocznikach odnaleźć można pojedyncze rubryki, najczęściej występujące oddzielnie, jako np. Książka, Film, Muzyka $\rightarrow$ Muza, bez przydzielenia ich do konkretnego działu ${ }^{30}$. W roku 2001 i częściowo 2002 wybrane kwestie kulturalne drukowano w ramach Variétés, niekiedy także w dodatkowej rubryce Idole i fani $\rightarrow$ Fani i idole, od numeru 12 (2002) pozostawiając jedynie drugą $\mathrm{z}$ wymienionych rubryk. Pierwsze wydanie w $2003 \mathrm{r}$. powitało czytelników m.in. nowym działem, wspomnianą Top kultura, drukowaną do numeru $10 \mathrm{w}$ tym samym roku włącznie. W numerach 11 i 12 zabrakło tego działu, jednak od wydania 14 pojawiły się dwie oddzielne rubryki: Zaproś ja do kina oraz Wasz didżej gra dzisiaj... $\rightarrow$ Wasz dj gra dzisiaj. Od numeru 16 (2003) zaproponowano czytelnikom dodatkowo propozycje wybranych lektur, przedstawiane w ramach rubryki Wokół książki ${ }^{31}$. Te trzy rubryki przetrwały niemal rok, jednak w pierwszym numerze po wakacjach $\mathrm{w}$ roku 2004 (14) zabrakło miejsca na recenzje książek. Uznano być może, że czytelników „Cogito” bardziej interesują nowości muzyczne i filmowe, pozostawiono bowiem dwie odpowiadające

${ }^{29}$ Dziennikarstwo i świat mediów, red. Z. Bauer i E. Chudziński, Universitas, Kraków 2004, s. 155.

30 Takich działów, jak to już zostało wcześniej powiedziane, w pierwszych latach pisma było niewiele, redakcja prezentowała proponowany materiał $w$ ramach mniejszych objętościowo i merytorycznie rubryk.

${ }^{31}$ Nazwa Wokół ksiq̨żki została zastąpiono w numerach 12 i 13 (2004) przez Ksiq̨żkę na wakacje. 
im rubryki. Kolejna zmiana w obrębie interesujących nas zagadnień nastąpiła od numeru $1 \mathrm{w} 2005$ r., kiedy rubryka muzyczna i filmowa zmieniły nazwę analogicznie na: Muza i Film, do których od numeru 12 w tymże roku dołączyła Książka, gdzie umieszczono Klub Cogito. W kolejnym (13) numerze tejże rubryki zabrakło, pojawiła się ona w wydaniu 14 w formie wakacyjnej jako Książka na lato. Od numeru 15 (2005) nastąpiły sygnalizowane wcześniej wyraźne zmiany, które znalazły swój wyraz także w obrębie zagadnień kulturalnych. Odtąd, aż do końca badanego okresu, rubryki Książka, Film, Muzyka zamieszczano w ramach działu Życie. Osobą odpowiedzialną za zagadnienia kulturalne była przez cały badany okres O. Siewko, aczkolwiek tylko sporadycznie w stopce redakcyjnej pojawiało się określenie jej funkcji.

Informacje kulturalne zajmowały od 1 do 4 stron, drukowane były w różnych częściach pisma, chociaż najczęściej w drugiej jego połowie.

Jak wynika $\mathrm{z}$ przedstawionego powyżej opisu, rubryka związana z recenzjami wybranych książek nie była stałym elementem w strukturze pisma. W numerach, w których jej zabrakło, pojawiał się Klub Cogito, w którym prezentowano tytuły, dostępne w księgarni wysyłkowej Wydawnictwa Aga-Press. Tę formę związaną z książką zdecydowano zaliczyć do kategorii Inne, jako informację bibliograficzną; pełna jej prezentacja zostanie przedstawiona w dalszej części rozdziału.

\subsubsection{Znajdź czas na bestseller ${ }^{32}$ : miejsce recenzji w układzie pisma ${ }^{33}$}

W ciągu pięciu analizowanych lat na łamach "Cogito” pojawiło się w sumie $\mathbf{2 0 0}$ recenzji, omówieni strzeszczeń. W tabeli 71 przedstawiono ich liczbę w kolejnych latach.

Tabela 71. Recenzje, omówienia i streszczenia książek zamieszczane na łamach „Cogito” w latach 2001-2005

\begin{tabular}{|c|c|}
\hline Rok & Liczba recenzji, omówień i streszczeń \\
\hline 2001 & 9 \\
\hline 2002 & 3 \\
\hline 2003 & 94 \\
\hline 2004 & 58 \\
\hline 2005 & 36 \\
\hline Ogółem & 200 \\
\hline
\end{tabular}

Źródło: badania własne.

32 Tytuł krótkiej wzmianki dotyczącej książki, „Cogito” 2003, nr 12, s. 34.

33 Przypomnijmy: do recenzji nie zaliczono omówień książek, prezentowanych w ramach Klubu Cogito. Jak już zostało to powiedziane, zakwalifikowano je do materiałów informacyjno-bibliograficznych. 
Najmniejsza liczba recenzji, omówień i streszczeń pojawiła się na łamach dwutygodnika w okresie, kiedy brakowało w nim rubryki recenzyjnej34. Niemal wszystkie odnotowane wówczas omówienia zamieszczono w rubryce: Variétés. W kolejnych badanych rocznikach liczba recenzji, jakkolwiek zdecydowanie wyższa, przejawiała tendencję zniżkową (94-5836). Było to w dużej mierze konsekwencją niesystematyczności jej zamieszczania. Jak wynika z przedstawionej wcześniej charakterystyki, była ona obecna (pod różnymi nazwami) na łamach pisma w 2003 i częściowo 2004 r., a następnie, po kilku miesiącach nieobecności, pojawiła się ponownie od numeru $14 \mathrm{w} 2005$ r. Kolejno funkcjonowała jako: Dobre powieści zawsze na topie $\rightarrow$ Dobra literatura $\rightarrow$ Literatura na topie $\rightarrow$ Top literatura ${ }^{35}$, następnie pojawiła się nazwa Wokół ksiq̨żki36, Książka na wakacje ${ }^{37}$, Ksiq̨żki na lato $^{38}$, by wreszcie przyjąć nazwę Książka ${ }^{39}$. Wybrane przykłady prezentują formę omawianej strony recenzyjnej (zdjęcia 187-192).

$34 \mathrm{~W}$ tym czasie systematycznie zamieszczano informacje bibliograficzne dotyczące książek w wysyłkowym Klubie Cogito. Zatem małą liczbę recenzji można tłumaczyć tym właśnie faktem.

35 Wymienione nazwy rubryki obowiązywały w numerach 1-10 w 2003 r., drukowano je w ramach działu Top kultura.

36 „Cogito” 2003, nr 16 -21; 2004, nr 1-11 włącznie.

37 "Cogito" 2004, nr 12 i 13.

38 "Cogito" 2005, nr 14.

39 „Cogito" 2005, nr od 15 do 22. 


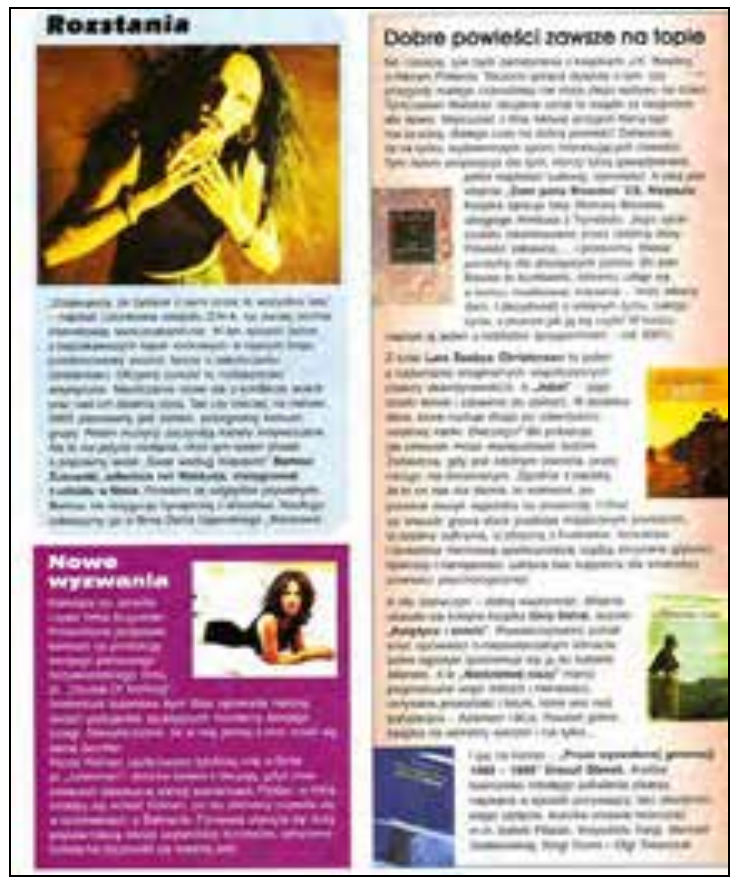

Zdjęcie 187. Przykładowa strona recenzyjna na łamach "Cogito"

„Cogito" 2003, nr 3, s. 30

Zdjęcie 188. Przykładowa strona recenzyjna na łamach "Cogito” „Cogito" 2003, nr 4, s. [52]

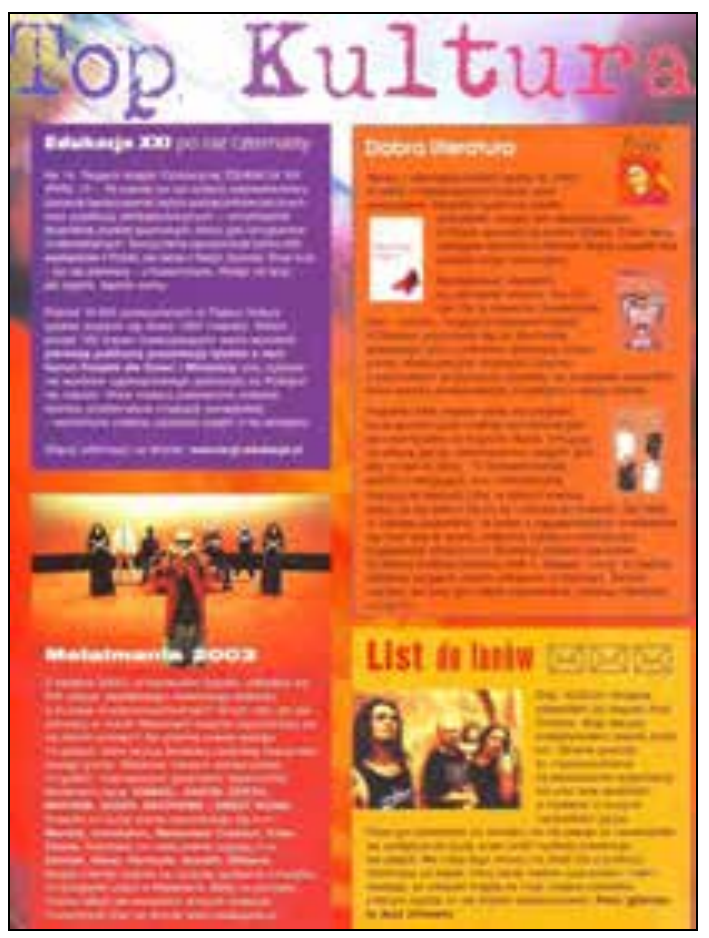




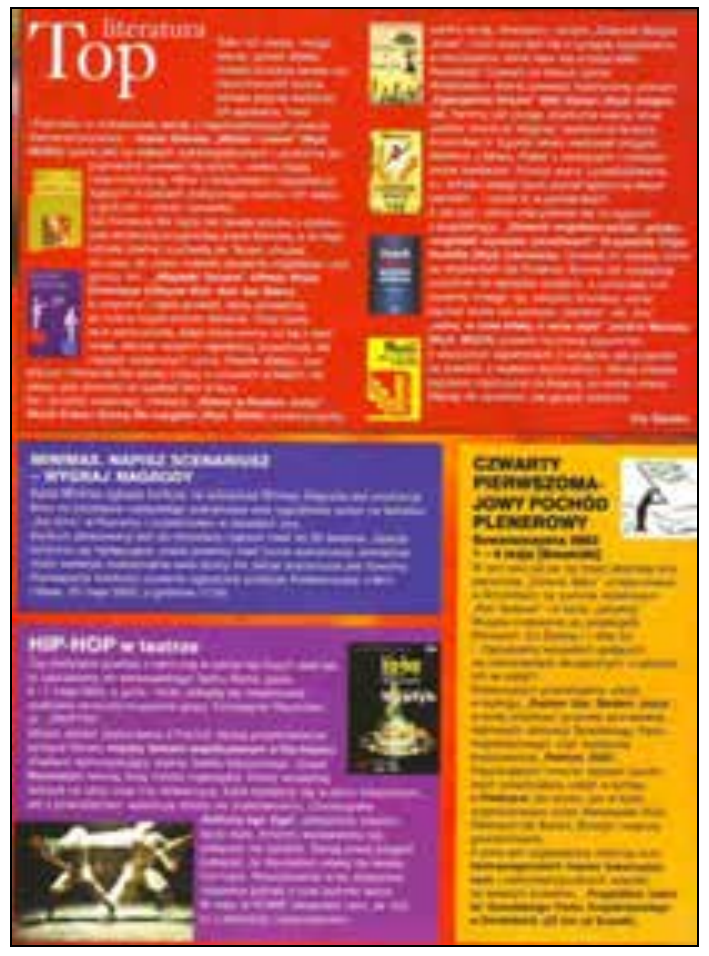

Zdjęcie 189. Przykładowa strona recenzyjna na łamach „Cogito” „Cogito" 2003, nr 8, s. [52]

Zdjęcie 190. Przykładowa strona recenzyjna na łamach "Cogito" "Cogito" 2003, nr 17, s. [22]

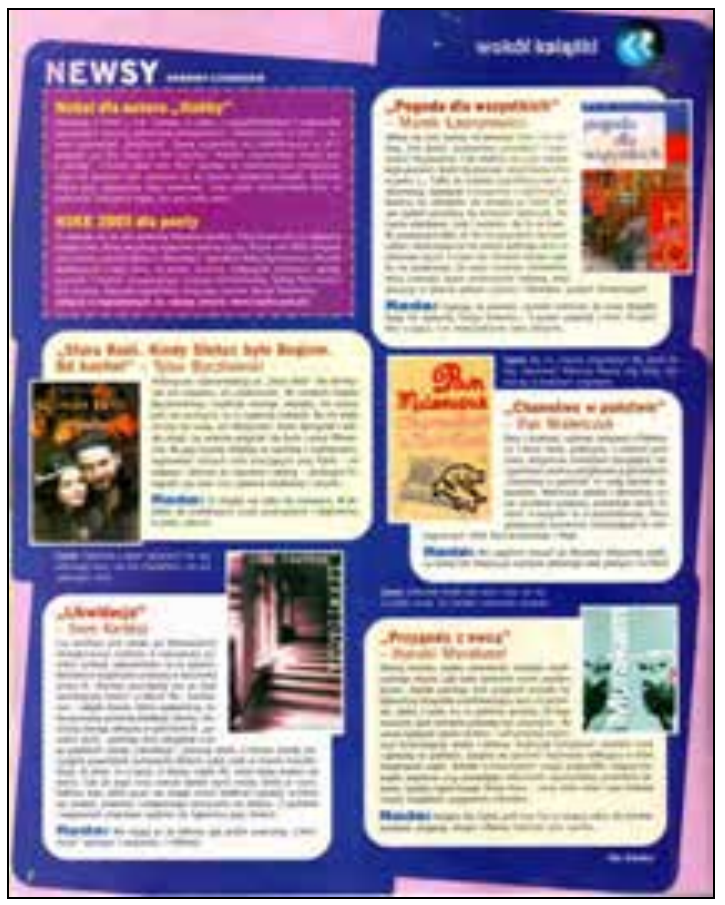




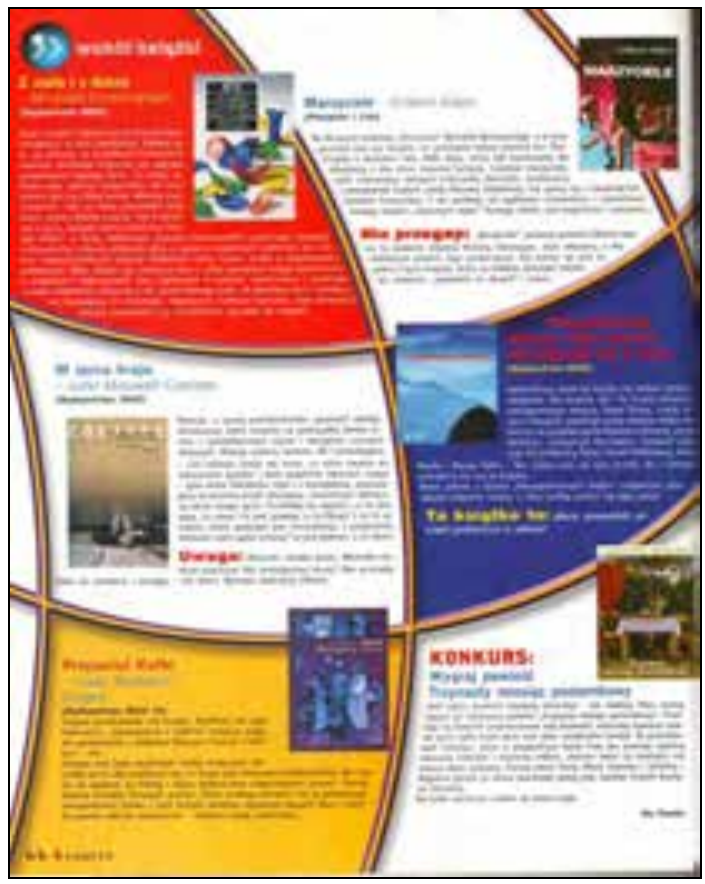

Zdjęcie 191. Przykładowa strona recenzyjna na łamach "Cogito”

„Cogito" 2004, nr 9, s. 66

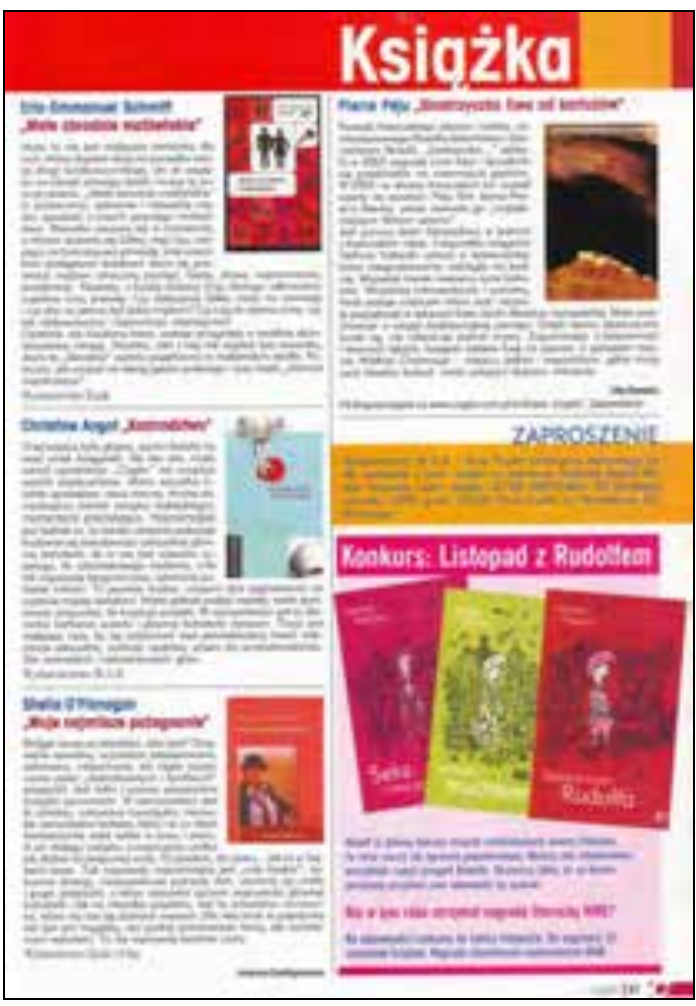

Zdjęcie 192. Przykładowa strona recenzyjna na łamach "Cogito" „Cogito" 2005, nr 19, s. 57

\section{Ksiażka}

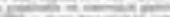

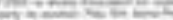

Triming

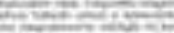

स6

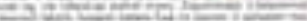

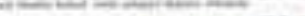

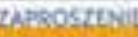

Cum

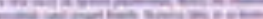

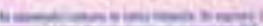

$180^{2}$ 
Przedstawione przykłady obrazują ewolucję interesującej nas strony recenzyjnej. W 2003 r. była ona stosunkowo skromna pod względem graficznym, $w$ pierwszych numerach dzieliła miejsce $\mathrm{z}$ innymi informacjami kulturalnymi. Kiedy zmianie uległa jej nazwa, na prezentację wybranych książek zaczęto poświęcać całą stronę, zaś przy poszczególnych recenzjach pojawiały się dodatkowe elementy: poza kopią okładki niekiedy był to wybrany cytat, czasem rada, która stanowiła jednocześnie ocenę proponowanego tytułu, innym razem uwaga, w której recenzent starał się raz jeszcze wskazać na te cechy prezentowanej lektury, które wzbudziły w nim szczególne uczucia lub na które przy czytaniu należało mieć szczególne baczenie. W kolejnych numerach pojawiał się na tej stronie również konkurs literacki bądź taki, w którym nagrodą była książka. W porównaniu z pierwotną koncepcją nowy pomysł pozwalał na wyraźniejsze oddzielenie od siebie poszczególnych omówień, wprowadzając również ciekawe rozwiązania graficzne. Strona stała się różnokolorowa, przy czym zachowano stałe tło dla poszczególnych recenzji: białe, czerwone, niebieskie i żółte. W 2005 r., po kolejnej modyfikacji rubryki, jej forma stała się prostsza, skromniejsza także pod względem kolorystyki. Jednocześnie zwiększono objętość poszczególnych omówień i przypomniano sobie o podawaniu nazwy wydawcy rekomendowanych książek. Przy jednej z nich zamieszczano odtąd systematycznie zaproszenie na stronę internetową pisma, na której czytelnik mógł odnaleźć więcej propozycji książkowych.

Na stronie recenzyjnej zamieszczano od jednej do sześciu omówień. Ich objętość wahała się od kilku do kilkunastu zdań. W 48 przypadkach były one anonimowe, pod pozostałymi odnaleźć można nazwiska: O. Siewko (w 128 przypadkach), J. Szeligowskiej (16-krotnie), E. Nowak (3 razy), A. Krasnodębskiej (czterokrotnie), L. Janiona, K. Zadros (raz).

\subsection{Zakres i charakter recenzji - przykłady ${ }^{40}$}

W trakcie pięciu poddanych analizie lat na łamach pisma zaproponowano w formie recenzji książki 159 autorów, w tym 54 pisarzy polskich i 105 obcych (zob. Aneks 53. Autorzy książek recenzowanych na łamach "Cogito" w latach 2001-2005). Stosunkowo rzadko sięgano częściej niż raz po książkę tego samego twórcy. W tabeli 72 zaprezentowano nazwiska tych, którzy pojawili się w recenzjach przynajmniej trzy razy.

40 Podrozdział obejmuje wszystkie recenzje, zamieszczone w periodyku, bez względu na ich lokalizację. 
Tabela 72. Pisarze, którzy pojawili się w recenzjach książek przynajmniej trzykrotnie na łamach „Cogito" w latach 2001-2005

\begin{tabular}{|l|c|l|}
\hline \multicolumn{1}{|c|}{ Dane twórcy } & Liczba recenzji & \multicolumn{1}{|c|}{ Tytuły recenzowanych książek } \\
\hline Arturo Pérez-Reverte & 4 & $\begin{array}{l}\text { Fechtmistrz } \\
\text { Królowa Południa } \\
\text { Ostatnia bitwa templariusza } \\
\text { Szachownica flamandzka }\end{array}$ \\
\hline Paul Auster & 3 & $\begin{array}{l}\text { Księga złudzeń } \\
\text { Myślałem, że mój ojciec jest Bogiem } \\
\text { i inne opowiadania z audycji rozgłośni } \\
\text { NPR } \\
\text { Noc wyroczni }\end{array}$ \\
\hline Vladimir Nabokov & 3 & $\begin{array}{l}\text { Pnin } \\
\text { Rozpacz } \\
\text { Zaproszenie na egzekucję }\end{array}$ \\
\hline Ewa Nowak & 3 & $\begin{array}{l}\text { Krzywe 10 } \\
\text { Wszystko, tylko nie mięta (dwukrotnie) }\end{array}$ \\
\hline Gabriel G. Márquez & 3 & $\begin{array}{l}\text { O miłości i innych demonach } \\
\text { Opowiadania } \\
\text { Sto lat samotności }\end{array}$ \\
\hline
\end{tabular}

Źródło: badania własne.

To skromne, $\mathrm{w}$ porównaniu $\mathrm{z}$ analogicznymi $\mathrm{w}$ poprzednich rozdziałach, zestawienie świadczy o dużej różnorodności twórców, wybieranych przez periodyk. Ponadto, nawet $\mathrm{w}$ tak skromnym wykazie dominują pisarze obcy, zaś jedyna rodzima autorka była pedagogiem współpracującym z dwutygodnikiem, stąd recenzje jej książek miały w tym przypadku charakter autopromocji samego periodyku. Pozostali autorzy znani byli szerszemu gronu czytelników, choć twórczość każdego z nich miała inny charakter.

Zaledwie w 15 przypadkach przywołano dwukrotnie nazwisko tego samego twórcy. W tej grupie znaleźli się: Michaił Bułhakow, Cuca Canals, Michael Cunningham, Salvador Dali, Joanna Fabicka, Ida Fink, Hella Haasse, Patricia Highsmith, Haruki Murakami, Vidiadhar S. Naipaul, Amélie Nothomb, Sheila 0'Flanagan, Jerzy Pilch, Eric Emanuel Schmitt oraz Mika Waltari. I tu literatura rodzima była skromnie reprezentowana: pojawiły się tylko dwa nazwiska polskich autorów, przy czym jedno z nich należało do twórcy bardzo popularnego $\mathrm{w}$ objętych analizą latach. $\mathrm{Z}$ jednej strony periodyk starał się prezentować książki pisarzy popularnych, goszczących na listach bestsellerów, i dzięki temu znanych szerszemu gronu odbiorców, albo takich, którzy znani byli dzięki otrzymanej nagrodzie. Obok omówienia książek autora Mojego pierwszego samobójstwa, na uwagę zasługuje prezen- 
tacja książek laureata Literackiej Nagrody Nobla, autora Domu pana Biswasa (warto zaznaczyć, że ich recenzje pojawiły się odpowiednio dwa i trzy lata po otrzymaniu przezeń tego prestiżowego wyróżnienia), a także recenzja książki Isabel Allende, Elfride Jelinek, Imre Kertésza, ale również Stephena Kinga, Krystyny Siesickiej czy Olgi Tokarczuk.

Z drugiej jednak strony, jeśli przyjrzymy się pełnej liście autorów recenzowanych tytułów, zauważymy, że dominowała jednak tendencja do przedstawiania książek twórców mniej znanych. Wśród pisarzy obcych pojawili się na przykład David Colbert, Francisco Coloane, Lars Saabye Christensen, Jane Dunn, Stephanie Gertler, Pete McCarthy, Arto Paasilinna czy Susan Vreeland. Natomiast wśród mniej znanych autorów polskich, których twórczość prezentowano $\mathrm{w}$ formie recenzji, znaleźli się m.in. Krzysztof Fordoński, Katarzyna Gławińska, Tomasz Markowicz, Bogdan Prejs, Agnieszka Rotkiewicz czy Mikołaj Wójcik.

Przeważająca część recenzji, omówień i streszczeń dotyczyła powieści, zaledwie trzykrotnie przedstawiono słowniki (na przykład Słownik angielsko-polski, polsko-angielski wyrazów zdradliwych Krzysztofa F. Rudolfa), raz sięgnięto po album (Kontynenty $w$ obiektywie), podobnie raz w oczach recenzentów uznanie znalazł atlas (Atlas. Archeologia świata) oraz komiks (Ueremi, t. 1). Kilkakrotnie zrecenzowano poezję (na przykład 128 Bardzo Ładnych Wierszy Stworzonych Przez Sześćdziesięcioro Ośmioro Poetek i Poetów Polskich Leszka Kołakowskiego) oraz zbiór opowiadań (m.in. Myślałem, że mój ojciec jest Bogiem i inne opowiadania z audycji rozgłośni NPR Paula Austera; Opowiadania, G. G. Márqueza; Przyjaciel Kafki Isaaca B. Singera).

Jak już wcześniej wspomniano, recenzje, omówienia i streszczenia obejmowały od kilku do kilkunastu zdań, nie zawsze podpisywanych przez ich autora. W większości przypadków tytuły tego typu omówień były jednocześnie tytułami proponowanych książek. Pod względem formalnym ta postać informacji o książce były bardzo niestarannie przygotowywana. Jedynym elementem bibliograficznym, poza autorem i tytułem proponowanej książki, podawanym przez recenzentów, była nazwa wydawcy, ale nawet i ona została pominięta w 91 (na 200) przypadkach. Nie uwzględniano nazwiska tłumacza $\mathrm{w}$ przypadku przekładu, nie dbano również o podanie miejsca i roku wydania opisywanego tytułu. Być może uznano, że braki te zrekompensuje czytelnikom kopia okładki proponowanej książki, umieszczana obok recenzji.

Ta forma informacji o książce składała się zazwyczaj z krótkiej prezentacji autora, zwięzłego streszczenia głównych wątków danej książki, niekiedy przedstawienia $w$ kilku słowach głównego bohatera oraz (zazwyczaj) krótkiej oceny polecanego tytułu. Częściej, niż było to w przypadku miesięczników „Filipinka” i „Dziewczyna”, określano adresata książki, 
stwierdzając np.: „dla smakoszy powieści psychologicznej”41, „wielbicielom dobrej powieści historycznej polecam..."42, „dla smakoszy dobrej literatury” 43 , „dla fanów twórczości Tolkiena” 44 , „dla wytrwałych i nietuzinkowych głów” 45 „lektura obowiązkowa dla wszystkich teatromanów!”46, „dla koneserów dobrej powieści!"47.

Treść lektury była rozmaicie przedstawiana. Niekiedy ograniczano się do podania kilku suchych faktów, kreśląc ogólne tło powieści, innym razem konstruowano streszczenie w sposób intrygujący, który miał rozbudzić w czytelniku ciekawość, kiedy indziej rozpoczynano opis od pytań. Oto kilka wybranych przykładów odpowiadających tym cechom:

Mamy lata pięćdziesiąte, powojenną Austrię, która jeszcze nie otrząsnęła się z II wojny światowej. Anna Rainer, Sophie i Hans mają po 17-19 lat, wchodzą w dorosłość, ale z bagażem nie tyle własnych przeżyć, co doświadczeń, lęków ich własnych rodziców. I choć młodzi próbują żyć inaczej, uwikłani są w swą przeszłość. Tworzą między sobą skomplikowane, nie zawsze etyczne, ale na pewno kontrowersyjne relacje ${ }^{48}$.

Relacja, a raczej pamiętnikarska spowiedź młodej dziewczyny, która mieszka na podupadłej farmie razem z apodyktycznym ojcem i dwojgiem czarnych służących... ${ }^{49}$.

Główny bohater, zwykły mieszkaniec zwykłego współczesnego miasteczka, żyje sobie spokojnie swoim zwykłym życiem. Jednak pewnego dnia przyjaciel przysyła mu tajemniczą fotografię przedstawiającą owce na pastwisku. Jedna z owiec ma na grzbiecie gwiazdę. Od tego momentu życie bohatera przestaje być zwyczajne...50.

Główną bohaterką jest Lilly, która opowiada różne historie z życia swoich znajomych, przyjaciół, historie są tyleż ciekawe, co czasem aż nieprawdopodobne. Bohaterami są Chinki, młode, piękne, stare, opuszczone przez najbliższych...51.

Czy myśleliście kiedyś o tym, ile jest wart żeton telefoniczny? Parę groszy czy może całe życie? Albo jak odróżnić człowieka od jego wiernej kopii? ${ }^{52}$

Jakbyś się czuł, budząc się pewnego dnia i nie wiedząc, kim jesteś, pozbawiony przeszłości i wspomnień?53

Czy pierwsza miłość zasługuje, by dać jej po latach drugą szansę ${ }^{54}$

\footnotetext{
41 „Cogito” 2003, nr 3, s. 30.

42 "Cogito" 2003, nr 8, s. 52.

43 "Cogito" 2003, nr 5, s. [47].

44 "Cogito" 2003, nr 6, s. [54].

45 "Cogito" 2005, nr 19, s. 57.

46 "Cogito" 2003, nr 5, s. [47].

47 "Cogito" 2003, nr 6, s. [54].

48 "Cogito" 2005, nr 21, s. [61].

49 "Cogito" 2004, nr 9, s. 66.

50 "Cogito" 2003, nr 17, s. [22].

51 „Cogito" 2005, nr 17, s. [61].

52 "Cogito" 2004, nr 7, s. 60.

53 "Cogito" 2003, nr 17, s. [22].

54 "Cogito" 2003, nr 19, s. [66].
} 
Oceny proponowanych książek przyjmowały różną formę: od osobistych wyznań („To jedna z najciekawszych biografii, jakie przeczytałam” ${ }^{55}$, „To się naprawdę świetnie czyta"56), poprzez odwołanie się do popularności danego tytułu („No i przebój ostatniego miesiąca” 57 , „Okrzyknięto ją rosyjską Masłowską, odważnym głosem młodych Rosjan” 58 , „Książka Niemiego zrobiła w Szwecji prawdziwą furorę"59), a kończąc na lapidarnych określeniach („rewelacja!”, „niezwykle inteligentna i realistyczna opowieść”, „kosmiczna, odlotowa powieść”, „urokliwa i subtelna powieśc”, "odjazd totalny").

Nadto, jak już wspomniano wcześniej, przy niektórych omówieniach pojawiały się dodatkowe elementy: cytat zaczerpnięty z proponowanej książki, rada lub uwaga. Często na tej samej stronie proponowano czytelnikom udział w konkursie literackim.

Poza rubryką do tego przeznaczoną, znalazło się 40 recenzji. Obok wcześniej wspomnianej (Variétés) omówienia pojawiły się w następujących miejscach: Active - style, Co się dzieje, Czas na debiut, Imprezownik, Lato uczuć, Okiem psychologa, Tu i teraz. Prezentacje książek w nich drukowane nie różniły się niczym szczególnym od tych zamieszczanych w rubryce recenzyjnej, choć, co ciekawe, przy tych opisach pojawiała się nierzadko nazwa wydawcy (często pomijana w omówionej wyżej rubryce), a w kilku przypadkach posiadały one odrębny tytuł (wśród 200 recenzji tak było było zaledwie 32 razy). Do ciekawszych pomysłów należały następujące tytuły: Kto kocha Kraków, czyta Mrożka, Powieść z kluczem... nie tylko dla faceta, Przekleństwo imienia, Strefa śmiechu z Jeremim60.

Recenzowane książki pochodziły z oferty 42 wydawców61 (Aneks 54. Wydawcy książek recenzowanych na łamach „Cogito" w latach 2001-2005). W tabeli 73 przedstawiono tych wydawców, których dorobek cieszył się największym zainteresowaniem recenzentów.

55 „Cogito" 2003, nr 4, s. 52.

56 "Cogito" 2005, nr 19, s. 57.

57 „Cogito" 2003, nr 8, s. 52.

58 "Cogito" 2004, nr 10, s. 56.

59 "Cogito" 2003, nr 10, s. [65].

60 Kolejno: „Cogito” 2003, nr 11, s. ]76]; nr 12, s. 36; 2001, nr 7, s. 40; 2003, nr 12, s. 83.

$61 \mathrm{~W} 91$ przypadkach pominięto ten element. Na potrzeby rozprawy brakujące informacje uzupełniono na podstawie "Przewodnika Bibliograficznego" w wersji on line, www.bn.org.pl, październik 2011. 
Tabela 73. Wydawcy najczęściej recenzowanych książek na łamach „Cogito” w latach 2001-2005

\begin{tabular}{|l|c|}
\hline \multicolumn{1}{|c|}{ Nazwa wydawcy } & Liczba tytułów \\
\hline Wydawnictwo Muza SA & 35 \\
\hline Wydawnictwo W.A.B. & 22 \\
\hline Oficyna Literacka Noir sur Blanc & 19 \\
\hline Dom Wydawniczy REBIS & 17 \\
\hline Wydawnictwo Książnica & 15 \\
\hline Wydawnictwo Literackie & 14 \\
\hline Społeczny Instytut Wydawniczy Znak & 10 \\
\hline
\end{tabular}

Źródło: badania własne.

Interesujący wydaje się fakt, że w zestawieniu (tab. 73) zabrakło jednej z największych oficyn w tamtym okresie, Wydawnictwa Prószyński i S-ka. Recenzenci "Cogito” zaledwie trzykrotnie sięgnęli po tytuły tego edytora, natomiast jego książki były znacznie chętniej prezentowane na łamach dwóch wcześniej przedstawianych pism. Pozostałe oficyny gościły w niemal równym stopniu w trzech omawianych periodykach. W przypadku "Cogito” rzadziej sięgano po propozycje mniej znanych edytorów, do których należeli: Agencja Edytorska Ezop, Wydawnictwo Europa, KOS i Wydawnictwo PUNKT.

Porównując wstępnie recenzje, streszczenia i omówienia, zamieszczane na łamach trzech omówionych pism młodzieżowych, należy zauważyć, że w przypadku „Cogito” były one pod względem merytorycznym ciekawiej przygotowywane (jak już było to sygnalizowane wcześniej), a zarazem najbardziej, spośród tego typu gatunków reprezentowanych w omawianych periodykach młodzieżowych, odpowiadały definicji recenzji. Znalazło się w nich miejsce na przedstawienie treści, osobiste zdanie recenzenta, a więc element wartościujący na temat proponowanej książki. Z pewnością recenzje, omówienia i streszczenia drukowane na łamach „Cogito”, nie były tak powierzchowne jak te, które czytelniczkom oferowano na łamach miesięcznika „Dziewczyna”.

Forma graficzna recenzji, podobnie jak całego dwutygodnika „Cogito”, w miarę upływu czasu ulegała poprawie, zaś w latach 2003-2005, kiedy zdecydowano o drukowaniu rubryki recenzyjnej, była już ciekawie opracowywana, choć należy podkreślić, że zyskała na przejrzystości dopiero po kolejnej modyfikacji, gdy anonsowana była tytułem Wokół książki.

Natomiast pod względem formalnym recenzje te pozostawiały wiele do życzenia. Wydawać by się mogło, że grono profesjonalistów, wśród których dominowali nauczyciele, powinno zdawać sobie sprawę z wagi podawania źródeł. Tymczasem, co już powyżej kilkakrotnie podkreślono, brakowało rzetelnego opisu bibliograficznego proponowanych lektur; w optymalnej 
wersji recenzji czytelnik odnaleźć mógł jedynie trzy elementy opisu bibliograficznego proponowanej lektury: nazwisko autora, tytuł książki i nazwę jej wydawcy.

Trudno znaleźć wspólny mianownik dla przedstawianych książek, chociaż wydaje się, co już podkreślono, że poza tendencją do prezentacji książek autorów obcych zarysowuje się tu skłonność redakcji do pisania o twórczości mniej znanych twórców, obok znacznie rzadszego przywoływania nazwisk znanych z pierwszych miejsc list bestsellerów. Świadczyć to może o założonym przez redakcję wysokim poziomie intelektualnym czytelników pisma, których mniej interesują powieści K. Siesickiej (tylko jeden tytuł omówiony), w ogóle nie ciekawią książki Katarzyny Grocholi, Helen Fielding czy Olgi Tokarczuk, (brak recenzji twórczości tych autorek), a chętniej sięgną po twórczość G. G. Márqueza, Vladimira Nabokova czy I. B. Singera.

\subsubsection{Mam pogodne usposobienie ${ }^{62}$ : wywiady}

W latach 2001-2005 na łamach omawianego dwutygodnika zamieszczono w sumie 38 wywiadów z osobami bezpośrednio bądź pośrednio związanymi $\mathrm{z}$ książką. W tabeli 74 przedstawiono ich liczbę $\mathrm{w}$ poszczególnych latach.

Liczba wywiadów w poszczególnych latach, choć wyrównana, jest jednocześnie skromna: średnio osiem w ciągu roku oznacza, że nie pojawiały się one nawet w co drugim numerze omawianego dwutygodnika.

Tabela 74. Wywiady z osobami związanymi ze światem literatury, zamieszczane na łamach „Cogito” w latach 2001-2005

\begin{tabular}{|c|c|}
\hline Rok & Liczba wywiadów \\
\hline 2001 & 7 \\
\hline 2002 & 6 \\
\hline 2003 & 9 \\
\hline 2004 & 7 \\
\hline 2005 & 9 \\
\hline Ogółem & 38 \\
\hline
\end{tabular}

Źródło: badania własne.

Rozmowy z przedstawicielami świata literackiego zamieszczano zazwyczaj w rubrykach, zatytułowanych Art-rozmowa, Gość Cogito $\rightarrow$ Gość numeru, Rozmowa Cogito, Spotkanie. Rzadziej tę formę prezentacji sylwetki

62 Tytuł wywiadu, przeprowadzonego z J. Chmielewską, „Cogito” 2002, nr 1, s. 4. 
znanego twórcy odnaleźć można było w ramach Akademii Cogito: obraz, słowo, scena, warsztaty dziennikarskie; Studia, rekrutacja...; w pojedynczych przypadkach w ramach takich rubryk, jak: Liderzy; Mówiq autorzy bestsellerów; Mówisz i masz; Studenci w oczach wykładowcy.

Zapis rozmowy zajmował przeważnie stronę lub dwie, wzbogacało je obowiązkowo zdjęcie rozmówcy i krótki biogram dotyczący jego osoby. Niekiedy na początku wywiadu drukowano lead, w którym sygnalizowano główne punkty wywiadu lub cytowano jego wybrane fragmenty. 0 ile w przypadku recenzji nie przywiązywano szczególnej wagi do ich tytułów, o tyle w odniesieniu do rozmów należy zauważyć, że poza dwoma przypadkami, gdy go pominięto, i czterema, gdy jego funkcję spełniało nazwisko rozmówcy, każdy z nich posiadał ciekawy, przykuwający wzrok tytuł. Oto kilka wybranych przykładów63: Człowiek jest kruchy i smaczny, Guru młodych, Herbert był kobieciarzem!, Jestem tu i teraz, Literatura jest dla maratończyków, Miłość napędza wszystko, Młodość z historiq w tle, Pisarzem być czy zostać, Uciekam od maniery, Wierzę w anioły, Życie jest ciagłym poszukiwaniem.

Wśród bohaterów tak zatytułowanych wywiadów znaleźli się m.in.: Joanna Chmielewska, Jacek Dukaj, Wojciech Jagielski, Zygmunt Kałużyński, Barbara Kosmowska, Wojciech Kuczok, Dorota Masłowska, Czesław Mi$\mathfrak{l o s z}^{64}$, Małgorzata Musierowicz, Mirosław Nahacz, Jerzy Pilch (dwukrotnie), Grzegorz Rosiński, Jacek Santorski, Sławomir Shuty, Joanna Siedlecka, Lew Starowicz, Andrzej Stasiuk, Janusz L. Wiśniewski. Niemal wszyscy goście pisma byli rodzimymi twórcami, a pełna lista ich nazwisk (zob. Aneks 55. Nazwiska osób związanych z książką, z którymi przeprowadzono wywiad na łamach „Cogito” w latach 2001-2005) wskazuje w znacznie większym stopniu niż było to w przypadku recenzji na zróżnicowane kryteria, którymi kierowała się redakcja pisma przy ich wyborze. Obok popularnych pisarzy młodzieżowych (D. Masłowska, M. Musierowicz, M. Nahacz) gośćmi periodyku byli również na przykład Jacek Santorski i Lew Starowicz. Do rozmowy zaproszono obok J. Pilcha, także twórcę bohatera komiksowego Thorgala, również satyryka i rysownika, Andrzeja Czeczota, ale i poetę i piosenkarza, Roberta Kasprzyckiego czy autorkę biografii Zbigniewa Herberta, Joannę Siedlecką.

O ile recenzje często pozostawały anonimowe, o tyle w przypadku wywiadów dbano o podanie nazwiska dziennikarzy, którzy je przeprowadzali. Byli to najczęściej: E. Barciszewska, K. Boczek, N. Kostrzewa, J. Szeligowska, A. Trojan i E. Woźnica.

63 Kolejno: „Cogito” 2003, nr 2, s. 12-13; 2005, nr 19, s. 6-7; 2002, nr 12, s. [10]; 2005, nr 15, s. 49; nr 17, s. 39; 2002, nr 20, s. [10]-11; 2005, nr 17, s. 17; 2003, nr 7, s. 66; 2001, nr 3, s. 40-41; 2003, nr 10, s. 16-[17]; 2001, nr 6, s. 4-5.

${ }^{64}$ Wywiad został wydrukowany po śmierci Cz. Miłosza; był to zapis rozmowy przeprowadzony z poetą kilka lat wcześniej. 
Powieściopisarzy pytano w niewielkim tylko stopniu o ich życie osobiste czy o to, jak sami siebie postrzegają, koncentrując się raczej na ich warsztacie pracy, źródłach pomysłów, a także na tym, w jakim stopniu bohaterowie ich książek posiadają swoje odpowiedniki w świecie rzeczywistym.

Na przykład W. Kuczok przyznał: „byłem wrażliwym chacharem”65 [w gwarze śląskiej - łobuzem - przyp. M.P.S.], J. Chmielewska stwierdziła m.in.: „mam pogodne usposobienie i raczej pogodnie traktuję całą egzystencję"66, zaś K. Grochola określiła siebie jako „Prawdziwą feministkę. Taką, jaką jest Wojciech Eichelberger"67. Interesujących informacji czytelnikom pisma dostarczyły odpowiedzi rozmówców na pytania związane $\mathrm{z}$ ich twórczością. D. Masłowska wyznała, że swego rodzaju prototypem jej powieści (Wojna polsko-ruska pod flaga biało-czerwonq) była wymyślona przez nią gra planszowa, zaś I. Sowa przyznała, że bohaterki swoich książek obdarzyła własnymi wadami (na przykład rozkojarzeniem). Bohater innego wywiadu, J. L. Wiśniewski, opisał swoje przygotowania do stworzenia wiarygodnych sytuacji i bohaterów powieści Zespoły napięć czy S@motność $w$ sieci, z których wizyta $\mathrm{w}$ gabinecie lekarza o specjalizacji kobiecej była jednym z przykładów.

Z kolei M. Nahacz nie musiał tworzyć takich sytuacji, jako że, jak wyznał:

Pisałem o sobie, otoczeniu, o ludziach urodzonych w tytułowym, moim roczniku. Książka jest zbudowana wokół autentycznej, bardzo udanej imprezy, która była czymś łączącym w sobie cechy innych balang jakoś tam typowych dla mojego otoczenia i chyba pokolenia, przynajmniej na ile je znam ${ }^{68}$.

Ciekawych, choć jednocześnie wzbudzających ambiwalentne odczucia wrażeń dostarczył czytelnikom pisma wywiad ze znaną podróżniczką i autorką książek, Beatą Pawlikowską: „o przysmakach z małp, larw i ludzi, indiańskich obyczajach męsko-damskich i dżungli"69 rozmawiała z nią A. Trojan, a choć pewne opisy mogły wzbudzić kontrowersyjne odczucia, to niektóre były interesujące (jak choćby stwierdzenie: „Różnimy się od Indian między innymi tym, że my chodzimy na polowanie do sklepu, a oni do dżungli"70).

${ }^{65}$ Dziecko na linii ognia, z W. Kuczokiem rozm. K. Boczek, „Cogito” 2003, nr 17, s. 20.

66 Mam pogodne usposobienie, z J. Chmielewską rozm. B. Zielińska, „Cogito” 2001, nr 1, s. 4.

67 Wierzę w anioły, z K. Grocholą rozm. K. Boczek, „Cogito” 2003, nr 10, s. [17].

68 Wywiad z M. Nahaczem, „Cogito” 2003, nr 9, s. 4.

${ }^{69}$ Człowiek jest kruchy i smaczny, z B. Pawlikowską rozm. A. Trojan, „Cogito” 2003, nr 2, s. 12.

70 Ibidem. 
Inny nieco charakter miały wywiady przeprowadzane ze specjalistami z dziedzin, które nierzadko gościły na łamach pisma. Psycholog, J. Santorski, podkreślając, że „Życie jest ciągłym szukaniem”, zwracał uwagę czytelników „Cogito", by

znaleźć sobie miejsce w świecie zgodne ze swoim temperamentem i predyspozycjami. Człowiek musi rozeznać się w sobie i uznać, co będzie dla niego najlepsze - ścieżka przedsiębiorczości i kariery czy pracy, która da pieniądze ${ }^{71}$.

Rozmowa z seksuologiem L. Starowiczem przyniosła wiele porad oraz wyjaśniła istotne dla młodego czytelnika kwestie ${ }^{72}$. Z kolei znana biografistka J. Siedlecka opowiedziała o swojej pracy przy pisaniu książki o Panu od poezji, podkreślając: „nie lubię pomników. Kto lubi? Młodzież szkolna? W każdym pomniku najciekawsze są dla mnie rysy i pęknięcia"73. Te wywiady wpisywały się $\mathrm{w}$ kształcąco-edukacyjny charakter pisma. Jego odmienną specyfikę podkreślało nawiązanie do Zbigniewa Herberta ${ }^{74}$, a także porady specjalistów w dziedzinach, które interesowały nastoletnich odbiorców, przedstawione $\mathrm{w}$ postaci nieporównywalnej pod względem formy z analogicznymi zagadnieniami, poruszanymi na łamach szczególnie miesięcznika „Dziewczyna”. Także wspomniane wcześniej wywiady z pisarzami kilkakrotnie zawierały wskazówki dla czytelników, na przykład nawiązując do często poruszanych kwestii dotyczących $\mathrm{z}$ rozwijania i pielęgnowania kompetencji literackich czytelników „Cogito”. M. Musierowicz radziła młodym nowicjuszom $\mathrm{w}$ fachu pisarskim:

Światło dzienne powinny widzieć tylko te utwory, które [autor - przyp. M.P.S.] uznaje za skończone i o których wie, że sam nic by już w nich nie zmienił. [...] Nie należy szukać wzorców, nie wolno pod żadnym pozorem nikogo naśladować. Trzeba być sobą, mówić po swojemu i niczego nie udawać75.

W przytoczonych powyżej przykładach, podobnie jak w większości rozmów zamieszczanych na łamach „Cogito”, widoczne były cechy, charakterystyczne dla wymienionych przez niemieckiego teoretyka Hansa-Joachima Netzera dwóch typów wywiadów ${ }^{76}$ : prezentowały one sobą zarówno fakty informacyjne, dotyczące rozmówcy, jak i przedstawiały jego przekonania, a w pewnym stopniu również osobowość. Ich forma, sposób prezen-

71 Życie jest ciagłym szukaniem, z J. Santorskim rozm. A. Prymak, „Cogito” 2001, nr 6, s. 4.

72 Nie tylko przyjemność, z L. Starowiczem rozm. P. Felis, „Cogito” 2003, nr 16, s. 26-27.

73 Herbert był kobieciarzem, z J. Siedlecką rozm. A. Trojan, „Cogito” 2002, nr 12, s. 11.

74 Jego poezja nierzadko była także analizowana we wspomnianych dodatkach zawierających materiał powtórzeniowy do matury.

75 Autor pisze na własnq odpowiedzialność, z M. Musierowicz rozm. M. Kuźnik, „Cogito” 2005, nr 22, s. [37].

76 Dziennikarstwo i świat mediów, red. Z. Bauer i E. Chudziński, Universitas, Kraków 2004, s. 190. 
tacji powodowały, że i ta forma informacji, związana poprzez osobę rozmówcy, z literaturą, wyróżniała się pozytywnie na tle wywiadów, przeprowadzanych na łamach miesięcznika „Dziewczyna”. Jednocześnie w większym niż w odniesieniu do recenzji stopniu redakcja kładła nacisk na wybór twórców znanych szerszej publiczności.

\subsubsection{Idealny prezent ${ }^{77}$ : reklamy książek}

O ile w przypadku dwóch wcześniej omawianych periodyków, „Filipinki” i „Dziewczyny” (zwłaszcza zaś drugiego tytułu), znaczną część reklam stanowiły ogłoszenia, proponujące zakup kosmetyków lub udział w kolejnych edycjach konkursów modowych, o tyle łamy „Cogito” zdominowane były przez anonse, zachęcające do kupna kolejnych numerów pisma z dodatkami specjalnymi, tablicami i arkuszami zawierającymi materiał powtórzeniowy do matury. Drugą grupę reklam stanowiły ogłoszenia promujące rozmaitego rodzaju informatory, repetytoria i słowniki. Kolejną grupę stanowiły reklamy przypominające o rozmaitych akcjach, organizowanych przez dwutygodnik. Niebagatelną grupę stanowiły również ogłoszenia promujące czasopismach, które mogły zainteresować odbiorców pisma. Zaledwie niewielką część wszystkich reklam stanowiły te, które proponowały literaturę młodzieżową. W sumie w trakcie pięciu analizowanych lat odnotowano 1343 ogłoszenia. A zatem, można wymienić następujące kategorie reklam, w których kolejno przedmiotem była:

1) książka,

2) autoreklama „Cogito” (wspomniany cykl dodatków specjalnych, akcje, inicjatywy pisma, związane z książką),

3) prasa.

Reklam, w których przedmiotem była książka, zamieszczono na łamach pisma 807. W tabeli 75 zaprezentowano ich liczbę w poszczególnych latach, natomiast w tabeli 76 przedstawiono typy książek, które były przedmiotem interesujących nas anonsów.

Tabela 75. Ogłoszenia wydawnicze zamieszczane na łamach "Cogito" w latach 2001-2005

\begin{tabular}{|c|c|}
\hline Rok & Liczba ogłoszeń wydawniczych \\
\hline 2001 & 291 \\
\hline 2002 & 220 \\
\hline 2003 & 101 \\
\hline 2004 & 115 \\
\hline 2005 & 80 \\
\hline Ogółem & 807 \\
\hline
\end{tabular}

Źródło: badania własne.

77 Hasło jednej z reklam, „Cogito” 2002, nr 19, s. [13]. 
Tabela 76. Typy książek reklamowanych na łamach „Cogito" w latach 2001-2005

\begin{tabular}{|l|c|}
\hline \multicolumn{1}{|c|}{ Typ książki } & Liczba reklam \\
\hline Beletrystyka, biografie, eseje i in. & 94 \\
\hline Encyklopedie & 34 \\
\hline Informatory & 57 \\
\hline Kalendarze $^{a}$ & 2 \\
\hline Leksykony & 6 \\
\hline Podręczniki & 5 \\
\hline Poradniki & 13 \\
\hline Repetytoria & 121 \\
\hline Rozmówki & 43 \\
\hline Słowniki & 367 \\
\hline Tablice maturalne & 9 \\
\hline Testy & 55 \\
\hline Vademecum & 1 \\
\hline Ogółem & 807 \\
\hline
\end{tabular}

a Zostały one uwzględnione w niniejszym zestawieniu ze względu na swój charakter: pierwszy z nich był rodzajem kalendarza-poradnika, drugi stanowił rodzaj samouczka językowego.

Źródło: badania własne.

Imponująca liczba ogłoszeń, jaka pojawiła się w ciągu dwóch pierwszych badanych lat, wynikała w znacznej mierze z charakteru tych inseratów, których przedmiotem przede wszystkim były rozmaitego rodzaju słowniki, informatory lub repetytoria, a tylko w niedużym stopniu beletrystyka. Tym samym specyfika tych anonsów składała się na spójny obraz omawianego periodyku, zdominowanego przez treści edukacyjno-kształceniowe. W tabeli 76 ta teza została potwierdzona.

Uwagę zwraca fakt, że najczęściej w ogłoszeniach wydawniczych pojawiała się propozycja zakupu słowników (tak było w 367 przypadkach) oraz różnego rodzaju repetytoriów (121 razy). Beletrystyka, biografie i eseje stanowiły przedmiot ogłoszeń zaledwie w 94 przypadkach. Stąd w zestawieniu zarówno nazwisk autorów polecanych tytułów, jak i na liście wydawców, reklamujących swoją ofertę dominowali odpowiednio: specjaliści - pedagodzy, językoznawcy i literaturoznawcy, zaś wśród wydawców oficyny specjalizujące się $w$ wymienionym typie literatury.

W inseratach odnaleźć można w sumie 133 nazwisk różnych autorów ${ }^{78}$, w tym zaledwie 45 pisarzy. W tabeli 77 zaprezentowano nazwiska tych, którzy pojawili się przy okazji promocji tekstów o charakterze edukacyjnym.

78 Do statystyki zaliczano nazwiska tylko pierwszych podanych autorów. 
Tabela 77. Autorzy dzieł naukowych i oświatowych najczęściej reklamowani na łamach „Cogito" w latach 2001-2005

\begin{tabular}{|l|c|l|}
\hline \multicolumn{1}{|c|}{ Dane twórcy } & $\begin{array}{c}\text { Liczba powtórzeń } \\
\text { danego nazwiska }\end{array}$ & \multicolumn{1}{|c|}{ Tytuły reklamowanych tekstów } \\
\hline Piotr Kaczmarski & 46 & $\begin{array}{l}\text { Testy z języka angielskiego. } 1 . \\
\text { Egzaminy na studia filologiczne oraz } \\
\text { testy międzynarodowe }\end{array}$ \\
\hline Małgorzata Dzieduszycka & 19 & Idiomy angielskie \\
\hline Lidia Kosonocka-Taber & 18 & $\begin{array}{l}\text { Angielski bez tajemnic, czyli uczymy } \\
\text { się na cudzych błędach }\end{array}$ \\
\hline D. Jemielniak & 9 & Angielski. Sztuka unikania błędów \\
P. Szymański & \multicolumn{2}{|l}{} \\
\hline
\end{tabular}

Źródło: badania własne.

Nazwiska tych autorów odnaleźć można zawsze przy okazji tego samego tytułu, wielokrotnie powtarzanego w ogłoszeniu.

Jak wcześniej zaznaczono, znacznie mniejszą liczbę nazwisk odnotowano przy analizie pełnej listy pisarzy. Wśród 45 pisarzy znalazło się 18 twórców polskich i 27 obcych, a zatem i w tym przypadku, podobnie jak było to w odniesieniu do recenzji, dominowali twórcy zagraniczni. Kiedy przyjrzymy się pełnemu zestawieniu, przekonamy się, że to nie jedyna zbieżność. W ogłoszeniach wydawniczych tego typu przeważali bowiem pisarze mniej popularni, choć jednocześnie najczęściej (dziewięciokrotnie) w inseratach pojawiło się nazwisko Grażyny Bąkiewicz, autorki znanych powieści młodzieżowych. Poza nią tyleż samo razy reklamowano książkę autorki, współpracującej z periodykiem, M. K. Piekarskiej. Dalsza analiza potwierdziła jednak tezę postawioną wyżej: pięciokrotnie zachęcano do kupienia książki Christophera Paolini, czterokrotnie reklamowano tytuł Bogdana Ogrodnika, trzy razy w inseratach pojawiło się nazwisko Neala Stephensona. Wśród pisarzy, których książki były przedmiotem ogłoszeń, dwukrotnie znaleźli się m.in.: Martin Bedford, Jonathan Carroll, Vivian Greek, David Lodge, Alex McAulay, Deborah Moggach oraz Tomasz Płużański (zob. Aneks 56. Autorzy książek reklamowanych na łamach "Cogito" w latach 2001-2005).

Reklamowane tytuły pochodziły w sumie z oferty 28 wydawców (zob. Aneks 57. Wydawcy książek reklamowanych na łamach „Cogito” w latach 2001-2005). W tabeli 78 przedstawiono te oficyny, których nazwa pojawiała się w reklamach najczęściej. 
Tabela 78. Wydawcy najczęściej reklamowanych książek na łamach „Cogito”w latach 2001-2005

\begin{tabular}{|l|c|}
\hline \multicolumn{1}{|c|}{ Nazwa wydawcy } & Liczba reklam \\
\hline Wydawnictwo Wiedza Powszechna & 324 \\
\hline Wydawnictwa Szkolne i Pedagogiczne & 104 \\
\hline Langendscheidt Polska & 68 \\
\hline Wydawnictwo Naukowe PWN & 64 \\
\hline Przedsiębiorstwo Wydawnicze Harald & 48 \\
\hline Wydawnictwo TELBIT & 21 \\
\hline Dom Wydawniczy REBIS & 43 \\
\hline Wydawnictwo Prószyński i S-ka & 13 \\
\hline Oficyna Wydawniczo-Poligraficzna „Adam” & 11 \\
\hline Wydawnictwo MAG & 9 \\
\hline
\end{tabular}

Źródło: badania własne.

Zestawienie jest logiczną konsekwencją tabeli 76. Rekordzistą jest w tym przypadku Wydawnictwo Wiedza Powszechna, specjalizujące się w ofercie słownikowej. Natomiast najwięksi edytorzy w badanym okresie, oferujący czytelnikom literaturę popularną, nie korzystali w ogóle albo tylko w nikłym stopniu z łamów „Cogito”. Potwierdza to wcześniej postawioną hipotezę, że ów periodyk postrzegany był na rynku raczej jako rodzaj „poradnika edukacyjnego” niźli periodyk młodzieżowy. Stąd na przykład Dom Wydawniczy REBIS, swoje (stosunkowo skromne) zainteresowanie tym tytułem jako nośnikiem promocji wyraził, pojawiwszy się tylko $w$ trzech jego wydaniach, proponując czytelnikom w sumie 21 tytułów, z czego 2 wydane były w serii Poradniki (7 nawyków skutecznego nastolatka Seana Coveya oraz Wszystko OK.? Psychologia dla nastolatków Dale`a i Hannah Carlson). Jeszcze skromniej prezentowało swą ofertę Wydawnictwo Prószyński i S-ka (proponując powieści G. Bąkiewicz) i Wydawnictwo W.A.B. (polecając m.in. książki Marka Krajewskiego).

Wszystkie inseraty wydawnicze, które odnaleźć można na łamach pisma, były starannie przygotowane, niektóre oficyny wykorzystywały za każdym razem ten sam schemat. Oto przykłady ogłoszeń wybranych edytorów (zdjęcia 193-199). 


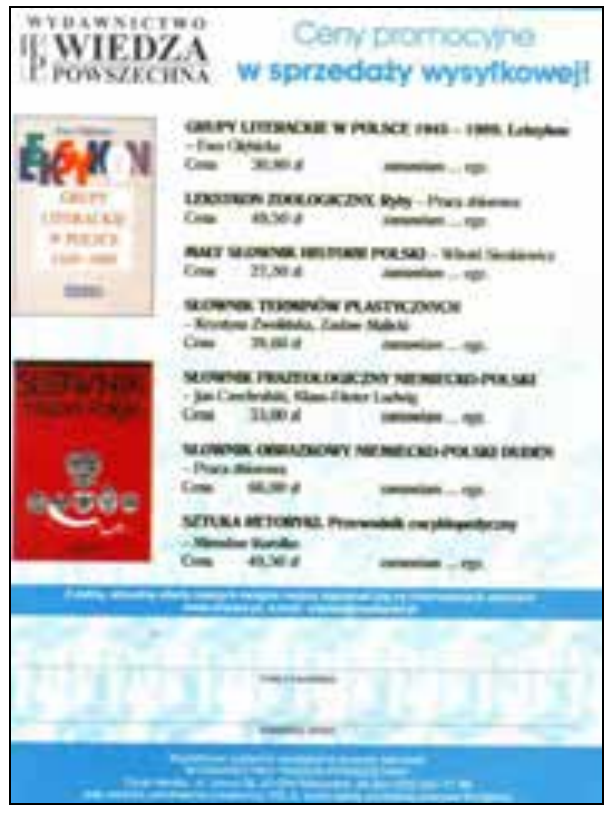

Zdjęcie 193. Przykładowe ogłoszenie wydawnicze zamieszczone na łamach "Cogito" „Cogito 2001, nr 2, s. 13

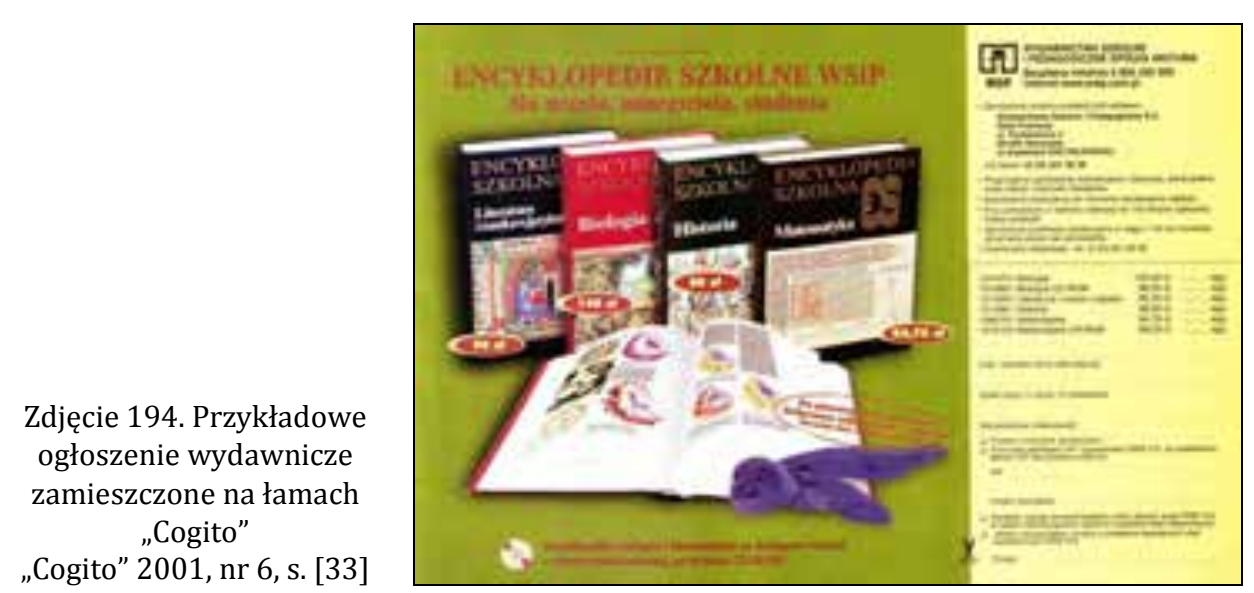

Zaprezentowane $\mathrm{w}$ dwóch grupach inseraty (pierwsza reklamująca słowniki, encyklopedie i lektury szkolne, druga proponująca sięgnięcie m.in. po beletrystykę) łączyły cechy wspólne: żywe, kontrastowe barwy, wyraźne kopie okładek proponowanych książek, zachęcające hasła reklamowe i (rzadziej) krótkie streszczenie polecanych tytułów oraz ich cena. Anonse obejmowały zazwyczaj niewielki moduł, drukowany u dołu strony. Jedynie WSiP oraz $\mathrm{w}$ jednym przypadku PWN skorzystało $\mathrm{z}$ reklamy całostronicowej. 


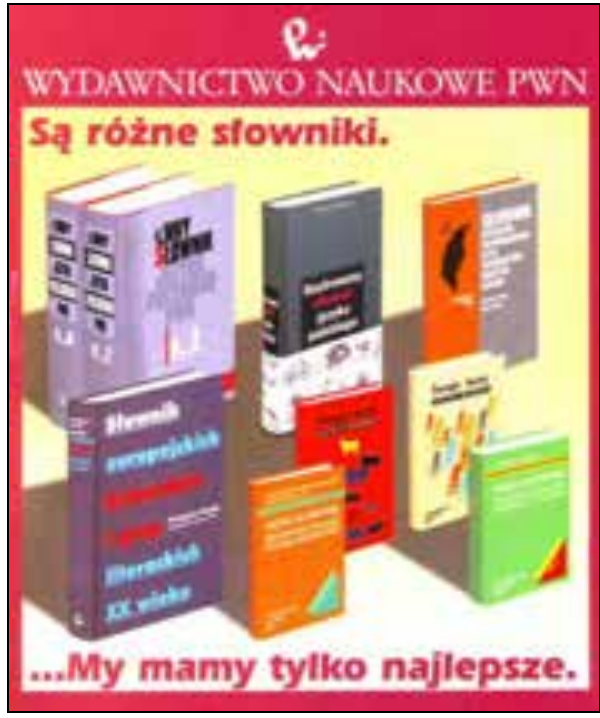

Zdjęcie 195. Przykładowe ogłoszenie wydawnicze zamieszczone na łamach „Cogito” „Cogito" 2001, nr 7, s. [23]

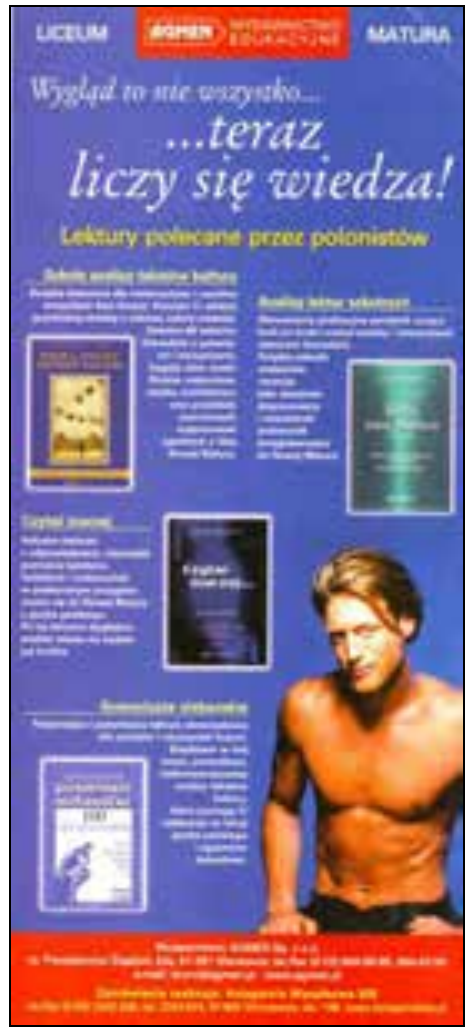

Zdjęcie 196. Przykładowe ogłoszenie wydawnicze zamieszczone na łamach "Cogito" „Cogito” 2001, nr 6, s. [47]

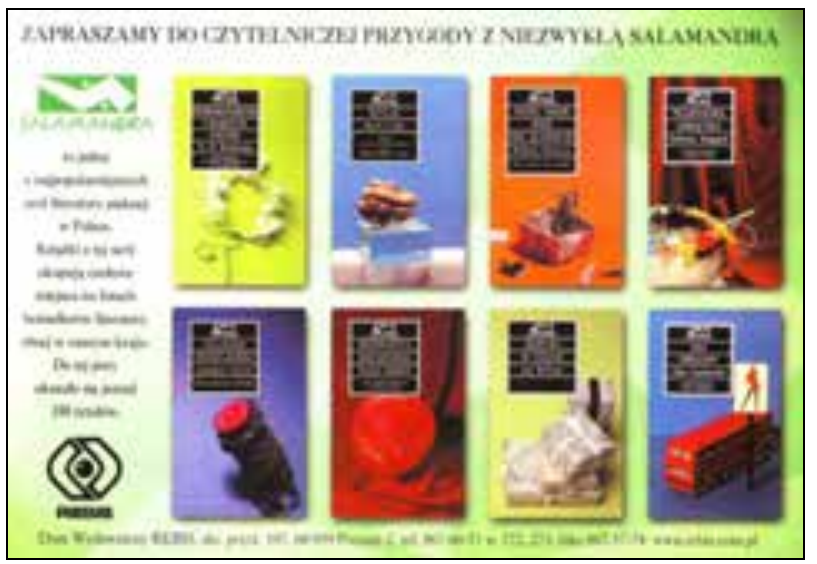

Zdjęcie 197. Przykładowe ogłoszenie wydawnicze zamieszczone na łamach "Cogito"

„Cogito” 2001, nr 11, s. [27] 


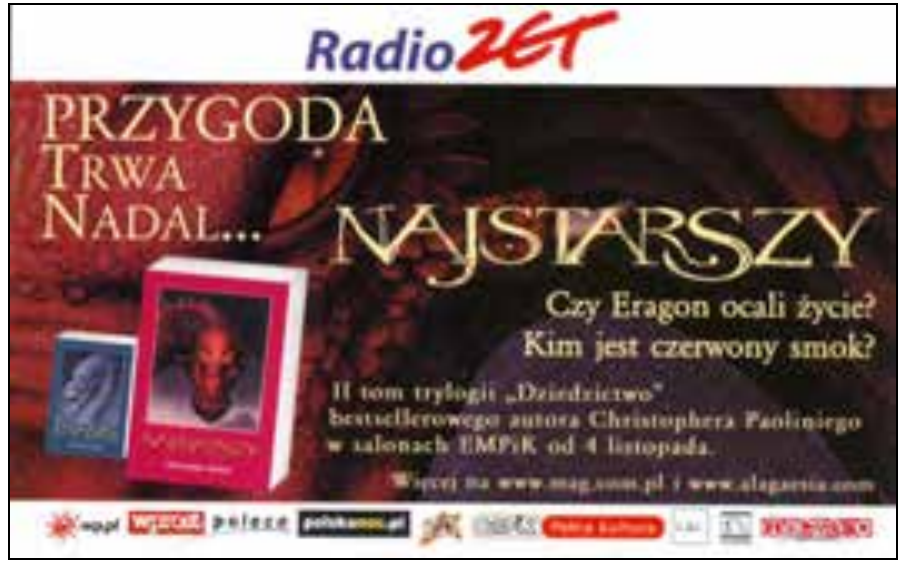

Zdjęcie 198. Przykładowe ogłoszenie wydawnicze zamieszczone na łamach "Cogito”

"Cogito" 2005, nr 19, s. 21

\subsubsection{Spotkaj swego pisarza ${ }^{79}$ : inne formy informacji o książce}

Na łamach „Cogito” odnaleźć można, poza już opisanymi, m.in. bogatą i zróżnicowaną grupę informacji, zaliczanych do gatunku wzmianek i notatek prasowych, tu określonych jako Inne. Obok nich, w tabeli 67. częściowo zobrazowano także liczbę i kategorię poszczególnych typów przekazu związanego z interesującym nas tematem. Warto niektóre z nich przypomnieć, i podobnie, jak w analogicznych przypadkach w poprzednich rozdziałach, przyporządkować je do poszczególnych grup:

- publikacje, nawiązujące do rynku wydawniczo-księgarskiego (32);

- adaptacje, ekranizacje oraz inscenizacje znanych dzieł (27);

- konkursy i akcje związane z książką, inicjowane bądź współorganizowane przez dwutygodnik, a także te, o których jedynie informował (60);

- inne (211) ${ }^{80}$.

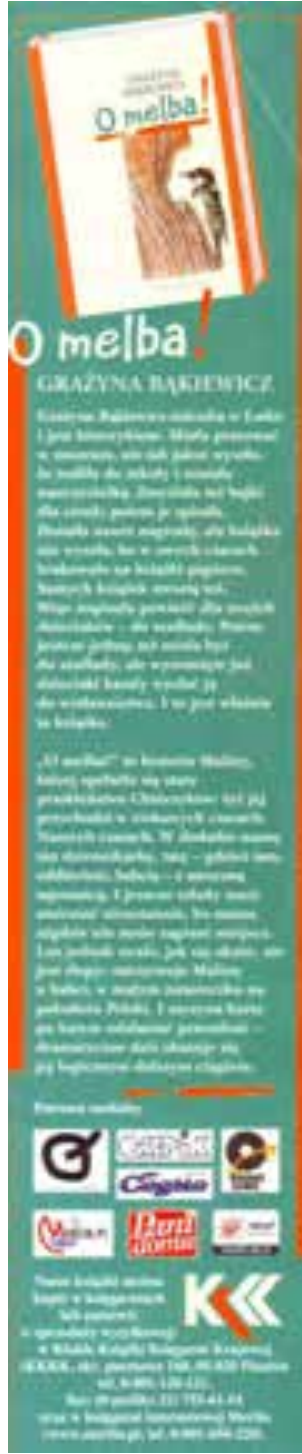

Zdjęcie 199. Przykładowe ogłoszenie wydawnicze zamieszczone na łamach "Cogito" „Cogito" 2002, nr 14, s. [15]

79 Tytuł notki, informującej o 14. Krajowych Targach Książki w Warszawie, „Cogito” 2003, nr 13, s. 64.

80 Zob. przyp. $b$ w tab. 70, s. 595. 
Podobnie, jak było $\mathrm{w}$ poprzednich przypadkach, tak i tu największą grupę stanowi kategoria Inne, ale uwagę zwraca również duża liczba rozmaitych konkursów, inicjowanych przez periodyk oraz niemała liczba publikacji, bezpośrednio bądź pośrednio związanych z książką. Zastanawiający jest natomiast brak listów od czytelników, którzy ustosunkowywaliby się do problemów związanych z interesującymi nas zagadnieniami, a poruszanych na łamach pisma oraz (poza trzema wątpliwymi wyjątkami81) brak portretów wybranych pisarzy. W pewnym stopniu kryteria tego typu publikacji spełniały dwa inne teksty, tu zaklasyfikowane jako ogólne, odnoszące się do wybranych twórców.

Wszystkie te informacje drukowane były w całym periodyku, choć niektóre posiadały swoje własne nazwy, jak np. Klub Cogito czy Czas na debiut.

\subsection{Wokół książki ${ }^{82}$ : teksty poświęcone książce}

Wśród 32 tekstów, związanych z literaturą, trudno odnaleźć konkretne i jednolite kryteria lub myśl przewodnią, którymi mogła kierować się redakcja. Pewnym tropem może być lokalizacja tego typu publikacji; niektóre z nich drukowano na przykład w takich rubrykach, jak Akademia Cogito, Bank informacji, Po studiach praca, Promuj talent, Studia w pytaniach i odpowiedziach. Inne jednak pojawiały się na stronach, na których zamieszczano zazwyczaj lżejsze teksty, na przykład w rubryce Miszmasz informacyjny. Nie wszystkie publikacje miały poważny charakter, część czytelnik powinien potraktować z przymrużeniem oka.

Te, które należały do pierwszej grupy, odpowiadały edukacyjno-poradnikowemu charakterowi "Cogito”, wpisując się w zagadnienia związane z rozwojem potencjalnych zdolności pisarskich czytelników pisma z jednej strony, z drugiej zaś odnosiły się do podejmowanych przez maturzystów decyzji o kierunkach studiów.

Przykładem może być choćby tekst, w którym radzono, „jak wydać książkę?"83. Proponowano udział w konkursach literackich, podjęcie próby samodzielnego wydania własnego debiutu lub „deptanie po piętach wydawcom"84. Jeden z fachowców z branży radził Kogitowcom rozesłanie fragmentów utworów do wybranych periodyków literackich, inny - poznanie tajników warsztatu pisarskiego. Temat ten podjęto ponownie, wskazując na dobrą koniunkturę wydawniczą, podkreślając jednocześnie, że szczególnie

81 Do tej kategorii można byłoby np. zaliczyć wspomnienie o Janie Pawle II, a także prezentację M. Piekorz, która reżyserowała ekranizację powieści W. Kuczoka Gnój.

82 M. Rzymski, Wokół książki, „Cogito” 2005, nr 15, s. 36-37.

83 E. Woźnica, Jak wydać książkę?, „Cogito” 2002, nr 13, s. 74.

84 Ibidem. 
duże szanse na opublikowanie swej twórczość mają ci, którzy opiszą rzeczywistość wokół siebie, środowisko, w którym żyją, a zrobią to „językiem barwnym, oryginalnym i niebanalnym" 85 . Po raz kolejny zachęcano do wzięcia udziału w organizowanych przez edytorów konkursach, prezentując zasady określone w inicjatywach tego typu, podejmowanych przez Świat Książki oraz Wydawnictwo Jacek Santorski \& Co. Również młodym poetom radzono, jak powinni promować swój talent, uczulając przy tym nastoletnich debiutantów:

Nie należy wysyłać innym dopiero co napisanych wierszy - stan euforii po napisaniu jest dość naturalny, a by obiektywnie ocenić wartość wiersza, trzeba nabrać do niego dystansu. To przychodzi z czasem ${ }^{86}$,

ostrzegając jednocześnie, by nie zasypywali wydawców zbyt dużą liczbą wierszy, a swe pierwsze kroki stawiali w mniejszych miastach, nawiązując kontakty z domami kultury lub bibliotekami, które niekiedy mogą pomóc w wydaniu tomiku wierszy. Sprecyzowano również zasady, do których powinien dostosować się debiutujący poeta, by jego wiersze były „coraz lepsze”: m.in. „czytać, czytać, czytać dużo poezji. Brać udział w warsztatach literackich - one czasem całkowicie zmieniają podejście do swojej twórczości. Uczestniczyć w spotkaniach literackich..." 87 .

Dbając o karierę zawodową swoich podopiecznych, redakcja pisała również o pracy z książką, przywołując m.in. dane statystyczne dotyczące liczby działających $\mathrm{w}$ Polsce wydawnictw i możliwości zatrudnienia w nich ${ }^{88}$. Wyjaśniano również, jaką rolę pełnią „Ludzie z branży” i, pamiętając o swej dydaktycznej funkcji, przypominano, że „aby wyprodukować książkę, potrzebna jest gruntowna wiedza" ${ }^{89}$. Wskazywano w związku $\mathrm{z}$ tym, gdzie i w ramach jakich specjalizacji na uczelniach wyższych można zdobyć odpowiednie wykształcenie. $\mathrm{Z}$ kolei w rubryce Tam będzie praca pisano o studiach bibliotekoznawczych i perspektywach, jakie daje ten właśnie kierunek. Podkreślano: „Choć czytelnictwo w Polsce spada, bibliotekoznawcy nie narzekają na brak zajęcia"90, wskazując na liczne możliwości zatrudnienia po ukończeniu nauki.

Niewielka część tekstów zaliczonych do opisywanej kategorii traktowała o kwestiach ściśle literackich. Dwukrotnie pisano o komiksie: raz podejmując próbę przybliżenia czytelnikom jego japońskiej odmiany, jaką jest

\footnotetext{
85 [br. aut.], Jak wydać powieść [pis. oryg.], „Cogito” 2004, nr 17, s. 60.

86 [br. aut.], Młodzi poeci, do piór!, „Cogito” 2002, nr 19, s. [67].

87 Ibidem.

88 M. Rzymski, Wokół książki, „Cogito” 2005, nr 15, s. 36-37.

89 Ibidem, s. 37.

90 K. Boczek, Etaty w bibliotece, „Cogito” 2003, nr 18, s. 43.
} 
manga91, następnie podając „Przepis na dobry komiks”92. Ostrzegano: „W komiksie trzeba umieć wszystko pokazać. Jak się okazuje, że się nie umie narysować konia, a koń jest niezbędny, to zaczyna się tragedia. Jeżeli chcecie tworzyć komiksy, musicie dużo rysować"93, jednocześnie powoływano się na opinie znanych polskich rysowników, mistrzów w swoim fachu, m.in. Janusza Christy.

Czy takimi mistrzami są J. Carroll, P. Coelho i William Wharton, co takiego jest $w$ ich książkach, że zajmują czołowe miejsca na listach bestsellerów? - zastanawiała się z kolei Anita Żak, za krytykami literackimi charakteryzując powieści tych pisarzy w taki oto sposób: „Mało skomplikowane słownictwo. Schematyczne i powierzchowne rysy psychologiczne postaci. Ten sam szablon powielany $\mathrm{w}$ kolejnych książkach..." ${ }^{94}$, równocześnie konkludując, posługując się opinią Mai Wolny, dziennikarki tygodnika „Polityka”: „każdy z trzech autorów daje czytelnikowi coś, czego głód można zauważyć w obecnym młodym pokoleniu młodych czytających. Literaturę magiczną właśnie”95. Po te powieści nastoletni czytelnicy sięgną znacznie chętniej niż po lektury szkolne, bo, jak pisze K. Zadros, autor innej publikacji, którą warto przytoczyć, większość licealistów-czytelników pisma - traktuje kanon obowiązkowych lektur jako „kolejny ponury obowiązek, materiał do wkucia, zabierający kilka cennych godzin, które można by spędzić w o wiele przyjemniejszy i pożyteczniejszy sposób" ${ }^{\prime 6}$. W tekście, który ukazał się w cyklicznej rubryce Prowokacje, K. Zadros zdecydowanie zaprotestował przeciwko usunięciu z listy lektur dzieł na przykład Adama Mickiewicza, argumentując dosadnie:

Ograniczając nasze wykształcenie do współczesnej literatury romansowo-rozrywkowej [...], choćby nie wiem, jak sprawnie i interesująco napisanej, wyprodukowalibyśmy w krótkim czasie generację półdebili, którzy myślą, że historia kultury zaczęła się wraz $\mathrm{z}$ wynalezieniem gier play-station, a ich poglądy na świat nie wychodzą poza poziom serialu Beverly Hills $90210^{97}$.

Był to jednak jeden z bardzo nielicznych tak zdecydowanych głosów na temat związany z interesującym nas zagadnieniem, choć należy zaznaczyć, że na łamach periodyku pojawiały się również teksty dotyczące współczesnej kultury, w których przywoływano także postacie pisarzy. W jednej $\mathrm{z}$ ważniejszych publikacji tego typu zastanawiano się nad zagadnieniem,

\footnotetext{
91 A. Kędzior, Komiks z ambicjami, „Cogito”2002, nr 1, s. 24-25.

92 [br. aut.], Przepis na dobry komiks, „Cogito” 2005, nr 19, s. 38-39.

93 Ibidem, s. 38.

94 A. Żak, Mędrcy czy grafomani?, „Cogito” 2001, nr 5, s. [18].

95 Ibidem, s. [19].

96 K. Zadros, Co Wy, k... wiecie o Mickiewiczu?!, „Cogito” 2001, nr 6, s. [36].

97 Ibidem.
} 
które znalazło się również w prezentowanych wcześniej tygodnikach opinii, a które dotyczyło współczesnych idoli. Są nimi „bohaterowie kultury popularnej":

Linda z wielką spluwą w ręku, Marilyn Manson z wampirycznym makijażem, Enrique Iglesias ze swoim romantycznym spojrzeniem, Stasiuk z nieodłącznym petem w zębach, Britney Spears z odsłoniętym pępkiem ${ }^{98}$.

\section{Postawiono tezę, że dziś}

idolami stają się ludzie przeciętni, zwyczajni, nie wyróżniający się niczym szczególnym. [...] Drzwiami i oknami pcha się teraz nowe zjawisko, jakim jest uwznioślanie przeciętności, pospolitości, głównie dzięki tzw. reality show w rodzaju Big Brothera ${ }^{99}$.

Obok idoli muzycznych i sportowych pojawiają się również, choć znacznie rzadziej, idole-literaci, jak choćby przywołany we wspomnianym tekście A. Stasiuk, porównywany z Markiem Hłaską, czy owiany „specyficzną aurą legendy, kultu czy jak chcą inni - mody"100 J. Pilch albo Marcin Świetlicki. W publikacji, szczegółowo tu przytaczanej, pojawiło się nadto istotne spostrzeżenie, na które myślący czytelnik periodyku zwrócił prawdopodobnie uwagę. Otóż, według P. Felisa, znani pisarze, niezależnie od tego, czy sami tego chcą, czy nie, istnieją także w obiegu kultury masowej, traktowani są nierzadko jako idole pop-kultur, rozdający autografy, udzielający wywiadów czy pozujący do zdjęć. Bywają częstymi gośćmi największych imprez, związanych z książką, i to oni przyciągają czytelników, którzy potrafią stać kilka godzin po to, by otrzymać dedykację od swego pisarza-idola101.

Na łamach „Cogito” kilkakrotnie pisano o takich możliwościach spotkania swego ulubionego twórcy, donosząc czytelnikom o największych imprezach, związanych z książką zarówno o Krajowych, jak i Międzynarodowych Targach Książki w Warszawie ${ }^{102}$. Teksty te pełniły przede wszystkim funkcję informacyjną: czytelnicy dowiadywali się z nich o spotkaniach, wystawach, a także pokazach (na przykład filmowych), zaplanowanych przez organizatorów i wydawców ${ }^{103}$. Warto podkreślić, że zapowiadano również Targi Książki Edukacyjnej104. Pisano też o innych imprezach,

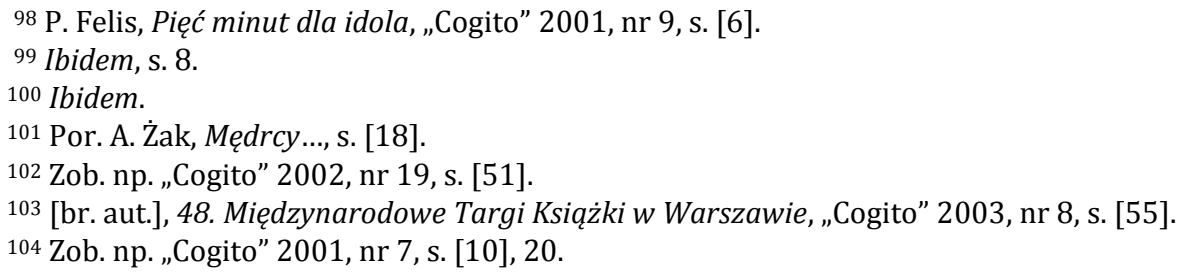


związanych z książką, informując na przykład o akcji Szał czytania105, zorganizowanej przez Instytut Informacji Naukowej i Studiów Bibliologicznych Uniwersytetu Warszawskiego, a objętej patronatem medialnym m.in. przez omawiany periodyk. Pisząc o tym przedsięwzięciu, przypomniano jego historię, która zaczęła się w 2000 r., przedstawiono program opisywanej edycji, w którym nie zabrakło zarówno spotkań z popularnymi autorami, wykładów, jak i zabaw literackich, konkursów czy występów teatralnych ${ }^{106}$.

Imprezy tego typu mogły zainteresować odbiorców „Cogito”, wytrawnych czytelników i miłośników słowa pisanego, którzy, być może, odnaleźli się wśród opisanych przez E. Nowak najczęściej spotykanych typów kolekcjonerów książek. Znalazł się wśród nich m.in. „model narcystyczny”, który

pragnie zaimponować wszystkim wokół, a przede wszystkim sam sobie. Cóż mu w tym lepiej pomoże, jak nie najlepszy przyjaciel człowieka? On czytał już wszystko i wszystko zna. W księgozbiorze ma bałagan, w każdej z pobliskich bibliotek zalega i kolekcjonuje biblioteczne ponaglenia, a w łazience na pralce, w kuchni na stole, w przedpokoju na butach wszędzie leżą książki. Niedbale rzucone, wyglądają całkiem naturalnie. Zupełnie jakby ktoś je naprawdę kochał. Kiedy wpadniesz do niego, otworzy ci z lekkim opóźnieniem, ale za to od razu nadziejesz się na „Wahadło” Umberto Eco. Niczego nie może ci jednak nigdy pożyczyć. I nie miej mu tego za złe. Gdyby coś ci pozwolił przeczytać, od razu by się wydało, że on nic nie ma do powiedzenia. Połyka książki w sensie dosłownym, czyli statystyczno-trawiennym ${ }^{107}$.

\subsection{Zapamiętaj, co przeżyłeś ${ }^{108}$ : konkursy i akcje}

Konkursy, związane z książką, a szerzej, literaturą, często gościły na łamach "Cogito". Analiza zgromadzonego materiału pozwoliła podzielić tego typu inicjatywy na trzy grupy:

1) regularnie organizowane konkursy o charakterze literackim i paraliterackim;

2) jednorazowe pomysły, także te, w których periodyk był współorganizatorem lub o których jedynie informował;

3) minikonkursy, w których nagrodą była wybrana lektura.

W pierwszej grupie wymienić należy inicjatywę towarzyszącą periodykowi od początku jego istnienia, która była w zasadzie jednym z trzech tego typu przedsięwzięć.

Od numeru $1 \mathrm{w} 1994$ r. w rubryce Czas na debiut proponowano czytelnikom rodzaj konkursów, dając jednocześnie szansę tym z nich, którzy czuli

\footnotetext{
105 Pisano o niej również na łamach tygodnika „Polityka”.

106 [br. aut.], Szał Czytania!!! „Cogito” 2001, nr 6, s. 10.

107 E. Nowak, Po co komu ksiq̨żki?, „Cogito” 2002, nr 1, s. [22].

108 „Cogito" 2004, nr 7, s. [62].
} 
w sobie żyłkę pisarską. Odtąd, także przez cały objęty badaniem okres, $\mathrm{w}$ tym miejscu pojawiały się przysyłane przez nich utwory. Do numeru 20 (2002) były to wyłącznie wiersze, od kolejnego wydania (21/2002) także proza. Oceniał je opiekun rubryki, L. Janion, następnie wybrane $\mathrm{z}$ nich drukowano na łamach pisma wraz z jego komentarzem i podziękowaniem, skierowanym do osób, których prace zostały wyróżnione, ale nie zamieszczone w piśmie ${ }^{109}$. Czas na debiut zajmował w ciągu pięciu lat od jednej do trzech stron, z tendencją do zmniejszania miejsca w periodyku przeznaczonego na tę formę kontaktu $\mathrm{z}$ odbiorcami.

Idea tego przedsięwzięcia, korespondująca z głównymi celami polityki redakcyjnej, była wielokrotnie przypominana: „Starajmy się poznawać poezję innych, by samemu pisać mądrzej!”110 czy: „Te strony są otwarte na wszelką twórczość literacką pod warunkiem, że będzie dobra i ciekawa"111. L. Janion prosił również czytelników o ich opinie na temat wybranych wierszy - te komentarze obiecywał przesyłać autorom. Wielokrotnie pojawiały się także konkretne rady, dotyczące warsztatu pisarskiego, jak choćby: „W opowiadaniach coś się powinno dziać, coś powinno czytelnika zaskoczyć, wybrany fragment życia, jaki opisujecie, powinien być znaczący, dać szansę na głębszą refleksję"112. Utwory, wydrukowane na opisywanych stronach stały się podstawą kolejnych wydań Antologii poezji Cogito113, zapoczątkowanych w 1997 r. Były one nie tylko szansą dla debiutujących autorów („Cogitowa pieczęć ma swoja wagę!”114), ale również możliwością dla tych, którzy do tej pory pisali „do szuflady”, albo nie potrafili ocenić własnej twórczości. Poznanie cudzej pozwalało, według L. Janiona, na nabranie dystansu do własnego literackiego dorobku.

Autor Wierszy dla niej często proponował czytelnikom temat, który mieli opisać w postaci wiersza, opowiadania, lub innej, wybranej przez nich formy, inicjując tym samym drobne konkursy literackie. Jedną z najciekawszych inicjatyw tego typu był konkurs Zapamiętaj, co przeżyłeś, ogłoszony w 2003 r., w numerze 18 pisma. „Zależy nam na prozie realistycznej,

109 Rubryka ta mogłaby stanowić przedmiot obszernego opracowania, tu jednak, ze względu na fakt, że stanowi tylko jedną z form związanych z książką, zostanie przedstawiona ogólnie.

110 „Cogito" 2001, nr 1, s. [76].

111 „Cogito” 2003, nr 1, s. [51].

112 K. Janion, Czas na prozę, „Cogito” 2003, nr 12, s. [82].

113 Na przykład w 2001 r. była to publikacja pt. Zanim wypełni się wiek. Antologia poezji Cogito, wybór L. Janion, AW Aga-Press, 2001; z okazji jubileuszu dziesięciolecia periodyku, wydano Dziesięć razy rok, także pod redakcją L. Janiona, opublikowane również przez wydawcę „Cogito”. Należy zaznaczyć, że niektórzy debiutanci, zaczynający swą przygodę z literaturą, dzięki omawianej rubryce wydawali własne tomiki poezji, o czym skrupulatnie informował L. Janion. Zob. np. „Cogito” 2005, nr 2, s. 38.

114 „Cogito” 2004, nr 12, s. 69. 
przedstawiającej świat uczuć i międzyludzkich relacji”115 - tak m.in. określono zasady, dodając jeszcze ograniczenia objętościowe każdej z prac (trzy strony maszynopisu). Do redakcji wpłynęły propozycje 108 autorów. Najczęstszymi wątkami, przewijającymi się w nich, były narkomania młodzieży i alkoholizm rodziców, choroby psychiczne, również tragiczna miłość. A zatem przeżycia, których lepiej nie zapamiętywać, wbrew hasłu przewodniemu konkursu. Na szczęście, większość z tych opowiedzianych historii była zmyślona, o czym świadczyły wytknięte przez jurora błędy116. Nagrodzone i wyróżnione prace były zamieszczane w kolejnych numerach pisma.

Inne tego typu konkursy, proponowane w rubryce Czas na debiut, to na przykład Historia do końca opowiedziana, Wiersz pisany gwarq, Wiersz z cytatem czy konkurs na pastisz.

Podobny charakter miała rubryka Młoda proza, prowadzona przez Lilkę Poncyliusz. Od wydania 7 (2001) rubryka zmieniła nazwę na Debiut, pojawiając się przemiennie z opisanym wyżej Czasem na debiut. Różniła się od niej tym, że czytelnicy mogli tu nadsyłać nie tylko utwory literackie, ale również takie, które można było zaliczyć do określonych gatunków dziennikarskich, jak np. esej, felieton, reportaż. Liczyła sobie od połowy do 2 stron, jednak od numeru 13 (2001) zaniechano jej drukowania.

Inną inicjatywą, realizowaną na łamach pisma, która mobilizowała czytelników do podjęcia wysiłków pisarskich, była Szkoła uczuć. Na stronach tak zatytuowanych drukowano opowiadania o miłości, przysyłane przez czytelników na konkurs Twoja historia uczuć. Szkoła uczuć pojawiała się w piśmie od 2003 r. i istniała do końca badanego okresu, zajmując od połowy do niemal dwóch stron. Znaczna część tytułów tych opowieści wskazywała na ich charakter, na przykład: Dlaczego mi to robi?, Mroczna przeszłość, Przegapić uczucie, Przestępstwo miłosne, Zakazana miłość.

Minikonkursem, również należącym do pierwszej grupy, o którym warto wspomnieć, był pomysł Dymki. Redakcja proponowała temat, prezentowała kilka rysunków, składających się na minikomiks, a zadaniem czytelników było uzupełnienie pustych „dymków” tak, by pasowały do przedstawionych obrazków.

Pozostałe konkursy miały charakter inicjatyw jednorazowych. W wielu z nich powracał pomysł napisania przez czytelników krótkiego opowiadania. Jednym z przykładów był Konkurs literacki, ogłoszony w 2003 r.117 Redakcja czekała na opisane przez czytelników historie na dowolny temat. Najciekawsze z nich obiecywano wydrukować na łamach pisma oraz na

115 L. Janion, Uwaga Konkurs!, „Cogito” 2003, nr 18, s. 68.

116 „Cogito" 2004, nr 7, s. [62].

117 Konkurs inspirowany zamieszczoną w recenzji informacją: „każdy ma do opowiedzenia jakąś historię. Przekonał się o tym Paul Auster, gdy cztery lata temu ogłosił w ogólnoamerykańskiej rozgłośni radiowej konkurs na opowiadanie”. Zob. „Cogito” 2003, nr 18, s. [66]. 
stronie internetowej periodyku, zaś autorzy otrzymać mieli dodatkowo zestawy dwóch ufundowanych przez Wydawnictwo W.A.B. powieści118.

Tego typu konkursów było dużo; do najciekawszych i jednocześnie zabawnych należał m.in. konkurs Napisz nowelę z Cogito!, ogłoszony w numerze 14 (2001). Jak pisano, była to szansa dla utalentowanych prozaików, którzy chcieliby „pójść w ślady Żeromskiego, Hłaski, Sapkowskiego, czy Pilcha [...]. Zyskać sławę, rozdawać autografy oszalałym fankom, zarabiać krocie, widywać swoją twarz na pierwszych stronach gazet..."119. Pomijając obiecane perspektywy, z których część była raczej nierealna, wystarczyło napisać $\mathrm{w}$ dowolnej formie frapującą opowieść. Jedynym warunkiem było to, aby wszystkie wyrazy, poza przyimkami czy zaimkami, zaczynały się na tę samą literę, by tak wymyślony tekst liczył nie więcej niż pół strony maszynopisu i był sensowny. Obok przedstawiono przykładową nowelę. Nagrodami były zestawy Encyklopedii multimedialnych PWN. Wyniki ogłoszono w wydaniu trzecim w $2002 \mathrm{r}$.

Czytelnicy mieli również możliwość wykazać się znajomością slangu swojego pokolenia, dzięki zabawnemu konkursowi Znaszli ten język? Podany przez redakcję fragment należało przetłumaczyć na język zrozumiały dla pozostałej części społeczeństwa. Oto fragment tekstu, z którym Kogitowcy musieli się „zmierzyć”:

Musieli mnie obcykać zza rogu. Trzy nabakane kartony w najkach. No, totalnie hardkorowa akcja. Podbijają do mnie i pytają, czy mam burak, bo mają zajawkę, żeby zrobić wałek. Kitram się, ale wstawiam ściemę, że nie mam. Oni na to kitują mi kielnie. Wyiskali buraka....120.

Innego typu wiedzą musieli pochwalić się czytelnicy pisma w konkursie Cytaty. Podane przez redakcję $\mathrm{w}$ języku angielskim sławne cytaty należało przetłumaczyć na język polski, podając ich autora lub utwór literacki, z którego je zaczerpnięto. Nagrodą główną był Praktyczny słownik angielsko-polski, polsko-angielski, ufundowany przez Wydawnictwo Naukowe PWN121. Podobny charakter, odwołujący się do wiedzy odbiorców periody$\mathrm{ku}$, miał konkurs Wyznanie miłosne: kto to powiedział? Zadaniem czytelników było odnalezieniu w danym numerze pisma pięciu wyznań miłosnych, znanych z literatury. Następnie należało odgadnąć adresata tychże słów, a także osobę, która je wypowiedziała ${ }^{122}$.

\footnotetext{
118 Konkurs literacki, „Cogito” 2003, nr 18, s. [66].

119 [br. aut.], Konkurs: Napisz nowelę z Cogito!, „Cogito” 2001, nr 14, s. [78].

120 [br. aut.], Konkurs: Znaszli ten język?, „Cogito” 2003, nr 5, s. 8.

121 [br. aut.], Konkurs: Cytaty, "Cogito” 2003, nr 3, s. [78].

122 [br. aut.], Konkurs: Wyznanie miłosne: kto to powiedział?, „Cogito” 2003, nr 2, s. [9].
} 
Periodyk był również współorganizatorem kilku interesujących nas przedsięwzięć, rozwijających zdolności pisarskie czytelników. W tej grupie znalazł się na przykład zorganizowany przez „Cogito” wspólnie z Collegium Civitas konkurs Wzór obywatela w polskiej demokracji, czyli Stworzenie Świata - JEJ ŚWIATA, rozstrzygnięty w połowie 2001 r. ${ }^{123}$

Liczną grupę stanowiły konkursy, o których dwutygodnik informował na swoich łamach. I tak na przykład pisano o adresowanym do „młodych dramaturgów” konkursie Szukamy polskiego Szekspira, organizowanym przez Polski Ośrodek ASSITEJ ${ }^{124}$, informowano o licznych konkursach poetyckich, jak choćby o V Ogólnopolskim Konkursie Poetyckim im. S. Czernika, Ogólnopolskim Konkursie Poetyckim im. ks. Jerzego Popiełuszki czy IX Ogólnopolskim Turnieju Jednego Wiersza „O Laur Plateranki”.

Książka często bywała nagrodą w różnego rodzaju konkursach, nie tylko literackich. W tej grupie znalazł się konkurs wiedzy o Uniwersytecie Jagiellońskim (charakterystyczny dla periodyku był fakt, że nagrodą były słowniki, encyklopedie i programy multimedialne) czy konkurs, w którym należało wymienić polskiego laureata Literackiej Nagrody Nobla z ostatnich lat. Nierzadko inicjatywy tego typu pojawiały się w rubryce recenzyjnej. Tu pytano na przykład o tytuły konkretnych książek, nazwiska pisarzy, którzy mieli gościć na targach książki lub też pytano o nazwiska reżyserów ekranizacji znanych powieści, odwołując się nierzadko do zamieszczanych na łamach pisma recenzji filmów, powstałych na podstawie znanej książki.

Jakkolwiek tego typu informacji, pośrednio z nią związanych, było stosunkowo niewiele (zaledwie 27), to jednak pisano o najważniejszych wydarzeniach tego typu, na przykład o kolejnej ekranizacji Quo vadis Henryka Sienkiewicza w reż. Jerzego Kawalerowicza, Zemście Aleksandra Fredry w reż. Andrzeja Wajdy, a w odniesieniu do twórczości obcych pisarzy donoszono na przykład o ekranizacji pierwszej części cyklu o Harrym Potterze Joanne K. Rowling, w reż. Chrisa Columbusa czy Władcy Pierścieni Johna R. R. Tolkiena. Wzmianki tego typu, zgodnie ze swoją definicją, były niewielkie objętościowo i spełniały przede wszystkim funkcję informacyjną, choć w kilku przypadkach ich autorzy usiłowali uczynić z nich pararecenzję. Uzupełniano je zazwyczaj kadrem z filmu lub zdjęciem aktorów w nim występujących. Ten typ informacji określono tu mianem „inne”. Zaliczono do nich również kolejne formy, o których należy wspomnieć.

Pierwszą z nich był Klub Cogito, który drukowano na łamach periody$\mathrm{ku}$ z kilkoma krótkimi przerwami przez cały badany okres, zmieniając kilkakrotnie razem z całym dwutygodnikiem jego wygląd. Klub... zajmował

123 „Cogito” 2001, nr 12, s. [80].

124 [br. aut.], „Szukamy polskiego Szekspira”, „Cogito” 2004, nr 4, s. [11]. 
od jednej do czterech stron, miał charakter informacyjno-bibliograficzny. Odnaleźć można było w tym miejscu propozycje wybranych i krótko przedstawionych przez redakcję książek, które czytelnicy mogli zamówić w wysyłkowej księgarni Wydawnictwa AGA-Press. Wystarczyło, by wypełnili zamieszczony obok kupon. W niektórych wydaniach proponowano, by Kogitowcy przysyłali własne propozycje ciekawych, ich zdaniem, książek, a wydawca ze swej strony obiecywał, że dołoży starań, by dany tytuł znalazł się w księgarni wysyłkowej. Proponowano rozmaitą liczbę tytułów (od 6 do 57), przydzielając je do określonych kategorii, przy czym dominowały te, które według redakcji mogły być przydatne maturzystom (na przykład Historia, Języki obce, Polonistyka, Słowniki i encyklopedie, ale i Do poczytania). Wielokrotnie jeden wybrany tytuł był szerzej omawiany, a jego charakterystyka przywodziła zazwyczaj na myśl skojarzenie ze streszczeniem, które czytelnicy mogli odnaleźć również we wspomnianych dodatkach specjalnych, przygotowujących ich do egzaminów.

Inne typy informacji, zaliczone do wspomnianej wyżej grupy, pojawiały się niesystematycznie na łamach pisma. Był to na przykład fragment powieści M. K. Piekarskiej Klasa pani Czajki (drukowany w latach 20042005), jednorazowo fragment powieści E. Nowak: Wszystko, tylko nie mięta. Nadto z okazji wakacji drukowano opowiadania na plażę, a także polecano książki na wakacje (dwukrotnie w 2004 r., w numerach 12 i 13).

W latach 2002-2003 nieregularnie prezentowano Nasz ranking. Było to zestawienie najpopularniejszych książek. Jako że nie podano źródła, można się domyślić, że wyboru dokonała 0. Siewko na podstawie tytułów, proponowanych w Klubie Cogito (w tym też miejscu w sześciu przypadkach znalazł swe miejsce ów ranking, wraz z informacją, że podane tytuły są do nabycia w rzeczonej księgarni). Zestawienie pojawiło się na łamach pisma sześciokrotnie125. Jego forma nie była stała: raz podzielony był na dwie części: Literaturę polskq i Literaturę obca, w których podano po pięć tytułów, innym razem wymieniono sześć książek w jednej kolumnie.

Dużą grupę stanowiły informacje związane z wydarzeniami życia literackiego. Wspomniano już o publikacjach, poświęconych targom książki, ale warto zauważyć, że poza dłuższymi tekstami, których autorzy podejmowali ten temat, odnaleźć można również krótkie wzmianki, sygnalizujące jedynie zbliżającą się imprezę. Tego typu notek, informujących o różnego rodzaju spotkaniach, targach, akcjach czy po prostu interesujących faktach z życia książki, znalazło się w dwutygodniku w sumie 156 (Aneks 58. Wybór tekstów związanych z literaturą i rynkiem wydawniczo-księgarskim, zamieszczonych na łamach „Cogito” w latach 2001-2005). Pisano o spotka-

125 M.in.: „Cogito” 2002, nr 17, s. [52]; nr 19, s. [53]; nr 20, s. [53]; 2003, nr 3, s. [53]; nr 5, s. [46]. 
niach autorskich, także z dziennikarzami „Cogito”: M. K. Piekarską, E. Nowak, L. Janionem, ale i z A. Liberą, K. Siesicką. Informowano o cyklicznych spotkaniach Apetyt na literaturę, o Elbląskich Nocach Teatru i Poezji oraz o Dniach Tischnerowskich. Pisano o rozmaitych akcjach, promujących książkę i czytelnictwo, na przykład o akcji Lubię czytać.

Donoszono o pojawieniu się na rynku kolejnych książek, na przykład Harry Potter i Zakon Feniksa (J. K. Rowling), Żaby i Anioły (K. Grocholi) czy Nauka Świata Dysk 2 (Terry Pratchetta). Nie zapominano o autopromocji, częstokroć przypominając o możliwości zakupu dwóch powieści: Wzrockowisko M. K. Piekarskiej i Wszystko, tylko nie mięta E. Nowak. Pisano o nagrodach literackich, na przykład o przyznaniu Nagrody Nike dla J. Pilcha czy o Literackim Noblu dla Johna M. Coetzee. Kilkakrotnie przywołano opinię znanego pisarza na poruszany przez dziennikarza temat (na przykład zapytano wybrane, znane osoby, co sądzą na temat współczesnej młodzieży. Wśród pytanych znalazł się m.in. Cz. Miłosz, J. Pilch i A. Sapkowski).

Większość tych informacji była kilkuzdaniowa, nieliczne miały nieco większą objętość, czasem wzbogaconą zdjęciem przedstawianego pisarza.

W znacznie mniejszym stopniu, niż było to w poprzednich przypadkach, przy wybranych publikacjach powoływano się na książki, z których skorzystano. Stosunkowo rzadko książka była jedną z nagród za poprawnie rozwiązaną krzyżówkę.

Pojawił się jednak pewien element, który obok innych łączył omawiane periodyki. Mianowicie i w tym przypadku redakcja zdecydowała się na zamieszczanie przez pewien czas wybranych „złotych myśli”. 0 ile jednak w przypadku „Dziewczyny” wszystkie one dotyczyły miłości, o tyle na łamach "Cogito” odnaleźć można aforyzmy odnoszące się na przykład do sensu życia („Tragedią współczesnego człowieka jest nie to, że wie on coraz mniej o sensie własnego życia, lecz że coraz mniej zajmuje się tym pytaniem" - Václav Havel), mądrości („Cały kłopot polega na tym, że głupcy są pewni siebie, a mądrzy pełni wątpliwości” - Helmut Schmidt) czy literatury („Klasyka to to, co wszyscy chcieliby czytać i czego nikt nie czyta" - Mark Twain).

W 2003 r. czytelnicy pisma dowiedzieli się, że „44 proc. Polaków powyżej 15. roku życia nie przeczytało w ubiegłym roku ani jednej książki - wynika z danych, zebranych przez Instytut Książki i Czytelnictwa Biblioteki Narodowej. Na szczęście, z ankiet wynika, że Kogitowcy czytają"126 oraz że „Tylko 23\% Polaków przeczytało w ubiegłym roku więcej niż 7 książek"127. Można jednak sądzić, że te dane, w obliczu tak dużej dawki informacji, dostarczanej przez „Cogito”, nie dotyczyły czytelników pisma.

126 „Cogito" 2003, nr 9, s. [43].

127 Tę informację podano na podstawie badań Instytutu Książki i Czytelnictwa Biblioteki Narodowej, „Cogito” 2003, nr 10, s. 24. 
Jakkolwiek sam periodyk nie należał do szczególnie zajmujących, na co wpływ miała duża ilość materiału związanego z programem szkolnym, zamieszczana $\mathrm{w}$ niemal każdym z numerów (wyjątkami były wydania wakacyjne), a także przeważający w nim dość ciężki, dydaktyczno-moralizatorski w odbiorze ton, to jednak należy podkreślić ambitny charakter pisma, jeśli chodzi o informacje związane z książką. Były one przede wszystkim niezwykle zróżnicowane pod względem przekazywanych treści. $\mathrm{Na}$ uwagę zasługują również opisane liczne konkursy oraz inicjatywy, w których książka, literatura, wiedza na ich temat odgrywała niebagatelną rolę. Duże znaczenie miał również Czas na debiut, promujący talenty literackie czytelników „Cogito”.

\subsubsection{Grunt to dobry pomyst ${ }^{128}$. Inne informacje: o prasie i środowisku dziennikarskim}

Liczba informacji o prasie, zamieszczana na łamach omawianego dwutygodnika, była nieco większa niż w przypadku dwóch wcześniej przedstawionych czasopism, ale i tu nie była imponująca. Ograniczała się do 18 kilku- kilkunastozdaniowych notatek, o różnym charakterze. I tak na przykład, w 2003 r. redakcja w pięciu wydaniach zaproponowała (wzorem niektórych pism dla dorosłych odbiorców) czytelnikom Przegląd prasy. Była to niewielka objętościowo rubryka, w której cytowano fragmenty wybranych publikacji z kilku polskich periodyków, na przykład z „Gazety Wyborczej”, „Newsweek Polska” czy „Polityki”. Raz sięgnięto po zawartość magazynu "Charaktery”, reklamowanego na łamach "Cogito”. Kilkakrotnie zamieszczono tzw. zajawki artykułów, które odnaleźć można było na łamach (reklamowanego w prezentowanym czasopiśmie) miesięcznika dla studentów „Twój Impuls”.

Znacznie większą grupę stanowiły reklamy rozmaitych periodyków (137 ogłoszeń). Przeważająca ich część promowała tytuły, znajdujące się w portfolio wydawcy „Cogito”, na przykład „Lider”, „Twój Impuls”, „Victor Gimnazjalista". Analiza zebranego materiału wykazała jednak również obecność ogłoszeń dotyczących tygodników opinii, jak choćby „Przekroju” czy „Wprost”. Ich promocja nie była zbyt częsta, dowodziła jednakże faktu, że ich wydawcy traktowali czytelników dwutygodnika „Cogito” jako swoich potencjalnych aktualnych lub przyszłych odbiorców, których zainteresowaniom odpowiadać może zawartość pism opiniotwórczych. Reklamowano również inne tytuły, jak na przykład „PC Format”, „Wiedzę i Życie”, czy magazyn wydawany w języku angielskim, „Anglorama”. Warto powiedzieć, 
że na łamach omawianego periodyku dwukrotnie pojawiły się reklamy EuroPress Polska, kolportera prasy.

Ogłoszenia zamieszczano w całym dwutygodniku, ich objętość obejmowała zazwyczaj całą stronę, rzadziej niewielki moduł, drukowany u dołu danej strony. Poniżej przedstawiono wybrane, charakterystyczne przykłady (zdjęcia 200-203, s. 631-632).

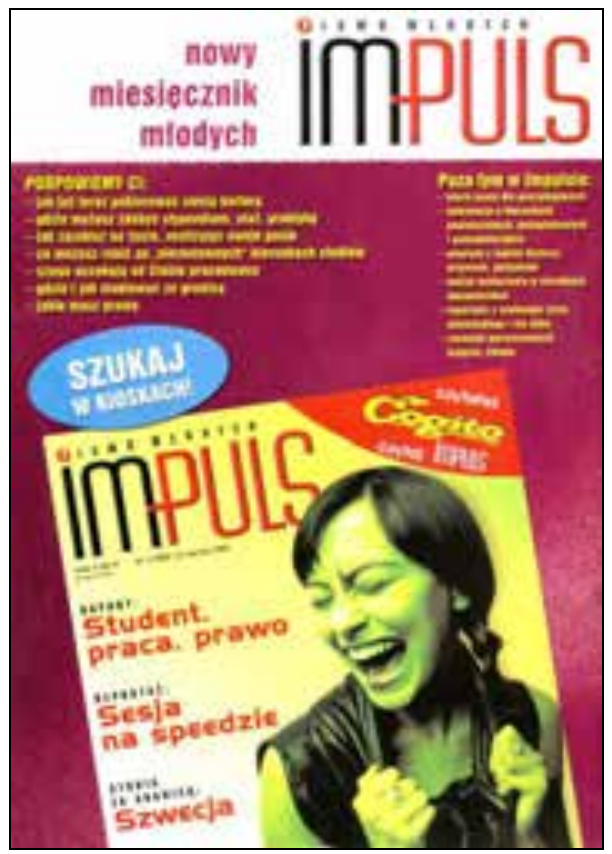

Zdjęcie 200. Wybrane ogłoszenia wydawnicze zamieszczone na łamach "Cogito"

„Cogito" 2002, nr 5, s. [2]

Niezależnie od proponowanego czasopisma, jego reklama była równie kolorowa i zawierała podobne w swym przesłaniu elementy: wyeksponowany tytuł, kopię okładki (okładek), zasygnalizowanie treści danego numeru i niekiedy hasło reklamowe („Najlepszy przyjaciel Twojego młodszego brata!”, „Chcesz mieć pogląd, czytaj >Przegląd<”, „Bądź nieprzeciętny"). Nie widać wyraźnych różnic w formie ogłoszeń własnych dwutygodnika a pozostałą grupą reklam. 

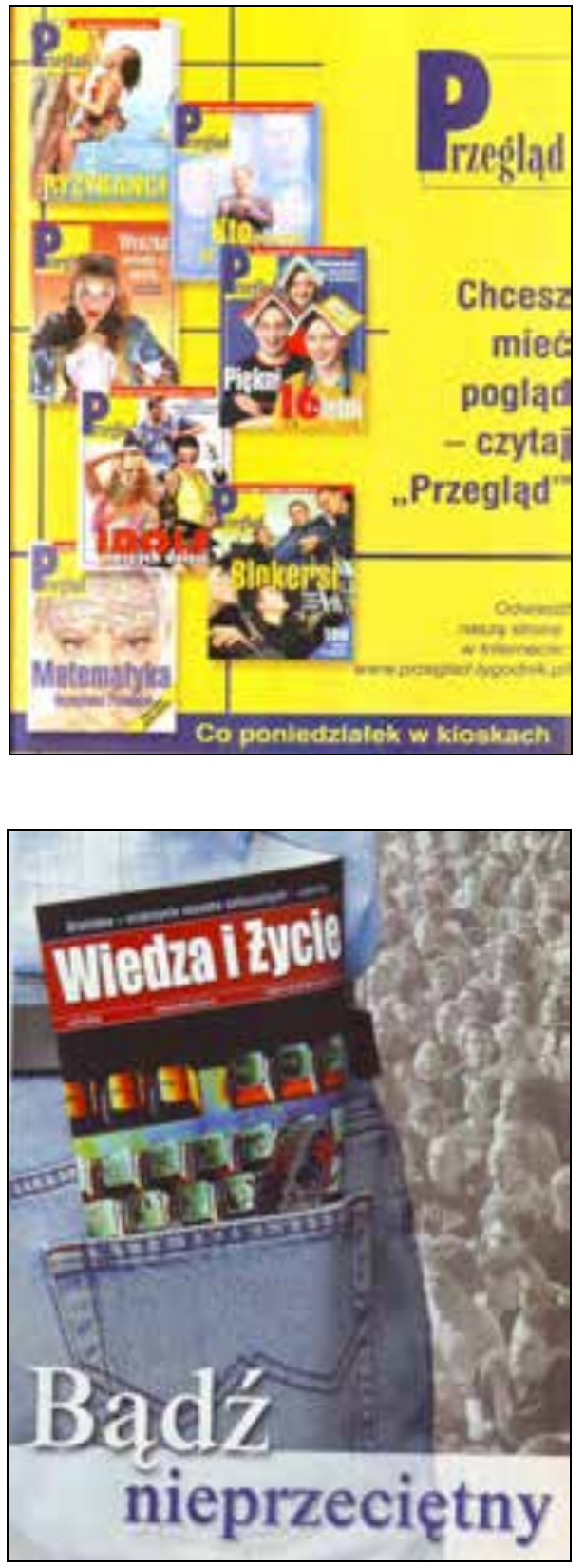

Zdjęcie 202. Wybrane ogłoszenia wydawnicze zamieszczone na łamach "Cogito” "Cogito" 2001, nr 14, s. [42]
Zdjęcie 201. Wybrane ogłoszenia wydawnicze zamieszczone na łamach "Cogito” „Cogito" 2002, nr 6

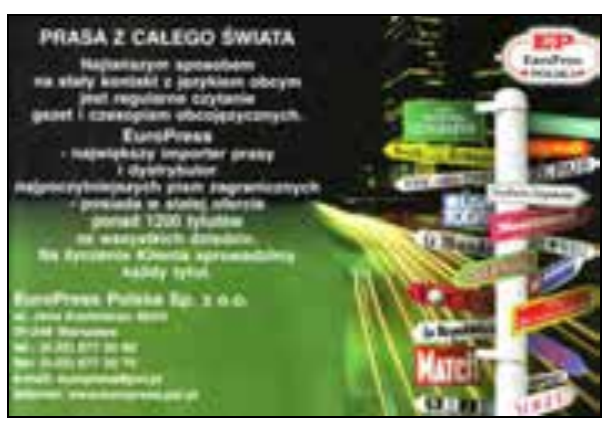

Zdjęcie 203. Wybrane ogłoszenia wydawnicze zamieszczone na łamach "Cogito" „Cogito" 2002, nr 3, s. [105] 
W roku 2001 jeden ze współpracowników dwutygodnika, Krzysztof Zadros, pisał:

Chciałbym, żeby „Cogito” zawierało teksty inteligentne, ambitne, niosące pogłębioną wiedzę o świecie, czasem, gdy trzeba - trudne, a przede wszystkim - prawdziwe. [...] A jeśli ktoś ma ochotę na ploteczki ze świata gwiazd, lekką rozrywkę czy artykuły o kosmetykach i fatałaszkach, to przecież takich pism w kioskach nie brakuje, prawda? Wierzę, że nasi Czytelnicy, jako ludzie myślący i nastawieni na umysłowy rozwój, oczekują od nas czegoś innego niż popkulturowej papki. [...] Życzę niezapomnianych przygód intelektualnych $\mathrm{z}$ „Cogito”!129

Wydaje się, że słowa te znajdowały swe odzwierciedlenie w zawartości pisma. Z pewnością forma przekazu, niezależnie od rodzaju proponowanych $\mathrm{w}$ nim treści, stała na wyższym poziomie, niż było to $\mathrm{w}$ przypadku dwóch wcześniej omawianych tytułów. Dobór proponowanych w postaci recenzji lektur także odbiegał od tych, do których zachęcali dziennikarze „Filipinki” lub „Dziewczyny”.

Patrząc na dwutygodnik „Cogito” w kontekście informacji o książce, zamieszczanych na jego łamach, można powiedzieć, że solidnie spełniał on swe zadanie w tym względzie, szczególnie promując literaturę, kulturę czytelniczą, poprzez liczne konkursy, w których nagrodą była wybrana lektura, bądź takie książki, które wymagały określonej wiedzy literackiej od adresatów pisma. Natomiast odbierając ten periodyk jako całość, należy zauważyć, że pod względem treści był on dość monotonny. Można to wytłumaczyć jego (założonym przez redakcję) przede wszystkim edukacyjnym charakterem, znajdującym swe odzwierciedlenie w postaci licznych wkładek, zawierających materiały powtórzeniowe do egzaminów maturalnych. Jednak równocześnie pozostałe treści, zamieszczane na jego łamach, prezentowane były w sposób czasami zbyt poważny, zasadniczy, by nie powiedzieć, „sztywny”, nie do końca, być może, przystający do wieku czytelników. Podobnie jak miesięcznik „Dziewczyna” prezentował poprzez swoją zawartość skrajnie rozrywkową formę, tak dwutygodnik "Cogito" nierzadko stawał na drugim, równie skrajnym biegunie, przesadnej powagi, przejawiającej się też niekiedy w prezentowanym tu humorze.

${ }^{129}$ K. Zadros, Słówko do Czytelników, „Cogito” 2001, nr 13, s. [2]. 


\title{
4.5. Przepis na prasę dla młodzieży ${ }^{1}$ : „Filipinka”, „Dziewczyna”, „Cogito" - wnioski porównawcze
}

\begin{abstract}
Młodzież w okresie dorastania szuka swojego miejsca w otaczającej ją rzeczywistości, buduje swoją pozycję w grupie rówieśniczej i społeczne identyfikacje, określa swoje plany na przyszłość. $\mathrm{Na}$ tym etapie rozwoju nastolatki intensywnie kształtują swój sposób myślenia o świecie, własny światopogląd ${ }^{2}$.
\end{abstract}

Jak wynika z przedstawionej analizy, każdy z prezentowanych periodyków młodzieżowych charakteryzował się w omawianym okresie swoistymi cechami. Pierwszy, sięgający korzeniami 1957 r., w dużym stopniu opierał swą popularność na opinii, ukształtowanej w toku długoletniej historii. Jednak, w przeciwieństwie do tygodnika „Polityka”, powstałego w tym samym czasie, „Filipinka” nie sprostała zaistniałym po 1989 r. warunkom, nie potrafiła, mimo starań, utrzymać się na wymagającym rynku prasowym, przegrywając konkurencję z innymi periodykami i w efekcie została zlikwidowana przez wydawcę, który nie widział dla niej miejsca w swojej ofercie. W tym przypadku dawna formuła, chociaż wielokrotnie modyfikowana, nie sprawdziła się w nowej rzeczywistości. Z kolei drugi z omówionych tytułów, znacznie młodszy miesięcznik „Dziewczyna”, należący do periodyków określanych mianem „kalek” pism zachodnich, bardzo szybko zyskał popularność, dzięki nowoczesnej szacie graficznej, nieskomplikowanej, czysto rozrywkowej treści i zaproponowaniu nastoletnim czytelnikom zawartości, nierzadko szokującej dorosłych, ale podobającej się młodszym odbiorcom. Natomiast ostatnie z przedstawionych czasopism, dwutygodnik "Cogito", najmłodszy z tej grupy tytułów, wypełnił niszę na polskim rynku prasowym, na którym brakowało dotąd periodyku o takim właśnie charakterze (nastawionym przede wszystkim na przekaz edukacyjny), dzięki czemu przetrwał kryzys, jaki stał się udziałem prasy młodzieżowej w badanym okresie.

Każdy z trzech tytułów adresowany był do zbliżonej grupy odbiorców, którą była młodzież szkolna, w wieku średnio 15-19 lat. 0 ile jednak dwa pierwsze periodyki kierowano głównie do dziewcząt, o tyle ostatni z nich, dzięki swej zawartości, mógł zainteresować w podobnym stopniu również chłopców.

1 Tytuł publikacji, zob. I. Kurowski: Przepis na prasę dla młodzieży, „Raport Prasowy” 1998, nr 2, s. 2-5.

2 Z. Zasacka, Nastoletni czytelnicy, Biblioteka Narodowa, Warszawa 2008, s. 188. 
„Filipinka” łączyła $\mathrm{w}$ sobie, zgodnie z założeniem redakcji, walory zarówno rozrywkowe, jak również wychowawcze i częściowo edukacyjne. „Dziewczyna”, jak już to zostało powiedziane, nastawiona była głównie na przekaz rozrywkowy, natomiast „Cogito” kładło nacisk przede wszystkim na czynniki edukacyjne, kształceniowe. Analiza zebranego materiału pozwoliła stwierdzić, że najbardziej ambitnym, wymagającym od swych czytelników określonej wiedzy pismem, był ostatni z wymienionych tytułów, w najmniejszym stopniu zaś miesięcznik „Dziewczyna”, wyrozumiały dla odbiorców, jeśli chodzi o ich ogólną wiedzę. Do takich założeń dostosowana była zawartość i forma przekazu każdego z pism.

W jakim stopniu każde z nich informowało czytelników o książkach? Czy wnioski, które w sposób niemal automatyczny mogą się w tym miejscu nasunąć, znalazły swe odzwierciedlenie w rzeczywistości? Czy, pomimo wyraźnych różnic, odnaleźć można wspólną dla tych tytułów płaszczyznę? Przyjrzyjmy się danym statystycznym, określającym liczbę każdej z analizowanych kategorii, związanych z informacją o książce, zamieszczaną na łamach omówionych periodyków:

Tabela 79. Porównanie liczby informacji o książce zamieszczanych na łamach „Filipinki”, „Dziewczyny” oraz „Cogito”

\begin{tabular}{|l|c|c|c|}
\hline \multicolumn{1}{|c|}{ Rodzaj informacji } & „Filipinka” & „Dziewczyna” & "Cogito” \\
\hline Recenzje, omówienia, streszczenia & 179 & $268^{a}$ & 200 \\
\hline Wywiady & 19 & brak & 38 \\
\hline Reklamy książek & 159 & 173 & 807 \\
\hline Sylwetki/portrety & 10 & 7 & 3 \\
\hline Listy bestsellerów & 8 & 11 & 6 \\
\hline Ekranizacje, adaptacje, inscenizacje & 49 & 35 & 27 \\
\hline Konkursy i akcje & 60 & 22 & 60 \\
\hline $\begin{array}{l}\text { Artykuły poświęcone książce i rynkowi } \\
\text { wydawniczo-księgarskiemu }\end{array}$ & 15 & 3 & 32 \\
\hline Listy czytelników & 3 & 4 & - \\
\hline Inne & $177^{b}$ & $166^{c}$ & $211^{d}$ \\
\hline
\end{tabular}

${ }^{a} \mathrm{~W}$ tej liczbie podano wyłącznie recenzje odredakcyjne.

${ }^{b}$ Ze względu na specyfikę i charakter zamieszczanych w omawianym periodyku informacji związanych z książką, do kategorii Inne zaliczono teksty, których autorem był pisarz, fragmenty powieści, komiks i opowiadania drukowane w odcinkach na łamach miesięcznika, rubrykę poetycką oraz wzmianki, donoszące o wydarzeniach związanych z literaturą.

${ }^{c}$ Do tej kategorii zaliczono w tym przypadku aforyzmy, opowiadania, minikomiks, fotostory, a także wzmianki, nawiązujące do problematyki, dotyczącej spraw związanych z książką.

d Zaliczono tu Klub Cogito, opowiadania, fragmenty powieści, komiks, rubrykę Czas na debiut, a także notki, informujące o wydarzeniach odnoszących się do książki.

Źródło: badania własne. 
Powyższe zestawienie prowadzi do interesujących spostrzeżeń. Należy jednak w tym miejscu przypomnieć, że ostatni z podanych w tabeli tytułów, jakim jest „Cogito”, był w badanym okresie dwutygodnikiem, w przeciwieństwie do dwóch pozostałych czasopism o częstotliwości miesięczników. Zatem w tym przypadku dokładniejszy obraz porównawczy zyskamy, przyglądając się średniej wybranych typów publikacji, przypadających na jeden numer. Zanim jednak przejdziemy do ich prezentacji, przeanalizujmy powyższe dane. Najmłodszy spośród omawianych tytułów, „Cogito”, zajmuje pierwsze miejsce $\mathrm{w}$ trzech spośród dziesięciu podanych powyżej kategorii. Na jego łamach znalazło się najwięcej ogłoszeń, reklamujących książki, wywiadów, a także (choć tu różnica jest już nieznaczna) artykułów, nawiązujących do spraw dotyczących książki. Zastanawiająca jest w przypadku tego periodyku niewielka liczba sylwetek/portretów, ale częściowo można ją wyjaśnić wspomnianą wcześniej zawartością dodatków specjalnych, przygotowujących czytelników do egzaminów maturalnych. Trudno jednakże znaleźć wytłumaczenie dla braku odzewu wśród odbiorców na kwestie związane z książką, poruszane na łamach pisma.

Zastanawiające są natomiast wnioski, dotyczące danych, odnoszących się do dwóch pozostałych periodyków.

Opinie, jakie można odnaleźć w literaturze, dotyczące miesięcznika „Dziewczyna”, a także dogłębna analiza jego zawartości pod kątem problematyki ujętej w tytule książki, wskazują wyraźnie na charakter tego wysokonakładowego, popularnego, kolorowego magazynu, na łamach którego zdjęcia dominowały nad treścią, zaliczając go tym samym do „prasy obrazkowej". Tymczasem, przyglądając się uzyskanym danym statystycznym, można zauważyć, że $\mathrm{w}$ periodyku tym zamieszczano $\mathrm{w}$ badanym okresie najwięcej, spośród analizowanych czasopism, recenzji, omówień, streszczeń i adnotacji odnoszących się do książek, najczęściej można było też znaleźć na jego łamach listy bestsellerów. Jednocześnie miesięcznik ten wyprzedził ambitniejszą „Filipinkę” w kategorii ogłoszeń wydawniczych. Natomiast najstarszy $\mathrm{z}$ omawianych $\mathrm{w}$ tym rozdziale tytułów zamieścił największą liczbę publikacji, zaliczonych do kategorii Portret/sylwetki i wspomnienia oraz Ekranizacje, adaptacje, inscenizacje, a także w grupie informacji, określonej jako Inne.

Dane te potwierdziła średnia tego typu informacji, która przypadała na jeden numer każdego z periodyków. Uzyskane obliczenia zobrazowano w tabeli $80^{3}$.

\footnotetext{
3 Pominięto pozostałe kategorie, również te omówione powyżej, ponieważ w tych przypadkach liczby były zbyt małe. Następnie bardziej szczegółowo porównano recenzje, ogłoszenia wydawnicze oraz konkursy i akcje organizowane przez prezentowane czasopisma.
} 
Tabela 80. Średnia liczby informacji, przypadająca na 1 numer

\begin{tabular}{|l|c|c|c|}
\hline \multicolumn{1}{|c|}{ Typ informacji } & $\begin{array}{c}\text { „Filipinka” } \\
(60 \text { numerów })\end{array}$ & $\begin{array}{c}\text { „Dziewczyna” } \\
\left(61 \text { numerów }{ }^{a}\right)\end{array}$ & $\begin{array}{c}\text { "Cogito” } \\
\left(106 \text { numerów }^{b}\right)\end{array}$ \\
\hline Recenzje, omówienia, streszczenia & 2,90 & 4,390 & 1,88 \\
\hline Reklamy książek & 2,65 & 2,830 & 7,61 \\
\hline Ekranizacje, adaptacje, inscenizacje & 0,81 & 0,570 & 0,25 \\
\hline Konkursy i akcje & 1,00 & 0,360 & 0,56 \\
\hline $\begin{array}{l}\text { Artykuły poświęcone książce i ryn- } \\
\text { kowi wydawniczo-księgarskiemu }\end{array}$ & 0,25 & 0,049 & 0,30 \\
\hline Inne & 2,95 & 2,720 & 1,99 \\
\hline
\end{tabular}

${ }^{a}$ W 2004 r. wydano 13 numerów.

${ }^{b}$ W latach: 2001, 2002, 2003, 2004 ukazywało się po 21 numerów, natomiast w 2005 r. wydano ich 22.

Źródło: badania własne.

Jak wynika z powyższych danych, na jeden numer miesięcznika „Dziewczyna” przypadały cztery omówienia, w przypadku „Filipinki” tego typu informacji było średnio dwie, zaś na łamach „Cogito” ich liczba była najmniejsza: jedna.

Należy jednakże pamiętać o podkreślanej kilkakrotnie formie owych omówień. Pomimo, że najwięcej znalazło się ich na łamach magazynu „Dziewczyna”, to jednocześnie w najmniejszym (w porównaniu z dwoma pozostałymi tytułami) stopniu spełniały one warunki, jakim odpowiadać powinna klasyczna recenzja. Były krótkie, przypominały notatki prasowe, a dane bibliograficzne ograniczano $w$ nich do podania najważniejszych elementów (autor, tytuł, nazwa wydawcy). Natomiast w przypadku "Cogito" jakkolwiek liczba tego typu informacji była najmniejsza, to jednak, jak to już wcześniej zaznaczono, zdawała się w największym stopniu spełniać wymogi stawiane zazwyczaj recenzjom, chociaż należy podkreślić, że i tu zbliżały się one niejednokrotnie niebezpiecznie blisko do gatunków czysto informacyjnych. Jednocześnie opis bibliograficzny, uzupełniający owe recenzje, był bardzo skromny: również i w tym przypadku najczęściej ograniczano się do podania trzech podstawowych danych: nazwiska autora, tytułu proponowanej książki oraz nazwy jej wydawcy. Warto natomiast podkreślić, że zamieszczane na łamach tego pisma omówienia były (w porównaniu $\mathrm{z}$ analogicznymi informacjami $\mathrm{w}$ dwóch pozostałych pismach) najobszerniejsze, częściej również określany był w nich adresat tak proponowanej lektury.

Postać omówień, pomieszczanych na łamach każdego z pism, była już szczegółowo przedstawiona wcześniej, w tym miejscu bardziej interesująca 
wydaje się być odpowiedź na pytanie, czy spośród proponowanych nastoletnim czytelnikom książek, prezentowanych $\mathrm{w}$ formie recenzji, można odnaleźć zbieżną płaszczyznę? W analizie wykazano, że listę wspólnych dla trzech pism autorów recenzowanych książek tworzy 11 pisarzy. W tej grupie znaleźli się: Isabel Allende, John M. Coetzee, I. Dienieżkina, Marta Fox, Stephen King, Nicola Kraus, Ewa Nowak, Arturo Pérez-Reverte, David Schickler, Krystyna Siesicka oraz Dorota Terakowska. W większości przypadków były to różne tytuły książek, jedynie w odniesieniu do I. Dienieżkiny i E. Nowak recenzenci każdego z periodyków omawiali te same lektury (analogicznie: Daj mi! i Wszystko, tylko nie mięta). Co ciekawe, w pięciu przypadkach ten sam tytuł danego autora polecano na łamach „Filipinki” i „Dziewczyny”, zaś inny na stronach „Cogito”.

Równie interesujące, a także w pewnym stopniu zaskakujące, jest zestawienie autorów recenzowanych książek, których odnaleźć można na łamach dwóch tylko periodyków.

Zbieżne zainteresowania wykazali w tym względzie szczególnie recenzenci „Filipinki” i „Dziewczyny”: analiza pozwoliła ustalić listę 28 nazwisk pisarzy, którzy pojawili się na łamach obydwu miesięczników w zamieszczanych tu recenzjach. Znaleźli się wśród nich m.in. Jonathan Carroll, Paulo Coelho, Helen Fielding, Jana Frey, Katarzyna Grochola, Kidd Sue Monk, Yann Martel, Mirosław Nahacz, Andrzej Sapkowski, Zadie Smith, Izabela Sowa, Sue Townsend, William Wharton oraz Janusz L. Wiśniewski. Byli to zatem w przeważającej części autorzy popularni w badanym okresie, których nazwiska nierzadko odnaleźć można było na listach bestsellerów. Niespodziewane wspólne zainteresowanie tą samą grupą twórców, jakie wykazały redakcje tych akurat periodyków, potwierdza wysuniętą wcześniej tezę, iż „Filipinka”, niegdyś ambitny tytuł, w miarę upływu czasu dostosowywała się do dominujących na rynku prasowym pism młodzieżowych, takich jak „Dziewczyna”. Dryfując w kierunku tego typu magazynów, redakcja „Filipinki” liczyła na zatrzymanie czytelniczek, częściej sięgających po kolorowe magazyny i rezygnujących z lektury tekstów, zamieszczanych na łamach swego wcześniej ulubionego tytułu. Zatem analiza zebranego materiału pozwoliła zweryfikować pierwotne założenie, iż ten miesięcznik podobny będzie bardziej do trzeciego $\mathrm{z}$ omawianych pism; wysunięte przypuszczenie okazało się mylne. Analiza wykazała również, że ci sami autorzy pojawili się zaledwie w 14 przypadkach przy okazji omawiania wybranej książki na łamach zarówno „Filipinki”, jak i „Cogito”. Byli to następujący pisarze: Victor Bockris, Michael Cunningham, Joanna Fabicka, Krzysztof Fordoński, Lian Hearn, Janet Joplin, Henning Mankell, Gabriel G. Márquez, Mariusz Maślanka, Haruki Murakami, Amélie Nothomb, Tomek Tryzna, Krzysztof Varga i Mikołaj Wójcik. Warto jednakże zaznaczyć, że w większości recenzenci obydwu pism wybierali różne książki tego samego autora, by zachęcić swych czytelników do lektury. Tylko w odniesieniu do sześciu twórców 
proponowali ten sam tytuł (m.in. wskazując na biografię W. Whartona, pióra Krzysztofa Fordońskiego czy książkę Tomka Tryzny: Idź, kochaj).

Jak można było się domyślać, najmniejszą wspólną grupę recenzowanych pisarzy odnotowano w przypadku miesięcznika „Dziewczyna” oraz dwutygodnika "Cogito”. Wśród siedmiu nazwisk pojawiły się: Grażyna Bąkiewicz, Kathryn Harrison, Barbara Mujica, Jerzy Pilch, Eric Emmanuel Schmitt, Lisa See oraz Olga Tokarczuk. Wydaje się, że w tym przypadku zbieżność była zupełnie przypadkowa, szczególnie, że i tu proponowano częściej różne tytuły tych samych autorów.

W przypadku ogłoszeń wydawniczych "Cogito" okazało się tym pismem, które edytorzy uznali za najbardziej odpowiadające promocji ich oferty. Na jeden jego numer przypadało średnio siedem inseratów, natomiast $\mathrm{w}$ odniesieniu do dwóch pozostałych periodyków było ich ponad trzykrotnie mniej, bo jedynie ok. dwóch. Wyraźne jest również zróżnicowanie wśród reklamodawców. Anonse, które odnajdujemy na łamach „Filipinki” były ogłoszeniami 9 oficyn, w odniesieniu do miesięcznika „Dziewczyna” odnotowujemy ich tylko 5, zaś w przypadku dwutygodnika „Cogito” było ich 28. Jedyną wspólną oficyną dla tych trzech pism było Wydawnictwo Prószyński i S-ka, ale ogłoszeń tego edytora było w każdym z nich niewiele. Stąd oferta o książkach, trafiająca do czytelników każdego z periodyków, była różna, choć w dwóch przypadkach można odnaleźć pewne zbieżności. Odbiorcy „Filipinki” mieli możliwość poznać ofertę głównie Wydawnictwa GREG i Akapit Pres, bo anonse obydwu oficyn pojawiały się w tym przypadku najczęściej. Kupujący miesięcznik „Dziewczyna” również zachęcani byli do poznania propozycji Wydawnictwa GREG, ale także m.in. niemieckiego koncernu Axel Springer. Natomiast czytelnicy ostatniego $\mathrm{z}$ badanych periodyków, „Cogito”, mieli okazję poznać ofertę głównie Wydawnictwa Wiedza Powszechna oraz oficyny Langenscheidt Polska. Od strony graficznej inseraty $\mathrm{w}$ każdym $\mathrm{z}$ omawianych magazynów były podobne, nierzadko będąc całostronicowymi, wielobarwnymi ogłoszeniami, zawierającymi podobne elementy: kopię okładki proponowanej książki, hasło reklamowe i dane dotyczące wydawcy.

Warto również zwrócić uwagę na konkursy, organizowane przez każde z trzech periodyków, jako że w tej kategorii najwyraźniej widać różnice, jakie pomiędzy nimi występują, jeśli chodzi o promocję książki.

Podobny charakter miały strony, poświęcone rozwijaniu zdolności literackich nastoletnich czytelników, występujące na łamach „Filipinki” i „Cogito”. W pierwszym przypadku była to rubryka Cześć, poeci i poetki, w drugim Czas na debiut. 0 ile jednak Natalia Usenko proponowała czytelnikom przysyłanie wierszy, o tyle Ludwik Janion zachęcał do próbowania swych sił również w twórczości prozatorskiej, jednocześnie często inicjując rozmaite konkursy literackie. Równocześnie widać większe zróżnicowanie 
i oryginalność, jeśli chodzi o konkursy związane z książką, zamieszczane na łamach „Cogito”, w porównaniu z dwoma pozostałymi czasopismami. W ich przypadku książka była znacznie częściej jedną z nagród w danym konkursie niż jego przedmiotem, jak było to na łamach ostatniego z prezentowanych tytułów. Czytelnicy "Cogito” niejednokrotnie musieli wykazać się określoną wiedzą, by zdobyć nagrodę $\mathrm{w}$ danym konkursie. Znamienne, że większość tego typu przedsięwzięć, inicjowanych przez redakcje „Filipinki” oraz „Dziewczyny”, opierała się na konkursach sms-owych, natomiast w przypadku "Cogito”, jakkolwiek nie stroniono od tego typu rozwiązań, to jednak preferowano tradycyjną, listowną formę kontaktu z czytelnikami. To jedna z cech, podkreślająca indywidualny charakter tego dwutygodnika. O ile miesięcznik „Filipinka” w miarę upływu czasu coraz wyraźniej zatracał swoją specyfikę, upodabniając się do magazynów typu „Dziewczyna”, o tyle "Cogito", pomimo stopniowo wprowadzanych modyfikacji, unowocześnień, pozostał w znacznym stopniu wierny pierwotnemu wzorowi, który odróżniał go od innych czasopism młodzieżowych. Ta konkluzja przekładała się również na informacje związane z książką.

Jakkolwiek każdy z periodyków stosował (choć w różnym stopniu) te same gatunki dziennikarskie (m.in. recenzje i wywiad), to jednak w przypadku każdego z nich widoczne były wyraźne różnice, choćby w doborze nazwisk autorów omawianych książek czy pomysłów na konkursy literackie. Cechą wspólną była zaś stosunkowo niewielka liczba publikacji dotyczących książki, zamieszczanych na łamach każdego z nich, równie nieduża liczba wywiadów 4 (w przypadku „Dziewczyny” odnotowano ich całkowity brak) oraz bardzo mały odzew wśród czytelników na kwestie związane $\mathrm{z}$ literaturą poruszane $\mathrm{w}$ tych periodykach. Zwraca za to uwagę znacząca liczba informacji dotyczących ekranizacji znanych dzieł, co wpisywało się w ogólną tendencję, szczególnie dwóch pierwszych magazynów, obszernego informowania o tym, co dzieje się w świecie filmu (zwłaszcza w kontekście śledzenia losów znanych aktorów, odtwarzających główne role $\mathrm{w}$ najgłośniejszych filmach badanego okresu). Warto również podkreślić dużą grupę, jaką tworzyły w każdym z trzech przypadków informacje, zaliczone do kategorii Inne. Poza opowiadaniami czy fragmentami przywoływanych książek miały one przeważnie postać wzmianki lub jej odmiany w formie notatki prasowej5. Poza recenzjami, pod względem liczby, dominowały zatem minimalne informacje prasowe oraz informacje poszerzone.

\footnotetext{
4 Warto zauważyć, że na łamach „Filipinki” i „Cogito” w pięciu przypadkach bohaterami wywiadów były te same osoby: K. Grochola, J. Jabłczyńska (jedna z odtwórczyń postaci w zekranizowanej powieści Nigdy w życiu), M. Nahacz, I. Sowa, A. Stasiuk.

5 Notatka, według Z. Bauera, jest „odmianą wzmianki wzbogaconej o dodatkowe fakty szczegółowe" (Dziennikarstwo i świat mediów, red. Z. Bauer, E. Chudziński, Universitas, Kraków 2004, s. 155).
} 
Ich uzupełnieniem były inseraty wydawnicze, które wraz $\mathrm{z}$ określonym charakterem reklamowanej oferty poszczególnych wydawców można uznać za pewien miernik zawartości każdego z tych pism $\mathrm{w}$ interesującym nas kontekście.

Jednocześnie, jeśli przyjąć, że każdy z omawianych periodyków był propagatorem uznawanych przez siebie wartości, pewnego rodzaju informatorem także po świecie kultury (rozumianej rozmaicie przez każde z pism) dla swych czytelników, to należy stwierdzić, że żaden z nich nie był godnym polecenia mistrzem $\mathrm{w}$ roli przewodnika po świecie książki, choć dwutygodnik „Cogito” czynił największe starania, by na to miano zasłużyć. 



\section{Rozdział 5}

\section{„ABY NIE UCICHŁ SZELEST PRZEWRACANYCH KARTEK..."1: PORÓWNANIE OMÓWIONYCH CZASOPISM}

Czasopisma, które stały się przedmiotem badań, tworzą grupę zróżnicowaną pod wieloma względami. Wydaje się, że trzy typy prasy, do których są zaliczane (pisma opinii, periodyki kobiece oraz tytuły adresowane do młodzieży) stanowią zamknięte segmenty, różniące się między sobą diametralnie. W każdym przypadku inny, jasno określony odbiorca determinuje ich zawartość, specyfikę przekazu, politykę redakcyjną, a nade wszystko cele, wynikające z definicji danego typu prasy. „Urabianie opinii publicznej i kształtowanie postaw" - to zadanie stojące przed prasą opiniotwórczą. „Ustawiczna dążność do podnoszenia wiedzy i poziomu kulturalnego” to m.in. cele prasy adresowanej dla płci pięknej. „Propagowanie pewnego stylu życia i myślenia, kształtowanie postaw, funkcja wychowawcza i edukacyjna" 2 - to z kolei domena periodyków przeznaczonych dla młodzieży. Pomimo oczywistych różnic już na tym etapie występują pomiędzy nimi pewne podobieństwa: „kształtowanie postaw”, choć rozmaicie rozumiane, w przypadku prasy opiniotwórczej i młodzieżowej zostało wyraźnie podkreślone, w odniesieniu do pism kobiecych zaś wynika pośrednio z pełnionej przez nie roli. Każde z nich popularyzuje określone opinie, sądy, tym samym kształtując poglądy swych czytelników na rozmaite kwestie, także na sprawy związane z kulturą, w tym z książką.

Każdy z omówionych periodyków zachował jednocześnie własną specyfikę, wynikającą m.in. z warunków, w których mierzyć się musiał z konkurencją na rynku prasowym. Analizowane tytuły zaistniały na nim w różnym okresie - ich ewolucję przedstawiono we wcześniejszych rozdziałach, w tym miejscu należy tylko przypomnieć pewne podstawowe fakty (tabela 81).

\footnotetext{
1 Tytuł wywiadu z R. Skąpskim, zob. aby nie ucichł szelest przewracanych kartek... [pis. oryg.] [rozm. A. Palacz], „Wydawca” 2002, nr 5, s. 5.

2 Przytoczone powyżej cytaty pochodzą z przywołanych wcześniej definicji poszczególnych typów prasy na początku każdego z poświęconych im rozdziałów.
} 


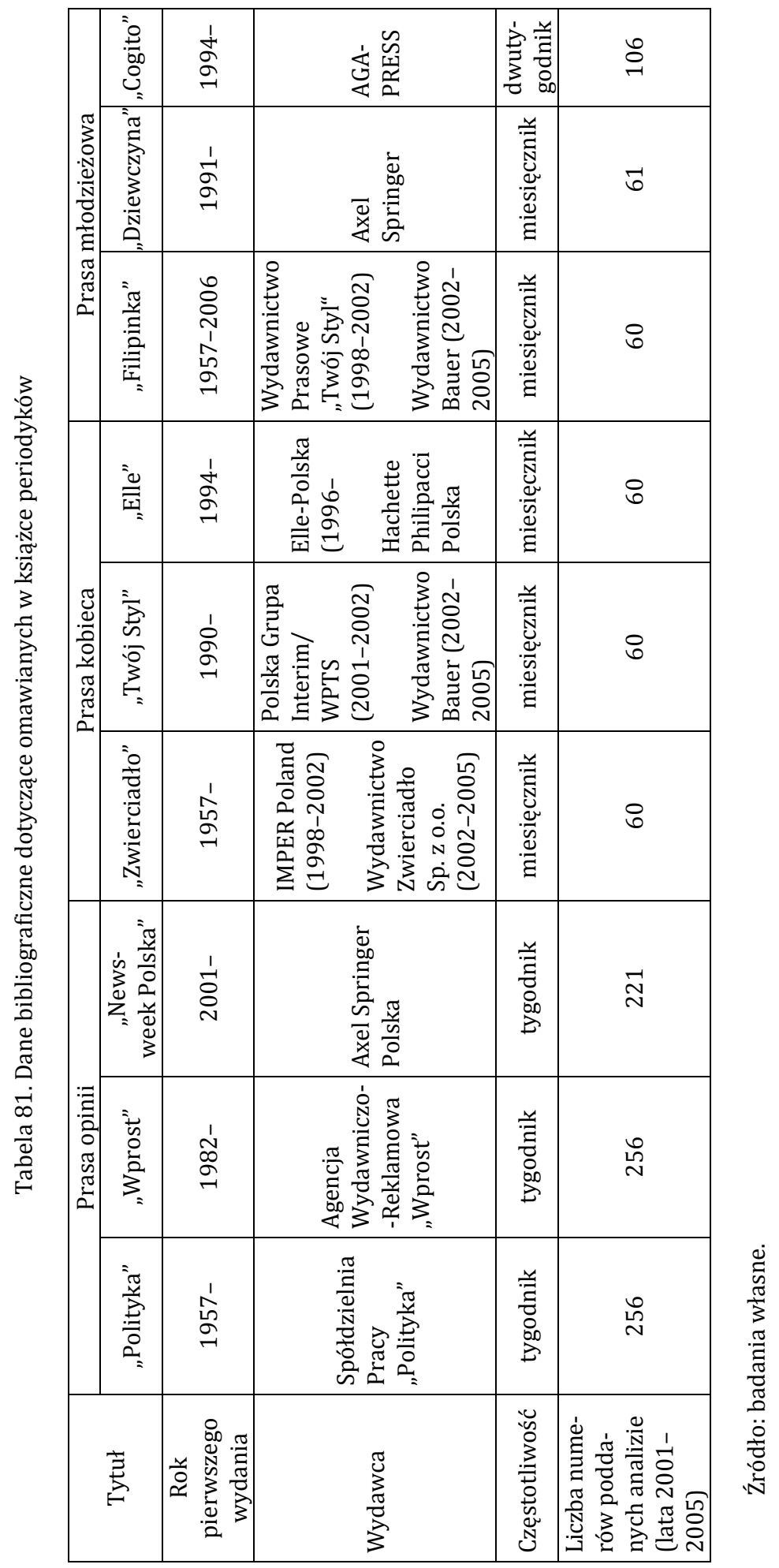


Historia trzech badanych periodyków („Filipinki”, „Polityki”, „Zwierciadła") sięga swymi korzeniami czasów PRL (każde z nich powstało w 1957 r.). Jednak, o ile dwa ostatnie przetrwały na wymagającym rynku prasowym, o tyle pierwszy w 2006 r. został zamknięty przez wydawcę, nie wytrzymując konkurencji z innymi tytułami pism młodzieżowych tego okresu. Jeden tytuł („Wprost”) powstał na początku lat 80. XX w., a zatem w specyficznej sytuacji politycznej panującej w kraju. Trzy inne pisma („Cogito”, „Dziewczyna”, „Twój Styl”) pojawiły się na początku lat 90. XX w., w okresie, gdy obserwowano intensywny, a wręcz żywiołowy rozwój wielu niezależnych inicjatyw wydawniczych, w czasie, gdy lawinowo powstawały nowe periodyki, a dawne tytuły podlegały przeobrażeniom lub były likwidowane. I wreszcie ostatni tytuł („Newsweek Polska”) pojawił się w Polsce na początku XXI w., a zatem w warunkach kryzysu ekonomicznego, jednocześnie w sytuacji dla rynku prasowego stosunkowo stabilnej, chociaż wyraźna była na nim rosnąca dominacja mediów elektronicznych.

Można zatem powiedzieć, że mamy tu do czynienia z trzema grupami czasopism: dawnymi („Filipinka”, „Polityka”, „Zwierciadło”), nowymi, które pojawiły się po 1989 r. ("Cogito”, „Twój Styl”), wydawanymi na licencji („Dziewczyna”, „Elle”, Newsweek Polska”) i tytułem, który zaistniał w ostatniej dekadzie PRL („Wprost”).

Cztery z przedstawionych periodyków należały do polskich wydawców, trzy inne wydawane były przez koncerny zagraniczne, dwa („Twój Styl” i „Filipinka”) podzieliły ten sam los: jakkolwiek przez kilka lat wydawane były przez rodzime spółki, to jednak w 2002 r. zostały wykupione przez tego samego niemieckiego wydawcę. Jednocześnie w badanej grupie trzy tytuły („Dziewczyna”, „Elle”, „Newsweek Polska”,) wydawane były na licencji polskiej, przy czym dwa z nich („Dziewczyna”, „Elle”) stanowiły „kalki” pism zachodnich.

Przechodząc rozmaite, opisane wcześniej perturbacje, poddając się częstym zmianom zarówno dotyczącym szaty graficznej, jak i w różnym stopniu, zawartości, poza jednym („Cogito”) wszystkie tytuły zdążały w tym samym kierunku, spotykając się jednym punkcie, jako nowoczesne kolorowe magazyny. Czy znalazło się w nich miejsce na prezentację literatury?

Analiza zebranego materiału wykazała, że każdy z periodyków informował swoich czytelników o książkach, chociaż czynił to w różnym stopniu i w inny sposób. Wybrane kategorie różniły się od siebie w zdecydowany, na tyle znaczący sposób, że należy je rozpatrywać na dwóch płaszczyznach: statystycznej i jakościowej. Jednocześnie należy zdawać sobie sprawę nie tylko z odmienności każdej z prezentowanych grup, ale również ze zróżnicowania, występującego pomiędzy poszczególnymi tytułami, zaliczonymi do tego samego typu prasy.

Przyjrzyjmy się najpierw określonym kategoriom i przyporządkowanym im liczbom (tabela 82). 


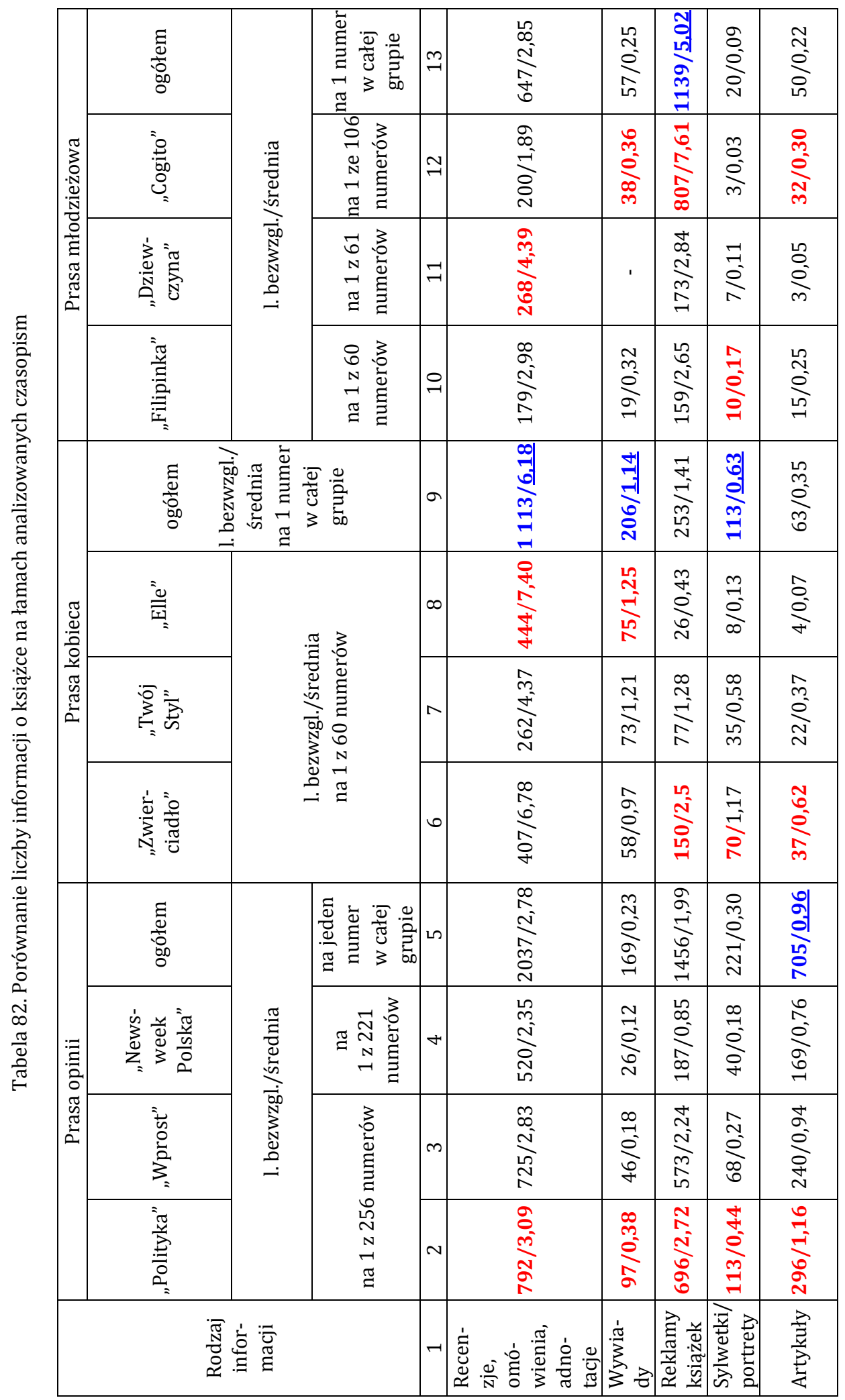




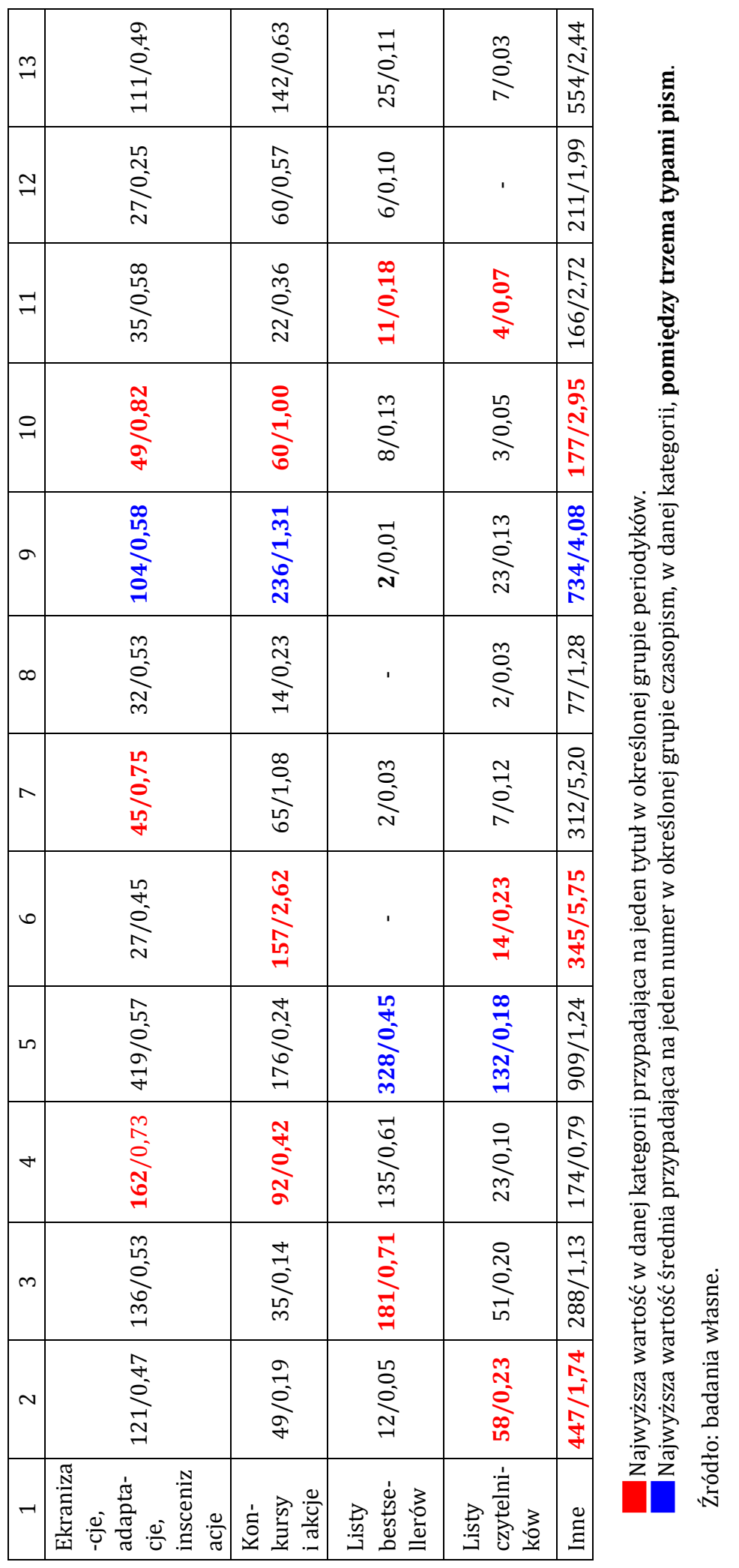


W tym miejscu należy przypomnieć, że badano czasopisma o różnej częstotliwości: były to trzy tygodniki, pięć miesięczników oraz jeden dwutygodnik. Stąd przy wartościach bezwzględnych podano średnią, przypadającą na jeden numer i nią kierowano się przy dalszej analizie.

Porównując pod względem liczebnym poszczególne grupy pism pomiędzy sobą, okazało się, że w 6 kategoriach (na 10) najwięcej informacji o książce średnio na 1 numer przypada w udziale prasie kobiecej. Jest to zaskakujący wniosek, szczególnie jeśli zwróci się uwagę na charakter dwóch z trzech omawianych w tej grupie tytułów. „Twój Styl” w mniejszym, natomiast „Elle” w większym stopniu, nastawione były na kreowanie określonego (opisanego $\mathrm{w}$ odpowiednich podrozdziałach) wizerunku kobiety. Temu podporządkowana była zawartość każdego z miesięczników. Zwłaszcza zaś zainteresowania i charakter francuskiego tytułu wydawanego na licencji polskiej zdawały się pierwotnie przeczyć tak znacznemu zainteresowaniu kwestiami związanymi z książką (zob. rozdz. 3.4). Pewną przeciwwagę stanowił miesięcznik „Zwierciadło”, tytuł znacznie ambitniejszy, prezentujący szerszy wachlarz zagadnień, niż było to w przypadku miesięcznika „Elle”.

Należy jednak podkreślić pewien bezsporny, jednocześnie jeden z podstawowych, jakie wysnuto na podstawie analizy zebranego materiału, fakt: nie podważając znaczenia wartości statystycznych, należy zwrócić uwagę na stopień zróżnicowania i jakość prezentowanego materiału, nieporównywalną pod względem wartości $w$ każdym $z$ magazynów $w$ tej grupie. Tym samym waga wyróżniającej ten typ prasy przewagi w przekazywaniu interesujących nas informacji nabiera innego znaczenia. Uwaga ta odnosi się zwłaszcza do pierwszej z prezentowanych kategorii, jaką jest recenzja. Szczególnie na łamach miesięcznika „Elle” (w którym znalazło się najwięcej tego typu informacji, przypadających średnio na jeden numer) miała ona często postać adnotacji treściowych lub krótkich wzmianek, w których co prawda drukowano kopie okładek proponowanych lektur, podawano podstawowe dane bibliograficzne, ale ich ocena, jeśli się pojawiała, miała nierzadko formę hasła reklamowego, sam opis książki zaś ograniczał się przeważnie do kilku zdawkowych zdań, o czym szerzej pisano wcześniej (zob. rozdział 3.4.3.1.). Stąd wartość tego typu omówień była $\mathrm{z}$ recenzyjnego i poznawczego punktu widzenia znikoma. Z drugiej strony, recenzje zamieszczane na łamach miesięcznika „Zwierciadło”, zwłaszcza w szczegółowo opisanej rubryce Moje ksiq̨żki Renaty Arendt-Dziurdzikowskiej były obszerniejszymi, poważniejszymi omówieniami, w znacznym stopniu odpowiadającymi temu gatunkowi dziennikarskiemu.

Pozostałe kategorie, przede wszystkim zaś wywiady oraz sylwetki/portrety wyraźnie wpisywały się w formułę omówionych magazynów 
kobiecych, zaliczanych do żurnali, ekskluzywnych tytułów dla kobiet, które już osiągnęły sukces, bądź do niego zmierzają, czytelniczek zainteresowanych życiem innych kobiet, nieprzeciętnych, tych, które zdobyły w życiu wysoką pozycję społeczną. Prezentacja takich osób pozwalała podkreślać wartości, propagowane przez te pisma, wskazując jednocześnie nierzadko drogę, którą kroczą odważne kobiety, i którą mogą również pokonać odbiorczynie przedstawionych periodyków.

Natomiast konkursy, a ich liczba była najwyższa w przypadku prasy kobiecej, potwierdzały ambicje tych czasopism, które niejednokrotnie podkreślały, że kobieta powinna rozwijać swoją osobowość, umiejętności i zdolności, w tym przypadku talent lub predyspozycje literackie.

Można powiedzieć, że w odniesieniu do miesięczników kobiecych część prezentowanych kategorii była charakterystyczna dla tego typu prasy.

Drugie miejsce pod względem średniej liczby informacji zaliczanych do wymienionych kategorii wśród omawianych typów pism zajmuje prasa opinii (3 z 10 kategorii). Na łamach periodyków z tej grupy znalazło się najwięcej artykułów, podejmujących kwestie związane z literaturą i rynkiem wydawniczo-księgarskim. Dziennikarze przedstawionych tygodników zastanawiali się nad kondycją współczesnej literatury, jej znaczeniem i funkcją, opisując jednocześnie rolę twórcy, który konkurować musi $\mathrm{z}$ „autorytetami” kultury masowej. Prezentowano rozmaite typy literatury, podkreślając ich zalety i wskazując wady. Pisano także o rynku wydawniczym w Polsce, m.in. o problemach, z jakimi borykają się edytorzy. Najwięcej też prezentowano zestawień bestsellerów, a także na łamach tych periodyków pojawiało się najwięcej listów od czytelników, zainteresowanych kwestiami literackimi. Pomimo, że średnia liczba recenzji, przypadających na jeden numer była $w$ przypadku prasy opinii najmniejsza, to już w tym miejscu należy podkreślić, że pod względem formalnym i merytorycznym były one bardzo starannie przygotowywane, szczególnie zaś na łamach tygodników „Polityka” i „Wprost”.

Najsłabiej pod względem liczbowym prezentowały się poszczególne kategorie zawierające ogółem informacje o książce, zamieszczane na łamach prasy młodzieżowej. Tu jedynie w odniesieniu do ogłoszeń wydawniczych średnia przypadająca na jeden numer wartość była najwyższa w porównaniu z dwoma pozostałymi typami prasy, głównie za sprawą dwutygodnika "Cogito".

Z kolei porównując pod względem statystycznym tytuły w obrębie poszczególnych typów prasy, należy podkreślić, że w przypadku prasy opinii najwięcej informacji (średnio na jeden numer) związanych $\mathrm{z}$ książką zamieścił tygodnik „Polityka” (w 7 z 10 podanych kategorii), wśród czaso- 
pism kobiecych „Zwierciadło” (6 kategorii), zaś w grupie periodyków młodzieżowych takim liderem była, co ciekawe „Filipinka” (4 kategorie).

Tytuły te prezentowały też najwyższy poziom merytoryczny i formalny przygotowywanych informacji związanych z książką w porównaniu ze swoimi konkurentami, należącymi do tego samego segmentu rynku.

Ze względu na objętość rozprawy nie jest możliwe szczegółowe porównanie każdej z wyodrębnionych kategorii. Zdecydowano o bliższym omówieniu trzech grup informacji, jako najbardziej reprezentatywnych: 1) recenzji, 2) reklam wydawniczych oraz 3) wywiadów. 


\subsection{Książka dla wszystkich?1: recenzje, omówienia, streszczenia}

W tej kategorii najbardziej widoczne jest (w zależności od periodyku) zróżnicowanie pod względem formalnym i merytorycznym zawartych w niej informacji.

Wszystkie czasopisma proponowały swoim czytelnikom specjalne strony lub rubryki (drukowane w obrębie działu kulturalnego), w których prezentowano książki, chociaż, co należy podkreślić, w przypadku dwutygodnika "Cogito" nie była to rubryka istniejąca przez cały badany okres. Dział kulturalny wraz z omówieniami książek drukowano zazwyczaj na końcu danego numeru, choć wyjątkiem była „Polityka”, w której informacje kulturalne zamieszczano z reguły na początku wydania, lub w jego środku. W trakcie badanego okresu przedstawione pisma wielokrotnie zmieniały swoją szatę graficzną, dostosowując się do zmieniających się warunków, w tym do coraz bardziej wymagających odbiorców. Wraz z tymi zmianami modyfikowano również wygląd rubryk poświęconych prezentacji książek. Najczęstsze zmiany odnotowano w przypadku tygodnika „Wprost”. Częste próby zmierzały w większości przypadków do uzyskania bardziej przejrzystego, czytelnego, ale także kolorowego przekazu zamieszczanych w tym miejscu treści. Nie zawsze jednak udawało się ten efekt osiągnąć; niekiedy wersja pierwotna była znacznie korzystniejsza od kolejnych pomysłów, szczególnie z punktu widzenia czytelnika. Graficy niektórych tytułów (na przykład miesięcznika „Dziewczyna”) osiągali efekt kolorowego komiksu, z przewagą zdjęć nad tekstem, w dodatku niedostatecznie od siebie oddzielonych, co wprowadzało na daną stronę chaos, a przynajmniej wrażenie zbędnego przesytu.

Jedynie w przypadku prasy opiniotwórczej książki omawiała duża grupa recenzentów, z reguły podawano też nazwisko osoby kierującej działem kulturalnym, w ramach którego drukowano interesujące nas materiały. Natomiast w przypadku prasy kobiecej był to zazwyczaj jeden recenzent, którego co pewien czas zastępowała kolejna osoba², zaś w prasie młodzieżowej tego typu informacje o książce rzadko były podpisywane pełnym imieniem i nazwiskiem recenzenta.

Jak już zaznaczono, postać recenzji była bardzo zróżnicowana. Pod względem objętości najpełniejsze omówienia występowały na łamach prasy opinii, zwłaszcza dwóch pierwszych tygodników: „Polityki” i „Wprost”.

1 Tytuł recenzji, jaka ukazała się na łamach „Zwierciadła”, zob. „Zwierciadło” 2005, nr 5, s. 91 .

${ }^{2}$ Wyjątek stanowiła (omówiona w rozdz. 3.2.3) autorska rubryka R. Arendt-Dziurdzikowskiej: Moje książki, którą odnaleźć można było w badanym okresie na łamach miesięcznika „Zwierciadło”. 
Podobną postać miały recenzje drukowane w dwóch magazynach kobiecych: „Zwierciadle” i „Twoim Stylu”. Znacznie skromniej prezentowały się omówienia i adnotacje treściowe, zamieszczane $\mathrm{w}$ trzecim badanym magazynie kobiecym, jakim było „Elle”. Ich forma przypominała zwięzłe notki informacyjne, nierzadko ograniczające się do jednego-dwóch zdań dotyczących treści książki i krótkiej oceny, przypominającej często hasło reklamowe. Podobną postać miały omówienia i adnotacje dotyczące wybranych lektur, drukowane na łamach dwóch periodyków młodzieżowych: „Dziewczyny” i „Filipinki”. Należy jednak powiedzieć, że ostatni wymieniony tytuł na początku badanego okresu zachował jeszcze dawne ambicje, starając się nieco szerzej prezentować wybrane lektury. Jednak w miarę upływu czasu forma tych omówień zbliżała się coraz bardziej do postaci informacji zamieszczanych na łamach „Dziewczyny”. Trzecie z pism młodzieżowych, przedstawionych w pracy, „Cogito”, wyróżniało się na tle swoich konkurentów, proponując swoim czytelnikom bogatszą prezentację książek, choć i w tym przypadku nie były to szczególnie rozbudowane recenzje.

Analiza tej kategorii informacji o książce pozwoliła wyodrębnić pewne elementy wspólne, które najczęściej pojawiały się w tego typu informacjach, proponowanych czytelnikom każdego z pism.

Starano się przede wszystkim przedstawiać główne wątki prezentowanej książki. Streszczenie było tym elementem, który odnaleźć można niemal we wszystkich recenzjach, omówieniach i adnotacjach, niezależnie od periodyku. Najbardziej było ono rozbudowane na łamach „Polityki” najmniej - w miesięcznikach „Elle” i „Dziewczyna”. Poza opisaniem fabuły proponowanej lektury, częstym elementem, który pojawiał się w recenzjach i omówieniach była również prezentacja autora. Miała ona różną objętość i charakter. Niekiedy były to krótkie stwierdzenia, przypominające, że autor znany jest czytelnikom dzięki wcześniej napisanemu bestsellerowi, otrzymanej nagrodzie albo wykonywanej pracy (poza pisaniem książek mógł to być znany felietonista, prezenter telewizyjny lub radiowy). Czasem w jednym zdaniu przypominano najważniejsze (nierzadko skandaliczne) fakty z życia pisarza. Ale pojawiały się również rozbudowane informacje związane z sylwetką autora. Szczególnie czytelnicy „Polityki”, „Wprost”, i „Newsweeka”, a mniejszym stopniu „Zwierciadła” mogli poznać więcej szczegółów biograficznych dotyczących autora proponowanej książki.

Trzecim najczęściej pojawiającym się elektem recenzji, omówień i adnotacji, który łączył wszystkie opisane periodyki, była ocena proponowanej książki. I w tym przypadku była ona rozmaicie wyrażana. Część czasopism w niektórych latach badanego okresu drukowała w dziale kulturalnym symbole graficzne, które miały odzwierciedlać wrażenia recenzenta po 
przeczytaniu danej lektury. Niezależnie jednak od owych graficznych oznaczeń, czytelnicy każdego z pism w wielu przypadkach mieli okazję poznać opinię dziennikarza, omawiającego dany tytuł. Na łamach prasy młodzieżowej opinia ta była prezentowana w najbardziej zwięzłej formie, szczególnie zaś odbiorcy miesięcznika „Dziewczyna” przyzwyczajeni byli do (nierzadko) jednowyrazowych określeń, charakteryzujących daną książkę („świetna”, „znakomita”). Miłośnik literatury, który chciałby poznać także uzasadnienie oceny, powinien sięgnąć po pisma z grupy opiniotwórczych albo też zainteresować się recenzjami, zamieszczanymi na łamach „Zwierciadła" (szczególnie w rubryce R. Arendt-Dziurdzikowskiej Moje ksiq̨żki) lub sięgnąc po odpowiedni numer „Twojego Stylu”, licząc, że akurat w wybranym wydaniu trafi na obszerniejszą ocenę $\mathrm{z}$ komentarzem recenzenta. Najczęściej opinie miały charakter pozytywny, poza specjalnie drukowanymi na łamach niektórych pism rubrykami (Niskie loty - „Polityka”; Od hitu do kitu czy Sława i chała - „Wprost”). Najwięcej negatywnych recenzji mieli okazję poznać odbiorcy tygodnika „Wprost”. Niskie oceny, wystawiane przez dziennikarzy tego periodyku, korespondowały z tekstami dotyczącymi krytyki, zamieszczanymi niejednokrotnie na jego łamach.

Analiza wszystkich recenzji, omówień i adnotacji pozwoliła również, poza wyodrębnieniem najważniejszych elementów recenzji, wskazać na dominującą funkcję tego typu informacji, charakterystyczną dla poszczególnych typów opisanych czasopism.

W recenzjach zamieszczanych w prasie opinii na pierwszy plan wysuwała się funkcja informacyjna, nierzadko $\mathrm{z}$ towarzyszącym jej oceniającym komentarzem; największe też było w tym przypadku zróżnicowanie proponowanych lektur („Polityka” i „Wprost”). Funkcja głównie informacyjna była także cechą charakterystyczną omówień zamieszczanych na łamach czasopism młodzieżowych, szczególnie zaś przywoływanego wielokrotnie miesięcznika „Dziewczyna”. Interesujące spostrzeżenie odnotowano podczas analizy tej formy informacji o książce, drukowanej w prasie kobiecej. Otóż wydaje się, że omówienia wybranych lektur były w tym przypadku często dobierane wyraźnie po to, by uzupełniać i jednocześnie propagować wzór kobiety, promowany przez te pisma.

Warto na chwilę zatrzymać się przy stronie formalnej recenzji, omówień i adnotacji, które odnaleźć można w badanych czasopismach. Niezależnie od objętości dbano, by obok tych informacji pojawiała się (niemal zawsze) kopia okładki proponowanej książki, i nierzadko, wyraźnie wyeksponowana, w różnym stopniu czytelna i nierzadko oryginalnie sfotografowana. Wydaje się, że na ten element wielu recenzentów zwracało znacznie większą uwagę niż na podanie podstawowych danych bibliograficznych, dotyczących proponowanej lektury. Często (szczególnie na łamach „Wprost”, „Elle”, „Dziewczyny”) informacje takie czytelnik odnajdował w omówieniu 
(ograniczały się one wtedy przeważnie tylko do autora i tytułu książki). Jednocześnie należy zwrócić uwagę na rażącą niekonsekwencję w podawaniu tego typu danych. Na tle innych czasopism najpełniejszy opis bibliograficzny książki pojawiał się przy recenzjach drukowanych w tygodniku „Polityka”.

Natomiast porównując periodyki w obrębie poszczególnych grup, można wskazać tytuły, które charakteryzowały się największym profesjonalizmem i takie, którym najwyraźniej tego brakowało. W ten sposób wyróżnić można następujące pary czasopism, w których różnice pomiędzy zamieszczanymi na ich łamach recenzjami były najbardziej widoczne: „Polityka” i „Newsweek Polska”, „Zwierciadło” i „Elle”, „Cogito” i „Dziewczyna”. Redakcje, szczególnie „Polityki” i „Zwierciadła”, w mniejszym stopniu „Cogito”, starały się prezentować swym czytelnikom rozbudowane omówienia książek, w których obok streszczenia głównych wątków pojawiała się krótka charakterystyka ich autorów, a także, nierzadko, element oceny, wyrażony nie tylko (w różnych okresach) za pomocą symboli graficznych, ale także osobistego komentarza.

Biorąc pod uwagę wszystkie omawiane pisma, na pochwalę zasługuje przede wszystkim tygodnik „Polityka” - bezsprzecznie recenzje tu drukowane były najlepiej przygotowywane i dzięki swym walorom najbliższe były temu gatunkowi dziennikarskiemu.

Pomimo różnego charakteru każdego z opisanych w pracy periodyków, udało się zatem wyodrębnić pewne cechy wspólne, które łączyły recenzje, omówienia i adnotacje dotyczące książek. Solidność prezentacji poszczególnych elementów tego typu informacji, stopień ich rozwinięcia były, jak wynika choćby z powyższego podsumowania, różne w każdym z czasopism.

Abstrachując w tym miejscu od oceny formy i wartości merytorycznej, przypomnijmy postawione we Wstępie pytanie: czy, niezależnie od innego dla każdego z czasopism typu odbiorcy, specyfiki każdego z periodyków, można wskazać na pewną wspólną grupę autorów, których książki, być może, omawiano na łamach poddanych analizie pism? O ile w przypadku prasy opinii i czasopism kobiecych ustalenie takiej płaszczyzny wydaje się całkiem realne, o tyle prasa młodzieżowa może budzić pewne obawy. Ale należy tu przypomnieć, że odbiorcami opisanych czasopism młodzieżowych byli czytelnicy zbliżający się do progu dorosłości (uczniowie szkół średnich), a zatem potencjalni odbiorcy także „poważniejszej” literatury. Opierając się na analizie materiału, można wyciągnąć kilka interesujących wniosków.

W latach 2001-2005 na łamach opisanych 9 czasopism ukazały się ogółem 3797 recenzji, omówień i adnotacji treściowych. Zaproponowano w ten sposób książki 1960 różnych autorów, w tym 700 twórców polskich i 1260 obcych. Pierwszym ciekawym spostrzeżeniem jest zatem to, że w tej kategorii informacji dominowały tłumaczenia. 
Zanim przedstawione zostaną wyniki badań, dotyczące wspólnych dla opisanych czasopism grup pisarzy, należy przypomnieć, że przypadku prasy opinii przeważnie prezentowano książki znane szerszej publiczności, te, które nierzadko gościły na listach bestsellerów. Podobnie było w przypadku prasy młodzieżowej, przy czym w miesięczniku „Dziewczyna” starano się pisać o książkach, które niekoniecznie osiągnęły wysokie pozycje w rozmaitych zestawieniach, ale o tych, które były w owym czasie modne. Podobnie czyniono w śledzącym najmodniejsze trendy magazynie „Elle”, adresowanym do kobiet. Poza tym tytułem, dwa pozostałe periodyki adresowane do pań starały się zachować pewien indywidualny charakter prezentowanych książek. Jak już wcześniej wspomniano, literatura tu omawiana wpisywała się w program zarówno „Twojego Stylu”, jak i „Zwierciadła”. Bohaterki proponowanych książek odpowiadały wzorowi lansowanemu przez owe magazyny: kobiety inteligentnej, ambitnej, silnej i zadbanej, zainteresowanej otaczającym ją światem. Zatem twórczość jakich pisarzy mogła sprostać równocześnie wszystkim tym wymaganiom, stawianym przez każdy typ prasy? Czy pomimo różnic, wynikających z charakteru i wieku odbiorcy poszczególnych typów pism, zróżnicowania formalnego i wartości merytorycznej recenzji udało się wyłonić wspólną płaszczyznę dla wszystkich tych periodyków, nie tylko w obrębie danego typu pism (co było już przedmiotem analizy w poszczególnych rozdziałach)? W tabeli 83 przedstawiono zestawienie, prezentujące tych twórców, którzy pojawili się przynajmniej w jednym periodyku, reprezentującym każdy z omawianych typów prasy33.

Tabela 83. Autorzy recenzowanych książek wspólni dla badanych czasopism w latach 2001-2005

\begin{tabular}{|c|c|c|c|}
\hline $\begin{array}{c}\text { Autor } \\
\text { recenzowanego } \\
\text { dzieła }\end{array}$ & Typ prasy & Tytuł czasopisma & Liczba czasopism ogółem \\
\hline 1 & 2 & 3 & 4 \\
\hline \multirow{3}{*}{ Paul Auster } & Prasa opinii & P W NP & \multirow{3}{*}{6} \\
\hline & Prasa kobieca & TS E & \\
\hline & Prasa młodzieżowa & $\mathrm{C}$ & \\
\hline \multirow{3}{*}{ Victor Boris } & Prasa opinii & $\mathrm{PW}$ & \multirow{3}{*}{5} \\
\hline & Prasa kobieca & $\mathrm{E}$ & \\
\hline & Prasa młodzieżowa & $\mathrm{F} \mathrm{C}$ & \\
\hline \multirow{3}{*}{ Grażyna Borkowska } & Prasa opinii & NP & \multirow{3}{*}{5} \\
\hline & Prasa kobieca & Zw TS E & \\
\hline & Prasa młodzieżowa & $\mathrm{F}$ & \\
\hline
\end{tabular}

3 Pomimo że zestawienie jest obszerne, zdecydowano, ze względu na jego walory porównawcze, umieścić je w całości w głównym tekście opisowym. 
Tabela 83 (cd.)

\begin{tabular}{|c|c|c|c|}
\hline 1 & 2 & 3 & 4 \\
\hline \multirow{3}{*}{ Dan Brown } & Prasa opinii & P W NP & \multirow{3}{*}{5} \\
\hline & Prasa kobieca & $\mathrm{E}$ & \\
\hline & Prasa młodzieżowa & $\mathrm{Dz}$ & \\
\hline \multirow{3}{*}{ Anna Brzezińska } & Prasa opinii & $\mathrm{P}$ & \multirow{3}{*}{4} \\
\hline & Prasa kobieca & Zw E & \\
\hline & Prasa młodzieżowa & $\mathrm{Dz}$ & \\
\hline \multirow{3}{*}{ Candace Bushnell } & Prasa opinii & $\mathrm{P}$ & \multirow{3}{*}{3} \\
\hline & Prasa kobieca & TS & \\
\hline & Prasa młodzieżowa & $\mathrm{Dz}$ & \\
\hline \multirow{3}{*}{ John Le Carré } & Prasa opinii & P NP & \multirow{3}{*}{4} \\
\hline & Prasa kobieca & $E$ & \\
\hline & Prasa młodzieżowa & $\mathrm{Dz}$ & \\
\hline \multirow{3}{*}{ Jonathan Carroll } & Prasa opinii & P NP & \multirow{3}{*}{6} \\
\hline & Prasa kobieca & $\mathrm{ZwE}$ & \\
\hline & Prasa młodzieżowa & $\mathrm{F} \mathrm{Dz}$ & \\
\hline \multirow{3}{*}{ Max Cegielski } & Prasa opinii & $\mathrm{W}$ & \multirow{3}{*}{4} \\
\hline & Prasa kobieca & TS E & \\
\hline & Prasa młodzieżowa & $\mathrm{F}$ & \\
\hline \multirow{3}{*}{ Paulo Coelho } & Prasa opinii & $\mathrm{PW}$ & \multirow{3}{*}{6} \\
\hline & Prasa kobieca & $\mathrm{ZwE}$ & \\
\hline & Prasa młodzieżowa & $\mathrm{F} \mathrm{Dz}$ & \\
\hline \multirow{3}{*}{ John M. Coetzee } & Prasa opinii & P W NP & \multirow{3}{*}{9} \\
\hline & Prasa kobieca & Zw TS E & \\
\hline & Prasa młodzieżowa & $\mathrm{F} \mathrm{Dz} \mathrm{C}$ & \\
\hline \multirow{3}{*}{$\begin{array}{l}\text { Michael Cunnin- } \\
\text { gham }\end{array}$} & Prasa opinii & $\mathrm{P} \mathrm{NP}$ & \multirow{3}{*}{6} \\
\hline & Prasa kobieca & Zw TS & \\
\hline & Prasa młodzieżowa & $\mathrm{Dz} \mathrm{C}$ & \\
\hline \multirow{3}{*}{ Irina Dienieżkina } & Prasa opinii & $\mathrm{W}$ & \multirow{3}{*}{5} \\
\hline & Prasa kobieca & TS & \\
\hline & Prasa młodzieżowa & F Dz C & \\
\hline \multirow{3}{*}{ Lawrence Durrell } & Prasa opinii & $\mathrm{P}$ & \multirow{3}{*}{3} \\
\hline & Prasa kobieca & TS & \\
\hline & Prasa młodzieżowa & $\mathrm{C}$ & \\
\hline \multirow{3}{*}{ Magda Dygat } & Prasa opinii & P W NP & \multirow{3}{*}{7} \\
\hline & Prasa kobieca & Zw TS E & \\
\hline & Prasa młodzieżowa & $\mathrm{F}$ & \\
\hline \multirow{3}{*}{ Umberto Eco } & Prasa opinii & P W NP & \multirow{3}{*}{7} \\
\hline & Prasa kobieca & Zw TS E & \\
\hline & Prasa młodzieżowa & $\mathrm{Dz}$ & \\
\hline & Prasa opinii & NP & \\
\hline Eva Ensler & Prasa kobieca & $\mathrm{ZwE}$ & 4 \\
\hline & Prasa młodzieżowa & $\mathrm{C}$ & \\
\hline
\end{tabular}




\begin{tabular}{|c|c|c|c|}
\hline 1 & 2 & 3 & 4 \\
\hline \multirow{3}{*}{ Karen Essex } & Prasa opinii & $\mathrm{W}$ & \multirow{3}{*}{3} \\
\hline & Prasa kobieca & $\mathrm{Zw}$ & \\
\hline & Prasa młodzieżowa & $\mathrm{Dz}$ & \\
\hline \multirow{3}{*}{ Jeffrey Eugenides } & Prasa opinii & $\mathrm{NP}$ & \multirow{3}{*}{6} \\
\hline & Prasa kobieca & Zw TS E & \\
\hline & Prasa młodzieżowa & $\mathrm{F} \mathrm{Dz}$ & \\
\hline \multirow{3}{*}{ Jasper Fforde } & Prasa opinii & W NP & \multirow{3}{*}{4} \\
\hline & Prasa kobieca & $\mathrm{Zw}$ & \\
\hline & Prasa młodzieżowa & $\mathrm{Dz}$ & \\
\hline \multirow{3}{*}{ Helen Fielding } & Prasa opinii & P W NP & \multirow{3}{*}{7} \\
\hline & Prasa kobieca & TS E & \\
\hline & Prasa młodzieżowa & $\mathrm{F} \mathrm{Dz}$ & \\
\hline \multirow{3}{*}{ Lynn Freed } & Prasa opinii & NP & \multirow{3}{*}{3} \\
\hline & Prasa kobieca & TS & \\
\hline & Prasa młodzieżowa & $\mathrm{C}$ & \\
\hline \multirow{3}{*}{ Rubén Gallego } & Prasa opinii & $\mathrm{NP}$ & \multirow{3}{*}{3} \\
\hline & Prasa kobieca & $\mathrm{Zw}$ & \\
\hline & Prasa młodzieżowa & $\mathrm{E}$ & \\
\hline \multirow{3}{*}{ Laurent Gaudé } & \begin{tabular}{|l|} 
Prasa opinii \\
\end{tabular} & $\mathrm{P}$ & \multirow{3}{*}{3} \\
\hline & Prasa kobieca & TS & \\
\hline & Prasa młodzieżowa & $\mathrm{C}$ & \\
\hline \multirow{3}{*}{$\begin{array}{l}\text { Manuela Gretkow- } \\
\text { ska }\end{array}$} & Prasa opinii & P W NP & \multirow{3}{*}{5} \\
\hline & Prasa kobieca & $E$ & \\
\hline & Prasa młodzieżowa & $\mathrm{F}$ & \\
\hline \multirow{3}{*}{ Katarzyna Grochola } & Prasa opinii & P W NP & \multirow{3}{*}{7} \\
\hline & Prasa kobieca & Zw E & \\
\hline & Prasa młodzieżowa & $\mathrm{F} \mathrm{Dz}$ & \\
\hline \multirow{3}{*}{ Joanne Harris } & Prasa opinii & $\mathrm{W}$ & \multirow{3}{*}{4} \\
\hline & Prasa kobieca & $\mathrm{Zw}$ & \\
\hline & Prasa młodzieżowa & $\mathrm{F} \mathrm{Dz}$ & \\
\hline \multirow{3}{*}{ Lian Hearn } & Prasa opinii & NP & \multirow{3}{*}{4} \\
\hline & Prasa kobieca & TS & \\
\hline & Prasa młodzieżowa & $\mathrm{F} \mathrm{C}$ & \\
\hline \multirow{3}{*}{ Hermann Hesse } & \begin{tabular}{|l|} 
Prasa opinii \\
\end{tabular} & $\mathrm{P}$ & \multirow{3}{*}{5} \\
\hline & Prasa kobieca & Zw TS E & \\
\hline & Prasa młodzieżowa & $\mathrm{F}$ & \\
\hline & Prasa opinii & $\mathrm{W}$ & \\
\hline Patricia Highsmith & Prasa kobieca & Z TS & 5 \\
\hline & Prasa młodzieżowa & $\mathrm{DzC}$ & \\
\hline & Prasa opinii & P NP & \\
\hline Nick Hornby & Prasa kobieca & Zw E & 5 \\
\hline & Prasa młodzieżowa & $\mathrm{Dz}$ & \\
\hline & \begin{tabular}{|l|} 
Prasa opinii \\
\end{tabular} & $\mathrm{NP}$ & \\
\hline Andrzej Horubała & Prasa kobieca & $E$ & 3 \\
\hline & Prasa młodzieżowa & $\mathrm{C}$ & \\
\hline
\end{tabular}


Tabela 83 (cd.)

\begin{tabular}{|c|c|c|c|}
\hline 1 & 2 & 3 & 4 \\
\hline \multirow{3}{*}{$\begin{array}{l}\text { Michael Houelle- } \\
\text { becq }\end{array}$} & Prasa opinii & P W NP & \multirow{3}{*}{5} \\
\hline & Prasa kobieca & TS & \\
\hline & Prasa młodzieżowa & $\mathrm{C}$ & \\
\hline \multirow{3}{*}{ John Irving } & Prasa opinii & $\mathrm{P} \mathrm{NP}$ & \multirow{3}{*}{6} \\
\hline & Prasa kobieca & Zw TS E & \\
\hline & Prasa młodzieżowa & $\mathrm{Dz}$ & \\
\hline \multirow{3}{*}{ Wojciech Jagielski } & Prasa opinii & $\mathrm{P}$ & \multirow{3}{*}{3} \\
\hline & Prasa kobieca & $E$ & \\
\hline & Prasa młodzieżowa & $\mathrm{F}$ & \\
\hline \multirow{3}{*}{ Krystyna Janda } & Prasa opinii & $\mathrm{W}$ & \multirow{3}{*}{5} \\
\hline & Prasa kobieca & Zw TS E & \\
\hline & Prasa młodzieżowa & $\mathrm{F}$ & \\
\hline \multirow{3}{*}{ Imre Kertész } & Prasa opinii & P W NP & \multirow{3}{*}{5} \\
\hline & Prasa kobieca & $\mathrm{Zw}$ & \\
\hline & Prasa młodzieżowa & $\mathrm{C}$ & \\
\hline \multirow{3}{*}{ Naomi Klein } & Prasa opinii & $\mathrm{PW}$ & \multirow{3}{*}{5} \\
\hline & Prasa kobieca & Zw E & \\
\hline & Prasa młodzieżowa & $\mathrm{C}$ & \\
\hline \multirow{3}{*}{ Krystyna Kofta } & Prasa opinii & P W NP & \multirow{3}{*}{6} \\
\hline & Prasa kobieca & Zw TS & \\
\hline & Prasa młodzieżowa & $\mathrm{F}$ & \\
\hline \multirow{3}{*}{$\begin{array}{l}\text { Barbara Kosmow- } \\
\text { ska }\end{array}$} & Prasa opinii & NP & \multirow{3}{*}{5} \\
\hline & Prasa kobieca & Zw TS E & \\
\hline & Prasa młodzieżowa & $\mathrm{Dz}$ & \\
\hline \multirow{3}{*}{ Jan Kott } & Prasa opinii & $\mathrm{W}$ & \multirow{3}{*}{3} \\
\hline & Prasa kobieca & $\mathrm{Zw}$ & \\
\hline & Prasa młodzieżowa & $\mathrm{F}$ & \\
\hline \multirow{3}{*}{ Hanna Kowalewska } & Prasa opinii & $\mathrm{P}$ & \multirow{3}{*}{4} \\
\hline & Prasa kobieca: & Zw TS & \\
\hline & Prasa młodzieżowa & $\mathrm{Dz}$ & \\
\hline \multirow{3}{*}{ Wojciech Kuczok } & Prasa opinii & P W NP & \multirow{3}{*}{7} \\
\hline & Prasa kobieca & Zw TS E & \\
\hline & Prasa młodzieżowa & $\mathrm{F}$ & \\
\hline \multirow{3}{*}{ Milan Kundera } & Prasa opinii & P W NP & \multirow{3}{*}{5} \\
\hline & Prasa kobieca & $\mathrm{Zw}$ & \\
\hline & Prasa młodzieżowa & $\mathrm{C}$ & \\
\hline \multirow{3}{*}{ Hari Kunzru } & Prasa opinii & P W NP & \multirow{3}{*}{5} \\
\hline & Prasa kobieca & Zw & \\
\hline & Prasa młodzieżowa & $\mathrm{F}$ & \\
\hline & Prasa opinii & P W NP & \\
\hline Mario V. Llosa & Prasa kobieca & Zw TS & 6 \\
\hline & Prasa młodzieżowa & $\mathrm{C}$ & \\
\hline
\end{tabular}




\begin{tabular}{|c|c|c|c|}
\hline 1 & 2 & 2 & 3 \\
\hline \multirow{3}{*}{ Robert Ludlum } & Prasa opinii & P NP & \multirow{3}{*}{4} \\
\hline & Prasa kobieca & $E$ & \\
\hline & Prasa młodzieżowa & $\mathrm{Dz}$ & \\
\hline \multirow{3}{*}{ Maciej Łuczak } & \begin{tabular}{|l} 
Prasa opinii \\
\end{tabular} & $\mathrm{W}$ & \multirow{3}{*}{3} \\
\hline & Prasa kobieca & $\mathrm{Zw}$ & \\
\hline & Prasa młodzieżowa & $\mathrm{Dz}$ & \\
\hline \multirow{3}{*}{$\begin{array}{l}\text { Aleksandra Mari- } \\
\text { ninia }\end{array}$} & Prasa opinii & $\mathrm{PNP}$ & \multirow{3}{*}{5} \\
\hline & Prasa kobieca & TS E & \\
\hline & Prasa młodzieżowa & $\mathrm{C}$ & \\
\hline \multirow{3}{*}{ Gabriel G. Márquez } & Prasa opinii & P W NP & \multirow{3}{*}{7} \\
\hline & Prasa kobieca & TS E & \\
\hline & Prasa młodzieżowa & $\mathrm{F} \mathrm{C}$ & \\
\hline \multirow{3}{*}{ Yann Martel } & \begin{tabular}{|l|} 
Prasa opinii \\
\end{tabular} & P NP & \multirow{3}{*}{5} \\
\hline & Prasa kobieca & TS & \\
\hline & Prasa młodzieżowa & $\mathrm{F} \mathrm{Dz}$ & \\
\hline \multirow{3}{*}{ Dorota Masłowska } & \begin{tabular}{|l|} 
Prasa opinii \\
\end{tabular} & P W NP & \multirow{3}{*}{5} \\
\hline & Prasa kobieca & $E$ & \\
\hline & Prasa młodzieżowa & $\mathrm{F}$ & \\
\hline \multirow{3}{*}{ Tomasz Matkowski } & \begin{tabular}{|l} 
Prasa opinii \\
\end{tabular} & $\mathrm{PW}$ & \multirow{3}{*}{4} \\
\hline & Prasa kobieca & $\mathrm{E}$ & \\
\hline & Prasa młodzieżowa & $\mathrm{Dz}$ & \\
\hline \multirow{3}{*}{ Frances Mayes } & \begin{tabular}{|l|} 
Prasa opinii \\
\end{tabular} & $\mathrm{W}$ & \multirow{3}{*}{4} \\
\hline & Prasa kobieca & Zw E & \\
\hline & Prasa młodzieżowa & $\mathrm{Dz}$ & \\
\hline \multirow{3}{*}{ Eduardo Mendoza } & \begin{tabular}{|l|} 
Prasa opinii \\
\end{tabular} & P NP & \multirow{3}{*}{5} \\
\hline & Prasa kobieca & Zw TS & \\
\hline & Prasa młodzieżowa & $\mathrm{C}$ & \\
\hline \multirow{3}{*}{ Henry Miller } & Prasa opinii & $\mathrm{W}$ & \multirow{3}{*}{3} \\
\hline & Prasa kobieca & $\mathrm{E}$ & \\
\hline & Prasa młodzieżowa & $\mathrm{C}$ & \\
\hline \multirow{3}{*}{ Katarzyna Miller } & Prasa opinii & $\mathrm{W}$ & \multirow{3}{*}{3} \\
\hline & Prasa kobieca & $\mathrm{E}$ & \\
\hline & Prasa młodzieżowa & $\mathrm{C}$ & \\
\hline \multirow{3}{*}{ Czesław Miłosz } & Prasa opinii & P W NP & \multirow{3}{*}{5} \\
\hline & Prasa kobieca & $\mathrm{E}$ & \\
\hline & Prasa młodzieżowa & $\mathrm{F}$ & \\
\hline \multirow{3}{*}{ Jan Miodek } & Prasa opinii & $\mathrm{W}$ & \multirow{3}{*}{3} \\
\hline & Prasa kobieca & $\mathrm{Zw}$ & \\
\hline & Prasa młodzieżowa & $\mathrm{F}$ & \\
\hline & Prasa opinii & NP & \\
\hline bán & Prasa kobieca & E & 3 \\
\hline & Prasa młodzieżowa & $\mathrm{C}$ & \\
\hline
\end{tabular}


Tabela 83 (cd.)

\begin{tabular}{|c|c|c|c|}
\hline 1 & 2 & 3 & 4 \\
\hline \multirow{3}{*}{ Sławomir Mrożek } & Prasa opinii & NP & \multirow{3}{*}{3} \\
\hline & Prasa kobieca & $E$ & \\
\hline & Prasa młodzieżowa & $\mathrm{C}$ & \\
\hline \multirow{3}{*}{ Barbara Mujica } & Prasa opinii & NP & \multirow{3}{*}{4} \\
\hline & Prasa kobieca & $\mathrm{Zw}$ & \\
\hline & Prasa młodzieżowa & $\mathrm{DzC}$ & \\
\hline \multirow{3}{*}{ Mirosław Nahacz } & Prasa opinii & $\mathrm{PW}$ & \multirow{3}{*}{5} \\
\hline & Prasa kobieca & $E$ & \\
\hline & Prasa młodzieżowa & $\mathrm{F} \mathrm{Dz}$ & \\
\hline \multirow{3}{*}{ Amélie Nothomb } & Prasa opinii & P NP & \multirow{3}{*}{7} \\
\hline & Prasa kobieca & Zw TS E & \\
\hline & Prasa młodzieżowa & F C & \\
\hline \multirow{3}{*}{ Joyce C. Oates } & Prasa opinii & P W NP & \multirow{3}{*}{8} \\
\hline & Prasa kobieca & Zw TS E & \\
\hline & Prasa młodzieżowa & $\mathrm{F} \mathrm{Dz}$ & \\
\hline \multirow{3}{*}{ Tony Parsons } & Prasa opinii & NP & \multirow{3}{*}{5} \\
\hline & Prasa kobieca & Zw TS E & \\
\hline & Prasa młodzieżowa & $\mathrm{Dz}$ & \\
\hline \multirow{3}{*}{ Beata Pawlikowska } & Prasa opinii & W NP & \multirow{3}{*}{5} \\
\hline & Prasa kobieca & Zw E & \\
\hline & Prasa młodzieżowa & $\mathrm{Dz}$ & \\
\hline \multirow{3}{*}{$\begin{array}{l}\text { Arturo Pérez-Re- } \\
\text { verte }\end{array}$} & Prasa opinii & P W NP & \multirow{3}{*}{9} \\
\hline & Prasa kobieca & Zw TS E & \\
\hline & Prasa młodzieżowa & F Dz C & \\
\hline \multirow{3}{*}{ Sandra Petrignani } & Prasa opinii & W & \multirow{3}{*}{3} \\
\hline & Prasa kobieca & TS & \\
\hline & Prasa młodzieżowa & $\mathrm{F}$ & \\
\hline \multirow{3}{*}{ Tomasz Piątek } & Prasa opinii & P W NP & \multirow{3}{*}{5} \\
\hline & Prasa kobieca & $E$ & \\
\hline & Prasa młodzieżowa & $\mathrm{C}$ & \\
\hline \multirow{3}{*}{ Wiktor Pielewin } & Prasa opinii & P W NP & \multirow{3}{*}{5} \\
\hline & Prasa kobieca & $\mathrm{Zw}$ & \\
\hline & Prasa młodzieżowa & $\mathrm{F}$ & \\
\hline \multirow{3}{*}{ Jerzy Pilch } & Prasa opinii & $\mathrm{P}$ & \multirow{3}{*}{4} \\
\hline & Prasa kobieca & $\mathrm{E}$ & \\
\hline & Prasa młodzieżowa & $\mathrm{DzC}$ & \\
\hline \multirow{3}{*}{ Agneta Pleijel } & Prasa opinii & NP & \multirow{3}{*}{3} \\
\hline & Prasa kobieca & $\mathrm{Zw}$ & \\
\hline & Prasa młodzieżowa & $\mathrm{F}$ & \\
\hline & Prasa opinii & P NP & \\
\hline Terry Pratchett & Prasa kobieca & $E$ & 4 \\
\hline & Prasa młodzieżowa & $\mathrm{Dz}$ & \\
\hline
\end{tabular}




\begin{tabular}{|c|c|c|c|}
\hline 1 & 2 & 3 & 4 \\
\hline \multirow{3}{*}{ Richard Russo } & Prasa opinii & NP & \multirow{3}{*}{3} \\
\hline & Prasa kobieca & $\mathrm{Zw}$ & \\
\hline & Prasa młodzieżowa & $\mathrm{Dz}$ & \\
\hline \multirow{3}{*}{ Andrzej Sapkowski } & Prasa opinii & $\mathrm{P}$ & \multirow{3}{*}{5} \\
\hline & Prasa kobieca & TS E & \\
\hline & Prasa młodzieżowa & F Dz & \\
\hline \multirow{3}{*}{ José Saramago } & Prasa opinii & $\mathrm{P}$ & \multirow{3}{*}{3} \\
\hline & Prasa kobieca & $\mathrm{E}$ & \\
\hline & Prasa młodzieżowa & $\mathrm{C}$ & \\
\hline \multirow{3}{*}{ David Schickler } & Prasa opinii & NP & \multirow{3}{*}{6} \\
\hline & Prasa kobieca & Zw E & \\
\hline & Prasa młodzieżowa & Dz F C & \\
\hline \multirow{3}{*}{$\begin{array}{l}\text { Eric Emanuel } \\
\text { Schmitt }\end{array}$} & \begin{tabular}{|l|} 
Prasa opinii \\
\end{tabular} & P NP & \multirow{3}{*}{6} \\
\hline & Prasa kobieca & TS E & \\
\hline & Prasa młodzieżowa & $\mathrm{DzC}$ & \\
\hline \multirow{3}{*}{ Alice Sebold } & Prasa opinii & P NP & \multirow{3}{*}{6} \\
\hline & Prasa kobieca & TS E & \\
\hline & Prasa młodzieżowa & $\mathrm{F} \mathrm{Dz}$ & \\
\hline \multirow{3}{*}{ Zadie Smith } & \begin{tabular}{|l|} 
Prasa opinii \\
\end{tabular} & P NP & \multirow{3}{*}{7} \\
\hline & Prasa kobieca & Zw TS E & \\
\hline & Prasa młodzieżowa & F Dz & \\
\hline \multirow{3}{*}{ Marek Soból } & \begin{tabular}{|l|} 
Prasa opinii \\
\end{tabular} & $\mathrm{P}$ & \multirow{3}{*}{3} \\
\hline & Prasa kobieca & $\mathrm{E}$ & \\
\hline & Prasa młodzieżowa & $\mathrm{Dz}$ & \\
\hline \multirow{3}{*}{ Izabela Sowa } & Prasa opinii & NP & \multirow{3}{*}{4} \\
\hline & Prasa kobieca & $\mathrm{Zw}$ & \\
\hline & Prasa młodzieżowa & F Dz & \\
\hline \multirow{3}{*}{ Andrzej Stasiuk } & Prasa opinii & $\mathrm{PNP}$ & \multirow{3}{*}{4} \\
\hline & Prasa kobieca & $\mathrm{Zw}$ & \\
\hline & Prasa młodzieżowa & $\mathrm{F}$ & \\
\hline \multirow{3}{*}{$\begin{array}{l}\text { Joanna Szczepkow- } \\
\text { ska }\end{array}$} & Prasa opinii & $\mathrm{W}$ & \multirow{3}{*}{4} \\
\hline & Prasa kobieca & $\mathrm{ZwE}$ & \\
\hline & Prasa młodzieżowa & $\mathrm{C}$ & \\
\hline \multirow{3}{*}{ Amy Tan } & \begin{tabular}{|l|} 
Prasa opinii \\
\end{tabular} & NP & \multirow{3}{*}{5} \\
\hline & Prasa kobieca & Zw TS & \\
\hline & Prasa młodzieżowa & F Dz & \\
\hline \multirow{3}{*}{ Dorota Terakowska } & \begin{tabular}{|l|} 
Prasa opinii \\
\end{tabular} & $\mathrm{P}$ & \multirow{3}{*}{7} \\
\hline & Prasa kobieca & Zw TS E & \\
\hline & Prasa młodzieżowa & $\mathrm{F} \mathrm{Dz} \mathrm{C}$ & \\
\hline & \begin{tabular}{|l|} 
Prasa opinii \\
\end{tabular} & P NP & \\
\hline Olga Tokarczuk & Prasa kobieca & Zw TS E & 7 \\
\hline & Prasa młodzieżowa & $\mathrm{DzC}$ & \\
\hline
\end{tabular}


Tabela 83 (cd.)

\begin{tabular}{|c|c|c|c|}
\hline 1 & 2 & 3 & 4 \\
\hline \multirow{3}{*}{ Jáchym Topol } & Prasa opinii & P NP & \multirow{3}{*}{5} \\
\hline & Prasa kobieca & Zw E & \\
\hline & Prasa młodzieżowa & $\mathrm{F}$ & \\
\hline \multirow{3}{*}{ Sue Townsend } & Prasa opinii & $\mathrm{PW}$ & \multirow{3}{*}{7} \\
\hline & Prasa kobieca & Zw TS E & \\
\hline & Prasa młodzieżowa & F Dz & \\
\hline \multirow{3}{*}{ Dubravka Ugrešcić } & Prasa opinii & $\mathrm{P}$ & \multirow{3}{*}{4} \\
\hline & Prasa kobieca & Zw E & \\
\hline & Prasa młodzieżowa & $\mathrm{F}$ & \\
\hline \multirow{3}{*}{ Erica Wagner } & Prasa opinii & $\mathrm{NP}$ & \multirow{3}{*}{3} \\
\hline & Prasa kobieca & TS & \\
\hline & Prasa młodzieżowa & $\mathrm{C}$ & \\
\hline \multirow{3}{*}{ Thomas Wharton } & Prasa opinii & NP & \multirow{3}{*}{4} \\
\hline & Prasa kobieca & Zw TS & \\
\hline & Prasa młodzieżowa & $\mathrm{Dz}$ & \\
\hline \multirow{3}{*}{ William Wharton } & Prasa opinii & NP & \multirow{3}{*}{4} \\
\hline & Prasa kobieca & $\mathrm{Zw}$ & \\
\hline & Prasa młodzieżowa & F Dz & \\
\hline \multirow{3}{*}{$\begin{array}{l}\text { Janusz L. Wiśniew- } \\
\text { ski }\end{array}$} & Prasa opinii & P W NP & \multirow{3}{*}{7} \\
\hline & Prasa kobieca & $\mathrm{ZwE}$ & \\
\hline & Prasa młodzieżowa & F Dz & \\
\hline \multirow{3}{*}{ Isabel Wolff } & Prasa opinii & NP & \multirow{3}{*}{3} \\
\hline & Prasa kobieca & $E$ & \\
\hline & Prasa młodzieżowa & $\mathrm{Dz}$ & \\
\hline
\end{tabular}

Uwaga: Zastosowano następujące skróty: $\mathrm{P} \rightarrow$ „Polityka”, W $\rightarrow$ „Wprost”, NP $\rightarrow$ „Newsweek Polska”, Zw $\rightarrow$ „Zwierciadło”, TS $\rightarrow$ „Twój Styl”, E $\rightarrow$ „Elle”, F $\rightarrow$ „Filipinka”, Dz $\rightarrow$ „Dziewczyna”, $\mathrm{C} \rightarrow$ „Cogito”.

Źródło: badania własne.

Jak wynika z zestawienia, książki zaledwie dwóch pisarzy omawiane były na łamach wszystkich badanych czasopism. Byli to J. M. Coetzee oraz A. Pérez-Reverte. W ośmiu periodykach przedstawiono z kolei książki J. C. Oates (tylko recenzenci „Cogito” nie sięgnęli po twórczość tej autorki). Z kolei czytelnicy siedmiu czasopism mieli możliwość poznać wybrane tytuły Magdy Dygat ${ }^{4}$, Umberto Eco ${ }^{5}$, Helen Fielding 6 , Katarzyny Grocholi,

\footnotetext{
4 W tym przypadku zabrakło tej autorki zarówno na łamach „Cogito”, jak i „Dziewczyny”.

${ }^{5}$ Brakowało omówień zarówno w "Cogito”, jak i „Filipince”.

6 Twórczość tej autorki pominięto w „Zwierciadle” i „Cogito”.

7 Próżno by szukać recenzji książek tej autorki w „Twoim Stylu” i „Cogito”.
} 
Wojciecha Kuczoka ${ }^{8}$, Gabriela G. Márqueza9 ${ }^{9}$ A. Nothomb ${ }^{10}$, Z. Smith ${ }^{11}$, Doroty Terakowskiej12, Olgi Tokarczuk ${ }^{13}$, Sue Townsend ${ }^{14}$ oraz Janusza L. Wiśniewskiego ${ }^{15}$. W niemal wszystkich przypadkach recenzowano jednak różne książki danego autora. Stąd trudno wysnuwać daleko idące wnioski, dotyczące grupy tych pisarzy, po książki których sięgnęli recenzenci niemal wszystkich opisanych czasopism. Można jedynie stwierdzić, że byli to twórcy, których nazwiska w owym czasie znane były szerszej publiczności i które mogły zainteresować odbiorców zarówno pism opinii, jak i periodyków kobiecych czy czasopism młodzieżowych. Ciekawsze wnioski natomiast nasuwają się, gdy przyjrzymy się pełnemu zestawieniu, przyporządkowując poszczególnych autorów do kolejnych periodyków. Największą wspólną płaszczyznę wykazują pisma opinii i prasa kobieca (w 13 przypadkach to właśnie w takiej konfiguracji pojawiły się wspólne dla nich nazwiska). W niewiele mniejszym stopniu prasa kobieca znalazła wspólną płaszczyznę z prasą młodzieżową ( 9 nazwisk). $W$ analizie wszystkich recenzji został potwierdzony ten wniosek. Wynikało to z faktu, iż zarówno „Filipinka”, jak i „Dziewczyna” adresowane były głównie do nastolatek, przyszłych czytelniczek prasy kobiecej. „Filipinka”, będąc przez pewien okres własnością wydawcy „Twojego Stylu”, w swej formule zbliżyła się do tego periodyku. Jak wspominano $\mathrm{w}$ rozdziale 4.2, redaktor naczelna tego czasopisma kobiecego przyznawała, że celem jest wychowanie przyszłych czytelniczek „Twojego Stylu”. Każdy z periodyków informował o bestsellerach, które mogły zainteresować odbiorcę konkretnego czasopisma.

\footnotetext{
8 Jego tekstami nie zainteresowali się dziennikarze zarówno „Dziewczyny”, jak i „Cogito”.

9 Nie było omówień jego twórczości w „Zwierciadle” i „Dziewczynie”.

10 Brakowało prezentacji we „Wprost” i „Dziewczynie”.

11 Nie proponowano jej książek we „Wprost” i „Cogito”.

12 Brak omówień na łamach „Wprost” i „Newsweek Polska”.

13 Brak recenzji we „Wprost” i „Filipince”.

14 Brak recenzji w „Newsweek Polska” i „Cogito”.

15 Brak prezentacji książek tego autora na łamach „Twojego Stylu” i „Cogito”.
} 


\subsection{Warto czytać1: reklamy książek}

Największą liczbę inseratów wydawniczych odnaleźć można było na łamach prasy młodzieżowej. Wynikało to jednak w dużej mierze z faktu, że na łamach jednego nich, „Cogito”, odnotowano ich najwięcej spośród wszystkich badanych czasopism. Była to jednakże oferta stosunkowo monotonna pod względem charakteru proponowanych tytułów. Jak pisano we wcześniejszym rozdziale, większość ogłoszeń promowała wydawnictwa szkolne i źródłowe, a prym wśród edytorów wiodło $\mathrm{w}$ tym przypadku Wydawnictwo Wiedza Powszechna.

Najbardziej zróżnicowana oferta reklamowa pojawiła się natomiast na łamach pism opiniotwórczych, szczególnie zaś czytelnicy tygodników „Polityka” i „Wprost” mieli do wyboru szeroki wachlarz tytułów, pochodzących od różnych wydawców. W tabeli 84 zawarto liczbę edytorów, którzy reklamowali swoją ofertę na łamach poszczególnych periodyków:

Tabela 84. Edytorzy, zamieszczający reklamy wydawnicze na łamach badanych periodyków oraz wspólne dla poszczególnych grup oficyny

\begin{tabular}{|c|c|c|c|c|c|c|c|c|c|}
\hline \multirow[b]{2}{*}{$\begin{array}{c}\text { Tytuł } \\
\text { czasopisma }\end{array}$} & \multicolumn{3}{|c|}{ Prasa opinii } & \multicolumn{3}{|c|}{ Prasa kobieca } & \multicolumn{3}{|c|}{ Prasa młodzieżowa } \\
\hline & Polityka' & ",Wprost" & $\begin{array}{c}\text { Newsweek } \\
\text { Polska" }\end{array}$ & $\begin{array}{l}\text { "Zwier- } \\
\text { ciadło" }\end{array}$ & Styl” & ,Elle" & „Filipinka” & $\begin{array}{l}\text { "Dziew- } \\
\text { czyna" }\end{array}$ & "Cogito" \\
\hline $\begin{array}{l}\text { Liczba } \\
\text { wydawców }\end{array}$ & 57 & 75 & 14 & 16 & 5 & 8 & 9 & 5 & 28 \\
\hline $\begin{array}{l}\text { Wspólni } \\
\text { dla danej } \\
\text { grupy pism } \\
\text { wydawcy }\end{array}$ & $\begin{array}{l}\text { Wydawn } \\
\text { Świat Ksi } \\
\text { Wydawn } \\
\text { Wydawn } \\
\text { Wydawn }\end{array}$ & $\begin{array}{l}\text { iictwo Pas } \\
\text { iążki } \\
\text { hictwo Uni } \\
\text { iictwo Nau } \\
\text { iictwo W.A }\end{array}$ & $\begin{array}{l}\text { al } \\
\text { yersitas } \\
\text { kowe PWN } \\
\text { B. }\end{array}$ & $\begin{array}{l}\text { Wydawn } \\
\text { Naukow }\end{array}$ & $\begin{array}{l}\text { ictwo } \\
\text { PWN }\end{array}$ & & $\begin{array}{l}\text { Wydawnic } \\
\text { i S-ka }\end{array}$ & ctwo Pró & Szyński \\
\hline
\end{tabular}

Źródło: badania własne.

Powyższe dane potwierdzają wniosek, że czytelnicy dwóch najstarszych tygodników opinii w Polsce mieli okazję poznać urozmaiconą ofertę wydawniczą, pochodząca od wielu edytorów. Łamy prasy kobiecej oraz dwóch poddanych analizie czasopism młodzieżowych („Dziewczyny” i „Filipinki”) okazały się mało zachęcające dla potencjalnych reklamodawców, chociaż, co było już podkreślane, nie brakowało w tych pismach reklam proponujących zgoła inny asortyment (na przykład kosmetyki, artykuły higieniczne). Niewielka liczba ogłoszeń może dziwić, szczególnie w odnie-

${ }^{1}$ Hasło reklamowe jednego z ogłoszeń wydawniczych, zob. „Polityka” 2005, nr 47, s. 102. 
sieniu do periodyków kobiecych. Powstaje w tym miejscu pytanie, czy przeszkodą była zbyt wysoka cena modułu reklamowego, przerastająca możliwości finansowe liczących się na rynku wydawców, czy też może ich obawa, że potencjalne adresatki ogłoszenia nie będą zainteresowane ofertą książek w takim stopniu, by opłacało się ją zamieszczać. Natomiast w przypadku prasy młodzieżowej, zwłaszcza zaś dwóch pierwszych tytułów, odpowiedź wydaje się znana. Czy czytelniczki „Dziewczyny”, a także „Filipinki”, z okresu, gdy stała się ona własnością niemieckiego wydawcy, były zapalonymi miłośniczkami słowa pisanego...? Wystarczy obejrzeć wybrane numery tych periodyków, zwłaszcza z ostatnich analizowanych lat, by odpowiedzieć na to pytanie. Redakcje (głównie miesięcznika „Dziewczyna") nie bez powodu drukowały tak skromne omówienia książek, że nierzadko przypominały one wraz z innymi informacjami kulturalnymi kolorowy kalejdoskop, pełen barwnych zdjęć, z niewielkim dodatkiem treści. Inną kwestią pozostaje pytanie, czy były to reakcje na faktyczne potrzeby nastolatek, czy też prasa tego typu serwując materiał podany w taki sposób, kształtowała pewien rodzaj mody, stylu, tego, co „powinno” się podobać, a co „powinno” nudzić (do tej ostatniej kategorii z pewnością, zdaniem redakcji, należały obszerniejsze teksty, w tym recenzje).

Pod względem graficznym ogłoszenia wydawnicze miały podobną postać, chociaż, zgodnie z tendencją, której wierne pozostały wspomniane periodyki młodzieżowe, na ich łamach przeważały całostronicowe, niezwykle kolorowe inseraty. W prasie kobiecej natomiast reklamy wydawnicze prezentowały się szczególnie okazale na łamach dwóch pierwszych czasopism: „Zwierciadła” i „Twojego Stylu”, z kolei na łamach „Elle” większość anonsów przyjmowała postać małych modułów, choć uwagę czytelników mogły i w tym przypadku zwracać żywe kolory i wyróżniająca się grafika.

Niemal wszystkie ogłoszenia wydawnicze zawierały te same elementy: kopię okładki proponowanej książki lub książek, niekiedy hasło reklamowe, zawsze dane wydawcy. Czasem elementem uzupełniającym był fragment proponowanej lektury, nieraz opinia znanego specjalisty na temat polecanego utworu, stosunkowo rzadko zdjęcie autora.

Wydaje się, że ta forma informacji o książce w przypadku dwóch $\mathrm{z}$ trzech badanych typów prasy, przynajmniej w odniesieniu do analizowanych periodyków, nie została w pełni wykorzystana. 


\subsection{Autor pisze na własnq odpowiedzialność1: wywiady}

Ogółem na łamach wszystkich badanych periodyków w ciągu pięciu lat pojawiły się 432 wywiady. W sumie przeprowadzono rozmowy z 355 osobami. Żaden z rozmówców nie był gościem wszystkich badanych periodyków. Jedynymi autorami, których miało szanse poznać najwięcej czytelników, byli K. Grochola ${ }^{2}$ i Jerzy Pilch ${ }^{3}$. Wywiady z nimi znalazły się na łamach pięciu z dziewięciu badanych czasopism.

Niezależnie od tytułu, każda zamieszczona w piśmie rozmowa wzbogacona była o zdjęcie bądź zdjęcia rozmówcy wraz z notką biograficzną na jego temat. $\mathrm{W}$ wielu przypadkach tekst poprzedzony był krótkim wprowadzeniem, w którym starano się zainteresować czytelników poruszanymi w rozmowie tematami. Niekiedy $w$ tym miejscu przypominano najciekawsze wydarzenie z życia danego twórcy lub też cytowano fragment zamieszczonej poniżej rozmowy.

Najwięcej wywiadów znalazło się na łamach prasy kobiecej, tam też były one najbardziej rozbudowane, i z punktu widzenia czytelnika, najbardziej interesujące. Najobszerniejsze (średnio pięć stron) drukowano na łamach „Zwierciadła”, najskromniejsze pod względem objętości pojawiały się w magazynie „Elle” (średnio strona). Wywiady tu zamieszczane były też najbardziej charakterystyczne, jako że, jak już zostało to powiedziane, wpisywały się w politykę każdego z tych pism w bardzo wyraźny sposób. Pieczołowicie wybierano rozmówców, nierzadko przeprowadzano tzw. podwójne wywiady: na przykład ze znanym pisarzem i jego żoną/partnerką lub popularną autorką i jej mężem/partnerem. Na łamach „Zwierciadła” i „Twojego Stylu” pytano zazwyczaj o twórczość danego autora, natomiast w przypadku „Elle” częściej były to rozmowy dotyczące jego życie prywatnego. 0 ile jednak rozmowy przeprowadzane przez dziennikarzy pierwszego i trzeciego magazynu miały przeważnie charakter rozrywkowy, o tyle wywiady drukowane na łamach „Twojego Stylu” poza funkcją rozrywkową spełniały również rolę wspomagającą główne idee pisma. Ich bohaterkami bywały nierzadko kobiety, które pokonując liczne przeszkody, osiągnęły w życiu wysoką pozycję społeczną, były silne psychicznie, a w życiu codziennym potrafiły radzić sobie z problemami.

Udanym uzupełnieniem wywiadów, zamieszczanych na łamach opisanych czasopism, były portrety wybranych twórców. I w przypadku tej

\footnotetext{
1 Tytuł jednego z wywiadów, zob. „Cogito” 2005, nr 22, s. [37].

2 Wywiad z nią pojawił się na łamach „Cogito”, „Elle”, „Filipinka”, „Twój Styl” oraz „Wprost”.

${ }^{3}$ Rozmowa z autorem Mojego pierwszego samobójstwa pojawiła się na łamach „Cogito”, „Elle”, „Polityki”, „Twojego Stylu” i „Zwierciadła”.
} 
kategorii najciekawsze obrazy kreślono na łamach czasopism kobiecych. Wiele $\mathrm{z}$ takich tekstów miało postać dłuższych, interesujących historii, opisujących życie wybranej osoby. Ulubioną przez dziennikarzy kilku periodyków postacią w tamtym okresie była Virginia Woolf i Sylvia Plath. Prawdopodobnie bodźcem do opisania ich losów były filmy, opowiadające o ich życiu, które w tamtym okresie cieszyły się dużą popularnością. Tę kategorię informacji, pośrednio związanej z książką, przedstawiono dokładniej w rozdziałach poświęconych konkretnym tytułom.

$\mathrm{Na}$ uwagę, poza omówionymi w tym rozdziale kategoriami, zasługują również konkursy i akcje, związane z książką, organizowane przez reprezentowane czasopisma. Tego typu inicjatywy oddawały specyfikę każdego z badanych tytułów. 0 ile w przypadku prasy opinii ich głównym celem była promocja książki i czytelnictwa, o tyle na łamach prasy kobiecej chodziło przede wszystkim o rozwijanie zdolności twórczych czy literackich wśród czytelniczek. Natomiast w przypadku czasopism młodzieżowych podstawowa funkcja, którą spełniać miały rozmaitego rodzaju konkursy, opierała się bądź to na rozrywce („Dziewczyna”) albo rozwijaniu wiedzy i kształceniu odbiorcy („Cogito”). Były to zatem, przenikające się pomiędzy sobą $\mathrm{w}$ różnym stopniu, realizowane poprzez tego typu inicjatywy trzy różne funkcje: informacyjna, rozrywkowa i poznawczo-kształceniowa, edukacyjna.

I takie też funkcje były, jak się zdaje, przypisane do poszczególnych typów prasy.

Warto jeszcze w tym miejscu nadmienić, że w każdym z periodyków, $\mathrm{w}$ formie specyficznej dla siebie, informowano o najważniejszych wydarzeniach literackich lat 2001-2005. W postaci przede wszystkim recenzji, ale także pośrednio dzięki wywiadom, czytelnicy tych czasopism mogli kształtować swoją własną opinię na temat na przykład ekranizacji cyklu powieści Johna R. R. Tolkiena, Joanne J. Rowling czy książek Andrzeja Sapkowskiego.

Analiza bogatego i niezwykle zróżnicowanego materiału pozwoliła stwierdzić, że $\mathrm{w}$ każdym z badanych typów prasy obecne były, w różnym stopniu, podstawowe kategorie zawierające informacje związane z książką.

Najbardziej wyrazistą grupę stanowiły recenzje, omówienia i adnotacje. Były one reprezentowane najliczniej, i chociaż ich forma nierzadko budziła zastrzeżenia, ważne jest, iż chociaż w takiej (szczątkowej) postaci trafiała do czytelnika.

Jednakże równocześnie należy raz jeszcze podkreślić, że o ile w przypadku prasy opinii w znacznym stopniu znajdowała zastosowanie klasyczna recenzja, pełniąca zarówno funkcję informacyjną, jak i nierzadko wartościującą, o tyle w niektórych czasopismach kobiecych i prasie młodzieżowej rolę recenzji pełniły przeważnie teksty ograniczone przede wszystkim do informacji i swego rodzaju reklamy. Natomiast elementy analizy, motywo- 
wanego wartościowania były w nich coraz bardziej ograniczane. Kierunek ewolucji tego gatunku dziennikarskiego zmierzał wyraźnie do zmniejszenia elementów oceniających, na rzecz eksponowania elementów informacyjnych i reklamowych. Te spostrzeżenia znajdują swoje potwierdzenie także w ogólnych sądach, dotyczących mediów:

niezależnie od tego, czy są to tzw. media tradycyjne [...], czy też nowoczesne media elektroniczne [...] - stały się we współczesnym świecie prawdziwą potęgą. Nazywane niegdyś czwartą władzą, powoli stają się pierwszą władzą, gdyż mogą nie tylko informować o wydarzeniach, ale owe wydarzenia inicjować, kreować tak, że informacji niebezpiecznie blisko do chwytu marketingowo-propagandowego ${ }^{4}$.

I taką rolę coraz częściej zdaje się spełniać informacja o książce, zamieszczana na łamach badanych czasopism.

${ }^{4}$ Media w Polsce. Pierwsza władza IV RP?, red. M. Sokołowski, Wydawnictwa Akademickie i Profesjonalne, Warszawa 2007, s. [7]. 


\section{ZAKOŃCZENIE}

Książka stała się w wielu cywilizacjach symbolem kultury, jej emanacją i instrumentem. Utrwalanie w książce - za pomocą pisma - ludzkiej myśli i języka stworzyło sprawne narzędzie zachowywania i przekazywania tekstów, narzędzie pokonujące przestrzeń i czas, bariery ekonomiczne, religijne, polityczne ${ }^{1}$.

Czasy nam współczesne narzucają niezwykle szybkie tempo życia. Dzięki nowoczesnym technologiom komunikacyjnym możliwa jest globalna wymiana informacji, w której media odgrywają niebagatelną rolę. Środki masowego przekazu końca XX w. były, jak pisze Małgorzata Bonikowska, „zdominowane pędem do informacji, zdobywaniem najświeższych newsów, maksymalizacją ilości wiadomości"2. Swoisty wyścig z czasem, nieustanna walka o klienta, konsumenta, widza, czytelnika stanowiły wyróżniki ostatniej dekady ubiegłego stulecia. Z kolei początek XXI w. oferuje odbiorcy olbrzymi wybór zróżnicowanych dóbr, w tym także informacji, którymi jest on otoczony ze wszystkich stron. Hasła reklamowe nawołujące do kupna wybranych produktów pojawiają się na ulicznych billboardach, wystawach sklepów, w środkach komunikacji miejskiej, w Internecie, telewizji, radiu i prasie. Tak olbrzymia dawka informacji dotyczących różnych dziedzin życia, nie pozwala współczesnemu człowiekowi na właściwą ich percepcję, w tym rzetelną ocenę, a następnie optymalny wybór. W zasadniczy sposób na decyzję wpływa dobrze pomyślana kampania, określony sposób przekazu skomentowanej informacji. Co gorsza, manipulacja, przypisywana mediom od dawna, dziś, dzięki m.in. rozbudowanej sieci agencji związanych z public relations, jest przez większość odbiorców w ogóle nie dostrzegana. Jednocześnie przyjmowane przezeń wybory, opinie są nierzadko odzwierciedleniem poglądów danego nadawcy - wybranego producenta, a w przy-

\footnotetext{
${ }^{1}$ K. Migoń, Uniwersum piśmiennictwa, jego właściwości, granice i sposoby istnienia, [w:] Uniwersum piśmiennictwa wobec komunikacji elektronicznej, red. K. Migoń, M. Skalska-Zlat, Wydawnictwo Uniwersytetu Wrocławskiego, Wrocław 2009, s. 12.

2 M. Bonikowska, Media w XXI wieku, [w:] Media a wyzwania XXI wieku, red. M. Bonikowska, Wydawnictwo Trio, Warszawa 2009, s. 17.
} 
padku mediów - dziennikarza. Zjawiska te dotyczą także kultury, która, jak się wydaje, sprzyjać powinna przecież rozwojowi indywidualnych zapatrywań, ocen i postaw.

Jaką pozycję $\mathrm{w}$ owym gąszczu informacji zajmuje przekaz związany z książką? Czy jest tu dla niej miejsce? Czy prasa, jako jeden ze środków masowego przekazu spełnia przypisane jej funkcje, pisząc o literaturze i książce?

Odpowiedzi na postawione we Wstępie pytania, które wyłoniły się w wyniku przeprowadzonej analizy zawartości wybranych czasopism, budzą ambiwalentne odczucia.

W każdym $\mathrm{z}$ badanych periodyków proponowano czytelnikom rubryki, poświęcone prezentacji książek. Redakcje tych czasopism przyznawały w ten sposób, że informacja tego typu jest potrzebna (choć można przypuszczać, że kierowano się $\mathrm{w}$ tym względzie różnymi przekonaniami). Jednocześnie zjawisko to nie było jednoznaczne i ukształtowane choćby zbliżoną skalą zainteresowania książką przez poszczególne periodyki. Rozpiętość w tym zakresie okazała się bardzo szeroka: najbardziej zróżnicowane formy związane $\mathrm{z}$ tą problematyką pojawiały się na łamach pism opiniotwórczych, najmniej - w czasopismach młodzieżowych. Opisane tygodniki, szczególnie zaś „Polityka” i „Wprost”, pretendowały do roli przewodników kulturowych, komentujących wybrane wydarzenia, miesięczniki młodzieżowe (zwłaszcza „Dziewczyna” i „Filipinka”) i jeden z magazynów kobiecych („Elle”) ograniczały swe ambicje w tym zakresie do roli informatorów (pozbawionych refleksji) o tym, co było aktualnie popularne, starając się podkreślać te aspekty poruszanych kwestii, które mogły być przede wszystkim intrygujące, a jednocześnie modne. Ciekawe zadanie natomiast stawiały przed sobą dwa pozostałe magazyny kobiece („Twój Styl” i „Zwierciadło”), które wykorzystując rozmaite formy informacji o książce, kreowały wybrany przez siebie wizerunek kobiety, wpisany w programy każdego z nich.

Analiza zebranego materiału pozwoliła stwierdzić, że na łamach każdego $\mathrm{z}$ czasopism pojawiały się następujące formy informacji o książce: recenzja, ogłoszenie wydawnicze, wywiad, portret/sylwetka. Jednakże swego rodzaju znakiem czasu było wykorzystanie tych gatunków dziennikarskich w bardzo nierównym stopniu.

Rzetelne recenzje pojawiały się tylko na łamach dwóch tygodników opinii, dwóch magazynów kobiecych oraz jednego czasopisma dla młodzieży. Cztery pozostałe periodyki zadowalały się namiastką recenzji, którą można byłoby określić mianem mikrorecenzji, ze wszelkimi znamionami notatki prasowej z elementami reklamowymi. Tym samym forma determinowała ich funkcję: ambitniejsze omówienia, które miał okazję poznać czytelnik pięciu z przedstawionych czasopism, poza oczywistą informacją, 
oferowały także komentarz oceniający, w którym zazwyczaj nie brakowało również uzasadnienia. Z kolei wspomniane mikrorecenzje pełniły funkcję informacyjno-reklamową, wpisując się w charakter czasopism, na łamach których były drukowane.

Druga podstawowa i jednocześnie jedna z najstarszych form informacji o książce, jaką są ogłoszenia wydawnicze, nie stanowiła stałego elementu każdego z czasopism. Na łamach prasy młodzieżowej i częściowo kobiecej ten typ promocji pojawiał się nieregularnie, w niektórych przypadkach bardzo rzadko, przy czym oferta proponowanych tytułów była tu stosunkowo monotonna (widoczne to było szczególnie w przypadku dwutygodnika „Cogito”). Najbardziej zróżnicowane propozycje pochodzące od wydawców odnaleźć można było na łamach pism opinii, zwłaszcza tygodników „Polityka” i „Wprost”. Pod względem formy anonse wydawnicze nie różniły się od siebie w sposób znaczący, być może tylko w przypadku prasy dla młodzieży były bardziej kolorowe. Zawierały jednak w większości przypadków te same elementy. Warto zauważyć, że zarówno w recenzjach, jak i inseratach dużą rolę odgrywała kopia okładki omawianej/reklamowanej książki, prezentowana mniej lub bardziej wyraźnie, co uzależnione było od wielkości zdjęcia ${ }^{3}$.

Nie można mówić o wspólnej dla wszystkich przedstawionych w pracy grup czasopism płaszczyźnie autorów książek - ta uwaga odnosi się zarówno do recenzji, omówień, adnotacji, jak i do ogłoszeń wydawniczych. Jakkolwiek w przypadku prasy młodzieżowej jest to zrozumiałe, to jednak można było sądzić, że w odniesieniu do tygodników opinii i periodyków kobiecych pojawi się znacznie większa wspólna grupa prezentowanych twórców. Tymczasem badane magazyny kobiece stały się swego rodzaju „prasą środka”. Na łamach tych czasopism pojawiło 13 nazwisk pisarzy, których książki recenzowano także w prasie opinii, i 9 autorów, których wybrali również recenzenci czasopism adresowanych do młodzieży. W obydwu przypadkach wydaje się jednak, że liczby te stanowią zbyt nikłą przesłankę do wysnuwania wniosków dotyczących wspólnych czy choćby podobnych wyborów dla opisanych dwóch typów prasy. Książki tylko dwóch pisarzy omawiane były na łamach wszystkich przedstawionych czasopism. Te obserwacje wskazują na wyraźnie różne zainteresowania recenzentów każdego z poddanych analizie grup czasopism, co prowadzi do zdecydowanego oddzielenia ich od siebie pod względem propozycji lekturowych. Bogactwo współczesnego rynku wydawniczego, jego zróżnicowanie pozwala na ukierunkowanie zainteresowań recenzentów pod kątem

$3 \mathrm{Na}$ znaczenie okładki, występującej w rozmaitych formach promocji książki zwrócił uwagę m.in. P. Narbutowicz, zob. P. Narbutowicz, Sprzedać ksiqż̇ke po okładce. Techniki perswazji na okładkach ksiq̨żek literackich wydawanych w Polsce, Biblioteka Analiz, Warszawa 2012. 
gustów (własnych czy narzuconych?) czytelników tygodników opinii, magazynów kobiecych i czasopism młodzieżowych. Pomimo istnienia bestsellerów, które powinny interesować dorosłych odbiorców, niezależnie od tego, czy są nimi kobiety czy mężczyźni, brakuje powszechników lekturowych na miarę dawnych powieści, które jednoczyły całą dorosłą publiczność czytelniczą. Wobec wspominanej koncentracji na rynku wydawniczo-księgarskim i prasowym, w odniesieniu do propozycji lekturowych wyraźny jest pluralizm wyborów proponowanych książek, co może prowadzić do tworzenia zamkniętych kręgów czytelniczych, których gusty literackie kształtowane są w sposób wyraźnie odmienny, w zależności od typu kupowanej prasy.

Znamiennym znakiem czasu był również brak w badanych czasopismach odcinków powieściowych, które były wszak jedną z najstarszych form upowszechniania literatury na łamach prasy. Jak się wydaje, zastąpiły je fragmenty wybranych powieści, drukowane jednorazowo (głównie przez tygodniki opinii i prasę kobiecą), a także tzw. fotostory, czyli rodzaj komiksu ze zdjęciami $\mathrm{w}$ miejsce rysunków (te z kolei można było odnaleźć w prasie młodzieżowej).

Znaczącą grupę na łamach każdego z przedstawionych periodyków stanowiła kategoria określona na potrzeby pracy jako Inne. Poza charakterystycznymi dla każdego z tytułów formami, były to krótkie notki, wzmianki, najnowsze doniesienia informujące o wydarzeniach związanych z książką, wybranym pisarzem lub określonym faktem. W przypadku prasy opinii informacje te stanowiły rodzaj uzupełnienia zamieszczanych w niej treści kulturalnych, natomiast na łamach szczególnie prasy młodzieżowej nabierały większego znaczenia, wpisując się w formułę tych czasopism.

Stosunkowo duża liczba spośród zebranych 24441 pozycji bibliograficznych, odnoszących się w różnym stopniu do podjętej problematyki miała postać wspomnianych krótkich, 1-3-zdaniowych wzmianek, w telegraficznym skrócie donoszących o wydarzeniach związanych z książką. Nie tylko skromna objętość tego typu notek, ale również ich merytoryczna wartość dowodzą, że również w tym zakresie następuje

trywializacja i nadmierne upraszczanie rzeczywistości, związane z wymaganiami odbiorcy masowego, a więc przeciętnego. W cywilizacji bardziej obrazu niż słowa dziennikarze dążą do maksymalnej przystępności przekazu, szukając coraz prostszych i atrakcyjniejszych form. To powoduje, że kwestie naprawdę istotne i trudne schodzą na dalszy plan, ustępując miejsca tematom miałkim, ale za to łatwym w odbiorze. Pojawia się zjawisko "gonienia" dziennikarzy za odbiorcą, schlebianie jego gustom i dopasowywania się do jego poziomu4.

Owe spostrzeżenia można odnieść do części badanych periodyków. Szczególny niepokój uwagi te powinny budzić w stosunku do czasopism

${ }^{4}$ Media a wyzwania..., s. 18. 
młodzieżowych („Dziewczyna”, która wydaje się najlepszym tego przykładem, była jednocześnie $\mathrm{w}$ badanym okresie najpopularniejszym spośród trzech przedstawionych tytułów w tej grupie pism), ale również i niektórych magazynów kobiecych (ich przedstawicielem byłby w tym przypadku magazyn „Elle”).

Podjęte badania pozwoliły zatem nie tylko wskazać i opisać formy obecności książki na łamach wybranych polskich czasopism, ale ukazały również pewne niepokojące zjawisko związane z uproszczeniem, a wręcz spłyceniem treści przekazu, odnoszącego się do tak istotnej części kultury, jaką jest literatura. Pamiętając, że

Funkcjonalizacja i demokratyzacja produkcji książkowej, z drugiej strony szczególna podatność tekstów literackich na cyrkulację w różnych środkach przekazu (prasie, radiu, telewizji, także w szkole) pokaźnie poszerzyły przestrzeń obiegu literatury, powodując, że książka już dość dawno temu przestała być jedynym jej medium ${ }^{5}$,

nie należy jednak zapominać, że jest ona lekarstwem nie tylko dla umysłu, ale również i dla duszy. Rola prasy powinna polegać na podkreśleniu wyjątkowego charakteru literatury, kształtując tym samym czytelniczą wrażliwość swych odbiorców.

Można mieć nadzieję, że przeprowadzone badania zachęcą do dyskusji nad obecnością książki w prasie współczesnej i sprawią, że przedmiotem zainteresowań $\mathrm{w}$ proponowanym zakresie staną się również inne typy czasopism.

5 K. Wodniak, Współczesna prasa kobieca a sprawy książki. Treści literackie w czasopismach: „Przyjaciółka”, „Twój Styl”, „Cienie i Blaski”, Wydawnictwo SBP, Warszawa 2004, s. 9. 



\section{BIBLIOGRAFIA}

\section{Wydawnictwa zwarte}

Czarnik Oskar St., Między dwoma Sierpniami. Polska kultura literacka w latach 1944-1980, Wiedza Powszechna, Warszawa 1993

Czarnik Oskar St., Proza artystyczna a prasa codzienna (1918-1926), Zakład Narodowy im. Ossolińskich, Wydawnictwo Polskiej Akademii Nauk, Wrocław i in. 1982

Dąbrowska-Cendrowska Olga, Niemieckie koncerny prasowe w Polsce w latach 1989-2008, Dom Wydawniczy Elipsa, Warszawa 2009

Dziennikarstwo i świat mediów, red. Bauer Zbigniew, Chudziński Edward, Towarzystwo Autorów i Wydawców Prac Naukowych Universitas, Kraków 2004

Encyklopedia wiedzy o prasie, red. Maślanka Julian, Zakład Narodowy im. Ossolińskich Wydawnictwo, Wrocław-Warszawa-Kraków-Gdańsk 1976

Franke Jerzy, Polska prasa kobieca w latach 1820-1918. W kręgu ofiary i poświęcenia, Wydawnictwo SBP, Warszawa 1999

Frycie Stanisław, Literatura dla dzieci i młodzieży w latach 1945-1970, Wydawnictwa Szkolne i Pedagogiczne, Warszawa 1988

Goban-Klas Tomasz, Niepokorna orkiestra medialna. Dyrygenci $i$ wykonawcy polityki informacyjnej w Polsce po 1944 roku, Oficyna Wydawnicza ASPRA-JR, Warszawa 2004

Gołębiewski Łukasz, Rynek książki w Polsce 2000, Biblioteka Analiz, Warszawa 2000

Gołębiewski Łukasz, Rynek książki w Polsce 2001, Biblioteka Analiz, Warszawa 2001

Gołębiewski Łukasz, Rynek książki w Polsce 2002. Wydawnictwa, Biblioteka Analiz, Warszawa 2002

Gołębiewski Łukasz, Rynek książki w Polsce 2003. Wydawnictwa, Biblioteka Analiz, Warszawa 2003

Gołębiewski Łukasz, Rynek książki w Polsce 2004. Wydawnictwa, Biblioteka Analiz, Warszawa 2004

Gołębiewski Łukasz, Rynek ksiq̨żki w Polsce 2005. Wydawnictwa, Biblioteka Analiz, Warszawa 2005

Gołębiewski Łukasz, Rynek książki w Polsce 2006. Wydawnictwa, Biblioteka Analiz, Warszawa 2006

Gołębiewski Łukasz, Rynek książki w Polsce. Edycja `98, Wydawnictwo „Herbud”, Warszawa 1998

Gołębiewski Łukasz, Rynek ksiq̨żki w Polsce. Edycja 1999, Wydawnictwo „Magazyn Literacki”, Warszawa 1999

Hombek Danuta, Reklama wydawnicza i księgarska w „Gazecie Warszawskiej” w latach 17641795, Wydawnictwo Wyższej Szkoły Pedagogicznej im. Jana Kochanowskiego w Kielcach, Kielce 1988

Jarowiecki Jerzy, Studia nad prasq polskq XIX i XX wieku, Wydawnictwo Naukowe WSP, Kraków 1997

Jenkins Henry, Kultura konwergencji. Zderzenie starych i nowych mediów, Wydawnictwa Akademickie i Profesjonalne, Warszawa 2007 
Kolasa Władysław M., Jarowiecki Jerzy, Polska bibliografia prasoznawcza 1996-2001, Polska Akademia Nauk Oddział w Krakowie, Komisja Prasoznawcza, Kraków 2005

Kondek Stanisław Adam, Władza i wydawcy, Biblioteka Narodowa, Warszawa 1993

Kowalczyk R., Prasa lokalna w Polsce, Instytut Nauk Politycznych i dziennikarstwa Uniwersytetu im. Adama Mickiewicza, Poznań 2000

Koźniewski Kazimierz, Historia co tydzień. Szkice o tygodnikach społeczno-kulturalnych 19441950, Czytelnik, Warszawa 1977

Ksiq̨żka dziecięca 1990-2005, red. G. Leszczyński i in., Wydawnictwo SBP, Warszawa 2006

Kumiega J., Leszczyńska A., Czasopisma dla dzieci i młodzieży w latach 1990-1996, WiMBP

[Wydawnictwo Wojewódzkiej i Miejskiej Biblioteki Publicznej im. Zbigniewa Herberta w Gorzowie], Wrocław 1996

Kwade Elżbieta, Rola magazynów prasowych w komunikacji literackiej, Wydawnictwo Uniwersytetu Śląskiego, Katowice 1981

Literatura dla dzieci i młodzieży (po roku 1980), t. 2, red. Heska-Kwaśniewicz Krystyna, Wydawnictwo Uniwersytetu Śląskiego, Katowice, 2009

Materiały pomocnicze do najnowszej historii dziennikarstwa, t. 26, red. Słomkowska Alina, Instytut Dziennikarstwa Uniwersytetu Warszawskiego, Warszawa 2004

Media a wyzwania XXI wieku, red. Bonikowska Małgorzata, Wydawnictwo Trio, Warszawa 2009

Media i dziennikarstwo w Polsce 1989-1995, red. Kopper Grzegorz i in., OBP UJ, Kraków 1996

Media w Polsce. Pierwsza władza IV RP, red. Sokołowski Marek, Wydawnictwa Akademickie i Profesjonalne, Warszawa 2007

Mielczarek Tomasz, Między monopolem a pluralizmem, Wydawnictwo Akademii Świętokrzyskiej, Kielce 1998

Mielczarek Tomasz, Monopol, pluralizm, koncentracja. Środki komunikowania masowego w Polsce w latach 1989-2006, Wydawnictwa Akademickie i Profesjonalne, Warszawa 2007

Mielczarek Tomasz, Od Nowej Kultury do Polityki. Tygodniki społeczno-kulturalne i społeczno-polityczne PRL, Wydawnictwo Akademii Świętokrzyskiej, Kielce 2003

Migoń Krzysztof, Uniwersum piśmiennictwa, jego granice i sposoby istnienia, [w:] Uniwersum piśmiennictwa wobec komunikacji elektronicznej, red. Migoń Krzysztof, Skalska-Zlata Marta, Wydawnictwo Uniwersytetu Wrocławskiego, Wrocław 2009

Narbutowicz Przemysław, Sprzedać ksiq̨żkę po okładce. Techniki perswazji na okładkach książek literackich wydawanych w Polsce, Biblioteka Analiz, Warszawa 2012

Nowakowski Piotr Tomasz, Modele człowieka propagowane w wybranych czasopismach młodzieżowych. Analiza antropologiczno-etyczna, Maternus Media, Tychy 2004

Olszański Leszek, Dziennikarstwo internetowe, Wydawnictwa Akademickie i Profesjonalne, Warszawa 2006

Pamuła Stanisław, Metoda analizy zawartości prasy, Wyższa Szkoła Pedagogiczna w Częstochowie, Częstochowa 1996

Pauluk Dorota, Sojka Agnieszka, Wizerunek nowoczesnej dziewczyny na łamach czasopism młodzieżowych wobec chrześcijańskiego ideału kobiety, Wydawnictwo Uniwersytetu Jagiellońskiego, Kraków 2010

Pisarek Walery, Analiza zawartości prasy, Ośrodek Badań Prasoznawczych, Kraków 1983

Prasa dawna i współczesna. Część piąta, red. Kosmanowa Bogumiła, Wydawnictwo Naukowe Instytutu Nauk Politycznych i Dziennikarstwa Uniwersytetu im. Adam Mickiewicza w Poznaniu, Poznań 2004 
Prasa dziecięca i młodzieżowa. Studia i materiały, red. Adamczyk Marek, Jarowiecki Jerzy, Instytut Kształcenia Nauczycieli, Oddział Doskonalenia Nauczycieli w Kielcach, Kielce 1992

Przybysz-Stawska Magdalena, „To się czyta”. Promocja w dodatkach do wybranych polskich gazet codziennych w latach dziewięćdziesiątych XX wieku, Wydawnictwo Ibidem, Kurowice/k. Łodzi 2006

Pyszny Joanna, „Czytać albo nie czytać...”. Informacje o literaturze i życiu literackim w popularnych magazynach ilustrowanych w latach 1967-1971, Wydawnictwo Uniwersytetu Wrocławskiego, Wrocław 1991

Rogoż Michał, Czasopisma dla dzieci i młodzieży Instytutu Wydawniczego „Nasza Księgarnia” w latach 1945-1989. Studium historycznoprasowe, Wydawnictwo Naukowe Uniwersytetu Pedagogicznego, Kraków 2009

Rosiński Kazimierz, Orkla Media. 10 lat w Polsce, Orkla Press Polska, Warszawa 2002

Sarnowska-Temeriusz Elżbieta, Kostkiewiczowa Teresa, Krytyka literacka $w$ Polsce $w$ XVI i XVII wieku oraz w epoce oświecenia, Zakład Narodowy im. Ossolińskich, Wrocław 1990

Słownik literatury dziecięcej i młodzieżowej, red. Tylicka Barbara, Leszczyński Grzegorz, Zakład Narodowy im. Ossolińskich, Wrocław 2002

Słownik literatury popularnej, red. Żabski Tadeusz, Towarzystwo Przyjaciół Polonistyki Wrocławskiej, Wrocław 1997

Słownik terminologii medialnej, red. Pisarek Walery, Towarzystwo Autorów i Wydawców Prac Naukowych Universitas, Kraków 2006

Sokół Zofia, Prasa kobieca w Polsce w latach 1945-1995, Wydawnictwo Wyższej Szkoły Pedagogicznej, Rzeszów 1998

Stepowicz Marek, Cechy formalne czasopism internetowych $w$ odniesieniu do analogicznych publikacji drukowanych, Wydawnictwo SBP, Warszawa 2000

Straus Grażyna, Wolff Katarzyna, Polacy i książki. Społeczna sytuacja ksiq̨żki w Polsce 1992, Biblioteka Narodowa, Warszawa 1996

Straus Grażyna, Wolff Katarzyna, Czytać, nie czytać..., kupować, nie kupować... Sytuacja książki w społeczeństwie polskim w 1998 r., Biblioteka Narodowa. Instytut Książki i Czytelnictwa, Warszawa 2000

Świat (z) kolorowych okładek. Prasa dla kobiet i dziewczyn $w$ perspektywie interdyscyplinar$n e j$, red. Zierkiewicz Edyta, Oficyna Wydawnicza ATUT - Wrocławskie Wydawnictwo Oświatowe, Wrocław 2010

Świtała Marcin, Zachowania konsumentów i marketing na rynku ksiq̨żki, Biblioteka Analiz, Warszawa 2003

Trzop Beata, Typy kultury popularnej na łamach czasopism kobiecych, Oficyna Wydawnicza Uniwersytetu Zielonogórskiego, Zielona Góra 2005

Valeriana. Eseje o komunikowaniu między ludźmi, red. Mikułowski-Pomorski Jan, Bajka Zbigniew, Ośrodek Badań Prasoznawczych Uniwersytetu Jagiellońskiego, Kraków 1996

W kręgu prasy: przeszłość - teraźniejszość - przyszłość, red. Gzella Grażyna, Wydawnictwo Uniwersytetu Mikołaja Kopernika, Torun 1999

Władyka Wiesław, Polityka i jej ludzie, „Polityka” Spółdzielnia Pracy, Warszawa 2007

Wodniak Katarzyna, Współczesna prasa kobieca a sprawy książki. Treści literackie w czasopismach: „Przyjaciółka”, „Twój Styl”, „Cienie i Blaski”, Wydawnictwo SBP, Warszawa 2004

Zasacka Zofia, Nastoletni czytelnicy, Biblioteka Narodowa, Warszawa 2008

Zaworska-Nikoniuk Dorota, Wzory kobiecości i męskości w polskiej prasie dla kobiet XXI wieku, Wydawnictwo Adam Marszałek, Toruń 2008 


\section{Artykuły (wybór)}

[br. aut.], Dziewczyna chce zmian, „Media i Marketing Polska” 2002, nr 3

[br. aut.], Popularyzacja literatury w niektórych tygodnikach ilustrowanych, „Biuletyn Zarządu Głównego RSW „Prasa” 1969, nr 123

[br. aut.], Strzał w dziesiątkę. „Newsweek Polska”, „Press” 2001, nr 9

[br. aut.], Tylko dla dziewcząt, „Kobieta i Życie” 1957, nr 11

[br. aut.], Za tydzień będzie „Filipinka”, „Kobieta i Życie” 1982, nr 7

[rozm. Andrzej Palacz], aby nie ucichł szelest przewracanych kartek..., „Wydawca” 2002, nr 5

Adamiec Witold, Co się stało z rynkiem książki?, „Notes Wydawniczy” 2000, nr 8

Adamiec Witold, O dostępności ksiq̨żki w latach siedemdziesiątych, „Rocznik Biblioteki Narodowej" 1986, t. 17/18

Adamiec Witold, Otwartość i sprawność, Przyczynek do analizy i oceny polityki wydawniczej $P R L$, „Rocznik Biblioteki Narodowej” 1987, t. 19

Bajka Zbigniew, Kapitał zagraniczny w polskiej prasie - lata 90-te, „Zeszyty Prasoznawcze” 1998, nr 1-2

Bańkowska-Bober Krystyna, Produkcja wydawnicza '93, „Notes Wydawniczy” 1994, nr 4

Barański Tomasz, Czekając na „Newsweeka”, „Press” 2001, nr 3

Binkiewicz Dorota, Pomyśleli, zaistnieli, „Press” 1998, nr 11

Burczyk Marek, Prasa a sprawy książki. Niby sporo, a tak niewiele, „Przegląd Księgarski i Wydawniczy" 1972, nr 16

Chlabicz Michał, „Wprost” do Warszawy, „Press” 2000, nr 11

Chorązki Władysław, Polskie media lokalne i sublokalne 1989-1999, „Zeszyty Prasoznawcze” 1999, $\mathrm{nr} 1 / 2$

Cira Katarzyna, Zagraniczne koncerny prasowe na polskim rynku dzienników regionalnych, „Zeszyty Prasoznawcze” 2000, nr 1-2

Czarkowska Jadwiga, Reklama książki od poczęcia, „Wydawca” 1994, nr 10

Dąbrowska Zuzanna, Powiedzmy to wprost, „Przegląd Tygodniowy” 1998, nr 40

Dąbrowska-Cendrowska Olga, Działalność wydawnicza koncernu „Axel Springer Polska” w latach 1994-2003, „Studia Bibliologiczne Akademii Świętokrzyskiej” 2005, t. 9

Dębski Paweł, Agent Marek Król, „Przegląd Tygodniowy” 1996, nr 4

Drozdowska-Wolska Beata, News na rynku, „Press” 2001, nr 8

Filas Ryszard, Aktywność czytelnicza Polaków przełomu wieków, „Zeszyty Prasoznawcze” 2001, nr 3-4

Filas Ryszard, Czytelnictwo prasy u progu 2000 roku, „Zeszyty Prasoznawcze” 1998, nr 1-2

Filas Ryszard, Dziesięć lat przemian mediów masowych w Polsce (1989-1999), „Zeszyty Prasoznawcze" 1999, nr 1-2

Filas Ryszard, Polski rynek prasy codziennej w I dekadzie XXI wieku (w szczególności po roku 2003), „Zeszyty Prasoznawcze” 2008, nr 3-4

Filas Ryszard, Polskie czasopisma w XXI wieku - rozwój czy kryzys?, „Zeszyty Prasoznawcze” 2007, nr 1-2

Filas Ryszard, Rośnie dominacja mediów elektronicznych - nowa faza przemian polskiego rynku, „Zeszyty Prasoznawcze” 2003, nr 3-4

Filas Ryszard, Rynek prasy codziennej w Polsce przed „Faktem” i z „Faktem”, „Zeszyty Prasoznawcze" 2003, nr 3-4

Filas Ryszard, Zmiany w czytelnictwie prasy w latach 1995-1996, „Zeszyty Prasoznawcze” 1997, $\mathrm{nr} 1 / 2$

Fiut Ignacy St., Pisma spot.-kulturalne w latach 1989-2000, „Zeszyty Prasoznawcze” 2000, nr $3 / 4$ 
Fiut Ignacy St., Prasa bezpłatna w Polsce w latach 1999-2001, „Zeszyty Prasoznawcze” 2002, z. $1-2$

Głombiowski Karol, Nauka o książce naukq o człowieku, „Studia o Książce” 1973, nr 4

Gołębiewski Łukasz, Po ośmiu latach wolnego słowa, „Wydawca” 1998, nr 5/6

Gomulicki Juliusz W., Dwieście lat recenzji literackiej, „Nowe Książki” 1959, nr 24

Grigo Anna, Dzień z życia redakcji, „Twój Styl” 2000, nr 10

Iłowiecki Maciej, Pół wieku w służbie..., „Nowe Państwo” 2007, nr 2

Jarowiecki Jerzy, Prasa dla dzieci i młodzieży (nurty, tendencje, zmiany), „Zeszyty Wszechnicy Świętokrzyskiej" 1996, nr 3

Jarowiecki Jerzy, Prasa dla dzieci i młodzieży w latach 1989-1995 (nurty, tendencje, zmiany), „Zeszyty Wszechnicy Świętokrzyskiej” 1996, nr 3

Jasionek Krzysztof, Młodzi wiedzq lepiej, „Press. Magazyn Ekstra” 2006, nr 7

Kajtoch Wojciech, O stylu popularnych pism młodzieżowych, „Polonistyka” 2002, nr 9

Kajtoch Wojciech, Odlotowe bez dwóch zdań!: kultura języka, stylu, perswazji w czasopismach dla młodzieży, „Zeszyty Prasoznawcze” 1999, nr 3/4

Kania Jan, Przemiany na rynku prasowym w Polsce w latach 1988-1996, „Handel Wewnętrzny" 1997, nr 1

KL, Orkla buduje swoją potęgę, „Press” 1996, nr 5

Kołodziej Jacek, Dobro, zło i inne wartości w czasopismach młodzieżowych, „Zeszyty Prasoznawcze" 2000, nr 1/2

Konecki Józef, „Zwierciadlanych” uwag kilka, Biuletyn Z.G. RSW „Prasa” 1972, nr 153

Krzemiński Adam, Polityka wydawcq „Forum”, „Polityka” 2001, nr 14

Krzysztofek Kazimierz, Erotyzm bez duszy, „Przegląd Tygodniowy” 1993, nr 20

Kurowski Igor, Przepis na prasę dla młodzieży, „Raport Prasowy” 1998, nr 2

Lemańska Małgorzata, Elle u Anny, „Press” 2006, nr 2

Lubiński Józef, Najważniejsze zasady i cele polityki PZPR $w$ dziedzinie komunikowania w latach 1948-1971, „Kwartalnik Historii Prasy Polskiej” 1991, nr 2

Marecka Idalia, Gazeta za darmo: nasila się rywalizacja na rynku prasy bezpłatnej, „Przegląd” 2001, nr 4

Martysiuk Ania [czytelniczka], Nareszcie, „Dziewczyna” 1991, nr 3

Mazurkiewicz Anna, „Filipinka” forever. Historia zmian zachodzacych w przestrzeni czasopisma, [w:] Świat (z) kolorowych okładek. Prasa dla kobiet i dziewczyn w perspektywie interdyscyplinarnej, red. Zierkiewicz Edyta, Oficyna Wydawnicza ATUT - Wrocławskie Wydawnictwo Oświatowe, Wrocław 2010

Mieroszowa Helena, „Zwierciadło” w moich oczach, „Prasa Polska” 1967, nr 7

Montgomery Katarzyna, Dziękujemy!, „Zwierciadło” 2012, nr 5

Myśliński Jerzy, Tygodniki społeczno-kulturalne. Lektura polskiej inteligencji, [w:] Valeriana. Eseje o komunikowaniu między ludźmi, red. Mikułowski-Pomorski Jan, Bajka Zbigniew, Kraków 1996

Nalewajk Anna, Sieć na kobiety, „Press” 2001, nr 2

Nalewajk Anna, Zadyszka, „Press” 2004, nr 5

Niesporek-Szamburska Bernadeta, Czasopisma dla dzieci i młodzieży, [w:] Literatura dla dzieci i młodzieży (po roku 1980), t. 2, red. Heska-Kwaśniewicz Krystyna, Katowice 2009

Niziołek Andrzej, Solista, „Press” 2007, nr 11

Olszewska Barbara, Edytorstwo współczesnych czasopism dla dzieci i młodzieży. Zarys problematyki, [w:] Książka dziecięca 1990-2005, red. Leszczyński Grzegorz i in., Warszawa 2006

Paciorek Anna, Pięciolatek „Cogito” i jego młodszy brat, „Rzeczpospolita” 1999, nr 35

Pawłowski Witold, Nagroda im. Fikusa dla Jerzego Baczyńskiego, „Polityka” 2002, nr 9 
Pilak Antoni, Prasowe ogłoszenia księgarskie jako źródło do dziejów ksiq̨żki (na podstawie ogłoszeń prasowych z pierwszej połowy XIX w., „Studia o Książce” 1976, t. 6

Pilot Daruiusz?, Bravo Tina, Gut Dziewczyna, „Gazeta Wyborcza” 1993, nr 39

Piwowarska Anna, Gatunki dziennikarskie na łamach trzech wcieleń „Filipinki” - podobieństwa i różnice, „Zeszyty Prasoznawcze” 2005, nr 1

Piwowarska Anna, Trzy oblicza Filipinki, „Zeszyty Prasoznawcze” 2003, nr 3-4

Płaneta Paweł, Świat przedstawiony w czasopismach młodzieżowych, „Zeszyty Prasoznawcze” $2000, \mathrm{nr} 1 / 2$

Prewęcka Karolina, „Newsweek przed zmianq, , Media i Marketing Polska” 2004, nr 17

Prewęcka Karolina, Będzie trio, „Media i Marketing Polska Raport Specjalny Magazyny” 2001, nr 16

Prewęcka Karolina, Kadr po kadrze, „, Media Polska” 1998, nr 12

Prewęcka Karolina, Opinie zawsze w cenie, „Media i Marketing Polska” 2002, nr 8

Prewęcka Karolina, Pieńkowska kieruje „Twoim Stylem”, „, Media i Marketing Polska” 2005, nr 7

Prewęcka Karolina, Twórczy doping, „Media i Marketing Polska” 2001, nr 21

Prewęcka Karolina, Wierny „Twój Styl”, , Media i Marketing Polska” 2002, nr 12

Prewęcka Karolina, Więcej opinii, „Media i Marketing Polska” 2001, nr 16

Prewęcka Karolina, Zmiana wizerunku, „Media i Marketing Polska” 1999, nr 21

Prewęcka Katarzyna, Wierny „,Twój Styl”, „Media i Marketing Polska” 2002, nr 12

Przybysz-Stawska Magdalena, „Wprost” $z$ Internetu. Budowanie nowego wizerunku prasy, [w:] Biblioteka Książka Internet 2010, red. Osiński Zbigniew, Instytut Bibliotekoznawstwa i Informacji Naukowej UMCS w Lublinie, Lublin 2010

Przybysz-Stawska Magdalena, Literatura w prasie polskiej na przykładzie tygodnika „Polityka”, [w:] Mistrzowie literatury czy dziennikarstwa?, red. Wolny-Zmorzyński Kazimierz, Furman Wojciech, Snopek Jerzy, Seria: Akademickie Warsztaty Dziennikarskie, Wydawnictwo POLTEXT, Warszawa 2011

Przybysz-Stawska Magdalena, Prasa w Internecie, czyli interaktywne formy spędzania wolnego czasu, [w:] „Cudne manowce?” Kultura czasu wolnego we współczesnym społeczeństwie, red. Muszyński Wojciech, Wydawnictwo Adam Marszałek, Olsztyn 2008

Przybysz-Stawska Magdalena, Rodzina w Twoim Stylu. Wzór współczesnej rodziny propagowany przez ekskluzywne pismo kobiece w latach 2007-2009, [w:] Wartości kulturowe w rodzinie: założenia, realia i egzemplifikacje, red. Muszyński Wojciech, Wydawnictwo Adam Marszałek, Toruń 2010

Przybysz-Stawska Magdalena, Stylowa kobieta. Portret współczesnej kobiety w Twoim Stylu (w latach 2000-2003), [w:] „Nowy wspaniały świat?”. Moda, konsumpcja i rozrywka jako nowe style życia, red. Muszyński Wojciech, Wydawnictwo Adam Marszałek, Torun 2009

Przybysz-Stawska Magdalena, Tradycja i nowoczesność czwartej władzy (na przykładzie tygodników opinii: „Polityki”, „Wprost” $i$ „Newsweek Polska”), UMK, Wydział Politologii i Studiów Międzynarodowych UMK Katedra Dziennikarstwa i Komunikacji Społecznej [w druku]

Przybysz-Stawska Magdalena, Wprost z Internetu. Budowanie nowego wizerunku prasy, [w:] Biblioteka, książka, informacja, Internet 2010, red. Osiński Zbigniew, Instytut Bibliotekoznawstwa i Informacji Naukowej UMCS w Lublinie, Lublin 2010

Rdzanek Jarosław, Reklama rynek stoi, „Wydawca” 1997, nr 11

Rostocki Andrzej, Nie do mnie te pretensje! Bilans 1999, „Notes Wydawniczy” 2000, nr 3

Sarzyński Piotr, Gazetowa Polka, „Polityka” 1992, nr 51 
Sawa-Czajka Elżbieta, Wizerunki kobiet w prasie polskiej (po 1989 r.), [w:] Transformacje mediów (1989-1995): materiały pomocnicze do najnowszej historii dziennikarstwa, t. 26, red. Słomkowska Alina, Warszawa 2004

Sierpiński P., „Polityka” Spółdzielnia Pracy, „Press” 2006, nr 8, Dodatek specjalny: Ranking wydawców

Sokół Zofia, Czasopisma dla dziewcząt w Polsce w latach 1990-2004, „Studia Bibliologiczne” 2008, t. 17

Sokół Zofia, Czasopisma dla młodzieży szkolnej (1990-1995), „Poradnik Bibliotekarza” 1996, nr 11

Sokół Zofia, Transformacja prasy dziecięco-młodzieżowej w latach 1990-1991, „Poradnik Bibliotekarza" 1996, nr 6

Sordylowa Barbara i in., O sytuacji polskich czasopism kulturalnych i naukowych, „Rocznik Biblioteki Narodowej" 1996, t. 32

Staniszewski Zdzisław, Szczepaniec Józef, Ogłoszenia prasowe jako źródło wiedzy o książce w Polsce wieku XVIII, „Ze Skarbca Kultury” 1960, z. 1

Stomma Ludwik, Dziewczyna, „Polityka” 1995, nr 9

Sygut Tomasz, Kto stoi za „Wprost”, „Przegląd” 2005, nr 11

Sygut Tomasz, Newsweekowe roszady, „Przegląd” 2004, nr 38

Sygut Tomasz, Rzeczywistość według „Newsweeka”, „Przegląd” 2004, nr 20

Szkutnik Zenon, Czasopisma elektroniczne - szanse i problemy, „Biblioteka” 1998, nr 2 Szocki Józef, Prasa dla dzieci i młodzieży, „Zeszyty Prasoznawcze” 1996, nr 3/4

Szocki Józef, Prasa dla dzieci i młodzieży. Czytelnictwo i funkcja, „Zeszyty Prasoznawcze” 1998, nr 3/4

Termer Janusz, Codzienne sprawy literatury, „Współczesność” 1968, nr 20, s. 5

Tobera Marek, Bibliologia wobec polskiego rynku książki w latach 1944-2007, „Przegląd Biblioteczny" 2008, z. 1

Tobera Marek, Rynek książki w Polsce (1989-2000), „Przegląd Biblioteczny” 2001, z. 3

Walicki Piotr, Beczka z piatą klepkq, „Media Polska” 1998, nr 5

Wilk Joanna, Wprowadzenie nowego produktu na rynek wydawniczy - studium przypadku „Newsweeka” $i$ „Faktu”, „Zeszyty Naukowe Wyższej Szkoły Bankowej we Wrocławiu” 2008, $\mathrm{nr} 10$

Wodniak Katarzyna, Miesięcznik „Twój Styl” w latach 1990-1995 jako nowy typ magazynu społeczno-kulturalnego, „Acta Univesritatis Wratislaviensis. Literatura i Kultura Popularna" 1998, nr VII

Wolff Katarzyna, Czy ksiq̨żki sq nam jeszcze potrzebne?, „Wydawca” 1997, nr 6/7

Załuski Jan, Zawiłe losy „Wprostu”, [w:] Prasa dawna i współczesna. Część piąta, red. Kosmanowa Bogumiła, Wydawnictwo Naukowe Instytutu Nauk Politycznych i Dziennikarstwa Uniwersytetu im. Adam Mickiewicza w Poznaniu, Poznań 2004

Zubowicz Beata, Rzeczywistość lukrowana, „Rzeczpospolita” 1997, nr 182

Żebrowska Danuta, Czasopisma dziecięce w III Rzeczypospolitej - rekonesans i próba charakterystyki, [w:] Biblioteka i informacja $w$ demokratycznym systemie edukacji dorosłych, red. H. Hovensberg i in., Jarocin-Linköping 1996

Żebrowska Danuta, Kulturotwórcza rola współczesnych polskich czasopism młodzieżowych, [w:] Edukacja kulturalna w społeczeństwie obywatelskim, red, Żebrowski Jan, Gdańsk 1997 


\section{Wydawnictwa ciągłe}

„Bibliografia Zawartości Czasopism”

"Cogito" (1994-2000), wybrane roczniki

"Cogito" (2001-2010)

"Dziennik Ustaw" (1988-2003)

„Dziennik Ustaw” 1990, nr 29, poz. 173.

„Dziewczyna” (1991-2000, 2006-2010), wybrane roczniki

"Dziewczyna” (2001-2005)

„Elle” (1994-2000, 2006-2010),

„Filipinka” (1957-2000, 2006-2009), wybrane roczniki

„Filipinka” (2001-2005)

"Media i Marketing Polska” (1991-2006)

„Newsweeek Polska” (2001-2005)

„Newsweek Polska” (2006-2010), wybrane roczniki

„Polityka” (1957-2000, 2006-2010), wybrane roczniki

„Polityka” (2001-2005)

„Press” (1991-2006)

„Press" 1998, nr 11

„Press” 2001, nr 7, 10

„Press” 2002, nr 12

„Przewodnik Bibliograficzny” (1990-2000)

„Ruch Wydawniczy w Liczbach” (1990-2000), wybrane roczniki

„Ruch Wydawniczy w Liczbach” (2001-2005)

„Twój Styl” (1990-2010), wybrane roczniki

„Twój Styl” (2001-2005)

„Wprost” (1982-2000, 2006-2010), wybrane roczniki

„Wprost” (2001-2005)

„Zeszyty Prasoznawcze” (1989-2011)

„Zwierciadło” (1957-2000, 2006-2010), wybrane roczniki

„Zwierciadło” (2001-2005)

\section{Netografia}

Axel Springer stawia na Internet, http://wirtualnemedia.pl/document,„339229,Axel_Springer_ stawia_na_internet.html, 28 marca 2009

Dojrzewalnia Róż. Kobiecość w rozkwicie, http://www.dojrzewalnia.pl/o_nas/o_dojrzewalni. html, kwiecień 2011

Drwal Agnieszka, Była sobie Filipinka, http://www.pinezka.pl/content/view/2153/209

http://ftpsuperbrands.home.pl/SB1_pdf/Twoj_Styl.pdf

http://polskapresse.pl

http://wkajt.republika.pl/anapi/roz1.htm.

http://wprost.com.pl/ar/11228/Rynek-praca-wlasnosc/?I=984, 14 września 2009

http://www.axelspringer.pl

http://www.bauer.pl

http://www.cogigto.pl

http://www.dziewczyna.pl

http://www.elle.pl

http://www.filipinka.pl

http://www.guj.pl

http://www.internetstandard.pl/news/102175/TygodnikPolityka.mainternetowe.ambicje.html 
http://www.mediabuy.pl/prasa/Elle/

http://www.mediabuy.pl/prasa/Elle/

http://www.mediabuy.pl/prasa/Zwierciadlo/, kwiecień 2011.

http://www.newsweek.pl

http://www.polityka.onet.pl.

http://www.prasa.reproterzy.pl

http://www.twoj.styl.pl

http://www.wirtualne media.pl/index.twój.styl, 3 luty 2009.

http://www.wirtualnemedia.pl, Anita Błaszczyk, U Bauera, ale w swoim stylu: „Twój Styl” ma nowego właściciela

http://www.wirtualnemedia.pl/artykul/tygodniki-opinii-co-to-takiego

http://www.wprost.pl

http://www.zkdp.pl

http://www.zwierciadlo.pl

Kromka Katarzyna, F jak Filipinka, http: // www.pinezka.pl/content/view/2153/209

\section{Prace magisterskie}

Darmach Katarzyna, „Polityka” $i$ „Wprost” u progu XXI wieku. Problemy zawartości i odbioru, Uniwersytet Łódzki, Katedra Bibliotekoznawstwa i Informacji Naukowej, promotor: prof. dr hab. Oskar S. Czarnik, 2004.

Głombińska Alicja, Przemiany tygodnika „Polityka” w latach 1990-1999, Uniwersytet Łódzki, Katedra Bibliotekoznawstwa i Informacji Naukowej, promotor: prof. dr hab. Oskar S. Czarnik, Łódź 2004

Kałużna Joanna, Współczesne pisma dla dziewcząt na przykładzie „Filipinki” $i$ „Dziewczyny”, Uniwersytet Łódzki, Katedra Bibliotekoznawstwa i Informacji Naukowej, promotor: prof. dr hab. Hanna Tadeusiewicz, Łódź 2004

\section{Akty normatywne}

Konstytucja Rzeczypospolitej Polskiej, Wydawnictwa Sejmowe, Warszawa 1997

Ustawa o wolności słowa - Prawo prasowe, Warszawa 1995

Ustawa z 23 grudnia 1988 r. o działalności gospodarczej, „Dziennik Ustaw” 1988, nr 41, poz. 324

Ustawa z 22 marca 1990 r. o likwidacji Robotniczej Spółdzielni Wydawniczej „Prasa-KsiążkaRuch”, „Dziennik Ustaw” 1990, nr 21, poz. 126

Ustawa z 11 kwietnia 1990 r. o uchyleniu ustawy o kontroli publikacji i widowisk, zniesieniu organów tej kontroli oraz zmiany Ustawy Prawo prasowe. „Dziennik Ustaw” 1990, nr 29, poz. 173

Ustawa z 15 października 1992 r. o zmianie Konstytucji Rzeczpospolitej Polskiej, „Dziennik Ustaw"1992, nr 7, poz. 33

\section{Inne}

Korespondencja z Wiesławem Kotem

Korespondencja ze Zdzisławem Pietrasikiem

Polityka. Tygodnik trzech pokoleń. Folder wewnątrzredakcyjny, źródło: PBC General - SMG / KRC (2006 r., CCS)

Wewnątrzredakcyjne materiały promocyjne tygodnika „Polityka” 



\section{INDEKS OSOBOWY}

W Indeksie pominięto nazwiska, które występowały w nazwach oficyn wydawniczych.

Abakanowicz Magdalena 384

Abbott Elizabeth 330

Abramow-Newerly Jarosław 224, 403

Achmatowicz-Schwendimann Anna 378, 379,384

Adamczewska Barbara 309

Adamczewski Piotr 54, 55, 56, 72, 91

Adamczyk M. [479]

Adamczyk Piotr 411

Adamiec Witold 12, 24

Adams Douglas 188

Aime Rosemary du 336

Akunin Boris 85, 267

Albiński Wojciech 201

Allende Isabel 394, 399-400, 416, 511, 513, 604,638

Allione Tsultrim 330

Althamer Paweł 312

Ananicz Mateusz 218

Anderman Janusz 295

Anderson Sherwood 242

Andruchowycz Jurij 217, 355, 474

Andrycz Nina 163, 381

Andrzejewski Piotr 128

Ansen David 227

Applebaum Anne 157, 237, 295

Ardito Stefano449

Arendt-Dziurdzikowska Renata 309, 316, 325-329, 334-335, 337, 361, 473, 648, 651,653

Armstrong Lance 199

Aszkenazy Olga 308

Auster Paul 75, 85, 87, 116, 244, 295, 394, $398,447,603-604,625,655$

Avedon Richard1 82

Awdziejczyk Ewa 439, 461

Axelsson Majgull 330, 513

Ayache Alain 330
Babel Isaia 397

Bachanek Joanna 492

Baczyński Jerzy 53, 54, 55, 57, 60, 211

Baczyński Marcin 275

Bahdaj Adam 110, 537

Bajer Magdalena 52

Bajerowicz Marcin 127

Bajka Zbigniew 35, 42, [45]

Bakuła Hanna 381

Balcerowicz Leszek 25, 110, 135, 138, 140

Balicka Mariola 131

Baliszewski Dariusz 190, 271

Banach Magdalena 335

Banaszkiewicz Grażyna 127

Banaszuk Beata 588, 590

Bancroft Anne 448

Bańkowska-Bober Krystyna 25

Baran Monika [ $\rightarrow$ Baran-Finotello Monika] 545

Baran Piotr 492

Baranowska Alicja 193

Barański Tomasz 210

Barciszewska Ewa 588, 609

Barcz Maria 430, 437, 439, 454, 464

Barlińska Jolanta 542

Bartel Barbara 547

Barth John 513

Barthelme Donald 513

Bartnik Monika 588

Batonowa Olena 112

Bauer Zbigniew 15, 36, 484, 596, 611, 640

Bąkiewicz Grażyna 536, 562, 577, 614-615, 639

Beauvoir Simone de 262, 347

Beckett Samuel 261

Bedford Martin 614

Behn Ari M. 415

Belina Sławomir 547

Belka Marek 281 
Bell Quentin 330-331

Bellow Saul 182

Bendyk Edwin 60, 72, 74

Berdadyn Marek 309

Berent Jolanta 588

Bereś Witold 235

Bereza Henryk 308

Berezowska Maja 305

Berg Scott A. 394

Berlin Isaiah 92

Bernsimon Gilles 436

Berry Andrew 157

Bertz Hela 526

Białecki Grzegorz 370, 372, 375

Białobrzeska Joanna 351

Białobrzeski Piotr 351

Białołęcka Ewa 348

Białoszewski Miron 190

Bielecki Czesław 135

Bielecki Jan K. 217

Bielicka Hanna 307

Bielicki Marian 305-306

Bielinowicz Justyna 240

Bielkiewicz Monika 492

Bielski Bohdan 430

Bieńczyk Marek 411

Bieńkowski Dawid 201

Bieszczadzka Ewa 372

Bijak Jan 52, 54, 55

Bikont Anna 114

Bilal Enki 170, 535

Biłos Jan 127

Binkiewicz Dorota 585

Blackburn Simon 170, 172

Blanchard Kenneth H. 157

Blige Mary J. 579

Blinowski Franciszek 49

Blixen Karen 412, 474, 563

Bloom Orlando 527

Błaszczyk Anita 377, 379

Błaszkiewicz Ryszard 378

Bocelli Andrea 348

Bockris Victor 512, 638, 655

Boczek Krzysztof 590, 620, 609-610

Boćkowska Aleksandra 232

Bogdalska Urszula 590

Bogusz Małgorzata 218

Bojarska Anna 309, 407, 414, 453, 455, 476
Bojarska Maria 309

Bojarska Mariola 361, 372

Bolecka Anna 358

Bołdak-Janowska Tamara 450

Boniek Zbigniew 110

Bonikowska Małgorzata [669]-670

Bonowicz Wojciech 115

Bońkowski Wojciech 409

Boratyńska-Komar Magdalena 309, 314, 316, 329, 331-332

Borkowicz Leonard 49

Borkowska Grażyna 394, 449, 655

Borowski Jacek 144, 204

Boruszkowska Agnieszka 580

Borys Andżelika 384

Bosacki Zenon 127

Boucher François 415

Boxsel Matthijs van 330

Boyes Roger 163

Boy-Żeleńska Zofia 361

Boy-Żeleński Tadeusz 101, 186, 361

Bójko Marcin 274

Brason M. 216

Bratkowski Piotr 217, 220-221, 224, 226, $230,236,240,242-243,245,261$, 264-266, 268, 272, 274-277, 280, 292

Bratkowski Stefan 135, 137, 197

Braun Andrzej 308

Britney Spears 622

Brodzik Joanna 537

Brøgger Suzanne 330

Brontë Emily 348

Brown Dan 32, 75, 158, 159, 189, 198, 279, $295,566,656$

Brożek A. 105

Brzechwa Jan 350, 362

Brzezińska Anna 73, 348, 453, 656,

Brzeziński Marek 131

Brzozowicz Grzegorz 437

Brzozowski Maciej B. 412

Brzozowski Tomasz 333

Budak Adam 531, 535

Budrewicz Olgierd 135, 158, 159

Budzyńska Małgorzata 562, 564

Bugajski Leszek 392, 398

Bukowska-Lechki Danuta 542

Bukowski Władimir 167

Bułhakow Michaił 461, 603 
Burczyk Marek 11

Bursa Andrzej 106

Burstein Dan 169

Bush Laura 106

Bushnell Candace 267, 570, 656

Buss David M. 172

Butenko Bohdan 157

Butkiewicz Olga 492

Butowska Lidia 309, 348

Butrym Julia 63

Buzan Barry 538

Buzan Tony 538

Bynga Jamie 276

Bystrzycka Zofia 306-306

Cabot Meg 30, 562

Caldwell Erskine 306

Cameron-Bandler Leslie 340

Camilleri Andrea 232, 331

Campbell Neve 580

Camus Albert 306

Canals Cuca 330, 603

Capponi-Borawska Tessa 430, 433, 436, 439, 448, 451, 456

Carlson Dale 579, 615

Carlson Hannah 579, 615

Carroll Beverly 336

Carroll Jonathan 76, 336, 412, 415, 448, $474,511,518,614,621,638,656$

Casas Carlos A. 190

Castro Fidel 102

Cegielski Max 103-104, 394, 432, 453, 463, 656

Celeda Agnieszka 70, 106

Celiński Andrzej 221

Celmer Zuzanna 308

Cembrzyńska Iga 311

Cenckiewicz Sławomir 201

Cervantes Miquel de 355

Chaciński M. 105

Chandler Raymond 80

Chatizow Joanna 547, 553-554

Chądzyńska Agnieszka 411

Chehab M. R. 276

Chełminiak Wiesław 140, 144, 185, 188

Chełmiński Jakub 226

Chęcińska Elżbieta 374

Chlabicz Michał 131
Chmielewska Joanna 27-28, 31-32, 34, 189, $191,202,278,381,570,605,609-610$

Chmielewska Małgorzata 384

Chmielewski Henryk J. 236, 432

Chmielewski Michał 492, 527

Chmielowski Henryk 348

Chodakiewicz Jan M. 201

Chodorowska-Zadros Iwona 547

Chojnacka Julia 534

Cholewa-Selo Anna 401

Chorązki Władysław 40

Choromański Michał 309

Choynowski Andrzej 378

Chrabota Bogusław 157, 403

Christ Hanno 168

Christa Janusz 236, 621

Christensen Lars S. 604

Christie Agatha 190, 453, 463, 562

Chrzanowska Agnieszka 347

Chudziński Edward 36, 484, 596, 611, 640

Chwalińska Teresa 588

Chwin Stefan 27, 72, 197, 237, 282, 295, 399, 453

Chyb Manana 314

Chylińska Agnieszka 430

Chyłkiewicz Jolanta 378

Chyra Andrzej 413

Cichocka Tatiana 309, 335, 337

Cichocki Tomasz 314

Cichoń Tomasz 144

Cielecka Magdalena 413

Cielemęcki Mirosław 130, 138-139

Cieszewski Marek 454

Cieślar Artur 309, 347

Cieślik Donata 546, 554

Cieślik Mariusz 72, 83, 157, 163, 183-184, $190,226,244,272$

Cieślik Monika 81, 243, 590

Cimoch Anna 588

Cira Katarzyna 42

Clancy Tom 190, 237

Claridge Laura 356

Clark Mary Higgins 566

Clarke Susanna 172, 184, 202,

Cleese John 463

Clinton Hillary 157

Cobain Kurt 199, 527

Coben Harlan 75, 85, 236-237, 248, 295, 448 
Coelho Paulo 26, 28, 32, 34, 76, 104, 157, 183-184, 227, 262, 309-310, 336, 361, $447,453,474,511,562,566,621,638$, 656

Coetzee John M. 31, 76, 92, 101, 183, 190, $238,261,272,295,394,447,474,511$, $629,638,656,662$

Colbert David 604

Colfer Eoin 30, 271

Collins Jackie 400

Coloane Francisco 604

Columbus Chris 627

Condon Richard 170, 172

Connelly Michael 267

Constant Benjamin 241

Cook Rachel 420

Cooper James F. 110

Corder Zizou 271

Cornweel P. 199

Cortland Barbara 34

Courths-Mahler Hedwig 34

Covey Sean 512, 615

Covey Stephen R. 157

Crichton Michael 157

Cunningham Michael 31, 238, 295, 394, 474, 603, 638, 656

Cywiński Piotr 131, 163, 205

Czachowska K. 362

Czarkowska Joanna 10

Czarnacka Iwona 348

Czarnecki Kamil 528

Czarnik Oskar St. 11-12, 20, [45], 51

Czarzasty Zygmunt 53

Czech Wanda 492

Czechow Antoni 261

Czeczot Andrzej 609

Czerwiński Piotr 547

Cziedryn Pem 327

Czubaj Mariusz 56, 63, 69, 70, 72, 81, 83, 87, $101,103-105,107,110,117,119$

Czuma Mieczysław 262

Czycz Stanisław 106

Czyżykiewicz Mirosław 335

Ćwiek Joanna 590

Ćwierczakiewiczowa Lucyna 409-410

Dachówna Regina 512

Dali Salvador 603

Damasio Antonio R. 157
Damięcka Anna 493

Dancewicz Renata 412

Danecki Janusz 331

Daniel Antoine B. 564

Danilewicz-Zielińska Maria 182

Daniszewska Julia 314

Dańkowska-Majke Maria 489

Darski Wojciech M. 191

Davies Norman 75, 92, 120, 158, 167, 227 , 237, 245-246, 295-296

Dąbrowska Anna 529

Dąbrowska Krystyna 305

Dąbrowska Monika 492, 499

Dąbrowska Zuzanna 130

Dąbrowska-Cendrowska Olga 36, 212, 378379

Dąbrowski Bogdan 461

Dąbrowski Jan 91

Dąbrowski Waldemar 30

Dehghanpisheh Babak 269

Delerm Philippe 272

Delon Alain 381

Delors Jacques 56

Demarczyk Ewa 351

Depko Andrzej 492

Deptuła Bogusław 430

Devoud Guillaume 431

Dębski Paweł 130

Diamant Anita 356

Dibdin Michael 170, 172

Dick Philip K. 111, 262

Dickens Charles 101, 111, 269, 354

Diehl Piotr 463

Dienieżkina Irina 103, 394, 518-519, 528, 638, 656

Divakaruni Chitra B. 448

Dolińska Katarzyna 429

Dołęga-Mostowicz Tadeusz 262, 271, 340

Domagalik Małgorzata 135-136, 141, 157 , $161,182,292,330-331,394,412-413$

Domosławski Artur 120

Doncova Daria 189

Dostojewski Fiodor 352, 511-512

Dowgiałło [Dowgiałło-Tyszka] Joanna 491493, 511-512, 543

Dowłatow Siergiej 189

Draga Sonia 410

Droga Katarzyna 585-590, 594

Drogi Zbigniew 585, 588 
Drozdowska-Wolska Beata 213

Droździk Paweł 448

Drucker Peter F. 182

Drwal Agnieszka 487-488

Dubiel Krzysztof 432

Dubois Jacek 309

Duda-Gracz Jerzy 182, 381

Dudek Antoni 82, 135

Dukaj Jacek 276, 609

Dumas Aleksander 110

Dunin-Wąsowicz P. 104

Dunn Jane 604

Durczok Kamil 230, 413

Durrell Lawrence 656

Dworak Grażyna 309

Dybczyński Jan 429-431

Dyduch Marek 138

Dydyński Grzegorz 309

Dygat Magda 361, 394, 448, 453, 455, 474, $511,516,656,662$

Dygat Stanisław 448

Dymna Anna 381

Dzido Marta 512

Dzieduszycka Małgorzata 614

Dziemidek Magdalena 543

Dzierżanowski M. 164

Dziewulska Maria E. 497

Dzięgielewska Beata 308, 312

Dziubalska Marta 494

Dziurdzikowska [? Arendt-Dziurdzikowska] Renata 374

Dziurdzikowski Andrzej 214, 216

Dźbikowski Stefan 309

Eco Umberto 29, 74-75, 81, 85, 88, 157, $235,238,243-244,295,394,448,450$, $474,566,623,656,662$

Egan Jennifer 566

Eichelberger Wojciech 309-310, 326, 345, 361,610

Eichmann Adolf 51

Eiseman Pat 276

Engelking Anna 579

Ensler Eve 656

Erdmann Sandra 548

Erenburg Ilja 100-101

Essex Karen 657

Estés Clarissa P. 327

Estkowski Ewaryst 480
Etcoff Nancy 157

Eugenides Jeffrey 657

Evans Dylan 179

Fabicka Joanna 511, 603, 638

Fabisińska Liliana 491

Fadiman Anne 163

Falandysz Lech 135

Falkowska Wanda 53

Fall Dagmara 543

Fallaci Oriana 182, 395

Farnik Blanka 373

Faulkner William 306

Fedorczyk Agnieszka 214, 236

Felis Paweł 590, 611, 621

Fels Florian 212, 213

Fest Joachim 167, 168

Fforde Jasper 657

Fiedler Arkady 106

Fielding Helen 28, 34, 76, 157, 394, 412, $416,448,461-463,474,511,530,570$, $605,638,657,662$

Fiell Charlotte 448

Fijor Jan M. 205

Fikus Dariusz 50

Filas Agnieszka 137

Filas Ryszard 35, 38-39, 41-44, 492

Filipiak Izabela 389, 400, 448, 450, 533

Filipowska Anetta 348, 369

Fink Ida 194, 603

Finkielkraut Alain

Fitzgerald Francis S. 347

Fitzgerald Zelda 347

Fiut Ignacy 35, 41, [45]

Flawiusz Józe f262

Foer Jonathan S. 189

Forden David 167

Fordoński Krzysztof 604, 638-639

Foremniak Małgorzata 410

Foss Clive 331

Fowles John 394

Fox Marta 511, 515, 562, 638

Franke Jerzy 300

Frankowska Anna 489

Fredro Aleksander 111, 416, 627

Freed Lynn 657

French Nicci 202

Frey Jana 536, 538

Friszke Andrzej 112 
Frycie Stanisław [479]-480

Frycz-Modrzewski Andrzej 101

Fuentes Carlos 194, 202, 217, 399

Furman Wojciech 100

Fuzowski Maksymilian 236

Gabryel Piotr 127-130, 138

Gaffney Patricia 566

Gaiman Neil 238, 269, 449

Gaj Anna 418

Gajdzińska Iwona 128

Gajdziński Piotr 131

Gajos Anna 309

Gajos Janusz 381

Galiński Tadeusz 306

Gallego Rubén 657

Gallo Max 170, 172, 340

Gałczyńska Kira 278

Gałczyński Konstanty I. 190, 283, 363

Gamble Robert 276

Garda Jagoda 537

Gardyszewska Agnieszka 492

Garlicki Andrzej 63, 72, 82

Gaudé Laurent 657

Gaweł Piotr 223

Gawęcka Kalina 489

Gawliński Robert 537, 548

Gawłowski Andrzej 309

Gawroński Jan 248

Germak Joanna 547

Gertler Stephanie 604

Gibran Khalil Gibran 330

Gidel Henry 199

Giełżyński Wojciech 52

Gierek Edward 25, 51-52

Giertych Roman 223

Gilbert Erin 453

Giles Jeff 227, 277

Gil-Kołakowska Ewa 542

Gilowska Zyta 384

Giziński Jarosław 236, 243

Glapiak Elżbieta 276

Glemp Józef 130

Glińska Agnieszka 120

Glogier M. [479]

Gławińska Katarzyna 604

Głombiowska Alicja 51, 55

Głombiowski Karol [9]

Głowacka Malwina 461
Głowacki Janusz 73, 237, 245, 262, 295, $394,399,474$

Gnauck Gerhard 262

Gnoiński Leszek 567

Goban-Klas Tomasz 13

Goldhagen Daniel J. 242-243

Golimowska Karolina 221

Gołębiewski Łukasz 15, 24-32, 34

Gombrowicz Witold 101, 111, 182, 416

Gomulicki Juliusz W. 453

Gomulicki Maurycy 453

Gomulicki Wiktor 453

Gomułka Stanisław 214

Gomułka Władysław 46, 49-50

Gondowicz Jan 163

Gonet 261

Gonzaque Saint B. 330

Gorbaczow Michaił 56

Gordon Hélène4 27

Gortatowicz A. 575

Goscinny Anne 453

Goscinny René 237, 262, 269

Gosek Daria 518-519

Goszcz Waldemar 411

Górecki Paweł 193

Górniak Edyta 548

Górnicka-Urban Dorota 494

Górzyński Sławomir 462

Grabarczyk Artur 590

Graff Agnieszka 311, 330, 361, 399-400, 419,474

Grajewski Andrzej 135

Granas Romana 49

Greek Vivian 614

Green Jane 248, 409

Greene Brian 157

Greer Germaine 331

Gretkowska Manuela 81, 188, 194, 198, 295, $361,399,411,417,428-429,453,511$

Griffiths Mark 579

Grigo Anna 372, 376, 401

Grimm Jacob 362

Grimm Wilhelm 362

Grisham John 75, 157, 196, 227, 238, 262, 295, 562, 566, 580

Grochmalski Piotr 128

Grochola Katarzyna 28, 31, 72, 74, 111, 158-159, 167, 169-171, 181, 184, 188, $237,267,278,295,328,394,399,401$, 
$407,411,417,447-448,453,461,463$, $474,511,518,605,610,629,638,640$, $657,662,666$

Grociak Przemysław 128

Gronkiewicz-Waltz Hanna 58, 72-73, 83, 91, 103, 312, 351, 384

Groński Ryszard M. 53

Grott Dobrochna 437

Gruczek Dominika 543

Gruszczyński Piotr 430, 437

Grynberg Henryk 27, 164, 237, 295

Gryz Cezary 168

Grzela Remigiusz 346-347

Grześczak Marian 193

Gucewicz Krystyna 448

Gudzowaty Aleksander 218

Gulden Arthur 196

Gumilow Lew 163

Gutek Alina 309, 314, 335, 337-348, 351, 354

Gutenberg Johannes 193, 194, 277, 362

Gutowski Adam 374

Haasse Hella S. 474, 604

Habielski Rafał 61

Haegenbarth Andrzej 127

Halek Hanna 348

Hall Aleksander 157

Halperin Ian

Hałoń Edward 114

Haman Wojciech 157

Handler Daniel 277

Hanh Thích Nhât 327

Hańczuk Anna 272

Harasimowicz Cezary 262

Harasimowicz-Waliszewska Barbara 214

Harris Joanne 511, 513, 518, 535, 657

Harrison Kathryn 394, 639

Hartwig Julia 27, 338, 381

Hassenmüller Heidi 518

Havel Václav 629

Hayder Joanna 226

Hazen Robert M. 156

Hearn Lian 638, 657

Hebda Paweł 590

Helperine I. 199

Hemingway Ernest 346

Hen Józef 161, 309

Henryk, książe duński 415
Hepburn Katharine 394

Herbert Mary Sidney 279

Herbert Zbigniew 76, 586, 609, 611

Hertz Zofia 182

Heska-Kwaśniewicz Krystyna [479], 481

Hesse Hermann 513, 657

Highsmith Patricia 603, 657

Himmler Heinrich 161

Hirszowicz Maria 113

Hitler Adolf 168

Hłasko Marek 106-107, 164, 266, 297, 309, 622,626

Hodgson Burnett F. 283

Hoffmowa Klementyna z Tańskich 480

Holewiński Wacław 201

Hołownia Szymon 225, 242-244, 292

Hołówka Jacek 62

Hombek Danuta 10

Horn John 227

Hornby Nick 238, 295, 332, 447, 570, 657

Horubała Andrzej 657

Horwath Witold 27

Hotchner Aaron E. 245

Houellebecq Michel 76, 295, 394, 658

Hovenberg Hans 480

Hrabal Bohumil 101, 237, 295

Hryniewicz Jan 430

Hübner Danuta 384

Huelle Paweł 27, 73, 85-87, 114, 262, 276, $282,330,348,394,461,474$

Hughes Ted 347, 408

Hugosson-Bujwid Krystyna 375

Hulsman John 217

Humieja Anna 372

Huniewicz Piotr 72

Hutt Joachim 198

Ice-T [właśc.Tracy Lauren Marrow] 579

Iglesias Enrique 622

Ignatowicz Mira 590

Iłowiecki Maciej 49

Imańska Iwona 11

Impert Magdalena 547

Indulski Grzegorz 219

Ionesco Eugène 261

Irving John 111, 189, 237, 242, 245-246, $295,474,562,658$

Irzykowski Karol 186

Ishida Chihiro 190 
Iwasiów Inga 331

Iwaszkiewicz Jarosław 149, 416

Jabłczyńska Joanna 640

Jachmann Joanna 226, 267

Jackowski Jan Maria 158-159

Jackson Peter 527

Jacobi Ivo 308

Jacobson Roy 80

Jacq Christian 157

Jaeggy Fleur 330, 511

Jagielski Wojciech 281, 609, 658

Jagiełło Krystyna 217, 243

Jagiełło Michał 110, 279

Jan Paweł II 32, 73, 157, 236-238, 269, 295, 619

Janas Iwona 461

Janasz Andrew de 279

Janda Krystyna 311, 658

Janecki Stanisław 128, 130, 132

Janicka Janina 305

Janicki M. 121

Janion Ludwik 588, 602, 624-625, 629, 639

Janion Maria 330, 331

Jankiewicz Magdalena 308

Jankowska Magdalena 454

Jankowski Grzegorz 214

Janowska Katarzyna 69, 86-88, 102, 106

Janssen Peter 272

Jansson Tove 101-102, 512

Jarco Magdalena 370

Jarnecki Michał 588

Jarniewicz Jerzy 64

Jaros Magda 386

Jarosik Eugeniusz 127, 129

Jaros-Kropidłowska Magda 399

Jaroszewicz Karolina 225

Jaroszewska Monika 492

Jarowiecki Jerzy 15-16, [479], 482-483, 551

Jaruzelska Monika 410

Jaruzelski Wojciech 308

Jasica Paweł 195

Jasienica Paweł 52

Jasiński Maciej 269

Jasionek K 494

Jastrun Tomasz 217, 264, 306, 308-310, $313-314,326,335,350,354-355,358$, $360-361,376,388,400,413-414$
Jastrzębska Agnieszka 386

Jastrzębska Zuzanna 489

Jastrzębski Jerzy 11

Jaworowska-Błońska Hanna 489

Jeleniewska Agnieszka 492

Jelinek Elfriede 101, 261, 604

Jemielniak Dariusz 614

Jenkins H. 41

Jenkins Sally 199

Jerofiejew Wiktor 85, 189, 217, 227, 272

Jeweell Lisa 248, 570

Jewiarz-Bartczak Maja 305

Jewtuszenko Jewgienij 261-262

Jędrzejczak Otylia 372, 384

Johnson Spencer 448

Jones Edward P. 189

Jones Malcolm 246, 276

Jones Susanna 564

Jong Erica 394, 579

Joplin Janet 638

Kacewicz Michał 285

Kacprzak Małgorzata 214

Kacprzyk-Sobieraj Marta 492

Kaczmarski Jacek 260, 414

Kaczmarski Piotr 614

Kaczorowski Aleksander 69, 72, 81

Kaczyński Jarosław 223

Kaczyński Lech 200

Kadaré Ismail 461

Kafka Franz 261

Kahlil Gidran 580

Kajtoch Wojciech 483

Kalicka Manuela 577

Kalisz Ryszard 221

Kałużna J. 489

Kałużyński Zygmunt 50, 55, 58, 74, 91, 111, 135-136, 164, 182, 196, 292, 403, 430, 609

Kamiński Ryszard 139

Kania Jarosław 35

Kaniewska-Lenarczyk Ewa 492

Kann Sarah 461

Kapuściński Ryszard 27, 32, 50, 85, 101$102,217,261,281,338$

Karnowski Michał 214, 285

Karpiński Michał 131-132, 190

Kartezjusz 586

Kasdepke Grzegorz 349 
Kasprzycki Robert 609

Kaszuba Krystyna 121, 203, 307, 370-372, 375-380, 383, 385, 429, 431, 491

Kathleen Tracy 567

Katner Grażyna 536

Kawalerowicz Jerzy 627

Kawczyńska Magdalena 492

Kazana Inga 492, 499

Kellerman Jonathan 267

Kempska-Rylska Leokadia 372

Kennedy Angus J. 202

Keret Etgar 167, 453, 511

Kertész Imre 101, 295, 604, 658

Keyes Marian 267

Kępiński Piotr 242, 261

Kęskrawiec Marek 219, 225

Kidd Sue Monk 515, 638

Kielar Marzanna B. 85, 348, 351, 389, 394

King Stephen74, 76, 236-237, 241, 295, $512,561-562,566,580,604,638$

Kipling Rudyard110

Kirch Leo 204

Kirszenstein [Szewińska] Irena 352

Kisielewski Jerzy 137

Kisielewski Stefan 129, 133, 137

Kisielewski Tadeusz A. 157

Kita Norbert 230

Klabiński Jacek 309

Klein Helmut 198

Klein Naomi 658

Klejnocka Katarzyna 214, 236

Klejnocki Jarosław 72

Kleniec Wojciech 201

Klimczyk Joanna 70, 314, 329, 331

Klimczyk Piotr 330

Klubowicz Marta 308

Klugman Aleksander 161

Kłeczek Małgorzata 309

Kłoczowski Jan A. 412

Kłys Tomasz 492

Knightley Keira 528

Kobro Katarzyna 347

Kobus Justyna 144, 157, 168, 183, 186, 190, 195, 196, 461

Kobyliński Szymon 50, 182

Kochanowski Jerzy 113

Koczot Stanisław 225

Koetzle Hans-Michael 240
Kofta Krystyna 85, 86, 282, 361, 375, 393, 399-400, 403, 412, 414, 658

Kolasa Władysław M. 16

Kolenda-Zalewska Katarzyna 432

Kolski Jan Jakub 461

Kołakowski Leszek 265, 309, 460, 604

Kołaszewska Aneta 464

Kołodziejczyk Beata 518

Kołodziejczyk M. 107

Kołodziejski Konrad 161, 193

Komar Mikołaj 432

Kondek Stanisław A. 12

Kondrat Ilona 372

Konecki Józef 306, 309

Konikowski Jacek 108

Konopnicka Maria 84

Konwicki Tadeusz 84-85, 88, 161, 215, 245, 262, 282-283

Koontz Dean 76

Kopaliński Władysław 101, 281, 394, 416

Kopf-Schroeder Doris 415

Kopiczyński B. 527

Kopiński Aleksander 201

Koral Jolanta 354

Korczyk Magda 531

Korniejenko Agnieszka 139

Korwin-Mikke Janusz 137

Korzeniecki Cezary 588

Korzeniowski Tomasz 279

Kosiński Jerzy 164

Kosiński Waldemar 127

Kosmowska Barbara 29, 127, 463, 609, 658

Kosonocka-Taber Lidia 614

Kosowska Anna 68

Kostkiewiczowa Teresa 10

Kostrzewa Natalia 609

Kot Wiesław 131, 144, 214, 226, 230, 236, 240-246, 248, 261, 270-271, 278, 280, 290, 292, 298

Koterbska Maria 81

Kotler Philip 158

Kotowska Katarzyna 349

Kott Jan 182, 658

Kowalczewska Agnieszka 226

Kowalczyk Iza 410

Kowalczyk Mariusz 204

Kowalczyk Ryszard 40

Kowalewska Agnieszka M. 284

Kowalewska Anna 
Kowalewska Hanna 448, 658

Kowalewski Włodzimierz 282

Kowalska Agnieszka 439

Kowalska Anna 512

Kowalska Joanna 226

Kowalska Kasia 536-537, 548

Kowalska M. 578

Koziczyński Bartek 492, 567

Koziński Agaton 204

Kozłowska Dorota 543

Kozub Piotr 492

Koźmińska Irena 119, 337

Koźniewski Kazimierz [45], 50, 53, 74

Krabbé Tim 450

Krajewski Marek 79, 114, 250, 295, 615

Krall Hanna 53, 73-74, 110, 198, 235, 237, $295,335,359$

Krasiński Jan 194

Krasnodębska Agnieszka 588, 590, 602

Krassowska-Kaszuba Monika 316

Kraszewski Józef I. 340, 416

Kraus Nicola 248, 394, 570, 638

Kreczmar Renata 588

Kres Feliks W. 157

Kret Jarosław 430

Kroh Antoni 157

Kromka Katarzyna 487, 494

Kropielnicki Hubert 226

Król Marek 56, 102, 128-130, 135, 137, $140,211,241$

Królak Jacek 78

Królikowska-Avis Elżbieta 408

Kruczkowski Leon 50

Kruczyński Wojciech 448

Krusiński Wojciech 70, 72

Kruszona Lech 129-130

Krynicka Krystyna 453

Krynicki Ryszard 106, 338, 453

Krzaklewski Marian 138

Krzemiński Adam 56, 60, 72, 83, 103-105, 109

Krzysztofek Kazimierz 543

Krzywicka Irena 417

Kubaszek Krzysztof 349

Kubiak Zygmunt 157, 182, 281

Kuc Monika 437

Kucia Monika 226, 492, 499, 513, 531, 535

Kuczok Wojciech 85-86, 114, 120, 160, 217, $226,237,282,292,295,330,360,394$,
$407,453,454,463,474,535,609-610$, $619,658,663$

Kuczyńska Krystyna 314

Kukliński Mariusz 183

Kukliński Ryszard 197

Kuliński Witold 489

Kumiega J. [479]

Kundera Milan 184, 190, 283, 295, 658

Kunzru Hari 194, 511, 658

Kuratowska Zofia 384

Kurkiewicz Juliusz 104

Kurkiewicz Roman 70

Kuroń Maciej 430

Kurovsky Agnes Hannie von 347, 634

Kurpiewski Lech 226, 277

Kurzajewska Izabella 430

Kurzępa Jacek 260

Kuśmierek Józef 137

Kutz Kazimierz 217

Kuziński Stanisław 49

Kuźnik Magda 590, 611

Kwade Elżbieta 11

Kwaśniewska Jolanta 384

Kwaśniewski Aleksander 55, 126, 140

Kwiatek Bartosz 276

Kwiecień Iwona 494

Kwieciński Tomasz 129

Labuda Barbara 311

Laclos de Pierre A. F. Ch. 512

Laden Osama bin 204

Lagardère Jean L. 428

Lahiri Jhumpa 330

Lamott Anne 513

Lanckorońska Karolina 113, 235

Lange Oskar 50

Lapierre Alexandra 412

Laprus-Mikulska Joanna 407, 410

Latałowska Dominika 454

Latawiec Bogusława 403

Latifah Qeen 463, 579

Laurence Rees 120

Lazareff Pierre 427

Le Carré John 75, 172, 656

Lec Stanisław J. 586

Legut Lucyna 521

Lehtolainen Leena 331

Lem Stanisław 34, 85, 110-111, 120, 185, $195,235,237,278,295,410,416$ 
Lemańska M. 432

Lepper Andrzej 193

Lesiak Agnieszka 545

Leszczyńska Izabela 273

Leszczyński Grzegorz 235, 270, 337, [479]480,483

Leśniak Tomasz 537

Leśniewski Bogumił 132

Levy Marc 189

Lewandowski Konrad T. 361

Lewandowski Roman 121

Lewartowska Zofia 300

Lewin Ludwik 331

Lewis Clive S. 362

Lewis Sinclair 242

Lew-Starowicz Zbigniew 309, 492

Libera Antoni 27, 83, 109, 198, 629

Ligocka Roma 157, 167-168, 172, 330, 335, $399,450,474$

Lilejko Nina 305

Linda Bogusław 622

Lindgren Astrid 526

Lipiec-Wróblewska Agnieszka 346

Lipińska Olga 375

Lipiński Eryk 305

Lipska Ewa 27, 73-74, 85, 87, 399-400

Lipszyc Jarosław 454, 437, 439, 444, 450

Lis Tomasz 128, 223, 238, 252

Lisiecka Katarzyna 543

Litorowicz-Siegert A. 410

Llosa Mario V. 190, 295, 658

Lloyd Josie 267, 570

Lodge David 76, 394, 614

Loon Karel van 243

Lubelska Krystyna 56, 70, 73, 121, 271, 378-379

Lubiańska Krystyna 127

Lubiński Józef 12, 226

Ludlum Robert 76, 83, 101, 238, 564, 659

Luffman Peter J. 213

Luft Monika

Lutczyn Edward 412

Lutomska Marianna 274, 588

Łabędzki Dariusz 235

Łakomski Marcin 588

Łatyński Marian 113

Ławniczak Diana 348

Łempicka Tamara 356
Łepkowska I. 401

Łętkowska Zofia

Łętowska Ewa 217, 384

Łobodziński Filip 226, 276, 432

Łojewski Jan Zb. 54

Łopieńska Barbara 59

Łubieńska Krystyna 460

Łubieński Tomasz 198

Łuczak Maciej 157, 171, 198, 659

Łukasiewicz Beata 543, 547, 578

Łukaszewicz Maciej182

Łukaszewicz Magdalena 226, 240, 245, 260, 275, 285

Łukomska Aldona 131

Łysiak Waldemar 162-163,

Mac Jerzy S. 130

Maciejak Agnieszka 492

Maciejewska Monika 193

Mackiewicz Anna 214

Mackiewicz Józef 200, 235, 262

Mackiewicz Stanisław 101

Mackiewicz Tomasz 185, 186

Maćkowska Katarzyna 384

Maier Corinne 415

Mailer Norman 245

Majcherek Janusz 236, 261

Majchrzak Wojciech 273

Majdanowicz-Pijanowska Maria 428-429

Majewska Katarzyna 348

Majewska-Opiełka Iwona 157

Makłowicz Robert 92, 411-412, 422

Makuch Karolina 518-519

Malinowska Joanna 588

Małek Jan Michał 200

Małgorzata, duńska królowa 415

Małkowicz K. 362

Mancewicz Stanisław 412

Mankell Henning 276, 638

Mann Wojciech 430, 433

Manson Marilyn 622

Mańkowski Tomasz 127

Mao, cesarz chiński 563

Márai Sándor 239, 330

Maranda Michał 113

Marczułajtis Jagna 311, 410

Marecka Idalia 41

Margolis Mac 272 
Marianowska Elżbieta 372

Marinina Aleksandra 189, 267, 448, 659

Markham Wendy 570

Markowicz Tomasz 604

Markowski Michał P. 350-351

Marquard J. 541

Márquez Gabriel G. 75, 79, 83, 102, 190, $238,272,295,394,511,603-605,638$, 659,663

Marszałek Anna Z. 86

Martel Yann 511, 562, 566, 638, 659

Martha Luisa, norweska księżniczka 415

Martysiuk Ania 542

Masella Justyna 492, 528

Masłowska Dorota 29, 72, 74, 81, 85, 87, $104,114,120,157,164,240,295,360$, $606,609-610,659$

Maślanka Julian [45], [299]

Maślanka Mariusz 90, [479], 638

Matkowski Tomasz 659

Matusiewicz Andrzej 270

Matuszkiewicz Irena 562

Matuszkiewicz Jerzy 127-128

Matuzik M. 105

Mauro Irena Conti di 448

Mayes Frances 659

Mazan Leszek 131

Maziarski Jacek 52

Maziarski Wojciech 214, 221

Mazowiecki Tadeusz 56

Mazur Bogusław 131, 286

Mazurek Robert 203

Mazurkiewicz Anna 491

Mazurkiewicz Iza 529

Mazurowska Renata 590

Mazur-Poniatowska Iza 439, 451

McAulay Alex 614

McCarthy Pete 604

McDonell Nick 535-536

McDowell Josh 63

McIver Denise 579

McKean David 170

Mc Laughin Ema 394

Meadows S. 239

Melchior Jacek 144, 157, 163, 183-184, 189, 193-194, 196, 314

Meller Marcin 80

Mello Anhony de 327, 449

Mendoza Eduardo 31, 659
Mentzel Zbigniew 453

Messner Reinhold 579

Metzger Andrzej 278

Meyer Agnieszka 400

Mętrak Krzysztof 182

Michalak Janusz 193

Michalski Cezary 201

Michalski Jan 574

Michałowska Mira 375

Michnik Adam 285

Mickiewicz Adam 278, 570, 621

Miecik Igor T. 121

Miecznicka Barbara 461

Mielczarek Tomasz 15, 35, 38, 43, [45]-46, $50-51,53,55,129,480,547$

Mielnik Jakub 260, 285

Mieroszowa H. 306

Mierzejewska Ewa 492, 543

Migdalska Maria 316

Mikołajczyk Katarzyna 543

Mikołajewski Jarosław 242, 338

Mikuła Karol 182

Mikułowski Jan [45]

Mikułowski-Pomorski J. [45]

Milewicz Barbara 427

Miliszkiewicz Janusz 316

Miller Frank 158, 237

Miller Henry 659

Miller Katarzyna 659

Miller Leszek 53, 135,138

Millet Catherine 158-159

Millet-Joris Françoise 305

Miłosz Carol 453

Miłosz Czesław 27, 52, 76, 85-86, 101, 106, $120,167-168,172,182,190,230,238$, 260-261, 264, 295-296, 410, 453, 512, $609,629,559$

Minc Hilary 138

Minkowska Grażyna 226

Miodek Jan 158, 334, 512, 659

Mitzner Piotr 372

Miziniak Wacław 128

Mizuro Magda 309, 314, 316, 329, 331-332

Młodzikowska Danuta 158

Młynarczyk Joanna 489

Moczulska Anna 429

Moczulska M. 431

Modelski Łukasz 386, 392, 397-398

Modrzejewska Helena 182 
Moebius 170

Moggach Deborah 614

Mojkowska Krystyna 306, 309

Molier 352

Molnár Ferenc 110

Monroe Marilyn 449

Montalbán Manuel V. 232, 238, 659

Montefiore Simon S. 80

Montgomery Katarzyna 304

Montgomery Lucy M. 110, 512, 537

Montignac Michel 463

Morrison Toni 398, 460

Morrissy Mary 474

Mossakowski Jan M. 182

Moszczeńska Iza 304

Moszyński Piotr 135-136

Mościcka Ewa 547

Mroziewicz Krzysztof 60, 80, 83, 92, 102, 120

Mrozińska Małgorzata 370

Mrożek Sławomir 27, 111, 197, 606, 660

Mucharski Piotr 230

Mujica Bárbara 639, 660

Murakami Haruki 190, 603, 638

Murdoch Anna 155

Murdoch Iris 352, 407

Musiałek Grażyna 214

Musierowicz Małgorzata 28, 31-32, 34, 191, $511,516,521,523,530,609,611$

Muszyński Wojciech 41, 372

Myjak Adam 200

Myśliński Jerzy [45]

Nabokov Vladimir 158, 603, 605

Nadzieja Marta 189

Nagorski Andrew 79, 221, 236, 239

Nahacz Mirosław 492, 512, 518-519, 536, $609-610,638,640,660$

Nahai Gina B. 518-519

Naipaul Vidiadhar S. 101, 183, 190, 603

Najdenowicz Fiolka 492

Nalewajk Anna 377, 431

Nałęcz Tomasz 135

Nałkowska Zofia 188

Napierała Zbigniew 211, 432

Narbutowicz P. 671

Nartowski Andrzej S. 372, 381, 384

Nasiłowska Anna 304, 326, 356, 411

Nazer Mende 515
Netzer Hans J. 611

Newman Paul 245

Neyman Elżbieta 113

Niedzielska Alina 374, 440, 452, 463

Nielsen Jerri 403

Niemczyk Zbigniew 218

Niemen Małgorzata 351

Niemi Mikael 355

Nienacki Zbigniew 105

Niesporek-Szamburska Bernadeta 481

Niewiadomska Anna 518

Niezgoda Agnieszka 83

Niwiński Andrzej 412

Niziołek Andrzej 211, 213, 215-216

Niziurski Edmund 105

Northcutt Wendy 170, 511

Nosowska Dorota 590

Nosowska Katarzyna 492

Nothomb Amélie 75, 79, 87, 394, 399, 450, $511,513,515,536,603,638,660,663$

Nowacki Dariusz 72, 236, 241-244

Nowak Andrzej 158-161

Nowak Ewa 588, 590, 602-603, 623, 628629,638

Nowak Katarzyna T. 331, 3999-401, 406, 410

Nowak-Jeziorański Jan 167, 260

Nowakowska Anna Maria 312, 337

Nowakowska Ewa 53, 62

Nowakowska-Butrym Ewa 55

Nowakowski Jerzy M. 139, 403

Nowakowski Andrzej 107

Nowakowski Piotr T. 551

Nowicka Beata 454, 437, 464

Nowicki Jan 309, 316

Nowina-Konopka Piotr 135

Nurowska Maria 172, 248, 282, 430, 570

O`Flanagan Sheila 603

O`Hagan Andrew 536

Oates Joyce C. 158, 449, 516, 566, 660, 662

Oberländer Theodor 305

Ochab Edward 51

Ochojska Janina 351, 384

Oczachowska Magdalena 309

Odija Daniel 276

Odojewski Włodzimierz 403

Ogrodnik Bogdan 614

Oiticica Christina 336 
Okh Sat 260

Okulicz Anna 489

Olbiński Rafał 135

Olbrot Agnieszka [479]

Olbryś Marta 588

Olczak-Ronikier Joanna 348, 400, 419

Olechowski Jarosław 273

Olecki Karol 218

Olejniczak Małgorzata 590

Olejnik Leszek 114

Olejnik Monika 351, 384

Oliver Jamie 410

Olszański Leszek 41

Olszański Tadeusz 56, 101

Olszewska Barbara 483

Olszewska Lucyna 308, 316

Oraczewska Zofia 304

Orlicka-Sapa Anna

Orłoś Kazimierz 76

Orłowicz Mieczysław 60

Orłowska Sylwia 492, 547

Orłowski E. 132

Orzechowska Joanna 88, 350

Orzeszkowa Eliza 188

Osęka Piotr 214, 305

Osękowski Czesław 112

Osho [pseud., właśc. Rajneesh Bhagwan Shree] 327

Osiatyński Wiktor 161

Osiecka Agnieszka 92, 158

Osiewska Anna 489

Osiński Zbigniew 131

Ososko Urszula 543

Ossowska Maria 113

Ossowski Stanisław 113

Ostałowska Irena 375, 489

Otrębska Jolanta 309

Owczarzak Tadeusz 127

Oz Amos 90, 276, 335

Ozminkowski Violetta 262

Ożogowska Hanna 562

Paasilinna Arto 604

Paciorek Anna 585-586, 588, 591

Pacuła Joanna 381

Padilla Ignacio 330

Pakulnis Maria 430

Palacz Andrzej 34, [642]

Paltrow Gwyneth 548
Paluchowicz Krzysztof 417

Pałasiński Jacek 170-171

Pamuk Orhan 101

Paolini Christopher 614

Papuzińska Joanna [479], 481

Paradowska Janina 60, 225

Parandowski Jan 28

Parsons Tony 31, 394, 415, 448, 570

Pascal Blaise 549

Paschalska Kaja 537

Passent Agata 232, 393-394, 399, 414

Passent Daniel 72, 82

Paszkowska Lily 590

Pattison Eliot 470

Patulska Grażyna 312

Pauluk Dorota 551

Pavić Milorad 158

Pawelczyk Grzegorz 137

Pawełczyńska Anna 201

Pawlak Antoni 214, 221

Pawlak Beata 59, 339-340

Pawlak Edward 127

Pawlak Milena 547

Pawlikowska Beata 158, 171, 199, 334, 610, 660

Pawłowicz Beata 454, 448, 453, 455, 463

Pawłowska Beata 312

Pawłowski Witold 57

Pearl Daniel 182

Pearson Allison 331, 409

Penc Józef 158

Pérez-Reverte Arturo 75, 80, 412, 474, 511, $515,535,603,638,660,662$

Perón Evita 331

Perón Juan 331

Petrignani Sandra 660

Pęczak Mirosław 54, 72, 107, 121,

Piasecka Monika 545

Piątek Tomasz 73, 87-88, 104, 158, 217, $267,295,454,453,538,660$

Piątkowska Monika 394

Picciotto Richard 248

Pieczyński Krzysztof 563

Piegat Piotr 590

Piekarska Małgorzata K. 588, 590, 614, 628-629

Piekarski Michał 378

Piekorz Magdalena 619

Pielewin Wiktor 237, 295, 660 
Pieńkowska Jolanta 370, 372, 379-380, 385, 468

Pietkiewicz Barbara 52, 86-87, 121, 432

Pietkiewicz Edward 372, 381

Pietrasik Zdzisław 54, 63, 65, 71-72, 85-86, 101, 106, 125

Pietrzykowska Agnieszka 590

Pietucha Piotr 361, 399

Pilak Antoni 11

Pilch Jerzy 27-28, 34, 56, 58, 62, 71-73, 83$85,101-102,115-116,118,120,194$ $229,244,261-262,292,335,454,393$, $399,476,603,609,622,626,629,639$, 660,666

Pilipiuk Andrzej 171, 176, 198

Pilot D. 543

Piłsudski Józef 304

Pinter Harold 261

Piotrowska Anna 279

Piotrowski Jacek 114, 312

Pipes Daniel 197

Pipes Richard 158

Pisarek Walery 15

Pisarzewska Katarzyna 29, 202, 462-463

Pitera Julia 214

Piwkowska Anna 338, 389, 394-395, 398

Piwowarska Anna 491, 494-496

Plagens Peter 227

Plath Sylvia 193, 347, 408, 667

Pleijel Agneta 660

Płażewski Jerzy 331

Płużański Tomasz 614

Po Zen Huang 448

Podemski Stanisław 53, 56

Podgórska Joanna 49-52, 60, 70

Podkański Wiesław 211- 213

Podsiadło Jacek 115

Polak Hanna 312

Polański Marek 182

Polański Roman 353

Politkowska Anna 197

Pomianowski Jerzy 217

Poncyliusz Lilka 590, 625

Poniedzielski Andrzej 309-310, 361

Poniżnik Elżbieta 541

Poniżnik Mirosław 541

Popescu Simona 356

Popiełuszko Jerzy 627

Popoff-Szczepańska Kaja 492, 530
Poprzeczko J. 54

Posłysz Zofia 305

Poświatowska Halina 348, 353, 449

Praszyński Roman 437, 439, 444, 448-45-, $453,454-455,460-461$

Pratchett Terry 76, 188, 448, 561-562, 629, 660

Prejs Bogdan 604

Prewęcka Karolina 213, 215, 291, 430, 494, 545

Pritchard Matthew 453

Prorok Leszek 309

Proust Marcel 537

Próchniewicz Dorota 588

Prus Bolesław 273, 340, 570

Prymak Aneta 611

Przebitkowski Radosław 91

Przecławska Anna 481

Przemyk Renata 537

Przybylski Jacek 590

Przybysz Janusz 127

Przybyszewska-Kujawa Beata 547

Przybysz-Stawska Magdalena 36, 41, 100, $131,133,372$

Puchalski 305

Pudlik Anita 127

Putrament Jerzy 49

Puźniak Marcin 270

Pyszny Joanna 11

Pytlakowski Piotr 121

Queneau Raymond 331

Quiz Z. C. 167

Racewicz Joanna 411

Raczek Tomasz 53, 135-136, 141, 144, 158, $170,172,196,202,292,403$

Radcliffe Daniel 574

Radkowski Michał 50

Raduńska Sonia 309, 361

Radwan Łukasz 140, 144, 164, 185, 192192, 196

Radwańska Dorota 417

Rakowski Mieczysław F. 13, [23], 49-53, 55, 82

Rapaczyńska Wanda 218

Raszyńska Jolanta 410

Rawik Joanna 372, 374

Rączkowski Bartek 492-499 
Rdzanek Jarosław 34

Rebane Alina 305-306

Reciak Katarzyna 347

Redlińska Izabela 590-593

Rees David 262, 269

Regis Ed 157

Reich Marzena 372

Reich-Ranicki Marcel 104, 167, 186, 262

Rej Mikołaj 106

Rembowska Aleksandra 437

Rendell Ruth 407

Rędzio Anna 547

Rhinehart Luke 580

Rhymes Busta 579

Rice Anne 580

Richardson Monika 215

Ridpath Michael 245

Rifkin Jeremy 158, 167

Robsky Casual 0. 415

Rock Maciek 580

Rodziewiczówna Maria 188

Rogacin Wojciech 285

Rogala Małgorzata 440

Rogalska Jolanta 543

Rogozińska Anna 83

Rogoż Michał [479]

Rokita Jan Maria 221, 223

Rolicki Janusz 25

Roman Wanda K. 113

Romanowicz Jacek 284-285

Romanowska Dorota 214, 262

Romanowska Krystyna 260, 432

Roquemaurel Gérald de 429

Rosicki Dariusz 214

Rosiński Grzegorz 188, 262, 609

Rosiński K. 491

Rosner Andrzej 263

Ross Alex 170

Rostocki Andrzej [23], 27-28

Rostocki Marek 53

Roston Anita 492

Rostron Magdalena 308

Roth Philip 76, 189

Rotkiewicz Agnieszka 604

Rowling Joanne K. 28-29, 32, 34, 196, 237, $278,295,362,529,562,566,574,627$, 629,667

Różewicz Stanisław 102, 202
Różewicz Tadeusz 28, 76, 102, 106, 202, 278

Różycka Agnieszka 428, 430, 437, 440, 451

Różycki Tomasz 106

Ruchniewicz Małgorzata 112

Rudolf Krzysztof F. 604

Rudzińska Ola 547

Rushdie Salman 76, 262

Rusin Kinga 375

Russo Richard 242, 661

Ruszczak Jarosław 588

Rutowicz Georges 335, 476

Rybak Agnieszka 120

Rybak Magda 309, 314

Rybiński Maciej 135-136, 158, 164

Rychter Magda 205

Ryciak Igor 214

Rylski Eustachy 158, 201

Rymkiewicz Marek 106

Rymuza Diana 547

Rzehak Katarzyna 381

Rzewuski J. A. 144, 159

Rzewuski Jerzy 144, 159

Rzymski Marcin 619-620

Sa Shan 394

Sadaj Ryszard 360

Sadkowski Wacław 235, 347

Sadurski Piotr 223

Sagan Françoise 167, 408

Saint-Exupéry de Antoine 346, 407

Saint-Exupéry de, Consuelo 346

Salak Małgorzata 270

Salinger Jerome D. 577

Samborski Jerzy 373

Samson Andrzej 337, 344, 476, 536

Samson Hanna 394, 447

Sand George 101

Sandemo Margit 34

Sanguszkowie, ród 110

Santor Irena 307

Santorski Jacek 333, 609, 611

Sańczuk Anna 272, 349

Sapkowski Andrzej 27, 31, 34, 73-74, 184, $188,193,195,352,516,562,574,626$, $629,638,661,667$

Sapota Bartek 492

Saramago José 76, 172, 399, 661

Saramanowicz Małgorzata 430, 453 
Sarnacka-Mahoney Eliza 413

Sarnowska-Temeriusz Elżbieta 10

Sartre Jean Paul 306, 347

Sarzyński Dariusz 590

Sarzyński Piotr 60, 72, 81, 105, 115, 301, 448

Sawa-Czajka E. 300

Sawicka Marta 144, 161, 163-164, 168, 183-184, 187-192, 194

Sawka Ewa336

Sawka Henryk336

Schab Klaus 217

Schaff Adam 50

Scheffer Karl 331

Schickler David 239, 638, 660

Schlink Bernard 83

Schmidt Helmut 629

Schmitt Eric Emmanuel 272, 453, 463, 572, $603,639,660$

Schulze Ingo189

Sebold Alice 494, 661

See Lisa 639

Segda Dorota 333

Selby Hubert jr 196

Semka Piotr 135

Sendler Marzena 492

Servan-Schreiber Jean-Luis 350

Seweryn Andrzej 448

Seweryn Andrzej 311

Shakib Siba 359, 566

Shalev Zeruya

Sheldon Dyan 536

Shree Bhagwana 327

Shuty Sławomir 73, 85, 87, 101, 114, 237, $242,276,282,609$

Sidorczyk Barbara 489

Siedlecka Joanna 158, 235, 609, 611

Siemaszko Ewa 201

Siemaszko Władysław 201

Siemieńska Ewa 201, 431

Siemion Piotr 160, 411

Sieniewicz Mariusz 79

Sienkiewicz Henryk 111, 195-196, 273, $278,340,627$

Sieradzka Anna 415

Sieradzki Sławomir 195

Sierpiński P. 56

Siesicka Krystyna 511, 521, 562, 566, 604$605,629,638$
Siewko Ola 588, 590, 597, 602, 628

Sikora-Pouivet Dorota 399, 408

Silverstone Alicia548

Simons Paullina 564

Singer Isaac B. 183, 189, 604-605

Singer Maxine 156

Siwczyk Krzysztof 460

Siwko Maria 494

Skalski Ernest 52, 221

Skąpski Mieczysław 126, [642]

Skąpski Rafał 34

Skiba Krzysztof 136, 164, 186, 198, 292, 403

Škvorecký Josef 403

Skwarnicki Marek 73, 136, 190, 194, 238

Skynner Robin 463

Słabek Henryk 114

Sławińska Kamila 189

Słobodzianek Tadeusz 120

Słojewski Jan Z. 101

Słomkowska Alina 300

Słucki Arnold 309

Smarzyńska-Karbownik Marta 413

Smith Mcall Alexander 562

Smith Richard M. 214

Smith Will 579

Smith Zadie 189, 245, 394, 399, 401, 518, $638,661,663$

Smoleń B. 331

Snicket L. 30

Snopek Jerzy 100

Sobaszek Grzegorz 226

Sobieraj Katarzyna 590

Sobieraj Małgorzata 590

Sobolewska Anna 281

Sobolewski Tadeusz 333

Soból Marek 661

Sochańska Bogusława 337

Sojka Agnieszka 551

Sokołowski Marek 14

Sokół Zofia 15, [299]-305, 372, 380, [479], $481,484,487,490,494-495,542$

Solik Aleksandra 518

Solorz-Żak Małgorzata 215

Solska Joanna 109

Sołtysik Andrzej 411

Sołżenicyn Aleksander 397

Sommer Grzegorz 214, 216

Somoza José C. 76, 394, 474 
Sontag Susan 84, 102, 182

Sordylowa Barbara [45]

Soros George 217

Sosnowski Jerzy 73-74, 88, 190, 448

Souad 536

Sowa Izabela $172,188,198,237,282,333$, $453,518-519,562,610,638,640,661$

Sowell Thomas 158

Spałeka Seweryn 156

Sparks Nicholas 453

Spears Britney 622

Spencer Scott 536

Spiegelman Art 269

Spinelli Jerry 271

Sroka Jarosław 219

Stachowiak Mariusz 127

Stachowicz Krystyna 309

Stachówna Grażyna 331

Stachura Edward 106-107, 190, 297

Stadryniak-Saracyn Beata 590

Stala Marian 235

Staniewicz Ewa 127

Stanisław August, polski król 161

Stanisławska Olga 403

Staniszewski Zdzisław 11

Stankiewicz Krystyna 429

Starowicz Lew 609, 611

Stasiak Piotr 108

Stasik Dariusz 214, 284

Stasiuk Andrzej 191, 235, 237, 266, 330, $333,347,407,512,518-519,609,622$, 640,661

Staszewski Kazik 81

Stauber Maria 186

Steel Danielle 34

Stefańska Agnieszka 462, 514

Stein Gertruda 385, 407

Stendhal [właśc. Beyle Marie-Henri] 80

Stephenson Neal 614

Stepowicz M. 43

Stępień Basia 410

Sting 394

Stomma Ludwik 58, 71-72, 74, 81, 84, 91, 430

Stomma Stanisław 182

Storch Maja 537

Stradowski Jan 135

Straus Grażyna [9], 25

Strożek Tomasz 542
Strumińska Felicja 487, 489

Strzałkowska Magdalena 119

Strzałkowska Małgorzata 70, 102,271, 349

Strzemborz Tomasz 182

Strzemiński Władysław 347

Stużyńska Magdalena 411, 537

Suchocka Hanna 384

Suchodolska Mira 225

Sumliński Wojciech 139

Surdykowski Jerzy 221

Surnik Iwona 348

Süskind Patrick 277

Suworow Wiktor 167-168

Swift Jonathan 193

Sygut Tomasz 130, 216, 217, 218

Sypniewska Ewa 431

Szabłowski Stach 309, 314, 363

Szacki Jerzy 97

Szaczkus Ola 531

Szafrańska Marta 492

Szałek Edyta 309

Szaniawski Józef 170, 284

Szaniawski Paweł 284

Szapołowska Grażyna 381

Szarlik Anita 193, 214

Szarłat Aleksandra 386, 399

Szarota Tomasz 63, 112

Szaruga Leszek 202

Szczawiński Wojciech 361

Szczepaniec Józef 11

Szczepańska Dorota 188

Szczepański Jan J. 182

Szczepkowska Joanna 333, 661

Szczodrowski Grzegorz 185

Szczuka Kazimiera 158

Szczygielski Marcin 170, 172, 199

Szczylik Cezary 383

Szczypiorski Andrzej 91, 118

Szekspir William 111, 197, 235, 277-279, 627

Szeliga Zygmunt 50

Szeligowska Joanna 590, 602, 609

Szewczyk Alicja 590

Szewińska Irena 351-352

Szkutnik Zdzisław 43

Szlendak Tomasz 330

Szmidt Jacek 372, 379

Sznajderman Monika 347

Szocki Jerzy 481, 541, 543 
Szokal Anna 316, 420

Szolc Izabela 395

Szostak Wit 172, 460

Szostkiewicz Adam 56, 72, 101, 106, 121

Szpotański Janusz 182

Sztuka Konrad 309, 361, 460

Szumowska-Lempart Ewa 543

Szwaja Monika 173, 340

Szwarcman Dorota 144

Szyłak Jerzy 235

Szymańska Czesława 305

Szymański Janusz 373

Szymański P. 614

Szymborska Wisława 27, 32, 74, 85, 106, $243,264,265,311,350,394,410,448$, 474

Śliwa Zuzanna 492

Śmiałkowski Kamil 144, 159, 163-164, 189, $192,214,226,235-236,264-265,269$, 292,527

Śnieg-Czaplewska Liliana 374

Śnieżanka Ewa306

Śnieżek Maciej 547, 554

Śpiewak Paweł 135

Środa Krzysztof 330

Świda-Ziemba Hanna 281

Świderska Eliza 590

Świetlicki Marcin 74, 115, 235, 338, 348, $351,448,450,462,622$

Święcicka Justyna 270

Świtała Marcin 10

Tadeusiewicz Hanna 489

Talarczyk Tomasz 127

Talko Leszek K. 394

Tan Amy 513, 661

Tarka Krzysztof 262

Tarlowska Irena 489

Tattersall Ian 448

Tauer Danuta 543

Taylor Graham P. 271

Schlink Bernard 83

Teoplitz Krzysztof T. 53

Terakowska Dorota 29, 331, 348, 361, 394, $400,453,456,460,463,638,661,663$

Terentiew Nina 202

Teresińska Monika 108, 373

Terlecka-Reksnis Małgorzata 348
Termer Janusz 11

Tetelowska Irena 16

Thackeray William M. 111

Thadden Rudolf von 120

Theil [Theilig] S. 279

Thomas Dana 227

Tkaczyk Witold 269

Tkocz Stanisław 182

Tobera Marek 24-25

Tochman Wojciech 336, 361

Todorov Pierre 429

Toer Pramoedya A. 330

Tokarczuk Olga 27, 188, 191, 237, 278, 311, $356,394,411,474,566,580,604,439$, 661,663

Tolkien John R. R. 29, 34, 235, 277, 352, $413,532,573,575,605,627,667$

Tomańska Justyna 521

Tomaszewicz E. 331

Tomaszowski Henryk 182

Tomiak Anna 399, 418

Tomkowski Jan 158, 186

Topol Jáchym 662

Torańska Teresa 430

Toruńczyk Barbara 363

Tosińska-Okrój Hanna 384

Townsend Sue 398, 512, 535, 638, 662-663

Trębski Krzysztof 138

Trojan Agnieszka 588, 590, 609-610

Troszczyńska Katarzyna 492

Truszkiewicz Ewa 348

Trybuła Adam 218

Tryzna Tomek 348, 638-639

Trzop Beata 300

Tudyka Aleksandra

Tukendorf-Ceglarska Sylwia 554

Tuleja Barbara 492

Turnau Grzegorz 411

Turski Marian 50, 55-56

Tuszyńska Agata 394

Tuwim Julian 190, 447

Twain Mark 629

Twardowski Jan 92, 194, 262, 351

Tylicka B. 480

Tylkowski Andrzej 348

Tym Stanisław 135

Tyrański W. 300

Tyrmand Leopold 164, 190

Tyszka Marcin 432 
Tyszkiewicz Beata 381

Tzu Sun 156

Uchański Wiesław 463

Ugrešić Dubravka 356, 662

Underwood Anne 279

Urban Jerzy 26, 50

Urbanowicz Juliusz 139

Urbanowski Maciej 201

Usarek Krystyna 305

Usenko Natalia 492, 537, 639

Varga Krzysztof 638

Vargas Fred 331

Verne Juliusz110

Vetere Richard 564

Viewegh Michal 244

Villas Violetta 351

Vollers Maryanne 403

Volter 20

Vorgrimler Herbert 198

Vreeland Susan 604

Waglewski Wojciech 411

Wagner Erica 662

Wajda Andrzej 215, 278, 627

Waldorff Jerzy 363

Walewski Paweł 60

Walicki Piotr 430

Wallace Max 199

Waller Robert James 356, 394

Waltari Mika 603

Wałęsa Lech 135

Wańkowicz Melchior 363

Warhol Andy 192

Warlikowski Krzysztof 461

Warszawski Dawid 217

Wasieczko Agnieszka M. 440, 451

Waters Sarah 340

Watny Magda 541-542

Watson Emma 574

Watson James D.

Weiner Jennifer 449

Weiser Benjamin 167, 198

Weiss Szewach 135, 189

Weiss Wiesław 567

Wencel Wojciech 158-159
Wendołowska Marzena 410

Werblan Andrzej 49

Wesołowska Marta 52

Węgierkiewicz Rafał 128

Wharton Thomas 662

Wharton William 27-28, 32, 237, 336, 353, $399,538,562,621,638,639,662$

Wharton Willy 453

Widłak Wojciech 349

Wieczorek Paulina 547

Wiernikowska Maria 311

Wierzbiański Bolesław 182

Wierzyński Maciej 221, 309

Więch Magdalena 547, 554

Więcka Aleksandra 266-267, 273, 285

Wiktor Mariola 314

Wilber Ken 327

Wilczak Dariusz 214, 219

Wilczak Jagienka 60

Wilczek Mieczysław 13, [23], 137

Wilcz-Grzędzińska Ewa 214

Wilczyński Wacław 136, 138

Wilde Oscar 158

Wildstein Bronisław 135-136, 140, 157158, 161, 202, 285, 292

Wilk Ewa 49-50, 52, 60

Wilk Joanna 211

Wilkanowicz-Devoud Marzena 428-429, 432-433, 435

Willmann Magdalena 554

Wilniewczyc Teresa 448

Wilson Julian 272

Wilson Robert 76

Winch Bożena 489

Windorbski Cezary 370, 375, 377

Winfrey Oprah 189

Winiecki Jan 217

Winklowa Barbara 361

Winnicka Ewa 432

Winterson Jeanette 448

Wisłocka Michalina 182, 352

Wiśniewski Janusz L. 30-31, 158, 168, $170-$ $171,174,248,278,295,340,399,511$, $570,609-610,638,662-663$

Witkiewicz Stanisław I. 158, 511

Witkowski Michał 453

Władyka Wiesław 54, 56, 70, 72, 74, 82, 118 
Włodarczyk Jarosław 235

Włodarczyk Piotr 223

Wodniak Katarzyna 11, 372, 385, 673

Wojaczek Rafał 107

Wojciechowski Dariusz 188

Wojciechowski Tomasz 198

Wojcik Danuta 308

Wojda Dennis 537

Wojewódzki Kuba 492, 536

Wojtak Maria 15

Wojtczak Edyta 307, 351

Wojtkowska Zofia 285

Wojtowicz Kinga 375

Wojtyna Ewa 590

Wolarski Wojciech 91

Wolff Katarzyna [9], 14, 25

Wolny Maja 56, 63, 107, 109, 448, 621

Wolny-Zmorzyński Kazimierz 100

Wolpert Lewis 363

Wolski Marcin 135,158, 164, 203, 237, 250

Wolski T. 213

Wood Elijah 527, 573

Woodward Kenneth L. 279

Woolf Virginia 101, 193, 331, 394, 407-408, $418,474,667$

Woroszylski Wiktor 52

Woydyłło Ewa 373

Woźniak Andrzej 378

Woźniak Witold 378

Woźnica Edyta 590, 609, 619

Wójcik Agnieszka 86

Wójcik Danuta 308

Wójcik Mikołaj 604, 638

Wójcki Tadeusz 127

Wróblewski Andrzej K.

Wróblewski Janusz 56, 109, 309, 314, 336

Wróblewski Jerzy 60, 63, 70, 72, 87, 335

Wróblewski Tomasz 131, 211-216, 218$219,222,226$

Wrześniowska Joanna 429

Wypustek Katarzyna 195

Wysłowska Joanna590

Wysocka Alicja 492

Wysocki Roman 412, 428

Wyspiański Stanisław 197, 340

Yalom Irvin 327

Yoshimoto Banana 330
Zabielska-Stadnik Iwona 314, 316

Zabłocki Michał 347, 351-352, 535

Zaczyński Michał 204

Zadros Krzysztof 590, 621, 633

Zafón Carlos R. 167, 413

Zagajewski Adam 85, 101, 182, 271, 338

Zając Magdalena 543

Zakrzewski Piotr 588

Zaleska Z. 300

Zaleski Marek 105

Zaleszczyk Zofia 381

Zalewska Katarzyna 226, 270-271

Zalewski Igor 203

Załuski Jan 127-128, 130

Zanussi Krzysztof 56, 58, 292

Zapaśnik Honorata 314

Zapolska Gabriela 549

Zaremba Piotr 220-221, 225, 236, 285

Zarembina Jolanta 216, 263, 277

Zarywski Zbigniew 200

Zasacka Zofia 634

Zasłona Iza 590

Zawieyski Jerzy 190

Zawiślański Stanisław 120

Zaworska Helena 144, 157,

Zaworska-Nikoniuk Dorota 300

Zboralska Kama 158

Zborowska Maria 183

Zeh Julia 103

Zembaty Maciej 381, 430

Zgliczyńska Iwona 492

Zieglar Ewa305

Zieleniewski Marek 128, 138

Zielińska Beata 590

Zieliński Michał 138, 140

Ziemkiewicz Rafał A. 214, 221, 225, 235, 237, 240, 282, 292

Ziębiński Robert 236, 241-242, 244

Zimmerer Katarzyna 309, 348

Zimny Piotr 128

Ziółkowska-Boehm Aleksandra 374

Zomkowski Jan 186

Zubczyński Roman 588

Zubowicz Beata 427

Zuchowa Anita 226

Zunderlich Stanisław 218

Zwierzyńska-Severi Eva 373

Zych Izabela 528 
Żabski Tadeusz 11

Żak Anita 621-622

Żakowski Jacek 56, 74, 87

Żebrowska Danuta [479]-480

Żebrowska-Piotrak Małgorzata 547

Żeromski Stefan 111, 340, 460, 626

Żmichowska Narcyza 188
Żmijewski Artur 430

Żółkiewski Stefan 49-50

Żółkowski Fortunat A. 10

Żuławski Andrzej 158, 399, 414

Żuławski Mirosław 373

Żurek Jerzy 394 


\section{WYKAZ ANEKSÓW*}

Aneks 1. Autorzy recenzji drukowanych na łamach „Polityki” w latach 2001-2005

Aneks 2. Autorzy książek recenzowanych na łamach „Polityki” w latach 2001-2005

Aneks 3. Wydawcy recenzowanych książek na łamach „Polityki” w latach 2001-2005

Aneks 4. Nazwiska osób związanych z książką, z którymi przeprowadzono wywiad na łamach „Polityki” w latach 2001-2005

Aneks 5. Autorzy książek reklamowanych na łamach „Polityki” w latach 2001-2005

Aneks 6. Wydawcy, którzy zamieścili swe anonse na łamach „Polityki” w latach 2001-2005

Aneks 7. Sylwetki twórców przedstawionych na łamach „Polityki” w latach 2001-2005

Aneks 8. Wybór tekstów związanych $\mathrm{z}$ literaturą i rynkiem wydawniczo-księgarskim, zamieszczonych na łamach „Polityki” w latach 2001-2005

Aneks 9. Wybór tekstów poświęconych rynkowi prasowemu, drukowanych na łamach „Polityki” w latach 2001-2005

Aneks 10. Laureaci Nagród Kisiela, lata 2001-2005

Aneks 11. Człowiek Roku tygodnika „Wprost” w latach 2001-2005

Aneks 12. Autorzy recenzji drukowanych na łamach „Wprost” w latach 2001-2005

Aneks 13. Autorzy książek recenzowanych książek na łamach Wprost” w latach 2001-2005

Aneks 14. Wydawcy książek recenzowanych na łamach „Wprost” w latach 2001-2005

Aneks 15. Osoby związane $\mathrm{z}$ książką, z którymi przeprowadzono wywiad na łamach „Wprost” w latach 2001-2005

Aneks 16. Autorzy reklamowanych książek na łamach „Wprost” w latach 2001-2005

Aneks 17. Wydawcy, którzy zamieścili swe anonse na łamach „Wprost” w latach 2001-2005

Aneks 18. Wybór tekstów związanych z literaturą i rynkiem wydawniczo-księgarskim, zamieszczonych na łamach „Wprost” w latach 2001-2005

Aneks 19. Autorzy recenzji drukowanych na łamach „Newsweek Polska” w latach 20012005

Aneks 20. Autorzy recenzowanych książek na łamach „Newsweek Polska” w latach 20012005

Aneks 21. Wydawcy recenzowanych książek na łamach „Newsweek Polska” w latach 20012005

Aneks 22. Nazwiska osób związanych z książką, z którymi przeprowadzono wywiad na łamach „Newsweek Polska” w latach 2001-2005

Aneks 23. Autorzy książek reklamowanych na łamach „Newsweek Polska” w latach 20012005

Aneks 24. Wydawcy, którzy zamieścili swe anonse na łamach „Newsweek Polska” w latach 2001-2005.

Aneks 25. Sylwetki twórców przedstawionych na łamach „Newsweek Polska” w latach 20012005

*Jak zaznaczono we Wstępie, aneksy, ze względu na swą objętość, zostały umieszczone na dołączonej do książki płycie CD. 
Aneks 26. Wybór tekstów związanych z literaturą i rynkiem wydawniczo-księgarskim, zamieszczonych na łamach „Newsweek Polska” w latach 2001-2005

Aneks 27. Wybór tekstów poświęconych rynkowi prasowemu na łamach „Newsweek Polska” w latach 2001-2005

Aneks 28. Wspólni dla tygodników „Polityka”, „Wprost”, „Newsweek Polska” autorzy recenzowanych książek w latach 2001-2005

Aneks 29. Autorzy recenzji zamieszczanych na łamach „Zwierciadła” w latach 2001-2005

Aneks 30. Autorzy książek recenzowanych na łamach „Zwierciadła” w latach 2001-2005

Aneks 31. Wydawcy książek recenzowanych na łamach „Zwierciadła” w latach 2001-2005. Strona recenzyjna: Moje książki

Aneks 32. Wydawcy książek recenzowanych na łamach „Zwierciadła” w latach 2001-2005 Strona recenzyjna: Ksiq̨żki $\rightarrow$ Nowości wydawnicze

Aneks 33. Nazwiska osób związanych z książką, z którymi przeprowadzono wywiady na łamach „Zwierciadła” w latach 2001-2005

Aneks 34. Wydawcy reklamujący książki na łamach „Zwierciadła” w latach 2001-2005

Aneks 35. Autorzy książek reklamowanych na łamach „Zwierciadła” w latach 2001-2005

Aneks 36. Wybór tekstów związanych z literaturą i rynkiem wydawniczo-księgarskim, zamieszczonych na łamach „Zwierciadła” w latach 2001-2005

Aneks 37. Autorzy książek recenzowanych na łamach „Twojego Stylu” w latach 2001-2005

Aneks 38. Wydawcy książek recenzowanych na łamach „Twojego Stylu” w latach 2001-2005

Aneks 39. Nazwiska osób związanych z książką, z którymi przeprowadzono wywiad na łamach na łamach „Twojego Stylu” w latach 2001-2005

Aneks 40. Wydawcy, którzy zamieścili swe ogłoszenia na łamach na łamach „Twojego Stylu” w latach 2001-2005

Aneks 41. Autorzy książek reklamowanych na łamach „Twojego Stylu” w latach 2001-2005

Aneks 42. Wybór tekstów związanych z literaturą i rynkiem wydawniczo-księgarskim, zamieszczonych na łamach „Twojego Stylu” w latach 2001-2005

Aneks 43. Autorzy książek recenzowanych na łamach „Elle” w latach 2001-2005

Aneks 44. Nazwiska osób związanych z książką, z którymi przeprowadzono wywiad na łamach „Elle” w latach 2001-2005

Aneks 45. Autorzy książek recenzowanych na łamach „Filipinki” w latach 2001-2005

Aneks 46. Wydawcy książek recenzowanych na łamach „Filipinki” w latach 2001-2005

Aneks 47. Autorzy książek reklamowanych na łamach „Filipinki” w latach 2001-2005

Aneks 48. Wydawcy reklamujący książki na łamach „Filipinki” w latach 2001-2005

Aneks 49. Wybór tekstów związanych z literaturą i rynkiem wydawniczo-księgarskim, zamieszczonych na łamach „Filipinki” w latach 2001-2005

Aneks 50. Autorzy książek recenzowanych na łamach „Dziewczyny” w latach 2001-2005

Aneks 51. Wydawcy książek recenzowanych na łamach „Dziewczyny” w latach 2001-2005

Aneks 52. Wybór tekstów związanych z literaturą i rynkiem wydawniczo-księgarskim, zamieszczonych na łamach "Dziewczyny” w latach 2001-2005

Aneks 53. Autorzy książek recenzowanych na łamach „Cogito” w latach 2001-2005

Aneks 54. Wydawcy książek recenzowanych na łamach „Cogito” w latach 2001-2005

Aneks 55. Nazwiska osób związanych z książką, z którymi przeprowadzono wywiad na łamach „Cogito” w latach 2001-2005

Aneks 56. Autorzy książek reklamowanych na łamach „Cogito” w latach 2001-2005

Aneks 57. Wydawcy książek reklamowanych na łamach „Cogito” w latach 2001-2005

Aneks 58. Wybór tekstów związanych z literaturą i rynkiem wydawniczo-księgarskim, zamieszczonych na łamach „Cogito” w latach 2001-2005 


\section{WYKAZ TABEL}

Tabela 1. Tytuły książek wydanych w Polsce oraz największe (pod względem liczby wydawanych tytułów) oficyny wydawnicze w latach 2001-2005

Tabela 2. Formy obecności książki i informacji o niej na łamach „Polityki” w latach 2001-2005

Tabela 3. Recenzje w dziale Kultura oraz w innych miejscach w „Polityce”

Tabela 4. Recenzje drukowane poza rubryką recenzyjną na łamach „Polityki” .................... 71

Tabela 5. Najczęściej recenzowani autorzy polscy na łamach „Polityki” w latach 2001-2005

Tabela 6. Najczęściej recenzowani autorzy obcy na łamach „Polityki” w latach 2001-2005

Tabela 7. Wydawcy najczęściej recenzowanych książek na łamach „Polityki” w latach 2001-2005

Tabela 8. Wywiady zamieszczane na łamach „Polityki” w latach 2001-2005

Tabela 9. Ogłoszenia wydawców książek na łamach „Polityki” w latach 2001-2005

Tabela 10. Najczęściej powtarzające się tytuły w reklamach wydawniczych na łamach „Polityki” w latach 2001-2005

Tabela 11. Autorzy książek reklamowanych przez wydawców (więcej niż 1 tytuł) na łamach „Polityki” w latach 2001-2005

Tabela 12. Wydawcy najczęściej zamieszczający inseraty na łamach „Polityki” w latach 2001-2005

Tabela 13. Laureaci Nagród Historycznych, przyznawanych przez „Politykę” w latach 2001-2005

Tabela 14. Formy obecności książki i informacji o niej na łamach „Wprost” w latach 2001-2005

Tabela 15. Recenzje zamieszczane na łamach „Wprost” w latach 2001-2005 .

Tabela 16. Recenzje w poszczególnych działach i rubrykach „Wprost” w latach 2001-2005

Tabela 17. Recenzje zamieszczane na łamach „Wprost” w poszczególnych działach i rubrykach innych niż typowa rubryka recenzyjna w latach 2001-2005

Tabela 18. Najczęściej recenzowani autorzy na łamach „Wprost” w latach 2001-2005 ... 158

Tabela 19. Wydawcy najczęściej recenzowanych książek na łamach „Wprost” w latach 2001-2005

Tabela 20. Wywiady zamieszczane na łamach „Wprost” w latach 2001-2005

Tabela 21. Ogłoszenia wydawców książek w latach 2001-2005 na łamach „Wprost” ....... 169

Tabela 22. Najczęściej powtarzające się tytuły w reklamach wydawniczych w latach 2001-2005 na łamach „Wprost”

Tabela 23. Autorzy książek reklamowanych przez wydawców (więcej niż 1 tytuł) na łamach „Wprost” w latach 2001-2005

Tabela 24. Wydawcy najczęściej zamieszczający inseraty na łamach „Wprost” w latach 2001-2005 
Tabela 25. Laureaci Nagrody Literackiej im. Józefa Mackiewicza 201

Tabela 26. Formy obecności książki i informacji o niej na łamach „Newsweek Polska” w latach 2001-2005

Tabela 27. Recenzje zamieszczane na łamach „Newsweek Polska” w latach 20012005

Tabela 28. Recenzje w dziale Kultura oraz w innych miejscach w „Newsweek Polska” w latach 2001-2005

Tabela 29. Najczęściej recenzowani autorzy polscy i obcy na łamach „Newsweek Polska" w latach 2001-2005

Tabela 30. Wydawcy najczęściej recenzowanych książek na łamach „Newsweek Polska" w latach 2001-2005

Tabela 31. Wywiady zamieszczane na łamach „Newsweek Polska” w latach 2001-2005

Tabela 32. Ogłoszenia wydawnicze zamieszczane na łamach „Newsweek Polska” w latach 2001-2005

Tabela 33. Autorzy, których książki reklamowano najczęściej na łamach „Newsweek Polska" w latach 2001-2005

Tabela 34. Wydawcy najczęściej zamieszczający inseraty na łamach „Newsweek Polska" w latach 2001-2005

Tabela 35. Laureaci konkursu literackiego Podporiusz .

Tabela 36. Porównanie liczby informacji o książce na łamach tygodników „Polityka”, "Wprost" i „Newsweek Polska”

Tabela 37. Średnia liczby informacji, przypadająca na 1 numer

Tabela 38. Wydawcy, którzy zamieścili reklamy na łamach „Polityki”, „Wprost” oraz „Newsweek Polska”

Tabela 39. Formy obecności książki i informacji o niej na łamach „Zwierciadła” w latach 2001-2005

Tabela 40. Recenzje zamieszczane na łamach „Zwierciadła” w latach 2001-2005 .

Tabela 41. Wydawcy książek najczęściej recenzowanych na łamach „Zwierciadła” w latach 2001-2005

Tabela 42. Wywiady z osobami związanymi ze światem literatury, zamieszczane na łamach „Zwierciadła” w latach 2001-2005

Tabela 43. Reklamy wydawnicze zamieszczane na łamach „Zwierciadła” w latach 2001-2005

Tabela 44. Autorzy książek reklamowanych przez wydawców (więcej niż 1 tytuł) na łamach „Zwierciadła” w latach 2001-2005

Tabela 45. Formy obecności książki i informacji o niej na łamach „Twojego Stylu” w latach 2001-2005

Tabela 46. Recenzje, omówienia i adnotacje zamieszczone na łamach „Twojego Stylu” w latach 2001-2005

Tabela 47. Wydawcy najczęściej recenzowanych na łamach „Twojego Stylu” książek w latach 2001-2005

Tabela 48. Ogłoszenia wydawnicze zamieszczane na łamach „Twojego Stylu” w latach 2001-2005

Tabela 49. Najczęściej powtarzające się tytuły w reklamach wydawniczych w latach 2001-2005 na łamach „Twojego Stylu”

Tabela 50. Autorzy książek reklamowanych przez wydawców (więcej niż 1 tytuł) na łamach „Twojego Stylu” w latach 2001-2005 . 
Tabela 51. Pisarze zamieszczający felietony na łamach „Twojego Stylu” w latach 2001-2005

Tabela 52. Formy obecności książki i informacji o niej na łamach „Elle” w latach 2001-2005

Tabela 53. Recenzje, omówienia, streszczenia na łamach „Elle” w latach 2001-2005 ....... 439

Tabela 54. Najczęściej recenzowani autorzy na łamach „Elle” w latach 2001-2005 ........... 447

Tabela 55. Wydawcy najczęściej recenzowanych książek na łamach „Elle” w latach 2001-2005

Tabela 56. Wywiady zamieszczane na łamach „Elle” w latach 2001-2005

Tabela 57. Ogłoszenia wydawnicze zamieszczane na łamach „Elle” w latach 20012005

Tabela 58. Porównanie liczby informacji o książce na łamach magazynów: „Zwierciadło”, „Twój Styl”, Elle” w latach 2001-2005

Tabela 59. Średnia liczby informacji, przypadająca na 1 numer

Tabela 60. Formy obecności książki i informacji o niej na łamach na łamach „Filipinki” w latach 2001-2005

Tabela 61. Recenzje, omówienia i streszczenia zamieszczane na łamach „Filipinki” w latach 2001-2005

Tabela 62. Wydawcy najczęściej recenzowanych książek na łamach „Filipinki” w latach 2001-2005

Tabela 63. Wywiady z osobami związanymi ze światem literatury, zamieszczane na łamach „Filipinki” w latach 2001-2005

Tabela 64. Ogłoszenia wydawnicze zamieszczane na łamach „Filipinki” w latach 2001-2005

Tabela 65. Formy obecności książki i informacji o niej na łamach „Dziewczyny” w latach 2001-2005

Tabela 66. Recenzje, omówienia i streszczenia książek na łamach „Dziewczyny” w latach 2001-2005

Tabela 67. Nazwiska pisarzy, którzy pojawili się w recenzjach książek przynajmniej trzykrotnie na łamach „Dziewczyny” w latach 2001-2005

Tabela 68. Wydawcy najczęściej recenzowanych książek na łamach „Dziewczyny” w latach 2001-2005

Tabela 69. Ogłoszenia wydawnicze zamieszczane na łamach „Dziewczyny” w latach 2001-2005

Tabela 70. Formy obecności książki i informacji o niej na łamach „Cogito” w latach 2001-2005

Tabela 71. Recenzje, omówienia i streszczenia książek zamieszczane na łamach "Cogito" w latach 2001-2005

Tabela 72. Nazwiska pisarzy, którzy pojawili się w recenzjach książek przynajmniej trzykrotnie na łamach „Cogito" w latach 2001-2005

Tabela 73. Wydawcy najczęściej recenzowanych książek na łamach „Cogito” w latach 2001-2005

Tabela 74. Wywiady z osobami związanymi ze światem literatury, zamieszczane na łamach „Cogito” w latach 2001-2005

Tabela 75. Ogłoszenia wydawnicze zamieszczane na łamach "Cogito" w latach 2001-2005

Tabela 76. Typy książek reklamowanych na łamach „Cogito” w latach 2001-2005 ...

Tabela 77. Autorzy dzieł naukowych i oświatowych najczęściej reklamowani na łamach „Cogito” w latach 2001-2005 
Tabela 78. Wydawcy najczęściej reklamowanych książek na łamach „Cogito” w latach 2001-2005

Tabela 79. Porównanie liczby informacji o książce na łamach „Filipinki”, „Dziewczyny” oraz „Cogito”

Tabela 80. Średnia liczby informacji, przypadająca na 1 numer 637

Tabela 81. Dane bibliograficzne dotyczące omawianych w książce periodyków 644

Tabela 82. Porównanie liczby informacji o książce na łamach analizowanych czasopism

Tabela 83. Autorzy recenzowanych książek, wspólni dla badanych czasopism w latach 2001-2005

Tabela 84. Edytorzy, zamieszczający reklamy wydawnicze na łamach badanych periodyków oraz wspólne dla poszczególnych grup oficyny 664 


\section{WYKAZ ZDJĘĆ}

Zdjęcie 1. Rubryka Wieczne Pióra ................................................................................................. 65

Zdjęcie 2. Rubryka Kultura/ksiq̨żki ........................................................................................... 66

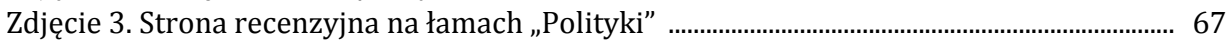

Zdjęcie 4. Strona recenzyjna na łamach „Polityki” ........................................................................ 67

Zdjęcie 5. Strona recenzyjna na łamach „Polityki” ................................................................... 69

Zdjęcie 6. Wybrane ogłoszenie wydawnicze zamieszczone na łamach „Polityki” ................. 95

Zdjęcie 7. Wybrane ogłoszenie wydawnicze zamieszczone na łamach „Polityki” ................. 95

Zdjęcie 8. Wybrane ogłoszenie wydawnicze zamieszczone na łamach „Polityki” ................. 96

Zdjęcie 9. Wybrane ogłoszenie wydawnicze zamieszczone na łamach „Polityki” ................ 96

Zdjęcie 10. Wybrane ogłoszenie wydawnicze zamieszczone na łamach „Polityki” .............. 97

Zdjęcie 11. Wybrane ogłoszenie wydawnicze zamieszczone na łamach „Polityki” .............. 97

Zdjęcie 12. Wybrane ogłoszenie wydawnicze zamieszczone na łamach „Polityki” .............. 98

Zdjęcie 13. Wybrane ogłoszenie wydawnicze zamieszczone na łamach „Polityki” .............. 98

Zdjęcie 14. Wybrane ogłoszenie wydawnicze zamieszczone na łamach „Polityki” .............. 99

Zdjęcie 15. Wybrane ogłoszenie wydawnicze zamieszczone na łamach „Polityki” .............. 99

Zdjęcie 16. Reklama Wydawców Prasy ........................................................................................ 122

Zdjęcie 17. Wybrane ogłoszenie wydawnicze zamieszczone na łamach „Polityki” .............. 123

Zdjęcie 18. Wybrane ogłoszenie wydawnicze zamieszczone na łamach „Polityki” ............... 123

Zdjęcie 19. Wybrane ogłoszenie wydawnicze zamieszczone na łamach „Polityki” ............... 123

Zdjęcie 20. Strona recenzyjna na łamach „Wprost” ......................................................................... 145

Zdjęcie 21. Strona recenzyjna na łamach „Wprost" ......................................................................... 146

Zdjęcie 22. Strona recenzyjna na łamach „Wprost" ....................................................................... 147

Zdjęcie 23. Strona recenzyjna na łamach „Wprost” ...................................................................... 148

Zdjęcie 24. Strona recenzyjna na łamach „Wprost" ...................................................................... 149

Zdjęcie 25. Strona recenzyjna na łamach „Wprost” ........................................................................ 150

Zdjęcie 26. Strona recenzyjna na łamach „Wprost” ......................................................................... 151

Zdjęcie 27. Strona recenzyjna na łamach „Wprost” ......................................................................... 152

Zdjęcie 28. Strona recenzyjna na łamach „Wprost” ........................................................................ 153

Zdjęcie 29. Strona recenzyjna na łamach „Wprost” ....................................................................... 154

Zdjęcie 30. Ranking Wprost i Empiku ............................................................................................. 165

Zdjęcie 31. Bestsellery Wprost ................................................................................................... 165

Zdjęcie 32. Wybrane ogłoszenie wydawnicze zamieszczone na łamach „Wprost” ............... 173

Zdjęcie 33. Wybrane ogłoszenie wydawnicze zamieszczone na łamach „Wprost” ............... 175

Zdjęcie 34. Wybrane ogłoszenie wydawnicze zamieszczone na łamach „Wprost" ............... 175

Zdjęcie 35. Wybrane ogłoszenie wydawnicze zamieszczone na łamach „Wprost” ................ 176

* Zdjęcia pochodzą ze zbiorów Biblioteki Narodowej w Warszawie, Biblioteki Uniwersyteckiej w Łodzi, Miejskiej Biblioteki Publicznej im. J. Piłsudskiego w Łodzi oraz z własnych zbiorów Autorki. 
Zdjęcie 36. Wybrane ogłoszenie wydawnicze zamieszczone na łamach „Wprost” ................ 176

Zdjęcie 37. Wybrane ogłoszenie wydawnicze zamieszczone na łamach „Wprost” ............... 177

Zdjęcie 38. Wybrane ogłoszenie wydawnicze zamieszczone na łamach „Wprost” ............... 177

Zdjęcie 39. Wybrane ogłoszenie wydawnicze zamieszczone na łamach „Wprost” ................ 177

Zdjęcie 40. Wybrane ogłoszenie wydawnicze zamieszczone na łamach „Wprost” ................ 177

Zdjęcie 41. Wybrane ogłoszenie wydawnicze zamieszczone na łamach „Wprost” ................ 178

Zdjęcie 42. Wybrane ogłoszenie wydawnicze zamieszczone na łamach „Wprost” ................ 179

Zdjęcie 43. Wybrane ogłoszenie wydawnicze zamieszczone na łamach „Wprost” ................ 179

Zdjęcie 44. Wybrane ogłoszenie wydawnicze zamieszczone na łamach „Wprost” ................ 180

Zdjęcie 45. Wybrane ogłoszenie wydawnicze zamieszczone na łamach „Wprost” ............... 180

Zdjęcie 46. Wybrane ogłoszenie wydawnicze zamieszczone na łamach „Wprost” ............... 205

Zdjęcie 47. Wybrane ogłoszenie wydawnicze zamieszczone na łamach „Wprost” ................ 205

Zdjęcie 48. Wybrane ogłoszenie wydawnicze zamieszczone na łamach „Wprost” ............... 207

Zdjęcie 49. Wybrane ogłoszenie wydawnicze zamieszczone na łamach „Wprost” ................ 207

Zdjęcie 50. Wybrane ogłoszenie wydawnicze zamieszczone na łamach „Wprost” ................ 207

Zdjęcie 51. Wybrane ogłoszenie wydawnicze zamieszczone na łamach „Wprost” ................ 207

Zdjęcia 52. Przykładowa strona recenzyjne na łamach „Newsweek Polska” ........................... 231

Zdjęcia 53. Przykładowa strona recenzyjna na łamach „Newsweek Polska” ........................... 232

Zdjęcia 54. Przykładowa strona recenzyjna na łamach „Newsweek Polska” ............................ 233

Zdjęcia 55. Przykładowa strona recenzyjna na łamach „Newsweek Polska” ........................... 233

Zdjęcia 56. Przykładowe ogłoszenie wydawnicze zamieszczone na łamach „News-

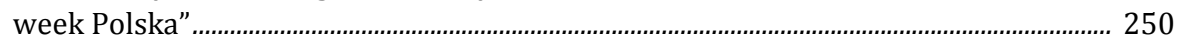

Zdjęcia 57. Przykładowe ogłoszenie wydawnicze zamieszczone na łamach „News-

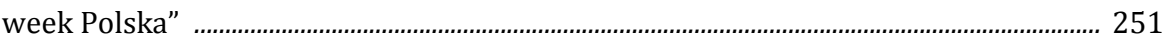

Zdjęcia 58. Przykładowe ogłoszenie wydawnicze zamieszczone na łamach „Newsweek Polska" ........................................................................................................................... 251

Zdjęcia 59. Przykładowe ogłoszenie wydawnicze zamieszczone na łamach „Newsweek Polska"

Zdjęcia 60. Przykładowe ogłoszenie wydawnicze zamieszczone na łamach „Newsweek Polska"

Zdjęcie 61. Przykładowe ogłoszenie wydawnicze zamieszczone na łamach „Newsweek Polska"

Zdjęcie 62. Przykładowe ogłoszenie wydawnicze zamieszczone na łamach „Newsweek Polska"

Zdjęcie 63. Przykładowe ogłoszenie wydawnicze zamieszczone na łamach „Newsweek Polska"

Zdjęcie 64. Hity września na łamach „Newsweek Polska” ........................................................... 255

Zdjęcie 65. Książki. Ranking na łamach „Newsweek Polska” .................................................... 256

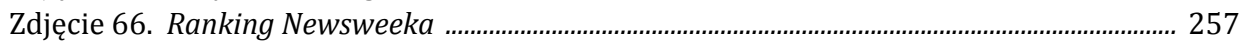

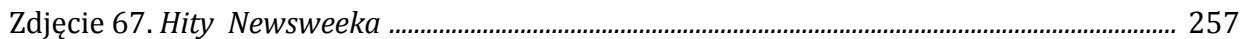

Zdjęcie 68. Ranking bestsellerów „Newsweek Polska” .............................................................. 258

Zdjęcie 69. Przykładowe ogłoszenie zamieszczone na łamach „Newsweek Polska” ........... 286

Zdjęcie 70. Przykładowe ogłoszenie zamieszczone na łamach „Newsweek Polska” ............. 287

Zdjęcie 71. Przykładowe ogłoszenie zamieszczone na łamach „Newsweek Polska” ............. 287

Zdjęcie 72. Przykładowe ogłoszenie zamieszczone na łamach „Newsweek Polska” ............. 288

Zdjęcie 73. Przykładowe ogłoszenie zamieszczone na łamach „Newsweek Polska” ............ 289

Zdjęcie 74. Przykładowe ogłoszenie zamieszczone na łamach „Newsweek Polska” ............. 289

Zdjęcie 75. Przykładowe ogłoszenie zamieszczone na łamach „Newsweek Polska” ............. 289 
Zdjęcie 76. Przykładowa strona recenzyjna na łamach „Zwierciadła” ....................................... 317

Zdjęcie 77. Przykładowa strona recenzyjna na łamach „Zwierciadła” ....................................... 317

Zdjęcie 78. Przykładowa strona recenzyjna na łamach „Zwierciadła” ......................................... 318

Zdjęcie 79. Przykładowa strona recenzyjna na łamach „Zwierciadła” ....................................... 318

Zdjęcie 80. Przykładowa strona recenzyjna na łamach „Zwierciadła” ....................................... 320

Zdjęcie 81. Przykładowa strona recenzyjna na łamach „Zwierciadła” ....................................... 320

Zdjęcie 82. Przykładowa strona recenzyjna na łamach „Zwierciadła” ....................................... 321

Zdjęcie 83. Przykładowa strona recenzyjna na łamach „Zwierciadła” ....................................... 321

Zdjęcie 84. Przykładowa strona recenzyjna na łamach „Zwierciadła” ....................................... 323

Zdjęcie 85. Przykładowa strona recenzyjna na łamach „Zwierciadła” ......................................... 323

Zdjęcie 86. Przykładowa strona recenzyjna na łamach „Zwierciadła” ......................................... 324

Zdjęcie 87. Przykładowa strona recenzyjna na łamach „Zwierciadła” ....................................... 324

Zdjęcia 88. Przykładowa strona recenzyjna na łamach „Zwierciadła” ........................................ 324

Zdjęcia 89. Przykładowa strona recenzyjna na łamach „Zwierciadła” ....................................... 324

Zdjęcia 90. Przykładowa strona recenzyjna na łamach „Zwierciadła” ....................................... 325

Zdjęcia 91. Przykładowa strona recenzyjna na łamach „Zwierciadła” ....................................... 325

Zdjęcie 92. Wybrane ogłoszenie wydawnicze zamieszczone na łamach „Zwierciadła” ...... 341

Zdjęcie 93. Wybrane ogłoszenie wydawnicze zamieszczone na łamach „Zwierciadła” ...... 342

Zdjęcie 94. Wybrane ogłoszenie wydawnicze zamieszczone na łamach „Zwierciadła” ...... 342

Zdjęcie 95. Wybrane ogłoszenie wydawnicze zamieszczone na łamach „Zwierciadła” ...... 342

Zdjęcie 96. Wybrane ogłoszenie wydawnicze zamieszczone na łamach „Zwierciadła” ...... 342

Zdjęcie 97. Wybrane ogłoszenie wydawnicze zamieszczone na łamach „Zwierciadła” ...... 343

Zdjęcie 98. Wybrane ogłoszenie wydawnicze zamieszczone na łamach „Zwierciadła” ...... 343

Zdjęcie 99. Wybrane ogłoszenie wydawnicze zamieszczone na łamach „Zwierciadła” ...... 344

Zdjęcie 100. Wybrane ogłoszenie wydawnicze zamieszczone na łamach „Zwierciadła” .... 345

Zdjęcie 101. Wybrane ogłoszenie wydawnicze zamieszczone na łamach „Zwierciadła” .... 364

Zdjęcie 102. Wybrane ogłoszenie wydawnicze zamieszczone na łamach „Zwierciadła” .... 364

Zdjęcie 103. Wybrane ogłoszenie wydawnicze zamieszczone na łamach „Zwierciadła” .... 365

Zdjęcie 104. Wybrane ogłoszenie wydawnicze zamieszczone na łamach „Zwierciadła” .... 366

Zdjęcie 105. Wybrane ogłoszenie wydawnicze zamieszczone na łamach „Zwierciadła” .... 366

Zdjęcie 106. Wybrane ogłoszenie wydawnicze zamieszczone na łamach „Zwierciadła” .... 367

Zdjęcie 107. Wybrane ogłoszenie wydawnicze zamieszczone na łamach „Zwierciadła” .... 368

Zdjęcie 108. Przykładowa strona recenzyjna na łamach „Twojego Stylu” ................................ 389

Zdjęcie 109. Przykładowa strona recenzyjna na łamach „Twojego Stylu” ................................. 390

Zdjęcie 110. Przykładowa strona recenzyjna na łamach „Twojego Stylu” ............................... 391

Zdjęcie 111. Przykładowa strona recenzyjna na łamach „Twojego Stylu” ............................... 391

Zdjęcie 112. Przykładowa strona recenzyjna na łamach „Twojego Stylu” ............................... 392

Zdjęcie 113. Przykładowa strona recenzyjna na łamach „Twojego Stylu” ............................... 392

Zdjęcie 114. Przykładowa strona recenzyjna na łamach „Twojego Stylu” ............................... 393

Zdjęcie 115. Przykładowe ogłoszenie wydawnicze zamieszczone na łamach „Twojego Stylu"

Zdjęcie 116. Przykładowe ogłoszenie wydawnicze zamieszczone na łamach „Twojego Stylu"

Zdjęcie 117. Przykładowe ogłoszenie wydawnicze zamieszczone na łamach „Twojego Stylu".

Zdjęcie 118. Przykładowe ogłoszenie wydawnicze zamieszczone na łamach „Twojego Stylu"

Zdjęcie 119. Przykładowe ogłoszenie wydawnicze zamieszczone łamach „Twojego 
Zdjęcie 120. Przykładowe ogłoszenie wydawnicze zamieszczone na łamach „Twojego Stylu"

Zdjęcie 121. Przykładowe ogłoszenie wydawnicze zamieszczone na łamach „Twojego

Stylu"

Zdjęcie 122. Przykładowe ogłoszenie wydawnicze zamieszczone na łamach „Twojego Stylu"

Zdjęcie 123. Przykładowe ogłoszenie wydawnicze zamieszczone na łamach „Twojego Stylu"

Zdjęcie 124. Przykładowe ogłoszenie wydawnicze zamieszczone na łamach „Twojego Stylu".

Zdjęcie 125. Przykładowe ogłoszenie wydawnicze zamieszczone na łamach „Twojego Stylu"

Zdjęcie 126. Przykładowe ogłoszenie wydawnicze zamieszczone na łamach „Twojego Stylu"

Zdjęcie 127. Przykładowe ogłoszenie wydawnicze zamieszczone na łamach „Twojego Stylu"

Zdjęcie 128. Przykładowe ogłoszenie wydawnicze zamieszczone na łamach „Twojego Stylu"

Zdjęcie 129. Rubryka poświęcona książce na łamach „Elle” ....................................................... 441

Zdjęcie 130. Rubryka poświęcona książce na łamach „Elle” ....................................................... 441

Zdjęcie 131. Strona recenzyjna na łamach „Elle” ........................................................................... 443

Zdjęcie 132. Strona recenzyjna na łamach „Elle” ............................................................................. 443

Zdjęcie 133. Strona recenzyjna na łamach „Elle” .............................................................................. 444

Zdjęcie 134. Strona recenzyjna na łamach „Elle” ............................................................................. 444

Zdjęcie 135. Strona recenzyjna (jedna z dwóch) na łamach „Elle” .............................................. 445

Zdjęcie 136. Strona recenzyjna (jedna z dwóch) na łamach „Elle” ............................................. 445

Zdjęcie 137. Strona recenzyjna na łamach „Elle” ............................................................................ 446

Zdjęcie 138. Wybrane ogłoszenie wydawnicze zamieszczone na łamach „Elle” .................... 457

Zdjęcie 139. Wybrane ogłoszenie wydawnicze zamieszczone na łamach „Elle” .................... 457

Zdjęcie 140. Wybrane ogłoszenie wydawnicze zamieszczone na łamach „Elle” .................... 458

Zdjęcie 141. Wybrane ogłoszenie wydawnicze zamieszczone na łamach „Elle” ..................... 458

Zdjęcie 142. Wybrane ogłoszenie wydawnicze zamieszczone na łamach „Elle” .................... 458

Zdjęcie 143. Wybrane ogłoszenie wydawnicze zamieszczone na łamach „Elle” .................... 459

Zdjęcie 144. Wybrane ogłoszenie wydawnicze zamieszczone na łamach „Elle” .................... 459

Zdjęcie 145. Wybrane ogłoszenie wydawnicze zamieszczone na łamach „Elle” .................... 465

Zdjęcie 146. Wybrane ogłoszenie wydawnicze zamieszczone na łamach „Elle” .................... 465

Zdjęcie 147. Wybrane ogłoszenie wydawnicze zamieszczone na łamach „Elle” .................... 466

Zdjęcie 148. Strona recenzyjna na łamach „Filipinki” .................................................................. 502

Zdjęcie 149. Strona recenzyjna na łamach „Filipinki” ................................................................... 502

Zdjęcie 150. Strona recenzyjna na łamach „Filipinki” .................................................................. 502

Zdjęcie 151. Strona recenzyjna na łamach „Filipinki” ................................................................. 503

Zdjęcie 152. Strona recenzyjna na łamach „Filipinki” .................................................................... 504

Zdjęcie 153. Strona recenzyjna na łamach „Filipinki” ..................................................................... 505

Zdjęcie 154. Strona recenzyjna na łamach „Filipinki” .................................................................. 506

Zdjęcie 155. Strona recenzyjna na łamach „Filipinki” ................................................................. 506

Zdjęcie 156. Strona recenzyjna na łamach „Filipinki” .................................................................. 507

Zdjęcie 157. Strona recenzyjna na łamach „Filipinki” ..................................................................... 507

Zdjęcie 158. Strona recenzyjna na łamach „Filipinki” ..................................................................... 508 
Zdjęcie 159. Strona recenzyjna na łamach „Filipinki” ...................................................................... 508

Zdjęcie 160. Strona recenzyjna na łamach „Filipinki” .................................................................... 510

Zdjęcie 161. Strona recenzyjna na łamach „Filipinki” ................................................................. 510

Zdjęcie 162. Wybrane ogłoszenie wydawnicze zamieszczone na łamach „Filipinki” ........... 522

Zdjęcie 163. Wybrane ogłoszenie wydawnicze zamieszczone na łamach „Filipinki” ........... 522

Zdjęcie 164. Wybrane ogłoszenie wydawnicze zamieszczone na łamach „Filipinki” ........... 524

Zdjęcie 165. Wybrane ogłoszenie wydawnicze zamieszczone na łamach „Filipinki” ........... 524

Zdjęcie 166. Wybrane ogłoszenie wydawnicze zamieszczone na łamach „Filipinki” ........... 525

Zdjęcie 167. Wybrane ogłoszenie wydawnicze zamieszczone na łamach „Filipinki” ........... 525

Zdjęcie 168. Wybrane ogłoszenie wydawnicze zamieszczone na łamach „Filipinki” ........... 540

Zdjęcie 169. Wybrane ogłoszenie wydawnicze zamieszczone na łamach „Filipinki” ........... 540

Zdjęcie 170. Przykładowa strona recenzyjna na łamach „Dziewczyny” ................................... 556

Zdjęcie 171. Przykładowa strona recenzyjna na łamach „Dziewczyny” .................................... 556

Zdjęcie 172. Przykładowa strona recenzyjna na łamach „Dziewczyny” ................................... 557

Zdjęcie 173. Przykładowa strona recenzyjna na łamach „Dziewczyny” ................................... 557

Zdjęcie 174. Przykładowa strona recenzyjna na łamach „Dziewczyny” ................................... 559

Zdjęcie 175. Przykładowa strona recenzyjna na łamach „Dziewczyny” ................................... 559

Zdjęcie 176. Przykładowa strona recenzyjna na łamach „Dziewczyny” ................................... 560

Zdjęci 177. Wybrane ogłoszenie wydawnicze zamieszczone na łamach „Dziewczyny” ...... 571

Zdjęcie 178. Wybrane ogłoszenie wydawnicze zamieszczone na łamach „Dziewczyny”

Zdjęcie 179. Wybrane ogłoszenie wydawnicze zamieszczone na łamach „Dziewczyny”

Zdjęcie 180. Wybrane ogłoszenie wydawnicze zamieszczone na łamach „Dziewczyny”

Zdjęcie 181. Wybrane ogłoszenie wydawnicze zamieszczone na łamach „Dziewczyny”

Zdjęcie 182. Wybrane ogłoszenie wydawnicze zamieszczone na łamach „Dziewczyny”

Zdjęcie 183. Wybrane ogłoszenie wydawnicze zamieszczone na łamach „Dziewczyny”

Zdjęcie 184. Wybrane ogłoszenie wydawnicze zamieszczone na łamach „Dziewczyny”

Zdjęcie 185. Wybrane ogłoszenie wydawnicze zamieszczone na łamach „Dziewczyny”

Zdjęcie 186. Wybrane ogłoszenie wydawnicze zamieszczone na łamach „Dziewczyny”

Zdjęcie 187. Przykładowa strona recenzyjna na łamach "Cogito”

Zdjęcie 188. Przykładowa strona recenzyjna na łamach "Cogito”

Zdjęcie 189. Przykładowa strona recenzyjna na łamach "Cogito”

Zdjęcie 190. Przykładowa strona recenzyjna na łamach „Cogito”

Zdjęcie 191. Przykładowa strona recenzyjna na łamach "Cogito"

Zdjęcie 192. Przykładowa strona recenzyjna na łamach "Cogito”

Zdjęcie 193. Przykładowe ogłoszenie wydawnicze zamieszczone na łamach "Cogito" 616

Zdjęcie 194. Przykładowe ogłoszenie wydawnicze zamieszczone na łamach „Cogito” ....... 616

Zdjęcie 195. Przykładowe ogłoszenie wydawnicze zamieszczone na łamach „Cogito” ....... 617

Zdjęcie 196. Przykładowe ogłoszenie wydawnicze zamieszczone na łamach „Cogito” ....... 617 
Zdjęcie 197. Przykładowe ogłoszenie wydawnicze zamieszczone na łamach „Cogito” ....... 617

Zdjęcie 198. Przykładowe ogłoszenie wydawnicze zamieszczone na łamach "Cogito” ....... 618

Zdjęcie 199. Przykładowe ogłoszenie wydawnicze zamieszczone na łamach „Cogito” ....... 618

Zdjęcie 200. Wybrane ogłoszenie wydawnicze zamieszczone na łamach „Cogito” .............. 631

Zdjęcie 201. Wybrane ogłoszenie wydawnicze zamieszczone na łamach „Cogito” ............... 632

Zdjęcie 202. Wybrane ogłoszenie wydawnicze zamieszczone na łamach „Cogito” .............. 632

Zdjęcie 203. Wybrane ogłoszenie wydawnicze zamieszczone na łamach „Cogito” ............... 632 


\section{OD REDAKCJI}

Magdalena Przybysz-Stawska jest absolwentką kierunku bibliotekoznawstwo i informacja naukowa na Uniwersytecie Łódzkim (1999 r., praca magisterska pt. Biblioteka u Pana Grohmana: reportaż na łamach „Gazety Wyborczej" jako rezultat przemian zachodzacych $w$ prasie polskiej w latach dziewięćdziesiątych), doktorem nauk humanistycznych w dziedzinie bibliologii (2004 r., doktorat pt. Problem wyboru: promocja ksiq̨żki w dodatkach do wybranych polskich gazet codziennych w latach dziewięćdziesiatych XX wieku), adiunktem (od 2004 r.) w Katedrze Bibliotekoznawstwa i Informacji Naukowej Uniwersytetu Łódzkiego.

Autorka prowadzi zajęcia dydaktyczne, dotyczące m.in. dawnej i współczesnej prasy, wykłady i ćwiczenia na temat tradycyjnych źródeł informacyjno-wyszukiwawczych, a także seminarium dyplomowe. Swoją wiedzę teoretyczną miała okazję uzupełnić doświadczeniem praktycznym nabytym w podjętej, w trakcie studiów, pracy w Bibliotece Głównej Politechniki Łódzkiej.

Zainteresowania naukowe Autorki koncentrują się wokół zagadnień związanych z obecnością książki, form informacji o literaturze, zamieszczanych na łamach polskiej prasy współczesnej. Dotychczasowy dorobek naukowy M. Przybysz-Stawskiej obejmuje ponad 30 publikacji, m.in. artykuły problemowe (w czasopismach recenzowanych i pracach zbiorowych) oraz sprawozdania. Jest również autorką książki: "To się czyta”. Promocja książki $w$ dodatkach do wybranych polskich gazet codziennych w latach dziewięćdziesiąych XX wieku (2006).

Autorka uczestniczyła w kilkunastu ogólnopolskich i międzynarodowych konferencjach naukowych. Brała udział w konkursie Aktualizacja kształcenia akademickiego bibliotekarzy pracujacych $w$ małych bibliotekach gminnych, organizowanym przez Polskie Towarzystwo Bibliologiczne Oddział Warszawski, a następnie realizowała zgłoszony przez siebie przedmiot w macierzystej Katedrze. Uczestniczyła w szkoleniach i kursach (np. Oferta Instytutu Monitorowania Mediów: Monitoring i platforma; Baza MediaContact; Biuro Personalne; Pozyskiwanie i wykorzystywanie środków pozabudżetowych $w$ szkolnictwie wyższym; Warsztaty technik pamięciowych). 
Należała do uczelnianej Komisji Stypendiów Socjalnych. W latach 20062008 pełniła funkcję sekretarza redakcji czasopisma naukowego „Acta Universitatis Lodziensis. Folia Librorum”, a od 2009 r. jest członkiem tejże redakcji. W 2008 r. była sekretarzem konferencji naukowej, organizowanej przez Katedrę Bibliotekoznawstwa i Informacji Naukowej Uniwersytetu Łódzkiego, Przestrzeń informacyjna książki. Jest członkiem Polskiego Towarzystwa Bibliologicznego oraz Stowarzyszenia Bibliotekarzy Polskich oraz Stowarzyszenia Przyjaciół Książki dla Młodych (Polskiej Sekcji IBBY). 